\title{
VAN BATAVIA NAAR WELTEVREDEN
}


Hans Groot - 978-90-04-25380-3

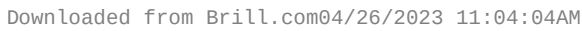
via free access 


\section{E R H A N D E L I N G E N}

VAN HET KONINKLIJK INSTITUUT

VOOR TAAL-, LAND- EN VOLKENKUNDE

\section{3}

\section{HANS GROOT}

\section{VAN BATAVIA NAAR WELTEVREDEN}

Het Bataviaasch Genootschap van

Kunsten en Wetenschappen

1778-1867

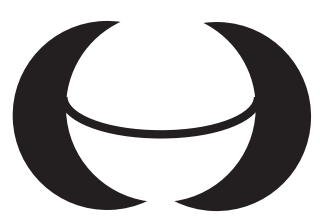

KITLV Uitgeverij

Leiden

2009 
Uitgegeven door:

KITLV Uitgeverij

Koninklijk Instituut voor Taal-, Land- en Volkenkunde

Postbus 9515

2300 RA Leiden

Nederland

website: www.kitlv.nl

e-mail: kitlvpress@kitlv.nl

KITLV is een instituut van de Koninklijke Nederlandse Akademie van

Wetenschappen (KNAW)

Afbeelding omslag: Het nieuwe genootschapsgebouw, tevens museum, aan Koningsplein-West in 1868, kort na de ingebruikneming. Fotograaf vermoedelijk Isidore van Kinsbergen (collectie Scott Merrillees).

Genootschapspenning door J.G. Holtzhey, Amsterdam 1779 (collectie Geldmuseum Utrecht 1977-0182).

Omslag: Creja ontwerpen, Leiderdorp

ISBN 9789067182935

(C) 2009 Koninklijk Instituut voor Taal-, Land- en Volkenkunde

Niets uit deze uitgave mag worden verveelvoudigd en/of openbaar gemaakt door middel van druk, fotokopie, microfilm of op welke andere wijze dan ook zonder voorafgaande schriftelijke toestemming van de copyrighthouders. 


\section{Inhoud}

Vooraf ix

Inleiding 1

Oudere literatuur 4

Nieuwere literatuur 8

Het genootschapsarchief 10

Een geschiedenis van 1778 tot 1867: vraagstelling en verantwoording 12

Historisch tableau 1770-1870 15

Cultuur-historisch tableau 23

Genootschapsonderzoek 38

Genootschappen: de negentiende eeuw 56

I Het oprichtingsjaar en de eerste twee decennia (1778-1799)

De oprichting: 24 april 177863

Bestuur: Radermacher, de initiatiefnemer 66

Relaties met andere genootschappen: Haarlem en Batavia 70

Bestuur: Radermacher en de zijnen 74

Persoonlijkheden: Josua van Iperen 82

De relatie met de overheid 86

Naamgeving: kunsten en wetenschappen 91

Doelstellingen 93

Ledenwerving en erkenning 95

Prijsvragen 104

Publicaties 115

Gebouwen: genootschapshuis en -tuin 123

Verzamelingen 129

Financiën 138

Persoonlijkheden: Moens en Wiegerman 143

Batavia - Paramaribo - Calcutta 150

Einde van de eeuw 152

II Een nieuw begin onder Bataafse, Franse en Britse vlaggen (1800-1816)

Bestuur rond de eeuwwisseling 157

Persoonlijkheden: Thomas Horsfield, Amerikaans natuurkundige 163

Bestuur onder Raffles 167

De relatie met de overheid 171

Publicaties 173 
Gebouwen: een nieuwe behuizing 177

Van Brits naar Nederlands 180

III Terug onder Nederlands bestuur (1816-1826)

Onder beschermheer Van der Capellen 185

Persoonlijkheden: Van der Vinne 193

De nieuwe wetten van 1823197

Een nieuw begin 208

De relatie met de overheid 212

De bibliotheek 218

Verzamelingen 221

De relatie met andere genootschappen 225

IV Japanse zaken en museumplannen (1826-1840)

Bestuur onder Du Bus de Gisignies 231

De relatie met de overheid 233

Persoonlijkheden: Domis, Von Siebold, Goethe 239

Museumplannen en Bauds besluit terzake 254

Gebouwen 263

Verzamelingen 267

Persoonlijkheden: Lenting en Van der Vinne 275

Aanwas van leden 285

V Van Hoëvell en de drukpers van het genootschap (1839-1848)

Van Hoëvell in het bestuur 291

Verzamelingen 294

Publicaties: naar een eigen drukkerij 298

Bestuur onder Van Hoëvell 302

Verzamelingen: oudheidkundige zorg 308

Publicaties: de drukkerij aan het werk 315

Publicaties: aandacht voor inheemse talen 320

Van Hoëvell president 326

Gebouwen 329

De relatie met de overheid: het conflict 332

Epiloog 346

VI Specialisering temidden van concurrenten (1849-1860)

Bestuur: reorganisatie en ledenverlies 349

De noodzaak tot specialiseren: de hand van Bleeker 357

Verenigingsleven - genootschapsleven 364

Concurrerende verenigingen en dubbellidmaatschappen 370

De relatie met de overheid 375

Financiën 388

Verzamelingen 391

Persoonlijkheden: Netscher en Munnich 396

De bibliotheek 401

Gebouwen 406

Publicaties: tekstuitgaven 411 
Persoonlijkheden: Roorda van Eysinga en Friederich 412

Het KITLV en het Tijdschrift voor Indische Taal-, Land- en

Volkenkunde 423

VII Naar een tempel aan het Koningsplein (1861-1867)

Een bestuur van ambtenaren 436

De relatie met de overheid 437

Het bestuur en de leden 438

Een nieuw reglement 440

Beheer en behoud van oudheden op Java 444

Verzamelingen: archeologische voorwerpen 461

Verzamelingen: etnologische voorwerpen 471

Publicaties: Indische taalkunde 483

Verzamelingen: handschriften en inscripties 492

Gebouwen: 'Een sieraad voor Neêrlandsch Indië's hoofdstad' 495

Een nieuw begin 512

Lijst van gebruikte afkortingen

Bijlage 1 Leden en vergaderingen

Bijlage 2 Drukwerk van de pers van het Bataviaasch Genootschap 1843-1848

Bibliografie 
Hans Groot - 978-90-04-25380-3

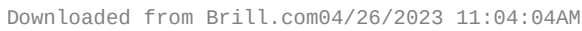
via free access 


\section{Vooraf}

Staande voor het Nationaal Museum in Jakarta, wordt de aandacht van de kijker vooral getrokken door de opvallende hoogbouw, die in 2004 gereed kwam. Pas daarna valt het oog op het bescheiden, neoklassieke gebouw uit 1867. Men zou kunnen denken dat het daar indertijd allemaal begon. Toch is zelfs dat negentiende-eeuwse gebouw al de vierde behuizing van het Bataviaasch Genootschap van Kunsten en Wetenschappen, de organisatie waaruit het Nationaal Museum is voortgekomen. Het genootschap, opgericht in 1778, vond eerst een plek in de oude binnenstad van Batavia om uiteindelijk bijna negentig jaar later aan het Koningsplein, tegenwoordig Medan Merdeka, zijn definitieve locatie te vinden.

Een Nationaal Museum, waarvan de geschiedenis teruggaat tot 1778 , is bepaald uitzonderlijk. Nieuwsgierigheid naar de geschiedenis van een zo eerbiedwaardige instelling stond dan ook aan het begin van de wording van dit boek. Tijdens een bezoek aan het museum vroeg ik me af waar ik met mijn vragen terecht kon. Zo'n museum en de even belangrijke Nationale Bibliotheek van Indonesië, die al eveneens uit het genootschap voortkwam, verdienen dat die geschiedenis vastgelegd wordt. Dit boek beschrijft van die geschiedenis het eerste traject, van de oude binnenstad van het achttiendeeeuwse Batavia naar het Weltevreden van 1814 en vervolgens naar het Koningsplein (1867).

Dat de twee nationale instellingen hun geschiedenis konden prijsgeven is te danken aan het museumgebouw en aan de collecties, die meer dan tweehonderd jaar hebben doorstaan. De interne geschiedenis kon worden bestudeerd aan de hand van de publicaties van het genootschap, maar vooral dankzij een genootschapsarchief dat in het Nationaal Archief van Indonesië wordt bewaard. Daaruit kwam een beeld naar voren van ups en downs, van toewijding en toeval, van mannen die gedreven waren en anderen die het erbij lieten zitten, kortom het relaas van een levende organisatie, die tijdens de koloniale periode een reputatie opbouwde door publicaties en door de collecties. Mijn aanvankelijke ambitie om de hele geschiedenis te beschrijven, tot de opheffing van het genootschap, heb ik moeten inperken tot de periode 
waar het minst van bekend is. Met de ingebruikname van het gebouw aan het Koningsplein sluit mijn studie af.

Het geschiedverhaal is chronologisch van opbouw. Tijdens het onderzoek had ik vaak het gevoel, dat ik het leven van een organisatie beschreef. Het feit dat Nationaal Museum en Nationale Bibliotheek van Indonesië, zoals zij nu zijn, in alle opzichten sporen vertonen van het vroegere genootschap, maakt dat ook een geschiedenis van 1778 tot 1867 voor die instellingen van belang is. Het gaat om hun kinder- en jeugdjaren en hun vroege volwassenheid.

Ik ben bijzondere dank verschuldigd aan mijn promotor, $\mathrm{mr}$ C. Fasseur, emeritus hoogleraar van de Rijksuniversiteit Leiden, voor wie de ongebruikelijk grote afstand tot een promovendus in Jakarta geen enkele belemmering vormde en die mij diverse malen in Jakarta bezocht om het onderzoek te volgen. Ik ben tevens dank verschuldigd aan de referent bij mijn promotie, professor dr W.W. Mijnhardt, die vanuit de Verenigde Staten commentaar op het manuscript leverde, en aan de hoogleraren-commissieleden dr. J.L. Blussé van Oud-Alblas, dr. A.N. Paasman en dr. H.D. Schneider.

Verder ben ik dank verschuldigd aan de directeur van het Nationaal Archief te Jakarta, Drs Djoko Utomo, en de beheerder van het archief van het Bataviaasch Genootschap, Mw Widiyanti, voor de toegang tot een archief dat nog geïnventariseerd werd tijdens het onderzoek voor dit boek. Verder ben ik veel dank verschuldigd aan de Nationale Bibliotheek en met Nationaal Museum van Indonesië, die de collecties van het genootschap beheren.

Voor het onderzoek heb ik hulp ondervonden van de vele archieven en bibliotheken waar ik vanuit Jakarta terecht kon. Ik noem in het bijzonder het Nationaal Archief, de Koninkliijke Bibliotheek en het Koninklijk Huisarchief in Den Haag, het KITLV en de Universiteitsbibliotheek in Leiden, de Rijksarchieven in Zeeland en Noord-Holland en de Oriental and India Office Collections (British Library) te Londen.

Voor de toegang tot de archieven van de Hollandsche Maatschappij der Wetenschappen in Haarlem, toen deze nog bij de Maatschappij berustten, was mevrouw S. Heyne Makkreel-De Vries bijzonder behulpzaam. Mr W. Dirksen hielp mij op weg in het archief van het Zeeuws Genootschap. Voor hulp op verschillende punten ben ik bijzonder dankbaar tegenover Louisa Balk, professor John Bastin, David Blake, Max de Bruijn, Jaap Erkelens, Annabel Gallop, mevrouw G. van der Meer, W. van Keulen, Scott Merrillees, José Pronk, Ronald Rijkse, mevrouw Chr. Schollaardt, A.F. Ubels, Paul van der Velde en Adriënne Zuiderweg.

Mijn collega's in Jakarta, Kees Groeneboer en Herman Poelman, lazen delen van het manuscript en gaven daardoor niet alleen morele ondersteuning. Frans Groot in Amsterdam las het hele manuscript door en gaf waardevolle aanwijzingen. 
Mijn werkgevers, het Ministerie van Onderwijs en Wetenschappen en later de Nederlandse Taalunie, steunden mijn onderzoek door studieverlof toe te kennen. Zonder de hulp van Lulus Yunindiah en vele hulpzame handen bij het Erasmus Taalcentrum te Jakarta was dit boek niet van de pers gekomen. Van dit boek verscheen in 2006 ten behoeve van mijn promotie aan de Rijksuniversiteit Leiden een beperkte oplage in eigen beheer onder de titel Van de Grote Rivier naar het Koningsplein. In die uitgave verwees ik voor het archief van het Bataviaasch Genootschap naar de voorlopige inventaris. Intussen is een definitieve inventaris gereedgekomen. In deze nieuwe uitgave bij het KITLV in Leiden verwijs naar de nieuwe nummering van het archief.

Noot over de schrijfwijze van geografische namen, eigennamen en over gebruikte terminologie

De Indonesische eigennamen zijn overgenomen zoals ze in de archiefstukken en gedrukte ledenlijsten werden aangetroffen. Voor de Indonesische geografische namen is gebruik gemaakt van de spelling zoals die in de laatkoloniale tijd gebruikelijk was.

Ik heb de voorkeur gegeven aan het gebruik van de term 'inheems' boven 'inlands' hoewel ik me bewust ben dat de term 'inlands' in de periode die ik beschrijf een neutralere klank had dan in de laat-koloniale tijd het geval was. Ik gebruik de term 'Indonesisch' ook als ik over de negentiende eeuw schrijf ter aanduiding van de Indonesische genootschapsleden, ter onderscheiding van Nederlandse, Europese of andere Aziatische genootschapsleden, omdat mij geen andere term geschikter voorkwam. 
Hans Groot - 978-90-04-25380-3

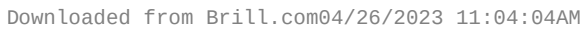
via free access 


\section{Inleiding}

Het Bataviaasch Genootschap van Kunsten en Wetenschappen is een begrip voor wie zich met Indonesische geschiedenis of andere Indonesië-studies bezighoudt. Over de geschiedenis van het genootschap is echter weinig gepubliceerd en daardoor betrekkelijk weinig bekend. Dit geldt vooral voor de eerste vijfenzeventig jaar van zijn bestaan, omdat toen behalve de bundels Verhandelingen nauwelijks andere eigen publicaties verschenen. Met het Tijdschrift van het genootschap en de gedrukte bundels Notulen van de bestuursvergaderingen kwam daar na 1850 geleidelijk aan verandering in. Voor de vroege geschiedenis van het genootschap, die ik laat eindigen in 1867 met het gereedkomen van het fraaie museumgebouw, is het genootschapsarchief de belangrijkste bron. Dat archief was tot 1992 moeilijk toegankelijk, maar is in dat jaar overgedragen aan het Arsip Nasional Republik Indonesia (Nationaal Archief) in Jakarta. Sinds het samenstellen van het Gedenkboek (1878) is het alleen incidenteel geraadpleegd. Dat dit archief nu beschikbaar is, maakte het aantrekkelijk om een studie naar die periode van de genootschapsgeschiedenis te ondernemen, waarover het minst bekend was. ${ }^{1}$

Het Bataviaasch Genootschap werd opgericht in Batavia in 1778 en bestond tot 1962, toen het zichzelf ophief door het museumgebouw met de collecties over te dragen aan de Indonesische overheid. Als Museum Pusat (Centraal Museum) werd het voortgezet tot het in 1979 de status kreeg van Museum Nasional (Nationaal Museum). Zo bestaat het nog steeds. ${ }^{2}$ De bibliotheek van het genootschap bleef in 1962 als bibliotheek van het Centraal Museum op haar plaats. In 1980 losgemaakt uit het museum, met een aparte status als Perpustakaan Nasional (Nationale Bibliotheek), kreeg zij in 1989 een eigen

1 Het archief is geïnventariseerd. In de noten verwijs ik naar de nieuwe nummering, die in 2005 in gebruik is genomen. Het verwijzingsysteem voor het genootschapsarchief, gebaseerd op een voorlopige inventaris, waarop ik mij baseerde voor de editie 2006 van dit boek, is hiermee komen te vervallen.

$2 \quad$ Al bij de 150-jarige herdenking in 1928 opperde de toenmalige vice-voorzitter, J. van Kan, dat er een toekomst als 'Landsmuseum' mogelijk was. Daarbij dacht hij wellicht aan een overname van het museum door de overheid (Verslag honderdvijftigsten gedenkdag 1928:29). Het zou nog tot 1962 duren voor het zover was. 
behuizing in het gebouw van het voormalige Gymnasium Koning Willem III. Het Nationaal Museum is echter nog altijd gevestigd in het gebouw uit 1867 aan Medan Merdeka Barat, vóór 1950 Koningsplein West. Het is bekend als Museum Gajah, het museum van de olifant, naar het door de koning van Siam in 1871 aan de stad Batavia geschonken beeld dat bij de museumingang staat. Het museum heeft in 2004 een grote, nieuwe vleugel in gebruik genomen, maar het negentiende-eeuwse gebouw is daarbij gespaard. Het genootschap ging vanaf 1950 door het leven als Lembaga Kebudajaan Indonesia Koninklijk Bataviaasch Genootschap van Kunsten en Wetenschappen. ${ }^{3}$ Hoewel het in 1962 ophield te bestaan, traceren het Nationaal Museum en de Nationale Bibliotheek met recht hun geschiedenis tot in de achttiende eeuw. Zij herdachten in 2003 hun 225-jarig bestaan.

Opgericht ten tijde van de Verenigde Oost-Indische Compagnie en opgeheven onder de eerste president van de Republik Indonesia, kon het genootschap bogen op een lange geschiedenis. Dat de stichting van een dergelijk genootschap in 1778 opmerkelijk was, ontging de oprichters niet. Toen in 1779 de eerste bundel Verhandelingen uitkwam, vermeldde de Zeeuwse predikant en secretaris van het genootschap, Josua van Iperen, met trots in het door hem geredigeerde voorbericht:

Zoodanig eene instelling, tot nut van het Gemeen, weten wij niet, dat nog,door eenige handeldrijvende Natie, in de oostersche gewesten uitgedacht of tot bestaan gebragt is geworden (VBG 1:8).

Van Iperen had gelijk, want pas in 1784 volgde in Calcutta de Asiatic Society, opgericht door Sir William Jones, hoge beambte van de East India Company en dus in een vergelijkbare positie als de oprichters van het Bataviaasch Genootschap, die in dienst waren van de VOC. Aan de faam die het genootschap aan dit eerstgeboorterecht ontleende, heeft het zelf steeds voedsel gegeven. Secretaris Pieter Bleeker formuleerde het in 1853 tegenover de verzamelde leden bij het vijfenzeventigjarig bestaan alsvolgt:

Gelijk het Nederland was beschoren, de lichtende ster te zijn der Europesche beschaving en wetenschap, door zijne gewigtigste aller uitvindingen, de boekdrukkunst, zoo, en wij mogen er trotsch op zijn, was het ook Nederland, hetwelk in buiten Europesche deelen het eerst de Europesche wetenschap overbragt (Bleeker 1853:1).

De lichtende ster van de Nederlandse uitvinding van de boekdrukkunst mag dan gevallen zijn, aan de faam van het genootschap als eerste in Azië doet

3 Indonesisch Cultureel Instituut. Het predikaat Koninklijk kreeg het genootschap in 1923. Na 1950 verdween het uit de nieuwe naam. 
niemand iets af. Ook bij latere gelegenheden werd het vroege oprichtingsjaar van het genootschap steeds gememoreerd: 'grijsaard onder de wetenschappelijke instellingen in het Oosten' (Van Dijk 1993a:364, citaat uit 1923), 'the senior oriental society of the world' (Beckingham 1979:1) en 'het eerste westerse cultureel en wetenschappelijk centrum in Azië' (De Jong 1998:188).

Eerbiedwaardig is het genootschap niet alleen om zijn lange levensloop, maar evenzeer om het feit dat het zoveel veranderingen heeft overleefd en werkzaam is geweest onder verschillende overheden. Eerst de Hoge Regering ten tijde van de VOC (tot 1795), daarna de Bataafse Republiek (1795-1806) en het Koninkrijk Holland (1806-1810), aansluitend het Franse Keizerrijk (1810-1811), vervolgens de Britse bezettingsmacht (1811-1816) en vanaf 1816 het Koninkrijk der Nederlanden. Na 1942 overleefde het de Japanse bezetting en de revolutietijd en bleef, met behoud van zelfstandigheid, onder de Indonesische Republiek bestaan tot 1962. Belangrijker is uiteraard wat de organisatie onder die verschillende vlaggen heeft verricht. Daarvan getuigen de publicaties, onder meer de Verhandelingen van het Bataviaasch Genootschap van Kunsten en Wetenschappen (1779-1950, 79 delen) en het Tijdschrift voor Indische taal-, land- en volkenkunde (1853-1957, 85 delen), als ook het museum met tienduizenden voorwerpen in afzonderlijke collecties en de bibliotheek met meer dan honderdduizend titels en met de belangrijkste verzameling van Indonesische handschriften.

De notulen van bestuursvergaderingen werden pas vanaf 1857 gepubliceerd. Daardoor zijn we over de periode 1778-1857 het slechtst geïnformeerd. Het Gedenkboek bij het honderdjarig bestaan (1878) door T.H. der Kinderen, destijds voorzitter van het genootschap, is het enige werk van grotere omvang. Het gevolg is dat in de literatuur steeds weer op hetzelfde wordt teruggegrepen, en dan nog eerder op het uitgebreide overzichtsartikel van P.J. Veth uit 1857 dan op het moeilijk toegankelijke gedenkboek. Onduidelijkheden blijven daardoor bestaan. Het beeld van de geschiedenis van het genootschap is gefragmenteerd. Deze studie beoogt die geschiedenis voor de oudere tijd van het genootschapsbestaan te schetsen en te verhelderen. Als eindpunt is daarbij het jaar 1867 gekozen omdat het genootschap in dat jaar in een nieuw gebouw zijn eerste levensfase afsloot en een nieuw leven begon. De nieuwe vestigingsplaats bood niet alleen eindelijk ruimte aan de toen al aanzienlijke collectie, maar maakte vooral ook het bestuderen, beschrijven en uitbreiden ervan mogelijk, wat in de vroegere, bekrompen en bouwvallige behuizing onmogelijk was geworden. Dit gebeurde aan de vooravond van grote veranderingen in de koloniale politiek: een nieuwe periode van expansie die in 1870 aanving.

Dat het onderzoek voor deze studie grotendeels in Jakarta werd verricht en dat gebruik kon worden gemaakt van het genootschapsarchief in het Nationaal Archief, was niet alleen een voordeel, maar een voorwaarde. 
Toekomstig onderzoek naar de tweede levensfase van het genootschap (18671962) zal ook steeds gebruik moeten maken van dit archief, al is de hoeveelheid gedrukte informatie voor die periode onvergelijkelijk veel groter. In deze inleiding komen de volgende zaken aan de orde: allereerst een bespreking van de literatuur over het genootschap en een verantwoording en vraagstelling van het onderzoek. Vervolgens worden de historische en cultuurhistorische achtergrond geschetst. Besloten wordt met een overzicht van het genootschapsonderzoek zowel betreffende de achttiende als de negentiende eeuw, dat in Nederland in de laatste dertig jaar veel heeft opgeleverd, en de implicaties voor deze geschiedenis van het Bataviaasch Genootschap. Daarna volgt in zeven hoofdstukken de geschiedenis, verdeeld in opeenvolgende periodes.

\section{Oudere literatuur}

Gerenommeerde genootschappen geven gedenkboeken uit bij eeuwfeesten of andere gedenkwaardige momenten. Der Kinderen deed dat voor het genootschap in 1878. Vóór dat jaar waren het evenzeer bestuursleden, die bij gelegenheid van algemene ledenvergaderingen terugblikten op de genootschapsgeschiedenis. ${ }^{4}$ Door de aard van Der Kinderens Gedenkboek en de verspreide vindplaatsen van de overzichten van die bestuurders kunnen we voor de vraag naar de rol die het genootschap heeft gespeeld in de studie van de taal-, land- en volkenkunde van de Indonesische archipel, om ons tot één belangrijke kwestie te beperken, maar moeilijk terecht.

Het kersverse bestuurslid, de predikant W.R. baron van Hoëvell, gaf in 1839 zijn 'Geschiedkundig Overzigt van de beoefening van Kunsten en Wetenschappen in Neêrland's Indië' uit in zijn eigen Tijdschrift voor Neêrland's Indië en bereikte zo een breed publiek. Zijn verhandeling omvat veel meer en bestrijkt een langere periode dan alleen de geschiedenis van het Bataviaasch Genootschap. Hoewel Van Hoëvells politieke carièrre pas in 1848 zou beginnen na zijn conflict met het gouvernement in Batavia, bracht hij hier al het belangrijke vraagstuk van de noodzakelijke onderwijsvoorzieningen in Nederlands-Indië ter sprake, waarmee hij probeerde het koloniale debat te sturen in de richting van onderwijsverbetering (Van Hoëvell 1839:43).

P.J. Veth schreef als buitenstaander de meest uitgebreide geschiedenis van het genootschap en wel in De Gids (1857). De redactie van dat tijdschrift suggereerde hem naar aanleiding van het verschijnen van het 25e deel van de Verhandelingen en de eerste jaargang van het Tijdschrift, een bespreking te 
maken, waarin hij ook 'een beknopt algemeen overzigt van dat merkwaardig Genootschap' mocht opnemen. Veth sloot aan bij het overzicht van secretaris Pieter Bleeker (1853), dat slechts voor een beperkt publiek van leden van het genootschap beschikbaar was geweest. De Amsterdamse hoogleraar gaf een bespreking van de vijfentwintig verschenen delen van de Verhandelingen en de eerste jaargangen van het Tijdschrift en behandelde ook belangrijke gebeurtenissen uit de geschiedenis van het genootschap. Als overtuigd liberaal kon hij niet veel waardering opbrengen voor de VOC-periode van het genootschap, gekenmerkt als die voor hem was door de 'schrale inhoud' van de stukken van oprichter Jacobus Radermacher. Na 1792 zakte het genootschap weg in een '20-jarigen slaap' (Veth 1857:226, 232, 248). Daarentegen zwaaide hij lof toe aan Thomas S. Raffles en diens liberale denkbeelden. Hij hekelde de conservatieve politiek van Nederlandse opvolgers, met uitzondering van Van der Capellen. Van Hoëvells inspanningen in de jaren tot 1848 kregen de verdiende aandacht van Veth, vooral de vooruitgang op het gebied van de taalkunde en de archeologie (Veth 1857: 703-4, 375, 395-6). Met de liberale zegepraal in het moederland in 1848 zette volgens Veth ook voor het Bataviaasch Genootschap een periode van grote bloei in. Die zag hij echter door het nieuwe Indische drukpersreglement van 1856 tenietgaan. De ruime aandacht voor de geschiedenis van het genootschap, in zes afleveringen van tezamen meer dan honderdtien pagina's in een algemeen en veelgelezen tijdschrift, had tot gevolg dat de lijnen die Veth trok, het beeld gingen bepalen in de latere geschriften over het genootschap. Met de kritische bespreking van de Verhandelingen zette hij het genootschap vaster op de kaart van de organisaties, die op het terrein van de taal-, land- en volkenkunde van NederlandsIndië werkzaam waren.

Het Gedenkboek (Der Kinderen 1878), een kloeke foliant, zou de nieuwsgierige naar de oudere geschiedenis van het genootschap voor eens en voor al tevreden moeten stellen. Het bestaat uit een eerste deel over het genootschap zelf, zijn ontstaan, wetten, bestuur en leden, prijsvragen en vergaderingen. Het aangekondigde tweede deel over de werken en de verzamelingen van het genootschap is nooit verschenen. Het gedenkboek vormt zo de helft van een niet afgerond project. Een bijkomend probleem is dat de geschiedenis van de totstandkoming van dit gedenkboek in de genootschapsnotulen niet te volgen is. Ook de voorbereidingen van de herdenking zelf zijn nauwelijks te documenteren uit de notulen. Heeft Der Kinderen het project grotendeels alleen voorbereid? Dat hij belangstelling had voor de genootschapsgeschiedenis, was al in 1862 gebleken toen hij als secretaris, samen met bibliothecaris J.A. van der Chijs, het voorstel deed om de vanaf 1778 bijgehouden genootschapsnotulen voor een uitgave te bewerken onder toevoeging van belangrijke stukken uit het archief. Daarmee zou dan samen met de publicatie van de latere notulen (vanaf 1857) een doorlopende documentatie beschikbaar 
komen. Tot zo'n uitgave werd besloten en Der Kinderen zou de bewerking ervan op zich nemen (Notulen 1:64). Of hij inderdaad die taak toen ter hand heeft genomen is niet na te gaan. In de notulen vanaf 1863 wordt er niet op teruggekomen. Rond de herdenking van 1 juni 1878 wordt evenmin aan het gedenkboek gerefereerd. Alleen werd Der Kinderen na afloop bedankt voor al het werk dat hij voor de jubileumviering verrichtte. Vervolgens kwamen er bedankbriefjes van verschillende instanties voor de ontvangst van het grote boek binnen (Notulen 16:66, 73-4, 82, 91, 97-8). Toch was er, bleek uit het dankwoord van Der Kinderen, een feestcommissie voor de herdenkingsbijeenkomst, over wier werkzaamheden in de bestuursvergadering niet werd gerapporteerd, terwijl op de verjaardag een uitgebreid feestprogramma werd gepresenteerd. ${ }^{5}$ Ook was het gedenkboek tijdig klaar. Waarom het tweede deel uitbleef, is even onduidelijk als hoe het eerste deel tot stand kwam.

Een tweede probleem is het karakter van het gedenkboek zelf. Als typisch specimen van oudere herdenkingsliteratuur van de hand van zittende bestuursleden van de herdenkende organisatie, is het overvoerd met talloze gegevens en laat het geen naam van voorgangers ongenoemd. Het is daardoor eerder een statistiek van het genootschap, dan een doorlopend verhaal over de eerste eeuw. De wetten, het bestuur, de beschermheren, de leden, de algemene vergaderingen en de prijsvragen worden opgesomd, er wordt een chrolonogische opgave van gedaan zonder dat er een samenhangend verhaal over het genootschap ontstaat. Zo worden in meer dan honderd pagina's alle bestuursveranderingen, inclusief vergaderdata, opgenomen, wat een ontoegankelijke lijst van mutaties oplevert. Weliswaar kleedt Der Kinderen de lijst hier en daar aan met een citaat uit een toespraak of een brief, maar de nadruk ligt hier op het aantreden en weer aftreden van bestuursleden. Iedereen moest genoemd worden. Een persoonsregister zou de toegankelijkheid van dit hoofdstuk niet alleen, maar van het boek als geheel zeer hebben bevorderd. Mede-bestuurslid Van der Chijs kon dat zeer goed, blijkens zijn werk voor het Tijdschrift. Hij was echter om gezondheidsredenen in april 1877 afgetreden als vice-voorzitter en naar patria vertrokken en er daarom niet bij betrokken.

Een derde probleem geldt de keuze die Der Kinderen gemaakt heeft. In belangrijke mate is die bepaald door het voornemen om in een tweede deel de werken en de verzamelingen van het genootschap te behandelen. Die onderwerpen komen daarom niet of nauwelijks aan de orde. Daardoor missen we informatie over de gebouwen die het genootschap in de loop der tijd heeft betrokken, over de genootschapspublicaties en over de geschiedenis van het kabinet of museum. Uiteraard werd Der Kinderens keuze van onderwerpen

5 De commissie die de feestviering had voorbereid, bestond uit vice-voorzitter N.P. van den Berg, bestuurslid L.W.G. de Roo en secretaris W.P. Groeneveldt. (Verslag honderdjarig bestaan 1878:3) 
ook bepaald door de gelegenheid en zijn eigen positie als voorzitter. Behoefte om kritische noten te kraken of minder gedenkwaardige zaken aan de orde te stellen had hij niet, waar vooral de lof van het genootschap moest worden gezongen. Der Kinderen hield de vuile was binnenskamers.

Hij was zich ervan bewust dat hij op anderen, met name op Veth (1857), voor had dat het archief voor hem beschikbaar was. Hij schetste dan ook in zijn voorbericht het grote verschil tussen de geschiedschrijver in Nederland en hemzelf in Batavia (Der Kinderen 1878:10). Alleen moeten we nu toegeven dat Veths geschiedenis veel toegankelijker is en meer 'geschiedenis' biedt dan Der Kinderens verbrokkelde informatie. ${ }^{6}$

Van belang aan Der Kinderens gedenkboek zijn de bijlagen, waarin stukken uit het genootschapsarchief, grotendeels betrekking hebbend op de periode tot 1800. Daarmee heeft hij een deel van het archief ontsloten (Der Kinderen 1878:1-86, bijlagen). Ook is het praktisch dat hij in een apart hoofdstuk over de beschermheren de informatie over deze beperkte categorie heeft samengevoegd. Onder het hoofdstuk 'Leden' vindt men vooral uitleg over de verschillende categorieën leden en de steeds andere invulling die er aanvankelijk aan termen als 'lid-correspondent', 'correspondent' en 'corresponderend lid' werd gegeven. Ook bracht Der Kinderen gegevens over aantallen leden bij elkaar, maar geen complete statistiek. Wel neemt hij in de tekst namen op van een aantal corresponderende leden en ereleden, onder wie koninklijke ereleden en beroemde geleerden. Merkwaardigerwijze liet hij Goethe ongenoemd, terwijl het archief daar wel uitsluitsel over geeft. In de bijlagen geeft Der Kinderen een lijst van de beschermheren, directeuren en bestuursleden. De ere, corresponderende, gewone en buitengewone leden zouden op lijsten in het tweede deel zijn verschenen.

Der Kinderen heeft, kortom, een half gedenkboek nagelaten. Vermoedelijk is hij de enige die het hele archief tot 1878 heeft doorgelezen. De indeling van het eerste deel maakt het niet geschikt, anders dan op een zeer bewerkelijke manier, om een indruk te krijgen van de meer formele aspecten van het genootschapsleven. De meer inhoudelijke aspecten bleven onbehandeld.

In het apart uitgegeven verslag van het eeuwfeest van 1 juni 1878 heeft voorzitter Der Kinderen het bezwaar van het ontbreken van een doorlopend geschiedverhaal enigszins goedgemaakt door tijdens de in de Willemskerk te Batavia gehouden bijeenkomst aandacht te besteden aan de geschiedenis. ${ }^{7}$ De

6 Het is te betreuren dat Der Kinderen de samenstelling van het Gedenkboek niet in samenwerking met E. Netscher en Van der Chijs ter hand heeft genomen.

$7 \quad$ Verslag honderdjarig bestaan 1878:7, feestrede van Der Kinderen, het historisch gedeelte ervan 10-38. Hij besteedde hier veel aandacht aan de oprichting en de oprichter, Radermacher, minder aan Raffles. Hij vroeg echter ook aandacht voor de periode 1790-1795 en corrigeerde daarmee het beeld dat Veth had gegeven. Ook noemde hij de censuurmaatregel van het gouvernement in 
feestredenaar bij de honderdvijftigste gedenkdag in 1928, vice-voorzitter J. van Kan, zag ervan af om in zijn rede een historisch overzicht vanaf 1778 in te vlechten. Hij verwees daarvoor naar de feestrede van Der Kinderen en diens gedenkboek uit 1878. Van Kan karakteriseerde de eerste honderd jaar als 'het lange tijdperk van Radermacher, Raffles en Van Hoëvell' daarmee aangevend waar de zwaartepunten in de eerste eeuw lagen (Verslag honderdvijftigsten gedenkdag 1928:22). Vanuit het standpunt van 1928 de periode vanaf 1878 overziende als een van grote wetenschappelijke vooruitgang, karakteriseerde hij de periode van vóór 1878 als een van 'goedaardige liefhebberij'. 'Gansch de werkzaamheid van het Bataviaasch Genootschap heeft zich losgemaakt van koloniaal dilettantisme en zich verheven tot Europeesch wetenschappelijk peil' (Verslag honderdvijftigsten gedenkdag 1928:25). Aangezien Van Kan zich vooral met de periode 1878-1928 en de toekomst bezighield is het verslag van 1928 minder van belang voor deze studie. Zijn karakterisering van de oudere periode als een van dilettanten zullen we leggen naast onze bevindingen.

\section{Nieuwere literatuur}

Na de opheffing van het genootschap hebben zich enkele wetenschapshistorici over de organisatie gebogen. Paul van der Veur schreef in 1973 een inleiding bij de geannoteerde inhoudsopgave van de Verhandelingen, die hij met Lian The samenstelde (Lian The en Van der Veur 1973). Het is een van de weinige Engelstalige studies ${ }^{8}$ over het genootschap. Uit de historische inleiding blijkt dat Van der Veur toegang heeft gehad tot de belangrijkste publicaties van en over het genootschap. Hij is dan ook goed geïnformeerd. ${ }^{9}$ Daarbij is hij de eerste die de periode tot 1950 overziet. Hij trekt grote lijnen en verliest zich niet in details. De geringe omvang van zijn inleiding en de opzet (inleiding tot de inhoudsopgave van de Verhandelingen) geven ook de beperkingen aan. Interessant is de indeling die hij maakt van de genootschapsgeschiedenis: 1778-1840 en 1840-1950. De scheiding legt hij bij 1840, omdat hij Van Hoëvell verantwoordelijk acht voor de nieuwe koers van het genootschap, de nadruk op tekstedities in de inheemse talen en op de zorg voor oudheden. Zo legt Van der Veur de waterscheiding bij het aantreden van Van Hoëvell, waar Veth het liberale revolutiejaar en het vertrekjaar van Van Hoëvell, 1848, als keerpunt ziet. Bleeker zag juist het jaar 1838, met de oprichting van het Tijdschrift

verband met de drukkerijkwestie (1847) als de ware oorzaak van Van Hoëvells vertrek.

8 Bibliothecaris P. Gediking schreef in 1929 een kort Engelstalig artikel voor het maandblad Inter-Ocean (Gediking 1929).

9 Toch plaatst hij de eerste Indonesische leden van het genootschap rond 1860, dat moet zijn: 1826, ten tijde van het afscheid van Van der Capellen (Lian The en Van der Veur 1973:16). 
voor Neêrland's Indië, als startpunt van een nieuwe tijd. Van der Veur wijst ook op de rol die het genootschap ten opzichte van de overheid speelde: 'expert advisor and constant watchdog', echter vooral in de periode na 1840 (Lian The en Van der Veur 173:9).

Een nog kortere schets, maar wel gebaseerd op eigen ervaring in Batavia, gaf de oud-bibliothecaris van het genootschap, A.J. Bernet Kempers, in het herdenkingsartikel Het Bataviaasch Genootschap van 1778 (Bernet Kempers 1979). Het is daarbij ruim geillustreerd, veel ruimer dan Der Kinderens gedenkboek. Bernet Kempers kon in kort bestek niet meer doen dan grote lijnen aanduiden. Toch bespreekt hij de behuizing, de oprichting, de doelstelling, de afhankelijkheid van de steeds wisselende Bataviase bevolking, de relatie tot de overheid ('semi-officiële instelling'), de publicaties en de verzamelingen (Bernet Kempers 1979:172). Hij ziet ook nog kans een aantal personen af te beelden uit de genootschapsgeschiedenis, onder wie de eerste Indonesische voorzitter, Ario Hoesein Djajadiningrat, na wiens overlijden (1960) het genootschap nog maar twee jaar zijn zelfstandigheid behield.

Waar Van der Veur en Bernet Kempers als enigen de hele periode van het bestaan van het genootschap overzien, wijdde H.A.M. Snelders ten tijde van het tweede eeuwfeest speciaal aan de periode 1778-1816 een artikel. Het verscheen in een periode dat genootschapsonderzoek in de belangstelling raakte (Snelders 1979). Na een inleiding over de plaats van wetenschap en onderwijs in de kolonie ten tijde van de VOC, de genootschappen in de achttiende eeuw in de Republiek en de oprichting van het Bataviaasch Genootschap, wijdt Snelders vooral aandacht aan de beginjaren en het verval van het genootschap, leidend tot de twintig jaar durende 'slaap' van 1792 tot 1812. Het verval wijt Snelders vooral aan de neiging tot geheimhouding van de VOC-directie in Amsterdam, voortkomend uit de behoefte om de eigen belangen te beschermen (Snelders 1979:75-7). Interessant is het statistisch materiaal dat Snelders in de tabellen aanbiedt: over de overwegende rol van de bestuursleden als auteurs aan de Verhandelingen, waar ook Van der Veur al op had gewezen (Snelders 1979:74, 81-2; Lian The en Van der Veur 1973:4). In de conclusie noemt Snelders de dominante deelname van de bestuursleden in de beginjaren de kracht van het genootschap. De vraag is of het niet eerder een zwakte was. Een analyse van de artikelen in de delen 1-8 en een vergelijking met de verdeling over verschillende takken van wetenschap in de publicaties van drie belangrijke Nederlandse genootschappen stelt Snelders in staat om aan te wijzen waarin het genootschap in Batavia afweek van de broeders in Nederland: minder aandacht voor geneeskunde, meer aandacht voor landbouw en techniek en voor geografie (Snelders 1979: 81-4). Lian The en Van der Veur hadden soortgelijk telwerk verricht - beperkt tot de Bataviase Verhandelingen, maar wel met betrekking tot de hele serie tot 1950 (Lian The en Van der Veur 193:19, 21-3). 
Na Snelders' publicatie is er geen meer gevolgd die uitsluitend aan het genootschap gewijd was, al komt in A. Zuiderwegs biografische artikel over oprichter Jacobus Radermacher het genootschap natuurlijk ter sprake (Zuiderweg 1991). Van de hierboven genoemde en besproken schrijvers hebben Van Hoëvell, Bleeker en Der Kinderen gebruik kunnen maken van het archief van het genootschap. Zij waren bestuursleden en verbleven te Batavia. Der Kinderen heeft daar voor zijn Gedenkboek het meest gebruik van gemaakt. Veth, die zoveel van Indië wist, maar er nooit is geweest, had geen toegang tot het archief. Evenmin de genoemde twintigste-eeuwse schrijvers. Zij baseerden zich op literatuur, niet in de laatste plaats op de vele eigen publicaties van het genootschap. Bernet Kempers kon bogen op zijn ervaring in Batavia als lid, bibliothecaris en redacteur van de genootschapspublicaties. Een genootschapsgeschiedenis die geen gebruik maakt van het genootschapsarchief, mist uiteraard belangrijke gegevens. Dit geldt in de eerste plaats voor de periode tot 1857, het moment waarop het bestuur de notulen van zijn vergaderingen ging afdrukken, eerst in het eigen Tijdschrift, vanaf 1862 in aparte bundels Notulen.

\section{Het genootschapsarchief}

Het genootschapsarchief, tot 1962 bewaard door het genootschap en na de overdracht aan de Indonesische overheid in 1962 in het museum achtergebleven, is aan het eind van de vorige eeuw (1992) overgedragen aan het Arsip Nasional Republik Indonesia. Het heeft een omvang van 35 meter. Er bestaat een recent gereed gekomen inventaris. ${ }^{10}$ Voor deze studie heb ik gebruikgemaakt van het eerste deel van het archief en wel tot 1867, incidenteel met enige doorloop tot 1870 . In dat gedeelte zijn de belangrijkste bundels die van de directievergaderingen (bestuursvergaderingen, 55 bundels, 1778-1864), de correspondentie (vijftien bundels over de periode 1778-1871) en drie bundels over de financiën (1823-1846). Tot deze bundeling van tot die tijd grotendeels losse stukken was in 1864 besloten op voorstel van bibliothecaris J.A. van der Chijs (Notulen 2:15, vergadering 9-1-1864). In het kader van de recente inventarisering van het archief zijn de bundels echter weer grotendeels losgemaakt, zodat de notulen en aanhangende stukken als losse nummers per vergadering moeten worden opgevraagd. Correspondentie, meestal de minuten van de uitgaande brieven van de secretaris naast de binnenkomende post, is niet alleen in de aparte bundels correspondentie te vinden, maar soms ook bij de

10 De inventaris is samengesteld door J. Erkelens in samenwerking met medewerkers van het ANRI. 
notulen van de bestuursvergaderingen gevoegd. Financiële zaken zijn ook in de verslagen van de bestuursvergaderingen opgenomen, voor zover tijdens die vergaderingen besproken. Zo zijn ook ledenlijsten verspreid opgenomen. Er is geen volledige ledenadministratie overgeleverd. De staat van het archief is wisselend. Het achttiende-eeuwse gedeelte is goed, het gedeelte tussen 1822 en 1840 op verschillende plaatsen slecht door verval van het papier en ernstige inktvraat, van 1840 tot 1870 is het doorgaans redelijk met incidentele beschadigingen.

Het archief is niet volledig: de jaren 1802-1821 vormen een gapend gat. Ik schat dat het minimaal gaat om één bundel notulen, die verloren is gegaan. Er is naar dat materiaal gezocht in de collecties van de Oriental and India Office Collections van de British Library in verband met de mogelijkheid dat Raffles een deel van het archief heeft meegenomen, maar dat heeft niet het verhoopte resultaat opgeleverd. Navraag bij Raffles-biograaf John Bastin leverde evenmin iets op. ${ }^{11}$ In een enkel geval zijn er in andere bundels stukken terecht gekomen die op die periode betrekking hebben. Hoewel er dus een flinke gat in het archief zit, is het een rijke Fundgrube. Opvallend is dat het archief vanaf het secretariaat van Jan van der Vinne (1822) een complete indruk maakt. Het nazien van het archief na 1857, speciaal het vergelijken van de geschreven met de gedrukte notulen, bleek van belang, om te kunnen vaststellen hoe open het bestuur naar buiten wilde treden. Opvallende censuur werd niet toegepast, maar er waren toch zaken die het bestuur liever onder zich hield. Dan gebruikte de secretaris het potlood om de zetter duidelijk te maken wat buiten de druk moest blijven. Al kunnen we zeggen dat vanaf 1853 met de publicatie van het eigen Tijdschrift en vanaf 1857 met de gedrukte Notulen in datzelfde Tijdschrift het genootschap veel beter te volgen was in zijn doen en laten, toch blijven er vragen onbeantwoord.

Het belang van het genootschapsarchief blijkt als men de gegevens eruit legt naast het Gedenkboek van Der Kinderen, die er het meest uit putte. Deze heeft uiteraard moeten selecteren voor zijn toch al ruim uitgevallen foliant, maar onderwerpen die ook maar enigszins gevoelig lagen en die betrekking hadden op de recente geschiedenis, heeft hij niet behandeld. Ik heb er, gezien de staat van het archief en de excentrische ligging van de bewaarplaats, voor gekozen om vaak in details te treden. Toekomstige onderzoekers die gebruik willen maken van het rijke archief, vinden er, in combinatie met andere archieven in Jakarta, materiaal dat zij niet uit de beschikbare literatuur kunnen halen. Zo komen door het karakter van deze studie vele onderwerpen ter sprake, die ontleend zijn aan archiefstukken, maar voor bepaalde

11 Prof. J. Bastin, de Raffles-expert en kenner van deze periode, zijn geen gegevens bekend over het ontbrekende deel van het archief. Schriftelijke mededeling van professor Bastin, 17-91996. 
onderwerpen zou aanvullend onderzoek wenselijk zijn. Zo zou bijvoorbeeld een uitgebreider studie over de zorg voor de oudheden in de Indonesisiche archipel zowel gebruik moeten maken van het genootschapsarchief, als dat van de Algemene Secretarie en van de later opgerichte Oudheidkundige Dienst en zijn opvolger, de Dinas Purbakala. Ook nader onderzoek naar de geschiedenis van de tekstedities in inheemse talen die door het genootschap zijn verzorgd en waarvan de filologische kant als ook de receptiekant aandacht verdient, kan vruchtbaar zijn. Voor dat laatste bevat het archief van het genootschap interessant materiaal: gegevens over de intekenprocedures op de uitgaven, over de prijzen, over de Indonesische intekenaren, enzovoort. Andere onderwerpen dienen zich aan voor uitgebreider onderzoek, ook na de voltooiing van deze geschiedenis van het Bataviaasch Genootschap over de periode 1778-1867: de geschiedenis van de bibliotheek, hier wel in grote lijnen besproken, maar voor detailonderzoek vatbaar: de boekbestellingen die meteen na de oprichting werden gedaan, de schenkingen van Radermacher, de bestellingen in de jaren 1840, enzovoort, waardoor de vroege geschiedenis van de Nationale Bibliotheek preciezer documenteerbaar wordt. Een zelfde suggestie kan worden gedaan voor de opbouw van de diverse verzamelingen in het kabinet of museum, over schenkingen en afstotingen, over aankoop en oorlogsbuit, evenzeer van belang, nu voor het Nationaal Museum in Jakarta. De samenwerking tussen het Leidse Nationaal Volkenkundig Museum en het Nationaal Museum, die in 2005 leidde tot een belangrijke tentoonstelling in zowel Jakarta als in Amsterdam, heeft zich tot op heden geconcentreerd op de periode na 1860 . Voor de eerdere jaren biedt het archief uitkomst op vele onderzoeksvragen.

\section{Een geschiedenis van 1778 tot 1867: vraagstelling en verantwoording}

Deze studie biedt niet een geschiedenis van het Bataviaasch Genootschap van 1778 tot 1962. Het aanvankelijke voornemen om de hele geschiedenis van het genootschap in één boek te verwerken, bleek te ambitieus. Het genootschap zelf is er debet aan: zijn geschiedenis is te rijk en te geschakeerd, het bronnenmateriaal te omvangrijk, de levensloop te lang om in één boekdeel gevat te kunnen worden. Het dwingt de lezer wel tot geduld. Het tweede deel van de geschiedenis (1867-1962) moet nog worden geschreven.

Waarom 1867 als eindpunt? 1867 is een eindpunt en een beginpunt in de geschiedenis van het genootschap. Rond 1840 begint het genootschap zich te realiseren dat het, om te kunnen overleven, van karakter dient te veranderen. Voordien was een breed encyclopedisch werkterrein geclaimd. Van Hoëvell was als bestuurslid, vice-voorzitter en voorzitter de motor van deze nieuwe ontwikkeling. Bepaalde taken moesten worden afgestoten, op andere terrei- 
nen moest men juist de aandacht in het bijzonder gaan richten. Een serieuze poging tot specialiseren kwam op gang. Het zou echter een langdurig proces zijn, voordat het genootschap zijn uiteindelijke werkterrein, dat van de Indonesische taal-, land-, en volkenkunde, inclusief de geschiedenis, gevonden had. Aan het eind van de jaren vijftig wilde het bestuur de natuurwetenschappen nog niet helemaal opgeven. In het Tijdschrift bepaalde het genootschap zich al tot het nieuwe werkterrein. In de loop van de jaren zestig van de negentiende eeuw kreeg deze ontwikkeling haar beslag en rond dat moment is het eindpunt vastgesteld voor deze eerste fase van de genootschapsgeschiedenis. Dat veranderingsproces is een onderwerp van deze studie.

Aan het eind van 1867 betrekt het genootschap het nieuwe, speciaal gebouwde museum en genootschapshuis aan het Koningsplein. Er komt daarmee een einde aan een periode van grote ruimtelijke zorgen, die het museum kwelden en er begint een nieuwe periode van bloei. Voor het eerst had het genootschap de beschikking over een speciaal als museum en genootschapshuis ontworpen gebouw. Tevoren was het behelpen geweest. De nieuwe behuizing stelde het genootschap in staat om zijn bezittingen naar behoren te beheren en te laten zien. Het kon het gebouw indelen op een wijze, die aan het publiek duidelijk maakte wat men van het museum kon verwachten: grote afdelingen etnologie en oudheidkunde, een geschiedkundige afdeling, een klein numismatisch kabinet en een ruim bemeten bibliotheek. Geen zoölogische en mineralogische afdelingen meer. Daarmee begint een periode van steeds grotere professionele betrokkenheid van wetenschappers bij het genootschap. Ruimte leidde tot bloei in het museum, wetenschappelijk geschoolde leden, dat wil zeggen taalkundigen, oudheidkundigen, etnologen zorgden voor wetenschappelijk verantwoord beheer van de collecties en voor publicaties van steeds hoger niveau. De bouw van het museum aan het Koningsplein en het betrekken van deze nieuwe locatie, de vierde behuizing van het genootschap, trekt daardoor een scheiding. Daarna volgt de periode van de taal-, land- en volkenkunde van Indonesië.

Hoe een geschiedenis van het Bataviaasch Genootschap te schrijven, vanuit welk perspectief, met welke vragen in het achterhoofd, op welke wijze aangepakt? Een geschiedenis van een genootschap maakt gebruik van de uitkomsten van het genootschapsonderzoek. Daarom zal het licht moeten vallen op genootschappelijke en organisatorische zaken, op de regels waaraan het genootschap zich onderwierp ten tijde van de oprichting, de doelstellingen die het formuleerde, de manier waarop het leden wierf, op de taakverdeling tussen directie, dagelijks bestuur en leden, op de activiteiten die het ondernam. Daarmee liet het genootschap zich aan de wereld zien. Het gezichtspunt van het onderzoek ligt bij de aard van de organisatie: een genootschap in Batavia.

Het specifieke van het Bataviaasch Genootschap was nu juist de situering 
in een koloniale context, zijn vestiging in de hoofdplaats van een uitgestrekt koloniaal rijk. Lange tijd het enige genootschap in zijn soort, heeft het in Batavia altijd een speciale plaats behouden, al kwamen er in de loop van de negentiende eeuw andere gezelschappen en genootschappen, verenigingen en maatschappijen bij. De positie van de erfgenamen van het genootschap in het huidige Jakarta, Nationaal Museum en Nationale Bibliotheek, bevestigt de speciale plaats die de moederorganisatie innam. Dat brengt mij bij het tweede gezichtspunt: Batavia als plaats voor een genootschap.

Een derde aspect is de relatie tussen het genootschap en de overheid in Batavia en daarmee de status van de organisatie, de vrijheid van handelen die het gegund werd, de mate waarin het zich als private, niet-gouvernementele organisatie kon ontworstelen of juist wilde vastklampen aan de overheid. Met deze relatie hangen verschillende onderwerpen samen die in het dagelijks leven van het genootschap diep ingrepen. Daartoe horen huisvesting, subsidiëring, adviesverlening.

De meer specifieke vragen die ten grondslag liggen aan het onderzoek en die het perspectief bij het schrijven bepaald hebben, zijn de volgende:

1 Hoe kon in een stad met een kleine, vlottende Europese bevolking, met zeer beperkte onderwijsvoorzieningen en met weinig kunstvoorzieningen, een genootschap met doelstellingen op het gebied van kunsten en wetenschappen ontstaan en blijven bestaan?

2 Waarin onderscheidt zich het Bataviaasch Genootschap van vergelijkbare genootschappen in de Republiek der Zeven Verenigde Provinciën en het Koninkrijk der Nederlanden? Met welke van die genootschappen onderhield het contacten en hoe verliepen die contacten? Met welk doel?

3 Hoe was de relatie tot de overheid in Batavia, dus de Hoge Regering tijdens de VOC-periode, haar opvolgers tijdens de Franse tijd, daarna de Engelse bezetters van Java en tenslotte de vertegenwoordigers van het Koninkrijk vanaf 1816? In hoeverre wist het genootschap zijn status als particuliere instelling te behouden? Kan het aangemerkt worden als een semi-overheidsinstelling? In hoeverre was het genootschap van de overheid afhankelijk?

4 Welke terreinen bestreek het genootschap en welke activiteiten ondernam het? Hoe veranderden de doelstellingen en het werkterrein in de loop van de eerste negentig jaar? Hoe en wanneer kreeg het genootschap zijn werkterrein van de taal-, land- en volkenkunde van de archipel?

5 Hoe was de inwendige structuur van het genootschap? Wat was de plaats van de leden, het bestuur, de toezichthouders, de beschermheren? Uit welke sociale lagen waren de leden en de bestuursleden afkomstig?

6 Welke redenen zijn er aan te voeren als verklaring voor de perioden van neergang of verminderde activiteit van het genootschap en hoe overleefde het deze perioden? 
Deze vragen bepalen het perspectief van de geschiedenis. De keuze van de presentatie van het gevonden materiaal, van de antwoorden op bovenstaande vragen, is uitgevallen in die van een chronologische beschrijving van zeven significante perioden uit de geschiedenis van het genootschap, corresponderend met zeven hoofdstukken. Vooraf echter een tweeluik van (cultuur-) historische aard.

\section{Historisch tableau 1770-1870}

Batavia als vestigingsplaats voor een genootschap van kunsten en wetenschappen. Wekt dat verwondering? Is het tijdstip van oprichting opvallend? Niet als we het jaar 1778 in verband brengen met de oprichting van vergelijkbare genootschappen in de Nederlandse Republiek in de achttiende eeuw. Dan volgt Batavia een beweging en stond het niet vooraan. Wel als we bedenken dat het Bataviaasch Genootschap het eerste van zijn soort in Azië was. Maar ook wel als we het oprichtingsjaar afzetten tegen de tijdsomstandigheden. De malaise in het VOC-bedrijf was sterk voelbaar. De oorlog met Engeland zou de scheepvaart van en naar Indië onherstelbare klappen toebrengen. Aan de vooravond van die oorlog beleefde de VOC echter juist een opbloei (Baudet en Fasseur 1977:314-5; Gaastra 1991:132, 147, 164-8). De opbrengsten van produkten op de veilingen in patria maakten de kosten aldaar en de verliezen van het bedrijf in Azië ruimschoots goed, juist in de jaren 1775-1780. Des te ernstiger was daarom de klap van de vierde Engels-Nederlandse zee-oorlog (1780-1784). Het genootschap zou echter die klap overleven.

Jakatra had al sinds 1610 een VOC-vestiging. In 1619 werd het als Batavia het rendez-vous voor de VOC-schepen en stapelplaats voor de VOC-goederen. Begonnen als handelspost, werd het de centrale vestigingsplaats van het bedrijf in Azië, waar de vloten uit Europa aankwamen en vertrokken en van waaruit met eigen schepen een ingewikkeld netwerk van handelscontacten in Azië werd onderhouden. Het kreeg een Kasteel, waarvanuit de Hoge Regering het Aziatische bedrijf leidde in samenspraak met de centrale directie in de Republiek, de Heren Zeventien, en naast dat Kasteel ontwikkelde zich de stad waar meer Europeanen woonden dan in welke andere vestiging van het Nederlandse bedrijf in Azië ook. Daarbij kreeg Batavia, in tegenstelling tot veel andere, kleinere handelsposten, te maken met het achterland, eerst de Bataviase Ommelanden, later met grote delen van de rest van Java, waarover de hoge ambtenaren, gouverneur-generaal en raden van Indië, bestuur voerden. Het is niet gewaagd te concluderen: als er ergens op de VOC-posten in Azië een genootschap van kunsten en wetenschappen opgericht zou worden, dan in Batavia. De handelaars werden bestuurders en waar de meesten kwamen en gingen, besloten anderen te blijven. Zo was Jacobus 
Radermacher (1741-1783), oprichter en eerste voorzitter van het genootschap, als onderkoopman in Batavia aangekomen in 1758 om de stad in 1763 als opperkoopman weer te verlaten voor een eerste terugreis naar Nederland. Hij kwam in Batavia terug in 1767 en zou er in 1783 voorgoed weggaan. Hij was toen raad-ordinaris en behoorde tot de bestuurlijke top (Zuiderweg 1991:1614). Adriaan Moens (1728-1792), zijn opvolger als genootschapsvoorzitter, was in 1750 als assistent naar Azië vertrokken. Hij was werkzaam op Ceylon en aan de Malabar-kust in India en stierf in 1792 in Batavia als directeur van de Amfioensociëteit. Meer dan veertig jaar was hij in dienst van de Compagnie, zonder het vaderland ooit terug te zien. ${ }^{12}$ De eerste is het voorbeeld van een repatriant, de tweede van een blijver.

Batavia was een stad met een Europees karakter door de Europeanen die er woonden, die er Europees bouwden (Kasteel, kerken, stadhuis) en door de instellingen die aan Europese steden deden denken, zoals de Schepenbank (stedelijke regelgeving en handhaving), het College van Heemraden (onderhoud van wegen en vaarten), en de Wees- en Boedelkamers (beheer van nalatenschappen). Gaastra noemt de vroedschap en het weeshuis als instellingen ontleend aan Hollandse steden, maar meldt tegelijk dat Batavia een 'relatief kleine Europese gemeenschap' had. Rond 1700 zouden er circa zesduizend inwoners 'van Europese afkomst' hebben gewoond, een ruime omschrijving, die ook de Eur-Aziaten omvat. Aan het eind van de achttiende eeuw was dat aantal wat teruggelopen (Van Goor 1993a:123; Gaastra 1991:71). De Jong en Groeneboer noemen lagere aantallen, omdat zij zich baseren op de noemer 'Europeaan', eerder dan 'van Europese afkomst', en komen dan voor 1739 op ruim 1250 Europese inwoners in Batavia en in 1795 ongeveer 550 (De Jong 1998:126, 180; Groeneboer 1993:66). Raben noemt op basis van de officiële tellingen het getal van 1143 Europeanen in 1779 in Batavia en de Ommelanden, maar legt uit dat een deel van de VOC-beambten in deze getallen niet begrepen zijn (Raben 1996:91, 97). Deze laatste cijfers zijn voor ons belangrijk, omdat het genootschap, zoals we later zullen zien, overwegend Nederlandse mannen als lid recruteerde, bovendien nog uit een bepaalde sociale laag en dus op een beperkt potentieel aan leden was aangewezen. De vraag is dan ook of de stad eigenlijk niet te klein was voor een levensvatbaar genootschap, dat zich richtte op de beoefening van kunsten en wetenschappen? Voor die Europese, stedelijke bevolking waren er wel voorzieningen: onderwijs (zeer beperkt), de kerk, ziekenhuizen, justitie, maar de bevolkingsgroep was klein, zeker in vergelijking met een Nederlandse provinciestad, laat staan in vergelijking met de belangrijker provinciesteden waar de grote genootschappen in

12 Carrièreverloop van Moens bij Der Kinderen 1878:57. Twee brieven van Moens aan de Stadhouder, met persoonlijke gegevens, in het Koninklijk Huisarchief, Archief Stadhouder Willem V, 333-19, Batavia 15-8-1783 en 29-10-1791. 
de Republiek gevestigd waren (Haarlem, Rotterdam, Vlissingen, Utrecht).

De omvang en de samenstelling van het Europese deel van de stedelijke bevolking hing uiteraard sterk samen met de aard en het welvaren van het VOC-bedrijf. $\mathrm{Nu}$ was dat bedrijf in de achttiende eeuw in een crisis geraakt. Gaastra heeft duidelijk gemaakt dat het niet zozeer om een teruggang van het handelsvolume ging, maar dat het probleem de teruglopende winstgevendheid van het bedrijf betrof. Het aantal schepen naar Azië bleef tot 1790 groot, het aantal personeelsleden dat uitgezonden werd, eveneens, veel meer dan in de winstgevende zeventiende eeuw. ${ }^{13}$ De problemen hadden te maken met verschuivingen in de interne Aziatische handel, het wegvallen van bepaalde markten, het opkomen van nieuwe concurrenten en het oplopen van de kosten in Azië, waardoor deze tak van het bedrijf, eens zo florerend, in de achttiende eeuw verliesgevend werd. Na 1770 liepen die verliezen in Azië enorm op. ${ }^{14}$ De stad Batavia groeide niet, onder andere door de fatale, steeds terugkerende malaria-epidemieën, die de bevolking decimeerden, en waarvan vooral nieuw aangekomenen dikwijls direct het slachtoffer werden (Van der Brug 1994).

Door de oorlog met Engeland in 1780 nam de verslechtering van de handelspositie van de VOC dramatische vormen aan: schepen werden onderschept, kostbare retourladingen naar Londen vervoerd en niet naar Amsterdam, nieuwe bevoorrading voor Batavia en de buitenkantoren ging verloren. Er kwamen daardoor ook minder nieuwe Europeanen aan, zodat de toch al krimpende Europese bevolking niet weer op peil werd gebracht (Gaastra 1991:167-9). Het proces van ondergang zou niet gestuit worden, ondanks alle discussies daarover in de Republiek, waar men naast de oorlogszorgen ook nog te maken had met patriotse woelingen en een stadhouderlijke greep naar de macht in 1787. De VOC was niet te redden en werd in 1795 bij decreet 'vernietigd' en in 1796 genationaliseerd door de overheid, die intussen niet meer die van de stadhouderlijke Republiek was, maar van de, na de inval van de Fransen, in 1795 ontstane Bataafse Republiek (Gaastra 1991:170).

De overheid had de failliete VOC overgenomen, zette het bedrijf voort en bereidde een beleidswijziging voor, een proces dat veel overleg vergde. De oorlog met Engeland, waaraan de nieuwe Fransgezinde Bataafse Republiek nog in 1795 ten prooi viel, was een volgende ramp voor het (nu althans in naam nationale) bedrijf in Azië. Heerste Frankrijk op het continent, Engeland beheerste de zeeën, ook de Aziatische, en het staatsbedrijf verloor de vestigingen aldaar. Negapatnam aan de Coromandelkust in India, belangrijk

13 Gaastra 1991:82, 115, tabellen van aantallen personen aan boord en van aantallen schepen van en naar Azië.

14 Met uitzondering echter van de jaren 1775-1780 toen de retouren heel veel goedmaakten (Gaastra 1991: 132, 147-148, 164-170; Baudet en Fasseur 1977: 314-5). 
voor de textielaanvoer, was in de oorlog van 1780-1784 verloren gegaan, in 1795 volgden de Kaap, Surat, Bengalen, de Coromandel- en de Malabarkust, Malakka en Padang, in 1796 Ceylon, Ambon en Banda (Van Goor 1993a:189). De Indiase kantoren waren verloren. Plaatsen in wat later de Indonesische archipel zou gaan heten, ontvielen het Nederlandse gezag. Batavia, dat toch al een deel van haar centrale positie in de loop van de achttiende eeuw had zien verschrompelen door rechtstreekse vaarten vanuit Nederland op Ceylon, Bengalen en China, zag nu haar positie als centrum van een handelsnetwerk verder verkleind. ${ }^{15}$ Er kwam wel particuliere handel voor terug, voor een deel van neutrale handelaren of Nederlandse handel onder neutrale vlaggen, maar de voormalige VOC-stapelplaats was afhankelijk van een overheid in Nederland, die opnieuw in oorlog verkeerde met de concurrent. Was in de jaren 1791-1792 het aantal beschikbare zeelieden in Batavia al te gering om gereedliggende schepen te laten vertrekken, dan kunnen we ons voorstellen hoe de vlag er enkele jaren later bijhing met nieuwe blokkades door de Britten en kaapvaart door de Fransen (De Jong 1998:161).

De staatkundige veranderingen in 1795 in Nederland lieten de kolonie niet onberoerd. Eerst kende Batavia zelf in december 1795 een kleine Bataafse beweging van patriotsgezinde vaderlanders, die daarmee de nieuwe realiteit onder Franse protectie erkend wilden zien. Kort daarop volgde een contrabeweging uit welke botsing de nog onder de VOC-vlag in 1792 uitgezonden commissaris-generaal S.C. Nederburgh (1762-1811) als overwinnaar te voorschijn kwam (Schutte 1974:157-61). Daarna volgde een oproep van de naar Engeland uitgeweken Stadhouder Willem V, die de koloniën opdroeg zich onder Engels bestuur te stellen. De toekomst zag er voor de geïsoleerde bestuurders en overige Europese bewoners van Batavia niet rooskleurig uit. In 1802 leken bij de vrede van Amiens tussen de Fransen, de Bataafse Republiek en de Engelsen de zaken ook voor de Nederlandse koloniën een keer ten goede te nemen, maar die vrede was van korte duur en de verloren gegane posten bleven verloren. In 1806 onstond het Koninkrijk Holland, in 1810 volgde de inlijving door Frankrijk als deel van het keizerrijk, veranderingen waarvan de inwoners van Batavia niet dan na de gebruikelijke reistijd van de schepen vernamen, als die schepen al aankwamen. De leidende families, soms al generaties in Indië en met fortuinen op het spel, deden er alles aan om de bestaande, voor hen gunstige situatie te handhaven. Commissies uit het vaderland konden daar niet veel aan veranderen. ${ }^{16}$

Over de hele periode tot 1806 ligt een doem van stagnatie, wegblijven van nieuwe krachten en van zien-te-overleven door ad-hoc oplossingen van

15 Gaastra 1991:115, overzicht van schepen naar en van Azië, uitgesplitst naar enkele regio's.

16 Schutte 1974:150-75, geeft een schets van de gebeurtenissen in Batavia tussen 1795 en 1800 . 
de zittende gouverneurs-generaal, P.G. van Overstraten, A.H. Wiese en J. Siberg. In plaats van VOC-schepen waren het tussen 1796 en 1802 Deense en Amerikaanse schepen die de retourgoederen ophaalden. Op de verkopen werd zelfs weer wat winst gemaakt (Schutte 1974:134-5). In Nederland werd overlegd hoe het nu verder met de koloniën zou moeten gaan. Een van de betrokkenen in die discussie was de patriot Dirk van Hogendorp, die in 1799 een felle aanklacht tegen de verouderde structuren had gepubliceerd. Pas in 1808 met het aantreden van H.W. Daendels (1762-1818) werd er aan de landsverdediging tegen de dreigende inval van de Engelsen iets gedaan. Toen breidde ook het contingent Europese stedelingen zich weer uit, al waren de meeste nieuwkomers militairen. Zijn beslissing om het Kasteel van Batavia te verlaten en in Weltevreden een nieuw centrum aan te leggen was even belangrijk voor de stadsontwikkeling als de aanleg van de Grote Postweg over Java voor de verbindingen op het eiland. Daendels hervormde het binnenlands bestuur en de rechterlijke macht en daardoor zette met hem een modernisering in (Van Goor 1993a:195-9;De Jong 1998:174-6). Zolang er oorlog heerste, was er geen uitzicht op uitbreiding van het contingent burgers en ambtenaren, waaraan de stedelijke structuren van het nieuwe stadscentrum kracht moesten ontlenen. In augustus 1811 landden de Britten met een invasieleger en zij namen Java binnen enkele weken van de Nederlanders over. Op Java was de Franse tijd eerder voorbij dan in Nederland.

Was Daendels nog een door een vreemde vorst aangestelde Nederlander met een patriots verleden, Raffles (1781-1826), die na de invasie als luitenantgouverneur achterbleef onder de vanuit India besturende gouverneur-generaal Lord Minto, was een buitenlander. Al had hij een Nederlandse moeder, het Nederlands was een vreemde taal voor hem. Hij bracht een contingent militairen en nieuwe bestuursambtenaren mee, waardoor het aanzien van de bestuurlijke top in Batavia veranderde. Deze werd Brits-Nederlands van samenstelling met voor de stadscultuur nogal wat veranderingen. De krant van Daendels werd tweetalig maar onder een Engelse naam, Java Government Gazette, en instanties kregen ook Engelse namen. Er werden nieuwe organisaties opgericht, waarvan Raffles beschermheer werd. Hij maakte de samenleving weer wat Europeser, minder Indisch. Pas met Daendels en Raffles traden krachtige bestuurders aan die met de oude, nog uit de VOC-tijd overgebleven machtige families, konden afrekenen. Daarmee eindigde de VOC-tijd pas echt. Nieuwere literatuur bespreekt Daendels' en Raffles' bestuursperioden danook als een doorlopende hervormingstijd, die met Van der Capellen vanaf 1816 onder Nederlandse vlag zou worden voortgezet.

Toen het driemanschap Van der Capellen-Elout-Buijskes in 1816 de macht uit de handen van luitenant-gouverneur J. Fendall, Raffles' opvolger, overnam, reageerden de blijvers in Batavia vermoedelijk met enige scepsis. $\mathrm{Na}$ het VOC-bewind waren ze Bataafs geweest, daarna Frans en Brits, nu weer 
Nederlands. Het tienjarig bestuur onder Van der Capellen, eerst samen met Elout en Buijskes, moest aanvangen met het herstel van het Nederlandse bewind, met de erkenning dat, zoals de Grondwet van 1815 zei, het opperbestuur bij de koning berustte. Een bewind van kooplieden had plaatsgemaakt voor dat van ambtenaren. Een nieuw koloniaal bestuur moest ook nog eens baten opbrengen voor het moederland, want zo bleven de verhoudingen. De kolonie was er voor het moederland en niet andersom. Van der Capellen concentreerde zich op Java, maar reisde ook, onder andere naar de Molukken. Hij nam een nieuwe ploeg ambtenaren en militairen mee, die het bestuursapparaat (onderwijs, gezondheidszorg, binnenlands bestuur, openbare werken, financiën) en de landsverdediging voor hun rekening moesten nemen en gaf zo een nieuwe impuls aan de modernisering die onder Daendels en Raffles was ingezet. Nederlands-Indië was niet langer een netwerk van handelsposten van de VOC, maar een kolonie van de staat of, liever gezegd, van de koning, aan wie tot 1848 door de Grondwet 'bij uitsluiting' het bestuur over de koloniën was opgedragen. Batavia was niet meer de belangrijkste stapelplaats onder de handelsposten, maar het bestuurscentrum van die kolonie. Aan de inkomstenkant stonden nieuwe belastingen, die echter niet opwogen tegen de inkomsten uit de VOC-handel van weleer. Er waren in de tussentijd handelaren uit andere landen gekomen, die een deel van de handel naar zich toe hadden getrokken. Conflicten met lokale vorsten of met de lokale bevolking leidden tot militaire acties in de Molukken, Palembang, West-Sumatra, Bandjarmasin, en tot het grootste conflict, de Java-oorlog (1825-1830). Het bestuur van Van der Capellens opvolger, commissaris-generaal L.P.J. du Bus de Gisignies, raakte bij alle aandacht die naar de Java-oorlog uitging, enigszins in het historische vergeetboek, terwijl hij juist moest proberen de financiën weer op orde te brengen. Hij probeerde, net als Van der Capellen, een stempel te zetten op de sociale structuur van Batavia door de oprichting van een Genootschap van Waterloo (De Prins 2002:198-203).

Grote economische veranderingen begonnen pas in 1830 met de invoering van het cultuurstelsel onder Du Bus' opvolger, J. van den Bosch. De Javaanse bevolking werd nu gedwongen een deel van haar grond te bebouwen met producten die vervolgens aan het gouvernement in Batavia toevielen, waarvoor de boeren als vergoeding plantloon ontvingen. Het gouvernement zorgde ervoor dat de producten (suiker, koffie, indigo) afgevoerd werden door de Nederlandsche Handel-Maatschappij (1824), zodat die in patria met winst konden worden verkocht tegen wereldhandelsprijzen. Nederlandse bestuursambtenaren en hun inheemse collega's moesten ervoor zorgen dat het systeem werkte en zodoende de winst waarborgen. Zij kregen een aandeel in die winst in de vorm van procenten. Tussen 1830 en 1870 bestond dat systeem en het leverde de Nederlandse staatskas de miljoenen aan Indische baten op die zo vaak in de literatuur zijn aangehaald (Fasseur 1978). Die lite- 
ratuur benadrukt ook steeds dat gedurende dit tijdperk het aantal Europese ambtenaren dat op Java en daarbuiten werkzaam was, zeer beperkt van omvang was, in vergelijking met de miljoenenbevolking mocht men spreken van 'een handje vol', en dat die Europese mannelijke burgerbevolking overtroffen werd door het aantal Europese militairen, dat onder andere voor oorlogen en expedities werd ingezet. Toelating van particulieren tot Indië, dat wil zeggen van hen die niet bij voorbaat van een overheidsbetrekking verzekerd waren, was aan strenge restricties gebonden. Vrijheid van meningsuiting - met kranten en ander drukwerk - was een goed uit het vaderland dat nog niet gerealiseerd was. Particulieren waren in de minderheid (De Jong 1998:211). Hoewel Batavia zich ontwikkelde als een stad van ambtenaren, militairen en personen werkzaam in de handel en de sector van de voorzieningen, bleef het een relatief kleine stad. Fasseur noemt voor 1860 een aantal Europeanen op geheel Java van ruim 22.000, waarvan ruim 7.500 mannen, 5.000 vrouwen en 9.500 kinderen (Fasseur 1978:5). De in Nederland geboren mannen en vrouwen vormden een nog aanzienlijk kleinere groep. Het aantal in Nederland geboren vrouwen dat in Indonesië woonachtig was, bleef altijd sterk achter. ${ }^{17}$ De groei van deze aantallen zette pas na de invoering van de Agrarische Wet in 1870 door. Het aantal ambtenaren bij het Europees binnenlands bestuur op Java, dat direct betrokken was bij het cultuurstelsel, kwam in 1860 niet boven de tweehonderd uit (De Jong 1998:208, 211), het aantal Nederlandse bestuursambtenaren in de buitengewesten net boven de honderd (Van den Doel 1996:73). Onderwijsvoorzieningen waren dan ook heel beperkt: Europese lagere scholen waren er in Batavia en in enkele belangrijke plaatsen op Java en daarbuiten. Voor voortgezet onderwijs was men lange tijd op het vaderland aangewezen, behalve voor kweekscholen voor inheemse artsen, onderwijzers en ambtenaren. In 1860 kreeg Batavia de eerste middelbare school die voorbereidde op hoger onderwijs in Nederland: het Gymnasium Koning Willem III. Hoger onderwijs kwam er pas in de twintigste eeuw. Om toegelaten te worden tot het corps hogere bestuursambtenaren was tot 1864 een opleiding in Nederland vereist. Al deze factoren maakten de groei van de Europese bevolking van Batavia niet explosief.

Tijdens de periode van het cultuurstelsel bleef aanvankelijk de aandacht geconcentreerd op Java. In de buitengewesten was vaak sprake van een heel kleine post, soms was de Nederlandse aanwezigheid een nominale zaak. Ministers van koloniën hielden in samenspraak met de opvolgende gouverneurs-generaal vast aan een streven, dat in de literatuur 'onthoudingspolitiek' wordt genoemd. Van den Bosch en J.C. Baud zetten deze politiek

17 Zie aantallen Europeanen, uitgesplitst naar mannen en vrouwen, in Nederland geborenen en niet, vanaf 1850, bij Groeneboer 1993:474-6. 
in. Baud volgde later als minister van koloniën (1840-1848) dezelfde lijn. ${ }^{18}$ Uiteraard waren de kosten verbonden aan oorlogvoering en machtsuitbreiding daarbij een factor van belang. Die onthouding was echter niet compleet, zodat na 1830, ondanks de beleidsbedoelingen toch expansie plaats vond op een heel geleidelijke manier. 'Het sluipende expansieproces' ging om gebieden op Sumatra, Borneo en Celebes en om Bali (Van den Doel 1996:74). Naast militairen waren er wetenschappers, taalkundigen en natuurkundigen, ook wel zendelingen, die gebieden buiten Java binnen het Nederlandse gezichtsveld brachten (Van den Doel 1996:hoofdstuk 3). Soms werden wetenschappelijke activiteiten met militaire expedities gecombineerd, zoals in het geval van Bali (1846-1849). Grootscheepser en systematische verovering van de buitengewesten, soms gepaard gaande met langdurige oorlog, vond pas na 1870 plaats.

De periode tot 1870 is geen onveranderlijk blok. Het cultuurstelsel kwam door bepaalde excessen (herendiensten, corruptie) onder vuur, hoewel het systeem van exploitatie van de kolonie ten behoeve van het moederland het zelfs bij sommige critici niet hoefde te ontgelden. Het ging onder meer om de tot hongersnood leidende excessieve overheidsdwang, waartegen opgetreden moest worden. Van Hoëvell introduceerde, terug in Nederland na ruim twaalf jaar in Batavia, het idee dat Nederland iets terug moest doen voor de bevolking van Indië nadat zoveel Indische miljoenen in de schatkist waren gevloeid (Van den Doel 1996:101). Pas heel geleidelijk kreeg het parlement in Den Haag meer te zeggen over koloniale zaken. Op de liberale grondwetswijziging van 1848 volgde de totstandkoming van het - voor de eerste maal bij de wet, dus in overleg met de Staten-Generaal vastgestelde - behoudende, maar in een aantal opzichten ook wel vernieuwende Regeringsreglement van 1854 . Multatuli's felle aanklacht tegen misstanden in het Europese en inheemse bestuur over Java, zoals verwoord in zijn Max Havelaar, of de koffiveilingen der Nederlandsche Handel-Maatschappij (1860) werd een mijlpaal in de conservatieve-liberale discussie, maar de liberale aanvallen op het cultuurstelsel en de pleidooien voor particulier ondernemerschap vonden aanvankelijk nauwelijks gehoor (Van den Doel 1996:105). In de jaren 1860 waren de liberale minister van koloniën I.D. Fransen van de Putte en gouverneur-generaal L.A.J.W. Sloet van de Beele verantwoordelijk voor een aantal hervormingen. Zo werden de cultuurprocenten van de ambtenaren en allerlei verplichte diensten aan de inheemse hoofden afgeschaft (Van den Doel 1996:108). Er werd aan de poten van het cultuurstelsel geknaagd door liberale leiders. Het duurde nog tot 1870, bij de invoering van de Suikerwet en de Agrarische Wet, voor het cultuurstelsel geleidelijk werd afgeschaft, waarna investeringen door particu- 
liere ondernemingen in de landbouwsector ruim baan kregen. Het jaar 1870 is in verschillende opzichten, zowel economisch als politiek, een draaipunt in de geschiedenis van Nederlands-Indië. De handboeken over de koloniale geschiedenis laten daar blijkens hun hoofdstuktitels ook een nieuwe periode beginnen. De instroom van ondernemers deed de Europese bevolkingsgroep toenemen, de vraag naar intensivering van het bestuur onder invloed van de terrein winnende ethische politiek eveneens. Voorzieningen voor de groeiende bevolking konden niet achterblijven.

\section{Cultuur-historisch tableau}

Batavia was gedurende de VOC-periode een handelsvestiging met een kleine Europese bevolkingsgroep en een zich langzaam uitbreidend achterland. De handelsbelangen waren zo dominant dat al het andere daaraan ondergeschikt was. Dat de vestigingsplaats bestuurlijke instanties op Europese leest vereiste om de Europese bevolkingsgroep te reguleren en te bedienen, sprak vanzelf, maar ook deze waren ondergeschikt aan het bestuur van de VOC-vestiging dat in het Kasteel zetelde. Rechtspraak, armenzorg, kerk, gezondheidszorg, onderwijs en andere stedelijke voorzieningen waren afhankelijk van de gouverneur-generaal en zijn raden van Indië en van de opperbestuurders, de Heren Zeventien in patria. Dat de rechtspraak en gezondheidszorg belangrijker waren dan kerk, armenzorg en onderwijs lijkt vanuit het perspectief van de handelaren voor de hand te liggen, al was de gouverneur-generaal reeds in de vroege zeventiende eeuw opgedragen voor scholen te zorgen. Onderwijs was niet helemaal afhankelijk van de overheid; particuliere voorzieningen, huisonderwijs, kleine schooltjes, waren er al in de zeventiende eeuw. Dat er in 1778 een genootschap van kunsten en wetenschappen kon (mocht) worden opgericht, is verwonderlijk als we deze gebeurtenis afzetten tegen wat er daarvoor aan onderwijs, kunsten en wetenschap was gedaan. Dat was niet veel en werd meestal gedragen door belangstellende individuen. Hoogstens werd het gedoogd door de Hoge Regering in het Kasteel en, mocht het al geïnitieerd zijn door die regering, dan was het veelal geen lang leven beschoren. Op het eerste gezicht is het Bataviaasch Genootschap een uitzondering: het overleefde allerlei crises en werd een van de langstlevende organisaties van de stad Batavia.

Voorzieningen op het niveau van basisonderwijs waren minimaal. Middelbaar of vervolgonderwijs was er in Batavia gedurende de hele VOCperiode nauwelijks. De Haan noemt twee perioden waarin een Latijnse school bestond: 1642-1656 en 1666-1669, een school die wilde voorbereiden op hoger onderwijs in Nederland, met name op de opleiding voor predikanten voor Indië. Onder gouverneur-generaal G.W. baron van Imhoff (1743-1750) werd 
in Batavia een Seminarium Theologicum opgericht voor de opleiding van predikanten voor de inheemse gemeentes, maar ook die instelling bestond niet lang (1743-1756). In 1753 waren er drieënvijftig externe en achttien interne leerlingen, in datzelfde jaar leverde de school twee afgestudeerden op (De Haan 1935a, I:640-2; Groeneboer 193:62). Veel van deze leerlingen kwamen aan het theologische gedeelte van de opleiding waarschijnlijk nooit toe, voor hen was het een algemene school als andere compagniesscholen. Met Van Imhoffs andere stichting: de Académie de Marine (1743-1755), een zeevaartschool, hebben we dan alle vormen van voortgezet onderwijs in Batavia in de VOC-tijd genoemd (De Haan 1935a, I:643-4; Groeneboer 1993:63-4).

Hoewel het onderwijs op Ceylon succesvoller was en de scholen voor vervolgonderwijs er een langer leven beschoren was, kan men uit het aantal afgestudeerden dat predikant werd, concluderen dat de langere levensduur niet direct synoniem was met een groter succes in termen van toestroom tot hoger onderwijs (Groeneboer 1993:73-87). In Batavia was in 1642 een College van Curatoren en Scholarchen ingesteld, een onderwijscommissie en -inspectie, maar dat betekende niet veel voor de kwaliteit van het onderwijs (De Haan 1935a, I:630). Dat in 1778 enkele maatregelen werden getroffen om de positie van het Nederlands in het onderwijs te verbeteren, betekende geen grote ommekeer (De Haan 1935a, I:632; Groeneboer 1993:55-9). Ook het onderwijs leed onder de crisis, de oorlog en de grote veranderingen in de Franse tijd. Pas in 1817 werd de eerste gouvernements lagere school opgericht, maar ook in de negentiende eeuw bleef onderwijs vooral basisonderwijs. Het Gymnasium Koning Willem III dateert van 1860. Beroepsopleidingen voor inheemse artsen (Batavia 1851), voor inheemse onderwijzers (diverse plaatsen vanaf 1851) en inheemse bestuurders (diverse plaatsen vanaf 1866) waren grotendeels niet in Batavia gevestigd. In de door ons besproken periode van het Bataviaasch Genootschap kunnen we daarom de onderwijssituatie ronduit slecht noemen, al is er sinds 1816 met kleine stappen steeds iets aan verbeterd.

Men was in Europese kring voor wat betreft het scheppen en onderhouden van een Europees intellectueel klimaat geheel aangewezen op wat Europa te bieden had: nieuw aangekomenen, dat wat de nieuw binnengekomen schepen meenamen aan boeken en ander drukwerk (kranten, tijdschriften), dat wat de blijvers hadden kunnen bewaren of weten te verzamelen. Met name Europees intellectueel klimaat en niet uitsluitend Nederlands, omdat in de VOC-periode veel niet-Nederlanders dienst namen, zij het voornamelijk, maar niet uitsluitend, in de lagere ambtelijke rangen. Menigeen die zich met serieuze wetenschap bezighield (E. Kaempfer, G.E. Rumphius) was buitenlander. Niet alle gouverneurs-generaal waren hoog opgeleid. Verschillende van hen doorliepen alle rangen van assistent of onderkoopman om toch als 'Zon van Indië' te eindigen. Het VOC-kader in Batavia bestond dus niet 
uit overwegend hoog opgeleide ambtenaren, maar vooral uit personen die ervaring hadden opgedaan in een lange staat van dienst. Universitair opgeleiden waren er weinig. Op zijn hoogst waren er enkele juristen, een enkele academisch opgeleide geneeskundige - de meeste geneeskundigen waren chirurgijn - en natuurlijk waren er de predikanten. De overigen hadden op zijn best enig onderwijs in Nederland of daarbuiten genoten. Uitzonderingen waren er, personen die zich jarenlang wijdden aan plantkunde, taalbeschrijving, observeren van land en volk, maar het feit dat zij op de vingers van twee handen te tellen zijn, is veelzeggend voor het intellectuele klimaat in Batavia en daarbuiten in de VOC-periode. Tegen de achtergrond hiervan is de oprichting van het genootschap des te opvallender: een genootschap met een heel smalle voedingsbodem, dat niet aansloot bij een rijk verleden.

De jubeltoon van voldaanheid waarmee Van Hoëvell in 1839 zijn tot opstel omgewerkte lezing over kunsten en wetenschappen in het VOC-gebied aankleedde, kan niet verhullen dat de substantie van zijn verhaal, zeker als het gaat om de periode tot 1800, mager is. In de bundel VOC en cultuur wordt in een zevental artikelen het onderwerp opnieuw besproken, waarbij cultuur in de ruime betekenis wordt opgevat en vooral de wetenschappen betreft. ${ }^{19}$ Uiteraard zonder jubeltoon en wel voorzien van al die nuances en onderbouwing van beweringen, die Van Hoëvell anderhalve eeuw eerder overbodig achtte. Van Goor zet drie kanttekeningen bij de steeds gehoorde opmerking dat in de compagniestijd zo weinig aan wetenschap overzee is gedaan: de achttiende eeuw werd lange tijd ten onrechte eenvoudigweg afgedaan als één lange periode van economische achteruitgang, die dan ook voor wetenschapsbeoefening ongeschikt was. Tegenwoordig wordt dat als een mythe beschouwd, al was de oorlog met Engeland (1780-1784) de doodsklap voor de Compagnie. De tweede kanttekening geldt de bedrijfsgeheimhouding van de VOC, die verlammend op wetenschapsbeoefening werkte. Van Goor erkent die factor, maar geeft aan dat er desondanks van wetenschappelijke activiteiten sprake was. Tenslotte wijst hij op de gerichtheid op Batavia voor wat betreft de dominante meningen over de geringe culturele activiteiten van de Compagnie. Hij laat zien dat de onderwijsvoorzieningen op Ceylon beter waren, en veel langer bestonden, dan voorzieningen in Batavia. Van Goor erkent echter na deze kanttekeningen: 'De wetenschapsbeoefening als zodanig was voor het functioneren van het bedrijf op zijn best een afgeleide doelstelling. Alleen voor de verbreiding van de godsdienst werd een uitzondering gemaakt '(Van Goor 1993b:2-5). Van Berkel spreekt van de VOC als van 'een onwillige Mecenas', en concludeert:

19 Bethlehem en Meijer 1993, vooral van belang in dit verband zijn de artikelen van J. van Goor, K. van Berkel, C. van Dijk en J.A. de Moor in deze bundel. 
Onderzoek in Indië was alleen mogelijk dankzij de VOC. Alleen haar dienaren waren in de gelegenheid een kleiner of groter deel van hun tijd te geven aan de studie van de tropische flora en fauna. [...] Maar als organisatie had de VOC niet een bepaalde beleidslijn uitgestippeld. Nu eens stimuleerde zij onderzoek, dan weer hield ze publicatie van de resultaten bewust op of verbood ze zelfs het onderzoek. ${ }^{20}$

Van Dijk noemt de bijdrage die de VOC in de zeventiende eeuw heeft geleverd aan de kennis van taal en volken in Zuid-Oost-Azië pover (Van Dijk 1993b:76).

'Verzamelen-beschrijven-onderzoeken', dat is de trits die Van Goor aan de basis plaatst van de wetenschappelijke activiteiten in de VOC-periode. Dat veel daarvan op de eerste plaats praktische kennis moest opleveren, dat wil zeggen kennis die nuttig en toepasbaar was in het VOC-gebied, is begrijpelijk. Dan kon het VOC-apparaat de activiteiten niet alleen gedogen, maar deze zelfs stimuleren en er gebruik van maken (Van Goor 1993b:3-6). Als we kijken naar de wetenschapsterreinen die bestreken werden, wordt plantkunde als eerste genoemd: bruikbaar voor chirurgijns en apothekers als het om geneeskrachtige kruiden ging of economisch van belang in het geval van handelsgewassen: koffie, indigo, suiker, enzovoort (Van Goor 1993b:910). Maar er werd ook systematisch plantkundig onderzoek gedaan, getuige de twaalfdelige Hortus Indicus Malabaricus (1678-1693) van Hendrik Adriaan van Reede tot Drakestein en het Amboinsche Kruidboek (1741) van Georg Everard Rumpf (Rumphius). Van Berkel noemt naast deze monumenten in de plantkunde in zijn artikel ook Jacobus Bontius' De medicina Indorum (1642) als resultaat van in Batavia verricht onderzoek, terwijl hij vermeldt dat al in de tijd van de voor-compagnieën ten behoeve van de hoogleraar plantkunde van de Leidse universiteit werd verzameld (Van Berkel 1993:47, 1998:133-7, 139-42). Deze uitgaven werden in de Republiek gedrukt.

Op het gebied van de taalkunde wordt gewezen op het directe nut dat taalkennis had voor de handels- en diplomatieke contacten, bij vertalingen van contracten en correspondentie, terwijl predikanten, die zelf vaak het taalkundig onderzoek deden, de opgedane informatie gebruikten voor bijbelvertalingen en om hun kennis van de vreemde volkeren te vergroten (Van Goor 1993b:13; Van Dijk 1993b:64-6). Van de Maleise woordenlijstjes, toegevoegd aan de verslagen van de eerste scheepsreizen naar Azië (Middelburg 1598) tot het Maleise woordenboek met de korte samenspraken van Frederik de Houtman (1603) en groter opgezette woordenboeken (zoals dat van S. Danckerts,1623), alles kon dienen tot verbetering van de contacten met de bevolking in Azië. Dat actieve zending niet hoog in het VOC-vaandel stond, 
hoewel de geestelijke verzorging van het VOC-personeel wel, blijkt uit het feit dat de eerste complete Maleise bijbel pas in 1733 in Amsterdam van de pers kwam. Het ging om de vertaling die de predikant Melchior Leijdecker (1645-1701) al in de zeventiende eeuw had gemaakt en die na veel dicussie en een lange periode van revisie pas jaren na zijn dood gereed kwam. Toen hadden de vertalers en revisoren inmiddels wel veel kennis van het Maleis opgedaan (Swellengrebel 1974:13-20). De kosten van geestelijke verzorging en van de uitzending van predikanten werden gedragen door de VOC. Sommige predikanten werden vrijgesteld voor het vertaalwerk, terwijl de VOC ook de drukkosten van de vertalingen voor haar rekening nam. Kerk en zending waren kortom VOC-zaken, al werd er aan actieve zending onder de inheemse bevolking niet veel gedaan.

Andere praktische wetenschap die in Indië bedreven werd, gold de navigatiekunst, sterrenkunde en geografie, alles gericht op de verbetering van kennis die voor het succesvol reizen onontbeerlijk was (Davids 1993:137-9). Gedrukte reisverslagen leverden vanaf het begin van de zeventiende eeuw naast de informatie over het reizen op zee ook informatie van volkenkundige aard op, die weer van nut was bij de contacten die men legde. De waarde van die verslagen wordt tegenwoordig wisselend beoordeeld. Van Dijk meent dat ze voor de historicus meer te bieden hebben dan voor de antropoloog (Van Dijk 1993b:734). Uitgebreider beschrijvingen van land en volk, taal en godsdienst leverden de predikanten Abraham Rogerius, De Open-Deure tot het verborgen Heydendom (1651) en Philippus Baldaeus, Naauwkeurige Beschryvinge van Malabar en Choromandel [...] en Ceylon (1672), beide onder meer over het hindoeïsme, en François Valentijn, Oud en Nieuw Oost-Indiën (1724-1726; Pott 1962: 55-7). In hun gevallen werd het praktisch-handzame van het reisverslag overschreden en werd de overstap naar vergelijkende godsdienstwetenschap gemaakt (Rogerius, Baldaeus), dan wel op encyclopedische wijze een uitgestrekt gebied onder verschillende gezichtspunten beschreven op basis van een groot aantal documenten (Baldaeus, Valentijn). Engelbert Kaempfers Beschryving van Japan (1733) behoort ook tot de categorie van uitgebreide land- en volkbeschrijving. Het ging om individuen die zich toelegden op het verzamelen en vermeerderen van kennis en het toegankelijk maken daarvan. Zij waren in dienst van de Compagnie, dan wel in ruste na beëindiging van de dienst. Van Goor deelt de personen die actief waren op dit vlak in categorieën in op basis van hun motieven: soms was het uit liefhebberij, soms omdat zij op zoek waren naar praktische kennis ter oplossing van door hen gesignaleerde problemen, soms omdat zij als veroveraar het veroverde gebied wilden beschrijven (Van Goor 1993b:8). Als voorbeeld van de laatste categorie noemt hij Cornelis Speelmans beschrijvingen van Goa en Midden-Java (Van Goor 1993b:14).

Intussen laat de recente literatuur twee dingen zien: er is nog wel wat te onderzoeken, te nuanceren aan het beeld van de VOC als wetenschapsmece- 
nas, tegelijk zal dat onderzoek niet aantonen dat die rol van de Compagnie verkeerd beoordeeld is. Kunsten en wetenschappen waren de stiefkinderen van de Compagnie. Van Hoëvell zag zich, terugblikkend op de periode 16001775 , al genoodzaakt zijn orgeltoon te dempen:

Maar, aan den anderen kant, laat het beschouwde tijdvak nog veel te wensen over. Wij zoeken daarin vruchteloos naar die algemeene belangstelling in den bloei der wetenschappen, naar die algemeene zucht om hare vruchten zoo ver mogelijk uit te spreiden, en naar die voortdurende zorg van de zijde der Regering, om voor hare belangen te waken en hare beoefening aan te sporen. Ene bekrompen staatkunde vreest voor hare krachten en rijkdommen, in plaats van die krachten en rijkdommen aan hare oogmerken dienstbaar te maken. (Van Hoëvell 1839:44.)

Van Hoëvell voegt aan dit oordeel nog enkele woorden toe over de schone kunsten, die, zo ze al beoefend werden, vooral in stilte onderwerp van aandacht van enkelingen zouden zijn geweest (Van Hoëvell 1839:45). Modern kunsthistorisch onderzoek door Scalliet laat echter zien dat er met name door schilders en tekenaars in Batavia en het hele VOC-gebied werd gewerkt, al zijn het geen schilders van het kaliber van Frans Post en Aalbert Eckhout, die in Brazilië actief waren. Uit de zeventiende eeuw zijn topografische schilderijen, stadsgezichten, marineschilderijen en portretten overgeleverd, uit de achttiende eeuw merkwaardig genoeg geen schilderijen, maar wel veel tekeningen en grafisch werk (Scalliet 1999:15). Uiteraard is er ook veel verloren gegaan, zowel in de Oost als op weg naar het vaderland. Er werden geen schilders in functie naar Batavia gestuurd, soms wel tekenaars, hoewel ook zij veelal als militairen uitkwamen. De achttiende-eeuwse tekeningen en het grafisch werk zijn meestal vooral documentair van belang, maar de waarde ervan mag niet onderschat worden. Het gaat om kaarten, topografische tekeningen, waaronder kustlijnen en stadsprofielen, aanlegplaatsen, maar ook stadsgezichten, genre-achtige taferelen en etnografisch interessant materiaal. Van de achttiende-eeuwse tekenaars bespreekt Scalliet de Duitser Johann Wolffgang Heydt (in Batavia 1737-1740), de Deen Johannes Rach (actief in het VOC-gebied 1762-1783) en de Nederlandse predikant Jan Brandes (in Batavia 1779-1785; Scalliet 1999:34-7). Van hen werkte Brandes vooral voor zichzelf in dagboekjes en aantekenschriften (M. de Bruijn en Raben 2004). Heydt en Rach waren niet als tekenaar uitgekomen, maar werden wel als zodanig aangesteld of waren zo werkzaam. Rach is als lid van het Bataviaasch Genootschap, leiding gevend aan een tekenatelier en uitvoerder van honderden topografische tekeningen in opdracht van allerlei burgers en compagniesdienaren, het interessantst. Omdat hij twintig jaar in Batavia werkzaam was, is in zijn corpus tekeningen een tweetal decennia gedocumenteerd. Van hem is het Bataviaasch Genootschap in verschillende stappen tweehonderdtwee tekeningen rijk geworden die nu in de collectie 
van de Nationale Bibliotheek bewaard worden en die onlangs gerestaureerd zijn (M. de Bruijn en Kist 2001). Uit die collectie Rach-tekeningen werd bij het honderdvijftigjarig bestaan van het genootschap (1928) een selectie als jubileumuitgave gepresenteerd (De Loos-Haaxman 1928).

Architectuur, toegepaste Europese kunst, het was, naast teken- en schilderkunst aanwezig in Batavia en op andere, grotere VOC-posten. Daarvan getuigde onder meer de in 2002 gehouden, grote herdenkingstentoonstelling 'De Nederlandse ontmoeting met Azië, 1600-1950' in het Rijksmuseum te Amsterdam (Zandvliet 2002). Over de uitvoerende kunsten, in de eerste plaats muziek en toneel, zijn wij ook wel geïnformeerd, onder andere door De Haan. We mogen ons dus niet door Van Hoëvell op het verkeerde been laten zetten door met hem aan te nemen dat de schone kunsten een nauwelijks bewerkt gebied bleven, al geldt hier wat ook voor de wetenschappen geldt: het was geen resultaat van VOC-beleid, we danken het een en ander aan de actieve inzet van enkelingen. Iets anders is of de term 'kunsten' in de naam van het genootschap verwees naar wat wij sinds het eind van de achttiende eeuw als 'schone kunsten', dat wil zeggen beeldende kunst, bouwkunst, en ook wel de toegepaste en uitvoerende kunsten zijn gaan opvatten. Daarop komen we terug als we de oprichting en naamgeving van het genootschap bespreken.

In verband met de voorgeschiedenis van de oprichting van het Bataviaasch Genootschap kijken wij wat nauwkeuriger naar de tweede helft van de achttiende eeuw.

Het bewind van gouverneur-generaal G.W. baron van Imhoff, die het Seminarium oprichtte met een eigen drukkerij en de zeevaartschool, en die bovendien een krant uitgaf onder de naam Bataviase Nouvelles (1744-1746), steekt gunstig af bij dat van anderen. Het bewind van zijn opvolgers J. Mossel, P.A. van der Parra en J. van Riemsdijk wordt gekenschetst als een terugval. 'Voor de wetenschappen werd genoegzaam niets gedaan' (Van Hoëvell 1839:46). Van Imhoffs bewind bracht een verbetering van onderwijsvoorzieningen. Hij gaf de Luthersen de vrijheid om hun eigen kerk te stichten en men dacht - door de krant - op meer openheid en vrijheid te kunnen hopen, kortom het was het bewind van een verlicht landvoogd. Bij zijn opvolgers ging het anders. Een uitzondering wordt gemaakt voor kerkelijke zaken, getuige een uitgave van de Portugese en Maleise bijbel onder Mossel en een nieuwe Nederlandse psalmberijming onder Van der Parra, die ook geld beschikbaar stelde voor de opleiding van predikanten voor de Indische kerk en die in het algemeen met de predikanten het beste voor had. ${ }^{21}$

Dat er in die periode in Batavia een man was die een fortuin aan de sterrenkunde besteedde, Johan Maurits Mohr (1716-1775), verdient aandacht, te 
meer daar zijn werkzaamheden direct aan de oprichting van het Bataviaasch Genootschap voorafgingen. Hij had bovendien contacten met de Hollandsche Maatschappij der Wetenschappen te Haarlem, waarvan hij lid was. Mohr was in 1716 in Eppingen in de Paltz geboren en studeerde in 1733 theologie in Groningen. Waarschijnlijk heeft hij daar niet alleen godgeleerde colleges bijgewoond, maar ook van de natuurwetenschappen geproefd, misschien wel van de colleges in de sterrenkunde. Later zegt Mohr dat de sterrenkunde een oude liefde van hem was. Als hij niet al in Groningen met de natuurwetenschappen in aanraking was gekomen, zou hij alle basiskennis door zelfstudie in Batavia hebben verworven, wat niet waarschijnlijk lijkt. In 1736 werd hij aangenomen als proponent voor de Indische kerk, in 1737 kwam hij aan in Batavia, waar hij tot zijn dood in 1775 zou blijven. Hij was daar achtendertig jaar dienstbaar aan de Portugese gemeente (Veth 1885; Zuidervaart 1999:314-20). Vanaf de oprichting in 1745 tot 1753 was hij tevens rector van het Seminarium en gaf daar ook les. Mohr was als revisor betrokken bij de uitgave van de Portugese bijbelvertaling van J.F. a d'Almeida (Batavia 17481753) en bij de uitgave van de Maleise bijbelvertaling in Arabisch-Maleis schrift (Batavia 1758). ${ }^{22}$ Door zijn talenkennis alleen al moet hij een bijzondere persoonlijkheid geweest zijn in Batavia. Door zijn tweede huwelijk in 1752 met Anna Elisabeth van 't Hoff, wier derde echtgenoot hij was, kwam hij in het bezit van een dusdanig fortuin dat hij zich kon wijden aan 'de natuur- en sterrekunde, mijne oude en meest begunstigde liefhebberij, met een voornemen om dezelve onder ons in eenig aanzien te brengen en te bevorderen' ${ }^{23}$ Veth meldt op gezag van P.A. Leupe, dat Mohr in 1750 en 1758 boeken voor astronomische waarnemingen uit Leiden werden gezonden. ${ }^{24}$ Mohr liet met toestemming van de Hoge Regering in 1765 een nieuw buiten aanleggen aan de Molenvlietse Dijk waarop een toren werd geconstrueerd voor het observeren van de sterrenhemel. Voor de inrichting daarvan liet hij tussen 1763 en 1773 een heel instrumentarium uit de Republiek overkomen. Bekende reizigers als Louis-Antoine de Bougainville met zijn sterrenkundige Véron, en James Cook met diens sterrenkundige Valentin Green en de natuurhistoricus Joseph Banks, die Mohr in 1768 en 1770 in zijn nieuwe sterrenwacht bezochten, waren onder de indruk, niet alleen van het gebouw, maar ook van de inrichting. Genootschapssecretaris F. baron von Wurmb schatte dat het gebouw Mohr tachtigduizend rijksdaalders had gekost. Het was een zeer opvallende constructie van zes verdiepingen, omdat het in tegenstelling tot

\footnotetext{
22 Over die bijbelvertalingen: Swellengrebel 1974:9-20 en Veth 1885:60-6.

23 Veth 1885:75, citaat uit een brief van Mohr aan Th. Hope te Amsterdam (2-11-1768).

24 Veth 1885:78. De correspondentie van Leupe met het genootschap leidde onder andere tot de publicatie van een serie bestellingen van instrumenten tussen 1765 en 1773, voor de verzending waarvan de Heren Zeventien toestemming verleenden (TBG 8:317-8).
} 
andere buitens waarvan we afbeeldingen kennen, niet in de breedte, maar in de hoogte was opgetrokken. Daardoor torende het buiten de stad uit boven andere buitens en de rijstvelden.

Belangrijker voor ons is, dat Mohr ook meteorologische waarnemingen deed en dat hij, voordat zijn sterrenwacht klaar was, elders al observaties had gedaan. Daaruit blijkt dat hij reeds eerder instrumenten, meteorologische en astronomische, uit de Republiek had laten komen. Bij de zogenaamde Venusovergang van 1761, het verschijnsel waarbij de planeet een baan beschrijft over de zon, op grond waarvan sterrenkundigen precieze lengte- en breedtebepalingen doen, had hij waarnemingen gedaan. Het verslag daarvan had hij aan de Leidse en Groningse universiteiten gestuurd. Het was vervolgens in Haarlem terecht gekomen bij de Hollandsche Maatschappij, die het in 1763 publiceerde: 'Waarneminge over den schijnbaaren loop van Venus over de zonneschijf'. Dat hij in datzelfde jaar tot lid van de Maatschappij werd benoemd, zal hem genoegen hebben gedaan. Ineens zag hij zich opgenomen in de kring van de geleerden van zijn tijd in het belangrijkste wetenschappelijk genootschap van de Republiek. Bij de volgende Venus-overgang, die van 1769 - waarvoor verschillende expedities vanuit Europa waren gestuurd - kon Mohr zijn nieuwe observatorium met zijn nieuwe instrumentarium gebruiken en laten zien. Door het bezoek van Cook, Banks en Green wist hij zich bovendien opgenomen in een grotere groep van waarnemers, die het verschijnsel in 1769 bekeken. De waarderende woorden van de bezoekers zullen hem, na de erkenning door de Hollandsche Maatschappij, opnieuw voldoening hebben gegeven. De verslagen van zijn waarnemingen met die van de Mercuriusovergang van hetzelfde jaar, verschenen in 1770 in de Verhandelingen van de Hollandsche Maatschappij en, meegenomen door Cook, in 1772 in de Philosophical Transactions van de Royal Society te Londen, het belangrijkste internationale tijdschrift voor de natuurwetenschappen. In 1772 publiceerde de Hollandsche Maatschappij ook een verslag van Mohr over de uitbarsting van de Papandajan, een vulkaan op West-Java (Zuidervaart 1999:556). Mohr was met zijn observatorium en zijn onderzoek doorgedrongen tot de internationale literatuur en behoorde als lid van de Haarlemse maatschappij tot een selecte groep van geleerden.

Niettemin bleef hij een eenling in de stad, en wist hij zich niet gesteund in zijn streven om de wetenschap vooruit te helpen. ${ }^{25}$ In een brief aan Thomas Hope uit 1768 schrijft hij bitter: 'Wij leven hier in een tijd waarin de haat en nijd regeert in den hoogsten graad, en men weet onder ons bijna van geen andere kunst of wetenschap, als die om geld te winnen en schielijk rijk te worden' (Veth 1885:77). Van der Parra (1761-1775), prachtlievend en de kerk 
goed gezind, had de reputatie niet op de bevordering van wetenschappen uit te zijn. Oud-gouverneur van Ceylon Joan Gideon Loten schreef in 1775 aan zijn broer over Van der Parra en Mohr:

De tegenwoordige Heer Gouverneur plagt een groot vijand van zulke studiën [als die van Mohr] te zijn, en ik twijfele niet of [hij] is nog zo in zijn hart. De helft van Zijn Eerwaardes [=Mohrs] collega's prediken dat het dreunt tegen deezen ongelukkigen zoon van Urania die een observatoire heeft gebouwd dat wel 30 duyzend ponden sterling heeft gekost. (Zuidervaart 1999:331.)

Al eerder had Loten zich negatief over Van der Parra uitgelaten eveneens naar aanleiding van Mohrs observatorium: 'dit is een nobele onderneeming en dat te meer onder regeeringe van eenen in alle wetenschappen onkundigen, en dezelve haatende' [gouverneur-generaal] (Zuidervaart 1999:330-1).

Waarom Mohr zich naar de woorden van Loten, de afgunst van de helft van zijn collega's op de hals had gehaald, zullen we niet gemakkelijk te weten komen. Was het afgunst op Mohrs welgesteldheid, afgunst op zijn veelzijdigheid? Of werd hij gewantrouwd om zijn bedrevenheid in de beoefening van de natuurwetenschappen? Dat laatste zou het geval kunnen zijn, waar de groep behoudende predikanten nogal invloed had tijdens het bewind van Van der Parra en door het isolement van Batavia de popularisering van de natuurwetenschappen er ver achter liep bij die in het vaderland. Mohrs eigen uitlatingen over het gebrek aan een voor wetenschapsbeoefening gunstig klimaat, gevoegd bij dat van anderen, mag de conclusie rechtvaardigen dat hij een van de weinigen is geweest in het Batavia van die dagen, die daar iets tegen ondernomen heeft, zij het met weinig resultaat. Na zijn dood in 1775 was er niemand die kundig genoeg en tevens vermogend genoeg was, om de sterrenwacht voort te zetten. Dat geeft andermaal aan dat Mohr geïsoleerd werkte. Mannen als Radermacher, Hooijman (vermogend collega-predikant), Von Wurmb (landgenoot van Mohr), die in 1778 de kunsten en wetenschappen in genootschapsverband zouden gaan bevorderen, zagen kennelijk geen mogelijkheid om Mohrs nalatenschap te benutten. Voor Radermacher en Hooijman was dat financieel in ieder geval geen probleem geweest. Aan astronomie werd in de eerste decennia na Mohr niets meer gedaan.

Mohrs buiten met het observatorium raakte in verval en kreeg andere functies. In 1844 restte er niet meer van dan wat fundamenten (Melvill de Carnbee 1844:177). Het instrumentarium werd verkocht en keerde grotendeels naar de Republiek terug, waar het de kern zou gaan vormen van het observatorium van Felix Meritis in Amsterdam (Zuidervaart 1999:319). Wel was een achromatische telescoop van Dollond uit Mohrs verzameling nog in 1853 met andere instrumenten in de verzameling van het genootschap aanwezig (Veth 1885:85). In 1858 waren er een oude miscroscoop en een telescoop, ook uit de collectie Mohr, een aanwijzing dat bij de verkoping in Batavia niet alles naar 
het vaderland terugkeerde (TBG 8:101). Had Radermacher misschien toch het een en ander aangekocht uit de veiling Mohr en had hij toegang tot papieren uit de nalatenschap van Mohr? Of had Radermachers mede-raadslid David Smith, die met Mohrs dochter getrouwd was, het een en ander aangebracht? Radermacher publiceerde in het tweede deel van de Verhandelingen over de uitbarsting van de Papandajan waarbij hij Mohrs bericht uit 1772 aanhaalde, maar misschien kende hij dat wel uit de Haarlemse Verhandelingen (Veth 1885:85-6). Mogelijk was men in Haarlem beter op de hoogte van waar Mohr mee bezig was dan in Batavia. Dat bij de oprichting van het genootschap in 1778 op geen enkele wijze naar Mohr werd verwezen, wijst op weinig aanraking tussen de sterrenkundige en eerste genootschapsbestuurders, tijdens het leven van Mohr. Opvallend is het wel dat Mohr ruime vrijheid werd toegestaan voor het botvieren van zijn liefhebberij, en gedurende het lange, zo verguisde bewind van Van der Parra boeken en instrumenten voor vele duizenden guldens mocht laten komen en een opvallend gebouw kon optrekken. Dat wijst niet op achterdocht of tegenwerking vanuit het Kasteel. En dat terwijl het genootschapsbestuur in 1779 zou rapporteren over de tegenwerking die de oprichters in de aanloop tot de oprichting hadden ondervonden. Mohr liet zich in ieder geval over Van der Parra voor wat betreft de behartiging van 'het aanzien en het welzijn van den publicquen Godsdienst en van zijne dienaren' gunstig uit (Veth 1885:77).

Op het gebied van oudheidkundig en eraan gerelateerd kunsthistorisch onderzoek op Java is de periode voor de oprichting van het genootschap bijna volledig blank. Krom wijt dit aan het 'stelsel der Compagnie' dat haar dienaren niet tot belangstelling in zaken als oudheden aanmoedigde. Hij meldt een beschrijving van hindoeïstische tempels uit 1733 door de Semarangse onderkoopman en fiscaal C.A. Lons als enige waar enkele gegevens uit te halen vallen en weet te melden dat tussen 1740 en 1746 enkele bezoekers tempels hebben gezien (Krom 1923, I:2-5). Des te opvallender is het dat de oprichters in het eerste Programma (1778) onder meer de 'Oudheden der volken' opnamen als hun werkterrein, waaruit men zou kunnen afleiden dat er enige bekendheid was met wat er op Java te ontdekken viel. Anderszins is de omschrijving van dat programma wel erg algemeen en encyclopedisch van aard en mag het aangehaalde niet als bewijs gelden dat de oprichters bewust kozen voor onderzoek naar Javaanse oudheden. Dat het bericht van Adriaan van Rijck over de volkeren rond de Bromo uit 1785, het oudste in de genootschapskring waarin opmerkingen over oudheden staan, pas in 1794 werd gedrukt, lijkt genoeg te zeggen over de geringe behoefte om zich actief met de oudheden te bemoeien. Krom legt het begin van het oudheidkundig onderzoek bij Raffles (1811-1816). Verzamelen en verplaatsen van beelden gebeurde al vóór Raffles.

Bij wie moesten de oprichters van 1778 aansluiten voor wat betreft de talenkennis? Die kennis was vooral dienstig gemaakt aan de bijbelvertaling. 
Alle andere talenkennis was dienstig aan handel en diplomatie en die twee waren voor de eerste genootschapsbestuurders verboden terrein, omdat zij, zoals we nog zullen zien, alle compagnieszaken hadden uitgesloten als onderwerp van studie. De compagnie had daar eigen tolken en vertalers voor. Voor de taalstudie ten dienste van bijbelvertaling was het Maleis, naast het Portugees als het meest urgent het eerst aangepakt. De Maleise vertaling van Leijdecker was afgemaakt door P. van der Vorm, waarna alsnog een revisie plaatshad door een commissie van vier predikanten onder wie Van der Vorm en G.H. Werndly. De laatste zorgde ook voor de eerste verantwoorde Maleise spraakkunst (1736). Toen de bijbel uitkwam - in 1733 in Amsterdam (in Romeins karakter) en 1758 in Batavia (in Arabisch-Maleis karakter) - was duidelijk dat de predikanten/vertalers/revisoren, de meeste kennis bezaten van het Maleis. Naast de gedrukte vertalingen en Werndly's spraakkunst was er niet veel om op voort te bouwen, althans niet in gedrukte vorm. Voor het Javaans begon de serieuze taalbeschouwing in verband met de bijbelvertaling pas in de negentiende eeuw. Maar ook hier was voor handel en diplomatie kennis bij tolken en vertalers aanwezig. Het genootschap vond dus - op het Maleis na - een zo goed als onbeploegde akker voor zich. Voor taal-, land- en volkenkunde in moderne zin, zo maakt Vermeulen duidelijk, biedt de achttiende eeuw de bakermat; die bakermat ligt echter aan Europese academies. Hij geeft aan dat in Batavia ten tijde van de eerste jaren van het genootschap vooral van volken- en zedenkundige beschrijvingen sprake is, dat land- en volkenkunde er nog niet waren doorgedrongen (Vermeulen 1996:33).

De indruk mag niet ontstaan dat het genootschap in 1778 in een cultureel-wetenschappelijke woestijn begon te werken. Al was er voor cultureelwetenschappelijke activiteiten geen organisatie werkzaam, er waren wel enige voorzieningen. Institutionele bibliotheken en privécollecties kunnen niet worden afgedaan alsof ze van geen belang waren. Er werden boeken meegenomen op de VOC-schepen, er werden ook boeken besteld. Er waren drukkerijen, die zelf boeken drukten, niet alleen gebruiksdrukwerk en VOCplakkaten. De druk van de Maleise bijbel was voor Batavia een belangrijk moment. Vanouds had het Kasteel een bibliotheek als voorziening voor de Hoge Regering. Daarnaast had de Bataviase Kerkenraad een bibliotheek voor de bedienaren van het goddelijk woord en De Haan meldt ook een boekerij bij de Raad van Justitie (De Haan 1935a, I:535). Hij zegt dat de medicus en plantkundige Jacobus Bontius in 1627 tweeduizend boeken meenam naar Batavia (De Haan 1935a, I:53). Er werden bij vertrek naar Nederland of bij overlijden veilingen georganiseerd, soms apart voor boeken. Veel van de veilingcatalogi zijn verloren gegaan, enkele zijn echter bewaard gebleven. Voor details kunnen we ook terecht bij catalogi van instituutsbibliotheken. Wij kunnen er hier niet en detail op ingaan en bepalen ons tot twee bibliotheken: die van Petrus van der Vorm (1664-1731) predikant, bijbelvertaler, geroemd om 
zijn 'weêrgalooze kennis van de Hebreeuwsche en andere Oostersche talen' (Van Troostenburg de Bruyn 1884:303). Van der Vorm was in 1688 in Batavia aangekomen, tien jaar op Ambon werkzaam geweest, vervolgens vanaf 1698 in Batavia. Hij stierf daar in 1731 na drieënveertig jaar in Indië. Van der Vorm liet een aanzienlijke bibliotheek na van zeshonderdvijftig boeken en manuscripten, die op 29 augustus 1731 in zijn huis aan de Tijgersgracht werd geveild (Catalogus Van der Vorm 1731). De catalogus laat zien dat het om een typische geleerdenbibliotheek ging. Meer dan zestig procent van de titels was van Latijnse, twintig procent van Nederlandse boeken. Meer dan vijfendertig manuscripten in het Arabisch en Maleis. Bij de boeken waren veel woordenboeken, spraakkunsten en natuurlijk vooral theologische werken. Kortom, de vakbibliotheek van een geleerde predikant, die bij de veiling verspreid werd onder liefhebbers, vakgenoten, onder wie verschillenden zelf soortgelijke collecties zullen hebben gehad. In de collectie ontbreken Nederlandse dichters en prozaschrijvers geheel en al.

Hoe belangrijk Van der Vorms bibliotheek was, kan worden opgemaakt uit een vergelijking met de in 1752 gedrukte catalogus van de zogenaamde Bataviasche Bibliotheecq, volgens De Haan de catalogus van de Kasteelbibliotheek. ${ }^{26}$ De catalogus is gedrukt in de drukkerij van het Seminarium, maar het VOC-vignet op de titelpagina gevoegd bij de afwezigheid van enige vermelding van de bibliotheek van hetzelfde Seminarium, doet mij ertoe neigen De Haan gelijk te geven. Deze bibliotheek met zevenhonderdvier nummers is maar zo'n vijftigtal titels groter dan de bibliotheek van Van der Vorm, twintig jaar eerder. Het zeldzame exemplaar van de catalogus dat zich in de Oriental and India Office Collection van de British Library bevindt, heeft bovendien aanvullingen uit onder meer 1754, toen de bibliotheek van de predikant Carel Braarda werd geveild, en andere toevoegsels van de bibliothecaris (Catalogus Bataviasche Bibliotheecq 1752). Plaats en jaar van uitgave van de titels is vermeld en er is ruimte overgelaten voor toevoegingen. Opvallend is dat de grootste categorie boeken de theologische titels betreft, tweehonderdvijftig van de zevenhonderdvier titels, waarbij de historische werken met maar zevenentachtig titels ver achterblijven, gevolgd door juridisch-politieke werken en mathematische (beide negenenvijftig), waarna de geografische werken (zevenendertig), spraakkunsten (zestien), woordenboeken (achtentwintig), natuurwetenschappelijke werken (negenentwintig) en de boeken van de Academie van Marine (eenentwintig) de rij sluiten. Belangrijk zijn de vijfenzestig manuscripten, waarvan de meeste in Oosterse talen. De bibliotheek had een veel algemener opzet dan die van

26 De Haan 1935a, I:535. Ik ga er althans vanuit dat de bibliotheekcatalogus waar hij op doelt, gedrukt in 1752, dezelfde is als die waarover ik spreek. 


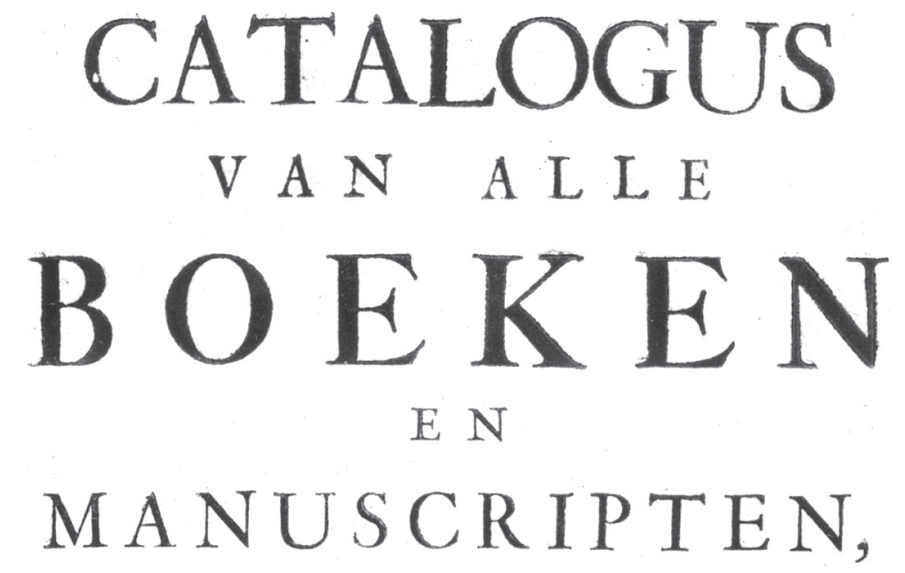

Welke behooren tot de Bataviasche

\section{BIBLIOTHEECQ.}

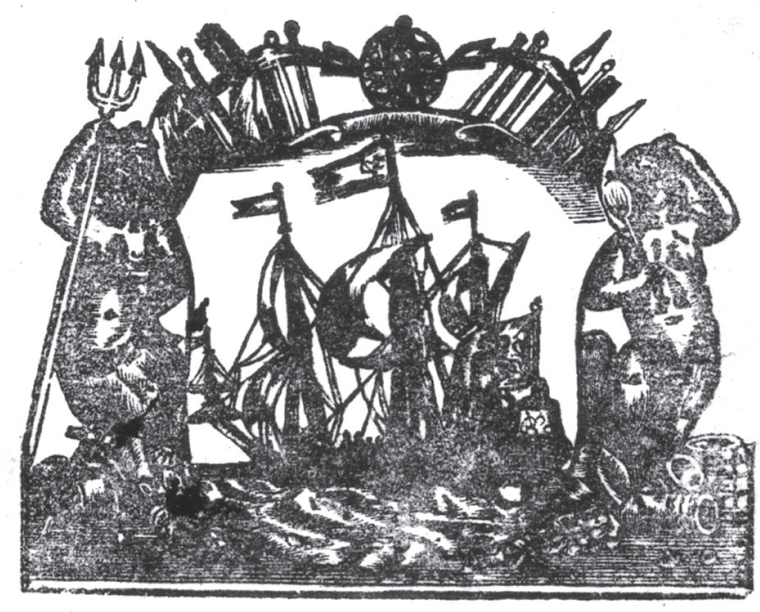

T E B A T A V I A,

Gedulkt by George Hendrik Heuscer in de Druckers van 't SEMINARIUM, Anno 5752 .

Titelpagina Catalogus Bataviasche Bibliotheecq, Batavia 1752 (collectie British Library/ OIOC Londen) 
Van der Vorm, met klassieke auteurs (zesentwintig) onder wie ook Cats en Vondel, medische werken (vier) en mengelwerk (drieëndertig). Het overheersende aantal theologische werken doet ons afvragen of voor de gelegenheid misschien ook de boekerij van het Seminarium of van de Kerkenraad was meegenomen in de catalogus. De bibliotheek was welvoorzien en geeft een idee van wat er in Batavia voorhanden was. De collectie van de predikant Carel Braarda, geveild in 1754, wordt eveneens geprezen als zeer rijk. ${ }^{27} \mathrm{Er}$ waren dan misschien geen boekhandels in Batavia - De Haan meldt de eerste boekhandel in 1834 (De Haan 1935a, I:534) - er werd wel verhandeld en er werd gedrukt. De drukkers traden dan zelf als verkopers op, weliswaar van hun eigen drukwerk, maar wellicht hadden zij ook wel ander werk in de aanbieding.

Een beeld van de cultuur-wetenschappelijke activiteiten in Batavia is uit bovenstaande op te roepen. Kunsten en wetenschappen waren geen terrein van compagnieszorg. Activiteiten op dit gebied werden veelal geïnitieerd, gedragen en volgehouden door individuen, soms tegengewerkt of tegengehouden door de regering, soms enigszins gesteund. Het best gecontinueerd was de zorg van de kerk voor de vertaling van de bijbel in het Maleis en het Portugees, waarvoor serieuze taalkennis een voorwaarde was. De zes tot acht Bataviase predikanten waren de meest constante groep academisch gevormden in Batavia. Al het andere dat voldoende wetenschappelijk niveau had, was het gevolg van de inspanningen van individuen en dreigde op te houden bij hun vertrek of bij hun overlijden. Door het ontbreken van een goede drukpers en door het beperkte boekkopende publiek, kwamen de belangrijkste publicaties op het gebied van de taal-, land- en volkenkunde (als we al van dit wetenschapsterrein mogen spreken) niet in Batavia, maar in de Republiek van de pers. Uitzondering zijn enkele bijbeledities en letterkundige uitgaven.

Het beeld is ongetwijfeld niet volledig. Het kan nader verfijnd worden door gedetailleerder onderzoek. Zo is bijvoorbeeld nader onderzoek naar de in Batavia aanwezige boekverzamelingen door andere veilingcatalogi daarbij te betrekken zeker belangrijk. ${ }^{28}$ De vraag is of het bestaande beeld op het gebied van kunsten en wetenschappen er fundamenteel door zal veranderen. Voor het Bataviaasch Genootschap geldt dat het niet uit het niets ontstond, maar dat Batavia in vergelijking met Nederlandse provinciesteden wel een schraal aanbod had van voorzieningen op het terrein van onderwijs, kunsten

27 Van Troostenburg de Bruyn 1884:589-91, vermeldt helaas niet hoe groot deze bibliotheek was.

28 A. Zuiderweg werkt aan een studie naar het literaire en culturele leven in Batavia in de zeventiende en achttiende eeuw en zal daarbij ook deze boekenveilingen betrekken. Zie vooralsnog Zuiderweg 2000. 
en wetenschappen. In zo'n wereld was de oprichting van een speciaal genootschap een bijzondere gebeurtenis.

\section{Genootschapsonderzoek}

Het onderzoek naar genootschappen in de achttiende en de eerste helft van de negentiende eeuw heeft sinds 1970 veel aandacht gekregen. De publicaties erover bevatten elementen, die verhelderend zijn voor de geschiedenis van het Bataviaasch Genootschap. Daarom komen ze eerst hier aan de orde. Veel ervan zal in het hoofdstuk over de oprichting en eerste periode (17781799) ter sprake komen, omdat juist de plaatsbepaling van de oprichters tegen de achtergrond van de vele in de Nederlandse Republiek werkzame genootschappen aandacht verdient. De belangrijkste facetten van het onderzoek van de laatste dertig jaar, van R.P.W. Vissers inventarisatie (1970) tot de samenvattende studie van J. Kloek en W.W. Mijnhardt (2001), worden hier weergegeven.

Visser publiceerde een eerste inventarisatie van achtenzeventig Nederlandse 'geleerde genootschappen' die alle in de achttiende eeuw waren ontstaan, in overgrote meerderheid na 1750. In navolging van de Royal Society (1662) en de Hollandsche Maatschappij der Wetenschappen (Haarlem 1752) waren zij vooral gericht op de beoefening van de natuurwetenschappen, de medische wetenschappen, de natuurlijke historie en de bevordering van de landbouw. Het Bataviaasch Genootschap paste in Vissers inventarisatie, omdat hij 'Nederlands' in ruime zin had opgevat en het genootschap in Batavia opnam in zijn lijst naast drie Paramaribose, die vanaf 1787 waren ontstaan (Visser 1970:175-86; Buursma 1978). Een inventarisatie uit 1983 door de Utrechtse literatuur-historicus Kloek van de Nederlandse literaire genootschappen tussen 1748 en 1800 opgericht, bracht honderdzestien van dit soort genootschappen aan het licht, later nog eens door C.B.F. Singeling met een tiental uitgebreid. Kloek rekende het Bataviaasch genootschap tot zijn literaire groep, omdat hij 'literair' een ruime betekenis had gegeven (Kloek 1983; Singeling 1986). Voor het Bataviaasch Genootschap met zijn encyclopedische doelstelling, zeker in de beginjaren, geldt dat het heel goed in verschillende groepen geplaatst kan worden, al zijn de strikt literaire bijdragen minimaal in aantal.

In 1980 werd een Utrechtse Werkgroep Genootschappen opgericht, die streefde naar registratie en systematisering van lopend genootschapsonderzoek. In 1983 presenteerden A. de Jonge en Mijnhardt in de tijdschriften van de multidisciplinaire Werkgroepen Achttiende Eeuw en Negentiende Eeuw een onderzoeksstramien voor nieuw te ondernemen of al lopend genootschapsonderzoek. Daarin komen vier aspecten aan de orde: de typologie van 
de genootschappen, de formele regelingen waaraan het genootschap zichzelf had onderworpen, een beschrijving van de activiteiten die het ondernam en tenslotte de sociale samenstelling van de groep leden (A. de Jonge en Mijnhardt 1983). In de tijdschriften van de werkgroepen verscheen in en na 1983 veel nieuw materiaal. De Werkgroep Negentiende Eeuw vond in het tweede eeuwfeest van het Alkmaarse genootschap Physica een aanleiding tot het houden van een symposium over genootschappen. Daarop volgden artikelen over afzonderlijke genootschappen en over aspecten van het genootschapsonderzoek.

Richtinggevend bij dit alles was en is vanaf de jaren zeventig het werk van de Utrechtse historicus Mijnhardt, die bijdragen publiceerde over Teylers Genootschappen in Haarlem (1978), de Maatschappij tot Nut van 't Algemeen (1984), de Vrijmetselarij (1986), en samenvattend over verschillende genootschappen in Tot Heil van 't Menschdom; Culturele genootschappen in Nederland, 1750-1815 (1988). ${ }^{29}$ In de jaren tachtig begon Kloek, eerst alleen, later in samenwerking met Mijnhardt, het onderzoeksterrein uit te breiden naar dat van de boek- en tijdschriftenproductie, de boekhandel, het lezerspubliek en het boekkopende publiek in de achttiende eeuw. Dit onderzoek had duidelijke raakvlakken met het genootschapsonderzoek en bewoog zich binnen een brede cultureel-historische context, zodat het niet verwonderlijk is dat Kloek en Mijnhardt werd gevraagd een studie te wijden aan het jaar 1800 als ijkpunt in de serie 'Nederlandse cultuur in Europese context'. Het resulteerde in 1800 - Blauwdrukken voor een samenleving (2001) waarin zij de twee onderzoeksterreinen lieten samenvallen.

In de eerste fase van het toegenomen genootschapsonderzoek werd duidelijk dat moeilijk zicht was te krijgen op het precieze aantal in de Republiek werkzame genootschappen. Naast de al genoemde aantallen, door Visser en Kloek bijeengebracht, signaleerde Mijnhardt in zijn artikel over de vrijmetselarij twaalf loges in 1756 en meer dan zestig nieuwe loges tussen 1756 en 1800 (Mijnhardt 1986:95). P.J. Buijnsters, die onderzoek deed naar leesgezelschappen in dezelfde periode, kwam tot een schatting van ruim driehonderd van dit type gezelschappen tot $1800 .{ }^{30}$ Lang niet alle genootschappen, gezelschappen, loges en maatschappijen lieten sporen na in archieven of bibliotheken. Vooral de kleinere, lokale organisaties die niet met prijsvragen, publicaties of openbare bijeenkomsten aan de weg timmerden, verdwenen in het niets. Vandaar dat over exacte aantallen geen zekerheid kan worden verschaft. De aantallen die het genootschapsonderzoek desondanks tot nu toe heeft opgeleverd, wijzen erop dat de Nederlandse Republiek honderden genootschap-

29 Mijnhardt 1978; Mijnhardt en Wichers 1984; Mijnhardt 1986; Mijnhardt 1988.

30 Buijnsters' onderzoek wordt vermeld bij Kloek en Mijnhardt 2001:100. Zie ook Mijnhardt 1988:105 en Buijnsters 1984. 
pen kende, lokale, provinciale en nationale. Mijnhardts onderzoek naar de situatie in Middelburg bijvoorbeeld bracht voor de periode tussen 1750 en 1800 daar al dertien genootschappen, loges en gezelschappen aan het licht en daar waren leesgezelschappen - vaak het moeilijkst te traceren - niet bij inbegrepen (Mijnhardt 1988:240). Amsterdam was in Vissers lijst van 1970 vertegenwoordigd met vijfentwintig genootschappen en dat aantal had alleen betrekking op de zogenaamde geleerde genootschappen.

Het is begrijpelijk dat het onderzoek zich onder meer richtte op een typologie van het genootschap om zo greep te krijgen op het onderwerp. Mijnhardt zorgde in 1983 voor een historisch gefundeerde indeling in vier generaties, waarbij genootschappen onderscheiden werden tegen de achtergrond van de ontwikkelingen in de achttiende eeuw. Daarbij ging hij uit van een eenvoudige definitie van genootschap: 'een geïnstitutionaliseerd en geformaliseerd fenomeen, dat wetten heeft', een definitie gebaseerd op het achttiende eeuwse woordenboek van M. Noël Chomel (1778) en op het negentiende eeuwse Woordenboek der Nederlandsche Taal (1882; Mijnhardt 1983:77). Het was niet de eerste keer dat een indeling in soorten genootschappen werd gemaakt. Al in 1785 had Andreas Bonn de indrukwekkende, voor sommigen onoverzichtelijke hoeveelheid genootschappen in een functionele indeling in vijven ondergebracht, een indeling die volgens Mijnhardt het bezwaar had dat er te weinig rekening was gehouden met de historische veranderingen en met de status van de verschillende genootschappen (Mijnhardt 1983:77). Hij stelde in zijn artikel, na een inleiding over de cultuur-historische achtergrond van de vloedgolf van genootschappen in de Republiek in de achttiende eeuw, daarom de volgende verdeling voor.

Tot de eerste generatie behoren de grote geleerde genootschappen die nationale aspiraties koesterden en die een nauwe band hadden met de overheid. Aan de overheid ontleenden zij hun bestaansrecht door een octrooi aan te vragen, waarnaast zij ook erkenning zochten in bescherming door de Stadhouder door hem het protectoraat aan te bieden (Mijnhardt 1983:80-91). Na de Hollandsche Maatschappij der Wetenschappen (Haarlem 1752) volgden in deze generatie onder meer het Zeeuwsch Genootschap der Wetenschappen (Vlissingen 1769), het Bataafsch Genootschap der Proefondervindelijke Wijsbegeerte (Rotterdam 1769) en het Provinciaal Utrechtsch Genootschap (1778). Met ledenwerving gericht op geleerden uit het hele land en met prijsvragen en gepubliceerde verhandelingen probeerden deze genootschappen een rol te spelen vergelijkbaar met die van de grote broers in Londen, Parijs en elders. Die dankten hun vrijheid van werken aan een koninklijk mandaat en mecenaat en waren al in de zeventiende eeuw ontstaan.

De tweede generatie genootschappen omvat een veel ruimere groep en is vooral tussen 1750 en 1770 ontstaan, grotendeels gelijktijdig met de naar verhouding tot het buitenland laat ontstane geleerde genootschappen. Ze omvat 
vrijmetselaarsloges, dichtgenootschappen, natuur- en letterkundige genootschappen en leesgezelschappen. Deze groep genootschappen was in vergelijking met de eerste generatie meer naar binnen gericht, actief in de eigen groep van leden. Zij zochten geen bevestiging van hun bestaan bij stads- of provinciaal bestuur, hadden geen octrooi nodig, maar werkten vooral voor zichzelf. Werden de genootschappen van de eerste generatie gedomineerd door het patriciaat, 'bij die van de tweede generatie beperkte de invloed van het patriciaat zich tot hoogstens het financiële en was het heft stevig in handen bij de middengroepen van intellectuelen, vrije beroepen, predikanten, kleine kooplieden en renteniers' (Mijnhardt 1983:87). De groei van de tweede generatie beperkte zich tot 1770 vooral tot Holland, Zeeland en Utrecht, daarna kwam zij ook in de landprovincies op. Met de eerste generatie had zij gemeen dat er wetten waren, terwijl deze tweede generatie soms nauwkeurig uitgewerkte boetebepalingen aan die wetten toevoegde, waardoor zij greep probeerde te houden op de leden en hen wilde dwingen actief mee te doen aan de genootschappelijke activiteiten.

In de derde generatie genootschappen, die in de loop van de jaren zeventig van de achttiende eeuw opkwam ziet Mijnhardt een neiging tot externalisering van het private, naar binnengekeerde karakter van de tweede generatie. Begaan onder andere met de slechte economische toestand in de Republiek en vanuit een gevoel van dreigende culturele verwording wilden deze genootschappen hervormingen propageren en zodoende verbeteringen op economisch en cultureel terrein bereiken. Ze betraden daarmee openlijk het terrein dat tot dan toe het privilege van de staat (provinciaal of nationaal) was geweest. De Oeconomische Tak (Haarlem 1777) van de Hollandsche Maatschappij der Wetenschappen en de Maatschappij tot Nut van 't Algemeen (Edam 1784), beide in korte tijd een groot succes met vele afdelingen (departementen), zijn de bekendste voorbeelden van deze hervormingsgezinde genootschappen. De Oeconomische Tak (vijfenvijftig departementen in 1778) richtte zich vooral op welvaartsverbetering, 'het Nut' (tweeënvijftig departementen in 1800) vooral op verbetering van onderwijs en opvoeding. Het waren de berichten van de Oeconomische Tak die Batavia bereikten vlak voordat het genootschap daar werd opgericht en veel van de doelstellingen van de Haarlemmers zijn in het Bataviase programma van 1778 terug te vinden. Met 'het Nut' had het genootschap een overeenkomstige ideologie in de zinspreuk Ten Nutte van het Gemeen, maar anders dan de mannen uit Edam werden die van Batavia geen pressiegroep voor volksopvoeding en onderwijsverbetering.

De vierde en laatste generatie ziet Mijnhardt in de zuiver politieke genootschappen en organisaties, zoals de patriotse exercitiegenootschappen in hun strijd om de politieke macht tussen 1780 en 1800, die de revoluties van 1787 en de bezetting door Frankrijk in 1795 als kernmomenten meemaakten. 
Mijnhardt had hiermee zijn historisch gefundeerde typologie geïntroduceerd, waarnaar iedere onderzoeker sindsdien verwijst.

W. van den Berg, die zich tezelfdertijd speciaal boog over de literaire genootschappen in de eerste helft van de negentiende eeuw, keek in zijn typologie naar het gesloten of open karakter van de organisaties die hij onder de loep nam. Waren de activiteiten (activering, beschaving, oefening) gericht op de eigen, beperkte groep en dus naar binnen gekeerd dan wel gericht op instructie, beschaving of esthetische genoegdoening van een groter publiek? Schuwde het genootschap de publiciteit of zocht het deze juist (W. van den Berg 1983:152-3)? Van den Berg noemde het gesloten type in de eerste plaats literair-sociologisch interessant, terwijl 'het open type daarnaast ook literairhistorisch relevant is vanwege de uitstraling en mogelijke doorwerking op een groter en niet geselecteerd publiek' (W. van den Berg 1983:153).

Mijnhardts proefschriftuit 1988 bouwde voort op zijn publicatie uit 1983. Hij behandelt in een historisch overzicht eerst de stand van zaken met betrekking tot het onderzoek naar genootschappen, waarna hij een panorama geeft van de genootschapstraditie in Europa, vanaf de Italiaanse academies tot de achttiende eeuwse dilettantengenootschappen. Daarna verplaatst hij het perspectief naar Nederland om de specifiek lokale omstandigheden van de nodige achtergrond te voorzien, waarna hij zijn genootschapsindeling opnieuw presenteert. In vier detailstudies werkt hij vervolgens het hoofdstuk over de genootschappen in Nederland uit: voor de geleerdensociabiliteit gebruikt hij het Zeeuwsch Genootschap (Vlissingen) als testcase, voor de dilettantensociabiliteit de vrijmetselarij met een toepassing op Middelburg, voor de hervormingsgezinde genootschappen de geschiedenis van 'het Nut' met een toepassing op Utrecht, en tenslotte als een overgangsgeval, de twee genootschappen van Teylers Stichting (Haarlem). Die vier toepassingen kunnen sindsdien gelden als modellen voor het genootschapsonderzoek in Nederland, omdat Mijnhardt aandacht besteedt aan oprichters, leden, wetten, doelstellingen, activiteiten en publicaties van de diverse genootschappen tegen de achtergond van de sociale en politieke ontwikkelingen van de stad, het gewest of de Republiek als geheel. Het onderzoek naar de politieke en levensbeschouwelijke achtergrond van genootschapsbestuurders en hun relaties tot de lokale of gewestelijke overheid levert een plaatsing op van de genootschappen in Nederland tussen 1750 en 1815: wat was hun politieke oriëntatie, welk wetenschapsideaal hingen zij aan, welke visie hadden zij op cultuur en opvoeding? Hoe reageerden zij op de grote politieke en ideologische bewegingen van de achttiende eeuw?

Mijnhardts genootschapsindeling bleef in 1988 in grote lijnen ongewijzigd. Wel brengt hij dan de genootschappen van de tweede generatie onder de noemer 'dilettantengenootschappen', daarmee het verschil benadrukkend met de eerste generatie van de geleerde genootschappen. De hervormings- 
gezinde en politieke genootschappen plaatst hij in dezelfde, derde generatie, waardoor de indeling in vieren vervangen is door een indeling in drieën (Mijnhardt 1988:98-116). In de recente studie van Kloek en Mijnhardt (2001) over de Nederlandse cultuur rond 1800 is de groep 'dilettantengenootschappen' vervangen door de neutralere term 'publieksgenootschappen', en 'hervormingsgezind' is vervangen door 'reformistisch', waarbij Kloek en Mijnhardt spreken van 'reformistische en politieke gezelschappen'. Voor het overige is de indeling in drie generaties van Mijnhardt uit 1988 gevolgd (Kloek en Mijnhardt 2001:113-7, 120-4).

De typologie van de genootschappen met het ermee samenhangend werkterrein en het karakter dat een genootschap kreeg door zijn ledenwerving, zijn aspecten die bij het Bataviaasch Genootschap aan de orde komen. Zo is het de vraag of de oprichters van het genootschap te Batavia zich spiegelden aan bepaalde genootschappen in het bijzonder. Kan uit de contacten die zij legden met genootschappen in het vaderland iets worden opgemaakt over de ambities die zij koesterden? Wilde het Bataviaasch Genootschap een rol spelen als die van de Haarlemse Maatschappij, dan wel een meer in zichzelf gericht dilettantengenootschap zijn? Hoe zit het met de rol van de overheid in Batavia? Is er sprake van een octrooi-aanvrage bij de overheid of bij de Stadhouder als opperbewindhebber van de VOC? Hoe was de groep leden samengesteld?

$\mathrm{Nu}$ is een strikte scheiding tussen soorten ofwel een rigide toepassing van de typologie bij een zo complex sociaal-historisch verschijnsel als genootschappen ondoenlijk. Die lag en ligt dan ook geenszins in de bedoeling van de onderzoekers als Mijnhardt, Van den Berg en Kloek. Mijnhardt verduidelijkt dat de grote geleerde genootschappen van de eerste generatie voor een deel voortkwamen uit informele gezelschappen, die in Haarlem, Vlissingen, Rotterdam al enige tijd bijeenkwamen, gezelschappen die zich omvormden en de formele structuur aannamen van een genootschap, waarna de overheid werd verzocht octrooi te verlenen (Mijnhardt 1983:81, 1988:89-90). Dit zijn voorbeelden van dilettantengenootschappen die zich ontwikkelden tot een genootschap van de eerste generatie. In Utrecht vormde een bestaand Konstgenootschap zich in 1778 om tot een geleerd genootschap en vroeg octrooi aan bij de provincie, waardoor het van status veranderde (Mijnhardt 1983:88). Ook voor Batavia is het relevant na te gaan of het genootschap een voorgeschiedenis kent in de vorm van een informeel gezelschap. Het feit dat in de eerste bundel van de Verhandelingen aan tegenwerking bij een eerdere poging tot oprichting van het genootschap wordt gerefereerd, wijst in die richting.

In verband met de voorgeschiedenis en oprichting van genootschappen is het van belang na te gaan welke banden oprichters en eerste bestuurders aanknoopten met andere organisaties. Zo is de oprichtingsgeschiedenis van 
de Maatschappij der Verdiensten met de spreuk 'Felix Meritis' (Amsterdam 1777), die uitgebreid beschreven is door H. Reitsma, belangrijk voor wat er in Batavia gebeurde. ${ }^{31}$ De Amsterdamse klokkenmaker Willem Writs stelde in 1776 aan medeleden van een bestaand leesgezelschap voor over te gaan tot de oprichting van een veel breder gerichte Maatschappij, een formalisering tot een dilettanten- of publieksgenootschap. Terwijl de eerste aanmeldingen voor de nieuwe maatschappij binnenkwamen, werd vanuit Haarlem de Oeconomische Tak gelanceerd, die departementen hoopte te mogen begroeten in vele steden, ook in de koloniën, uiteraard ook in Amsterdam. Er vonden onderhandelingen plaats tussen H.H. van den Heuvel, namens de Oeconomische Tak, en Writs en zijn medebestuurder van het eerste uur bij de Amsterdamse Maatschappij in oprichting, Benjamin Bosma, waarbij van de kant van de Haarlemmers werd gehoopt dat de Maatschappij zich tot een departement van de Oeconomische Tak zou omvormen. Om verschillende redenen mislukten de plannen van de Tak. De Amsterdammers waren te democratisch gezind voor Van den Heuvel. Bovendien was het plan van de Oeconomische Tak te nationaal voor de lokaal-patriottische Amsterdammers. Naast de serieuze bedoelingen was er in de plannen van Writs en de zijnen ook plaats voor vermaak en ontspanning, waar de Haarlemmers niet voor voelden. Zo kwam er toch een aparte Maatschappij. In november 1777 vond de eerste vergadering plaats. In de wetten echter komen, met betrekking tot het departement Koophandel van 'Felix' - de Maatschappij deelde zich op in vijf departementen: koophandel, natuurkunde, muziek, letterkunde en tekenkunde - veel verwijzingen voor naar de ideeën van de 'Oeconomische Tak'. Reitsma zegt dan ook over die vroege periode van 'Felix':

Men kan ook, nogmaals met een verwijzing naar de generatieindeling van Mijnhardt, stellen dat de Maatschappij, na in haar oprichtingsfase rakelings langs de derde generatie [die van de hervormingsgezinde genootschappen] gescheerd te zijn, zich gaandeweg vestigde in de tweede generatie (Reitsma 1979:112).

Naast de vraag of het Bataviaasch Genootschap naar de generatie-indeling van Mijnhardt nu in de eerste, tweede dan wel derde groep thuishoort, is de uitdrukkelijke uitnodiging vanuit Haarlem om ook in Batavia een departement van de Oeconomische Tak op te richten, een aspect dat goed bekeken dient te worden. Zeker lijkt de mogelijkheid groot dat de uitnodiging de uiteindelijke stichting dichterbij heeft gebracht. Is ook Batavia in de oprichtingsfase 'rakelings langs de derde generatie van Mijnhardt gescheerd', om de woorden van Reitsma over Felix te parafraseren? Immers, in parallellie

31 Reitsma 1979:101-39, gevolgd door artikelen van Knolle 1979 over het departement Tekenkunde en van Snelders 1983b over het departement Natuurkunde van Felix Meritis. 
met het Amsterdamse Felix kwamen ook in Batavia nogal wat koopmansvoorstellen en landbouwvragen in het programma terecht.

Een ander aspect van het genootschapsonderzoek betreft de vraag hoe het te verklaren is dat in de Nederlandse Republiek juist na 1750 zo'n groot aantal nieuwe genootschappen werd opgericht. Hoe bijzonder was de situatie in de Republiek? In hoeverre week die af van de situatie in de omringende staten en wat was het nieuwe daarvan? Dat er een grote toename in het aantal genootschappen was, juist in de tweede helft van de achttiende eeuw, namen de tijdgenoten al waar. In antwoord op een Zeeuwse prijsvraag, die orde hoopte te scheppen in de steeds toenemende groep geleerde genootschappen, schreef Andreas Bonn zijn 'Rakende de schikkingen, welken door de gezamenlyke geleerde maatschappijen in ons vaderland zouden kunnen gemaakt worden' (1785), die door het Zeeuwsch Genootschap werd gepubliceerd (Mijnhardt 1988:78-9). De gedachte achter de Zeeuwse prijsvraag was, dat het zicht op de vele prijsvragen van verschillende genootschappen zoek raakte, dat verdubbelingen konden plaatshebben of dat door de overvloed aan prijsvragen menige vraag onbeantwoord bleef. In Batavia werd in 1780 al een prijsvraag gewijd aan de Europese genootschappen en tijdschriften, waarbij het beste plan voor een geleerd genootschap en voor een letterkundige periodiek werd gevraagd. ${ }^{32}$

R. Vermij reageerde op Mijnhardts proefschrift door vraagtekens te zetten bij genootschappen als specifiek element van de Verlichting, zeg maar: als typisch voor de achttiende eeuw (Vermij 1993). Hij signaleert voorbeelden van zeventiende-eeuwse gezelschappen en collegia, die zichzelf via wetten gereglementeerd hadden en die als voorlopers van de achttiende-eeuwse genootschappen kunnen gelden. Hij benadrukt daarmee juist de continuiteit en de traditie in vormen van sociabiliteit (of genootschappelijkheid), gedefinieerd als: de behoefte aan gezellig verkeer. Ook trekt hij een minder scherpe grens tussen geleerden- en publiekssociabiliteit als het om de de vroege genootschapsgeschiedenis gaat. Hij wijst bijvoorbeeld op de rol van amateurs in de Royal Society, op die van geleerden in Nil Volentibus Arduum (Amsterdam 1668) en op het mogelijk informele karakter van het Utrechtse Collegie der Scavanten. Zijn conclusie luidt:

Het 'verlichte' genootschap onderscheidde zich van zijn voorgangers doordat het verlicht was, dat wil zeggen doordat men er verlichte idealen hoog hield. Maar dat betekent alleen dat men in zulke genootschappen de intellectuele mode van de eigen tijd volgde. Het betekent niet dat de Verlichting een voorwaarde was voor het ontstaan van zulke genootschappen. (Vermij 1993:22.)

32 Programma 1782:7 (Perpusnas B 32/2) vermeldt de extra prijsvraag voor rekening van een onbekende, met een beloning van honderd gouden ducaten. De prijsvraag dateert echter al van 1780 . 
Mijnhardt reageerde met een repliek (1994) waarin hij beklemtoonde dat, hoewel er ook in de zeventiende eeuw al sprake was van institutionalisering en strakke regelgeving bij gezelschappen en genootschappen, er toch specifieke veranderingen in de genootschappelijkheid of sociabiliteit ('de behoefte aan menselijk contact in groepsverband'), in de achttiende eeuw zijn waar te nemen, die samenhangen met 'sociaal-economische verschuivingen en ideeën-historische verandering' (Mijnhardt 1994:103). Hij blijft ondanks Vermij's claim dat zeventiende-eeuwse collegies (collegium, culturele kring voor het publiek) en societates (societas, geleerdenkring) niet scherp van elkaar te scheiden zouden zijn, van mening dat het zinvol is om publiekssociabiliteit en geleerdensociabiliteit, ook voor de zeventiende eeuw, te onderscheiden. De collegies als vervangers van de middeleeuws-corporatieve vormen van sociabiliteit (broederschappen, gilden, schutterijen, rederijkerskamers) kwamen in de Republiek relatief vroeg op en de corporaties verloren in de Republiek sneller dan in andere landen terrein, maar daarmee vallen collegies niet eenvoudig samen met vroege verlichte genootschappen, aldus Mijnhardt. Hij hecht aan het idee van het specifieke van de achttiende-eeuwse ontwikkeling, die overigens gezien moet worden in relatie tot de ontwikkelingen in de omringende landen en dan een opvallend overeenkomstige chronologie vertoont, in nauwe samenhang met de zich verbreidende, nieuwe sociale filosofie.

Het verlichte genootschapstype kwam tot ontwikkeling nauw verbonden met een eigen sociale filosofie waarin gepoogd werd met behulp van een nieuwe sociabiliteit meer inzicht te verwerven in de problemen rond de instandhouding en verbetering van de burgerlijke samenleving (Mijnhardt 1994:108-9).

Later nam Vermij de discussie met Mijnhardt nog eens op, toegespitst op de vraag, hoe modern de verlichte genootschappen waren, waarbij hij niet veel van zijn eerdere standpunt prijsgaf:

Niet te ontkennen valt dat in de tweede helft van de achttiende eeuw nieuwe elementen hun intrede doen in het genootschapswezen, die hun kern hebben in de maatschappelijke en politieke ontwikkelingen van deze periode. Maar wat er verandert, is niet het genootschap zelf, maar de samenleving. (Vermij 1999:46.)

Overigens wijst hij dan ook op het zich ontwikkelende nieuwe burgerschapsideaal als verklaring voor de grote proliferatie van genootschappen in de Republiek na 1750. Het interpretatieverschil komt kortgezegd hierop neer: Vermij ziet het genootschap in de zeventiende eeuw al een vaste plaats in de samenleving innemen, waarvan de achttiende-eeuwse genootschappen een voortzetting zijn, vast ingebed in de traditie. Mijnhardt ziet in de achttiende eeuw onder invloed van sociaal-economische en culturele veranderingen, met name onder invloed van de opkomst van een nieuwe sociale filosofie, een 
ander type genootschap ontstaan, dat niet eenvoudig als een voortzetting van eerdere vormen van sociabiliteit kan worden geïnterpreteerd.

In 1800 - Blauwdrukken voor een samenleving presenteren Kloek en Mijnhardt de achttiende-eeuwse genootschappen met samenhangende onderwerpen in een apart deel onder de titel 'Contouren van een communicatiegemeenschap'. Daarmee zijn de genootschappen ingebed in een totaal van maatschappelijke en culturele verschijnselen. Overigens werden die achtergrond en context ook door Mijnhardt (1988) en opnieuw in zijn discussie met Vermij behandeld. De synthese van Kloek en Mijnhardt bouwt daarop voort en incorporeert het onderzoek naar lezerspubliek, boekproductie en boekdistributie. ${ }^{33}$ Achtereenvolgens behandelen de auteurs de veranderingen in het denken over mens en samenleving, de ontwikkelingen op het gebied van de boek- en tijdschriftenproduktie, de explosieve proliferatie van gezelschappen en genootschappen en de nieuwe, zogenaamde communicatiegemeenschap, die ten gevolge van deze ontwikkelingen ontstond.

Aan de basis van de ontwikkelingen, die resulteren in deze communicatiegemeenschap, zien Kloek en Mijnhardt de fundamentele veranderingen in het denken over de mens en zijn plaats in de samenleving, teweeggebracht door de zeventiende-eeuwse denkers Hugo de Groot en John Locke. Hun ideeën maakten de weg vrij voor een nieuwe visie, die de mens bevrijdde uit het door het christelijk denken bepaalde stramien van een alombepalend heilsplan, waarin de mens afhankelijk was van goddelijke genade. Daarvoor in de plaats kwam een natuurrechtelijk stelsel (De Groot), op basis waarvan anderen nieuwe concepten ontwikkelden, zoals dat van het geloof in de veranderbaarheid van de samenleving en de rol van het individu daarin (Locke). Een centrale plaats neemt het denken van de Schot Frances Hutcheson in, die het begrip 'moral sense' introduceerde en de eraan gekoppelde beschavende werking van sociaal verkeer in familiekring, vriendenkring en gezelschappen. Er ontstond een ideologie, waarvan het centrale concept was, dat sociabiliteit en intellectuele activiteit de sleutels waren tot de deugd (Kloek en Mijnhardt 2001:67-72). Een belangrijke rol in het uitdragen van deze ideologie vervulden de spectatoriale geschriften, in Engeland die van Addison en Steele, in Nederland Justus van Effens Hollandsche Spectator, die als commentatoren de optimistische boodschap van het nieuwe sociabiliteitsideaal naar voren brachten. Van Effen lokte daarmee gedurende tientallen jaren vele navolgingen uit. Evenzeer belangrijk waren de deugd propagerende romans, in Engeland onder meer Samuel Richardons Clarissa die ook in Nederland werd vertaald en nagevolgd, onder andere in de invloedrijke roman Historie van Mejuffrouw

33 Ik ga hier uitgebreider in op de visie van Kloek en Mijnhardt (2001), de meest recente publicatie, die een handvat biedt voor verder onderzoek. Ik verwijs in het vervolg naar dit werk, eerder dan naar Mijnhardt 1988. 
Sara Burgerhart van Betje Wolff en Aagje Deken. Bij de verbreiding van deze ideologie bleken de dissenters (lutheranen, remonstranten en doopsgezinden) een voortrekkersrol te spelen (Kloek en Mijnhardt 2001:73-80).

De toename van de boekproduktie en de hogere alfabetiseringsgraad in de achttiende eeuw - meer lezers kregen toegang tot kennis en daarmee tot de publieke discussie daarover - zijn belangrijke factoren in het ontstaan van wat Kloek en Mijnhardt omschrijven als een nationale communicatiegemeenschap. De verdubbeling van het aantal verschenen boektitels in de achttiende eeuw, vergeleken met de zeventiende, gekoppeld aan verbeteringen in het boekenbedrijf, betere informatieverstrekking, netwerkvorming tussen boekhandels in de Republiek en tenslotte het ontstaan van de leenbibliotheek bij de boekverkoper, leidde tot een betere spreiding van een grotere informatiestroom (Kloek en Mijnhardt 2001:81-5). Een belangrijke rol was weggelegd voor de periodieke pers. Daartoe behoorden de kranten en de Spectators, die al in de eerste helft van de eeuw verschenen en wekelijks of tweewekelijks hun moraliserende commentaren leverden, als ook het algemeen-culturele tijdschrift en vooral de politieke bladen in de patriottentijd. Voorbeelden van die algemeen-culturele periodieken zijn de maandelijkse Vaderlandsche Letteroefeningen (vanaf 1761) en het weekblad De Algemeene Konst- en Letterbode (vanaf 1788), die informatieve recensies en artikelen leverden, maar niet, zoals de spectatoriale tijdschriften, als zedenmeester optraden. Voor het bredere publiek waren het de populaire-wetenschappelijke werken op geografisch en geschiedkundig gebied, zedenkundige romans en burgerlijke drama's, naast de Spectators en de algemeen-culturele tijdschriften, die vorm gaven aan een rijker geschakeerd lectuuraanbod. Kloek en Mijnhardt plaatsen echter kanttekeningen bij de suggestie dat er van een leesrevolutie sprake was. In de eerste plaats bleef de maatschappelijke elite vooral de koper van boeken, ook van de nieuwe genres. Er was dus vooral sprake van verbreding van het aanbod voor een publiek, dat toch al las. Een grotere groep kopers kocht voornamelijk functioneel: dat wat nuttig was voor het beroep of van direct belang voor het werk. Verder waren boeken en abonnementen op tijdschriften duur, wat de verspreiding beperkte. De praktische oplossing van dit laatste probleem werd gevonden in het leesgezelschap en het leesmuseum, waardoor boeken en tijdschriften meer circuleerden. Echter ook tot deze instellingen hadden in de eerste plaats diegenen toegang die al lazen. Niettemin kan men spreken van een ontwikkeling van intensief lezen (weinig lectuur steeds weer herlezen door een kleine groep) naar extensief lezen (meer en gevarieerder leesmateriaal voor een breder publiek). Een bredere groep ontwikkelde lezers vulde de groep geleerde lezers uit de elite aan (Kloek en Mijnhardt 2001:86-102).

Sociabiliteit, 'de behoefte én de vaardigheid om in gezelschap te verkeren, en daarmee een maatschappelijke deugd bij uitstek', is een ander aspect van de communicatiegemeenschap, naast dat van het toegenomen belang van 
het gedrukte woord (Kloek en Mijnhardt 2001:103). Publiekssociabiliteit in de vorm van broederschappen, schutterijen, gilden en rederijkerskamers, die een corporatief karakter hadden, dat wil zeggen dat zij zich op een oorkonde baseerden, was er reeds in de vroegmoderne tijd. Die vormen van sociabiliteit gingen in de zeventiende eeuwse Republiek verloren. Geleerdensociabiliteit was er in de Republiek al vroeg, maar in de vorm van informele kringen, die in tegenstelling tot de absolutistisch geregeerde, omringende landen niet door de staat geïncorporeerd werd in officiële academies als de Académie des Sciences (Parijs 1666). Dat soort door de staat erkende en beschermde genootschappen ontstond in de Republiek pas na 1750 en daarin was de Republiek achterlijk (Kloek en Mijnhardt 2001:104-6). In de teloorgang van de oude corporatieve sociabiliteitsvormen en het ontstaan van een nieuwe publiekssociabiliteit: besloten, naar binnen gerichte genootschappen die op privé-initiatief tot stand kwamen, was de Republiek nu juist voorlijk. Al in de tweede helft van de zeventiende eeuw komen die nieuwe genootschappen op, maar de echte proliferatie ervan is voorbehouden aan de tweede helft van de achttiende eeuw.

Mijnhardt en Kloek nemen hier de discussie met Vermij weer op en benadrukken opnieuw het specifieke van de Nederlandse achttiende eeuw. Dat specifieke verklaren zij onder meer uit de hoge urbanisatiegraad, die een behoefte aan sociale en culturele differentiatie met zich meebracht. Verder uit een zekere vrijheid die de lokale overheden de burgerij lieten, overheden die niet probeerden alle gezelschappen en genootschappen te beheersen. De explosieve groei van het aantal genootschappen na 1750 schrijven zij echter toe aan de toegenomen rol van het gedrukte woord, waardoor ook de informatie over de natuurwetenschappen binnen bereik van een groter publiek kwam. Het volgen van lezingen over de natuur als spiegel van Gods almacht, verlucht met natuurkundige proeven, maakte het publiek rijp voor de genootschapskring waarin dit allemaal kon worden besproken, herhaald en uitgebreid. Verder was er de belangstelling voor de taal, letterkunde en geschiedenis, waarmee men zich afzette tegen het oppermachtige Frankrijk en de Franse taal en cultuur. Tenslotte was er de factor van de politieke en economische crisis, het gevoel van achteruitgang, zowel wat betreft de handelspositie van de Republiek alsook en daarmee samenhangend van dezelfde Republiek als machtsfactor binnen Europa. Deze factoren vormen de achtergrond voor de sterk toegenomen genootschapsactiviteit na 1750 .

De inhaalslag op het gebied van de geleerdensociabiliteit vond tussen 1750 en 1780 plaats. Toen vestigden zich in Haarlem, Vlissingen, Rotterdam en Utrecht de grote genootschappen die hun leden recruteerden uit de Nederlandse geleerdenstand, terwijl zij bestuurd werden door 'directeuren' uit het patriciaat die voor de financiering moesten zorgen en die tegelijk de band met de overheid garandeerden, een band die verder via een provinciaal 
octrooi werd vastgelegd. Het initiatief voor de oprichting van deze genootschappen kwam uit diezelfde patriciaatskring, terwijl voortgebouwd werd op de voorgeschiedenis van een informele geleerdenkring. Met de stichting van deze genootschappen, zo zeggen Kloek en Mijnhardt, liep de Republiek weer in de pas met de omringende landen, waar dit soort centra van geleerdheid al eerder ontstonden (Kloek en Mijnhardt 2001:112-3). Via prijsvragen en verhandelingen gaven de genootschappen vorm aan hun programma en daarmee waren ze naar buiten gericht. Voor het stimuleren van nieuw onderzoek hadden ze echter geen geld. De naar binnen gerichte publieksgenootschappen, die geen lokale of gewestelijke erkenning zochten, omvatten geleidelijk aan een veel grotere groep burgers, niet zozeer de regenten en de universitair geschoolden, maar de vrije beroepen, de autodidacten en vooral de dissenters. Tot deze publieksgenootschappen die tot 1770 vooral in Holland, Zeeland en Utrecht opkwamen, daarna ook in de andere provincies, maar niet in de generaliteitslanden, rekenen Kloek en Mijnhardt de vrijmetselaarsloges, de natuurkundige genootschappen, de literaire- en kunstgenootschappen en de genootschappen die het hele scala van kunsten en wetenschappen wilden bestrijken (Kloek en Mijnhardt 2001:113-7). De rol van de Nederlandse taal werd van belang geacht. Met het nadrukkelijke gebruik van het Nederlands zetten de genootschappen zich af tegen de Latijnse Scholen, athenea en universiteiten, waardoor zij een ander publiek binnenhaalden dan de tot geleerden beperkte genootschappen. De beoefening van taal-, letterkunde en geschiedenis was verwaarloosd en dit koppelde men aan de neergang van de Republiek. Hernieuwde aandacht voor deze sectoren van het intellectuele leven zou de algemene toestand van de Republiek ten goede komen. Ondertussen werd door de beoefening van de natuurwetenschappen niet alleen kennis verbreid, maar ook op een wijze die voor een breed publiek aanvaardbaar was, gelegitimeerd door de gedachte dat de goddelijke almacht in de natuur weerspiegeld werd. De meest bescheiden vorm van publiekssociabiliteit vormden de leesgezelschappen, waar echter duizenden mensen deel aan hadden.

Buiten de zeer populaire publiekssociabiliteit vallen de reformistische en politieke gezelschappen van na 1775, die niet naar binnen gericht waren en juist economische, maatschappelijke en politieke hervormingen voorstonden en daarmee de concurrentie met de staat, soms zelfs de strijd met de gevestigde orde aangingen. De Oeconomische Tak (Haarlem 1777), de Maatschappij tot Nut van 't Algemeen (Edam 1784) en de vele burgersociëteiten en exercitiegenootschappen (na 1780) zijn uitingen van het groeiende zelfbewustzijn van de burgerij, die de behoefte voelde om zelf actief mee te doen aan het verbeteren van de maatschappij. Deze genootschappen hadden duizenden leden en met name de Maatschappij tot Nut van ' $t$ Algemeen met een programma gericht op volksopvoeding en verbetering van het onderwijs werd een succes. De successen van de politieke genootschappen hingen 
natuurlijk samen met de politieke veranderingen in 1787 en 1795 (Kloek en Mijnhardt 2001:120-4).

Kloek en Mijnhardt schetsen de contouren van een wordende communicatiegemeenschap: een nationale entiteit die rond 1800 bestaat, die zich bedient van het Nederlands en die mede dankzij de grotere verbreiding van het gedrukte woord en de enorme groei van het aantal genootschappen tot stand kwam. Gesloten geleerdencircuits en tot lokale gemeenschappen beperkte circuits van ontwikkelden gingen in deze boven-lokale, bovengewestelijke gemeenschap op (Kloek en Mijnhardt 201:127-9). Dankzij het onderzoek naar de samenstelling van de grote genootschappen en dankzij onderzoek naar het boekkopende publiek kunnen de auteurs iets zeggen over de participatie aan die communicatiegemeenschap. Op een bevolking van ruim twee miljoen inwoners in de Bataafse Republiek, verdeeld over vijfhonderd duizend huishoudens in 1800, kocht ongeveer zes procent ofwel tussen de vijfentwintig- en dertigduizend van de huishoudens met enige regelmaat lectuur. De Maatschappij tot Nut van 't Algemeen had in 1800 zevenduizend vijfhonderd leden en had dus een lid in één van iedere vijfenzestig huishoudens. De grote geleerde genootschappen drongen door tot één op ruwweg iedere tweeduizend huishoudens via een paar honderd actieve personen (Kloek en Mijnhardt 2001:129-35). Deze culturele elite, de actieve leden van de grote geleerde- of van de grote letterkundige genootschappen, de spraakmakende en schrijvende gemeente bestond uit niet meer dan enkele honderden personen. Via de genootschappen en gezelschappen, zeker via de succesvolle Nutsdepartementen en de leesgezelschappen stonden echter duizenden, als lezers, toehoorders, discussianten in contact met deze elite en legden zij samen met de overige lezers de basis voor de publieke opinie. Was het tijdens het ancien régime moeilijk voorstelbaar om aanzien te verwerven anders dan door politieke macht, rijkdom en economisch vermogen, rond 1800 kon ook een cultuurdrager tot de maatschappelijke elite doordringen (Kloek en Mijnhardt 2001:135-9).

De beschrijving van de communicatiegemeenschap, waarin genootschappen zo'n belangrijke plaats innamen, roept een vraag op met betrekking tot het onderzoek naar de geschiedenis van het Bataviaasch Genootschap. Wat van het voor de Republiek gereconstrueerde, verfijnde netwerk van boekdrukkers en -verkopers, van de breed geschakeerde productie van Spectators, culturele tijdschriften, kranten, politieke pamfletten en van de nieuwe letterkundige genres als het burgerlijk drama en de zedenkundige roman is herkenbaar in Batavia? Wat van het rijkgeschakeerde genootschapspanorama van de Republiek nam Batavia over? En wat kwam er van de nieuwe Europese ideeënwereld overgevaren? In onze schets van de cultuur-historische achtergrond van dit onderzoek is het antwoord reeds gegeven. Het luidt kortheidshalve: heel weinig. Aan de communicatiegemeenschap die Kloek 
en Mijnhardt schetsen heeft de Bataviase Europese bevolking maar op een zeer afgeleide wijze deel gehad: dat wat via de schepen aangevoerd werd aan lectuur, dat wat bepaalde personen uit de Republiek lieten overkomen, dat wat het genootschap zelf produceerde en naar de Republiek opzond. De lange heen- en terugreis namen samen al anderhalf jaar in beslag. Voor bestellingen kon men dus anderhalf tot twee jaar rekenen. De beperkte keuze aan lectuur, het ontbreken van een goed gefourneerde boekverkoper, de beperkte drukmogelijkheden, alles werkt in vergelijking met de Republiek uit in het nadeel van Batavia: ver weg, slecht bereikbaar, matig voorzien van boeken, kranten en tijdschriften, om nog maar te zwijgen van de eenzijdig samengestelde Europese bevolking die sterk aan veranderingen onderhevig was door aankomst en vertrek en door de talloos vele slachtoffers eisende malariaepidemieën in de tweede helft van de achttiende eeuw. Ook dan kunnen we het idee van die communicatiegemeenschap echter niet zo maar opzij zetten als niet van toepassing op Batavia. Uit het simpele feit van de oprichting van een Europees genootschap mogen we opmaken dat in ieder geval de initiatiefnemers de band met de Republiek en wat daar gebeurde als een belangrijk gegeven voelden. Als de Republiek werd voorzien van een scala aan genootschappen, kon Batavia dan achterblijven? Via het nieuwe genootschap kreeg men deel aan het intellectuele leven in de Republiek, wat nog versterkt werd door de later te beschrijven contacten met afzonderlijke genootschappen.

De vraag die we ons moeten stellen, wordt dan: wie waren het die Batavia opgenomen wilden zien in de reeks van Nederlandse steden waar belangrijke genootschappen gevestigd waren? Voorzagen zij de extra problemen die dit met zich meebracht? Hoe dachten zij deze op te lossen? Was er een voorgeschiedenis? Hoewel de eerste bestuursleden trots konden opmerken dat hun genootschap het eerste in zijn soort was in Azië, was het niet het eerste vorm van sociabiliteit. Batavia kende vóór 1778 al drie vrijmetselaarsloges, die Mijnhardt rekent tot vormen van de besloten dilettanten- of publiekssociabiliteit. Voor de oprichting van de eerste, La Choisie (1762/41766), had Radermacher, de oprichter van het Bataviaasch Genootschap, in 1762 het initiatief genomen, kort voor zijn vertrek naar de Republiek (Stevens 1994:55). Gedurende zijn verlof in Nederland werd hij tijdens het Grootoosten, de bijeenkomst van Nederlandse loges (1764), benoemd tot grootsecretaris. Als we in aanmerking nemen dat Radermachers vader, Johan Cornelis, lid was de eerste Nederlandse loge La Sincérité (1734) en daarna in 1735 benoemd werd tot de eerste Nederlandse grootmeester, verwondert het ons niet dat zoon Jacobus Cornelis in zijn voetstappen trad. ${ }^{34}$ Het feit

34 Over de geschiedenis van de vrijmetselarij in Nederland, vanuit het gezichtspunt van genootschapsideologie, Mijnhardt 1986: 87-108, in het bijzonder 94-6. Zie ook Mijnhardt 1988: hoofdstuk V. 
dat tijdens het Grootoosten in Den Haag van 1764 in aanwezigheid van de drieëntwintigjarige Radermacher junior de erkenning van de Bataviase loge werd besproken, ongetwijfeld toegelicht door de jonge vertegenwoordiger uit Batavia, zegt genoeg (Stevens 1994:59). Dat La Choisie al ten onderging terwijl Radermacher nog in Nederland verbleef, doet niets af aan het belang van zijn rol in de oprichting.

De tweede loge, La Fidèle Sincérité, werd in 1767 opgericht, terwijl Radermacher nog in Nederland was. In de stichtingsbrief van de derde loge, La Vertueuse (1769), werd hij niet genoemd, hoewel hij toen in Batavia terug was. Hij werd echter wel lid van deze loge en was er in 1779-1780 voorzitter van (Stevens 1994:79). We weten van Radermacher en het Bataviaasch Genootschap veel meer dan van zijn betrokkenheid bij de vrijmetselarij, vooral omdat de gegevens rond de vroege Bataviase loges zo onvolledig zijn, maar het feit dat hij bij twee van de drie loges betrokken was en zijn rol bij het Grootoosten in Den Haag ten tijde van zijn verblijf in de Republiek, maken hem tot een even belangrijke figuur in de vrijmetselarij als in het genootschap. Op de naamlijst van de leden van La Choisie, die om erkenning van de loge hadden gevraagd, komt naast Radermachers naam ook die van zijn schoonfamilie Verijssel voor. Behalve Radermacher behoorde geen van de andere oprichters bij La Choisie tot de eerste bestuursgroep van het Bataviaasch Genootschap, maar er lag dan ook zestien jaar tussen beide stichtingen. Overlappende lidmaatschappen tussen de loges en het genootschap kwamen later in ruime mate voor. Onderzoek hiernaar door J. Hageman in de negentiende eeuw en door P. van der Veur in de twintigste bracht aan het licht dat vierendertig van de genootschapsleden uit 1781, oftwel ongeveer een derde van de Bataviase leden, ook vrijmetselaar was (Stevens 1994:81). Nog niet gepubliceerd onderzoek door Zuiderweg maakt duidelijk dat in de periode 1778-1816 bijna eenderde van de genootschapsleden (honderdnegen leden van de driehonderdnegenenveertig) vrijmetselaar was. ${ }^{35}$ Dit bevestigt de getallen die Stevens (1994) op grond van oudere literatuur noemt in zijn studie naar de vrijmetselarij in Nederlands-Indië en Indonesië.

Voor ons zijn deze gegevens om twee redenen van belang. Op de eerste plaats komt de oprichting van het genootschap in een ander perspectief te staan: er was in Batavia al genootschapsactiviteit in de vorm van loges. Het feit dat Radermacher aan de wieg van beide soorten sociabiliteit heeft gestaan, stelt hem in een duidelijker licht. Hoe valt overlapping in lidmaatschappen te verklaren? Gelman Taylor (1988) heeft een poging tot interpretatie gedaan in haar studie naar de Bataviase mestiezencultuur. Zij ziet de opkomst van de loges in Batavia in het licht van een streven van bepaalde burgers om de 
overheersende Indische cultuur terug te dringen ten gunste van een zekere mate van europeanisering. Zij spreekt in dit verband zelfs over aanvallen op de Indische cultuur (Gelman Taylor 1988:115). Door lid te zijn van de loge gaf men aan dat men toch vooral tot de Europese bevolkingsgroep wilde worden gerekend en niet tezeer geïdentificeerd wilde worden met de Indische cultuur, waarvan mannen door hun huwelijk in Batavia vaak deel uitmaakten. Als we Gelman Taylors interpretatie doortrekken naar de schets van Kloek en Mijnhardt van de communicatiegemeenschap, kunnen we ook zeggen: die vrijmetselaars traden toe tot de communicatiegemeenschap van hun broeders in Nederland en maakten daardoor op afstand toch deel uit van die gemeenschap. Gelman Taylor interpreteerde in het verlengde hiervan ook de oprichting van het Bataviaasch Genootschap als een element in de strijd tegen de in Batavia dominante Indische cultuur ten gunste van een duidelijker Europese cultuur. 'Loge en Genootschap werden gevormd door migranten die de idealen van hun eigen cultuur wilden bevestigen. Het waren weloverwogen aanvallen op de mestiezencultuur van de inwoners van Batavia met Europese status' (Gelman Taylor 1988:120). Anderszins moet de overeenkomst in het ledenbestand wel worden gerelativeerd door de bijzondere situatie in Batavia: een kleine Europese gemeenschap met daarbinnen een ontwikkelde, nog kleinere bovenlaag. Het kon niet anders of in twee organisaties die elkaar niet in de weg zaten, kwamen overlappende lidmaatschappen voor. Voor de ontwikkelde bovenlaag was er niet veel keuze.

In het propageren van het Nederlands in loge en genootschap is in ieder geval een overeenkomst vast te stellen tussen de aanvallen op de Indische cultuur, zoals Gelman Taylor dat noemt, en het nadrukkelijke propageren van het gebruik van de Nederlandse taal in de dilettantengenootschappen in de Republiek, waardoor deze zich afzetten tegen het Frans en soms ook tegen de door het gebruik van het Latijn ontoegankelijke uitkomsten van de geleerdencultuur. Het is in ieder geval nuttig om te zien of er binnen het genootschap meer aanwijzingen zijn voor een zich afzetten tegen een Indische mestiezencultuur.

Tenslotte vragen wij ons af of er niet nog meer vormen van sociabiliteit werden gevonden. De achterdochtige regering in het Kasteel had kennelijk tegen de vorming van de loges geen bezwaar. Een eed van geheimhouding kon dan wel het behandelde in de loge tegen indringende blikken beschermen, het was onmogelijk en net als in de Republiek evenmin nodig om in het kleine Batavia het bestaan van de loges te verhullen. Het was de regering bekend dat de loges werden opgericht. Regeringsleden maakten er deel van uit. Is het mogelijk dat andere gezelligheidsvormen voor 1778 ons ontgaan omdat ze te informeel waren georganiseerd? Zo zijn mij alleen leesgezelschappen bekend uit de negentiende eeuw. Het lijkt niet onmogelijk dat belangstellende lezers uit de academisch gevormde stand (de predikanten 
en de juristen) al eerder voor gezamenlijke rekening boeken lieten komen om zo de kosten te drukken en lectuur in circulatie te brengen. Het lijkt zelfs onwaarschijnlijk dat dit in het achttiende-eeuwse Batavia niet gebeurde, waar in de Republiek van honderden leesgezelschappen sprake is. Zelfs het genootschap vertoonde in de eerste jaren trekken van een leesgezelschap. De eerste aanwijzingen voor zelfstandige leesgezelschappen moeten we echter nog krijgen. De Haan noemt het eerste leesgezelschap (Tot nut en inspanning) in 1833 (De Haan 1935a, I:536). Het kan goed zijn dat er eerdere voorbeelden zijn, waar we de sporen nog van moeten terugvinden.

Gezelligheid met drank was te vinden in de herbergen en logementen. Die fungeerden mogelijk ook als koffiehuis. Ze hadden ruimte voor bijeenkomsten. Zolang de vrijmetselaars geen eigen gebouw hadden, troffen zij elkaar in het Heerenlogement of het Moorse Hospitaal, zoals dat ook in Europa gebeurde. In het Heerenlogement aan de Moorsegracht werden sinds 1757 toneelvoorstellingen gegeven, in ieder geval tot 1787. Daar moet in de marge van het toneel en van de logebijeenkomsten ook wel enige gezelligheid zijn geweest (Zuiderweg 2000:137). De Haan zegt dat De Klerk in 1776 signaleerde dat Batavia een sociëteit ontbeerde. Hij zegt althans dat men 'te deezer hoofdplaatze de leevenswijs zooveel mogelijk [diende] te beschaven door het opregten van publicque zamenkomsten, die de zeeden verbeeterden en gelegenheid gaven tot gepaste huwelijken' (De Haan 1935a, I:565). Voor De Klerk ontbraken dus duidelijk gemengde samenkomsten. De sociëteit kwam uiteindelijk wel tot stand, al lopen de berichten over de oprichting uiteen van 1788 tot 1807. Het was die sociëteit, de Harmonie in de Buitennieuwpoortstraat, die Daendels naar Weltevreden wilde verplaatsen, wat uiteindelijk pas in 1815 gebeurde en zelfs toen bleef er in de oude stad nog enige tijd een oude Harmonie-sociëteit bestaan. De Haan signaleert dat de Engelsen verbaasd waren over wat ze aantroffen.

Zij stonden beduusd van deze eigenaardige samenleving, waaruit alle gezelligheid en vreugde gebannen scheen, waar noch een tooneel noch eenige andere openbare vermakelijkheid bestond en zelfs geene lokalen voor bijeenkomsten, behalve dan de Vrijmetselaarsloges (De Haan 1935a, I:565).

Dat was uiteraard in 1811, maar veel ervan moet ook voor de periode ervoor geldig zijn geweest. De Haans woorden moeten echter wel altijd getoetst worden aan andere bronnen.

Op de vrijmetselarij na was er tot 1778 geen georganiseerde, duidelijk zichtbare sociabiliteit in Batavia. Over de informele vormen van sociabiliteit hebben we geen gegevens. We mogen niet uitsluiten dat er leesgezelschappen bestonden, zoals in het vaderland. Het Bataviaasch Genootschap kwam tegemoet aan De Klerks behoefte aan beschavende samenkomsten. De Klerks schoonzoon Radermacher nam het initiatief, net als in het geval van de vrijmetselarij. 
Genootschappen: de negentiende eeuw

Tot nu toe is bijna uitsluitend gesproken over de achttiende eeuw. Tijdgenoten verwonderden zich in die eeuw al over de grote groei van het verschijnsel genootschap, zodat dat men van de eeuw der genootschappen ging spreken. Pas nu het onderzoek naar de negentiende eeuw is uitgebreid, zijn we in staat daar een correctie op aan te brengen. De negentiende eeuw was evenzeer en zelfs nog sterker een eeuw van genootschappen. Misschien hebben de staatkundige veranderingen, die tussen 1795 en 1813 in Nederland plaatsvonden, te zeer de aandacht getrokken naar wat in de negentiende eeuw nieuw was en wat afweek van het voorgaande. Genootschappen echter bleven bestaan en er vond zelfs een opmerkelijke expansie plaats. Daarvan getuigen alleen al de vele nieuwe departementen van de Maatschappij tot Nut van 't Algemeen, die al bij het tweede eeuwfeest van de Maatschappij (1984) zijn gedocumenteerd, en de honderden rederijkerskamers, die dankzij Westers' studie voor het eerst in een cultureel-maatschappelijk perspectief zijn geplaatst (Westers 2003; Mijnhardt en Wichers 1984). Zeker voor Batavia geldt dat de negentiende eeuw pas de echte groei van het verschijnsel genootschap te zien gaf. De veranderingen van na 1795 hadden in het vaderland op sociaal en maatschappelijk vlak grote gevolgen. Organisaties die geworteld waren in de achttiende eeuwse elite, ondervonden daar de weerslag van. Het Zeeuwsch Genootschap en het (Rotterdamse) Bataafse Genootschap beleefden tussen 1795 en 1813 een sterke teruggang van hun activiteiten, waarover ze later in hun correspondentie met hun Bataviase lotgenoot rapporteerden, maar ze krabbelden onder het nieuwe koninkrijk weer overeind. Het Bataviaasch Genootschap had van de onzekere tijden evenzeer te lijden. Het trad tussen 1794 en 1812 nauwelijks naar buiten. In 1812 werden onder de Britten eerst de activiteiten hernomen en na 1816 ook de contacten met Rotterdam, Middelburg en Haarlem hersteld. Dat in Haarlem de zaken minder drastisch terugliepen, was te danken aan de actieve secretaris Marinus van Marum, die ook op nationaal niveau een rol speelde.

De verandering van federatieve republiek naar eenheidsstaat betekende dat onderwijs, kunsten en wetenschapen niet meer zaken waren van lokaal of provinciaal niveau of afhankelijk waren van particulier initiatief, maar dat zij staatsaangelegenheden waren geworden. $\mathrm{Nu}$ was het de Nationale Vergadering, die zich over het hoger onderwijs en de wetenschapsbevordering boog. Johan van der Palm werd als Agent van Nationale Opvoeding in feite de eerste minister van onderwijs en wetenschappen van Nederland al heette het toen nog de Bataafse Republiek en was er nog geen apart ministerie (Mijnhardt 1997:20). Met de instelling van het Koninkrijk Holland en het aantreden van Lodewijk Napoleon als vorst kwam sterker het Franse voorbeeld van een staat met nationale instellingen naar voren. Daarbij behoorde het idee 
dat de wetenschappen op nationaal niveau dienden te worden gestimuleerd door een speciaal daartoe ingesteld instituut. Lodewijk Napoleon stelde in 1808 het Koninklijk Instituut van Wetenschappen, Letterkunde en Schoone Kunsten in, dat een leidende rol moest gaan spelen. Het koninkrijk had ineens een nationaal genootschap. Van het Instituut en van de Koninklijke Akademie van Wetenschappen, waar het Instituut in 1851 in werd getransformeerd, is tussen 1997 en 2004 de geschiedenis in een aantal publicaties vastgelegd. Daarin worden de veranderingen die de komst van het Instituut en de Akademie hebben betekend voor de wetenschapsbeoefening in Nederland behandeld. ${ }^{36}$

Weliswaar hadden de achttiende-eeuwse geleerde genootschappen hun leden gerecruteerd over de eigen provinciegrenzen heen en zo meer dan een lokale of regionale betekenis gehad, nu was er in Amsterdam een instelling waar geleerden uit het hele land konden samenkomen. Het nieuwe instituut had een adviesfunctie voor de overheid: over allerlei kwesties werden wetenschappelijk gefundeerde adviezen gevraagd. De plaats van de bekende geleerde genootschappen (Haarlem, Middelburg, Utrecht, Rotterdam) aan de top van de Nederlandse wetenschapspiramide was ineens door Amsterdam weggekaapt, al was hun rol daarmee niet meteen uitgespeeld. Het betekende echter niet dat de hooggeleerde heren die in de eerste, tweede en derde klasse van het Instituut plaatsnamen - de vierde klasse van de schone kunsten was niet voor hooggeleerden ingesteld - zich vanaf 1808 met zuiver wetenschappelijk onderzoek en theorievorming konden bezighouden. De overheid vroeg op allerlei terreinen advies en die adviezen vroegen om praktische toepassingen van wetenschap, vooral van de eerste klasse van de natuurwetenschappen (Mijnhardt 1997:27-30; Hooykaas 2000:12-3). In 1816 werd door Koning Willem I het Instituut bevestigd in zijn bestaan onder de naam Koninklijk-Nederlandsch Instituut van Wetenschappen, Letterkunde en Schoone Kunsten. De adviesfunctie bleef onder het verenigd koninkrijk gehandhaafd. In de jaren 1840 kwam onder aanvoering van J.R. Thorbecke kritiek op het functioneren van het Instituut, wat in 1851, toen hij als minister van binnenlandse zaken de verantwoordelijke bewindsman was, leidde tot de opheffing van het Instituut en de oprichting van de Koninklijke Akademie van Wetenschappen. Aanvankelijk was die alleen voor de natuurwetenschappen bedoeld, maar in 1855 kwam er een tweede klasse voor de letterkunde (inclusief geschiedenis). Voor de schone kunsten en de dichtkunst was geen plaats meer. De Akademie werd het voertuig voor professionele wetenschapsbeoefening, liefhebbers van wetenschap en kunst waren vanaf 1851 buitengesloten (Hooykaas 2000:25). Aan de universiteiten, die aan het begin van de eeuw nog steeds onderwijsinstituten waren, geen onderzoeksinstitu- 
ten, vond in de loop van de negentiende eeuw ook een verandering plaats. Daar werd de brede wetenschapsopvatting die nog uit de achttiende eeuw dateerde, langzaam ingeperkt doordat hoogleraren zich steeds meer tot een eigen vakgebied beperkten. Ook daar was van specialisering en professionalisering sprake (Van Berkel 2004:9).

De komst van het Instituut en de Akademie betekende niet dat de genootschappen uitgespeeld waren. Integendeel. In een terugblik op de negentiende eeuw in een artikel over de Akademie rond 1900 heeft Mijnhardt een analyse gepresenteerd van de veranderingen die plaatsvonden in de genootschapswereld. Hij benoemt de waargenomen veranderingen in een beweging van egalitair naar elitair (Mijnhardt 2004:17-27). Tot 1795 was er sprake van twee aparte circuits, dat van het grote geleerde genootschap waarvan de gezamenlijke geleerde leden niet meer dan een paar honderd personen omvatten, en het veel grotere circuit van de publieksgenootschappen (het Nut en de vele lokale genootschappen) met rond de tienduizend betrokken personen. In de Bataafse en Franse tijd werd de scheiding tussen deze twee circuits veel minder duidelijk. Mijnhardt spreekt van ineenvloeiing. Verantwoordelijk daarvoor was de opmars van het burgerideaal, waardoor op den duur niemand het volwaardig burgerschap en daarmee ook het lidmaatschap van genootschappen kon worden ontzegd. 'De genootschapscultuur had een egalitair vernis gekregen' (Mijnhardt 2004:18). Door deze veranderingen kwam de dilettant, de amateurliefhebber, in de genootschappen sterker naar voren, een verschijnsel dat al in de late Republiek was voorbereid. De Maatschappij tot Nut van 't Algemeen adopteerde de ideeën over de vormende waarde van kunst, wetenschap en cultuur en droeg die uit onder een veel groter publiek dan onder het selecte gezelschap dat de genootschappen van een eerdere generatie had bereikt. In genootschappen gingen leden niet meer alleen luisteren naar voordrachten, maar zelf doen: tekenen, musiceren, dichten, natuurkundige proeven nadoen. 'Vandaar was het maar een kleine stap tot het verheerlijken van de middelmaat en de afkeer van de uitzonderlijkheid' (Mijnhardt 2004:19).

Dat egalitaire beschavingsideaal leidde na 1850 tot een enorme groei binnen het genootschappelijke landschap: de Nutsdepartmenten, de rederijkerskamers, muziekverenigingen en toneelverenigingen, terwijl leesgezelschappen eveneens in grote aantallen bleven voorkomen. Bij de Nutsdepartmenten is niet van een explosieve groei sprake, maar de toename van 289 departementen in 1850 tot 343 in het topjaar 1883, is nog steeds aanzienlijk (Mijnhardt en Wichers 1984:359-60). Westers heeft met zijn studie naar de bloei van de rederijkerskamers in hun negentiende-eeuwse context vooral de relatie tussen burgerlijk beschavingsideaal en de opkomst van de rederijkerskamers zichtbaar gemaakt. Hij heeft meer dan tweehonderd van deze genootschappen kunnen identificeren, waarvan de toename het meest opvallend is tussen 1860 en 1875 (Westers 2003:49). Hoewel de eerste rederijkerskamer van 
de negentiende eeuw het uit 1833 daterende Leidse studentengezelschap 'Rederijkerskamer voor Uiterlijke Welsprekendheid' was, schrijft Westers de meeste invloed toe aan de Amsterdamse 'Kamer van 1844' en het uit 1846 daterende 'Achilles'. Deze twee kwamen voort uit onvrede met het in de hoofdstedelijke schouwburg opgevoerde toneel en zij namen als het ware het heft in eigen hand. Zij gingen zich oefenen in toneelspel en voerden ook toneelstukken op. Met name vanaf 1850 ontstonden, ook in de kleinere plaatsen, gezelschappen die zich richtten op de oefening van uiterlijke welsprekendheid. Het voordragen betrof nu niet eigen werk (zoals in de dichtgenootschappen) maar het werk van anderen. Het voordragen van dichtwerk, het houden van verhandelingen en in mindere mate het houden van lees- en schrijfoefeningen vormde de belangrijkste bezigheden op de gewone avonden van de kamers. De scholingsdoelstelling van de kamers kwam onder meer tot uiting in de betrekkelijk jonge leeftijd van de werkende leden, maar op den duur werd gezelligheid en ontspanning zeker zo belangrijk (Westers 2003:3540). Aan het eind van de negentiende eeuw, maar vooral aan het begin van de twintigste maakt de naam 'rederijkerskamer' steeds meer plaats voor die van 'toneelvereniging' (Westers 2003:51). Van het voordragen van gedichten en het houden van verhandelingen was het focus van de rederijkerskamers definitief naar het toneel verschoven.

De grote populariteit van de rederijkerskamers wil niet zeggen dat ze voor iedereen toegankelijk waren. Werkende leden kwamen aanvankelijk uit de handelselite en de hogere middengroepen. Vertegenwoordigers van de lagere middengroepen waren lang niet altijd welkom. Tot rond 1860 troffen elite en middengroepen elkaar, nadien trok de elite zich terug en werd de rederijkerskamer het domein van uitsluitend de middengroepen. Westers wijst erop dat dit gelijk oploopt met de afnemende waardering voor het begrip 'burger', in het begin van de eeuw nog een erenaam, in de tweede helft van de eeuw hoe langer hoe meer geladen met minachting (Westers 2003:243-64). Interessant daarbij is de sociale stratificatie die in de lidmaatschappen zichtbaar wordt. Onderwijzers en hulponderwijzers waren steunpilaren voor de rederijkerij, predikanten juist niet, zij voelden zich meer tot het Nut aangetrokken. Vanuit het Nut werd op de rederijkerij neergekeken (Westers 2003:273-86).

Voor Nederlands-Indië doet zich het merkwaardige verschijnsel voor dat de Maatschappij tot Nut van 't Algemeen, afgezien van het departement Soerabaija (1833), helemaal een zaak is van de jaren 1850. De overige vijf departementen zijn na 1850 ontstaan en waren in 1860 weer opgeheven (Mijnhardt en Wichers 1984:369). Over rederijkerskamers in Indië zijn we slecht ingelicht. Van Zonneveld signaleert een in 1843 door F.C. van der Meer van Kuffeler in Soerakarta opgerichte kamer, terwijl dezelfde na zijn overplaatsing naar Padang ook daar een kamer oprichtte. Van Kuffeler is interessant omdat hij tijdens zijn studieperiode in Leiden lid was van het zojuist genoemde studen- 
tengezelschap van 1833, het eerste dat zich rederijkerskamer noemde (Van Zonneveld 1992:110-3). Westers noemt de Soerakartase kamer, ouder dan de Amsterdamse 'Kamer van 1844', de eerste rederijkerskamer buiten de studentenwereld (Westers 2003:65). Overigens was Van Kuffeler tussen 1843 en 1848 lid van het Bataviaasch Genootschap. De enige traceerbare rederijkerskamer in Batavia lijkt de kamer 'Rhetorica' te zijn, die in 1861 werd opgericht. De secretaris van de Javasche Bank, H. Rochussen, lid van het genootschap, was de oprichter. ${ }^{37}$ Er is op het punt van de genootschappen in de negentiende eeuw in Nederlands-Indië nog heel wat werk te verrichten. Aan muziekverenigingen en liefhebberijtoneel was geen gebrek.

Terugkerend naar de ontwikkelingen in Nederland kunnen we de groei van het genootschapsleven in verband brengen met de toegenomen deelname aan het onderwijs. Nadat de Wet op het Lager Onderwijs (1806) vruchten afwierp, verbreedde zich nu ook de deelname aan het vervolgonderwijs. De burgerij kwam op en daarmee ging de burgerlijke cultuur van de middelmaat overheersen, maar niet blijvend. In de tweede helft van de eeuw kwam een tegenbeweging op gang, waardoor het burgerlijk beschavingsideaal werd ondergraven. Na 1870 ging de liberale elite die dat beschavingsideaal had omarmd, juist opnieuw zoeken naar culturele onderscheiding. Mijnhardt spreekt daarom in dit verband van een opkomst van een elitair ideaal. Zowel in de uitvoerende kunst en de literatuur als in de wetenschap werd gezocht naar onderscheiding, het bijzondere, het uitstekende. Daarmee werd langzamerhand een nieuw elitair model zichtbaar, al was burgercultuur rond 1900 natuurlijk niet verdwenen (Mijnhardt 2004:25-6).

Temidden van deze ontwikkelingen veranderden ook de geleerde genootschappen van karakter. Het is van belang daarbij stil te staan, omdat het Bataviaasch Genootschap zich vanaf het begin sterk vereenzelvigde met juist een drietal van deze genootschappen. Niet alleen in de sterk teruggelopen activiteiten tussen 1795 en 1815 kwamen Batavia, Middelburg en Rotterdam overeen, ook in veranderende oriëntatie liggen parallellen. Mijnhardt geeft aan dat het Zeeuwsch Genootschap door de geïsoleerde ligging, de afwezigheid van hoger onderwijs in Zeeland en door een traditie van provinciaal particularisme gedwongen werd zijn landelijke ambities op te geven en zich terug te trekken op de bevordering van provinciale geschiedenis en oudheidkunde (Mijnhardt 2004:27-8). Dezelfde factoren dwongen het Bataviaasch Genootschap om in de negentiende eeuw de breed encyclopedische begindoelstellingen van 1778 te verlaten en zich terug te trekken op de Indische taal-, land- en volkenkunde. Aspecten van dezelfde specialisering zien we

37 Perpustakaan Nasional B 342 bevat een reglement van deze kamer van 12-3-1861. Andere bestuursleden, O. de Bruijn Kops, D.J. Guykens en M.P. Pels, waren geen genootschapslid. 
in de oprichting van verenigingen van natuurkundigen en geneeskundigen in Batavia kort na 1850. Ook de Hollandsche Maatschappij specialiseerde zich steeds meer door een prominentere plaats te geven aan de natuurwetenschappen. Het had daarbij in de loop van de negentiende eeuw grote problemen om het prijsvrageninstituut tot een succes te maken. Daarin is een parallel met ontwikkelingen in Batavia zichtbaar, waar de prijsvragen alleen tot 1795 een zeker succes hadden (Visser 2002).

Naar het oordeel van Mijnhardt was overigens de Koninklijke Akademie de enige organisatie die het nieuwe elitaire en competitieve genootschapsideaal wist te realiseren. Hij zoekt een verklaring daarvoor in de nauwe relatie met de staat, waardoor de Akademie rond 1900 de centrale organisatie van de Nederlandse wetenschapsbeoefening was geworden (Mijnhardt 2004:313). Ook hier denken wij direct aan de nauwe relatie tussen het Bataviaasch Genootschap en het gouvernement, alsook aan de adviesfunctie die het genootschap voor de Indische overheid vervulde. In de financiële steun van die overheid (gebouwen, subsidie) zien we een parallel tussen Akademie en Bataviaasch Genootschap.

Voor het genootschap in Batavia zouden de andere staatkundige verhoudingen in de negentiende eeuw snel voelbaar worden. Al in 1816 kwam de door koning Willem I benoemde eerste directeur tot de zaken van landbouw, kunsten en wetenschappen op Java en naburige eilanden, de Amsterdamse hoogleraar C.G.C. Reinwardt, in Batavia aan. In diens aanvankelijk nog kleine directie zat de kiem van wat in de jaren 1860 zou uitgroeien tot het Departement van Onderwijs en Eredienst. Dat Reinwardt tot voorzitter van het genootschap werd gekozen zegt genoeg over de nauwe relatie tussen overheid en genootschap. Het feit dat hij in Amsterdam tevens directeur was geweest van 's Lands Kabinet van Natuurlijke Historie verklaart waarom het verzamelen voor Nederlandse collecties, niet meer voor collecties van bevriende genootschappen of particuliere verzamelingen zoals die van de Stadhouder in de achttiende eeuw, een wenselijkheid was geworden. Met die opdracht was Reinwardt dan ook vertrokken naar de Oost.

Nieuwe nationale instituties voor verzamelingen waren eerst door Lodewijk Napoleon geëntameerd. Hij liet Nederland bij zijn vertrek de Koninklijke Bibliotheek in Den Haag en het Koninklijk Museum (later Rijksmuseum) in Amsterdam na. Onder Koning Willem I kwamen andere musea met nationale verzamelingen tot stand, met sommige waarvan het Bataviaasch Genootschap in de negentiende eeuw te maken kreeg. Het eerste daarvan was het Koninklijk Kabinet van Zeldzaamheden (1816, Den Haag) waarin de Chinese collectie van J.Th. Royer was ondergebracht naast voorwerpen uit het bezit van het Koninklijk Huis, onder meer volkenkundige voorwerpen uit de stadhouderlijke verzameling. Dit kabinet, dat in het Mauritshuis gevestigd werd, zou in de jaren 1820 en 1830 drie grote 
Japanse verzamelingen opnemen, onder meer die van Von Siebold. In Leiden kwam in 1818 het Rijksmuseum voor Oudheden onder de hoogleraar C.J.C. Reuvens tot stand, in 1820 gevolgd door het Rijksmuseum voor Natuurlijke Historie onder C.J. Temminck. Toen voor de collectie Von Siebold, kort na de definitieve overname door de staat (1837), in Leiden een eigen gebouw werd aangekocht, werd dit het begin van het Rijks Etnografisch Museum, het huidige Rijksmuseum voor Volkenkunde. Leiden had aldus een drietal voor de wetenschapsbeoefening en het verzamelen in Nederlands-Indië belangrijke instituties opgebouwd. Overigens was de taakafbakening in het begin niet erg scherp, maar door ruilingen van deelcollecties tussen Amsterdam, Den Haag en Leiden ontstond in de loop van de negentiende eeuw meer duidelijkheid. ${ }^{38}$ Belangrijk is dat het genootschap niet meer kon volstaan met de oriëntatie op een drietal bevriende genootschappen in het vaderland. Er waren belangrijke nieuwe organisaties bijgekomen, die niet meer van particuliere fondsen afhankelijk waren, maar door de staat in het leven waren geroepen.

Daarnaast bleven ook de universiteiten belangrijke partners van het Bataviaasch Genootschap. Van de achtentwintig corresponderende leden in het vaderland, die in 1782 waren benoemd, waren er zeventien hoogleraar. Toen in 1855 de Tweede Klasse van de Akademie werd ingesteld met de benoeming van vierentwintig hoogleraren, stond de helft van hen al als corresponderend lid in Batavia genoteerd. Ook de Leidse hoogleraar Thorbecke en zijn Utrechtse tegenstander in het debat over het voortbestaan van het Instituut, de hoogleraar G.J. Mulder, waren beiden corresponderend lid van het Bataviaasch Genootschap, Thorbecke nog lang nadat hij in het vaderland zijn ongenoegen over de genootschapscultuur had geventileerd en voor zijn benoeming in de nieuwe Tweede Klasse (1855) had bedankt. ${ }^{39}$ De aansluiting van het genootschap bij de universiteiten werd in ieder geval via een selectie van belangrijke vaderlandse hoogleraren in de negentiende eeuw voortgezet. Daarnaast verzamelde het genootschap in de jaren 1820 voor verschillende hoogleraren plantkunde en hun universitaire hortus.

De ontwikkelingen die eerst vanaf 1795, en daarna onder het verenigd koninkrijk plaatsvonden op het gebied van bestuur, universiteiten, musea en instituten worden vooral zichtbaar in de wijze waarop het genootschap in Batavia zich sterk maakte voor zijn eigen positie tegenover instellingen die zich in Nederland op het zelfde werkterrein van de Indische natuur en de taal-, land en volkenkunde bewogen. In deze studie komt de aanraking tussen die instellingen herhaaldelijk ter sprake.

38 Zie voor de geschiedenis van het volkenkundig verzamelen en het Koninklijk Kabinet van Zeldzaamheden, Effert 2003. Voor de geschiedenis van de Leidse musea in relatie tot de Leidse universiteit, Otterspeer 1992.

39 Hooykaas 2000:19-23. Over de Tweede Klasse van 1855, Krul 2000:98-101. 


\section{HoOFDSTUK I}

\section{Het oprichtingsjaar en de eerste twee decennia (1778-1799)}

Op 24 april 1778 werd het Bataviaasch Genootschap van Kunsten en Wetenschappen opgericht. Over de aard van de oprichtingsbijeenkomst zijn we echter slecht ingelicht. Er is geen verslag van overgeleverd, er bestaat geen stichtingsdocument, maar over de datum bestaat geen twijfel. Op 5 oktober 1778, tijdens de vierde bestuursvergadering sinds 1 juni van dat jaar, werd besloten een stempel voor de genootschapspenning te laten maken bij de Amsterdamse penningmaker J.G. Holtzhey, waarmee dan in Batavia gouden en zilveren medailles konden worden geslagen. In het ontwerp voor het stempel werd de oprichtingsdatum meegenomen:

Aan d'eene kant: Een Cocosboom waaraan het Bataviasche wapen hangt en Een Lanschap in het verschiet met het omschrift Bataviaasch Genoodschap opgerigt den 24 April 1778. Aan d'andere kant: Mercurius met de Zee in het verschiet en het omschrift; Ten nutte van het gemeen. ${ }^{1}$

Verder werd er aan de oprichting tijdens de bestuursvergaderingen van het eerste jaar niet gerefereerd. In 1778 kwam de oprichtingsdatum velen onder ogen toen het Programma werd gedrukt en gedistribueerd (Programma 1778: titelpagina, 3, 10). Een jaar later schreef secretaris Josua van Iperen, de editeur van het eerste deel van de Verhandelingen, er in het 'Voorberigt' over:

Op den 24 april 1778 kreeg het Genootschap eenigszins zijn volkomen beslag, door de inteekening van den hoogedelen Heer Gouverneur Generaal en van alle de leden der Hooge Regering, te Batavia aanwezig, als directeuren, en van eene menigte der aanzienlijkste heeren en beambten dezer hoofdstad, als leden (VBG $1: 8)$.

1 ANRI KBG Dir 0001, 21. Exemplaren van de penning onder andere in het Nationaal Museum (Jakarta), het Rijkspenningenkabinet (Leiden) en Teylers Museum (Haarlem). Afbeelding in Treasures 1997:155. Zie ook Catalogus gedenkpenningen 1903-6; Van der Meer 1978, 1983. 


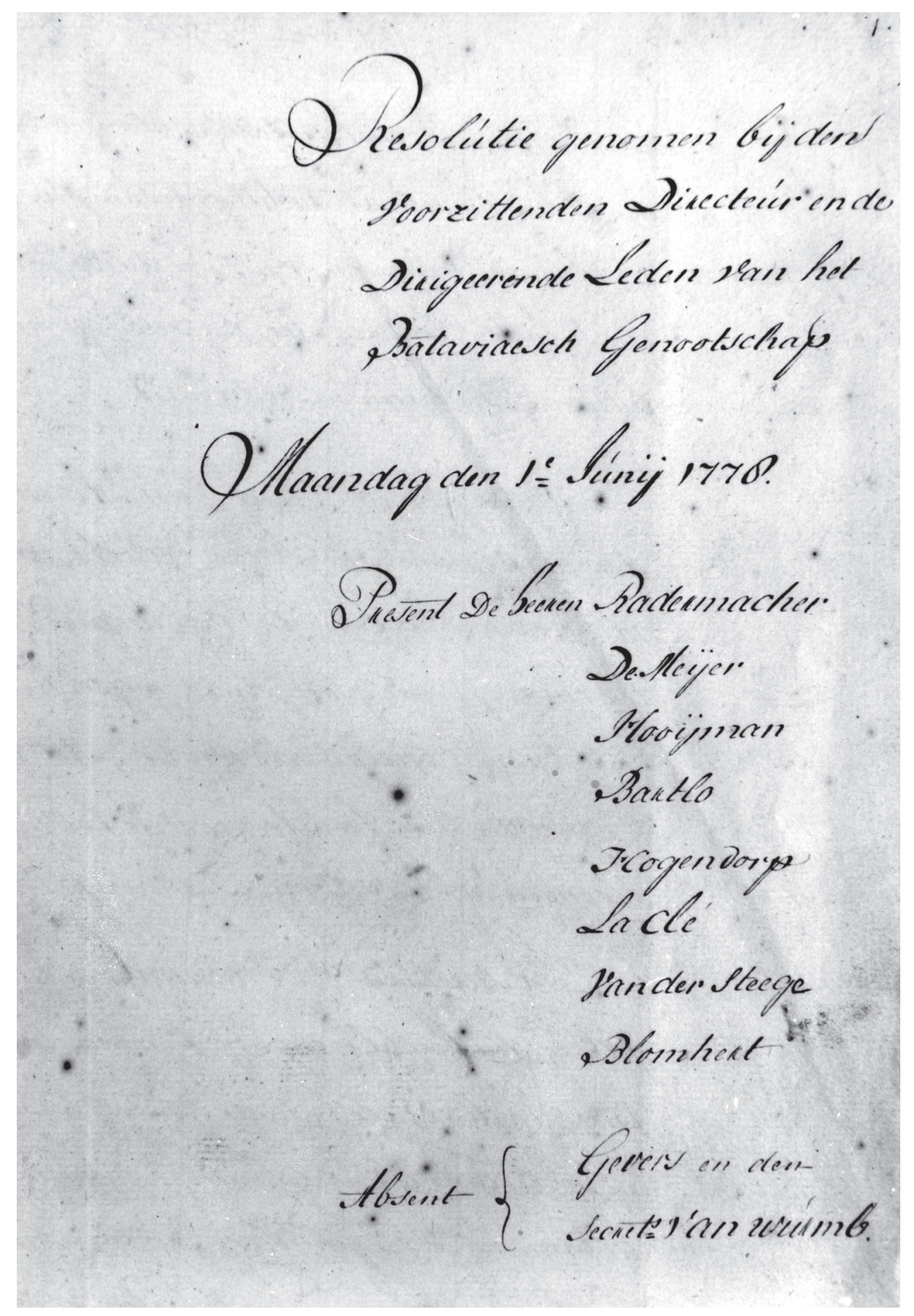

Openingsblad van de notulen van de eerste bestuursvergadering, 1 juni 1778 (collectie ANRI Jakarta, KBG Dir 0001) 
De combinatie van de woorden 'eenigszins' en 'volkomen' doet twijfel rijzen. Het woord 'inteekening' wijst erop dat er op die dag een vergadering plaatsvond van de Hoge Regering, de oprichters en een groep leden waarbij de aanwezigen hun naam zetten onder een document of op een ledenlijst. Een dergelijk document is echter niet overgeleverd. J.C.M. Radermacher zelf liet zich in zijn toespraak tijdens de eerste algemene vergadering niet erg duidelijk uit over 24 april 1778, 'wanneer wij de eerste grondbeginselen tot stichting lagen'. Het vervolg van Radermachers woorden suggereert echter eerder dat de instemming van de regering in Batavia niet op dezelfde dag plaatsvond:

sedert den 24sten april van het verloopen jaar behaagde het U Hoog-Edelheden, niet alleen aan onze spits voor te gaan; maar ook, na dat onze instelling, door U als onze overheid, den 30sten juni daarop, was bevestigd, te bevelen, dat een iegelijk, zonder onderscheid, onze ondernemingen mogt begunstigen (VBG 1:45-6).

Ik concludeer dat op 24 april 1778 door de Hoge Regering met het initiatief werd ingestemd en dat de gouverneur-generaal en de leden van de Raad van Nederlands-Indië ermee akkoord gingen dat zij als directeuren een rol in de nieuwe organisatie zouden gaan spelen. Daarmee was voor de oprichters het genootschap een feit. Het kreeg een structuur die leek op die van de geleerde genootschappen in de Republiek.

De formele instemming van de Hoge Regering kwam op 30 juni van dat jaar, toen het concept voor het eerste Programma aan haar was voorgelegd en werd besloten 'aan een zo edel en lofwaardig voornemen de hulpzame hand te bieden, [en] de bestuurders van dat genootschap te authoriseren tot het aangaan van zodanig een sociëteit, onder de zinspreuk: Ten nutte van het gemeen' (Van der Chijs 1885-1900, X:269). In het plakkaat van 30 juni wordt de datum van 24 april niet genoemd. Tussen 24 april en 30 juni zal tussen oprichters aan de ene kant en de leden van de regering aan de andere over de zaak zijn gesproken. De plannen voor het nieuwe genootschap konden door de voorzichtige regering pas worden goedgekeurd nadat die, in de vorm van het concept-programma, door alle leden van de regering waren 'rondgelezen'. ${ }^{2}$ Het 'volkomen beslag' in de woorden van Van Iperen, lijkt daarom eerder gekoppeld te moeten worden aan de datum van 30 juni $1778 .^{3}$ Na die 30e juni kon het genootschap immers naar buiten treden. ${ }^{4}$ Hoewel we

2 Van der Chijs 1885-1900, X:269. De formulering van de resolutie van 30 juni 1778 luidt dat het 'schriftuur', het concept-programma, door de gouverneur-generaal was 'binnen gebragt' en door de leden van de regering was 'rond gelezen'.

3 Van Iperen kwam pas in februari 1779 in Batavia aan en had de gebeurtenissen van 1778 dus alleen van horen zeggen. Vandaar dat enige voorzichtigheid met zijn woorden geboden is.

$4 \quad$ Het is veelzeggend dat het verslag van de eerste bestuursvergadering van 1-6-1778 pas na 3-8-1778 is genoteerd. Op die dag werd besloten de resolutiën in een boek te noteren (ANRI KBG Dir 0001,17, vergadering 3-8-1778). 
dus van het gebeuren op de oprichtingsdag weinig of niets weten, is er rond die oprichting veel te vertellen: over de oprichters, over het initiatief van een genootschap in de hoofdplaats van Nederlands-Indië, over de doelstellingen van het genootschap en zijn activiteiten in de eerste jaren.

\section{Bestuur: Radermacher, de initiatiefnemer}

De eer van de oprichting is vanaf het begin gegaan naar Jacobus Cornelis Mattheus Radermacher (1741-1783), ten tijde van de oprichting raad extraordinair van Nederlands-Indië en via zijn vrouw gerelateerd aan de toenmalige gouverneur-generaal, Reinier de Klerk (Zuiderweg 1991:161-77; Der Kinderen 1878:bijlagen, 73-77). Radermacher had een belangrijke positie in het ambtelijk apparaat van Batavia en had die positie door zijn relaties in de Republiek en door zijn huwelijk weten te vestigen.

Zijn vader was Johan Cornelis Radermacher (1700-1748), die functies vervulde aan het hof van de Oranjes, als rentmeester-generaal en thesauriergeneraal, en die in 1735 de eerste grootmeester was geweest van de Grootloge der Vrijmetselaars in Den Haag. De jonge Radermacher verloor zijn vader al in 1748 waarna hij onder de hoede werd genomen van zijn oom Samuel. Deze was burgemeester van Middelburg en bewindhebber van de VOC, posities waarin hij door zijn zoon Daniël werd opgevolgd. Jacobus' oudste broer, Johan Cornelis, volgde de voetsporen van zijn vader in dienst van de Oranjes. Dat Jacobus eind 1757 als zestienjarige in de rang van onderkoopman vanuit Zeeland naar Indië kon vertrekken, was zeker aan zijn familie te danken (Stevens 1994:27, 32, 55; Levenschets 1855:338-9). Hij kwam in Batavia snel vooruit: tweede administrateur in de Grote Winkel (1758), tweede administrateur in het Graanpakhuis (1759), koopman in 1761, opperkoopman in 1762, toen nog maar net 21 jaar oud (De Haan 1910-12, I:124-6). Hij trouwde in 1761 met een dochter van de al overleden raad van Nederlands-Indië Hugo Verijssel, Margaretha Sophia, geboortig uit een vooraanstaande familie. Margaretha's moeder, geboren Sophia Westpalm, was na Verijssels dood in 1754 gehuwd met De Klerk, toen nog raad extra-ordinair (Gelman Taylor 1988:121-2). Zo huwde Jacobus een erfdochter wier stiefvader in de raad zat.

Waarom Radermacher na minder dan vijf jaar in Indië te zijn geweest in 1763 al naar de Republiek terugreisde, in plaats van in Batavia verder te werken aan zijn carrière, is onduidelijk. De Haan suggereert dat hij als opperkoopman, met de erbij komende functies, zich zo'n vroege thuisreis - hij was 22 - kon permitteren (De Haan 1910-12, I:125). Misschien hoopte hij juist in de Republiek sneller en verder vooruit te komen. Uit het jaar van zijn vertrek dateert een voorstel tot herstructurering van de Compagnie Bedenkingen over den tegenwoordigen staat der Nederlandsche Oost Indische Maatschappij in Indië, 
waarin hij personeelsbezuinigingen voorstelt en het nut of onnut schetst van de verschillende kantoren in Azië (Steur 1984:66-7). Het feit dat Radermacher in 1766 zijn Bedenkingen aanbood aan de Amsterdamse bewindhebber Thomas Hope, maakt het aannemelijk dat hij voor zichzelf een beleidsfunctie in het bedrijf in gedachten had. Veel succes had hij niet met zijn sollicitatie, want in 1766 scheepte hij zich met vrouw en twee in Nederland geboren zoontjes op eigen kosten in, om naar Indië terug te gaan. Hij had dus geen benoeming op zak. Dat was op zijn minst opvallend. Zijn fortuin moet al aanzienlijk zijn geweest.

De ruim tweeënhalf jaar die het gezin Radermacher in Nederland had doorgebracht, werden goed besteed. Jacobus, die ongetwijfeld als jongen uit een goed milieu de Latijnse School had bezocht, zag zijn relaties met Zeeland bevestigd door een benoeming tot pensionaris-honorair in Vlissingen (1764), promoveerde in 1766 in Harderwijk in de rechten en legde direct daarop de eed als advocaat af in Arnhem. Waarom koos hij voor Harderwijk en niet voor het prestigieuze Leiden ${ }^{5}$ Aan de Gelderse universiteit kon hij op een snelle wijze een academische titel behalen. In Leiden zouden er hogere eisen aan hem zijn gesteld. Op zijn promotie volgden enkele pogingen om naar Batavia terug te keren in zijn oude rang (Zuiderweg 1991:162-3). In 1764 was hij bij de bijeenkomst van de Nederlandse vrijmetselaarsloges in Den Haag tot grootsecretaris benoemd. Bij diezelfde bijeenkomst werd de status van de door hem in Batavia opgerichte loge La Choisie (1762) besproken. Radermacher was zijn vader gevolgd in diens betrokkenheid bij de vrijmetselarij. Het blijft de vraag of Radermacher in 1763 zijn vertrek naar de Republiek zag als definitief. Was de terugkeer naar Batavia zijn tweede optie? Feit is dat zijn voorgenomen terugkeer in 1766 eerst op tegenstand stuitte, al zijn de omstandigheden niet duidelijk (Zuiderweg 1991:163).

Eenmaal terug in Batavia vond hij direct emplooi: onderschepen (1767), schepen (1768), baljuw (1768). In deze stedelijke functie was hij verantwoordelijk voor de rust en orde in de stad Batavia, zozeer tot tevredenheid van de bewindhebbers in patria, dat die hem uiteindelijk in 1775 tot raad extra-ordinair benoemden. In mei 1776 werd hij als zodanig bevestigd (Der Kinderen 1878:bijlagen, 85). Toen de stiefvader van zijn vrouw, De Klerk, directeur-generaal werd (1775) en later gouverneur-generaal (1777), was zijn uitgangspositie verder verbeterd. Na de dood van zijn vrouw in 1781 hertrouwde Radermacher met de dertienjarige Anna Jacoba Bosch, wier moeder, Catharina Maria Gallas, de derde vrouw was van Radermachers mede-raadslid, David Joan Smith, een van de vermogendste mannen in de

$5 \quad$ Nagtglas 1890, I:460, zegt dat Radermacher in Leiden studeerde, maar hij verwart Jacobus met een van zijn broers. Nagtglas slaat ook het hele eerste verblijf van Radermacher in Batavia over en laat hem pas in 1767 vertrekken. 
raad. Radermacher had een goede hand van kiezen van invloedrijke en vermogende schoonvaders (De Haan 1910-12, I:61-5).

Hij wilde echter meer. In oktober 1777 stuurde hij met de retourvloot aan de Stadhouder, naast een verslag over het gebeurde in Oost-Indië in de jaren 1776-1777, een aparte brief waarin hij de opperbewindhebber vroeg om in het geval hem het ambt van president van de Raad van Justitie zou worden toevertrouwd, daar de benoeming tot raad ordinair aan te verbinden. ${ }^{6}$ Tezelfdertijd meldde hij, dat hij 'zeer gekwelt [was] met het Podagra' (jicht). Hij haakte naar een positie bij de rechterlijke macht. Ondertussen moest hij het doen met de functie van president van schepenen (1777) en werd hij kolonel van de burgerij. Het verzoek om promotie tot raad ordinair herhaalde hij nog eens in oktober 1780, heel concreet met de vraag of hij op de plaats van de overleden raad ordinair Johannes Craan kon worden benoemd. Zoals gebruikelijk onderstreepte Radermacher zijn hoogachting voor de Stadhouder door voorwerpen mee te sturen voor diens kabinet. In 1777 gingen er eenenzeventig munten mee, een kaart van Java, een tekening van de begrafenis van de kapitein der Chinezen, en enkele Japanse voorwerpen, zoals kopererts, een kaart van Edo (Tokio) en twee Japanse vissenboeken. In 1778 volgden een Makassaars harnas en een kaartspel, een kistje met Ambonese vlinders en wandelende bladen. ${ }^{7}$ Hij droeg zo bij aan de uitbouw van het door Aernout Vosmaer beheerde en rijk voorziene stadhouderlijke kabinet. De benoeming tot raad ordinair kwam voor Radermacher in 1781, maar dat nieuws bereikte Batavia, ten gevolge van de oorlog die tussen de Republiek en Engeland was uitgebroken, pas in 1783 (Der Kinderen 1878:77). Een bedankbrief aan de Stadhouder voor de benoeming dateert van 30 juni 1783. Nog voor het einde van het jaar verliet hij opnieuw Batavia, dit maal voorgoed. ${ }^{8}$ Radermacher voerde in zijn rekest aan de Hoge Regering het motief aan voor zijn ontslag: zijn gezondheid was sterk achteruitgegaan. In patria hoopte hij te herstellen. Hij vertrok als vice-admiraal van de retourvloot op 17 november $1783 .{ }^{9}$

Ten tijde van de oprichting van het genootschap was Radermacher presi-

6 Twee brieven van Radermacher aan de Stadhouder, beide van 15-10-1777 in Koninklijk Huisarchief, Archief Stadhouder Willem V, 331-21, nr 1 en 2. Nr 1 met een Kort detail over het in Indië voorgevallene tot eind augustus 1777.

7 Twee brieven van Radermacher aan de Stadhouder, van 15-10-1780 en 25-10-1780 in Koninklijk Huisarchief, Archief Stadhouder Willem V, 331-21, nr 5 en 6. De geschonken voorwerpen worden vermeld in nr 1 en 3 uit dezelfde bundel.

8 Bedankbrief aan de Stadhouder, 30-6-1783, Koninklijk Huisarchief, Archief Stadhouder Willem V, 331-21, nr 8.

9 De Haan 1910-12, I:125-6, vermeldt dat rond dit nogal plotselinge vertrek de schijn hangt van betrokkenheid bij het in de Grote Kas opgetreden tekort van één miljoen, waardoor directeur-generaal Hendrik Breton zijn baan verloor. Van der Tempel 1980:136, meldt dat De Haan geen bewijzen geeft voor deze suggestie. 
dent van het college van schepenen, voorzitter van de curatoren en schoolopzieners over de stadsscholen (een onderwijscommissie), kolonel van de Bataviasche burgerij en commissaris over de Bataviasche Bovenlanden. Deze laatste functie gaf hij in 1780 weer op, waarna hij Commissaris van de Fortificatiën werd. Hij was een van de drie leden van de regering met een universitaire titel, ${ }^{10}$ al is in het geval van Radermacher de studietijd aan de Harderwijkse hogeschool nihil geweest: hij schreef zich in en promoveerde.

Afkomstig uit een regentenfamilie, invloedrijk, ambitieus, vermogend, actief in de vrijmetselarij, behoorde Radermacher na zijn benoeming tot raad extra-ordinair tot de bestuurlijke top van Batavia. Hij was geïnteresseerd in de wetenschap, had in Batavia een bibliotheek en verzamelde natuurkundige instrumenten. Ook verzamelde hij zeldzaamheden, rariteiten in het achttiende-eeuwse spraakgebruik, zoals Javaanse muziekinstrumenten. Voor Radermacher behoorden de contacten met genootschappen tot de zaken die bij zijn stand hoorden, die aansloten bij zijn interesse en die tot statusverhoging leidden. Neef Daniël Radermacher, Jacobus' zaakwaarnemer in Zeeland, was een van de eerste directeuren van het Zeeuwsch Genootschap der Wetenschappen. ${ }^{11}$ Hij werd in 1771 tevens directeur van de Hollandsche Maatschappij der Wetenschappen, het oudste van de groep gerenommeerde, op bevordering van de wetenschap in de Republiek gerichte genootschappen. ${ }^{12}$ Daniël behoorde tot de bestuurlijke top van de provincie Zeeland. Hij was actief in het genootschapsleven in de Republiek. Jacobus Radermacher zelf beoogde tot de groep van invloedrijke regenten-directeuren van die genootschappen toe te treden, in het voetspoor van neef Daniël en anderen. Het eervolle Haarlemse directeurschap werd echter pas in 1777 werkelijkheid, toen hij raad extra-ordinair was. Voor zo'n directeurschap waren vooral maatschappelijk aanzien en vermogen van belang. Radermacher, weliswaar amateur-naturalist, hoorde op grond van afkomst, invloed en vermogen vooral in de directeurscategorie thuis, eerder dan onder de leden. In 1777 werd hij directeur in Haarlem, in 1778 ook in Vlissingen, in 1779 lid-correspondent in Rotterdam.

Het is duidelijk waarom Radermacher op Haarlem mikte: het was het genootschap met het meeste aanzien. In de Maatschappij te Haarlem binnenkomen was voor hem moeilijker dan in Zeeland, waar familieleden hem konden steunen. Met een positie in Haarlem kon hij ook zijn academische status wat oppoetsen. In de oprichtingsfase en in de eerste jaren na 1778 zou de relatie tot Haarlem voor het aanzien van het genootschap in Batavia van groot

\footnotetext{
10 De anderen waren Willem Arnold Alting en Thomas Schippers, beiden eveneens jurist.

11 Mijnhardt 1988:188-9; Levenschets 1855:338; Nagtglas 1890, I:460-1.

12 Daniël Radermacher trad pas in 1780 toe tot het Rotterdamse genootschap, neef Jacobus al een jaar eerder.
} 
belang blijken. De relatie tussen de genootschappen van Haarlem en Batavia betekende vooral dat Haarlemse respectabiliteit op Batavia afstraalde. Dat gold ook voor Radermacher persoonlijk.

Relaties met andere genootschappen: Haarlem en Batavia

De Haarlemse elite die in 1752 tot de oprichting van de Hollandsche Maatschappij der Wetenschappen besloot, had zich gespiegeld aan de grote, gerespecteerde academies in Parijs en Londen. Zij had het tijd gevonden dat ook de Republiek voor de bevordering van de wetenschap zo'n organisatie kreeg. Begonnen met een kleine groep van Haarlemse directeuren, de financiers van de activiteiten, breidde de groep zich snel uit buiten de stad en buiten de provincie. De leden van de maatschappij waren wetenschappers van aanzien, die geen contributie hoefden te betalen, maar wel wetenschappelijke bijdragen geacht werden in te zenden. De jonge Prins van Oranje, de latere Stadhouder Willem V werd tot directeur-beschermheer benoemd. Daarna vroeg de maatschappij octrooi aan bij de Staten van Holland in de hoop daarmee het alleenrecht te kunnen claimen, maar daar staken de andere Hollandse steden een stokje voor. Het octrooi kwam er wel (1761), maar hield alleen een erkenning van de Maatschappij in, geen monopolie (Bierens de Haan 1970:34-5). Vorstelijke protectie en erkenning door de natie was een patroon dat in Parijs en Londen voor de academies was ontstaan, maar dat in feite al tot de Italiaanse renaissance terugging. Haarlem volgde het patroon van de grote zusters in de Franse en Engelse hoofdsteden. In het jaar van de octrooiverlening waren er al directeuren uit verschillende andere provincies, waren er al tien prijsvragen uitgeschreven, waarvan vijf bekroond, en waren de eerste delen Verhandelingen uitgegeven. De leden, hoogleraren aan universiteiten maar ook zelfstandig werkende geleerden en amateurs, die meedongen naar de prijzen van de Maatschappij, moesten zorgen voor de reputatie. De uitslagen van de prijsvragen, in de Verhandelingen gepubliceerd, bevestigden die reputatie. De leden kwamen uit de hele Republiek en vanaf 1758 ook uit het buitenland. Aanvankelijk waren de buitenlandse leden Nederlanders die buitengaats verbleven, in de jaren 1760 kwamen er steeds meer 'echte' buitenlandse leden bij. ${ }^{13}$ De Haarlemse Maatschappij wist zich gevestigd en het feit dat in 2002 het tweehonderdvijftigjarig bestaan herdacht werd van deze levende en actieve organisatie bewijst dat het initiatief van de Haarlemse burgemeesters en vroedschapleden in 1752 uitermate levensvatbaar was.

13 Bierens de Haan 1970: bijlage VII, voor overzichten van directeuren, binnenlandse en buitenlandse leden. 
In 1769 volgden in Vlissingen het Zeeuwsch Genootschap der Wetenschappen, in Rotterdam het Bataafsch Genootschap der Proefondervindelijke Wijsbegeerte, en in 1778 in Utrecht het Provinciale Utrechtsche Genootschap van Konsten en Wetenschappen. Deze drie spiegelden zich op hun beurt weer aan de Haarlemmers, die zich tegen de vestiging in Rotterdam van wat zij zagen als een concurrent, tevergeefs te weer stelden. De Zeeuwse, Hollandse en Utrechtse Staten erkenden de nieuwe organisaties en Willem V aanvaardde ook bij hen het beschermheerschap. Het patroon van Haarlem: wetenschapsbevordering door geleerden onder de bescherming van de rijke elite, werd door de andere geleerde genootschappen gevolgd. In de praktijk kwam het neer op het uitschrijven van prijsvragen waarmee geld of gouden en zilveren medailles konden worden verdiend, waarna de bekroonde inzendingen werden gepubliceerd. De genootschapsbesturen ambieerden over de grenzen van de provincie heen te werken en recruteerden dus leden in de Republiek en daarbuiten. Dit in tegenstelling tot de meer lokale genootschappen, waarvan de ambities minder hoog reikten (Kloek en Mijnhardt 2001:103-26).

De band met Batavia was er in Haarlem niet vanaf het begin, maar dat is niet verwonderlijk, omdat in de eerste jaren Haarlem en Holland domineerden. De amateur-astroloog en predikant Johan Maurits Mohr was in 1763 als eerste Indische lid tot de rangen van de Haarlemse leden verkozen. Gouverneur-generaal Petrus van der Parra was in 1768 de eerste Bataviase directeur in Haarlem. Op hen volgden als lid de arts S.C. Kriel (Batavia 1765) en als directeuren Johannes Bacheracht (Bengalen 1770) en Iman Falck (Ceylon 1774). Mohr en Kriel hadden zich onderscheiden door astronomische en weerkundige waarnemingen naar Haarlem te zenden. Van der Parra dankte zijn uitverkiezing aan het hoge ambt dat hij bekleedde. Bacheracht en Falck hadden zich als vermogende bevorderaars van de wetenschap doen kennen. Voor Radermacher kwam pas toen hij raad extra-ordinair was het Haarlemse directeurschap binnen bereik. De directeuren hielden hun gelederen gesloten voor wie maatschappelijk nog niet voldoende gevestigd was.

Met de inzending van naturalia voor het bijna toevallig ontstane Naturaliënkabinet van de Maatschappij - het was niet de bedoeling van de oprichters geweest een kabinet of museum te stichten - werd de band met de koloniën verder aangehaald. Toen er eenmaal zoiets als een kabinet was, konden meer voorwerpen uit de koloniën niet uitblijven. Een collectie van meer dan dertien duizend schelpen, afkomstig van de overleden gouverneurgeneraal Mossel (1762), zendingen van de directeuren Bacheracht (1770) en Falck (1773) uit Bengalen en Ceylon vonden hun weg naar Haarlem (Bierens de Haan 1970:246-67; Sliggers en Besselink 2002:83-100, 130-42). Een prijsvraag over de verspreiding van het evangelie in de koloniën, bekroond in 1775, haalde de band met de vaderlanders overzee verder aan, want dit 
onderwerp ging de godvruchtige gouverneurs en directeuren in de VOCvestigingen direct aan.

De band van Haarlem met Batavia werd in 1777, bij gelegenheid van het vijfentwintigjarig bestaan van de Maatschappij nauwer aangehaald. Van de negen nieuwe directeuren die in dat jaar werden benoemd, waren er vier in Indië werkzaam: gouverneur-generaal Jeremias van Riemsdijk, directeur-generaal Reinier de Klerk, Jacobus Radermacher en de directeur van Bengalen, Johannes Ross. De plotselinge verruiming van het aantal directeuren in de koloniën stond in verband met een ontwikkeling, die in 1777 zijn beslag kreeg in Haarlem, te weten de oprichting van de Oeconomische Tak van de Hollandsche Maatschappij (Bierens de Haan 1970:160-76). Deze afdeling van de Maatschappij was voortgekomen uit een Haarlemse prijsvraag uit 1771 naar de oorzaken van het verval van de Hollandse koophandel en naar de mogelijkheden tot verbetering. Die was in 1774 gewonnen door Hendrik van den Heuvel, griffier bij het hof van justitie in Utrecht. Hij stelde voor om de Hollandsche Maatschappij te hervormen naar het voorbeeld van Britse Society for the Encouragement of Arts, Manufactures and Commerce en haar zo als een meer effectief instrument in te zetten. Van den Heuvel werkte dat voorstel uit, maar het vond in de ogen van zijn mede-directeuren geen genade. In plaats daarvan werd tot het inrichten van een aparte tak van de Maatschappij besloten 'om, door het belooven en geeven van prijzen, den Koophandel, den Land- en Akkerbouw, Fabrycken [industrie], Visscherijen, enz.enz. in ons lieve Vaderland en de Colonien van den Staat aan te moedigen' (Bierens de Haan 1970:166). De Oeconomische Tak bleef onder de directie staan van de Hollandsche Maatschappij, maar schreef eigen prijsvragen uit. De Tak bleek een onmiddellijk succes: bij de eerste jaarvergadering waren van de meer dan 2500 leden, verdeeld over 57 departementen, 85 gedeputeerden in Haarlem aanwezig. Ook in West-Indië constitueerden zich departementen (Bierens de Haan 1952:10-1).

De Maatschappij had de plannen voor de oprichting van de nieuwe afdeling een zeer ruime verspreiding gegeven. Ook de directeuren Falck op Ceylon en de vier nieuwe directeuren in Batavia en in Bengalen ontvingen de informatie over de Oeconomische Tak met de suggestie om zich bij de beweging in het vaderland aan te sluiten. In de loop van 1778 kwam die informatie in Batavia aan. Van Riemsdijk was intussen overleden en zijn plaats was ingenomen door De Klerk. De laatste schreef op 15 oktober 1778 aan de secretaris van de Haarlemse Maatschappij, C.C.H. van der Aa, dat hij vijf brieven had ontvangen, die tussen 22 mei en 5 december 1777 uit Haarlem waren verstuurd, onder meer over zijn uitverkiezing tot directeur en de oprichting van de Tak. Hij zou 'alles contribueeren, wat tot berijking der gewenschte oogmerken nodig en dienstig [was]; - Zijnde alhier reeds een genoodschap opgeregt, daar ik mijn behuwd schoonzoon Radermacher, als 
meede Directeur de directie van heb opgedragen.' ${ }^{14}$ Met dezelfde retourvloot stuurde Radermacher eveneens een brief naar Van der Aa om te bedanken voor het vererende directeurschap van Haarlem. In zijn brief ging hij explicieter in op de brieven uit Haarlem en de oprichting van het Bataviaasch Genootschap:

UwelEd. brief van den 9e July 1777 over het opregten van een Oeconomische Tak der Maatschappij heeft hier een menigte van gegoede ingesetenen doen besluiten een genoodschap op te regten dan dewijl ik d'eer hebbe UwelEd. als Directeur van 't zelve hier nader over te schrijven, zo voege ik hier alleen bij mijn vriendelijk versoek dat het de Hollandsche Maatschappij moge behagen eenige van onse leeden tot de haere te verkiesen. ${ }^{15}$

Radermacher stelde vervolgens voor om Willem Alting, de nieuwe directeur-generaal, en Johannes Craan, raad extra-ordinair, tot directeuren te benoemen en de Lutherse predikant en medebestuurslid Johannes Hooijman en de onderkoopman, tevens secretaris van het Bataviaasch Genootschap, Frederik baron Von Wurmb tot lid. Deze voorstellen van Radermacher werden meteen geaccepteerd. De uitbreiding vond in 1779 plaats.

De formuleringen van De Klerk en Radermacher lieten nog in het vage hoe de relatie tussen het nieuwe Bataviaasche Genootschap en de Oeconomische Tak van Haarlem zou zijn. De oprichting werd in hun brieven aan het Haarlemse initiatief gekoppeld, daarmee de Haarlemmers de eer gevend die hun toekwam. In het Programma van 1778, dat opgesteld was in mei en in augustus in twaalfhonderdvoud werd verspreid, werd eveneens het oprichten van de Oeconomische Tak vermeld als een factor die de Bataviasche ingezetenen aan het werk had gezet, maar tegelijkertijd werd de volledige onafhankelijkheid van de nieuwe organisatie onder woorden gebracht: 'in een veel uitgestrekter ontwerp [dan dat van de Oeconomische Tak] en onäfhanglyk van eenig ander Genootschap' (Programma 1778:5). In het Voorberigt tot deel 1 van de Verhandelingen (1779) noemt het Genootschap zich 'om zoo te spreken, eene dochter van de Hollandsche Maatschappij der Wetenschappen' (VBG 1:5). Deze formulering was afkomstig van de Bataviase secretaris Josua van Iperen, die nog niet in Batavia was ten tijde van de oprichting en bij het opstellen van het eerste programma. In een latere brief, in januari 1780, kort voor Van Iperens onverwachte dood, schreef deze nog eens in een brief aan zijn Haarlemse collega-secretaris Van der Aa:

14 R. de Klerk aan C. van der Aa, Batavia 15-10-1778. RANH HMW 53 (correspondentie 1778).

15 J. Radermacher aan C. van der Aa, Batavia 15-10-1778. RANH HMW 53 (correspondentie 1778). 
Deze dient tot geen ander einde, dan aan UWEdw. mitsgaders de Heeren Directeuren en Leden der Hollandsche Maatschappij, op nieuw van mijne bijzondere hoogachtinge, en die van ons Bataviasch Genootschap te verzekeren. Wij hebben ons Genootschap, met volle recht, aangemerkt als de Dochter van de Hollandsche Maatschappij, en niets zal ons meer eere en playsier doen, dan dat wij derzelver moederlijke liefde, trouwe en bescherminge mogen ondervinden, haar ten dienste staan en gehoorzamen mogen. ${ }^{16}$

De diplomatieke woorden van Van Iperen wijken nogal af van de volslagen onafhankelijkheid die de oprichters in het programma van 1778 hadden geclaimd. Juist omdat we zo slecht zijn geïnformeerd over de periode voorafgaande aan 1 juni 1778, waarin de Haarlemse brieven arriveerden, besproken werden en waarin uiteindelijk het besluit viel geen departement van de Oeconomische Tak te vormen, kunnen we alleen maar concluderen, dat het idee van een departement wel heeft gecirculeerd, maar dat uiteindelijk de zelfstandigheid de voorkeur had. Vond Batavia zich te belangrijk dan dat het zich aan Haarlem ondergeschikt zou maken? Een eigen genootschap maakte zowel Batavia als de oprichters zelf respectabeler. Was Radermacher of De Klerk bang dat nauwe aansluiting bij Haarlem in Amsterdam niet goed zou vallen? Overigens zou de band met Haarlem hartelijk zijn en blijven. Dat blijkt onder andere uit de herhaalde geldzendingen naar de Spaarnestad, waarmee de directeuren van Haarlem speciale 'Bataviase' prijsvragen konden uitschrijven, en verder uit het over en weer benoemen van directeuren en leden. ${ }^{17}$ Exclusief was deze relatie overigens niet. Vlissingen en Rotterdam ontvingen dezelfde bedragen voor prijsvragen uit naam van Batavia. Ook daar werden Bataviase leden en directeuren benoemd.

\section{Bestuur: Radermacher en de zijnen}

Dat Jacobus Radermacher een opmerkelijk man was door aan de wieg te staan van zowel de eerste loge in Batavia als van het Bataviaasch Genootschap, is duidelijk. Zijn naam is daarnaast verbonden aan een aantal verbeteringen in de stedelijke infrastructuur, namelijk de aanleg en verbetering van wegen en het ontsteken van straatverlichting (1780). Verder bevorderde hij het culturele leven door concerten te organiseren en het theater op te richten dat Jan Bouhon in 1780 leidde. Als baljuw, later als president van het college van schepenen en van de onderwijscommissie, en als kolonel van de burgerij was

16 Josua van Iperen aan C. van der Aa, Batavia 14-1-1780. RANH HMW 55 (correspondentie 1780).

17 H. Breton (1783) en A. Moens (1784) werden directeur in Haarlem, H.N. Laclé en J.C. Metzlar beiden in 1783 buitengewoon lid. 
hij medeverantwoordelijk voor stedelijke aangelegenheden. Der Kinderen, die als voorzitter van het genootschap het honderdste verjaardagsfeest van 'Radermachers stichting' organiseerde, somt in zijn biografische schets deze kwaliteiten op en zag in de archieven van de Indische regering 'menig stuk, dat blijk geeft van zijn helder inzicht en van zijn nimmer verflauwenden ijver om, naar zijn beste weten, de belangen van den lande te behartigen' (Der Kinderen 1878:bijlagen 76-7; Kalff 1899:471).

Radermacher was bij 'zijn stichting' vergezeld van een aantal personen: 'een aanzienelyk getal uit Comp.s burgers en dienaren', in de woorden van het plakkaat waarmee de regering in 1778 haar instemming betuigde. 'Een menigte van gegoede ingesetenen', in Radermachers eigen woorden in een particuliere brief uit hetzelfde jaar. ${ }^{18}$ In het gedrukte Programma van augustus 1778 kenmerkten de personen die door het Haarlemse initiatief werden aangestoken, zichzelf als behorend tot de kring van 'menschlievende en vermogende Ingezetenen deezer Hoofdplaatze' en als 'vermogende en welgezinde Stadsgenooten' (Programma 1778:3, 5). Pas in het voorbericht tot het eerste deel van de Verhandelingen (1779), toen Van Iperen in Batavia was, verschoof de nadruk enigszins naar 'liefhebbers', behorend tot 'het geletterd en letterminnend Oost-Indië', maar ook toen nog werd benadrukt dat de eerste leden behoorden tot de 'aanzienlijkste heeren en beambten dezer hoofdstad' (VBG $1: 5,7-8)$.

Het is duidelijk dat Radermacher zich omringd wist door rijke medeburgers met een zekere positie. Deze moesten daarbij een positieve instelling hebben ('welgezind') tegenover de letteren maar vooral tegenover de bevordering van de welvaart. De nadruk op 'vermogen' en 'aanzien' stond voorop, liefde voor de letteren kwam op de tweede plaats. Wie tot de kleine kring van de mede-oprichters behoorden, weten we niet met zekerheid. We kunnen het gissen als we kijken naar de eerste groep directeuren en naar het eerste bestuur. Dat het hele college van raden van Nederlands-Indië aantrad als directeur, aangevoerd door Reinier de Klerk, biedt ons echter weinig houvast. Dat Radermacher aan de Maatschappij in Haarlem direct na de oprichting in Batavia voorstelde om zijn mederaadsleden Alting en Craan tot directeur te benoemen en zijn medebestuursleden Hooijman en Von Wurmb als lid, geeft in ieder geval te denken: zij wel, de anderen niet. Daarmee was het groepje met een dubbel lidmaatschap (directeur of lid in Haarlem én Batavia) aangegroeid tot acht, want Falck op Ceylon, Ross in Bengalen en De Klerk en Radermacher zelf hoorden daarbij. ${ }^{19}$

18 Van der Chijs 1885-1900, X:269. Radermachers woorden in reeds aangehaalde brief aan C. van der Aa, RANH HMW 53 (correspondentie 1778, 15-10-1778).

19 Iman Falck wist natuurlijk pas een paar maanden later dat het in Batavia tot een genootschap was gekomen. 
Het college van directeuren bestond naast opperdirecteur De Klerk uit tien mannen, van wie directeur-generaal Willem Alting als eerste genoemd werd. Naar jaar van benoeming als raadslid volgden daarna: Hendrik Breton, voorzitter van het college van Heemraden, Johannes Vos, ontvanger-generaal, Willem Fockens, voorzitter van het college van Weesmeesters, Thomas Schippers, president van de Raad van Justitie, Jacobus Craan, politiek commissaris en directeur van de Amfioensociëteit, tevens Radermachers collegacommissaris over de Bovenlanden. Verder de al genoemde Smith, directeur van de Bank-Courant en de Bank van Lening, Radermacher zelf en tenslotte nog de na hem benoemde raadsleden Hendrik van Stockum en Jan Poock. Zij waren zonder uitzondering aanzienlijk en vermogend en konden zonder problemen bijdragen in de kosten van het nieuwe genootschap. Net als in Haarlem en in Vlissingen was dat een belangrijke taak van de directeuren. Zonder hun weldadig ingrijpen zou het genootschap een vroege dood zijn gestorven. Door zijn familieband met De Klerk zal het Radermacher gelukt zijn de collega-raadsleden te overtuigen mee te doen. $\mathrm{Zij}$ gaven gewicht aan het nieuwe genootschap. Als de nieuwe organisatie een succes zou blijken te zijn, zou het ook weer glans kunnen geven aan de individuele directeuren. Met Haarlem waren er banden. In Vlissingen was Adriaan Moens, in 1778 nog hoofd op het kantoor aan de Malabar-kust, al sinds 1776 directeur. Radermacher volgde daar in 1778, De Klerk pas in 1780 en Alting in 1782. Bij het Bataafsch Genootschap in Rotterdam werden ook De Klerk en Alting honorair lid (1778 en 1785), terwijl Radermacher zelf daar in 1779 tot lidcorrespondent werd benoemd (Van Lieburg 1985:223). Aan de top was het Bataviaasch Genootschap door meervoudige directeurschappen en lidmaatschappen verbonden met Haarlem, later ook met Vlissingen en Rotterdam.

De directeurengroep was - anders dan in Haarlem - een gesloten groep, niet groter dan het aantal leden van de Raad van Nederlands-Indië. In Haarlem groeide die groep juist in de eerste jaren van zeven bij de oprichting door zestien nieuwe benoemingen in de periode 1753-1757. Soms werd er slechts één nieuwe directeur benoemd; in het jubileumjaar 1777, zoals we reeds zagen, zelfs negen. In Batavia hield men de directeuren-eer beperkt door het te koppelen aan het lidmaatschap van de Hoge Regering. Zoals de vroedschapsleden in Haarlem in 1752 hun bescherming aan de Hollandsche Maatschappij gaven, zo deden de leden van de raad in Batavia hetzelfde tegenover het genootschap. Zoals zij daar zaten in hun vergadering in het Kasteel, vormden zij meteen, niemand uitgesloten, het hoogste orgaan van het genootschap.

Radermacher werd bestuursvoorzitter ('voorzittende directeur') en kreeg tien bestuursleden ('dirigeerende leden') naast zich. In het Programma heet het dat ze bij intekening (schriftelijke stemming) door de leden waren gekozen uit hun midden. Uit de ledenlijst, die aan het programma van 1778 is toegevoegd, een lijst van 104 inwoners van de hoofdplaats van Nederlands-Indië, 
valt hun status in de Bataviase maatschappij af te lezen. Na Radermacher volgden

- Mr Jacob de Meyer, lid van de Raad van Justitie en ad-interim advocaatfiscaal,

- Josua van Iperen, predikant bij de Nederduits Gereformeerde Gemeente,

- Johannes Hooijman, predikant bij de Lutherse gemeente,

- Sirardus Bartlo, schepen en lid van de onderwijscommissie,

- Mr Willem van Hogendorp, koopman en tweede administrateur op Onrust,

- Hendrik Laclé, koopman en secretaris van Weesmeesters,

- Jacobus van der Steege, arts en verbandmeester in het Binnenhospitaal,

- Mr Egbert Blomhert, notaris en lid van de onderwijscommissie,

- Mr Paulus Gevers, onderkoopman en tweede administrateur in de Suikerpakhuizen,

- Frederik baron von Wurmb, onderkoopman en boekhouder in het hospitaal.

Zo zag het bestuur van het eerste uur er uit. Twee predikanten, twee kooplieden en twee onderkooplieden, twee bestuurders, een vertegenwoordiger van het justitiële apparaat, een medicus en een notaris. Vijf van hen voerden de meestertitel. Zij waren met de Groningse medicus Van der Steege en de twee predikanten de universitair opgeleiden, die aldus ruim in de meerderheid waren. Onder hen waren drie genootschapsmannen: Radermacher (Haarlem, Vlissingen en - in 1779 - Rotterdam), Van Hogendorp (Rotterdam en Vlissingen) en Van Iperen (Haarlem, Vlissingen, Leiden). Van de groep eerste bestuursleden, die in ieder geval ten dele met de groep oprichters samenvalt, behoren Van Hogendorp, Hooijman, Van der Steege en Von Wurmb naast Radermacher zelf tot de kleurrijkste en voor het genootschap belangrijkste personen.

Mr Willem van Hogendorp (1735-1784) stond als koopman in de middenmoot van de Bataviase hiërarchie. Hij stond daarom zowel op de lijst van de bestuursleden als op de eerste ledenlijst op die onopvallende plaats. In de helft van het bestuur en van de medeleden moest hij zijn meerderen of senioren erkennen. Hij was als zoon uit een Rotterdams regentengeslacht in 1773 na een financieel débacle zonder zijn gezin naar Indië vertrokken om nieuw fortuin te zoeken. Hij was getrouwd met Caroline van Haren, dochter van de Friese edelman en schrijver Onno Zwier van Haren, die voor een klassiek treurspel het Bantamse hof als plaats van handeling had gekozen en sultan Agung als zijn hoofdpersoon (Agon, Sulthan van Bantam 1769). Willem en Caroline kregen twee spraakmakende zoons: Dirk van Hogendorp (1761-1822), die in de koloniale discussie rond 1800 van zich zou laten horen, en de staatsman Gijsbert Karel (1771-1834), die in de aanloop tot de herwonnen onafhankelijkheid en de stichting van het Koninkrijk van 1813 een cruciale rol speelde. 
Vader Willem werd na aankomst in Indië eerst resident van Rembang, maar in het herstellen van zijn fortuin slaagde hij vooral als administrateur op het eiland Onrust voor de kust van Batavia door handel te drijven met eigen schepen, naast het behartigen van de Compagniesbelangen aldaar (Nieuwenhuis 1978:66; Timmer 1998:142-5). Van Hogendorp had in Rotterdam het nieuwe Bataafsch Genootschap gesteund tot hij zijn rol als weldoener had moeten opgeven, toen hij berooid de Republiek verliet. In het nieuwe Bataviaasch Genootschap speelde hij een actieve rol: door aan de Verhandelingen bij te dragen en door geld ter beschikking te stellen voor extra prijsvragen. Hij schreef twee programmatische novellen, die in Batavia werden gedrukt: Sophronisba (1779) over de heilzame werking van de inenting tegen pokken en Kraspoekoel (1780) over de slechte behandeling van slaven. Het schip waarop hij met zijn vergaarde schatten thuisvoer, verging in 1784 bij de Kaap.

Van Hogendorp licht als enige een tipje op van de sluier, die hangt over de precieze samenstelling van de groep oprichters. In een brief aan de Stadhouder van 21 oktober 1778 noemt hij Radermacher als de eerste van de oprichters, verder Hooijman en 'nog iemand, die ik zelfs niet noeme'. Aangezien Van Hogendorp zegt dat door de oprichting van het genootschap zijn vriendschap met Radermacher nog sterker is geworden, is hij zelf vermoedelijk de derde in de trias, waarbij hij bescheidenheidshalve zijn naam niet noemt (Der Kinderen 1878:145). Het is de enige aanwijzing dat het genootschap door deze drie mannen is opgericht. Het is niet uitgesloten dat Van Hogendorp alleen de drie belangrijkste onder de oprichters noemde en andere namen wegliet. Na het afscheid van Van Hogendorp noteerde de toenmalige voorzitter Moens: 'het is jammer, dat zijn Ed. [Van Hogendorp] en de predikant Hooijman met elkander niet konden harmonieeren' ${ }^{20}$ Waarom Radermacher wel Hooijman en Von Wurmb en niet Van Hogendorp in Haarlem voordroeg, is onduidelijk.

Johannes Hooijman (in Batavia 1765-1789), predikant van de Lutherse gemeente, heeft de reputatie dat hij meer geïnteresseerd was in handel en landbouw, dan in de kerkelijke bediening waarin hij benoemd was. Steeds wordt vermeld dat hij het landgoed Pondok Gede bij Batavia bezat en dat hij vermogend was. Radermacher stelde hem in 1778 direct voor als lid bij het Haarlemse Maatschappij, aan welke hij bij zijn dood - hij werd in 1789 vermoord op zijn landgoed - duizend gulden legateerde voor een goedvaderlandse prijsvraag. Het zullen zijn activiteiten om de landbouw te bevorderen geweest zijn, die Radermacher ingaven hem aan Haarlem voor te stellen als lid. Immers, de Oeconomische Tak was ook in de landbouw overzee geïnteresseerd. In 1782 zou Hooijman corresponderend lid van het 
Bataafsch Genootschap in Rotterdam worden (Van Lieburg 1985:223). De Haan vermeldt zonder bron dat Hooijman als 'zeer ondeugend en losbandig' bekend stond (De Haan 1935a, I:239,615; Bierens de Haan 1970:207-8). Hij was vermogend, stelde geld ter beschikking voor prijsvragen, stimuleerde landbouwexperimenten en schreef daarover in de Verhandelingen. In hem zien we, net als in Van Hogendorp en Radermacher, hoe (bestuurs)leden tegelijk weldoeners waren en aan de feitelijke werkzaamheden van het genootschap deelnamen. In dat opzicht onderscheidde Batavia zich van Haarlem waar de directeuren voor het geld zorgden en de leden voor de inhoudelijke bijdragen. Met Laclé was Hooijman het langst aanblijvende bestuurslid: zij zaten in 1789 nog op het kussen.

In tegenstelling tot Radermacher en Van Hogendorp, die de thuisreis niet overleefden, en Hooijman die net als Radermacher onder moordenaarshanden zijn einde vond, overleefde de arts Jacobus van der Steege (1746-1812) zijn Bataviase verblijf wel. Hij beleefde in 1789 een glorieuze thuiskomst in de stad van zijn alma mater, Groningen, na zestien jaar afwezigheid. Hij was uit Leeuwarden afkomstig, had medicijnen gestudeerd en had in Groningen ook een praktijk gehad. In 1773 was hij naar Batavia vertrokken in de rang van onderkoopman. Na aankomst werd hij verbandmeester bij het Binnen-hospitaal, maar zijn fortuin vergaarde hij als regent van het Buiten-hospitaal, waartoe hij in 1780 door Alting werd benoemd, een functie waar veel geld aan vastplakte (De Graaf 1998:15-9). Hij nam vijfeneenhalf miljoen gulden mee naar huis (Schutte 1974:28, 177). Als arts was hij actief bij de inenting tegen pokken, waar Van Hogendorp als publicist en geldschenker bij betrokken was. Aan de Verhandelingen droeg hij onder meer een stuk bij over de pokkeninenting en over de medische kant van magnetisme. Hij werd pas na zijn thuiskomst in Groningen, waar de miljonair een opvallende stedeling was, tot directeur van de Haarlemse Maatschappij gekozen, tot directeur in Vlissingen (1789) en tot gewoon lid in Rotterdam bij het Bataafsch Genootschap (1790). De Haarlemse secretaris Van der Aa vroeg Van der Steege enige malen om zijn oordeel over 'koloniale' prijsvragen. Hij verhuisde na de omwenteling van 1795, die hij als Patriot begroette, naar Holland en werd in 1800 lid van de Raad der Aziatische Bezittingen. Hij stierf in Amstelveen in 1812.

Karl Friedrich baron von Wurmb (1742-1781, in Batavia veelal aangeduid als Frederik van Wurmb) was in de Bataviase stedelijke hiërarchie, voor zover die weerspiegeld werd door de eerste ledenlijst, een van de nederigste beambten. Als bestuurslid stond hij onderaan, op de ledenlijst is hij eveneens het laagst geplaatste bestuurslid. Hij was een uit Saksen afkomstige militair van verarmde adel en was op voorspraak van een van de adjudanten van de Stadhouder in 1774 als onderkoopman uitgevaren. Aanvankelijk boekhouder in het kantoor van het hospitaal, wat hij ten tijde van de oprichting 
van het genootschap nog was, werd hij in 1780 administrateur van de pakhuizen, waar kennelijk wat bij te verdienen was. Bij zijn onverwachte dood op 39-jarige leeftijd in december 1781, liet hij na afrekening van de schulden, dertigduizend gulden na (Der Kinderen 1878:13-4, 44-6; Van Gelder 1997:175, 184-5, 202-3, 213, 236). Radermacher moet hem in het genootschap hebben gehaald om zijn kennis van en kunde op het gebied van de natuurwetenschappen. De waardering van de voorzitter voor de Duitser moet groot geweest zijn, want hij werd de eerste beheerder van de genootschappelijke verzamelingen, maakte beschrijvingen van planten en dieren, en werd de eerste secretaris. Hij behoorde bij het selecte groepje dat in 1778 direct door Radermacher werd voorgedragen voor een lidmaatschap in Haarlem. Zijn uitverkiezing tot corresponderend lid van het Rotterdamse genootschap in 1782 kwam te laat. Zijn kwaliteiten werden door Radermacher zo hoog geacht en voor het genootschap van zodanig groot belang dat deze zich na het 'smartelijke' overlijden tot de hoogleraar in de botanie C.P. Thunberg in Uppsala wendde om te verzoeken een waardige opvolger voor Von Wurmb naar Batavia te sturen. Von Wurmbs dood, bijna vier jaar na de oprichting, was na het overlijden van collega-secretaris Van Iperen, die nog geen jaar als bestuurslid fungeerde (1780) het tweede grote verlies. Achttien brieven uit de Bataviase jaren (1775-1781) aan zijn broer in Duitsland, die in 1794 in Gotha werden uitgegeven, zijn de voornaamste bron voor het leven van Von Wurmb in Batavia (Von Wurmb 1794). Het archief van het Bataviaasch Genootschap uit de eerste jaren biedt waardevolle aanvullingen

We mogen Hooijman, Van Hogendorp, Van der Steege en Von Wurmb tot de kern van het genootschap rekenen in het oprichtingsjaar en in de eerste jaren van het bestaan: de mannen rond Radermacher. Door de meervoudige lidmaatschappen van genootschappen, ten dele op voordracht van Radermacher, waren zij opgenomen in het veel bredere genootschapsleven in het vaderland en hadden zo op afstand deel aan het intellectuele leven van hun tijd. Bovendien waren zij door hun bijdragen aan de eerste delen van de Verhandelingen (1779-1781), waarin de namen van de andere bestuursleden van het eerste uur, De Meyer, Bartlo, Laclé, Blomhert en Gevers nu juist ontbreken, degenen die als actief lid en bestuurslid konden worden aangemerkt. De anderen waren door organisatorische of geldelijke steun van belang, of legden alleen hun maatschappelijk gewicht in de schaal. Hun activiteiten hebben geen duidelijke sporen nagelaten.

\section{Werkzaamheden}

De werkzaamheden van het genootschapsbestuur zijn voor de periode tot 1799 als volgt samen te vatten: leiding geven aan het genootschap, waarvan de vergaderverslagen getuigen. Verder: het stimuleren en verbreiden van kennis 
en praktische wetenschap, zoals het zich uitte in het uitschrijven van prijsvragen, het uitgeven van publicaties en het aanleggen van verzamelingen.

Van de werkzaamheden van het genootschap zijn nauwkeurige verslagen te vinden in de notulenboeken van de bestuursvergaderingen, waarvan de eerste delen de periode 1778-1802 beslaan, en in de bijbehorende bundels correspondentie. ${ }^{21}$ Onderstaand overzicht geeft aan hoe die vergaderingen over de periode tot 1799 zijn verdeeld.

Bestuurs- en algemene vergaderingen tot 1799

\begin{tabular}{lcc}
\hline periode & bestuursvergadering & algemene vergadering \\
\hline $1778-1782$ & 36 & 1 \\
$1783-1787$ & 10 & - \\
$1788-1792$ & 45 & 3 \\
$1793-1797$ & 17 & 1 \\
$1798-1799$ & - & - \\
totaal & 108 & 5 \\
\hline
\end{tabular}

Verdeling van de vergaderingen naar voorzitters

\begin{tabular}{lccc}
\hline Voorzitter & Periode & bestuur & algemeen \\
\hline Radermacher & $1778-1783$ & 38 & 1 \\
Moens & $1783-1792$ & 53 & 3 \\
Wiegerman & $1792-1799$ & 17 & 1 \\
\cline { 3 - 4 } totaal & & 108 & 5 \\
\hline
\end{tabular}

In het Programma had het genootschap, zoals gebruikelijk was bij deze streng gereglementeerde organisatievorm, zich vastgelegd op een ritme van maandelijkse bestuursvergaderingen en twee maal per jaar een algemene vergadering. In de praktijk bleek dit te ambitieus. In de genootschapsjaren 1778-1799 werd niet eens een gemiddeld jaarritme van vijf bestuursvergaderingen en één algemene vergadering gehaald. In de periode onder Radermacher en Moens werd gemiddeld meer dan vijf keer per jaar vergaderd. Daarbij moet echter worden aangetekend dat dit vooral de jaren 1778-1781 en 1789-1794 betrof, de tussenliggende jaren waren gekenmerkt door teruglopende activiteiten. Voor de algemene vergaderingen was alleen de periode 1790-1793 van regelmaat sprake. Tot de gebeurtenissen van buiten die grote invloed hadden op het genootschapsleven en het vergaderritme, behoorden de oorlog

21 Ik kies ervoor hier de eerste periode af te sluiten in 1799, na 22 jaar. Het gaat om drie bundels notulen en vier bundels correspondentie en varia. Zeer waarschijnlijk was er een vierde notulenboek over de periode 1803-1816. Door het zoekraken daarvan begint de negentiende eeuw met een slecht gedocumenteerde periode van ruim tien jaar. 
met Engeland, de Patriotse troebelen in het vaderland en het 'herstel' van de Stadhouder in 1787, en de achteruitgang in de Compagnie, die leidde tot de liquidatie ervan.

In de literatuur over het genootschap is een stereotiep beeld ontstaan: opgericht door Radermacher en onder hem tot bloei gebracht, na zijn vertrek vervallen tot inertie totdat Raffles het nieuw leven inblies. Dat beeld moet op twee punten gecorrigeerd worden. In de jaren 1778-1781 waren er regelmatig bestuursvergaderingen, maar de algemene vergadering werd slechts één keer gehouden. De jaren 1782-1783 laten zien dat er een teruggang was, ten gevolge van de oorlog tussen de Republiek en Engeland. Nadat op 12 juni 1781 in Batavia bekend was geworden dat de oorlog met de Britten was uitgebroken, vergaderde het genootschap alleen nog in juli, augustus en november van dat jaar en daarna pas weer in augustus $1782 .{ }^{22}$ De tweede correctie betreft de situatie na Radermachers vertrek. Onder de tweede voorzitter, de Zeeuw Adriaan Moens, blijkt regelmatig te zijn vergaderd, vooral vanaf 1788 . In de vier jaren 1790-1793 werd telkens een algemene vergadering gehouden. Onder Radermacher in ruim vijf jaar maar één keer. Ook verschenen in Moens' jaren nog twee delen van de Verhandelingen. Het bestaande beeld van totale rust tussen 1784 en 1812 is hiermee bijgesteld. Het is aantrekkelijk een verband te zien tussen de 'herstelde rust' in het vaderland na de Pruisische inval van 1787 en de toegenomen activiteiten na 1788. Onder Wiegerman verliep, vooral na 1794, de boel. In 1795 werd er maar één keer vergaderd en daarna pas weer in $1800 .^{23}$

\section{Persoonlijkheden: Josua van Iperen}

Over Josua van Iperen (1726-1780) is hier nog niet uitgebreid geschreven. Zijn op handen zijnde komst was ten tijde van het drukken van het eerste programma bekend en er werd op gerekend dat hij direct bereid zou zijn aan het nieuwe genootschap mee te werken. Hij kan dan ook tot de mannen rond Radermacher worden gerekend.

De Zeeuw Van Iperen was voor het beginnende genootschap een droomlid, een aanwinst van betekenis door zijn kennis en door zijn betrekkingen in Nederland, vooral met verschillende genootschappen. Radermacher zorgde er dan ook voor dat er naast Von Wurmb nog een secretarisplaats werd gecreëerd. Doordat hij ouder was en hoger in rang zal Van Iperen de eerste secretaris zijn geworden, al werd dat onderscheid formeel niet gemaakt. Hij

22 Radermacher meldde de datum van het ontvangen van de oorlogstijding in een brief aan de Stadhouder op 1-9-1781. Koninklijk Huisarchief, Archief Stadhouder Willem V, 331-21, nr 7.

23 ANRI KBG Dir 0020, 33, vergadering 4-5-1795 en 31-3-1800. 
werd zelfs al in het bestuur gezet terwijl hij nog in Veere was en zijn vertrek voorbereidde. Er is geen correspondentie overgeleverd waaruit blijkt dat hij tevoren is geconsulteerd over deze uitverkiezing.

Van Iperen was in 1726 in Middelburg geboren, waar hij de Latijnse School bezocht. Hij studeerde theologie in Groningen en Leiden, promoveerde in Groningen in 1752 in de vrije kunsten en wijsbegeerte, na eerdere pogingen om in de godgeleerdheid te promoveren. Daarna leek voor hem eerder een toekomst als geleerde dan als predikant weggelegd. Twee keer was hij kandidaat voor een hoogleraarsplaats, in Franeker in 1752 en Harderwijk in 1756, maar beide keren viel de keuze op een ander. Hij bleef zestien jaar als predikant in 'het onbeduidende Lillo', een garnizoensplaats aan de Schelde. ${ }^{24}$ In 1766 werd hij beroepen in Veere; al met al geen bliksemsnelle carrière voor een predikant.

Was zijn benoeming aan een universiteit gestrand, Van Iperen probeerde toch tot de geleerde wereld door te dringen. In 1755 richtte hij zich tot de Hollandsche Maatschappij in Haarlem met zijn manuscript, Redenkundige bedenkingen over de cometen en nieuwe sterren, dat al na een maand op advies van J. Engelman ter zijde werd gelegd, waarna Van Iperen het in Middelburg liet drukken (1758). ${ }^{25} \mathrm{Hij}$ stuurde zijn gedrukte Proeve van taalkunde, als eene wetenschap behandeld in 1755, in 1758 een bericht over de wonderbaarlijke terugkeer van het gehoor bij Antwerpse dames die op een wagen hotsten, een bericht dat waard geoordeeld werd om opgenomen te worden in de Verhandelingen van de maatschappij, en in 1759 een verhandeling over 'De Geboortesterre van onzen zaligmaker', die alweer strandde op een afwijzing van een kundige beoordelaar (Zuidervaart 1999:200-2). Van Iperen bleef echter proberen de directeuren in Haarlem te bewegen hem als lid aan te nemen door berichten en verhandelingen in te sturen over allerlei onderwerpen: over molbegravers (1758), scheurbuik (1759), over wiskundeonderwijs (1761). Een geschiedenis van de Hollandsche Maatschappij zelf, die hij in januari 1765 inzond met het verzoek om er fouten uit te halen vóór hij tot publicatie in een tijdschrift zou overgaan, deed de Haarlemse directeuren uiteindelijk overstag gaan. Nog datzelfde jaar werd besloten Van Iperen voor het lidmaatschap voor te dragen. ${ }^{26}$ Daarmee had hij een belangrijk doel bereikt. Hij was opgenomen in de onofficiële academie van de Republiek. Na zijn uitverkiezing bleef hij berichten sturen over landbouwkundige onderwerpen, over bouw-

24 Nagtglas 1890, I:456-64; Encyclopedie van Zeeland 1980,II:94; Troostenburg de Bruyn 1884:223, 240-1, 250, 295-6, 302-3; Groot 2004:335-6.

25 RANH HMW 12 (Notulen 1752-1767), vergadering van 7-10-1755 en 4-11-1755. RANH HMW 31 (correspondentie 1756), waaronder zich het stuk bevindt. Over deze kwestie Zuidervaart 1999:200.

26 RANH HMW 12 (Notulen 1752-1767) p. 93, 183-4, 191, 210, 221, 229, 297, 301, 307 en 406; 410 over zijn voordracht tot lid op 5-2-1765. 
zaden (1765), over gebruik van as en vuilnis in de landbouw (1765), maar ook over de zwangerschap van zijn vrouw (1768). ${ }^{27}$ Een verhandeling over de landbouw in Brabant zou als enige de Verhandelingen van de Hollandsche Maatschappij halen, naast enkele van zijn korte berichten (Nagtglas 1890, I:462-4).

In 1772 werd Van Iperen door de Staten van Zeeland naar Den Haag afgevaardigd om deel te nemen aan de werkzaamheden van de commissie die een nieuwe psalmberijming voorbereidde. Die vergaderde in 1773, het jaar waarin de Maatschappij der Nederlandsche Letterkunde in Leiden hem in haar gelederen opnam. ${ }^{28}$ Op dat moment was de predikant al lid van het Zeeuwsch Genootschap, maar de erkenning voor een Zeeuw binnen de eigen provinciegrenzen was gemakkelijker te behalen dan die door de Haarlemse en Leidse maatschappij, welke twee lidmaatschappen hem dan ook meer glans gaven. Door zijn lidmaatschap van drie genootschappen die tot de belangrijkste van het land behoorden, kon Van Iperen gerekend worden tot de kring van geleerden met landelijke bekendheid, tot de kring van amateurgeleerden in de natuurwetenschappen, de sterrenkunde voorop. Hij was evenzeer geïnteresseerd in aangrenzende vakgebieden tot de toepassingen in de landbouw toe.

Van Iperens uitverkiezing door de classis Walcheren tot gedeputeerde tot de Oost-Indische kerkzaken in 1774, een positie die hij tot 1776 vervulde, vormde een aanloop tot zijn beslissing een benoeming tot predikant in Indië te aanvaarden. Zijn biograaf Nagtglas noemt zijn bekrompen financiële positie als reden voor het vertrek naar Batavia. Lillo en Veere waren bescheiden standplaatsen. De Indische benoeming kwam in april 1777, waarna Van Iperen pas in juli 1778 met vrouw en vijf kinderen uit Vlissingen wegvoer, een gedurfde onderneming voor een man van 52 jaar (Van Iperen 1779a). Het nieuws van zijn op handen zijnde vertrek was in Batavia aangekomen met dezelfde schepen waarmee het nieuws van de geboorte van de Oeconomische Tak Indië bereikte.

Dankzij Van Iperens nauwe relatie met de genootschappen in Vlissingen en Haarlem en dankzij het feit dat de archieven van beide organisaties zo goed als ongeschonden zijn overgeleverd, zijn we goed ingelicht over de reis, het oponthoud aan de Kaap en het eerste jaar in Batavia. Er zijn brieven aan de Haarlemse secretaris Van der Aa en aan de Vlissingse secretarissen Justus Tjeenk en Jona te Water, alle drie predikant. Op 20 december 1778 schreef Van Iperen van de Kaap aan Van der Aa, ter begeleiding van een notitie over

27 RANH HMW 12 (Notulen 1752-1767), 436, 449, 477.

28 Handelingen Letterkunde 1782:IV, heeft een notitie over Van Iperens overlijden (UBL 1499 A 7-75). Ledenlijst 1499 A 7-1 in dezelfde convoluut geeft 13-7-1773 als datum van uitverkiezing tot lid in Leiden. 
op zee geobserveerde insecten. Hij gaf daar de Haarlemse directeuren mee te kennen dat hij de contacten wilde aanhouden en zijn plichten als lid serieus bleef nemen. In 1779 besloot men in Haarlem het bericht over de zee-insecten door Marinus van Marum gereed te laten maken voor publicatie. ${ }^{29}$

Aan Jona te Water schreef Van Iperen eveneens op 20 december 1778, aan de vooravond van het vertrek naar Batavia. De brief, die tegelijk als geleide diende voor een kistje met stenen voor de Zeeuwse verzameling, is meer vertrouwelijk van toon en vertelt meer over het verblijf aan de Kaap. 'Ik zal hier, met mijne Familie, al eenige Dukaten en Spaansche Matten laaten zitten. Een Predikant van Batavia is hier een groot dier, en moet zijn fatzoen houden.' Van Iperen werkte in drie pagina's alle Kaapse zaken af: mineralogie, het weer, nieuws over de kerkgemeente, zorgen om de bediening van de gemeente door slechts twee predikanten op twee duizend zielen, de Kaapse fauna, de levenswijze van de Kaapse boeren en de zeden in de Tafelvallei, de goedkoopte van vaderlandse goederen aan de Kaap en de noodzaak om er een Latijnse School op te richten. ${ }^{30}$ Aan de bewindhebbers van de Compagnie in Zeeland zei Van Iperen al acht brieven te hebben geschreven over de 'merkwaardigheden van mijne Zeereizen'. ${ }^{31}$

Van Iperens publicaties en zijn lidmaatschappen van verschillende genootschappen in het vaderland verzekerden hem van een positie in het genootschap. Aan zijn Zeeuwse ambtgenoot Jona te Water schreef Van Iperen opgetogen in oktober 1779:

Uit het dood Ter Veere in het levendig Batavia gelukkig overgekomen, voor het uiteinde van Sprokkelmaand [februari 1779], ben ik met opene armen ontvangen: en mij is de aanzienelijkste rang onder de Dirigerende Leden van ons Bataviasch Genootschap, met een pressement, opgedraagen; en vervolgens een Secretariaat, dat mij dompelt in eene zee van letterkundige bezigheden. Men doet mij de eere aan, om mij, van alle kanten, over de gewigtigste zaaken, te raadpleegen. Ik ben ook Scriba, van de Commissie over de Verbeteringe der Waterleidingen, om, ware 't mogelijk Batavia gezonder te maaken. Kortom ik vinde hier gelegenheid om alles, wat ik vermag, ten voordeele van het Gemeen, aan te wenden: iets, waar ik naar, al mijn leven, verlangd hebbe. [...] Met een woord, te Veere was ik een Bedelaar, en hier ben ik een Heer, die voor 's Gravenhage of Amsterdam niet zou willen opstaan. ${ }^{32}$

29 RANH HMW 54 (correspondentie 1779) bevat de brief van 20-12-1778 aan C. van de Aa met de 'Waarneeminge van de Zee-insecten' met een tekening van acht glaasjes met waarnemingen gedaan met een microscoop.

30 Zeeuwse bibliotheek, Hs 2013, J. van Iperen aan J. te Water, 20-12-1778.

31 Deze brieven blijven vooralsnog onvindbaar. Met dank aan Louisa Balk (NA Den Haag), die een zoekactie ondernam.

32 Zeeuwse Bibliotheek, Hs 2054, brief aan Ds J. te Water, geschreven vanaf het Molenvliet, Batavia, Oct. 1779. 
Voor Van Iperen was de rol die hij in Batavia in het genootschap kreeg een erkenning, waar hij in de Republiek tevergeefs naar had gestreefd. Hij was jaren in twee kleine plaatsen werkzaam geweest en had minstens in een stad als Haarlem, Rotterdam of Vlissingen beroepen moeten worden om zelfs maar een kans te krijgen meer in het hart van een genootschap te geraken. Hij was in Batavia openbare lessen gaan geven (Van Iperen 1779b, $1779 \mathrm{c})$, waarvoor hij toegejuicht werd en waardoor hij ging dromen van een hogere positie. 'Waarom zou men mij dan de titel van Professor, en een klein Augmentum misgunnen?'33 De dood van Van Iperen, nog geen jaar na zijn aankomst in Batavia ten gevolge van de nieuwkomersziekte malaria, was daarom niet alleen een slag voor zijn gezin, maar ook voor het genootschap (Wachter 1781, Groot 2004:345-6).

\section{De relatie met de overheid}

Van het begin af was het bestaan van het genootschap gekoppeld aan goedkeuring door de overheid in Batavia. Aan het eind van de eeuw was de situatie sterk veranderd. De afhankelijkheid van de overheid en daarmee van het wel en wee van die overheid kunnen we juist tegen de achtergrond van de woelige jaren van omwenteling in terugblik bekijken.

In de zeer beknopte voorgeschiedenis van de oprichting, zoals die in het eerste deel van de Verhandelingen voorkomt, werd gerefereerd aan de tegenstand die het idee van een genootschap in Batavia had ondervonden (VBG 1:6, Voorberigt). In het een jaar eerder verschenen Programma was daarvan geen melding gemaakt. Het ligt hoe dan ook voor de hand om de 'tegenstander(s)' in de kringen van de gouverneur-generaal en de Raad van Indië te zoeken. Wie anders hadden het voor het zeggen? Als onder de nieuwe, in 1777 aangetreden gouverneur-generaal Reinier de Klerk het op de Oeconomische Tak van Haarlem geïnspireerde plan van Radermacher zo snel gehoor vond, is het verleidelijk om de aanvankelijke tegenstand bij eerdere pogingen bij de voorganger van De Klerk, Van Riemsdijk (1775-1777) en de zijnen te zoeken. Hem wordt echter in die beknopte geschiedenis helemaal niets aangewreven, terwijl De Klerk evenmin excessief wordt geprezen om zijn instemming. Daarmee blijft niet alleen een stukje van de voorgeschiedenis onzeker, ook blijft onduidelijk waaruit die 'tegenstand' had bestaan. Er zijn geen brieven van Radermacher of Van Iperen die hierop meer licht werpen. Van Riemsdijk, indien hij al achter de tegenstand zat, was niet erg lang aan het bewind, al had hij natuurlijk als directeur-generaal een zware stem gehad naast Van der Parra. 
Van der Parra was geen liefhebber van de wetenschap, maar hielp wel de predikanten. Vooralsnog blijft het onduidelijk hoe serieus die tegenstand moet worden genomen. Het archief van het genootschap biedt geen uitkomst.

Toen de goedkeuring voor de oprichting van de kant van de Hoge Regering op 30 juni 1778 formeel afkwam, kon het genootschap aan het werk. Als college van directeuren waren de gouverneur-generaal en de raadsleden van Indië aan het hoofd van het genootschap geplaatst. Maar de algemene vergadering, het moment waarop die directeuren hun stem konden laten horen tegenover het bestuur en de leden, werd niet tweemaal per jaar gehouden, zoals de wetten het voorschreven, maar slechts vijf keer in de hele periode tot 1799. Daaruit blijkt geen overdreven rechtstreekse bemoeienis met het genootschap.

Op twee andere manieren probeerde het bestuur de bestaanszekerheid van het genootschap te verzekeren: door het beschermheerschap van de Stadhouder en de instemming van de Heren Zeventien te verkrijgen. De instemming van de Heren Zeventien was in het eerste jaar van bestaan nog onzeker. Van Iperen hield zijn hart vast in een brief aan de Vlissingse collegapredikant Jona te Water:

Ai lieve, draag toch zorg, dat de Nijd en een Veranderlijkheid onzer verkiesbare Regeringe ons Genootschap hier niet overhoop werpen. Mogte de Heeren Bewindhebberen daar voor waaken! De Colonie plukt al vruchten van dezen boom. [...] Doe toch Uw best, om het genootschap bij de Heeren Zeventienen bevestigd te krijgen. ${ }^{34}$

In een brief aan secretaris Van der Aa van de Haarlemse Maatschappij vlak voor zijn dood liet Van Iperen zich in bijna gelijke bewoordingen uit. ${ }^{35}$ De instemming van de bewindhebbers kwam per brief van 10 november 1780 . $\mathrm{Zij}$ reageerden op het hun toegezonden eerste deel van de Verhandelingen en spraken de verwachting uit, dat het genootschap vooral aandacht zou besteden aan zaken die van belang waren voor het welzijn van de Compagnie. Echter konden de bewindhebbers niet nalaten om de bedrijfsgeheimen veilig te stellen:

En in de Uitgave van desselfs Stukken de vereischte Omzigtigheid zal gebruiken, ten Einde geene Zaaken door den druk onder het Oog van het publicq te brengen, welke van dien aard zijn, dat derselver Kennis zo veel mogelijk, alleen in den boesem van de Compagnie dient te blijven; En die overzulx ten minsten van harentwegen of met haare Toestemming niet behooren te worden bekend gemaakt. ${ }^{36}$

34 Zeeuwse Bibliotheek, Hs 2054, brief van J. van Iperen aan J. te Water, Batavia, October 1779.

35 RANH HMW 55 (correspondentie 1780), J. van Iperen aan C.C.H. van der Aa, Molenvliet bij Batavia, 14-1-1780.

36 ANRI KBG Dir 0016, vergadering 13-8-1781. 
Toestemming had de Hoge Regering in Batavia al gegeven, Amsterdam liet daarna alleen nog een waarschuwing horen. In de 'verpligtingen' van 1778 had het genootschap zich al tegen eventuele tegenstand in Batavia of Amsterdam ingedekt door te zeggen dat het zich geheel en al buiten compagnieszaken zou houden. In de grondwetten van 1791 werd dat nog eens herhaald (Programma 1778:7; Grond-wetten 1791). Zo leek het genootschap goed ingebed in de structuren van de VOC in Batavia. Het had ook duidelijk voordelen bij de formele toestemming van de regering. Het kon publicaties laten drukken door de compagniesdrukker, kon gebruik maken van de postverzending naar zowel de buitenkantoren als naar patria en daarvandaan post terug ontvangen. Geschenken voor de Stadhouder en voor de genootschappen in het vaderland gingen met de schepen mee zonder dat daarvoor betaald werd. Geld kon geïnd worden door storting in de compagnieskas, terwijl wissels op personen en instellingen in de Republiek met de retourvloten mee konden. Functionarissen in de Kamers konden hand- en spandiensten verlenen. Kortom, het genootschap had veel belang bij de overheid.

De Bataviase overheid schreef de directeuren en gouverneurs op de buitenkantoren eind 1778 aan om medewerking te vragen in een aantal natuurhistorische zaken. ${ }^{37}$ In feite werden de directeuren/gouverneurs aan het werk gezet, al konden zij het op hun beurt doorschuiven naar hun minderen. Niet alleen moest er worden geantwoord, er moesten ook inzendingen volgen. Dit patroon zou in de negentiende eeuw herhaaldelijk worden gevolgd. De overheid - soms weer aangezet door de overheid in Den Haag of instellingen in het Koninkrijk - deed een rechtstreeks beroep op haar ambtenaren om zich in te zetten voor de taal-, land- en volkenkunde van Indonesië.

De achttiende-eeuwse jaren overziende, valt het rechtstreekse ingrijpen van de overheid in het dagelijkse genootschapsleven erg mee. Het programma van 1778 werd pas gedrukt 'na bekomene goedkeuringe van hunnen Hoog Edelheden'38 en ook latere publicaties, programma's, prijsvragen, grondwetten werden gedrukt na aan de gouverneur-generaal te zijn voorgelegd. Het is niet na te gaan of de regering van dit recht op inzage vooraf ook gebruik maakte door tekstwijzigingen voor te stellen. Het plakkaat van de regering van 30 juni 1778 had geen wurggreep aangelegd. Het vooraf laten lezen van uitgaven voorkwam ook problemen. In 1789 werd bij het aantreden van Theodorus Vermeer als vice-voorzitter besloten 'de korte notulen' van de bestuursvergaderingen aan de gouverneur-generaal af te geven, alsof dat een nieuwigheid was. ${ }^{39}$ Het lijkt echter waarschijnlijk dat zulks al veel eerder

37 ANRI KBG Dir 0001, 35. Voorbeelden van de gedrukte circulairebrief plus vragenlijst in ANRI KBG Dir 0980, nr [5] en [56].

38 ANRI KBG Dir 0001, 7, vergadering 1-6-1778.

39 ANRI KBG Dir 0020,149-150, vergadering 13-7-1789. 
gebeurde. Immers, de bestuursvoorzitter was steeds zelf raadslid.

Slechts hoogst zelden krijgt men bij het lezen van de notulen het gevoel dat de regering ingreep en een onderwerp maar liever zichzelf voorbehield. Van zo'n ingreep lijkt sprake in het geval van een Portugese grammatica voor Nederlanders die in februari 1792 met een brief van A.E. van Braam Houckgeest uit China binnenkwam. Het leek een nuttig werkje voor een stad waar veel Nederlanders woonden die in de omgang thuis het Portugees bezigden. Het werd gelezen en gecorrigeerd en het genootschap besloot er drie duizend exemplaren van te laten drukken. Een interessante beslissing, want het genootschap zou daarmee uitgever zijn geworden van een publicatie die niet een van de eigen uitgaven was en niet in een oplage die alleen voor leden en correspondenten geschikt leek. Al weer iets dat in de negentiende eeuw heel gewoon zou worden. Door de dood van Moens werd het drukken even aangehouden. Het manuscript moest van de corrector worden teruggevraagd en aan voorzitter Wiegerman worden teruggegeven, waarna we er niets meer van vernemen. Greep hier de overheid in? ${ }^{40}$ In 1794 werd een discussie over een alternatief voor het begraven in de kerken en op kerkhoven binnen de stad in de kiem gesmoord: 'begreepen thands de Leden om voor als nu met dit artikel zig niet in te laaten'. Daarmee was een suggestie van twee maanden eerder van tafel geveegd, ook in dit geval tijdens het voorzitterschap van Wiegerman. ${ }^{41}$ Deze twee gevallen zijn niet genoeg om te concluderen dat Radermacher, Moens en Wiegerman aan de leiband van De Klerk en Alting liepen waar het om genootschapszaken ging. Wel mogen we niet vergeten dat de voorzitter uit de kring van de regering kwam. Hij had dagelijks contact met zijn mederegeringsleden en zag de volledige raad in ieder geval twee maal per week. Er was daardoor veel gelegenheid om vooroverleg te plegen, eer het genootschapsbestuur bijeenkwam. Wij mogen niet uitsluiten dat via de voorzitter de regering in het Kasteel meebestuurde. Tot een conflict kwam het niet. Wel was het genootschappelijke leven erg gemakkelijk te beïnvloeden door omstandigheden van buiten, zoals de oorlog met Engeland, de crisis in het VOC-bedrijf en de omwenteling van 1795 in de Republiek waardoor Batavia door zijn afgelegenheid in een nog groter isolement belandde. Eind 1795 zou de overheid zelf in een heel onduidelijke stuatie terechtkomen en moest een ieder in Batavia zich afvragen of het waard was om de oude prinsgezinde voorkeur aan te houden nu dezelfde Prins naar Engeland was uitgeweken. Was het nuttiger om het Bataafse patriottisme aan te hangen?

40 ANRI KBG Dir 0029, 285-286, vergadering 14-2-1792; 292, vergadering 2-4-1792; 296, vergadering 22-11-1792; 307, vergadering 4-2-1793 en 309, vergadering 25-2-1793.

41 ANRI KBG Dir 020, 328, vergadering 2-6-1794 en 331, vergadering 4-8-1794. Korte tijd later werd besloten het begraven te laten zoals het was, omdat het de kerken en de doodgravers van inkomsten voorzag (Van der Chijs 1885-1900, XI:815). 


\title{
PROGRAMMA
}

\author{
VAN HET
}

\section{BATAVIAASCH \\ GENOOTSCHAP}

Tot nut van KUNSTEN EN WEETEN SCHAPPEN in het gemeen,

DOCH IN HET BYZONDER,

Ter bevorderinge van de Welvaart der Oosfterfche Volkplantingen van den ftaat der

Verëenigde Nederlanden

Opgericht te BATAVIA den $24^{\text {ften }}$ April 1778 .

Onder de Zinspreuk

TEN NUTTE VAN HET GEMEEN:

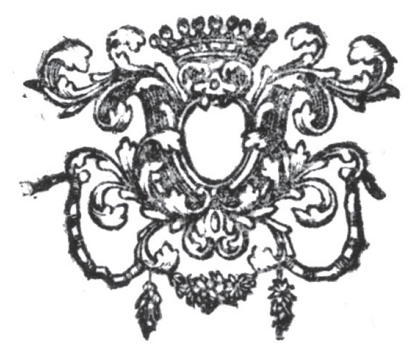

$$
\text { TE B A T A V I A, }
$$

Gedrukt in d'E: Compagnies Boek-drukkery, By EGBERT HEEMEN 1778.

Titelpagina van het eerste genootschapsprogramma, Batavia 1778 (collectie British Library/OIOC Londen) 
Naamgeving: kunsten en wetenschappen

Hoewel de naam die de nieuwe organisatie in $1778 \mathrm{kreeg}$, weinig specifiek lijkt en het programma, voor zover dat uit de naam af te lezen viel, ruim en algemeen was geformuleerd, verdient de naamgeving nadere aandacht. In een periode waarin talloze nieuwe genootschappen werden opgericht, die zich door hun naam wilden onderscheiden van andere en iets van hun oogmerken aan de naam probeerden mee te geven, paalde deze een territorium af. Met de keuze van 'genootschap', en niet 'gezelschap', 'sociëteit' of 'maatschappij', kozen Radermacher en de zijnen voor de meest gebruikte term, de term die het langst voor deze organisatievorm in gebruik zou blijven. Immers, in de drie andere termen hebben andere betekenissen de overhand gekregen. In het achttiende-eeuwse taalgebruik - daarop is al door anderen gewezen werden termen als gezelschap, genootschap, maatschappij en sociëteit vaak door elkaar gebruikt, zelfs ter aanduiding van een en dezelfde organisatie, zelfs door (bestuurs)leden van een bepaalde organisatie ter aanduiding van zichzelf. ${ }^{42}$ Radermacher koos voor de term die ook door de belangrijkste, verwante organisaties in Zeeland (1769), Rotterdam (1769) en Utrecht (1778) was gekozen. Het Haarlemse 'maatschappij' werd niet overgenomen. Die naam zou in Batavia verwarring met de VOC kunnen opleveren, die vaak als 'de Maatschappij' werd aangeduid.

Hadden de Zeeuwen en de Haarlemmers zich in hun naam tot 'wetenschappen' beperkt, Radermacher en de zijnen kozen voor 'kunsten én wetenschappen', zich aansluitend bij de collega's uit het Sticht: Provinciaal Utrechtsch Genootschap van Konsten en Wetenschappen. De combinatie kwam echter ook al voor bij de voorloper van het Zeeuwsch Genootschap: het Genootschap ter Bevordering van Nuttige Kunsten en Wetenschappen (1765). Bij Teylers Stichting (1778) kwam ook na de bevordering van de godsdienst, de aanmoeding van kunsten en wetenschappen, en het nut van het algemeen op een goede tweede plaats. Ook de Maatschappij Tot Nut van 't Algemeen (Amsterdam 1787) zou in Edam in 1784 beginnen als Genootschap van Kunsten en Wetenschappen. De combinatie van 'kunsten én wetenschappen' was dus bekend, en werd in verband gebracht met een brede doelstelling. Andere genootschappen omschreven in hun naam het minder uitgestrekte gebied dat zij bewerkten: letterkunde, wiskunde, natuurkunde, medische wetenschap of vaderlands recht.

'Kunsten' moet daarbij niet in de moderne betekenis van schone, beeldende of uitvoerende kunsten worden opgevat. Het Woordenboek der Nederlandsche

42 Singeling 1991:8; Kloek en Mijnhardt 2001:104. Op Vissers lijst uit 1970 van 78 geleerde genootschappen komen er 45 voor met in de naam 'genootschap', 17 met 'gezelschap', zeven met 'maatschappij' en maar twee met 'sociëteit' (Visser 1970:175-86). 
Taal zegt in 1916: 'Vroeger werd niet altijd hetzelfde onderscheid tussen kunsten en wetenschappen gemaakt als thans'. Het omschrijft 'kunst' in de oude betekenis als 'kennis, kunde, wetenschap' (WNT VIII,1: 554, 559). Pas het Koninklijk Instituut (Amsterdam 1808), de voorloper van de Koninklijke Nederlandse Akademie van Wetenschappen (1851), nam in zijn naam de toevoeging 'schoone kunsten' op. Door de publicaties van F.J. Riedel over de esthetica, in Nederland vertaald door H. van Alphen als Theorie der schoone kunsten en wetenschappen (1778-1780), begonnen de 'schone kunsten' zich van de andere kunsten en wetenschappen te onderscheiden. Het is veelzeggend dat de publicatie van Riedel-Van Alphen pas bij het Instituut van 1808 leidde tot het opnemen van de onderscheidende term 'schone' in de naam. Weglaten van dit epitheton zou kennelijk in 1808 menigeen op het verkeerde been hebben gezet. In 1778 waren kunsten en wetenschappen nog veeleer een tweeeenheid, grotendeels synoniemen.

De naamgeving lag bij de eerste publicatie, het Programma van 1778, nog niet helemaal vast. In de 21 artikelen werd veel geregeld, maar de naam komt er in zijn definitieve vorm niet in voor. Er wordt gesproken van 'het genootschap' of 'het Bataviaasch Genootschap'. Op de titelpagina van het programma omschreven de oprichters hun nieuwe organisatie uitgebreid als 'het Bataviaasch Genootschap tot nut van Kunsten en Weetenschappen in het gemeen, doch in 't byzonder ter bevordering van de Welvaart der Oostersche Volkplantingen van den staat der Verëenigde Nederlanden' en in de aanhef van de tekst werd het 'tot nut van kunsten en weetenschappen' van de titelpagina herhaald. Ook de erkenning door de Hoge Regering in Batavia van 30 juni 1778 sprak van 'een Genootschap tot nut van konsten en wetenschappen in het gemeen, doch in 't byzonder [...]'. Het 'nut' verdween echter al spoedig uit de naam, omdat het in een andere combinatie in de zinspreuk van het genootschap voorkwam: 'Ten Nutte van het Gemeen'. In deze zinspreuk, te lezen als 'tot voordeel van de gemeenschap, het gemenebest, de staat, het vaderland', kwamen de bedoelingen het meest pregnant naar voren. Bij de publicatie van het eerste deel van de Verhandelingen (september 1779) stond de naam vast. Het was het Bataviaasch Genootschap van Kunsten en Wetenschappen.

Het streven om nuttig te zijn voor de maatschappij blijkt nog duidelijker uit de onderwerpen van de vragen die in het Programma werden opgegeven. Wetenschap was vooral toegepaste wetenschap, kunst werd gebruikt de zin van kunde in het toepassen van kennis. In het Voorberigt tot de Verhandelingen $(1,1779)$ wordt de meervoudige vraagstelling over tyfus ('rotkoors') aangeduid als 'kunstvragen'. In 1781 worden de belangstellende inzenders van antwoorden op een prijsvraag naar de oorzaak van de aanslibbing van de Bataviase kust aangeduid als 'kunstminnaars' (VBG 1:34; VBG 3:14). Uit dit gebruik van 'kunst' blijkt opnieuw dat 'kunsten' in de eerste genootschapsjaren zeer dicht bij 'wetenschappen' lag en er moeilijk van waren te schei- 
den. De vragen die in het Programma van 1778 werden opgesomd, waren stuk voor stuk praktisch gericht, en vroegen beschrijvingen, verzamelingen, toepassingen, eerder dan zuivere kennis, theorieën of theorievorming. Ook in dit opzicht sloot Batavia zich bij Haarlem aan, waar in de naam van de Maatschappij weliswaar alleen de 'wetenschappen' voorkwamen, maar waar in Van der Aa's eerste voorrede tot hun Verhandelingen het ondersteunen en aanmoedigen van 'Weetenschappen en Konsten' eveneens in één adem werden genoemd. Een blik op de bekroonde Haarlemse prijsvragen in de periode 1753-1777 laat zien wat later in Batavia ook zou gebeuren: er werden praktische oplossingen gevraagd, toegepaste kennis, er werden oorzaken bevraagd waaraan de oplossingen van problemen moesten zijn gekoppeld. Veelzeggend is dat de eerste bekroonde prijsvragen in Haarlem gingen over de verzanding van rivieren en het wegslaan van het strand bij Petten (Bierens de Haan 1952:5, 209). In de eerste prijsvraag werd met nadruk gezegd dat men niet zat te wachten op 'Theoretise Raisonnementen' (Bierens de Haan 1952:202).

De naam lag in 1779 vast en die zou zo blijven. Veelal werd kortweg gesproken van het 'Bataviaasch Genootschap'. De 'kunsten en wetenschappen' bleven in de naam tot aan de omdoping in het Indonesisch in 1950, ondanks de verschuivingen in de aandacht van het genootschap. De 'kunsten' in negentiende- en twintigste-eeuwse (Westerse) betekenis kwamen helemaal niet meer aan bod. Respect voor de ouderdom van het genootschap weerhield latere bestuurders ervan om de 'kunsten' uit de naam weg te halen. Later zorgde de groeiende aandacht voor Indonesische kunstnijverheid ervoor dat de aandrang om de naam te wijzigen gering was.

\section{Doelstellingen}

Het belangrijkste document voor een verkenning van de doelstellingen ('oogmerken') van het genootschap vormt het Programma dat in de eerste maand van zijn bestaan werd geconcipieerd en werd gedrukt door compagniesdrukker Egbert van Heemen. Het bevatte het reglement ('verpligtingen', later vaak 'wetten' genoemd), een lijst van prijsvragen, een ledenlijst, een verslag van de eerste bestuursvergadering en de tekst van het instemmende plakkaat van de Hoge Regering. De kleine publicatie van 52 pagina's is een zeldzame brochure geworden, al liet het bestuur er twaalfhonderd van drukken, waarvan er minstens veertig naar de Republiek werden verstuurd. Het enige mij bekende exemplaar bevindt zich in de bibliotheek van de Oriental and India Office Collections te Londen. De tekst ervan werd in gewijzigde vorm in het 'Voorberigt' van de eerste bundel Verhandelingen (1779) opgenomen.

De openingswoorden van het programma zeggen, dat de taak van iedere 
sterveling is, te streven naar zijn eeuwig heil en vervolgens naar de bevordering van de welvaart 'der tydelyke t'zamenleevinge'. Uit de gedachte dat het najagen van eigenbelang verwerpelijk is en dat de belangen van de gemeenschap vóór horen te gaan, werd het genootschap geboren, waarbij de oprichting van de Oeconomische Tak als aanleiding fungeerde. Dit gedachtegoed is heel herkenbaar achttiende-eeuws en lag aan de basis van heel wat genootschappen.

Pas in artikel 5 van de 21 bepalingen waaraan de oprichters zich wilden binden, kwamen de uitgewerkte doelstellingen aan de orde. Vooraf werd een aantal praktische en organisatorische zaken geregeld: wie de leiding zou hebben, wie tot het lidmaatschap kon geraken en hoe vaak men zou vergaderen. Daarna volgden de doelstellingen. Eerst in negatieve zin: wat het genootschap niet zou doen. Het zou zich buiten alles houden wat ook maar enigszins de Oost-Indische Compagnie zou aangaan. Daarmee voldeed het aan een voorwaarde die essentieel was voor zijn levensvatbaarheid. Anders was er uit het Kasteel en vervolgens van de Heren Zeventien een verbod gekomen.

Daarna verwoordde het programma de eigenlijke doelstelling:

maar [het] zal daar tegen alle Kunsten en Weetenschappen poogen te bevorderen; al wat de natuurlyke Historie, Oudheden, Zeden en Gewoonten der Volken aangaat, zal het greetig ontvangen; echter is zyn voornaam doelwit, tot voorwerpen van zyn onderzoek te laaten dienen, zulke zaaken, die ten nutte van Landbouw, Koophandel en byzondere Welvaart deezer Volkplantinge kunnen strekken, en in allen opzichte als uitvoerlyk beöordeeld worden (Programma 1778:7).

Het ongespecificeerde 'alle kunsten en wetenschappen' wilde het bevorderen. De natuurlijke historie, oudheidkunde en volkenkunde van alle volken mochten onderwerp zijn van inzendingen (voorwerpen of alleen verhandelingen?). Pas op de derde plaats, maar dan wel als een 'voornaam doelwit' kwamen de op de Oeconomische Tak geïnspireerde landbouw, handel en de welvaart van 'deze volkplanting', het hele gebied van de VOC in Azië. Hoe belangrijk dit doel was, blijkt wel uit het feit dat Mercurius op de genootschapspenning prijkte en niet Minerva.

Het is verleidelijk om al in het begin van het aangehaalde citaat een beperking tot de regio te lezen, maar enige restrictie valt er niet anders dan zeer impliciet uit te halen. Dat, gevoegd bij de samenvatting op het titelpagina van het programma 'Tot nut van Kunsten en Weetenschappen in het gemeen, doch in het byzonder, ter bevordering van de Welvaart der Oostersche Volkplantingen van den staat der Verëenigde Nederlanden' doet ons concluderen dat er een encyclopedische begindoelstelling was. Die werd aangevuld met een praktische, meer gerichte tweede doelstelling die een geografische beperking in zich droeg tot het VOC-gebied.

De oprichters lieten zich als verlichte mannen kennen door zich, na een 
opsomming van zesenveertig vragen, die beantwoording behoefden en die het brede scala van landbouw, visserij, nijverheid, werktuigkunde en geneeskunde betroffen, nadrukkelijk niet op een superieur Westers standpunt te plaatsen. Zij gaven aan dat inheemsen de aangewezen personen waren om voor de beantwoording van die vragen bouwstenen aan te dragen:

En dewyl, zoo wel in het onderzoek der bovengemelde vraagen, als ter bevorderinge onzer kennisse omtrent den waaren toestand deezer Gewesten, noodig is, het gevoelen van den kundigen Land-zaat in te neemen; verzoekt het Genootschap een iegelyk, de gedachten der Inlanders, op zulke zaaken die binnen den kring hunner kennisse staan, altoos af te vraagen, en deeze lieden, door alle vriendelyke behandelingen, tot eene vrymoedige verklaaring aan te wakkeren (Programma 1778:23).

Dat inheemsen ook tot het lidmaatschap konden worden gekozen, daar werd niet van gerept. Het zou een genootschap van VOC-beambten en vrije (Nederlandse) burgers worden. Het eerste Indonesische lid zou pas in 1826 worden begroet. In het verlengde van bovengemelde aanbeveling om de 'landzaat' als informant te gebruiken, meldden de oprichters nog dat zij bijzonder gespitst waren op het ontvangen van 'alle berichten over Volken, Taalen, Zeden, Oudheden en Geschiedenissen dezer Gewesten' (artikel 17). Ook al waren die in te zenden berichten geen antwoorden op een van de 46 vragen, men kon toch 'staat maaken op de edelmoedigste vergeldinge' (Programma 1778:23). Het is juist dit artikel dat de kern vormt van de beperking tot de taal-, land- en volkenkunde van Indonesië, die in de loop van de negentiende eeuw bij uitsluiting het aandachtsgebied van het genootschap zou worden. Een beweging die in de volgende decennia zichtbaar wordt van encyclopedisch, alles omvattend, naar specialistisch, beperkt van aandachtsgebied.

Als ruimdenkend deden de mannen van het eerste uur zich andermaal kennen, toen zij ter afsluiting van het reglement voorspelden dat rijke overvloed en groot genoegen te verwachten waren 'wanneer het ons zal mogen gebeuren, eene menigte van zwaarigheden door een nauwkeurig onderzoek te overwinnen, en vooral die treffende Elenden, waardoor zoo menig Landzaat, en zoo veele Vreemdelingen dagelyks verlooren gaan'. In deze passage over verbeteringen op het gebied van ziekte en hygiëne vindt de landzaat een plaats vóór de Europese vreemdeling (Programma 1778:26).

\section{Ledenwerving en erkenning}

In het Programma van 1778 werd in het eerste artikel van het reglement vastgesteld dat het genootschap bestond uit een opperdirecteur en directeuren, respectievelijk de gouverneur-generaal en de leden van de Hoge Regering, 
en uit leden, 'gekooren uit de aanzienelykste, kundigste en welgezindste Ingezetenen, niet alleen deezer Hoofdplaatze, maar uit alle Bezittingen der Edele Compagnie in deeze Gewesten' (Programma 1778:5). De ambities bleven niet tot de stad Batavia beperkt. Er waren dus twee categorieën: directeuren en gewone ('ordinaire') leden. In de tweede bestuursvergadering, op 3 augustus 1778, werden er 117 directeuren en leden geteld, van wie er een maand later al 56 de contributie, het fournissement van vier ducaten of elf rijksdaalders, hadden betaald. ${ }^{43}$ Uiteraard waren dat vooral Bataviase leden; de buitenplaatsen konden nog nauwelijks van de nieuwe organisatie weten.

In het Programma stonden 104 Bataviase leden geteld naast de elf directeuren, samen 115 personen, waarnaast nog de veertig namen van mannen buiten Batavia aan wie het werd toegestuurd. In hetzelfde jaar kwam het eerste grote contingent leden van buiten Batavia binnen. Gouverneur Johannes van der Burgh van Java's Noord-Oost-Kust meldde 21 leden uit zijn gouvernement aan. ${ }^{4}$ Tegen de tijd van de eerste algemene vergadering, op 8 maart 1779, waren er 160 leden. In het midden van hetzelfde jaar, dus ruim een jaar na de oprichting, werden er 192 geteld. ${ }^{45}$

Afgaande op deze cijfers kan van een goede start worden gesproken, zeker wanneer we met de hoogte van de contributie rekening houden. Die was niet gering. Er was kennelijk geen grote aarzeling om toe te treden. Uit de ledenlijsten die in de Verhandelingen verschenen, blijkt dat de aantallen in de achttiende eeuw goed op peil bleven, steeds rond de 200. In 1794 - de laatste gedrukte gegevens van de eeuw - waren er 204 leden. Het topjaar was 1790: 209 leden. Dat hoge aantal werd bereikt door de benoeming van 62 Bataviase leden en nog eens 77 op de buitenkantoren in een periode van hernomen activiteit en ter voorbereiding op een betere presentatie tijdens de algemene vergadering van 1790. Wat het overzicht niet weergeeft, is de terugloop in de jaren 1785-1789. In 1784 werden voor het laatst nieuwe leden benoemd, daarna pas weer op 4 februari $1790 .{ }^{46}$ Een soortgelijk verloop moet na 1794 zijn opgetreden. ${ }^{47}$

\footnotetext{
43 ANRI KBG Dir 0001, vergadering 3-8-1778 en 7-9-1778.

44 ANRI KBG Dir 0001, 30, vergadering 7-12-1778. Programma 1778:27-39, voor de namen van de directeuren en leden te Batavia, 40-45 voor de leden buiten Batavia. Er waren op Java's Noord- en Oost-Kust maar drie personen aangeschreven. De oogst van 21 nieuwe leden was dus een succes.

45 ANRI KBG Dir 0001, 53, vergadering 8-3-1779, bevat de eerste ledenlijst na de opsomming in het Programma 1778. Die kwam tot de som van één opperdirecteur, negen directeuren, vijf directeuren op de buitenkantoren en 145 leden van wie er 105 in Batavia verbleven. Zie ook de ledenlijst in VBG 1:61-84.

46 ANRI KBG Dir 0020,109-110, vergadering 4-11-1784; 176-183, vergadering 4-2-1790.

47 De gegevens uit VBG 4 (1786) hebben nog betrekking op 1783. In dat jaar nam Radermacher de kopij voor dat deel mee naar de Republiek om het daar te laten drukken.
} 
De aanmeldingen van de buitenkantoren waren voor de hele periode goed: naast de al genoemde reactie van de Noord-Oost-Kust van Java, waren er vóór de eerste algemene vergadering, dus nog binnen het eerste genootschapsjaar, reacties uit Cheribon, Souratte, Ceylon, Ternate, Padang en Bengalen. ${ }^{48}$ In Hougly (Bengalen) stond Radermachers broer Samuel op de lijst.

Overzicht van leden volgens de opgaven in de Verhandelingen 1-7

\begin{tabular}{lccccccc}
\hline & 1779 & 1780 & 1781 & 1786 & 1790 & 1792 & 1794 \\
\hline Aantal leden & 192 & 201 & 207 & 206 & 209 & 195 & $204^{49}$ \\
\hline
\end{tabular}

Aan ledenwerving lag een ledenprofiel ten grondslag. Behalve de maatschappelijke status en een zeker vermogen telde of men 'liefhebber' was, behorend tot 'het geletterd en letterminnend Oost-Indië'. In de circulairebrief die met het Programma in augustus 1778 werd meegestuurd en die een wijde verspreiding kreeg, zei het bestuur zich verzekerd te weten van de 'waare zucht voor het lieve Vaderland en deeze Colonie' van de aangeschreven heren, aan wie werd verzocht zich in te zetten ter bereiking van de 'nuttige oogmerken' van het genootschap. ${ }^{50}$ Voor Batavia kan het niet anders of het eerste bestuur had de lijst van collega's-VOC-beambten en vrije burgers nagelopen om te zien hoe groot het aantal belangstellenden zou kunnen zijn. Dat de eerste lijst meteen meer dan honderd Bataviase namen bevatte, was een gunstige aanwijzing. Nog blijken moest of alle aangeschreven personen vereerd zouden zijn en de contributie voor het lidmaatschap zouden willen betalen. De ambities waren ook in dit opzicht groot. Men wilde een flink deel van de Nederlandse groep in Batavia insluiten. De circulaire was voor wat betreft de mogelijke leden op de buitenkantoren en op Java gestuurd naar zeventien gebieden: Ambon, Banda, Ternate, Makassar, Malakka, Coromandel, Ceylon, de Kaap, Java's Noord-Oost-Kust, Bengalen, Souratte, Sumatra's West-Kust, Malabar, Bantam, Timor, Banjarmasin en Palembang (in deze volgorde), soms gericht tot één persoon, in het geval van Ceylon tot vijf personen. Op de brief met het programma werd goed gereageerd. In het midden van 1779 waren er al 73 leden buiten Batavia. Dat aan de roep om zich aan te sluiten buiten

\footnotetext{
48 ANRI KBG Dir 0001, 45, vergadering 8-3-1779.

49 In bijlage $1 \mathrm{~A}$ is het aantal leden over deze periode uitgesplitst naar vier categorieën, directeuren, dirigerende leden, leden in Batavia en leden op de buitenkantoren. Vergelijk ook het overzicht bij Snelders 1979:75-6. Voor de gegevens over 1794 raadpleegde ik het zeldzame exemplaar in de bibliotheek van de RUL van het eerste stuk van deel 7 van VBG (1794) dat niet voltooid werd.

50 Exemplaren van deze gedrukte circulaire in de bundel correspondentie ANRI KBG Dir 0980, nr [1] en [55].
} 
Batavia iets langzamer gehoor werd gegeven, is niet verwonderlijk gezien de afstanden die de circulaire van 1 augustus 1778 moest afleggen. Ondanks die afstand bleef het aantal leden buiten Batavia, ook na het enthousiaste begin, in de achttiende eeuw goed op peil.

Twee vragen zijn van belang: wie waren die leden en hoe hoog was hun plaats op de maatschappelijke ladder? Als we kijken naar de oudste, alfabetische ledenlijst, die van maart 1779, die in het archief is overleverd, blijken er 160 namen, 144 van contribuanten. ${ }^{51}$ Directeuren betaalden geen contributie, maar traden wel als mecenas op. De leden waren vermogend genoeg om de elf rijksdaalders per jaar op te brengen, een aanzienlijke som die de scheidslijn tussen liefhebbers met vermogen en aanzien en onvermogende liefhebbers trok. Misschien was de hoogte van de contributie mede vastgesteld om de oprichters in staat te stellen een scheidslijn te trekken tussen wie zij wel en niet als lid wilden toelaten. Op de lijst van 105 Bataviase leden en 39 leden van buiten Batavia, komen we een keur van beroepen tegen.

Leden van het Genootschap (lijst 1779)

\begin{tabular}{lcc}
\hline functies & Batavia & Buitenkantoren \\
\hline Opperkoopman & & \\
Resident/Gezaghebber & 6 & 4 \\
Koopman & 15 & 8 \\
Onderkoopman & 21 & 7 \\
Militair & 10 & 1 \\
Schipper & 8 & \\
Rechterlijke functies & 8 & 1 \\
Predikant & 6 & \\
Medische functies & 6 & 6 \\
Schepen/oud-schepen & 6 & \\
Boekhouder & 4 & 39 \\
Overige functies & 15 & \\
Totaal & 105 & \\
\hline
\end{tabular}

Inzicht in de hiërarchie van het ledenbestand geeft de lijst die in de eerste bundel Verhandelingen, later in 1779, werd afgedrukt. De Bataviase leden zijn

51 De lijst aan het Programma 1778 toegevoegd, die overigens niet alfabetisch, maar hiërarchisch was gerangschikt, reken ik niet mee, omdat die niet op basis van contributiebetaling was opgesteld, hoewel voor Batavia kennelijk wel instemming was gevraagd.

52 Onder dezen zaten een paar hoog geplaatsten: twee secretarissen van de Hoge Regering, de commissarissen van de Bank en van de Inlander, twee weesmeesters, twee vendumeesters, het opperhoofd van het Generale Soldijkantoor, twee gezworen klerken van schepenen, een geheimschrijver, een bouwmeester ('fabryk'), de onder-equipagemeester en ook Jacob van Heemskerk, die in afwachting was van zijn vertrek naar Padang om daar gezaghebber te worden. 
daar, net als in het programma van een jaar eerder, niet alfabetisch opgenomen, maar ingedeeld 'naar den rang, dien zy by de Maatschappye bekleden', dus afhankelijk van ieders positie binnen het VOC-bedrijf. Radermacher nam de tiende plaats in op de lijst van zestien directeuren, waartoe ook de raden extra-ordinair op de buitenkantoren werden gerekend. De lijst van de gewone leden werd aangevoerd door de eerste en tweede secretaris van de Hoge Regering, Dirk Goetbloed en Adriaan de Bock, die werden gevolgd door een lid en oud-lid van de Raad van Justitie, de kolonel-hoofd van de militie, de ad-interim advocaat-fiscaal, de baljuw, de drossaard van de Bataviase Bovenlanden en een oud-drossaard, en de eerste opperkoopman van het Kasteel. Dit hooggeplaatste Bataviase tiental werd gevolgd door militairen, predikanten, opperkooplieden, kooplieden en schippers om te eindigen bij de nederige rangen, nog maar net verkoren tot het lidmaatschap: onderkooplieden, procureurs, gezworen klerken en als laatsten de adjunct gezworen klerk van de Raad van Justitie, Pieter Leonardus van Eys en de opperstuurman Pieter Johan van Rhede. Bij hen sloten zich de rijen. Gewone klerken, schrijvers en schoolmeesters hoorden tot het lagere kader en waren uitgesloten. Bij de 73 leden op de buitenkantoren op dezelfde lijst waren de scheidslijnen overeenkomstig. Bovenaan stonden de gouverneurs, directeuren en gezaghebbers, onderaan de onderkooplieden, boekhouders, een pakhuismeester en enkele lagere officieren (vaandrig en cornet). ${ }^{53}$

In de circulaire van 1 augustus 1778 was geen duidelijke indicatie gegeven waar de scheidslijn lag, maar wie de brief met het programma van het genootschap kreeg, kon zich uitverkoren voelen. De brief ging met vierhonderd exemplaren van het programma naar de honderd Bataviase leden en met driehonderd exemplaren naar de buitenkantoren. ${ }^{54}$ Een ruime verspreiding en ook een teken dat men rekende op uitbreiding. De aangeschrevenen konden exemplaren van het programma uitdelen en zo voor het genootschap reclame maken. De aan het programma toegevoegde lijst van Bataviase leden alsmede de lijst van veertig 'Heeren [buiten Batavia] aan welke dit Programma verzonden en aangeprezen word $t^{\prime}$ fungeerde als indicator van het beoogde ledenbestand. ${ }^{55}$ Wie de lijst goed bekeek, begreep waar de scheidslijn lag. Degenen die zich daarna aansloten, hadden eerst kunnen zien of zij bij de nieuwe organisatie pasten. Als hun naam op de lijst voorkwam,

53 VBG 1:164-84. De gouverneurs-directeuren op de buitenkantoren waren in het Programma 1778 niet als directeur van het genootschap opgenomen. Op de lijst in VBG 1 (1779) komen zij als zes raden extra-ordinair wel op de lijst van directeuren voor, die daardoor zestien namen bevatte.

54 ANRI KBG Dir 0001, 10-11, vergadering 3-8-1778.

55 Programma 1778:27-45. Ook VBG 1:75 heeft deze indicatie. Niet: leden buiten Batavia, maar heren aan wie het programma is toegezonden. Toch staat op die lijst al een aantal namen van personen die op de eerste mailing van 1778 hadden gereageerd. 
konden zij bijna niet minder dan op de uitnodiging ingaan. Als hun naam er niet op stond, konden zij bekijken of er personen van hun rang en stand op voorkwamen: een reden om mee te willen doen. En zo breidde het ledenbestand zich uit. Vijf leden op 6 september 1779 (predikant, koopman en drie onderkooplieden), drie leden op 27 december 1779 (eerste klerk, opperhoofd van het soldijkantoor en regent van het Moorse hospitaal), twee leden op 1 april 1780 (schipper en oppermeester). ${ }^{56}$ Toen procureur Jan de Groote op 2 juli 1781 op eigen verzoek lid mocht worden, kreeg hij direct de opdracht om een alfabetisch register te maken, de nederigste werkzaamheden voor een laag geplaatst lid. ${ }^{57}$ Overigens was het gebruikelijk om voorgesteld te worden als lid. Zelfaanmeldingen zijn hoogst zeldzaam.

Vanaf 1780 werden de leden in Batavia als 'ordinaire' leden aangeduid en die in de andere vestigingen van de compagnie als 'extra-ordinair'. In 1779 waren al de eerste 'correspondenten' aangezocht: de boekhandelaars Reijnier Arrenberg in Rotterdam en Johannes Allart in Amsterdam, die in de Republiek herdrukken van de genootschapsuitgaven mochten gaan verzorgen en bij wie boeken en tijdschriften besteld werden. Later werden zij als 'gemagtigden' aangeduid. ${ }^{58}$ De eerste wetenschappelijke correspondent was in februari 1781 de Fransman David Charpentier de Cossigny, die vanuit Mauritius een verhandeling over de productie van indigo had gestuurd. ${ }^{59}$ In hetzelfde jaar werden twintig 'leden-correspondenten' op de buitenkantoren benoemd om het inzamelen van de contributie gemakkelijk te maken. Tegelijk werd de eerste correspondent in Europa, buiten de Republiek, benoemd: Georg Christoph Lichtenberg in Gotha. ${ }^{60}$ Hoewel dus sommigen ook binnen het VOC-gebied als 'correspondent' werden aangeduid, was het duidelijk dat zij geen wetenschappelijke status hadden Op de buitenkantoren fungeerden zij als penningmeester. Buiten het VOC-gebied waren het mannen met een reputatie als geleerde. Dit werd nog duidelijker toen in augustus 1782 deze categorie aanzienlijk werd uitgebreid met de benoeming van 28 personen in het vaderland met wie het genootschap al meer dan twee jaar in correspondentie stond. Behalve de secretarissen van de genootschappen in Haarlem, Vlissingen, Rotterdam, Utrecht en Groningen (het Genootschap ter bevordering van het Vaderlandsch Regt) ging het om een keur van hoogleraren, medici, theologen, taalkundigen, plantenkundigen als G. Bonnet,

56 ANRI KBG Dir 0003, 9, vergadering 27-12-1779, art. 6, en KBG Dir 0006, vergadering 1-41780 , art. 5.

57 Of Jan Groot de Jonge, zoals hij voorkomt op de ledenlijst in VBG 3:36? ANRI KBG Dir 0015,

375 , vergadering 2-7-1781.

58 ANRI KBG Dir 0001, 72-76, vergadering 7-6-1779.

59 ANRI KBG Dir 0012, vergadering 5-2-1781, art. 8.

60 ANRI KBG Dir 0014, 366-367, vergadering 7-5-1781. 
J.A. Vos, P. Hofstede, A. Vosmaer, N.L. Burman, E. Scheidius, P. Hennert, H.A. Schultens en P. Camper. Naast de belangrijkste genootschappen in de Republiek waren nu ook de belangrijkste universiteiten en hogescholen met Batavia verbonden.

Bovendien werd het buitenland verder bewerkt: Sir Josua Banks van de Royal Academy, de Marquis de Condorcet van de Parijse Académie, de botanicus C.P. Thunberg uit Uppsala, secretaris J.E. Euler van de Petersburgse Academie en A.F. Busching, directeur van het Gymnasium in Berlijn. Verder werden de Deense missionarissen in Tranquebar, de missionarissen in Peking en supercargo (opzichter) P. Kintsius in Peking aangewezen als 'correspondenten in India'. ${ }^{61}$ De indrukwekkende lijst van correspondenten in de Republiek, in Europa en daarbuiten maakt duidelijk dat het genootschap, zo het nog niet als achtenswaardig te boek stond, geen mogelijkheid tot het leggen van contact ongebruikt liet om erkenning te ontvangen.

Tenslotte vergat het bestuur niet om naast de wetenschappelijke correspondenten adellijk en bestuurlijk Nederland te informeren. Daarmee probeerde het niet alleen bekendheid te verwerven, maar ook erkenning en respect af te dwingen voor het initiatief om zo ver van huis een genootschap van kunsten en wetenschappen op te richten. Na de erkenning door de Hoge Regering te hebben ontvangen, schoot het genootschap meteen zo hoog mogelijk: de Stadhouder moest beschermheer worden, zoals hij dat ook was van de belangrijkste genootschappen in het vaderland. Op 15 oktober 1778 schreef Radermacher daarover aan Willem V, onder aanbieding van het Programma. 'Mogt het uw Doorlugtigste Hoogheid behage onse Eerbiedige hulde aen te neemen en het zelve met uw Doorlugtigste Hoogheids protextie te verëeren zo vleije ik mij dit genoodschap door zijne verdubbelde pogingen geen onëer aen onse Republicq zal doen'.62 Daags daarna deed Reinier de Klerk hetzelfde verzoek. Op 21 oktober deed Van Hogendorp er aan de Stadhouder nog een schepje bovenop. ${ }^{63}$ Met de retourvloot van dat jaar werd Willem V dus drie maal bewerkt om beschermheer te worden. Hoewel Radermacher

\footnotetext{
61 ANRI KBG Dir 0018, 400-402, vergadering 6-8-1782. Het grootste deel van de correpondenten had al een jaar eerder post gekregen uit Batavia met het programma (het voorbericht van VBG 3). Zie ANRI KBG Dir 0016, 379-385, vergadering 13-8-1781. De complete lijst van Mecenaten, Gemachtigden en Correspondenten in ANRI KBG Dir 0019 [24]. In het programma voor 1782 werd de naamlijst van de wetenschappelijke correspondenten voor het eerst gedrukt, 29 in de Republiek, vijf in het Europese buitenland, en vier in China, Tranquebar en op Mauritius. Zie Programma 1782. Later werd dit programma herdrukt in VBG 4 (1786), Rotterdam en Amsterdam. Oud-secretaris J.C. Metzlar nam de lijst toen in Rotterdam ongewijzigd over.

62 Koninklijk Huisarchief, Archief Stadhouder Willem V, 331-21, correspondentie Radermacher, nr 3, 15-10-1778.

63 Brief van R.de Klerk van 16-10-1778, in Koninklijk Huisarchief, Archief Stadhouder Willem V, 333-10, nr 1. Van Hogendorps brief van 21-10-1778 geciteerd bij Der Kinderen (1878:145-6).
} 
zijn pogingen herhaalde in 1779, bij de aanbieding van het eerste deel van de Verhandelingen, en in 1780 bij het aanbieden van het tweede deel, kwam het niet tot de stadhouderlijke bescherming. Bij de aanbieding van de gouden medaille aan Willem V, met het programma van 1782, kwam Radermacher er dan ook niet meer op terug. Het is niet duidelijk of beleefdheidshalve niet langer werd aangedrongen, dan wel of er een signaal uit Den Haag was gekomen, dat het beschermheerschap de Stadhouder niet gelegen kwam. ${ }^{64}$

In 1778 ging het programma ook naar de drie 'maatschappijen', waarmee steeds de genootschappen in Vlissingen, Haarlem en Rotterdam werden bedoeld. ${ }^{65}$ In september 1779 werd aan het eerste deel van de Verhandelingen een wijdere verspreiding gegeven. Ook de Hertog van Brunswijk, de vroegere voogd van de Stadhouder, en de Prins van Nassau-Weilburg, getrouwd met de zuster van de Stadhouder, kregen hun exemplaar. Verder gingen er boeken naar de raadpensionaris van Holland P. van Bleiswijk en griffier $\mathrm{H}$. Fagel, naar de Amsterdamse kamer (zes exemplaren), advocaten F.W. Boers en D.A. Meerman van der Goes, beiden te Amsterdam, verder de eerste edele van Zeeland, W.C.H. baron van Lynden van Blitterswijk, en de boekhandelaren Allart en Arrenberg. In totaal gingen er vijfentwintig exemplaren naar de Republiek. ${ }^{66}$

De eerste reacties op de zendingen van 1778, brieven uit Haarlem en Vlissingen, kwamen pas in februari en april 1780 ter sprake. Zij waren medio 1779 geschreven en verstuurd. Tot die tijd was alle correspondentie geconcentreerd in het VOC-gebied: berichten van Java, Makassar, de Kaap, Cheribon. De correspondentie die op gang kwam met de zustergenootschappen was een vorm van erkenning. Haarlem, Vlissingen en Rotterdam gingen in op het verzoek om prijsvragen uit te schrijven op kosten van het genootschap in Batavia. ${ }^{67}$ Zelfbewust vergrootte het bestuur het correspondentienetwerk. In 1781 ging het derde deel van de Verhandelingen met zeventig brieven naar de Republiek, veertien ervan handgeschreven, zesenvijftig met een gedrukte circulaire. Behalve naar de Prins van Oranje, de Hertog van Brunswijk en de

\footnotetext{
64 Koninklijk Huisarchief, Archief Stadhouder Willem V, 331-31, correspondentie Radermacher als voorzitter Bat. Gen. nr 3, brief van 1-10-1782 van Radermacher en Metzlar waarbij het programma en de medaille worden aangeboden. Helaas zijn het programma noch de medaille aanwezig in het Huisarchief. In een aanbiedingsbrief van Radermacher en Metzlar van 7-11-1781 bij dl 3 van VBG wordt evenmin langer op de aanvaarding van het beschermheerschap aangedrongen (Koninklijk Huisarchief, Archief Stadhouder Willem V, 331-31 nr 2).

65 ANRI KBG Dir 0001, 11, vergadering 3-8-1778.

66 ANRI KBG Dir tussen 0002 en 0003, 7, vergadering 6-9-1779.

67 Brief uit Haarlem van secretaris C. van der Aa, dd 17-6-1779, in ANRI KBG Dir 0980, nr [26]. Brief van I. Winkelman en J. Tjeenk, s.d. maar vermoedelijk ook mei 1779, id. nr [24]. Vermelding van de Haarlemse brief tijdens de vergadering van 7-2-1780, ANRI KBG Dir 0004, art. 9. Zeeuwse brief besproken tijdens de vergadering van 1-4-1780, art. 2, ANRI KBG Dir 0004.
} 
Prins van Nassau-Weilburg, gingen de geschreven brieven naar de zes kamers van de VOC, advocaat Boers, de twee boekhandelaren van het genootschap en de drie zustermaatschappijen. De circulaires gingen naar hoogleraren, predikanten, provinciale en stedelijke bestuurders en VOC-bewindhebbers, vertegenwoordigers van de adel, gemachtigden in Nederland en ook naar familieleden: Radermacher zorgde dat zijn neef Daniël in Middelburg, zijn broer Johan in Amsterdam en zijn zoon Frans Reinier in Middelburg op de verzendlijst kwamen. Zes Latijnse brieven met boeken gingen naar de geleerde correspondenten in Londen, Uppsala, St. Petersburg, Parijs, Berlijn en Gotha. ${ }^{68}$

Met directeuren, ordinaire en extra-ordinaire leden, gemachtigden, weldoeners en correspondenten, verspreid over Azië, Europa en Afrika, met zustergenootschappen waarmee het samenwerkte, met uitgeschreven prijsvragen en uitgaven, had het Bataviaasch Genootschap in betrekkelijk korte tijd een organisatie opgezet die vergelijkbaar was met genootschappen in de Republiek. Hoewel het veel van de drie zustergenootschappen kopieerde, waren er toch aanzienlijke verschillen. Door de overeenkomst in naam van de betrokken personen - directeuren en leden - leek het Bataviaasch Genootschap uiterlijk meer op dat van Haarlem dan het feitelijk deed. De directeuren in Haarlem bepaalden het beleid en droegen het genootschap financieel met jaarlijkse bijdragen. In Batavia was de directeursfunctie bijna geheel ceremonieel en traden de directeuren op als weldoener, zij het incidenteel. In Batavia betaalden de leden jaarlijks contributie, in Haarlem betaalden de leden juist niet. $\mathrm{Zij}$ droegen berichten en verhandelingen bij en waren daartoe ook verplicht. De beleids- en bestuursfunctie van de directeuren in Haarlem werd in Batavia gedragen door de dirigerende leden, een uit de leden gekozen bestuur. In Batavia kwamen de directeuren nauwelijks bijeen, met uitzondering van de vijf algemene vergaderingen waar zij tevens het bestuur en de leden troffen.

Menig lid in Batavia zal van kunsten en wetenschappen geen flauw benul hebben gehad, maar de contributie hielp. Het gemis aan geleerde leden werd opgevangen door een netwerk van correspondenten op te bouwen. Alleen, hoe gerenommeerd zij ook waren, zij droegen geen kopij bij voor de Verhandelingen. Zij gaven het genootschap door correspondent te zijn enig aanzien. De rol van de leden in Haarlem, Vissingen en Rotterdam, werd in Batavia in de eerste jaren grotendeels vervuld door het bestuur. Het zorgde zelf voor de kopij. De bestuursleden bepaalden ook het beleid. Dat die groep zo klein was, zou op korte termijn al een probleem blijken te zijn. Uit het vaderland kwamen heel weinig bijdragen. Gevolg daarvan was dat de 
Verhandelingen lang niet met de regelmaat van één deel per jaar zouden verschijnen. Tussen 1779 en 1792 verschenen zes delen, deel 7 werd pas in 1814 voltooid. Het ledenbestand in Batavia en de rest van Indië was zeer verschillend van dat in Haarlem, Rotterdam en Vlissingen. Daarom liepen de ambities van Radermacher om een geleerd genootschap te worden à la Haarlem spoedig spaak. Restte een genootschap van liefhebbers, maar van het open type, een publieksgenootschap met de ambities van een geleerd genootschap en met elementen die aan het reformistische genootschap doen denken.

Daarmee past het Bataviaasch Genootschap niet duidelijk in één van de drie categorieën waartoe Mijnhardt en Kloek besloten (Kloek en Mijnhardt 2001:113-7). Het lijkt een genootschap dat kenmerken van alle drie categorieën in zich verenigde. Dat hoeft niet te verwonderen, waar in het Batavia van 1778 het Bataviaasch Genootschap als enige naast de Loge aan de sociabiliteitsbehoefte van de burgerij tegemoet kwam. Met loge en genootschap had het publieksgenootschap een grotere kans van bestaan dan het geleerde genootschap, waarvoor de voedingsbodem te gering was. Een sterk reformistisch genootschap zou spoedig in conflict raken met de regering, vandaar dat bij het programma van 1778 de handels- en landbouwvragen waren verpakt in een kader van algemeen omschreven kunsten en wetenschappen.

\section{Prijsvragen}

Prijsvragen uitschrijven was voor alle genootschappen van naam, die zich niet wilden beperken tot een kleine informele en lokale kring, dé manier om zich te doen kennen. Daarnaast was het uitgeven van verhandelingen natuurlijk een manier om naam te maken. Waren de prijsvragen bedoeld om de creativiteit van inzenders te stimuleren, in de verhandelingen van het genootschap kwamen de uitgelezen inzendingen voor. Om de prijzen die aan deze vragen of probleemstellingen gekoppeld waren, ging het de inzenders natuurlijk op de eerste plaats. Gouden en zilveren medailles of geldbedragen telden zwaar. Daarnaast was de eer bekroond te zijn door een gerenommeerd genootschap met de eraan verbonden publicatie van de inzending in de serie boekwerken een niet geringe immateriële beloning. Menigmaal kregen inzenders geen prijs maar wel een eervolle vermelding, soms werden ook inzendingen met een eervolle vermelding gepubliceerd. Het Bataviaasch Genootschap week niet af van het inmiddels in Nederland bekende stramien en schreef meteen in het eerste programma maar liefst 46 vragen uit. Daarmee sloot het aan bij de Oeconomische Tak van de Hollandsche Maatschappij. Had de gerespecteerde Haarlemse moeder-Maatschappij der Wetenschappen zich beperkt tot maximaal twee prijsvragen per jaar, de economische dochter wist van geen ophouden en schreef er in de eerste twintig jaar maar liefst 753 uit 
(Bierens de Haan 1952:43). De mannen in Batavia volgden in eerste instantie hun Haarlemse (economische) broeders, eerder dan de deftige heren van de Maatschappij.

Indachtig de gekozen zinspreuk (Ten Nutte van het Gemeen) werd om de oplossing gevraagd van allerlei problemen die te maken hadden met de economie van Nederlands-Indië en die zo de samenleving ten goede zou komen. De 46 prijsvragen vielen uiteen in de categorieën landbouw (23), visserij (2), nijverheid ('fabryken', 8), werktuigkunde (8), geneeskunde (3) en letterkunde (2). Ze spoorden niet alleen aan tot nadenken, maar vooral tot doen: het ontwerpen van een beter soort ploeg voor de droge rijstbouw, het aanplanten van moerbeibomen, peper en cacao, het winnen van zijde en wol, het verbeteren van de visvangst in de natte moesson, het bakken van vloertegels, een oplossing voor een baggerprobleem, om er slechts enkele te noemen. De Oeconomische Tak, uit wiens programma inspiratie was geput, werd door het bestuur vooral nagevolgd in het daadkrachtig onder de aandacht van het publiek brengen van 'economische' onderwerpen. Zelfs de vaderlandslievende ideologie van de Tak, alles ten dienste van het herstel van de voor het vaderland essentieel geachte handel, onderschreef het Bataviaasch Genootschap van harte. Wie zich daar niet bij aansloot mocht zich 'geen rechtschapen Nederlander' noemen (Programma 1778:4). In de eerste circulaire van het genootschap werd dan ook naar de vaderlandsliefde van de geadresseerden verwezen. ${ }^{69}$

De in het programma vooropgestelde bevordering van 'alle kunsten en wetenschappen' werd aldus geconcretiseerd in de oplossing van een aantal heel praktisch geformuleerde doelen. Die vormden het 'voornaam doelwit' van het nieuwe genootschap (Programma 1778:7). Alleen bij geneeskunde werd duidelijk gevraagd om een 'Tractaatje of kort Opstel' over buikloop, met 'Theoretische en Practische gronden [...] Oorzaaken, Teekenen dier Oorzaaken, Geneezings-Aanwyzingen en meest-dienstige Hulpmiddelen'. Tegelijk werd ook een vraag gesteld naar een soortgelijk opstel over verstopping van de ingewanden. Zelfs in de afdeling Letterkunde was een van de vragen praktisch geformuleerd: wie aantoonde het Maleis, Javaans, Chinees of andere oosterse talen beter te beheersen dan men gewoon was om zich heen te zien, zou voor een prijs in aanmerking komen. Na deze taalverwervingsopdracht volgde de tweede en laatste letterkundige vraag bijna als een toegift: 'Voor die het beste Nederduitsche Vaers maakt, en daarin aantoont den Invloed der Wetenschappen op de Zeden' (Programma 1778:20-2). Het was meteen de enige vraag waaruit geen specifieke relatie met de Indische situatie sprak. Die vraag kon door ieder genootschap, waar ook gesitueerd, gesteld zijn. 
De 46 vragen werden de wereld ingestuurd 'zonder de minste voorkeur of bepalingen van tijd'. Daarmee week het genootschap af van het vaderlandse gebruik om meteen bij de opgave van prijsvragen de uiterste inzenddatum te vermelden. De motivering van de afwijking van dit gebruik klonk duidelijk: 'vermits zulks met de gelegenheid dezer landen niet overeenkomt'. Daarmee kon niet anders dan de geïsoleerde ligging ten opzichte van de Europese republiek der letteren bedoeld zijn. Was het bestuur wijs om zo min mogelijk beperkingen op te leggen, bang dat binnen de beperkte Europese gemeenschap weinig animo zou bestaan voor de vragen? Het ontbreken van een uiterste inzenddatum betekende dat antwoorden uit Indië, in het bijzonder van Bataviase inwoners in het voordeel zouden zijn: wie het eerst komt, die het eerst maalt. Antwoorden uit de Republiek waren pas na ongeveer twee jaar te verwachten. Het feit dat het bestuur de potentiële inzenders stimuleerde om vooral de 'kundige Land-zaat' bij de beantwoording te betrekken, geeft aan dat inderdaad vooral aan inzenders uit Indië, niet zozeer uit Europa, werd gedacht (Programma 1778:7, 22-3). Het benadrukte het Bataviase karakter, niet het nationale. De beloning voor goedgekeurde inzendingen werd gesteld op honderd rijksdaalders. Voor geleerden in Europa had het bestuur andere plannen.

Het programma met de 46 vragen en opdrachten was het genootschap echter nog niet genoeg. Wie buiten die vragen om een nuttige ontdekking had gedaan of op een andere wijze ijver en kunde aan de dag had gelegd, kon ook in aanmerking komen voor een beloning. Tenslotte zouden jaarlijks nog twee bijzondere prijsvragen aan de lijst van 46 worden toegevoegd, waarvoor een gouden medaille of honderd gekartelde dukatons beschikbaar waren. Al tijdens de eerste bestuursvergadering van 1 juni 1778 werden er nieuwe prijsvragen uitgeschreven, nu wel met een tijdslimiet. Vóór eind juni 1779 moesten de antwoorden binnen zijn. De eerste ging over het begraven buiten Batavia, in plaats van in de kerken en op kerkhoven binnen de stad, een hygienisch probleem dat ook in het vaderland druk besproken werd. De tweede handelde over de waterhuishouding in Batavia die om herstel van sluizen vroeg. Radermacher stelde persoonlijk honderd dukaten $(f 315)$ ter beschikking voor de oplossing van een ander probleem van stedekundige hygiëne en stadsveiligheid: de beste manier om Batavia 's nachts te verlichten en overdag te besproeien. Aangestoken door deze daad van vrijgevigheid stelde Willem van Hogendorp honderd dukaten beschikbaar voor een verhandeling over de effectiviteit van het inenten tegen de gevreesde kinderziekte (pokken) in de oosterse volksplantingen. ${ }^{70}$ Het aantal vragen telde toen al vijftig.

70 ANRI KBG Dir 0001, 3-6. In het Voorberigt van VBG 1 (1779) werden deze prijsvragen herhaald, echter niet die over het verlichten en begieten van de stad, de door Radermacher voorgestelde vraag. Was die in 1779 al achterhaald? Of had het genootschap zich begeven op het terrein van de Hoge Regering? 
Net als in het vaderland moesten inzenders op alle vragen zich verschuilen achter een spreuk, hun naam op een verzegeld briefje zetten met de spreuk buitenop zodat een onbevooroordeelde mening kon worden uitgesproken zonder dat men wist wie de inzender was. Verder moesten alle inzendingen in het Nederlands zijn geschreven met een duidelijke stijl en in een leesbaar handschrift. In 1779 en 1780 volgden nieuwe prijsvragen. ${ }^{71}$ Op 7 februari 1780 stelde Radermacher een herschikking van de bijzondere prijsvragen voor, niet van de 46 van het eerste programma, maar van de later uitgeschreven vragen. Een verlenging van de inzendtermijn tot drie jaar moest belangstellenden uit de Republiek een reële kans te geven mee te dingen naar de prijzen op de bijzondere vragen. ${ }^{72}$ Radermachers voorstel was bedoeld om enige structuur aan te brengen in de procedure voor de nieuw aangekondigde en nog openstaande vragen. Op dat moment kon op 55 vragen ingezonden worden. Zo werd voor eind 1782 het antwoord ingewacht op de intrigerende vraag: 'Waarom is het zitten in het schijnzel der maan hier gevaarlijker dan in Europa / Welke zijn de eigentlijke kwalen die er uit onstaan, en welke zijn de beste middelen om die te geneezen?'73 Er werd een verband gelegd tussen het zitten in de maneschijn en de slechte gezondheid op het kerkhof voor Europeanen dat Batavia heette, in plaats van tussen het zitten in de tropennacht en de 's avonds en 's nachts stekende muggen. Van der Brug toonde aan dat de 'gezond' geachte visvijvers die een groot deel van het gebied aan de noordkant van Batavia besloegen, als broedplaats dienden voor de malariamug (Van der Brug 1994:136-8).

Radermachers herschikking van de prijsvraagsystematiek was duidelijk bedoeld om de aansluiting met Europa te bevorderen. Speciale prijsvragen met een looptijd van één jaar waren gericht geweest op lokale inzenders. Die waren na 1780 vervallen. Verder waren er nog de prijsvragen die op verzoek van het Bataviaasch Genootschap werden uitgeschreven door de genootschappen te Haarlem, Vlissingen en Rotterdam, waarvoor de termijnen golden die in die steden gebruikelijk waren.

De ogenschijnlijk drukke prijsvraagpraktijk duurde echter niet lang. In de bestuursvergaderingen tot 1782 namen de prijsvragen, de binnengekomen antwoorden en het beoordelen daarvan een belangrijk deel van de vergadertijd in beslag. Daarna was het tien jaar lang stil voor wat betreft nieuwe prijsvragen. Een schema maakt duidelijk hoezeer de hele zaak vooral tussen 1778 en 1780 speelde en daarna alleen in de meest actieve jaren onder Moens (1790-1792) nog eens terugkeerde.

71 ANRI KBG Dir 0001,37-38, vergadering 1-2-1779; 58-59, vergadering 12-4-1779; ANRI KBG Dir 0003, 50-56, vergadering 27-12-1779; ANRI KBG Dir 0004, 67-83, vergadering 7-2-1780.

72 ANRI KBG Dir 0004, 67, vergadering 7-2-1780.

73 ANRI KBG Dir 0004, 75, vergadering 7-2-1780. 
Prijsvragen tot 1800

\begin{tabular}{lrl}
\hline 1778 & 46 & (programma) \\
1778 & 4 & \\
1779 & 5 & \\
1780 & 12 & \\
1781 & 1 & \\
1790 & 2 & \\
1791 & 2 & \\
1792 & 3 & \\
Totaal & 75 & \\
\hline
\end{tabular}

De eerste bekroningen werden na ruim een jaar uitgedeeld. Op 10 mei 1779 meldden de notulen dat Radermacher, Hooijman en Von Wurmb op een reisje naar de Bataviase bovenlanden de tuinen van de oud-predikant Johannes Wasmuth (geen lid) en oud-weesmeester David du Fau de la Longue (lid) hadden geïnspecteerd, die zich met succes hadden toegelegd op het planten van peper en cacao. Ter aanmoediging kregen beiden een zilveren medaille. Net als bij de Oeconomische Tak liet het bestuur zien dat het niet alleen om het inzenden van verhandelingen ging, maar evenzeer om in de praktijk gebrachte oplossingen.

Tijdens dezelfde vergadering van mei 1779 waren de eerste verhandelingen binnengekomen als antwoord op vragen uit het programma zowel als op de extra vragen van 1778. Deze inzendingen gingen over voldoende houtaanvoer voor suikermolens, over visaanvoer tijdens de westmoesson (Programma 1778: vraag 7 en 24), over inenting tegen pokken en over het verlichten van Batavia bij nacht. Er werden in 1779 twintig inzendingen gedaan. Daarvan werden er uiteindelijk vier bekroond: Christiaan Jacobi (geen lid), provisioneel onderkoopman bij het kantoor van de Hoge Regering, kreeg op 9 augustus 1779 de eerste gouden medaille voor zijn inzending over hout als brandstof voor suikermolens. Tijdens dezelfde vergadering kreeg een verhandeling over de behandeling van buikloop een zilveren medaille, ondanks de bedenkingen die er tegen waren ingebracht. Bernard Wolf (geen lid) was de inzender. ${ }^{74}$ De tweede gouden medaille werd op 6 september uitgereikt aan Andries Duurkoop, oud-majoor en heemraad van de Bataviase Ommelanden voor zijn inzending over de heersende ongezondheid in Batavia. ${ }^{75} \mathrm{Op} 4$ oktober 1779 werd de laatste medaille van dat jaar toegekend: luitenant-ingenieur J.B. Pilon (lid) kreeg een zilveren medaille voor zijn ontwerp van een water- 
pomp waarvan een model te bezichtigen was in het genootschapshuis. ${ }^{76}$

Hiermee was het genootschap in 1779 met 55 prijsvragen, twintig inzendingen, waarvan vier bekroond, naast nog twee aanmoedigingsprijzen voor ijverige landbouwers, zeker toegekomen aan een belangrijk deel van zijn voornemens. Ook waren nu de eerste prijsverhandelingen voor de genootschapsbundel beschikbaar. De complete lijst van bekroningen laat echter zien dat het enthousiasme van de jaren 1778-1779 op het punt van de prijsvragen en bekroningen niet bleek vol te houden. Tot 1800 werden niet meer dan negen inzendingen en antwoorden bekroond en vier aanmoedigingsprijzen uitgedeeld. ${ }^{77}$

Bekroningen/ aanmoedigingsprijzen tot 1800, gedaan in Batavia

\begin{tabular}{llll}
\hline jaar & naam & medaille & gepubliceerd in \\
\hline 1779 & J. Wasmuth & zilver & - \\
1779 & D. de la Longue & zilver & - \\
1779 & Chr. Jacobi & goud & VBG 2 \\
1779 & B. Wolf & zilver & $V B G 2$ \\
1779 & A. Duurkoop & goud & $V B G 2$ \\
1779 & J.B. Pilon & zilver & - \\
1780 & J.B. Pilon & goud & - \\
1780 & onbekend & zilver & - \\
1780 & H. Wachter & zilver & - \\
1782 & L. Bicker & 100 ducaten & VBG 4 \\
1782 & P.M. van Nielen & zilver & VBG 4 \\
1784 & C. de Kock & zilver & - \\
1793 & C. Terne & goud & $V B G 7$ \\
\hline
\end{tabular}

Hoe het bestuur te werk kon gaan bij het beoordelen van inzendingen, blijkt uit het geval van de beantwoording van de tweede prijsvraag van 1778: ‘Dewijl het eenigste middel om deeze stad van water te voorzien, schijnt te zijn, de herstelling der sluizen: welk is daer toe het beste plan? NB Men verzoeke bij de beantwoordinge van deeze laatste vraage, de noodige teekeningen, en eene uitrekening van de onkosten. ${ }^{78}$ Op de vergadering van 9 augustus 1779, ruim een jaar na de uitschrijving, kwam er een 'Beschrijving

\footnotetext{
76 ANRI KBG Dir tussen 0002 en 0003, 30. VBG 2:Voorbericht 7.

77 Van de bekroningen waren alleen die van Duurkoop, Pilon (2x), de onbekende van 1780 en die van Bicker, Van Nielen en Terne voor speciale prijsvragen. De overige zijn geïnspireerd op de vragen of aanmoedigingen uit het Programma van 1778. Wachter kreeg zijn eremetaal als bewijs van waardering voor de lijkrede op Josua van Iperen. Dessave Cornelis de Kock was inzender van specimina van hennep en touw, waarmee hij vanuit Colombo getuigde van zijn belangstelling.

78 ANRI KBG Dir 0001, 4, vergadering 1-6-1778.
} 
van Draagbaare Sluijzen' binnen, die tegelijk een antwoord gaf op vraag 41 van het Programma, naar het probleem van het uitdiepen van de stadsgrachten. Een kundige beoordelaar van buiten zou de inzending onderzoeken. Op 4 oktober 1779 kon Josua van Iperen verslag doen van een onderzoek naar de bruikbaarheid van de inzending, onderzoek dat in tegenwoordigheid van de inzender, Pilon, eerder ontwerper van de bekroonde waterpomp, plaatsvond

in den Thuijn van den Heer Mr. Pieter Poelman, Lid van dit Genootschap, alwaar ook verscheenen waren de Heeren Medeleden Duurkoop, de Keijzer, Wimmercrantz, en de Roo, welke alle na rijpe overwegingen verklaarden ten verzoeke van het Bataviasch Genootschap, de Autheur de Heer Pilon tegenwoordig zijnde, dat gemelde uitvindinge en opstel de aanmoediging van het Genootschap verdiende. ${ }^{79}$

Interessant bij het ingestelde onderzoek is de samenstelling van de commissie: dominee Van Iperen, het bestuurslid dat voldoende technisch-praktisch inzicht had om als verslaggever op te treden, de oud-majoor en lid van het college van Heemraden, Jan Andries Duurkoop (zelf bekroond voor zijn inzending over de heersende ongezondheid), die kennelijk de kundige beoordelaar van buiten de bestuursgelederen was, verder bouwmeester Cornelis de Keijzer, onderkoopman en landmeter Hermanus de Roo en de baas van Pilon, de Zweedse kapitein-luitenant-ingenieur, Swen Johan Wimmercrantz. Verder was de inzender er zelf. Het onderzoek vond plaats op de buitenplaats van $\mathrm{Mr}$ Pierre Poelman, oud-raad van Justitie en oud-water-fiscaal, nummer vier op de ledenlijst van 1779 en dus een man van aanzien. Op Poelmans buitenplaats kon Pilons verplaatsbare dam gedemonstreerd worden. De fortuinlijke luitenant Pilon, in korte tijd tweemaal bekroond en daardoor een parel aan de kroon van het genootschap, zou in 1791 geroyeerd worden omdat hij, net als vijf anderen, na herhaalde sommeringen, zijn lidmaatschapsgeld niet had betaald..$^{80}$

Met vier bekroningen in 1779 en nog eens twee in 1780, allemaal uitkomsten van de in 1779 binnengekomen twintig inzendingen, had het genootschap zich ruimhartig betoond. Zelfs de bedenkingen die er bestonden tegen Pilons tweede inzending, hielden hem niet af van het edelmetaal. ${ }^{81}$ In 1780 kwamen

\footnotetext{
79 ANRI KBG Dir tussen 0002 en 0003, 34, vergadering 4-10-1779.

80 Duurkoop was via zijn echtgenote in het bezit gekomen van het fortuin van oud gouverneur-generaal Van Imhoff en kwam in 1792 nog voor op de ledenlijst (VBG 6:Voorberigt 29). Poelman kwam nog wel voor op de lijsten van 1780 en 1781, maar niet meer in 1790. In het Koninklijk Huisarchief is een brief van Poelman aan Stadhouder Willem V van 18-10-1775 waarin hij zegt kort voor zijn zestigste verjaardag als waterfiscaal ontslag te hebben genomen, een landgoed te hebben gekocht en niet naar Nederland te zullen terugreizen. Poelmans zoon Steven was toen net benoemd tot tweede administrateur van de Westzijdse Pakhuizen. Deze Steven zou later Raad van Indië worden. Koninklijk Huisarchief, Archief Stadhouder Willem V, 331-32.

81 Ondanks de aanbevelingen van de commissie Van Iperen was de oplossing van Pilon in
} 
er maar zes nieuwe inzendingen binnen, al waren daaronder de eerste uit de Republiek. In 1781 kwamen opnieuw zes nieuwe inzendingen aan. In dat jaar werd er niet bekroond. Pas in 1782, tijdens de enige bestuursvergadering van dat jaar, werd weer een bekroning toegekend. Toen was voor de prijsvraag uit 1778 van Willem van Hogendorp naar de verbeteringsmogelijkheden van de koepokinenting de keuze aan het bestuur uit vijf inzendingen, waarvan er drie uit de Republiek kwamen. Twee genootschapsmannen uit de Republiek sleepten de prijzen weg. Lambertus Bicker, arts in Rotterdam en secretaris van het Bataafsch Genootschap aldaar, was de winnaar van Van Hogendorps honderd gouden dukaten. Zijn Utrechtse confrater, Petrus van Nielen, directeur van het Provinciaal Utrechts Genootschap, kreeg een zilveren medaille. ${ }^{82}$ Beiden werden corresponderend lid van het genootschap in Batavia.

In 1783 viel het doek over de prijsvragen. In dat jaar verneemt men er in de notulen niets meer over en na Moens' aantreden als voorzitter lezen we ook niets meer over inzendingen of bekroningen. Uitzondering is de aanmoedigingprijs in 1784 voor Dessave de Kock in Ceylon, niet vanwege een inzending op de prijsvragen, maar om waardering te laten blijken voor diens pogingen om de nijverheid te stimuleren. Eveneens was Harmanus Wachter in 1780 beloond voor zijn Lijk- en Lofrede op Josua van Iperen. In het programma voor 1782 waren de 46 vragen uit 1778 en de overige, nog openstaande prijsvragen herhaald, zowel in een Nederlandse als een Franse versie. De lijst kwam ook voor in het in Nederland gedrukte vierde deel van de Verhandelingen, maar het haalde niet veel uit. Het genootschap was in een malaise terecht gekomen. In de jaren 1785-1788 werd maar drie keer vergaderd. Een goed werkende prijsvraagactiviteit kon alleen blijven bestaan als het bestuur er steeds aandacht op vestigde. Van buiten was er kennelijk evenmin veel animo om inzendingen te doen. Van de dertien bekroningen tussen 1779 en 1793 waren er negen in de jaren 1779-1780 toegekend. Ondanks het feit dat na 1788 zeven nieuwe prijsvragen werden uitgeschreven, leidde dit nauwelijks tot succes. Alleen in 1793 werd nog een verhandeling bekroond, die in 1794 als eerste stukje van deel 7 van de Verhandelingen werd gedrukt en rondgestuurd. ${ }^{83}$

decemer 1779 nog eens besproken. In de aanvang van 1780 werd de inzending niet als voldoende beoordeeld en toch bekroond. Pilons draagbare sluis of draagbare dam was dienstig om het water 'in de goede moesson te stoppen waar men wilde'. ANRI KBG Dir 0004, 64-65, vergadering 7-2-1780.

82 ANRI KBG Dir 0018, 390-405, art. 4, vergadering 6-8-1782. In dezelfde vergadering (art. 16) werd wel een nieuwe inzending van Charpentier de Cossigny uit Mauritius gemeld.

83 Het zeldzame Leidse exemplaar van VBG 7 (1794) bevat naast de verhandeling van C. Terne over kindervoeding alleen een bijdrage van A. van Rijck over de bevolking op de Bromo (UB Leiden, G 150 7). De bijdragen van Terne en van Rijck kwamen, opnieuw gezet, in 1814 in het volledige 7e deel van de VBG terecht. Dit stukje van deel 7 (1794) is rondgestuurd, blijkens een brief in ANRI, Familie-archieven T 93, B 713, nr 8 van secretaris Ross aan Gouverneur Beth te 
In het programma van 1778 was als één van de 'verplichtingen' opgenomen dat een kleine helft van de jaarlijks binnenkomende 'penningen' zou worden gebruikt voor 'ééne of meer nuttige vraagen' uit te schrijven door 'ieder der drie Maatschappyën, in ons Vaderland opgericht te Haarlem, Rotterdam en Vlissingen' (Programma 1778:11). Op 3 augustus 1778 werd besloten 100 dukaten (f 315,-) aan elk van de drie genootschappen te sturen. ${ }^{84}$ Tot 1782 volgden nog vier soortgelijke zendingen. ${ }^{85}$ Met deze beslissing en de eerste geldzending van 1778 werd de basis gelegd voor een samenwerking die een aantal jaren zou voortduren. De Hollandsche Maatschappij, het Bataafsch Genootschap en het Zeeuwsch Genootschap zouden ieder een verschillend aantal prijsvragen op kosten van het Bataviaasch Genootschap uitschrijven. Het zouden er vijf worden in Haarlem, zeventien in Rotterdam en tien in Vlissingen, totaal 32 'Nederlandse' prijsvragen, die bij de 75 in Batavia kunnen worden opgeteld. ${ }^{86}$

De Haarlemmers waren met hun vijf prijsvragen $(1779-1782,1784)$ het minst succesvol. De drie prijsvragen over gezondheid en geneeskunde, over de opvoeding van de Bataviase jeugd en over de mogelijkheden om het gebruik van het Nederlands in Azië te bevorderen, vonden maar een matig aantal inzenders, acht in totaal. Op twee van de vragen, die over het Nederlands in Azië en over de geneeswijzen van Oost-Indische volkeren, ook van Chinezen, kwam zelfs geen enkel antwoord binnen. De Haarlemmers herhaalden de vragen verschillende malen, tenslotte zelfs zonder ze aan inzendtermijnen te binden, maar het kwam tot geen enkele bekroning. De vraag uit 1793 die in Haarlem werd uitgeschreven naar aanleiding van het legaat van Jan Hooijman van duizend gulden had een zelfde negatief resultaat. ${ }^{87}$ De Haarlemmers waren wel van mening dat de uitgeschreven prijsvragen de band met Batavia moesten weerspiegelen. Zij kozen onderwerpen die in Batavia aanspraken.

De Rotterdammers waren zeer ijverig en schreven tussen 1779 en 1791 zeventien prijsvragen uit, maar op zes ervan waren zij evenmin fortuinlijk.

Makassar, 14-11-1794. Met dank aan Max de Bruijn, die mij wees op het bundeltje papieren over het Bataviaasch Genootschap in dit familie-archief.

84 ANRI KBG Dir 0001, 9-10, vergadering van 3-8-1778. Het ging blijkens een overzicht van inkomsten en uitgaven op die dag gemaakt, om een totaal voor de drie genootschappen van 427 rijksdaalders en 24 stuivers.

85 RAZ KZGW 62 (ingekomen stukken 1779-1784), fol. 372 bevat een afrekening voor $f$ 1.593.12.- voor de vijf geldzendingen van 1778-1782. De bedragen voor Haarlem en Rotterdam waren hetzelfde. Totaal ontvingen de drie genootschappen dus: $f$ 4780.16.--

86 Der Kinderen (1878:258-61, bijlagen 63-4) noemt zes 'Nederlandse' prijsvragen, maar daarbij is hij afgegaan op de mededelingen in het archief in het toenmalige Batavia, die verre van volledig zijn.

87 Zie over de Haarlems-Bataviase prijsvragen: J.G. de Bruijn 1977: no 38, 41, 44, 48, 53 en 70 (legaat Hooijman); Bierens de Haan 1970:206-7. 
Daarop kwamen zelfs geen antwoorden binnen. Op de overige elf kwamen in totaal twintig inzendingen. Het kwam tot zes bekroningen. De Rotterdammers voelden zich, anders dan hun collega's in Haarlem, niet gebonden om prijsvragen uit te schrijven die in verband stonden met Indië. Slechts twee hadden een duidelijk verband met de kolonie: een vraag naar efficiëntere productie van arak, naar aanleiding van een artikel in de Bataviase Verhandelingen, en een tweede vraag naar de ziektes die uit Oost-Indië naar het vaderland werden meegebracht. Op deze vragen kwamen geen antwoorden binnen. De bekroonde prijsvragen gingen over electrische verschijnselen (3), schadelijke dampen, het toenemend gebruik van brillen en over de rotting van planten. De zes bekroningen vonden plaats tussen 1780 en 1796, alle bekroonde verhandelingen werden gepubliceerd. Opvallende winnaar was de Haarlemmer Marinus van Marum (1750), Groninger van geboorte en sinds 1776 als arts in Haarlem werkzaam. In 1777 werd hij directeur van het Naturaliënkabinet van de Hollandsche Maatschappij en later (1784) directeur van het Kabinet van Liefhebberijen van Teylers Genootschap in dezelfde stad. Van Marum zou als vrijgesteld arts en als wetenschapper een centrale rol spelen in het Haarlemse genootschapsleven en zich ook doen gelden in de genootschappen buiten Haarlem en buiten de Republiek (Mijnhardt en Wiggers 1984:73-88). Hij werd op drie van de zes 'Bataviase' bekroningen in Rotterdam winnaar, de eerste uit 1780 over electriciteit, de tweede over het zelfde onderwerp in 1782, toen in samenwerking met A. Paets van Troostwijk en een jaar later nog eens in samenwerking met dezelfde Paets op een prijsvraag over schadelijke dampen. ${ }^{88}$ Paets van Troostwijk won overigens nog eens in 1783, toen samen met J.R. Deiman, alweer een vraag over electriciteit. De andere Rotterdamse winnaars waren P.J. van Maanen en A. van Stipriaan Luïcius. De laatste nog openstaande 'Bataviase' prijsvraag in Rotterdam werd in 1808 ingetrokken.

De Zeeuwen tenslotte schreven tussen 1779 en 1789 tien prijsvragen uit op verzoek van Batavia, waarvan er maar twee waren met een onderwerp dat getuigde van een band met Oost-Indië: over ziekenbezoekers op de OostIndische kantoren en over de manier waarop zendelingen moslims zouden kunnen overtuigen van de waarheid van de christelijke godsdienst. ${ }^{89} \mathrm{Op}$ de laatste kwam geen inzending. Op de andere negen prijsvragen kwamen wel inzendingen binnen. Negen van de tien brachten het uiteindelijk tot een bekroning. Een van de bekroonden, de Leidse stadsgeneesheer Cornelis Terne, die had geschreven over het begraven binnen steden en kerken, alom als ongezond afgewezen, maar nog steeds gepractiseerd (bekroond in 1785

88 Van Lieburg 1985: 25-26, 53, 116, over de Bataviasche prijsvragen. Van Lieburg noemt er 16, maar uit zijn eigen overzicht elders in zijn boek blijken het 17 prijsvragen te zijn. Ook nummer P43 hoort ertoe.

89 Een derde had verband met West-Indië: de gezondheid onder de negers aldaar. 
met een zilveren medaille) zou in 1793 ook in Batavia een bekroning in de wacht slepen. ${ }^{90}$ Met negen bekroningen op tien prijsvragen en met minstens 25 inzendingen was Vlissingen succesvoller dan de zustersteden Haarlem en Rotterdam. Of was men in Vlissingen misschien wat milder in het beoordelen? Men kan ook concluderen dat de Zeeuwen onderwerpen wisten te kiezen die aanspraken. Er werden zeven gouden medailles uitgereikt en vijf zilveren. Zes van de tien prijsvragen hadden te maken met gezondheid, gezondsheidzorg en hygiëne. ${ }^{91}$ In het algemeen waren de Zeeuws-Bataviase prijsvragen praktisch-sociaal getint. Alleen een scheepsbouwkundige vraagstelling in 1780 had een praktisch-technisch karakter. Opvallend is wel dat de prijsvragen die qua thematiek aansloten bij de koloniale wereld waar het prijzengeld vandaan kwam, niet aansloegen bij de inzenders in de Republiek. Rotterdam en Vlissingen waren vooral succesvol met hun niet op Indië gerichte vragen.

Dat de oprichters vanaf het begin aansluiting zochten bij deze Hollandse en Zeeuwse genootschappen, geeft aan dat zij zich bewust waren van de beperkte mogelijkheden om vanuit Batavia met succes een prijsvraagactiviteit te voeren. Vandaar dat zij in eerste instantie op twee fronten inzetten. Voor lokale (Indische) inzenders de Bataviase vragen, voor de Europese inzenders de vragen in de Republiek. Dat zij aansluiting zochten bij genootschappen die al ruime ervaring hadden met prijsvragen - in Haarlem was de eerste Bataviase prijsvraag de 38e die de Maatschappij uitschreef, in Rotterdam en Vlissingen was het telkens de veertiende prijsvraag - leek een verstandige keuze. Dat de drie genootschappen direct op het voorstel ingingen, hoeft niet te verwonderen. Batavia stuurde geld, in het vaderland mocht men onderwerpen uitkiezen.Voor beide partijen was er eer te behalen. In de praktijk werkte het ook goed uit. Van de 32 prijsvragen die in de Republiek voor het Bataviaasch Genootschap werden uitgeschreven, werden er vijftien bekroond. Op negen van de prijsvragen kwam geen enkele inzending binnen. Uit het schamele aantal van dertien bekroningen op 75 vragen in Batavia valt

$90 \quad$ Ik was bij mijn onderzoek in Middelburg zeer geholpen door het voorbereidende werk van W. Dirksen (conservator handschriften KZGW), H. van der Voorde en G. Trimpen Burger. Mijnhardt (1988:179-217) gaat in op de Zeeuwse prijsvragen. Helaas ontbreken mij de precieze gegevens over inzendingen op prijsvraag 14 en 16 van 1779-1780. Op de overige prijsvragen $(19,21,25,26,28,31,33$ en 36) waren 23 inzendingen. Op 14 en 16 minimaal elk één (zij werden immers bekroond). Voorzichtigheidshalve zet ik het aantal inzendingen op minimaal 25. De prijsvraag over het begraven buiten steden en kerken was ook in Batavia uitgeschreven, niet verwonderlijk gezien de actualiteit van het onderwerp.

91 No 14 over scheepsbouw en gezondheid, 19 over een hospitaal of oude-mannenhuis voor ex-zeevarenden, 21 over het begraven buiten kerken en steden, 25 over het voorzien in goede 'krankbezoekers' in dienst van de VOC, 31 over de ziekte der negers in West-Indië en 33 over de pokken (Mijnhardt 1988:189-93). 
te concluderen dat de oprichters het juist hadden gezien: prijsvragen konden in de Republiek met meer succes worden uitgeschreven. Batavia's ligging maakte het minder geschikt voor een prijsvraagpraktijk en als die toch werd uitgevoerd, konden niet de strenge vaderlandse gewoonten worden aangehouden.

\section{Publicaties}

Naast het uitschrijven van prijsvragen kon een genootschap vooral door het uitgeven en verspreiden van publicaties van zich doen horen. Een genootschap zonder eigen publicaties beperkte zijn actieradius meestal tot een kleine kring, veelal op lokaal niveau. Tot die categorie behoorde het merendeel van de gezelschappen en genootschappen in de Republiek, wier activiteit vooral uit het organiseren van voordrachten en het voor gezamenlijke rekening kopen en lezen van lectuur bestond. Het Bataviaasch Genootschap echter koos voor de ambitieuze opzet van publieke organisatie met algemene vergaderingen, prijsvragen en publicaties. Het wilde zijn actieradius niet tot Batavia beperken. Dat die ambities al te hoog gesteld bleken, bewijst de geschiedenis van de publicaties. De jaarlijkse uitgave van een programma en een bundel verhandelingen kon alleen in de jaren 1778-1781 gerealiseerd worden.

Nadat in augustus 1778 het eerste programma was gedrukt en verspreid, boog het bestuur zich in oktober over de samenstelling van de eerste bundel. ${ }^{92}$ Men was zich ervan bewust dat er niet terstond een grote toevloed van antwoorden op de 46 vragen uit het programma zou zijn, maar dat stemde het bestuur niet pessimistisch. Zelfs zonder antwoorden dacht men stof genoeg te hebben voor het eerste deel. ${ }^{93}$ In de vergadering van november las bestuurslid Van der Steege een bijdrage voor over het inenten tegen pokken, de eerste echte kopij voor de Verhandelingen. Vervolgens werd nog diezelfde maand 36 riem papier gekocht, waarvoor de som van 230 rijksdaalders werd betaald. ${ }^{94}$ Tijdens de eerste vergadering van 1779 werd besloten de Verhandelingen in een oplage van zeshonderd exemplaren te laten drukken, de helft te verdelen onder de directeuren en leden en de andere helft bedoeld voor de verkoop. Ook besloot men boekhandelaar Arrenberg in Rotterdam aan te schrijven over een herdruk in de Republiek. Kort daarop

92 Op 4 september waren de brieven met de programma's voor de buitenkantoren overhandigd aan de secretarie van de regering ter verzending. ANRI KBG Dir 0001, 8, vergadering 7-91778.

93 ANRI KBG Dir 0001, 23-24, vergadering 5-10-1778.

94 ANRI KBG Dir 0001, 27-28, vergadering 2 -11-1778. 


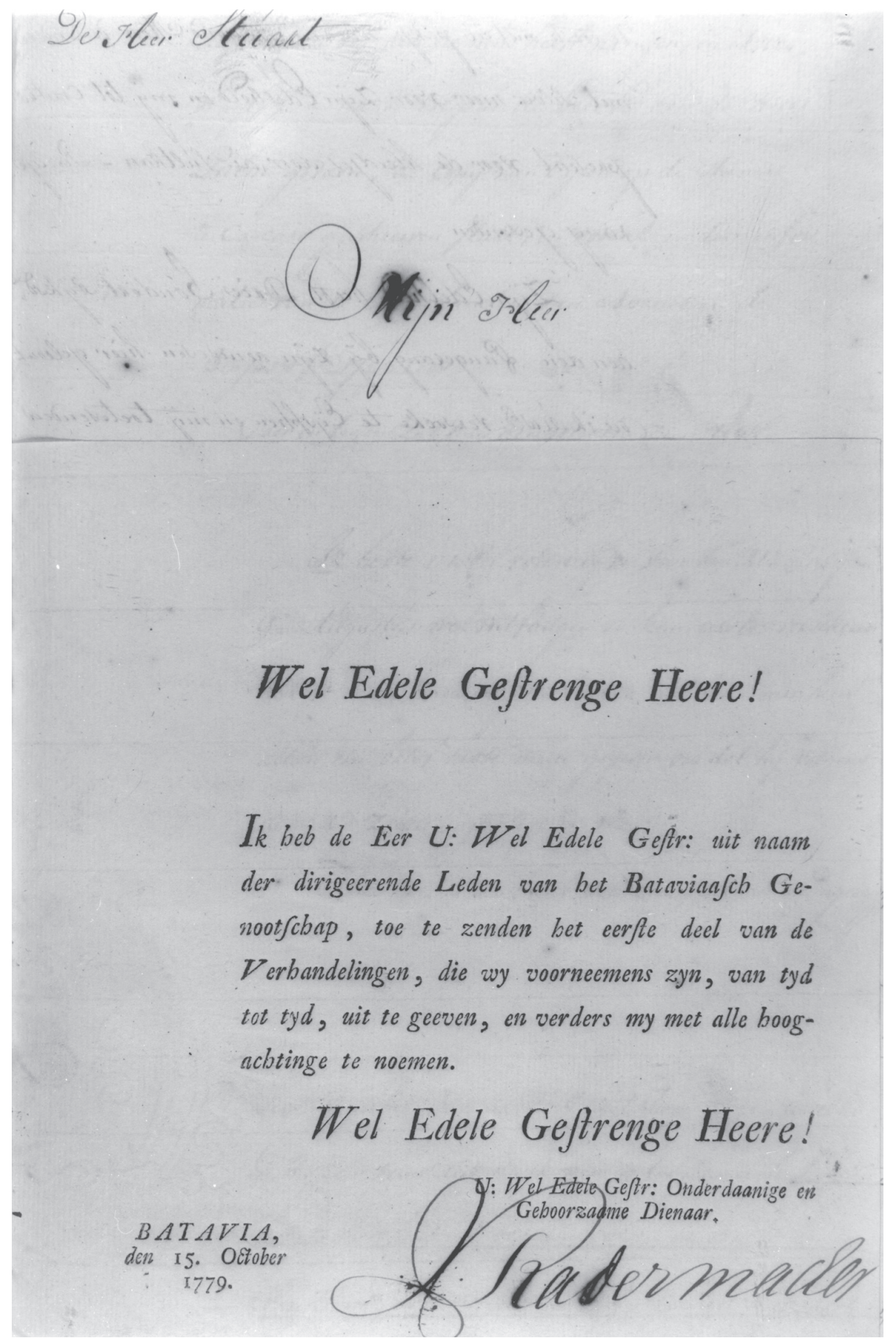

Gedrukte circulaire van het genootschap ten geleide van deel 1 van de Verhandelingen, 15 oktober 1779 (collectie ANRI Jakarta, KBG Dir 0980) 
zou diens Amsterdamse collega J. Allart aan hem worden gekoppeld, zodat er twee vertegenwoordigende boekverkopers in de Republiek waren. Van de opbrengst van de Nederlandse herdruk hoopte men bij Arrenberg het abonnement op de verhandelingen van alle Europese genootschappen te kunnen betalen. ${ }^{95}$ In maart 1779 was men met drukken begonnen, in september was Compagniesdrukker Egbert Heemen klaar en kon het eerste deel van een serie van zeven achttiende-eeuwse delen verspreid worden. Van de eerste bundel verscheen in Leipzig een vertaling (Abhandlungen 1782). In 1779 verscheen in Batavia geen nieuw programma, maar het 'voorberigt' van het eerste deel van de Verhandelingen werd wel bij wijze van programma naar de buitenkantoren gestuurd.

Het bestuur, dat tegelijkertijd als redactie optrad, had de inhoud grotendeels uit eigen gelederen bijeen moeten garen. Het meest substantieel waren de bijdragen van Radermacher zelf, van Van Iperen en Hooijman. Het enige niet-bestuurslid dat had bijgedragen, was de onderkoopman Jacobus Paringauw, die over katoenbewerking had geschreven. Radermacher droeg met Van Hogendorp een beschrijving van de Oost-Indische bezittingen en van Batavia bij, maar ook over plantkunde en tijdrekening waren er bijdragen van zijn hand. Van Iperen introduceerde een vertaling van een Javaans geschiedverhaal, schreef over het verbeteren van zeekaarten en leverde een beschrijving van een Balinese albino. Hooijman schreef uitvoerig over de landbouw in de Ommelanden. Zowel de jurist-koopman-bestuurder Radermacher als de predikanten Hooijman en Van Iperen lieten zien dat zij niet bang waren om zich buiten hun vakgebied te begeven. De notulen van de bestuursvergaderingen laten zien dat men zich niet kritisch over de aangeboden kopij uitliet. Bijdragen van bestuursleden werden niet afgewezen. Er was behoefte aan kopij en men had haast met het drukken van het eerste deel.

Met die eerste grote publicatie, dertien bijdragen van zeven auteurs van wie er zes bestuurslid waren, liet het bestuur nogmaals zien waar het genootschap zich op wilde richten: alle bijdragen staan in verband met de Aziatische bezitingen van de VOC of hebben voor de Nederlanders aldaar relevante onderwerpen. 'Bataviaasch' moest dus niet alleen worden gelezen als 'gevestigd in Batavia' maar ook als: zich bezighoudend met alle zaken die op Azië betrekking hadden. Geografie en plaatsbeschrijving, geneeskunde, landbouw, plantkunde, volkenkunde en Javaanse geschiedenis waren de terreinen van dit eerste deel. Voor sommige bijdragen, zoals de beschrijving van Batavia en de VOC-bezittingen, konden de auteurs Radermacher en Van Hogendorp gebruikmaken van het regeringsarchief in het Kasteel. 


\title{
VERHANDELINGEN
}

\author{
VA N H E T
}

\section{B A T A V I A A S C H}

GENOOTSCHAP

D E R

KONSTENENWETENSCHAPPEN.

EERSTE DEEL.

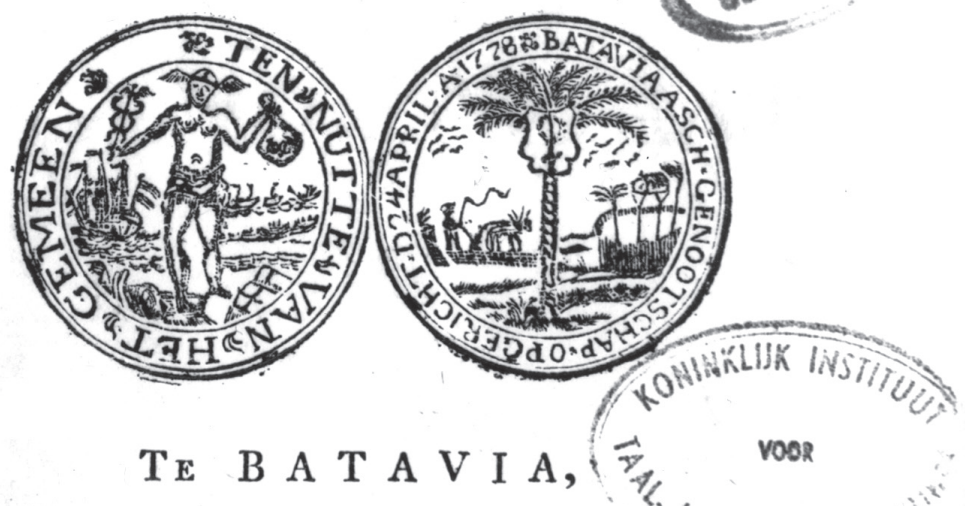

Gedrukt in d'E: Compagnies Boek-drukketty en wulai By EGBERT HEEMEN 1779. 


\section{VERHA N D L I N G E N}

$\begin{array}{llllll}\mathrm{A} & \mathrm{N} & \mathrm{H} & \mathrm{E} & \mathrm{T}\end{array}$

\section{B A T A V I A A SCH \\ GENOOTSCHAP, \\ D E R}

KONSTEN EN WETENSCHAPPEN.

T W E E D D E EL。

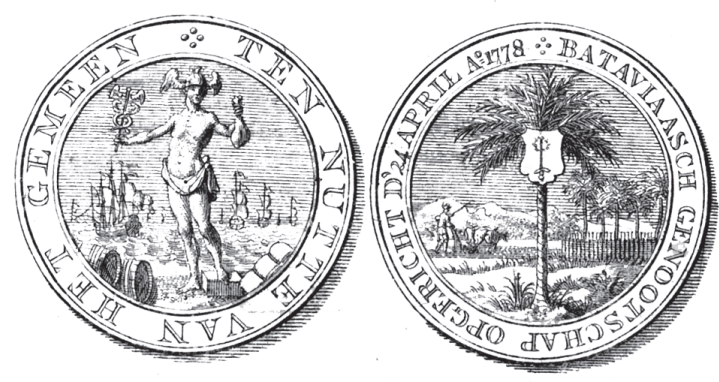

TE ROT TER D A M, B Y

R E I N I E R A R R E N B E R G.

TEA M S T E DA M, B Y

J O HA N N E S A L L A R T

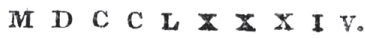

Met Privilegie yan de Staaten van Holland en Woit. friesland.

Titelpagina van deel 2 van de Verhandelingen, herdruk Rotterdam/Amsterdam 1784 (collectie KB Den Haag) 
Bij het samenstellen van het tweede deel was de kopijnood iets minder groot. Er waren vier antwoorden op prijsvragen, waarvan drie bekroond (Duurkoop, Jacobi en Wolf) en één niet bekroond, maar wel het drukken waardig gekeurd (Bijlon). Vijf actieve bestuursleden leverden opnieuw grotendeels de kopij. Van hen kwam 85\% van de gedrukte tekst. De 27, deels korte bijdragen handelden weer voor het merendeel over met Azië in verband staande onderwerpen. Dierkunde, taalkunde en contemporaine geschiedenis voegden zich bij de onderwerpen van deel 1, maar er waren ook enkele meer algemene bijdragen die pasten bij het opgegeven doel, het bevorderen van alle kunsten en wetenschappen.Van Iperen droeg bij over het nut van kennis van de geschiedenis, Radermacher verdedigde een verlicht standpunt over de doodstraf en het pijnigen als straf, terwijl Van Hogendorp met Voltaire in discussie ging over een bijbelpassage aangaande de rijkdommen van David in verband met de tempelbouw in Jerusalem. De enige literaire bijdrage aan de Verhandelingen in deze eeuw kwam van Van Iperen. Het is een lange, pessimistische treurzang, 'De Belemmeringen', over het onderspit dat deugd en wijsheid delven tegen schijndeugd, gewoonte, eigenzinnigheid en onwetendheid. In een korte 'Toezang' tot het Bataviaasch Genootschap stelde Van Iperen zijn gevoelsgenoten gerust. Juist in Batavia wist men deugd en wijsheid te eren en te combineren (VBG 2:151-61).

De eerste vijf delen (1779-1790) bleven vooral gevuld met werk van de bestuursleden. Pas in deel zes sloeg de balans door naar andere leden. Toen droeg alleen Andries Tesseire nog een beschrijving bij van de Omme- en Bovenlanden van Batavia. Volgens een telling van Snelders zijn 73 van de 95 artikelen in deel 1-6 afkomstig van bestuursleden, terwijl er slechts 25 auteurs te noteren vallen. ${ }^{96}$ In de delen 3-7 (1781-1794) werden nog slechts drie prijswinnende verhandelingen opgenomen: L. Bicker en P. van Nielen over de inenting tegen pokken en $\mathrm{C}$. Terne over babyvoeding. Zo was het draagvlak voor de Verhandelingen klein. De dirigerende leden vormden het bestuur, de redactie én leverden het overgrote deel van de kopij. Dat kleine draagvlak, dat in de loop van de eerste decennia niet breder werd, was het zwakke punt van de organisatie. Alleen een enthousiast en ijverig bestuur kon het genootschap in leven houden. Corresponderende leden zaten te ver af. Toch slaagde het bestuur er grotendeels in om de Bataviasche Verhandelingen Aziatisch te laten blijven. In de delen 3-5 kwamen alleen dergelijke 'Aziatische' bijdragen voor. Pas voor deel 6 moest de redactie een noodgreep doen. De algemeenmusicologische verhandeling van Johannes Gratiaen - twee derde van het boekdeel - had geen Aziatische connectie.

96 Snelders 1979:81. Als we het eerste stuk van dl 7 (1794) met de bijdragen van C. Terne en A. van Rijck meetellen, om zo de hele 18e eeuw mee te rekenen, worden de getallen 73 van de 97 artikelen, maar dit wijzigt Snelders oordeel uiteraard niet. 
Uit de notulen kan men de redactiewerkzaamheden ten dele volgen. Omdat die notulen veelal niet meer zijn dan aangeklede besluiten en signaleringen is het niet gemakkelijk om een redactiebeleid te reconstrueren. Toch is er een aantal opvallende feiten. Van de meer dan dertig inzendingen op prijsvragen, die in de periode 1779-1782 binnenkwamen, werden er in deel 1-4 van de Verhandelingen niet meer dan zes opgenomen, dit ondanks de welwillende, vooral als aanmoediging bedoelde woorden waarmee sommige afgewezen inzendingen in de voorberichten werden gesignaleerd. Hier tegenover stonden de bijdragen van bestuurs- en redactieleden die juist in overgrote meerderheid de delen vulden. Kennelijk was het gemakkelijker kritisch te zijn tegenover anderen, dan tegenover elkaar. Toch kwam niet alles, wat de bestuursleden in de bestuursvergaderingen ter sprake brachten, in de delen van het genootschap terecht.

De komst van Van Iperen in Batavia werd meteen aangegrepen om hem in te schakelen bij de produktie van de Verhandelingen. Eerst was de assistent Dorsman tot corrector van de drukproeven aangesteld tegen tien rijksdaalders per maand, zodat de Zeeuwse predikant zich vooral over inhoudelijke en redactionele zaken kon buigen. ${ }^{97}$ Van Iperen kreeg als secretaris naast Von Wurmb op 10 mei 1779 de taak om aantekeningen te maken van de vergaderingen, resoluties op te stellen, de correspondentie te onderhouden en de drukproeven na te zien. Dorsman was aldus niet meer nodig, maar Van Iperens spoedige dood veranderde dat weer. Von Wurmb werd toen penningmeester en beheerde de bibliotheek, het kabinet van natuurlijke bijzonderheden en zou de meteorologische waarnemingen doen. ${ }^{98}$

Door Van Iperens ontijdige dood kon alleen deel 1 van de Verhandelingen door hem worden verzorgd. Hij had er het voorbericht en de ledenlijst voor opgesteld. Van Iperens ambtgenoot, Jacob Caspar Metzlar, volgde hem op als secretaris-redacteur en was als zodanig verantwoordelijk voor deel 2-4. Metzlar reisde eind 1783 huiswaarts met het retourschip 'Java', en was zo getuige van het 'allerijsselijkst bloedbad', de muiterij aan boord waardoor Radermacher zelf en Metzlars echtgenote Petronella Weppelman stierven. Zijn rol als secretaris-redacteur werd overgenomen door de koopman, en het lid van de Weeskamer, Hendrik Nicolaas Laclé.

Radermacher en Metzlar namen de kopij voor deel 4 mee naar Holland, waar Arrenberg en Allart voor de uitgave zouden zorgen (1786). Behalve de prijsverhandelingen van Bicker en Nielen en de uitgave van Von Wurmbs nagelaten natuurhistorische aantekeningen, waren de zes overige bijdragen van Radermacher zelf, zijn nagelaten geschriften. Zij vulden daardoor meer 
dan de helft van dit 'Hollandse' deel van de Verhandelingen. ${ }^{99}$ Opvolgervoorzitter Moens maakte in april 1785, in een brief aan Zeeland, duidelijk waarom deze noodsprong werd gemaakt. 'Het Genootschap alhier is nog in stand; het 4e Deel wordt te Rotterdam bij de boekdrukker Arrenberg gedrukt, dewijl in den gepasseerden Oorlog daartoe hier geen papier voor handen was.' ${ }^{100}$ Moens had het presidium van het genootschap niet dan na de nodige aandrang op zich genomen. Hij had in 1783 al aan zijn vriend Jona te Water in Vlissingen geschreven dat er in Batavia geen gunstige sfeer voor het genootschap heerste:

geld te winnen scheind hier de groote hoofd zaak zijn: mijn tijdgenoot, de Heer van Iperen was voor mijn komst ter dezen plaatse reeds overleeden; d'heer raad ordinair Radermacher, de Lutersche Predikant Hooijman en eenige andere wijnige, zijn in dit op zigt hier witte Raven. ${ }^{101}$

In 1785 had de Lutherse predikant al op zich genomen om het programma voor dat jaar te formuleren. De drukke koopman-secretaris Laclé had vervolgens kans gezien een deel van zijn werkzaamheden af te schuiven: de zorg voor de bibliotheek en het kabinet waren op Hooijman overgegaan, waarna hij nagenoeg alles deed wat er in het bestuur te doen viel. ${ }^{102}$ In 1787 meldde Moens dat Hooijman deel 5 van de Verhandelingen onder handen had, maar dat hij een drukbezet man was. ${ }^{103}$ Hooijman werd tegelijk de enige genoemd die zich nog voor het genootschap inzette.

Het werk aan het vijfde deel viel Hooijman kennelijk zwaar. Het werd in vergelijking met de vier voorgaande delen een dun boekje van 235 pagina's met negen bijdragen, waarvan vijf van de bestuursleden Hooijman, Le Dulx en Tesseire. Drie andere waren van de Portugese plantkundige F. Noronha. De drukgeschiedenis van dit magere vijfde deel was even lang als die van deel vier, waaraan door de moord op Radermacher bloed kleefde. Pas in maart 1791 kon het gedistribueerd worden. Het is deels de verdienste van Moens dat deel 5 en 6 uitkwamen. Anders dan Radermacher heeft hij geen tekst bijgedragen aan de Verhandelingen, maar hij zorgde wel voor de continuïteit in het genootschap.

Deel 7 kon met de beste wil van de wereld niet meer in de achttiende eeuw voltooid worden. De opvolger van Moens, voorzitter Jan Hendrik Wiegerman,

99 Van de kopij van VBG 4 is in het archief van Radermacher, onderdeel van het archief Vosmaer, het grootste deel bewaard gebleven. Alleen de teksten van Bicker en Nielen ontbreken hieraan. NA 2.21.271 Archief Vosmaer nr 840-846. Netschrift met correcties in Radermachers hand.

100 A. Moens aan J. te Water, Batavia 30-4-1785. Zeeuwse bibliotheek, Hs 2077.

101 A. Moens aan J. te Water, Batavia, 31-10-1783. Zeeuwse bibliotheek, Hs 1982.

102 ANRI KBG Dir 0020, 119-121, vergadering 15-3-1785.

103 A. Moens aan A. Drijfhout te Vlissingen, Batavia 12-9-1787, RAZ KZGW 59, fol. 302-304. 
ook hij raad ordinaris, lid van het eerste uur en directeur van het genootschap sinds 1789, maakte wel een goede start: hij stelde voor een algemene catalogus van de bezittingen van het genootschap op te stellen en zag ook nog kans in 1793 een algemene vergadering bijeen te roepen. In 1794 werd besloten, bij gebrek aan kopij voor een volledig deel van de Verhandelingen, in ieder geval een eerste stuk van deel 7 te drukken en te verspreiden.

Om echter aan de Leden des Genootschaps dit Jaar eenige Voldoening te bezorgen, is verstaan de afgedrukte materie als kunnende uitmaaken des VIIde Deels eerste Stuk tegen den tijd er inzameling van fournissementen uit te geeven, en te gelijk met de gewoone Rekeningen den Leden te overhandigen. ${ }^{104}$

Zo kwam het eerste stukje van het zevende deel in 1794 bij Compagniesdrukker Pieter van Geemen uit als laatste publicatie van de eeuw. Het bestond uit de al genoemde prijsverhandeling van de Leidse arts $C$. Terne en een verhandeling van A. van Rijck over de zeden en gewoonten van de inwoners van de Bromo, meer niet. In 1814, toen het zevende deel onder Britse vlag als een volledig deel uitkwam, werden deze twee verhandelingen herdrukt.

De slotsom is niet erg positief voor wat betreft de publicaties van het genootschap in de achttiende eeuw: zes delen Verhandelingen en een stukje van het zevende, vijf programma's en nog een keer een aparte uitgave van de Wetten (1791). Nadat eerst de oorlog met Engeland roet in het eten had gegooid en na 1788 iets van een herleving was begonnen, zakten de genootschapsactiviteiten na 1794 zo goed als helemaal in.

\section{Gebouwen: genootschapshuis en -tuin}

Al snel na de oprichting werd de behoefte gevoeld aan een eigen gebouw om de verzameling, hoe beperkt die in de aanvang ook was, op te slaan en om aan andere genootschapsactiviteiten onderdak te bieden. Voor de algemene vergaderingen was gebruik van ruimte in het Kasteel toegezegd, voor de maandelijkse bestuursvergaderingen was het huis van de voorzitter voldoende. Radermacher kondigde al in de vierde vergadering (oktober 1778) aan dat hij in de behoefte aan een eigen huis dacht te kunnen voorzien.

Den Heer Voorzitter gaf vervolgens aan de Vergadering te kennen dat hij in der tijd geneegen zou zijn tot gebruik aan het Genootschap te geven een Huis tot Inwooning van den Secretaris en van daarinne te plaatsen een Bibliotheek van de beste Boeken, eenige Manuscripten en een Cabinet van Naturaliaas. ${ }^{105}$ 
VERHANDELINGEN

V A N H E T

\section{B A T A VIASCH CENOOTSCHAP}

D E R

KUNSTENEN WEETENSCHAPPEN.

V Y F D E D E E L.

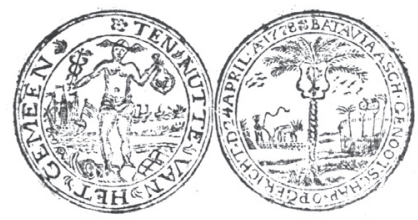

T E B A T A I A,

Gedrukt in d'E: Compagnies Bock-drukkery

By PIETER VAN GEEMEN I\$gO.

Titelpagina van deel 5 van de Verhandelingen, Batavia 1790 (collectie KITLV Leiden)
Het is de eerste keer dat er sprake is van een bibliotheek en een kabinet, het begin van wat in tweehonderd jaar een aanzienlijke verzameling zou worden. Het huis was echter niet meteen beschikbaar. Radermacher wilde bovendien, vóór hij tot de schenking overging, eerst een catalogus maken, zodat de verzameling geïnventariseerd en wel kon overgaan. Hij bezat een huis aan de Grote Rivier en een tweede huis, dat hij noemde: 'thuys in de stad', waarmee hij het oudste deel van de stad aanduidde. ${ }^{106}$ Het is niet duidelijk in welk huis vergaderd werd. In december 1778 wilde het bestuur niet langer wachten en op voorstel van Radermacher werd toen besloten een huis te huren voor vijftien rijksdaalders per maand, waar de instrumenten en boeken konden worden bewaard en waar natuurkundige proeven konden worden verricht. Von Wurmb zou toezicht houden en kasten en tafels kunnen laten maken. De huishuur werd vanaf begin 1779 betaald en timmerman Philip Aengler werd aangesteld als oppasser met als taak de bibliotheek en de kabinetten schoon te houden. Daarvoor ontving hij vijf rijksdaalders per maand. ${ }^{107}$ De eerste behuizing is echter niet te lokaliseren, de eigenaar werd aangeduid als 'de heer van Warem'. ${ }^{108}$

De notulen die melding maken van het huren van een huis bevatten tevens de eerste catalogus van de bezittingen van het acht maanden oude genootschap: een lijst van negen instrumenten en andere voorwerpen en van tien boeken. De herkomst van deze bescheiden verzameling is niet te traceren in de notulen. Mogelijk waren de voorwerpen bij de oprichting

106 Van beide stukken grond waarop de huizen stonden, zijn kaarten in het familie-archief Vosmaer, NA 2.21.271, 848-45 en 849-5. Het laatste wordt op het kadastrale kaartje aangeduid als het huis van de baljuw Radermacher en heeft achterop een aantekening van Radermacher. Het eerste noemt Radermacher zelf: het huis op de Grote Rivier.

107 ANRI KBG Dir 0001, 63-64, vergadering 3-5-1779.

108 ANRI KBG Dir tussen 0002 en 0003, 17, vergadering 4-10-1779 (niet in inventaris opgenomen), meldt dat van maart tot en met augustus 90 rijksdaalders huishuur is betaald aan Van Warem(?). De notities zijn slecht leesbaar. In Naamboek 1783:41, komt de naam voor van keurmeester Jacobus van Warem Jr. 
al of anders in de eerste maanden bijeengelegd door de bestuursleden, vooral ten behoeve van secretaris Von Wurmb, die met het nemen van natuurkundige proeven was belast. Hij kon daarbij gebruik maken van een electriseermachine, een electrofoor, een luchtpomp, een microscoop, een thermometer en een barometer. Verder waren er drie 'glazen met Insecten van Ambon', lijsten met glas waarachter de insecten waren uitgestald, een stel buffelhorens van het eiland Roti en twee koperen platen 'van een onbekend gebruik, op het Eiland Timor uit de grond gedolven', ongetwijfeld inscripties bevattend. ${ }^{109}$

Vijf van de tien boeken gingen over electriciteit. Linnaeus voerde met twee titels de drie plantenkundige publicaties aan, verder was er een boek over mineralen en een reisverzameling. ${ }^{110}$ Natuurkunde, biologie, plantkunde en geneeskunde vielen binnen de bedoelingen van het genootschap. Dat was uit het programma en uit deze kleine verzameling af te lezen. Vooralsnog ontbrak aan de verzameling alles wat met de bevordering van landbouw, visserij en nijverheid te maken had. Wel was begonnen met het bewaren van insecten, buffelhoorns en koperen platen met inscripties. Er waren nog geen berichten over volken, talen, zeden, oudheden en geschiedenis van de volken van Azië.

Tijdens de algemene vergadering in het Kasteel van maart 1779 kondigde voorzitter Radermacher aan dat het genootschap een tuin wilde kopen buiten de stad om te dienen als hortus. Misschien was dit wel bedoeld als een suggestie voor de rijke aanwezigen. Niet lang daarna tenminste deed schepen Sirardus Bartlo een gift. Een deel van zijn tuin aan de Amanusgracht ging over naar het genootschap, dat Von Wurmb opdroeg er een kleine hortus botanicus aan te leggen. Op het stuk grond stond een stenen huis met zeven kamertjes

109 ANRI KBG Dir 0001, 31-32, vergadering 7-12-1778.

110 Auteurs: J.A. Sigaud, J.A. Nollet, C. Linnaeus, J.G. Walerius, N.L. de Lacaille en D. de Gorter. 


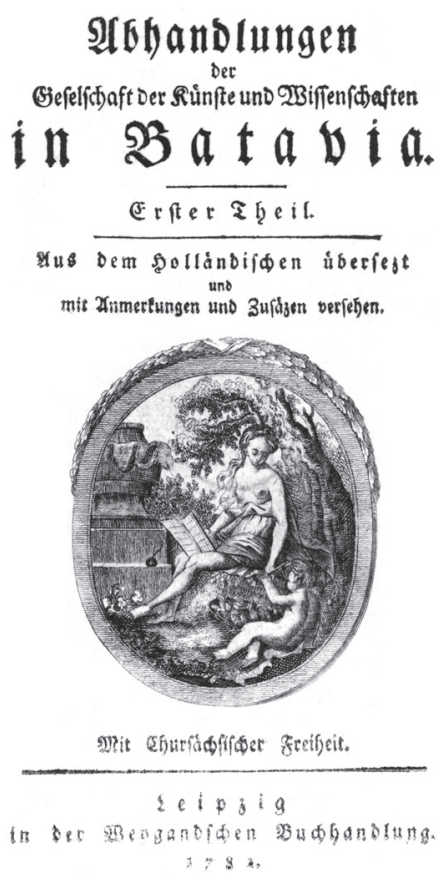

Titelpagina van de Duitse vertaling van deel 1 van de Verhandelingen, Leipzig 1782 (collectie UB Leiden) en een gang. Het had een getaxeerde waarde van honderd rijksdaalders. ${ }^{111}$ Zo had het genootschap dan huis en tuin. Met het huis was het echter niet tevreden. In augustus 1779 verzocht het bestuur de voorzitter een groter huis te huren voor de bibliotheek en het naturaliakabinet, maar ook om aan Von Wurmb plaats te bieden. ${ }^{112}$ Die wenk nam Radermacher ter harte en hij droeg in de laatste vergadering van 1779 , op 27 december, zijn huis aan de Grote Rivier met meubels, acht kasten met boeken, manuscripten, instrumenten, naturalia én twee slaven over aan het Bataviaasch Genootschap. ${ }^{113}$ Ineens had het zo niet alleen een eigen huis, maar ook een uitgebreide verzameling. Sterker nog, Batavia had op 1 januari 1780 een eigen museum.

Radermachers huis lag aan de westzijde van de Grote Rivier, in het meest zuidelijke blok. De tekening van het stuk grond laat zien dat het terrein niet doorliep tot de Jonkersgracht. Van de voorzijde van het huis keek men over
dsche Kerk. Er is echter geen afbeelding de Grote Rivier heen naar de Hollandsche Kerk. Er is echter geen afbeelding
van het huis bekend. Het was zodanig op orde bij de overdracht dat meteen besloten werd om de bibliotheek en de rest van de verzameling op woens-

111 ANRI KBG Dir 0001, 65, vergadering 10-5-1779. ANRI, familie-archief B 713/1 is een donatiebrief van het stuk grond van Bartlo aan het Bataviaasch Genootschap. Bepaald wordt dat het weer aan Bartlo zal vervallen als het genootschap het niet meer nodig heeft. ANRI KBG Dir 0019 (bijlagen bij de resoluties vanaf 1779) bevat diverse stukken die betrekking hebben op deze overdracht: [29-32] en [3], het laatste een getekend kaartje van het stuk grond.

112 ANRI KBG Dir 0002, 5-6, vergadering 9-8-1779.

113 Het moet het huis zijn, waarvan in de collectie-Vosmaer een kadastrale kaart aanwezig is, die echter niets anders laat zien dan het stuk grond waarop het stond. Aan de westkant van de rivier tegenover de Hollandsche Kerk, tussen de rivier en de Jonkersgracht, maar niet doorlopend tot die gracht. NA 2.21.271, Archief Vosmaer, nr 848-45. Kort tevoren had Radermacher voor duizend rijksdaalders in hetzelfde blok C, maar dan grenzend aan de Jonkersgracht een huis gekocht van Carel Jan Boers, geheel ingebouwd door andere huizen, namelijk van W. Timmers, de weduwe Marcus en Jacob Fransz. Uit de omschrijving blijkt dat dit huis niet grensde aan het huis dat aan het genootschap werd overgedragen (ANRI familie-archief B 713/2). 
dagochtenden van acht tot tien uur open te stellen voor het pubiek, waarbij een van de secretarissen aanwezig zou zijn om uitleg te geven. Zelfs uitleen werd mogelijk, maar alleen voor leden. Boeken mochten door hen tegen een getekend ontvangstbewijs worden meegenomen mits ze uiterlijk drie weken later zouden worden teruggebracht. ${ }^{114}$

Daarmee was een belangrijke beslissing genomen. Het genootschap stelde de bibliotheek en de andere verzamelingen open voor het publiek, al waren er restricties voor de uitleen. Dat particuliere collecties konden worden bezocht, op afspraak dan wel te verstaan, was in de Republiek bekend. Maar openstelling voor een ruimer publiek, met aankondiging van de openingstijden, was minder gewoon. Het Naturaliënkabinet van de Hollandsche Maatschappij was opengegaan in 1772, twee jaar later gevolgd door de schilderijengalerij van Willem $\mathrm{V}$ aan het Buitenhof (Sliggers en Besselink 2002:8). Het eerste echte museum was in Londen opengegaan in 1753, het British Museum. Batavia sloeg dus, in vergelijking met patria, geen slecht figuur.

In februari 1780 werd de openingsduur al verlengd tot drie uur, waarbij aan koster Palm het toezicht op de bibliotheek werd opgedragen. ${ }^{115}$ Von Wurmb was belast met de betaling van tien rijksdaalders per maand aan Dorsman voor het nakijken van de drukproeven, hetzelfde bedrag voor Palm voor zijn toezicht en voor de toezichthouder in de tuin, vijf rijksdaalders voor de twee slaven die Radermacher had overgedragen ('de jongen en de meid') en tenslotte nog twee rijksdaalders en vierentwintig stuivers voor de 'witte papousche meid'. Kosten voor het personeel aldus: zevenendertig rijksdaalders en vierentwintig stuivers per maand. ${ }^{116}$ De twee slaven, de Balinese Titus en Maria had Radermacher gekocht van de Licentmeester C.J. Boers, die 
naar het vaderland terugging en van wie hij ook een huis had gekocht voor duizend rijksdaalders. ${ }^{117}$

Het genootschapshuis zou tot 1814, het jaar van de verhuizing naar het zuiden van de stad in gebruik blijven, hoewel we over de latere jaren, vanaf 1795, slecht zijn ingelicht. De tuin was aanvankelijk aan de zorgen van Von Wurmb toevertrouwd. Na zijn dood in 1781 leek het wel of er niemand meer naar omkeek. In 1783 werd twintig rijksdaalders per maand uitbetaald aan de Zweed Clas Friederich Hornstedt, in maart 1784 werd dat bedrag tot veertig rijksdaalders verhoogd, vanwege zijn kunde in de botanie. Aan hem werd opgedragen de tuin weer op orde te brengen en hij kreeg daarvoor van Hooijman en Van der Steege instructies. ${ }^{118}$ Hornstedts verblijf was toen al bijna ten einde. Hij vertrok naar de Republiek met onder zijn hoede een levende orang-oetang voor het Zeeuwsch Genootschap. In 1788 werd van verder gebruik van het stuk grond van Bartlo afgezien. De tuin was te afgelegen, werd weinig bezocht, was verwaarloosd en kostte daarbij toch nog twintig rijksdaalders aan maandelijks onderhoud. Frederik Schouwman, koopman en eerste administrateur in de Medicinale Winkel, al lid sinds de oprichting en sinds 1784 bestuurslid, kondigde aan dat hij op de grond van de voormalige hortus medicus van Jacob Mossel, die hij in bezit had, een nieuwe kruiden- en plantentuin wilde aanleggen en openstellen. Het bleef echter duidelijk zijn eigen tuin en hij droeg die niet aan het genootschap over. De geschiedenis van de eigen genootschapstuin eindigt dus in 1788. 119

117 Notariële Akte voor de overname van de slaven in ANRI KBG Dir 0019, [33].

118 Radermacher had op 10-12-1781, direct na de dood van Von Wurmb op 5-12-1781, een brief aan Thunberg in Uppsala geschreven met verzoek om 'een bekaam Jongman toetesenden, die Kennis heeft der Natuurlijke Historie, en teffens in Staat is, deselve door goede Teekeningen te verrijken' (ANRI KBG Dir 0019, [16]). Hornstedt was vermoedelijk al in 1783 begonnen te werken voor het genootschap. In november 1783 werden twintig rijksdaalders per maand aan hem uitbetaald (ANRI KBG Dir 0019, [22], overdrachtspapier van Radermacher van 10-11-1783). In maart 1784 is er sprake van een verhoging van zijn betaling van twintig naar veertig rijksdaalders per maand. In hetzelfde jaar voer Hornstedt echter thuiswaarts (ANRI KBG Dir 0020, 83, vergadering van 27-3-1784, en 95, vergadering van 11-6-1784). Verder ANRI KBG Dir 0981, [7] over Hornstedts thuisvaart met de orang-oetang in een brief van A. Moens aan J. te Water, Batavia, 15-11-1784.

119 ANRI KBG Dir 0020, 139-141, vergadering 25-4-1788. Boelman 1936:56 zegt ten onrechte dat Hooijman deze tuin zou inrichten. VBG 5 :Voorberigt 20-21 zegt overigens niet dat het een genootschapstuin is. De verwarring tussen Hooijman en Schouwman is echter veroorzaakt door een fout van Der Kinderen 1878:52. 
Verzamelingen

In het begin van 1779 was er een genootschapshuis en kon er op een meer energieke wijze met het verzamelen worden begonnen. Immers, er was een plek om een en ander op te slaan en tentoon te stellen. Toen Radermacher enkele maanden daarvoor zijn plannen voor een grote schenking bekendmaakte aan zijn medebestuursleden, riep hij meteen zijn collega's op om zijn voorbeeld te volgen: 'Met versoek aan de gezamentlijke Heeren [bestuurs] leeden, indien zij iets merkwaardigs mochten bekomen hetzelve ten gebruike van het Genoodschap te bewaaren, verklaarende de gezamentlijke Heren Leden daartoe zeer geneegen te zijn.'120 Tezelfdertijd werd een werkverdeling gemaakt. Radermacher zou zich over de mineralen ontfermen, Hooijman over het plantenrijk en Van der Steege over het dierenrijk. Zo was in de studie van de drie rijken der natuur voorzien. Op diezelfde dag werd ook een door Radermacher opgestelde bestellijst goedgekeurd om naar de bekende Amsterdamse instrumentenmaker John Cuthbertson te worden gestuurd. Deze moest leveren: vier thermometers, vier barometers, twee hygrometers, twee windmeters, twee bakken om neerslag te meten, twee peilkompassen (om declinatie te meten), twee magneten en twaalf stalen magnetische ringen ('tot medicinale proeven omtrent het dierlijk meganismus'). ${ }^{121} \mathrm{De}$ instrumenten had men onder meer nodig voor weerkundige observaties. Waarnemingen doen en daarvan verslag afleggen hoorde tot het werk van secretaris Von Wurmb. De medicus Van der Steege was bezig met de medische toepassingen van magnetisme.

De oproep tot het afstaan van 'merkwaardigheden' werd gehoord en beantwoord. Directeur-Generaal Alting was de eerste van wie in de notulen een geschenk wordt vermeld, namelijk het manuscript van een Perzische grammatica, vermoedelijk hetzelfde manuscript dat twee maanden later werd aangeduid als een vertaling van de Perzische grammatica van William Jones, gemaakt door Caspar Leonard Eilbracht, boekhouder en vertaler voor het Perzisch en Arabisch bij het kantoor te Hougly (Bengalen). Hij en zijn broer Jacob, eveneens in Hougly werkzaam, boden later aan meer vertalingen te maken. ${ }^{122}$ Het is de eerste keer dat we de overheid iets zien doorschuiven naar het genootschap, zij het nog op een onofficiële manier, alsof Alting het op persoonlijke titel deed. In de loop van de negentiende eeuw zou dat heel

120 ANRI KBG Dir 0001, 25. In VBG 1:39, bleken ook de leden opgeroepen te worden. Bovendien werd vooral naar naturalia gevraagd.

121 ANRI KBG Dir tussen 0002 en 0003, 20, vergadering 4-10-1779. Zie ook VBG 1:Voorberigt 38. Voor deze bestelling zou F. de Wilde in Amsterdam, gemachtigde voor het Genootschap, op 14-12-1779 een rekening sturen van $f$ 1812.-.- (ANRI KBG Dir 0980, [20]).

122 ANRI KBG Dir 0001, 40, vergadering 27-2-1779; 58, vergadering 12-4-1779. 
gebruikelijk worden, zodanig dat het genootschap op een aftakking van het Departement van Onderwijs en Eredienst zou gaan lijken.

Behalve door incidentele schenking zou de verzameling worden uitgebreid op twee manieren: in de eerste plaats door aankoop van wat in Batavia op de markt verscheen en door bestellingen in het vaderland te plaatsen, zoals de instrumenten uit Amsterdam. In de tweede plaats door bij leden in en buiten Batavia via circulaires op een systematische wijze gegevens en de aanbieding van voorwerpen uit te lokken. Het aankoopbeleid kunnen we niet dan zeer schetsmatig aflezen uit een beleidsdocument als het al besproken programma van 1778. Het bestuur zou 'greetig ontvangen, al wat de natuurlyke Historie, Oudheden, Zeden en Gewoonten der Volken aangaat'. Aankopen kunnen illustreren of het genootschap zich hieraan hield. Bij de eerste financiële verantwoording, op 12 april 1779, bleek in Batavia te zijn gekocht: een luchtpomp, een windmeter, een prisma, drie barometers en twee thermometers voor een gezamenlijk bedrag van honderdzeven rijksdaalders. Meteorologische waarnemingen en natuurkundige proeven stonden hoog genoteerd. Ook waren er boeken aangeschaft: de negendelige natuurlijke historie van G. Buffon, de reizen van F. Hasselquist en van Schauw, Burmans Flora Indica, de Recherches sur les Modifications de l'Atmosphère van J.A. Luc en het Herbarium Vivum van J.H. Kniphof voor een gezamenlijk bedrag van 118 rijksdaalders. ${ }^{123}$ Van wie deze boeken werden gekocht, blijkt niet uit de gegevens, maar er blijkt uit dat er in Batavia een markt was voor wetenschappelijke boeken en voor instrumenten.

In de tezelfdertijd opgestelde aanvulling op de bescheiden catalogus van december 1778 komen nog andere boeken voor: vijf delen van de Verhandelingen van het Zeeuwsch Genootschap, Van Swindens Observations sur le Froid, vier stukken van het Journal Littéraire van 1776 en twee delen platen bij Buffons Histoire Naturelle. Daarnaast was er de Perzische grammatica van Jones vertaald door Eilbracht, en waren er drie manuscripten in oosterse talen en één gedrukt oosters boek. Jammer genoeg werden deze niet verder aangeduid. ${ }^{124}$ Van deze boeken blijkt niet dat ze gekocht zijn, want ze komen niet voor in de afrekening, in tegenstelling tot de eerder genoemde. Ik concludeer daarom dat ze door leden of bestuursleden bijeen zijn gelegd in antwoord op Radermachers oproep van oktober 1778. Onder de 'merkwaardigheden' op de lijst staan een tafel van Ambons hout, Javaanse spinnen achter glas, vier partijen Ceylonese insecten, vier partijen medicinale planten en wortels afkomstig van Ceylon, en een partij hoorns en schelpen van het zelfde eiland. Uiteraard is het onmogelijk om in extenso te blijven aangeven 
wat er bij het genootschap binnenkwam, maar deze complete aanvulling op de tien boeken en de tien instrumenten en voorwerpen die al in december 1778 waren geregistreerd, geeft een beeld van wat men met de bibliotheek en de verzameling 'merkwaardigheden' voor had. De vierentwintig titels, meer dan veertig banden omvattend, legden de nadruk op natuur- en plantkunde en oosterse talen. Er zijn wetenschappelijke tijdschriften en seriewerken onder en tenslotte reisverhalen. Het was het begin van een wetenschappelijke bibliotheek en vormde een afspiegeling van de ambities van de mannen van het eerste uur. De verzameling uit het planten- en dierenrijk bevestigt de nadruk die viel op het verkennen van de eigen omgeving. De enige proeven van nijverheid betroffen van een bananenboom gemaakte katoen en bananenblad dat als papier was geprepareerd. Voor het opbergen van dit alles had men intussen een rode kast met goudgeverfde lijsten laten maken. Verder waren er drie rood-gouden tafels en twee houten lijsten met glas voor het tentoonstellen van insecten.

Het was vooralsnog een bescheiden begin, maar na april 1779 werd er heel snel uitgebreid. Zodanig zelfs dat in augustus 1779 voor het laatst een volledige catalogus werd opgesteld. Alle navolgende catalogi zijn niet meer dan een aanduiding van de indeling van de verzameling, tot de eerste gedrukte catalogus van de bibliotheek in $1846 .{ }^{125}$ Het opstellen van de catalogus van 1779 is een aanwijzing voor de betrekkelijk snelle groei die het genootschap doormaakte. Het boekstaven van die groei wijst tevens op zelfbewustzijn. Men deed niet onder voor andere genootschappen. Het was de functie van de voorberichten in de Verhandelingen om daar trots op te wijzen.Van Iperen kon dan ook begin 1780 in een brief aan zijn collega Jona te Water te Vlissingen hoog opgeven van wat in korte tijd was bereikt.

Ons Bataviasch Genootschap bezit reeds een schoon Huis en de noodige slaaven op de Groote Rivier, als mede eene Bibliotheek en Kabinetten van Kunst en Natuur, die onze schatten van Vlissingen verre overtreffen. Zoodanige eene verzamelinge, als deze denkelijk worden zal, verdient alleen, dat Zijne Hoogheid Protector, de Heeren Bewindhebberen Maecenaten en de Geleerde van Nederland uitlandsche Correspondenten worden; en dat het zelve voldure, zoo lang als de Colonie. ${ }^{126}$

Deze wens van Van Iperen, die een maand later zelf overleed, kwam uit. Bij de onafhankelijkheid van Indonesië bestond het Koninklijk Bataviaasch Genootschap nog steeds.

125 Echte catalogi van december 1778, april 1779 (aanvulling) en augustus 1779 (in extenso), in ANRI KBG Dir 0001, vergadering 7-12-1778 en 12-4-1779 en ANRI KBG Dir tussen 0002 en 0003 , vergadering 4-10-1779. De overdracht van Radermachers verzameling, vermeld in VBG 1:39-41, maar niet in extenso beschreven. Een grove inventaris in ANRI KBG Dir 0020, 47-51.

126 Van Iperen aan J. te Water, Batavia, januari 1780. Zeeuwse Bibliotheek, Hs 2014. 
De voornaamste weldoeners in de eerste jaren waren voorzitter Radermacher zelf en zijn collega in de Raad, David Joan Smith, die voorzitter was van het college van Weesmeesters en commissaris van de Soldij. Radermacher schonk naast zijn huis een verzameling boeken en andere voorwerpen, verdeeld over acht kasten, die in december 1779 overging, maar die al in het eerste deel van de Verhandelingen werd aangekondigd. Ineens was het genootschap de trotse bezitter van een Encyclopédie van Diderot en D'Alembert in 28 delen en een complete Voltaire in 68 delen, naast Portugese, Maleise, Tamilse en Singalese uitgaven van christelijke aard, alles verdeeld over de eerste vier kasten. Daarnaast een kast met grondstoffen, delfstoffen, en andere naturalia. Kast zes was voor opgezette dieren en gedroogde planten, kast zeven voor mineralen en ertsen en de munten en kast acht voor de physische en mathematische instrumenten. Verder had Radermacher al een verzameling Javaanse muziekinstrumenten aan het genootschap overgedragen, waarover Von Wurmb moest schrijven. ${ }^{127}$

Radermacher was een vermogend man, een groot verzamelaar en een genereus mecenas. Het is jammer dat we niet meer te weten kunnen komen over het tijdstip waarop hij met verzamelen is begonnen. Moeten wij ervan uitgaan dat hij bij zijn terugkeer naar Batavia in 1767 zulke omvangrijke boekwerken als de Encyclopédie en de complete Voltaire meenam? En dat terwij1 hij zijn eigen reiskosten en dus ook extra voor meegebrachte vracht moest betalen? Hoe kwam hij aan het achtdelige Opus Botanica van J.W. Weinmann, dat hij in juni 1779 ter beschikking stelde van Von Wurmb, die plantenkundig onderzoek deed en het toezicht had gekregen over de opbouw van de hortus botanicus? ${ }^{128}$

David Joan Smith was al op tweeëndertigjarige leeftijd raad extra-ordinair en dankzij vier achtereenvolgende huwelijken met vermogende erfdochters een van de rijkste mannen van Batavia. Zijn vierde vrouw was het enige kind van dominee Mohr en via haar kwam misschien wel het niet geveilde deel van de verzameling-Mohr bij het genootschap terecht (Gelman Taylor 1988:11724). Smith bedacht het genootschap met enkele interessante schenkingen. De eerste was een verzameling 'Persiaansche en Sancretaansche [Sanskritische] Manuscripten, zoo 't schijnt, van eene groote waarde'. In oktober 1779 werden deze dertien manuscripten geboekstaafd. ${ }^{129}$ Veel deskundigheid op het gebied van het nieuw verworven materiaal was niet aanwezig, want besloten

\footnotetext{
127 VBG 1:Voorberigt 41. Het kwam jammer genoeg niet van deze verhandeling. Van Wumbs negentien bijdragen aan $V B G$ liggen geheel op natuurhistorisch gebied.

128 ANRI KBG Dir 0001, 79 , vergadering 7-6-1779.

129 ANRI KBG Dir tussen 0002 en 0003, vergadering 4-10-1779, art. 5 en p 21. Onheilspellend voegt de opsteller van de notulen eraan toe: 'ten zij dezelve op de enen of andere wijze in het Vaderland wierden gereclameerd'. Zie aldaar ook de catalogus van dezelfde datum.
} 
werd dat Van Iperen drie hoogleraren in de oosterse talen in het vaderland moest aanschrijven en hun een lijst van de collectie sturen met verzoek om raad. Het ging om S. Rau, N.G. Schroeder en E. Scheidens, respectievelijk aan de hogescholen van Utrecht, Groningen en Harderwijk werkzaam. In december 1779 liet Smith er een verzameling landkaarten en profielen van Batavia en de Ommelanden op volgen. ${ }^{130}$ In 1780 schonk hij 'alle Papieren en Manuscripten der Macassaren, die bij de Verovering van Goa, in die stad, gevonden zijn, waarbij ook de Zeguls van de Koning, een staf van Commando, als mede een glas door de berugte Aro Palakka gebruikt.' ${ }^{131}$ Bij de verovering van de stad Goa in 1776 was de Indische regering in het bezit gekomen van deze regalia. 'Gevonden' zeggen de notulen liever dan 'meegenomen' of 'veroverd'. Radermacher refereerde in een brief van 15 oktober 1778 aan de Stadhouder aan 'onze verovering van de stad Goa'. ${ }^{132}$ Tenslotte schonk Smith in 1781 enkele waardevolle atlassen. Toen bibliothecaris Van der Chijs in 1864 een grote controle hield in de bibliotheek waarbij hij alle in de notulen vermelde, binnengekomen boeken noteerde, moest hij vaststellen dat deze atlassen spoorloos waren verdwenen (Jaarboek 3:235-6). De schenkingen van Smith, die zo te zien uit particulier bezit afkomstig waren - hoewel er bij de papieren, manuscripten en regalia van Goa vraagtekens te plaatsen zijn - doen vermoeden dat er grote schatten in handen van privé-personen waren aan het einde der achttiende eeuw. De grens tussen regeringsbezit en particulier bezit was niet altijd precies te trekken.

Andere opvallende of belangwekkende schenkingen in de opbouwperiode van de verzameling betreffen een collectie van honderdvijftig gedroogde planten van de Kaap van fiscaal Carel Jan Boers (mei 1779), insecten, hout, bladeren, bloemen en vruchten van Ambon van gouverneur Bernard van Pleuren (november 1779), een 'witte Papoen, Negerin, of Kakkerlakke, zijnde een Meisje' van Ternate (november 1779), een Egyptische mummie uit de Malabar (bestemd voor het Zeeuwsch genootschap) van directeur Adriaan Moens (april 1780), Japans papier van E.R.C. van Bekstein (februari 1781) en een beeld van Vishnu van J.J. Cellarius en Falck (juli 1781). ${ }^{133}$ Het is slechts een bloemlezing uit wat gemeld werd in de eerste jaren, gevarieerd naar zowel aard als naar afkomst. Het laat zien dat het kabinet van het genootschap de mogelijkheid had een centrum te worden van alles wat wetenswaardig en

\footnotetext{
130 ANRI KBG Dir 0003, vergadering 27-12-1779, art. 5.

131 ANRI KBG Dir 0009, 324-325, vergadering 4-9-1780.

132 Koninklijk Huisarchief, Archief Stadhouder Willem V, 331-21 nr 3, corr. van Radermacher als Raad van Indië, brief van 15-10-1778.

133 ANRI KBG Dir 0001, 60, vergadering 3-5-1779. KBG Dir tussen 0002 en 0003, 42-43, vergadering 1-11-1779; KBG Dir 0006, 353, vergadering 1-4-1780; KBG Dir 0008, 370, vergadering 1-4-1780, art. 3.
} 
opmerkenswaard was in het hele VOC-gebied. Het laat tevens zien dat de roep van het genootschap om op de hoogte te worden gebracht van bijzonderheden die de regio betroffen, weerklank had gevonden. Veel structuur is er in de aanwinsten niet te ontdekken. Het genootschap was blij met alles.

De collectie kon door deze schenkingen zo snel groeien, dat de catalogus van augustus 1779, dus nog vóór het opnemen van de collectie Radermacher, was uitgegroeid tot vijftien manuscripten en 30 boeken in oosterse talen (waaronder men ook zeven Portugese boeken rekende), 43 titels van boeken in het Nederlands, Frans en Latijn (waaronder diverse seriewerken), vijftien natuurkundige instrumenten, 31 rariteiten, 37 muziekinstrumenten en vier geraamtes, waaronder dat van een Makassaars meisje. Het is helaas de laatste catalogus die in deze periode in extenso is opgenomen. ${ }^{134}$ De inventarislijst van 1783 is grover en noemt alleen categorieën, geen afzonderlijke titels of voorwerpen meer. ${ }^{135}$

Voor wat betreft de uitbouw van de bibliotheek is het van belang te weten welke boeken en tijdschriften voor Batavia in het vaderland werden besteld. Daaruit kunnen we opmaken wat in Batavia ontbrak en hoe de ideale bibliotheek er in de ogen van de genootschapsbestuurders uit zag. Al bij het eerste contact met de drie genootschappen in Haarlem, Rotterdam en Vlissingen werd hun verzocht al hun verhandelingen op te sturen. 'Wij wenschten ook wel machtig te zijn alle de ingekomene verhandelingen en Programmata van de Maetschappije, en verzoeken UwelEd. ons dezelven te willen toezenden.' ${ }^{136}$ Die moesten minstens in de bibliotheek voor handen zijn, als teken van verbondenheid en als voorbeeld ter navolging.

In mei 1779 bleek Radermacher te beschikken over een partij recente tijdschriften en boeken, die hij uit het vaderland had ontvangen 'ten gebruike van het Genootschap'. Hij stelde deze ter beschikking van zijn medebestuursleden, omdat hij van mening was dat het Europese 'letternieuws' ten nutte van de kolonie ook aan anderen moest worden meegedeeld. Gezien het ontbreken van welke vermelding dan ook van deze 'nieuwspapieren' in de notulen van voorgaande vergaderingen, moeten we wel concluderen dat deze boeken en tijdschriften door Radermacher waren besteld vóór de oprichting van het genootschap. Het interessante is, dat het genootschapsbestuur zich meteen tot het lezen ervan zette en dus als een leesgezelschap ging fungeren. De boeken en tijdschriften werden verdeeld onder Radermacher, Van Iperen, Hooijman, Von Wurmb, Van Hogendorp en Van der Steege, en er zouden leesverslagen volgen. Wat lazen ze toen? Franse, Engelse en Nederlandse

134 ANRI KBG Dir tussen 0002 en 0003, 21-29, vergadering 4-10-1779.

135 ANRI KBG Dir 0020, 47-51.

136 RANH HMW 53 (ingekomen correspondentie 1778), brief van het genootschap aan secretaris Van der Aa, Batavia 1-6-1778. 
tijdschriften, natuurkundige en natuurhistorische werken in het Frans en het Nederlands. Radermacher leek met deze lectuur duidelijk uit op brede informatie uit de Europese Republiek der Letteren. ${ }^{137}$

Een maand later al schreef het genootschap een uitgebreide brief aan de boekdrukkers en -verkopers Arrenberg en Allart. Naast het verzoek tot het herdrukken van de Bataviase Verhandelingen voor een Nederlands publiek, bevatte de brief ook een lijst van boeken die men wilde ontvangen en waarvoor een wissel van driehonderd gulden werd ingesloten. Deze lijst van Nederlandse, Franse, Engelse en Duitse boeken en tijdschriften was veel uitgebreider dan wat Radermacher een maand eerder had ontvangen en het toont de ambitie van de bestuursleden om de bibliotheek te laten uitgroeien tot een echte Europees voorziene boekerij met een zowel algemeen als een wetenschappelijk doel. ${ }^{138}$ Arrenberg en Allart kregen de opdracht om 'voorts nog alle boeken [van] Smaak die groote aftrek hebben' mee te zenden. ${ }^{139} \mathrm{Er}$ werden geen beperkingen opgegeven, anders dan de omvang van het eerste voorschot van driehonderd gulden aangeeft. Radermacher moet geweten hebben dat dit flink wat geld zou gaan kosten. Er waren bovendien bestellingen bij Holtzhey (munten) en Cuthbertson (instrumenten) gedaan.

Toen een paar maanden later de collectie van het genootschap bij die van Radermacher was gevoegd in het huis aan de Grote Rivier, had koster Palm, die vanaf februari 1780 de boeken aanreikte op de woensdagochtenden in ieder geval al een aantal kasten vol onder zijn beheer. Jammer genoeg ontbreken er bezoekers- en uitleenregisters.

Naast uitbreiding van de collectie door schenking en door aankopen zowel in Batavia en als in het vaderland, werd uitbreiding nagestreefd door rechtstreekse verzoeken te richten tot leden en niet-leden. Bij de eerste poging werd de regering ingeschakeld. Die stuurde op 30 december 1778 een circulaire aan de buitenkantoren met het verzoek om antwoord op de erbij gaande veertien vragen onder medezending van de gevraagde naturalia, alles te richten aan Radermacher. De circulaire met de vragen en instructies vormt de eerste gerichte poging van het genootschap om de kennis van land en volk uit te breiden door inschakeling van rapporteurs in het veld. ${ }^{140}$ De gouverneurs,

ANRI KBG Dir 0001, 61-63, vergadering 3-5-1779. Vermeld worden daar het Journal des Scavans, l'Esprit des Journaux, La Connaissance des Temps, Gentleman's Magazine, Boekzaal der Geleerde Werelt, Vaderlandsche Letteroefeningen, de Verhandelingen van de genootschappen van Rotterdam, Haarlem en Vlissingen, Roziers Observations Physiques, Boddaerts Samenstel en het vervolg op Houttuijns Natuurlijke Historie.

138 ANRI KBG Dir 0001, 74-76, vergadering 7-6-1779.

139 ANRI KBG Dir 0001, 76, vergadering 7-6-1779.

140 De Notulen melden niets vooraf over deze via de regering verzonden circulaire. Wel wordt er op 4-1-1779 aan gerefereerd. ANRI KBG Dir 0001, 35. Een kopie van de brief in ANRI KBG Dir 0980, [56]. De circulaire aldaar nr [5], zie ook nr [3]. Zie verder Van der Chijs 1885-1900, X:343-5. 
directeuren, commandeurs, opperhoofden en residenten op de buitenkantoren hadden het programma van het genootschap al eerder ontvangen, dus de brief van de regering kwam niet onvoorbereid. Hoewel de vragen worden aangeduid als betrekking hebbend op de 'Natuurlyke Historie van India' gaan pas de vragen 8-14 over de weersomstandigheden, over dieren- en plantenrijk, mineralen en ertsen. De lijst vangt aan met vragen naar land en volk, naar kaarten en naar taal, boeken, zeden en gewoonten (geboorten, huwelijken, begrafenisssen), tijdrekening en kennis van de sterrenhemel. In zeven heel bondige vragen werd de basis gelegd voor een verzameling gegevens die buitengewoon waardevol kon worden, als er maar op gereageerd zou worden. De bijzondere medewerking van de kantoorhoofden werd gevraagd om uit te zien naar lieden 'in lage of geringe Qualiteyten gesteld [...], Lieden van de Zeevaard, de Militie en Ambagtsgezellen' die bij goede medewerking aan de beantwoording van de vragen en inzending van naturalia een behoorlijke beloning zouden krijgen en misschien zelfs eerder bevorderd zouden worden. Kennelijk zagen genootschap en regering niet zoveel in het rondsturen van vragen zonder dit te koppelen aan een beloning. Dat was goed gezien.

Het genootschap herhaalde de oproep nog eens in mei 1779 in een brief aan de hoofden van buitenkantoren waarbij ook het voorbericht van deel 1 van de Verhandelingen meegestuurd werd. ${ }^{141}$ Von Wurmb vertoonde in mei 1779 kamferbladen en -bloemen uit West-Sumatra, een eerste aanwijzing voor reacties op de regeringscirculaire. In dezelfde maand stelde hij nog een meer specifieke lijst op van zaken die men uit Japan wenste te ontvangen. ${ }^{142}$ Bij de West-Sumatraanse zending werd niet vermeld of ze een reactie waren op de regeringsoproep van 30 december 1778. Een uitvoerige zending uit Malakka van februari 1780 refereerde echter wel aan de circulaire van de Hoge Regering. Gouverneur Pieter de Bruijn en de zes overige bewoners van het kasteel te Malakka hadden zich bepaald uitgesloofd om te voldoen aan de veertien vragen van het genootschap. Ze stuurden een beschrijving van Malakka en van de gewoonten der Maleiers, een bericht over gambir, een brief over tinerts, voorbeelden van gambir en tinerts, een uitgebreid Nederlands-Maleis woordenboek in vier delen, de wetten uitgegeven door de koningen en de sultans van Malakka en tenslotte een misdracht van een varken. ${ }^{143}$

Hoe serieus het bestuur de zaak opnam, blijkt wel uit het 'Naberigt' van 15 september 1779 bij het eerste deel van de Verhandelingen. Van Iperen gaf een uitvoerige beschrijving van de wijze waarop naturalia verzorgd, gedroogd,

141 ANRI KBG Dir 0980, [3], gedrukte brief van 10-5-1779.

142 ANRI KBG Dir 0001, 60, vergadering 3-5-1779, en 79, vergadering 10-5-1779.

143 ANRI KBG Dir 0980, [14], brief gedateerd 14-2-1780. De verhandeling van Abraham Couperus over de teelt van gambir kwam VBG 2 terecht. 
verpakt en verzonden moesten worden. Ook hier bleken de ambities niet gering. Bij voldoende voorraad zouden de kabinetten van de universiteiten en dat van de Stadhouder van exemplaren worden voorzien, als de leiding van die instellingen zou opgeven wat men wilde ontvangen. Batavia was bereid daar alle kosten voor op zich te nemen in ruil voor het ontvangen van Europese, Amerikaanse, Afrikaanse en Levantse zeldzaamheden. Een dusdanig ambitieus ruilverkeer met Europa zou overigens nooit succesvol worden, al zijn er ook in de achttiende-eeuwse genootschapsperiode diverse zendingen Europawaarts gegaan. ${ }^{144}$ In 1780 deed het bestuur nog eens een poging. Eind augustus ging er weer een gedrukte brief uit naar de buitenkantoren, dit keer vergezeld van een uitvoerige Memorie en een aparte Lijst van diverse 'simpliciaas' (natuurhistorische voorwerpen). Er werd niet aan de eerdere pogingen gerefereerd, maar van zes categorieën naturalia werd aangegeven welke specimina men wilde hebben. Op de bijgaande lijst stond opgegeven welke 87 planten en stoffen men van welke kantoren in het bijzonder wilde ontvangen. ${ }^{145}$

Het bestuur luisterde welwillend naar verzoeken uit het vaderland en schakelde vervolgens leden op buitenkantoren in. Aernout Vosmaer, de directeur van de Stadhouderlijke verzamelingen, die al eerder een orangoetan op sterk water had ontvangen, riep eind december 1789 de hulp in van het genootschap, in de hoop Aziatische fossielen te ontvangen, alsmede een Kahau-aap en schedels van een Alfoer, Javaan, Chinees, Moor, Singalees, Malabaar, Pers en Arabier. Vosmaers verzoek werd aan veertien buitenkantoren doorgestuurd. ${ }^{146}$

Het verzamelen werd dus serieus aangepakt. Aan Radermacher, Van Iperen, Von Wurmb en hun collega's lag het niet dat de antwoorden niet meteen binnenstroomden. Toch was er, tegen de tijd dat Radermacher zich opmaakte om naar Europa terug te gaan, een heuse verzameling bijeengebracht. Tien kasten borgen boeken, handschriften, kaarten en tekeningen. We mogen dan rustig spreken van een bibliotheek. Die stond aan de Grote Rivier in het benedenhuis opgesteld, verdeeld over de voorkamer en de galerij. In de achterkamer bevonden zich vijf kasten met de dieren op sterk water, schelpen, planten, mineralen en munten en grondstoffen. Boven waren eveneens twee kamers. De ene bevatte de muziekinstrumenten, Japanse kleren, kleren van andere volkeren en modellen. De bovenachterkamer bevatte de mathematische instrumenten en de geraamtes. Insecten waren in acht verschillende

\footnotetext{
144 Van Iperen in VBG 1:Naberigt XIV.

145 ANRI KBG Dir 0980, [53], gedateerd Batavia Ult. Aug. 1780.

146 ANRI KBG Dir 0981, [ 67] en [68]. Concept-brief van secretaris Ross aan de buitenkantoren van 20-11-1790 en concept-antwoord aan Vosmaer op zijn brief van 20-12-1789, eveneens van Ross van dezelfde datum. Zie ook Sliggers en Wertheim 1994.
} 
lijsten achter glas te bewonderen. Radermacher liet bij zijn vertrek dus een kabinet en bibliotheek achter. ${ }^{147}$ Batavia had een museum. Hij verliet het genootschap op een moeilijk moment, toen het zeer te lijden had onder de oorlogsgebeurtenissen in Europa en Azië. Het zou nog tot 1789 duren voordat het herstel optrad, door het ingrijpen van zijn opvolger, Adriaan Moens.

\section{Financiën}

In het overgeleverde archief over de periode tot 1802 bevindt zich geen apart kasboek. Bij de overdracht van Radermacher aan Moens werd ook geen apart kasboek vermeld, terwijl de overige papieren wel in de inventaris voorkomen. ${ }^{148}$ Er was geen aparte penningmeester. De secretaris of een van de secretarissen deed de financiën erbij. ${ }^{149}$ In de notulen treffen we wel opmerkingen aan over inkomsten en uitgaven, soms ook overzichten, maar niet systematisch en zeker niet volledig. Zo legde secretaris Laclé de jaarlijkse verantwoording af op 18 maart 1785, daarna pas weer op 18 juni 1787, terwijl we daarna weer twee jaar moeten wachten tot 13 juli 1789 . We zijn met name over die periode onvolledig geïnformeerd en niet toevallig werd er toen slecht beheerd: er was een negatief saldo van 427 rijksdaalders in 1787 en van 833 in 1789. ${ }^{150}$ Juist over de periode waarin bijna alle gegevens over het genootschap ontbreken, 1795-1799 is wel een jaarlijks overzicht van inkomsten en uitgaven in het notulenboek opgenomen. Dat danken we aan de predikant Johan Theodoor Ross, in november 1790 als secretaris aangetreden en dankzij wie het genootschap in de latere woelige jaren tot het Engelse intermezzo (1811-1816) überhaupt nog bleef bestaan. Ross legde op 31 maart 1800 aan zijn bestuursleden de summiere, vijfjaarlijkse 'Cassa-rekening' voor, het resultaat van het nauwkeurig bijhouden van inkomsten en uitgaven. Hij presenteerde de cijfers laconiek alsof het heel gewoon was om dat na vijf jaar stilte weer te doen, zonder verdere uitleg over de manier waarop hij voor de financiën had gezorgd. 151

147 Inventaris van Radermacher zelf van 1-7-1782, ANRI KBG Dir 0019, [36], en opnieuw van juli 1783 in ANRI KBG Dir 0020, 50-51.

148 ANRI KBG Dir 0020, 47-51.

149 Uitzondering was een korte periode na 1-11-1790. Op die datum nam de predikant Johan Theodoor Ross het secretariaat over van Carel Saxe, terwijl Gijsbert Welgevare als thesaurier aantrad. ANRI KBG Dir 0020, 238, vergadering 1-11-1790. Welgevare werd kort daarop tot raad extra-ordinair benoemd en dus werd zijn positie die van directeur. Vanaf toen deed Ross de financiën er weer bij.

150 ANRI KBG Dir 0020, 116-117, vergadering 18-3-1785; 134-135, vergadering 18-6-1787; $146-$ 148 , vergadering 13-7-1789.

151 ANRI KBG Dir 0020, 333-337. 
De belangrijkste inkomsten en uitgaven in Batavia waren in rijksdaalders. Rekeningen in de Republiek werden in guldens voldaan. De zilveren rijksdaalder was in Indië zestig stuivers waard, tegenover vijftig in Nederland. De Nederlandse gulden telde uiteraard twintig stuivers. Enkele keren waren er inkomsten en uitgaven in dukaten, zowel giften als betalingen aan prijswinnaars. De kooplieden waren wel aan dit omrekenen gewend. De eerste bron van inkomsten was het lidmaatschapsgeld, het fournissement genoemd. Van het begin af aan lag dit op elf rijksdaalders per lid. Bestuursleden waren niet uitgesloten van de betaling. De leden moesten wel aan de betaling worden herinnerd, niemand kwam uit zichzelf het fournissement aandragen. Daarom werden er briefjes gedrukt, die door een loper langs de Bataviase adressen werden bezorgd om de invordering te doen. Voor de extra-ordinaire leden op de buitenkantoren werd een eenvoudige oplossing gevonden. Per kantoor werd een van hen aangesteld tot lid-correspondent, die verantwoordelijk was voor het innen van de contributie ter plaatse. Deze werd dan in de compagnieskas van het buitenkantoor gestort, zodat in Batavia verrekening met het genootschap kon plaatsvinden. ${ }^{152}$ Daarbij ging er wel eens iets mis. W. Beekman uit Semarang moest zich in 1791 verantwoorden toen de Semarangse penningen niet arriveerden. Ze waren daar niet in de compagnieskas gestort. Beekman werd de les gelezen door gouverneur-directeur Van Overstraten en de 201 rijksdaalders werden afgeschreven, een aanzienlijke som. ${ }^{153}$

De inkomsten uit contributie waren zeer onregelmatig, terwijl het ledental tamelijk stabiel lijkt te zijn. Van de ijver van de secretaris, die het jaarlijkse proces van inzamelen in gang moest zetten, was het resultaat natuurlijk afhankelijk. Bedragen van 617 en 896 rijksdaalders, ingeboekt voor de jaren 1778 en 1779, wijzen er op dat niet alle leden betaalden. ${ }^{154}$ In de erop volgende jaren, onder Von Wurmb en Metzlar, werd er slecht gerapporteerd over de financiën. Onder Saxe en Ross werd dat beter en daarom weten we dat tussen 1790 en 1793 meer dan vijf duizend rijksdaalders binnenkwam aan contributie. ${ }^{155}$ Dit grote bedrag voor deze periode in vergelijking met kleine bedragen in de beginjaren rechtvaardigt alweer een correctie op het ontstane beeld van een reeds bij het vertrek van Radermacher in 1783 ter ziele gegaan genootschap. Na 1795 droogden de inkomsten uit fournissementen echter op.

152 ANRI KBG Dir 0014, 366-367, vergadering 7-5-1781, bevat de lijst met 20 namen van de aangestelde leden-correspondenten.

153 ANRI KBG Dir 0020, 271, vergadering 5-9-1791; 281, vergadering 9-1-1791, waar een brief van Van Overstraten van 21-12-1791 wordt besproken.

154 ANRI KBG Dir 0001, 19, vergadering 7-9-1778; 54, vergadering 12-4-1779.

155 ANRI KBG Dir 0020, 255, vergadering 28-2-1791; 281-282, vergadering 9-1-1792; 320-323, vergadering 7-10-1793; en 326, vergadering 3-2-1794. De bedragen zijn Rds 1067 in 1790, Rds 1486 in 1791 en Rds 2703 in 1792-1793. 
In 1796 werd nog eenmaal 33 rijksdaalders ingeboekt. ${ }^{156}$

Van contributie alleen kon het genootschap niet bestaan. Dat ondervond Radermacher al snel toen er in 1779 een 'kwaad slot' ontstond van 1485 rijksdaalders, dat hij overigens meteen aanzuiverde. ${ }^{157}$ Er was in het eerste jaar veel betaald aan papier, drukker en binder, aan boeken en instrumenten en aan de drie maatschappijen in het vaderland. Giften stroomden binnen. In de eerste financiële verantwoording wordt een gift van honderd dukaten van de Malabar gemeld, vermoedelijk van de latere voorzitter Adriaan Moens. In het jaar erop kwam er nog zo'n gift uit dezelfde bron. ${ }^{158}$ Oud-Shabandar Boers schonk vijfhonderd rijksdaalders voor hij naar het vaderland vertrok (1779), gouverneur B. van Pleuren van Ambon gaf eenzelfde bedrag (1779), Johan van der Burgh, gouverneur van de Noord-Oost-Kust van Java, stuurde honderd dukaten (1780), Smith en Alting uit de Bataviase directeurenkring volgden met ieder vijfhonderd rijksdaalders (1780), de baas van Onrust Daniël Krijgsman schonk er nog eens honderd (1780). ${ }^{159}$ Dankzij giften kon Radermacher eind 1779 een florissant saldo melden van Rds 3658.26.-. ${ }^{160}$ Overigens was dit enthousiasme onder schenkers wel beperkt tot de eerste jaren. De eerste rekening voor instrumenten en papier uit het vaderland bedroeg meteen $f 3695$ voor de betaling waarvan een obligatie van vijftienhonderd rijksdaalders van Radermacher voldoende bleek. ${ }^{161}$

Ook in later jaren sprongen vermogende mannen in, al is niet altijd duidelijk voor welke bedragen. Radermachers opvolger Moens zuiverde in de periode 1786-1789 alleen al tekorten aan tot een bedrag van bijna zeven duizend gulden door rekeningen in het vaderland te voldoen, die de gemachtigde van het genootschap, Frans de Wilde, stuurde. Bij het vertrek van secretaris Laclé noteerde zijn opvolger Saxe een tekort van 909 rijksdaalders dat door een gift van duizend rijksdaalders door Moens werd aangezuiverd. ${ }^{162}$ Zulke bedragen waren uit de contributie niet op te brengen. Het bevreemdt dan ook niet dat Moens probeerde de uitgaven in toom te houden door De Wilde in 1787 uitdrukkelijk opdracht te geven 'ons niets te zenden als geleerde Journaalen ten zij wij iets anders expresse ontbieden'. In een brief aan dezelfde De Wilde

\footnotetext{
156 ANRI KBG Dir 0020, 333-337, vergadering 3-5-1795.

157 ANRI KBG Dir tussen 0002 en 0003, vergadering 4-10-1779, art. 4.

158 ANRI KBG Dir 0001, 54, vergadering 12-4-1779. VBG 2:Voorberigt 3.

159 ANRI KBG Dir tussen 0002 en 0003, vergadering 1-11-1779 (Boers en Van Pleuren); KBG Dir 0010, vergadering 2-10-1780 (Smith en Krijgsman); KBG Dir 0011, vergadering 4-12-1780 (Alting). Verder KBG Dir 0980, [12] (Van der Burgh).

160 ANRI KBG Dir 0003, vergadering 27-1-1779, art. 3.

161 Of deze obligatie ook een schenking van Radermacher is, wordt niet duidelijk. ANRI KBG Dir 0008, vergadering 3-7-1780 voor de rekening van Frans de Wilde uit Amsterdam.

162 ANRI KBG Dir 0020,130-131,vergadering 18-6-1787; 146-147, vergadering 13-7-1789; 165, vergadering 5-10-1789; 254, vergadering 18-2-1791.
} 
van november 1788 ging hij in op de achtergronden van deze wens. In juni 1787 had De Wilde nog flinke partijen boeken opgestuurd.

Dog wij verzoeken dat voortaan geen artikels het zij Boeken het zij Instrumenten of iets van die natuur hoegenaamd aan ons Genootschap gezonden worden, zonder onze speciaale aanschrijvinge daartoe, alzo wij alle zulke artikels buijten ons speciaal verzoek ons toegezonden wordende, niet zouden accepteeren veelmin de betalinge fourneeren, terwijl wij buijten des niet weinig sensibel zijn, dat ons Genootschap tans ook zoo werkzaam niet meer is als bevoorens zoo door het overlijden als door het te Huijsvaaren van de kundigste Directeuren en Leeden, waarbij ook komt dat men hier niet gelijk in Europa een voorraad van geleerde Lieden heeft, die met de borst op kunsten en wetenschappen vallen, en dezelve voor hunnen geliefkoosde bezigheid houden. ${ }^{163}$

Hadden boekhandelaren Arrenberg en Allart in de beginjaren nog een ruime opdracht gekregen ('alle boeken van Smaak'), na Radermachers vertrek had Moens moeten vaststellen dat de ambities van zijn voorganger te hoog hadden gelegen voor de beperkte groep actieve bestuurders en leden. Zijn ingeperkte opdracht aan De Wilde voor Allart geeft aan dat die ambities moesten worden bijgesteld. De ruimhartigheid van Radermacher en Moens zegt niet alleen iets over de betrokkenheid van beide mannen bij het Genootschap, van wie Moens zei dat hij met tegenzin het voorzitterschap had aanvaard, maar ook over het vermogen waarover zij beschikten. Zonder dit mecenaat zou het genootschap in zeer korte tijd failliet zijn gegaan. Nu overleefde het een hele serie crises.

Het geheel van uitgaven overziende kunnen we met een flinke marge van onzekerheid komen tot de volgende samenvatting. De grote uitgaven in de Republiek beliepen: $f 4.780$,- voor de drie zustermaatschappijen ten behoeve van de prijsvragen, verder diverse rekeningen via Frans de Wilde voor munten, instrumenten en boeken/tijdschriften, die konden oplopen tot meer dan $f$ 3000. Ik schat dat aan deze rekeningen tussen $f 13.000$ en $f 14.000$ is betaald. De jaarlijkse uitgaven in rijksdaalders in Batavia liepen erg uiteen.

Bij de overdracht van Radermacher aan Moens werden de maandelijkse vaste lasten begroot op vijfentachtig rijksdaalders. Dat bedrag gold de personeelskosten. ${ }^{164}$ Eerder waren deze veel lager geweest: eind 1779 voor Von Wurmbs maandelijkse kosten nog maar vierendertig rijksdaalders. Overige kosten in Batavia liepen zeer uiteen. In 1778-1779 was alleen al 750 rijksdaalders uitgegeven aan papier, drukker, binder en plaatsnijder. In de laatste jaren van de eeuw, toen het genootschap nauwelijks nog iets ondernam, werd toch nog tussen 300 en 600 rijksdaalders per jaar uitgegeven.

Bij de overdracht van Radermacher aan Moens werden de inkomsten uit

163 Twee concepten van brieven van A. Moens aan Fr. de Wilde te Amsterdam, 20-4-1787 en 22-12-1788. ANRI KBG Dir 0980, [28] en [43].

164 ANRI KBG Dir 0019, [22]. 
contributie geschat op 1300 rijksdaalders per jaar, maar het aantal jaren dat dit bedrag gehaald werd, was gering. Ik ga liever uit van gemiddeld 1000 over een periode van circa 16 jaren (1778-1793), dus 16.000 rijksdaalders. Daarbij gevoegd de verschillende giften en door de bestuursleden verrichte betalingen van circa 8.000 rijksdaalders, dan concludeer ik dat er in de achttiende eeuw circa 24.000 rijksdaalders is omgegaan. De zuinige Ross hield op 31 december 1799 nog Rds 1117.363/4 over, maar hij had dan ook goed beheerd. De bestuursleden waren in het algemeen geen verkwisters. Toen in 1790 voor het eerst sinds jaren weer een algemene vergadering was gehouden en er na afloop een exorbitant hoge rekening van 180 rijksdaalders werd overhandigd door bakker Grondeler voor geleverd gebak, vond het bestuur dat dit niet uit de kas mocht worden betaald en namen de bestuursleden zelf de betaling op zich. ${ }^{165}$

Al leverden de secretarissen geen regelmatig financieel overzicht over deze jaren, toch valt er veel uit af te leiden. Het dagelijks bedrijf in en om het genootschapshuis komt tot leven als we de bedragen koppelen aan de personen die werkzaamheden voor het genootschap verrichtten. Bij het vertrek van Radermacher liet hij de volgende verplichtingen achter:

- koster Palm die toezicht hield op de bibliotheek onder andere tijdens de openingsuren van boekerij en kabinet (Rds 10 per maand),

- de assistent J. Dorsman die de drukproeven controleerde (Rds 10 per maand),

- de opziender in de botanische tuin (Rds 20 per maand),

- Clas Hornstedt voor zijn botanische werkzaamheden en tekenarbeid (rds 20 per maand),

- de slaaf Titus en zijn vrouw Maria voor hun werkzaamheden in het huis (ieder Rds 2.24.- per maand),

- hun kind (40 stuivers per maand),

- de slaaf Mars ook voor werkzaamheden in het huis (Rds 2.24.- per maand),

- de kopiïst Jacobs voor het schrijfwerk (Rds 10 per maand)

Acht volwassenen en een kind stonden op de loonstaat van het genootschap aan het eind van 1783. ${ }^{166}$ Of Titus en zijn vrouw Maria er aan het eind van de eeuw nog waren, zegt de afrekening van Ross niet. In 1799 was er alleen nog de meid (Maria?, 55 rijksdaalders voor het hele jaar), de schrijver (160 rijksdaalders per jaar) en een huurjongen die bij het vertrek van de bibliothecaris was achtergebleven (57.24.- rijksdaalders voor het jaar 1799). Het lijkt erop alsof Ross met zijn uitgaven van minder dan 300 rijksdaalders in het 
voorlaatste jaar van die eeuw niet meer hoefde te doen dan enig toezicht te houden op een huis waar stond opgetast wat onder Radermacher en Moens was verzameld. Of er toen wel eens iemand kwam kijken, is de vraag. Enkele kleine uitgaven voor reparaties aan het huis en voor de aanschaf van arak wijzen op minimale bezigheden. ${ }^{167}$

\section{Persoonlijkheden: Moens en Wiegerman}

Door de nadruk die in de literatuur steeds gelegd wordt op het inzakken van de genootschappelijke actviteiten onmiddellijk na het vertrek van Radermacher, zijn diens achttiende-eeuwse opvolgers, Adriaan Moens (17831792) en Jan Hendrik Wiegerman (1792-1799) zo goed als uit de geschiedenis van het genootschap verdwenen. Met name voor Moens, die tien jaar de voorzittershamer hanteerde, is dat ten onrechte. Hij heeft zich van het begin af aan erg bij het genootschap betrokken betoond en ook het nodige gedaan om het voortbestaan ervan te bestendigen. Onder Wiegermans voorzitterschap daarentegen verviel het genootschap tot nagenoeg totale inactiviteit.

Moens werd geboren in Middelburg (1728), waar hij de Latijnse School bezocht. In een persoonlijke brief uit 1786 geeft hij een beknopte autobiografie, waaruit blijkt dat hij tot de theologie 'lust en geneegentheid' had. Hij leerde Hebreeuws en Grieks en legde zich toe op geometrie, logica, fysica en metafysica. Terwijl hij na het voltooien van de 'triviale school' voorbeschikt leek student in de godgeleerdheid te worden, raakte, als we hem geloven mogen, zijn hoofd gedurende de aanloop tot de universitaire studie op hol en besloot hij naar Indië te gaan. In december 1750 vertrok hij als assistent van de Kamer Zeeland. Hij bleef echter zijn belangstelling voor de wetenschap houden, al was de aandacht ervoor door latere drukke werkzaamheden veroordeeld tot de 'snipperuurtjes' die hij ervoor overhield. ${ }^{168}$ Hij werd geplaatst in Colombo waar hij bijna twintig jaar doorbracht, pas later als koopman (1764), opperkoopman (1767) en hoofdadministrateur (1769). Het was geen bliksemcarrière in vergelijking met Radermacher, die op zijn eenentwintigste jaar al opperkoopman was. Moens' drie zoons werden in Colombo geboren uit zijn tweede huwelijk, met Sara Raquet. Hij had verder een dochter, mogelijk uit zijn derde huwelijk, met Helena Metternach. ${ }^{169}$ Hij werd in 1770

\footnotetext{
167 ANRI KBG Dir 0020, 333-337, vergadering 3-5-1795.

168 Zeeuwse Bibliotheek, Hs 2076, brief van Moens aan Jona Te Water, Batavia 22-4-1786.

169 NNBW 2:929-30. De dochter wordt vermeld in een brief aan de Stadhouder van 29-10-1791. Koninklijk Huisarchief, Arch. Stadhouder Willem V, 333-19. Het Koninklijk Huisarchief en het archief van het KZGW (deels RA Zeeland, deels Zeeuwse Bibliotheek) bezitten een bijzondere verzameling Moens-correspondentie.
} 
directeur in Cochin op de Indiase Malabar-kust, waar hij opnieuw jarenlang zou werken. In 1773 benoemd tot raad extra-ordinair, verhuisde hij in 1781 naar Batavia, waar hij in 1783 raad ordinair en directeur-generaal werd, de tweede man na gouverneur-generaal Alting. Die functie behield hij tot zijn ontslag in 1789, waarna hij als derde man een plaats in de raad bleef houden en tot directeur van de Amfioensociëteit werd benoemd. Dat leverde uiteraard een goed pensioen op. In een brief aan de Stadhouder van 1791 dankte de half-blinde Moens de opperbewindhebber van de VOC niet alleen voor het eervol ontslag en de positie die hij in de Raad van Indië behield, maar eveneens voor het feit dat zijn drie zoons, na hun rechtenstudie in Leiden, in de vroedschap van Haarlem, Vlissingen en Zierikzee waren benoemd, terwijl hij zijn enige dochter gehuwd wist met een commies bij de landsmagazijnen in Hellevoetssluis. ${ }^{170}$ Tot zijn dood in 1792 bleef Moens aldus in Batavia wonen. Meer dan veertig jaar in Compagniesdienst, het grootste deel daarvan in Ceylon en op de Malabar-kust doorgebracht, was Moens in Batavia gescheiden van zijn vier kinderen in Nederland, die hij niet meer terug zou zien, maar die hij bij de Stadhouder voor verdere bescherming aanbeval.

Moens hield door regelmatige briefwisseling contact met het vaderland. Voor hem was dat bovenal Zeeland, waar hij in 1776 tot directeur van het Zeeuwsch Genootschap werd benoemd. Als dank stuurde hij de waarnemingen van een Engelse astronoom, die de ligging van Cochin op de lengte- en breedtegraden had bepaald. ${ }^{171}$ Door de secretarissen Tjeenk en Te Water van het genootschap werd hij gedurig op de hoogte gebracht van allerlei Zeeuwse zaken, terwijl hij zelf voor nieuws van de Malabar en later uit Batavia, zorgde. In 1779 meldde hij aan Tjeenk onder aanbieding van enkele zeldzaamheden, dat hij zich met een Engelse predikant, ene Smith, die goed thuis was in wiskunde en astronomie, bijzonder had vermaakt. Van Smith had hij geleerd beter gebruik te maken van een microscoop, wat overigens voor Moens niet een nieuw instrument was. Hij verzucht dan tegenover Tjeenk:

Jammer is het, dat de studie om geld te winnen, de Hoofd studie in Indiën schijnd te zijn, dan het opgerigt genoodschap van weetenschappen te Batavia, indien er met ernst de handen aan gehouden word, en bij continuatie bekwame Mannen in het zelvde gevonden worden, geeft groote Hoop, dat de weetenschappen in Indiën ook eens mogen aangekweekt, bemind en aangemoedigd worden, hetgeen ongemeen veel toebrengen zal tot het algemeen welzijn en verbeteringe der Zeeden, in dit dartele en wellustige werelds-deel. ${ }^{172}$

170 Brief aan de Stadhouder van 29-10-1791, Koninklijk Huisarchief, Archief Stadhouder Willem V, 333-19.

171 RAZ KZGW 61 (ingekomen stukken 1776-1778), fol 179-180, A. Moens aan W. Tjeenk, Cochin 5-10-1777.

172 Moens aan W. Tjeenk, Cochin 15-12-1779. Zeeuwse Bibliotheek, Hs 486. 
Voor het genootschap, waarvan zijn oude vriend Van Iperen intussen secretaris was geworden, zag hij een rol weggelegd bij de verbreiding van het christendom 'tot verligtinge en gelukkigmakinge van zo veele duizende Zielen, die door de blindheijd zo van het Mahometaan als van het Heijdendom vervreemd zijn van het Evangelium en ag! dat dan ook het Joodendom haast volgen mogt.' ${ }^{\prime 73}$ De godvruchtige Moens had al eerder bij Tjeenk geïnformeerd of er een fonds was voor de financiering van bekeringswerk, waar hij dan aan wilde bijdragen. ${ }^{174} \mathrm{Hij}$ nam zijn directeurschap in Vlissingen ernstig en stuurde een hele serie bijzonderheden vanuit Cochin en Batavia: twee bekers uit slangenhout (1780), een Egyptische mummie (1783), een beker uit een rhinoceroshoorn (1785), versteend hout uit Cheribon, schelpen (1790), vlinders van Ambon en tinnen medailles (1792). ${ }^{175}$ Een Japanse zending uit 1790 vermeldde een staand horloge in een kastje van lakwerk, een doos met keukengereedschappen en drie verschillende soorten papier. ${ }^{176}$ Het meest spectaculair was misschien wel de mummie die Moens van een Engelsman had overgenomen en die in 2000 nog in Teylers museum werd tentoongesteld, tesamen met enkele andere van Moens' geschenken (Sliggers en Besselink 2002:124, 126, 138, 171, 174). De mummie was al in oktober 1780 door Radermacher aan Zeeland aangekondigd, maar had door de oorlogsomstandigheden een extra lange reis gemaakt, die haar onder meer in het Noorse Trondheim had gebracht. ${ }^{177}$

Moens' angstige voorgevoel over de toekomst van het genootschap verwoordde hij in oktober 1783, kort voordat hij het voorzitterschap overnam. In een brief aan Jona te Water zegt hij nog eens dat het in Indië allemaal om geld draait, terwijl hij zelf weinig tijd heeft om toe te geven aan zijn 'zugt voor Gods-dienst en wetenschappen [...] gezwijge datt men hier zo wijnige vind, die zich met de borst daar op toe leggen'. ${ }^{178}$ Moens nam bij Radermachers vertrek het voorzitterschap tijdelijk over, omdat geen ander daartoe bereid was. Hij hoopte dat er iemand zou aankomen die de functie beter kon waarnemen. ${ }^{179}$ Eenmaal directeur-generaal en voorzitter van het genootschap leidde dat tot zijn benoeming tot directeur bij de Hollandsche Maatschappij

173 Moens aan W. Tjeenk, Cochin 15-12-1779. Zeeuwse Bibliotheek, Hs 486.

174 Moens aan W. Tjeenk, Cochin 15-12-1779. Zeeuwse Bibliotheek, Hs 486.

175 RAZ KZGW 131 en 133 Lijsten van geschenken aan Zeeuwsch Genootschap.

176 Het klokje is afgebeeld in Sliggers en Besselink 2002:128, bij de mummie. Zie ook RAZ KZGW 6 (notulen 1787-1796), fol. 148, vergadering van 29-6-1790. Deze geschenken waren ongetwijfeld met de retourvloot van 1789 verzonden.

177 Brief van Radermacher aan secretarissen Tjeenk en Te Water, Batavia 15-10-1780. RAZ Arch. KZGW 62 (ingekomen stukken 1779-1784) fol 269. Idem 5 (notulen 1782-1787) fol 52-53. De mummie bleek op 28-2-1783 pas van de Oost-Indische Kamer te Middelburg te zijn afgehaald.

178 Moens aan Jona te Water, Batavia, 31-10-1783. Zeeuwse Bibliotheek, Hs 1982.

179 RAZ KZGW 59, fol. 302-4, brief van Moens aan Drijfhout, 12-9-1787. 
in Haarlem (1784), waar hij ook geschenken aan stuurde. Intussen maakte hij mee dat de activiteiten in Batavia zeer verslapten, zodat hij daarover herhaaldelijk klaagde en aangaf dat Hooijman bijna de enige was die nog iets voor het genootschap deed. ${ }^{180}$ Hij noemde zichzelf als voorzitter een 'bedroefde figuur' en 'een schraale Directeur', zich bewust dat het genootschap een schaduw leek van wat het tot 1783 was geweest. ${ }^{181}$ Wel hielp hij het genootschap uit de brand door de tekorten in de kas aan te vullen, al moest hij tegelijkertijd de rem zetten op de aankopen uit het vaderland.

In 1789 herleefde het genootschap, nog steeds onder Moens. Nadat er twee jaar niet was vergaderd, werd eerst ter versterking van het bestuur de functie van vice-voorzitter ingesteld, waarvoor Theodorus Vermeer werd aangewezen. Vermeer was predikant bij de Nederduitse gemeente te Batavia, genootschapslid sinds de oprichting en in 1784 in het bestuur gekomen. ${ }^{182}$ In augustus 1789 werd besloten 'het genootschap zo veel mogelijk tot zijne eerste constitutie te doen terugkeeren, en den voortgang der zaken beter te bevorderen, [en] dat voortaan op den eersten Maandag in de maand Vergadering zal worden gehouden.' ${ }^{183}$ Toen Laclé in september het secretariaat overdroeg aan Carel Saxe, hoopte hij dat het genootschap zou terugkeren tot zijn oude glorie, maar hij zag tegelijkertijd 'tegenheden',

het heete Lugtgestel, die vijand van den ingespannen geest, de verafgelegenheid van geleerde Genootschappen, van veele bijzondere geleerden Lieden en van de voortbrengzelen van derzelver vernuft, de veele bezigheeden van Elk uwer in zijn beroep, het gedurig verlies van Leden uit uwe Vergadering. ${ }^{184}$

Ook Moens had herhaaldelijk in zijn brieven gewezen op de afgelegenheid van het vaderland en het thuisvaren of overlijden van waardevolle (bestuurs-) leden. Niettemin hernam het bestuur het maandelijks vergaderen en werden de zaken aangepakt. De genootschapspapieren en voorwerpen die in de verzameling ontbraken, kwamen terug uit de boedel van de kort daarvoor vermoorde Hooijman. De bibliotheek en de instrumenten werden gecontroleerd, de correspondentie met het vaderland werd hervat, nieuwe bestellingen werden geplaatst ter vervanging van ontbrekende tijdschriften en er werd een nieuw programma opgesteld, zodat in het begin van 1790 weer plannen konden worden gemaakt voor een algemene vergadering, die sinds 1779 niet

180 RAZ KZGW 59, fol. 302-4, brief van Moens aan Drijfhout, 12-98-1787.

181 Zeeuwse Bibliotheek, Hs 2120, brief van Moens aan Jona te Water, Batavia 10-6-1785; en Hs

2076, brief van Moens aan Jona te Water, Batavia 22-4-1786.

182 ANRI KBG Dir 0020, 149, vergadering 13-7-1789.

183 ANRI KBG Dir 0020, 152, vergadering 4-8-1789.

184 ANRI KBG Dir 0020, 160, vergadering 7-9-1789. 
meer was gehouden. ${ }^{185}$

Onderstaand schema laat zien dat er een piek was in het vergaderritme in de jaren 1790-1793, ook de jaren waarin deel 5 en 6 uitkwamen.

Vergaderingen vanaf 1788

\begin{tabular}{ll}
1788 & 2 \\
1789 & 5 \\
1790 & 16 \\
1791 & 14 \\
1792 & 10 Moens overleed in november 1792 \\
1793 & 9 \\
1794 & 6 \\
1795 & $1(?)$ \\
\hline
\end{tabular}

Zo ving na een aanloopje in 1789 in 1790 de tweede jeugd van het genootschap aan. Een stempel in de boeken moest de ontvreemding ervan tegengaan, 140 nieuwe leden werden aangezocht om het teruggevallen ledental op peil te brengen en op 8 maart 1790 kon in het Kasteel - zonder de zieke Moens - worden vergaderd. Vermeer hield een geleerde oratie en gouverneur-generaal Alting antwoordde. Bestuurslid Le Dulx besloot met een verhandeling over de klapperboom als natuurlijke bliksemafleider (VBG 5:Voorberigt). Na de vergadering werd in mei het bestuur weer op peil gebracht. Naast de oudgedienden in het bestuur, Moens (1783), Vermeer (1784) en Frederik Schouwman (1784), waren er de nieuwelingen Guillaume Le Dulx (1789), Andries Teisseire (1789), Carel Saxe (1789), Gijsbert Welgevare (1790), en Jeremias Schill (1790). Een maand later kwamen Hendrik Guitard en Johannes Ross daar nog bij. Er werden weer prijsvragen uitgeschreven en via de druk bekend gemaakt en eindelijk kwam deel 5 van de Verhandelingen uit (1791). ${ }^{186}$ Het genootschap was uit zichzelf weer opgestaan en Moens en Vermeer, de laatste vermoedelijk nog meer dan de eerste, kwam daar de eer voor toe.

Vermeer was sinds 1771 predikant en preekte sind 1779 ook eens per twee weken in het Frans. Zijn naam kwam voor aan het hoofd van het rijtje van vijf predikanten die in het eerste Programma (1778) als lid opgenomen werden, maar van hen koos Radermacher Hooijman en Van Iperen in het bestuur. Later verving Jacob Metzlar (1780) de overleden Van Iperen en daarna was in 1784 pas Vermeer aan de beurt. Boterde het niet tussen Radermacher en Vermeer? Misschien was hij te steil voor Radermacher en paste hij beter bij de theologant Moens. Vermeer was prominent aanwezig bij de vier algemene

185 ANRI KBG Dir 0020,146-169, vergaderingen tussen 13-7-1789 en 2-11-1789.

186 ANRI KBG Dir 0020,170-240 geeft in de verslagen van de zestien vergaderingen van dat jaar een goed overzicht van de hernomen activiteiten. 
vergaderingen van 1790-1793, telkens op de verjaardag van de Stadhouder in het Kasteel gehouden, waar hij namens het bestuur sprak. Moens was ziek (1790) of liet graag deze taak over aan de predikant-vice-voorzitter. Twee van zijn toespraken werden gedrukt (VBG 5-6). Zijn toespraak over de vrijheid van denken (1792) is helaas niet overgeleverd. Vermeer sprak niet alleen, hij regelde ook de zaken in de aanloop tot de algemene vergadering. Kennelijk was Moens maar al te blij dat hij - ziek en half blind - in Vermeer zo'n goede vervanger had gevonden. Toen na Moens' overlijden in december 1792 als nieuwe voorzitter van het genootschap Jan Hendrik Wiegerman door gouverneur-generaal Alting was aangewezen, was het alweer Vermeer die de opvolger van Moens met een sierlijke toespraak verwelkomde. ${ }^{187}$ Wiegerman was al vanaf het begin lid geweest van het genootschap, toen hij nog vice-president van de raad van Schepenen was. In 1789 was hij op basis van zijn toetreden tot de Raad van Indië directeur van het genootschap geworden. Op het moment van Moens' dood waren er verschillende raadsleden die eerder tot dat hoge college waren toegetreden, onder wie Johannes Siberg en Adriaan de Bock, maar mogelijk hadden die voor de eer bedankt. Ten tijde van zijn benoeming tot voorzitter was Wiegerman president van de Weeskamer en Buitenregent van de hospitalen.

Wiegerman leek zijn voorzitterschap aanvankelijk serieus te nemen. Hij wilde de bezittingen van het genootschap laten catalogiseren en nakijken in welke staat de goederen waren. In 1793 werd er een taakomschrijving voor de bibliothecaris gemaakt, werden weer 34 nieuwe leden voorgedragen en werd - voor het laatst in die eeuw - een algemene vergadering gehouden. Ook werd de bestelling van tijdschriften, die in 1789 was gedaan, herhaald, omdat nog niets was gearriveerd, en werd de nieuwe electriseermachine van Marinus van Marum in Haarlem besteld. ${ }^{188}$ Niets wees erop, dat er een grote verandering zou plaatshebben tussen het tijdperk-Moens en dat van Wiegerman. Mogelijk was alleen de rol van Vermeer wat minder prominent. Hij stierf in 1799.

De aankomst van de uit Nederland gezonden Commissie-Generaal, de laatste poging in deze jaren om orde op zaken te stellen in het slecht renderende VOC-bedrijf in Azië, was aan het genootschap niet voorbijgegaan. Direct na hun aankomst op 3 november 1793 werd voorgesteld beide heren, Sebastiaan Nederburgh en Simon Frijkenius tot directeur van het genootschap te benoemen, tegelijk met acht leden van de Raad van Indië, die nog niet eerder tot directeur waren benoemd. Dat er snel onenigheid kwam tussen beide commissarissen, waardoor zij niet meer in het zelfde huis konden 
blijven wonen en Nederburgh bij Wiegerman introk, zal de tijd die de voorzitter voor het genootschap ter beschikking had, hebben beperkt. Toch was hij op alle zes bestuursvergaderingen van 1794 aanwezig. ${ }^{189}$ Wiegerman was in 1793 als Commissaris-ter-zee en -te-velde actief betrokken bij verdedigingsmaatregelen tegen mogelijke invallen, toen Engeland en Frankrijk in oorlog waren geraakt. Inmiddels president van Heemraden, werd hij in 1795 tot raad ordinair benoemd en hij zal in de politieke verwikkelingen van die dagen in het kamp van Alting, Siberg en Nederburgh meer tijd hebben besteed aan politiek dan aan kunsten en wetenschappen (Schutte 1974:151). Na 5 november 1794 werd zes jaar lang niet meer in genootschapskring vergaderd. In genoemd jaar was het al niet gelukt om deel 7 van de Verhandelingen te drukken. In 1795 werd door secretaris Ross nog een afrekening gemaakt van zijn uitgaven. Dat kasboek bleef hij bijhouden, maar pas in 1800 kwamen de overgebleven zeven bestuursleden weer bij elkaar om ernaar te kijken. Het genootschap was onder de druk van de tijden ingeslapen, alleen Johan Theodoor Ross paste op de zaak. Voorzitter Wiegerman verdween stilletjes uit het genootschap. In 1800 bleek hij overleden te zijn.

Uit de schamele archiefgegevens van het genootschap over de jaren 17951800 is niet dan zeer speculatief op te maken over de redenen van het staken van de activiteiten na november 1794. Secretaris Ross had in 1795 nog van 71 Bataviase leden contributie ontvangen. Kennelijk was bij die leden nog niet het gevoel ontstaan dat de activiteiten gestaakt waren. In 1796 liet de secretaris het wat betreft de contributies ook maar zitten. Der Kinderen suggereert dat ontevredenheid van het bestuur met de structuur van het genootschap de oorzaak zou zijn geweest van het stremmen van de activiteiten, maar dit lijkt teveel teruggeredeneerd vanuit 1800, toen een hervormingsvoorstel werd gelanceerd (Der Kinderen 1878:59). Het kan niet anders of de omstandigheden buiten het genootschap waren bepalend. Net als tijdens de oorlog met Engeland in de jaren tachtig was de verbinding met het vaderland heel onregelmatig geworden. Na de inval van de Fransen in de Republiek en de erop gevolgde grote onzekerheid over de toekomst van Batavia en Java, onder andere door de gevreesde inval van de Engelsen, kregen activiteiten op het gebied van kunsten en wetenschappen een lage prioriteit. Bewapening en hervorming kwamen voorop te staan. Daarbij was de VOC genationaliseerd en had aldus de vertrouwde structuur van Heren Zeventien in de Republiek en Hoge Regering in Batavia opgehouden te bestaan. Toch zou het genootschap niet, zoals vaak beweerd wordt, tot Raffles moeten wachten eer het opnieuw kon opstaan. Voor het in 1800 nog overgebleven deel van het bestuur was de inactiviteit ineens genoeg. Het ging tot actie over. 
Batavia - Paramaribo - Calcutta

In de literatuur wordt de Asiatic Society (Calcutta 1784) steeds vermeld om met enige trots het eerstgeboorterecht van het Bataviaasch Genootschap in Azië te claimen en daarmee het genootschap in een gunstig daglicht te stellen. Merkwaardig genoeg waagt men zich dan niet aan een vergelijking van de twee organisaties die vanuit een Europees perspectief betrekkelijk dicht bij elkaar ontstonden, bovendien in hetzelfde tijdvak. Daarnaast is het interessant om te kijken naar Paramaribo, waar in dezelfde periode een rijk geschakeerd gezelschaps- en genootschapsleven ontstond. Helaas is van die Paramaribose activiteiten niet veel overgeleverd. Vanwege de chronologie is de vergelijking met Paramaribo het eerst aan de beurt.

De vrijmetselaarsloge Concordia in Paramaribo kreeg in 1761 de stichtingsbrief, in dezelfde tijd dat Radermacher in Batavia La Choisie oprichtte. Concordia was daarmee de eerste loge in Zuid-Amerika (Van Kempen 2002, I:86). In 1780 werd er het Kollegie van Natuur-Onderzoekinge opgericht, dat tot 1789 bestond en zich bezighield met een breed terrein van landbouw, natuurlijke historie, natuurwetenschap en geneeskunde, een programma dat interessante overeenkomsten biedt met het genootschap in Batavia. Het Kollegie van Letterkunde Docendo Docemur (1783) richtte zich vooral op de verbetering van het onderwijs. In vergelijking met Batavia had Paramaribo meer gezelschappen en genootschappen, al is van sommige niet meer dan de naam bekend, hetgeen kan wijzen op een korte levensduur of een niet al te intensief genootschapsleven. Zo is er het letterkundig genootschap Nuttig en Aangenaam (vermeld in 1792) en waren er in de jaren 1780 verschillende leesgezelschappen. De meeste sporen zijn nagelaten door het Genootschap De Surinaamsche Lettervrinden (1785-1795) dat vier bundels Letterkundige Uitspanningen (1785-1787) naliet en uit wier boezem een apart Genootschap van Surinaamsche Landbouw (1788) ontstond. Andere landbouwkundige genootschappen waren Tot Nut en Vergenoegen (1792) en Nuttig en Vermakelyk (vóór 1792) en de Eensgezintheid. Daarnaast wordt er nog een genootschap Wis en Natuurkunde vermeld. De Maatschappij tot Nut van 't Algemeen kreeg een departement in Paramaribo in 1794.

De meeste van deze gezelschappen en genootschappen hebben niets nagelaten in druk en al helemaal geen archief. Ze staan vermeld in almanakken of in kranten of contemporaine literatuur. Misschien dat sommige ervan bij nader inzien gelijk zijn aan andere. Zo vermeldt Visser een Genootschap ter Bevordering van de Natuurlijke Historie (1787) op gezag van de West Indische Encyclopedie. Van Kempens uitvoerige studie over de Surinaamse literatuur, waar bovenstaande organisaties aan zijn ontleend, noemt echter het Kollegie van Natuur-Onderzoekinge, dat vermoedelijk met het genootschap uit 1787 samenvalt (Visser 1970:nr 56). Het interessantst zijn het Genootschap De 
Surinaamsche Lettervrinden en het Kollegie van Natuur-Onderzoekinge, omdat die in principe het meest met het genootschap in Batavia gemeen hadden. Opvallende verschillen zijn er ook. Zo waren de Surinaamsche Lettervrinden veel meer met de dichtkunst bezig dan in het vroege Batavia ooit in genootschapsverband werd beoefend.

Hoe kon in vergelijking met Batavia het genootschapsleven in Paramaribo tussen 1780 en 1795 zo veel geschakeerder zijn? Had het Bataviaasch Genootschap bijna een monopolie - zo leek het - de inwoners van Paramaribo, dat juist in het laatste kwart van de achttiende eeuw een opvallende ontwikkeling beleefde door de trek van de plantages naar de stad, konden kiezen uit een veel ruimer aanbod. De aandacht voor landbouwvraagstukken hoeft niet te verwonderen in een plantagegemeenschap. Van Kempen wijst op het open karakter van de Surinaamse genootschappen. De joden waren van het lidmaatschap niet uitgesloten en drukten door hun ruime aanwezigheid een stempel op het culturele leven (Van Kempen 2002, I:94). Men is geneigd te denken dat het culturele klimaat in Paramaribo opener en dynamischer was dan dat in Batavia. Hoewel we natuurlijk ook mogen aannemen dat er in Batavia leeskringen of leesgezelschappen waren, zijn de Paramaribose vermeldingen van andere, vooral letterkundige en landbouwkundige genootschappen te overvloedig om niet opnieuw vraagtekens te zetten bij de situatie in Batavia: waren er meer organisaties maar hebben die geen sporen nagelaten? Of was het Bataviaasch Genootschap zo sterk van start gegaan en zodanig aan de overheid gebonden dat andere genootschappen overbodig werden, geen kans zouden hebben gehad? Was het bewind in Suriname veel toeschietelijker dan in Batavia?

Waar geen van de Surinaamse genootschappen van letterkunde of kunsten en wetenschappen een lange levensduur kende, was dat nu juist wel het geval met de Asiatic Society, die tot op de dag van vandaag bestaat. Er zijn opvallende overeenkomsten en verschillen tussen Calcutta en Batavia. Beide zijn ontstaan op initiatief van hoge beambten van de VOC en de East India Company. In Calcutta was Sir William Jones, rechter bij de Supreme Court, de initiator. Jones wilde nadrukkelijk geen wetten of reglementen omdat de zuivere interesse voor het werkterrein van de Society het onnodig maakte om reglementen uit te vaardigen. Zijn organisatie was dan ook selectiever in het opnemen van leden: er moest van echte belangstelling sprake zijn. Omdat er geen contributie werd geheven (tot 1796) was er geen behoefte aan leden om de kas te spekken. Van 30 oprichters groeide de Society in 1790 tot 101 personen, ongeveer de helft van het aantal leden in Batavia. Wel was de Society net als het genootschap een club voor de elite. De van de Oeconomische Tak overgenomen praktisch gerichte doelstellingen van het Genootschap ontbraken in Calcutta: in de woorden van Jones ging het om 'History, civil and natural, the Antiquities, Arts, Sciences, and Literature of Asia' (Mitra 1885). Evenmin 
waren er in Calcutta prijsvragen om aandacht te vragen voor de praktische vraagstukken waar de mannen in Batavia een oplossing voor zochten. De Society sloeg daardoor van het begin af aan meer een wetenschappelijke weg in.

De banden met de overheid waren in Calcutta veel losser. De Society kreeg pas in 1804 een stuk grond om er een eigen gebouw op te zetten en werd pas vanaf 1837 gesubsidieerd. In dat opzicht was de Society in Calcutta veel meer een private onderneming. Overeenkomsten waren: de jaarlijkse algemene vergaderingen (al werden die in Batavia slechts een paar keer gehouden) en de onmogelijkheid in beide steden om de voorgenomen jaarlijkse publicatie van een boekdeel te realiseren. Ook in Calcutta kwamen in de achttiende eeuw slechts zes delen Asiatick Researches van de pers (1788-1799). Beide organisaties namen zo goed als gelijktijdig inheemse leden op in hun kring. In Batavia gebeurde dat in 1826, in Calcutta in 1829. Belangrijk verschil is wel dat de Indiërs in Calcutta een veel prominentere rol zouden hebben als tekstediteurs en dat al vanaf een vroeger tijdstip, dan in Batavia het geval was. De Biblioteca Indica is grotendeels door Indiërs verzorgd.

Het zal het oude antagonisme zijn geweest tussen Nederland en Engeland, tussen VOC en EIC, dat maakte dat er bijna geen banden waren tussen Batavia en Calcutta in de achttiende eeuw en dat terwijl vanuit een wetenschappelijk standpunt gezien, met name voor wat betreft geschiedenis en oudheidkunde, een nauwe betrokkenheid van het begin af aan van nut zou zijn geweest. $\mathrm{Nu}$ bestonden de twee organisaties tot in de negentiende eeuw naast en los van elkaar. Raffles' komst naar Batavia zou er iets aan veranderen.

\section{Einde van de eeuw}

Het Bataviaasch Genootschap lijkt als eerste in zijn soort in Azië een pioniersrol gespeeld te hebben in een werelddeel waarvan grote delen toen nog onbekend waren. In Batavia was het genootschap echter niet het eerste als het gaat om genootschapsactiviteiten. De vrijmetselarij was in 1762 voorgegaan. Het is wel opvallend dat zowel bij de vrijmetselarij als bij het genootschap dezelfde man, Radermacher, een voortrekkersrol vervulde. Batavia had als vestigingsplaats van Europese kooplieden al een geschiedenis van honderdvijftig jaar achter de rug. Voorzieningen als de kerk en het onderwijs plus de stedelijke voorzieningen die bij een vestigingsplaats hoorden, maakten het ook weer niet ongehoord dat er een typisch achttiende-eeuwse organisatie als een genootschap van kunsten en wetenschappen ontstond. Universitair gevormden speelden daarbij een actieve rol, maar binnen die groep juist weer degenen die al een band hadden met genootschappen in het vaderland en die Batavia een voorziening wilden geven die het in hun ogen ten onrechte ont- 
beerde. De oprichters sloten niet aan bij werkzaamheden die eerder in Batavia waren ondernomen, zoals het sterrenkundige onderzoek van Mohr of de taalkundige ondernemingen van de bijbelvertalende predikanten. Daarmee lieten zij ook merken dat het een persoonlijk gekleurd initiatief was en eisten zij eer voor zichzelf op: Radermacher, Van Hogendorp, Hooijman, Van der Steege, Von Wurmb en later Van Iperen gaven vorm aan hun eigen ambities, maar goten die in een vorm die de vaderlanders in de regering in Batavia en het VOC-hoofdkantoor in de Republiek niet onbekend was. Daarmee voorkwamen ze een overheidsveto.

Het genootschapsbestuur zocht aansluiting bij drie van de belangrijkste vaderlandse geleerdengenootschappen, maar de ambities om een soortgelijke rol te spelen als die organisaties in patria liepen spaak op de Bataviase en Oost-Indische realiteit. De actieve groep leden was beperkt tot vrijwel alleen het bestuur. Het opperbestuur in het Kasteel bemoeide zich nauwelijks met het initiatief. Daarbij miste het Bataviaasch Genootschap de belangrijkste voedingsbodem van de geleerdengenootschappen in Haarlem, Vlissingen en Rotterdam: de geleerden die het zich tot een eer rekenden lid te zijn en die aan de verplichting, het inzenden van verhandelingen, voldeden. Het uitgeven van bundels Verhandelingen kon onmogelijk met een ritme van één per jaar geschieden. De prijsvragen leverden alleen in de eerste jaren inzendingen op, daarna kwam de klad in die activiteit. Van de geleerde ambities van de oprichters bleef niet meer over dan die van het bestuur, zodat het genootschap lange tijd als eerste en enige in Oost-Indië een bestaansreden had omdat het de eerste en de enige was en omdat er altijd wel enkele actieve bestuursleden achterbleven. Zo overleefde het, in tegenstelling tot wat de literatuur zegt, het vertrek van Radermacher wel degelijk en verviel het pas na 1794 tot inertie. De contacten met de genootschappen in het vaderland hadden zeer te lijden onder de tijdsomstandigheden (oorlog, economische malaise) en onder de grote afstand die steeds bereisd moest worden. Verder was de gemeenschap in Batavia te klein en te gevoelig voor de malaria-aanvallen dan dat er gezonde omstandigheden voor een langdurige bloei aanwezig waren.

De overheid in het Kasteel trad van het begin af aan welwillend op, verstrekte faciliteiten en ondersteunde enkele malen de genootschapsactiviteiten door het verzamelen onder de aandacht van haar ambtenaren te brengen. De resultaten van het laatste waren beperkt, ondanks uitvoerige instructies. Zonder die overheid kon het niet en het genootschap leed dan ook onder de malaise die leidde tot de liquidatie van de VOC. Het genootschap had toen niet meer de bescherming, zonder welke het niet kon bestaan en verviel tot zo goed als nietsdoen.

In de beginjaren waren de doelstellingen dubbelzinnig: het genootschap streefde universele, encyclopedische doelen na, maar werd door de actualiteit (economische malaise) en door de geografische ligging in een andere rich- 
ting gestuurd. De Oeconomische Tak in Haarlem werd nagevolgd in zijn op economisch herstel gerichte streven naar het oplossen van praktische problemen, terwijl de voordelen van de speciale ligging het genootschap een voorsprong boden, die het van het begin af aan uitbuitte: het was een Bataviaasch Genootschap en verzamelde in de regio en over de regio. De publicaties waren dan ook voor het overgrote deel aan de situatie in Azië gewijd. De encyclopedische doelstellingen werden wel herhaald, maar niet actief nagestreefd. Daardoor werd het genootschap een regionaal genootschap en niet een nationaal. Voor de nationale ambities lag het te excentrisch en was het te ver verwijderd van het Europese centrum van de wetenschap.

Het genootschap steunde van het begin af vooral op een handjevol gedreven personen. $\mathrm{Zij}$ wilden meedoen met wat in Europa bij hun stand hoorde en richtten daartoe het genootschap op. Belangstelling voor kunsten en wetenschappen was er zeker, maar evenzeer was er de behoefte om die in te kaderen op eenzelfde manier als dat in patria gebeurde. Het genootschap was net zo goed een manifestatie van groepsgevoel als een oprechte uiting van belangstelling voor kunsten en wetenschappen. De band met genootschappen in Nederland was meer dan alleen een kwestie van praktisch voordeel. Het gaf de bestuursleden de sensatie dat Batavia niet onderdeed voor Holland en Zeeland. Ze maakten deel uit van eenzelfde belangrijke, nationale beweging. Daarentegen waren de omstandigheden in Batavia anders. De leden waren contribuanten, maar zelden inzenders van studies of verzamelingen. De basis van het genootschap in Batavia was daarmee erg smal en het aan sterfte en vertrek onderhevige ledental kon alleen op peil gehouden worden door herhaalde, actieve werving van nieuwe leden. Het lidmaatschap hoorde bij de 'verplichtingen' van een sociale laag. De hoge contributie trok een lijn in de bevolking, maar maakte het lidmaatschap daardoor ook begeerlijk: de leden vormden samen de elite. Het opperbestuur bestond uit de raadsleden van Indië. Het bestuur uit merendeels academisch gevormde hoge en bemiddelde ambtenaren onder leiding van een van de raadsleden van Indië. Het was naast de contributie in belangrijke mate afhankelijk van weldoeners.

Het genootschap was niet sterk genoeg om ongevoelig te zijn voor de grote gebeurtenissen van de tijd: de oorlog met Engeland, de economische achteruitgang van de Republiek, de grote wisselingen in de Franse tijd, maar het had evenzeer te lijden van twee andere factoren, die intrinsiek waren. Het voortdurend vertrekken van leden en weer aankomen van nieuwelingen en de verafgelegenheid van het thuisland werkten niet bevorderlijk voor een levendige genootschapspraktijk. De bevolking van Batavia was te weinig stabiel voor zo'n organisatie. Vergelijk daarmee de steunpilaarfunctie van secretarissen in Vlissingen, Haarlem en Rotterdam, die tientallen jaren aanbleven in besturen die evenzeer stabiel waren. Daar kon Batavia niet tegenop. Dat het overleefde, heeft vooral te maken met het plichtsgevoel van mannen 
na Radermacher, die niet wilden laten verloren gaan wat de oprichter had bewerkt, Hooijman, Moens, Vermeer en Ross in de eerste plaats. Het mag een wonder heten dat het genootschap in 1800 de periode van onzekerheid overleefde en wakker werd. 
Hans Groot - 978-90-04-25380-3

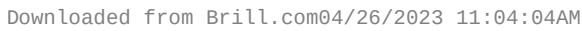
via free access 


\section{Hoofdstuk II}

\section{Een nieuw begin onder Bataafse, Franse en Britse vlaggen (1800-1816)}

\section{Bestuur rond de eeuwwisseling}

De bekende patriot en criticus van het oude regime, Dirk van Hogendorp, had bij zijn terugkeer in patria na zijn opzienbarende vertrek uit Batavia de toestand van het genootschap aan het eind van de eeuw niet bondiger kunnen weergeven dan met de beginzin van de paragraaf over 'Konsten en Weetenschappen' in zijn bekende Berigt van den tegenwoordigen toestand der Bataafsche bezittingen in Oost-Indiën: 'Batavia heeft een Genootschap van Konsten en Weetenschappen gehad, en zulks bestaat in naam nog' (Van Hogendorp 1799:132). Hij zei zich te schamen er meer over te zeggen en noemde de aanstelling van de gouverneur-generaal en de raden van Indië tot opperdirecteuren bij de oprichting in 1778 een 'slaafsche stap', bedoeld om vervolging te voorkomen in 'het rijk van geweld en dwingelandij'. De drie voorzitters tot 1799 kregen er van langs: Radermacher was niet geleerd, maar had zich dan in ieder geval nog een voorstander van kunsten en wetenschappen getoond. De tweede voorzitter - Moens' naam werd niet genoemd - was alleen gekozen omdat 'hij ten minsten geen kwaad aan de zaak zoude doen' en onder Wiegerman, 'die naauwelijks zijn naam kan schrijven, en zelfs niet recht weet, of hij een Nederlander of een Duitscher is', was het genootschap 'zo goed als tot niet geraakt' (Van Hogendorp 1799:132-3). Van Hogendorp, die zelf in 1784 lid was geworden van het genootschap, kan door zijn vader Willem zijn ingelicht over de toestand in het genootschap in de beginjaren. Willem van Hogendorp behoorde immers tot de oprichters en tot de groep bestuursleden van het eerste uur.

Dirk zelf, als geducht patriot de geest van de nieuw tijd goed aanvoelend, brak zijn staf over de oude orde in Batavia. Onder de dwingelandij van de vijanden van de Verlichting kon geleerdheid niet bloeien. Het was nog opmerkelijk dat het genootschap 'merkwaardige en wel uitgewerkte stukken' had uitgegeven in een wereld zonder 'nieuwspapieren of couranten'. Hij verwees zoals elders in zijn geschrift naar de veel gunstiger situatie in de Engelse 
koloniën en voorzag een periode van bloei voor de kunsten en wetenschappen zodra er vrijheid zou heersen.

Indien wij het geluk mogen hebben, de vrijheid op Batavia en Java eens te zien invoeren, dan zal het genootschap van konsten en weetenschappen, bestuurd door mannen van verstand, kunde en geleerdheid, die tot hun voorzitter niet een Edelheer, maar den verstandigsten uit hun midden zullen verkiezen, weder herleeven, en door zijne werkzaamheden het licht der waarheid, zoo wel over Java als over onze andere bezittingen in Oost-Indië, alom verspreiden (Van Hogendorp 1799:133-4).

Dat de woorden van Van Hogendorp in de kring van het genootschap enige weerklank hebben gevonden, is aannemelijk. Andries Teisseire en Carel van Naerssen zaten al sinds 1789, respectievelijk sinds 1791 in het genootschapsbestuur. $\mathrm{Zij}$ hadden in december 1795 behoord tot de adressanten die het oude bewind onder gouverneur-generaal Alting en commissaris Nederburgh hadden opgeroepen om de nieuwe vrijheid, die met de inval van de Fransen op de Bataafse Republiek was neergedaald, ook in de kolonie te omhelzen. $\mathrm{Zij}$ behoorden tot de groep van vijf die het adres aan de commissarissengeneraal kwam overhandigen, waarmee ze wel geen revolutie, maar dan toch een bescheiden hervormingsbeweging initieerden (Schutte 1974:157). Een van de vraagpunten, het zoveel mogelijk afschaffen van 'de uiterlyke tekenen van distinctie' (Schutte 1974:158), komen we ook tegen in de eerste signalen van de ommekeer in het genootschap in 1800. Het Parijse gelijkheidsideaal van 1789 drong zo in december 1795 tot Batavia door en, voor zover wij dat kunnen reconstrueren, eerst in maart 1800 tot het genootschap.

De bijeenkomsten van het genootschapsbestuur van het jaar 1800 zijn daarom zo belangrijk, omdat na vijf jaar van nagenoeg gehele rust het oude regime in de vorm van de Bataviase regering als hoogste orgaan van het genootschap werd afgeschud. $\mathrm{Nu}$ had die regering in de onzekere jaren van isolement en oorlogsdreiging veel aan gewicht ingeboet en ook had zij geen hand uitgestoken om het verval in het genootschapsleven te stuiten. Nadat Wiegerman in 1799 was overleden, kwamen op 31 maart 1800 de zeven overgebleven bestuursleden voor het eerst sinds jaren weer bij elkaar. Wiegerman was de enige in het bestuur geweest die de oprichting nog had meegemaakt. Het bestond nu uit Frederik Schouwman (sinds 1784 bestuurslid), Andries Teisseire (1789), Jeremias Schill (1790), Johan Theodorus Ross (1790), Carel van Naerssen (1791), Albertus Henricus Wiese (1794) en Willem Michaël Döckers (1794). Deze mannen trokken zich de 'veragterde toestand van zaaken en belangen des genootschaps' aan. Zij zorgden voor een Bataafse revolutie in het klein. De 'uiterlijke tekenen van distinctie', die in het verleden de verhoudingen binnen het genootschap in belangrijke mate bepaalden, werden afgeschaft. Er werd gekozen voor - wat in maart 1800 nog heette - 
'eene meer eenvoudige inrigting, bij minder ostentatie, en bepaalder inzigten', maar wat twee maanden daarna niets minder bleek te zijn dan het aan de kant zetten van de Hoge Regering als opperdirecteuren van het genootschap: 'Het geheel bestier der zaaken [...] zal staan aan eene Vergadering van Dirigeerende Leden'. Dit nieuwe bestuur zou zichzelf aanvullen en het voorzitterschap zou onder de bestuursleden rouleren. ${ }^{1}$ De relatie met de regering zou beperkt blijven tot één bezoek per jaar, af te leggen door de voorzitter, een tweede bestuurslid en de secretaris, met als doel de bescherming van de regering te verzoeken. ${ }^{2}$ Daarmee was in de keurige woorden van het bestuursverslag de kleine revolte voltooid. Kunde en bekwaamheid waren criteria geworden voor het lidmaatschap, rang en stand waren in onbruik geraakt, aanzien werd als selectiecriterium afgeschaft. In augustus 1802 werd nadrukkelijk besloten de 'kwaliteiten' van de leden - functies en titels - niet meer in de ledenlijst op te nemen. ${ }^{3}$ Tenslotte werd het instituut van de algemene vergadering opgeheven en werd de hoogte van de contributie aan de welwillendheid en draagkracht van de leden overgelaten. Door de hoogte van de contributie vrij te laten, werd de poort opengezet naar een grotere groep belangstellenden. Tegelijk werd met het afschaffen van de algemene vergadering de stem van die nieuwe leden bij voorbaat gesmoord. De Raad van Indië stemde met de voorgestelde wijzigingen in, ook met het verlies van de eigen positie in het genootschap. ${ }^{4}$ Overigens zou later in het genootschap een tegenbeweging zichtbaar worden. In dat opzicht weerspiegelen zich in het genootschap de bewegingen en contra-bewegingen van de jaren 17951816 in moederland en kolonie.

Dat in de vijf jaar voorafgaande aan de democratische ommezwaai zo goed als niets was gebeurd, was treurig genoeg. Het is juist de stilstand in de genootschapsactiviteiten van die jaren, die Van Hogendorp zijn sarcastische woorden ingaf. De Bataviase bevolking en vooral de elite waaruit het genootschapsbestuur werd gerecruteerd, had wel iets anders aan het hoofd gehad dan het beheer van de boeken en de verzamelingen in Radermachers huis. Het uitgeven van Verhandelingen en het uitschrijven prijsvragen leken futiele bezigheden in vergelijking met wat er in Europa en op de wereldzeeën gebeurde. De zorgen om het genootschap vielen in het niet bij de ondergang van de VOC en de dreigende inval van de Fransen, die de koloniën zouden willen bezetten om te voorkomen dat ze in de handen van de Engelsen vielen. Alleen de brave genootschapssecretaris Ross had er in de jaren 1795-1799 voor gezorgd dat op de genootschapszaken was gelet. In Van Hogendorps Berigt

ANRI KBG Dir 0020, 334-339, vergaderingen 31-3-1800 en 2-5-1800.

ANRI KBG Dir 0020, 342.

ANRI KBG Dir 0020, 345, vergadering 2-8-1802.

ANRI KBG Dir 0020, 345. 
was Ross daarvoor met ere genoemd. ${ }^{5}$ We mogen aannemen dat hij naast het beheer van de financiën ook toezicht was blijven houden op het genootschapshuis. In 1802 nam hij die taak ook weer formeel op zich. Opnieuw was het een predikant, die belangrijk onderhoudswerk verzette.

Daarmee lijkt Johan Theodoor Ross (1755-1824), werkzaam bij de Nederduitse gemeente, degene geweest te zijn die het genootschap door zijn moeilijkste jaren heenhielp. Misschien verdient hij naast Raffles daarom de titel van redder van het genootschap. Hij werd daarvoor in de vergadering van 2 augustus 1802 door zijn medebestuursleden bedankt. ${ }^{6}$ Ross was in 1788 aangekomen en in 1790 tot het genootschap toegetreden. Hij zou in 1808 door Daendels tot professor-honorair in de theologie worden benoemd in een stad waar geen universiteit was. In deze hoedanigheid werd hij in 1812 door Raffles bevestigd. In 1816 werd hij korte tijd voorzitter van het genootschap, terwijl hij eerder onder Raffles als secretaris was blijven dienen. Hij droeg in 1816 het secretariaat over aan pastoor Ph. Wedding. ${ }^{7} \mathrm{Na} 26$ jaar in het bestuur, begonnen onder Adriaan Moens, zal hij zelfs daarna nog, tot zijn dood in 1824, als vraagbaak hebben gediend voor latere secretarissen.

In het bestuur was in de twee jaar sinds 1800 al weer heel wat veranderd. Tesseire was overleden, Wiese en Schouwman waren afgetreden, Van Naerssen was vertrokken. De nieuwe bestuursleden die op 2 augustus 1802 aantraden waren Jan Jacob Vogelaar, Christaan Arnold, Louis Zomerdijk, Josua Leistman en Jan Kloprogge. Er waren achttien nieuwe leden benoemd. ${ }^{8}$ Van de hoopvolle nieuwe impuls die het genootschap zich zelf had gegeven, inclusief een nieuw reglement, is verder weinig zichtbaar, althans weinig achterhaalbaar in de eerste jaren van de eeuw. In de laatste vergadering van 1802, op 7 december, kwam een pakket uit Haarlem binnen met een brief uit 1794 (na acht jaar onderweg te zijn geweest), schonk voorzitter Vogelaar zeven koperen platen met 'fraai gesneden Oostersch schrift' en werd het pas gedrukte reglement (de nieuwe inrichting) getoond. ${ }^{9}$ Van dat drukwerkje heb ik geen enkel exemplaar in handen kunnen krijgen. De inhoud zal zijn overeengekomen met wat de resolutiën van 1800 daarover al hadden gezegd.

5 Van Hogendorp 1799:132. Ross heeft ook de financiën van jaar tot jaar bijgehouden, zo blijkt uit het verslag van de vergadering van 31 maart 1800 . Het saldo bedroeg toen Rds 1117.361/2.,- (ANRI KBG Dir 0020, 334-337, vergadering 31-3-1800).

6 ANRI KBG Dir 0020, 343-349, vergadering 2-8-1802.

7 De Haan 1935b:633-4. ANRI KBG Dir 1505, nr [17], overdracht van het secretariaat van Ross aan Wedding.

8 ANRI KBG Dir 0020, 346, vergadering 2-8-1802.

9 ANRI KGB Dir 0020, 353, vergadering 7-12-1802. Van dat drukwerkje heb ik geen enkel exemplaar kunnen terugvinden. De uitgave wordt vermeld in het Voorberigt VBG 7 (1814):2. Vanwege de zeldzaamheid nam Der Kinderen 1878 de tekst uit de resolutien in het archief als bijlage op. 
Juist hier is het resolutieboek van 1783-1802 vol en moest de secretaris overgaan naar een nieuw deel, het vierde sinds de oprichting in 1778. Maar dit vierde deel ontbreekt in het genootschapsarchief, zodat we pas weer met het resolutieboek van 1821 geïnformeerd zijn over de bestuursvergaderingen. Tussen deze jaren (1802-1820) ligt de belangrijke, later steeds bezongen periode van Raffles' voorzitterschap. Het is niet aannemelijk dat Ross, steeds een stipt werkend secretaris, in deze jaren geen verslagen heeft gemaakt. Het is waarschijnlijker dat dit resolutieboek is weggeraakt. Bij de overdracht van het secretariaat in 1816 van Ross aan Wedding werd het aantal resolutieboeken dat de nieuwe secretaris in handen kreeg, geteld als vier. Daarvan zijn er slechts drie terug te vinden in het genootschapsarchief, en wel over de periode $1778-1802 .{ }^{10}$

Zo hebben we over de periode vanaf 1803 te maken met een groot gat en zijn we alleen ingelicht door bronnen buiten het genootschapsarchief en bronnen van later datum. Het doorgaans goed ingelichte bestuurslid dominee W.R. van Hoëvell deed in zijn geschiedkundig overzicht van kunsten en wetenschappen in de kolonie (1839) wel een boekje open, maar juist over de periode na de 'omwentelingen in Europa' (1795) is hij weinig precies.

Het werd zelfs noodzakelijk den kring der werkzaamheden aanmerkelijk te beperken, de algemene vergaderingen te staken, en de verzamelingen van het Genootschap onder de leden des bestuurs te verdeelen, opdat deze ze tot meer gunstige tijden als eigendom des Genootschaps mogten bewaren (Van Hoëvell 1839:53).

Van Hoëvell gaat in zijn relaas verder met de Vrede van Amiens (1802), zodat wij mogen aannemen dat genoemde mededeling betrekking heeft op de jaren 1795-1802. We moeten er echter van uitgaan dat Van Hoëvell ook toen (1839) niet kon beschikken over een uitgebreid genootschapsarchief voor de jaren 1802-1820. Hij moet de informatie over de opgedeelde verzamelingen uit mondelinge overlevering hebben gehad, maar als bewijs dat de verzamelingen inderdaad waren verdeeld, is het niet overtuigend.

We tasten echter niet helemaal in het duister over de activiteiten tot de komst van de Engelsen in 1811. In een bundel losse stukken over de periode 1817-1827 zit in het genootschapsarchief een tot 1815 bijgewerkte ledenlijst die als kopij heeft gediend voor deel 8 van de Verhandelingen (1816). De lijst is - evenals zijn gedrukte pendant - chronologisch ingericht naar het criterium:

10 ANRI KBG Dir 0001-0020 bestaat uit drie banden. De vierde bundel wordt genoemd in ANRI KBG 1505 (bundel losse stukken over de periode 1817-1827), nr [17], transport RossWedding. Ook Der Kinderen heeft het over een gat in het genootschapsarchief tussen 1802 en 1821. Hij heeft echter een ledenlijst van 1815 in de bundel ANRI KBG 1505 kennelijk niet in handen gehad. Daar vallen nog wat gegevens uit af te lezen. 
van het oudste lid tot het jongst aangekomen lid. Bovendien is bij de namen van alle in 1815 nog aanwezige leden de datum van de vergadering waarop zij tot het lidmaatschap werden uitverkoren, genoteerd. Zo zien we dat in 1815 nog slechts twee personen van het eerste uur (1778) aanwezig waren. Het ging om de oud-gouverneur-generaal J. Siberg (1801-1805) en W.V.H. van Riemsdijk, beiden afkomstig uit vooraanstaande Bataviase families en al zevenendertig jaar lid. In totaal waren nog maar zestien leden over van vóór 1795. Nog gelukkiger is dat de opsteller van de lijst ook voor de periode na 1802 heeft opgegeven wanneer de opgesomde nieuwe leden werden benoemd. Dat moet in bestuursvergaderingen zijn gebeurd. ${ }^{11} \mathrm{Zo}$ zien we dat er in 1803 minstens een keer is vergaderd, in 1806 twee keer, in 1807 en 1809 elk een keer. De opsteller van de lijst moet te rade zijn gegaan bij een resolutieboek, anders had hij niet zo precies kunnen weten wanneer ieder tot het lidmaatschap was verkozen. Zo kunnen wij zien dat er tegenover zestien leden die het oude regime nog hadden meegemaakt, nog eens zestien leden stonden die tussen 1802 en 1811 waren aangetreden en opnieuw vijfenveertig nieuwkomers tussen 1812 en 1815. Van hen hadden acht Franse namen en drieëntwintig Engelse, zodat het genootschap een echte internationale organisatie was geworden. ${ }^{12}$ Het betekent dat het genootschap rond 1810 ongeveer dertig Bataviase leden geteld zal hebben. Van leden op buitenkantoren was al lang niets vernomen. Een enkele brief van Christiaan Hoffmann uit Ambon (1802) in het genootschapsarchief over zijn inentingsactiviteiten tegen de pokken, 'deeze eerste kunst bewerking en derzelve heilzame uitwerking' bewijst dat de contacten minimaal waren. Hoffmann wist niet van Wiegermans dood, evenmin kennelijk van Van Hogendorps en Van der Steeges uitgebreide rapporten over de pokkeninenting, maar wist wel dat hij bij het genootschap moest zijn voor zijn rapportage. Zijn verslag gaat terug naar zijn eerste pogingen in 1787 om de inenting bij de ongelovige gelovigen aanvaard te krijgen. Net als Horsfield in dezelfde tijd, had Hoffmann een steuntje in de rug nodig. ${ }^{13}$

C.G.C. Reinwardt, die in 1816 met de Commissie-Generaal op Java aankwam en in wiens portefeuille na het herstel van het Nederlandse gezag op Java de zorg voor kunsten en wetenschappen was ondergebracht, deed het in 1821 in een toespraak tot de algemene vergadering van het genootschap voorkomen alsof in de jaren 1792-1806 voortdurend was vergaderd. Sprekend over die periode zei hij - de notulant is pastoor Wedding:

\footnotetext{
11 ANRI KBG Dir 1505, nr [15-16]. Twee exemplaren van de bedoelde lijst.

12 Op de lijst zijn de namen van de inmiddels overleden leden doorgestreept. De manuscriptversie in het archief wijkt in geringe mate af van de gedrukte versie in VBG 8 (1816).

13 ANRI KBG Dir 1507, brief van Christiaan Hoffman aan president en leden van het Bataviaasch Genootschap, Amboina 14-6-1802.
} 
De Omstandigheden in Europa werden meer en meer bedenkelijk en het 6e deel der Verhandelingen [1792, HG] toont ons reeds, dat het Genootschap niet meer konde voortgaan om de vruchten van haren arbeid door den druk publiek te maken.-Niet tegenstaande de daarop volgende bijna gehele Afscheiding van deeze Colonie van het Moederland, zogten altoos de ijverige bestierers van dien Tijd, het Genootschap, hoe wel kwijnend, in het Leven te houden. De maandelijksche vergaderingen der dirigerende Leden van het zelve, werden altoos volgehouden en uit de spaarzaam uitkomende Vaderlanders, werden altoos ijverig nieuwe Leden in plaats der overledenen gesteld. ${ }^{14}$

Hoe juist Reinwardt was geïnformeerd, is nog de vraag. Was hem misschien het verleden door Ross wat te rooskleurig voorgesteld? In ieder geval bevestigen zijn woorden wat ook de eerder genoemde ledenlijst ons zegt: er werd vergaderd, er werden nieuwe leden gekozen, ook vóór 1811. Reinwardt en Van Hoëvell spreken elkaar volledig tegen. De een houdt het op maandelijks vergaderen, de ander op helemaal niet vergaderen.

\section{Persoonlijkheden: Thomas Horsfield, Amerikaans natuurkundige}

Het is frustrerend dat we over de activiteiten tot de komst van de Britten niet meer weten dan enkele namen van leden gekoppeld aan de datum van bestuursvergaderingen. Van Hoëvell meldt dat Ross in die jaren aan het hoofd van het genootschap stond, maar hij meldt niets concreters over het genootschap dan dat het betrokken was bij de activiteiten van de Amerikaanse plantenkundige Thomas Horsfield, die in 1802 tot lid was benoemd en zeventien jaar in de archipel zou blijven, voornamelijk op Java. ${ }^{15}$ De Britse historicus John Bastin heeft uit diverse bronnen een uitvoerig biografisch Memoir over Horsfield samengesteld, dat als inleiding diende tot de heruitgave van diens Zoological researches in Java, and the neighbouring islands. ${ }^{16}$

Horsfield (1773-1859) was in 1798 in de medicijnen gepromoveerd aan de universiteit van Philadelphia, had in 1800 als scheepsarts Batavia aangedaan en was er in 1801 teruggekeerd met de bedoeling langer te blijven. Hij werd in 1802 tot opperchirurgijn benoemd in gouvernementsdienst met als opdracht onderzoek te doen naar inheemse kruiden en planten (Horsfield 1990:7-8, Memoir). Zelf zegt hij van een eerste verslag over geneeskrachtige planten

\footnotetext{
14 Verslag van de algemene vergadering van 21-2-1821 in de hand van Wedding in ANRI KBG Dir 0022.

15 Van Hoëvell 1839:54-6. Horsfield was een van de leden die op 2-8-1802 werden benoemd. ANRI KBG Dir 0020, 345.

16 Horsfield 1990, oorspronkelijk verschenen in Londen 1821-1824. Bastin noemt Horsfield in de titel van zijn Memoir 'First American naturalist of Indonesia' (Bastin 1990).
} 
dat voor advies naar het Bataviaasch Genootschap ging:

This report was submitted to the Council of the Batavian Society of Arts and Sciences, and through the recommendation of that body I received a more extensive appointment which offered me an opportunity to extend my researches not only to the Vegetable Kingdom, but also to Zoology and Geology, although the Materia Medica of Java was at this time still the chief object of my attention (Horsfield 1838-52:1, postscript; Bastin en Moore 1982).

In de samenvatting uit 1852 geeft Horsfield een ontwikkeling weer die over de jaren plaatshad. In het gouvernementsbesluit van 3 maart 1803 ging het de regering eerst en vooral om geneeskrachtige planten (Horsfield 1990:11, Memoir). Het genootschap gaf begin 1804 opnieuw een gunstig advies op Horsfields verzoek om na korte trips uit 1802 in de omgeving van Batavia nu een langere reis te mogen ondernemen. De toestemming van het gouvernement werd na het ontvangen van dit advies verkregen en in mei 1804 vertrok hij voor een reis over Java die hem pas weer in september 1812 naar Batavia zou terugvoeren. Tijdens deze jaren ontwikkelde Horsfield zich verder van medicus tot plantenkundige, dierkundige en geoloog.

Tijdens die acht jaren rapporteerde hij regelmatig aan het Bataviaasch Genootschap en het gouvernement, zo blijkt uit het relaas uit 1812, dat hij voor Raffles samenstelde over zijn activiteiten in de eerste jaren op Java. Zeven van zijn opstellen uit de jaren 1803-1806 werden pas in 1814 door het genootschap gedrukt, maar dat uitstel had te maken met gebrek aan drukletter en andere drukkersbenodigdheden in het door oorlogsomstandigheden geïsoleerde Batavia. Er kwam tot 1814 niets van de drukpers in de serie Verhandelingen. Het zevende deel was twintig jaar eerder in de druk blijven steken. ${ }^{17}$ De opstellen van Horsfield, gevoegd bij oude artikelen van twintig jaar eerder, completeerden het nieuwe deel 7. Zijn vele bijdragen in de Verhandelingen (1814-1816), merendeels teruggaand op observaties van zijn reizen in de jaren 1803-1812, wijzen erop dat de vertraging van de druk niet aan hem lag. Met Raffles als voorzitter werd de uitgave hervat met een dubbele, Nederlands-Engelse titel, Transactions / Verhandelingen.

Rond de jaarwisseling van 1805-1806 stuurde Horsfield dubbele exemplaren van geneeskrachtige kruiden naar het genootschap en hij rapporteerde in maart 1806 over zijn vorderingen vanuit Oost-Java. Het Bataviaasch Genootschap was dus voor hem de organisatie waarop hij steunde. Hij wist dat bij toekomstige verzoeken het gouvernement weer advies zou kunnen vragen aan het genootschap (Horsfield 1990:19-21, Memoir). Op een van zijn

17 Een zeldzaam exemplaar van dl 7 van de VBG (1794) heeft de UB Leiden G 150 7. Blijkens correspondentie in het familie-archief Beth (ANRI T 93 B 713/8) zijn er exemplaren hiervan rondgestuurd. 
reizen (1806) ontmoette hij de Franse natuurkundige J.B.L.C.Th. Leschenault de la Tour, een collega, die net als Horsfield eerst in Batavia lid was geworden van het genootschap, alvorens zijn onderzoekingen op Java te beginnen. ${ }^{18}$ De aanwezigheid van deze beide natuurkundigen laat zien dat het gouvernement geen moeilijkheden in de weg legde aan wetenschappelijk onderzoek of wetenschappelijke reizigers. In het geval van Horsfield stimuleerde de overheid het onderzoek in samenspraak met het genootschap. Leschenault de la Tour bracht bezoeken aan het Tengger-gebergte en het Ijen-plateau, waarvan hij verslag deed ${ }^{19}$ en hij werd in Oost-Java ingeschakeld door de gouverneur van Java's Noord-Oost-kust, N. Engelhard, bij het aanleggen van een particuliere, botanische verzameling (De Haan 1912-14, I:85). In het bestuur was zelfs iemand als Ross, die in andere tijden nog had meegemaakt dat het genootschap meer profiteerde van de overheid, niet in staat om van het in Indië aanwezige potentieel beter gebruik te maken. Horsfields langdurige afwezigheid uit Batavia en de gebrekkige communicatie met wetenschappers in Europa leidden ertoe dat zijn publicatie over experimenten met het gif van de Oepasboom te laat kwam. De experimenten waren in 1806 gedaan, het verslag pas in 1814 gepubliceerd. Leschenault de la Tour had er in 1809 in Parijs al over gepubliceerd. Het is een voorbeeld van het grote nadeel van de afstand Europa-Azië bij het verbreiden van wetenschappelijke ontdekkingen. In 1814 zou Marsden Raffles op de publicaties wijzen, die sinds 1809 over dit onderwerp waren verschenen (Horsfield 1990:38, Memoir). Horsfields opstel over dit onderwerp was toen net gedrukt $(V B G 7,1814)$.

Raffles zou direct op zijn eerste reis over Java, enkele maanden na zijn aankomst in 1811, een uitgebreid onderhoud met Horsfield hebben in Soerakarta en goed gebruik maken van diens kwaliteiten. ${ }^{20}$ Het kan niet anders of we moeten - zelfs bij de onzekerheid door het ontbreken van een deel van het genootschapsarchief - besluiten dat het genootschap in de periode tot 1811 zwak bemand was en weinig middelen bezat. Geld (bij Engelhard) en macht (bij Raffles) bewerkten wat het machteloze en arme genootschap niet wist te bereiken. Horsfield werd door de opeenvolgende landvoogden, DaendelsJanssens-Raffles-Fendall, steeds weer in zijn functie aangehouden, teken dat

18 Horsfield in zijn 'Memorandum' (1829) over zijn verhouding tot Raffles, geschreven op verzoek van Lady Sophia Raffles (S. Raffles 1991:630). Leschenault de La Tour werd op 16-11-1806 lid van het genootschap (ANRI KBG Dir 1505, nr [15-16]) en zou nog datzelfde jaar op reis zijn gegaan op Java, aldus Horsfield.

19 Afschrift van verslagen in de Mackenzie-collectie in Oriental and India Office Collection (OIOC London), Eur. Mss minor coll. 288-4 en 288-5 Mack.Pr.7. Ook 288-13 en 288-14. De beschrijving van Tengger is van 15-2-1806. Raffles zou deze verslagen van Engelhard gekregen kunnen hebben.

20 Hierover Horsfield in S. Raffles 1991:603. Zie ook Wurtzburg 1984:196 en De Haan 1912-4, $\mathrm{IV}: 2262$. 
het gouvernement zich bewust was van het belang van dit soort onderzoek. Daendels gaf Horsfield opdracht om afschriften te maken voor het gouvernement van alle stukken die hij tot 1808 bij het Bataviaasch Genootschap had ingediend en Janssens vroeg nog in 1811 aan het genootschapsbestuur hoe het gouvernement het beste gebruik kon maken van diens talenten (Horsfield 1990:29, 32, Memoir). Zo bleef de Amerikaan van 1802 tot 1811 steeds in contact met het genootschap. Overigens was Horsfield het genootschap jaren later nog dankbaar voor de aanbeveling bij het gouvernement toen hij nog opperchirurgijn was, aanbeveling waaraan hij mede zijn grote bewegingsvrijheid en bijbehorende bezoldiging te danken had (Horsfield 1838-52:1, Postscript).

Het genootschap zelf kon zich in 1814, terugblikkend op de jaren 18021811 in het 'Voorberigt' tot het eindelijk verschenen zevende deel van de Verhandelingen, geen andere wapenfeiten herinneren dan de komst van Thomas Horsfield en zijn indiensttreding bij het gouvernement na het gunstige advies. Nogal moedeloos rechtvaardigt de opsteller van het voorbericht, J.I. van Sevenhoven, de stilstand van die jaren.

Geen wonder dat in zulke duisterheid der tijden, in zoo benarden en afgesneden toestand, waarin deze kolonie zich bevond, en onder het weg sterven van vele nutte Leden, die niet te herplaatsen waren, de lust der overblijvende kwijnde of vergong, en de Letter-oefeningen meestal stilstonden (VBG 7, 1814:6).

En Raffles zelf rechtvaardigde in een toespraak tot de algemene vergadering op 24 april 1813 onder verwijzing naar dezelfde omstandigheden de geringe activiteit met de woorden: 'Cut off from all communication with the Mothercountry, and distracted by internal jealousies and disputes, Science drooped, and this Society, which at one time maintained so distinguished a character, almost ceased to be known' (VBG 7, 1814:3).

Bronnen van vóór 1811 zijn schaars: de Bataviasche Koloniale Courant, opgericht door Daendels, nam in de periode 1810-1811 niets op wat op activiteiten van het genootschap wijst, terwijl de Java Government Gazette na september 1812 wel met regelmaat vergaderingen van het genootschap meldde en versloeg. Na de vergadering van juni 1809, waarvan we alleen weten dat er twee leden werden benoemd, zijn we tot januari 1811 niet geïnformeerd. Bij cartografische actviteiten, zoals die onder Daendels werden ondernomen voor de aanleg van de Postweg, was het Bataviaasch Genootschap niet betrokken. We vragen ons af of de bibliotheek en de verzamelingen in het genootschapshuis aan de Grote Rivier een desolate indruk maakten rond 1811. Kwamen er nog wel eens mensen? Was zo te zien tussen 1795 en 1800 nog voorzien in klein onderhoud door een aantal uitgaven, zoals voor de bibliothecaris, de schrijver, de jongen en de meid (slaven), over de toestand in het huis na 1802 weten we niets. 


\section{Bestuur onder Raffles}

Hoeveel te meer is er bekend over de periode van Thomas Stamford Raffles (1781-1826). Een snelle blik op het materiaal laat al zien dat hij zijn eigen publiciteit verzorgde. Na jaren kwamen er weer Verhandelingen uit, waarin zijn toespraken stonden, die in feite het genootschapsprogramma verwoordden. Hij was daarmee de strateeg van het genootschap. Raffles bleef Horsfield steunen en zorgde ervoor dat diens werk gepubliceerd werd: de helft van deel 7 en meer dan de helft van deel 8 van de Verhandelingen is van Horsfields hand. Andere Raffles' getrouwen: Colin Mackenzie, John Leyden en John Crawfurd zorgden voor de rest. Bijdragen van Nederlandse leden waren minimaal. Ook via de Gazette zorgde Raffles voor berichtgeving. Bovendien hielp hij het genootschap aan een nieuwe behuizing, aan de zijkant van de Harmonie, het nieuwe sociëteitsgebouw. Zijn uitgebreide verzamelingen en de boekstaving van zijn en andermans werk in zijn History of Java (1817) deden de rest. Daardoor kon Raffles de geschiedenis ingaan als de persoon die het Bataviaasch Genootschap nieuw leven inblies en werd hij na Radermacher de tweede belangrijke figuur in de genootschapskroniek. De periode 1811-1816 verdient daarom nadere belichting. Echter geldt ook voor deze periode dat het archief weinig of niets bevat. Een deel van het materiaal blijkt met Raffles naar Londen te zijn gegaan.

De toestroom van Europeanen naar Batavia, die op de overname van Java door de Britten in september 1811 volgde, betekende een impuls voor het gezelschaps- en genootschapsleven. Waren de Britten tijdens de blokkades in de Frans-Engelse oorlogen eerder verantwoordelijk geweest voor het isolement van Java, waardoor de aanvoer van Europeanen stokte, nu zorgden ze voor ontsluiting. Raffles was geboren in de Caraïbische Zee aan boord van het schip waarop zijn vader kapitein was. Zijn moeder was Nederlandse. Als jongeman in dienst van de East India Company gekomen, werkte hij tot 1805 op het hoofdkantoor in Londen. Daarna werd hij naar Penang uitgezonden. Door governor-general Lord Minto werd hij in 1809 uitgekozen als diens agent voor de Maleise staten met als standplaats Malakka. Toen de invasieplannen voor Java in augustus 1811 werden uitgevoerd koos Minto Raffles tot zijn secretaris. De overmeestering door de Britten van het slecht verdedigde Java onder Janssens was in een maand gebeurd.

Raffles was zich direct bewust van het bestaan van het genootschap en van de noodzaak om aandacht te besteden aan de wetenschap. In een brief aan William Marsden, de auteur van History of Sumatra, van 5 oktober 1811, schrijft hij: 'Lord Minto is now here and we have in contemplation to bring forward the Batavian Asiatic Society as soon as circumstances permit' (Wurtzburg 1984:181). De passage is niet helemaal duidelijk: overwogen Minto en zijn luitenant-gouverneur Raffles een Bataviase afdeling van de Asiatic Society 
van Calcutta op te richten of verwees de brief naar de noodzakelijkheid om het Bataviaasch Genootschap vooruit te helpen? Ik houd het op het laatste. Wel geeft het aan dat Minto en Raffles nog geen maand na de val van Meester Cornelis al nadachten over wetenschappelijke activiteiten.Het zou overigens nog een jaar duren voordat het Engelse bestuur zodanig op orde was, dat de aandacht voor het Bataviaasch Genootschap tot iets leidde (Schrieke 1930).

Het eerste nieuwe lid van het genootschap in deze periode was overigens niet Raffles zelf maar de Schotse genie-officier, luitenant-kolonel Colin Mackenzie (1754-1821). ${ }^{21}$ Hij was in India werkzaam geweest als landmeter en cartograaf en had daar een historisch-archeologische verzameling aangelegd. Op de expeditie naar Java leek hij een geschikte persoon juist vanwege zijn cartografische vakkennis (Blake 1991). Hij kreeg direct na de overname een opdracht tot het inventariseren van kaarten en archieven in Batavia, maar ook op de Noord-kust, in de periode waarin de nieuwe overheid gegevens over de kolonie verzamelde. Hij legde en passant ook een eigen verzameling aan die nu als de Mackenzie Collection in de Oriental and India Office Collections van de British Library wordt bewaard, waar zich tevens een deel van Raffles' papieren bevindt. ${ }^{22}$

Het ligt voor de hand dat we Mackenzies uitverkiezing tot het lidmaatschap tijdens een bestuursvergadering op 28 september 1812 in verband brengen met zijn ambtelijke taak: gegevens uit de archieven bijeenzoeken, en met zijn hobby: verzamelen. Hij had de bibliotheek en de verzamelingen van het Genootschap of wat daarvan nog over was, misschien al bekeken vóór hij in november 1811 op een reis van negen maanden over Java vertrok. ${ }^{23}$ Zo niet, dan zal hij na terugkeer in Batavia zijn vondsten hebben willen afzetten tegen de collectie van het genootschap. Bij zijn terugkomst in augustus 1812 was hij als onderzoeker en verzamelaar bekend. Hij was in september, net als Horsfield, in Batavia en daarvan profiteerde het genootschap door beide mannen aan zich te binden. De Java Government Gazette vond de uitverkiezing tot lid van de militair een uitgebreid bericht waard, hetzelfde bericht waarin de hernomen activiteiten van het genootschap werden gemeld. Er werd gewag gemaakt van de grote verzamelingen die Mackenzie op zijn reis had vergaard. Dat de manuscripten enkele maanden eerder uit de kratonbibliotheek

21 Volgens de ledenlijst uit 1815 in ANRI KBG Dir 1505, nr [15-16] zou Mackenzie al op 3-21812 tot lid benoemd zijn. Dit wordt tegengesproken door een krantenbericht van 3-10-1812, Java Government Gazette, 4. Op 28 september zou volgens dezelfde ledenlijst Captain W. Robison zijn benoemd.

22 Over het gebruik dat Raffles maakte van het door Mackenzie verzamelde materiaal: Weatherbee 1978.

23 In de Mackenzie collection zitten verschillende stukken, meest vertalingen in het Engels, die in verband staan met het Bataviaasch Genootschap, maar ook bijvoorbeeld een vertaling van Van Hogendorps Berigt van den tegenwoordigen toestand in manuscriptvorm. 
in Djokjakarta waren meegenomen na de plundering van het paleis werd niet vermeld: 'he has obtained a variety of valuable and curious information and made large collections of antiquities, manuscripts and inscriptions' (Java Government Gazette 3-10-1812:4).

Mackenzie zou op basis van de verzamelde gegevens zijn hoogste chef, Lord Minto in Calcutta, rapporteren. Het uitgebreide dagboek van zijn verblijf op Java gevoegd bij zijn ambtelijke verslag en de verzamelingen laten zien dat hij systematisch en veel verzamelde. Zijn taak in de commissie voor het ontwerpen van een nieuw grondbelastingstelsel, waarvoor het opmeten van het hele landbouwareaal nodig was, vroeg ook wel om een systematische aanpak. ${ }^{24}$ Mackenzie was bij het genootschap als het ware een voorloper van Raffles. Deze zou een maand later, 23 oktober 1812, contact leggen: hij nodigde alle in Batavia overgebleven leden, dertig in getal, uit voor een diner bij welke gelegenheid Van Sevenhoven op verzoek van het bestuur een exposé gaf van de geschiedenis en de doelstellingen van het genootschap. ${ }^{25}$ Thomas Horsfield had de week daarvoor, op 14 oktober 1812, een paar interessante natuur-historische uiteenzettingen gegeven in een ledenvergadering. ${ }^{26}$ Zijn verzameling natuur-historische specimina zou naar het museum van de East India Company in Londen verscheept worden (Java Government Gazette 31-10-1812:2).

In september 1812 was zo het genootschap weer in het nieuws. De krant vermeldde voorzichtig dat de enkele jaren geleden gestaakte activiteiten van het genootschap waarschijnlijk zouden worden hervat. De luitenantgouverneur had zich tijdens het diner, in antwoord op Van Sevenhovens schets van de geschiedenis van het genootschap, opgeworpen als behartiger van zijn belangen

by removing any obstacles which a jealous policy might formerly have thrown in the way of liberal inquiry, by providing a more commodious place for their meetings, and facilitating the publications of their transactions by the Governement Press (Java Government Gazette 31-10-1812:2).

Een statutenwijziging werd voorgesteld, waartoe een commissie aan het werk toog.

Een nieuwe vergaderruimte en toegang tot de overheidsdrukkerij waren

\footnotetext{
24 Mackenzie 1952:100-70; De Haan 1935b:599-604; Weatherbee 1978:63-93.

25 Java Government Gazette, 31-10-1812, p. 2. De tekst van de toespraak van Van Sevenhoven ook in de OIOC, Mackenzie collection Mack Pr. 1 (minor collection 287). De vertaler was M.L. Mesman.

26 OIOC, Mackenzie collection Mack.Pr. 1 bevat een minuut van een nota door Van Sevenhoven over deze Horsfield-stukken, waaruit op te maken valt dat Van Sevenhoven het bestuur adviseerde over de publicatie.
} 
voor het genootschap belangrijke punten. Daendels had een begin gemaakt met het verplaatsen van het regeringscentrum naar Weltevreden en zo was het oude genootschapshuis van Radermacher aan de Grote Rivier een excentrische plek geworden. Daendels had de ongezonde kuststrook verlaten voor het gezonder geachte Zuiden. De gevolgen van het wonen en werken in de oude stad had het genootschap jarenlang aan den lijve ondervonden. Waardevolle bestuursleden stierven aan de lopende band, het ledenbestand moest steeds worden aangevuld. De toezegging van Raffles was daarom in meer dan een opzicht belangrijk: betere en nieuwe ruimte niet alleen, ook opnieuw centraal gelegen in een gezondere omgeving. Dacht niemand in die maanden aan de mogelijkheid om Horsfields verzameling in Batavia onder te brengen en aan het museum van het genootschap uitbreiding te geven? Mackenzie werkte in opdracht van Lord Minto, dus hij verzamelde voor het Britse gouvernement . Zijn 'eigen' (particuliere) verzameling nam hij als vanzelfsprekend mee. Horsfield was zijn werkzaamheden echter begonnen in dienst van de Bataafse regering, aangesteld als hij was in 1802. Kennelijk was het voor Raffles een uitgemaakte zaak dat deze verzamelingen Brits zouden worden. ${ }^{27}$ Overigens is het in zowel krantenverslagen als in Raffles' eigen programmatische toespraken veelbetekend stil op het punt van verzamelen van de kant van het genootschap. Kon dat maar beter aan de Britten worden overgelaten?

De krant vermeldt evenmin welke formele rol Raffles in oktober 1812 op zich had genomen. Hij wierp zich zeker op als beschermheer, maar vreemd genoeg komt het formele beschermheerschap in de krant niet ter sprake. Pas in februari 1813 werd Raffles voorzitter (president), terwijl toen op zijn voorstel besloten werd om Lord Minto het beschermheerschap aan te bieden. In de Verhandelingen $(7,1814)$ heet het dat Raffles eerst de open plaats van beschermheer op zich nam - dat moet dan in oktober 1812 zijn geweest waarna het genootschap daarna deze plaats aan Lord Minto aanbood. Na het gemankeerde beschermheerschap van Prins Willem V was zo voor het eerst die plaats bezet, overigens helemaal in tegenstelling tot de geest van 1800. In het nieuw ingerichte genootschap van toen was voor een beschermheer geen plaats geweest.

Vanaf september 1812 werd met regelmaat vergaderd. Verslagen werden gepubliceerd in de Java Government Gazette. Raffles' lidmaatschap komt echter niet in de krant voor. In de ledenlijst in het archief staat zijn naam bovenaan bij de vergadering van 15 februari 1813, de dag waarop nog zeventien

27 De Raffles collection in de OIOC London bevat correspondentie tussen Horsfield en gouvernementssecretaris Assey uit 1816 over de overdracht van de collectie aan het museum van de EIC, overdracht die dan ter kennis gebracht zal worden van de al aanwezige commissarissengeneraal (OIOC, Eur Mss 237, Mss Eur F 31, pp. 322-4). 
anderen lid werden. Er zouden later dat jaar nog zestien anderen volgen. Vierendertig nieuwe leden in één jaar tijd. Raffles zelf werd toen voorzitter, terwijl het genootschapsbestuur in de jaren ervoor geen vaste voorzitter had gekend, volgens de democratische 'inrichting' van 1800. In 1812 nog rouleerde het onder B.F.W. baron von Lutzow, de oud-legeraanvoerder, J. Paschen, Van Sevenhoven, oud-secretaris van de regering en H.W. Muntinghe, bij de Britse verovering president van de Raad van Justitie en raad extra-ordinair. Muntinghe was de enige van het bestuur die hoge functies in de regering bleef bezetten en die naast Ross in het kernbestuur van het genootschap onder Raffles overeind bleef. Vanaf 1813 was de Britse signatuur van het ledenbestand veel sterker. $H$. Muntinghe werd vice-voorzitter, terwijl Ross en Daniel Ainslie de secretarissen werden. De aankondigingen over het genootschap in de Java Government Gazette verschenen telkens in twee talen: de Nederlandse mededelingen ondertekend door Ross, de Engelse door Ainslie. In de redactiecommissie voor de Verhandelingen nam Mackenzie plaats en in de museumcommissie gouvernementssecretaris Ch. Assey. Raffles vervreemdde het oude bestuur niet helemaal van zich. Von Lutzow en Van Sevenhoven kregen een plaats in de redactie, het zogenaamde committee over de papieren. ${ }^{28}$ Jeremias Schill en Ross waren de enigen in het nieuwe bestuur van 1813 die nog de veranderingen van 1800 hadden meegemaakt.

\section{De relatie met de overheid}

Met Muntinghe naast Raffles aan het hoofd van het genootschap was de door de generatie van 1800 zo gewenste 'eenvoudige' inrichting niet in ere gehouden. Immers met de landvoogd en het tweede lid van de Council aan het roer was het genootschap meteen weer afhankelijk geworden van de overheid. Die overheid deed er vervolgens alles aan om die afhankelijkheid te bevestigen. Het gebruik van de gouvernementele drukpers en het vooruitzicht van een nieuw genootschapshuis deden het genootschap voelen dat het niet zelfstandig kon opereren. De Engelse vertegenwoordiging in de beide comités, voor de publicaties en het museum, betekende dat de Britten het genootschap goed controleerden.

In november 1812 was voor het eerst weer een algemene vergadering gehouden zonder ceremonieel, in het huis van Muntinghe. Op de verjaardag van het genootschap op 24 april 1813 werd een algemene vergadering gehouden met ceremonieel: in Government House en onder voorzitterschap

28 Java Government Gazette, 20-2-1813:2 noemt deze samenstelling. In 1814 bleek die alweer sterk gewijzigd. Zie het Voorberigt van VBG 7 (1814). 
van de luitenant-gouverneur van Java. ${ }^{29}$ De programmatische veranderingen van 1800, een eenvoudige inrichting, weinig ostentatie, geen algemene vergaderingen, waren teruggedraaid. Bij die veranderingen moeten we even stilstaan.

Was bij de democratische, nieuwe opzet van 1800 in het eerste artikel vooropgezet dat het genootschap zou bestaan uit 'de kundigste en geschiktste Lieden dezer Hoofdplaats, zonder eenige aanmerking van staat of rang', in 1813 was dit Franse gelijkheidsbeginsel geschrapt en stond voorop dat het genootschap 'onder de bijzondere bescherming van het Britsche Gouvernement [zou] blijven voortduren'. Die 'bescherming' was in 1800 niet afwezig geweest, maar stond toen duidelijk op het tweede plan. Zozeer waren de verlichte geesten van 1800 gespitst geweest op een breuk met het verleden dat zij de doelstellingen van het genootschap verschoven naar artikel 8, waar zij eerst wilden vastleggen dat het bestuur alle macht in handen had, een bestuur dat zich zelf door coöptatie zou aanvullen. Door de contributie vrij te laten hoopten de hervormers van 1800 het genootschap open te stellen voor al diegenen die in het verleden buitengesloten waren geweest door de hoogte van het bedrag, elf rijksdaalders per jaar. Dit alles werd onder toezicht van Raffles veranderd: in de nieuwe inrichting van 1813 waren zelfs vijf artikelen aan de leden gewijd. In 1813 stond 'eene zucht tot uitbreiding der Wetenschappen' aan de basis van een gewenst lidmaatschap, maar daaraan vooraf ging nog de eis van 'bekende braafheid', waardoor een ballotage-element werd ingevoerd dat nieuw was of liever gezegd: dat leek op het verafschuwde rang en stand van vóór $1795 .{ }^{30}$ De contributie en het entreegeld werden vastgesteld op tien Spaanse matten elk.

De opvallendste verschillen zijn derhalve duidelijk: in 1800 wilde het genootschap zich zelfstandig opstellen, in 1813 stelde het zich juist onder de bescherming van het Britse gouvernement. In 1800 zag het genootschap het bestuur als de kern van de organisatie en had het voor de leden weinig ontzag, schafte het zelfs de algemene ledenvergaderingen af. Daarmee gooide het met het badwater ook het kind weg, want wat was een genootschap zonder 'genoten'? En wat was de rol van de leden als die zich niet minstens een keer per jaar konden doen horen? De mannen van 1813 herstelden de leden in hun eer, daarmee ook de algemene ledenvergadering, terwijl de bestuursstructuur heel precies aan bepalingen werd gebonden. Toch was de herziening van 1813 een restauratie: gouverneur-generaal Minto als beschermheer en luitenant-gouverneur Raffles als voorzitter zorgden voor toezicht van

\footnotetext{
29 De Java Government Gazette gaf er pas op 4-12-1813 een verslag van omdat het de briefwisseling tussen Minto en het genootschap wilde afdrukken.

30 'Het conceptplan van Inrigting' is geciteerd naar bijlage E uit Der Kinderen 1878:xix-xxi. De 'Nieuwe Inrigtingen' van 1813 naar VBG 7, 1814:viii-xii.
} 
boven; het genootschap was zijn zelfstandigheid kwijt. Overigens was het genootschap, of in ieder geval Raffles, zich bewust van de 'terugkeer' tot de opzet van 1778. In zijn toespraak van 1813 althans maakte hij melding van de mooie vooruitzichten die zich openden nu het genootschap zich toelegde op zijn oorspronkelijke bedoelingen (VBG 7, 1814:2).

Wat de herzieners van 1813 onveranderd lieten, waren de grote lijnen van de doelstellingen, zoals die in een apart artikel waren opgenomen: zij streefden, naar de formulering uit deel 7 van de Verhandelingen, het algemeen nut na op een nauwkeurig bepaald terrein:

opheldering en uitbreiding der Natuurlijke historie, van talen, oudheden, zeden en gewoonten der Indische volken en andere bijzonderheden deze Landen betreffende bestemmen eigenaardig door plaatselijke betrekking het bijzonder doel van het Genootschap, welk tevens de bevordering van den Landbouw en andere aangelegenheden tot de welvaart der Volkplanting behoorende niet uit het oog zal verliezen (VBG 7, 1814:ix).

Toegevoegd aan de formulering uit 1800 was het element taalstudie. Ten opzicht van de oorspronkelijk doelstelling van 1778 was een inperking gemaakt. Het encyclopedische 'alle kunsten en wetenschappen' had toen voorop gestaan en de beperking tot 'deze volkplanting' had alleen gegolden op het terrein van landbouw, koophandel en bijzondere welvaart. De ongespecificeerde kunsten en wetenschappen waren nu ingeperkt.

\section{Publicaties}

Voor een nadere blik op de werkzaamheden van het genootschap in de jaren 1812-1815 zijn we aangewezen op twee toespraken van voorzitter Raffles van 24 april 1813 en van 11 september 1815 (VBG 7 en 8). Een apart programma, zoals in de periode 1778-1792 vijf maal was gedrukt, verscheen niet. Verder staan ons twee delen Verhandelingen ter beschikking.

In de eerste toespraak toonde Raffles zich een diplomaat door, als nieuwe voorzitter van een van oorsprong Nederlandse organisatie, aan de voorgeschiedenis ruime aandacht te besteden en tegelijkertijd een aantal belangrijke leden in het zonnetje te zetten: Radermacher, Ross, Muntinghe, Engelhard, Couperus en Van Naerssen. Twee van hen zaten ook in zijn eigen Council (VBG 7,1814:3-4,10, 16-7). Door de inhoud van deel 7 van de Verhandelingen samen te vatten stak hij opnieuw de loftrompet, nu op de buitenlanders, waarbij hij de werkterreinen noemde, die ook in de toekomst aandacht verdienden: natuurlijke historie (Horsfield), oudheidkunde (Mackenzie over Prambanan) en volkenkunde (Leyden over Borneo, VBG 7, 1814:11,14-6). Twee in deel 7 aanwezige Nederlandse bijdragen noemde Raffles niet: medi- 
sche wetenschap (Terne) en volkenkunde (Van Rijck), maar die waren dan ook al twintig jaar oud en werden in 1814 in feite herdrukt.

Als aandachtspunten en onderzoeksterreinen noemde hij vervolgens expliciet:

1 taalstudie, met name van het Javaans als toegangspoort tot de vroege geschiedenis van het eiland, alsook tot het denken en de gebruiken van de Javaan. Een plan voor een instituut voor taalstudie was in overweging. Het idee van gerichte studie van het Javaans was al onder Janssens geboren, mogelijk geinstigeerd door de jonge J. Chr. Baud, die onder Raffles in dienst van het gouvernement was gebleven. ${ }^{31}$

2 onderzoek naar gebieden buiten Java (voorbeeld: Horsfields onderzoek naar Bangka).

3 onderzoek naar inheemse wetten en instellingen (VBG 7, 1814:13-6).

Raffles concretiseerde tenslotte een aantal desiderata waarbij hij de Asiatic Society van Calcutta als voorbeeld stelde, die haar onderzoek over geheel Azië uitstrekte. Hij beval het Bataviaasch Genootschap aan zich vooral tot dichter bij Java gelegen gebieden te beperken. Hij noemde als onderzoeksgebieden: Bali, Borneo, Celebes, Halmaheira, Nieuw-Guinea, de noordelijke eilanden bij de Filippijnen en Japan (VBG 7, 1814:18-33). Daarmee gaf hij aan dat het Bataviaasch Genootschap beter de collega's in Calcutta niet in de wielen kon rijden.

Precies uitgewerkt is Raffles' programma niet, maar hij gaf wel aan welke gebieden aandacht moesten krijgen. Belangrijk zijn vooral twee aspecten: taalstudie en onderzoek naar nog weinig bekende gebieden. Hoe dat taalonderzoek, dan wel dat geografisch-etnologische onderzoek zou moeten worden aangepakt, daar gaat de toespraak niet op in. Dat Raffles zijn idee niet opgaf, blijkt uit het feit dat hij in 1823 in Singapore het Singapore Institute oprichtte voor de studie van de talen en culturen van Zuidoost-Azië (Van den Doel en De Schaepdrijver 1996:30-1).

In de toespraak van 11 september 1815, de vierde verjaardag van de Britse overname, deed Raffles evenmin een uitgewerkt programma uit de doeken, maar hij gaf wel een uitgebreid verslag van onderzoek dat door anderen was verricht, zonder steeds expliciet aan te geven of de resultaten van dat onderzoek door het genootschap zouden worden gepubliceerd. Na een lange lofzang op de overleden beschermheer Lord Minto, kwamen achtereenvolgens aan de orde: Horsfields verslag van zijn Bangka-onderzoek (dat in Londen zou worden uitgegeven), Borneo en Celebes (zonder vermelding van wie de soms zeer gedetailleerde onderzoeksgegevens afkomstig waren), Java (onder

31 Een instituut voor het Javaans kwam er pas in 1832 en wel te Surakarta (Fasseur 1993:60-3). Over Janssens' plannen om leerlingen voor het Javaans in Surakarta en Djokjakarta te plaatsen, aldaar p. 28. 
andere werden gemeld de opmetingen van tempels door captain G.P. Baker en het taalonderzoek door Reverend Th. Trowt), Bali, de geschiedenis van Java en tenslotte enige mededelingen over Japan (gebaseerd op mededelingen van Ainslie). ${ }^{32}$ Het overzicht geeft een interessante stand van zaken, waarin Raffles zowel de internationale literatuur over het onderwerp heeft verwerkt (W. von Humboldt, W. Jones, J. Banks, E. Kaempfer) als recente vondsten en beschrijvingen waarbij hij het ene tegen het andere afzet. Op verschillende plaatsen komt taalonderzoek ter sprake. Dat blijft een kerntaak voor het onderzoek in de archipel. Daarnaast blijkt uit de verslaggeving dat er in de voorliggende tijd gedetailleerd onderzoek was verricht en dat Raffles kon putten uit nauwkeurige verslagen. Als er geen in uitgewerkte doelstellingen en onderzoeksprojecten geformuleerd programma was, dan kunnen we toch uit deze redevoering aflezen waarover het in het Genootschap moest gaan. Raffles formuleerde zijn tweede verslag toen hij al wist dat zijn vertrek uit Java vaststond en tevens wist dat hij niet degene zou zijn die de overdracht aan de Nederlanders zou kunnen uitvoeren. Hij zou zijn ambt aan Fendall overdragen en naar Londen terugreizen. Toch is er in de toespraak van september 1815 niet direct van een afsluiting, laat staan van een afscheid sprake. Dat de toespraak pas na zijn vertrek verscheen, maakt het toch tot een afscheidsredevoering en tegelijk tot een programma voor de toekomst.

Raffles maakte op enkele plaatsen expliciet melding van onderzoeksresultaten die in de Verhandelingen zouden worden gepubliceerd: over Kawiinscripties gevonden in Oost-Java, Cheribonse manuscripten en ontcijferde inscripties op koperplaten, over de aard van het Javaanse schrift en over Tenggerse gebedsformules (VBG 8:36, 44, 53). In de Verhandelingen zijn echter deze beloofde opstellen niet verschenen. Moeten we aannemen dat deze opstellen behoorden tot het materiaal dat Raffles in 1816 meenam naar Londen voor deel 9 van de Verhandelingen, zoals aangekondigd in het voorberigt van deel $8 ?^{33}$ In 1816 keken de achterblijvers nog hoopvol uit naar dit in Londen te drukken 9e deel. In 1823, toen eindelijk deel 9 in Batavia uitkwam, waren er niets dan bittere woorden voor de niet nagekomen beloften van Raffles.

Wij verheugen ons dezelve [de 'keurige bouwstoffen' van het nieuwe deel 9] in de plaats te kunnen stellen der stoffe, waarvan in het Voorberigt van het VIII Deel dezer Verhandelingen melding wordt gemaakt, welke met de toenmalig afgetreden Voorzitter van dit Genootschap, den Heer Raffles, naar Engeland is medegegeven, ten einde aldaar de uitgave van het IX Deel te bespoedigen; doch wiens

32 VBG 8 (1816), Discourse, 5-11 (Bangka), 11-4 (Borneo), 14-23 (Celebes), 23-58 (Java), 58-69 (Bali), 70-86 (geschiedenis van Java) en 86-95 (Japan).

33 VBG 8:1,Voorberigt, dateert van na maart 1816. 'Drukte ter pers, en gedeeltelijk mangel aan de vereischte soort van drukpapier' worden hier aangevoerd als reden voor de late verschijningsdatum. We mogen aannemen dat verschijning in september 1815 in de bedoeling lag. 
beloften dien aangaande geheel onvervuld zijn gebleven, zonder dat de medegenomene, en aan zijne bezorging toevertrouwde stukken zelfs aan de Directie terug zijn gezonden (VBG 9:iii-iv).

Ook hier wreekt zich weer het ontbreken van het genootschapsarchief over die jaren, want in de verslagen van bestuursvergaderingen heeft ongetwijfeld een en ander gestaan over dit plan om deel 9 in Londen te laten drukken. De meegenomen en niet terugbezorgde stukken vormen een interessant raadsel. Dat Raffles beladen naar Londen terugkeerde, is bekend: dertig ton in tweehonderd grote kisten ${ }^{34}$ verpakt, teveel om op te sommen, maar in ieder geval ook veel geschreven materiaal dat hij voor zijn History of Java zou gebruiken. Met argwaan kijken we naar de bijlagen van dit werk (achter deel 2) waarin enkele interessante teksten voorkomen: uitgebreide woordenlijsten in bijlage $\mathrm{E}$ en $\mathrm{F}$, de verhandelingen over Celebes en Bali ( $\mathrm{F}$ en $\mathrm{K}$ ), en vertalingen van Kawi-inscripties (bijlage I). Raffles had in zijn toespraak van september 1815 over deze 'extensive vocabularies' gesproken, alsook over de te verschijnen Kawi-inscripties, terwijl er in dezelfde toespraak paragrafen gewijd zijn aan Bali en Celebes. Een deel van het 'Londense deel 9' lijkt aldus in Raffles' belangrijke werk over Java te zijn terechtgekomen. Toch hebben de bestuursleden van 1823, die Raffles' History kenden en die kennelijk zo bitter aan hem terugdachten, niet verder gewezen dan naar de man en niet naar de bijlagen in het werk, waar ze de bewijzen voor Raffles' handelwijze konden vinden. Dat Raffles dus kopij voor de Verhandelingen heeft gebruikt in zijn werk over Java, is door de bestuursleden in 1823 niet vermeld.

De bekende historicus van de Britse periode van Java en Raffles-deskundige John Bastin is niets bekend over een deel 9 van de Verhandelingen / Transactions, dat in Londen gedrukt had moeten worden. Hij verwijst echter wel naar de Malayan Miscellanies (1820-1821), twee door de Sumatran Mission Press in Benkoelen uitgegeven bundels Indonesianica, verschenen kort nadat Raffles het gezag in Benkoelen had overgenomen. ${ }^{35}$ Bastin suggereert dat eventueel vier van de verhandelingen in deel 1 en nog een vijfde in deel 2, stukken die niet direct op Sumatraanse zaken betrekking hebben, zouden kunnen behoren tot het Bataviase materiaal, in 1816 meegenomen naar Londen en in 1817 naar Benkoelen. ${ }^{36}$ Zo zou dan het 'Londense deel 9' ten dele in het grote

\footnotetext{
34 Niet meegeteld twaalf grote kisten met Horsfields verzameling. Die misten de boot en werden Raffles met de eerstvolgende mogelijkheid nagestuurd. Een collectie voor Sir Joseph Banks haalde Raffles' schip wel. Zie Bastins Memoir in Horsfield 1990:59.

35 Brief van John Bastin, 17-9-1996.

36 Het gaat om nr 2 over Bali, nr 7 over Timor, Roti, Savu, Solor, etc., nr 8 van J. Hunt over Kalimantan, nr 10 van J. Hunt over Sulo. Uit deel 2 noemt J. Bastin nr 9 van J. Methven over de Dayaks.
} 
werk over Java en ten dele in de Benkoelense delen kunnen zijn gedrukt. Omdat bij Raffles' vertrek uit Benkoelen in 1824 met het schip de 'Fame' ook zijn hele collectie en alle papieren in vlammen opgingen, is verder zoeken hiernaar weinig zinvol. De ondergang van de Fame met de levende have alle dieren kwamen om, maar alle passagiers, onder wie het echtpaar Raffles, konden worden gered - met een grote verzameling levende en gedroogde planten, met duizenden natuurkundige tekeningen en talloze manuscripten, oudheidkundige voorwerpen, muziekinstrumenten, enzovoort, enzovoort, is een culturele ramp geweest. Het tekent Raffles dat hij, terug in Benkoelen, in afwachting van een volgend schip direct aan de slag ging om een deel van de Sumatraanse gegevens opnieuw te verzamelen. Als Raffles in 1816 niet eerst naar Londen was gegaan met zijn tweehonderd kisten, had die ramp nog groter kunnen zijn geweest.

\section{Gebouwen: een nieuwe behuizing}

In de periode van Raffles' voorzitterschap valt nog een belangrijke gebeurtenis: de ingebruikneming op 24 augustus 1814 van de nieuwe genootschapslokalen op Weltevreden, op het terrein van de Sociëteit De Harmonie. De datum was veelbetekenend: de verjaardag van Prins Willem van Oranje, de pas aangetreden Souvereine vorst van Nederland, later Koning Willem I. Terwijl de feitelijke overdracht van de kolonie nog bijna twee jaar op zich zou doen wachten, werd juist op die dag het nieuwe lokaal betrokken tijdens een algemene vergadering onder Raffles, in het verslag waarvan expliciet naar de keuze van de datum wordt verwezen.

Op deze heugelijke dag, zijnde de Verjaardag van Zijne Koninklijke Hoogheid den Heere Prinse van Oranje, Souverein Vorst der Vereenigde Nederlanden, bepaald zijnde ter plegtige inwijding van het Nieuwe Locaal op Rijswijk, door het Gouvernement aan het Genootschap goedgunstig afgestaan. ${ }^{37}$

In de gekozen datum kondigden de nieuwe tijden zich al aan. De ingebruikneming vond aldus plaats twee jaar na de eerste belofte hierover van Raffles tijdens een ontmoeting met de leden, op 28 september 1812. Toen had hij - in de woorden van de krant - gesproken van 'a more commodious place for their meetings' (Java Government Gazette 31-10-1812:2).

De plannen voor de verhuizing van de Sociëteit De Harmonie van het gebouw in de Buiten Nieuwpoortstraat in de oude stad dateerden al van

37 OIOC Raffles Collection, Eur Mss 237 (Mss Eur F 31) Extract Resolutien Algemeene Vergadering Bataviaasch Genootschap 24-8-1814. 


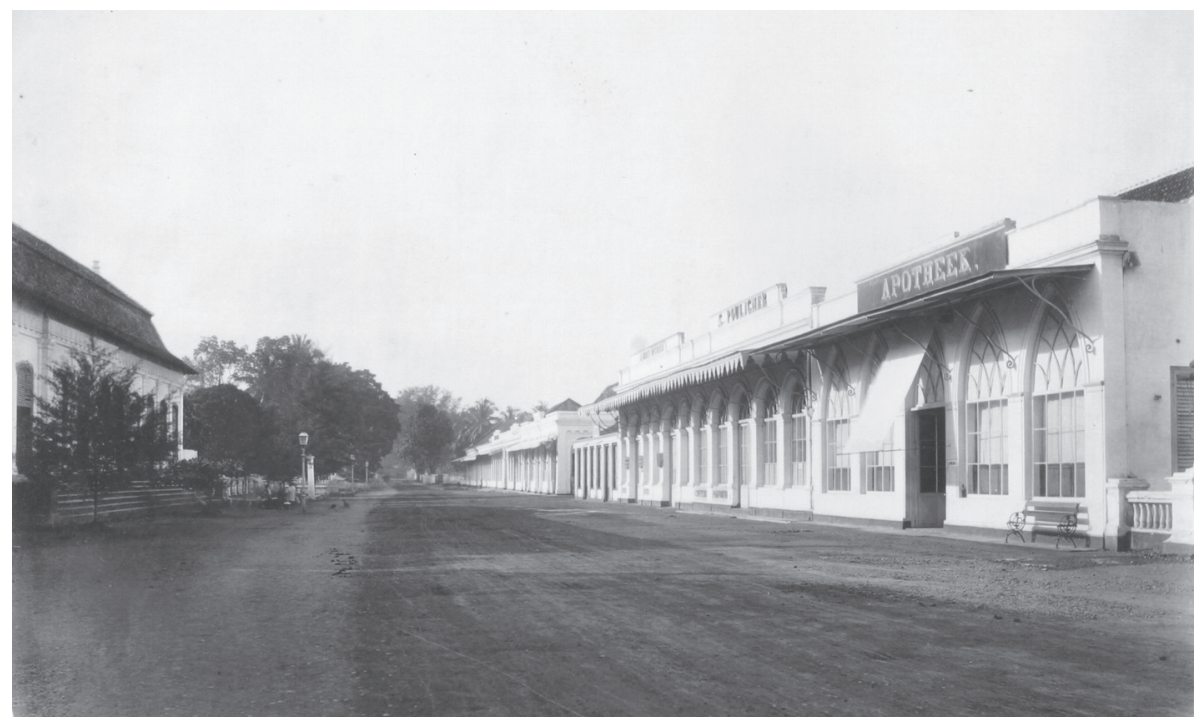

Rijswijkstraat met links gedeeltelijk zichtbaar het gebouw van het Bataviaasch Genootschap, gelegen achter het sociëteitsgebouw De Harmonie, Woodbury \& Page circa 1870 (collectie KITLV Leiden 26618)

1810. Daendels had echter toen alleen de sociëteit op het oog. Uit niets blijkt dat hij het Bataviaasch Genootschap in zijn plan had opgenomen. De werkzaamheden aan de nieuwe Harmonie waren gestart in 1810 en in 1811 gestaakt bij gebrek aan geld, maar ook omdat de dreigende aanval van de Engelsen verlammend werkte (Verhoeven 1939:19). Onder Raffles was de bouw grotendeels op basis van de plannen van 1810 hervat om pas in 1814 gereed te komen. Het Bataviaasch Genootschap betrok de nieuwe ruimte zelfs enkele maanden voor de Sociëteit zelf in het gebouw trok, het genootschap in augustus 1814, de sociëteit op 18 januari 1815. In feite moeten we niet van gebouw maar van een complex van gebouwen spreken. Het bestek laat een geheel zien van zeker acht gebouwen en gebouwtjes, voor een deel tegen elkaar aangelegen, onder meer het sociëteitshuis, twee aparte zalen, een kolfbaan, een woning voor de beheerder (kastelein), een achterbouw en een winkelcomplex. De voorgevel van de Sociëteit lag langs de Molenvlietse vaart op Rijswijk, de zijgevel aan de Rijswijkstraat, die naar het Zuiden, naar Tanah Abang liep. Het is niet onmogelijk dat Raffles in 1812, ten tijde van zijn belofte aan het genootschap, de Harmonie al in gedachten had. In juli 1812 was het nieuwe bestek voor het complex gemaakt en in oktober was de financiële kant van de zaak rond, juist in de tijd dat Raffles de leden van het genootschap bij zich thuis ontving. 
Het genootschap betrok in augustus 1814 de ruimte, oorspronkelijk bedoeld voor een galerij waar winkels en warongs in voorzien waren en die lag aan de Rijswijkstraat, aan de zuid-westzijde van het sociëteitsterrein. In het contract voor de aannemer werd het aangeduid als 'een gebouw [...] verdeelt in 10 vertrekken, ieder met twee vertrekken bestaande en bestemd tot 10 warongs, ieder vertrekje 10 à 12 voet' (Verhoeven 1939:525, 529-31). Het hele gebouw werd aan de buitenkant 110 voet lang en 26 voet breed (circa 33 bij 8 meter), een naar verhouding nogal ondiep gebouw. Aan de oorspronkelijke indeling zal wel het een en ander veranderd zijn want uit het genootschapsarchief blijkt niet dat men in 20 kleine kamertjes trok. Die winkels of warongs hadden de sociëteit door verpachting aan inkomsten moeten helpen, waardoor het de bouwkosten kon afbetalen, maar doordat het gouvernement de financiering overnam, was dit niet meer nodig.

Zo werd dan op de verjaardag van de souvereine vorst

des voormiddags ten $\mathrm{X}$ uuren de Heer Luitenant Gouverneur en President dezes Genootschaps Tho. S. Raffles door eene Commissie van twee Leden en de secretarissen van 's Gouvernements Huize afgehaald en alzoo binnengeleid zijnde, door alle de aanwezige Leden en een aantal Personen ter bijwoning dezer Plegtigheid toegelaten, eerbiedig verwelkomd. ${ }^{38}$

Hoe de plechtigheid verder verliep, werd niet gemeld. De krant had er alleen een vooraankondiging van gedaan op 20 augustus, waarbij gemeld werd dat het ieder lid vrij stond 'een paar vrienden, ter bijwooning dezer plegtigheid, door de byzonderheid van den Dag zo opgeluisterd, in te leiden' (Java Goverment Gazette 20-8-1814:2). De beschrijving van het ceremonieel doet erg denken aan de manier waarop de gouverneur-generaal in de jaren 1779 en 1790-1793 werd afgehaald door een commissie van in- en uitgeleide op weg naar de algemene vergadering.

Van de verhuizing van de verzamelingen van het genootschap ontbreekt elk spoor, terwijl het ons zou interesseren te weten wat er overgebracht werd van de oude naar de nieuwe stad. Of de museumcommissie in de periode van het Britse bestuur iets gedaan heeft, blijft een raadsel. Na de ingebruikneming werd het genootschapslokaal - zoals het steeds werd aangeduid - uitgeleend voor de bestuursvergaderingen van de Java Auxiliary Bible Society, waaruit we mogen afleiden dat het in ieder geval over een goede vergaderzaal beschikte.

In 1835 zou het genootschap ook de beschikking krijgen over het gebouw van de kolfbaan, gelegen naast het sociëteitshuis aan de Molenvlietsevaart,

38 Extract uit de resolutien van de algemene vergadering op 24-8-1814, in de Raffles Collection, OIOC Londen, Eur. Mss 237 (Mss Eur F 31). Dit uittreksel uit de resolutiën is het enige spoor van de resolutieboeken uit de Britse periode, dat ik heb kunnen vinden. 
aan de noord-oostzijde van het Harmonie-terrein. Toen de kolfbaan geen succes bleek, was daar de Algemene Secretarie in gevestigd geweest. F. Verhoeven wijst op de mooie combinatie in de jaren tot 1835: sociëteitsgebouw, genootschapslokaal en museum plus de kantoren van de Algemene Secretarie op een en hetzelfde terrein. 'Staatsbestuur, kunsten en wetenschappen, officieele feesten en sociëteitsgezelligheid broederlijk bijeen!' (Verhoeven 1939:531)

\section{Van Brits naar Nederlands}

Raffles' afscheid als voorzitter viel kort voor zijn vertrek naar Europa. Op 22 maart 1816 werd er een algemene vergadering gehouden, tijdens welke hij het voorzitterschap neerlegde en hem de eer te beurt viel een opvolger aan te wijzen, op suggestie van bestuurslid Van Sevenhoven. Raffles koos niet Muntinghe of Van Sevenhoven, maar de honoraire hoogleraar Ross, misschien vanwege zijn verdiensten als redder van het genootschap in de jaren tot 1811. Ook anciënniteit kan een rol hebben gespeeld. Ross was tenslotte de langstdienende. Het vice-voorzitterschap veranderde eveneens. Dit kwam bij Baron von Lutzow, terwijl Muntinghe naast Van Sevenhoven in de redactie van de Verhandelingen kwam te zitten. Moeten we aan een uitschakeling van Muntinghe denken of was hij bij het vertrek van zijn broodheer ook zijn belangstelling voor een bestuursfunctie kwijt?

Ross sprak bij de gelegenheid een dankrede aan het adres van de aftredende voorzitter uit, die de dag erna ook nog eens op papier aan Raffles werd overhandigd. De achterblijvers spraken de wens uit dat zij een borstbeeld mochten ontvangen van hun scheidende voorzitter 'om te worden geplaatst in de zaal van ons Genootschap in die leedige Nis, welke bestemd was om het Beeltenis te ontfangen van wijlen onzen edelen en geëerbiedigden beschermer de Graaf van Minto' ${ }^{39}$ Dat borstbeeld zou er ook komen, maar pas na ruim honderd jaar. Op 23 december 1929 werd het in de historische zaal van de vierde behuizing, het Museum aan het Koningsplein, door vertegenwoordigers van de Malayan Branch (Singapore) van de Royal Asiatic Society aan voorzitter $\mathrm{Ch}$. Welter overhandigd. Het siert nog altijd het Nationaal Museum in Jakarta. ${ }^{40}$

Raffles vertrok op maandag 25 maart 1816. Zijn neef Thomas Raffles

\footnotetext{
39 Java Government Gazette, 24-3-1816:1, zegt dat deze bijeenkomst op vrijdag 22 maart plaatshad. VBG 8:II (Voorberigt) zegt 16-3-1816. Het citaat naar de krant. De dankrede aan Raffles ook in de $V B G 8$ (1816).

40 Zie Verslag van de Openbare Vergadering der Directie van het Koninklijk Bataviaasch Genootschap van Kunsten en Wetenschappen, 23-12-1929, TBG 70:53-7 en het speciale Rafflesnummer van Inter-Ocean 9 (1930) aflevering 3.
} 
schreef later over de enorme vracht die hij meenam. 'This, then, was no small item in the expense of homecoming', schrijft Raffles' biograaf droog (Wurtzburg 1984:393). Bij al die vracht ook veel papier, onder meer de bouwstoffen voor zijn History of Java en de stukken die deel 9 van de Verhandelingen hadden moeten worden. Deel 8 was nog niet uit en zou na Raffles' vertrek verschijnen. Raffles' opvolger, John Fendall, gaf in de hem resterende vijf maanden geen blijk van belangstelling voor het Bataviaasch Genootschap. In de krant staat in die laatste maanden van het Britse bestuur niets meer over het Genootschap. Raffles stuurde in 1817 wel een exemplaar van zijn boek over Java aan het genootschap en Fendall wikkelde de zaak met Horsfield af: voor drieduizend Spaanse dollars ging het overgebleven deel van de collectie van de Amerikaanse natuurkundige naar Londen, ook dit deel dus niet naar het het museum van het Bataviaasch Genootschap (Horsfield 1990:60-6).

Raffles heeft veel betekend voor het Bataviaasch Genootschap: een opleving, een reorganisatie, nieuwe leden, hervatting van de uitgave van de Verhandelingen (na 20 jaar stilzwijgen), toegang tot de drukpers, een nieuw gebouw, inspirerende, programmatische bijdragen tot de vergaderingen en aan de publicaties, contacten met Britse onderzoekers. Het is niet gering en hij krijgt er terecht lof voor.

Raffles deed nog veel meer, dat niet het Bataviaasch Genootschap ten goede kwam: hij nam Horsfield over uit Nederlandse dienst, gaf hem faciliteiten, gebruikte Horsfields mogelijkheden en zag - toen de Britse regeerperiode afliep - kans om de Amerikaan voor de Engelse compagnie te behouden. Hij stuurde al in 1812 een deel van de Horsfield-verzameling naar Engeland - grotendeels in Nederlands dienstverband verzameld - en liet er in 1814 de steenvondsten van Bangka op volgen. Hij bracht Horsfield ook in contact met Sir Joseph Banks, president van de Royal Society, een groot verzamelaar, voor wie de Amerikaan tot vier keer toe een collectie gedroogde planten bijeenbracht. Raffles nam tenslotte een groot deel van de collectie persoonlijk mee naar Londen in 1816. ${ }^{41}$ In 1818 liet Raffles zijn adjudant, Captain Travers, op een diplomatieke missie naar Batavia vanuit Benkoelen, de Amerikaan ophalen, waarna deze vanuit Sumatra naar Londen vertrok (S. Raffles 1991:62830). Hoezeer ook de Nederlands-Indische regering van 1802 de kwaliteiten van de man had herkend, het is vooral via de Britse drukpers dat deze medicus-natuurkundige zijn kennis over Java wereldkundig heeft gemaakt in zijn vanaf 1821 in Londen verschenen publicaties. Vooral de Britse verzame-

41 Horsfield beschreef in 1829 in zijn 'Memorandum' voor Lady Sophia Raffles, die toen bezig was een biografie te schrijven over haar overleden echtgenoot, zijn (Horsfields) relatie met Raffles. In het memorandum wordt een deel van de correspondentie geciteerd waaruit blijkt dat de verhouding vriendschappelijk was (S. Raffles 1991:602-32). 
lingen hebben van zijn onderzoek op Java geprofiteerd. ${ }^{42}$ Daarentegen bleef er voor zover bekend slechts een kleine verzameling gedroogde planten van Horsfield in Batavia achter, de collectie die hij rond de jaarwisseling van 18051806 naar Batavia stuurde. Het betekende wel dat Reinwardt in 1816 en de Natuurkundige Commissie van 1820 niet konden voortbouwen op wat tussen 1802 en 1816 was verricht. Zij begonnen weer opnieuw.

De manier waarop Raffles een kundig cartograaf en historicus als Colin Mackenzie inschakelde bij het verzamelen van gegevens over Java, onder andere historisch-archeologisch materiaal, is een ander voorbeeld van zijn voortvarendheid. Het is tekenend dat Mackenzie's naam niet in het voorwoord van de History of Java voorkomt en dat Raffles hem zelfs in 1815 obstakels in de weg legde, toen deze via de militaire tekenaar H.C. Cornelius probeerde om zijn gegevens over Java aan te vullen. Raffles deed het verzoek van Mackenzie af als een particuliere zaak, die Cornelius niet hoefde te behandelen. Er hoefde geen aanvullend materiaal naar Calcutta gestuurd te worden. Zag Raffles Mackenzie toen als concurrent, die zelf wel eens met een studie over Java voor de dag zou kunnen komen (De Haan 1935b:603-4)? Anderszins is Raffles' teleurstelling en verdriet over het overlijden van Dr. John Leyden in de eerste weken van het Britse bestuur op Java een bewijs van zijn hoop dat Leyden zijn kennis had kunnen inzetten voor de studie van Javaanse zaken. En dat op een moment dat Raffles nog helemaal geen plannen had om zelf een boek over Java te publiceren. Leydens bijdrage aan de Verhandelingen bleven daardoor beperkt tot aantekeningen over Borneo, gemaakt op de heenreis naar Batavia.

Raffles zag het belang in van de studie van Javaanse tempelresten. Misschien wordt hij wat teveel als de 'ontdekker' van de Boroboedoer geprezen, waar immers mannen als Engelhard - jammer genoeg zonder respect voor de tempels - eerder Javaanse oudheden exploreerden en exploiteerden, maar het feit dat hij het onderzoek op gang bracht, als nieuwsgierige stimulator optrad en zelf ook de tempels ging bezoeken, zegt genoeg over de onderzoeksdrift die noodzakelijk is om de wetenschap vooruit te helpen. Dat het Bataviaasch Genootschap er op dat moment weinig tegenover kon zetten en daardoor bij het vertrek van Raffles een groot verlies leed, zegt genoeg over het zittende bestuur en over de leden.

Raffles' betrokkenheid bij de Bataviase maatschappij blijkt tenslotte ook nog uit het feit dat hij de Java Auxiliary Bible Society aanvoerde, het societeitsleven stimuleerde - gesteund door een vrouw die Europese elegantie in Batavia terugbracht - en de Java Benevolent Institution oprichtte, die de

42 Bastin in zijn Memoir, Horsfield 1990:43, 49, 55-7, 59-63 over de verschillende verzamelingen die niet voor het Bataviaasch Genootschap bestemd waren. 
afschaffing van de slavernij voorstond (Van de Wall 1930). Daaruit bleek dat zijn aandacht niet ophield bij wetenschap. In veel opzichten volgde Van der Capellen Raffles' voetsporen, zodat eerder 1811 dan 1816 als een breuk kan gelden, ook voor het genootschap. Doordat Raffles het genootschap nieuw leven inblies, hoefde Van der Capellen dit niet boven aan zijn lijst van werkzaamheden te stellen en kon hij zich eerst aan andere zaken wijden. 
Hans Groot - 978-90-04-25380-3

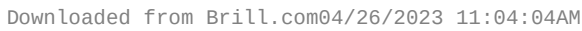
via free access 


\section{HoofDSTUK III}

\section{Terug onder Nederlands bestuur (1816-1826)}

\section{Onder beschermheer Van der Capellen}

Bij de voorbereidingen op het vertrek naar Batavia van de CommissieGeneraal, die het bestuur uit Britse handen zou overnemen en het Nederlandse gezag zou herstellen, werden onderwijs, kunsten en wetenschappen niet vergeten. Aan de delegatie werd een Directeur tot de zaken van Landbouw, Kunsten en Wetenschappen op Java en naburige eilanden toegevoegd. De benoemde ambtenaar was de Amsterdamse hoogleraar en directeur van 's Lands Kabinet van Natuurlijke Historie, Caspar Georg Carl Reinwardt (1773-1854), Duitser van oorsprong. Hij werd benoemd op 15 januari 1815 voor een periode van twee jaar met een mogelijkheid van verlenging. Het zouden voor hem zes jaren in Batavia worden. De overgang van de federatie van provincies via de Bataafse Republiek, het Franse bestuur en het Koninkrijk Holland naar het verenigd Koninkrijk der Nederlanden had de zorg voor kunsten en wetenschappen bij de centrale overheid gebracht. Onderwijs, taal en nationale verzamelingen waren onderwerpen die vanuit Den Haag en Brussel werden geregeld, zij het nog niet onder een apart minsiterie.

Uit het benoemingsbesluit van Reinwardt kunnen we een en ander aflezen over de bedoelingen van de regering. ${ }^{1}$ De nieuwe directeur kreeg de zorg opgedragen voor land- en bosbouw, gezondheid en opvoeding, onderwijs, geologie, plant- en dierkunde, waaraan werd gevoegd dat hij verzamelingen moest aanleggen voor zijn Amsterdamse kabinet. Tenslotte zou hij op reis moeten gaan en gegevens verzamelen over 'zeden, taal en denkwijze der inwoonderen, hunnen godsdienst en hunnen regeringsvorm' om zodoende na afloop een beredeneerd verslag hierover te kunnen indienen. In het artikel uit het benoemingsbesluit dat hierover ging, werd gerefereerd aan het onderzoek dat Colin

1 Benoemingsbesluit met bijlagen in De Vriese 1858, zijn editie van Reinwardts, Reis naar het oostelijk gedeelte van den Indischen Archipel, 33-48. 


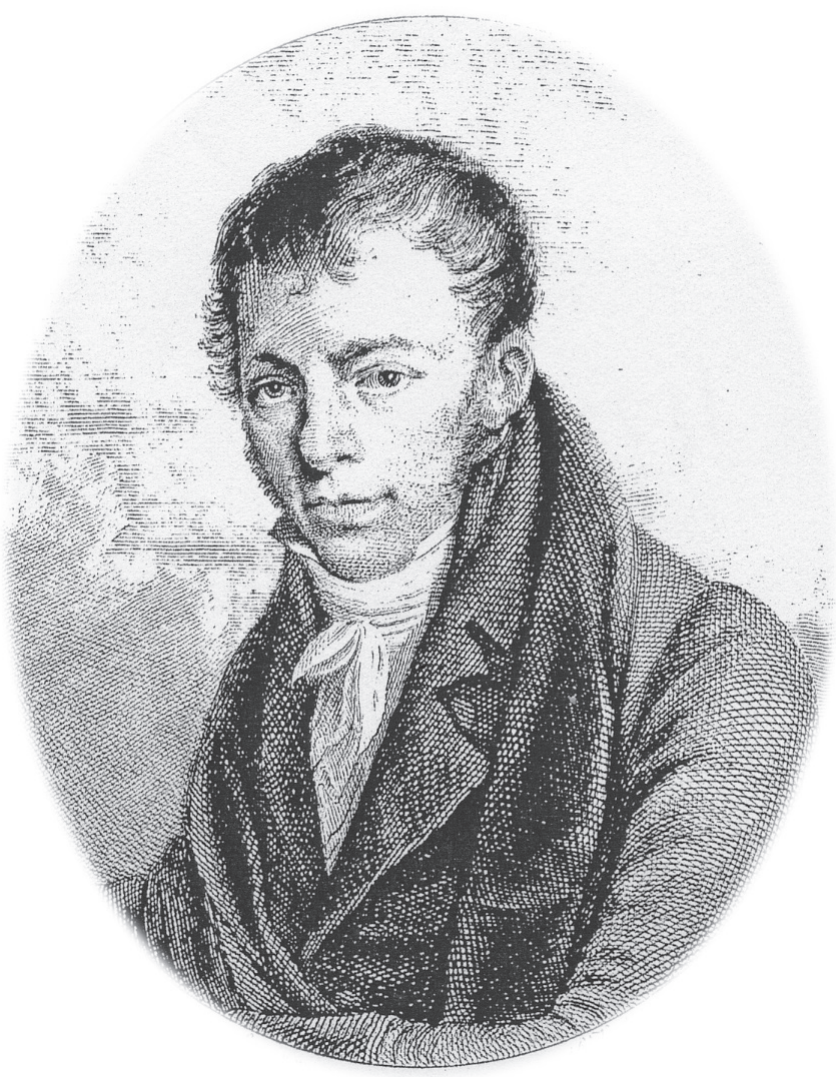

Portret van Caspar Georg Carl Reinwardt, van 1815 tot 1822 Directeur tot de Zaken van Landbouw, Kunsten en Wetenschappen op Java, gravure door R. Vinkeles (collectie RKD/Iconografisch Bureau Den Haag)

Mackenzie op Java had gedaan onder het Engelse bestuur, de uitslag waarvan Reinwardt in het bijzonder moest zien te achterhalen. Zijn eigen onderzoek moest daarbij aansluiten (De Vriese 1858:33-4).

De formulering van het besluit paalde een werkterrein af dat nauw overeenkwam met het terrein waarop het Bataviaasch Genootschap zich bewoog. De nieuwe 'inrigtingen' van 1802 en 1814 omschreven dat immers als volgt: 'Opheldering en uitbreiding der Natuurlijke historie, van talen, oudheden, zeden en gewoonten der Indische volken en andere bijzonderheden deze Landen betreffende'. ${ }^{2}$ Als we het belang van kunsten en wetenschappen 
mogen afleiden uit de vragenlijst die Reinwardt bij zijn aanstelling kreeg voorgelegd en die hem tot nadere richtlijn moest dienen bij zijn werkzaamheden, kunnen we niet anders dan concluderen dat deze een sluitpost vormden. Eerst kwamen in de lijst geografie en demografie aan de orde, vervolgens delfstoffen, planten en dieren, grondstoffen, landbouw, veeteelt, nijverheid en handel en als allerlaatste kunsten en wetenschappen. In die laatste afdeling kwam een vraag voor over het genootschap:

Is het Genootschap van Kunsten en Wetenschappen te Batavia, opgerigt in het jaar 1778, nog in aanwezen, en heeft hetzelve eenigen voortgang gemaakt met het uitgeven van verhandelingen? Zoo ja, dan wenscht men daarvan ten minste vier volledige exemplaren te erlangen (De Vriese 1858:47).

Departementschef van Koophandel en Koloniën, Johannes Goldberg, leek bij zijn vraag geïnspireerd door Dirk van Hogendorp, voor wie in 1799 het genootschap nog slechts in naam bestond. Van wat er sindsdien gebeurd was, van de natuuronderzoekingen van Horsfield tot Raffles' stimulerende arbeid, bleek weinig bekend, al was de naam van Mackenzie wel tot Den Haag doorgedrongen. Waar de taken van Reinwardt zo duidelijk raakten aan het werkterrein van het genootschap, mocht verwacht worden dat de directeur snel contact zou opnemen met de liefhebbers van kunsten en wetenschappen aan de Rijswijkstraat.

De nieuwe directeur, die pas op 16 oktober 1815 met de 'Evertsen' vertrok, het schip waarmee ook commissaris C.Th. Elout naar Indië voer, zal mogelijk in zijn voorbereidingsperiode van negen maanden en anders nog wel tijdens het lange oponthoud aan de Kaap in januari 1816 meer informatie hebben gekregen over het genootschap, zodat hij bij zijn aankomst in Batavia op 27 april 1816 niet meer hoefde te vragen of het nog 'in aanwezen' was. Hij had twee personen mee mogen nemen die hem bij zijn werk in het bijzonder konden helpen en zijn keuze was gevallen op de tekenaar Adriaan Bik en op de Harderwijkse hortulanus Willem Kent. Deze keuze tekent de aandacht die Reinwardt zou gaan besteden aan het onderzoeken en het afbeelden van de natuur en het aanleggen van verzamelingen daaruit. Verder kwamen tegelijk de arts $\mathrm{H}$. Bosscha en de ingenieur C. Alesum uit, voor werk dat met dat van Reinwardt verband hield (Van der Kemp 1918:61).

Commissaris Elouts kenschets van de Bataviase maatschappij in de eerste dagen na de overdracht van het gezag door John Fendall aan de nieuwe gouverneur-generaal, C.A.G.P. baron van der Capellen, geeft zicht op wat Reinwardt in Batavia aantrof op zijn werkterrein: 'Ik heb enkele zeer bekwame

element 'talen' is er in 1814 aan toegevoegd. De nieuwe wetten van 1800 werden in 1802 gedrukt, maar daarvan is geen exemplaar overgeleverd. Citaten dus naar de manuscriptversie uit 1800 in het archief van het genootschap, met als toevoeging de 'talen' van Raffles. 
menschen aangetroffen, maar liefhebberij tot kunsten en wetenschappen is hier maar bij zeer weinigen en de zamenleving verliest daardoor veel.' ${ }^{3}$ Het Genootschap had zo'n vijftien Britse leden, onder hen zeer waardevolle, verloren bij het vertrek van Raffles en Fendall. De laatste had niet eens meer de moeite genomen lid te worden. ${ }^{4}$ Reinwardt en de Commissie-Generaal troffen het genootschap aan onder het voorzitterschap van Ross en met als eerstgenoemden op de ledenlijst J. Siberg, W.V.A. van Riemsdijk, W.H. van Ysseldijk, N. Engelhard en nog elf anderen van de oude garde van vóór 1795.

Het genootschap bood niet direct na de gezagsovername het beschermheerschap aan de nieuwe landvoogd aan. Sinds het overlijden van Lord Minto was die erefunctie vacant. Het zou nog een jaar duren voor Van der Capellen de plaats innam. Wel nam hij in oktober 1816 al het voorzitterschap over van het Javaasch Medewerkend Bijbelgenootschap in een met ceremonieel ingeluide bijeenkomst, gehouden in het lokaal van het Bataviaasch Genootschap. In het zelfde jaar werd hij beschermheer van het nog door Raffles gestichte Javaasch Menschlievend Genootschap, dat de slavenhandel bestreed (Van der Kemp 1918:159-60, 209-14). Het Bijbelgenootschap en het Menschlievend Genootschap hadden beide meer leden dan het Bataviaasch Genootschap. Ook de sociëteit De Harmonie op Rijswijk had meer leden.

Van der Capellen trad dus in de voetsporen van Raffles en het lag voor de hand dat hij dit ook zou doen ten aanzien van het Bataviaasch Genootschap, te meer waar hij in het bestuur van de twee bovengenoemde verenigingen mensen aantrof die ook in het bestuur van het genootschap van kunsten en wetenschappen zaten: Wedding, Van Sevenhoven en Du Puy, Von Lutzow en Engelhard. Wedding nam op 22 oktober 1816 bij het Bataviaasch Genootschap het secretariaat over van Ross, die tijdelijk het voorzitterschap waarnam, en kreeg zo het archief in handen: negen bundels papieren, twee stempels met het embleem van het genootschap, enkele gouden en zilveren medailles, sleutels van het mineralenkabinet en de kas met 632 Spaanse matten. ${ }^{5}$

Philippus Wedding was in 1810 in Batavia aangekomen om er als pastoor onder de katholieken werkzaam te zijn. In 1814 was hij bibliothecaris van het genootschap geworden en in 1815 werd hij door Raffles benoemd tot bewaarder van de Hollandse archieven in het gouvernementskantoor aan het Molenvliet. Onder het herstelde Nederlandse gezag vervulde hij die functie ook nog. Hij was tevens lid van het Bijbelgenootschap, waaruit het open karakter van deze organisatie blijkt: katholiek en protestant naast elkaar. Dat hij bij het genootschap tot een bestuursfunctie werd benoemd

3 In een brief van 28-8-1816 aan Mr D.J. van Lennep te Amsterdam. Geciteerd naar Van der Kemp 1911:118.

$4 \quad$ De naamlijsten van het genootschap staan in Java Directory 1816 en in Almanak 1817.

5 ANRI KBG Dir 1505, nr 17-18, overdracht van het secretariaat op 22-10-1816. 
past in de emancipatie van de katholieken in de kolonie, die onder Daendels was ingezet, en die in het verenigd Koninkrijk een realiteit was met enkele miljoenen katholieken bezuiden de grote rivieren. Toen Wedding in 1816 in de Rijswijkstraat aantrad als secretaris trof hij in de boeken 72 leden aan, van wie er vermoedelijk niet meer dan veertig in Batavia verbleven, en nog eens zes honoraire en corresponderende leden. ${ }^{6}$ Wedding zou op zijn beurt in 1821 het secretariaat weer overdragen. Van zijn activiteiten als secretaris is in het archief zo goed als niets terug te vinden. Hij overleed in 1825 (De Haan 1935b:663; Van der Kemp 1918:199-201).

Het zou tot 1 juli 1817, bijna een jaar na de gezagsovername, duren eer het genootschap tot actie overging. Tijdens de algemene vergadering werd besloten aan Van der Capellen het beschermheerschap aan te bieden, waarna een deputatie hem hiervan op de hoogte stelde. De landvoogd nam het vriendelijk aan. Commissaris Elout kreeg het honorair en corresponderend lidmaatschap aangeboden en nam dat eveneens aan. Het derde commissielid, de marineman A.A. Buijskes, kon wegens uitstedigheid de eer niet in ontvangst nemen. Men denkt onwillekeurig even aan de komst in Batavia van de commissie-generaal in 1793, bestaande uit Nederburg en Frijkenius, beiden direct tot directeur van het genootschap gekozen. Bij het aantreden in 1817 van de nieuwe beschermheer veranderde tegelijk het bestuur: Reinwardt werd voorzitter en Van Sevenhoven vice-voorzitter. Een hele rij nieuw aangekomen ambtenaren werd tot het lidmaatschap verkoren, zeventien personen, onder wie verschillende die later bestuursfuncties zouden gaan bekleden: H.M. de Kock, H.J. van der Graaf, J. Bowier, D. Lenting, P. Merkus en J. van der Vinne. Uit de mededeling in de krant over de vergadering blijkt dat Van der Capellen zelf niet aanwezig was (Bataviasche Courant 5-7-1817).

Reinwardt was ondertussen druk doende met zijn ambtelijke taken. De opbouw van het onderwijs in en buiten Batavia, waarvoor hij enkele onderwijzers uit Nederland kreeg gestuurd, en de reorganisatie van de Geneeskundige Dienst in een militaire en een burgelijke naast een vaccinatiedienst vroegen zijn aandacht (Kerkhoff 1989). In Buitenzorg werd in 1817's Lands Plantentuin gesticht op voorstel van Reinwardt en we mogen aannemen dat hij daar vaak verbleef (Van der Kemp 1914b). Er is wel begrip op te brengen voor het feit dat Reinwardt niet veel tijd had voor het genootschap. Zijn functie was tweeledig. Als directeur was hij verantwoordelijk voor een directoraat in opbouw, een directoraat dat bovendien een ruim werkterrein omvatte. Daarnaast was hij wetenschapper met de uitdrukkelijke opdracht om verzamelingen aan te leggen. Daarin ging zijn energie zitten, terwijl hij veel op reis was. Was hij

6 In tegenstelling tot wat in de achttiende eeuw gebruikelijk was, bleven leden die weggingen van Batavia of uit Nederlands-Indië gewoon lid. Zij kregen geen bijzondere status. 
niet op reis, dan was hij meestal in Buitenzorg, waar Van der Capellen het liefst verbleef (Van der Kemp 1918:55-98; Van der Kemp 1914a:158-61). Het zou mede daardoor tot 1821 duren eer hij zich met het genootschap inliet, althans zo lijkt het, en tot die tijd deed Wedding, de secretaris, wat hij kon. In juli 1817 adverteerde deze in de krant dat deel 8 van de Verhandelingen voor leden beschikbaar was. Hij ontving post van het Koninklijk Instituut, het Zeeuwsch Genootschap en de Groningse universiteit, maar overigens lijkt het erop dat het genootschap weer sluimerde. ${ }^{7}$ Uit niets blijkt dat Reinwardt zich actief met de zaken van het genootschap bemoeide. Intussen bloeide in Batavia het sociaal-culturele leven op. De Bataviasche Courant van 1820 meldt bijeenkomsten van de sociëteiten De Harmonie, De Militaire Eendracht en voorstellingen van het Tooneel Gezelschap en van het Spectacle Français. In dit gezelligheidsleven speelde het Bataviaasch Genootschap geen rol. In de krant van dat jaar wordt het slechts zijdelings vermeld (Bataviasche Courant: januari-februari en 11-11-1820).

Het was Van der Capellen die in 1821 de aanzet gaf tot een serie vergaderingen. Hij stelde belang in het wel en wee van het genootschap, waarvan hij al vier jaar beschermheer was en tot dan toe te weinig activiteiten had opgemerkt. Voor het eerst, voor zover valt na te gaan, bezocht Van der Capellen een algemene vergadering op 21 februari 1821. Sinds 1817 was zo'n vergadering niet meer gehouden. Daags tevoren had het bestuur de vergadering voorbereid en was Ross tot vice-voorzitter gekozen, ter vervanging van Van Sevenhoven die resident was geworden in Palembang. Secretaris Wedding maakte van die vergadering een verslag waarin hij Reinwardts toespraak kort samenvatte. Ter verontschuldiging voor de sluimertoestand van het genootschap sinds 1816, voerde Reinwardt het volgende aan:

Naar de wederbezitneming van deeze Colonie door het vaderlandsch Gouvernement, werden de pogingen om het Genootschap in stand te houden, niet verminderd, dan veelvuldige Politiesche en diplomatische Bezigheden, welke de beste tijd tot wetenschappelijke beöeffeningen wegnamen, en echter naar zulk ene lange afscheiding dezer Colonie van het moederland noodzakelijk [waren], hadden tot dus verre verhinderd, om door het uitgeven van nieuwe Verhandelingen te tonen, dat het Genootschap niet onledig was geweest, en dat dierhalve deeze vergadering belegd was om reeds te voren beraamde middelen tot in stand houding van het Genootschap aan de Vergadering ter goedkeuring voor te leggen. ${ }^{8}$

De 'beraamde middelen' om het genootschap in leven te houden werden niet vermeld, maar we mogen aannemen dat daarbij hoorde het beleggen van

ANRI KBG 1505 bevat enkele losse brieven uit 1817-1819.

ANRI KBG Dir 0022 bevat een verslag van de bestuursvergadering van 20-2-1821 in de hand van Wedding en een verslag van de algemene vergadering van 21-2-1821. 
maandelijkse bijeenkomsten waarop voor de leden lezingen zouden worden gehouden. Het archief bevat een intekenlijst waarop de eenentwintig vergadermaanden in 1821 en 1822 staan vermeld, waarop sprekers zich konden intekenen. Reinwardt was de eerste en zou op 4 april 1821 spreken 'Over de hoogte en verdere Natuurlijke Gesteldheid van enige Bergen in de Preanger Regentschappen', de vrucht van zijn tochten in de buurt van Buitenzorg en Bandoeng en het enige opstel van hem dat in de Verhandelingen is opgenomen. Zelf kon hij niet aanwezig zijn op die dag, terwijl de door hem geleverde tekst met moeite voorgelezen kon worden.

Secretaris Wedding kondigde in de krant vier vergaderingen in 1821 aan: 4 april, 2 mei, 4 en 30 juli (Bataviasche Courant 31-3-1821, 28-4-1821, 30-6-1821, 28-7-1821). We moeten aannemen dat de goede voornemens in deze vier bijeenkomsten zijn blijven steken, want daarna was er pas weer een vergadering op 22 juni 1822, toen de Commissie over de Papieren zich beraadde over wat er moest gebeuren na het vertrek van Reinwardt. Deze was 'stilzwijgend' vertrokken, waaruit we moeten opmaken dat hij geen afscheid had genomen van het genootschap. Dat zegt genoeg over zijn geringe betrokkenheid. Voor het eerst werd er een behoorlijk verslag gemaakt. Dit tekent de overgang van het secretariaat van Wedding naar Jan van der Vinne, een verandering die het genootschap veel goeds zou brengen, want deze fiscaal bij de Raad van Justitie en inspecteur van het onderwijs, zou een beter secretaris blijken te zijn. ${ }^{9}$ P. Maurisse, president van het Hooggerechtshof, volgde Reinwardt op. Vice-voorzitter Ross trok zich met een beroep op zijn hoge leeftijd terug uit het bestuur, dat verder zou bestaan uit: Bowier, J. Ekenholm, Lenting, G. Blom, C.L. Blume en G. Buijskes. Justitia was goed vertegenwoordigd in het nieuwe bestuur: Maurisse en Buijskes van het Hooggerechtshof, Blom en Van der Vinne van de Raad van Justitie, verder Bowier en Blume van de Geneeskundige Dienst. Wedding en Lenting vertegenwoordigden de geestelijkheid. Op de algemene vergadering van 28 augustus 1822 werden de bestuursveranderingen bevestigd. Aftredend vice-voorzitter Ross blikte nog eens terug op de taak van het genootschap in de jaren tot 1816.

Het Bataviaasch Genootschap diende en kon ook niet anders beschouwd worden als een kanaal voor Vaderlandsche en andere Genootschappen, waaruit men opheldering konde erlangen in duisterheden omtrend het wetenschappelijke van deze Oostersche Gewesten. Dat was ook het doel der oprigters. Als op zich zelf staand Genootschap, zoude men altoos dezelfde zwarigheden ontmoeten, welke men gedurig ontmoet had en welke van een in de Colonien opgerigt Genootschap onafscheidelijk waren. De geringe Europeesche bevolking in dezelven, de bezigheden en werkzaamheden, ja, zelfs het doel dergenen, welke zich naar de Colonien

9 ANRI KBG Dir 0022, verslag vergadering 22-6-1822. Het gaat om een kladverslag in de hand van Wedding en een nette versie van Van der Vinne. 
begeven, waren onverzettelijke hinderpaalen voor een op zich zelven staand genootschap in dezelven. ${ }^{10}$

Had Reinwardt in 1821 zich vooral beroepen op drukke bezigheden, die voortvloeiden uit de overname van het bestuur van de Engelsen, Ross had met zijn langere kennis van zaken op fundamentele problemen gewezen. Te weinig Europeanen, te ver afgelegen van het vaderland, dát waren de oorzaken van de stagnatie. Bovendien had hij de functie van het genootschap vooral gezien als een van dienstbaarheid aan genootschappen en verzamelingen in het vaderland.

Reinwardt had bij zijn vertrek nog geregeld dat het genootschap een electriseermachine, een luchtpomp en een standaard el kreeg, niet direct een geweldige uitbreiding van de genootschappelijke verzameling. Hij had tevens de aanzet gegeven tot de instelling van een commissie ter opsporing van op Java verspreide oudheden. Daarin waren de tekenaar A. Bik en de schilder A. Payen benoemd door het gouvernement, dat aan het genootschap vroeg om een derde lid voor te stellen dat meteen voorzitter zou worden. Het bestuur besloot de resident van Pati, D.W. Pinket van Haak, voor te dragen, die daarvoor eerst nog lid van het genootschap moest worden. Het voorstel van Reinwardt van 31 mei 1822 bevatte nog een ander element: in het gebouw van het Bataviaasch Genootschap zou een verzameling oudheidkundige voorwerpen worden bijeengebracht. De commissie, die een inventarisatie zou moeten maken van 'alle de gedenkstukken van Oudheid als Tempels en andere Gebouwen, beelden en verdere Overblijfsels van vroegere kunst, die op Java verspreid zijn', moest zowel voorstellen doen om deze resten tegen 'verder bederf en beschadiging te beveiligen', alsook aangeven welke 'vervoerbare stukken nog geschikt zijn om bewaard te worden en mitsdien zouden verdienen te worden geplaatst in het kabinet van Oudheden in Batavia te vestigen'. ${ }^{11}$ Het genootschap werd door het gouvernement gevraagd in het gebouw de nodige 'schikkingen' te treffen voor het inrichten van zo'n kabinet. Hiermee werd de basis gelegd voor de archeologische verzameling die nu nog een belangrijk onderdeel is van het Nationaal Museum in Jakarta. In 1823 zou het gouvernement de residenten op Java opdragen goed te zorgen voor het bewaken van de Javaanse oudheden en daar de regenten en lagere inheemse hoofden verantwoordelijk voor te stellen (Notulen 13:bijlage A).

Reinwardts oproep tot het inventariseren, beveiligen en naar Batavia vervoeren van verplaatsbare oudheden kwam te laat voor de collectie oudheden die

10 ANRI KBG Dir 1508, algemene vergadering 28-8-1822, klad van Wedding en nette versie van Lenting.

11 ANRI KBG 0022 bevat een extract van Gouvernementsbesluit 11-6-1822 nr 3 bij het verslag vergadering 22-6-1822. 
onder zijn toezicht reeds naar Nederland was verscheept. Daaronder waren de beelden van Singosari, die N. Engelhard aan het begin van de eeuw had laten weghalen van hun oorspronkelijke plaats in de Oost-Javaanse tempels en naar zijn gouverneurshuis in Semarang had laten vervoeren. Die collectie kwam zo in het Rijksmuseum van Oudheden in Leiden terecht, later in het Rijksmuseum voor Volkenkunde in dezelfde stad. In het kader van de tentoonstelling 'Shared Heritage' waren vijf van de 'Leidse' beelden in 2005 in Jakarta te zien, voor het eerst sinds bijna tweehonderd jaar terug in het land van herkomst.

Zo liet Reinwardt op de valreep nog iets na aan het genootschap: een nieuwe taak in het beheer van een door een gouvernementscommissie vast te stellen collectie verspreide oudheidkundige voorwerpen. Voor het overige echter waren zijn bijdragen tot het in stand houden van het genootschap minimaal. Eén algemene vergadering voorgezeten, voor één vergadering in 1821 een voordracht ingeleverd en deze afgestaan voor de Verhandelingen. Uit niets blijkt dat van zijn verzamelactiviteiten door het genootschap werd geprofiteerd. Wél door de Leidse en de eigen Amsterdamse verzamelingen, terwijl vier voor het vaderland bestemde zendingen door schipbreuk op de oceaanbodem belandden. Toen hij naar Leiden vertrok, waar hij hoogleraar werd, heeft hij daar nog in zijn onderwijs kunnen profiteren van het feit dat hij zich een ijverig verzamelaar had betoond. Het beredeneerde verslag over 'zeden, taal en denkwijze, der inwoonderen' aan de regering, dat hem bij zijn aanstelling in 1815 was opgedragen en waarmee men had gehoopt de achterstand op de Britten terug te winnen, is er niet gekomen. Vandaar dat menigeen teleurgesteld was over de uitkomst van Reinwardts uitzending. Voor het genootschap gold dat zeker. ${ }^{12}$ Dat Reinwardt 'zoovele zorgen had gewijd' aan het genootschap, zoals Veth in zijn biografische schets zegt, daarvan blijkt weinig. Die zorgen hebben althans in het genootschapsarchief geen sporen nagelaten (Veth 1884a:120). Dezelfde Veth spreekt over de periode van 1816 tot 1821 als een van 'gedwongen rust', veroorzaakt door Reinwardts andere bezigheden. Daarmee kwam hij dichter bij de waarheid.

\section{Persoonlijkheden: Van der Vinne}

De 'gedwongen rust' of de 'geleerde Sluimer' die de jaren 1816-1822 kenmerkte, schoot Van de Capellen in het begin van 1823 in het verkeerde keelgat. ${ }^{13} \mathrm{Na}$ de algemene vergadering van augustus 1822 had de aftredende secretaris

12 De Vriese 1858, inleiding tot Reinwardt, Reis naar het Oostelijk gedeelte van den Indischen Archipel leest als een apologie voor de teleurstellende resultaten. Over deze kwestie ook Van der Kemp 1918:86-9.

13 De laatste woorden zijn van het lid J.E. van Doornik uit een brief aan het genootschap van 23-8-1823. ANRI KBG Dir 0027, vergadering 4-9-1823. 
Wedding in een brief verslag gedaan aan de landvoogd, waarin hij begon met de situatie te schetsen als een van 'verval en werkeloosheid'. Het genootschap zou moeten worden teruggebracht 'op die voet welke het was voor de komst der Engelschen op dit Eiland'. ${ }^{14}$ Van der Capellen bleek in zijn antwoord na terugkomst van zijn reis over Java in december 1822 tamelijk pessimistisch. De gedachte was in hem opgekomen dat het genootschap 'liever gansch mogt worden ontbonden, dan het langer geheel werkeloos te zien voortkwijnen.' ${ }^{15}$ Hij liet vervolgens zijn secretaris J. Schneither op 27 januari 1823 een brief schrijven aan secretaris Van der Vinne om te informeren, wat de nieuwe directie had gedaan om het genootschap te verlevendigen. Met de nieuwe directie bedoelde hij de groep die na het vertrek van Reinwardt was aangetreden onder leiding van Maurisse en Van der Vinne zelf. Als die nog niets hadden ondernomen om die verlevendiging te bereiken, 'verlangt Z.Ex. daarvan de redenen te kennen om te weten of van Hare Zijde daartoe iets kan worden bijgebracht, dan wel te kunnen beslissen of het niet doelmatiger zal zijn de Suppressie van een zoo geheel onvruchtbaar genootschap te bewerken.' ${ }^{16}$ Voor het eerst was de opheffing van het genootschap ter sprake gebracht.

Secretaris Van der Vinne werd persoonlijk door de landvoogd aangesproken op zijn verantwoordelijkheid om het genootschap tot meer werkzaamheden aan te sporen, en hem werd verteld dat verschillende leden, onder wie Reinwardts opvolger in Buitenzorg, Blume, bereid zouden zijn daaraan mee te werken. Van der Capellen gaf als zijn mening te kennen dat, mocht het nieuwe bestuur niet in staat zijn het genootschap tot meer actie aan te zetten,

het verkieselijker zou zijn geweest alles in statusquo te hebben gelaten, dan aanleiding te geven tot verwachtingen die het voor de beminnaars der wetenschappen, en voor de opregte vereerders van dit vroeger zoo bloeijend gesticht smartelijk moet vallen, zoo spoedig weder onvervuld te zien vervallen en verdwijnen. ${ }^{17}$

Van der Vinne antwoordde per kerende post. Hij moest tot zijn leedwezen melden dat er door het nieuwe bestuur, dat vier maanden in functie was, nog niets was verricht en wees direct een schuldige aan:

Die stagnatie is aan niemand te wijten dan aan den heer afgetreden Secretaris Wedding. Zoo wel de heer President Maurisse als ik zelven hebben ettelijke malen bij welmelden heer Wedding aangedrongen op de overgave der boekwerken, papieren, penningen enz., behorende tot het Secretariaat en de administratie van

14 Conceptbrief zonder datum, maar blijkens het erbij gevoegde antwoord van Van der Capellen te dateren op 14-9-1822. Het concept is in de hand van Wedding. ANRI KBG Dir 1508 nr 3.

15 ANRI KBG Dir 1508, nr 4, brief van Van der Capellen van 12-12-1822.

16 ANRI KBG Dir 0982, nr 3, J. Schneither aan J. van der Vinne.

17 ANRI KBG Dir 0982. 
het Genootschap, en zonder de welke het onmogelijk was de werkzaamheden voorttezetten. ${ }^{18}$

Zo had het bestuur in 'een schandelijke ledigheid' verkeerd, terwijl ieders verwachtingen 'stijf gespannen waren op de verrigtingen der nieuwe Directie'. Van der Vinne zei dat het hem leed zou doen als het genootschap onder zijn secretariaat zou worden opgeheven en ging in op het aanbod van zijn hoogste baas om hulp te bieden: een brief van de landvoogd aan Wedding met als opdracht dat deze binnen drie dagen het secretariaat moest overdragen, kon voor een doorbraak zorgen. Kennelijk is dat gebeurd, hoewel in het archief niets van zo'n overdracht van Wedding aan Van der Vinne getuigt. Wedding had wel op 1 september 1822 aan Van der Vinne geschreven dat ingevolge het vier dagen eerder door de algemene vergadering genomen besluit het secretariaat naar Van der Vinne over was gegaan, maar kennelijk geen verdere stappen ondernomen. ${ }^{19}$ Van der Vinne begon nu zijn stipte archivering met deze brief, waarna we vanaf 1823 over veel materiaal beschikken. Dit staat in schril contrast met de magere archiefoogst over de jaren 1816-1822.

Men vraagt zich af waarom Van der Capellen pas in 1823 tot deze ingreep besloot. Waarom niet eerder, tijdens het bestuur van Reinwardt en Wedding, toen het genootschap al onder zijn bescherming stond? Lezen we in de brief van Schneither de irritatie van de landvoogd over het uitblijven van activiteiten onder het duo Maurisse - Van der Vinne, waarom hadden Reinwardt en Wedding niet in gelijke mate irritatie opgewekt? Was het begrijpelijk in het geval van Reinwardt omdat deze ambtelijke met wetenschappelijke taken moest combineren? Had hij teveel respect voor Wedding, die hij uit andere genootschappen kende? Of was Van der Capellen misschien uit Holland op het idee gebracht dat de maat van werkeloosheid vol was? Hoe dan ook: onder de nieuwe voorzitter en met een energieke secretaris bleek te kunnen wat ruim zes jaar niet was gebeurd.

Het genootschap begon een nieuw leven. Er werd vanaf mei 1823 in dat jaar nog negen keer vergaderd door het bestuur. Van der Vinne liet via de krant aan de leden weten dat zij vanaf 1 januari 1822 contributie verschuldigd waren en dat hij op grond van het beslotene in een algemene vergadering van 28 augustus 1822 geautoriseerd was om die te innen (Bataviasche Courant 21-6-1823). In augustus bleek dat het lid J.E. van Doornik had geweigerd aan deze oproep te voldoen, omdat hij in de veronderstelling verkeerde dat hij honorair lid was. Op 23 augustus 1823 gaf hij toch toe, maar kon niet nalaten te refereren aan de periode van nietsdoen:

18 ANRI KBG Dir 0982, nr 4, J. van der Vinne aan de gouverneur-generaal.

19 ANRI KBG Dir 0982, nr 1, brief van P. Wedding aan J. van der Vinne, 1-9-1822. 
Voorts wensche ik dat het Bataviaasch Genootschap van K. \& W. het welk zedert bijna Zeven Jaren in een geleerden Sluimer heeft verkeert na een zoo langen rust met verjongde krachten zal ontwaken en voortbrengselen van geleerdheid en van gekuischten Smaak zal opleveren welke de republiek der Letteren, gedurende al dien tijd, met even zoo veel geduld als regtmatige aanspraak is wagtende geweest, terwijl dezelven daarbij steeds het oog gevestigd hield op het geen de Engelsche Geleerden te Calcutta gedurende dien tijd de geleerde wereld hebben mede gedeeld. $^{20}$

Van Doorniks wens kwam uit: in hetzelfde jaar nog verscheen het negende deel van de Verhandelingen, er werd een apart Programma gedrukt en de algemene vergadering vond plaats op 7 oktober 1823. De gouverneur-generaal drukte zijn tevredenheid uit door een tienvoudige contributie te betalen. Deze verdiensten zijn voornamelijk op het conto van de nieuwe secretaris te schrijven.

Jan van der Vinne (geb. Amsterdam 1793) was een van de ambtenaren die in september 1816 met de 'Nassau' in Batavia aankwamen om het werk van de Commissie-Generaal te ondersteunen. Hij was opgeleid als ingenieur en wilde in dat vak in Indië werkzaam zijn. Het tekent hem dat hij had verzocht een kist boeken op de 'Nassau' te mogen inschepen. Hij werd in 1817 secretaris bij de directie Landbouw, Kunsten en Wetenschappen en werkte aldus voor Reinwardt (Van der Kemp 1918:73-5). Daarnaast werd hij inspecteur van het onderwijs. Toen hij in 1822 secretaris van het genootschap werd, was hij fiscaal bij de Raad van Justitie. Van der Vinne werd later directeur der Middelen en Domeinen en eindigde als directeur van Financiën in de jaren 1840. Bij het genootschap bracht hij het tot vice-voorzitter. Pieter Simon Maurisse was in 1816 eveneens met de 'Nassau' aangekomen voor zijn tweede verblijf in Indië. Aan zijn eerste verblijf was een einde gekomen na een botsing met Daendels. Hij werd in 1816 benoemd tot president van het Indisch Hooggerechtshof, maar behoorde niet tot de personen die in 1817 lid werden van het genootschap, terwijl andere nieuw aangekomen ambtenaren dat wel werden. Hij is vermoedelijk in een van de vergaderingen van 1821 lid geworden en werd in 1822, na Reinwardts vertrek, door waarnemend voorzitter Ross voor het voorzitterschap gepolst, waartoe hij tijdens de algemene vergadering van 28 augustus 1822 werd gekozen. ${ }^{21} \mathrm{Hij}$ bleef voorzitter tot 1828 , toen zijn gezondheid hem tot aftreden dwong.

In het duo Maurisse-Van der Vinne lijkt toch vooral Van der Vinne de stuwende kracht te zijn geweest. In zijn lange loopbaan in het genootschap, die

\footnotetext{
20 ANRI KBG Dir 0027, vergadering 4-9-1823, brief van J.E. van Doornik, Kedang 23 augustus 1823.

21 Zie over Maurisse terloops bij Van der Kemp 1911:149. Maurisse komt niet voor op eerdere ledenlijsten. Van de vergaderingen in 1821-1822 zijn slechts enkele verslagen overgeleverd. Daarin komt zijn naam niet voor.
} 
na een onderbreking wegens verblijf in patria weer werd opgenomen, wordt zichtbaar dat hij zich voor het genootschap zeer inspande. De uitvoerige correspondentie en de gedetailleerde notulen van bestuursvergaderingen bewijzen dat hij zijn taak als secretaris serieus nam. Maurisse en Van der Vinne zouden vanaf 1823 aan het genootschap 'op het voetspoor der Vaderlandsche Genootschappen' leiding geven. De voorbereidingen tot de eerste algemene vergadering en de publicaties van dat jaar geven een goed zicht op wat zij daarmee op het oog hadden. ${ }^{22}$

Voor de structuur van het genootschap, de doelstellingen en de uitwerking daarvan was een vernieuwd reglement nodig, de Nieuwe Wetten (1823). Het bestuur greep daarvoor terug op het reglement van 1778 onder verwijzing naar de veranderingen die daarin waren aangebracht in 1802. Nadrukkelijk werd niet te veel verwezen naar de veranderingen uit de periode-Raffles. Daarvan werd al in 1822 opgemerkt, dat die 'op eene te hooge schaal waren gemeten' zonder dat uit de notulen blijkt in welk opzicht de Britten waren doorgeschoten. ${ }^{23}$ Expliciet werd ook door het bestuur van 1823 gesproken over een terugkeer naar de 'oude instellingen van 24 April 1778 [en werd besloten deze tot] hoofdgrond-slag der doeleinden van het Genootschap aantenemen'. ${ }^{24}$ Het maar ten dele overnemen van de wijzigingen van 1802 en het totaal voorbijgaan aan de nieuwe reglementen van 1814, betekende in feite een restauratie. Een belangrijke rol werd weggelegd voor het bestuur, een ontwikkeling die al door het bestuur van 1802 was ingezet. Wel behielden de nieuwe bestuursleden het instituut van de algemene vergadering, die allerlei zaken, door het bestuur voorgesteld of al afgehandeld, moest fiatteren. Het democratische, open karakter van 1802, met voorbijgaan aan rang en stand, werd weer ongedaan gemaakt. Het was niet in de geest van de tijd, en ook niet in de geest van de beschermheer, Van der Capellen, om die democratische golf te handhaven. Een nadere blik op deze reglementswijzigingen en de consequenties ervan vraagt om de volgende uitweiding.

\section{De nieuwe wetten van 1823}

Voor een juist begrip van de betekenis van de reglementswijzing van 1823 kijken we eerst naar de oorspronkelijke reglementen van 1778, waarop het bestuur van Maurisse en Van der Vinne zei terug te grijpen. De tussen die

\footnotetext{
22 ANRI KBG Dir 0023, vergadering 28-5-1823 onder Maurisse.

23 ANRI KBG Dir 0022, vergadering 22-6-1821, punt 4, de eerste vergadering na het vertrek van Reinwardt.

24 ANRI KBG 0023, vergadering 28-5-1823, p. 19 punt 16. Het is de eerste vergadering na de algemene vergadering van 28-8-1822.
} 
twee jaren gelegen wijzigingen van de wetten kunnen we daarbij niet negeren. Het gaat zodoende om vijf reeksen van artikelen die de basis vormen van het genootschapsleven:

1778 eenentwintig artikelen, verschenen in het Programma van dat jaar ${ }^{25}$

1791 zestien artikelen, verschenen als Grond-wetten ${ }^{26}$

1802 zeventien artikelen, aangeduid als 'Nieuwe Inrigting' 27

1814 zestien artikelen, verschenen als Nieuwe Inrigtingen / New Regulations ${ }^{28}$

1823 vijfenveertig artikelen, verschenen als Nieuwe Wetten ${ }^{29}$

Bij het beoordelen van deze vijf pogingen tot regulering van het genootschap kijken wij in het bijzonder naar de volgende onderwerpen:

1 de relatie tot de overheid

2 de doelstellingen

3 de toegang tot het lidmaatschap; de contributie

4 de positie van het bestuur

5 de prijsvragen

6 het museum en de bibliotheek

7 de plaats van de algemene vergadering

\section{De relatie tot de overheid}

Dirk van Hogendorp oordeelde in 1799 dat het genootschap zich in 1778 geheel en al had uitgeleverd aan de Hoge Regering in Batavia en hij sprak in dit verband van een 'slaafsche stap'. Inderdaad was bij de aanhef (artikel 1) van wat veelzeggend 'verplichtingen' werden genoemd, al vastgesteld dat het genootschap bestond uit de gouverneur-generaal, de leden van de Hoge Regering en daarna pas uit leden. Herhaaldelijk waren beperkingen ingebouwd: de 'gunstige Concessie van Zyn Hoog Edelheid' maakte vergadering

25 Programma 1778, geciteerd naar het enig mij bekende exemplaar (OIOC, India Office Library Records T 39068). De tekst ook in VBG 1 (1779). Opsteller van de tekst was vermoedelijk Radermacher zelf.

26 Grond-wetten 1791, geciteerd naar het enig mij bekende exemplaar (Perpusnas B 32/1a). Tekst niet verschenen in VBG. Wel bij Der Kinderen 1878 bijlage D. Opsteller van de tekst was vermoedelijk Ross.

27 ANRI KBG Dir 0020, p.338-42, hier geciteerd naar het manuscript in de notulen van het Bataviasch Genootschap. In 1802 gedrukt in een onbekende oplage. Secretaris Ross liet op 7-121802 enkele exemplaren van de Nieuwe Inrigting aan zijn collega's-bestuursleden zien (Dir 0020, p. 353). Tekst ook bij Der Kinderen 1878, bijlage E. Opstellers van de tekst: J. Schill, W.M. Döckers en Ross.

28 Hier geciteerd naar de VBG 7 (1814), VIII-XII. Opstellers van de tekst: Ross en Dupuy.

29 VBG 9: 55-74. Opstellers Maurisse en Van der Vinne. Ze ook Wetten 1823. 
in het Kasteel mogelijk (artikel 4), de uitsluiting van genootschapsactiviteiten waar die op het terrein van de compagnie zouden kunnen komen (artikel 5), de voorrang van de Hoge Regering en de Heren Zeventien bij het vaststellen van onderwerpen voor prijsvragen (artikel 7).

In vergelijking met hun voorgangers koos het bestuur in 1791 voor een minder strak regime. Wel werden de gouverneur-generaal en de raden van Indië als opper-directeur en directeuren gehandhaafd (artikel 2), maar niet dan nadat eerst was vastgesteld, dat het genootschap uit leden zou worden gevormd en wie die leden waren. Vergaderen bleef men eens per jaar in het Kasteel - 'naa verkreegen vergunning van Zyne Hoog-Edelheid' (artikel 6) - en het genootschap zou zich buiten alles houden wat met de Compagnie te maken had, terwijl de Hoge Regering en de Heren Zeventien nog steeds voorrang hadden bij het bepalen van prijsvragen (artikel 11).

Pas de revolutionairen van 1802 zetten een radicale stap. Het instituut van opper-directeur en directeuren werd afgeschaft. De Hoge Regering moest zich tevreden stellen met het weinig verplichtende 'onder de bijzondere bescherming en begunstiging van de Hooge Regeering dezer Landen' (artikel 2). Geen rol dan die van beschermer, geen voorrechten. Het enige was dat de gouverneur-generaal eens per jaar een delegatie van drie bestuursleden mocht verwachten 'om hunnen pligtplegingen afteleggen'.

Onder Raffles was deze formulering aangehouden, 'onder de bijzondere bescherming van het Britsche Gouvernement' (artkel 1), maar hieraan leek het genootschap eerder hulp en rechten te kunnen ontlenen. Wel was Lord Minto beschermheer en Raffles voorzitter, maar zij waren in vergelijking tot hun voorgangers van vóór 1795 van een verlichter soort, hoewel zij daardoor wel bevestigden wie op Java de baas waren.

Van der Vinne en de zijnen kozen er in 1823 voor om de relatie tot de gouverneur-generaal en de Raad van Indië helemaal niet in de nieuwe wetten op te nemen. Het genootschap kreeg wel hulp van de regering, terwijl Van der Capellen als beschermheer optrad, maar het legde zich in de wetten daarop niet vast. Het beschermheerschap werd niet in de reglementen genoemd en men komt geen enkele verwijzing naar de overheid tegen. Daarmee had het genootschap zich in 1823 formeel losgemaakt van de regering, al zou het voor subsidies van de regering afhankelijk blijven.

De nieuwe wetten van 1823 sloten aldus voor wat betreft de relatie met de overheid eerder aan bij de nieuwe inrichting van 1802 dan bij de oorspronkelijke wetten van 1778 .

\section{De doelstellingen}

De 'verplichtingen' van 1778 gaven - na de uitsluiting van alles wat de OostIndische Compagnie ook maar enigszins zou kunnen aangaan - achtereen- 
volgens als doelstellingen op:

- het bevorderen van alle kunsten en wetenschappen;

- (het bevorderen van) al wat de natuurlijke historie, oudheden, zeden en gewoonten der volken aangaat (zonder expliciete geografische beperking);

- (het bevorderen van) landbouw, koophandel en bijzondere welvaart van de volksplanting als een voornaam doelwit (artikel 5).

Verder zou het graag alle berichten ontvangen over volken, talen, zeden, oudheden en geschiedenissen van deze gewesten (artikel 18). Zo werd het encyclopedische eerste element en het dubbelzinnig geformuleerde tweede element in het vervolg ingeperkt tot 'deeze volkplanting' en 'deeze gewesten'.

De grondwetten van 1791 beperkten de bevordering van 'allerlei kunsten en wetenschappen' direct door aan te geven dat het 'greetig' zou ontvangen datgene 'waar toe de ligging en gesteldheid des lands niet ongunstig is',

- (in het bijzonder) alles wat betrekking heeft op de natuurlijke historie, oudheden, zeden en gewoonten der Indische volken;

- hoofdvoorwerp van onderzoek zou zijn de landbouw, koophandel en de welvaart van de volkplanting (artikel 10).

Hoewel de elementen overeenkomen, waren de doelstellingen van 1791 toch minder omvattend, meer op de regio toegespitst, terwijl de formulering van de praktische doelstelling (landbouw, koophandel) minder dwingend was.

De revolutionairen van 1802 schrapten de 'koophandel' geheel en al uit de doelstellingen. Daar wilden ze na de liquidatie van de VOC kennelijk niet mee van doen hebben. 'Het Algemeen nut is de bedoeling van het Genootschap in den bepaalden Kring zijner inzichten en bemoeienissen' (artikel 8), zo luidde de nogal vage formulering. Voor het overige sloot men bij de grondwetten van 1791 aan.

- Opheldering en uitbreiding der natuurlijke historie, van oudheden, zeden en gewoonten der Indische volken; en

- de bevordering van de landbouw en andere aangelegenheden met betrekking tot de welvaart van de volkplanting (artikel 8), perkten het algemene nut daarna in.

In 1814 namen de Britten de formulering letterlijk over, met toevoeging alleen van taalstudie. Zo was de praktische doelstelling (landbouw, koophandel) minder dwingend geformuleerd, terwijl een inperking zichtbaar werd van 'alle kunsten en wetenschappen' en 'alle volken' (1778) naar wat op uitsluitend op Indië betrekking had.

In 1823 werd een omslachtige nieuwe formulering gekozen waar echter de bekende elementen weer in zaten, aangevuld met enkele verlichte doelstellingen:

- bevordering en verspreiding van kunsten en wetenschappen; 
- voortplanting en uitbreiding van beschaving en verlichting in NederlandsIndië;

- beperking tot de natuurlijke historie van deze gewesten, oudheden, talen, zeden, gewoonten en geschiedenissen der Indische volkeren;

- alle andere statistische, geografische en wetenschappelijke aangelegenheden (artikel 2);

- bevordering, verbetering en aanmoediging van den landbouw, landhuishoudkunde, volksvlijt, 'fabrieken', nuttige handwerken en andere takken van nijverheid, die in verband stonden met de welvaart en de beschaving van de kolonie (artikel 3).

Wat opvalt is, dat de doelstelling van het genootschap na vijfenveertig jaar in hoofdlijnen weer terug was bij het oprichtingsjaar. Zelfs in de (iets uitgebreider) formulering van 1823 komt men de meeste elementen uit 1778 tegen. Het tweeledige 'verzamelen van gegevens over' en 'bevorderen van landbouw,' was behouden. Wel was de geografische beperking, in 1778 nog weinig precies, in 1823 nauwkeurig aangebracht. Verder was de koophandel uit de doelstellingen verdwenen, maar het genootschap had daarvoor in de plaats een expliciet beschavingsdoel geformuleerd.

\section{De toegang tot het lidmaatschap, de contributie}

In 1778 had het genootschap opengestaan voor 'de aanzienelykste, kundigste en welgezindste Ingezetenen' uit alle bezittingen van de compagnie (artikel 1), die zouden worden opgesomd in een ledenlijst volgens 'den rang, dien zy by de maatschappye bekleeden' (artikel 20). Daarmee was een dubbele inperking gemaakt: rang én stand.

In 1791 waren de termen gelijk gebleven: aanzienlijk, kundig en welgezind als criterium voor het lidmaatschap. De volgens rang opgestelde ledenlijst werd niet meer vermeld. De radicalen van 1802 braken met het verleden. Leden konden worden: 'de kundigste en geschiktste Lieden te dezer Hoofdplaats zonder eenige aanmerking van staat of rang' (artikel 1).

Was in 1778 de contributie vastgesteld op vier ducaten of elf rijksdaalders (artikel 12) en in 1791 op dat bedrag gehandhaafd (artikel 16), in 1802 had men de contributie vrijgelaten. Men mocht bijdragen naar vermogen (artikel 14). Niemand hoefde zich buitengesloten te voelen door de hoogte van het 'fournissement'.

De Britten herstelden op milde wijze de ballotage, maar wel in de geest van het genootschap in Calcutta: 'bekende braafheid en eene zucht tot uitbreiding der Wetenschappen zal een genoegzaam vereiste zyn om als lid te worden aangenomen' (artikel 3). Er werd aan toegevoegd dat niemand lid zou worden die niet eerst zou hebben laten merken daar prijs op te stellen (artikel 4). Daarmee wilde men breken met het verleden: in Radermachers 
tijd was de hele top van de compagniesambtenarij in de Indische bezittingen gestimuleerd om lid te worden, of liever gezegd tot lid gemaakt, waarbij niet belangstelling voor wetenschap telde, maar wel het groepsgevoel onder Europeanen in Indië. De Britten stelden een entreegeld in naast de heringestelde contributie: tien Spaanse matten bij de aanvang van het lidmaatschap en verder elk jaar nog eens tien.

Van der Vinne en de zijnen sloten in 1823 aan bij de formulering van de Britten: 'Braafheid, verdiensten, kundigheden of zucht tot beoefening en aankweeking van kunsten en wetenschappen zullen de hoofdvereischten zijn' (artikel 10), waarbij 'braafheid' en 'zucht' tot beoefening van de wetenschap van de Britten kwam, terwijl 'kundigheid' al in 1778 in de omschrijving voorkwam. Ook de formulering uit 1814 over de instemming die ieder nieuw lid moest geven met zijn uitverkiezing werd behouden. De contributie werd gesteld op veertig gulden per jaar en een entreegeld op tweeëntwintig gulden.

Er zijn enkele opvallende elementen: in 1778 ging het om aanzienlijke compagniesdienaren en speelde belangstelling voor de wetenschap een ondergeschikte rol. Een positie in de Compagnie was voldoende om lid te kunnen worden. Pressie van bovenaf speelde zeker een rol. Bovendien zorgde de hoge contributie voor uitsluiting van de lagere ambtenaren. In 1802 brak men radicaal met dit standselement en werd de contributie vrijgemaakt. Bovendien werd belangstelling voor de wetenschap een voorwaarde voor het lidmaatschap. De Britten legden evenzeer expliciet het verband met belangstelling voor wetenschap, maar brachten wel weer een drempel aan door de hoogte van de contributie vast te stellen. In 1823 werd dat overgenomen en zelfs nog verhoogd, waardoor rang (en ermee samenhangend inkomen) een rol bleef spelen. Statusgevoel zal bij het aannemen van het lidmaatschap een rol zijn blijven spelen.

Intussen was het nog maar de vraag of de leden echt vrij waren om te weigeren. Met Raffles als voorzitter en Van der Capellen als beschermheer was er wel degelijk een element van 'erbij horen'. Toch zien we aan een persoon als Maurisse, dat deze zich niet meteen in 1817 als lid liet registreren.

\section{De positie van het bestuur}

In 1778 werd de band met de Hoge Regering uitgedrukt door de samenstelling van het bestuur: de voorzitter moest een van de directeuren zijn en dus een lid van de Hoge Regering. De andere bestuursleden mochten uit de leden komen. De voorzitter heette 'directeur' en aan hem moesten alle berichten worden geadresseerd, terwijl er onder de dirigerende leden (de term die voor het bestuur werd gekozen) wel een secretaris was (artikel 19). De voorzitter (oprichter Radermacher) kon aldus de hele gang van zaken bepalen. Taak van het bestuur was: het voorbereiden van de algemene vergaderingen, het beoor- 
delen van binnengekomen verhandelingen en gedane proeven (artikel 3) .

In 1791 werd een ruimere omschrijving gegeven aan de functie van de zogenaamde dirigerende leden: 'het gewoon bestier der zaaken, beoordeeling van ingekomen verhandelingen en berigten, onderzoek van gedaane proeven, en alle verder daaglyksche beschikking over 's Genootschaps belangen zal staan aan eene vergadering van Dirigeerende Leden'. Voorzitter zou nog wel een lid van de Hoge Regering moeten zijn, maar zijn positie was minder prominent.

De radicalen van 1802 zetten de gouverneur-generaal en de Raad van Indië aan de kant, al was die daad minder revolutionair dan ze lijkt, als we bedenken dat de Compagnie opgehouden had te bestaan. In Batavia was nog niet duidelijk op welke wijze de regering in Den Haag de machtspositie van de nieuwe Indische regering zou gaan invullen. De vergadering van de dirigerende leden (zo bleef het bestuur heten) regelde alles: verkiezing van leden, aanschaf van benodigdheden, het doen van 'navorschingen en opgaaven', het beoordelen en uitgeven van verhandelingen, 'en alle verdere beschikking over 's Genootschaps belangen' (artikel 3). De bestuursleden zouden zichzelf aanvullen en bovendien zou het voorzitterschap per maand rouleren. Zij zouden wel maandelijks vergaderen, behalve als de noodzaak ertoe ontbrak, terwijl de algemene vergadering in feite werd afgeschaft. Het is duidelijk dat dit bestuur de band met de regering doorsneed, maar het deed het in feite ook met de leden, met wie geen geregeld, tenminste jaarlijks contact meer hoefde voor te komen.

De nieuwe inrichting onder het Britse gezag voorzag wel in bestuursfuncties, maar het college had geen naam (bestuur, dirigerende leden). In artikel 13 wordt aangegeven dat uit het midden van het genootschap een president, vicepresident en twee secretarissen zouden worden gekozen, terwijl er een commissie voor de beoordeling van binnengekomen stukken en verhandelingen zou zijn en een commissie voor het toezicht op bibliotheek en kabinet. De taak van dit vierhoofdige bestuur (vroeger waren het er elf, tien of negen geweest) werd niet nader omschreven, waardoor de president en zijn vice-president en secretarissen in feite de vrije hand hadden in een heleboel zaken.

De nieuwe wetten van 1823 vertrouwden het 'geheele bestuur der zaken van het genootschap' opnieuw toe aan een negenkoppig bestuur, zoals die van 1802 hadden gedaan. De voorzitter was een van de bestuursleden, maar er werden aan hem geen voorwaarden gesteld. Opvullen van vacatures mocht door het bestuur gebeuren, onder goedkeuring van de algemene vergadering. Bestuursleden waren verplicht de vergaderingen bij te wonen op straffe van een boete van vijf gulden. Van der Vinne hield niet van absenteïsme. Op die vergaderingen zouden zij de correspondentie afhandelen, huishoudelijke zaken regelen, commissies voor de bibliotheek, het museum en voor het doen van proeven benoemen en alles voorbereiden voor de algemene vergaderingen. 
De bestuursstructuur had in 1823 elementen overgenomen uit verschillende voorgaande regelingen. $\mathrm{Zij}$ sloot niet bij 1778 aan in zoverre het bestuur toen een hoger orgaan boven zich had, de opperdirectie. In feite sloot de regeling van 1823 een ontwikkeling af die in 1791 was begonnen (de 'opper-directie' was minder prominent aanwezig), in 1800 radicaal was doorgeslagen (het bestuur was het genootschap) en in 1814 (zonder de naam van het bestuur) was blijven bestaan. De algemene vergadering als controlerende en instemmende instantie was echter weer ingesteld, waarmee werd aangesloten bij de oprichtingssituatie van 1778.

\section{Prijsvragen}

Het uitschrijven van prijsvragen was voor de oprichters van het genootschap een van de belangrijkste aspecten van het genootschapsleven geweest. Zij hadden daar in 1778 tien van de eenentwintig 'verplichtingen' aan gewijd. Zij hadden ervoor naar de belangrijkste Nederlandse genootschappen gekeken en regels opgesteld die op de hunne leken. Tot in details werd alles beregeld. In het eerste programma werden meteen zesenveertig vragen geformuleerd terwijl er nog plaats was voor andere prijsvragen, die door de drie vaderlandse 'maatschappijen' op kosten van Batavia konden worden uitgeschreven. Het genootschap was in veel opzichten van start gegaan als een prijsvragen-genootschap.

De grondwetten van 1791 wijzigden daar nogal wat in. Slechts drie van de zeventien artikelen gingen over prijsvragen. Voor prijsvragen uitbesteed aan de vaderlandse genootschappen, was geen plaats meer. Bijna verontschuldigend begint artikel 12 met: "T is toch de meening van het Genootschap jaarlyks twee of meerder Prysvraagen uitteschryven', waarna in precies één bladzijde en sterk vereenvoudigd de regeling voor deze prijsvragen werd opgegeven. De ambities van de oprichters met hun zesenveertig vragen ineens waren onuitvoerbaar gebleken en dus kozen hun opvolgers voor iets kleiners.

De radicalen van 1802 gingen een stap verder: 'Eigenlijke Prijsvraagen zal het Genootschap uit eigen Fonds niet voorstellen' (artikel 7). Ook bij andere genootschappen (in het vaderland) zou het niet meer te rade gaan. Alleen als een bijzonder lid voor eigen rekening een prijsvraag wilde voorstellen, zoals in het verleden wel was gebeurd, zou het bestuur daaraan willen meewerken. Hiermee waren de prijsvragen afgeschaft. Onder de Britten werd daarbij aangesloten. In hun wetten stond geen enkele bepaling over prijsvragen.

De nieuwe wetten van 1823 stelden de prijsvragen echter weer in en wijdden zelfs weer veertien van de vijfenveertig artikelen aan dit onderwerp, een gedetailleerde regeling die niets aan het toeval overliet. Het voornaamste doel was echter om aldus 'spoediger bouwstoffen' voor de Verhandelingen te 
krijgen. Juist op het punt van deze prijsvragen sluit het genootschap in 1823 aan bij de voorgangers van 1778, al staat bij de negentiende-eeuwers een praktische reden voorop, namelijk het vullen van de Verhandelingen. In 1778 waren de prijsvragen een zaak waarmee eer en roem voor het genootschap kon worden geoogst en het op gelijke voet met de beroemde 'vaderlandse maatschappijen' kon komen.

\section{Verzamelingen, museum en bibliotheek}

Bij de oprichting van het genootschap was niet gedacht aan het aanleggen van verzamelingen, aan een museum of bibliotheek. Daarover vinden we niets in het programma van 1778. Hoewel het genootschap in 1791 beschikte over zowel een bibliotheek als over een kabinet, meldden de grondwetten van dat jaar er niets over. Het uitbreiden of onderhouden daarvan behoorde niet tot de doelstellingen zoals die toen werden vastgelegd. In de praktijk echter was de verzameling van Radermacher uitgebreid en waren daar systematische pogingen toe ondernomen.

Het conceptplan van 1802 voorzag voor het eerst in zowel het een als het ander: men streefde naar een verzameling van allerlei naturalia en zeldzaamheden 'in deze Landen verkrijgbaar' (artikel 11) en wilde een kleine bibliotheek van de beste en nieuwste werken 'tot het bijzondere vak van 's Genootschaps werkzaamheden betrekkelijk' aanhouden en aanvullen, terwijl het zich van de andere en kapotte boeken zou ontdoen (artikel 12).

In 1814 werd het verzamelen niet expliciet in de wetten als doelstelling opgenomen, al werd wel vermeld dat het 'fonds', uit de contributies verkregen, gebruikt zou worden voor de aanschaf van boeken, natuurkundige instrumenten en 'andere zaken tot bevordering deszelfs oogmerk' (artikel 8). Onder dat laatste zou men impliciet ook het aanleggen van een verzameling naturalia kunnen rekenen. Overigens werd in dit artikel ook op zuinigheid aangedrongen, alsof met vreesde dat het verzamelen te veel geld zou gaan kosten. Wel werd een comité van vier leden aangesteld voor het toezicht op de bibliotheek, het kabinet van naturalia, de natuurkundige instrumenten en 'andere zeldzaamheden in het Museum van het Genootschap berustende' (artikel 13). Museum en bibliotheek zouden dan voor ieder lid twee keer per week gratis toegankelijk zijn of voor 'vreemdelingen' die door een lid vergezeld zouden zijn (artikel 16). Hoewel dus het uitbreiden van de verzamelingen niet geëxpliciteerd was, kon men wel in de wetten lezen dat er geld aan besteed zou worden.

De hervormers van 1823 wijdden in drie artikelen (6-8) een tamelijk ambitieus plan aan het museum en de bibliotheek van het genootschap, die tot 'grootere volkomenheid [gebracht zouden worden] ten einde tot luister der hoofdplaats te kunnen strekken' (artikel 6). Daartoe zouden 
alle liefhebbers en beoefenaars van kunsten en wetenschappen in Indië en elders worden opgeroepen bij te dragen 'het zij in leven, het zij bij hunnen dood'. Gerefereerd werd aan de veelvuldige giften uit het verleden, terwijl de voorkeur van het bestuur nu uitging naar 'alle naturalia en zeldzaamheden, in deze landen vergaderd, voornamelijk de nieuw ontdekte' (artikel 6). Verwondering wekt het, dat niet expliciet wordt gesproken van de oudheden die ingevolge de werkzaamheden van de commissie Pinket van Haak, Bik en Payen (1822), zouden worden verzameld om in een kabinet van oudheden te worden tentoongesteld. Tenslotte werd de openstelling van museum en bibliotheek in de wetten geregeld: woensdag en zaterdag van 8.00 tot 13.00 uur voor alle leden, maar er zou niets uitgeleend worden. Het genootschap zou een systematische catalogus van de bibliotheek en het kabinet (museum) uitgeven (artikel 8).

Zo was dan in 1823 de door een schenking in 1778 ontstane verzameling van Radermacher tot een museum en bibliotheek van het genootschap geworden, een ambitieuzer plan dan de bescheiden schaal waarop zich de hervormers van 1802 hadden gericht. Weliswaar was in 1778 in het programma van deze verzamelingen geen sprake, maar in navolging van de vaderlandse maatschappijen, Vlissingen en Haarlem voorop, werd het als vanzelfsprekend aan de genootschapsactiviteiten toegevoegd. In 1823 was 'tot luister der hoofdplaats' nieuw. In 1778 was het eerder de persoonlijke roem van de directeuren geweest die hen tot schenkingen had aangezet.

\section{Algemene vergaderingen}

De algemene vergadering, twee maal per jaar te houden, was in 1778 in de eerste plaats ingesteld in verband met de prijsvragen: die moesten beoordeeld worden en er moesten nieuwe worden uitgeschreven. Toch was er ook toen een algemene en open formulering aan toegevoegd: 'en verder, door eene nauwkeurige vergelykinge tusschen het oogmerk deezer instellinge en de byzondere gelegenheid deezer Landen, zoodanige bepaalingen vast te stellen, als zy [de aanwezige leden] noodzaakelyk zullen oordeelen' (artikel 2). Of het de bedoeling was hiermee de leden een grote stem te geven, is de vraag, waar immers alle besluitvorming door de regering zou kunnen worden geblokkeerd. In de rest van de tekst is van de algemene vergadering alleen sprake als de data (februari en augustus, artikel 3) en de plaats van samenkomst (het Kasteel van Batavia, artikel 4) werden bepaald.

In 1791 was pas in het zesde artikel sprake van de algemene vergadering als de jaarlijkse samenkomst van de leden in de grote gaanderij van het Kasteel. In artikel 8 werd de taak van het bestuur omschreven als voorbereidende instantie voor zaken waarin deze vergadering 'finaale uitspraak' zou doen: de beoordeling van binnengekomen en het uitschrijven van nieuwe 
prijsvragen en het benoemen van nieuwe leden. Dat laatste, een stem bij het vaststellen van de toelating van nieuwe leden, gaf in principe de verzamelde leden enige nieuwe invloed, al blijft het de vraag of iemand ter vergadering de moed had de toegang van een nieuw lid te blokkeren.

De mannen van 1802 hadden het instituut van de algemene vergadering zo goed als uitgekleed.

Zonder Algemeene Vergadering der Leden te houden, dan bij volstrekte noodzakelijkheid, zal in zulke gevallen, waar kennis en advies van alle Leden mogt vereischt worden, door Dirigeerende Leden aan Dezelve de noodige Kondschap gegeeven en schriftelijke rondvraag gedaan worden (artikel 15).

Daarmee leek het rondschrijven en rondvragen de plaats van de vergadering te hebben ingenomen en het lijkt waarschijnlijk dat dit het einde van het genootschap zou zijn geweest als niet in de Britse periode een ommekeer was bewerkstelligd.

Deze ommekeer was zelfs zo sterk, dat in 1814 niet werd gekozen voor één of twee algemene vergaderingen per jaar, maar voor maandelijkse algemene vergaderingen, 'tot bevordering van het heilzaam oogmerk van het Genootschap en deszelfs werkzaamheden' (artikel 12). Dit was een ommekeer, omdat hiermee de leden die geregeld bijeen zouden komen ook de gang van zaken in het genootschap konden bepalen, zo lijkt het. Het genootschap ging hierdoor op de Asiatic Society van Calcutta lijken. Zowel het bestuur - een soort kernbestuur geworden van voorzitter, vice-voorzitter en twee secretarissen - als de algemene vergadering waren van karakter veranderd en gemoderniseerd. Aangezien er geen prijsvragen meer werden uitgeschreven en bij iedere vergadering door iedereen nieuwe leden konden worden voorgesteld (en niet op één moment per jaar gefiatteerd), moet het de bedoeling zijn geweest om de algemene vergadering van een ceremoniële tot een werkbijeenkomst te maken, dit in navolging van Calcutta.

In 1823 sloot men daarbij aan en werd de algemene vergadering tot een soort vergroot bestuur: minstens twee maal per jaar, of zo vaak als nodig zou zijn, zou bijeengekomen worden (artikel 22) om verslag te horen van de werkzaamheden, overzicht van de financiën te krijgen, alle zaken van belang te horen, uitslag van de prijsvragen te vernemen, en tenslotte alle voorstellen en mededelingen te vernemen 'aan hare beslissing of goedkeuring onderworpen' (artikel 23). De algemene vergadering zou ook besluiten over de toelating van nieuwe leden, zij het op voordracht van het bestuur. Daarmee was de algemene vergadering, afgeschaft in 1802 en heringesteld als werkbijeenkomst in 1814, opnieuw een belangrijk verenigingsorgaan. 


\section{Een nieuw begin}

Het nieuwe bestuur had reden de toekomst met een zeker vertrouwen tegemoet te zien. De vergaderingen waren in 1823 hervat. Het gouvernement ondersteunde het genootschap financieel. Het genootschapshuis op Rijswijk was aan een opknapbeurt toe en deze werd voor rekening van het gouvernement uitgevoerd na heen en weer-geschrijf over vrij eigendom of vrij gebruik van het gebouw. Oud-secretaris Wedding kon verwijzen naar de resoluties uit de Engelse tijd, waarop de aanspraak op onderhoudsplicht kon worden gebaseerd. Het gouvernement was genereus en nam de kosten op zich. Het kwam met $f 5.048$ over de brug. ${ }^{30}$ Daarmee was een precedent geschapen. Het ging om een overheidsgebouw, afgestaan aan het genootschap, maar de eigenaar bleef verantwoordelijk voor het onderhoud. Deze kwestie zou in de bezuinigingsjaren onder commissaris-generaal Du Bus de Gisignies herhaaldelijk terugkomen in de vergaderingen.

Op de Landsdrukkerij konden in 1823 herdrukken van deel 1 en 2 van de Verhandelingen worden vervaardigd en daar verscheen in dat zelfde jaar deel 9, waar sinds 1816 op werd gewacht. Papier werd door het genootschap zelf in Nederland gekocht. De nieuwe lithografische pers van het gouvernement mocht worden gebruikt, terwijl nog apart $f 1.400$ door de overheid werd bijgedragen aan de illustraties van een verhandeling van Blume over nieuw beschreven soorten eiken. ${ }^{31}$ In zijn 'Verslag van den Staat des Genootschaps', door voorzitter Maurisse in aanwezgheid van de beschermheer voorgelezen op de algemene vergadering van 7 oktober 1823, werd de generositeit van het gouvernement gememoreerd (VBG 9:41-2, 44-5). Van der Capellen had vertrouwen geput uit de vliegende start die het nieuwe bestuur had gemaakt, zij het dat enig aansporen van zijn kant nodig was geweest. De eveneens op 7 oktober 1823 aangenomen precies uitgewerkte nieuwe wetten boden een grondslag waar het bestuur, gesteund door de algemene vergadering, op kon voortwerken. Het nieuwe deel 9 bestond uit Reinwardts enige bijdrage, twee

\footnotetext{
30 ANRI KBG Dir 0023, vergadering 28-5-1823, punt 15, waar de reparaties op $f 5.000$ werden begroot. Tijdens vergadering 3-7-1823, punt 5 (ANRI KGB Dir 0025) werd een brief van de raad van financiën besproken, waarin gevraagd wordt inzicht te geven in de bescheiden die zouden aantonen dat het genootschapshuis is opgetrokken op gouvernementskosten en ter beschikking is gesteld aan het Bataviaasch Genootschap. Zie verder vergadering 14-8-1823, punt 10 (ANRI KBG Dir 0026). Op 4-9-1823 is er al een gouvernementsbesluit van 21-8-1823 nr. 6 binnen, waarin de gelden voor de reparaties aan het gebouw ter beschikking worden gesteld (ANRI KBG Dir 0027, punt 3).

31 ANRI KBG Dir 0027, vergadering 4-9-1823 (punt 4), betreft gouvernementsbesluit van 21-81823 no 6, waarbij $f 1.400$ wordt vrijgemaakt voor 6 koperen platen, Hollands drukpapier ter beschikking wordt gesteld, en de Algemeen Secretaris de opdracht krijgt de druk van dl 9 VBG zo veel mogelijk te bevorderen. Het besluit maant tot spoed bij de gereedmaking van dit nieuwe deel.
} 
plantkundige opstellen van Blume en een plaatsbeschrijving van Palembang door Van Sevenhoven.

Op de algemene vergadering werden voor het eerst sinds 1790 weer prijsvragen uitgeschreven. Batavia sloot zich aan bij de gebruiken in patria. De keuze viel op drie categorieën: geneeskunde, plaatsbeschrijving en taalkennis/geschiedenis. De onderwerpen zijn veelzeggend voor de belangstelling van de nieuwe groep bestuursleden. ${ }^{32}$ De onderwerpen betroffen:

1 De ongezondheid van de Oost-Indische gewesten, Java en Batavia in het bijzonder. Gevraagd werd een op onderzoek gebaseerde verhandeling naar de juistheid van de 'ongunstige begrippen' die hierover heersten. Tevens werd een beknopte instructie gevraagd voor nieuwe reizigers naar de Oost: hoe zich voor te bereiden en zich in het begin van het verblijf, maar ook later, te gedragen om gezond te blijven?

2 Een verhandeling over cholera, oorzaken en verloop van de ziekte en de geneeskundige behandeling, mede naar aanleiding van een recente epidemie.

3 Een topografische en statistische verhandeling over de stad Batavia met een beschrijving van de verschillende bevolkingsgroepen met hun gewoonten en gebruiken, vooral van de Europese bevolking, de regering, kunsten en wetenschappen, dit alles ter verbetering en actualisering van bestaande beschrijvingen, waarbij rekening gehouden moest worden met wat vroeger over dit onderwerp was geschreven.

4 Een korte beschrijving (samenvatting) van het Maleische Soelaletú-Isalathin (Arabisch), ofwel Penoeronan segala radja (Maleisch) ofwel De stam of de afkomst der koningen met uittreksels, vertalingen en stijlvoorbeelden, omdat dit werk zowel door de stijl en de taal, als door het onderwerp belangrijk werd geacht.

De voorstellen voor prijsvragen 1, 3 en 4 kwamen van Lenting, het voorstel voor nummer 2 van Van der Vinne. ${ }^{33}$ Tijdens de vergadering werden slechts deze vier prijsvragen (1-4) bekendgemaakt. Van der Capellen stelde echter ter vergadering voor het aantal tot zes uit te breiden door toevoeging van een tweetal op het gebied van de Javaanse taal, Javaanse geschiedenis of letterkunde. Daarvoor kon het bestuur overleggen met de voorzitter van de commissie voor de opsporing van oudheden, Pinket van Haak, die het Javaans goed beheerste. Ze zouden vervolgens zonder meer in het programma van 1823 mogen worden gepubliceerd, zonder verdere raadpleging

32 Zie het 'Programma en Berigt van het Bataviaasch Genootschap voor het jaar 1823' in VBG 9:15-21. Ook in de Bataviasche Courant van 1-11-1823. De uitvoerige omschrijvingen van de prijsvragen worden in mijn tekst samengevat.

33 ANRI KBG Dir 0027, vergadering 4-9-1823, punt 11. 
van de algemene vergadering. ${ }^{34}$ Pinket van Haak zou echter later die maand de vererende opdracht afslaan omdat hij zich niet capabel achtte, waarna uiteindelijk de bestuursleden Wedding en Lenting de vijfde en zesde prijsvraag formuleerden. ${ }^{35}$ Daardoor kwamen in het programma zes prijsvragen terecht, zowel in de Bataviasche Courant als in deel 9 van de Verhandelingen.

5 Een beschrijving uit Javaanse bronnen van de vroege periode van de Nederlandse aanwezigheid op Java met bijzondere aandacht voor de voorspelling in die bronnen (of eventueel in volksverhalen) dat een vreemde natie van verre zou komen om het land in bezit te nemen.

6 Een overzicht van de Javaanse letterkunde, met inhoudsopgave en vertaalde uittreksels uit belangrijke stukken.

De ingreep van de gouverneur-generaal, die kennelijk zijn stempel wilde drukken op wat het bestuur had voorbereid, had aldus een heel duidelijk resultaat. Wat Van der Capellen voorstelde, daar kon de vergadering niet omheen. De landvoogd zag zijn aanwezigheid niet als louter ceremonieel, maar hij dacht mee en stimuleerde de discussie en het onderzoek.

De praktische doelen (geneeskunde en plaatsbeschrijving) werden gecombineerd met opgaven op het gebied van het Maleis (historisch en literair-historisch gericht). Met de Javaanse prijsvragen van Van der Capellen erbij was de nadruk nog meer komen te liggen op de studie van Indonesische bronnen. Bovendien was het de bedoeling dat deze Javaanse prijsvragen zodanig geformuleerd werden, dat de 'Elèves voor de Inlandsche Talen of andere beminnaars derzelve' die konden beantwoorden. ${ }^{36}$ Deze élèves waren in 1819 aangesteld om onderwijs te krijgen in de belangrijkste talen van de archipel, waarvoor ze onder de hoede van hoge ambtenaren waren geplaatst (Fasseur 1991:32-3). Men mag niet vergeten dat Raffles uitdrukkelijk op de studie van het Javaans had gewezen. Mogelijk is diens aanbeveling, gekoppeld aan Van der Capellens eigen ervaringen op reis, de inspiratiebron geweest voor diens improvisatie ter vergadering. Afwezig zijn prijsvragen over landbouw, nijverheid en economie, onderwerpen die wel in de doelstellingen van het genootschap waren opgesloten, en die in de achttiende eeuw zo'n dominerende plaats hadden ingenomen. Plaatsbeschrijving en problemen van gezondheid sloten wel weer heel duidelijk aan bij de praktisch gerichte prijsvragen en

34 Het ongepubliceerde verslag van de algemene vergadering van 7-10-1823 door Van der Vinne in ANRI KBG Dir 0029.

35 ANRI KBG Dir 0031, brief van Pinket van Haak, 14-10-1823 bij verslag vergadering 13-111823, punt 2 en de bijlagen. Daar ook een soortgelijke brief van J.G. van den Berg, die na Pinket van Haak was aangezocht. Al voor de vergadering van 13-11-1823 was de zaak door Wedding en Lenting opgelost. Op 1-11-1823 was de complete lijst van zes prijsvragen in de Bataviasche Courant verschenen.

36 ANRI KBG Dir 0982, nr 15, conceptbrief van secretaris Van der Vinne aan Pinket van Haak, 8-10-1823. 
publicaties van vóór 1795. Verschillend is wel dat de prijsvragen nu veel beter beredeneerd werden. De inzenders kregen meer aanwijzingen over de gewenste antwoorden. Was voor 1795 het Nederlands de enig mogelijke taal voor inzenders, nu kon ook in het Latijn, Frans, Engels of Duits worden ingezonden. Ook nu zou het prijsvraagstelsel niet succesrijk blijken, ondanks de uitgeloofde gouden en zilveren medailles of geldbedragen van $f 300$ en $f 100$. Pas in 1842 werd er opnieuw geprobeerd het leven in te blazen. Vooralsnog was de Europese gemeenschap te klein en Europa te ver weg. Bovendien was er in Europa te veel concurrentie van andere genootschappen.

Bij de discussies over de vernieuwde opzet van het genootschap in mei 1823 werd, ter voorbereiding op de algemene vergadering van oktober dat jaar, in de kring van het bestuur uitgebreid over veranderingen gesproken. Ook werd aan de relaties naar buiten gedacht. Men wilde in het vaderland en elders 'leden-correspondenten' benoemen om de wederzijdse relaties goed te houden en tegelijk weer 'aanraking en briefwisseling aanknopen' met de vaderlandse genootschappen. In het jaar ervoor was zelfs door de vice-voorzitter gememoreerd dat het genootschap alleen in dienst van de vaderlandse genootschappen kon bestaan, als een kanaal voor het doorsluizen van wetenswaardigheden over de kolonie. In de eerste vergadering van 1823 werd al besloten om de corresponderende leden ervan op de hoogte te stellen dat het genootschap

deszelfs sedert eenige tijd, uit hoofde van tusschengekomen omstandigheden verflaauwde werkzaamheden, weder heeft hervat en begonnen; dat het Genootschap zich er een waar genoegen uit maakt, om de afgebroken correspondencie weder aanteknopen en levendig te houden. ${ }^{37}$

Uit het archief van het genootschap blijkt dat de vaderlandse genootschappen en andere instellingen al uit de toezending van de delen 7 en 8 van de Verhandelingen hadden begrepen dat er in Batavia van een wederopleving van de activiteiten op het gebied van kunsten en wetenschappen, zij het onder Britse vlag aangevangen, sprake was. Zo schreef secretaris J. de Kanter van het Zeeuwsch Genootschap der Wetenschappen op 3 augustus 1818:

Gelijk het ons Genootschap hartelijk verheugde te vernemen, dat Uwed. weder uitzichten voedden om het Bataviasch Genootschap tot vorigen luister op te voeren, en het zal ons uiterst aangenaam zijn, daar van te eeniger tijd de daarstelling te mogen vernemen. ${ }^{38}$

Maurisse had onder de bestuursleden, gewone en corresponderende leden velen moeten gedenken die waren overleden, maar tegelijk kon hij in 1823 
anderen begroeten die het genootschap kwamen versterken: J.W. de Sturler en P.F. von Siebold in Japan, H.W. Tijdeman en C.J. Temminck in Leiden, E.J. Kops in Utrecht, R.H. Arntzenius in Den Haag, D.A. Overbeek in Chinsurah, J.H. Bletterman in Canton, Poleman aan de Kaap, W.A. Bürcke op Mauritius en N. Wallich in Canton. De toespraak van Maurisse ademde dan ook tevredenheid (VBG 9; Bataviasche Courant: 1-11-1823). Tegen het einde van 1823 was er weer contact met diverse personen en instellingen op drie continenten.

Het genootschap was sinds 1817 gegroeid van tweeënzeventig tot honderdelf leden, van wie er achtenveertig in Indië verbleven, vijfendertig van hen in Batavia. In 1823 telde het tweeëntwintig corresponderende en negen honoraire leden. De toename was voor meer dan de helft gerealiseerd na het vertrek van Reinwardt in 1822 (VBG 9:37). Eind 1823 bleek er $f 2.768$ te zijn binnengekomen aan intreepenningen en contributie over 1822-1823. Wedding had kennelijk in de jaren 1817-1822 van de contributie geen werk gemaakt. Er werd tegen $f 30$ per maand een bode aangesteld, A. Eekhart, die toezicht hield op het gebouw en die bij de vergaderingen rode wijn, madeira, bier en seltzerwater leverde. Verder waren er twee jongens ('boejangs') voor $f 9$ per maand. Tot 1800 was er sprake geweest van de 'slaven in het huis' van het genootschap. Van der Vinne was erin geslaagd ook de financiën een gezonder grondslag te geven. ${ }^{39}$

\section{De relatie met de overheid}

Al enkele malen is de houding van de overheid ten opzichte van het genootschap ter sprake gekomen. De tijden waren sinds de Frans-Engelse oorlogen veranderd. De streng controlerende Compagnie was afgelost door een moderner bestuur onder de Britten. Raffles had een deel van het op gouvernementskosten afgebouwde Harmoniecomplex ter beschikking gesteld aan het genootschap en de druk van de Verhandelingen bevorderd door de overheidsdrukpers ter beschikking te stellen. Andere gelegenheden tot het drukken van stukken in de kolonie waren er immers niet of nauwelijks. ${ }^{40}$

\footnotetext{
39 ANRI KBG Dir 1331, bundel financiën 1823-1832 bestaat uit een uit de band gehaald en in aparte omslagen gedaan kasboek dat in slechte staat verkeert. Het raadplegen ervan zou het totale uiteenvallen betekenen. De erbij gevoegde ontvangst- en betaalbewijzen over de periode 1825-1832 zijn echter heel goed te raadplegen. Hieraan kunnen veel gegevens worden ontleend. Wel kan worden afgelezen uit het kasboek dat Van der Vinne in februari 1823 een kas van $f 495,18$ van Wedding overnam. Over 1817-1821 is niets naders bekend, maar uit het feit dat Van der Vinne in de krant aankondigde dat er weer contributie zou worden geïnd en wel vanaf 1822, mag men afleiden dat voordien deze inning achterwege was gebleven.

40 Pas in het midden van de negentiende eeuw ontstond er ruimte voor particuliere drukkers. In de eerste helft van dezelfde eeuw was bijvoorbeeld de drukpers van de Engelse zending een uitzondering (Fasseur 1997:86-7).
} 
De stimulerende houding van Raffles tijdens diens korte verblijf was een impuls geweest voor het genootschapsleven. Van der Capellen trad in dit opzicht in Raffles' voetsporen. Hij besloot tot de verbouwing van het 'lokaal' aan de Rijswijkstraat, waarmee het gouvernement zich verantwoordelijk toonde voor het gebouw. In 1824 besloot luitenant gouverneur-generaal De Kock tijdens Van der Capellens afwezigheid het gewone onderhoud aan het genootschapslokaal tot een maandelijks bedrag van $f 22$ te laten komen ten koste van het gouvernement 'wordende de fungerende Directeur der Civiele Gebouwen aangeschreven, om dit Gebouw vervolgens te doen begrijpen in het onderhoud van 's Lands Civiele Gebouwen te Batavia'. ${ }^{1}$ Daarmee was een belangrijke financiële zorg van het bestuur afgevallen. Voor groot onderhoud zou in de toekomst ook weer een oplossing worden gevonden. De controlerende overheid van voor 1795 was een subsidiërende overheid geworden.

Dat de Landsdrukkerij gebruikt kon worden voor het drukwerk, de Verhandelingen op de eerste plaats, was een tweede belangrijke vorm van hulp aan het genootschap, waarbij het gouvernement opnieuw in de voetsporen van Raffles trad. Weliswaar kwam pas in 1823 het negende deel van de pers, zeven jaar na Van der Capellens komst. De delen 10 en 11 volgden snel (18251826). Verder was er een hele serie herdrukken nodig van voorgaande delen om de boekenvoorraad voor nieuwe leden en voor buitenlandse relaties op peil te brengen. Van der Vinne had hierdoor in de eerste jaren van zijn secretariaat herhaaldelijk contact met de drukkerij: in 1823 werd een eerder opgelegde herdruk van deel 1 en 2 afgemaakt ${ }^{42}$, in 1824 volgden deel 3 en $4^{43}$, in 1825 deel 1 opnieuw (3e druk) en deel 8 (2e druk) ${ }^{44}$, in 1826 nog eens een derde druk van deel $2 .{ }^{45}$ De oplagen van de herdrukken beliepen meestal

41 ANRI KBG Dir 0041, vergadering 9-9-1824, punt 5. Extract uit Register der Handelingen en Besluiten van de Luitenant Gouverneur-Generaal van 17-8-1824 nr 6 is als bijlage 2 toegevoegd. Besloten werd om de maandelijkse uitgaven voor het onderhoud zelf te doen en vervolgens aan het einde van het jaar het bedrag terug te vragen.

42 ANRI KBG Dir 0023, vergadering 28-5-1823, punt 9 en 10, vermeldt 120 exemplaren van deel 1 (2e druk) en eenzelfde aantal van deel 2.

43 ANRI KBG Dir 0034, vergadering 15-4-1824 meldt 200 exemplaren van de 2e druk van deel 4, terwijl in Dir 0038, vergadering 17-6-1824, een nieuwe druk van deel 3 wordt gemeld. In juli 1824 is de druk van deel 4 al gereed en wordt de sierlijke uitvoering geprezen (Dir 0039, vergadering 15-7-1824).

44 ANRI KBG Dir 0046, vergadering 10-2-1825 vermeldt de tweede druk van deel 3 . Dir 0048, vergadering 14-4-1825 vermeldt besluit tot het opleggen van een derde druk van deel 1 en een tweede druk van deel 8, zodra deel 10 zal zijn gedrukt.

45 ANRI KBG Dir 0057, vergadering 13-4-1826, punt 15 vermeldt het aanbieden van een exemplaar van de derde druk van deel 1. Dir 0058, vergadering 13-7-1826, punt 11 vermeldt het aanbieden door de waarnemend opziener van 's Landsdrukkerij van een exemplaar van het herdrukte deel 2 aan en meldt dat de herdruk van deel 8 ter perse is. 
120 tot 200 exemplaren. Nieuwe delen werden opgelegd in 400 exemplaren. ${ }^{46}$ Daarnaast hielp het gouvernement nog eens apart met de druk van plaatwerk en met extra Hollands drukpapier, terwijl de nieuwe lithografische pers mocht worden gebruikt. ${ }^{47}$ Daarmee hield het niet op: soms werd extra karton ter beschikking gesteld voor de verzending van boeken en ook een keer veertig el groen laken voor de vergadertafel om de vergaderzaal een waardiger aanzien te geven. ${ }^{48}$

Toegang tot de drukpers betekende niet dat penningmeester-secretaris Van der Vinne goedkoop uit was. Voor deel 9 gaf hij $f 2.776$ uit, waarvan $f 1.050$ bestemd voor de tekenaar Bik, die Blumes eiken had getekend en laten etsen, verder $f 500$ voor bindpapier, $f 736$ voor het bindwerk aan vierhonderd exemplaren en nog eens $f 490$ als douceur voor drukkers, zetters en voor opzichter G. van der Storm van de drukkerij. De laatste ontving daarvan $f 150 .{ }^{49}$ Daarmee was het uitgeven en herdrukken van de Verhandelingen veruit de duurste activiteit. De opbrengst uit verkoop was te verwaarlozen, want leden ontvingen de nieuwe delen kosteloos. Voor niet-leden werd de prijs van deel 9 op $f 8$ gesteld, een set van deel 1-9 kwam op $f 40$ te staan. ${ }^{50} \mathrm{Al}$ nam het gouvernement dus niet alle kosten voor zijn rekening, de drukkerij was onontbeerlijk bij de productie van enkele nieuwe delen en verschillende herdrukken. Het genootschap was aldus voor zijn bloei en voortbestaan afhankelijk gebleven van het gouvernement.

De relatie tot het gouvernement had nog een aspect, waarmee het genootschap inhoud gaf aan zijn ambities op het gebied van kunsten en wetenschappen. Het betreft de adviseursrol, die het genootschap al vervulde in de jaren vanaf 1802 voor de activiteiten van Thomas Horsfield. Op de instelling van de commissie ter opsporing van Javaanse oudheden met Bik, Payen en Pinket van Haak volgde de opdracht aan de residenten om goed voor de oudheden te zorgen. Het genootschap werd gevraagd leiding te geven aan die commissie en voorbereidingen in het gebouw te treffen voor de plaatsing van de voorwerpen die zouden binnenkomen. ${ }^{51}$ We kunnen dit beschouwen als een vorm van delegatie. De commissie onder leiding van een lid van het Bataviaasch Genootschap voerde een overheidstaak uit. Dat het genootschap

46 ANRI KBG Dir 0052, vergadering 5-1-1826, punt 23 vermeldt het besluit tot het opleggen van 400 exemplaren van deel 11. Misschien was dit aantal voor de delen 9 en 10 lager.

47 ANRI KBG Dir 0027, vergadering 4-9-1823, punt 4, Gouvernementsbesluit van 21-8-1823 nr

6.

ANRI KBG Dir 0034, vergadering 15-4-1824, punt 2.

ANRI KBG 0033, vergadering 25-3-1824, bijlage 4, Aantooning van de kosten voor dl 9 van de Verhandelingen door Van der Vinne. Door de overheid was al $f 1.400$ betaald voor de platen bij Blumes verhandeling over de eiken.

50 ANRI KBG Dir 0033, vergadering 25-3-1824, punt 2 en 3.

51 ANRI KBG Dir 0022, vergadering 22-6-1822, punt 6 met bijlage. 
zijn taak serieus nam, blijkt uit het feit dat Pinket van Haak al na de eerste bestuursvergadering, een half jaar na zijn benoeming, een brief ontving om hem te vragen of er al voortgang was geboekt in de werkzaamheden, vooral gezien het feit dat het genootschap de oudheden zou ontvangen en plaatsen. ${ }^{52}$ Dat het werk van deze commissie op weinig zou uitlopen, doet niets af aan het principe. Voor het gouvernement was het genootschap in 1822 een advieslichaam. Het gouvernementsbesluit van 24 juli 1823, waarin aan de residenten de zorg voor de Javaanse oudheden werd opgedragen is een resultaat van het werk van de commissie. ${ }^{53}$ Het was wel het enige. Het genootschap zou nog twintig jaar moeten wachten op de verplaatsbare oudheden. De energieke predikant Van Hoëvell zou pas in de jaren 1840 voor de toestroom van beelden en tempelfragmenten zorgen.

Een tweede rol speelde het genootschap bij het versturen van gedroogde en levende planten naar instellingen in het vaderland, meestal universitaire plantentuinen. Het was de opvolger van Reinwardt als directeur tot de zaken van landbouw, kunsten en wetenschappen, Carl Ludwig Blume, tevens directeur van de plantentuin in Buitenzorg, die in oktober 1824 zijn medebestuursleden per brief het voorstel deed om het gouvernement te vragen mee te werken aan het versturen van planten en zaden die overbodig waren in verzamelingen in Buitenzorg (Van Steenis 1990). Voorganger Reinwardt had dit buiten de zaken van het genootschap gehouden. Door de ter beschikkingstelling van dit botanische materiaal zou nu de relatie met de 'vaderlandsche en uitlandsche maatschappijen' bestendigd worden en het contact met geleerden onderhouden blijven. Het bestuur stemde met dit voorstel in. ${ }^{54} \mathrm{Op}$ de algemene vergadering van 2 februari 1825 meldde voorzitter Maurisse, dat de gouverneur-generaal had ingestemd met het verzoek om jaarlijks materiaal aan het genootschap ter beschikking te stellen om het vervolgens 'onder Gouvernements tusschenkomst' te verzenden aan 'andere maatschappijen en mannen van verdiensten' (VBG 10:58-9). Besloten werd om eerst Leiden te voorzien, daarna Utrecht, Groningen en het Amsterdamse Atheneum Illustre, vervolgens in Haarlem de Hollandsche Maatschappij en tenslotte de Gentse universiteit. In juni 1825 bleek Blume de eerste zending van zes kisten voor Leiden al gereed te hebben. Reinwardt was daar hoogleraar geworden. Het materiaal werd verscheept met de 'Tasman', nadat de gezagvoerder rijkelijk van goede raad was voorzien door Blume over de afdekking met dekens

52 Pinket van Haak was op 10-9-1822 als voorzitter benoemd. Op 28-5-1823 wilde het bestuur weten wat er is geworden van de opdracht (ANRI KBG Dir 0022, vergadering 28-5-1823, punt 3-5).

53 Notulen 13:bijlage A: Bepalingen op het stuk van gevonden of opgedolven Oudheden in Nederlandsch-Indië.

54 ANRI KBG Dir 0042, vergadering 28-10-1824, punt 7 en de bijlage (afschrift) van Blume. 
vanaf de Kaap Verdische eilanden om de levende planten te beschermen tegen kou, wind en regen. Kapitein Theunisse zou $f 25$ premie krijgen voor iedere kist waarvan eenderde van de planten levend zou aankomen. ${ }^{55} \mathrm{Al}$ in augustus werd een verzameling zaden aan het genootschap ter beschikking gesteld voor de Gentse hoogleraar en hortulanus, J.G.S. van Breda. ${ }^{56}$ In 1826 zouden planten naar Utrecht en Leuven worden gestuurd, terwijl uit Leiden bericht binnenkwam dat van de eerste zending de helft levend was aangekomen en wel binnen vijf maanden. Kapitein Theunisse verdiende zijn beloning, aldus Reinwardt. ${ }^{57}$

Het genootschap fungeerde aldus als sluis bij het doorgeleiden van planten en zaden naar Europa. Het was als het ware een afgeleide instantie van de plantentuin, dat het materiaal uitkoos, terwijl alleen met gouvernementshulp het vervoer naar de ontvangende instanties te realiseren viel. Waarom de plantentuin, in casu directeur Blume, de zaak niet geheel aan zijn eigen instelling voorbehield, blijft een vraag. Onduidelijkheid over ieders taak ontstond al snel. Voorzitter Maurisse stoorde zich bij de eerste zending naar de Leidse hortus aan de voortvarendheid waarmee de verzending door Blume en zijn collega-ambtenaar bij financiën, hoofdadministrateur Muller, was geschied. Daardoor was het volgens Maurisse niet duidelijk genoeg dat het genootschap de verzendende instantie was. ${ }^{58}$ Maurisse liet zo blijken dat hij zich bewust was van de rol die het genootschap kon spelen en tegelijk van het belang dat erin gelegen was dat het genootschap die rol ook claimde. Men kon denken dat de overheid de zendingen verzorgd had. Overdracht van deze twee taken - beheer van oudheden en verspreiding van botanisch materiaal over vaderlandse instellingen - was een eerste stap in de richting van een organisatie die wij semi-overheid zouden noemen. In het spel tussen overheid en genootschap zouden in de negentiende eeuw subsidie en delegatie van taken een steeds belangrijker rol spelen.

De verkleefdheid van het genootschap met de overheid werd nog benadrukt door het feit dat contributie van leden buiten Batavia kon worden geïnd door storting in 's Lands kas via de residentiekantoren, waarna in Batavia verrekening plaatsvond. ${ }^{59}$ Toch bleef het genootschap formeel op zich zelf staan, vervulde het taken in nauw overleg met het gouvernement, maar trad

\footnotetext{
55 ANRI KBG Dir 0050, vergadering 14-7-1825, punt 3 en bijlagen 1-6.

56 ANRI KBG Dir 0051, vergadering11-8-1825, punt 6 met als bijlage een brief van Blume van 21-7-1825.

57 ANRI KBG Dir 0057, vergadering 13-4-1826, punt 5 en als bijlage de brief van Blume van 28-3-1826. Een brief van Reinwardt van 24-11-1826 met geleidebrief van de hoofddirecteur van financiën (Dir 0060, vergadering 8-6-1826, punt 12 en bijlagen).

58 ANRI KBG Dir 0983, nr 39, brief van Maurisse aan Van der Vinne van 24-3-1825.

59 Meteen al in 1823 werd gedacht aan deze manier van contributie-inning. ANRI KBG Dir 0023, vergadering 28-5-1823, punt 11.
} 
zelfstandig op in de contacten met personen en instanties in de archipel, in andere koloniale gebieden en in Europa. Daarbij was natuurlijk een bemoeilijkende, tegelijk vergemakkelijkende factor dat de gouverneur-generaal de beschermheer was. Via hem konden snel zaken worden geregeld, maar dat moest gebeuren zonder de onafhankelijkheid op te geven. Toen in september 1824 werd besloten ter gelegenheid van de terugkeer van de beschermheer na zijn Molukse reis in de Rijswijkstraat een illuminatie uit te voeren, bestaande uit 'eene soort van tempel, welke in het fronton of de kroonlijst ten opschrift voert, met groote duidelijke Romeinsche letters: voor onzen beschermheer' had men waarschijnlijk niet gedacht dat dit een lieve $f 415$ zou gaan kosten. Het bedrag kon, gezien de toestand van de kas, niet gemakkelijk door de penningmeester worden voldaan. Besloten werd dat de bestuursleden de kosten zelf zouden dragen. Kennelijk was dit nog niet uitgevoerd toen de penningmeester op 2 februari 1825 tijdens de algemene vergadering de toestand van de kas toelichtte. Bij die gelegenheid vroeg de aanwezige Van der Capellen zelf een toelichting op de post voor de illuminatie van september 1824, waarna opnieuw besloten werd, dat dit niet uit de genootschapskas mocht worden gefinancierd. ${ }^{60}$ Door deze ingreep, die de bestuursleden in hun portemonnee voelden, gaf de beschermheer aan dat de relatie met het gouvernement zuiver moest blijven: als de bestuursleden hadden besloten tot deze lofbetuiging aan de beschermheer, moesten ze daarvoor ook zelf betalen. De contributie van de leden mocht daarvoor niet gebruikt worden.

Van de andere kant toonde Van der Capellen zich een weldoener voor de bibliotheek en het kabinet. Hij liet bij zijn vertrek een pracht-uitgave achter uit zijn eigen verzameling, de Description de l'Egypte in 132 katernen met 700 gravures, voortgekomen uit de Napoleontische inspanningen langs de Nij1. ${ }^{61}$ Van der Capellen trok zo duidelijke lijnen, ruime persoonlijke steun aan het genootschap, ruime overheidssteun ook. Hij stelde belang in het genootschap, getuige zijn aanwezigheid bij en actieve deelname aan vergaderingen. Hij probeerde de genootschapszaken ook van gouvernementszijde te beïnvloeden. In 1822 deed hij dat door een rol weg te leggen voor het genootschap bij het beheer van oudheden, in 1823 door het bestuur met kracht wakker te schudden en het genootschap met opheffing te dreigen in het belang van de algemene zaak. Met deze verdeling van belangen tussen genootschap en overheid en bij deze steun was het onder Van der Capellen gemakkelijk leven,

\footnotetext{
60 ANRI KBG Dir 0041, vergadering 9-9-1825, punt 11, en Dir 0042, vergadering 28-10-1825, punt 2. Verder verslag van de algemene vergadering, Dir 0045, 2-2-1825.

61 ANRI KBG Dir 0055, vergadering 9-2-1826, bijlage 10 financieel overzicht van Van der Vinne. Voorzitter Maurisse droeg $f 200$ bij. Blume $f$ 60, Payen $f 30$. Verder van diezelfde vergadering punt 7, waar twee brieven van adjudant P.J. van Zuylen van Nijevelt worden besproken van 19-11 en 2-12-1825 over de boekschenking van Van der Capellen.
} 
zeker zolang er een actief bestuur was en een capabele secretaris. Bij het wisselen van de wacht zou blijken dat het ook anders kon gaan.

\section{De bibliotheek}

Over de toestand van de bibliotheek en van de verzameling naturalia en zeldzaamheden, als museum of kabinet betiteld, zijn we aan het begin van deze periode slecht ingelicht. Zelfs over de Engelse activiteiten op dit punt weten we weinig of niets. Het lijkt onwaarschijnlijk dat Raffles in 1814 een nieuw genootschapslokaal opende, waar alleen een vergadertafel stond. Zelfs onder Raffles was er een Committee of the Museum en was er een bibliothecaris. Over uitbreiding ervan horen we niets. De omvang van de verzameling boeken, handschriften en objecten in 1816 vormt een groot vraagteken. Kijken we daarom naar wat er voor de uitbreiding en voor beheer werd gedaan onder Van der Capellens beschermheerschap. Wierp zijn hulp ook vruchten af in de bibliotheek en het kabinet?

De bibliotheek was in de Engelse periode door Wedding beheerd, en dat was bij de bestuurswisseling van 1817 zo gebleven tot in 1821 de medicus E. Petit, uitgekomen met de Commissie-Generaal, deze functie van hem overnam. ${ }^{62} \mathrm{Hij}$ mocht van het bestuur meteen twee hulpkrachten in dienst nemen, waaruit we mogen afleiden dat hij iets met de collectie boeken van plan was. ${ }^{63}$ In de jaren van Weddings secretariaat-bibliothecariaat (na 1816) waren er wel boeken binnengekomen van de zogenaamde vaderlandse genootschappen (Haarlem, Zeeland), van universiteiten (Groningen), van het genootschap uit Philadelphia en uit Malakka. Het Koninklijk Instituut te Amsterdam had in 1815 al bij de voorbereidingen voor Reinwardts vertrek boeken voor het Bataviaasch Genootschap meegegeven. ${ }^{64}$ Ook de commissaris-generaal van onderwijs stuurde boeken en vroeg om de Verhandelingen. ${ }^{65}$ Het genootschap was dus, ondanks de barre tijden van isolement en vreemde overheersing, niet helemaal afgesneden geweest van nieuwe boeken. Het is echter onduidelijk hoe groot de collectie nog was. Even onduidelijk is het of er iets werd aangekocht. Afrekeningen over de periode 1816-1821 zijn niet overgeleverd. Wat Petit heeft kunnen bewerken, is evenmin duidelijk. In 1823 werd het nieuw aangetreden bestuurslid Guillaume de Serière, predikant bij de hervormde

\footnotetext{
62 Ph. Wedding stond in de Almanak 1820 nog als bibliothecaris vermeld.

63 ANRI KBG Dir 0022, vergaderingen 20-2-1821 en 4-4-1821.

64 Enkele aanbiedingsbrieven uit die periode in de verzameling gemengde stukken 1817-1827, ANRI KBG Dir 1505, nr 1-8.

65 Zie brief van commissaris-generaal O. Repelaer van Driel uit Brussel ter aanbieding van J.C. Sepp, Flora Batava, ANRI KBG Dir 155, nr 2 en 3.
} 
gemeente, gevraagd een catalogus te maken. In november van dat jaar had hij al 190 titels beschreven. Daaruit mogen we concluderen dat de bibliotheek in 1817 enige omvang had. De Serières verslag over de staat van de bibliotheek was echter treurigstemmend.

Dat in het algemeen gesproken de Bibliotheek er allerelendigst uitziet, maar dat zich nogtans in dezelve een aantal zeer kostbare en ook enkele zeer rare werken bevinden, welke gelukkiger wijze, wat den tekst betreft, door den wurm niet zijn aangestoken. ${ }^{66}$

De manuscripten en godgeleerde werken waren zozeer geschonden, dat ze beter weggegooid konden worden. De Serière wilde nieuwe, losse boekenkasten aanschaffen ter vervanging van de oude, die door de witte mier waren aangevreten. Tijdens de algemene vergadering van 23 oktober 1823 werden de aanwinsten sinds 1817 getoond: nog geen 20 titels in misschien 30 banden (VBG 9:37-9). Een paar maanden later was de Serière klaar met zijn catalogiseerwerkzaamheden en ging hij verder met het bind- en innaaiwerk, waarvoor hij twee boekbinders mocht aannemen. ${ }^{67}$ De bibliotheek beschikte toen over circa 450 titels, niet meer dan enkele kasten. ${ }^{68}$

De aandacht die De Serière aan de boeken besteedde, leidde ook tot uitbreiding: de secretaris en de bibliothecaris werden gemachtigd op venduties aankopen te doen. ${ }^{69}$ Helaas kwam daar vooralsnog weinig van: tot 1826 werd slechts één keer een werk aangekocht, andere boeken kwamen binnen als gift van leden of door uitwisseling met bevriende genootschappen. ${ }^{70}$ Van bestellingen in Nederland was in het geheel geen sprake, terwijl het genootschap in de achttiende eeuw herhaaldelijk in ruime mate boeken en tijdschriften liet overkomen. De Serière, sinds de algemene vergadering van 24 april 1824 officieel benoemd tot bibliothecaris en opziener van het kabinet, kon aldus alleen giften verwelkomen. Van aanschafbeleid was geen sprake. Hij riep wel op tot een jaarlijkse geldelijke inschrijving onder de leden, die zodoende de bibliotheek en het kabinet konden helpen verrijken. Het plan werd in 1824 gelanceerd en via intekening uitgevoerd (VBG 10:19). Van der Vinne had een lijst samengesteld van 23 Bataviase leden, van Engelhard en Muntinghe tot H.J. van der Graaff, geen bestuursleden, die kennelijk geacht konden worden tot giften in staat te zijn. Bij de giften, die weldra binnenstroomden, waren 'aan-

\footnotetext{
66 ANRI KBG Dir 0031, vergadering 13-11-1823, punt 7, Verslag van de bibliothecaris.

67 ANRI KBG Dir 0033, vergadering 25-3-1824, punt 16.

68 Van der Chijs noemt dit aantal in een onvoltooide 'Geschiedenis van de Bibliotheek van het Bataviaasch Genootschap' (Jaarboek 3:239).

69 ANRI KBG Dir 0034, vergadering 15-4-1824, punt 9-10.

70 In 1825 werd de Atlas historique, généalogique, chronologique et géographique van A. le Sage aangekocht voor $f 70$ (ANRI KBG Dir 0043, vergadering 20-1-1825).
} 
zienlijke boekgeschenken' van Van Van der Capellen en anderen, werken van Von Humboldt, Hooft en Montaigne door De Kock geschonken en de Abrégé de l'Histoire des Voyages door G.F. Meylan. Ook Maurisse zelf en Muntinghe lieten zich niet onbetuigd. De lijst is interessant en laat opnieuw zien dat er noal wat werken circuleerden die men in een geleerdenbibliotheek zou verwachten. Sommige van die boeken waren interessant voor een bibliotheek in Batavia: woordenboeken, spraakkunsten, reisbeschrijvingen, verhandelingen van andere genootschappen. Verder was er veel vaderlandse geschiedenis (Hoofts Historien in drie verschillende edities, Bor, Wagenaar), maar uit de aard van de zaak was het toch een vrij toevallige verzameling. ${ }^{71}$

Voorzitter Maurisse was tijdens de algemene vergadering van 24 april 1824 tevreden. De verzamelde leden konden, luisterend naar zijn toespraak, het oog slaan op de door De Serière herplaatste boeken in de verschillende kasten ('welke wij rondom ons zien staan'). Maurisse kon het bestaan melden van de 'bijna volledige, en, zoo veel mogelijk, beredeneerde catalogus der boeken, waarbij men dezelve vermeld en gerangschikt zal vinden naar het vak van wetenschap, waartoe ieder werk behoort'. De Serière had dus gekozen voor een systematische plaatsing van de boeken. Maurisse kon opnieuw enkele schenkingen melden. Voor de algemene vergadering van 2 februari 1825 werd De Serière, wiens overplaatsing naar Soerabaija aanstaande was, gevraagd zijn werkzaamheden zo veel mogelijk af te ronden. Hij meldde dat er belangrijke werken waren, die van buiten geheel en van binnen gedeeltelijk beschadigd waren en voor het op orde brengen waarvan geen geld beschikbaar was. Besloten werd toen de al te zeer beschadigde boeken te vernietigen. ${ }^{72}$ Auditeur-militair G.J. Sieburgh werd de opvolger van De Serière als bibliothecaris. ${ }^{73}$ Tijdens de algemene vergadering zelf meldde de aftredende bibliothecaris nog dat hij slechts dertig van de honderd 'behoeftige' boeken op orde had kunnen brengen. Hoeveel hij er had weggegooid, wordt niet vermeld. ${ }^{74}$ Hoewel Maurisse meldde dat de boekerij in goede staat was, kon deze nog niet worden 'geactiveerd'. Kennelijk was het leden nog niet toegestaan te lezen of te lenen. De Serière zei zelf heel bescheiden van zijn eigen arbeid: 'Het Kabinet begint pas te bestaan. De Bibliotheek moet in order gebracht. Het Museum uitgebreid worden. ${ }^{75}$ De gouverneur-generaal stelde

71 ANRI KBG Dir 1510 bevat in de omslag over 1825 een lijst van 5 pagina's van giften in boekvorm of in de vorm van voorwerpen. Hieraan vooraf gaat de lijst van Van der Vinne met 23 namen van leden in Batavia, die tot giften konden worden aangespoord.

72 ANRI KBG Dir 0043, vergadering 20-1-1825, punt 11.

73 ANRI KBG Dir 0044, vergadering 2-2-1825, punt 2.

74 ANRI KBG Dir 0044, handgeschreven verslag van Van der Vinne van de algemene vergadering van 2-2-1825.

75 Van der Vinnes weergave van de woorden van de aftredende bibliothecaris (ANRI KBG Dir 0044, vergadering 2-2-1825). 
het bestuur de vraag hoe het De Serière dacht te eren. Daarvoor bedacht hij ter vergadering de nieuwe figuur van het honorair bestuurslid. Zo was de afgetreden bibliothecaris toch nog - hoewel in Soerabaija - met zijn medebestuursleden in Batavia verbonden. De catalogus van de bibliotheek verscheen overigens pas in 1846 in druk.

\section{Verzamelingen}

De geschiedenis van het kabinet of het museum verloopt in deze periode langs gelijke lijnen. In 1817 werd de commissie voor het museum die in de Britse tussentijd had bestaan uit twee personen, uitgebreid tot vier: J.C. Goldman, Meylan, G. Reinking en J. van Boeckholtz. Uit niets blijkt of deze commissie ook iets gedaan heeft. In 1822 opende zich het mooie perspectief van een kabinet van oudheden, waarvoor de commissie Pinket van Haak aan het werk zou gaan. Dat er intussen iets in het 'museum' stond, mogen we aflezen uit het feit dat bestuursleden Lenting en Van der Vinne in februari 1823 iemand meenden te hebben gevonden die naast de boeken en manuscripten ook de instrumenten en rariteiten kon gaan catalogiseren. ${ }^{76}$ Uiteindelijk kwam ook dit werk op De Serières schouders neer.

De eerste voorwerpen voor het kabinet golden de drie instrumenten die door Reinwardt bij zijn terugreis naar Nederland aan het genootschap werd overgedragen. Maurisse memoreerde dit tijdens de algemene vergadering van 1823 en schonk er zelf nog een 'grof-pond met de tien-deelige verminderingen' bij. ${ }^{77}$ Waar Maurisse zo geheel en al zwijgt van de rest van het museum, kunnen we ons daar beter in 1823 niet al te veel van voorstellen. Ook hier kwam de oproep aan leden om voorwerpen te schenken niet zo zeer als een teken dat men een welomschreven verwervingsbeleid voerde, als wel dat de ruimte er was en dat een genootschap nu eenmaal een museum of kabinet had. Totdat iemand zich werkelijk met de zaak ging bemoeien, was men ook hier afhankelijk van wat binnenkwam: een inscriptie in zilver uit Palembang (Van Sevenhoven, maart 1824), een kalkkegel uit residentie Buitenzorg (Blume, mei 1824), Nieuw-Zeelandse wapens, riemen en kleding (A.F. Winter, juli 1824), twee hertenkoppen, een struisvogelei en een casuarie-ei, een houten bak in gebruik in een goudmijn met twee stukjes gouderts en een bijbelvertaling uit de zestiende eeuw (Lenting, juli 1824), een aantal Borneose voorwerpen van de bestuursambtenaar Muller (De Kock, oktober 1824). ${ }^{78}$ Het was als

76 ANRI KBG Dir 0024, vergadering 12-6-1823, punt 10.

77 ANRI KBG Dir 0024, vergadering 22-6-1822, punt 5 bevat een afschrift van het gouvernementsbesluit over de overdracht van Reinwardts voorwerpen, 15-6-1822.

78 ANRI KBG Dir 0033, 0037, 0039, 0042, vergaderingen van 1824. 
rij voorwerpen nogal verschillend van aard en betekenis. De oproep van 24 april 1824 voor het museum zou weinig effect sorteren. De Kock was de enige die naast boeken ook voorwerpen aanmeldde: enige Dayakse wapens en andere Borneose zeldzaamheden, zes Zuid-Afrikaanse pieken en een Padangse sabel. ${ }^{79}$ De Serière was ook hierin actief: hij zag dat de zaak ordelijk moest worden weggezet en stelde in juni 1824 voor om het zijvertrek aan de noordkant van het genootschapshuis tot bewaarplaats te bestemmen 'der instrumenten, rariteiten, voorwerpen van natuurlijke historie, enz.' Hij mocht met het oog op een 'doelmatige schikking, plaatsing en bewaring' rekken en stellingen aanschaffen. ${ }^{80}$ Daarvoor was er kennelijk geen aparte ruimte geweest.

De geldelijke inzameling die op 24 april was gestart voor de 'oprigting en uitbreiding van het Kabinet en het Museum van het Bataviaasch Genootschap, en tot het in behoorlijken staat brengen van deszelfs Boekerij' bracht veel op. Aan kop stond Van der Capellen met $f$ 1000. Op afstand volgden met $f 200$ Maurisse, Chassé en Tiedemans, en met $f 150$ Merkus. Elf personen tekenden in voor $f 100$, onder hen Wedding, Blom, De Kock, Van der Vinne, Popkens, Bousquet, Schneither, Hogendorp, Haeck en Muntinghe. De inzameling bracht $f 4.385$ op, verdeeld over 52 personen, van wie er 36 voor minder dan $f 100$ inschreven. De Serière had in de korte tijd voor zijn vertrek naar Soerabaija heel wat teweeggebracht. ${ }^{81}$

Bij het vertrek van De Serière werd de stadsapotheker A. Perret tot directeur van het Museum en Kabinet benoemd. Hij wilde meteen met het opstellen van instrumenten en voorwerpen beginnen, waaruit we mogen afleiden dat De Serière zich vooral met de boeken had bemoeid en niet of nauwelijks aan het museum was toegekomen. Het museum en het kabinet - de twee termen werden naast elkaar gebruikt - alsof het duidelijk onderscheiden afdelingen waren - werden direct na Perrets aantreden verrijkt met een 'schoone collectie schedels van onderscheidene Natien uit deze Archipel' (L.E. Fischer, april 1825), een zilveren Visnu uit Birma (D.A. Overbeek, mei 1825), het model van een sluis met waaierdeuren (Peereboom, juli 1825) en een Javaanse vlaggenstok (J. Tromp, augustus 1825). ${ }^{82}$ In de praktijk zal apotheker der eerste klasse Perret waarschijnlijk ook voor het museum en kabinet niet veel hebben gedaan. Daardoor kwam het werk neer op secretaris Van der Vinne en zijn ijverige medelid dominee Lenting. Van der Vinne was een druk man met vele functies. Lenting echter had het evenzeer druk. Vandaar dat

79 ANRI KBG Dir 1506 (omslag 1825), lijst van 5 pagina's vermeldt boeken. Alleen De Kock tekende ook met voorwerpen in.

80 ANRI KBG Dir 0038, vergadering 17-6-1824, punt 7.

81 ANRI KBG Dir 0055, vergadering 9-2-1826.

82 ANRI KBG Dir 0048-51, vergaderingen van 1825. 
het genootschap in de Rijswijkstraat er soms wat bekaaid af kwam, getuige onderstaand briefje van Lenting aan Van der Vinne, geschreven bij de laatste thuis op 24 februari 1825:

\begin{abstract}
Amice!
Het spijt mij dat gij heden morgen niet te huis zijt; want morgen kom ik niet op Weltevreden. En Zaturdag zijt gij misschien bezig het Institut [Bataviaasch Genootschap] te inspecteren. Indien gij dit laatste somtijds aan mij zoudt willen opdragen, moet ik $\mathrm{u}$ in voorraad zeggen, dat wij Zaturdag vergadering der Directie van het Bijbelgenootschap hebben, waardoor ik verhinderd wordt. Intusschen heeft Jufr. Severijn mij geklaagd, dat niemand van ons des Zaturdags naar haar komt omzien en dat een van ons beiden daar in geene vier weken geweest zijn. Ga gij er dus overmorgen naar toe, of draag het aan den pastoor [Wedding] op.

[over de bij Van der Vinne achtergelaten drukproeven:] Daar zijn een paar dirigerende leden in ons Genootschap die gij met dit werk zeer wel kunt belasten en die tot dus verre niet veel meer gedaan hebben dan de vergaderingen bijtewonen, namelijk de pastoor \& Blom. Laten zij ook wat doen. Ik zend u dus de tweede proef ongecorrigeerd terug. ${ }^{83}$
\end{abstract}

Kennelijk waren Van der Vinne en Lenting degenen, die het meeste bestuurswerk verrichtten, waarbij Lenting vooral als editeur van de Verhandelingen optrad. Deze zeldzame, huishoudelijke brief gunt ons een blik in de dagelijkse gang van zaken in het genootschap. In geen vier weken was er iemand van het bestuur in de Rijswijkstraat geweest. Bij de zaterdagse opening hield kennelijk ene juffrouw Severijn toezicht.

Dominee De Serière was te midden van al die juristen en een enkele medicus en ingenieur degene die het meeste tijd voor catalogiseerwerk had gehad. Zijn theologische opleiding zal hem historische belangstelling hebben bijgebracht, maar verder was hij een amateur, zoals collega-dominees voor hem. In de oudheidkundige commissie zaten een tekenaar, een schilder en een ambtenaar, die wat Javaans kende. Geen wonder dat in dit stadium de opbouw of uitbreiding van het museum vooral aan het toeval werd overgelaten: wat zeldzaam was of onbekend, was waard om bewaard te worden. Een van de weinige vakmensen op het gebied van de natuurlijke historie, met name plantkunde, Reinwardt, had voor het genootschap zo goed als niets gedaan, hoewel hij ruim vijf jaar voorzitter was geweest. Gelukkig was zijn assistent en opvolger, Blume, in dit opzicht van meer betekenis. Aan zijn goede verhouding met secretaris Van der Vinne danken we in ieder geval enkele aardige brieven die op ons onderwerp (verzamelen) licht werpen. Zo bijvoorbeeld van midden 1824: 
Goenoeng Parang 26 July 1824

Zeer geachte Vriend,

Mijne afwezigheid van Batavia heeft mij belet aan de vergadering van het Genootschap deel te nemen, dewijl ik reeds op den 23e der voorledene maand de omstreken van Batavia verlaten heb. Op den 30en Juny heb ik met Valette en Winter den Krater bezocht van den Tankuwang Prahu, alwaar wij een kleine toch interessante verzameling van onderscheidene vulkanische voortbrengselen hebben bijeengebracht, welke door ons voor het Genootschap is bestemd, en welke ik dadelijk na mijne terugkomst te Tjikao naar Batavia zal afzenden.

Den van Dr Burke ontvangene catalogus van gewassen [van de plantentuin in Mauritius] zende ik hierbij terug als dezelve reeds bezittende, maar dank u evenwel voor Uw vriendelijk aanbod. Gij zult mij verpligten door bijgaanden brief te laten afgeven en mij ook te verwittigen wat omtrent de druk van het $\mathrm{X}$ deel onzer verhandelingen is besloten.

Met vriendschap

Dr C L Blume 84

Blume, die sinds juni 1822 in het bestuur zat en die als opvolger van Reinwardt qualitate qua werd gevraagd, droeg vier studies bij aan de Verhandelingen. Hij was de drijvende kracht achter de verzending van planten en zaden naar collegae-hortulani in Europa en was - voor zover in Batavia - bij bestuursvergaderingen aanwezig en dacht aan het welzijn van het genootschap. Zijn verhandelingen zijn vooral gewijd aan plantkunde (eiken, pepersoorten, de begroeiing van de vulkaan Salak). Zijn stuk over de vulkaan Gede met onder ander geologische en plantenkundige informatie heeft hij in een wat vrijere vorm gegoten, waarvan hij secretaris Van der Vinne al bij aanbieding op de hoogte stelde:

Ik kan u bij deze een stuk voor het tiende deel der verhandelingen toezenden; Gij zult daaruit zien, dat ik deze keer in een geheel ander genre gevallen ben door eene stof te kiezen die voor elk verstaanbaar is. Somtijds dragen mijne uitdrukkingen in dit stukje den Karakter van het romanesque; doch dit is alleen toeteschrijven aan het voorwerp dat zich hier ter behandeling aanboodt. Het zal mij aangenaam zijn indien deze opstel uwe goedkeuring wegdragt. ${ }^{85}$

Van der Capellen had gelijk, toen hij in 1823 juist Blume liet noemen als een voorbeeld van een persoon die aan de bloei van het genootschap kon bijdragen. De plantenkundige was echter door zijn vele reizen en zijn werk in Buitenzorg te vaak afwezig om voor het museum een rol van betekenis 
te kunnen spelen. Wel was hij degene die zijn medebestuursleden wees op een verzameling natuurkundige instrumenten van een zekere Andriesse uit Semarang, die op de markt was voor een bedrag van $f 1.500$. Het genootschap vond dat, in oktober 1824, te duur. ${ }^{86}$ Het liet een soortgelijke kans in 1826 niet lopen. Toen werd een kleinere collectie, bestaande uit een 'physische apparatus' en een 'compleete toestel voor de Fantasmagorie' (een toverlantaarn avant-la-lettre) van Gisseler van Lenteloo te Batavia overgenomen voor $f 300 .{ }^{87}$

\section{De relatie met andere genootschappen}

Met leden op Java en op de buitenkantoren in Azië en met corresponderende leden in Europa had het genootschap in de achttiende eeuw al beschikt over een uitgestrekt netwerk van betrekkingen. Het uitbouwen en onderhouden van dit netwerk vroeg uiteraard zorg en was onder meer afhankelijk van de goede inspanningen van een secretaris en van de verbindingen in Azië en met Europa. De periode 1795-1816 was voor het onderhouden van die betrekkingen, vooral met verder van Batavia afgelegen posten en met Europa, een probleem geweest. De zich herstellende verhoudingen en de overdracht van de Aziatische bezittingen aan het nieuwe koninkrijk hadden als het ware uitgenodigd dit netwerk eveneens te herstellen.

Als eerste wapenfeit kon het genootschap de Engelse delen 7 en 8 van de Verhandelingen versturen. Vermoedelijk deed secretaris Wedding dit na de algemene vergadering van 1 juli 1817, toen Reinwardt voorzitter werd. Het lag voor de hand dat de drie vaderlandse genootschappen die vanaf het begin nauw bij de Bataviase zusterorganisatie betrokken waren, als eerste deze nieuwe delen kregen toegestuurd. Het Zeeuwsch Genootschap der Wetenschappen antwoordde op 3 augustus 1818 bij monde van secretaris J. de Kanter met een bedankbrief voor de nieuwe delen. 88

De collega's uit Haarlem reageerden niet en kregen dus in 1824 van secretaris Van der Vinne het pakket nog eens, nu ook met deel 9 met een begeleidingsbrief over de 'volslagen staat van werkeloosheid' van het eigen Bataviaasche Genootschap en het verzoek aan de Haarlemmers om de werken van de Hollandsche Maatschappij der Wetenschappen, verschenen sinds 1793 op te sturen. Van der Vinne had kennelijk zijn archief en de bibliotheek

\footnotetext{
86 ANRI KBG Dir 0042, vergadering 28-10-1824, punt 4.

87 ANRI KBG Dir 0052, vergaderig 5-1-1826, punt 14; Dir 0053, vergadering13-1-1826, punt 6; Dir 0055, vergadering 9-2-1826, punt 6.

88 ANRI KBG Dir 1505, brief van J. de Kanter aan Bataviaasch Genootschap, gedateerd Middelburg 3-8-1818.
} 


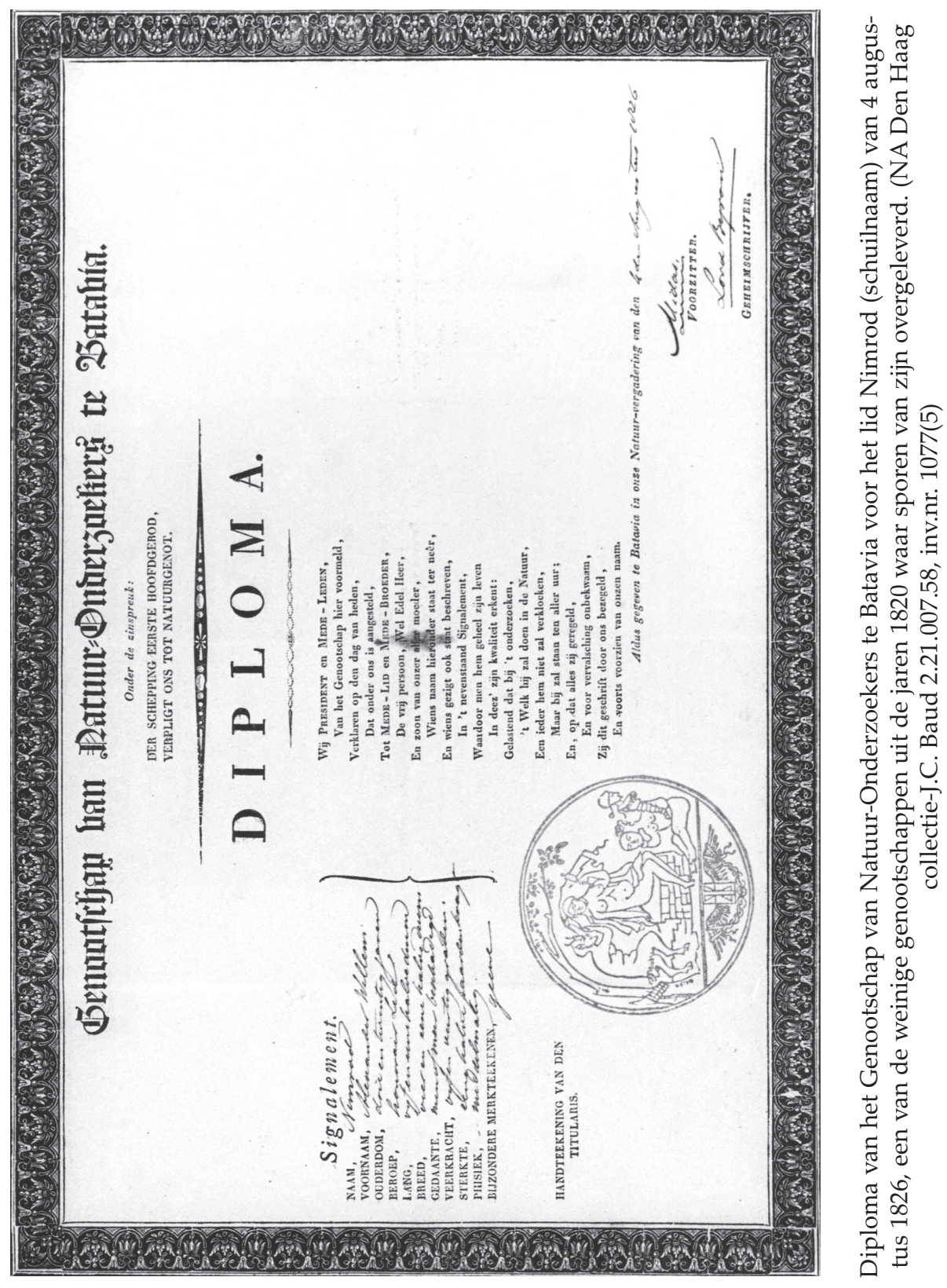


goed nagekeken en kunnen vaststellen dat er een breuk van meer dan dertig jaar in de betrekkingen was gevallen. ${ }^{89}$ In 1825 stuurde secretaris M. van Marum van de Haarlemse Maatschappij weer boeken naar Batavia. ${ }^{90}$ Van der Vinne gaf aldus gevolg aan de al in 1823 genomen beslissing om weer 'aanraking en briefwisseling' aan te knopen met vaderlandse genootschappen en maatschappijen. ${ }^{91}$

Het Bataafsch Genootschap der Proefondervindelijke Wijsbegeerte in Rotterdam had zelf enige tijd gesluimerd, was in 1823 weer programma's gaan rondsturen en had ongeveer tegelijkertijd post uit Batavia gekregen. Tweede secretaris J.B. Ockerstein schreef:

Aangenaam was het ons, na gelijk lotgeval, de ontwaking te vernemen van het Bataviaasch Genootschap, hetwelk mede een geruimen tijd had gesluimert. Hetzelve was in vroegre Jaren, meer dan eenig ander, met het onze verbroedert, en wij haasten ons derhalven UWE geluk te wenschen. ${ }^{92}$

Zo waren de banden met de drie belangrijke vaderlandse genootschappen weer aangeknoopt.

Vanaf 1817 waren instellingen blijven schrijven, reagerend op toezending van boeken of op berichten over de wederopstanding van het genootschap onder Raffles en onwetend van de geringe activiteit waarin het genootschap intussen al weer was vervallen. Brieven uit Amsterdam, Brussel, Middelburg, Groningen, Malakka en Den Haag uit 1817-1820 getuigen van het vertrouwen dat men in het genootschap stelde. ${ }^{93}$ Kennelijk waren deze reacties antwoorden op brieven van secretaris Wedding, want zij bevinden zich niet in het deel van het archief dat door Van der Vinne zo accuraat is bijgehouden. In het verslag van Maurisse voor de algemene vergadering van 1823 noemde hij onder de instellingen en personen die boeken hadden geschonken voor de bibliotheek van het genootschap, onder meer het Ministerie voor het publiek onderwijs, nationale nijverheid en de kolonien, het Koninklijk Instituut (Amsterdam), de rector en de senaat van de universiteit van Groningen, het Zeeuwsch Genootschap der Wetenschappen, het Natuur- en Scheikundig Genootschap (Groningen), het Provinciaal Utrechtsch Genootschap, de

89 ANRI KBG Dir 0982, nr 21, conceptbrief van Van der Vinne aan de Hollandsche Maatschappij der Wetenschappen, 8-4-1824.

90 ANRI KBG Dir 0982 nr 93, conceptbedankbrief na ontvangst door Van der Vinne op 21-31826.

91 ANRI KBG Dir 0023, vergadering 28-5-1823 bevat onder punt 16 een aantal beslissingen over de hervatte activiteiten.

92 ANRI KBG Dir 0041, vergadering van 9-9-1824, brief van Bataafsch Genootschap, Rotterdam s.d., vermoedelijk eind 1823 besproken tijdens die vergadering. Antwoord van Van der Vinne, 13-9-1824 in ANRI KBG Dir 0982, nr 30.

93 ANRI KBG Dir 1505, bundel stukken over de periode 1817-1827, nrs 1-8, 27-9, 49-50. 
Hollandsche Maatschappij der Wetenschappen (Haarlem), de voormalige luitenant-gouverneur Raffles, J.R. Vos (Chinsurah), de American Philosophical Society (Philadelphia), W. Milne (Malakka) en Blume (Buitenzorg) (VBG 9:37-8). Zo was dan het genootschap tegen het eind van 1823 ook weer in contact met diverse instellingen en personen op drie continenten. Het had in zijn structuur gekozen voor regelingen 'op het voetspoor der Vaderlandsche Genootschappen' en het had de contacten met die genootschappen weer aangeknoopt. Het behoorde tot de republiek van de letteren die de overgang van Republiek naar Koninkrijk had overleefd. De toespraak van Maurisse in 1823 is er zodoende een van tevredenheid.

Andere genootschappen en organisaties volgden tezelfder tijd. ${ }^{94}$ Een blik op de lijst van de corresponderende leden in deel 10 van de Verhandelingen (1825) zegt genoeg over het snel uitbreidende netwerk: Leiden, Utrecht, Delft, Den Haag, Amsterdam, Haarlem, Groningen, Franeker, Antwerpen, Gent, Brussel, Parijs, Göttingen, Wenen, Uppsala, Kaap de Goede Hoop, Mauritius, Calcutta, Chinsurah (Bengalen), Canton en Japan. En hierbij zijn nog niet gerekend de verschillende buitenlandse (gewone) leden onder wie personen van betekenis als Horsfield, Mackenzie en Raffles (VBG 10:65). Toen Van der Vinne in 1826 tussen mei en juli de correspondentie verzorgde en het nieuwe deel van de Verhandelingen wegstuurde kwam hij tot zeventig brieven en pakjes die Batavia op zes schepen verlieten, allemaal met buitenlandse bestemmingen. ${ }^{95}$ Tenslotte stuurde hij diverse kranten het programma van het genootschap of een nieuw deel van de Verhandelingen ter recensie toe, in 1823 naar de Haarlemsche Courant, de Kunst-en Letterbode, de Boekzaal der Geleerde Wereld, de Vaderlandsche Letteroefeningen en de redacteur van de Nederlandsche Staatscourant, in 1824 ook nog naar de Recensent ook der Recensenten. ${ }^{96}$ Van der Vinne was een bekwaam secretaris. Zijn werkzaamheden hebben zeker bijgedragen tot het vergroten van de bekendheid van het genootschap in Europa en elders. Het feit dat de berichten met informatie over algemene vergaderingen zo ruim verspreid werden en de Verhandelingen ook via de tijdschriften weer onder de aandacht van een groter lezerspubliek kwamen, tekent de kwaliteitssprong die gemaakt was bij de overdracht van het secretariaat van Wedding aan Van der Vinne.

Wat het Bataviaasch Genootschap op de genootschappen in het vaderland voor had, was de nabijheid van interessante en onbekende gebieden en het potentieel dat daarin gelegen was. Contacten met Calcutta, Malakka en Penang, Canton en Japan, waren naast de contacten in de Indonesische archipel, een goudmijn, als ze goed werden aangeboord. Daarom bijvoorbeeld

94 ANRI KBG Dir 0982, nr 25, conceptbrief van 17-4-1824 van Van der Vinne.

95 ANRI KBG Dir 1505 bevat de verzendlijsten onder nr 62-67.

96 ANRI KBG Dir 0982, nr 15a-b, 16a. 
stelde Blume direct Ph.F. von Siebold voor als corresponderend lid (1823) toen bekend werd dat deze chirurgijn-majoor voorbestemd was om als geneesheer naar Japan te gaan. ${ }^{97}$ Toen Von Siebolds eerste brieven binnenkwamen, begin 1825, zorgde hij voor een primeur door het eerste Aziatische lid aan het genootschap voor te dragen: zijn collega, de geneesheer van de keizer van Japan, Katsura Gawa Hoken alias Wilhelmus Botanicus. In dezelfde vergadering, waarin Siebolds brieven werden besproken, op 10 februari 1825, stelde bestuurslid Blom, procureur-generaal bij het Hooggerechtshof, de eerste twee Indonesische leden voor, de Penambahan van Sumenep, Noto Kosumo, en de regent van Bezoeki, Raden Adipati Aria Prawiera Adie Ningrat. De laatste antwoordde op 26 maart 1826 vanuit zijn woonplaats met een dankbrief voor de uitverkiezing. ${ }^{98}$ Het was een historische beslissing die op 13 januari 1826, de afscheidsvergadering van Van der Capellen, bekrachtigd werd: het genootschap had voor het eerst niet-Europese leden. ${ }^{99}$ Overigens stond het genootschap hiermee niet vooraan. Het Javaasch Weldadig Genootschap was in 1820 al voorgegaan. De Penambahan van Sumenep en de regent van Semarang, Adimongolo, waren daar toen al lid van (Almanak 1820).

Een andere interessante geografische uitbreiding van de belangstelling van het genootschap betrof Bengalen, waar het in Chinsurah sinds 1823 twee corresponderende leden had: resident D.A. Overbeek en de arts J.R. Vos. ${ }^{100}$ Zowel Overbeek als Vos reageerden met een bedankbrief op hun uitverkiezing tot het lidmaatschap. De laatste liet deze vergezeld gaan van vijf boeken in vijf verschillende talen, waaronder zulke exotische als het Harotees en Bengaals. Vos had vroeger ook al uit Rotterdam stukken gestuurd naar het genootschap. ${ }^{101}$ In 1825 was Overbeek in Batavia en op advies van Blom werd toen een speciale vergadering belegd, waarin Overbeek een uitleg kon geven over de 'brahmaanse godsdienst' en over de geschiedenis, godsdienst en mythologie van de hindoes. Overbeek bracht een zilveren Visnu mee voor het genootschap en een aantal boeken. Naar zijn uitleg werd nogal uitgekeken, zo lijkt het, want beschermheer Van der Capellen, die anders alleen op algemene vergaderingen aanwezig was, maakte hier een uitzondering en wilde naar Overbeek komen luisteren. Overbeek gaf onder meer commentaar op de in deel 1 en 2 van de Verhandelingen verschenen vertaling van de Sadjara

97 Von Siebold werd voorgesteld door Blume op 12-6-1823. Zijn acceptatiebrief is van 15-61823. ANRI KBG Dir 0024 en 0025, vergaderingen van 12-6-1823 en 3-7-1823.

98 ANRI KBG Dir 0057, vergadering 13-4-1826.

99 ANRI KBG Dir 0044, vergadering 10-2-1825, waar het voorstel van Blom vermeld wordt. ANRI KBG Dir 0053-4, vergaderingen 13-1-1826 voor de bekrachtiging.

100 ANRI KBG Dir 0024, vergadering 12-6-1823, Overbeek werd door Blom voorgedragen terwijl Vos tijdens de Alg.Verg. van 7-10-1823 lid werd (VBG 9:23.

101 ANRI KBG Dir 0033, vergadering 25-3-1824, brief van Overbeek; de brief van Vos bij de vergadering van 15-4-1824. ANRI KBG Dir 0034. 
Radja Djawa en zou na terugkeer in Chinsurah proberen zelf een verhandeling te schrijven. Hem werd tevens gevraagd om in Bengalen boeken voor het genootschap te kopen over de geschiedenis, de godsdienst en de 'fabelleer' van de hindoes. ${ }^{102}$ Overbeeks commentaar verscheen in deel 10 van de Verhandelingen. In deel 11 droeg hij een kort opstel bij over Boeddha en het boeddhisme, terwijl Vos in deel 10 een opstel over cholera schreef.

Zo had het genootschap onder Van der Capellen een netwerk hersteld, dat in Europa en Azië zijn zwaartepunten had en het centrum in Batavia. Toen de landvoogd vertrok na de afscheidsvergadering van 13 januari 1826, kon hij terugzien op drie jaren waarin het genootschap, mede door zijn nadrukkelijke steun, kon bogen op een aantal geslaagde ontwikkelingen: nieuwe delen Verhandelingen, een bloeiend genootschapsleven met regelmatige vergaderingen, aandacht voor de bibliotheek en het kabinet, een aanzienlijke uitbreiding van het ledenbestand, waarin voor het eerst ook Aziaten waren opgenomen. Bij zijn afscheid waren er twee beschermheren, elf bestuursleden, achttien ereleden, 48 corresponderende leden, 44 gewone leden in Batavia, 48 gewone leden buiten de hoofdplaats en nog eens 32 gewone leden buitenslands. Met 201 leden was het genootschap in ruim twee jaar verdubbeld en had het een gelijke omvang als in de achttiende eeuw (Almanak 1826). 


\section{Hoofdstuk IV}

\section{Japanse zaken en museumplannen (1826-1840)}

\section{Bestuur onder Du Bus de Gisignies}

Het vertrek van Van der Capellen beroofde het genootschap van een actieve beschermheer. Als teken van waardering werd hem tijdens een afscheidsvergadering op 13 januari 1826 het honorair beschermheerschap aangeboden. De beslissing tot het instellen van deze erefunctie was een week ervoor (5 januari) door het bestuur genomen. Tevens was besloten luitenant-gouverneur-generaal H.M. de Kock in de openvallende plaats van (gewoon) beschermheer te benoemen. Hij werd daarmee na Lord Minto en Van der Capellen de derde persoon in die functie. ${ }^{1}$ De Kock was commandant van de troepen in Indië en trad sinds 1 januari 1826 als waarnemend landvoogd op. Hij was sinds 1823 lid van het genootschap en in hetzelfde jaar in het bestuur benoemd. ${ }^{2}$ Tijdens de afwezigheid van Van der Capellen op diens reizen had hij getoond het genootschap goed gezind te zijn, maar na het uitbreken van de Java-oorlog in 1825 had hij andere zorgen aan het hoofd. De Kock woonde de vergadering van 5 januari 1826 bij en stelde toen de latere gouverneur-generaal en minister van koloniën J. van den Bosch als erelid voor. Over de zich op weg naar Batavia aan boord van de 'Bellona' bevindende, nieuwe commissaris-generaal Léonard du Bus de Gisignies (1780-1849) werd met geen woord gerept.

Du Bus was voor de duur van drie jaar door de koning met buitengewone volmachten bekleed met duidelijke instructies voor een heel ander financieel beleid. Onder Van der Capellen was door te grote ruimhartigheid en achter-

1 Raffles leek de eerste beschermheer te zullen worden, maar hij verkoos de voorzittersplaats en suggereerde Lord Minto de eer te gunnen. De opperdirecteuren en directeuren in de achttiende eeuw kunnen moeilijk als beschermheren worden gezien, waar het genootschap immers Willem $\mathrm{V}$ voor de eer had uitgekozen, die op het aanbod niet inging. ANRI KBG Dir 0052-53, vergaderingen 5-1-1826 en 13-1-1826.

2 ANRI KBG Dir 024, vergadering 12-6-1823, punt 5. De algemene vergadering van 7-10-1823 bevestigde eerst De Kock als lid, waarna hij direct in het bestuur werd opgenomen (ANRI KBG Dir 0029). 
wege blijvende financiële rapportage het zicht op de beschikbare middelen onduidelijk geworden. Dat had in het moederland de nodige irritatie opgeroepen. Van melkkoe dreigde de kolonie een bodemloze put te worden. Dat er een andere wind zou gaan waaien bij het in functie treden van Du Bus, viel te verwachten. Erg welkom was hij dan ook niet. Van der Capellen, die lange tijd nodig had om te vertrekken, ging haastig scheep toen de 'Bellona' de rede van Batavia naderde. Het kwam tussen de gaande en komende man tot een kort onderhoud aan boord van het schip, waaraan Du Bus slechte herinneringen overhield. Hij voelde zich met te weinig eerbewijs behandeld (De Prins 2002:116-8). De sfeer in Batavia was tegenover de voormalige gouverneur van de provincie Zuid-Brabant niet erg positief. Hij was niet welkom en zijn komst veroorzaakte een scheuring in de gelederen van de koloniale gemeenschap: voor of tegen Du Bus (De Prins 2002:117-20).

$\mathrm{Du}$ Bus de Gisignies had bij zijn aantreden weinig ceremoniële functies aangenomen. Bij het Nederlandsch-Oost-Indisch Bijbelgenootschap was De Kock als beschermheer en voorzitter aangesteld, bij het Zendelinggenootschap was hij eveneens beschermheer, functies waarin hij Van der Capellen was opgevolgd. Het Javaasch Weldadig Genootschap bleef zonder voorzitter. De nieuwe gouverneur-generaal J. van den Bosch zou in 1830 deze erefuncties overnemen. Natuurlijk was Du Bus, afkomstig uit het katholieke Zuiden, een exponent van een andere levensopvatting, maar in het Batavia van Van der Capellen was ook pastoor Wedding bestuurslid van het Bijbelgenootschap geweest. De speciale taak die Du Bus was opgedragen, gekoppeld aan de beperkte duur van zijn aanstelling - hij zou drie jaar blijven - kan bij de geringe animo tot het aanbieden van erefuncties hebben meegespeeld. Het lijkt erop dat de functies overgedragen waren aan De Kock op het moment van Du Bus' aankomst. Hij liet hoe dan ook deze taken aan De Kock over (Almanak 1826). De lijn loopt aldus van Raffles en Van der Capellen via De Kock naar Van den Bosch voor wat betreft een aantal organisaties op het terrein van kunst, wetenschap, bijbelstudie en zending.

Wel richtte Du Bus al op 19 februari 1826, nauwelijks twee weken na zijn aankomst, een afdeling van het in Brussel gevestigde Genootschap van Waterloo op, dat in korte tijd meer dan 400 leden telde. De werkende leden en het bestuur van de nieuwe organisatie weerspiegelden de bestuurlijk top van Batavia én van het Bataviaasch Genootschap. De Kock, Maurisse, Blom, Bousquet, Radijs en Van der Vinne werden lid. De laatste werd secretaris, ook van dít genootschap. Het is duidelijk dat Du Bus, die in Brussel voorzitter van het genootschap was geweest, aan deze nieuwe organisatie meer belang hechtte. De massale toeloop liet zien dat zijn ambtenaren hem daarin gewillig volgden. De Bataviasche Courant nam mededelingen over het nieuwe genootschap en aanvullingen op de ledenlijst in diverse afleveringen van het jaar 1826 op. Het leek alsof de geest van de slag van Waterloo na jaren ook ineens 
het enthousiasme van de vaderlanders overzee wekte. De eerste viering van de ondergang van Napoleon door het genootschap te Batavia werd opgeluisterd door algemene toejuichingen toen bekend werd dat de kraton van Plered door de troepen van kolonel J.D. Cochius was ingenomen. ${ }^{3}$ Zo konden de nationale gevoelens tot uiting komen in een bijeenkomst van een organisatie die geïnitieerd was door de nieuwe man, een genootschap bovendien met nationale ambities. Bij de toeloop tot het nieuwe genootschap stak het ledental van het Bataviaasch Genootschap, maar net 200, mager af.

Op 10 maart 1826 besloot het bestuur van het Bataviaasch Genootschap de commissaris-generaal het erelidmaatschap aan te bieden. Een maand later bleek een commissie uit het bestuur hem te hebben bezocht om hem hiervan op de hoogte te stellen en hem tegelijkertijd over het genootschap in te lichten. ${ }^{4}$ Op den duur kon Du Bus met deze verhoudingen - hij erelid, De Kock beschermheer - niet leven.

\section{De relatie met de overheid}

Het genootschap zou al snel van de bestuurswisseling in de Indische regering merken. De eerste tekenen van Du Bus de Gisignies' financiële beleid werden voelbaar, toen het in mei 1826 van de Landsdrukkerij een brief ontving met een rekening voor papier, dat nodig was voor een herdruk van deel 2 en voor de druk van deel 11 van de Verhandelingen. Er werd protest aangetekend, omdat het genootschap van het betalen van papier was vrijgesteld. In de vergadering van 8 juni, waar deze kwestie besproken werd, kwam ook een brief ter tafel van de hoofddirecteur van Financiën, die onder verwijzing naar een besluit van de commissaris-generaal van 2 mei 1826 bekend maakte 'dat de actueele staat van financien niet langer toelaat dat de kosten van het onderhoud van het Locaal des Genootschaps ten laste van den lande vallen, moetende de zelve worden bestreden uit de particuliere kas van het Genootschap. ${ }^{5}$ Hierop volgde een brief van de resident van Batavia over het maandelijks onderhoud ten bedrage van vijftien gulden. ${ }^{6}$ Nog weer later kwam er een brief over de onmogelijkheid om papier door te verkopen aan het genootschap. Secretaris Jan van der Vinne noteerde in de notulen van de

3 Dat gebeurde op 19 juni 1826, een dag na de verjaardag van de slag bij Waterloo. Zie de ledenlijsten van het Genootschap van Waterloo in de Almanak van Nederlandsch Indië vanaf 1826. Bataviasche Courant 22-2-1826, 18-3 en 29-3, 7-5, 21-6 en 28-6-1826. De krant van 21-6-1826 voor het verslag van de eerste viering.

4 ANRI KBG Dir 0056, vergadering 10-3-1826, punt 11; Dir 0057, vergadering 13-4-1836, punt 2.

$5 \quad$ ANRI KBG Dir 0060, vergadering 8-6-1826, punt 4 en 13.

$6 \quad$ ANRI KBG Dir 0058, vergadering 13-7-1826, punt 7. 
vergadering van 10 augustus 1826 laconiek: 'Dat hij reeds van de verdere aanvrage van papier uit 's Lands pakhuizen heeft afgezien.' ${ }^{7}$ Bij de algemene vergadering van 21 december 1826, waar maar drie bestuursleden aanwezig waren, maar wel alle in Batavia aanwezige leden, werd gemeld dat Du Bus het erelidmaatschap had aanvaard. ${ }^{8}$ Over de tegenvallers waar het genootschap mee te kampen had, viel volgens het verslag van die vergadering geen woord. Toch leek het gunstige tij van Raffles en Van der Capellen voorbij. Vooral het onderhoud van het gebouw aan de Rijswijkstraat en een vergoeding voor drukwerk aan de Landsdrukkerij zou in korte tijd in de kas van het genootschap voelbaar worden. Het genootschap leek op zichzelf teruggeworpen, de overheid keerde zich af.

De algemeen secretaris van het gouvernement, tevens bestuurslid van het genootschap, J. Bousquet, zag uit hoofde van zijn functie deze brieven passeren. Hij wist als geen ander dat bezuinigingen het genootschap troffen, want alle maatregelen gingen uit van zijn bureau. Hij woonde echter slechts één keer in 1826, direct na zijn uitverkiezing tot bestuurslid, een vergadering bij. In 1827 werd er slechts vijf keer door het bestuur vergaderd. Waarnemend voorzitter Lenting en secretaris-penningmeester Van der Vinne, fiscaal bij de Raad van Justitie, waren steeds aanwezig. Verder was procureur-generaal van het Hooggerechtshof G.T. Blom een ijverig bestuurslid, terwijl de vicepresident van het zelfde gerechtshof G. Buijskes zich twee maal liet zien. Interessant was de mededeling van Blom, in april 1827, dat hij van Du Bus had begrepen dat deze

gaarne in nadere aanraking met het Genootschap zou wenschen te komen, ten einde aan hetzelve eenige inzigten medetedeelen, welke welligt in het belang van het Genootschap zouden zijn, en misschien tot strekking hebben, om hetzelve, tot zijnen voormaligen werkkring en nut terug te brengen.

In de ogen van Du Bus waren de zaken binnen het genootschap aan het verlopen. De woorden van Blom klonken in de weergave van de secretaris tamelijk vaag, maar het bestuur ging erop in. Lenting en Van der Vinne gingen de landvoogd uitnodigen om in het bestuur zijn inzichten te komen toelichten. ${ }^{9}$ Terwijl nog op de afspraak werd gewacht, trok de directeur van Produkten en Civiele Magazijnen ook nog eens het gratis drukken van de Verhandelingen bij de Landsdrukkerij in. ${ }^{10} \mathrm{Nu}$ moest niet alleen voor papier, maar ook voor de met het drukken gemoeide manuren worden betaald.

De belangstelling van de commissaris-generaal leidde pas anderhalf jaar

ANRI KBG Dir 0061, vergadering 10-8-1826, punt 4.

ANRI KBG Dir 0063, algemene vergadering 21-12-1826.

ANRI KBG Dir 0066, vergadering 19-4-1827, punt 7.

10 ANRI KBG Dir 0069, vergadering 24-1-1828, punt 4. 
later tot iets naders. Het genootschap drong niet aan en kennelijk had Du Bus evenmin haast. Het bestuur was intussen bijna tot nietsdoen vervallen. Maandenlang kwam het niet bijeen. Op 7 november 1828 kwam het tijdens een buitengewone bestuursvergadering, gevolgd door een algemene vergadering tot een kleine coup. Du Bus had het initiatief genomen tot deze vergaderingen van het genootschap 'ten einde eene opwekking te verschaffen, om deszelfs belangrijke werkzaamheden die door den drang van Omstandigheden sedert eenigen tijd zijn gestremd geweest met vernieuwde veerkracht te hervatten. ${ }^{\prime 1}$ De vergadering met Lenting, Buijskes, Bousquet, De Serière en Van der Vinne werd gedomineerd door Du Bus vanaf het moment dat hij zich bij hen voegde. Hij had bezwaar tegen de kandidaatstelling van bepaalde leden voor bestuursfuncties en wilde niet dat de uit Soerabaija teruggekeerde De Serière zijn plaats zo maar weer innam. Daarom dwong hij een andere kandidatenlijst af. Blume, die in Nederland was, mocht niet van de bestuurslijst worden geschrapt. Die zou nog kunnen terugkeren. Ook voor het gewone lidmaatschap had Du Bus suggesties. Zijn twee neven kwamen op de lijst te staan. De eerste was Léonard Henri du Bus, in het kabinet van zijn naamgenoot werkzaam en met hem naar Batavia gereisd, de tweede, Charles Louis, was al sinds 1819 als militair op Java (De Prins 2002:189-90). De commissaris-generaal voegde nog vijf anderen aan de lijst van kandidaatleden toe. ${ }^{12}$

Erelid Du Bus werd ook in de er direct opgevolgde algemene vergadering in de voorzitterstoel gekozen, zodat hij zijn stempel op de bijeenkomst kon drukken. Hij begon met te zeggen dat hij daar niet als hoofd van de regering zat, maar die mededeling zal door de aanwezigen als een dooddoener zijn opgevat. Tot nieuwe bestuursleden werden gekozen: De Serière, P. Merkus, C.M. Baumhauer, J. Schneither en E.A. Fritze, allen ambtenaar bij het binnenlands bestuur, al was De Serière als predikant uitgekomen (Fasseur 1997:41). Staande de algemene vergadering werd een aparte, besloten bestuursvergadering gewijd aan de verkiezing van een nieuwe voorzitter. Algemeen secretaris en rechterhand van de commissaris-generaal, Bousquet, bleek met zes stemmen tegen vier de voorkeur te hebben boven de president van het Hooggerechtshof, de latere gouverneur-generaal Pieter Merkus. Het erelid deed aan deze stemming over het voorzitterschap zelf mee. Bousquet stribbelde nog wat tegen door zich te beroepen op zijn drukke werkzaamheden, maar accepteerde uiteindelijk. Lenting, die het voorzitterschap had waargenomen, bleef bestuurslid.

Bousquets eerste voorstel als voorzitter was om Du Bus tot honorair

11 ANRI KBG Dir 0070, buitengewone bestuursvergadering 7-11-1828, punt 5-10.

12 ANRI KBG Dir 0070, buitengewone vergadering 7-11-1826. Dir 0077, vervolg van deze vergadering. 
beschermheer te benoemen, waardoor hij naast Van der Capellen en boven De Kock kwam te staan. Het was bijna een rehabilitatie voor de geringe égards bij en na het vertrek van Van der Capellen jegens Du Bus betoond. De vergaderde leden namen dit voorstel aan, zodat het genootschap nu twee honoraire beschermheren had én een gewoon beschermheer. Du Bus beloofde 'nuttige bijdragen' te leveren om de toestand van 'werkeloosheid' op te doen houden. Verder kondigde hij het verschijnen van het twaalfde deel van de Verhandelingen aan. Belangrijker nog was zijn mededeling over plannen tot het stichten van een botanische tuin en een museum in Weltevreden, waaraan hij toevoegde 'dat het voorzeker aangenaam voor het Gouvernement zal zijn, dat het Bataviaasch Genootschap het zijne ertoe bijdrage om deze instelling op eenen zoodanigen voet te brengen, als de omstandigheden immer zullen gedoogen.'13 Tenslotte deelde Du Bus nog mee dat de natuurkundigen in overheidsdienst, leden van de Natuurkundige Commissie, de opdracht hadden gekregen van alle naturalia die zij verzamelden, drie exemplaren aan het gouvernement ter beschikking te stellen, twee voor het Koninklijk Kabinet in het vaderland en één voor het nieuw op te richten museum. In de woorden van secretaris Van der Vinne, die het verslag opstelde, heette het dat de vergadering het plan toejuichte en dat in het bestuur zou worden bezien hoe het genootschap zich 'met de door het Gouvernement geprojecteerde instelling kan verwantschappen.' ${ }^{14}$ Nogal koele bewoordingen voor een plan van zijn hoogste baas. De bestuursvergadering en de algemene vergadering waren wel goed bezocht. De secretaris moest later met bode A. Eekhart $f$ 63,50 afrekenen voor de verteringen: veertien flessen wijn, twee flessen madeira, twee flessen bier, zes kruiken spawater, voor drie gulden aan jenever en brandewijn en verder koffie, thee en klein gebak en vijftien gulden voor kaarsen en olie. ${ }^{15}$

De voornaamste reden voor Du Bus' belangstelling voor het genootschap leek het welslagen van zijn plan voor een nieuwe botanische tuin en een nieuw museum. Het voornemen tot de oprichting van die twee nieuwe instellingen lichtte Du Bus na de bestuurswijziging dadelijk toe. Het genootschap moest zich daarvoor gaan inzetten en daarom moest Lenting als voorzitter wijken voor Bousquet. In de vergadering die gedomineerd werd door Du Bus en Bousquet durfde kennelijk niemand te vragen wat er met de bestaande instellingen zou gaan gebeuren. Zou de in 1817 opgerichte tuin in Buitenzorg blijven bestaan? Zou de Natuurkundige Commissie aan de nieuwe tuin worden verbonden of juist vanuit Buitenzorg blijven werken? Zou het kabinet/

13 ANRI KBG Dir 0071, verslag van Van der Vinne van de algemene vergadering, punt 6 en

8.

14 ANRI KBG Dir 0071, punt 8.

15 ANRI KBG Dir 1331 bevat een kwitantie van 4-12-1828 voor de verteringen van beide vergaderingen. 
museum van het Bataviaasch Genootschap, dat al sinds 1779 bestond, in het nieuwe museum opgaan? Zou het nieuwe museum zich alleen met natuurwetenschappen bezighouden? De woorden van Van der Vinne in zijn verslag overlezende, lijkt het er het meest op dat Du Bus het genootschap inschakelde voor zijn eigen plannen, of dat hij tegenwerking wilde voorkomen. De koele ontvangst in Batavia en het gevoel buitengesloten te zijn, hadden hem kennelijk ingegeven dat hij met eigen instellingen meer eer kon inleggen, zoals hem met het Genootschap van Waterloo gelukt was.

De nauwere betrokkenheid van de commissaris-generaal bij de belangen van het genootschap wierp wel direct goede vruchten af. Hij kwam terug op de eerder genomen bezuinigingsmaatregelen. Tijdens de eerste bestuursvergadering van 1829 werd besloten de honorair beschermheer te vragen om het besluit tot het intrekken van het gratis gebruik van de Landsdrukkerij door het genootschap te herroepen. Het gouvernement besloot op 24 februari 'dat de Verhandelingen, en andere werken van het genootschap gratis ter Landsdrukkerij worden ter pers gebragt' ${ }^{16}$ Ook andere signalen wezen erop dat de kille bezuinigingswind van 1826-1828 was omgeslagen in een sfeer van welwillendheid. In april 1829 kwam de toestemming van de commissaris-generaal aan het genootschap om stukken uit het archief van het gouvernement te lichten en die door publicatie bekend te maken. In mei 1829 schonk het gouvernement de bij de Landsdrukkerij resterende exemplaren van Blume's Flora, waarover het genootschap vrijelijk mocht beschikken. In juli van dat jaar stuurde de directeur van de drukkerij 200 exemplaren van Roorda van Eijsinga's Maleise woordenboek en Van Angelbeeks Maleise spraakkunst, alsook een zelfde aantal van de titeluitgave van de Isma Jatiem, die ook in de Verhandelingen was verschenen. Daarmee kon secretaris Van der Vinne vele leden in Indië en Europa gelukkig maken.

In dezelfde maand besloot De Kock dat het genootschap om advies moest worden gevraagd over de plannen van Von Siebold om met zijn collecties naar Nederland door te reizen. ${ }^{17}$ In ieder geval was de relatie met het gouvernement in 1829 weer hersteld. De verslagen van de zes bestuursvergaderingen laten zien dat er van een duidelijke toename van activiteiten sprake was. Er kwamen tientallen boeken binnen voor de bibliotheek, er was correspondentie met allerlei personen en instellingen in Europa, er kwamen kisten met mineralen uit Japan en verschillende leden stuurden kopij in voor de Verhandelingen. De ingreep van Du Bus moet daarom als positief worden beschouwd.

16 ANRI KBG Dir 0072, vergadering 6-2-1829, punt 11, en Dir 0073, vergadering 6-3-1829, punt 8 en bijlage 11 .

17 ANRI KBG Dir 0074, vergadering 23-4-1829, punt 16 en bijlage 13; Dir 0075, vergadering 2-7-1829, punt 5 en 14, bijlage 3-5, 10; Dir 0076, vergadering 10-9-1829, punt 5 en bijlage 2. 
Toch had het genootschap te lijden gehad, niet alleen van de bezuinigingen, ook door andere factoren. Bij het vertrek van Van der Capellen was er nog een goed bezet bestuur geweest van elf leden. Toen aan het eind van hetzelfde jaar 1826 deel elf van de Verhandelingen uitkwam, waren er al vier open plaatsen, terwijl één bestuurslid naar Soerabaija was vertrokken. Pas in november 1828 zouden die plaatsen worden opgevuld. Na de afscheidsvergadering met Van der Capellen was er in december 1826 nog één keer een algemene vergadering geweest, maar die had een beperkte betekenis gehad. Men wilde nieuwe leden benoemen om zo de genootschapskas te steunen en belangstellenden voor de maandelijkse lezingen te werven. ${ }^{18}$ Vervolgens liet de zojuist beschreven vergadering onder Du Bus tot 1828 op zich wachten en de daaropvolgende algemene vergadering tot het jaar 1832 .

Ook het aantal bestuursvergaderingen liep terug: in 1826 nog tien, in 1827 vijf, in 1828 twee, in 1829 zes en in 1830 drie. Ondertussen stagneerde de druk van de Verhandelingen. Met veel moeite kwam deel elf nog net in 1826 van de pers, daarna was het wachten tot 1830 op deel twaalf. Het ligt voor de hand om naast de aanvankelijke tegenwerking van de commissaris-generaal te denken aan de Java-oorlog, die grote opschudding teweeg bracht in de Europese gelederen. Het actieve lid H.J. Domis, resident te Pasoeroean, schreef in 1827 aan Van der Vinne: 'de zaken staan aan den kant van Java niet zeer voordeelig', waarna de anders zo alerte Van der Vinne ruim een jaar wachtte met antwoorden, om zich onder verwijzing naar de tijdsomstandigheden voor dat oponthoud te verontschuldigen. ${ }^{19}$ Beschermheer De Kock moest zich vanuit Magelang eveneens verontschuldigen met verwijzing naar zijn ambtsplichten die het hem onmogelijk maakten tijd aan iets anders te wijden. ${ }^{20}$ Nog in februari 1830 beriep het genootschap zich in een brief aan het gouvernement waarin het verzocht om enkele stukken te mogen publiceren op de

noodlottige tijdsomstandigheden waaronder deze gewesten gebukt zijn geweest, en welke het genootschap beroofd hebben van de medewerking van vele van deszelfs verdienstelijke medeleden, wier aandacht geheel gevestigd op de handhaving van publieke rust en veiligheid of op de algemeene belangen van den Staat, hen niet heeft toegelaten om zig bezig te houden met zoodanige voorwerpen, waarvan de beschouwing en behandeling meer eigenaartig behoort tot eenen Staat van rust, en vrede, en tot eene geregelde orde van zaken, en niet door het geklik der wapenen moet worden gestoord. ${ }^{21}$

18 ANRI KBG Dir 0062, vergadering 29-11-1826, punt 35; Dir 0063, vergadering 21-12-1826.

19 Brief van H.J. Domis van 27-12-1827, ANRI KBG Dir 0069, vergadering 24-1-1828, punt 3 en bijlage 3. Minuut-antwoord van Van der Vinne, 4-2-1829, ANRI KBG Dir 0984, 1829 nr 8.

20 Brief van H.M. de Kock, Magelang 21-2-1829, ANRI KBG Dir 0073, vergadering 6-3-1829, punt 31 en bijlage 10 .

21 ANRI KBG Dir 0080, minuut-brief van 22-2-1830 bij de vergadering 6-5-1830, punt 2 en bijlage 2 . 
Toen de oorlog voorbij was, nadat Diponegoro in 1830 in Magelang door beschermheer De Kock was gevangengenomen, werd opgelucht naar die goede afloop verwezen. Men ging ervan uit dat het met het genootschap ook weer beter zou gaan. Du Bus had in januari 1830 het gezag overgedragen aan gouverneur-generaal J. van den Bosch, die bijna ongemerkt beschermheer werd en ook niet veel aandacht aan het genootschap besteedde. Het museumplan bleef onder zijn beheer onafgewerkt liggen. Du Bus, die na zijn 'coup' als eerste vermeld werd onder de honorair beschermheren (1829), werd direct na zijn vertrek weer op de tweede plaats gezet, na Van der Capellen. In 1835 raakte hij de titel van erebeschermheer kwijt en werd hij in de ledenlijst weer als erelid vermeld, zoals hij indertijd ook was begonnen. Van der Capellen bleef tot zijn dood de ereplaats bezetten. Meteen na Du Bus' vertrek verliep het Genootschap van Waterloo. Had het in 1829 nog 500 leden geteld, in 1830 viel het direct terug tot een onbeduidend groepje. In 1831 voerde Van den Bosch er nog wel het bestuur van aan, maar in 1834 werd het genootschap niet eens meer in de almanak vermeld. Het was teveel een organisatie van Du Bus geweest. De politieke veranderingen in het koninkrijk vanaf 1830 maakten bovendien het steeds maar herdenken van een slag, die in het opstandige België had plaatsgevonden minder opportuun. Het Bataviaasch Genootschap zou juist in de loop van de jaren 1830 groeien in ledental. De overvleugeling door Du Bus' genootschap was tijdelijk van aard geweest.

\section{Persoonlijkheden: Domis, Von Siebold, Goethe}

In deze jaren kon het genootschap steunen op twee belangrijke bestuursleden: waarnemend voorzitter Lenting en secretaris Van der Vinne. Zonder hun voortdurende aanwezigheid, zonder hun initiatieven en het bijhouden van de administratieve zaken, financiën en archivering inbegrepen, zou het genootschap de verschillende stormen mogelijk niet hebben overleefd. Het genootschap steunde daarnaast op leden van buiten Batavia, die de correspondentie onderhielden en die bijdragen instuurden voor de Verhandelingen. Twee van hen verdienen extra aandacht: Hendrik Jacob Domis (1782-1842) en Philipp Franz von Siebold (1796-1866).

\section{Domis}

Deze Alkmaarse burgemeesterszoon kwam in 1806 naar Indië, waar hij na lagere functies in Batavia te hebben bekleed, onder Janssens in Cheribon terechtkwam. Daar trouwde hij in 1811 met de dochter van de resident, Sara Francina Waterloo (ENI s.v. Domis; De Haan 1935b:536). Onder het Engelse bestuur verhuisde hij naar Semarang. Langzaam maar zeker klom hij op tot 
hij in 1822 resident van deze plaats werd. Tijdens de bestuursvergadering van het genootschap op 25 maart 1824 werd hij kandidaat gesteld voor het lidmaatschap, wat hij mogelijk naast zijn positie als resident ook aan zijn brede belangstelling te danken had. Hij reageerde meteen met een positieve bedankbrief en stuurde in augustus een beschrijving met oudheidkundige elementen over Salatiga, de Merbaboe en de zeven tempels van Oengaran. Ook stuurde hij tekeningen mee van hindoe-beelden die hij in zijn tuin had staan en een afschrift van een inscriptie in zijn bezit. ${ }^{22} \mathrm{Na}$ suggesties te hebben ontvangen van secretaris Van der Vinne over zijn Salatiga-stuk - hij moest nog maar eens kijken wat Raffles, Crawfurd en Mackenzie over het zelfde onderwerp hadden geschreven - werkte hij zijn eerste opstel om en daarna kon het in deel 10 van de Verhandelingen (1825) opgenomen worden. ${ }^{23}$ Hij gaf toe dat zijn kennis van het hindoeïsme beperkt was, waardoor hij er niet over kon uitweiden. Voor hetzelfde deel van de Verhandelingen droeg Domis een opstel bij over een in 1824 geboren, misvormde baby (VBG 10:105-30, 131-46).

Een paar maanden na het inzenden van laatstgenoemde verhandeling overleed Domis' echtgenote, Sara Francina, op 33-jarige leeftijd na een miskraam. De bedroefde weduwnaar, vader van zes jonge kinderen, deed er uitvoerig kond van in de Bataviasche Courant (27-11-1824). Die krant was voor Domis niet alleen het medium voor het bekendmaken van geboorten en overlijden in de eigen familie, hij gebruikte het ook voor aankondigingen van het overlijden van inheemse functionarissen, zoals de regenten van Demak en Semarang in 1826 in twee of drie talen (Nederlands, Javaans en Maleis), aankondigingen die niet zo gewoon waren in die jaren. Hij was tegenover het genootschap genereus. Op de oproep van 1825 om steun in de vorm van geld en voorwerpen voor de verzameling, reageerde Domis direct met een storting van vijftig gulden, een Molière-uitgave 'fraay gebonden in Engelsche banden, verguld, velin papier' voor de bibliotheek en een 'Braminsche Lamp' voor het kabinet. Domis bleek een verzamelaar van oudheden te zijn. Op het terrein van zijn woning stonden, zoals reeds vermeld, beelden, die van tempels afkomstig waren. ${ }^{24} \mathrm{Hij}$ zette daarmee een traditie voort die door Engelhard als gouverneur van Java's Noord-Oostkust was ingezet.

Domis liet zich ook op ander gebied van een bijzondere zijde zien. Hij beschikte over een kleine drukpers en een beperkte hoeveelheid lood,

22 ANRI KBG Dir 0033, vergadering 25-3-1824, punt 7; Dir 0035, vergadering 24-4-1824; Dir 0037, vergadering 28-5-1824, punt 3 met bijlage; Dir 0040 vergadering 12-8-1824, punt 5.

23 ANRI KBG Dir 0982, nr 45, brief van Van der Vinne aan Domis, 31-1-1825. ANRI KBG Dir 0047, vergadering 10-3-1825, punt 3 over een brief van Domis, 16-2-1825 met het omgewerkte stuk. Lenting had in 1824 bezwaar gemaakt tegen plaatsing van het stuk en verwezen naar Raffles', Crawfords en Mackenzies publicaties over het onderwerp (Dir 0042, vergadering 28-101824, punt 13).

24 ANRI KBG Dir 0051, vergadering 11-8-1825, punt 2 met bijlage. 
waarmee hij drukwerk verzorgde. Van een in 1825 gemaakte reis liet hij zijn Javaanse bediende een verslag drukken: Journaal eener reis van Welerie naar het gebergte Praauw (door H.J. Domis. Resident te Samarang. Gedrukt te Samarang, door Karto Di Wirio, 1827). De lezers bood hij vooraf zijn verontschuldigingen aan voor de onvolmaaktheid van het drukwerk. Hij had onder andere een tekort aan bepaalde hoofdletters. Het boekje ziet er daardoor aandoenlijk uit. ${ }^{25}$ Het genootschap vond de tekst interessant genoeg voor een herdruk en nam het op in deel 12 van de Verhandelingen (1830). Ook in 1827 verschenen er van de hand van twee van zijn kinderen, weer gedrukt op het drukpersje thuis, drie afleveringen van een Hollands-Javaans woordenboekje, 'behelzende de woorden, die in de dagelijksche verkeering het meeste te pas komen'. Als auteurs stonden te boek W.J.C de Senerpont Domis (eerste en derde stukje) en H.F. de Senerpont Domis (tweede stukje). Tjokro Di Wirio was de drukker. ${ }^{26}$ In een brief aan de voorzitter van het genootschap, die een goed beeld geeft van Domis, bood hij een exemplaar aan.

Ik heb het mij steeds als een groote behoefte voorgesteld voor een Ambtenaar in deze gewesten en voornamentlijk in de Javaansche bovenlanden, om het Javaansch, ten minsten te kunnen spreeken - en het is mij altoos gebleeken dat men zich daarom niet bekommerde. Dit is de reden dat ik mijne Kinderen die Taal heb doen leeren, en door hen onder mijne leiding een Javaansch en Hollandsch woordenboekje heb doen vervaardigen en ten mijnen huize door Javaansche Jongelingen heb doen drukken.

Ik neem, om dat mij het bestaan van een diergelijk werkje niet bekend is, de vrijheid om dit aan het Genootschap aan te bieden en te verzoeken, indien hetzelve zulks waardig keurt, daar aan hare gewone bescherming te verleenen. ${ }^{27}$

De Bataviasche Courant kreeg een exemplaar en wijdde er een welwillende bespreking aan, waarin de omstandigheid dat Domis zelf twee Javanen het drukkersvak leerde en zijn kinderen tot het werk aan het woordenboekje aanzette, natuurlijk werd gememoreerd (29-5-1827). Bij zijn overplaatsing naar Pasoeroean in 1827 gingen de Javaanse jongelingen en het drukpersje mee, zodat het drukwerk daar kon worden voorgezet. Het impressum van het eerste aflevering van de Aantekeningen van H.J. Domis vermeldt expliciet: 'Gedrukt te Pasoeroean, ten huize van den schrijver, door deszelfs inlandschen schrijver Tjokro Di Wirio'. Tussen 1829 en 1832 verschenen zeven boekjes onder dezelfde verzameltitel, het laatste al met de nieuwe standplaats Soerabaija als impressum (1832). Intussen was Domis lid geworden van de Royal Asiatic Society, wat hij ter aanbeveling op de titelpagina's vermeldde.

\footnotetext{
25 Exemplaar Perpusnas XXI 580.

26 Exemplaar KITLV Mgg 79. Het exemplaar Perpusnas XLIII 202 is zoek.

27 ANRI KBG Dir 0067, vergadering 19-7-1827 over de brief van Domis, 15-5-827 (Semarang) als bijlage bij het verslag is gevoegd, punt 8 en bijlage 5 .
} 
In Pasoeroean was nog een aparte editie uitgekomen van het vijfde stukje van de Aantekeningen over het Tengger-gebergte, dat uiteindelijk ook in deel 12 van de Verhandelingen zou terechtkomen. ${ }^{28}$

Zo was Domis met vier bijdragen aan de uitgaven van het genootschap tussen 1825 en 1832 een niet onbelangrijke auteur. Hij kwam dan ook voor op de lijst van zestien namen die begin 1829 door Lenting, De Serière en Van der Vinne werd opgesteld met oog op het verkrijgen van kopij voor deel 12. ${ }^{29}$ Domis behoorde tot de kleine groep van actieve leden op wie men voor nieuwe kopij dacht te kunnen steunen. Hij reageerde per ommegaande op de aanschrijving van de secretaris met een exemplaar van zijn gedrukte WeleriePraauw-reis en stuurde ook stukken van anderen op. ${ }^{30} \mathrm{Hij}$ zond zijn gedrukte aantekeningen naar het genootschap, omdat het bereik van zijn drukpersje beperkt was. Niet alles werd echter met enthousiasme ontvangen. Lenting vond het stuk over Salatiga 'vrij mager' en de beschrijving van de residentie Pasoeroeran 'hier \& daar wat beuzelachtig en over het algemeen sopperig. Evenwel overgewerkt \& verkort zijnde, kan er iets goeds van komen'. ${ }^{31}$ Domis koos niet alleen voor het genootschap als publicatiebron. De geringe frequentie van de Verhandelingen - 1825, 1826, 1830, 1832 - was voor hem een reden om ook de Bataviasche Courant te gebruiken als forum. ${ }^{32}$ Sommige van zijn bijdragen voor de krant kwamen in zijn zevendelige serie Aantekeningen terecht.

In 1834 ging Domis met verlof naar Nederland, maar hij keerde niet terug naar Indië. Hij publiceerde over Nederlands-Indië in De Oosterling, terwijl er van zijn aantekeningen over Pasoeroean in 1836 nog een uitgebreider editie verscheen in Den Haag. ${ }^{33}$ Als gewoon klerk naar Indië vertrokken, keerde hij als resident en publicist terug naar Nederland. Niet zoals Von Siebold universitair geschoold, was hij het type van de ware liefhebber van kunsten en wetenschap waar het genootschap op steunde. Zijn door het genootschap

28 Perpusnas XXI 235 is een bijna complete serie van de Domis' Aanteekeningen (1829-1832), alleen het zesde stukje ontbreekt. Van deel 5 zijn twee edities. Een ervan heeft gediend als kopij voor deel 12 van VBG. In 1827 had Domis zijn Tengger-aantekeningen al aangeboden in manuscriptvorm. Van der Vinne reageerde er pas ruim een jaar later op. Domis ging gewoon door met het drukwerk. Zie ANRI KBG Dir 0069, vergadering 24-1-1828, punt 3 en bijlage 3; Van der Vinnes late antwoord van 4-2-1829, waarin hij Domis bericht dat het Tenggerstuk zal worden opgenomen in deel 12 van VBG is te vinden in ANRI KBG Dir 0984, $1829 \mathrm{nr} 8$.

29 ANRI KBG Dir 072, vergadering 6-2-1829, punt 3.

30 ANRI KBG Dir 0073, vergadering 6-3-1829, punt 6 en bijlage 7.

31 ANRI KBG Dir 0983, nr 33, Lenting aan Van der Vinne, 10-9-1824, en nog eens op 23-3-1830, Dir 0986, 1830 nr 17.

32 Bataviasche Courant 1828 nr 18, 34, 38, 109; 1829 nr 9; 1830 nr 127; 1831 nr 60. Ook in eerdere jaargangen, vanaf 1824 bijdragen van Domis.

33 ENI 1 (s.v. Domis). Van de herdruk uit 1836 van de aantekeningen over Pasoeroean is een exemplaar aanwezig in bibliotheek van het KITLV b 56. Het exemplaar Perpusnas XX 427 is zoek. 
gedrukte bijdragen liggen op het terrein van de land- en volkenkunde en laten zien dat er in Midden- en Oost-Java nog veel onbekende gebieden waren. Over het feit dat zij door een liefhebber geschreven waren zonder een gedegen opleiding, kon het bestuur van het genootschap zich heenzetten. Domis overleed in Brummen in 1842.

\section{Von Siebold}

Philipp Franz von Siebold (1796-1866) was geboren in Würzburg uit een artsengeslacht. Hij werd in hetzelfde beroep opgeleid, maar had daarnaast belangstelling voor natuurlijke historie en een drang om verre landen te bereizen. In 1822 solliciteerde hij in Nederland naar een functie van militair arts met de bedoeling naar Indië te gaan. In september van dat jaar naar Batavia vertrokken om als chirurgijn-majoor werkzaam te zijn, kwam hij daar in februari 1823 aan. Hij werd door Van der Capellen toegevoegd aan het nieuw benoemde opperhoofd van Deshima, kolonel J.W. de Sturler (Wijnmalen 1871; Kouwenhoven en Forler 2000:11-13). Nog voor hun vertrek naar Japan werden zowel De Sturler als Von Siebold, 'bestemd geneesheer bij de handel op Japan', aan het genootschap verbonden. ${ }^{34}$ Blume zal tussen februari en juni 1823 uitvoerig met zijn land- en vakgenoot Von Siebold hebben overlegd over diens aanstaande reis, vooral over zaken waarvan de Buitenzorgse plantentuin kon profiteren. Von Siebold was voor zijn vertrek geruime tijd in Buitenzorg. Secretaris Van der Vinne informeerde de nieuwe 'Japanse' leden nog voor hun vertrek over hun lidmaatschap en Von Siebold antwoordde op 15 juni met een dankbare Latijnse brief voor zijn uitverkiezing. ${ }^{35}$ De schepen met de nieuwe krachten voor het kunstmatige eiland voor de kust van Nagasaki kwamen daar in augustus 1823 aan, waarna Von Siebold direct met zijn werk als factorij-arts en met zijn onderzoek naar Japanse zaken begon. Tijdens de algemene vergadering van 7 oktober 1823 werden De Sturler en Von Siebold bevestigd als corresponderend lid in het gezelschap van een hele groep anderen. ${ }^{36}$

Doordat strenge bepalingen het aantal schepen beperkten dat per jaar van Nagasaki naar Batavia mocht vertrekken, moest het genootschap tot begin 1825 wachten voordat er bericht van Von Siebold binnenkwam. De gouverneur-generaal had echter een jaar eerder al post (Kouwenhoven en Forler 2000:30). In twee Duitse brieven van 29 november en 3 december 1824 aan

\footnotetext{
34 ANRI KBG Dir 0024, vergadering 12-6-1823, punt 6.

35 ANRI KBG Dir 0982, nr 2-3, brieven van Van der Vinne aan De Sturler en Von Siebold, 12-6-1823 en 13-6-1823. ANRI KBG Dir 0025, vergadering 3-7-1823, punt 2-3 en bijlage op p. 36, antwoord van Von Siebold.

36 ANRI KBG Dir 0029, verslag algemene vergadering 7-10-1823. .
} 
het genootschap meldde de arts het bestuur dat hij de gouverneur-generaal twee verhandelingen had gestuurd, 'Epitome Linguae Japonicae (Kort begrip der Japansche taal)' en 'Beantwoording eeniger nieuwsgierige vragen over de Japansche Vroedkunde', beide bestemd voor de Verhandelingen als Van der Capellen ze daarvoor wilde afstaan. Voor het eerste stuk zou hij nog houtsneden nazenden. Verder stelde hij drie nieuwe corresponderende leden voor: de al genoemde keizerlijke geneesheer Wilhelmus Botanicus, en de medici Ignaz Döllinger (Von Siebold's leermeester in Würzburg) en T.F.J. Nees von Esenbeck (Bonn). Het bestuur hield de beantwoording van de brieven even aan tot het vertrek van de voor Japan bestemde schepen en vroeg aan het gouvernement naar de twee verhandelingen. ${ }^{37}$ Deze omslachtige methode had te maken met de positie van Von Siebold en zijn collega's in Japan. Zij waren opgesloten op Deshima, informatie over Japan en in het Japans werd van hen weggehouden en hun was door de Japanners verboden informatie over het land te vergaren. Het gouvernement moest eerst zien wat ter publicatie werd aangeboden om te voorkomen dat de Japanners te weten kwamen, dat er al veel over hen en hun land bekend was, waardoor de handelsbetrekkingen konden worden geschaad en het aanwezige personeel in gevaar kon worden gebracht. ${ }^{38}$ Overigens verkeren de Duitse brieven van Von Siebold, ook de latere, in een erbarmelijke staat door verregaande inktvraat. Doordat Blume er ten behoeve van het bestuur vertalingen van maakte, zijn ze bruikbaar. Deze brieven zijn tot nu toe niet gebruikt, maar voor de Siebold-studie van groot belang. De arts in Japan was zich goed bewust van de betekenis van zijn stukken voor het genootschap en ging er zonder meer vanuit dat er direct gepubliceerd kon worden. Hij gaf uitgebreide instructies over hoe het stuk over het Japans zou moeten worden gedrukt en lichtte de illustraties toe (in de vertaling van Blume, niet vrij van germanismen).

De platen zelve heb ik nog niet - deze zijn nog in eene sloep bij slechten wind op zee. Maar dat doet niets; nu kan de druk volkomen te Batavia bezorgd worden; en komen dezelve heden of uiterlijk morgen vroeg niet aan, dan zend ik toekomende jaar met het eene schip de platen en met het andere de afdrukzels op goed Japansch papier, dan kan men ze dadelijk bij de verhandelingen voegen. Doch

\footnotetext{
37 ANRI KBG Dir 0046, vergadering 10-2-1825, punt 6 en bijlagen.

38 Uit een brief van Von Siebold aan de gouverneur-generaal, 26-11-1824, waarvan een extract aan het genootschap werd gestuurd, blijkt dat hij drie verhandelingen instuurde. Naast de al in de tekst genoemde ook nog een over de oorsprong van de Japanners, gebaseerd op een Japanse kroniek. Waarom Von Siebold die verhandeling ook niet meteen aan het genootschap meldde, is onduidelijk. Aan Van der Capellen meldde de factorij-arts verder dat hij aan de Académie in Parijs en aan de Asiatic Society in Calcutta eveneeens verhandelingen had gestuurd en ook al aan Reinwardt - in Leiden - had geschreven, allemaal brieven die via Batavia reisden. Zie ANRI KBG Dir 1506, een Latijnse brief van november 1824 en een extract uit de brief aan de gouverneurgeneraal.
} 
moet ik u nog op iets opmerkzaam maken; ik kon er geene Europische letters laten bijvoegen, (want weetje, het is stipt verboden Japansche Karakters bekend te maken) daarom moet gij van 3 der platen de met potlood bijgevoegde letters en getallen op bijzondere koperen platen doen graveren en dan ook de afdrukken drukken - dat gaat zeer goed. Wat zullen deze letters een opzien in Europa maken. Bezorg slechts de correctie goed - jammer ware het indien fouten die door het slechte afschrift mogelijks mede onderloopen, werden gedrukt. De redacteur van deze Grammatica moet die bestuderen, dan kan er geen fout inkomen. ${ }^{39}$

De wijze waarop de auteur vanuit het geïsoleerde Deshima meedacht over de technische problemen van de uitgave van zijn verhandeling zegt iets over zijn gedrevenheid.

Nadat door de algemeen secretaris de twee verhandelingen aan het genootschap waren overgedragen, waren deze direct aan Blume in Buitenzorg voorgelegd. In april 1825 werd al over het drukken van het stuk over het Japans gesproken. Maurisse zou het corrigeren van het Latijn voor zijn rekening nemen, terwijl Blume zijn mening nog moest geven. ${ }^{40}$ Laatstgenoemde was nogal gereserveerd over het stuk over het Japans, zodat in mei werd besloten dat het herzien moest worden en dan pas voor deel 11 van de Verhandelingen zou kunnen worden gebruikt. Blume was vooral bang dat Von Siebold zijn studie van het Japans niet grondig genoeg had uitgevoerd:

Intusschen geloof ik, dat het doelmatiger ware, indien de schrijver minder spoed met de uitgave van dit werk zocht te maken en zich langeren tijd met het in orde brengen zijner verzamelde waarnemingen [...] wilde bezig houden; immers zoude dit de waarde van zijn werk merkelijk verhoogen. Men kan namelijk van Doctor Von Siebold, die zich sedert zoo korten tijd (11/2 Jaar) in Japan bevindt, niet verwachten, dat hij eene grondige kennis der Japansche taal hebbe verkregen. ${ }^{41}$

Blume beval een studie van jaren aan en beperkte zich tot het noteren van enkele schrijffouten. Intussen had voorzitter Maurisse ook 'duisterheden' in stijl en spelling van het Latijn geconstateerd, vandaar dat er met Von Siebold in nader overleg werd getreden. Overigens ontbrak in het verslag van de bestuursvergadering elk commentaar op het stuk over de verloskunde. Van der Vinne schreef daarop uitgebreid aan Von Siebold over beide stukken en stuurde het commentaar van Maurisse en Blume mee, alsook de stukken zelf met hun aantekeningen in de marge. Voorlopig zou niet worden gedrukt. ${ }^{42}$

\footnotetext{
39 ANRI KBG Dir 0046, vergadering 10-2-1825, bijlagen.

40 ANRI KBG Dir 0048, vergadering 14-4-1825, punt 4.

41 ANRI KBG Dir 0049, vergadering 18-5-1825, punt 7 en bijlagen. Von Siebold had hooguit één jaar en drie maanden aan zijn stuk kunnen werken, aangenomen dat hij er direct na aankomst in augustus 1823 aan was begonnen.

42 ANRI KBG Dir 0984, nr 60, 26-6-1825, minuut van Van der Vinnes brief; de stukken zelf
} 
Toch ging in juli 1825 het voorwoord voor deel 10 van de Verhandelingen naar de drukker, mét de verhandeling over de verloskunde, dit ondanks de brief die Van der Vinne hierover aan de auteur op Deshima had geschreven. In Lentings voorbericht tot deel 10 werd van geen twijfel over het stuk over de verloskunde gesproken, integendeel, zonder aarzeling was tot de de druk besloten, ook op basis van Blumes positieve oordeel (VBG 10:vii). Over het tweede stuk, over het Japans, was Lenting heel diplomatiek. Het ontbreken van de illustraties bij het stuk was de reden waarom de druk tot deel 11 zou worden uitgesteld (VBG 10:viii-ix). Ondertussen ging Lenting uitgebreid in op het belang voor het genootschap en de geleerde wereld van de bijdragen van Von Siebold, en ook op een al door hem in een brief aan de gouverneurgeneraal aangekondigd (derde) stuk over de oorsprong van het Japanse volk. Uit dezelfde brief citeert Lenting Von Siebold waar hij zegt dat zijn verloskundestuk in feite gebaseerd was op een verhandeling van een van zijn Japanse leerlingen, de arts Mimazunzo uit Nagasaki, en dat de vraag-antwoord-vorm waarin het stuk gegoten was hem het beste geschikt leek. Lenting introduceerde Von Siebold bij de lezers met de eer die zo'n belangrijk corresponderend lid waardig was. ${ }^{43}$ Zo was Von Siebold aan de kring van de lezers van het Bataviaasch Genootschap bekendgemaakt. Hij zou aan elk van de delen 10-14 van de Verhandelingen (1825-1833) bijdragen leveren.

Hij stuurde met de volgende schepen een Japans boekwerk over spelling en schrijfstijl en een geschiedenis van het Sanskriet, aldus meldde Lenting op 9 februari 1826. Een maand later was ook een brief van 4 december 1825 binnen met de gecorrigeerde versie van het stuk over het Japans en met negen houtblokken waarmee de illustraties moesten worden gedrukt. Von Siebold verontschuldigde zich dat hij het stuk over de syntaxis, het aanvankelijk beloofde tweede gedeelte van de taalkundige verhandeling, niet had kunnen afmaken en lichtte toe dat hij voor zijn studie van het Japans geheel afhankelijk was van zijn Japanse informanten, speciaal van zijn tolk Gonashi. ${ }^{44}$ Blandford, de Engelse graveur in Batavia, die in samenwerking met tekenaar

werden meegestuurd. Er is geen afschrift van Maurisses commentaar, het commentaar van Blume is gevoegd bij de vergaderstukken, ANRI KBG Dir 0049, vergadering 18-5-1825. Of werd het vroedkunde-stuk niet meegestuurd?

43 Tussen voorzitter Maurisse en bestuurslid Lenting was enig misverstand over wie het voorbericht zou opstellen. Beiden hadden een tekst geleverd en toen Maurisse ermee naar de drukkerij reed, bleek dat Lenting de volgorde van de verhandelingen in deel 10 had veranderd. Daarover was Maurisse verbolgen, maar hij accepteerde Lentings tekst ondanks dat hij 'niet weinig in [z]ijne getrouwe verwachting [was] bedrogen' (ANRI KBG Dir 0050, vergadering 14-71825, bijlage 20). Over dezelfde zaak een kattebelletje van Lenting aan Van der Vinne waarin hij (L.) juist van zijn tekst afziet ten gunste van die van Maurisse ('maak er geen water om vuil'), ANRI KBG Dir 0981, brief van Lenting, 6-7-[1825] - nr 57.

44 Ook deze brief van Von Siebold valt uit elkaar door inktvraat. De vertaling (weer van Blume?) is echter goed leesbaar. ANRI KBG Dir 0055, vergadering 10-3-1826, punt 10 en bijlage. 
Adriaan Bik werkzaamheden voor het genootschapsdrukwerk uitvoerde, besloot dat de houtsneden niet in gravures moesten worden omgezet, maar dat ze als zodanig - dus met de houtblokken - konden worden afgedrukt. ${ }^{45}$ Over de aard van de wijzigingen die in het stuk waren aangebracht, vinden we in het archief geen commentaar meer. Pas in december 1826 kon het elfde deel met het stuk over het Japans aan de leden worden aangeboden. Von Siebold bleek de strenge regels die er golden voor de beperking van informatie-uitvoer telkens te overtreden. Zowel het gedrukte boek over het Japans als de houtblokken met de lettertekens vielen onder het verbod, om nog maar te zwijgen van de zeer informatieve verhandelingen.

De brieven van Von Siebold kwamen steeds in het begin van het jaar aan en waren eind november-begin december geschreven. Het strenge schema van de scheepvaart op Japan bepaalde de intensiteit van de contacten. Zo kwam in februari 1827 bij de bestuursvergadering de post van december 1826 ter sprake met het nieuws over de verhandeling over de oorsprong van de Japanners, die via het gouvernement aan het genootschap ter publicatie was aangeboden. Von Siebold verzocht om drukproeven te mogen ontvangen, omdat hij zelf toezicht wilde houden op de correctie. Dat betekende dat pas op zijn vroegst in februari 1828 de gecorrigeerde proeven terug zouden kunnen zijn in Batavia. In een tweede brief bedankte Von Siebold voor het ontvangen deel 11. Hij gaf geen commentaar en was kennelijk tevreden met de wijze waarop de verhandeling over het Japans was gedrukt. Verder gaf hij enkele ophelderingen op zijn eigen stuk over de oorsprong van de Japanners, deelde mee dat zijn collega in Deshima, de apotheker H. Bürger, ook enkele verhandelingen had ingestuurd en stelde voor hem tot corresponderend lid te benoemen. Von Siebold had ook enkele kisten met Japanse naturalia voor het genootschap gestuurd, die het moest opvragen bij het gouvernement. Deze bleken echter geadresseerd te zijn aan het gouvernement en intussen aan de leden van de Natuurkundige Commissie H. Boie en H. Macklot te zijn aangeboden. ${ }^{46}$ Door een misverstand bleek de Duitse verhandeling over de oorsprong van de Japanners vanuit Buitenzorg onvertaald te zijn teruggestuurd naar Japan, waardoor Van der Vinne er Von Siebold opnieuw om moest vragen. Dat alleen kostte al een jaar. ${ }^{47}$

Van de goede veranderingen die zich in 1828 aankondigden met de plot-

45 Niet genotuleerd, maar de Engelse brief van Blandford, 16-7-1826, is wel bij de vergaderstukken van 10-8-1826 te vinden (ANRI KBG Dir 0061). Blandford deed ook het graveerwerk voor de Flora van Blume.

46 ANRI KBG Dir 0065, vergadering 22-2-1827, brieven van 12 en 17-12-1826, punt 5-6 en bijlagen.

47 ANRI KBG Dir 0067, vergadering19-7-1827, punt 9 en bijlage 6. ANRI KBG Dir 0984, 1827 $\mathrm{nr}$ 45, oorspronkelijk 35, is de minuut van een brief van Van der Vinne, 26-6-1827, waarbij hij aan Von Siebold de verhandeling terugvraagt. 
selinge belangstelling van de commissaris-generaal voor het genootschap, maakte het bestuur gebruik om in 1829 aan het gouvernement te vragen om nog eens al Von Siebolds 'letterkundige stukken, die over Japan handelden, en speciaal het tweede stuk over de Japansche taal' te mogen ontvangen. Voorzitter Bousquet, algemeen secretaris van het gouvernement, meende te weten dat alle stukken bij de commissaris-generaal waren. ${ }^{48}$ Wel kreeg het genootschap de vier kisten met naturalia van Von Siebold, die in 1825 waren aangekomen, overhandigd. ${ }^{49}$ Omdat intussen een uit 1827 daterend uitvoerig stuk over de Japanse flora via het gouvernement was binnengekomen en voor publicatie vrijgegeven, werd besloten deel 12 van de Verhandelingen met dat opstel te beginnen. De algemeen secretaris gaf te kennen dat alle Sieboldstukken die voor publicatie geschikt werden geacht aan het genootschap waren overgedragen. ${ }^{50}$ Dat het gouvernement heel precies bleef toekijken op de zaken van Japan, bleek in mei 1829 toen het geen toestemming gaf aan het genootschap om te beschikken over de historische studie van het nieuwe opperhoofd van Deshima, Meylan, over de handel van de Europeanen op Japan. Na veel heen en weer geschrijf zou deze in 1833 toch verschijnen. ${ }^{51}$

Von Siebold zelf had intussen moeilijke tijden doorgemaakt. Zijn vertrek, waartoe al in juni 1827 in Batavia was besloten, liep in september 1828 letterlijk schipbreuk voor de kust van Nagasaki door een tyfoon. De rijke collecties, die al waren ingeladen, konden grotendeels zonder schade van boord worden gehaald van het schip waarmee Von Siebold zelf naar Batavia zou reizen, maar niet zonder dat de Japanse autoriteiten lucht kregen van wat er zich allemaal aan boord bevond. Het zogenaamde Von Siebold-incident, dat zich bijna anderhalf jaar voortsleepte, leidde ertoe dat hij pas in december 1829 naar Batavia vertrok, overigens wel weer met een grote collectie Japonica (Kouwenhoven en Forler 2000:44). Hangende zijn langdurige wachttijd in Japan had het gouvernement op 10 juli 1829 besloten het Bataviaasch Genootschap om advies te vragen over Von Siebolds toekomst. Mocht de onderzoeker van plan zijn na zijn terugkeer van Japan

de vruchten zijner natuurkundige en wetenschappelijke nasporingen in Nederland in het licht te geven [dan zal] eene proeve zijner verrigtingen aan het Bataviaasch genootschap van kunsten en wetenschappen ter beoordeling worden onderworpen, ten einde daarna te kunnen [vastgesteld] worden of er termen bestaan

\footnotetext{
48 ANRI KBG Dir 0072, vergadering 6-2-1829, punt 7.

49 ANRI KBG Dir 0073, vergadering 6-3-1829, punt 3.

50 ANRI KBG Dir 0074, vergadering 23-4-1829, punt 16 en bijlage 13, brief van de algemeen secretaris.

51 ANRI KBG Dir 0075, vergadering 2-7-1829, punt 3 met resolutie van het Indisch Gouvernement.
} 
om hem tot voorschreven einde, het zij met verlof, dan wel in Kommissie, naar Nederland te zenden. ${ }^{52}$

Het ging hier om de toekomst van een belangrijke onderzoeker en van een grote collectie natuurkundige en andere voorwerpen, boeken en manuscripten.

Op 28 januari 1830 kwam Von Siebold met zijn collecties in Batavia aan. Aangezien hij van plan was om met de eerste scheepsmogelijkheid naar Europa te vertrekken en hij zijn collecties - waaronder levende dieren en planten - mee wilde nemen, was het zaak zo snel mogelijk toestemming te verkrijgen. Ondertussen moest hij toezicht op de collecties houden, met name op de levende have. Op 10 februari 1830 verontschuldigde hij zich bij Van der Vinne voor het feit dat drukte en ziekte hem tot dan toe hadden belet de secretaris te bezoeken. Lenting had Von Siebold een paar dagen later wel ontmoet en drukte bezorgdheid uit over de kommervolle omstandigheden waarin deze zich bevond: 'Ik geloof dat onze vriend het zeer bekrompen heeft. Zoude er uit de kas des Genootschaps geene som van $f 300-f 400$ ter zijner beschikking kunnen gesteld worden?' Later trok Lenting - na overleg met medebestuurslid, het hoofd van de geneeskundige dienst, Fritze - dit voorstel weer in. 53

Op 19 februari 1830 was er een bestuursvergadering, grotendeels gewijd aan Von Siebold, om hem in de gelegenheid te stellen ingevolge de resolutie van de Indische regering 'de vruchten van zijne arbeid in Japan aan het Genootschap medetedeelen' ${ }^{54}$ Zijn verzoek om met het gereedliggende schip, de 'Java', te mogen vertrekken, was al bij het gouvernement ingediend, dat nu wachtte met zijn beslissing op het advies van het genootschap. De uitkomst van de vergadering was voor de onderzoeker derhalve van het grootste belang. Door zijn drukke werkzaamheden had Von Siebold voor het genootschap geen schriftelijk verslag kunnen maken. Zijn verzoek om de vier kisten met naturalia, die nog bij het genootschap berustten terug te ontvangen voor verder onderzoek in Nederland, werd goedgunstig toegestaan. De verhandeling over de oorsprong der Japanners, die abusievelijk weer naar Deshima was teruggestuurd en door Siebold ook voor publicatie in Parijs aan Remusat en Klaproth was aangeboden, stond hij nu voor de Verhandelingen af. Het zou zijn vierde opstel voor het genootschap worden.

Daarna volgde het pièce de résistance van de vergadering: Von Siebold

52 Extract besluit luitenant gouverneur-generaal dd 10-7-1829, bij vergadering 10-9-1829 (ANRI KBG Dir 0076).

53 ANRI KBG Dir 0986, nr 9 (Siebold aan Van der Vinne, 10-2-1830) en nr 6-8 (Lenting aan Van der Vinne, 11-2 en 13-2-1830 en nog een ongedateerde brief).

54 ANRI KBG Dir 0079, vergadering 19-2-1830. Het volgende is daaraan ontleend. 
vertoonde de lijsten van onder andere dieren, planten, zaden, mineralen. Het ging om vijf bijlagen, die aan de vergaderstukken zijn toegevoegd:

a naturalia die tussen 1824-1827 van Japan naar Batavia waren verstuurd voor het Koninklijk Museum 'dan wel alhier in de Botanischen tuin voorhanden'. (Onduidelijk is het Koninklijk Kabinet van Zeldzaamheden in Den Haag dan wel het Leidse Rijksmuseum van Natuurlijke Historie bedoeld zal zijn.)

b naturalia die tussen 1823 en 1828 en in 1829 naar Batavia waren vervoerd (anders dan de onder a genoemde verzamelingen).

c naturalia die door Von Siebold in 1828 voor eigen rekening verzameld waren, maar ter beschikking gesteld van het gouvernement.

d een overzicht van zijn letterkundige werkzaamheden of onder zijn toezicht verricht werk (beschrijvingen, verhandelingen, bouwstoffen, onder andere van Japanse geleerden).

e Japanse rariteiten voor rekening van Von Siebold bijeengebracht ten behoeve van het Koninklijk Kabinet in Den Haag.

De lijsten met duizenden opgesomde exemplaren van planten en dieren, kisten met zaden en delfstoffen, zoogdieren, vogels, vissen, schaal- en schelpdieren, insecten (levend, opgezet, op sterk water, in de vorm van geraamtes), herbaria, manuscripten, boeken, schilderijen, gekalligrafeerde kunst, munten, gereedschappen, modellen, en vele andere voorwerpen; het leest als een museum waarin men de weg kwijt is geraakt. Het kan niet anders of de aanwezige bestuursleden, Bousquet, Lenting, Fritze en Van der Vinne, waren onder de indruk. Von Siebold verluchtte zijn uitleg bovendien door voorbeelden en exemplaren te tonen. Uiteindelijk zegde hij toe om het vervolg van zijn taalkundige verhandeling over het Japans ter beschikking te stellen en verzocht hij het genootschap hem te willen steunen in zijn verzoek aan het gouvernement om met zijn collecties naar Nederland te mogen vertrekken.

De vier bestuursleden - onder wie voorzitter Bousquet die als algemeen secretaris rechtstreeks toegang had tot de nieuwe gouverneur-generaal, J. van den Bosch - besloten, met Von Siebold buiten de vergadering, dat hij niet van zijn verzamelingen gescheiden moest worden. Zij overwogen bovendien dat de collecties zo groot waren dat in Indië ten enenmale de middelen ontbraken om 'die bouwstoffen tot een geheel te formeren'. Verder overwogen zij dat de levende have zonder de zorgen van Von Siebold niet goed in het vaderland zou aankomen. Daarom volgde het advies aan het gouvernement om Von Siebold 'in kommissie naar Nederland te zenden ten einde aldaar de resultaten zijner waarnemingen en opmerkingen gedurende zijn verblijf in Japan in het licht te geven'. ${ }^{55}$ Daaraan werd toegevoegd het advies de onderzoe- 
ker op het schip de 'Java' met zijn collecties te laten meereizen. Het gezond verstand had gezegevierd. Waarschijnlijk was het genootschapsbestuur niet eens in de verleiding gekomen om Von Siebold in Batavia te houden om zijn werk aldaar te laten uitvoeren. De omvang van de collecties, de duur van het onderzoeksproject én de eraan verbonden kosten, waren van dien aard dat geen enkele instelling in Indië voor overname in aanmerking kwam. Op 20 februari schreef Van der Vinne een uitgebreid advies aan het gouvernement. ${ }^{56}$ Voorzitter Bousquet overlegde op 24 februari nog eens schriftelijk met Van der Vinne wat hij met gouverneur-generaal Van den Bosch zou bespreken. ${ }^{57}$ Kort daarop kwam de beslissing van het gouvernement. Conform het advies van het genootschap werd besloten dat Von Siebold in overheidsdienst bleef en in staat zou worden gesteld van Japan zijn levenswerk te maken. Op 5 maart 1830 vertrok hij naar Nederland (Kouwenhoven en Forler 2000:115-159).

Na zijn vertrek zou het genootschap nog twee van zijn 'Japanse bouwstoffen' in de Verhandelingen opnemen: de 'Verhandeling over de afkomst der Japanners' (deel 13, 1832), en 'Iets over acupunctuur (naaldensteekkunde); getrokken uit eenen brief van den Japansch-keizerlijken naaldensteker Isi Saka Sotels' (deel 14, 1833). De verhandelingen over de verbouw van thee van Von Siebold en Bürger werden in 1830 wel door de algemeen secretaris aan het genootschap ter beschikking gesteld voor publicatie, maar daarvan kwam het uiteindelijk niet. Het gouvernement vond bij nader inzien publicatie van de theestukken niet raadzaam. Von Siebolds oud-medewerker Bürger liet weten dat hem door het gouvernement uitdrukkelijk was verboden iets over de theecultuur te publiceren. ${ }^{58}$ Van der Vinne was ontevreden over het lot van dit laatste stuk van Von Siebold. Hij meldde met name de tegenwerking van het gouvernement over de stukken met betrekking tot de theecultuur, waardoor deel 16 in 1834 nog altijd niet was verschenen. Het zou pas in 1836 zonder de bewuste stukken verschijnen. ${ }^{59}$ Van Bürger verscheen toen wel een opstel over de productie van koper in Japan.

Von Siebold zou in het vervolg nauwelijks meer contact hebben met het genootschap. Het beloofde vervolg op het taalkundige opstel over het Japans bleef uit. De schrijver had in Nederland zijn handen vol aan zijn Nippon, de Flora en Fauna Japonica, dan dat het genootschap nog bijdragen van hem mocht verwachten. Zijn collectie verkocht hij aan de Nederlandse staat, maar hij kon er in Leiden over blijven beschikken. Daar kwam zij uiteindelijk

\footnotetext{
56 ANRI KBG Dir 0984, 1830, nr 2, minuut.

57 ANRI KBG Dir 0986, nr 13 dd 24-2-1830.

58 Kabinetsmissive van de gouverneur-generaal, 17-6-1833 (ANRI KBG Dir 0087, vergadering 20-2-1834, punt 19 en bijlagen 31 en 32).

59 ANRI KBG Dir 0088, verslag algemene vergadering 6-3-1834 en de aantekeningen erbij van Van der Vinne.
} 
terecht in het Rijks Etnographisch Museum, nu Museum voor Volkenkunde. Als corresponderend lid vanuit Deshima had hij een wezenlijke bijdrage geleverd aan de niveauverbetering van de Verhandelingen. Bovendien had hij in zijn stukken over verloskunde en acupuntuur Japanse medici aan het woord gelaten en zo een nieuwe blik op de geneeskunde in dat land geopend. Zijn bijdragen maken hem tot een van de meest prominente leden van zijn tijd. Het genootschap op zijn beurt had het gouvernement gewezen op de meest wenselijke voortzetting van Von Siebolds wetenschappelijke project, de studie en bekendmaking van Japan in Nederland via overheidsfinanciering.

\section{Goethe erelid}

De beroemdste geleerde en letterkundige die ooit lid is geweest van het genootschap is zonder twijfel Johann Wolfgang von Goethe geweest. In 1932 wijdde de toenmalige secretaris van de directie van het genootschap C.C.F.M. le Roux in het eigen Tijdschrift voor Indische Taal-, Land-en Volkenkunde een kort artikel aan de omstandigheden waaronder dit lidmaatschap tot stand kwam (Le Roux 1932:1-12). Hij nam toentertijd de archiefstukken uit de periode 1823-1836 grondig door en kwam tot de conclusie dat er geen brieven van Goethe in het archief van het genootschap voorkwamen, waarmee hij gehoopt had zijn herdenkingsartikel te kunnen aankleden. Nader, recenter onderzoek bevestigt deze conclusie. ${ }^{60}$ Er zijn echter nog wel een paar interessante details aan het verhaal van Le Roux toe te voegen. Goethe werd tot erelid benoemd tijdens de algemene vergadering van 21 december 1826, waarbij voorzitter Maurisse ontbrak en van het bestuur alleen Lenting, Van der Vinne en diens assistent Sieburgh aanwezig waren. Hoe kon het lidmaatschap van zo'n grootheid onopgemerkt blijven, zodat het in 1932 bijna als een verrassing ter gelegenheid van Goethes honderdste sterfdag gepresenteerd werd? Het elfde deel van de Verhandelingen was in november 1826 verschenen. Op de ledenlijst aldaar kwam Goethes naam nog niet voor; de benoeming dateerde immers van een maand later. Daarna kwam pas in 1830 een nieuw deel uit, maar zonder ledenlijst en evenmin met een verslag van de algemene vergaderingen, zodat de naam van Goethe niet in de internationaal verspreide Verhandelingen werd genoemd. Wel werd de beroemde letterkundige vermeld in het verslag van de vergadering van december 1826, op 10 januari 1827 opgenomen in de Bataviasche Courant, als 'Z.E. de Baron von Göthe, Minister van Staat en geheimraad van den Hertog van Saxe-Weimar, enz., enz.' Ook werd Goethe genoemd op de ledenlijsten van het genootschap die jaarlijks

60 Dr Renate Carstens (Jena) deed na mij nog eens navrage bij het ANRI en liet een derde maal een onderzoekje instellen met hetzelfde negatieve resultaat. Carstens 2008:495-513. 
in de Almanak van Nederlandsch Indië werden opgenomen en wel vanaf 1827 (Bataviasche Courant 10-1-1827; Almanak 1827-33). Onbekend was het feit in Batavia dus niet. Het was zonder merkbaar gevolg gebleven, Goethe had niet bijgedragen aan de Verhandelingen en daardoor was zelfs het erelidmaatschap in de vergetelheid geraakt.

Te weinig is bekend over de man die Goethe voor het lidmaatschap voordroeg, de Antwerpse medicus J.R.L. von Kirckhoff, officier van gezondheid der eerste klasse. Joseph-Romain-Louis de Kerckhove (1789-1867), die zich ook wel Kerckhoffs of De Kirckhoff noemde, was een Limburger, die in Heidelberg en Straatsburg medicijnen had gestudeerd, waarna hij in het Franse en Pruisische leger diende (De Seyn 1935:264-5). Vanaf 1815 in Nederlandse dienst, werkte hij eerst in Luik en daarna in Antwerpen, waar hij vanaf 1822 als zelfstandig arts praktijk hield. Hij was zelf in 1823 voorgedragen voor het corresponderend lidmaatschap van het Bataviaasch Genootschap door zijn collega-medicus en lid, R. Radijs, chef van de Geneeskundige Dienst in Batavia en later ook lid van het bestuur. Von Kirckhoff maakte veel werk van zijn contacten met Batavia. Hij schreef tussen 1823 en 1829 vanuit Antwerpen alleen al negentien brieven aan secretaris Jan van der Vinne, die zelf door Von Kirckhoffs bemiddeling erelid van het genootschap voor mineralogie te Jena was geworden, waarvan Goethe voorzitter en Von Kirckhoff ere-vice-voorzitter was. Kirckhoff bouwde kennelijk een netwerk van lidmaatschappen op. Hij bombardeerde het genootschap in Batavia met voorstellen voor de benoeming van corresponderende en ereleden en liet zijn voorstellen gepaard gaan van boekenzendingen ter adstructie van het gewicht van de voorgestelde personen. De overdaad aan voorstellen irriteerde het bestuur op 29 november 1826. Toen werden door de Antwerpenaar zeven nieuwe leden voorgesteld, onder wie Goethe, terwijl daarvoor in hetzelfde jaar al twee keer eerder over voorstellen van hem was gesproken. Van der Vinne moest doorgeven dat 'besturende leden niet gehouden zijn, alle personen, die tot het lidmaatschap worden voorgesteld, op de Lijst der Kandidaten te plaatsen'. De laatste brief van Von Kirckhoff werd daarom buiten beschouwing gelaten. ${ }^{61}$ Goethe werd toch als erelid aangenomen en Van der Vinne stuurde hem daarvan bericht, zond Goethe ook de Verhandelingen en later nog eens - tegelijk met andere ereleden - enkele andere publicaties. Goethe heeft geen antwoord gestuurd, althans daarvan wordt geen melding gemaakt in de verslagen van vergaderingen in 1827-1832. Ongetwijfeld had zelfs een klein bedankbriefje van het Duitse erelid nog wel een opmerking aan de vergadering ontlokt, zoals dat bij post van andere ereleden het geval was.

61 ANRI KBG Dir 0052 en 0062, vergadering 5-1-1826 en 10-8-1826, het citaat uit een verslag van de vergadering 29-11-1826, punt 6 n.a.v. een brief van 29-6-1826 (ANRI KBG Dir 0062). 
Tenslotte nog dit: in wier gezelschap verkeerde Goethe in de gelederen van de ereleden? Uit de Engelse periode had het genootschap in 1823 slechts vijf ereleden meegenomen: C.P. Thunberg (Uppsala), M.R. van Alderwerelt, W. Marsden, A. Seton en W. Milburn. Daar waren bijgekomen de commissarissen-generaal Elout en Buijskes en in 1823 de oud-voorzitters Reinwardt en Ross. In 1825 waren er zeven nieuwe ereleden, de staatsman G.K. van Hogendorp en minister A.R. Falck, C.R.F. Kraaijenhoff, verder de voorzitter van de Hollandsche Maatschappij te Haarlem J.P.van Wickevoort Crommelin, de juristen P.N. Quarles van Ufford en J.D. Meijer en de Duitse hoogleraar J.T. Blumenbach (Göttingen). In 1826 nog commissaris-generaal Du Bus de Gisignies en de toekomstige gouverneur-generaal J. van den Bosch, de regeringscommissaris J.H. Tobias en het Tweede Kamerlid D.F. van Alphen. Toen Goethe zich daarbij voegde in december 1826 bestond de kring van ereleden uit twintig personen van heel verschillend kaliber. Hij zal ongetwijfeld de befaamde Zweedse botanicus Thunberg van naam gekend hebben, Marsdens beschrijving van Sumatra kende hij misschien, de Göttingse hoogleraar Blumenbach waarschijnlijk wel. In 1833 werd Wilhelm von Humboldt op de kandidatenlijst gezet voor het erelidmaatschap, maar toen was Goethe al overleden. De categorie van de ereleden was aldus toch een merkwaardige mengelmoes van personen, die als enige gemeenschappelijke eigenschap konden bogen op aanzien.

\section{Museumplannen en Bauds besluit ter zake}

Het denkbeeld van Du Bus de Gisignies om een nieuwe botanische tuin en een nieuw museum in Weltevreden te stichten, in november 1828 bij het genootschap gelanceerd, kreeg meteen tijdens de eerste eropvolgende bestuursvergadering aandacht. In februari 1829 werd gesproken over de betrokkenheid ('verwantschapping') van het genootschap 'met het beheer van den plantentuin en het te Weltevreden opterigten museum'. De nieuwe plantentuin was al onder het beheer van de Hoofdcommissie van Landbouw gesteld, zo werd gezegd, maar de noodzaak van 'aanraking' met een wetenschappelijk genootschap werd gesignaleerd. Uiteindelijk werd besloten een commissie te formeren bestaande uit de bestuursleden P. Merkus (president van het Hooggerechtshof en lid van de Raad van Indië), J. Baumhauer (oudresident van Cheribon) en J. Tromp (ingenieur van de Civiele Gebouwen), die als opdracht kreeg te bezien op welke manier tuin en museum 'onder het beheer van of in aanraking met het Genootschap zouden behooren 
te komen'. ${ }^{62}$ Ook kreeg de commissie de opdracht na te denken over een gebouw dat het museum moest gaan huisvesten. Van deze commissieleden verdient James Tromp enige aandacht. Hij was vanaf 1818 als adjunct-hoofdinspecteur van de Waterstaat werkzaam, na 1827 als ingenieur eerste klasse van de Civiele Gebouwen in de residentie Batavia, vanaf 1832 als hoofdingenieur. Deze functie vervulde hij tot 1853. Het jaar daarna werd de dienst Burgerlijke Openbare Werken (BOW) ingesteld. Tromp werd in 1823 als lid van het genootschap benoemd en kwam in 1832 in het bestuur, waar hij tot 1859 in bleef zitten, een van de langst dienende bestuursleden. Als hoofdingenieur van de Civiele Gebouwen had hij als geen ander te maken met de huisvesting van het genootschap. ${ }^{63}$

Dat een nieuw op te richten plantentuin niet onder het beheer van de Natuurkundige Commissie zou komen, maar bij de Hoofdcommissie van Landbouw werd ondergebracht, is een aanwijzing dat Du Bus bewust zijn eigen weg koos en niet de paden ging die door zijn voorganger waren gebaand. De Natuurkundige Commissie over Nederlandsch-Indië was in 1820 opgericht, toen het erop leek dat Reinwardt spoedig naar het vaderland zou terugkeren en zijn wetenschappelijke opdracht niet gereed zou zijn. Hoewel het voorstel ertoe uit Nederland kwam, was het toch een instelling die met Van der Capellen werd geassocieerd. Door het instellen van de Natuurkundige Commissie was aan het onderzoek dat Reinwardt was opgedragen een permanent karakter gegeven. Du Bus had kort na zijn aankomst de Hoofdcommissie van Landbouw ingesteld en met deze nieuwe commissie bemoeide hij zich van het begin af intensief. Het was een eigen initiatief en stond niet in de opdracht die Koning Willem I aan hem had gegeven. Hij liet onder meer proeven doen met thee en kaneel, moerbeiboemen voor zijderupsen en nopal voor cochinelle, waaruit verfstof kon worden gewonnen. In het verlengde van het werk van de commissie lag de Indische tentoonstelling van voortbrengselen van vlijt en nijverheid, die Du Bus organiseerde (De Prins 2002:174-6). Op deze tentoonstelling van 1829, waarvan de catalogus bekend is, werden naast landbouw- en nijverheidsprodukten ook een tachtigtal tekeningen, lithografieën en schilderijen getoond in een afdeling 'Gemengde Voorwerpen'. Verder was daar ook Japans materiaal in verwerkt. Of die Japanse voorwerpen door Von Siebold waren gestuurd, is niet duidelijk uit de nogal sobere vermeldingen in de catalogus. De naam van Adriaan Bik wordt genoemd bij de lithografieën, maar niet de naam van Payen, van wiens werk

\footnotetext{
62 ANRI KBG Dir 072, vergadering 6-2-1829, punt 4.

63 Het gebouw van de boedelmeesters, dat vrij was gekomen, werd als mogelijkheid genoemd voor de huisvesting van het nieuwe museum, ANRI KBG Dir 0072, vergadering 6-2-1829. Over de Waterstaat voor 1854, het jaar van de oprichting van de dienst BOW, Ravesteijn en Kop 2004:34-7.
} 
kennelijk niets beschikbaar was. Het was vermoedelijk de tentoonstelling van 1829, waarvan Van Hoëvell de catalogus zag, die hem in 1839 deed opmerken dat Du Bus verantwoordelijk was voor een 'tentoonstelling van belangrijke voorwerpen van kunst en smaak'. ${ }^{64}$ Mogelijk kwamen het museumplan en de Indische tentoonstelling voort uit Du Bus' behoefte om in Batavia iets na te laten waaraan zijn naam verbonden zou blijven. 65

In oktober 1829 werd door het gouvernement een perceel aan het Waterlooplein voor het nieuw opterichten museum bestemd. De hoofdbaljuw van Batavia, Van der Vinne, gaf dat aan het genootschap, dus aan zichzelf, door. ${ }^{66}$ De aanleg van de nieuwe gouvernementstuin met een meer educatieve en op landbouw gerichte taak, waar de Buitenzorgse plantentuin zich vooral richtte op de botanie, was toen al begonnen. Achter het onder Du Bus afgebouwde paleis van Daendels was een flink terrein afgezonderd voor deze nieuwe tuin, in april 1829 officieel Tuin Du Bus genaamd. De voormalige Paradeplaats (Champs de Mars) was al in 1826 omgedoopt in Plein van Waterloo ter herinnering aan de bekende veldslag, voor de eeuwige herdenking waarvan in datzelfde jaar een Bataviase afdeling van het gelijknamige genootschap was opgericht. In 1828 was de Nederlandse leeuw daar op een zuil gezet, midden op het plein. Als daar ook nog een nieuw museum zou verrijzen, zou Du Bus op het plein blijvend zijn stempel hebben gedrukt: gouvernementskantoor, tuin en museum, in de onmiddellijke omgeving van het monument met de Nederlandse leeuw. De plannen van de commissarisgeneraal bleven voor wat het museum betreft bij plannen. De tuin verviel en werd in de jaren vijftig van de negentiende eeuw volgebouwd met officierswoningen. De straatnamen bleven tot in de twintigste eeuw naar de Tuin Du Bus verwijzen. ${ }^{67}$

Du Bus vroeg vanuit Buitenzorg op 25 november 1829 - kort voor zijn vertrek naar Europa - hoe het stond met de plannen voor het museum. ${ }^{68}$ Daarop moest de commissie wel met het eindrapport voor de dag komen. Op 2 december deed het verslag. Ingenieur Tromp had een ontwerp gemaakt

\footnotetext{
64 Catalogus der voorwerpen van Nederlandsch Indische landbouw en nijverheid (1829), 57 p. Van Hoëvell kan deze catalogus uit de bibliotheek van het Bataviaasch Genootschap gekend hebben. In de gedrukte catalogus van de genootschapsbibliotheek van 1864 wordt hij vermeld. Van Hoëvell 1839:98.

65 De Prins 2002:175, laat in het midden of de tentoonstelling meer dan eens is gehouden. Bloembergen 2003:250, vermeldt op gezag van de ENI (s.v. tentoonstellingen) dat die van 1829 de enige was, waarna de nijverheidstentoonstellingen in de jaren vijftig tot nieuw leven werden gewekt.

66 ANRI KBG Dir 0078, vergadering 2-12-1829, punt 12 en bijlage 11.

67 Boelman 1936:74-9. Op twintigste-eeuwse plattegronden ziet men achter het paleis van Daendels nog de Tuin du Bus I en II lopen. Nu heten die straten Jalan Dr Wahidin I en II.

68 ANRI KBG Dir 0078, vergadering 2-12-1829, bijlage 4.
} 
voor een gebouw op het perceel aan het Waterlooplein en daar een begroting aan toegevoegd van bijna $f$ 52.000. Voorzitter Bousquet concludeerde dat het onmogelijk zou zijn zoveel geld te reserveren voor dit project en zocht naar goedkopere alternatieven. Hij stelde voor de woning van de leden van de Natuurkundige Commissie in Buitenzorg te bestemmen als tijdelijke opslagplaats voor de exemplaren uit de natuurlijke historie die de kern van het nieuwe museum moesten gaan vormen. Er was nog niet veel voor handen. Dat leek de anderen geen goed idee: Buitenzorg was te vochtig, bovendien was zo'n verzameling in een privéwoning voor het publiek moeilijk toegankelijk. Na lange discussie werd het bestuur het eens over het volgende voorstel, dat aan het gouvernement werd voorgelegd.

1 De naast de Harmonie aan Rijswijk leegstaande kolfbaan, waar korte tijd de Algemene Secretarie gebruik van had gemaakt, zou op de zuinigste wijze moeten worden verbouwd en tot Indisch Museum moeten worden bestemd.

2 De Natuurkundige Commissie zou exemplaren van door haar verzamelde en tekeningen van nog niet verzamelde naturalia moeten afstaan aan het genootschap ter opname in het Indisch museum.

3 Alle hoofden van plaatselijk bestuur zouden de opdracht moeten krijgen aan te vangen met verzamelen en conserveren. De ijverigsten zouden een beloning ontvangen.

4 De Natuurkundige Commissie zou voorschriften dienen op te stellen over de wijze van verzamelen.

Het voorstel om de kolfbaan te gebruiken voor een 'Indisch Museum' kwam van Schneither en Fritze. Zij stelden vast dat zo'n voorlopig museum kon profiteren van de nabijheid van het genootschap, doordat de opziener het toezicht op de nieuwe instelling erbij kon doen. ${ }^{69}$ Daags na de vergadering deed Van der Vinne uitvoerig schriftelijk verslag aan Du Bus van het nieuwe plan. Kort daarop meldde Tromp, dat de commissaris-generaal in principe had ingestemd met het kolfbaanplan en dat bekeken moest worden welke veranderingen er aan dat gebouw moesten worden aangebracht. ${ }^{70}$ Zo leek het aparte Du Bus-museum, een jaar na de lancering van het idee en een paar weken vóór het vertrek van de initiator, toch binnen de kring van het genootschap te komen en wel op het terrein van de Harmonie, niet aan het Plein van Waterloo. Het ambitieuze plan was teruggebracht tot een museum op een locatie die het genootschap in staat zou stellen de plannen van Du Bus te annexeren.

Daarna gebeurde er in 1830 en 1831 niets met het museumplan. Du Bus

\footnotetext{
69 ANRI KBG Dir 0078, vergadering 2-12-1829, punt 5.

70 ANRI KBG Dir 0984, 1829 nr 12, minuut van Van der Vinnes brief, 3-12-1829. De brief van ingenieur Tromp aan het genootschap in dezelfde bundel, nr 78.
} 


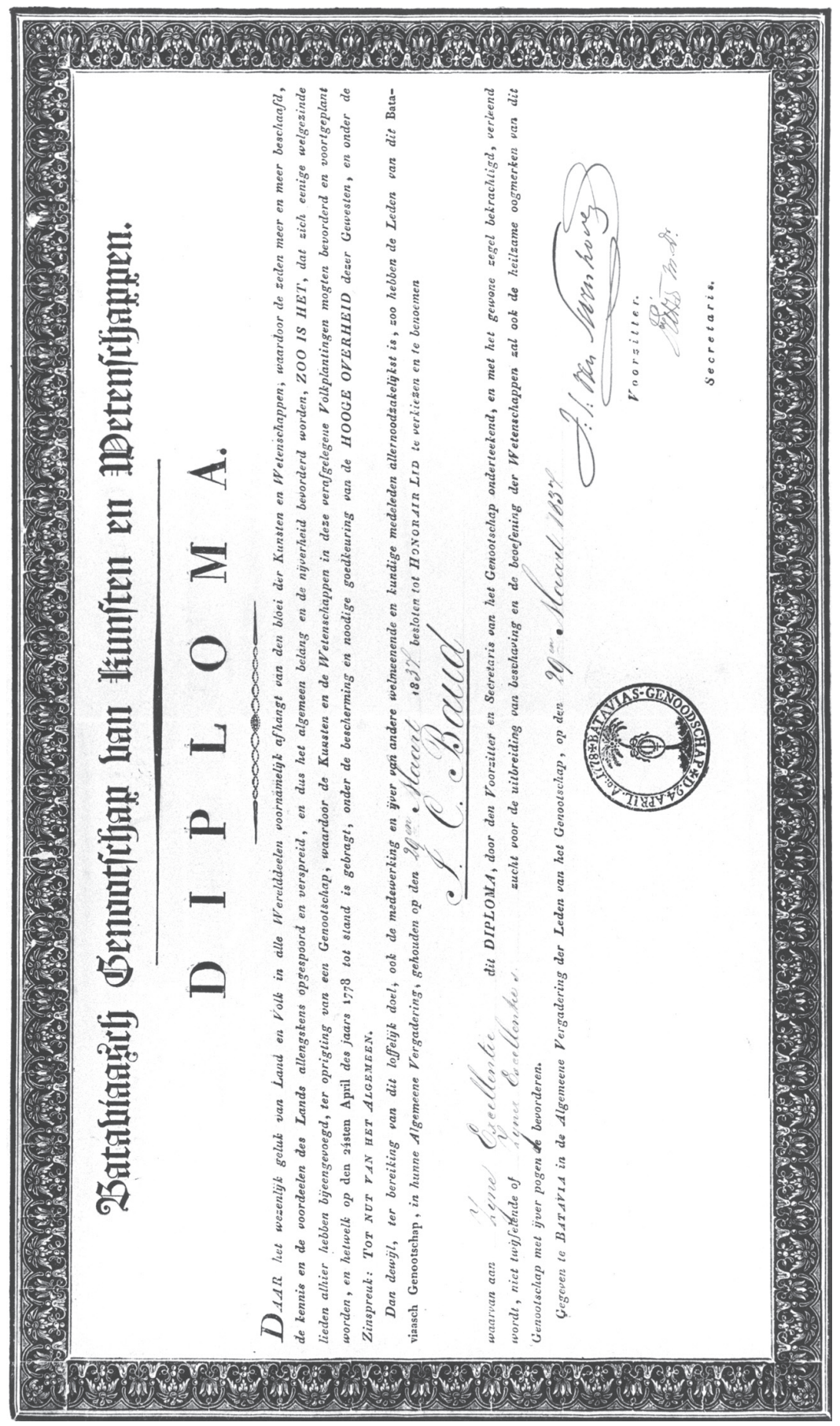

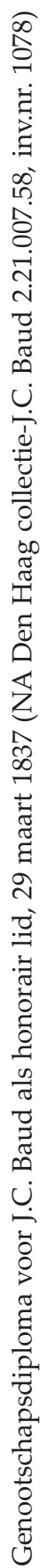


had op 16 januari 1830 zijn functie neergelegd en was door gouverneurgeneraal Van den Bosch opgevolgd. De ziekte en het overlijden van voorzitter J. Bousquet in 1831 verklaren ten dele de vertraging. In 1831 en 1832 werd er maar een paar keer vergaderd. Omdat er zo weinig bijeengekomen werd, reageerde Van der Vinne op 8 maart 1832 namens het bestuur op een brief van de gouverneur-generaal, die van het genootschap wilde weten hoe het dacht over plannen om vanuit Nederland zoölogische specimina toe te sturen om zo in Batavia een apart zoölogisch kabinet in te richten. Kennelijk was door personeelswisselingen niet meer precies bekend dat er nog een museumplan op een beslissing lag te wachten. Van der Vinne antwoordde met een exposé over het plan voor een museum in de tuin Du Bus en de kolfbaanvariant. Hij voegde er nu een verzoek aan toe om het genootschap maandelijks een bedrag van $f 200$ ter beschikking te stellen, opdat het plan om van het eigen kabinet nu iets te maken, kon worden uitgevoerd. Wat er was, mocht de naam van kabinet niet eens dragen. ${ }^{71}$ Terwijl bestuurslid J. van der Schoor in dat zelfde jaar 1832 nog voorspelde dat het gouvernement onder Van den Bosch wel gunstig op het aangevulde voorstel zou beschikken, moest voorzitter Merkus in februari 1834 melden dat zijn pogingen om de inmiddels aangetreden gouverneur-generaal ad interim Baud voor het plan te interesseren schipbreuk hadden geleden. ${ }^{72}$ Anderhalf jaar later zou Baud echter anders over de zaak beslissen.

Jean Chrétien Baud (1789-1859) was in Den Haag geboren en in 1810 als marineman met gouverneur-generaal Janssens naar Indië meegekomen. Hij maakte aldus het staartje van de Franse overheersing mee en bleef vervolgens onder Raffles dienen om in 1816 weer in Nederlandse dienst over te gaan. In 1819 werd hij algemeen secretaris onder Van der Capellen, om al in 1821 naar Den Haag terug te keren. In de jaren 1811-1821 was hij geen lid van het genootschap, wat gezien zijn latere belangstelling voor kunsten en wetenschappen - hij was een van de oprichters van het KITLV - opmerkelijk was. In Nederland was hij betrokken bij de oprichting van de Nederlandsche Handelmaatschappij en klom daarna op in het Ministerie van Nationale Nijverheid en Koloniën. In 1833 was hij terug in Indië om Van den Bosch op te volgen. Eerst was hij vice-president van de Indische regering, kort daarop gouverneur-generaal, tot hij in 1836 op zijn beurt werd opgevolgd door D.J. de Eerens. In 1833 werd hij wel tot lid van het genootschap benoemd. Baud zou van 1840 tot 1848 een belangrijke rol spelen als minister van koloniën.

Het museumplan sleepte zich aldus voort, tot de Indische regering in 1835

\footnotetext{
71 ANRI KBG Dir 0984, 1832 nr 12, brief van Van der Vinne aan de gouverneur-generaal, 8-31832.

72 ANRI KBG Dir 0085, vergadering 12-12-1832, punt 15; Dir 0087, vergadering 20-2-1834, punt 2 .
} 
liet weten niets te zien in het plan zolang het genootschap niet kon zorgen dat er vast toezicht was van iemand die met de natuurlijke historie bekend was. Er werd met nadruk verwezen naar de vele personele veranderingen in het bestuur die een zwak punt waren voor de plannen om een heus natuurhistorisch museum op te bouwen. ${ }^{73}$ Het genootschap was het hier wel mee eens. Het had kort tevoren twee steunpilaren, Van der Vinne en Lenting, verloren, die beiden naar Nederland waren gegaan. Het bestuur was bereid om iets aan die continuïteit te doen en wilde ook geld reserveren voor het museumplan, maar vroeg toch ook weer om 'eenige ondersteuning van Regeringswege in de toebereiding van het locaal [de kolfbaan] tot bewaarplaats bestemd. ${ }^{74}$ Uiteindelijk kwam pas op 13 augustus 1835 het antwoord van het gouvernement en daarmee een ontknoping die nogal afweek van wat Du Bus de Gisignies in 1828 had voorgesteld. Het veel kleinere en minder kostbare kolfbaanplan, dat uit de koker van het genootschapsbestuur kwam, werd uitgevoerd. Over het duurdere ontwerp van Tromp voor het perceel op het Waterlooplein werd niets meer gezegd.

De aansluiting bij het Bataviaasch Genootschap zou veel hechter worden dan het oorsponkelijke voorstel suggereerde. Het genootschapsbestuur zou de directie van het museum gaan vormen, maar aan deze directie werden vier personen toegevoegd: de chef van de Geneeskundige Dienst, de voorzitter van de Hoofdcommissie van Onderwijs, de hoofdingenieur van de Waterstaat en een lid van de Natuurkundige Commssie. Daarmee was de overheid nauw bij het toezicht betrokken. Het genootschap moest met de Harmonie gaan overleggen over het gebruik van de kolfbaan, waar het museum in gevestigd zou worden. De Natuurkundige Commissie moest meewerken door exemparen van naturalia ter beschikking te stellen, want het ging in de eerste plaats om een museum voor natuurlijke historie. Tenslotte besloot het gouvernement om tweehonderd gulden per maand bij te dragen en bekendheid te geven aan het museum door circulaires rond te sturen, opdat plaatselijke autoriteiten zouden meewerken aan het verzamelen van voorwerpen. Daartoe kon de Natuurkundige Commissie enkele inheemse beambten in dienst nemen, die voor verzamelen en prepareren konden zorgen. ${ }^{75}$ Alles zou moeten gebeuren in samenwerking met het Koninklijk Museum te Leiden. Dat laatste kan niet anders dan een vergissing zijn. Er werd gedacht aan het in 1820 opgerichte Rijksmuseum van Natuurlijke Historie, dat in Leiden was gevestigd en waarvan de doelstellingen goed aansloten bij het nu in Batavia voorgestelde verzamelbeleid voor naturalia. De opsteller van het besluit verwarde dit Leidse museum met het in 1816 opgerichte Koninklijk Kabinet van Zeldzaamheden

ANRI KBG Dir 0092, vergadering 29-5-1835, punt 2.

ANRI KBG Dir 0092, vergadering 29-5-1835.

ANRI KBG Dir 0092-93, vergadering 9-9-1835, punt 2. 
in Den Haag, dat een meer historische en volkenkundige verzameling bezat en een collectie schilderijen.

Het regeringsbesluit werd in zijn geheel geciteerd in het voorwoord van de Verhandelingen (VBG 16), ingeleid door een voorgeschiedenis. Daarmee was ook voor het eerst een breder publiek ingelicht over de plannen voor het museum. Het besluit sprak nadrukkelijk van een 'Museum voor natuurlijke historie, oudheden, zeldzaamheden, enz.', maar het ging in de toelichting toch vooral om de voorwerpen voor het natuurkundige gedeelte van het museum. Over de oudheden, zeldzaamheden ('enz.') werd verder niet uitgeweid. Het plan was tweeslachtig. Het wilde een voortzetting en uitbreiding zijn van het bescheiden, maar breed georiënteerde kabinet van het Bataviaasch Genootschap, maar het faciliteerde toch vooral het verzamelen van naturalia.

Voorzitter Merkus kreeg alle lof voor zijn interventie bij Baud. De beoogde aanvullende leden voor de directie van het museum werden benoemd, waarna men met nieuwe ijver aan de uitvoering begon. In het 'Voorberigt' tot deel 16 van de Verhandelingen werd nadrukkelijk het woord 'kabinet' gebruikt ter aanduiding van de kleine verzameling die voordien had bestaan. $\mathrm{Nu}$ zou het om een echt museum gaan met een eigen, versterkte directie. Toch kan men niet nalaten te denken aan alle pogingen die voordien al gedaan waren om een heus museum op te richten, te beginnen met de schenking van Radermacher in 1779. Er was al eens een opengesteld museum geweest met openingstijden en regels voor de toegang, oproepen aan leden en ambtenaren om bij het collectioneren te helpen, oproepen om geldelijke steun. Dit was een nieuwe poging om de zaken goed aan te pakken.

Hoe waren nu de oudheden in het museumbesluit gekomen? Daarop geeft het laatste artikel van het besluit antwoord. Er werd verwezen naar een brief van de Leidse hoogleraar in de archeologie, C.J.C. Reuvens, die bij het gouvernement navraag had gedaan naar de uitkomst van de werkzaamheden van de oudheidkundige commissie van 1822. In die brief van augustus 1832 had Reuvens het gouvernement onder meer aanbevolen om voor de zorg van de oudheden een apart genootschap in Indië op te richten. ${ }^{76}$ Baud vroeg eerst maar eens bij het genootschap wat er geworden was van de maatregelen van 1822, waarbij de commissie tot het opsporen van oudheden was ingesteld. Hij vroeg ook welke oudheden er waren verzameld en bij het genootschap waren ondergebracht, maar meldde niet dat zijn vragen door Reuvens' brief waren ingegeven. Het genootschap moest toegeven dat de commissie Pinket van Haak-Bik-Payen tot niets had geleid, en schreef dat toe aan gebrek aan fondsen. Het vond dat nu opnieuw de plaatselijke besturen over de zaak van 
verzamelen en verzenden van verplaatsbare oudheden konden worden aangeschreven. ${ }^{77}$ Pas in tweede instantie had voorzitter Merkus begrepen dat de vraag van de gouverneur-generaal was ingegeven door de brief van Reuvens en toen kwam hij er nog eens op terug. Oproepen tot de bestuurshoofden om medewerking waren zonder antwoord gebleven, er was geen geld en evenmin deskundigheid voor een apart genootschap voor oudheidkunde. In zo'n nieuwe organisatie zag Merkus niets. Het genootschap adviseerde om opnieuw de residenten aan te schrijven over de oudheden. Was er eerder niet gereageerd op de aanschrijvingen uit Batavia, het genootschap verwachtte dat een circulaire nu meer succes zou hebben. ${ }^{78}$ Het kaatste echter de bal van het gebrek aan fondsen opnieuw naar het gouvernement.

Van het tegenwoordig verlicht bestuur durven wij echter verwachten, dat onze herhaalde, doch immer machteloze pogingen zullen worden ondersteund en wij menen dat voor het tegenwoordige eene krachtige ondersteuning daarin zoude bestaan, dat van regeringswege de plannen van den Hoogleeraar Reuvens en onze bedoelingen omtrent dit onderwerp in dezen brief blootgelegd, aan de verschillende residenten worden bekendgemaakt. ${ }^{79}$

In het antwoord had het genootschap nog wel naar Bik verwezen, een van de commissieleden uit 1822 en nu bestuurslid. Door zozeer te benadrukken dat er geen geld beschikbaar was, had het genootschap Baud ingegeven dat hij eindelijk een beslissing over de subsidieaanvraag ten behoeve van het museum moest nemen. Baud nam uiteindelijk ook de oudheden in zijn besluit op, en koos niet voor een apart genootschap, zoals Reuvens dat had voorgesteld. ${ }^{80}$ Evenmin koos hij voor een louter natuurkundig museum, zoals Du Bus in gedachten had.

Zo had de brief van Reuvens niet tot het beoogde resultaat geleid. De hoogleraar had als beheerder van de Javaanse oudheden in het Leidse museum meermalen om hulp gevraagd. In 1832 had hij zijn geduld verloren. Er gebeurde zijns inziens te weinig. Vandaar dat hij op de oprichting van een aparte instelling aanstuurde, opdat die de zorg voor de archeologische monumenten 'op vaste voet' zou brengen. Hij stelde zich een Maatschappij tot Uitgave van Javaansche Monumenten voor en stuurde daarvoor de conceptartikelen al mee. Zijn zorg werd uiteraard alleen maar groter bij de wetenschap dat menig ambtenaar beelden en fragmenten van monumenten

\footnotetext{
77 ANRI KBG Dir 089, vergadering 20-12-1834, punt 2 en bijlage 1, dd 10-10-1834.

78 ANRI KBG Dir 0090, vergadering 25-3-1835, punt 20.

79 ANRI KBG Dir 092, vergadering 6-4-1835, concept-antwoord aan de gouverneur-generaal, 6-4-1835.

80 De brief van Reuvens is gevoegd bij de stukken van vergadering 29-5-1835, maar te vinden achter het verslag van 21-10-1835, ANRI KBG Dir 0093.
} 
meenam en die als zijn eigendom beschouwde. Reuvens' brief en Bauds museumbesluit zouden voor de oudheidkundige verzameling echter nog weinig betekenen. De eerste die effectief zorgde dat er een aanzienlijke verzameling monumentale oudheden bij het genootschap binnenkwam, zou Van Hoëvell zijn en toen was er al weer een aantal jaren verstreken. De oprichting van de Oudheidkundige Commissie (1901) en de Oudheidkundige Dienst (1913) luidde pas een definitieve regeling in van de zorg voor oudheden in Indië.

Dat het gouvernement het genootschap serieus nam met zijn nieuwe museum blijkt uit de verslagen van bestuursvergaderingen vanaf 1835 . Verschillende voorwerpen werden aan het genootschap aangeboden. Er tekende zich een patroon af dat zich met grotere regelmaat voordeed. Het genootschap kreeg van het gouvernement via de algemeen secretaris, dan wel van lokale bestuurders, veelal residenten of assistent-residenten, voorwerpen aangeboden ter overname. Soms ook wel van particulieren. Vaak ging het om opgegraven, waardevolle voorwerpen, zoals munten en sieraden of sculpturen in edele metalen, dan weer om etnografica: wapens, kleding, landbouwinstrumenten. Een enkele maal ging het om een buitenkansje zoals de grote collectie van de afgezette sultan van Bantam, waarover later meer. Er werd geschonken, dan wel moest er voor de voorwerpen worden betaald aan de vinder of aan degene die de voorwerpen zelf had verworven. In het geval dat het genootschap moest betalen, stond het steeds voor de keuze: wat is het waard, wat is het ons waard, willen we dat ervoor geven? Zo kwam het vanaf 1835 ook voor dat voorwerpen werden afgewezen, dan wel dat een aangeboden groep voorwerpen deels wel en deels niet werd overgenomen/ aangekocht. Het genootschapsmuseum werd een depot voor het gouvernement, dat door een steeds verder ingrijpen in het binnenlands bestuur, vooral op Java, meer dan in het verleden in het bezit kwam van oudheidkundige en volkenkundige voorwerpen, voor het beheer waarvan het niet over een eigen instantie beschikte.

\section{Gebouwen}

De verzamelingen waren nog steeds zeer verschillend van aard en de voorwerpen vertoonden weinig samenhang. Met het aanwassen ervan deden zich meer en meer de problemen van het beheer gelden, zowel logistiek (kasten, vitrines en schappen, flessen en potten, kamfer en sterk water) als wetenschappelijk-museologisch (indeling van de collectie, indeling van de ruimten, opstellen van de voorwerpen, beschrijving van de voorwerpen). Ook praktische zaken moesten worden geregeld, zoals bewaken en schoonhouden. De boeken en de manuscripten vroegen daarbij om speciale zorg. Zolang het was 
gegaan om enkele tientallen voorwerpen in een 'kabinet van zeldzaamheden' hadden de bestuursleden het toezicht wel aangekund en overzicht over de beperkte stroom binnenkomende voorwerpen kunnen houden. Nu de ambities hoger kwamen te liggen, moesten al deze zaken aandacht krijgen. Baud had dat probleem duidelijk gezien toen hij, voorafgaande aan het besluit over het museum in 1835, het probleem van de continuïteit en de vakkennis in de genootschapskring had gesteld. We kunnen dus concluderen dat met het besluit van Baud en de koppeling van vakmensen aan de directie van het museum, een stap in de richting van professionalisering werd gezet, waar al lang op werd gewacht. Door de subsidiëring en door de depotfunctie werd de band tussen overheid en genootschapsmuseum aangehaald.

Aan de geschiktmaking van de ruimtes werd in 1836-1839 hard gewerkt. Het gouvernement begon met de betaling van $f 2.400$ per jaar voor het museum, met terugwerkende kracht vanaf augustus 1835, en hoofdingenieur Tromp regelde de eerste verbouwingswerkzaamheden. ${ }^{81}$ Er werd verbouwd aan het genootschapslokaal in de Rijswijkstraat, dat in 1814 was betrokken. De vergaderruimte was daardoor niet beschikbaar voor de vergaderingen van het eigen bestuur, van de kerkenraad en van de onderwijscommissie, waar het vaak voor werd uitgeleend. ${ }^{82}$ Aan de oostzijde van het gebouw moesten vier ramen worden dichtgemaakt en er werd een deuropening aangebracht, waardoor het achterterrein direct vanuit het gebouw bereikbaar was en men naar het museum kon lopen zonder eerst via de Rijswijkstraat en Rijswijk te hoeven gaan. Een paar treden gaven toegang tot het terrein. ${ }^{83}$

Het meeste werk was nodig aan het museumgebouw, de voormalige kolfbaan. In mei 1836 werd door de betaling van $f 650$ aan de Harmonie de overdracht van dat gebouw aan het genootschap bezegeld. ${ }^{84}$ Daarna konden de aanpassingen van start gaan. De vloeren moesten worden opgehoogd, de vensterluiken worden vervangen, ontvreemde ruiten worden vernieuwd, schuiframen maakten plaats voor openslaande ramen en tussen de twee belangrijkste afdelingen kwam een glazen deur in plaats van een open boog. Het kolfbaangebouw kreeg er een keukentje bij en twee bediendenvertrekken. Voor het optrekken van een laboratorium voor de leden van de Natuurkundige Commissie, dat eerst in het museum plaats had gevonden, moest een wagenloods van de Harmonie worden afgebroken. Verder moesten afdakgalerijen worden geplaatst. Het genootschap vroeg voor de

\footnotetext{
81 ANRI KBG Dir 0096, vergadering 7-4-1836, punt 3 en 4; en Dir 0097, vergadering 2-7-1836, punt 19 .

82 ANRI KBG Dir 0096, vergadering 7-4-1836, punt 14.

83 Een begroting voor $f$ 1.542,04 van 5-5-1836 van J. Tromp geeft inzicht in deze veranderingen aan het genootschapsgebouw. ANRI KBG Dir 1507, omslag 1836.

84 ANRI KBG Dir 1332, omslag 1836, kwitantie van 18-5-1836.
} 
verbouwing $f 5.252$ aan en dat bedrag kwam er, zij het dat de betaling naar 1838 werd verschoven. ${ }^{85}$ In het gouvernementsbesluit over dit onderdeel van de verbouwing werd overigens gesproken van een laboratorium voor het Museum van Natuurlijke Historie, terwijl leden of assistenten van de Natuurkundige Commissie in dat laboratorium zouden werken. ${ }^{86}$ De afbakening van verantwoordelijkheden tussen genootschap en Natuurkundige Commissie was in het besluit niet zo duidelijk geworden. Tijdens de bouw werd besloten dat het laboratorium groter zou uitvallen. In plaats van vijftig voeten lang werd het tachtig voeten lang (ongeveer vierentwintig meter). Verder was er schilderwerk te verrichten, onder meer aan de kasten in het museum. ${ }^{87}$ De totale kosten van de verbouwing bedroegen $f 7.836$. Daarvan had het gouvernement het leeuwendeel voor zijn rekening genomen. Het restant werd door het genootschap betaald, dat echter door de subsidie van $f 2.400$ per jaar deze kosten weer op het gouvernement verhaalde.

Het was vooral het bestuurslid Tromp die op de gebouwen lette. Door de verbouwing en nieuwbouw beschikte het genootschap nu over twee gebouwen, terwijl het de vraag was van wie het aparte laboratorium nu eigenlijk was. Was het een onderdeel van het museum of de werkplaats van de zelfstandige Natuurkundige Commissie? Evenzeer zouden de leden van die commissie en hun assistenten het museum deels als een verlengstuk van hun werk beschouwen. Baud had met zijn besluit onduidelijkheid gecreëerd. Voor de uitvoeringsaspecten was als gebruikelijk de secretaris het meest instrumenteel: na het vertrek van Van der Vinne en het korte secretariaat van Lenting in 1834 werd Mr C. Visscher secretaris, die echter eind 1835 al weer vervangen werd door de boekhouder M.H. Halewijn. Pas met het aantreden in januari 1836 van de medicus E.A. Fritze, later hoofd van de Militair-Geneeskundige Dienst, kwam er weer een doortastende persoon die veel voor het museum kon doen en die ook langere tijd bij het genootschap betrokken zou blijven. Fritze kreeg meteen te maken met een personeelsprobleem: de door de Natuurkundige Commssie aangestelde conservator B.N. Overdijk beviel niet en bedreigde het net geboren museum na twee maanden al met de ondergang. Hij werd door zijn chef, tevens lid van de Natuurkundige Commissie en bestuurslid van het genootschap, P. Diard, vervangen door D.H.R. van Gelder en toen ging het wel. Overdijk zou in het vervolg onder Van Gelder werken. Beiden waren begonnen met het rangschikken van de zoölogi-

85 ANRI KBG Dir 0102, vergadering 20-6-1837, punt 7; en Dir 0105, vergadering 30-10-1837, punt 34 en bijlage 34-37 en 45 .

86 Kopie van het besluit dd 23-10-1837 voor de (ver)bouw tot een bedrag van $f 5.252,84$ in ANRI KBG Dir 1507, omslag 1837.

87 In 1839 werd er een overzicht gemaakt van alle kosten die voor de verbouwing waren gemaakt. ANRI KBG Dir 1332 (1839). Aan dit overzicht vallen veel gegevens te ontlenen. 
sche voorwerpen. Fritze wilde de opzichter en de inheemse beambten, die als schoonmakers werkzaam waren, vervangen door nieuw aan te stellen inheemse jagers, dat wil zeggen functionarissen die met het verzamelen van naturalia waren belast en hen dat onderhoudswerk erbij laten doen. Hij wilde deze tien gulden per maand betalen. Diard en Tromp protesteerden dat dit zou leiden tot 'luiheid en liederlijkheid' maar Fritze hield vast: het werd tien gulden. Zo werd de toestroom van naturalia op gang gebracht. Met het in de verschillende residenties op Java aanstellen van zulke jagers werd nog even gewacht totdat het museum op 'zekere hoogte' zou zijn gebracht. ${ }^{88}$ Een paar maanden later bleken er al weer problemen met Overdijk en waren de jagers weggelopen, omdat zij een betere beloning ontvingen wanneer ze voor particulieren werkten. ${ }^{89}$ Dat waren de aanvangsproblemen voor het management van het nieuwe museum.

In deze situatie van opbouw en verbouwing trof Prins Hendrik het genootschap toen hij het tijdens zijn maandenlange reis door de archipel met een bezoek vereerde en wel op 27 augustus 1837 (Fasseur 1997:232). Hij was het eerste en tegelijk het enige lid van het Nederlandse Koninklijk Huis dat ooit een bezoek heeft gebracht aan het koloniale rijk. Tijdens de aan het bezoek van de prins voorafgaande algemene vergadering werd besloten hem tot erelid te benoemen en tot beschermheer van het Nederlands Koloniaal Museum, 'welken titel men aan het nieuwe opterigten museum wenschte te geven'. Het was de eerste keer dat men deze naam gebruikte en vreemd genoeg bleef in die naam de relatie tot het genootschap onuitgedrukt. De prins kreeg een uitleg over de geschiedenis van het genootschap door voorzitter Van Sevenhoven, een Franse toespraak door directeur Diard over de betekenis voor politiek, landbouw en wetenschappen van zo'n museum en tenslotte een uiteenzetting door Bürger over 'wezen en aard der vulcanen'. Daarna volgde uiteraard een bezichtiging van het museum. ${ }^{90}$ Hoewel de verbouwing in mei 1836 energiek ter hand was genomen, was lang niet alles klaar. Wel was er al voor duizenden guldens aan vitrinekasten uitgegeven en waren de jagers actief bezig met het binnenbrengen van naturalia. Voor het jagen op insecten was zelfs een aparte insectenjongen aangesteld. Voor het opbergen van de vangst waren honderden doosjes gemaakt. Misschien kreeg de prins daar iets van te zien. En wellicht werd hem de koningstijger getoond, waarvoor een hok was gebouwd. ${ }^{91}$ De prins kreeg ter herinnering aan zijn

\footnotetext{
88 ANRI KBG Dir 0096, vergadering 7-4-1836, punt 11-13, 16.

89 ANRI KBG Dir 0097, vergadering 21-7-1836, punt 4 en 5.

90 ANRI KBG Dir 0103, algemene vergadering 27-8-1837.

91 In ANRI KBG Dir 1332 is het bundeltje 1835 onvolledig. Over de jaren 1836-1839 kan men de aankopen voor het museum reconstrueren. In januari 1836 werden van het departement van oorlog 24 witte stolpflessen en 50 liter arak gekocht. In februari betaalde Tromp voor de derde
} 
bezoek een complete ingebonden set van de 16 delen van de Verhandelingen, voor het inbinden waarvan de binder $f 112$ ontving. Verder kreeg hij een speciaal gekalligrafeerd diploma van zijn erelidmaatschap en beschermheerschap van het museum. De kunstenaar Snell kalligrafeerde dat voor honderd gulden. ${ }^{92}$ Helaas heeft de prins in de brieven naar zijn ouders geen verslag van zijn bezoek aan het genootschap gedaan. ${ }^{93}$

Met een directie, een koninklijke beschermheer, een eigen gebouw - al was het dan een verbouwde kolfbaan -, met een conservator en jagers, en met voorwerpen van allerlei aard, was het Indisch Museum of het Nederlands Koloniaal Museum een feit. Dat hetzelfde museum in afrekeningen aan het genootschap ook werd aangeduid als het Bataviaasch Museum van Natuurlijke Historie geeft aan dat de naam niet meteen was ingeburgerd. ${ }^{94}$ In juni 1839 werd de verbouwing afgerekend en leken de werkzaamheden voltooid. ${ }^{95}$ In juli 1839 werd het museum geopend voor het publiek: op zaterdag en zondag en tevens op andere feestdagen van zeven tot twaalf uur. ${ }^{96}$

\section{Verzamelingen}

De aandacht voor het museum (kabinet) en de bibliotheek roept direct de vraag op naar de manier waarop het genootschap verzamelde: welke collecties had het op het oog en hoe dacht het bestuur deze collecties op te bouwen en uit te breiden? De royale gift van Radermacher in de beginfase van de genootschapsgeschiedenis en de kleinere schenkingen die daarop waren gevolgd, waren uitgegaan van de goede gevers, danwel uitgelokt door oproepen daartoe in circulaires en voorberichten tot de Verhandelingen. De impulsen die van het genootschap zelf uitgingen, verdienen nadere beschouwing omdat we daaruit een verzamelbeleid zouden kunnen afleiden.

Over het Engelse tussenbestuur is op dit punt zo goed als niets bekend. Het gaf ons de indruk dat Raffles voor zichzelf en het eigen land verzamelde, niet

keer $f 500$ uit voor kasten. In maart 1836 waren er drie jagers: Amon, Goemok en Djamieng. In juli 1836 werd $f 140$ betaald voor twee insectenkasten en werd $f 24$ betaald voor de jager en de insectenjongen. In juni 1837 was een groot deel van het werk voltooid, maar tot in februari 1839 gingen de uitgaven aan het museum door. In augustus 1837 rekende Van Gelder $f$ 40,25 voor het maken van een tijgerhok en $f 13$ voor het vervoer van de 'Tijger Roijaal'.

92 ANRI KBG Dir 1332 (omslag 1837) bevat een kwitantie voor Schneither en een voor Snell.

93 Mededeling Koninklijk Huisarchief, brieven van 19 en 24-2-1998 van de heer A.F. Ubels. De serie extra fraai gebonden delen van de $V B G$ en het diploma dat de prins ontving, zijn niet traceerbaar.

94 Afrekeningen van conservator Van Gelder in ANRI KBG Dir 1332 (nov. 1836).

95 ANRI KBG Dir 1332 bevat in omslag 1839 een afrekening van 22-6-1839. Het genootschap betaalde zelf aan de verbouwing $f 2.583,74$.

96 ANRI KBG Dir 0116, vergadering 11-7-1839, punt 6. 
voor het Bataviaasch Genootschap. Reinwardt verzamelde voor kabinetten en musea in het vaderland. Ook de in 1816 door Willem I benoemde Belgische schilder Antoine Payen werd uitgezonden om het Indische landschap vast te leggen ten behoeve van het publiek in het nieuwe koninkrijk (Scalliet 1995:30-4, 1999:44-5). De in 1820 opgerichte Natuurkundige Commissie voor Nederlandsch-Indië, die een grote stimulans voor het Indische natuuronderzoek zou betekenen, stelde evenzeer verzamelingen voor het vaderland samen. Toen er in Leiden in 1837 een aparte begeleidingscommissie van de drie hoogleraren Reinwardt, Blume en Temminck werd samengesteld, betekende dat eens te meer dat de belangen van de vaderlandse verzamelingen werden veilig gesteld. Het gouvernementsbesluit van 1835 over de steun aan het Bataviase museum voor natuurlijke historie zal de drie hoogleraren eerder zorgen hebben gebaard, dan dat het een opluchting betekende. Met alle goede bedoelingen van Van der Capellen ten opzichte van het Bataviaasch Genootschap stond toch tijdens zijn bestuur het verzamelen voor Nederland voorop. Tijdens de laatste maanden van Reinwardts aanwezigheid in Batavia werd het verzamelen van archeologische voorwerpen voor een in te richten kabinet van oudheden bij het genootschap aan de orde gesteld. We zagen al dat de oproep daartoe aan de residenten op Java niets uithaalde. Het gebeurde bovendien pas, nadat verschillende belangrijke zendingen met archeologische vondsten, onder meer van de al genoemde beelden van Singosari uit de collectie Engelhard, naar Leiden waren gegaan. Die vormden daar met tientallen andere door Reinwardt gestuurde beelden, en tekeningen en beschrijvingen van tempels de kern van de Indische afdeling van het nieuwe Rijksmuseum van Oudheden (1818), waarmee de hoogleraar Reuvens aan de slag kon. ${ }^{97}$

Toen Van der Vinne secretaris werd en zich actief ging bezighouden met de genootschapszaken, moet ook hij gezien hebben dat er een grote stroom objecten scheep ging en dus niet naar de Rijswijkstraat verhuisde. Niettemin diepte hij direct een voorbeeld van de achttiende-eeuwse circulaires uit het archief op, waarmee destijds vertegenwoordigers van de Hoge Regering waren opgeroepen om aan het verzamelen te slaan ten behoeve van het genootschap. In mei 1823, de eerste vergadering waar Van der Vinne effectief optrad, bracht hij op dat er in het archief nog exemplaren waren van de gedrukte vragenlijst die men gewend was mee te geven naar de buitengewesten. Een gewijzigde en aangevulde versie zou meegegeven worden aan het nieuwe hoofd van het kantoor in Deshima, De Sturler, en ook in de toekomst

97 Effert 2003:5-6 spreekt van ruim 40 beelden die onder Reinwardt naar Leiden verhuisden. De drie dertiende-eeuwse beelden van Singosari vormen nu een hoogtepunt in het vernieuwde Museum voor Volkenkunde te Leiden. Zie over de beelden van Singosari uit de collectie Engelhard ook Krom 1923, I:9. 
voor anderen gebruikt kunnen worden. De eerste lijsten van 1778 (Eenige Vragen aangaande de natuurlyke Historie van India, die verzogt worden in margine te beantwoorden) en 1780 (Memorie der Zaken met dewelke den Bezorger het Bataviaasch Genootschap zal verpligten) werden bewerkt tot een lijst van 22 vraagpunten, waarin opgesloten een verzoek om allerlei voorwerpen aan het genootschap toe te zenden. ${ }^{98}$ Of de gewijzigde lijst van 1823 inderdaad uitging naar alle windsteken is nog de vraag: er zijn geen antwoorden in het archief te vinden die daarop wijzen. Vooralsnog was Deshima dus het beste voorzien van instructies. Maar juist Japan leverde via deze vestiging een drietal belangrijke collecties op voor het Koninklijk Kabinet van Zeldzaamheden in Den Haag, namelijk die van het opperhoofd Jan Cock Blomhoff (1826), van de arts Von Siebold (1831) en van de pakhuismeester Johan van Overmeer Fisscher (1832). Daarbij speelde zowel het actieve acquisitiebeleid van de Haagse directeur R.P. van de Kasteele een rol alsook het feit dat genoemde verzamelaars in Nederland gemakkelijker dan in Batavia hun collectie te gelde konden maken (Effert 2003).

In het bericht dat het genootschap in 1823 in de Bataviasche Courant liet plaatsen, was van een echte oproep, anders dan impliciet via het bedanken van gulle gevers in het verlopen jaar, geen sprake (Bataviasche Courant 1-11-1823). Wel was in 1824 een explicieter oproep gedaan tot het schenken van boeken, handschriften en zeldzaamheden voor de bibliotheek en het kabinet, waartoe per brief in 1825 ook de belangstellenden en leden in de buitengewesten waren aangespoord. Ook giften in geld waren welkom. Deze verzoeken waren echter algemeen geformuleerd en kunnen nauwelijks als een uiting van gericht verzamelbeleid worden aangemerkt. ${ }^{99}$ Wel bleken de oproepen van 1824 en 1825 te zijn gehoord. ${ }^{100}$

De ingreep van Du Bus de Gisignies in 1828 ten gunste van een nieuw museum voor natuurlijke historie dwong het genootschap weer na te denken

98 ANRI KBG Dir 1505 bevat een nieuwe versie met 22 vraagpunten (nr. 26), terwijl van de oude lijst van 1778 met 14 punten twee zwaar beschadigde exemplaren meegebonden zijn, kennelijk de exemplaren die Van der Vinne voor dit doel heeft gebruikt. Betere exemplaren van die circulaires van 1778 in ANRI KBG Dir 0980, nr [3] en [56]. Van de Memorie van 1780 nr [53] in dezelfde bundel. Zie verder de notulen van de vergadering 28-5-1823, punt 17 (ANRI KBG Dir 0023).

99 ANRI KBG Dir 0034, vergadering 15-4-1824, punt 10, waarna de oproep op 24 april tijdens de algemene vergadering werd gedaan (ANRI KBG Dir 0046, vergadering 10-2-1825, punt 10). ANRI KBG Dir 982, nr 50 is een concept-oproep aan de gouverneur van Makassar en andere gezaghebbers en residenten tot inschrijving op een lijst voor de vorming van een fonds tot verbetering van het museum.

100 ANRI KBG Dir 0055, vergadering 9-2-1826, bijlage, vermeldt een bedrag van $f 4.215$ aan schenkingen voor het fonds, maar moeilijk kan worden gezegd dat dit een nieuw verzamelbeleid inluidde. ANRI KBG Dir 0983,omslag 1825, bevat een lijst van Van der Vinne die betrekking heeft op dezelfde inzameling. Op die lijst kwam het bedrag uit op $f 4.385$. 
over een verzamelbeleid. Immers, de nadruk die leek te gaan vallen op het verzamelen van naturalia, week wel zeer af van het verleden, toen oudheidkundige en zeldzame voorwerpen als ook voorbeelden van kunstnijverheid waren genoemd en verzameld. Vandaar dat Lenting in juli 1829 voorstelde om een brief te sturen naar alle gouverneurs, residenten en gezaghebbers in Nederlands-Indië om in het bezit te komen van manuscripten, wapens, kledingstukken en gereedschappen. De brief is door Lenting, mogelijk in samenwerking met Van der Vinne, opgesteld. Zij ging uit van het genootschap, al werd wel het gouvernementele plan Du Bus voor een apart museum vermeld. ${ }^{101}$

Lenting signaleerde dat de boekerij van het genootschap wel een collectie boeken en handschriften in Europese talen had, maar wat eraan ontbrak waren 'Indische geschriften in de verschillende landstalen van dezen Archipel'. Hij karakteriseerde het genootschap als 'een asiatische wetenschappelijke maatschappij', waarbij het laatste woord in de negentiende-eeuwse betekenis van 'genootschap' te lezen is. Zo'n verzameling van Indische geschriften zou het bestuur ten dienste van wetenschapsbeoefenaren van oosterse mythologie, geschiedenis en letterkunde moeten aanleggen. De voorwerpen waarover het kabinet van het genootschap beschikte, waren volgens Lenting onvoldoende 'eigenaartig' omdat ze net zo goed in de collecties van Europese genootschappen konden voorkomen of ook werkelijk voorkwamen. Vandaar dat de wetenschapsbeoefenaren die naar Batavia kwamen, teleurgesteld waren als ze in het kabinet van het Bataviaasch Genootschap aantroffen wat ze in Europa al hadden gezien. Daarom de oproep aan de gouverneurs, residenten en andere belangstellenden om behulpzaam te zijn bij het verzamelen van 'nationale' voorwerpen, die 'tot leidraad kunnen verstrekken om meer en meer de huishouding, den morelen toestand, de meerdere voorderingen van den bewoner dezer Archipel in landbouw, werktuigbouwkunden, enz. bekend te maken'. Lenting bepleitte dus het verlaten van het algemeen encyclopedische karakter dat het genootschap in de achttiende eeuw had gehad en dat gezien de staat van de collectie op dat moment nog prevaleerde.

De beoogde voorwerpen werden vervolgens door Lenting in vier categorieën verdeeld.

1 Geschriften in de landstalen, originele of afschriften, van algemeen belang of in het bijzonder voor de kennis van mythologie, geschiedenis, landbouw- of werktuigbouwkunde.

2 Exemplaren van werktuigen in gebruik in landbouw, huishouding of industrie met de benaming ervan in de landstaal en in het Nederlands (als

101 ANRI KBG Dir 0075, vergadering 2-7-1829, punt 17, en ANRI KBG Dir 0984, Conceptbrief juli, later 13-11-1829, nr 71 en nr 55 verzendlijst. 
er een benaming voor is in die taal). Van te grote of te zware voorwerpen konden modellen worden gestuurd.

3 Exemplaren van wapens voor oorlog of jacht met opgave van de benaming en de tijd waarin ze gebruikt werden.

4 Exemplaren van kledingstukken voor de verschillende standen in de inheemse maatschappij met namen en opgave wanneer zij gedragen werden.

Ter aanmoediging voegde Lenting er nog aan toe: 'ook het geringste voorwerp uit eene der drie bovengemelde klassen [2, 3 en 4] zal wanneer hetzelve slechts nationaal is, met dankbaarheid worden aanvaard.' Hij voegde er nog aan toe dat voorwerpen die 'bij den eersten opslag nietig en niets beduidend schijnen, eene groote wetenschappelijke waarde en belangrijkheid krijgen, zoodra men dezelfde voorwerpen van onderscheidene plaatsen afkomstig bij elkander verzameld heeft'. Met deze formuleringen deed Lenting zich kennen als een persoon met belangstelling voor de vergelijkende etnologie, die erin slaagde de bedoelingen van het verzamelbeleid voor een publiek van zeer divers opgeleide bestuursambtenaren duidelijk te maken. Opvallend is de keuze van de term 'nationaal', waar die in deze context niet anders kon betekenen dan 'behorend tot deze natie', ofwel de bevolking van de Indonesische archipel. De band met patria werd niet genoemd. Nog opvallender is het feit dat met geen woord gevraagd wordt om naturalia, evenmin om oudheidkundige voorwerpen. De belangstelling van de opsteller van deze brief gaat geheel uit naar de taal- en volkenkunde. Het is echter een circulaire die helder aangeeft wat het genootschap wilde. Misschien ging Lenting er op dat moment nog vanuit dat het museum voor natuurlijke historie aan het Waterlooplein op de Tuin Du Bus er zou komen en dat een specialisering de uitweg was voor het genootschap om toch een eigen kabinet te behouden.

Was het kabinet (of museum) dan kennelijk in 1829 nog te weinig toegesneden op de wereld waarin het genootschap was ontstaan, de bibliotheek stond er evenmin goed voor. Op 1 juli meldde de nieuwe opziender van de bibliotheek en het kabinet, P. van der Meer, dat veel boeken in slechte staat verkeerden, in september werd besloten over te gaan tot openbare verkoping van dat deel dat niet meer te behouden was. De catalogus die in december werd gepresenteerd voor de verkoping, biedt een interessante blik op wat er tot dan toe was bewaard en een treurige blik op wat er stond afgestoten te worden. De catalogus omvatte 97 nummers, sommige echter bestaande uit series van tientallen delen. Het totaal besloeg ruim 500 boekdelen, waaronder veertien delen van Diderots Encyclopédie, een complete Valentijn (een ander exemplaar bleef behouden), 27 delen van de Zweedse academie, 59 delen van de Hollandsche Maatschappij van Haarlem en 21 delen van het Zeeuwsch Genootschap der Wetenschappen. Uiteindelijk zouden de boeken toch niet op een veiling verkocht worden maar ondershands van eigenaar verwis- 
selen. De bibliotheek leed een gevoelig verlies. ${ }^{102}$ Van der Meer meldde op 2 februari 1830 aan Van der Vinne dat er verscheidene Chinese handelaren hadden geboden, maar dat de 'defecte en afgekeurde boeken' niet meer dan $f 116$ hadden opgebracht. ${ }^{103}$ De treurige toestand van de bibliotheek was een reden voor Lenting om voor te stellen beide beschermheren, Du Bus en De Kock, aan te schrijven en een beroep te doen op hun weldadigheid om zo bibliotheek en kabinet op een hoger peil te brengen. ${ }^{104} \mathrm{Du}$ Bus meldde dat hij vooral juridische werken had meegenomen uit Europa. Die konden volgens Du Bus zelf 'niet voegzaam' aan het genootschap worden aangeboden.

De slepende zaak van het museumvoorstel uit 1828, dat pas in 1835 door Baud werd afgehandeld, was voor een goed verzamelbeleid niet erg bevorderlijk. De circulaire van Lenting leverde wel iets op maar veel minder dan hij zelf had gehoopt. Het duurde tot augustus 1835 eer het gouvernementsbesluit over het op te richten museum voor natuurlijke geschiedenis, taal, volken en oudheidskunde (formulering van het genootschap) of museum voor natuurlijke historie, oudheden, zeldzaamheden, enz. (formulering van het gouvernement) het genootschap een steuntje in de rug gaf. Plaatselijke autoriteiten werden in het besluit aangespoord om actief mee te werken aan het opsporen en verzenden van voorwerpen van natuurlijke historie. Dat Baud vooraf besloot om het museum in de kolfbaan een beter toegeruste directie te geven, waardoor op termijn ook gehoopt mocht worden op een effectiever verzamelbeleid en dus op een betere museumcollectie, leek een verstandige beslissing.

De overheid liet nog eer het museumbesluit viel, zien dat het vertrouwen in het genootschap had en wel door een deel van de collectie van de sultan van Bantam af te staan. De economische moeilijkheden met Bantam, een gebied van groot belang voor de peperhandel, kenden een lange geschiedenis, die in 1752 ten einde leek te komen door de erkenning van de soevereiniteit van de Compagnie door de sultan. Daendels maakte het gebied in 1809 tot een domein van het koninkrijk, verbande de sultan naar Ambon en plaatste een nieuwe sultan aan het hoofd. Raffles hief het sultanaat in 1813 zelfs helemaal op, plaatste Bantam onder Europees bestuur en begon er het landrentesysteem toe te passen. Van der Capellen had op zijn beurt weer te maken met ongeregeldheden in het gebied. De aanwezigheid van de voorma-

102 Zie de catalogus als bijlage 2 bij vergadering 2-12-1829 (ANRI KBG Dir 0078), verslag vergadering 2-7-1829, punt 8 en bijlage 8 (Dir 0075) en van 10-9-1829, punt 3 (Dir 0076). Over de verkoop: vergadering 19-2-1830, punt 2 (Dir 0079).

103 ANRI KBG Dir 1331 (omslag 1830), brief van P. van der Meer aan J. van der Vinne, dd 2-21830 .

104 ANRI KBG Dir 0078, vergadering 2-12-1829, punt 5 en bijlage 4. De minuut van de brief aan De Kock en Du Bus te vinden in ANRI KBG Dir 0984, nr 73. 
lige sultansfamilie bleef problemen opleveren, zodat in 1832 opnieuw werd besloten tot haar verbanning (De Jong 1998:184-5; ENI s.v. Bantam). Daarbij werden de eigendommen van de sultan in beslag genomen. De titulaire, want immers afgezette, sultan werd naar Soerabaija 'verwijderd' en zijn 'preciosa, wapenen, kleedingstukken, poesakas, manuscripten, enz.' overgebracht naar 's Lands Civiele Pakhuizen. Op 9 oktober 1833 viel het eerste gouvernementsbesluit over de eigendommen. Er werd een verdeling gemaakt over de afdeling inlandse zaken van de Algemene Secretarie (de manuscripten en de papieren), het genootschap (een aantal zeldzaamheden, waaronder een gamelanspel dat nog steeds in het Nationaal Museum staat) en de resident van Bantam (een ander, onvolledig gamelanspel). De resident van Batavia kreeg de opdracht om een aantal vorstelijke voorwerpen (paijongs, geborduurde muilen, vlaggen, een houten arend, priestergewaden en negen vorstelijke stoelen) geheel te vernietigen en andere voorwerpen te slopen, de restanten te verkopen en wat niet te verkopen viel, te verbranden. ${ }^{105}$ Van de collectie 'merkwaardigheden en zeldzaamheden' die het genootschap ontving, waren de meest waardevolle voorwerpen een tweetal met goud bewerkte zeekokosnoten (boea djinggi of kelapa laoet), het gamelanspel en drie krissen met scheden van edelmetaal. Van een borstkleed met Arabisch opschrift en een daarbij behorend groen hemd werd opgemerkt, dat zij 'door de Mahomedanen als Zeldzaame en heilige voorwerpen werden aangemerkt.' Tenslotte waren er nog een paddestoel (djamoer), twee inheemse wapens (kogang pemgarad) en twee korte degens (golok). Op 11 december 1833 werd het gamelanspel door 47 koelies van de provisie- en arakpakhuizen naar het gebouw aan de Rijswijkstraat gebracht. Het overbrengen kostte het genootschap 42 cent per koelie. ${ }^{106}$

Het was daarmee echter niet uit. Het genootschap mocht in november 1834 een keuze maken uit wat er nog over was van de boedel van de sultan. ${ }^{107}$ Bestuursleden Tromp en Bik namen in december deze taak op zich. In maart 1835 deden echter Fritze en Visscher in het bestuur verslag. Zij waren huiverig voor verder kiezen, aangezien een deel van een (ander) gamelanspel al verdwenen bleek en zich ook aan de overige voorwerpen 'voor den inlander voorouderlijke herinneringen hechtten' ${ }^{108}$ Een interessante observatie van Fritze en Visscher, waarmee zij getuigden van enig inlevingsvermogen.

105 Gouvernementsbesluit 9-10-1833 n 13. Afschrift in ANRI KBG 1506, omslag 1833.

106 Ontvangstbewijs voor een bedrag van $f$ 19,74 aan kapitein Baroedien, 11-12-1833. ANRI KBG Dir 1332 (omslag 1833). In de vergadering 20-2-1834 (punt 34) werd pas voor het eerst van deze aanwinst melding gemaakt (ANRI KBG Dir 0087). Het gouvernementsbesluit was van 9-101833, no 13.

107 Gouvernementsbesluit 21-11-1834 n 10. Afschrift in ANRI KBG Dir 1506 (omslag 1834).

108 ANRI KBG Dir 0089, vergadering 20-12-1834, punt 3, en Dir 0090, vergadering 25-3-1835, punt 6 en bijlage $3,5,7-8$. 
Toch kozen zij wel twee gouden hoofdkronen, twee krissen met vergulde schedes, een krishandvat en vijf speren. De boeken en handschriften konden beter in het genootschapslokaal onderzocht worden, aldus de commissie. In juni 1835 besloot het gouvernement de handschriften van de sultan en ook die van de sultan van Tidore over te dragen aan het genootschap. Het ging om 116 manuscripten, bijna allemaal in het Arabisch, waarvoor de eigenaar $f 719,50$ kreeg vergoed. ${ }^{109}$ Uit dezelfde afrekening blijkt dat het genootschap andere voorwerpen had ontvangen ter waarde van $f 3.675$. Het meest waardevol waren de rijkssieraden: de twee boea djinggi ( $f 1400)$, de twee kronen $(f 1200)$ en het gamelanspel ( $f 800)$. Het genootschap hoefde voor deze overname niet te betalen. De afrekening van juni 1835 laat veel andere interessante dingen zien. Het defecte gamelanspel dat Fritze en Visscher hadden gezien, werd verkocht. Metaal van wapens afkomstig, moest in zee worden gegooid. Juwelier Smit ontving $f 96$ voor het slopen en versmelten van goud en zilver. De opbrengst van de geveilde preciosa - andere dan die naar het genootschap waren gegaan - had nog eens $f 9.587$ bedragen. Uiteindelijk kreeg de sultan een bedrag van $f 23.240,54 \frac{1}{2}$, althans dat leek zo. Het bedrag moest door de directeur van Financiën worden belegd in certificaten van Nederlandsch Indische achterstand. De sultan zou daarvan dan jaarlijks de rente ontvangen. De kosten voor de juwelier en de taxatiekosten kwamen ook voor rekening van de sultan. ${ }^{110}$ De geschiedenis van (het uiteenvallen) van deze collectie toont ons hoe het gouvernement de afwikkeling van een politieke zaak ter hand nam en wat de gevolgen daarvan waren voor het cultureel erfgoed van het sultanaat Bantam. Voor het genootschap was het een enorme aanwinst: een grote verzameling Arabische handschriften en een aantal kostbaarheden en zeldzaamheden die tot nu toe behoren tot de topstukken van het museum. Het gamelanspel genaamd 'soeka rame' en de kronen worden als zodanig in recente publicaties over het Nationaal Museum genoemd en afgebeeld. ${ }^{111}$

De overname van delen uit de collectie van de sultan van Bantam stond niet op zichzelf. In antwoord op Lentings circulaire uit 1829 stuurde Du Puy uit Bangka in 1833 een kistje met mineralen en 21 voorwerpen, naast een studie over Bangka. ${ }^{112}$ Nog in hetzelfde jaar bood de resident van Batavia

109 ANRI KBG Dir 0092-3, Extract besluit van de gouverneur-generaal dd 20-6-1835, als bijlage 1 bij vergadering 9-9-1835. Verder bijlage 11, lijst van de manuscripten, bij vergadering 8-1-1836, in ANRI KBG Dir 0094; ook notulen algemene vergadering 13-1-1836 (ANRI KBG Dir 0095).

110 Afschrift gouvernementsbesluit 20-6-1835 n 2 in ANRI KBG Dir 1507 (omslag 1838).

111 De Bantamse kroon werd afgebeeld op het stofomslag van Treasures 1998, aldaar ook p. 142, al staat daar vermeld dat de acquisitiedatum onbekend is. Daar wordt op p. 48 ook het gamelanspel afgebeeld met de vermelding: acquisitie 1941. Uit het archief blijkt dat het gamelanspel als bestaande uit 54 onderdelen geteld werd (Treasures vermeldt 68 onderdelen) en in 1833 binnenkwam. ANRI KBG Mus 0027, omslag 1833-1839.

112 ANRI KBG Dir 0087, vergadering 20-2-1834, punt 38 en bijlagen 69-70. 
in Bantam in de grond gevonden archeologische voorwerpen aan. Een deel ervan werd gekozen (en er werd voor betaald) de rest ging terug. ${ }^{113}$ In januari 1836 was er van het gouvernement een aanbod om archeologische sieraden over te nemen. De sieraden waren door een Javaan bij Pajitan opgegraven en de assistent-resident vroeg aan het gouvernement welk vindersloon er dan kon worden berekend. Het genootschapsbestuur stelde voor een circulaire hierover af te wachten. De voorwerpen hadden geen waarde en werden teruggestuurd. ${ }^{114}$ Later dat jaar werden er kisten met zoölogische voorwerpen overgedragen. ${ }^{115}$ Uitgezocht moest worden wat er naar Nederland ging en wat in Batavia bleef. Het feit dat het gouvernement in Batavia, maar ook afzonderlijke residenten het genootschap nu als een instantie zagen waar voorwerpen konden worden bewaard en getoond was een grote stap vooruit. Het gaf het genootschap een semi-gouvernementele rol, waarin het meer en meer zou groeien tot het uiteindelijk een centraal museum zou worden.

\section{Persoonlijkheden: Lenting en Van der Vinne}

Predikant Diederik (Dirk) Lenting (1789-1877) en ingenieur Jan van der Vinne (geb. 1793) waren in de jaren 1822-1834 de twee belangrijkste bestuursleden. Van der Vinne kwam al even ter sprake in het hoofdstuk over de periode Van der Capellen, nu moet hij wat uitgebreider besproken worden, in samenhang met Lenting. Beiden werden, aangekomen in het kielzog van de commissarissen-generaal, op 1 juli 1817 lid, maar moesten merken dat zij tot een genootschap toetraden dat tot medio 1822 nauwelijks bestond. Toen werden beiden opgenomen in het bestuur, Van der Vinne als secretaris, Lenting als gewoon bestuurslid. Van der Vinne had de tussenliggende jaren in Batavia doorgebracht en zou de ambtelijke carrière in de hoofdplaats vervolgen. Lenting was in Semarang geplaatst, had Oost-Java bezocht en was met Buijskes naar de Molukken geweest. In 1822 was hij naar Batavia teruggekomen voor de bediening van de Maleise en de Hollandse gemeente van de Hervormde Kerk en meteen in het bestuur opgenomen. ${ }^{116}$ Van der Vinne zou het secretariaat en het penningmeesterschap bijna twaalf jaar vervullen, in feite eerder elf jaar doordat hij pas in februari 1823 echt aan de slag kon. Hij trad af in maart 1834 vanwege verlof naar patria. Na zijn terugkeer in Batavia (1836) vond

\footnotetext{
113 ANRI KBG Dir 0089, verg. 20-12-1834, punt 4.

114 ANRI KBG Dir 0094, vergadering 8-1-1836, punt 1 en bijlage 1.

115 ANRI KBG Dir 0096, vergadering 7-4-1836, punt 5 en bijlage 6.

116 Zie over Lenting: Van der Kemp 1918:137-40. H.M.J. Maier “"Ik ben daarenboven sterfelijk”; dominee Lenting in Batavia', ongepubliceerde lezing, die niet op Lentings betrokkenheid bij het genootschap ingaat, maar vooral zijn predikantenbestaan belicht.
} 
hij pas in 1839 weer een plaats in het bestuur, maar bleef die toen bezetten tot zijn definitieve vertrek in maart 1843. Hij was aldus 26 jaar lid en bezette twee periodes van samen ruim vijftien jaar een bestuursplaats. Dit alles naast functies in dienst van het gouvernement als secretaris bij Reinwardt, fiscaal bij de Raad van Justitie, hoofdbaljuw van Batavia, resident van de hoofdplaats, directeur van 's Lands Produkten en Civiele Magazijnen, directeur over Middelen en Domeinen en laatstelijk directeur van Financiën. Hij deed zo te zien nooit iets met zijn ingenieursopleiding. Het onderwijs liep als een rode draad door Van der Vinnes carrière: hij begon immers bij Reinwardt en werd inspecteur van het onderwijs. Zelfs naast zijn laatste functie bij financiën was hij nog voorzitter van de Hoofdcommissie van Onderwijs. Tenslotte vervulde hij diverse bestuursfuncties in verenigingen (het toneel, de sociëteit, het Genootschap van Waterloo, enzovoort). Een buitengewoon actieve man, geen wonder dus dat het genootschap veel aan hem had, uiteraard het meest in zijn bijna twaalf jaren als secretaris-penningmeester, en tijdens de latere jaren als vice-voorzitter.

Lenting was ononderbroken bestuurslid van augustus 1822, ook hij eerder effectief vanaf februari 1823, tot zijn vertrek in december 1834 . Hij nam eerst na het terugtreden van voorzitter P. Maurisse in december 1826 en later na de dood van voorzitter J. Bousquet in 1831 voor langere tijd het voorzitterschap waar. In maart 1832 werd hij officieel tot voorzitter gekozen. In maart 1834 maakte hij plaats voor P. Merkus en schoof door naar de secretarisstoel, die door Van der Vinne was vrijgemaakt. Korte tijd later vertrok hij zelf, na twaalf jaar bestuurslid te zijn geweest, waarvan bijna vierenhalf jaar voorzitter. Als wetenschappelijk geschoold man met belangstelling voor de inheemse talen had hij ook een specifieke inbreng in het bestuur. Hij bracht een deskundigheid in die buiten hem niet aanwezig was.

Van der Vinne en Lenting sloegen meteen in 1823 de handen ineen. Zij stelden samen de conceptprijsvragen op voor de algemene vergadering en bogen zich over de toestand van de bibliotheek. ${ }^{117}$ Van der Vinne nam het herdrukken van de Verhandelingen ter hand, vestigde de aandacht op de kopij voor deel 9, suggereerde aandacht voor Japan en wilde de corresponderende leden in de buitengewesten en in het buitenland weer bij de zaak betrekken. Er gingen meteen tientallen brieven uit en het was dus geen wonder dat hij direct een klerk nodig had voor het schrijfwerk. ${ }^{118}$ Hij stelde door zijn taakopvatting een norm en de periode Wedding (1816-1822) steekt er daardoor des te schriller bij af. Het feit dat het archief eigenlijk in 1822 begint en niet in

117 ANRI KBG Dir 0023, vergadering 12-6-1823, punt 10, en Dir 0027, vergadering 4-9-1823, punt 11 en bijlage 37-41.

118 ANRI KBG Dir 0024, vergadering 12-6-1823, punt 4 en voor Van der Vinnes activiteiten de verslagen van de eropvolgende vergaderingen. 
1816 is al een aanwijzing. Wedding was kennelijk niet zo goed in het archiveren. Dat Van der Vinne na Weddings dood op diens boedelveiling nogal wat voorwerpen aankocht voor het genootschap, waaronder een ring met negen sleutels en een kurkentrekker, geeft te denken. Vermoedelijk waren het sleutels van het gebouw of wel van kasten in het gebouw van het genootschap, terwijl de kurkentrekker nodig was voor de flessen wijn tijdens de bestuursvergaderingen. ${ }^{119}$

Tussen Van der Vinne en Lenting gingen voortdurend briefjes heen en weer. Vooral die van Lenting zijn bewaard, omdat Van der Vinne zo goed het archief bijhield. Daardoor zijn ook Van der Vinnes formele brieven in tientallen minuten bewaard gebleven. De toon was - begrijpelijk tussen twee heren die goed met elkaar overweg konden en die over zo veel zaken moesten overleggen - vriendelijk en zonder omslag: 'Hiernevens het stuk van Nahuis terug. Ik vind het wel wat middelmatig, onvolledig en zonder orde; maar wat zullen we doen? We hebben niets beter. Ergo imprimatur. Dat stuk van Domis is naar mijn inzien ook al vrij mager' ${ }^{120}$ Uit briefjes blijkt dat beiden als er een lichte wrijving met voorzitter Maurisse was daarover gemakkelijk schreven ('maak er geen water om vuil'). Kennelijk was de houding onderling vertrouwelijk en tegenover Maurisse gereserveerd. ${ }^{121}$

Lenting kreeg binnen het bestuur al snel de plaats van redacteur van de Verhandelingen. Hij beoordeelde stukken, stelde een volgorde vast en formuleerde het voorbericht. Tenslotte keek hij ook nog de drukproeven na en was daarvoor herhaaldelijk in de Landsdrukkerij te vinden. Hem werd uitgebreid lof toegezwaaid toen deel 10 van de pers kwam. ${ }^{122}$ Hij kende bij zijn vertrek uit Nederland misschien al Maleis en specialiseerde zich meer en meer in die taal. Naast zijn werk als predikant kon hij zodoende ook als taalkenner optreden. Hij werkte aan het Maleise woordenboek van Leijdecker waarvan het eerste deel in 1835 uitkwam (Swellengrebel 1974:14). Hij was een propagandist van het Hoog-Maleis voor de prediking van het evangelie. In het bestuur van het genootschap had hij in 1826 een centrale plaats veroverd.

119 Van der Vinne kocht op 8 juli 1825 uit Weddings boedel enige wapens, een brandspiegel, een inclinatiekompas, een luchtpomp en een telescoop. Op 28 juli een monster (op sterk water?), een kruikje met kwikzilver, de sleutelbos, een kurkentrekker en naturalia. ANRI KBG Dir 1331 (omslag 1825), kwitanties van die data. Totaal bijna $f 460$.

120 Het ging om G.H. Nahuis' stuk over Benkoelen en H.J. Domis' stuk over Salatiga en de Merbaboe, beide in VBG 10 (1825). Brief van Lenting van Van der Vinne van 10-9-1824 in ANRI KB Dir 0983, nr 33.

121 Kattebelletje van Lenting aan Van der Vinne 6-7-1825 in ANRI KBG Dir 0983, nr 57.

122 Voor dl 9 is niet zeker dat Lenting het voorbericht schreef, vanaf dl 10 wel. Zie ANRI KBG Dir 0031, vergadering 13-11-1823, punt 9 en bijlagen. Er waren twee voorberichten (Maurisse en Lenting?). Dir 0050, vergadering 14-7-1825, punt 12 en bijlage 21. Dir 0052, vergadering 5-1-1826, punt 4 . 
Ieder vergaderverslag telde diverse punten die door hem naar voren werden gebracht. Hij stelde nieuwe leden en bestuursleden voor en bleef op de uitstaande prijsvragen letten. Het wekt dan ook geen verwondering dat de Verhandelingen onder Lenting en Van der Vinne met regelmaat verschenen. Tussen 1823 en 1833 verschenen de delen 9-15. Die verschijningsfrequentie stak gunstig af tegen die van de delen 1-8, waar het genootschap meer dan 35 jaar over had gedaan. Alleen tussen 1826 en 1830 zat een gat. In de onder Lentings redacteurschap verschenen delen was een grote variëteit aan onderwerpen te bespeuren. Japan was in zes van de zeven delen vertegenwoordigd met de stukken van Von Siebold en een grote studie van Meylan over de geschiedenis van de handel van de Europeanen met Japan. Deel 14 was zelfs helemaal aan Japan gewijd. Reinwardt, Blume en Von Siebold tekenden voor plant- en natuurkunde in vier van de delen. Verder was er veel aandacht voor plaatsbeschrijving (Palembang, Salatiga en de Merbaboe, Benkoelen, Lingga, Tengger en de Kokoseilanden) en voor volkenkunde (Dayak en Japan). Geschiedenis (de Java-oorlog, Japan, oudere Javaanse geschiedenis), medicijnen (ziekten in het leger, cholera, acupunctuur, een misvormd kind) en linguïstische onderwerpen sloten de rij. Overigens behoorde daarbij de eerste serieuze spraakkunst van het Javaans van A.D. Cornets de Groot, die na zijn dood in 1829 door J.F.C. Gericke voor het genootschap gereed was gemaakt. De goede verschijningsfrequentie in de jaren 1823-1833 mogen we voor het overgrote deel aan de onvermoeibare Lenting toeschrijven.

In februari 1826 werd op zijn voorstel besloten iedere vierde donderdag van de maand een bijeenkomst te beleggen waarop een verhandeling zou worden voorgelezen of een 'onderhoudend algemeen gesprek over allerlei onderwerpen' gehouden. Apotheker A. Perret, die ook het kabinet/ museum onder zijn hoede had, zou enkele natuurkundige proeven doen op de openingsavond. De eerste algemene vergadering op het kasteel in 1779 waarop proeven met een electriseermachine werden gedaan, komt in de herinnering. Er werd een lijst opgesteld van tweeëntwintig spreekbeurten op de donderdagen tussen mei 1826 en januari 1828. Al snel waren er veertien liefhebbers. Uiteindelijk verzorgde niet Perret, maar Van Doorninck de eerste lezing, een politiek-filosofische beschouwing van alle koloniën des aardbols. ${ }^{123}$ Lenting was als predikant een beroepsspreker en zette zijn werk in de kringen van het genootschap voort. Hij sprak zelf als tweede in de serie. Tussen 25 mei 1826 en 10 mei 1827 hadden elf van deze bijeenkomsten plaats. In de financiële papieren wordt gesproken van bijeenkomsten van het 'leesgezelschap'. Drukbezocht waren de avonden niet, als we moeten afgaan

123 ANRI KBG Dir 0055, vergadering 9-2-1826, punt 13, en Dir 0059, vergadering 11-5-1826, punt 2. In bundel ANRI KBG Dir 1505 zit een lijst met een rooster, nr 71. 
op de consumpties die verteerd werden: meestal niet meer dan voor vijftien gulden, waar bij de algemene vergaderingen toch al veelal bedragen vanaf veertig gulden werden verteerd. ${ }^{124}$ Dat het 'leesgezelschap', een succesformule in genootschapsland in het vaderland, in Batavia geen blijvend succes bleek, kon Lenting moeilijk verkroppen. Hij kwam zelfs tijdens zijn laatste bestuursvergadering in december 1834 nog eens met een soortgelijk plan. Zou het niet goed zijn de leden in Batavia bijeen te roepen om zich met elkaar 'op eene nuttige en doelmatige wijze te onderhouden, zonder tot het houden van redevoeringen of wetenschappelijke mededeelingen verpligt te zijn'? De lezingenavonden moesten voor Lenting in een andere vorm terugkomen. ${ }^{125}$ Een genootschap was er voor genootschappelijke contacten. Het was er niet alleen voor het bestuur en voor een jaarlijkse algemene vergadering. Er moest regelmatig contact tussen de leden zijn, vooral bij gelegenheid van vormende bijeenkomsten. Daarnaast deed Lenting zich ook nog kennen als gulle gever voor het kabinet. Hij schonk bij diverse gelegenheden voorwerpen uit zijn verzameling: onder andere in 1826 een stel hoeden van Menado en Ambonse hertenhoorns ('Laat een van uwe oppassers dezelve maar dadelijk wegbrengen'), in 1829 allerlei voorwerpen van de Molukken. ${ }^{126}$

$\mathrm{Na}$ het terugtreden van Maurisse werden in 1827 en 1828 de vergaderingen duidelijk gedomineerd door Van der Vinne en Lenting. Zij waren toen al jarenlang de trouwste bestuursleden. In die jaren ontbrak Van der Vinne slechts één keer, Lenting nooit. In 1827 vergaderde het bestuur herhaaldelijk met maar drie of vier leden, zij tweeën waren altijd present. Toen Lenting in januari 1827 voorstelde de kandidaten voor een bestuursplaats niet meer bij openbare stemming in de algemene vergadering, maar bij ballotage vast te stellen, dreigde de kring van de zich steeds aanvullende bestuursleden wel erg een vriendenkring te worden. ${ }^{127}$ De ingreep van Du Bus in november 1828 maakte daar een einde aan. Lenting verloor zijn dominante plaats aan algemeen secretaris J. Bousquet en zong ook duidelijk een toontje lager. Het bestuur was weer voltallig, het duo Van der Vinne-Lenting minder dominant aanwezig.

Lenting zag kans, toen hij eenmaal vast op de voorzittersplaats zat (1832), om nog een ander idee te lanceren. De naar zijn smaak geringe verschijningsfrequentie van de Verhandelingen, maar vooral het feit dat deze in de kolonie alleen voor leden verkrijgbaar waren, gaf hem in dat het genootschap een

124 ANRI KBG Dir 1331, omslagen 1826-1827. Alleen de eerste avond met verteringen voor

$f 30$ was een uitzondering.

125 ANRI KBG Dir 0089, vergadering 20-12-1833, punt 25.

126 ANRI KBG Dir 0062, vergadering 29-11-1826, punt 25 en bijlage 27; Dir 0078, vergadering 2-12-1829, punt 19.

127 ANRI KBG Dir 0064, vergadering 11-1-1827, punt 3. 
eigen tijdschrift zou moeten uitgeven 'om den lust tot nuttige lectuur bij de ingezetenen optewekken en zoodoende tot verspreiding van kunde en beschaving onder hen mede te werken'. ${ }^{128}$ Ook hier klonk weer de opvoeder in Lenting door. Hij had er al een plan voor op papier gesteld. In 1833 werd er over dat plan doorgepraat, er werden mogelijke problemen overwogen, maar toch werd besloten een commissie in te stellen. Lenting, Merkus, Fritze en Van der Vinne gingen aan de slag. In 1834 werd het voorlopig uitgesteld, iedereen had het te druk. ${ }^{129}$ Zo bleef Lentings plan liggen, maar zijn ideeën bleven leven. Onmiddellijk na Lentings vertrek nam voorzitter Merkus het plan weer op om vergaderingen met een meer open karakter te houden (het leesgezelschap). En Lentings ambtgenoot Van Hoëvell zette het tijdschriftplan door, zij het dat zijn Tijdschrift voor Neêrland's Indï (1838) geen tijdschrift van het genootschap werd.

Ook tijdens zijn voorzitterschap (1832-1834) bleef Lenting het redacteurswerk doen. Hij was niet te voornaam geworden om telkens naar de drukkerij te gaan om te zien dat het werk aan deel 15, de ingewikkelde Javaanse spraakkunst van Cornets de Groot waarvoor Gericke vanuit Soerakarta het editeurswerk deed, goed werd uitgevoerd. ${ }^{130}$ Ook het toezicht op de bibliotheek bleef hem zorgen baren:

Amice!

De Heer Mentz schrijft mij in zijn briefje van heden, dat men onderscheidene fraaye werken als onder anderen een deel van Raffles, History of Java en een atlas van Australië aan Michielsz die bij hem inwoont, ten gebruike heeft gegeven. Zoude Lazinchy dat zoo durven doen? Of zouden het de zwarte jongens zijn? Minzaam

\section{TT Lenting}

Dit briefje van 9 juni 1833 aan Van der Vinne geeft een aardige blik in de alledaagse gang van zaken. Bode Laschenskie was niet gemachtigd zonder toestemming boeken uit te lenen, maar misschien hadden de schoonmakers of de wakers het wel gedaan. ${ }^{131}$ Hier wreekte zich het feit dat alle bestuursleden druk bezette mannen waren, die het genootschap 'erbij deden'. Weliswaar was er een duidelijke taakverdeling, maar het secretariaat, het penningmeesterschap en het redacteurschap van de Verhandelingen alsmede het toezicht op

ANRI KBG Dir 0085, vergadering 12-12-1832, punt 36.

129 ANRI KBG Dir 0086, vergadering 21-2-1833, punt 27; Dir 0087 vergadering 20-2-1834, punt

42.

130 Diverse brieven van Van der Vinne, Lenting en Gericke in de bundel correspondentie over 1833, ANRI KBG Dir 0987.

131 ANRI KBG Dir 0987, nr 90. 
de dagelijkse gang van zaken in het genootschapslokaal vielen alle onder de verantwoordelijkheid van het tweetal Van der Vinne-Lenting. Tromp lette wel op de staat van het gebouw, wat overigens ook tot zijn functie van ingenieur van de waterstaat hoorde.

Een blik in de financiële verantwoording laat zien met welke mensen Van der Vinne en Lenting te maken hadden. Er was een bode, A. Eekhart, van 1824 tot 1830 voor dertig gulden per maand, die twee boedjangs (jongens) aan het werk hield voor het schoonhouden en bewaken voor negen gulden per maand. Van der Vinne had vanaf augustus 1826 voor vijftig gulden per maand een schrijver, Schrader genaamd. Onder bode Laschenskie, die in juli 1830 aantrad was er ook korte tijd een schoonmaker E. Roos die twintig gulden per maand verdiende. Na Laschenskie was er korte tijd een Indonesische toezichthouder, Bapak Tamigens, maar hij werd in 1836 opgevolgd door D.H.R van Gelder. Toen was het werk door het nieuwe museum en het tweede gebouw zodanig toegenomen dat hij zestig gulden per maand mee naar huis nam. ${ }^{132}$

Van der Vinnes slechte gezondheid noodzaakte hem aan het begin van 1834 om verlof aan te vragen. Hij was zeventien jaar in Batavia geweest. Hij kondigde dat in februari aan en verzocht om tijdens zijn afwezigheid lid van de directie te mogen blijven. Daartegen had het bestuur bezwaar, dus hij moest aftreden. Tegelijkertijd kondigde Lenting aan dat hij het voorzitterschap wilde neerleggen. De reden is nogal opmerkelijk, waar hij al sinds december 1831 de voorzittersplaats (zij het eerst waarnemend) bezette. Hij vond nu dat er iemand van hoger rang op die plaats moest zitten, mogelijk omdat hij toch te weinig dacht te hebben bereikt en meer verwachtte van een hoger geplaatst voorzitter. 'In vroeger tijden [is] steeds een Raad van Indië voorzitter van het Genootschap geweest.' Dus werd besloten om Pieter Merkus, lid van de Raad van Indië, aan de algemene vergadering voor te dragen voor het voorzitterschap. Lenting zou dan de plaats van Van der Vinne innemen. Mogelijk blies op de achtergrond gouverneur-generaal Baud een partij mee bij deze stoelendans. Of had Lenting misschien een afspraak met Van der Vinne, die immers in het bestuur had willen blijven, zodat Lenting in de tussentijd de secretarisplaats zou warm houden? ${ }^{133}$ De voorstellen werden aangenomen op 6 maart 1834, de laatste vergadering onder Lenting. In

132 De financiële administratie over de jaren 1823-1832 is niet te reconstrueren omdat het kasboek over die jaren door inktvraat is aangetast. Er zijn wel honderden kwitanties die een licht werpen op wat er omging. Daaraan zijn voorgaande gegevens ontleend. ANRI KBG Dir 1331 en 1332 over de jaren 1823-1832 en 1833-1846. De eerste bundel begint met een kasboek over de hele periode 1823-1832, maar dat gedeelte valt uit elkaar. Over de jaren 1825-1832 zijn er ontvangstbewijzen. ANRI KBG Dir 1332 heeft een goed raadpleegbaar kasboek over de periode 1833-1846, maar alleen betaalbewijzen over de jaren 1833-1839.

133 ANRI KBG Dir 0087, vergadering 20-2-1834, punt 43 en bijlage 74. 
zijn afscheidstoespraak noemde deze nog eens zijn drie geesteskinderen: de Verhandelingen, het tijdschriftplan en de lezingenavonden. Interessant waren de bouwstenen die Van der Vinne als scheidend secretaris aan de nieuwe voorzitter had aangedragen voor diens toespraak tot de vergadering. Het is een aardig stuk, waarin hij puntsgewijs en zonder overbodige plichtplegingen de voorzitter aangeeft waar hij heen moet. Soms met humor als hij kortheidshalve aangeeft: 'en verdere gewone redekavelingen'. Onder de punten die Lenting en Merkus onvermeld lieten in hun toespraken zien we Van der Vinnes frustratie over de geringe medewerking van het gouvernement:

de weinige geneigdheid van het Gouvernement, om het genootschap in de oprigting van een Museum te ondersteunen, waartoe het Ligchaam van bestuur, na het verwerpen van het vroegere kostbare plan, een zeer gewijzigd en onkostbaar voorstel gedaan had.

Merkus zou hierna in samenspraak met Baud wel tot een oplossing komen voor het museum. Verder noemde Van der Vinne nog: 'de ongeneigdheid van het Gouvernement om ons te veroorloven eenige stukken bij ons dadelijk ontvangen, of uit Gouvernements archief, voor als nog in het licht te geven.' In het bijzonder vermeldde hij de episode met de stukken van Von Siebold en Bürger over de theecultuur, waardoor de druk van deel 16 werd opgehouden tot 1836. Aan de grote ijver, die Van der Vinne aan de dag had gelegd, paarde hij ook een kritische geest. Merkus verwerkte Van der Vinnes opmerkingen op zo'n diplomatieke wijze dat van de kritiek van de scheidende secretaris niets overbleef. 134

Aan het eind van het jaar was ook voor Lenting de tijd van afscheid aangebroken. Op 20 december 1834 werd er mede over zijn aftreden als secretaris vergaderd. Hij droeg de kopij voor deel 16 over, handelde veel correspondentie af en droeg het secretariaat over aan C. Visscher, terwijl J.G. Peitsch thesaurier werd. Omdat nu ook de zorg voor bibliotheek en museum beter moest worden geregeld werden daar commissarissen voor aangesteld uit het bestuur: Visscher voor de bibliotheek en Tromp en Bik voor het museum. ${ }^{135}$ Lenting vielen vriendelijke afscheidswoorden van Merkus ten deel, maar hij was te verbouwereerd om adequaat te kunnen reageren. Vandaar een afscheidsbrief aan de nieuwe voorzitter op 24 december $1834{ }^{136}$ Ook na zijn vertrek zou Lenting vanuit zijn woonplaats Zeist, waar hij tussen 1839 en 1855 als predikant werkzaam was, nog herhaaldelijk met het genootschap corresponderen.

Van der Vinne was in 1836 weer terug. Hij schreef op 31 oktober een briefje aan het genootschap. Het duurde maanden eer hij zijn oude plaats als direc-

ANRI KBG Dir 0088, vergadering 6-3-1834.

ANRI KBG Dir 0089, vergadering 20-12-1834, punt 25-28, 31.

ANRI KBG Dir 0090, vergadering 25-3-1835, punt 16 en bijlage 24. 
teur over Produkten en Civiele Magazijnen weer kon innemen en daarover beklaagde hij zich in mei 1837. Het viel hem extra zwaar, aangezien hij totaal werkeloos was in zijn betrekking tot het Bataviaasch Genootschap, waarvan hij naar zijn zeggen sinds 1819 (moet zijn 1822) secretaris was geweest. Het was een regelrechte sollicitatie aan het adres van het genootschap om hem weer snel op te nemen in het bestuur. ${ }^{137}$ Het genootschap nam de suggestie echter niet op. In 1839 werd op de eerste algemene vergadering in bestuursvacatures voorzien door nieuwe personen aan te zoeken: de militair jhr. C van der Wijck en de predikant Van Hoëvell werden gevraagd, niet Van der Vinne. Daarop liet de gegriefde Van der Vinne via Van Hoëvell weten dat hij overwoog zijn lidmaatschap op te zeggen. Op een gewone bestuursvergadering werd daarop uitgebreid over de positie van Van der Vinne gedelibereerd. Daags tevoren had het bestuur al een verzoenende brief aan de oudsecretaris geschreven om hem af te brengen van zijn voornemen. Verwezen werd naar het oprichtingsbesluit van Baud uit 1835 betreffende het Museum voor Natuurlijke Historie - Van der Vinne was toen in Nederland - op grond waarvan de voorzitter van de Hoofdcommissie van Onderwijs qualitate qua in de directie van het museum zat en dus de vergaderingen van het bestuur bijwoonde. Hij werd uitgenodigd 'in ons midden zitting te nemen'. Van der Vinne nam dit aanbod aan. ${ }^{138}$ Vanaf 19 juni 1839 woonde hij de vergaderingen weer bij. Bijna drie jaar lang was van zijn goede diensten geen gebruik gemaakt. De notulen geven geen aanwijzingen voor het negeren van Van der Vinne. Zijn optreden na 1839 doet vermoeden dat hij wel erg zelfstandig te werk ging. Misschien had hij die reputatie al eerder en speelde dat mee bij de aarzeling om hem terug te vragen in het bestuur.

Dat hij deze onelegante handelwijze van het bestuur verder liet voor wat het was, bleek uit zijn inzet vanaf zijn herintrede. Hij werkte met Van Hoëvell een voorstel uit voor een verdeling van het genootschap in vijf werkgebieden, opdat de steeds groeiende hoeveelheid werk efficiënter en professioneler zou kunnen worden afgedaan. ${ }^{139}$ Zelf nam hij plaats in de eerste commissie die zich bezig ging houden met geschiedenis, geografie, etnologie en archeologie.

In de loop van 1840 ging het toch fout met het genootschap. Voorzitter Merkus was waarnemend gouverneur-generaal geworden en had daardoor geen tijd meer, vice-voorzitter Van der Schoor had weinig interesse. In 1841 lagen de werkzaamheden helemaal stil. Op 14 maart 1842 greep Merkus in,

137 ANRI KBG Dir 0099, vergadering 12-1-1837, punt 9 en bijlage, en Dir 0102, vergadering 20-6-1837, punt 4 en bijlage 2.

138 ANRI KBG Dir 0120, algemene vergadering 11-4-1839, punt 12; Dir 0113 vergadering 11-61839 en Dir 0115, vergadering 19-6-1839. De brief aan Van der Vinne van 18-6-1839 in ANRI KBG Dir 0988 (1839 -1).

139 ANRI KBG Dir 0120, vergadering 19-8-1839, punt 4 en bijlage 1. 
nadat Van der Schoor was overleden: hij stelde voor een nieuwe vice-voorzitter aan te stellen. De vergadering koos met meerderheid van stemmen Van der Vinne. ${ }^{140}$ Eindelijk zat hij op de plaats waar hij hoorde. Hij liet ook meteen zien hoe het hoorde. De episode 1841 werd snel vergeten, het genootschap gonsde van activiteiten. Enigszins haalde Van der Vinne zijn gram toen hij in de algemene vergadering van 25 mei 1842 uitgebreid het woord mocht voeren bij afwezigheid van de voorzitter. Merkus werd veel vergeven omdat zijn ambt hem daarop recht gaf, Van der Schoor werd op een beschaafde manier de mantel uitgeveegd, beschaafd omdat hij inmiddels was overleden, maar de toonzetting was duidelijk: het genootschap had beter verdiend dan tot 'stilstand' te zijn gebracht. Uitvoerig ging de vice-voorzitter vervolgens in op de gebeurtenissen sinds 1840 en op de lopende zaken, zo uitvoerig dat ter verpozing een spreekbeurt moest worden ingevoegd, die Van der Vinne ook zelf hield. Hij vond het niet nodig om het bestuur op het peil van twintig personen te houden en dreef door dat het van nu af aan uit vijftien leden zou bestaan. Tot slot sprak hij waarschuwend tegen het bestuur te hopen dat deze directie 'die vroeger al niet geheel van eenige apathie vrij te pleiten [was] geweest' nu met verdubbelde ijver actief zou werken in het belang van het genootschap. ${ }^{141}$ De presentatie was er een van groot zelfbewustzijn, hier sprak iemand die daar recht toe had. Datzelfde blijkt ook uit andere zaken die in het jaar 1842 speelden. Van der Vinne handelde af en vertelde later aan het bestuur wat hij gedaan had. Het was duidelijk dat hij apathie geen kans zou geven.

In 1843 kwam een einde aan zijn verblijf in Batavia. Op 23 februari kondigde hij zijn vertrek aan in het genootschapsbestuur. Tegelijk vertelde hij dat hij met voorzitter Pieter Merkus had gesproken over diens plaats in het genootschap. Merkus wilde terugtreden als voorzitter en terugkeren als beschermheer om zodoende wat losser van de organisatie te komen staan. Van der Vinne had hem daarvan weten te weerhouden, met als motief dat het genootschap in hem juist zo'n goed voorzitter had. Merkus had zich hierbij neergelegd. Zo werd er weer een vice-voorzitter gekozen: Van Hoëvell. In hem zou het genootschap net zo'n actief en eigenzinnig leider hebben als het in Van der Vinne verloor. ${ }^{142}$ Tijdens de algemene vergadering van 5 oktober 1843 werd Van der Vinne op voordracht van Van Hoëvell tot erelid benoemd. In de brief die hij daarover in Den Haag kreeg, werd hij geëerd als 'een der voornaamste bevorderaars der belangen dezer schoone wetenschappelijke instelling'. ${ }^{143}$

140 ANRI KBG Dir 0127, vergadring 14-3-1842.

141 ANRI KBG Dir 0130-31, vergadering 25-5-1842.

142 ANRI KBG Dir 0135, vergadering 23-2-1843, na punt 5.

143 Minuut van een brief van 10-10-1843 aan Van der Vinne in Den Haag in ANRI KBG Dir 0991 (1843 / oktober-december nr 4). 


\section{Aanwas van leden}

Het genootschap had tussen 1778 en 1794 steeds rond de 200 leden gehad. Daarna hadden het failliet van de VOC en oorlogen en bezettingen hun tol geëist. Raffles had onder zijn voorzitterschap (1811-1816) toch nog een 80-tal leden op de been weten te brengen. Het is veelzeggend dat het na de komst van Van der Capellen in de Oost tot 1822 moest duren eer de groei van het ledental inzette. Aan het eind van Van der Capellens door wederinbezitneming, opbouw en culturele stimulering gekenmerkte bestuursperiode (1826) was het ledental weer terug op 200. ${ }^{144}$ Tot 1840 zou deze groei doorzetten. In dat jaar waren er 373 leden. Dat ging gepaard met drie grote stappen vooruit: naar 201 leden in 1826, naar 283 leden in 1832 en 328 leden in 1837. Er is voldoende reden om daar nog eens nader naar te kijken. Daarbij moet steeds bedacht worden dat het totale aantal leden aanzienlijk groter was dan het aantal betalende leden. De contributie van veertig gulden per jaar werd alleen gevraagd aan de gewone leden, die in Nederlands-Indië woonachtig waren. Zij moesten zich bij hun voordracht afvragen of ze het niet geringe bedrag voor het lidmaatschap over hadden. Aan verlofgangers werd geen contributie gevraagd, aan de corresponderende leden evenmin. Het aantal corresponderende leden lag daardoor steeds tamelijk hoog. Ereleden betaalden uiteraard geen contributie.

$\mathrm{Na}$ de actieve inzet van Van der Capellen en de iets mindere van Du Bus hadden de beschermheren Van den Bosch en De Eerens zich niet veel met het genootschap bemoeid. Baud, die tijdens zijn periode als landvoogd nu juist de knoop van een apart museumgebouw doorhakte, bleef in die jaren gewoon lid. Daar moeten we echter geen andere reden achter zoeken dan slordigheid of onzorgvuldigheid. Toen Van den Bosch aantrad vergat men hem het beschermheerschap eenvoudigweg aan te bieden, zodat hij als zodanig in de Almanak van Nederlandsch Indië (1831) stond aangemeld zonder dat hij van de eer wist. Om er niet verder de aandacht op te vestigen, liet men het toen maar zo. Baud werd in februari 1833 als lid voorgedragen, toen hij net terug was in Indië. Het lidmaatschap werd hem discreet door zijn mede-raadslid Pieter Merkus aangeboden. ${ }^{145}$ Vanaf juli 1833 zou Baud als gouverneur-generaal optreden en het lidmaatschap van zo'n hooggeplaatste kon niet ter goedkeuring van de algemene vergadering worden voorgelegd. Voor het bestuur was Merkus' mededeling dat de landvoogd graag lid wilde worden voldoende. ${ }^{146}$ Het is onduidelijk waarom het bestuur toen niet meteen een stapje verder

\footnotetext{
144 Voor overzichten van ledentallen verwijs ik naar bijlage 1.

145 ANRI KBG Dir 006, vergadering 21-2-1833, punt 26.

146 ANRI KBG Dir 0087, vergadering 20-2-1834, punt 3. Baud heet 'bij uitzondering dadelijk geaccepteerd' als lid.
} 
ging en Baud tot beschermheer maakte. Pas in 1837 werd die plaats na een formeel aanbod door De Eerens ingenomen.

Als we nu iets preciezer naar de ontwikkeling van het ledental kijken, moeten we wel concluderen dat de ongeveer 80 leden van 1816 tot 1821 vooral papieren leden zijn geweest, want de contributie werd niet geïnd en vergaderd werd er nauwelijks. Onder Van der Capellen, de stimulator, kunnen we haast van een eindspurt spreken: 99 leden in 1822, 116 in 1824, 128 in 1825 en bij zijn vertrek in januari 1826201 leden. Toch moet er ter vergelijking bij gezegd dat het Javaasch Bijbel-genootschap in 1817 al honderden leden had. De Harmonie op Rijswijk had toen 83 leden, de oude Harmonie in de benedenstad 65 leden. Het Javaasch Menschlievend (later: Weldadig) Genootschap, voortzetting van Raffles' Java Benevolent Society, had toen eveneens meer leden dan het Bataviaasch Genootschap. Bovendien kende dit genootschap in 1820 drie Indonesische leden, wat bij het genootschap in de Rijswijkstraat pas in 1825 aan de orde kwam. ${ }^{147}$

In 1825-1826 deed het genootschap een reuzesprong. In de Almanak voor 1825 hadden nog 128 leden opgenomen gestaan, maar bij de algemene vergadering van 2 februari 1825 werden er 53 nieuwe leden voorgesteld. ${ }^{148}$ Op de afscheidsvergadering van Van der Capellen, 13 januari 1826, kwamen er nog eens 31 nieuwe leden bij, zodat de nieuwe lijst van 201 leden nog in de Almanak voor 1826 kon worden opgenomen. Lenting had van dit laatste aantal van 31 nieuwe leden, dertien voor zijn rekening genomen. De voorstellen daartoe kwamen van hem. ${ }^{149}$

Onder Du Bus had het genootschap aanvankelijk te lijden, maar dat was niet merkbaar aan het ledental. Als we kijken naar de betalende leden, dan schommelde hun aantal rond de honderd. Ook daar kan een bepaald patroon in worden ontdekt. Na het ingrijpen van Du Bus stond het aantal betalende leden op 95. Dat zakte echter onder het voorzitterschap van J. Bousquet weg tot 70. Direct na diens overlijden (1831), toen Lenting het voorzitterschap op zich nam, werd een lijst van maar liefst 51 nieuwe kandidaatleden opgesteld. ${ }^{150}$ Op de eerste algemene vergadering onder zijn leiding op 22 maart

147 Voorstel van Blom hierover was van 1825. De algemene vergadering van 13-1-1826 keurde het idee goed (ANRI KBG Dir 0053).

148 VBG 10:xlii-vi bevat de complete lijst. Bij de algemene vergadering van een jaar daarvoor waren er zeventien nieuwe leden voorgesteld.

149 VBG 11:xii-iv bevat de complete lijst. Zie ook ANRI KBG Dir 0052, vergadering 5-1-1826, punt 27-28, en Dir 0053, vergadering 13-1-1826, punt 2. Omdat niet altijd vermeld staat wie het voorstel voor een nieuw lid doet, kan het aantal 'Lenting-leden' nog wel groter zijn.

150 ANRI KBG Dir 0082, vergadering 12-12-1831. Het was tegelijk de enige vergadering van dat jaar, grotendeels gewijd aan het wegwerken van de punten die door de ziekte van Bousquet waren blijven liggen. Tijdens die vergadering werden Van Hoëvells latere tegenspelers C. Visscher en H.F. Hora Siccama lid. 
1832 werden 80 nieuwe leden aangenomen, waarna het aantal leden op 283 kwam. Tenslotte trad Lenting als voorzitter terug, maar niet dan nadat er tijdens zijn laatste algemene vergadering, op 6 maart 1834, nog eens 22 nieuwe leden werden aangenomen. ${ }^{151}$ Onder Lentings voorzitterschap (1831-1834) kwamen er meer dan honderd nieuwe leden bij. Het aantal betalende leden breidde zich uit van 70 (in 1831) tot 116 (in 1834).

Na het vertrek van Van der Vinne en Lenting (1834) liep het totale aantal leden wat terug van 281 (in 1834) naar 248 (in 1835). Onder voorzitter Peter Merkus echter werd er weer het nodige aan gedaan. Bij zijn eerste eigen algemene vergadering, op 9 april 1835, werden 33 nieuwe leden voorgedragen. In 1836 stond het aantal op $266 .{ }^{152}$

Merkus was degene die Bauds steun kreeg voor de museumzaak, waardoor het genootschap na 1835 zijn werkzaamheden aanzienlijk kon uitbreiden. Merkus had zich tegen de invoering van het cultuurstelsel verzet en moest daardoor eind 1835 zijn plaats in de Raad van Indië opgeven. Zijn afscheidstoespraak bij zijn aftreden als voorzitter op 13 januari 1836, op de dag af tien jaar na Van der Capellens afscheid van het genootschap, was emotioneel.

Na een verblijf van 20 jaren het vaderland gaande bezoeken, verlaat ik Java met een gevoel van weemoed, alleen te overwinnen door de troostende gedachte van het eenmaal te zullen wederzien. Java, het gezegend Java, dies ingezetenen, dies instellingen blijf ik in mijn hart dragen. Ook de instelling van dit ons genootschap zal mij dierbaar blijven. Dat het in bloei en in nut moge toenemen, dat het voor deszelfs leden meer en meer een bron zij van zedelijk en verstandelijke genoegens. ${ }^{153}$

Merkus zou in juni 1839 zijn voorzittersplaats weer innemen, na zijn terugkeer uit Nederland. Later zou hij als gouverneur-generaal de voorzittersstoel blijven bezetten, al betekende het in de praktijk dat vice-voorzitters Van der Vinne en Van Hoëvell het meeste te vertellen hadden.

Na Merkus' vertrek en tot diens terugkeer zat zijn collega, lid van de Raad van Indië Van Sevenhoven op de voorzittersstoel (1836-1839). Hij was degene onder wiens toezicht het nieuwe museum tot stand kwam en aan wie de eer toekwam Prins Hendrik rond te leiden. In het jaar 1837 werden twee algemene vergaderingen gehouden, tijdens welke tezamen 100 nieuwe leden

151 ANRI KBG Dir 0084, algemene vergadering 22-3-1832, punt 6. Dir 0088, algemene vergadering 6-3-1834, punt 6.

152 ANRI KBG Dir 0091, vergadering 9-4-1835.

153 ANRI KBG Dir 0095, algemene vergadering 13-1-1836 en Dir 0094, van gewone bestuursvergadering van 8-1-1836. 
werden aangenomen, onder hen het nieuwe erelid Prins Hendrik. ${ }^{154}$ In 1837 sprong het aantal leden voor het eerst boven de 300 en het zou stijgen van 339 (in 1838) tot 373 in (1840). Het aantal betalende leden stond in 1838 op 162, in 1840 op 173.

Het zijn vooral de beschermheer Van der Capellen en de voorzitters Lenting, Merkus en Van Sevenhoven geweest die door hun drijvende kracht het aantal leden hebben doen toenemen. Was de opleving van activiteiten na de terugkeer van Nederlandse bestuurders langzamer dan verwacht, toen Van der Capellen zich er eenmaal mee bemoeide, resulteerde dat in een groter aantal leden. Het feit dat dikwijls hoge bestuursambtenaren op de voorzittersstoel zaten onder het toeziend oog van de gouverneur-generaalbeschermheer, droeg er het nodige toe bij. Toen het gouvernement de band met het genootschap in 1835 strakker aantrok door onder voorwaarden het museum te subsidiëren, leidde dat tot een verdere toename van de activiteiten en tot opnieuw meer leden: van 248 (in 1835) tot 373 (in 1840). Zo zou het museumbesluit van Baud ook in dit opzicht van belang blijken. Na 1836 kwam het ledental niet meer beneden de 300 .

De ware betekenis van de ontwikkelingen rond het museum, die in 1835 hun beslag kregen, is echter gelegen in het institutionaliseringsproces dat toen vorm kreeg. Daarvoor had het verzamelen voor het kabinet of museum onderdeel uitgemaakt van de genootschappelijke activiteiten. Du Bus had gespeeld met de gedachte van een apart museum. Baud had dit plan in zijn besluit opgenomen, er het exclusief natuurhistorische karakter aan ontnomen, maar het ook weer teruggevoerd in de schoot van het genootschap. Het museum kreeg echter een apart gebouw en een aparte directie, al was het genootschapsbestuur daarin goed vertegenwoordigd. De jaarlijkse subsidie voor het genootschap was ook bedoeld voor het museum, niet voor de Verhandelingen of voor de bekostiging van andere activiteiten. Daarmee was de basis gelegd voor een museum als aparte instelling in Nederlands Indië, een basis waarop in de jaren 1840-1848 een belangrijke archeologische collectie kon worden gevormd. Baud komt de eer toe deze basis in 1835 te hebben gelegd. 


\section{Hoofdstuk v}

\section{Van Hoëvell en de drukpers van het genootschap (1839-1848)}

Wolter Robert baron van Hoëvell (1812-1879) staat bekend als een van de vernieuwers in de koloniale politiek in Nederland na 1848. Voor zijn rol als Tweede Kamerlid (1849-1862) in het politieke debat is in allerlei studies plaats ingeruimd. Het belang daarvan is zodanig dat het verhaal over de aanloop tot zijn politieke carrière zich meestal concentreert op de verschillen van mening met het gouvernement in Batavia over de drukpers en op zijn betrokkenheid bij de protestvergadering van de Bataviase ingezetenen in het sociëteitsgebouw De Harmonie op 22 mei 1848. Daardoor zijn andere aspecten van Van Hoëvells verblijf in Nederlands-Indië minder goed voor het voetlicht gebracht. Ook Van de Velde, die in 2000 een biografie van P.J. Veth publiceerde, waarin hij uitgebreid op Van Hoëvell ingaat, heeft vooral aandacht voor het Harmonie-incident en de vernieuwersrol van Van Hoëvell in het koloniale debat na 1848, dit uiteraard in relatie tot Veth. ${ }^{1}$ Het feit dat er nog geen moderne biografie over Van Hoëvell bestaat, leidt ertoe dat gegevens veelal worden ontleend aan de oudere literatuur. ${ }^{2}$ Zo valt er juist over de jaren tot 1848 nog veel in te vullen: over zijn rol als tijdschriftredacteur, predikant en bestuurslid van verschillende particuliere organisaties, waaronder het Bataviaasch Genootschap. Bij die functies hoorden zaken, waarbij hij zich betrokken toonde, zoals de persvrijheid, de Indische taal-, land- en volkenkunde, het museum van het genootschap, de toestand van het onderwijs. Omdat Van Hoëvell in de belangrijkste ontwikkelingen binnen het genootschap in de jaren 1840-1848 een rol speelde als bestuurslid, vice-voorzitter en voorzitter, kunnen we de genootschapsgeschiedenis van die jaren koppelen aan zijn persoon. Daarbij spelen veranderingen in het verzamelbeleid en de

$1 \quad$ Stapelkamp 1986:11-20 en Bosma en Raben 2003:193-203 behandelen het Harmonie-incident. Van de Velde 1998:52-80 gaat in op de relatie Veth-Van Hoëvell. Zie ook Van de Velde 2000.

2 Met name de herdenkingsartikelen van Veth 1884b:234-94 en Van Soest 1879:199-232, waarbij Van 't Veer 1958:101-44 aansloot. Voor Van Hoëvells rol in het debat over het cultuurstelsel: Fasseur 1978. Een archief Van Hoëvell is niet overgeleverd. 


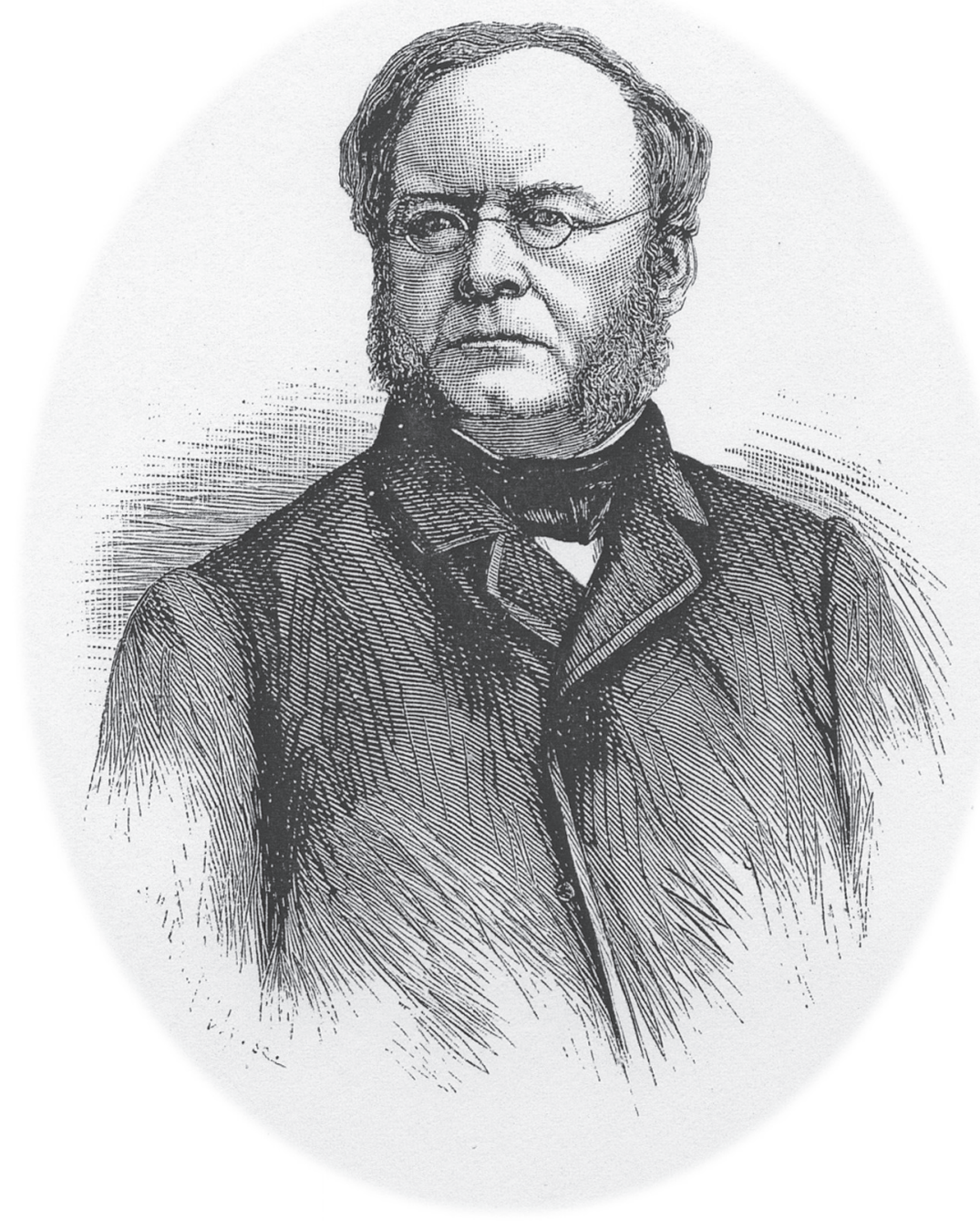

Portret van Wolter Robert baron van Hoëvell, president van het genootschap, lithografie uit Eigen Haard 1879 (collectie RKD/Iconografisch Bureau Den Haag) 
geschiedenis van de eigen drukpers van het genootschap een rol, het laatste vooral omdat het bijdroeg tot Van Hoëvells vertrek in 1848. In het kader van deze studie ligt vanzelfsprekend de nadruk op Van Hoëvell en het genootschap.

\section{Van Hoëvell in het bestuur}

Wolter Robert was in 1812 in Deventer geboren als zoon van de officier G.W.W. baron van Hoëvell en E.J.J. van der Capellen, een volle nicht van de gouverneur-generaal. De jonge Van Hoëvell volgde onderwijs in Groningen, waar hij na de Latijnse School theologie ging studeren. In 1831 nam de aspirant-predikant deel aan de Tiendaagse Veldtocht als lid van een studentencompagnie. In 1836 gepromoveerd in de theologie, vertrok hij, na te zijn getrouwd, naar Batavia om in 1837 als 24-jarige zijn werk als predikant der eerste klasse aan te vatten voor zowel de Nederlandse als de Maleise gemeente van de Hervormde Kerk. Naar het schijnt volgde zijn vertrek naar Batavia na een advies van zijn aangetrouwde oom, de voormalige gouverneur-generaal.

Opvallend in dat eerste jaar is niet zo zeer de uitverkiezing tot lid van het genootschap tijdens de algemene vergadering ter gelegenheid van het bezoek van Prins Hendrik. Hij was een van de vele leden, waarmee het genootschap in dat jaar versterkt werd. ${ }^{3}$ Eerder is opvallend dat hij meteen in 1837 met zijn collega-predikant S.A. Buddingh en met de directeur van de Landsdrukkerij, J.J. Brest van Kempen, het plan smeedde om een tijdschrift op te richten. In april 1838 rolde de eerste aflevering van het Tijdschrift voor Neêrland's Indië van de pers. Er is nog weinig bekend over de voorgeschiedenis van deze tijdschrift-oprichting en dan wel in het bijzonder in verband met het Bataviaasch Genootschap. Waarom een zelfstandig tijdschrift, weliswaar met instemming en hulp van het gouvernement, waarom niet een tijdschrift van het Bataviaasch Genootschap? Dat laatste zou pas in 1852 gebeuren met de oprichting van het Tijdschrift voor Indische Taal-, Land- en Volkenkunde.

In 1832 lanceerde de toen net benoemde genootschapsvoorzitter Lenting een plan voor een tijdschrift, uit te geven onder bescherming van het genootschap. ${ }^{4}$ De Verhandelingen vond hij minder geschikt om kunsten en weten-

3 In de vergadering van 27-8-1837 werden twee honoraire, vijf corresponderende en 24 gewone leden benoemd. Op de eerdere algemene vergadering van 29-3-1837 waren al 69 nieuwe leden benoemd. Onder hen waren S.A. Buddingh (later voorzitter), F.W. Junghuhn, P. Mijer (later secretaris), C.F. Pahud, A. von Humboldt, A. Waitz en C. van der Wijck (de beide laatsten waren later bestuurslid). ANRI KBG Dir 0101 en Dir 0103.

$4 \quad$ ANRI KBG Dir 0085, vergadering 12-12-1832, punt 36. 
schappen te verbreiden, omdat ze alleen de leden bereikten en een te lage verschijningsfrequentie hadden. Lenting dacht aan een breder lezerspubliek. Van Hoëvell stond iets dergelijks voor ogen, toen hij vijf jaar later het plan realiseerde. Waarschijnlijk heeft hij geweten van het gestrande plan van Lenting. Als lid had Van Hoëvell in 1837 echter nog geen invloed op het bestuur van het genootschap. Hij zag mogelijkheden om zijn eigen tijdschriftplan buiten de genootschapskring te realiseren. Het in het bestuur gesignaleerde probleem van de Landsdrukkerij, die leed onder een tekort aan personeel, wist hij te omzeilen door de directeur van de drukkerij zelf voor het plan te winnen en hem in de redactie op te nemen. Juist in 1837, toen het genootschap besloot dat het drukken van deel 17 van de eigen Verhandelingen sneller en goedkoper in Nederland kon gebeuren, op grond van een berekening van Brest van Kempen zelf, kon Van Hoëvell de voorbereidingen voor het nieuwe tijdschrift afronden in samenwerking met diezelfde drukkerij. ${ }^{5}$ Er moeten andere factoren een rol hebben gespeeld, dat de ene bundel Verhandelingen niet en een tijdschrift met verschillende afleveringen en met een flinke oplage wel kon worden gedrukt. Was er voor de directeur en het personeel van de drukkerij meer te verdienen aan een periodiek, dan aan de onregelmatig verschijnende Verhandelingen? Men was van de Landsdrukkerij afhankelijk, omdat een drukpers in de handen van particulieren nog ongehoord was. Zoiets zou pas na 1848 van de grond komen.

Van Hoëvell had eer van zijn initiatief: een regelmatig verschijnend Tijdschrift voor Neêrland's Indië, twee delen per jaar van 1838 tot 1843, tien boekdelen in klein octavo van gemiddeld meer dan 500 pagina's in een oplage van ongeveer 500 exemplaren. Na 1843 werd het aantal delen per jaar uitgebreid tot vier (Van Delden 1990:11). In dezelfde periode gaf het Bataviaasch Genootschap drie octavo-delen van zijn Verhandelingen (17-19) uit van ongeveer gelijke omvang bij een oplage van 400 exemplaren, waarvan slechts de helft van de persen van de Landsdrukkerij kwam. ${ }^{6}$ In de resoluties van het bestuur van het genootschap staat in de jaren 1837-1838 nergens een vermelding van het nieuwe tijdschrift, dat toch door drie leden van het genootschap werd opgericht. Voelde het genootschapsbestuur zich niet betrokken bij zo'n voorgenomen periodiek? Of voelde het zich gepasseerd en had het graag meegedaan met het plan? De notulen geven op die vragen geen antwoord. ${ }^{7}$

Bij de uitverkiezing van Van Hoëvell tot bestuurslid op 11 april 1839 zal zijn redacteurschap van het tijdschrift een rol hebben gespeeld. Hij was

5 ANRI KBG Dir 0100, vergadering 22-3-1837, punt 10.

6 Een gedeelte van deel 17 van VBG (1839) werd in Leiden gedrukt, terwijl deel 18 (1842) op de pers van de Engelse zending te Parapattan werd gedrukt.

7 De geschiedenis van het TNI moet nog geschreven worden. Van Delden 1990 geeft een korte beschrijving bij een uitgebreide inhoudsopgave 
inmiddels een bekend persoon geworden in de kleine Europese gemeenschap van Batavia. Het tijdschrift verscheen al een jaar. De rol van Buddingh en Brest van Kempen, de laatste in 1839 als redactielid opgevolgd door de raadsheer bij het Hooggerechtshof, Pieter Mijer, was veel kleiner dan die van Van Hoëvell. Vandaar dat het tijdschift altijd als 'zijn' tijdschrift wordt beschouwd (Van Delden 1990:11). Mijer (1812-1881) was in Batavia geboren en had zijn schooltijd in Nederland doorgebracht. Hij studeerde rechten in Leiden en promoveerde daar in 1832. Hij werd in 1835 referendaris bij de Algemene Secretarie en verhuisde in 1837 naar het Hooggerechtshof, eerst als griffier, in 1838 als raadsheer, in 1846 als vice-president. ${ }^{8}$ Mijer was lid geworden van het genootschap in maart 1837, was in 1839 in het bestuur gekomen en had in 1842 het secretariaat op zich genomen. Hij was een medestander van Van Hoëvell bij de Harmonie-vergadering van 1848. Later werd hij minister van koloniën, maar was toen een koloniaal conservatief, die in het liberale kamp in ongenade was gevallen.

Van Hoëvell werd in het bestuur gekozen tegelijk met de directeur-kolonel van de genie, jhr. C. van der Wijck. In dat bestuur troffen zij aan: genootschapssecretaris en hoofd van de Geneeskundige Dienst E.A. Fritze, hoofdingenieur van de Civiele Gebouwen J. Tromp, het lid van de Raad van Justitie A.J. Bik, landeigenaar J. Tiedeman, het lid van het Hooggerechtshof C. Visscher, de algemeen boekhouder M.H. Halewijn, generaal-opperbevelhebber F.D. Cochius, directeur van 's Lands Plantentuin en hoofd van de Natuurkundige Commissie P. Diard en diens medelid in die commissie, de natuurkundige H. Bürger. Voorzitter Merkus was nog niet terug van Europees verlof en zijn vervanger net vertrokken, zodat de secretaris tijdelijk het bestuur aanvoerde. In het bestuur waren Merkus en Fritze de langstzittenden (vanaf 1821, respectievelijk 1828). Na de aanvulling met twee nieuwe leden en na de terugkomst van Merkus in juni 1839 was het weer op volle sterkte. Gouverneur-generaal D.J. de Eerens was beschermheer.

Van Hoëvell kwam spoedignazijn aankomstin Bataviain tal van organisaties te zitten: in het bestuur van het Nederlandsch-Oost-Indisch Bijbelgenootschap en dat van het Javaasch Medewerkend Zendelinggenootschap, in de Hoofdcommissie van Onderwijs en in de Commissie tot Ondersteuning van Behoeftige Christenen, om slechts de belangrijkste te noemen. In de kerkenraad nam hij met zijn collega's Buddingh en N. Pluim Mentz in 1839 de leiding. Het onderwijs was vanaf het begin van Van Hoëvells verblijf een onderdeel van zijn werkzaamheden. Met Fritze werkte hij in 1839, nog vóór hij in het genootschapsbestuur plaatsnam, een plan uit voor de oprichting van een

$8 \quad$ Van Deventer 1884:71-92. Aan Mijers bestuursfunctie binnen het genootschap wordt hierin nauwelijks aandacht besteed. Mijer zelf maakte hier evenmin melding van in zijn Rede, uitgesproken bij zijn overgave van het bestuur aan opvolger James Loudon, in 1872 (Mijer 1872). 
gymnasium in Batavia, waarvoor de opstellers dachten geld te kunnen vinden in de opheffing van het Instituut voor de Javaanse taal te Soerakarta. Hoewel het plan niet van de grond kwam - het gymnasium Koning Willem III werd ruim vijftien jaar na Van Hoëvells vertrek opgericht (1864) - geeft het aan dat de zaak van goed onderwijs in Indië hem aan het hart ging (Fasseur 1993:679). Bij de protestvergadering van mei 1848 speelden ook juist de thema's van de gebrekkige onderwijsmogelijkheden en de verplichting voor aanstaande ambtenaren om hun opleiding in Nederland te volgen de hoofdrol.

\section{Verzamelingen}

Toen Van Hoëvell lid van het genootschap werd, op de dag dat het Nederlandsch Koloniaal Museum gedoopt werd, beleefde dat museum een periode van grote drukte. Toen hij in het bestuur plaatsnam, was de verbouwing zo goed als klaar en was het verzamelen van naturalia de belangrijkste activiteit geworden. Het regeringbesluit over het museum was bijna vier jaar van kracht. Secretaris Fritze had veel werk aan de nieuwe activiteiten en de leden van de Natuurkundige Commissie speelden er een grote rol in. Van de verzamelde specimina uit het planten- en dierenrijk gingen twee exemplaren naar Nederland, terwijl een derde exemplaar in het museum in Batavia werd geplaatst, dit alles volgens de bepalingen van het regeringsbesluit over de subsidietoekenning van 1835. Incidenteel stuurde het museum in Leiden kisten met natuur-historische voorwerpen aan wat het noemde: het Bataviasche Museum van Natuurlijke Historie. In een brief die de directie van het Koloniaal Museum te Batavia eind 1838 had gericht tot collega C.J. Temminck van het Rijksmuseum van Natuurlijke Historie te Leiden, werden een paar uitgangspunten verduidelijkt: 'Het Museum alhier is toegewijd aan de verschillende takken der natuurlijke historie, de oudheidkunde en de voortbrengselen van nijverheid en kunstvlijt van de bewoners dezer gewesten'. Het museum zou zich beperken tot voorwerpen van 'deze gewesten', in het bijzonder die van natuurlijke historie om zo het museum te Leiden, 'waarvan het museum alhier zich gaarne als eene filiaal inrigting wenschte aangemerkt te zien', van dienst te zijn. ${ }^{9}$ Weliswaar was het nieuwe museum door een bepaling in de subsidieverlening aan het Leidse museum verbonden, maar door zich als een filiaal te afficheren, werd het wel moeilijker om te verzamelen op andere terreinen dan die waarop het museum voor natuurlijke historie in de sleutelstad actief was. Zo was de Javaanse oudheidkunde in een ander museum in Leiden

9 Beide citaten uit een conceptbrief van 14-12-1838 van de directie van het museum te Batavia aan de directeur van 's Rijks Museum te Leiden. ANRI KBG Dir 0110, vergadering 1-11-1838, bijlage $66 \mathrm{~b}$. 
ondergebracht en waren etnografica vooral in het Haagse Koninklijk Kabinet te vinden. Secretaris Fritze was zich bewust van het feit dat door het nieuwe beleid de aandacht eenzijdig op de naturalia was komen te liggen. 'Door de meerdere aandacht, die men tijdelijk aan de natuurhistorische voorwerpen heeft moeten schenken' was de archeologische, etnografische én voorwerpen van 'volksindustrie en nijverheid' niet veel aandacht toebedeeld, aldus Fritze in 1839. En door de opstelling in de tot museumgebouw veranderde kolfbaan kon het lijken alsof het uitsluitend om een museum van natuurlijke historie ging. ${ }^{10}$ Sinds 1836 waren er jagers en een insectenvanger aan het werk en wat dat opleverde moest worden geprepareerd door de assistent van de Natuurkundige Commissie, in doosjes worden geplaatst, in kasten worden gezet, van etiketten worden voorzien. Er groeide in het museum een collectie opgezette dieren en rond het gebouw een kleine dierentuin. De eerste koningstijger zat in augustus 1837 in zijn hok. Er werden een aap en een baviaan aangekocht voor $f 101$ en er moesten kippen aangekocht worden voor het voederen van de wilde honden en bananen voor de apen. ${ }^{11}$ In december 1838 stuurde de resident van de Preanger regentschappen een tweede koningstijger (vervoerskosten veertig gulden). ${ }^{12}$ In februari 1840 werd het kadaver van een rhinoceros javanicus uit Bantam opgehaald. ${ }^{13}$

Tijdens de algemene vergadering van 11 april 1839 kon Fritze melden dat de werkzaamheden van het tien man sterke bestuur nogal waren toegenomen, omdat 'elk wetenschappelijk vak bijzondere zorg en belangstelling vorderde, welke alleen in den bijzondere beoeffenaar van hetzelve aangetroffen worden'. Het was een inleiding op een reorganisatie van het genootschap en een opdeling van de werkzaamheden: 'Dat alzoo de Oudheidkunde, de Ethnographie of volkskunde, de natuurkunde en eindelijk de Boekerij ieder als afzonderlijk Departement onder een bepaalde persoon behoort te staan'. ${ }^{14}$ Fritze was zich ervan bewust dat de natuurlijke historie nu voldoende aandacht kreeg en dat de andere vakken op soortgelijke wijze moesten worden aangepakt.

De woorden van Fritze wijzen in de richting van een verdere professiona-

10 Aldus het niet ondertekende 'Voorberigt' in VBG 17:V, waarschijnlijk afkomstig van secretaris Fritze.

11 De in het genootschapsarchief bewaarde financiële stukken over 1833-1846 geven interessante aanvullingen op de notulen. ANRI KBG Dir 1332 bevat gegevens over de eerste uitgaven voor jagers in februari 1836, een insectenvanger in juni 1836. In april 1837 werden honderden doosjes aangeschaft voor het opbergen van naturalia, in juni wordt voor het eerst de 'tijger royaal' gesignaleerd, in oktober 1837 de aankoop van dieren op een vendutie.

12 ANRI KBG Dir 0106, vergadering 1-3-1838, punt 22, 47, en Dir 0107 vergadering 6-4-1838, punt 55 .

13 ANRI KBG Dir 1333. Op 28-2-1840 kostte dit $f 16$ aan vervoer, inclusief de huur van een prauw.

14 ANRI KBG Dir 0112, algemene vergadering 11-4-1838, punt 3, 7. 
lisering die het genootschap heel goed kon gebruiken. Was het in 1778 met een encyclopedisch beginselprogramma opgericht, zestig jaar later heerste het gevoel dat beperking ('tot deze gewesten') en specialisatie (oudheidkunde, etnografie en natuurlijke historie) de collecties ten goede zouden komen. Na 1850 zou het - met de oprichting van nieuwe verenigingen voor natuurkunde en geneeskunde in Nederlands-Indië en met de oprichting van het eigen Tijdschrift voor Indische Taal-, Land- en Volkenkunde - komen tot verdere inperking van het werkterrein van het genootschap.

Van Hoëvell had op de eerste algemene vergadering na zijn intrede in het bestuur, op 19 juni 1839, een historische verhandeling gehouden over de beoefening van kunsten en wetenschappen in Indië. In deze lezing had ook hij de samenwerking geschetst, die tot stand was gekomen tussen de Natuurkundige Commissie en het genootschap. Van Hoëvell noemde dan ook nadrukkelijk het museum het Koloniaal Museum van Natuurlijke Geschiedenis. ${ }^{15}$ Fritze en hij stemden duidelijk overeen. Het was de predikant die op 23 juli 1839 terugkwam op het reorganisatievoornemen van Fritze in een poging het evenwicht te herstellen. Hij stelde een taakverdeling voor binnen het bestuur. ${ }^{16} \mathrm{Na}$ de uitbreiding tot twintig personen eerder dat jaar, was dat meer dan nodig. Het bestuur werd te groot om zonder taakafbakening verder te gaan. Tijdens de vergadering van 9 augustus, waarbij zeventien bestuursleden aanwezig waren, kwam het tot een splitsing in vijf afdelingen op voorstel van Van Hoëvell en Van der Vinne. Het waren de volgende werkgebieden:

1 Historie, geografie, etnologie en archeologie

2 Oosterse talen

3 Fysica, chemie en 'oeconomia ruralis'

4 Natuurlijke geschiedenis

5 Redactie voor de werken van het genootschap

Van Hoëvell nam plaats in de afdeling oosterse talen met zijn collega-predikant van de Engelse zending H.W. Medhurst, en in de redactie van de werken van het genootschap met Mijer en Brest van Kempen. ${ }^{17}$

De tweede afdeling zou zich bezighouden met het Arabisch, Javaans, Maleis, Soendanees en het beheer krijgen over de Arabische boeken en handschriften van de Sultan van Bantam en over de Javaanse en Maleise handschriften. De bibliotheek zou onder beheer komen van de eerste afdeling, waar het nieuwe bestuurslid Buddingh zich speciaal met de boeken zou belasten. Aangezien Van Hoëvell tot de opstellers van het reorganisatievoorstel behoorde, mogen we aannemen dat hij zijn eigen belangen bij de verdeling van taken in het oog

15 Van Hoëvell 1839:100-3. Hij publiceerde zijn verhandeling als 'Geschiedkundig overzigt van de beoefening van kunsten en wetenschappen in Neêrland's Indië' in zijn eigen tijdschrift.

16 ANRI KBG Dir 0117, vergadering 23-7-1839, punt 10.

17 ANRI KBG Dir 0120, vergadering 9-8-1839, punt 4, bijlage nr 1. 
heeft gehouden. Bij de oosterse handschriften en dus de ermee samenhangende taalstudie lag zijn belangstelling, ook in verband met de zending en zijn functie bij het Indisch Bijbelgenootschap. In de redactie van de Verhandelingen had hij een direct en niet te onderschatten belang als redacteur van het Tijdschrift voor Neêrland's Indië. Hij en zijn mederedacteuren van het tijdschrift zaten in drie van de vijf afdelingen. Op deze wijze konden zij een blik houden op aangeboden kopij en de zaken eventueel op elkaar afstemmen.

$\mathrm{Na}$ het instellen van deze afdelingen kregen de vergaderingen een vaster patroon, waarin verslaggeving door een afdelingsvertegenwoordiger een terugkerend punt was. Van Hoëvell deed in september 1839 het voorstel om een kundige 'Arabier' aan te stellen voor het ordenen van de Arabische bibliotheek en de handschriften over te brengen naar de Engelse kerk, waar ze beter konden worden bestudeerd. ${ }^{18}$ Onder het toeziend oog van Medhurst werkte een inheemse schrijver vierenhalve maand aan het 'arrangeren en gedeeltelijk in het Maleitsche overbrengen' van de Arabische en Javaanse manuscripten. ${ }^{19}$ Er bleken toen 370 oosterse handschriften te zijn. ${ }^{20}$ Helemaal zonder aandacht bleven de etnologische en archeologische voorwerpen in het museum niet. Buddingh en Mijer, nieuwkomers in het bestuur, bleken zich in oktober 1839 te hebben belast met het 'op orde brengen' ervan. Ze hadden plankjes met etiketten laten maken, waarvoor een klerk met een fraaie en duidelijke letter de opschriften mocht gaan maken. Hoe groot de collectie op dat moment was, vermeldt het verslag van Buddingh niet. ${ }^{21}$

Aan het eind van 1839 leek Van Hoëvell zich een vaste plaats in het genootschap te hebben verworven door met voorstellen te komen en mee te werken aan een gerichtere aanpak van taken. Zijn voordracht van juli 1839 laat zich lezen als een programma voor de toekomst. Hij bracht er twee wensen in naar voren: aandacht voor de studie van de talen van de archipel én verbetering van het onderwijs in de kolonie. Toen hij op de laatste vergadering van 1839 voorstelde de maandelijkse lezingen voor de leden te hervatten, boden hij en Medhurst aan om drie avonden te verzorgen over Indische literatuur, wat neerkwam op een verslag van hun bevindingen bij het bestuderen van de oosterse handschriften. Collega Buddingh wilde de echtgenotes en dochters van de leden toelaten.22

Van Hoëvell raakte aldus op een interessant moment nauw betrokken bij de activiteiten van het genootschap. Zijn belangstelling lag niet bij het

\footnotetext{
18 ANRI KBG Dir 0121, vergadering 19-9-1839, punt 13b, bijlage nr 14.

19 Op 23-3-1840 rekende Medhurst $f 98$ loon af voor deze inheemse schrijver. ANRI KBG Dir 1332 (1840) kwitantie nr 7.

20 ANRI KBG Dir 0122, vergadering 24-10-1839, punt 12.

21 ANRI KBG Dir 0122, vergadering 24-10-1839, punt 10 en bijlage 7.

22 ANRI KBG Dir 0123, vergadering 20-12-1839, punt 17.
} 
verzamelen van naturalia. Hij moet met lede ogen hebben gezien dat daar het meeste geld naar toe ging. De vergoeding voor assistent B. Overdijk van de Natuurkundige Commissie voor zijn werk als conservator en custos van het genootschap bedroeg tweehonderd gulden per maand en slokte de hele gouvernementssubsidie op. ${ }^{23}$ Over de jaren 1841-1842 ging van de inkomsten, ruim $f$ 13.000, twee derde naar het museum, waarvan weer een groot deel naar Overdijk voor diens salaris. ${ }^{24}$ Het zou niet lang duren of een radicale verandering stuurde het museum een heel andere richting in. Van Hoëvell speelde daar een belangrijke rol in.

\section{Publicaties: naar een eigen drukkerij}

Met de publicaties van het genootschap was het minder goed gesteld. Bij het vertrek van Lenting (eind 1834) hadden Fritze en Visscher de zorg voor de Verhandelingen op zich genomen. Nadat Visscher voor langere tijd naar Sumatra's Westkust was vertrokken, was het werk op Fritze neergekomen, die als waarnemend secretaris al genoeg te doen had. Het probleem zat bij de Landsdrukkerij. Het drukken van deel 16 had veel vertraging opgelopen. Uiteindelijk kon de secretaris in september 1836 melden dat de druk voltooid was. ${ }^{25}$ Meteen begonnen de klachten over het langzame drukken van deel 17, dat een bewogen geschiedenis kreeg. Nadat opnieuw herhaaldelijk was geklaagd over stagnatie, ten gevolge van te weinig personeel of door gebrek aan drukletters, werd in 1837 besloten in Leiden te laten drukken, wat ook nog goedkoper zou zijn. ${ }^{26}$ Ondertussen was echter een gedeelte al wel op de Landsdrukkerij gereed gekomen. ${ }^{27}$ Zo moest in 1839 met moeite het Leidse en het Bataviase gedeelte worden samengevoegd tot een ordentelijk deel 17. De platen bij een verhandeling van F. Junghuhn in dat deel waren daarbij nog in Bonn gedrukt. Het drukken in Leiden was duurder uitgevallen dan begroot en had bovendien veel tijd gekost. Die weg bleek op den duur onbegaanbaar. Intussen was in de Verhandelingen duidelijk geworden hoe groot het aandeel van de natuurwetenschappen in het genootschap werd. Van de tien bijdragen in deel 17 waren er zeven van leden van de Natuurkundige Commissie,

23 ANRI KBG Dir 1332 (1840), 19-2-1840. Hij wordt daar als conservateur van het museum en custos van het genootschap aangeduid.

24 ANRI KBG Dir 1332 (1842) bevat een overzicht van inkomsten en uitgaven over twee jaar: 1840-41.

25 ANRI KBG Dir 0098, vergadering 8-9-1836, punt 16. Opziender Chun van de Landsdrukkerij stuurde direct een rekening in voor $f 400$. Dit was een fooi voor de zetters en de drukkers, want het drukwerk gebeurde in principe gratis.

26 ANRI KBG Dir 0100, vergadering 22-3-1837.

27 ANRI KBG Dir 0101, algemene vergadering 29-3-1837, punt 2. 
L. Horner (geologie, mineralogie), P.W. Korthals, Junghuhn en K. Hasskarl (allen plantenkunde). Horner voerde met drie opstellen de lijst aan.

Voor het idee van het inrichten van een eigen drukkerij, dat voor het eerst in de resoluties van 1838 voorkomt, was het bestuur niet meteen gewonnen. Nog in 1838 moest de secretaris met de directeur van de Landsdrukkerij gaan onderhandelen over een recht op voorrang bij het drukken en wel tegen de gegarandeerde betaling van honderd gulden per maand. En dat terwijl de Verhandelingen in principe gratis gedrukt konden worden, een privilege dat door Du Bus was hernieuwd. ${ }^{28}$ Het aanbod van Medhurst om deel 18 te drukken op de pers van de Engelse zending te Parapattan, gedaan in 1840, was dan ook een uitkomst, want het Leidse experiment was te duur voor herhaling. ${ }^{29}$ Deel 18 (1842) verscheen met als impressum 'gedrukt te Parapattan', en bevatte, geheel in afwijking van het voorgaande, geen enkele bijdrage van leden van de Natuurkundige Commissie. Bijna het hele deel was gewijd aan het Favorlangs(Formosaans)-Duitse woordenboek van G. Happart.

In maart 1842 meldde Medhurst dat er voor volgende delen geen beroep meer kon worden gedaan op de Engelse pers, waarna Tromp signaleerde dat een drukpers van de Javasche Bank bij de Landsdrukkerij ongebruikt stond, terwijl daar bovendien een overschot aan drukletters was. Liever dan 'op 's lands of particuliere drukkerijen [en met] vele zorgen, moeijelijkheden en teleurstellingen' zou het genootschap uit eigen middelen in de druk van de Verhandelingen voorzien. Hoofdopziener H.L.E. Chun van de Landsdrukkerij had zelfs al voorgerekend dat dit het genootschap op ongeveer $f 1,40$ per gedrukt exemplaar zou komen te staan. ${ }^{30}$ Men krijgt andermaal de indruk dat het probleem bij de drukkerij niet zo zeer het drukmateriaal en het personeel, als wel het geld was. Als het genootschap maar had willen betalen, was er misschien zonder moeilijkheden aan deel 17 en 18 gewerkt. De Landsdrukkerij drukte intussen rustig voort aan het Tijdschrift voor Neêrland's Indië. Van Hoëvell had met de directeur van de drukkerij kennelijk wél een goede regeling getroffen.

Op een verzoek van het genootschap had het gouvernement in april 1842 het drukkersmateriaal ter beschikking gesteld, terwijl de directeur van de Javasche Bank zijn in onbruik geraakte pers afstond. Meteen werd aan Chun gevraagd onder welke voorwaarden hij wilde drukken. ${ }^{31}$ Vice-voorzitter

\footnotetext{
28 ANRI KBG Dir 0107, vergadering 6-4-1838, punt 4.

ANRI KBG Dir 0126, vergadering 25-9-1840.

ANRI KBG Dir 0128, vergadering 23-3-1842.

ANRI KBG Dir 0130, vergadering 19-5-1842. Het gouvernementsbesluit dateert van 29-4$1842 \mathrm{nr} 3$ en werd op 28-6-1842 gevolgd door een tweede besluit (nr 7) waarmee het afstaan van een beter stel drukletters werd goedgekeurd, nadat het eerste stel onbruikbaar was gebleken. Zie afschriften van deze besluiten in ANRI KBG Dir 1509, omslag 1842.
} 
Van der Vinne kondigde tijdens de algemene vergadering van 25 mei 1842 aan dat het drukken van de Verhandelingen nu voortaan uit eigen middelen zou worden bekostigd met een drukpers en drukletters, die waren afgestaan aan het genootschap. ${ }^{32}$ In september 1842 hadden hij en de nieuwe secretaris Mijer zich van de 'doelmatige inrigting' van het lokaal 'waar 's Genootschaps Drukkerij is gestabiliseerd' op de hoogte gesteld. Deze ruimte was vooralsnog in de gebouwen van de Landsdrukkerij gesitueerd, maar het voelde toch als een eigen drukkerij. ${ }^{33}$

De drukker kon aan de slag als de financiële basis veilig was gesteld. Chun had het genootschap een goede prijs voorgesteld van dertig gulden per vel druks bij een oplage van vijfhonderd exemplaren voor de Verhandelingen en bedongen dat hij in de ledige uren particulier drukwerk mocht aannemen voor eigen rekening. Dit zou een extra bron van inkomsten voor hem zijn, waardoor het genootschap goedkoop uit was. Er ontstond een vreemde constructie. Chun bleef opziener van de Landsdrukkerij, maar drukte daar in een aparte ruimte in opdracht van het genootschap tegen een afgesproken, lage prijs de Verhandelingen en mocht dan verder zijn gang gaan op die pers van het genootschap. Het vreemde van de constructie bleef niet lang onopgemerkt.

Op 5 oktober 1842 schreef directeur van Produkten en Civiele Magazijnen Halewijn, onder wiens verantwoordelijkheid de Landsdrukkerij viel, aan zijn medebestuursleden van het genootschap dat hem 'in ervaring was gekomen' dat er 'particulier werk is, en wordt gedrukt, met het materieel, uitsluitend bestemd voor 's Genootschaps verhandelingen'. Hij deed het verzoek op te geven op grond waarvan Chun daartoe vergunning had gekregen. ${ }^{34}$ De reactie binnen het bestuur op deze brief van collega Halewijn was geïrriteerd. Vice-voorzitter Van der Vinne schreef daags erna aan Mijer:

De Heer Halewijn had zijnen brief wel tehuis hebben kunnen houden. Het is waarlijk als of het Ind.Gouv. alle licht schuwt en ook van de uitwerking der intelligencie een monopolie wil maken.

Waarom zoude aan het Bat. Gen. of aan deszelfs drukker Chun minder vergund zijn te drukken, dan aan Medhurst op Prapattan geschiedt? en dan wel op het zelfde oogenblik dat's Lands Drukkerij het voor handen werk niet af kan maken.

Ik vereenig mij geheel met uwe beschouwingen, vervat in uw hierbij teruggaand briefje, hetwelk ik u verzoek in de minuut te willen deponeren, en tevens eene voordragt aan het Gouvt te doen, ten einde de bedoelde zwarigheid uit den weg te ruimen en Chun te laten drukken wat hij verkiest even als Medhurst. ${ }^{35}$

32 ANRI KBG Dir 0130-31. Aanspraak door Van der Vinne op 25-5-1842 tot de algemene vergadering.

33 ANRI KBG Dir 0132, vergadering 14-9-1842.

34 ANRI KBG Dir 0990, okt.-nov. 1842, nr 4, brief van 5-10-1842 nr 4841.

35 ANRI KBG Dir 0990, okt.-nov.1842, nr 2, brief dd 6-10-1842 van J. van der Vinne aan P. Mijer. 
Halewijn kreeg als antwoord dat van particulier drukwerk was afgezien, waarmee de zaak gesust leek, maar de gouverneur-generaal kreeg een door Mijer opgesteld verzoekschrift waarin uit de doeken werd gedaan dat het genootschap met Chun een regeling had getroffen dat hij geen betaling zou ontvangen voor het genootschapsdrukwerk (bedoeld werd: geen salaris) in ruil voor toestemming om particulier drukwerk aan te nemen. Het gouvernement werd nu gevraagd een eerder besluit van 28 juni 1842 over het afstaan van de drukletters aan te passen en Chun het aannemen van los drukwerk voor particulieren toe te staan. ${ }^{36}$

De Indische regering was echter beducht voor deze ontwikkeling en schuwde kennelijk inderdaad - naar de woorden van Van der Vinne - alle licht. Op bovengenoemd verzoek kwam op 11 november 1842 het antwoord dat de drukpers voor de Verhandelingen bestemd was en niet bedoeld om van het Bataviaasch Genootschap een drukkerij of uitgeverij te maken. ${ }^{37}$ Het hele plan van de drukkerij leek daarmee een doodgeboren kindje. Halewijns visie had bij de regering geprevaleerd. Het bestuur gaf het echter nog niet op. Van der Vinne stelde voor aan het gouvernement te vragen of de drukletters niet tegen de halve inkoopsprijs in volledig eigendom overgenomen konden worden, kennelijk in de verwachting dat de beperkende maatregel ten aanzien van particulier drukwerk dan zou vervallen, omdat men kon verwijzen naar de praktijk van een andere particuliere drukpers, die van de Engelse zending. ${ }^{38}$ Het gouvernement stemde op 11 januari 1843 in met de overname door het genootschap van een stel drukletters, in vier jaar af te betalen, maar het bleef bij de weigering om toestemming te verlenen tot het drukken voor particulieren. ${ }^{39}$ Intussen had Chun, die voor dertig gulden per vel de Verhandelingen had denken te kunnen drukken omdat hij inkomsten verwachtte uit particulier drukwerk, zijn prijs verhoogd tot vijfenveertig gulden per vel. Van der Vinne was echter niet bereid te zwichten voor het gouvernement. Hij stelde voor opnieuw en nu onder expliciete verwijzing naar andere drukkerijen zoals de zendelingpers op Parapattan waar 'zonder de minste censuur, uitgebreidere werken van wetenschappelijke en godsdienstige strekking' werden uitgegeven, de toestemming voor particulier drukwerk te vragen. Dreigend werd er nu aan toegevoegd dat het genootschap, mocht de toestemming niet worden

36 ANRI KBG Dir 0990, oktober-november 1842, nr 1, brief van 6-10-1842 van de directie van het genootschap aan de directeur van Produkten en Civiele Magazijnen. Verder nr 5, conceptbrief 7-10-1842 van de directie van het genootschap aan de waarnemend gouverneur-generaal.

37 ANRI KBG Dir 0133, vergadering 1-12-1842, punt 1. Afschrift van het gouvernementsbesluit van 11-11-1842 nr 11 in ANRI KBG 1509, omslag 1842.

38 ANRI KBG Dir 0133, vergadering 1-12-1842, punt 1. Verzoek aan de waarnemend gouverneur-generaal 5-12-1842 in ANRI KBG Dir 0990, december 1842.

39 ANRI KBG Dir 0134, vergadering 9-2-1843, punt 2a. Een afschrift van het gouvernementsbesluit van 11-1-1843 nr 26, in ANRI KBG Dir 1509, omslag 1843. 
gegeven, het uitgeven van de Verhandelingen zou staken. Van der Vinne had niet kunnen nalaten de Verhandelingen te betitelen als 'dat voornaam, zoo niet eenig doel van deszelfs [het genootschaps] bestaan' ${ }^{40}$ Daarmee ging hij voorbij aan de belangrijke ontwikkelingen in het genootschapsmuseum, die hij ondergeschikt maakte aan het verkrijgen van de eigen drukpers.

Interessant is intussen dat de spelers van dit spel binnen en tegen de bureaucratie elkaar goed kenden. Merkus was gouverneur-generaal ad interim, maar bleef tegelijk voorzitter van het genootschap. Van der Vinne was zelf directeur van Financiën en de tot algemeen secretaris benoemde Visscher bleef bestuurslid van het genootschap. Visscher had ongetwijfeld de hand in de gouvernementsbesluiten over de drukkerij. Hij had in 1838 zijn plaats als secretaris weer ingenomen, maar liet zich op de vergaderingen zelden zien vanwege drukke bezigheden in Buitenzorg. In maart 1842 had hij het secretariaat aan Mijer overgedaan, die bij het Hooggerechtshof werkzaam bleef. Halewijn had zonder voorafgaand overleg met zijn medebestuursleden, maar wellicht wel aangespoord door Visscher, de knuppel in het hoenderhok gegooid door te vragen waar het drukken van ander werk dan de Verhandelingen op gebaseerd was. Van der Vinne dreigde het gouvernement aan het hoofd waarvan zijn eigen voorzitter stond met het staken van de Verhandelingen. Merkus had juist in de periode dat de zaak van de drukkerij speelde, overlegd met Van der Vinne en hem voorgesteld dat hij (Merkus) het voorzitterschap op zou geven in ruil voor het beschermheerschap. Merkus' wens was wellicht ingegeven door het moeilijke parket waarin zijn eigen genootschap hem bracht, maar hij liet zich door Van der Vinne overreden en bleef aan. Deze rapporteerde dit in de vergadering van 23 februari 1843, en hij en zijn mede-bestuursleden 'wensten zich geluk', dat de gouverneur-generaal als voorzitter wilde blijven fungeren. Van der Vinne intussen kondigde zelf zijn vertrek naar Nederland aan. Hij zou opgevolgd worden door Van Hoëvell die zich aldus meteen met het heikele punt van de drukpers zag opgezadeld. ${ }^{41}$

\section{Bestuur onder Van Hoëvell}

Van Hoëvell leidde als vice-president op 21 maart 1843 voor het eerst een vergadering van het bestuur. Merkus had al een jaar lang de vergaderingen niet meer voorgezeten en zich daarvoor verontschuldigd onder verwijzing naar zijn drukke bezigheden in Buitenzorg. ${ }^{42}$ De predikant leek tot op dat moment

\footnotetext{
40 ANRI KBG Dir 0134, vergadering 9-2-1843, punt 2-6. Verzoek van het genootschap aan de gouverneur-generaal 13-2-1843 in ANRI KBG Dir 0991, omslag 1843.

41 ANRI KBG Dir 0135, vergadering 26-2-1843, punt 7.

42 Tijdens de vergadering van 14-3-1842 had Merkus zich voor de stagnatie in 1841 veront-
} 
geen rol van betekenis te spelen in de oprichting van de genootschapsdrukkerij, maar hij zal die zaak, in verband met zijn eigen tijdschrift, nauwlettend hebben gevolgd. Tijdens de juist genoemde vergadering kreeg hij er meteen mee te maken. Bestuurslid Halewijn had het spel over de drukkerij-inoprichting nog niet uitgespeeld. Hij was door de gouverneur-generaal om advies gevraagd over de dringende brief van het Bataviaasch Genootschap van 13 februari 1843 met de aangekondigde, dreigende stopzetting van de uitgave van de Verhandelingen. Op 10 maart adviseerde Halewijn zijn hoogste baas om de zaak terug te draaien en de particuliere drukkerij in de kiem te smoren. Op de vergadering van 21 maart, waar Halewijn zelf aanwezig was, zal mogelijk een hartige discussie zijn gevoerd, waarbij Medhurst - ook aanwezig - uit eigen ervaring op de werking van de Zendelingpers toelichting kon geven. Halewijn had de gouverneur-generaal conform een eerder advies van de directeur van de Landsdrukkerij aangeraden om de Verhandelingen weer op die drukkerij te laten drukken tegen een zodanige vergoeding als de genootschapsfinanciën zouden toelaten. Het genootschap zou de drukpers en de drukletters weer moeten inleveren en hoofdopziener Chun moest worden verboden er een particuliere onderneming op na te houden.

Het bestuur gooide Halewijn op het voorgestelde terugdraaien van de regeling voor de voeten, dat dit onmogelijk was. Het verwees naar diens eigen verklaring van 1840 over personeelsgebrek en bezuinigingen bij de drukkerij, die het verder drukken van de Verhandelingen onmogelijk hadden gemaakt. De directie wenste de Verhandelingen niet 'op de landsdrukkerij of elders, dan op hare eigen inrigting te doen drukken, en [...] zij is mitsdien niet genegen, de thans in eigendom ontvangen types, aan de lands Drukkerij terugtegeven'. Verder zou het genootschap naar een andere opziener uitkijken, om zodoende het probleem van de bijklussende Chun op te lossen. ${ }^{43}$ Deze ferme taal wees op een frontale botsing met Halewijn. Op de volgende vergadering bleek de zaak echter een goede wending te hebben genomen. Halewijns advies was niet gevolgd - hij woonde deze vergadering niet bij - en Van Hoëvell kon met tevredenheid melden dat het gouvernement op 5 mei 1843 toestemming had gegeven tot het doen drukken van 'stukken van geringen omvang, welke slechts tot bepaalde einden voor den handel en ten gerieve van particulieren moeten dienen, zoo als manifesten, rekeningen, uitklaringen, catalogussen en dergelijke'. ${ }^{44}$ Het open einde, 'en dergelijke', zou later nog voor heel wat

schudigd, die hij mede toeschreef aan het waarnemen van de post van gouverneur-generaal. ANRI KBG Dir 0127.

43 ANRI KBG Dir 0136, vergadering 21-3-1843. Aldaar ook als bijlage de brief van Halewijn, 10-3-1843.

44 ANRI KBG Dir 0137, vergadering 27-5-1843. Een afschrift van het gouvernementsbesluit van 5-5-1843 nr 8, in ANRI KBG Dir 1509, omslag 1843. 
verwikkelingen zorgen. Het personeel van de Landsdrukkerij mocht niet bij de genootschapspers werken noch daar toezicht houden in de tijd dat het geacht werd op de overheidsdrukkerij te werken. Tenslotte werd de prijs voor de over te nemen drukletters vastgesteld op $f 3.377,80$. Het lood was nu niet uitgeleend, maar in eigendom overgenomen. We moeten ervan uitgaan dat Merkus' voorzitterschap van het genootschap een goede uitwerking heeft gehad. Vermoedelijk heeft eerst Van der Vinne en daarna Van Hoëvell bij hem geïntervenieerd. Anders is het moeilijk te begrijpen waarom Merkus de adviezen van Halewijn naast zich neerlegde.

Chun bleek na deze gunstige wending meteen zijn ontslag te hebben genomen bij de Landsdrukkerij en hij was - met de pers, drukletters en al het andere materiaal van het genootschap - verhuisd naar de gebouwen bij de Harmonie. Daar waren nu behalve het museum in de voormalige kolfbaan, het genootschapsgebouw, het laboratorium van de Natuurkundige Commissie en de conciergewoning ook een eigen drukkerij gevestigd. ${ }^{45}$ Vermoedelijk zag Chun, die in de voorliggende periode al de nodige berekeningen had gemaakt, in de nieuwe drukpers goede mogelijkheden. Van Hoëvell zal in de aanloopfase al rekening hebben gehouden met het onderbrengen van zijn tijdschrift bij de nieuwe drukkerij, waar meer vrijheid zou zijn dan onder het toeziend oog van Halewijn. Bovendien was aan Van Hoëvell door de dood van mede-redacteur Brest van Kempen een toeverlaat bij de Landsdrukkerij ontvallen, reden te meer om een veiliger haven voor zijn tijdschrift te zoeken.

Had de pers in de tien maanden van strubbelingen over haar status ongebruikt gestaan? In juli 1842 was Chun - toen nog in zijn dubbelfunctie - begonnen met het zetten van de eerste kopij voor de eigen pers. Het ging om de Proeve eener beschrijving en verklaring der oudheden en opschriften op Soekoe en Tjetto van C.J. van der Vlis. Deze in Soerakarta woonachtige afgevaardigde van het Nederlandsch Bijbelgenootschap was uitgezonden voor de studie van het Javaans. Hij had op voorstel van de tweede afdeling op zich genomen de Arabische, Javaanse en Maleise handschriften van het genootschap te beschrijven, een taak waarvoor een inheemse schrijver onder Medhursts toezicht in 1839-1840 al voorwerk had verricht. Van der Vlis was hiermee in Batavia begonnen en had na zijn vertrek uit de hoofdplaats een deel van de handschriften naar Soerakarta toegezonden gekregen om het werk daar te kunnen voortzetten. ${ }^{46}$ Erg voorzichtig ging het genootschap dus niet om met deze rijke collectie. Van der Vlis, die zich ter plekke ontwikkelde tot archeoloog, had in oktober 1840 een eerste versie van zijn Proeve aan het

45 ANRI KBG Dir 0137, vergadering 27-5-1843, punt 15.

46 ANRI KBG Dir 0124, vergadering 19-2-1840, punt 24 en Dir 0126, vergadering 25-9-1840, punt 12,15 en 45 . 
gouvernement gestuurd ter ondersteuning van zijn verzoek om een toelage van honderd gulden per maand voor de aankoop van Javaanse en Kawihandschriften. Door een stagnatie in het bestuurswerk in 1840-1841 was het advies dat het gouvernement hierover aan het genootschap had gevraagd, nooit gegeven. Toen dat er in maart 1842 alsnog kwam, had het genootschap en passant aan het gouvernement gevraagd de Proeve te mogen drukken. ${ }^{47}$ Intussen had de ijverige Van der Vlis zijn onderzoekingen voortgezet en was er al een tweede versie gereed. Op 4 april 1842 schreef hij aan Van der Vinne dat hij door de medewerking van resident J. Mayor van Soerakarta in de gelegenheid was geweest 'om de bijna ontoegankelijke Oudheden op Tjatto gelegen, 3 à 4 palen van Soekoe, door hooge bosschen en Glagavelden omringd, te onderzoeken.' 48 Voor het drukken van Van der Vlis' verhandeling waren Javaanse lettertekens nodig en die werden in bruikleen gegeven door de Landsdrukkerij. In augustus 1842 stuurde Van der Vlis de eerste gecorrigeerde drukproeven terug. De intensieve briefwisseling tussen Van der Vinne en Van der Vlis kwam door de dood van de jonge javanicus in het zelfde jaar tot een einde. Als een in memoriam verscheen de grote verhandeling, met gelithografeerde afbeeldingen, als eerste proeve van de eigen drukkerij. ${ }^{49}$

Van Hoëvell bood in september 1842 aan om een editie van een Maleis handschrift met een vertaling in het Nederlands en met aantekeningen gereed te maken. ${ }^{50}$ Zo werd na de archeologische studie van Van der Vlis de rest van het $19 \mathrm{e}$ deel van de Verhandelingen bestemd voor de omvangrijke Sjaïr Bidasari, de eerste van een nieuwe serie tekstedities waarmee het genootschap aantoonde waar het een belangrijke taak zag weggelegd. Na de Javaanse spraakkunst van A.D. Cornets de Groot (1833), studies over Javaanse cultuur door J.F.C. Gericke (1836) en H. MacGillavry (1836), het woordenboek van het Favorlangs (1842) was met de verhandeling van Van der Vlis en de teksteditie van Van Hoëvell de weg van de archeologie, de filologie en de taalstudie ingeslagen.

Zoals gezegd was Chun in september 1842 begonnen om de 'ledige' uren van de genootschapspers te gebruiken voor drukwerk in eigen beheer. Waarschijnlijk deed hij dat tussen het lastige drukproces aan Van der Vlis' Soekoe-verhandeling door. De Javaanse tekstgedeelten werden uit lood van de Landsdrukkerij gezet, voor de vertaling en de toelichtingen kon Chun het

\footnotetext{
47 ANRI KBG Dir 0128, vergadering 23-3-1842, punt 15.

48 ANRI KBG Dir 0129, vergadering 20-4-1842, brief van Van der Vlis, dd 4-4-1842 als bijlage 6 bij het verslag van deze vergadering.

49 VBG 19 (1843). Van der Vlis had in deel 18 (1842) al een bijdrage geleverd over een Formosaanse woordenlijst, die hij uit Utrecht kende, dit als aanvulling op het Favorlangs-Duitse woordenboek van G. Happart in dat deel.

50 ANRI KBG Dir 0132, vergadering 14-9-1842, punt 22.
} 
zetwerk met het eigen lood van het genootschap laten doen. Na het herhalen van het verbod om los drukwerk aan te nemen, in november 1842, zal dat drukwerk voor particulieren hebben stilgelegen totdat het gouvernement daarvoor in mei 1843 toestemming gaf. Het was immers in niemands belang om Halewijn en zijn baas Merkus te irriteren. Wat Chun echter vóór november 1842 drukte aan extra's, is moeilijk te achterhalen.

Toen vice-president Van Hoëvell in mei 1843 opgelucht kon melden dat de eigen drukkerij - mét het drukwerk voor particulieren - voort kon gaan, was waarschijnlijk ook de Sjaïr Bidasari al grotendeels gedrukt. ${ }^{51}$ Voor het zetwerk van deel 19 van de Verhandelingen zal niet alleen materiaal maar ook personeel van de Landsdrukkerij zijn ingezet. Na de verhuizing van de pers van de Landsdrukkerij naar de gebouwen van het genootschap bij de Harmonie zal Chun voor het zetwerk in de diverse talen afhankelijk zijn geweest van een aantal voormalige medewerkers. Pas aan het einde van het bestaan van de drukkerij (1848) krijgen we inzicht in de omvang van het personeel.

Van Hoëvell, die zich gestoord had aan de stilstand van de genootschapswerkzaamheden in 1841 - er werd in dat jaar niet één keer vergaderd - had zijn mede-directieleden op 6 september 1841 met een pinnig briefje laten weten, dat hij de aanmaning om contributie te betalen naast zich zou neerleggen. 'De Ondergetekende is van voornemens deze pretentie en de jaarlijksche contributie in het vervolg te voldoen, zoodra het Bataviaasch Genootschap van Kunsten en Wetenschappen weder teekenen van leven zal gegeven hebben.' ${ }^{52}$ Van der Vinne had al in juni 1840 in een particuliere brief geschreven: 'Ons Genootschap schijnt wel geheel in te sluimeren. Met de wetenschappen wil het in Indië nog niet best gaan. ${ }^{53}$ Dezelfde Van der Vinne had echter de zaak in 1842 stevig ter hand genomen en Van Hoëvell had een voorbeeld waarop hij kon terugvallen, als het ging om doortastend optreden. In het voetspoor van zijn voorganger zou hij de vergaderingen met dezelfde energieke hand leiden. Dat bleek al direct in de eerste vergadering, toen het bestuur in de drukperskwestie niet voor Halewijn zwichtte en bleef staan op het opzetten van een eigen drukkerij.

Van Hoëvell begon in maart 1843 energiek aan zijn vice-voorzitterschap. Hij stelde voor de beschadigde en onbruikbare boeken uit de bibliotheek te verkopen, een budget vast te stellen voor aankoop van nieuwe boeken, in het bijzonder voor boeken over 'deze gewesten' en boekenkasten te laten

\footnotetext{
51 Van Hoëvell liet op 21-3-1843 de al afgedrukte vellen van deel 19 zien en sprak de verwachting uit dat het werk eraan binnen twee maanden gereed zou zijn. ANRI KBG Dir 0136, vergadering 21-3-1843, punt 9.

52 ANRI KBG Dir 0128, vergadering 23-3-1842, brief van Van Hoëvell, 6-9-1841, bijlage 15-16.

53 ANRI KBG Dir 0998, omslag 1840, brief van 13-6-1840 aan J.I. van Sevenhoven, die kort daarop naar Indië terugkeerde, maar Batavia niet levend bereikte.
} 
vervaardigen. Verder wilde hij 'defecte vogelhuiden' (van opgezette vogels) verkopen, skeletten zonder waarde verwijderen en de catalogus van het natuurkundig gedeelte van het museum laten drukken. Tenslotte wilde hij een catalogus van het etnologisch kabinet laten vervaardigen, kasten voor dit kabinet laten maken en de 'beide localen' van het museumgebouw behoorlijk afsluiten met een hek. ${ }^{54}$ Twee maanden later was Van Hoëvell al een stap verder en overwoog hij het hele 'Museum van Natuurlijke Voorwerpen in te trekken' en te vervangen door een Museum van Oudheden. Het lid van de Natuurkundige Commissie L. Schwaner moest het genootschap hierover van advies dienen. ${ }^{55}$ Dat advies was snel beschikbaar en kon al in juli worden besproken. Schwaner vond de toestand van de natuurhistorische verzameling zorgwekkend en adviseerde om het grootste gedeelte ervan naar Leiden over te brengen. Op 20 juli 1843, nog geen twee maanden nadat het denkbeeld voor het eerst door Van Hoëvell zelf was gelanceerd, viel de beslissing om de hele collectie zoogdieren, vogels, amfibieën en insecten naar het museum in Leiden te sturen en voor wat betreft de natuurlijke historie alleen nog mineralen, schaal- en schelpdieren te verzamelen. ${ }^{56}$ Een resterend deel van de opgezette vogels zou in 1844 in Batavia worden verkocht. ${ }^{57}$ De snelheid waarmee dit voorstel de status van een genootschapsresolutie kreeg, wekt op zijn minst verbazing. Er moet een krachtige hand achter hebben gezeten, die het museumbesluit van 1835 in één handomdraai van de natuurlijke historie in de richting van de oudheden zette. De indiener van het voorstel vond het kennelijk niet nodig om vooraf te zien hoe de subsidiegever zou reageren, terwijl die juist het aspect van de natuurlijke historie in het museumbesluit van 1835 had willen steunen. Met de Verhandelingen gebeurde hetzelfde. Op het door de leden van de Natuurkundige Commissie gedomineerde deel 17 (1839) volgden drie delen waarin de natuurlijke historie geheel ontbrak.

Van Hoëvells verslag tegenover de leden tijdens de algemene vergadering van 5 oktober 1843 leest als een verantwoording van genomen beslissingen en als beleidsvoornemens voor de nabije toekomst (VBG 19:xix). In een half jaar tijd was de opzet van het genootschapsmuseum helemaal omgegooid. Daardoor zou de relatie met het Rijksmuseum voor Natuurlijke Historie in Leiden veranderen. Voor oudheidkunde en etnologie lag een relatie met andere instellingen voor de hand: het Museum van Oudheden in Leiden en het Koninklijk Kabinet van Zeldzaamheden (deels in Den Haag en voor

\footnotetext{
54 ANRI KBG Dir 0136, vergadering 21-3-1843, punt 7.

55 ANRI KBG Dir 0137, vergadering 27-5-1843, punt 3.

56 ANRI KBG Dir 0138, vergadering 20-7-1843, punt 6.

57 Catalogus eener belangrijke verzameling van vogels toebehoorende aan het Bataviaasch Genootschap, exemplaar vermeld in de catalogus Perpusnas als XLII 247, maar niet beschikbaar.
} 
wat betreft de Von Siebold-collectie in Leiden) voor de volkenkunde. De ommezwaai van natuurlijke historie naar oudheidkunde met als nieuw aandachtspunt taal- en letterkunde kan op het conto van Van Hoëvell worden geschreven, al was deze nog onder Van der Vinne voorbereid.

\section{Verzamelingen: oudheidkundige zorg}

Geheel onverwacht kwam deze aandacht voor de oudheden in 1843 niet. Sinds 1823 moesten de residenten over de Javaanse oudheden waken. De belofte van een archeologische collectie voor het genootschap, in het gouvernementsbesluit van 1823 opgenomen, was door het uitblijven van reacties uit de residenties en het slecht functioneren van de oudheidkundige commissie een dode letter gebleven. Naar aanleiding van Bauds museumbesluit (1835), waarin de oudheden opnieuw waren genoemd als aandachtspunt, leek de geschiedenis zich te herhalen. Tussen 1835 en 1840 werden geen oudheidkundige aanwinsten gemeld. Van zijn bezorgdheid voor de oudheden gaf de minister van koloniën, diezelfde Baud, blijk in zijn brief van 22 juli 1840 aan gouverneur-generaal C.S.W. graaf van Hogendorp, waarin de komst van de Fransman Ernest de Sancigny werd aangekondigd. Deze had van de koning toestemming gekregen tot het brengen van een wetenschappelijk bezoek aan Indië met een gecombineerd etnografisch-archeologisch doel. Baud had de koning gewezen op het gevaren, die er scholen in zo'n reis van 'een vreemde archeologist'. Het gouvernementsbesluit van 28 december 1840, dat volgde op Bauds bezorgde brief, waarschuwde in scherpe bewoordingen tegen 'een ieder [die] zich meester maakt van de beelden en andere voorwerpen die hij vinden kan en dezelve als zijn eigendom beschouwt, terwijl het dubbel belangrijk wordt nu een vreemd archeologist Java bezoeken zal'. Het besluit verbood het vervoer van oudheden buiten Java zonder toestemming van de gouverneur-generaal en gaf de plaatselijke autoriteiten opdracht om binnen drie maanden lijsten in te leveren van alle oudheden in hun residenties en daarna nieuwe ontdekkingen steeds te melden. ${ }^{58}$ De stilte waarin het genootschap in 1841 gehuld was, maakte dat het gouvernementsbesluit in die kring onopgemerkt bleef.

In 1842 was er eerst het vooruitzicht van de kopij van Van der Vlis over Soekoe en Tjetto voor de Verhandelingen. Daarna bracht Van der Vinne op

58 Gouvernementsbesluit 29-12-1840 nr 13 bevat de verwijzing naar de brief van Baud, 22-71840 nr 60/380a en herhaalde de gouvernementsbesluiten van 24-7-1823 nr 7 en 13-8-1835 nr 18. ANRI KBG Dir 1508, omslag 1840 bevat twee versies van het besluit, het eerste getekend door de adjunct gouvernementssecretaris Schaap, het tweede, met scherpere bewoordingen door gouvernementssecretaris Diepenheim, waaruit hier wordt geciteerd. 
12 augustus 1842 namens het bestuur in een brief aan het gouvernement de zaak van het beheer van de Javaanse oudheden ter sprake. Onder verwijzing naar het museumbesluit van 1835 en het oudhedenbesluit van 1840, werd gevraagd om verplaatsbare monumenten en voorwerpen naar Batavia te laten vervoeren. Dat zou moeten gebeuren

zonder kwetsing der begrippen en instellingen van de Javasche bevolking en zonder nadeel voor 's Gouvernements belangen, met aanbeveling aan de Directie van het Genootschap om voor de verzorging en bewaring dier objecten, als nationaal eigendom, de noodige zorg te dragen en te waken, dat geen enkel stuk daarvan verloren ga. ${ }^{59}$

Het genootschap vroeg tegelijkertijd om een afschrift van de lijsten die de residenten volgens het besluit van 1840 hadden moeten insturen. Het bestuur was bezorgd dat genoemd besluit zou leiden tot zodanige beduchtheid bij lokale autoriteiten voor het verplaatsen van beelden, dat het museum helemaal niet in het bezit zou komen van oudheidkundige voorwerpen.

Het verzoek aan het gouvernement werd kracht bijgezet door de al in Batavia aanwezige beelden te verplaatsen naar een overdekte galerij achter de vergaderzaal van het gebouw in de Rijswijkstraat, als teken van het goede beheer waarvoor het genootschap borg stond. Eerder waren die oudheden onbeschermd op het Harmonieterrein opgesteld geweest. Bik, oud-lid van de archeologische commissie van 1823, droeg zorg voor de herplaatsing. ${ }^{60}$ Verder was het genootschap door algemeen secretaris Visscher in november 1842 op de hoogte gesteld van de resultaten van de reis die de chirurgijn der derde klasse J. Munnich had gemaakt naar Midden-Java om het 'heliographische toestel van Daguerre' uit te proberen op oudheden. ${ }^{61}$ Het was de eerste serieuze toepassing van de vroege fotografie in dienst van het onderzoek naar oudheden. Het reisverslag van Munnich was met enkele daguerréotypen opgevraagd om te zien hoe die gelukt waren. De aandacht voor oudheidkundige voorwerpen was dus juist vóórdat Van Hoëvell de plaats van Van der Vinne innam, toegenomen.

Voordat het gouvernement antwoordde op de brief van het genootschap van 12 augustus 1842 nam het nog een ander besluit, opnieuw ingegeven door een brief van minister Baud, ditmaal uitgelokt door een reactie van de directeur van het Museum van Oudheden te Leiden, Conrad Leemans. Die had, geschrokken van het 'uitvoerverbod' van 1840, gevraagd of dat verbod zich ook uitstrekte tot oudheden die op het moment van het besluit al inge-

59 ANRI KBG Dir 0132, vergadering 14-9-1842.

60 ANRI KBG Dir 0132, vergadering 14-9-1842.

61 ANRI KBG Dir 0134, vergadering 9-2-1843. Brief van 11-11-1842 van de algemeen secretaris aan het genootschap. 
pakt en wel klaarstonden om naar Nederland te worden vervoerd. Het is duidelijk dat Leemans vreesde dat hem iets zou ontgaan. Verder zou volgens de Leidse directeur het verbod niet op bronzen en munten moeten slaan. Hij deed de suggestie van een recht op overname van oudheidkundige voorwerpen door de overheid, voordat particulieren deze konden kopen. Een nieuw gouvernementsbesluit van 17 augustus 1842 herhaalde andermaal dat het waken over de oudheden een taak van de residenten was. Beelden in tuinen en rond woningen van inheemsen moesten beschermd of gered en verzameld worden, maar het wegvoeren van oudheden van de oorspronkelijke plaatsen werd ten zeerste afgekeurd. Verder werd de uitvoer niet volstrekt verboden, onderworpen als die was aan goedkeuring van de gouverneur-generaal. Voorwerpen die al in 1840 in particulier bezit waren, zouden eerst aan het Indisch gouvernement moeten worden aangeboden, eer ze door wegschenking of verkoop aan anderen zouden kunnen toevallen. Buiten Nederland zou so wie so niets terecht mogen komen. ${ }^{62}$ Tenslotte kreeg Leemans de beschikking over de beelden van de voormalige resident van Semarang generaal-majoor C.J. Riesz, die in 1840 al voor zijn museum klaarstonden.

Aan het eind van 1842 reageerde het gouvernement op de brief van het genootschap van augustus met een besluit, waarbij het genootschap afschriften ontving van de door de residenten ingezonden lijsten van oudheden en werd uitgenodigd specifieke verzoeken in te dienen tot het ontvangen van voorwerpen op die lijsten. ${ }^{63}$ Het genootschap beschikte nu voor het eerst over belangrijke overzichten van tempels en ruïnes (A), beelden (B) en beschreven stenen (C) en had daarmee een inzicht van wat er op Java nog op de oorspronkelijke plaatsen stond en wat er verplaatst was naar huizen, tuinen en erven van ambtenaren, particulieren en inheemsen. Het reageerde op 1 maart 1843 met een verzoek om toezending van 146 beelden en 28 beschreven stenen van de lijsten B en C. ${ }^{64}$ Dit verzoek was geredigeerd door secretaris Mijer, maar in nauw overleg met Van Hoëvell opgesteld, die danook het concept voor akkoord verklaarde. Als nieuwe vice-voorzitter had hij de zaak meteen overgenomen.

Nadat de Algemene Secretarie bezwaar had gemaakt tegen de procedure, omdat voor de afzonderlijke voorwerpen toestemming moest worden gegeven door de plaatselijke autoriteiten, schreef het genootschap op 27 april 1843 aan de residenten van Pekalongan, Bagelen en Kadoe een brief om goedkeuring te vragen voor de verzending van 44 voorwerpen. De residentvan Bagelen, J.G.O.S. von Schmidt auf Altenstadt, had alleen bezwaar tegen

\footnotetext{
62 Afschrift gouvernementsbesluit 17-8-1842 nr 11 in ANRI KBG Dir 1509, omslag 1842.

63 Afschrift gouvernementsbesluit 3-12-1842 nr 18 in ANRI KBG Dir 1509, omslag 1842.

64 ANRI Archief Algemene Secretarie, gouvernementsbesluit 5-10-1843 nr 4 bevat de originele brief van 1-3-1843. Het door Van Hoëvell goedgekeurde concept van de brief in ANRI KBG Dir 0991, omslag januari-maart 1843, nr 28.
} 
het verplaatsen van zes beelden uit de pasanggrahan van Kalialang (Diëng). Voor het overige gingen hij en zijn collega's akkoord, zodat het genootschap op 7 september 1843 voor 38 beelden een fiat van de drie residenten kon overleggen. Op 5 oktober 1843 keurde het gouvernement de overbrenging van die 38 beelden goed. 65 Daags erna diende Van Hoëvell een verzoek in om op een kerkelijke reis naar Kadoe, Djokjakarta, Soerakarta, Bagelen en Pekalongan gebruik te mogen maken van gouvernementspostpaarden, wat hem werd toegestaan. In december 1843 deed de vice-voorzitter een mondeling reisverslag aan zijn medebestuursleden. Men krijgt de indruk dat het meer een archeologische dan een kerkelijke reis was geworden. Van Hoëvell zegt zelf dat hij de reis ondernam om te zien of de 38 aangewezen beelden inderdaad voor verzending naar Batavia in aanmerking kwamen. ${ }^{66} \mathrm{Hij}$ had in Pekalongan negen beelden bij het residentiehuis geselecteerd en de overige afgewezen wegens te grote mate van beschadiging. Verder had hij in Kadoe 45 nieuwe beelden geselecteerd en bij een bezoek aan Diëng met W.A. van der Ham vastgesteld dat de zes beelden in Kalialang best naar Batavia konden vertrekken. Omdat resident C.L. Hartman van Kadoe in juli 1843 al gezegd had geen bezwaren te hebben, stond het gouvernement op 11 december 1843 de overbrenging van de 45 beelden toe, die op het terrein van het residentshuis en op dat van de controleur in de residentie Kadoe stonden. ${ }^{67}$ Op 7 januari 1844 keurde het gouvernement nog eens de overbrenging van een tiental beelden uit Semarang, Oengaran en Salatiga goed. ${ }^{68}$ De reis had dus direct positieve gevolgen voor de museumcollectie. Een kleine honderd beelden en stenen konden aan de reis naar Batavia beginnen.

Nog vóór zijn reis naar Midden-Java had Van Hoëvell een reeds aangekondigde veiling in Semarang van de verzameling metalen archeologische voorwerpen uit de nalatenschap van de overleden resident van Djokjakarta F.G. Valck kunnen voorkomen door een bod op de hele collectie te doen. Voor een bedrag van $f 4.500$ gingen 254 voorwerpen over naar het oudheidkundig kabinet van het museum. ${ }^{69}$ Door deze aankoop en de komst in de eropvol-

\footnotetext{
65 ANRI Archief Algemene Secretarie gouvernementsbesluit 5-10-1843 nr 4 bevat als bijlagen de correspondentie van de residenten, de brief van 7-9-1843 van het genootschap.

66 Verslag van de reis aan het bestuur, 14-12-1843, ANRI KBG Dir 0140, vergadering 14-121843.

67 ANRI KBG Dir 1509, omslag 1843 bevat afschrift gouvernementsbesluit 11-12-1843 nr 36.

68 ANRI KBG Dir 1509, omslag 1844 bevat afschrift van gouvernementsbesluit 7-1-1844 nr 62. Het ging om zeven beelden van het terrein van het residentshuis te Semarang, een steen uit Oengaran, drie beelden uit Banjoekoening, toen al in Semarang en de beelden (hoeveel wordt niet gemeld) bij het assistent-residentshuis te Salatiga. Dus zeker meer dan elf beelden.

69 ANRI KBG Dir 0138, vergadering 20-7-1843, punt 7, en Dir 0139, vergadering 12-9-1843, punt 2. Op 13-9-1843 werd de thesaurier gemachtigd deze aankoop te betalen. ANRI KBG Dir 0991 (correspondentie augustus-september 1843) nr 9.
} 


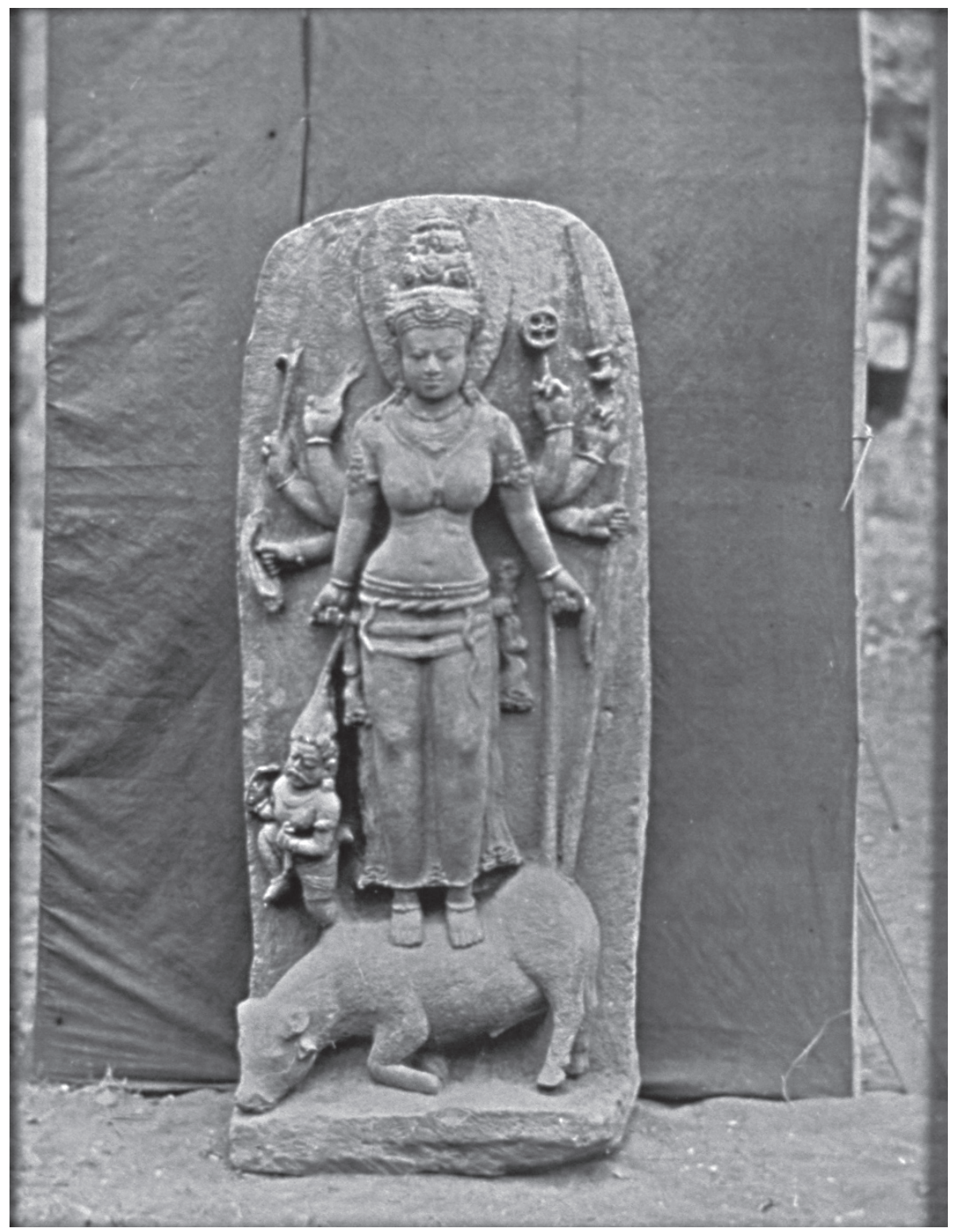

Doerga uit de collectie van het genootschap, daguerréotypie door A. Schaefer (1845), opname gemaakt op het terrein van het genootschapsgebouw in de Rijswijkstraat (collectie Prentenkabinet Leiden PK-F-60.827) 


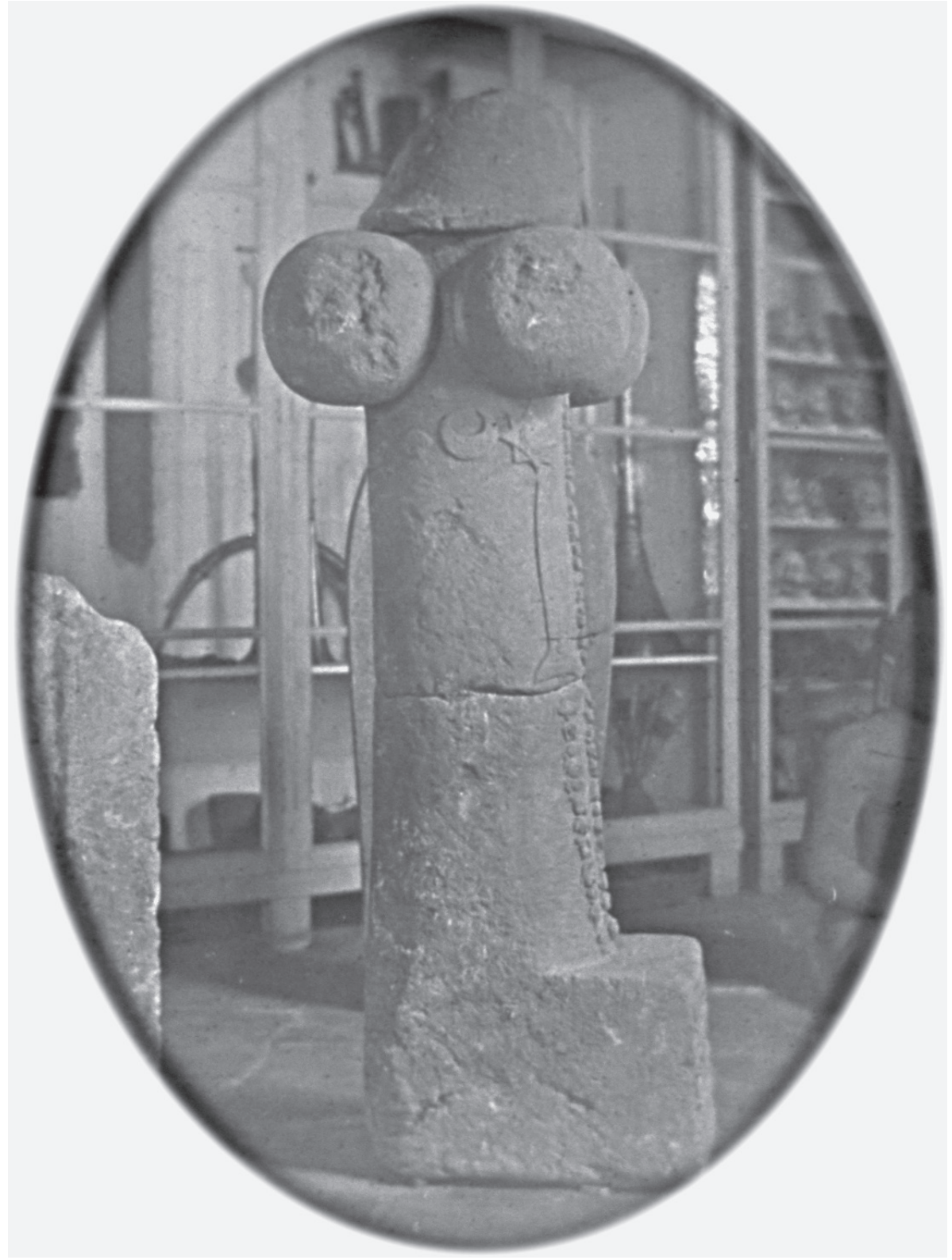

Lingga uit de collectie van het genootschap, daguerréotypie door A. Schaefer (1845) opgenomen in het gebouw van de voormalige kolfbaan dat als museum dienst deed (collectie Prentenkabinet Leiden PK-F-60.843) 
gende maanden van de tientallen beelden was het museum ineens de belangrijkste plek geworden voor de studie van Javaanse oudheden. In de grote en kleinere Midden- en Oost-Javaanse tempels konden dan beelden in situ worden bestudeerd. Die mochten sinds 1840 niet meer verplaatst worden.

Tijdens de algemene vergadering van 5 oktober 1843 meldde Van Hoëvell, dat met de aanwinst van de collectie Valck meegeteld het oudheidkundig kabinet 324 voorwerpen bevatte, naast nog 29 oude munten (VBG 19:43). Er moeten dus vóór de verwerving van die collectie al een zeventigtal voorwerpen zijn geweest. In de algemene vergadering van 4 februari 1845 kon hij de toevoeging van 43 nieuw aanwinsten melden, alle direct gevolg van zijn reis van eind 1843 (VBG 20:23). Op 8 mei 1847 meldde hij aan de algemene vergadering nog eens 33 oudheidkundige aanwinsten (VBG 21:58). De collectie bestond aldus bij Van Hoëvells vertrek in 1848 uit minstens 400 oudheidkundige voorwerpen, de munten niet meegerekend.

Kleine tegenslagen waren er voor Van Hoëvell ook. De krijttekens die hij eind 1843 op talloze beelden in Kadoe bij de Boroboedoer had gezet, in afwachting van een beslissing over het verzoek deze naar Batavia te mogen vervoeren, waren door zware regenval uitgewist. $\mathrm{Nu}$ was niet meer bekend welke op de nominatie stonden om naar Batavia te verhuizen. ${ }^{70}$ We zien in terugblik hoe Van Hoëvell met krijt in de hand was rondgegaan om aan te geven wat hij graag naar Batavia vervoerd zag. Het strenge besluit van 1840 dat juist de oudheidkundige voorwerpen op hun plaats wilde houden, gold niet voor gemotiveerde verzoeken van deskundigen als Van Hoëvell, blijkens de stroom beelden die op reis ging.

De nieuwe resident van Djokjakarta, A.A. Buijskes, die net als zijn collega's benaderd was om toezending van oudheden te regelen, was een voorzichtig man en antwoordde op het genootschapsverzoek dat het transportloon te hoog zou zijn. Zijn tweede argument is interessanter: 'dat het vervoeren derzelve naar mijn inzien niet aangenaam aan het Hof alhier zal wezen, aangezien de Hofgrooten zich daardoor zouden inbeelden dat het Gouvernement met dien vervoer, zeker het een of ander inzigt heeft'. ${ }^{71}$ Het genootschap legde zich bij de bezwaren neer, al ging Van Hoëvell op zijn 'kerkelijke' reis van eind 1843 ook in Djokjakarta langs. Hij zal geprobeerd hebben de resident te overreden, maar kennelijk zonder resultaat. In zijn reisverslag komt hij op zijn bezoek aan die stad niet terug. Overigens kon Van Hoëvell het punt van de hoge transportkosten ontzenuwen. Die zouden door het genootschap worden gedragen. In november 1844 werden aan de residenten van Semarang, Kadoe en Bagelen betalingen gedaan van samen meer dan

70 ANRI KBG Dir 0145, vergadering 20-5-1845, punt 7.

71 ANRI KBG Dir 0138, vergadering 20-7-1843, punt 2 en bijlage 18. 
honderdtachtig gulden voor de overbrenging van oudheden. ${ }^{72}$ De resident van Kadoe, F.H. Doornik, schreef in november 1845 dat 76 koelies onder twee hoofden zes stenen van Kadoe naar Semarang hadden gedragen voor een bedrag van $f$ 97,70. In dezelfde maand schreef de resident van Banjoemas, P.J. Overhand, dat 58 koelies en één hoofd tien stenen beelden hadden vervoerd van Banjoemas naar Poerworedjo. Voor de 21 palen tussen die twee plaatsen was aan de dragers $f 24,78$ betaald. Het tarief was twee cent per man per paal (ongeveer 1500 meter), een dermate laag bedrag per persoon $(f 0,42)$ dat van verkapte herendiensten sprake lijkt te zijn. ${ }^{73}$

Even leek het of het genootschap de subsidie van $f 2.400$ per jaar misliep, toen het gouvernement in oktober 1844 vroeg of die subsidie, sinds 1835 uitbetaald, nog vereist was nu het doel van het museum zo totaal veranderd was. Geschrokken schreef het genootschap nog in dezelfde maand om welke reden het zoölogisch kabinet was ingetrokken, dat de dieren al naar Leiden waren verzonden en dat het tractement van de conservator tot honderd gulden was teruggebracht. De resterende honderd gulden per maand was nauwelijks voldoende voor de transportkosten van de oudheidkundige voorwerpen. Verder zou het lokaal van het oudheidkundig kabinet aanpassingen moeten ondergaan. Kortom die $f 2.400$ waren in de komende jaren nog zeer nodig. Sterker nog, het genootschap verzocht om een suppletie van nog eens $f 600$ per jaar. Het gouvernement bleek te berusten in de voortgezette toekenning van de subsidie, maar het verzoek om verhoging van het bedrag werd genegeerd. ${ }^{74}$ De omkering van de doelstelling van het museum was hiermee door het gouvernement goedgekeurd.

\section{Publicaties: de drukkerij aan het werk}

Van Hoëvell had zich door de strubbelingen over de drukkerij niet van de wijs laten brengen en zijn aandacht verdeeld tussen die drukkerij, het museum en de taalstudie. Van het losse drukwerk in de beginfase, dat de aandacht van Halewijn had getrokken, is niets teruggevonden. Noch in het archief van het genootschap, noch in de Nationale Bibliotheek is er een collectie van dit druk-

\footnotetext{
72 ANRI KBG Dir 1332, 29-11-1844, betaald $f$ 32, $f$ 61, $f$ 47,20 en $f$ 44,20 aan de drie residenten.

73 ANRI KBG Dir Mus 0027, omslag 1 - 1844-1846 bevat diverse brieven over de ontvangst en de vervoerskosten van oudheden. Brief resident Kadoe, 27-10-1845 en brief resident Banjoemas, 3-11-1845.

74 ANRI Archief Algemene Secretarie, gouvernementsbesluit 28-10-1844 nr 6 bevat de brief van het genootschap, 7-10-1844 en de tekst van het besluit, daarbij het advies van de Raad van Indië, dat ook helemaal voorbijging aan de gevraagde verhoging.
} 
werk bewaard. ${ }^{75}$ In 1842 werd Van der Vlis' verhandeling gedrukt, die echter moest wachten tot 1843 eer zij - in deel 19 van de Verhandelingen - beschikbaar kwam voor de leden. Voor het overige drukte het genootschap in 1843 twee uittreksels, respectievelijk uit de eigen besluiten en uit het register van besluiten van de gouverneur-generaal om aan de grote veranderingen in het museumbeleid bekendheid te geven. ${ }^{76}$ Van de zeven titels die in 1843 gedrukt zijn, hebben er vier direct betrekking op het genootschap: de genoemde uittreksels, deel 19 van de Verhandelingen en een aparte uitgave van het verslag van Van Hoëvell dat hij had gelezen tijdens de algemene vergadering van 5 oktober 1843. Daarnaast waren er drie andere uitgaven: een kerkelijke toespraak van Buddingh, een reglement (Bijwet) van de vrijmetselaarsloge De Ster in het Oosten en het jaarverslag van het Engelse weeshuis te Parapattan.

Deze bescheiden start van zeven titels met 1100 pagina's drukwerk kreeg in 1844 een sterker vervolg: vijftien titels, 3400 pagina's drukwerk. Van deze vijftien titels hadden nog maar twee direct betrekking op het genootschap. De andere laten zien dat de drukkerij ging floreren door drukwerk voor particulieren. Van Hoëvell bracht - met toestemming van het gouvernement - het Tijdschrift voor Neêrland's Indië onder bij de drukkerij én een nieuw tijdschrift, Natuur-en Geneeskundig Archief voor Neêrland's Indië, waarvan de officier van gezondheid P. Bleeker de drijvende kracht was. Daarnaast verschenen er twee toneelstukken, een Gedenkboek van oud-studenten van de Leidse universiteit door Mijer, opnieuw een uitgave voor de vrijmetselaarsloge en een Frans leesen vertaalboekje. De grote variëteit in deze vijftien uitgaven laat zien dat naast de toegestane 'manifesten, rekeningen, uitklaringen en catalogussen', een hele andere categorie, omvangrijker teksten van de pers begon te komen.

De trend van 1844 zette zich voort in 1845 en volgende jaren. Onderstaand overzicht van de traceerbare uitgaven geeft een indruk van de omvang van de werkzaamheden in de drukkerij.

De cijfers geven een indicatie van de hoeveelheid zetwerk die in de genootschapsdrukkerij werd verwerkt, maar niet meer dan dat. De hoeveelheid druk- en bindwerk is uiteraard alleen te kwantificeren als we meer weten over oplagen. $\mathrm{Nu}$ is dat voor het hele corpus ondoenlijk. Voor sommige titels echter is het wel te achterhalen. De Verhandelingen (3 delen gecompliceerd drukwerk), het Tijdschrift voor Neêrland's Indië (17 delen van gemiddeld 450 pagina's), het Natuur- en Geneeskundig Archief (4 delen van gemiddeld 550 pagina's) bijvoorbeeld hebben oplagen gehad van gemiddeld 500 exemplaren. Er zijn echter ook uitgaven geweest met een oplagecijfer van tussen de 100 en 200 exemplaren.

De cijfers geven aan dat de drukpers, in eerste instantie afgestaan voor het

75 Mogelijk is het drukkerij-archief in 1848 overgegaan naar de koper, de firma Lange. Een deel ervan is misschien door Van Hoëvell meegenomen naar Nederland.

76 Een exemplaar hiervan in ANRI KBG Dir 0138, vergadering 20-7-1843, nr 6. 
Overzicht uitgaven drukkerij Bataviaasch Genootschap 1843-1848

\begin{tabular}{lcc}
\hline jaar & titels $^{*}$ & pagina's zetwerk \\
\hline 1843 & 7 & 1.100 \\
1844 & 15 & 3.400 \\
1845 & 9 & 4.500 \\
1846 & 19 & 3.400 \\
1847 & 14 & 3.100 \\
1848 & 9 & 1.600 \\
Totaal & 73 & 17.100 (afgerond) \\
\hline
\end{tabular}

* Seriewerken zijn in dit overzicht bij elkaar opnieuw als titel meegerekend. Een titel bestaande uit meer dan één boekdeel, is als één titel opgenomen. De zes jaargangen, zeventien delen van het TNI tellen dus in het schema mee als zes titels. Titeluitgaven en overdrukken zijn niet als apart nummer ingevoerd, omdat ze geen apart zetwerk opleverden.

drukken van de Verhandelingen, al spoedig werd gebruikt voor een veelvoud van uitgaven die niet vielen onder de door het gouvernement toegestane 'catalogi, manifesten, rekeningen, en dergelijke'. We tellen op 73 titels slechts drie delen Verhandelingen. Aan het bovengenoemde getal van 17.100 pagina's zetwerk is dan ook nog een onbekend getal toe te voegen voor het kleinere handelsdrukwerk dat Chun wist aan te trekken. Tenslotte was er nog drukwerk voor de onderwijscommissie en het Indisch Bijbelgenootschap, dat verscheen zonder de vermelding dat de genootschapspers het had verzorgd. Tijdens zijn verslag voor de algemene vergadering van 5 oktober 1843 meldde Van Hoëvell niet alleen dat de eerste bundel Verhandelingen (deel 19) van de eigen pers was gerold. Hij meldde tevens dat de drukkerij twee lokalen van het genootschapsgebouw in de Rijswijkstraat in beslag had genomen en dat een derde ruimte ook voor de drukkerij werd vrijgemaakt (VBG 19:78). Zo kreeg het gebouw dat in 1814 bedoeld was voor winkels en warungs toch nog een commerciële bestemming.

Als we de chronologische titellijst (bijlage 2) bekijken naar herkomst, valt nog iets op. Naast de drie delen Verhandelingen hebben nog zeven titels rechtstreeks betrekking op het genootschap. Men zou kunnen zeggen dat het genootschap hierbij als zijn eigen uitgever optrad. Dertien andere titels zijn te kenmerken als uitgaven van Van Hoëvell persoonlijk of van de organisaties waarvan hij eveneens bestuursvoorzitter was (Tijdschrift voor Neêrland's Indië, Tijdschrift ter Bevordering van Christelijken Zin, publicaties voor het weeshuis en het Indisch Bijbelgenootschap, preken en toespraken). Dan zijn er tweeëntwintig titels van Van Hoëvells vrienden, collega's en bekenden (Buddingh, Bleeker, Mijer, Ritter). En tenslotte de restcatagorie van allerlei drukwerk: letterkundig, documentair-statistisch, vrijmetselaarsuitgaven, leerboekjes. 


\title{
BIBIIO탐표소
}

\section{Societatis Axtium Scientiaxunque}

\author{
QUAE BATAVIAE FLORET,
}

\section{CATALOGUS SYSTEMATICUS}

CORATTE

\section{B L E E K E R}

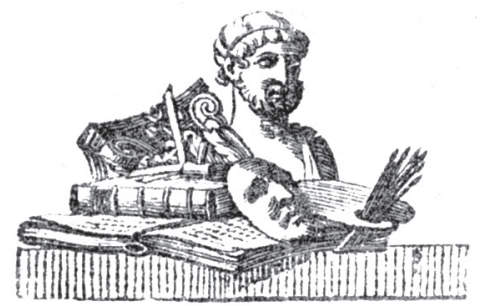

TIJPIS SOCIET. ART. SGIENT. BATAV.

1846.

Titelpagina van de eerste gedrukte bibiotheekcatalogus van het genootschap door W. Bleeker, 1846. (collectie KITLV Leiden) 


\begin{tabular}{ll}
\hline Overzicht uitgaven naar herkomst \\
\hline Genootschapsuitgaven & 10 \\
Uitgaven van Van Hoëvell zelf & 13 \\
Uitgaven van vrienden/relaties & 22 \\
Overige uitgaven & 28 \\
\cline { 2 - 2 } Totaal & 73 \\
\hline
\end{tabular}

Het vermoeden rijst dat de drukpers, althans op basis van deze lijst van 73 traceerbare uitgaven, vanaf 1844 meer dan voor het drukwerk van het genootschap, gebruikt werd voor uitgaven van Van Hoëvell zelf, voor de door hem geredigeerde tijdschriften, voor uitgaven van zijn vrienden, relaties, bekenden en door hen geredigeerde tijdschriften en uitgaven. Met andere woorden: het was meer de Van Hoëvell-drukkerij dan de drukkerij van het Bataviaasch Genootschap. Dit moet men in gedachten houden als we het conflict bespreken dat in 1847 ontstond rond deze drukpers, en dat eerder een conflict was tussen Van Hoëvell en algemeen secretaris Visscher, dan een conflict tussen het genootschap en het gouvernement.

Een andere blik in de omvang van het bedrijf gunt ons de opziener van de drukkerij, E. Führi, opvolger van Chun, toen deze in juli 1848, op het hoogtepunt van het later te bespreken conflict, een verzoek tot het bestuur richtte om de drukkerij te redden door deze te kopen. Hij gaf in juli 1848 op dat er twintig employees bij de drukkerij werkzaam waren. Hij legde tevens een indrukwekkende lijst van drukwerk/uitgaven over, waaraan in de maanden ervoor was gewerkt. ${ }^{77}$

Moeilijker is het al vóór 1848 de dagelijkse gang van zaken in de genootschapsdrukkerij te beschrijven. In het archief van het genootschap treffen wij wel verslagen aan van de bestuurs- en algemene vergaderingen; er is veel correspondentie, zowel inkomend als uitgaand, overgeleverd. Een archief van de drukkerij zelf is echter niet overgeleverd. Juist in het laatste jaar van het bestaan van de drukkerij is er echter wel in ruime mate materiaal in de vergaderverslagen te vinden, zodat ons beeld toch op voldoende materiaal berust. Het gebrek aan materiaal over de drukkerij zelf, over de jaren 18421848, heeft te maken met de rol die Van Hoëvell had als toezichthouder. Hiermee ontlastte hij het bestuur en de bestuursvergaderingen, bezorgde zichzelf veel werk maar schiep tegelijkertijd een vrijplaats voor eigen drukwerk. Uit de afloop van de korte drukkerij-geschiedenis weten wij dat Van Hoëvell ook de enige in het bestuur was die inzicht had in wat er financieel omging. Niettemin was er een aantal kwesties waarin hij niet om het bestuur heenkon. 


\section{Publicaties: aandacht voor inheemse talen}

Weliswaar had nu het genootschap een eigen drukkerij, het drukkersmateriaal was nog beperkt. Toen in 1843 het zetwerk moest beginnen voor de teksteditie plus vertaling van het Javaanse dichtwerk Wiwoho, door J.C.F. Gericke in gereedheid gebracht, moest opnieuw een beroep worden gedaan op de Landsdrukkerij voor Javaanse drukletters. Overigens werd die toestemming bij gouvernementsbesluit prompt gegeven, zoals al eerder voor de teksteditie van de Sjaïr Bidasari met Maleise drukletters was gebeurd. ${ }^{78}$ De Landsdrukkerij had er echter de voorkeur aan gegeven om het Maleise en Javaanse lood niet naar de drukkerij van het genootschap te laten vervoeren, maar het drukwerk in eigen huis te doen. ${ }^{79}$ De Nederlandse vertalingen werden wel in de genootschapsdrukkerij op Rijswijk gezet. Voor het Maleis en het Javaans was men nog steeds van de overheid afhankelijk. Van Hoëvell signaleerde in de eerste vergadering van 1844 dat, terwijl Gerickes Wiwoho werd gedrukt, het zetwerk aan C.F. Winters editie van de Romo moest wachten, wat niet het geval zou zijn als het genootschap over een eigen 'Javaansche pers' zou beschikken.

Op 9 maart 1844 ging de tweetalige prospectus voor de teksteditie van de Romo tijdens de vergadering rond. ${ }^{80}$ De reclametekst was eerst in het Javaans gesteld, daarna volgde het Nederlands. De uitgave zou bij intekening worden aangeboden aan de residenten op Java die daarvoor niet alleen onder de Europese ingezetenen maar ook onder de geletterde Javanen intekenaren moesten zien te vinden. Ook in deze zaak handelde Van Hoëvell voortvarend. De gouverneur-generaal ontving op 19 maart al een verzoek waarin onder verwijzing naar de lange wachttijden bij de Landsdrukkerij voor de Maleise Bidasari (achttien maanden druktijd) en de Javaanse Wiwoho (in maart 1844 al een paar maanden) en vanwege het grote belang van deze uitgaven voor de taalstudie, verzocht werd Javaans en Maleis lood te mogen bestellen in Europa.

Wij verzoeken Uwe Excellentie daarom eerbiedig, zoo spoedig mogelijk, voor rekening van het Bataviaasch genootschap van Kunsten en Wetenschappen, uit Nederland te ontbieden een compleet stel Maleische en Javaansche drukletters met al hetgeen daartoe behoort, met inachtneming van het voorkomende bij den hier overgelegden staat, met vergunning om het daarvoor benodigde actien aan de Indische Kas te mogen terugbetalen op zoodanige wijze, als Uwe Excellentie billijk zal oordeelen. ${ }^{81}$

78 ANRI KBG Dir 0140, vergadering 14-12-1843, punt 1, waaruit blijkt dat met het verzoek daartoe van 14-8-1843 op 21-9-1843 was ingestemd.

79 Zo blijkt uit een brief aan de gouverneur-generaal van 19-3-1844 waarin de strubbelingen met de Landsdrukkerij nog niet waren opgelost. ANRI KBG Dir 0992, omslag januari-mei 1844, nr 19.

80 ANRI KBG Dir 0141, vergadering 9-3-1844 punt 12 en bijlage 17.

81 ANRI KBG Dir 0141, vergadering 9-3-1844, punt 12 en bijlage 17. 
De gouverneur-generaal, nog steeds genootschapsvoorzitter Merkus, wilde niet beslissen voordat hij inzicht had in de kosten van een dergelijke bestelling en kon overzien of het genootschap die kon dragen. ${ }^{82}$ Deze zouden, inclusief een nieuwe Stanhope drukpers, $f 3.380$ bedragen volgens een opgave van de Landsdrukkerij. Daarna rekende Van Hoëvell snel uit dat de bestelling alleen al uit de intekening op de Romo van Winter kon worden voldaan. Deze had namelijk in korte tijd 550 belangstellenden - 'Europische en inlansche' - opgeleverd, die allen voor vijftien gulden per exemplaar garant stonden. De net aangetreden gouverneur-generaal ad interim, jonkheer J.C. Reijnst, die de op 2 augustus 1844 overleden Merkus opvolgde, wilde toen de bestelling niet meer tegenhouden. Op 1 september 1844 kreeg het genootschap voor $f 3.380$ wissels én toestemming om in zes maandelijkse termijnen dit bedrag te voldoen, zodat de bestelling uit kon gaan. ${ }^{83}$ Oud-vice-voorzitter Van der Vinne werd benaderd om vanuit Den Haag toe te zien op een snelle aflevering. De firma Enschede kreeg de opdracht en de Delftse hoogleraar voor het Javaans Taco Roorda hield op verzoek van Van der Vinne toezicht op de goede uitvoering ervan. ${ }^{84}$ Van der Vinne rapporteerde in juli 1845 per brief dat aan de Javaanse en Maleise letters door de firma Enschede en Zonen uitstekend werk was verricht. Dit baseerde hij op een meegestuurde brief van Roorda. Wel was de bestelling $f 650$ duurder uitgevallen. Een letterproef werd ten bewijze meegestuurd. ${ }^{85}$ De voorzitter moest toegeven dat aan de terugbetaling van de wissels voor het eerdaags te verwachten drukmateriaal wegens gebrek aan geld niet kon worden voldaan. Na een omstandige toelichting luidde zijn advies aan zijn medebestuursleden: ontheffing vragen bij het gouvernement. ${ }^{86} \mathrm{Op} 11$ januari 1846 kwam de ontheffing, een goedgunstige beslissing van de nieuwe gouverneur-generaal, J.J. Rochussen, met wie Van Hoëvell, direct na zijn aankomst te Buitenzorg, was gaan kennismaken. In april 1846 stond al het nieuw aangekomen materiaal in de drukkerij opgesteld en kregen Van der Vinne en Roorda dankbrieven voor hun bemiddeling. ${ }^{87}$

Intussen was de gedachte om tekstedities in de Verhandelingen te drukken en die daarnaast ook los bij intekening aan te bieden een succes gebleken. De eerste intekening, Romo, leek meteen $f 8.000$ op te gaan leveren, al moesten de intekenaren nog wel betalen en tot 1847 wachten eer zij hun exemplaar

82 ANRI KBG Dir 0143, een afschrift van het gouvernementsbesluit 27-5-1844 nr 35 bij het verslag van de vergadering van 18-7-1844.

83 ANRI KBG Dir 0143, vergadering 22-10-1844, punt 1, en bijlage 1, een afschrift van gouvernementsbesluit 1-9-1844 $\mathrm{nr} 2$.

84 ANRI KBG Dir 0992, omslag november-december, nr 5, brief aan Van der Vinne, 7-11-1844.

85 ANRI KBG Dir 0147, vergadering 15-12-1845, punt 4f en bijlagen 3-6. Brief van Van der Vinne, 10-7-1845 met ingesloten brief van Taco Roorda, 17-4-1845.

86 ANRI KBG Dir 0147, vergadering 15-12-1845, voorstellen van de voorzitter.

87 ANRI KBG Dir, 0147-8, vergadering 23-4-1846 (niet in inventaris), punt 3a, h en k. 
in de hand konden houden. Gericke, door dit gunstige vooruitzicht op een gedachte gebracht, vroeg het genootschap op 4 oktober 1844 om op dezelfde wijze ook de intekening op de Wiwoho te bevorderen, waarvan naast de kwarto-editie in twee talen voor de Verhandelingen nog duizend exemplaren in folio van alleen het Javaans konden worden opgelegd, die hij zelf aan de man wilde brengen. Hij bepleitte het project door onder andere duidelijk te maken waarom voor de Javaanse lezers een boek op folio-formaat met een grote Javaanse letter nodig was.

Waarschijnlijk is $\mathrm{u}$ allen niet onbekend de gewoonte van den inlanders op Java om des avonds en soms een gedeelte van den nacht, bij den flaauwen schijne eener Dilah (lampje) op zijn matje te zitten motjo'n (zingende lezen). Zelden zal men de Javaan over dag zich daarmede bezig zien houden. ${ }^{88}$

De geschiedenis van de Wiwoho-uitgave is voor wat betreft de intekening op het werk in het archief goed te documenteren. Op 4 maart 1843 had secretaris Mijer op initiatief van Van Hoëvell een brief geschreven aan de javanici in Soerakarta met het verzoek om Javaanse handschriften voor uitgave in de Verhandelingen ter beschikking te stellen. Van de vijf aangeschreven personen, J.F.C. Gericke, C.F. Winter, J.A. Wilkens, D.L. Mounier en W.A. van der Ham, had alleen Gericke nog in dezelfde maand positief gereageerd. ${ }^{89}$ Drie maanden later deelde hij mee dat hij de Wiwoho had gekozen, waarvan hij een 'zuiveren en correcten tekst' had kunnen verkrijgen. ${ }^{90}$ Winter, die aanvankelijk afwijzend reageerde omdat de afschaffing van het Instituut voor de Javaansche Taal hem genoodzaakt had zijn ledige uren ten dienste van de Soesoehoenan te besteden, was toch gevraagd om een editie van de Romo te verzorgen, waarop ook hij op 8 juni 1843 positief reageerde. ${ }^{91}$ Enige onderlinge rivaliteit tussen Gericke en Winter zal aan die tweede reactie niet vreemd zijn geweest. Winter wilde bij Gericke niet achterblijven. Op 28 augustus 1843 stuurde Gericke een uitgebreide brief ten geleide van zijn vertaling en editie van de Javaanse tekst. ${ }^{92}$ Van Hoëvell sprak op zijn reis over Java in Soerakarta met Gericke en Winter en moest in december rapporteren dat het tussen hen niet boterde. Aan een gezamenlijke arbeid van die twee

88 ANRI KBG Dir 0143, vergadering 22-10-1844, punt 7 en bijlage 34. De verklaringen tussen haakjes in het citaat zijn van Gericke.

89 ANRI KBG Dir 0137, vergadering 27-5-1843, punt 4. Brief van Gericke, 25-3-1843, waarin hij belooft een handschrft te zullen kiezen en te vertalen met behulp van enkele bekwame Javanen die al in zijn dienst waren.

90 ANRI KBG Dir 0138, vergadering 20-7-1843, de brief van Gericke, 26-6-1843 als bijlage.

91 Brief van Winter dd 22-3-1843, als bijlage bij de vergadering van 27-5-1843, ANRI KBG Dir 0137.

92 ANRI KBG Dir 0139, vergadering 12-9-1843, punt 4, brief van Gericke bijgevoegd als bijlage 
geleerden viel niet te denken. ${ }^{93}$

In september 1843 was het gebruik van Javaans lood uit de Landsdrukkerij toegestaan, zodat het zetwerk kon beginnen. Aan het werk voor de Wiwoho was begonnen, terwijl het manuscript van de Romo in maart 1844 ook al binnen was. Van Hoëvell meldde in de bestuursvergadering dat met het drukken van de Romo moest worden gewacht, omdat het genootschap nog niet zelf over een Javaanse pers beschikte. ${ }^{94}$

Op voorstel van Gericke nu was in november 1844 de intekening op de aparte editie van de Wiwoho geopend. Terwijl voor de intekening op de Romo weinig bekend is, bevinden zich in het archief over 1845 wel de gegevens over die op de Wiwoho. Tussen februari en september 1845 kwamen dertien brieven binnen uit de verschillende residenties op Java met de betalingen die in het kasboek werden geregistreerd. Koploper was de resident van Soerakarta, die 81 exemplaren bestelde voor een bedrag van $f$ 486. Bij zijn brief van 1 juli 1845 kon hij een lijst voegen van de intekenaren, aangevoerd door de Soesoehoenan, aangeduid als 'Z.H. de Keizer' (voor twee exemplaren), gevolgd door 31 prinsen van het hof voor gezamenlijk zestig exemplaren en tenslotte enkele andere Javaanse heren van stand. Slechts vijf Nederlanders stonden vermeld op de intekenlijst. Aan dit hoge aantal zal niet weinig bijgedragen hebben, dat Gericke zelf in Soerakarta woonde. Mogelijk had hij voor zijn eigen boek gecolporteerd. Goede resultaten behaalde de intekening ook in Semarang (59), Banjoemas (61), Pasoeroean (48), Kadoe (31), Tegal (28), Bagelen (28) en Kedirie (28). Minder intekenaren waren te noteren uit de residenties Bantam (3) en Cheribon (3), die immers niet tot het Javaanse cultuurgebied behoorden. Het gouvernement was voorgesteld 100 exemplaren af te nemen, maar het beperkte de bestelling tot 50 stuks, bestemd voor de opleiding voor ambtenaren voor het binnenlands bestuur in Delft. ${ }^{95}$ Er werd bij elkaar op 469 exemplaren ingetekend voor een bedrag van $f 2.814 .{ }^{96}$ Op 10 februari 1845 kon Van Hoëvell, niet zonder trots aan de leden op de algemene vergadering het voltooide deel 20 van de Verhandelingen met de Wiwoho aanbieden.

Met deze tekstedities had het genootschap onder Van Hoëvells leiding een nieuw werkterrein aangeboord. Het is vooral Van Hoëvell zelf geweest die in zijn contacten met javanici in Soerakarta krachtig aan de uitvoering ervan heeft gewerkt. Zijn eerste verslag als vice-voorzitter voor de algemene

\footnotetext{
93 Verslag van Van Hoëvell tijdens de vergadering van 14-12-1843, punt 1, ANRI KBG Dir 0140 .

94 ANRI KBG Dir 0141, vergadering 9-3-1844.

95 ANRI KBG Dir 0993, omslag 1845, bevat een afschrift van het gouvernementsbesluit 20-3$1845 \mathrm{nr} 37$.

96 ANRI KBG Dir 1334, omslag 1845 voor de correspondentie, en ANRI KBG Dir 1333, kasboek 1845 voor de bedragen.
} 
vergadering, op 5 oktober 1843, waarin hij de Indische taal- en letterkunde als belangrijkste werkterrein van het genootschap voorop plaatste, is evenals de programmatische redevoeringen van Raffles een kleine dertig jaar eerder, een warm pleidooi voor concentratie op de studie van de talen en teksten van de archipel. Hij had zelf het voorbeeld gegeven met de editie van de Sjaïr Bidasari, die hij tijdens die vergadering gedrukt en wel kon aanbieden. Hij kon de tekstedities van Gericke en Winter aankondigen, maar hij kon deze nieuwe activiteit ook in een kader plaatsen van de studies die met William Jones in Calcutta waren begonnen. Waar aanvankelijk de taalstudie praktisch gericht was geweest, dat wil zeggen ten dienste van de handelsondernemingen, de zending en na 1843 ook voor de aanstaande ambtaren bij het binnenlands bestuur bij hun opleiding te Delft, kon Van Hoëvell in 1843 het wetenschappelijk perspectief schetsen, waarin de nieuwe activiteit van tekstedities en taalstudie moet worden gezien.

Zoo was het voor onze eeuw en onzen leeftijd weggelegd, om te streven naar eene volledige kennis van al de Indische talen en letteren, ten einde daardoor te onderzoeken, hoe de onderscheiden groote volkeren van Azië hun aandeel in de wereld-geschiedenis vervuld hebben. Wat het resultaat dezer pogingen zal wezen kan niet door ons beoordeeld worden; dat resultaat zal het deel zijn der nakomelingschap: en ook dan eerst zal deze groote onderneming door het publiek in al hare waarde geschat worden: dan eerst, wanneer groote gapingen, die thans nog in de kennis van het Oosten bestaan, zullen zijn aangevuld, en wanneer de resultaten der studie in de algemeene geschiedenis hunnen plaats hebben ingenomen, dan eerst zal men, in de beoefening der Indische talen, meer dan enkel practisch nut erkennen. (VBG 19:22-3)

Van Hoëvell sprak deze woorden op een moment dat het Instituut voor de Javaansche Taal, opgericht in 1832 net ter ziele was gegaan. In 1842 had minister van koloniën Baud, die het Instituut uit zijn Indische jaren goed kende, besloten tot de oprichting van de Koninklijke Academie te Delft, waar de opleiding van ambtenaren voor Indië ter hand zou worden genomen. Teleurstelling over dat wat het Instituut in Soerakarta had opgeleverd, speelde daarbij een belangrijke rol. De studie van het Javaans werd van Soerakarta naar Delft overgeplant (Fasseur 1993:55-76). Romo-editeur Winter was een van de getroffenen, want hij dreigde brodeloos te worden en in zijn brief aan het genootschap van 22 maart 1843 deed hij dan ook zijn beklag.

Het grieft mij zoo wel voor het vak der Javaansche taal en letteren, en voor de beoefenaars daarvan, als voor mij zelve, dat ik, door mijn ontslag als onderwijzer, onbevoegd verklaard ben, tot het geven van onderwijs in een taal, waarvan de leerstoel sedert eenige maanden van Soerakarta naar Delft is overgeplaatst. ${ }^{97}$

97 Brief van 22-3-1843 van Winter aan het genootschap in antwoord op een verzoek van Mijer. ANRI KBG Dir 0137, vergadering 27-5-1843, punt 4 en bijlagen 12-14. 
Van Hoëvell zelf, die zich inzette voor onderwijs in Indië en zich juist verzette tegen uitsluiting van personen die niet in Nederland waren opgeleid, zag door de sluiting van het instituut ook de toelevering van Javaanse tekstedities en vertalingen in het gedrang komen. Hij had geen belang bij de Delftse stichting. Winter zou in 1844 zijn tractement weer terugkrijgen om met Wilkens samen voort te werken aan het Javaanse woordenboek.

Het feit dat van 1843 tot 1848 in de drukkerij onder Van Hoëvells toeziend oog aan de uitgave van vier belangrijke teksten, in verschillende edities, werd gewerkt, bewijst dat het niet bij een beleidsvoornemen bleef en dat de sluiting in Soerakarta geen onoverkomelijke gevolgen had voor zijn plannen. Met de systematische aandacht voor teksten en talen was een nieuwe fase in de genootschapsgeschiedenis ingeslagen. Wat Raffles al als hoogstnoodzakelijk had aangekondigd, en waar hij zelf ten dele uitvoering aan had gegeven, getuige zijn History of Java, werd nu in genootschapskring werkelijkheid. Van Hoëvell was in dat proces niet alleen initiator, maar ook uitvoerder, stimulator, terwijl hij door zijn toespraken tot de algemene vergadering kon laten zien dat hij als taalkundige en filoloog onderlegd was. Een overzicht van de uitgevoerde edities laat dat zien. Niet toevallig vallen de jaren van uitgave samen met die van Van Hoëvells vice-voorzitterschap en voorzitterschap.

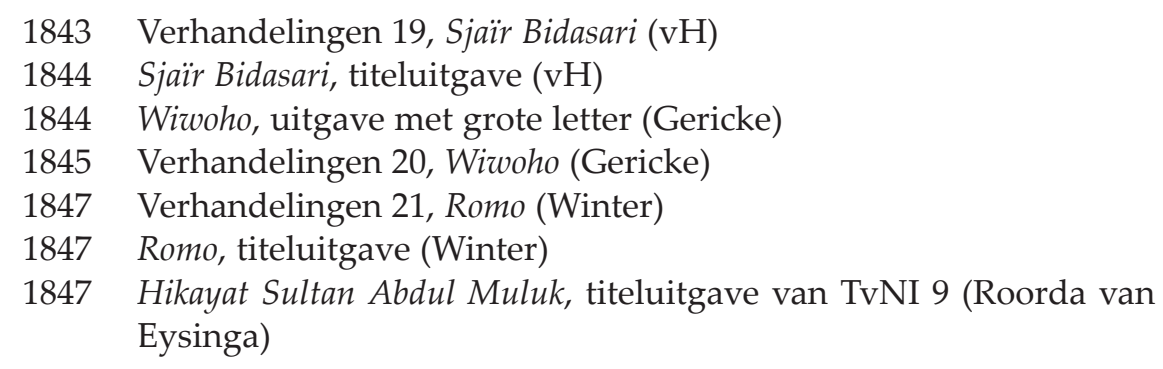

Tegelijkertijd gebruikte Van Hoëvell ook zijn eigen forum, het Tijdschrift voor Neêrland's Indië, voor publicaties van C.F Winter en J.A. Winter, Wilkens en Mounier, P.P. Roorda van Eysinga en R. Friederich en van hemzelf over wetenschappelijk werk van de Duitse taalkundigen Von Schlegel en Lassen, over het Javaans, het Maleis en het Sanskriet, om uitwerking te geven aan zijn programma, studie van de Indische talen ter vergroting van de kennis van het Oosten. Zal Van Hoëvell ingestemd hebben met de samenstelling van deel 22 van de Verhandelingen, het eerste na zijn vertrek, dat grotendeels aan de ichtyologische studies van Bleeker gewijd was? Wel vond in het deel daarna (23, 1850) een uitgave van de Ardjoeno-Wiwoho van editeur Friederich een plaats, waarmee duidelijk werd dat tekstedities hun belang bleven houden. 


\section{Van Hoëvell president}

Terwijl de drukkerij op volle toeren draaide, het museum zich uitbreidde door de zendingen oudheden uit Midden-Java en de verscheping van de zoölogische verzameling naar Leiden werd voorbereid, verliep de overgang van een museum voor natuurlijke historie naar een gecombineerd oudheidkundig museum met een etnologische afdeling en een restant aan schelpen en mineralen niet zonder schokken. Conservator Overdijk, tevens assistent van de Natuurkundige Commissie, zag zich van zijn inkomen van tweehonderd gulden per maand beroofd, en schoffeerde Van Hoëvell tijdens een bezoek van de laatste aan het museum op 15 januari 1844. De vice-voorzitter had hem voorgehouden dat zijn conservatorswerk ten einde liep en dat hij zijn tractement alleen nog uit 'kassian' (medelijden) ontving. Daarop was Van Hoëvell door de woedende conservator 'niet alleen op verregaande wijze gebrutaliseerd, maar letterlijk uitgescholden', aldus het slachtoffer aan secretaris Mijer. ${ }^{98}$ Overdijk had gedreigd alle vogels van hun etiketten te beroven en toen bibliothecaris Bleeker later die dag in het museum kwam, bleken de 'jongens', de inheemse jagers en helpers, van de conservator opdracht te hebben gekregen de etiketten metterdaad te verwijderen. Bleeker voorzag dat dit de waarde van de vogels bij de aankomende vendutie danig zou verminderen. Hij had Overdijks opdracht daarop weer ongedaan proberen te maken en Van Hoëvell had de boosdoener onmiddellijk geschorst. Drie dagen later bleek de schade toch te zijn toegebracht. Overdijk bleef geschorst, kreeg nog drie maanden zijn halve tractement, terwijl Bleeker het toezicht op het museum erbij ging doen. Daarvoor kreeg hij de andere helft van het conservatorstractement. Van Hoëvell stelde voorzitter Merkus op de hoogte en vroeg hem Overdijk ‘bij voorkomende gelegenheid in eene voor hem geschikte landsbediening te plaatsen' ${ }^{99}$

In maart 1844 klaagde secretaris Mijer over de zwaarte van zijn functie en vroeg ontheffing aan, al wilde hij wel in het bestuur blijven zitten. Het secretariaat was een zware post geworden onder de twee actieve vice-voorzitters Van der Vinne en Van Hoëvell. Vanaf 1 maart 1842 had Mijer er een bezoldiging voor gekregen van tweehonderdvijftig gulden per maand, omdat er nogal wat werk aan de post verbonden was. ${ }^{100}$ Van Hoëvell zag Mijer niet graag gaan en bood aan om het tijdrovende corrigeren van de drukproeven van hem over te nemen. Ook bood hij aan toezicht te houden op de drukkerij,

98 Op 18-1-1844 werd ten huize van Van Hoëvell aan deze zaak een buitengewone vergadering gewijd. ANRI KBG Dir 0140 verslag van deze bijzondere vergadering (niet in inventaris, te vinden achter Dir 0140). Brief van Van Hoëvell aan Mijer, 15-1-1844, bijlage 42 bij het verslag. Brief van Bleeker aan Van Hoëvell van dezelfde dag, bijlage 41.

99 Verslag van de vergadering 18-1-1844 achter ANRI KBG Dir 0140.

100 ANRI KBG Dir 1334, omslag 1842, brief van Mijer, 14-3-1842 aan de thesaurier. 
wat hij - voegde hij er aan toe - eigenlijk al deed. Zijn eigen tijdschrift werd er immers gedrukt. Bleeker zou dan bibliothecaris blijven met toezicht op het museum en het etnologisch kabinet. Zo werd op 9 maart 1844 besloten. Bleeker bevestigde dit ook nog eens in een briefje van 5 april 1844 over zijn werkzaamheden als bibliothecaris: het toezicht op de drukkerij zou tot Van Hoëvells werkzaamheden behoren. ${ }^{101}$ Deze nieuwe werkverdeling was, in de woorden van Van Hoëvell zelf, geen grote verandering, hooguit een verlichting voor Mijer en verzwaring voor de bibliothecaris en de vice-president. Het genootschap werd in deze periode door dit drietal, Van Hoëvell-BleekerMijer, geleid, waarbij de primus zich in principe met alles bemoeide. Bleeker, gevraagd om onderwerpen voor de directievergadering van 9 maart 1844, klaagde bij de vice-voorzitter:

De ratten zijn in het Museum bijzonder talrijk en verlekkerd op de pooten der grootere vogels. Dagelijks wegsluiten der vogels [in kasten] en goede vallen, zullen dit inconvenient verhelpen. Ik herinner mij op dit moment niets, wat van belang is, in de vergadering te brengen. ${ }^{102}$

Hieruit blijkt dat Van Hoëvell tevoren nog wel met Bleeker overlegde over vergaderpunten. Bleekers eigen studieterrein, dat van de ichtyologie, viel nu juist onder de afgestoten zoölogische afdeling. De bovenaangehaalde brief aan Van Hoëvell was Bleeker begonnen met de woorden: 'volgens afspraak, deze [brief] tot schriftelijke herinnering aan mijn verzoek om een teekenaar voor mijn visschen'. Blijkbaar had Van Hoëvell Bleeker te veel nodig dan dat diens vissen met de zoölogische afdeling mede geheel het veld moesten ruimen. Besloten werd de lithografische afdeling van de genie maandelijks honderd gulden te betalen voor de werkzaamheden die zij voor de Verhandelingen zou verrichten. Zo werd kennelijk ook aan het verzoek van Bleeker voldaan, wiens vissenstudies in deel 21 (1846-1847) voor het eerst vertegenwoordigd zouden zijn. Overigens zouden de vogels nog in 1844 uit het museum verdwijnen. Het gouvernement betaalde $f 1.500$ voor het inpakken van de zoölogische verzameling voor Leiden. Wat niet voor Leiden was bestemd werd in februari en juni 1844 op twee verschillende venduties verkocht. Het bracht $f 180,48$ en $f 1.387,48$ op. Er was aldus ruimte geschapen voor het oudheidkundig kabinet, terwijl het geld goed van pas kwam, want de uitgaven stegen gestaag. ${ }^{103}$ Het etnologisch kabinet werd verplaatst van het genootschapsge-

101 ANRI KBG Dir 0141, vergadering 9-3-1844, punt 18. Ook Dir 0142, vergadering 18-7-1844, bijlage 23 .

102 Brief van Bleeker aan Van Hoëvell, 7 maart 1844. ANRI KBG Dir 0141, vergadering 9-3-1844, bijlage 18 .

103 ANRI KBG Dir 1334, omslag 1844 voor de correspondentie, en Dir 1333 voor de kasgegevens van 1844 . 
bouw in de Rijswijkstraat naar het museum, waar de ruimte aldus meteen weer werd gebruikt (VBG 20:37).

Van Hoëvells belangstelling lag bij de taalstudie en de oudheden. Zelfs de etnologie had al minder zijn aandacht. Daar paste Bleeker op. Eigenzinnig was hij in ieder geval in de zaak van het afstoten van de gamelan van de sultan van Bantam en een deel van de kostbaarheden uit diens collectie. Die gamelan was groot en stond volgens Van Hoëvell in de weg. Hij had eind 1843 met Merkus over de zaak gesproken, die volgens Van Hoëvell zelf geen bezwaar had tegen afstoting. Korte tijd later bleek echter dat de Algemene Secretarie er wel degelijk bezwaren tegen had, waarop Van Hoëvell er nogmaals met de gouverneur-generaal over had gesproken. De rest van het bestuur vond echter dat op de afstoting van die Bantamse voorwerpen niet moest worden aangedrongen. ${ }^{104}$ In deze zaak bleek Van Hoëvell helemaal op zijn eigen kompas te varen. Dat hij de Bantamse collectie, waartoe ook de handschriften behoorden, die wel degelijk zijn aandacht kregen, niet als één geheel zag en bereid was deze uiteen te laten vallen, getuigde niet van veel historisch besef. Mogelijk overheersten bij Van Hoëvell in dit geval praktische, misschien ook wel financiële overwegingen. Met de afstoting van de gamelan zou plaats vrij zijn gekomen. Bovendien zouden de kostbaarheden geld opbrengen, dat voor andere zaken kon worden gebruikt.

In 1844 werd het genootschap getroffen door de dood van voorzitter Merkus, juist toen men midden in de bestelling van drukpers en drukletters gewikkeld was. Waarnemend gouverneur-generaal Reijnst kreeg het voorzitterschap van het genootschap aangeboden, maar daar voelde deze niet voor. Daarmee kwam een einde aan de door Van Hoëvell in 1843 nog als uniek bestempelde situatie dat de gouverneur-generaal tegelijk voorzitter van het genootschap was. Tijdens de eerste eropvolgende bestuursvergadering, op 22 oktober 1844, kwam het wegvallen van de voorzitter niet ter sprake. Pas op op de eerste vergadering in 1845, op 14 januari, stelde het oudste bestuurslid, generaal Cochius, de vacante voorzittersplaats aan de orde. Hij stelde daarop voor dat Van Hoëvell zelf de nieuwe voorzitter zou worden. Het bestuur stemde daarmee in en Van Hoëvell liet zich niet lang bidden. Het vice-voorzitterschap werd afgeschaft, hetgeen bij alle toegenomen werkzaamheden van het bestuur opmerkelijk mag heten. ${ }^{105}$ Niemand had bezwaren en dus

104 Brief van Van Hoëvell aan Mijer, 21-12-1843, waarin deze zegt dat Merkus niets tegen de verkoop van de gamelan en de kostbaarheden had. ANRI KBG Dir 0140, bijlage 43 achter verslag vergadering 18-1-1844 (na Dir 0140). Bij de vergadering 9-3-1844 lag een brief van de Algemene Secretarie op tafel waarin het plan voor de verkoop werd afgekeurd. Het genootschap zou moeten onderzoeken of er een museum in Nederland belangstelling voor had. ANRI KBG Dir 0141, vergadering 9-3-1844, punt 2.

105 ANRI KBG Dir 0144, vergadering 14-1-1845, $\mathrm{nr}$ 8, onder welk punt de opvolging voor het eerst ter sprake komt. In de resolutie van de vergadering18-10-1844 (ABG 196) komt het overlij- 
verdween de functie, waaraan Van der Vinne en Van Hoëvell zo goed vorm hadden gegeven. De laatste had vanaf dat moment de leiding. Reijnst werd beschermheer.

\section{Gebouwen}

De groeiende collectie oudheden en de verplaatsing van de etnografica naar het museumgebouw hadden het aanzicht van de museale collectie aanzienlijk veranderd. Tijdens zijn al genoemde verslag aan de algemene vergadering op 4 februari 1845, zijn eerste als voorzitter, kon Van Hoëvell melden dat er naast de drieënveertig oudheidkundige aanwinsten ook etnografica waren binnengekomen. Hij meldde de verwerving van beelden van Bali, wapens van het gouvernement verkregen en een collectie van dertig voorwerpen van de Dajaks. ${ }^{106}$ Bleeker schreef op 13 januari 1845 over het ruimtegebrek in het museum op Rijswijk. Een deel van de mineralen en schelpen was in het genootschapsgebouw in de Rijswijkstraat opgesteld en wel in de vergaderzaal van het genootschap. Daarvan was al eerder een deel voor de bibliotheek afgeschermd, terwijl een deel van het museum eigenlijk moest worden ingeruimd voor de mineralen die Junghuhn, Bleeker zelf en de apotheker bij het Indische leger P.J. Maier aan het genootschap hadden geschonken.

Ik heb reeds de vroegere Vogelzaal van het Museum, in overeenstemming met de heer Van Hoëvell, te dien einde ingerigt, en ook met de overplaatsing der mineralien reeds een begin gemaakt. Ik houd mij tevens onledig met het determineren der nog onbenoemde exemplaren, waarvan ik reeds een catalogus opmaak.

Bleekers suggestie voor de ruimtenood was om het museumgebouw met een vleugel uit te breiden en daarvoor een paar 'onzindelijke bijgebouwen' van de Harmonie af te laten breken. ${ }^{107}$

In april 1845 werd echter een radicaler voorstel gedaan. In plaats van een nieuw aan te bouwen vleugel werd gewezen op een vrijkomend huis met bijgebouwen, dat grensde aan het museumgebouw op Rijswijk en dat de eigenaar, F.H.C. van Motman, wel van de hand wilde doen. Het gebouw was vrij groot en de vraagprijs hoog. Door een muur door te breken zou het met het museumgebouw verbonden kunnen worden en dan zou het genootschap alle andere gebouwen die het op het Harmonie-terrein bezette, kunnen

den van Merkus niet ter sprake.

106 VBG 20:23-31, 37. Het impressum van dit deel zegt 1844, maar pas in 1845 verspreid, verslag door Van Hoëvell van 4-2-1845.

107 ANRI KBG Dir 0144, vergadering 14-1-1845, punt 5.10, bijlage 18 is de brief van Bleeker, 13-1-1845. 
opgeven. Listig ging het voor het gouvernement bedoelde conceptvoorstel over de mogelijke aanschaf in op de ruimtenood van sommige gouvernementscolleges die dan eindelijk betere huisvesting zouden kunnen krijgen in de gebouwen die het genootschap zou vrijmaken. Tenslotte kwam de aap uit de mouw: het gouvernement zou

zich de tegenwoordige localen van het Genootschap in geval van ontruiming, [...] wenschen toeteeigenen en tegen eene bepaalde som van hetzelve [het genootschap] overtenemen, welke som de Directie zou kunnen doen strekken tot gedeeltelijke afbetaling van den koopschat der woning van den Heer Van Motman, die op ca $f 25.000$ geraamd wordt.

Om het gouvernement nog extra onder druk te zetten werd verwezen naar een subsidie van $f 10.000$ die de Bataviaasche Schouwburg onlangs had ontvangen. ${ }^{108}$

Het is de vraag of het voorstel de regering ooit heeft bereikt. Het ongehoorde ervan was dat het gouvernement van het genootschap gebouwen zou aankopen die door de overheid waren neergezet en betaald en vervolgens ter beschikking van het genootschap waren gesteld, soms nog weer eens op kosten van de overheid waren verbouwd. Speculeerde de opsteller erop dat de status van de gebouwen onduidelijk was? Bestuurslid Tromp kende door zijn lange staat van dienst de status van de gebouwen. Hoe dan ook, in de verslagen van vergaderingen na april 1845 vinden we er geen verwijzingen naar, evenmin in de correspondentie. Wel stelde Van Hoëvell in september voor om een vaag omschreven deel van de 'naturalien, zoo als schelpen, zeegewassen en andere welke weinig wetenschappelijke waarde hebben, alsmede eenige physische instrumenten, welke defect en irreparabel zijn' te verkopen. ${ }^{109}$ Dit was in 1845 een tweede poging om ruimte te scheppen en om de in 1843 ingezette trend te vervolgen: geen museum voor natuur-historie, maar wel voor oudheden en etnologie. Daarnaast kon de bibliotheek met boeken over de archipel als studiecentrum voor de talen en voor bestudering van handschriften dienen.

Net als in het geval van de collectie van Bantam bleek, dat Van Hoëvell ook wel eens bakzeil moest halen. Het moment werd niet gunstig geacht voor het indienen van een voorstel tot een dure aankoop van gebouw voor het genootschap. En ongunstig was het moment, want in mei 1845 konden de wissels voor de aanschaf van drukpers en het Javaanse en Maleise lood, dat nog niet eens was aangekomen, niet aan de directeur-generaal van Financiën worden

108 ABG 198, vergadering 14-1-1845, bijlage 34, echter gedagtekend april 1845. Het concept is door Van Hoëvell goedgekeurd.

109 ANRI KBG Dir 0146, vergadering 24-9-1845. 
betaald en moest uitstel worden gevraagd. ${ }^{110}$ Verder diende opziener Chun een rekening in van $f 3600$ voor de druk van deel 19 van de Verhandelingen en voor de kosten gemaakt voor het inrichten van de drukkerij. Ook die rekening kon niet worden voldaan, al beloofde het genootschap dat wel te zullen doen voor eind mei 1846. Chun zou dus nog een jaar moeten wachten. ${ }^{111}$

Gelukkig leek een ander project wel te gaan lukken: in 1845 verzocht het genootschap het gouvernement om sergeant Rudolph Friederich, die in Bonn en Berlijn oosterse talen had gestudeerd maar die op het militaire depot werk onder zijn niveau deed, te mogen aanstellen. Over zijn merkwaardig curriculum komen we nog te spreken. Hij zou de catalogus van de 346 oosterse handschriften afmaken waaraan eerst door een inheemse arabist, vervolgens door Van der Vlis en daarna door W.C.H. Toewater was gewerkt. Friederich verhuisde van het depot naar de Rijswijkstraat. ${ }^{112}$ Eigener beweging had hij zich bij Van Hoëvell gemeld en die had ogenblikkelijk actie ondernomen, na overleg met Cochius. Pas in 1851 echter meldde Friederich bij Van Hoëvells opvolger, Buddingh, dat de catalogus klaar was. Voor het oponthoud was echter eerder Friederichs langdurige afwezigheid verantwoordelijk. In opdracht van het genootschap en gesteund door het gouvernement ging hij in 1846 mee met de militaire expeditie naar Bali om taalkundig, oudheidkundig en volkenkundig onderzoek te doen. ${ }^{113}$

De drukkerij stond er toen goed voor. Met het nieuwe drukmateriaal - de Stanhope-pers en de Javaanse en Maleise drukletters - had deze onderneming zich geheel onafhankelijk gemaakt van de Landsdrukkerij. Het drukkersbedrijf kon zich uitbreiden door meer werk aan te nemen en meer personeel aan het werk te houden. In het jaar 1846 verschenen negentien verschillende uitgaven, waaronder drie tijdschriften. De eerste gedrukte systematische catalogus van de genootschapsbibliotheek kwam uit in dat jaar, maar ook de Desiderata van het genootschap, die een programma vormden van wat het nog in de zin had. Voor C.F. Winters teksteditie van de Romo kon het genootschap vol trots de nieuw verworven letterkasten gebruiken, evenals voor de beschrijving van de Javaanse oudheden in het museum. Daarnaast was er ander drukwerk voor Van Hoëvell, 'zijn' bijbelgenootschap en weeshuis, twee van zijn kerkelijke redevoeringen, naast werk van collega Buddingh, een studie over Batakse cultuur door T.J. Willer en een bundel gedichtjes voor de

\footnotetext{
110 Dat uitstel werd verleend bij gouvernementsbesluit 12-6-1845 nr 37, ANRI KBG Dir 1510, omslag 1845.

111 ANRI KBG Dir 0145, vergadering 20-5-1845, punt 2 en 3, bijlagen 1-4.

112 Gouvernementsbesluit 9-7-1845, nr 37. Afschrift in ANRI KBG Dir 1510, omslag 1845.

113 Gouvernementsbesluit 28-2-1846, waarvan een afschrift in ANRI KBG Dir 1510, omslag 1846. Het genootschap kreeg ten behoeve van Friederich van het gouvernement $f 400$ voor de voorbereidingen en $f 50$ per maand als toelage.
} 
Oost-Indische jeugd. Kortom een zeer grote variatie aan drukwerk. De drukkerij gaf als het ware een visitekaartje af voor de jaren die kwamen.

\section{De relatie met de overheid: het conflict}

In september 1845 was er een nieuwe gouverneur-generaal, Rochussen, aangetreden, onder wiens ogen het conflict tussen de algemeen secretaris en Van Hoëvell zich zou afspelen. Rochussen was minister van financiën geweest en zou het muntwezen in de kolonie reorganiseren en tevens de blik op de buitengewesten richten. Diezelfde maand nog was een commissie benoemd die hem het beschermheerschap ging aanbieden. In december 1845 meldde Van Hoëvell dat hij samen met secretaris De Geer bij Rochussen was geweest. Er zou gezocht worden naar een gelegenheid om in een plechtige zitting het beschermheerschap officieel aan te bieden. Dat gebeurde in de algemene vergadering van 14 januari 1846. ${ }^{114}$ Rochussen was overigens de laatste beschermheer in de negentiende eeuw die vergaderingen van het genootschap bijwoonde. Pas in de twintigste eeuw zou jhr. A.C.D. de Graeff dat opnieuw doen. ${ }^{115}$ Juist in het eerste jaar van Rochussens beschermheerschap kwam de drukkerij tot volle ontwikkeling. Hij gaf van vertrouwen in de zaak blijk door het genootschap de schulden kwijt te schelden, die het gemaakt had voor de aanschaf van Javaans en Maleis lood en voor een nieuwe drukpers. Dat gaf het genootschap de mogelijkheid om energiek door te werken aan de uitgave van tekstedities.

Aan het eind van het succesjaar 1846 zorgde Visscher voor opschudding die het einde van de drukkerij zou inleiden. In maart 1842 had hij zijn secretarisplaats bij het genootschap opgegeven, omdat zijn werk het praktisch onmogelijk maakte de vergaderingen bij te wonen. Hij bleef echter wel bestuurslid. Van Hoëvell leerde Visscher beter kennen als algemeen secretaris, rechterhand van de gouverneur-generaal en van de Raad van Indië en hoofd van het ambtelijk apparaat in Buitenzorg. In Van Hoëvells geschiedenis van de opkomst en ondergang van de Indische jaargangen van zijn Tijdschrift, waarmee hij de eerste Nederlandse jaargang in 1849 opende, zwaaide hij grote lof toe aan Visschers voorganger, jhr. J.P. Cornets de Groot, maar voor hem zelf had redacteur Van Hoëvell alleen maar bittere woorden (Van Hoëvell 1849: 10-1). De moeilijkheden stonden los van het Bataviaasch Genootschap. Ze betroffen Van Hoëvell als redacteur van zijn eigen tijdschrift.

114 ANRI KBG Dir. 146, vergadering 24-9-1845, Dir. 147, vergadering 15-12-1845 en na Dir. 147, vergadering 14-1-1846.

115 Voorzitter J. van Kan in zijn toespraak tot de nieuwe beschermheer, jonkheer B.C. de Jonge op 27-8-1932, Jaarboek 1:169-70. 
Ze waren in de kern een probleem van de in de kolonie hoogstens oogluikend gedoogde vrijheid van drukpers. Materieel gezien was er natuurlijk wel een band, want Van Hoëvells tijdschrift werd sinds 1844 gedrukt op de pers in het genootschapsgebouw, die draaide onder de verantwoordelijkheid van het bestuur. De vrijheid van handelen van de tijdschriftredacteur Van Hoëvell en de perikelen bij de drukkerij lagen daardoor in elkaars verlengde. Van Hoëvell en geen ander binnen het bestuur was het hoofd van de drukkerij en dus verantwoordelijk voor de ruime uitleg die gegeven was aan het gouvernementsbesluit over die drukkerij.

Voor het Tijdschrift was het eigenlijk van het begin af aan een wonder dat de drie redacteuren eerst twee, later vier delen per jaar konden doen uitkomen. Voor de kolonie was zo'n tijdschrift in 1838 volslagen nieuw. Het gouvernement werkte mee door toestemming te geven, door de Landsdrukkerij in te schakelen en een aantrekkelijk tarief te bieden. Steeds was duidelijk gemaakt dat het schrijven over politiek ('Gouvernements en persoonlijke aangelegenheden') taboe was. Van Hoëvell had behoefte aan een goede relatie met het gouvernement, omdat daar berichten over de archipel binnenkwamen, vaak rapporten en verslagen van ambtenaren die in opdracht waren geschreven met informatie die de redactie kon gebruiken. De Algemene Secretarie, waar die stukken samenkwamen, beschikte over het grootste archief en was de bron waaruit de redactie van tijd tot tijd wilde putten. Bij twijfel over geschiktheid voor publicatie zou de redactie de algemeen secretaris raadplegen. Toen de redactie in 1844 - in navolging van een tweede periodiek ( De Kopiïst, vanaf 1844 het Indisch Magazijn) - aankondigde zich ook met politiek ('staatkunde') te gaan bezighouden, greep algemeen secretaris Visscher in. E. de Waal, redacteur van De Kopiïst en later zelf minister van koloniën, was toen werkzaam bij de Algemene Secretarie. De Waal werd kennelijk meer vertrouwd dan een buitenstaander als Van Hoëvell.

Er ontspon zich een briefwisseling tussen de algemeen secretaris en Van Hoëvell die zich met onderbrekingen tot 1848 zou voortslepen. Weliswaar had de redactie in 1844 een zekere vrijheid gekregen om meer stukken met wetenschappelijke strekking te publiceren (alles uiteraard omkleed met voorwaarden), maar hoe dood deze mus was, bleek al in 1845 toen enkele passages in een artikel van Junghuhn over Javaanse prinsen het ongenoegen van het gouvernement opwekten. Kwam Van Hoëvell er toen nog met een reprimande van af, in 1847 hield de algemeen secretaris twee afleveringen van het Tijdschrift tegen omdat er geen duidelijke toestemming bleek voor publicatie van een artikel over Lombok van de regeringsambtenaar H. Zollinger. Omdat Van Hoëvell op dat moment op reis was stokte de uitgave van het tijdschrift. Van Hoëvell maakte zich zorgen over zijn abonnees en vervolgens werd de correspondentie met het gouvernement meer persoonlijk van toon en bitter.

De zich uitbreidende drukkersactiviteiten van het genootschap deden juist 
Visscher eind 1846 in de pen klimmen met het verzoek aan het genootschap uit de doeken te doen op grond van welk gouvernementsbesluit het over was gegaan tot het drukken van 'boeken, werken en brochures van omvang' die in de Javasche Courant aangekondigd waren. ${ }^{116}$ Het had ook moeilijk onopgemerkt kunnen blijven dat de drukkerij naast de sinds mei 1843 toegestane 'manifesten, rekeningen, catalogussen en dergelijke', nog heel wat anders drukte dan de Verhandelingen. Het wonderlijke was wel dat Visscher pas eind 1846 ingreep, terwijl de genootschapspers een jaar eerder al volop draaide. Van Hoëvell antwoordde op 18 december 1846 in een uitgebreide brief. De directie

meende, door het dienstbaar maken van de drukkerij des Genootschaps aan de verspreiding van nutte kennis en wetenschap in 't Algemeen, aan hare hooge roeping te beantwoorden en geheel te handelen in den geest van het Gouvernement, en nu ziet zij eenklaps [...] dat zij zich op een verboden en in 't oog der Regering ongeoorloofd terrein bevindt.

Over het aan het genootschap toegestane drukken van 'manifesten, rekeningen, catalogussen en dergelijke' zegt hij: 'Toen nu in de laatste jaren echter bij de ingezetenen de lust en behoefte ontstond, om stukken van wetenschappelijken inhoud te laten drukken, heeft de Directie gemeend, dat deze onder het woord "dergelijken" moesten begrepen worden'. Tenslotte zei Van Hoëvell, dat voor werk van grotere omvang altijd apart toestemming was gevraagd en dat ander werk weer voor goede doelen had gediend. Listig voerde hij erbij aan dat de regering het genootschap had gesterkt in de gedachte dat het op de goede weg was, door zelf op bepaalde uitgaven in te tekenen: 'Zoo teekende nu wijlen Z.E. Mr P. Merkus voor tien exemplaren in op de nagelaten Leerredenen van Dr. Toewater' ${ }^{117}$

Het gouvernement was niet onder de indruk van de opgegeven verklaring en op 29 januari 1847 kwam het besluit waarin de beperkingen van 1843 werden herhaald en de ruime interpretatie die eraan was gegeven werd afgekeurd. In het vervolg moest voor alles wat groter was dan een manifest, rekening, en dergelijke toestemming worden gevraagd aan de Algemene Secretarie. ${ }^{118}$ Hiermee had Visscher Van Hoëvell in een dubbele houdgreep: voor het voortbestaan van zijn tijdschrift en zijn drukkerij was hij afhankelijk van de algemeen secretaris.

116 Brief van algemeen secretaris Visscher aan directie van het genootschap 12 december 1846. ANRI KBG Dir 0152-7 bevat in zes aparte omslagen de correspondentie over 1847. De brief van Visscher in Dir 0157, nr 1.

117 ANRI KBG Dir 0157, nr 2, conceptantwoord dd 18-12-1846 van de besturende leden van het genootschap aan de gouverneur-generaal in Van Hoëvells hand, 13 pagina's.

118 Gouvernementsbesluit geciteerd in VBG 21, I:104-11. Afschrift in ANRI KBG Dir 1551, omslag 1847. 
In de eerste bestuursvergadering na deze briefwisseling, pas op 22 april 1847, werd het beperkende gouvernementsbesluit gesignaleerd, maar niet besproken, althans niet in het verslag vermeld. Dat wekt op zijn minst verwondering, want het was een ingrijpende verandering voor de drukkerij, waar onder meer financiële consequenties aan verbonden waren. ${ }^{119}$ Wel was er in februari meteen een briefje naar beschermheer Rochussen gegaan om hem een exemplaar van Buddinghs Twaalftal Kerkelijke Reden aan te bieden, dat al ter perse was toen de regering de beperkingen afkondigde. ${ }^{120}$ Tijdens de algemene vergadering van 8 mei 1847 werd het drukkerijprobleem gesignaleerd, maar er werd geen oplossing gevonden. Het uitgebreide verslag van die datum ging wel in op allerlei andere gebeurtenissen die van belang waren: de geringe respons die de leden hadden gegeven op de in 1846 rondgezonden Desiderata van het genootschap, de aanwinsten van de oudheidkundige en geologische kabinetten van het museum, de uitbreiding van de bibliotheek en de moeilijkheden ondervonden bij het catalogiseren van de etnografica. Verder besteedde Van Hoëvell veel aandacht aan de wetenschappelijke zending van Friederich naar Bali en aan de vele publicaties van natuurkundigen in de tijdschriften, waarmee hij vergoelijkte dat de Verhandelingen hierin geen rol speelden. Misschien moeten we in de combinatie van het uitvoerige verslag met het zonder commentaar opnemen van het gouvernementsbesluit van 29 januari 1847, een poging zien om via de leden met het gouvernement te polemiseren: de enige wetenschappelijke organisatie van Nederlands-Indië werd juist in een bloeiperiode beknot in haar activiteiten door het functioneren van haar drukkerij te bemoeilijken (VBG 21, I:104-11).

In de verslagen van de algemene vergaderingen van de jaren 1843, 1845 en 1846 was Van Hoëvell helemaal voorbijgegaan aan de beperkingen die aan de drukpers waren opgelegd. Hij had juist de mogelijkheden die er waren ontstaan voor een efficiëntere uitgave van de Verhandelingen en andere genootschapspublicaties besproken, met name ook door de aanschaf van eigen zetsel uit Nederland voor de uitgaven in de inheemse talen. Aan de vrijheid van drukken van andere uitgaven, ging hij wijselijk voorbij. Er waren echter geen argusogen voor nodig om te zien dat Van Hoëvell de beperkingen negeerde. De hoeveelheid drukwerk en de aankondigingen ervan in de Javasche Courant maakten het zeer zichtbaar. Omdat er al enkele jaren met succes was gedrukt hoopte Van Hoëvell op publieke instemming. Vandaar dat hij het gouvernementsbesluit in zijn geheel publiceerde. Commentaar op het besluit zou overigens sommige van zijn medebestuursleden in het harnas hebben gejaagd. 
Had Van Hoëvell, toen hij op 12 mei 1847 vertrok voor een grote reis over Java en Madoera, die hem een paar maanden van Batavia weg zou houden, een voorgevoel van wat er kon gebeuren? Had hij de hoop dat hij met zijn verslag en de openbaarmaking van het gouvernementsbesluit in de Verhandelingen de publieke opinie voor zich kon innemen? Dacht hij dat de zaak zich tijdens zijn afwezigheid ten goede zou keren? Hij had kopij voor het tijdschrift achtergelaten met instructies voor de proeflezers. Hij zal zeker met de opziener van de drukkerij afspraken hebben gemaakt. Snel zou blijken dat hij het bestuur te weinig bij de drukkerijzaken had betrokken. Wel ging het bestuurswerk op reis gewoon door. Van Hoëvell stuurde uit Cheribon op 22 mei een aantal getekende brieven terug aan de nieuwe secretaris Bleeker en drong er bij hem op aan dikwijls te schrijven om hem, de afwezige voorzitter, op de hoogte te houden. Een vervanging voor het voorzitterschap tijdens zijn afwezigheid was kennelijk niet aan de orde geweest. Hij had in Bandoeng een

allerinteressantst uitstapje gemaakt naar de Negara-wanggie, in het gebergte van Toenggoel, ten einde de door Junghuhn gevonden oudheden te zien. Overigens heb ik mij nog alleen met kerkelijke en godsdienstige aangelegenheden kunnen bezighouden. ${ }^{121}$

Een paar dagen later, op 2 juni 1847, sloeg op last van de regering de resident van Batavia, P. van Rees, toe. Hij vroeg in een brief aan het bestuur van het genootschap of de bewering van boekverkopers Lange \& Co juist was, dat de brochure Chronique théatrale was gedrukt op de pers van het genootschap, terwijl er op gedrukt stond: Imprimérie de Lange et Cie. Hetzelfde wilde hij weten van een gedicht van W.L. Ritter en van een verzameling Maleise samenspraken van W.A.P. Roorda van Eysinga. ${ }^{122}$ Het is duidelijk dat de overheid een overtreding van de strenge regels van januari 1847 vermoedde. Voor alle drukwerk anders dan het sinds 1843 toegestane was afzonderlijke toestemming van de Algemene Secretarie nodig. Op 9 juli herhaalde de resident zijn vraag, waarop secretaris Bleeker antwoordde dat hij de brief naar voorzitter Van Hoëvell had doorgestuurd omdat aan hem het toezicht over de drukkerij was toevertrouwd. ${ }^{123}$ Van Hoëvell had in Semarang een antwoord ontworpen, dat de secretaris namens het bestuur aan de resident van Batavia had

121 ANRI KBG Dir 0152, brief van Van Hoëvell aan Bleeker, Cheribon 22-5-1847.

122 Brief van de resident van Batavia, 2-6-1847 aan het bestuur, ANRI KBG Dir 0157. Van de in de brief genoemde werken zijn er twee terug te vinden in de Perpusnas: Chronique théatrale concernant Monsieur Robert, (Perpusnas B 342 p), 12 p. Roorda van Eysinga Jr., Verzameling van eene menigte noodzakelijke zamenspraken met inlanders, (Perpusnas XLVI 699) viii + 80 p. Het gedicht van Ritter heb ik niet kunnen identificeren.

123 Brief van resident en antwoord van Bleeker in ANRI KBG Dir 0152, nr 45 en 47. 
moeten zenden, maar Bleeker had na ruggespraak met zijn mede-bestuursleden het consigne gekregen dat de brief terug kon naar Van Hoëvell met het verzoek (in de woorden van het oudst aanwezige lid, generaal Cochius) 'de Directie daarin verder niet te moeijen'. ${ }^{124}$ Het was duidelijk dat het bestuur de ernst van de situatie inzag en zich beriep op de eigenzinnigheid van Van Hoëvell waardoor de drukkerij geen bestuurszaak heette te zijn. Van Hoëvell was diep beledigd door de reactie van het bestuur en de vergadering van 24 augustus 1847, de eerste na zijn terugkeer, begon dan ook in mineur.

Eerst stelde Van Hoëvell zijn grief tegen het bestuur aan de orde. De bestuursleden hadden op basis van het vertrouwen waarop Van Hoëvell dacht te mogen rekenen, van het begin af aan moeten begrijpen dat het gebruik van het impressum van Lange gefraudeer was waar Van Hoëvel zelf geheel buiten stond. Hij had het gedicht van Ritter afgewezen voor zijn tijdschrift en het was achter zijn rug toch gedrukt. Hij gaf wel toe dat er een overeenkomst bestond, inhoudende dat de genootschapspers voor boekverkoper Lange met korting van alles kon drukken. (De vraag is of de medebestuursleden daarvan wisten.) Opziener Bolt van de drukkerij had over de Franse brochure met Lange overlegd, maar dat ontkende Lange. En de verzameling Maleise samenspraken van Roorda was eigenlijk al gedrukt en afgeleverd aan Lange toen de beperkende maatregelen van januari 1847 afkwamen. ${ }^{125}$ De belediging die Van Hoëvell had gevoeld in het niet zonder meer doorsturen van zijn antwoord aan de resident van Batavia, gold alle bestuursleden. De beledigende woorden van Cochius hadden de voorzitter extra gegriefd. Overigens was generaal Cochius bij deze vergadering afwezig. De zaak leek afgedaan met een verklaring van de aanwezigen dat het allemaal op een misverstand berustte, waarna Van Hoëvell omstandig geprezen werd.

Daarna kwam Van Hoëvell over de drukkerij in het algemeen te spreken: had iemand van de aanwezigen iets aan te merken op het beheer van de drukkerij? Nadat thesaurier M. Rudolph had opgemerkt, dat zijns inziens uit de financiën bleek dat de drukkerij ten nadele van de kas van het genootschap werkte, deelde de voorzitter mee dat hij per 1 januari 1848 het beheer van de pers en de drukkerij wilde overdragen. Besloten werd eerst te bezien of de drukkerij wel zonder te veel kosten kon worden aangehouden. Nadat dit was besproken, kwam Van Hoëvells laatste punt aan de orde: hij vroeg eervol ontslag als president van het genootschap. In de nota die hij voorlas sprak hij vol bitterheid over de

altoosdurende strijd tegen de Regering, tegen hare beginselen van onderdrukking van den geest, en geheimhouding, tegen haren vrees dat de gedachten zich 
in Indië vrij en onbelemmerd zouden kunnen openbaren, en er uit wrijving van gevoelens en meningen licht zou kunnen ontstaan.[...] Dien strijd ben ik moede, te meer omdat ik zoo weinig ondersteuning, medewerking en weerklank vind, te meer dewijl de zaak van ontwikkeling en vooruitgang in den laatsten tijd meer verloren dan gewonnen heeft, en ik vrees, dat de strijd, hier in Indië gevoerd, nimmer eene overwinning zal ten gevolge hebben. Daarom trek ik mij terug uit dien kamp, en zal ik mijne wapenen overbrengen op een ander terrein, waar ik ze vrijer kan gebruiken. ${ }^{126}$

De tekst van de toespraak laat zien dat Van Hoëvell niet wars was van dramatiek. Op effectvolle wijze bespeelde hij de zeven aanwezige bestuursleden die zich dan ook aangesproken voelden. De verwijten aan hun adres werden tegengesproken en de passage die refereerde aan de discussie hierover, werd in het verslag doorgestreept, alsof er over gebrek aan steun, medewerking en weerklank niet was gesproken. De aanwezigen waren vol lof en probeerden de aftredende voorzitter van zijn voornemen af te houden. Op voorstel van Mijer, met W. Bosch Van Hoëvells belangrijkste bondgenoot in het bestuur, wilde hij dan wel tot 1 januari 1848 aanblijven. ${ }^{127}$ Ondertussen blijkt uit niets of de resident van Batavia een antwoord kreeg op zijn vragen en hoe dat dan wel luidde.

De vijf resterende vergaderingen onder Van Hoëvell tussen 28 oktober 1847 en 27 juli 1848 hadden veel weg van het afhandelen van wat niet meer omkeerbaar leek: Van Hoëvells aftreden en het einde van de drukkerij. Dit alles ruim vóór de protestvergadering van 22 mei 1848 in de Harmonie waarop Van Hoëvell het woord zou voeren. In augustus 1847 speelde Van Hoëvell al met de gedachte zich terug te trekken uit het strijdperk en zich op een andere plek, waar vrijer gevochten kon worden, te vestigen. Zijn woorden kunnen niet anders gelezen worden als een toespeling op vertrek naar Nederland. De kwestie van de drukkerij en de belemmeringen die aan zijn tijdschrift waren opgelegd tijdens zijn reis over Java en Madoera droegen gelijkelijk bij tot de verbittering die uit zijn woorden tot het genootschapsbestuur spreekt.

In oktober 1847 concludeerde de thesaurier dat zelfs de inkomsten van 1848 niet voldoende zouden zijn om de schulden van 1847 te voldoen, waaronder een bedrag van $f 6.432,97$ te betalen aan de drukkerij. Deze had een eigen boekhouding, waaruit ten overvloede nog eens bleek dat het genootschap niet meer dan als vlag had mogen dienen van een welhaast particuliere onderneming. Van Hoëvell kondigde tijdens de oktobervergadering aan dat hij het beheer over de drukkerij misschien toch wel zou willen blijven voe-

126 ANRI KBG Dir 0150, vergadering 24-8-1847, punt 4. Bijgevoegd de complete tekst van Van Hoëvells toespraak.

127 ANRI KBG Dir 0150, vergadering 24-8-1847, punt 4. Het was de eerste vergadering zonder Bleeker. Waarnemer voor het secretariaat was De Wilde. 
ren, afhankelijk van het antwoord op zijn rekest aan het gouvernement van de dag ervoor, waarin hij gevraagd had te bevestigen dat zijn goede trouw als tijdschriftredacteur niet in twijfel werd getrokken (Van Hoëvell 1849:418). Dat rekest bevatte echter ook een dermate felle en persoonlijke aanval op algemeen secretaris Visscher, dat het onwaarschijnlijk leek dat de zaak nog ten goede kon keren. Verbitterd of niet, Van Hoëvell had de strijd nog niet helemaal opgegeven.

Het gunstige antwoord van gouverneur-generaal Rochussen van 8 december 1847 leek Van Hoëvell nog de mogelijkheid te bieden zijn positie te redden. Kennelijk was Rochussen hem welgezind, het regeringsbesluit liet Visscher echter niet vallen. Van Hoëvell maakte tijdens de vergadering van 6 januari 1848 bekend dat hij wel aan het hoofd van de drukkerij wilde blijven staan, maar daarmee was voor de zeven aanwezige medebestuursleden de kous niet af. Die zagen zich het liefst helemaal bevrijd van de last van de verantwoordelijkheid voor de drukkerij. Die zou dan helemaal onder Van Hoëvell komen te vallen, wat neerkwam op het formaliseren van de bestaande situatie. Had de aftredende voorzitter dit voorstel misschien in andere omstandigheden gretig aangenomen, nu was zijn reactie halfhartig: liefst wilde hij op zijn beurt die verantwoordelijkheid overdragen aan de hoofdopziener, E.G.L. Führi. Dat kon het bestuur kennelijk weinig schelen, want met dit voorstel ging het accoord. ${ }^{128}$ Het gouvernement kon er echter niet mee akkoord gaan. Op 15 januari 1848 werd toestemming gegeven om voort te gaan met de herdruk van het Nieuwe Testament in het Maleis, werk in opdracht van het Indisch Bijbelgenootschap, waarvoor volgens de nieuwe bepalingen aparte toestemming nodig was. De regering wilde daarbij vastgesteld zien dat Van Hoëvell en niet het bestuur verantwoordelijk was voor de drukkerij. Toestemming tot het drukken van soortgelijke of andere grotere uitgaven kon in de toekomst aan het genootschapsbestuur alleen gegeven worden.

nadat eens en voor altijd door overlegging van een Extract uit het Register hunner Handelingen [uit de resoluties van het genootschapsbestuur], dan wel op eenige andere wijze aan de Regering zal zijn aangetoond, dat het beheer en bestuur van hunnen drukkerij en dus ook de verantwoordelijkheid, welke rust op hem, die iets drukt, door hen overgedragen is aan de President van het Bataviaasch Genootschap van Kunsten en Wetenschappen Dr W.R. Baron van Hoëvell, Leeraar bij de Protestantsche Gemeente te Batavia, en door dezen is aanvaard. ${ }^{129}$

Het uittreksel dat het bestuur op 30 maart 1848 stuurde, bevatte echter als uitkomst de overdracht van verantwoordelijkheden van voorzitter Van Hoëvell

128 ANRI KBG Dir 0158, vergadering 6-1-1848.

129 Volgens de tekst van het gouvernementsbesluit van 15-1-1848, nr 10. ANRI KBG Dir 1512, omslag 1848. 
aan Führi. ${ }^{130}$ In april 1848 werd die oplossing door het gouvernement van de hand gewezen. ${ }^{131}$ Daarmee was het lot van de drukkerij bezegeld: het bestuur van het genootschap wilde de verantwoordelijkheid ervoor niet dragen, Van Hoëvell zelf evenmin, tenzij hij die weer mocht overdragen aan Führi, maar dat was voor het gouvernement onacceptabel. De drukkerij was daarmee niet meer te beheren. Het besluit werd op de bestuursvergadering van 20 juli 1848 gesignaleerd, maar of het veel stof tot discussie opleverde, blijkt niet uit het verslag. Na 27 maart 1848 had het bestuur niet meer vergaderd. Het lijkt erop of de kwestie van de drukkerij voorzitter Van Hoëvell ontmoedigd heeft en het genootschap immobiliseerde: niets meer over aanwinsten voor het museum, tekstedities of uitbreiding van de bibliotheek. Er was duidelijk sprake van een impasse. Bleeker, die met Van Hoëvell een goed contact had, zag dat in toen hij in juli 1847 Van Hoëvells brief uit Semarang niet had durven doorsturen aan de resident van Batavia en het bestuur had geraadpleegd. Voor het eerst had het genootschap een conflict met het gouvernement plus een intern conflict en het bestuur probeerde te redden wat er te redden viel door afstand te nemen tot Van Hoëvell.

De ontmoediging had echter ook andere gronden. Het waren in 1848 in Europa roerige tijden. Ook Nederland werd daarin betrokken. In maart 1848 trad het conservatieve kabinet, waarvan ook Baud deel uitmaakte, af, om plaats te maken voor een vooruitstrevender bewind. De koning was in één nacht van conservatief liberaal geworden. Thorbecke kreeg de opdracht een nieuwe Grondwet te schrijven.

Terwijl de zaak van de drukkerij stukliep op een weigering van het gouvernement, was Van Hoëvell vol enthousiasme geraakt over de ontwikkelingen in het vaderland en de op handen zijnde grondwetswijziging die ook voor de kolonie gevolgen zou hebben. Hij schreef erover in zijn eigen Tijdschrift voor Neêrland's Indië. Opnieuw kwam hij in conflict met de Algemene Secretarie, want hij begaf zich weer op het terrein van de politiek. Zijn aandacht richtte zich op een wijziging van het radikaal, de benoembaarheid tot ambtenaar die gekoppeld was aan een in Europa voltooide opleiding. In de zich wijzigende omstandigheden zag de predikant met enkele medestanders, onder wie Bosch en Mijer, een mogelijkheid om die zaak via een rekest onder de aandacht van de koning te brengen. Daartoe werd op 22 mei 1848 in de Harmonie een vergadering belegd. Die vergadering, die hij voorzat, was echter door anderen aangegrepen om tevens zaken van verstrekkender aard te bepleiten, waaronder aangelegenheden die ook Van Hoëvell ter harte gingen.

130 De formulering werd vastgesteld op de vergadering 27-3-1848, nr 2a (ANRI KBG Dir 0159), de brief aan de gouverneur-generaal hierover dateert van 30-3-1848.

131 Gouvernementsbesluit van 26-4-1848, nr 13. Zie ANRI KBG Dir 0161, vergadering 20-7-1848 nr 1.d. Een extract van het besluit ook in ANRI KBG Dir 1512, omslag 1848. 
Hoorde hij tot de gematigden die zich hadden willen bepalen tot de afschaffing van het in Indische kring gehate radikaal, anderen wilden tevens de vrijheid van drukpers, de slavernij, het munt- en bankstelsel, de opiumregie en het onderwijs in het algemeen aanpakken. Het lag niet aan Van Hoëvell dat de vergadering van 22 mei een onrustig verloop had, maar hij was er vanaf dat moment mee geassocieerd, al had hij de zaal verlaten eer de storm opstak. Een formele afkeuring van het gouvernement en van het kerkbestuur volgde en was aanleiding voor hem om zijn ontslag in te dienen. In Nederland zou hij eerherstel zoeken (Stapelkamp 1986; Bosma en Raben 2003:193-8).

Daarbij kwam nog het ultimatieve besluit van het gouvernement van 8 juni 1848, dat was ingegeven door een rapport van algemeen secretaris Visscher van 30 mei, waarin deze op drie punten bezwaren maakte tegen aflevering 1 en 2 van het Tijdschrift voor Neêrland's Indië, jaargang 1848. De bezwaren golden het behandelen van koloniaal beleid en politiek in het algemeen, het laatste naar aanleiding van de berichten van de op handen zijnde grondwetswijziging, die Van Hoëvell had aangegrepen om uiteen te zetten dat dan ook voor Nederlands-Indië goede tijden aanbraken. Er was voor het gouvernement voldoende aanleiding om de toestemming tot uitgifte van het tijdschrift in te trekken of te schorsen, maar Van Hoëvell kreeg nog één kans (Van Hoëvell 1849:1-6). Die kans kon en wilde Van Hoëvell toen niet meer nemen; het was te laat. Het spel tussen Visscher en Van Hoëvell was door de laatste verloren. Zo was Van Hoëvell in 1847-48 op drie punten in rechtstreekse aanvaring gekomen met het gouvernement: de drukkerij, het tijdschrift en de vergadering in de Harmonie.

Bij de voorlaatste vergadering van het bestuur van het genootschap voor zijn vertrek naar Nederland, op 20 juli 1848, wachtte hem een bittere verrassing. Aanwezig was de algemeen secretaris zelf, weliswaar nog steeds lid van het bestuur, maar sinds ruim zes jaar afwezig bij de bestuursvergaderingen. Er was maar één mogelijke reden voor zijn aanwezigheid: zien dat de drukkerijkwestie goed afgehandeld werd, in overeenstemming met de bedoelingen van het gouvernement, en verder Van Hoëvells gangen in diens laatste weken in Batavia in de gaten houden. Van Mijer, net als Van Hoëvell betrokken bij de Mei-beweging, was er een brief waarin hij bedankte als bestuurslid. Het lijkt erop alsof ook Mijer de grond te heet onder de voeten werd. De vergadering besloot Mijer te vragen in ieder geval nog bij de eerstvolgende vergadering aanwezig te zijn, gezien de belangrijke zaken die afgehandeld moesten worden. Het enige vergaderonderwerp was het aftreden van Van Hoëvell als voorzitter en als toezichthouder op de drukkerij. Voor wat de drukkerij betreft waren er twee voorstellen: een verzoek van Führi om de drukkerij te mogen kopen - hij had zich al tot het gouvernement gewend om toestemming te krijgen zich als zelfstandig drukker in Batavia te kunnen vestigen - en een voorstel van boekhandelaars Lange \& Co om de drukkerij 
voor $f 8.000$ over te nemen. Van Hoëvell tekende daarbij aan dat hij zelf nog ruim $f 5.000$ tegoed had van de drukkerij. ${ }^{132} \mathrm{Na}$ deliberatie werd besloten de vergadering te verschuiven naar 27 juli, omdat er te weinig bestuursleden aanwezig waren. Voor de 27e zou iedereen met aandrang worden uitgenodigd. Ondertussen zou Tromp zich met de onderhandelingen met Lange bezighouden. Van Hoëvell zou aanblijven tot het einde van de maand, de hele directie zou verantwoordelijk zijn voor de drukkerij, het werk op de drukkerij zou tot eind juli worden voortgezet voor rekening van Van Hoëvell, en Führi mocht blijven drukken, maar alle drukproeven moesten door Visscher voor akkoord worden getekend. ${ }^{133}$ Zo hield Visscher als censor het heft in handen. Van Hoëvell moest zolang de financiën niet geregeld waren deze vernederende situatie accepteren, want hij zat te wachten op zijn $f 5.000$ en stond op het punt te vertrekken.

Tijdens de laatste vergadering onder Van Hoëvell, op 27 juli 1848, met zeven andere bestuursleden onder wie Visscher, maar opnieuw zonder Mijer en zonder thesaurier Rudolph, werd de zaak afgehandeld. Zonder veel omslag zegt het verslag dat besloten werd 'zich van de drukkerij te ontlasten'. Naast het al genoemde voorstel van Lange \& Co en het verzoek van opziener Führi lagen er voorstellen van P.P. Roorda van Eysinga en van de thesaurier Rudolph zelf, allen geïnteresseerd in de overname van de drukkerij. Over het voorstel van de laatste, $f 8.000$ contant plus het aanbod de Verhandelingen te drukken voor $f 24$ per vel, zou verder onderhandeld worden. Kennelijk was Rudolph een betere partij dan boekhandelaar Lange. Het bestuur wilde hem vragen zijn bod te verhogen tot $f$ 9.000. Van Hoëvell kreeg zijn geld, $f 4.932,97$, een aanzienlijk bedrag, waaruit andermaal bleek dat hij veel geld in de onderneming had zitten. Uit de stukken blijkt niet hoe penningmeester Rudolph aan dat bedrag gekomen was. ${ }^{134}$

Daarna werd

onder dankbetuiging voor het bij ZEd. gedurende ettelijke jaren gesteld vertrouwen, het voorzitterschap door den heer dr. W.R. baron van Hoëvell nedergelegd en ZEds ontslag uit de directie met den dank der leden voor de veelvuldig bewezene diensten aangenomen.

Collega-predikant Buddingh werd met meerderheid van stemmen tot voor-

132 ANRI KBG Dir 0160, vergadering 20-7-1848. Verzoek van Fuhri als bijlage bij vergadering 27-7-1848, Dir 0161.

133 ANRI KBG Dir 0160, vergadering 20-7-1848, punt 2.

134 'Korte staat der kas' door Rudolph, als bijlage 1 bij verslag van vergadering 27-7-1848, ANRI KBG Dir 0161. Uit het overzicht van 'nog te ontvangene en te doene calculatieve uitgaven' blijkt geen enkele uitgave voor de drukkerij, behalve het bedrag van $f$ 4.932,97 dat aan Van Hoëvell moest worden betaald. Boekhandelaar Kemink (Utrecht) was nog $f 1.500$ tegoed. 
zitter gekozen. Tenslotte stelde Van Hoëvells bondgenoot en hoofd van de Geneeskundige Dienst, Bosch, voor Van Hoëvell tot erelid te benoemen. 'De heer dr. van Hoëvell, hierover zijn dank betuigende, nam afscheid als president en lid der directie.' ${ }^{135}$

Waarnemend secretaris Munnich stelde voor de Javasche Courant een kennisgeving op die op 29 juli 1848 werd geplaatst. Ze geeft een zakelijke samenvatting van de bestuurswisseling onder verwijzing naar Van Hoëvells op handen zijnde vertrek zonder enige vermelding van de redenen voor dat vertrek. In het concept voor de kennisgeving, dat gelukkigerwijze in het archief is bewaard, had Munnich verwezen naar de afscheidwoorden van de aftredende voorzitter en afgesloten met:

Men koestert de hoop dat gunstiger omstandigheden dan dien welke zijn vertrek veroorzaakten, hem weldra in ons midden zullen doen terugkeeren, om hier op nieuw zijn talenten en krachten aan den bloei van kunsten en wetenschappen, aan den voortgang van godsdienst, verlichting en beschaving te wijden.

Maar Visscher maakte gebruik van zijn taak als censor en schreef op het concept:

ik veroorloof mij de vraag, of het wel in de bedoelingen van den Heer van Hoëvell liggen kan, openlijk te vermelden, dat men hoop koestert, dat hij onder gunstiger omstandigheden, dan dien welke zijn vertrek veroorzaakten, in ons midden wederkeren zal. Is de mededeeling van dit zijn voornemen, aan de Directie van het Genootschap, niet meer eene vertrouwelijke mededeeling, alleen bestemd voor de Directeuren [bestuursleden] en niet voor openlijke verkondiging. De toespeling op de omstandigheden van het vertrek kan aanstoot geven, en nadelig terugwerken zelfs op de wetenschappelijke belangen van het genootschap. Ik geef in overweging de beide laatste zinssneden te laten vervallen. ${ }^{136}$

Secretaris Munnich legde zich neer bij Visschers bezwaren. Van Hoëvell zelf zou in zijn Afscheidsrede van 6 augustus 1848 in de Willemskerk openlijk over zijn verhoopte terugkeer spreken, maar Visscher wilde de toespeling naar het conflict met het gouvernement en de kerkenraad niet in de krant (Van Hoëvell 1848:29). De bijeenkomst van 22 mei had al voor genoeg opschudding gezorgd en bleef de gemoederen voorlopig bezighouden. De rekesten aan de koning, de gouverneur-generaal en de Tweede Kamer, die uit de vergadering voort waren gekomen, zorgden daarvoor. Dat Van Hoëvell de eer aan zichzelf had gehouden en ontslag had genomen met het voornemen om in Den Haag de zaak af te handelen, kwam het gouvernement waarschijnlijk 
goed uit. Gouverneur-generaal Rochussen schreef tenminste op 26 augustus 1848 aan de kortelings afgetreden minister van koloniën Baud met enige opluchting: 'Zie daar onze volkstribuun van Hoëvell naar Nederland - alles is rustig en onder appèl. Maar op die kalanten heb ik toch maar een voorwaardelijk vertrouwen' (W.A. Baud 1983, II:370). Baud had in zijn brief van 21 juli 1848 al gerefereerd aan de brochure van P. Veth, De openbaarheid in koloniale aangelegenheden, waarin deze Van Hoëvells Javaanse reisbeschrijving aankondigde. Met enige ironie schreef Baud: 'Hongersnoden en epidemiën, door de overdrijving der Europesche kultures te weeg gebragt, zullen er eene groote rol in spelen!' (W.A. Baud 1983, III:266).

Het genootschap verkocht onder voorzitter Buddingh de drukkerij uiteindelijk toch aan boekhandelaars Lange \& Co voor de som van $f 10.000$ waarvan de helft contant en een regeling dat Lange de Verhandelingen zou gaan drukken. ${ }^{137}$ In de eerste vergadering onder Buddingh werd gemeld dat de schulden aan Van Hoëvell waren afbetaald. Algemeen secretaris Visscher bleef een actief bestuurslid en woonde onder het voorzitterschap van Buddingh, maar ook onder diens opvolger Bosch de meeste bestuursvergaderingen bij en probeerde zo het genootschap in het gareel te houden. Het zal Van Hoëvell niet veel deugd hebben gedaan dat zijn tegenspeler Visscher in 1854 het voorzitterschap van Bosch overnam.

Zo kwam met het vertrek van Van Hoëvell een einde aan het korte bestaan van de zelfstandige drukkerij. Die was tussen 1842 en 1848 in werking geweest en had slechts ten dele voor het genootschap gefunctioneerd. Alleen voor de Verhandelingen en enkele losse genootschapsuitgaven kunnen we daarom spreken van een eigen uitgeverij. Voor het overige fungeerde de drukpers als een commerciële drukkerij. Er werkte ten tijde van de verkoop van de onderneming twintig employees. Dat gevoegd bij de aanzienlijke lijst van voltooid drukwerk, geeft zicht op de omvang van de onderneming. Op zichzelf was dat een niet geringe verworvenheid in de kolonie en dat het zes jaar kon voortduren is mede te danken aan het crediet dat Van Hoëvell bij het gouvernement had, zowel bij Merkus en Reijnst als bij Rochussen. De baten voor het genootschap waren gering. Ze bestonden vooral in de publicatie van de Verhandelingen. De zorgen waarvoor het in 1847 en 1848 door de drukkerijkwestie geplaatst werd, waren aanzienlijk. De baten voor Van Hoëvell zijn moeilijk te berekenen.

In het eerste verslag van Buddingh voor de algemene vergadering op 8 maart 1849 werd de geschiedenis van de drukkerij kort behandeld. Het beheer en bestuur erover, zo zegt Buddingh daar, werden toevertrouwd aan Van Hoëvell. 
Het bleek echter weldra, dat de heer van Hoëvell met vele moeijelijkheden te kampen had. En daar nu, bij zijn vertrek van hier, noch de Directie en corps, noch iemand harer Leden, genegen was om ten aanzien der drukpers eene groote verantwoordelijkheid op zich te nemen [...] zoo werd men verpligt tot den verkoop er van te besluiten. Intusschen is hierdoor iets zeer belangrijks tot stand gekomen, namelijk de inrigting van eene particuliere Drukkerij in N.I. En deze particuliere Drukkerij is, door de krachtige medewerking der Regering en de bemoeijenis van het Bataviaasch Genootschap, zoo goed geörganiseerd en zoo compleet aan den kooper geleverd, dat zij met de Lands-Drukkerij kan wedijveren. (VBG 22:18-9.)

De rol van Van Hoëvell bij de opbouw van de drukkerij is er in de bewoordingen van Buddingh wel wat mager afgekomen, waar de kwaliteit van de instelling aan de medewerking der regering én aan de bemoeijenis van Van Hoëvell zelf te danken was. Van Hoëvell's medestander Bosch had tijdens de vergadering van 27 februari 1849 nog geprobeerd de passage pregnanter geformuleerd te krijgen: 'dat geen van de overige leden der Directie genegen was de morele verantwoordelijkheid der Drukkerij op zich te nemen, als hebbende deze tot veelvuldige verwikkelingen en moeielijkheden met de regering aanleiding gegeven.' ${ }^{138}$ Dat de passage in deze vorm op 8 maart 1849 in de Harmonie aan de leden is voorgelezen, lijkt onwaarschijnlijk. Ze werd niet gedrukt in het verslag. Van dat verslag gaat de suggestie uit dat de drukkerijkwestie los staat van Van Hoëvells vertrek. Dat is, ook al blijkens Bosch' interventie, onjuist.

Van Hoëvells verdiensten als actief en doortastend bestuurslid, vice-voorzitter en voorzitter van het genootschap liggen vooral in de hervormingen die onder zijn oog en door zijn toedoen tot stand zijn gekomen. Het afstoten van het zoölogisch kabinet en het daarentegen uitbreiden van het geologischmineralogisch kabinet, maar vooral het opbouwen van de oudheidkundige verzameling, waardoor deze archeologische afdeling de kern zou worden van het museum, zorgden voor een totale verandering van het aanzien van de collectie. Daarnaast was de ruime aandacht voor de studie van de talen en teksten van de archipel, resulterend in taalkundige publicaties en tekstuitgaven een duidelijke vernieuwing. De aandacht voor de bibliotheek en het openleggen van de collecties door het publiceren van catalogi zorgden voor een professioneler aanpak, dan het genootschap voorheen had gekend. Van Hoëvell gaf duidelijk leiding. Zijn autoriteit werd erkend. In zijn verslagen aan de algemene vergaderingen en in zijn rekesten aan het gouvernement liet hij steeds duidelijk zien waarop het beleid van het Bataviaasch Genootschap (zijn beleid) gericht was. 
Epiloog

Van Hoëvell bleef het genootschap nog wel enige tijd bezighouden en het genootschap hem. Op 24 september 1848 - hij was toen nog op zee - werd hem een brief geschreven om te vragen naar vier verhandelingen die Friederich voor het genootschap had geschreven over zijn verblijf op Bali en die hij in 1847 aan Van Hoëvell had gestuurd. Verder werd hem gevraagd naar het manuscript van het Dajakse woordenboek van Becker en Hardeland. ${ }^{139}$ Van Hoëvell antwoordde uit Groningen op 19 december dat hij van de vier verhandelingen niets wist, wel van voor hemzelf bestemde aantekeningen van Friederich, waarvan hij bereid was een afschrift te sturen. Tenslotte gaf hij als antwoord op de vraag naar het woordenboek een steek aan het adres van Buddingh:

Het heeft mij zeer veel leed gedaan, dat de President des Genootschaps, mijn geëerde opvolger, niet van mijn aanbod heeft gebruik gemaakt, om ZWEW persoonlijk aanwijzing te doen van al de stukken, verzamelingen, papieren enz. die het Genootschap behooren.

Getergd antwoordde Buddingh op 5 april 1849 dat hij op de afgesproken woensdag de hele ochtend had gewacht op Van Hoëvell die niet was verschenen. ${ }^{140}$

Friederich was degene die - als ondergeschikt tweede bibliothecaris nogal wat te lijden had gehad van Van Hoëvell. Hij althans schreef op verzoek van Visscher in een brief bij een rapport over zijn wetenschappelijke zending naar Bali:

dat hij gedurende zijn verblijf op Bali eene reeks van rapporten, in den beginne in den vorm van brieven, naderhand als uitgearbeide stukken aan den toenmaligen Praesident van het genootschap [Van Hoëvell] ingezonden heeft, dat echter die stukken voor de Directie onbekend gebleven zijn te rekenen. Thans begint de toenmalige Praesident met het uitgeven van deze stukken in Holland; het eerste is verschenen in de 5 de aflevering van het Tijdschrift voor Nederlandsch Indië, verschijnende te Groningen. Op deze wijze gelooft de ondergeteekende, dat wel langzamerhand voor het debiet van den vroegeren Praesident die stukken het daglicht zullen zien, wier publicatie te regter tijd en op de behoorlijke plaats, dat is in 1847 tot 1848 en op Batavia, aan den ondergetekenden denkelijk eene reeks van onaangename ondervindingen zoude gespaard hebben. ${ }^{141}$

Friederich schreef de moeilijkheden die hij in 1848 had ondervonden inzake

139 ANRI KBG Dir 0162, vergadering 22-9-1848, punt 2.c. en bijlage 27.

140 ANRI KBG Dir 0167, vergadering 27-3-1849, punt 7 en bijlagen 18 en 19.

141 ANRI KBG Dir 0172, vergadering 27-11-1849, bijlage 7, brief van Friederich aan het genootschap, 26-7-1849. 
financiële kwesties en die leidden tot een nog af te betalen, aanzienlijke schuld van hem aan het genootschap, toe aan de onduidelijke toezeggingen van Van Hoëvell. ${ }^{142}$ Zo bitter was hij ten aanzien van zijn vroegere baas, dat hij in januari 1850 een beschuldigende nota opstelde waarin hij de oud-voorzitter aanwees als verantwoordelijk voor het verdwijnen van tussen de twaalf en twintig Maleise en tien Balinese handschriften, studies van Argensola en Lassen, een fraai metalen (bronzen?) Brahma, een beker met de dierenriem en een Dajaks hoofd (masker?). Van Hoëvell kreeg er een brief over op 2 februari 1850. Een sneer aan het adres van Van Hoëvell in een brief van 1 februari 1850 van het genootschap aan de gouverneur-generaal over een openstaande rekening ('welk een en ander verklaarbaar is uit de wijze op welke de voormalige drukkerij des genootschaps werd beheerd') en een verzoek van Visscher om bij Van Hoëvell navraag te doen naar twee verhandelingen over steenkoolwinning op Borneo die hij al in 1846 had moeten terugsturen naar de Algemene Secretarie, dragen bij aan de indruk dat hij een slechte pers achterliet. ${ }^{143}$ Sterker nog, het lijkt alsof er een dossier met gegevens werd aangelegd dat in de strijd tegen hem zou kunnen worden gebruikt.

Of Friederich de zaak tegenover $\mathrm{H}$. Neubronner van der Tuuk tijdens diens bezoek aan de bibliotheek en het museum van het genootschap in 1849 te zwart heeft voorgesteld, blijft een vraag. Er zouden, volgens Friederich, aldus Van der Tuuk in een brief aan H.C. Millies, alleen nog kasten gestaan hebben waar ooit handschriften in gezeten hadden die door een 'autocraat' waren meegenomen naar Nederland (Groeneboer 2002:87-8). Buddingh meldde in hetzelfde jaar 1849 echter dat Friederich werkte aan de catalogus van de ongeveer 400 oosterse handschriften, voor het merendeel afkomstig van de voormalige vorsten van Bantam, en op 24 oktober 1851 kon Friederich opgewekt aan Bleeker berichten dat het werk aan de catalogus van de handschriften voltooid was. ${ }^{144}$ Maar begrijpelijk is Friederichs reactie aan Van der Tuuk wel. Deze trof hem aan in 1849 in een tijd waarin hij in grote financiele zorgen zat, die ondermeer waren terug te voeren op verkeerd begrepen toezeggingen die Van Hoëvell gedaan had en die het genootschap niet kon nakomen.

142 ANRI KBG Dr 0162, vergadering 22-9-1848 punt 2.c. en bijlagen 4-20.

143 ANRI KBG Dir 0175, vergadering 29-1-1850, punt 2.1. en bijlagen 28-30. Dir 0183, vergadering 29-10-1850, punt 6 en bijlage 50 .

144 VBG 22:18, verslag van Buddingh. Verder ANRI KBG Dir 0188, vergadering 26-10-1851, bijlage 2, brief van Friederich aan Bleeker, 24-10-1851. 
Hans Groot - 978-90-04-25380-3

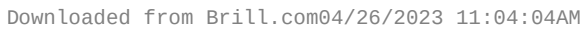
via free access 


\section{Hoofdstuk vi}

\section{Specialisering temidden van concurrenten (1849-1860)}

\section{Bestuur: reorganisatie en ledenverlies}

Het vertrek van Van Hoëvell had een schok teweeg gebracht in de gelederen van het genootschap. Bestuursleden Willem Bosch, chef van de Geneeskundige Dienst, Pieter Mijer, vice-president van het Hooggerechtshof van NederlandsIndië, en Jurriaan Munnich, officier van gezondheid, hadden tot de medestanders van Van Hoëvell behoord. Bosch en Mijer waren mede-ondertekenaars van het adres aan de koning dat in mei 1848 opschudding had veroorzaakt. Secretaris Pieter Bleeker, ook een medestander, was in 1847 overgeplaatst naar Semarang, later naar Soerabaija, nadat hij kritiek had geuit op het gouvernementsbeleid (Bleeker 1877:23). Bij zijn afwezigheid had Munnich zijn plaats waargenomen. De generaals jhr. C. van der Wijck en F.D. Cochius hadden met de resident van Batavia, J.F. Hora Siccama, aan de kant van algemeen secretaris Visscher gestaan. Het vertrek van Van Hoëvell voorkwam een scheuring in het genootschap. Van de overgebleven bestuursleden trok alleen Mijer de consequentie. Hij beriep zich op zijn drukke ambtsbezigheden ${ }^{1}$, liet zich bij het genootschap nog maar zelden zien en verliet tenslotte in 1850 het bestuur. Cochius, Van der Wijck en Hora Siccama vertrokken naar Nederland. Met hun vertrek was de angel uit het conflict tussen de liberale vleugel en de conservatief-regeringsgetrouwe groep onder leiding van Visscher getrokken.

De nieuwe voorzitter, Buddingh, was geen Van Hoëvell-aanhanger, zoals bleek uit de bittere woorden over zijn collega-predikant na diens vertrek. Steven Adriaan Buddingh (1811-1869) was in 1834 in Leiden gepromoveerd in de theologie en meteen vertrokken naar Batavia, uitgekomen als huisonderwijzer. $\mathrm{Al}$ in 1835 werd hij echter tot predikant benoemd (D. Buddingh 1870:238-43). Hij was twee jaar werkzaam toen Van Hoëvell in Batavia kwam.

1 De notulen van de vergadering van 20-7-1848 (ANRI KBG Dir 0161) vermelden een brief van Mijer die zich genoodzaakt ziet door werkdruk het directielidmaatschap op te geven. Pas in 1850 werd in zijn vervanging voorzien (ANRI KBG Dir 180, vergadering 27-8-1850, punt 12). 
Buddingh werd eerder dan zijn collega tot lid van het genootschap benoemd, maar kwam later dan hij in het bestuur. ${ }^{2}$ In het genootschap werd Buddingh door zijn collega voorbijgestreefd. Wel betrok Van Hoëvell hem bij de oprichting van het Tijdschrift voor Neêrland's Indië. Door hun werk voor de kerk, hun lidmaatschap en bestuursfuncties van allerlei organisaties hadden zij jarenlang veel bemoeienis met elkaar. Buddingh voerde de redactie van het almanakje Lakschmi (1840-1842) en van hem verschenen diverse preken en gedichten in druk. Hij was in de aanvang waarschijnlijk een geestverwant van Van Hoëvell, maar diens Tijdschrift was toch al snel een éénmanszaak, zoals de drukkerij dat was en de leiding van het genootschap eveneens. Buddingh was niet betrokken bij de Harmonie-beweging van 1848 en kon daarom in dat jaar het voorzitterschap overnemen. Door het gouvernement overgehaald, begon hij een nieuw tijdschrift, het Indisch Archief (1849-1851), dat niet alleen op de financiële steun van de overheid kon rekenen, maar ook door het overheidsarchief van kopij werd voorzien. Het was een duidelijke poging om Van Hoëvells Tijdschrift voor Nederlandsch Indië de wind uit de zeilen te nemen, dat met een gemoderniseerde titel in Nederland verscheen en daar de spreekbuis werd van de liberale groepering in de koloniale politiek (Van Delden 1993:167). Buddingh werd in zijn tijdschriftonderneming duidelijk gesteund door Visscher. Het Indisch Archief werd echter geen tijdschrift van het genootschap. Daarvoor was het tijdstip niet geschikt. Dat paste bovendien niet in Visschers bedoelingen. Bij Buddinghs verlof naar Nederland ging het Indisch Archief ter ziele (1851). Hijzelf keerde in 1852 terug als inspecteur-generaal op een vijf jaar durende kerkelijke inspectiereis door de archipel. Na 1851 had hij met het genootschap niet meer van doen.

Visscher aanvaardde eveneens de consequenties uit de episode-Van Hoëvell. Was hij in de jaren veertig lange tijd een papieren bestuurslid geweest, nu volgde hij het genootschap van dichtbij en was hij bij nagenoeg alle vergaderingen aanwezig. In 1852 werd hij, inmiddels lid van van de Raad van Indië geworden, tot vice-president van het genootschap gekozen, toen deze functie weer werd ingesteld, en in 1854 tot president. Hij kon controle uitoefenen op de organisatie tot zijn vertrek uit Indië in 1857. ${ }^{3}$ Het Van Hoëvell-kamp had daarmee afgedaan. Wel bleef de zaak van de openbaarheid onder Visscher spelen. De naar Batavia teruggekeerde Bleeker stelde in 1854 voor om de notulen van de directievergaderingen 'bij uittreksel' te publiceren

2 Buddingh tijdens de algemene vergadering van 29-3-1837, Van Hoëvell op 27-8-1837 (beiden gewoon lid). ANRI KBG Dir 0101, 0103, vergaderingen van die data. Van Hoëvell werd op 11-4-1839, Buddingh op 19-6-1839 tot bestuurslid verkozen. Vergaderingen van die data in Dir $0112,0114$.

3 ANRI KBG Dir 0193, vergadering 24-4-1852, punt 7; Dir 0202, vergadering 28-3-1854, punt 3. 
in het nieuw opgerichte Tijdschrift voor Indische Taal-, Land- en Volkenkunde. ${ }^{4}$ Dat voorstel werd aangenomen, maar secretaris Bleeker, ongelovig, ontlokte Visscher een nadere bevestiging. Hij liet hem op de eerste bladzijde van de notulen van 28 maart 1854 noteren dat hij, Visscher, geen bezwaar had tegen het openbaar maken ervan. Toch werden de notulen pas drie jaar later in het tijdschrift geplaatst, en wel direct na het vertrek van Visscher, niet de notulen vanaf 1854, maar pas die van 23 februari 1857. Het kan geen toeval zijn dat juist de man die Van Hoëvell bestreed op het punt van de openbaarheid van bestuur en vrijheid van meningsuiting, tijdens zijn voorzitterschap de notulen niet gedrukt wilde zien. Hij behoorde tot een generatie die de door Thorbecke geïnitieerde veranderingen, zoals het politieke debat over de kolonie, als een ongewenst modernisme beschouwde.

Het effect van de publicatie van de notulen in het tijdschrift was duidelijk. Daardoor waren de leden en het lezende publiek niet langer aangewezen op mededelingen tijdens de schaarse algemene vergaderingen en op de verslagen ervan in de Verhandelingen of in de Javasche Courant. Ze werden via het tijdschrift veel regelmatiger en bovendien veel uitgebreider geïnformeerd over wat er in het bestuur omging. Ging het in de gedrukte notulen vooral om samenvattingen en besluiten, de argumentatie ervoor kon uit de toegevoegde correspondentie worden gehaald. ${ }^{5}$ De discussie over het wel en wee van het genootschap was hierdoor een publieke zaak geworden.

De reeks presidenten in de periode 1849-1860, zes in getal, geeft al aan dat er veel mutaties waren. Na Buddingh volgden Bosch (1850) en Visscher (1854), daarna de commandant van het Indische leger, generaal F.V.A. de Stuers (1857), het lid van de Raad van Indië P.J.B. de Perez (1858), en tenslotte generaal J. van Swieten, ook hij legercommandant (1859). Na de benoeming van 61 nieuwe leden op 8 maart 1849 telde het genootschap elf bestuursleden, 21 honoraire leden, 173 corresponderende leden (onder wie een Japanner als enige Aziaat), 175 gewone leden in Nederlands-Indië (onder wie slechts twee Indonesiërs) en 68 gewone leden buiten Nederlands-Indië. Het ging in totaal om 448 leden, een aantal dat alleen in 1851 overtroffen werd. ${ }^{6}$ Wilde het genootschap laten zien dat na Van Hoëvell onder een nieuw bestuur geenszins van een malaise sprake was?

Voorzitter Buddingh ging in zijn jaarrede van 8 maart 1849 in op de wens

4 ANRI KBG Dir 0202, vergadering 28-3-1854, punt 6. De notitie van C. Visscher op pagina 1 van de bedoelde notulen, gedateerd 2-10-1854.

$5 \quad$ Zo bijvoorbeeld in TBG 8 (1859) een brief aan de gouverneur-generaal over de samenvoeging van drie Bataviase organisaties, waaronder het Bataviaasch Genootschap. In TBG 9 (1860) over de financiële noodtoestand binnen het genootschap.

$6 \quad$ Nieuwe ledenlijst in VBG 22 (1849). In bijlage 1, waarbij de opgaven in de Almanak als uitgangspunt dienden en die het ledental van begin 1849 opnam, staat het aantal nog op 410 . 
dat het genootschap actiever naar buiten zou treden. Hij verweet de aanwezige leden inertie en gaf als voorbeeld, dat de lezingencyclus van Munnich over het menselijk lichaam voortijdig moest worden gestaakt wegens gebrek aan belangstelling (VBG 22:4). Hij signaleerde een 'zekere lusteloosheid, en onverschilligheid voor de wetenschap'. In mei 1850 werd een 'aanmerkelijk verlies aan gewone leden' gesignaleerd. Het genootschap telde toen nog 404 leden, een teruggang met tien procent. Bosch stelde voor dat de door het bestuur opgestelde lijst van kandidaatleden aangevuld zou worden door een beroep te doen op de

Chefs van departementen, residentiën en gouvernementen in Neêrlandsch Indië, als meer in het bijzonder bekend met de personen onder hunner bevelen dienende of in hunnen residentiën of gouvernementen woonachtig, met de uitnoodiging dat zij eene voordragt tot het gewoon lidmaatschap des genootschaps zullen doen van die personen, welke hun bekend zijn als beoefenaars of voorstanders van kunsten en wetenschappen. ${ }^{7}$

Het was alsof de oude tijden van vóór 1800 terugkeerden. Het overheidsapparaat werd ingeschakeld om het ledenbestand op peil te brengen. Op eigen kracht kon het genootschap het kennelijk niet. De gedrukte circulaire hierover ging op 1 juni 1850 uit. $^{8}$

Een tweede golf van opzeggingen onder de gewone leden kwam op gang toen het in 1852 door de directie goedgekeurde concept van nieuwe wetten aan de leden werd voorgelegd. De wetten van 1823 waren al eerder onderwerp van discussie geweest. In 1840 had het bestuurslid J.C. Meder voorgesteld een algehele herziening door te voeren. Dat voorstel was toen gesneuveld in een periode van inactiviteit. ${ }^{9}$ Toen Bleeker in 1847 in Semarang verbleef, stelde hij een radicale verandering voor. Het genootschap moest worden omgevormd tot de Academie van Wetenschappen en Schoone Kunsten van Batavia, verdeeld in vier klassen:

1 de natuurkundige wetenschappen,

2 de etnografische en filologische wetenschappen,

3 de technologische en landbouwkundige wetenschappen, en

4 de schone kunsten.

Ook de Verhandelingen zouden moeten worden omgedoopt tot de Werken der Academie van Schoone Kunsten en Wetenschappen van Batavia. In de titel van deze 'Werken' gingen de kunsten voor de wetenschappen uit. Bleeker

ANRI KBG Dir 0179, vergadering 28-5-1850, punt 7.

ANRI KBG Dir 0180, vergadering 27-8-1850, bijlage 22.

Een rondschrijven uit 1840 hierover met aantekeningen van Meder, Van Hoëvell, Bik, Tiedeman, Diederichs, Tromp, Van der Vinne en Van der Schoor in ANRI KBG Dir 1512, omslag 1848. 
had ook bedacht dat het aantal leden moest worden beperkt tot vijfkonderd gewone leden in Nederlands-Indië, hoogstens zestig corresponderende leden en twintig honoraire leden. ${ }^{10}$

Het lijdt geen twijfel dat hij zich had laten inspireren door het Koninklijk Instituut van 1808. Zelfs in de naam deed zijn academie denken aan het Instituut, dat overigens pas in 1851 omgevormd werd tot 'Akademie'. De 'Schoone Kunsten' kwamen uit de naam van het Amsterdamse Instituut. Voor Bleeker was het genootschap teveel een organisatie van dilettanten gebleven. Zijn ambities gingen uit naar een officieel, opnieuw van overheidswege goedgekeurd instituut, dat door dezelfde overheid zou worden gesteund. Dat hij het woord 'genootschap' wilde vervangen door 'academie' was veelzeggend. Bleeker wilde de wetenschapsbeoefening op een hoger peil brengen en daarmee Batavia meer aanzien geven. De organisatie moest daarvoor hervormd worden en zou tegelijk bureaucratischer worden. Het bestuur had in 1848 weinig gevoeld voor Bleekers academie-voorstel. De naam moest ongewijzigd blijven, het aantal leden hoefde niet beperkt te worden, indeling in klassen werd evenmin nodig geacht. Commentaar kwam van P.J. Godefroij en jhr Van der Wijck, anderen hadden het te druk. Bleeker kon zelf zijn voorstel niet verdedigen, omdat hij in Soerabaija verbleef.

Toch was hij in 1852 weer de voortrekker van nieuwe herzieningsplannen. Dit maal koos hij eieren voor zijn geld en liet de naam van het genootschap ongemoeid. Ook de indeling in klassen, afgekeken van het moederlandse Instituut, liet hij zitten. Wel werden er in zijn voorstel vijf werkgebieden afgebakend, nu aangevoerd door 'geschiedenis, talen, oudheden, zeden, gewoonten en instellingen der Indische en andere Oostersche volkeren'. Ook werden door Bleeker opnieuw de 'natuurlijke en aardrijkskundige gesteldheid van den Indischen Archipel' en het 'dieren-, planten- en delfstoffenrijk in Indië' aangewezen als terreinen die aandacht verdienden, terwijl al in 1850 de Natuurkundige Vereeniging was opgericht onder aanvoering van juist Bleeker. In die oprichting zag hij kennelijk nog onvoldoende aanleiding om het werkterrein van het genootschap in te perken. Het meest in het oog springende element in het door het bestuur aanvaarde voorstel was het idee om het aantal gewone leden te beperken tot 120 en de contributie te verhogen van veertig tot honderdtwintig gulden per jaar. Een besloten, beperkt toegankelijk genootschap zou aantrekkelijker zijn en de contributieverhoging zou daarmee voor lief worden genomen, zo leest men in de toelichting. ${ }^{11}$

10 Het voorstel van Bleeker met commentaar van medebestuursleden in ANRI KBG Dir 1512, omslag 1848.

11 Het Ontwerp van Wetten werd met een aparte Memorie van toelichting voor de leden gedrukt en verspreid (Ontwerp van wetten 1852). Een exemplaar (12 gedrukte pagina's) in ANRI KBG Dir 1514, omslag 1852. 
Het voorstel veroorzaakte onrust in het genootschap en het bestuur vreesde een 'min gunstige uitwerking'. Bestuurslid L.W.C. Keuchenius, raadsheer bij het Hooggerechtshof, rapporteerde in november 1852 dat de voorgestelde verhoging van het lidmaatschapsgeld de aanleiding was voor die onrust. ${ }^{12}$ Slechts twee leden hadden met het voorstel ingestemd, zestien leden hadden bedenkingen aangevoerd, negentien leden hadden in de aangekondige verhoging aanleiding gevonden hun lidmaatschap meteen maar op te zeggen. ${ }^{13}$ Secretaris Bleeker moest bij de jubileumbijeenkomst ter gelegenheid van het 75-jarig bestaan van het genootschap op 12 december 1853 melden dat de afwijzende reactie van de leden ertoe had geleid dat van de wijziging voorlopig was afgezien (VBG 25:14). Hij zei nog dat het doel van de herziening was geweest de gewone leden meer bij de werkzaamheden van het genootschap te betrekken. Uiteindelijk zouden de nieuwe wetten pas op 1 januari 1862 van kracht worden, zonder de contributieverhoging. Het lidmaatschap van het genootschap was met veertig gulden per jaar - sinds 1823 ongewijzigd - nooit goedkoop geweest. Het KITLV stelde zijn contributie voor gewone leden bij de oprichting in 1851 op twaalf gulden (Kuitenbrouwer 2001:30).

Het aantal gewone leden in Nederlands-Indië liep terug van 175 (in 1849) tot 136 (in 1853). Gewone leden buiten Nederlands-Indië (verlofgangers) waren er nog maar 36 (in 1853) tegenover 68 (in 1849). ${ }^{14}$ In 1861 was het aantal gewone leden in Indië weer terug op 184 (TBG 12:160). Deze verbetering ten opzichte van 1853 heeft te maken met de specialisering en professionalisering van de genootschapswerkzaamheden en met het effect dat een regelmatig verschijnend, eigen tijdschrift had op de betrokkenheid van de leden. Ook leidde het actieve bestuursoptreden na het vertrek van Visscher tot meer belangstelling.

In 1849 waren er niet meer dan drie Aziaten lid van het genootschap, leden die nog onder Van der Capellens beschermheerschap waren toegetreden. Er was sinds 1826 in dit opzicht dus niets veranderd. Ook de periode-Van Hoëvell had hierin geen verandering gebracht. Die drie Aziatische leden waren de Japanner Katsura Gawa Hoken (alias Wilhelmus Botanicus, corresponderend lid), de sultan van Soemenep, Pakoe Natta Ningrat Logo en de regent van Besoeki, Tommegong Ario Prewiro Adi Ningrat, beiden gewoon lid. Dat er 27 jaar lang geen nieuwe Indonesische leden waren bijgekomen is wel opvallend. In de uitvoering van het cultuurstelsel speelden de inheemse regenten een belangrijke rol. Resident en regent waren broers van elkaar

12 ANRI KBG Dir 0190, vergadering 24-4-1852, punt 4; Dir 0194, vergadering 29-6-1852, punt 3; Dir 0195, vergadering 26-10-1852, punt 2/8; Dir 0196, vergadering 30-11-1852, punt 3.

13 ANRI KBG Dir 1514, omslag 1852, bevat 24 brieven van leden met hun reacties op het voorstel.

$14 \quad$ Ledenlijsten in VBG 22 en 25. 
en wel in de verhouding (die ook een duidelijke hiërarchie uitdrukte) van oudere tot jongere broer. Toch waren het overwegend de oudere broers die lid waren. Het genootschap was teveel een organisatie van Nederlanders in de hoofdplaats dan dat de regenten zich er bij betrokken voelden.

In 1853 werden in de aanloop tot de 75e verjaardag van het genootschap veertien nieuwe leden voorgesteld onder wie de regent van Bandoeng, Raden Toemengong Soeria Karta Adi Negoro, de regent van Demak, Pangeran Aria Tjondro Adi Negoro en zijn collega van Bodjonegoro, Raden Adhipati Tirto Noto. ${ }^{15}$ Tot deze lidmaatschappen werd besloten, nadat de betrokkenen zich verdienstelijk hadden betoond tegenover het genootschap. Het lidmaatschap was een teken van dankbaarheid. De regent van Besoeki trok zich in 1855 echter terug, zodat het aantal Indonesische leden beperkt bleef tot vier. In hetzelfde jaar werd de eerste Afrikaan als gewoon lid genoteerd, de 23-jarige Ghanese prins Akwasi Boachi. ${ }^{16}$ Of de prins van Ashantee, wiens naam sinds het verschijnen van Arthur Japins historische roman De zwarte met het witte hart (1997) bekendheid heeft gekregen, zijn medeleden onder de Javaanse elite ooit op een vergadering ontmoette, blijkt niet uit de notulen. Hij was na zijn opleiding in Delft ingenieur van het mijnwezen geworden en al vanaf de oprichting in 1850 lid geweest van de Natuurkundige Vereeniging in Nederlandsch Indië. Ook van de nieuwe Nederlandsch-Indische Maatschappij van Nijverheid was hij vanaf 1853 lid. Het Bataviaasch Genootschap stond dus niet vooraan om de Afrikaanse prins op te nemen. ${ }^{17}$

Later werd opnieuw naar Japan gekeken. Bestuurslid Elisa Netscher, commies bij de Algemene Secretarie, stelde in juli 1857 voor om in het licht van de nieuwe betrekkingen met Japan vijftig exemplaren van het genootschapstijdschrift door het gouvernement te laten overnemen voor dat land en de commissaris in Deshima te vragen of er Japanse kandidaten zouden zijn voor het corresponderend lidmaatschap. In december was er antwoord van die commissaris. Deze liet weten dat het door de regering aangekochte tijdschrift aan de Japanse regering was aangeboden, maar dat er nog geen zicht was op abonnementen uit Japan. Wel werd op zijn voorstel de directeur van de

15 Voor zij op de lijst werden gezet, had Visscher bij de residenten ter plaatse nagevraagd of het lidmaatschap op prijs zou worden gesteld. ANRI KBG Dir 0200, vergadering 24-10-1853, punt 9.

16 ANRI KBG Dir 0207, vergadering 30-1-1855, punt 2.h; Dir 0209 vergadering 11-4-1855, punt 3.

17 Zie het Natuurkundig Tijdschrift voor Nederlandsch Indië 2 (1851) waar Akwasi Boachi in de ledenlijst is opgenomen. Hetzelfde tijdschrift 4 (1853), verslag algemene vergadering. Op de ledenlijst van de Nederlandsch-Indische Maatschappij van Nijverheid in het Tijdschrift voor Nijverheid 1 (1854) staat geen enkele Indonesiër vermeld, maar wel de naam van de Ashantijnse prins. 
Japanse marine, Nagai Ginba Ka Nami tot corresponderend lid benoemd. ${ }^{18}$ In 1859 werden nog twee Javaanse vorsten tot honorair lid benoemd nadat zij aan Netscher geschenken voor het genootschap hadden meegegeven: Pangeran Adhipati Ario Mangkoenegoro en Pangeran Adhipati Ario Soerio Sasra Ningrat. De regent van Magelang, Raden Adhipati Ario Danoe Ningrit werd tezelfdertijd tot buitengewoon lid benoemd en de kapitein der Chinezen in Yogyakarta, Liem Tiam Sing, tot gewoon lid. ${ }^{19}$ Het ging, kortom, om een handjevol Aziaten in een genootschap van overwegend Europeanen, in grote meerderheid Nederlandse bestuursambtenaren, officieren en predikanten. De groep corresponderende leden - 159 personen in 1850 - kan voor het overgrote deel als 'slapend' worden aangemerkt. Met hun naam gaven zij het genootschap aanzien, maar van hen werd verder niets vernomen. In de groep 'gewone leden buiten Nederlands-Indië' zaten in 1853 nog oude bekenden als Blume, Horsfield en Junghuhn, terwijl andere geleerden (Von Humboldt, Lassen, Reinwardt, Von Siebold) erelid dan wel corresponderend lid waren gebleven. Zij droegen niet bij aan de Verhandelingen, noch aan het Tijdschrift. Een aparte en nieuwe (kleine) categorie vormden de ambtenaren voor de inheemse talen en anderen voor wie het lidmaatschapsgeld te hoog was. Om hen toch aan het genootschap te binden was de titel 'buitengewoon lid' ingesteld, waarvan onder meer A.B. Cohen Stuart, F.C. Wilsen en C.F. Winter gebruik maakten. Het genootschap was bovendien een mannenbolwerk. De dames, echtgenotes en dochters van leden, waren welkom bij de opvoedkundige lezingen van Munnich, maar voor het overige was het mannengezelschap voor hen gesloten. In dat opzicht week het genootschap niet af van de meeste geleerdengenootschappen in het vaderland, maar uiteraard speelde in Indië mee, dat het aantal Europese vrouwen gering was. Leesgezelschappen of natuurkundige gezelschappen van en voor dames waren er in het vaderland wel. In de achttiende eeuw waren er ook vrouwen lid van dichtgenootschappen.

De leden, zo had Bleeker in 1853 gemeld, voelden zich te weinig bij de genootschapsactiviteiten betrokken. Het bestuur trok het zich aan door na te denken over de doelstellingen en het reglement. Een radicale verhoging van het lidmaatschapsgeld was eerder een manier om leden af te stoten. De lezingen van Munnich over het menselijk lichaam waren slecht bezocht, maar er werd niet gedacht aan andere, meer populaire onderwerpen. Ook werd de jaarlijkse algemene vergadering, dé gelegenheid voor de Bataviase leden om elkaar in het genootschapsgebouw in de Rijswijkstraat te ontmoeten, niet altijd gehouden. In de hier beschreven periode van twaalf jaar vonden er 
slechts zes plaats, de laatste in 1856. Dieptepunt waren de jaren 1854-1857, onder Visscher, toen de directie slechts zeventien keer bijeenkwam in vier jaar en er niet meer dan twee algemene vergaderingen werden gehouden. Het verschijnen van het tijdschrift (1852) zou echter wel gunstig uitwerken.

De Geneeskundige Dienst had een sterke vertegenwoordiging in het bestuur met de officieren van gezondheid Bosch, Godefroij, G. Wassink, Bleeker, M.J.E. Müller en Munnich. Ook de legertop was goed vertegenwoordigd met de generaals De Stuers, Van der Wijck en Van Swieten en kolonel R.B.G. de Vaijnes van Brakell, hoofd van de genie. Na Van Hoëvells vertrek was Buddingh de enige predikant tot ook hij voor verlof naar Nederland vertrok. Daarna traden met F.U. van Hengel (1852) en J.F.G. Brumund (1855) pas weer predikanten aan. Medici, militairen, predikanten en bestuursambtenaren zaten in de Rijswijkstraat aan de bestuurstafel.

\section{De noodzaak tot specialiseren: de hand van Bleeker}

In de periode 1849-1860 vond het genootschap definitief zijn eigenlijke werkterrein, dat van de taal-, land- en volkenkunde van de archipel. Het proces van specialiseren, van afstoten van taken en verzamelingen en van systematisch verzamelen en publiceren op het nieuw afgebakende terrein, nam echter lange tijd in beslag. Doortastende beslissingen of een vastberaden doorvoering ervan ontbraken nogal eens. Het algemene, breed-encyclopedische werkterrein van de ongespecificeerde 'kunsten en wetenschappen' was op den duur onhaalbaar. Het steeds wisselende bestuur en de weinig constante ledenpopulatie - zeker in vergelijking met de genootschappen in de achttiende-eeuwse Republiek en het negentiende-eeuwse Koninkrijk - maakten het genootschap te zeer afhankelijk van de toevallige deskundigheden en voorkeuren van zittend bestuur en gewillige leden.

In 1843 was al besloten de zoölogische verzameling over te doen aan het museum in Leiden en verder op dit terrein niet meer te verzamelen. De collectie geologische vondsten, de mineralen, en de schelpenverzameling waren wel aangehouden. Bleekers voorstel van 1847, om het genootschap te hervormen en in te delen in klassen, elk met een eigen werkterrein en een eigen tijdschrift, was te ambitieus gebleken. De indiener ervan zei zelf in 1853 in terugblik, dat het bestuur de tijd er niet rijp voor achtte. ${ }^{20}$ De ambities van Bleeker gingen verder dan de verdeling van werkzaamheden binnen het bestuur, die in 1839 door Van Hoëvell was voorgesteld en die wel was ingevoerd. Toen

20 Bleeker 1853b:13-14. Overigens plaatste Bleeker in zijn 'Levensbericht' van 1877 dit initiatief in 1849 (Bleeker 1877). Bleekers voorstel dateert van 1-2-1847 (ANRI KBG Dir 1512, omslag 1848). 


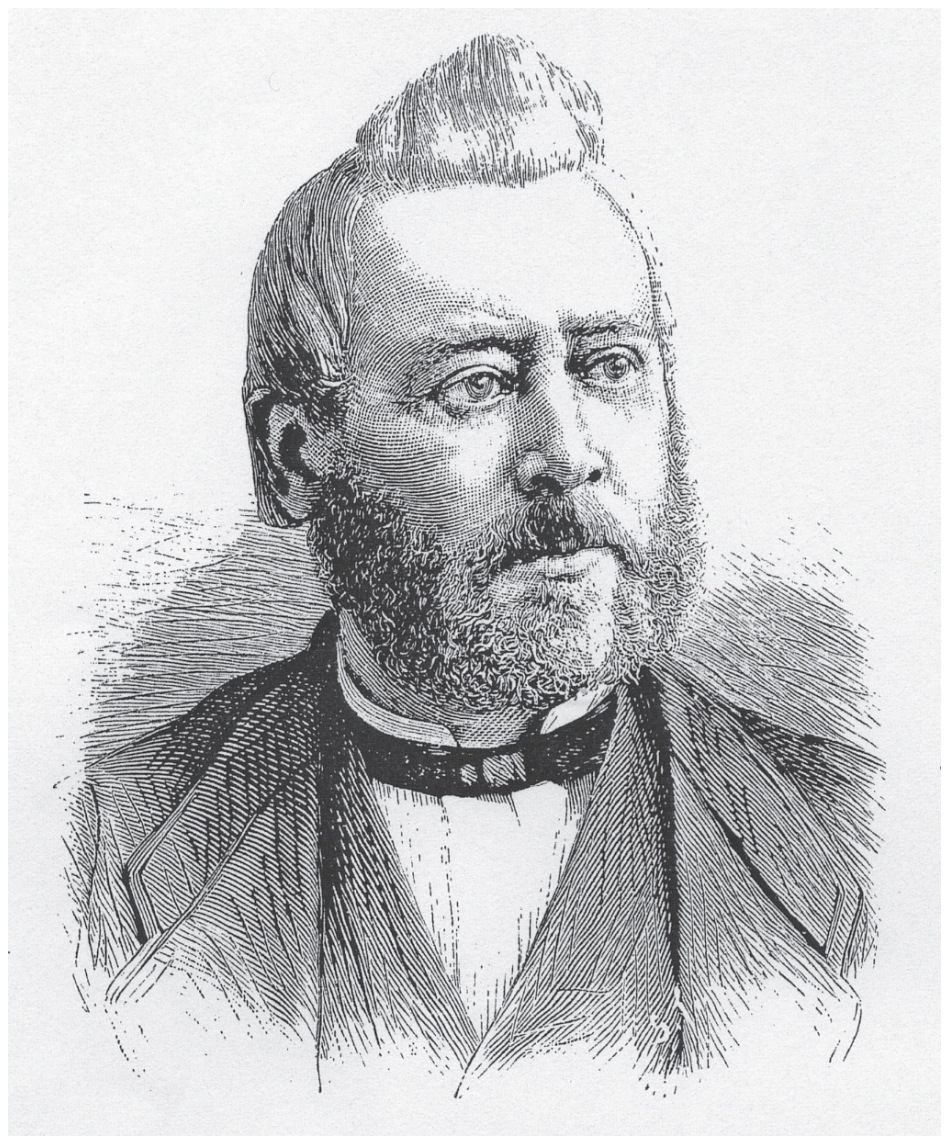

Portret van Pieter Bleeker, secretaris van het genootschap, lithografie uit Eigen Haard (collectie RKD/Iconografisch Bureau Den Haag)

was er sprake van vijf afdelingen, ieder met enkele bestuursleden die in het bijzonder voor hun afdelingen verantwoordelijk waren. Dat had geleid tot een duidelijker taakafbakening, het begin van professionalisering. Na Van Hoëvells vertrek was echter deze scheiding in afdelingen weggevallen. In de genootschapsnotulen werd er niet meer naar de verslagen van de afzonderlijke afdelingen verwezen. Bleekers ideeën vonden geen weerklank. Toen het voorstel van 1852 met een nieuwe verdeling in vijf werkterreinen sneuvelde vanwege de contributieverhoging, was daarmee tevens een poging mislukt om de doelstellingen van 1823 te herschrijven en aan te passen aan de nieuwe tijd. De beweging die door Van Hoëvell was ingezet, stagneerde.

Pieter Bleeker (1819-1878), geboren in Zaandam uit wat hijzelf omschreef als 'eenvoudige burgerlieden', was niet academisch gevormd, maar had zich 
grotendeels door zelfstudie opgewerkt van apothekersbediende tot stedelijk heelmeester en plattelandsgeneeskundige. ${ }^{21}$ Daartoe had hij onder meer een half jaar in Parijs gestudeerd. Toch had hij moeilijkheden ondervonden om zich in Nederland te vestigen. Dat deed hem uiteindelijk besluiten in dienst te treden bij het Nederlands-Indisch leger, waar hij als officier van gezondheid kon werken (1841). Vanaf 1842 in Batavia werkzaam bij de Geneeskundige Dienst, wijdde hij zijn vrije tijd geheel aan zijn hobby, de vissen in de Indonesische wateren. In de Verhandelingen publiceerde hij daarover tussen 1846 en 1857 maar liefst 32 opstellen. In totaal ontdekte en beschreef hij in zijn leven ruim 1100 soorten. Zijn Atlas Ichtyologique des Indes Orientales (1862-1878) zou zijn levenswerk worden. Hij was de oprichter en vanaf 1844 tot zijn vertrek naar Semarang in 1847 de drijvende kracht achter het Natuuren Geneeskundig Archief voor Neêrland's Indië. In dat tijdschrift verschenen vele bijdragen van zijn hand. De eerste jaargang was zelfs bijna voor de helft door hem met eigen bijdragen gevuld. ${ }^{22}$

Bleekers conflict met de overheid naar aanleiding van een brief over hoge portokosten voor wetenschappelijke publicaties, geplaatst in het Tijdschrift voor Neêrland's Indië (1846), leidde tot zijn overplaatsing. Een pessimistische kijk op de toekomst van het wetenschappelijk werk in Indië na de conservatieve maatregelen van 1848, publiceerde hij in datzelfde revolutiejaar in de Journal of the Indian Archipelago aan het eind van een artikel over de vissen van Soembawa.

Batavia, but a short time past the centre of science in Netherlands India, shall speedily be so no more. The scientific periodicals [...] on whose existence these possessions might pride themselves, have all fallen to the ground. The year 1848 will be noted in the history of Netherlands India as the last year of the decennium of its scientific activity. (Journal Indian Archipelago 2:634.)

De rechtstreekse aanval op het bestuur van Rochussen, nota bene in een Singaporees tijdschrift, leidde bijna tot Bleekers ontslag, maar de legerleiding was hiertoe niet bereid. Het feit dat de geneeskundigen militairen waren, redde Bleekers Indische carrière. Zijn conflict met het gouvernement was een afspiegeling op kleinere schaal van het grotere conflict dat Van Hoëvell met de overheid over de vrijheid van drukpers uitvocht. Het tekent Bleeker dat hij zich over deze zaken uitsprak en daarmee zijn positie riskeerde. Van Hoëvell

21 Het navolgende is grotendeels gebaseerd op ENI, s.v. Bleeker; Bleekers eigen 'Levensbericht', zijn 'Verslag der werkzaamheden' in VBG 24 en zijn 'Overzigt' in VBG 25 (Bleeker 1852, 1853b, 1877).

22270 van de 635 pagina's beslaan zijn gesigneerde bijdragen, maar ongetwijfeld is een groot deel van de 'Wetenschappelijke Berigten' ook door hem geschreven of geredigeerd. 
had in hem dan ook een strijdmakker voor het vrije woord.

Bleeker was als bibliothecaris van het genootschap verantwoordelijk voor de eerste gedrukte catalogus van het boekenbezit (Bleeker 1846). Ook in het Natuur-en Geneeskundig Archief had hij zich als bibliograaf doen kennen door overzichten te publiceren. Vanaf 1846 was hij bestuurslid en secretaris van het genootschap. Dat hij bij zijn terugkeer in Batavia in 1849 het idee van een nieuw natuurkundig en geneeskundig tijdschrift opbracht, lag voor de hand. Nadat zijn eigen tijdschrift was gestrand en dat van Van Hoëvell met de oprichter was meegereisd naar Nederland, vond Bleeker Buddinghs Indisch Archief (1849-1851) geen geschikt forum voor zijn natuurwetenschappelijke artikelen. ${ }^{23}$ Daarom richtte hij in 1850 met zeven anderen de Natuurkundige Vereeniging in Nederlandsch Indië op, die nog in hetzelfde jaar een eigen Natuurkundig Tijdschrift voor Nederlandsch Indië begon uit te geven. Juist in die tijd waren er tegen het plan voor een eigen tijdschrift van het genootschap (naar Buddinghs woorden: zijn plan) bezwaren gerezen (VBG 23:18). Gezien Bleekers wel uitgevoerde tijdschriftplannen buiten de kring van het Bataviaasch Genootschap (1850) is het de vraag of niet juist tegenwerking van binnen het genootschap de oprichting vertraagde. Visscher, de achterdochtige algemeen secretaris, stond immers achter het door het gouvernement gesteunde Indisch Archief. Het zou daarom nog tot 1852, na de ondergang van dat blad, duren eer het eigen tijdschrift er zou komen. Het hoeft niet te verbazen dat, toen in 1851 de Vereeniging tot Bevordering van de Geneeskundige Wetenschappen in Nederlandsch Indië werd opgericht, Bleeker eveneens tot de oprichters behoorde. In 1852 begon ook die vereniging met het uitgeven van een eigen tijdschrift. Bleeker was inmiddels hoofd van de opleiding voor inheemse artsen in Batavia, de zogenaamde Dokter Djawa-school, geworden (De Moulin 1989).

Dat Bleeker in de genootschapsdirectie niet verder kon opklimmen - het voorzitterschap leek niet voor hem weggelegd, het secretariaat was het hoogst haalbare - heeft waarschijnlijk te maken met zijn positie als ondergeschikte in de Geneeskundige Dienst en zijn kritische houding tegenover het gouvernement. Zijn superieuren bij die dienst, eerst Godefroij, na 1845 Bosch, waren al lid van het bestuur. Bij de opvolging van Van Hoëvell in 1848 ontbrak Bleeker door zijn overplaatsing. Toen Buddings opvolging in 1850 aan de orde kwam, was zijn baas, Bosch, beschikbaar. Toen Bosch in 1854 aftrad was vice-voorzitter Visscher, geen vriend van Bleeker, de gedoodverfde kandidaat. De schrik zat er sinds 1848 in. Zeker zou men met deze actieve medicus een tweede Van Hoëvell aan het hoofd van het genootschap hebben gezet. Ambtelijke

23 Bovendien was er in 1849 door J. Swaving een aanval op Bleeker in het Indisch Archief gedaan (Van Delden 1993:17). 
rangen en standen speelden in het oude genootschap kennelijk een grotere rol dan in de nieuwe verenigingen, waar Bleeker wel vanaf de aanvang een leidende positie innam. Of speelde Bleekers opleiding hem parten? Hij was geen academisch gevormd geneeskundige, al hadden de Leidse en Utrechtse Universiteit hem wel met een doctoraat geëerd en werd hij in 1855 lid van de Koninklijke Akademie. Het lijkt een complex van factoren, waardoor Bleeker bij het genootschap niet en bij de andere organisaties wel op de voorzitterszetel terecht kwam.

Naast zijn werk als hoofd van de opleiding voor inheemse artsen en zijn bestuurs- en redactiefuncties, zag Bleeker tussen 1850 en 1860 kans om door te werken aan zijn verzameling vissen, die in zijn Atlas zouden komen. Het gouvernement had voor de uitgave in $1852 f 22.000$ toegezegd, maar het project was te groot en te duur voor Batavia en zou pas na Bleekers pensionering in Nederland vorm krijgen (Koloniaal Verslag 1852:40-1; 1853:94-5; 1854:72). Hij stuurde duizenden vissen, zoogdieren, schelpdieren en insecten naar Nederland, die in het Leidse Museum voor Natuurlijke Historie terecht kwamen en bleef binnen het genootschap vechten voor een plaats voor de natuurwetenschappen, ook ná de oprichting van de Natuurkundige Vereeniging. Zijn vertrek naar Nederland in september 1860 was dan ook niet alleen voor het genootschap, maar voor het Bataviase verenigingsleven in het algemeen een verlies. Vóór zijn vertrek veroorzaakte hij nog opschudding doordat zijn 'Algemeen Overzigt' door H.J. Lion, maar zonder Bleekers naam, in de maileditie van het Bataviaasch Handelsblad was geplaatst. Het artikel werd bekend, eerst in Nederland, daarna door overdrukken in de kolonie, door de kritische toon ten opzichte van het regeringsbeleid. Lion onthulde echter niet wie de schrijver was; dat deed pas Bleeker zelf in zijn eigen Levensbericht van $1877 .{ }^{24}$

Terug in Nederland bleef Bleeker een publieke figuur. Hij voerde tussen 1862 en 1866 de redactie van het Tijdschrift voor Nederlandsch Indië, nam daarmee de leiding over van Van Hoëvell, die zelf lid werd van de Raad van State. Bleeker schreef ten tijde van de grote cholera-epidemie van 1866 een brochure over de bestrijding van deze ziekte. Het door hem aanbevolen geneesmiddel kreeg als 'Bleekers-drank' landelijke bekendheid. Hij was ook actief in het Koninklijk Instituut voor Taal-, Land- en Volkenkunde en het Indisch Genootschap. Van beide organisaties was hij tot tweemaal toe voorzitter. Zijn lijst van publicaties, opgenomen achter zijn levensbericht en net als het bericht door Bleeker zelf opgesteld, telt bijna 700 nummers. ${ }^{25}$

Bleeker had in Batavia door zijn activiteiten buiten het genootschap

24 Bleeker 1877:40-1, en Termorshuizen 2001:509-14. Ook Termorshuizen 1998 ('De bittere waarheden van Henri Lion') en Fasseur 1997:103.

25 Telling volgens de ENI 1, s.v. Bleeker. 
de organisatie zelf tot nadenken aangezet over het eigen werkterrein. De Natuurkundige Vereeniging claimde door haar oprichting en in haar tijdschrift een belangrijk deel van het werkterrein dat totdien aan het genootschap had toebehoord. Weliswaar was het verzamelen van zoölogische specimina afgeschaft, maar Bleekers vissen bleven tot 1857 verschijnen in de Verhandelingen. Daarvan voerde de auteur dan ook zelf de redactie. Erg consequent was het niet dat de ichtyologie een belangrijk aandeel in de Verhandelingen behield, terwijl het genootschap zich meer wilde gaan toeleggen op de taal-, land- en volkenkunde. Bleeker legde de algemene ledenvergadering op 27 april 1852 uit dat de Natuurkundige Vereeniging veel had veranderd in de werkzaamheden van het genootschap, maar hij somde bij de zelfde gelegenheid ook de vissensoorten op, waaraan de helft van deel 24 van de Verhandelingen was gewijd. Hij sprak in 1852 de hoop uit dat een volgens Akademie-model in hoofdklassen verdeeld genootschap met inbegrip van de natuurwetenschappen toch gerealiseerd zou worden. Zo'n uitspraak leek tegen de ontwikkelingen in te gaan, waar immers de klasse van de natuurwetenschappen een eigen vereniging had gekregen. Al met al was er geen duidelijke beleidslijn binnen het genootschap en geen strenge afbakening tussen de twee organisaties: Bataviaasch Genootschap en Natuurkundige Vereeniging. Bleeker leek zelf eerder een rem te zijn op de ontwikkeling naar een genootschap van uitsluitend taal-, land- en volkenkunde.

De oprichting van een eigen tijdschrift zou een belangrijke stap betekenen. ${ }^{26}$ Op 27 april 1852 hield Bleeker de algemene vergadering voor dat het tijdschrift vooral gezien moest worden als opvolger van het Indisch Archief (VBG 24:11-2). De periodiek zou in 1852 als het Tijdschrift voor Indische Taal-, Land-en Volkenkunde verschijnen en pas in 1957 in de 85e jaargang ter ziele gaan. Hoewel Bleeker zelf tot 1860 in de redactie zat, bleef het nieuwe tijdschrift, denkelijk onder invloed van Netschers strakke redactiebeleid, voor vissenstukken gesloten. Het tijdschrift hield zich aan zijn naam.

Hoe weinig vastberaden het genootschap optrad bij het verder afbakenen van het nieuwe werkterrein, bleek uit het feit dat dat tijdens de algemene vergadering van 1852 twee prijsvragen werden herhaald, een naar fossielen op Java, de ander naar de aard van minerale bronnen. Die hadden, zou men denken, aan de Natuurkundige Vereeniging kunnen worden overgelaten. In 1857 werd een deel van de collectie, de modellen van werktuigen en gebouwen, aangeboden aan de Maatschappij van Nijverheid, zij het eerder om een praktische reden. Er was plaatsgebrek in het eigen museum. ${ }^{27}$ We krijgen geen antwoord op de vraag of met deze overdracht niet meteen de etnologische 
verzameling werd uitgekleed. Toen in hetzelfde jaar bibliothecaris Munnich voorstelde de mineralen en de geologische verzamelingen af te stoten, was het bestuur huiverig en wilde het die voorlopig voor de lokalen van het genootschap behouden. ${ }^{28}$ Een voorbeeld alweer van een weinig doortastend beleid. Aanwijzingen voor de toenemende specialisatie zijn wel het direct doorschuiven van nieuwe geschenken naar de Natuurkundige Vereeniging en de Maatschappij voor Nijverheid en het verder afzien van het ontvangen van meteorologische waarnemingen uit Deshima. ${ }^{29}$

Terwijl zich aldus het terrein van de taal-, land- en volkenkunde, met onduidelijkheden en inconsequenties, aftekende, meende secretaris Bleeker in 1859, kort voor zijn vertrek naar Nederland, de zaak weer eens aan de orde te moeten stellen. In de vergadering van 7 oktober erkende hij overtuigd te zijn 'dat eene beperking der vroegere rigting van het genootschap onvermijdelijk is geworden door de zustergenootschappen die naast haar zijn ontstaan', maar hij was toch van oordeel 'dat die rigting zich niet uitsluitend mag beperken tot de Indische taal-, land- en volken- en oudheidkunde'. Juist met oog op de aanbieding van natuurhistorische opstellen voor de Verhandelingen wilde hij wel weten wat de directie daarvan vond. Deze kans om een beslissing te nemen tot definitieve inperking liet het bestuur zich opnieuw ontgaan. Mogelijk uit respect voor de secretaris en redacteur van de Verhandelingen die bij al zijn andere verenigingsactiviteiten het genootschap trouw was gebleven, liet het aantekenen 'dat de natuurwetenschappen, evenmin thans als vroeger van de werkzaamheden des genootschaps zijn uitgesloten'. ${ }^{30}$ Deze standpuntbepaling bleef echter zonder gevolg. Bleekers laatste ichtyologische bijdrage was in 1857 in de Verhandelingen verschenen; er zouden er geen meer volgen. Indonesische taal-, land- en volkenkunde, inclusief de archeologie, geschiedenis en numismatiek vormden het terrein van het genootschapstijdschrift én van de Verhandelingen. Natuurwetenschappen en geneeskunde waren door zustergenootschappen overgenomen. Een blik in de eerste jaargangen van het Tijdschrift voor Indische Taal-, Land-en Volkenkunde bevestigt dit reeds. De inperking en verdere specialisering zouden eerder een winstpunt dan een verlies betekenen. De grootse 'akademie-plannen' van Bleeker pasten niet in de beperkte wereld van het Batavia van 1847-1860, waar van hoger onderwijs nog geen sprake was. Met Bleekers vertrek was het genootschap van de natuurwetenschappen 'bevrijd'. 
Verenigingsleven - genootschapsleven

Leek het tot 1848 alsof het Bataviaasch Genootschap de enige organisatie was die zich op het gebied van kunsten en wetenschappen bewoog - een claim waaraan het zeer gehecht was -, in een paar jaar tijd ontstond er een waaier van verenigingen, genootschappen en maatschappijen, waardoor het wetenschappelijk leven drastisch veranderde. Er was in 1848 al een scala van organisaties waar de burgerij haar sociale aspiraties in kwijt kon, enkele al van gerenommeerde ouderdom. Zo waren er de sociëteiten de Harmonie (1815) en Concordia (1820), het nieuwe Concordia (1836) en de Eendragt (ook 1836). Op het terrein van de uitvoerende kunsten waren er het Bataviaasch Liefhebberijtooneel (1817) en de in 1847 opgerichte Maatschappij van Toonkunst. De Bataviaasche Wedloop Sociëteit organiseerde paardenrennen. Organisaties als de Hoofd-Kommissie van Weldadigheid (1831) en de Kommissiën tot Ondersteuning van Behoeftige Christenen (1829) leidden de charitas in goede banen en dan waren er de kerkelijke organisaties, het Nederlandsch Oost-Indisch Bijbel-genootschap en het Javaasch Medewerkend Zendeling Genootschap. Deze organisaties konden echter, gezien vanuit het perspectief van het genootschap als totaal anders worden aangemerkt. Ze begaven zich op een ander terrein.

Het terrein van het genootschap was echter toch wel betreden door anderen, al trokken die nog niet zo de aandacht en werden ze niet als echte concurrenten beschouwd. In dit verband moeten worden genoemd: het wetenschappelijk genootschap onder de zinspreuk 'Tot nut en beschaving' (1847), de Vereeniging Musis (eveneens 1847), en de afdeling van de Maatschappij tot Nut van 't Algemeen (1851). Dat deze alle rond 1848 ontstonden, geeft al aan dat er iets aan het veranderen was. Sommige van deze genootschappen en maatschappijen waren naar binnen gericht of hadden eerder maatschappelijke aspiraties, dan wetenschappelijke pretenties. Zo bereikte een leesgezelschap als Musis een beperkte groep, terwijl het Nut zich op openbare voorzieningen (onderwijs, bibliotheken, spaarbanken) toelegde. Ze maakten het hoe dan ook, tezamen met de in de vorige alinea genoemde organisaties, voor een bredere groep uit de Europese bevolking van Batavia mogelijk keuzes te maken. Er was een differentiatie ontstaan in sociaal, maatschappelijk en wetenschappelijk verkeer, van nieuwe leesgezelschappen en vakverenigingen tot het oude genootschap en de kerkelijke organisaties, die het Bataviaasch Genootschap aanspoorde tot nadenken over de eigen plaats binnen een veranderende context. Het dwong het genootschap zich te profileren en - wilde het overleven - te professionaliseren.

Enkele van de organisaties dienen wat nader bekeken te worden, omdat zij door hun doelstellingen en structuur het Bataviaasch Genootschap meer nabij kwamen. In dat verband is de claim van 'de oudste en de enige' die het 
genootschap opeiste maar ten dele waar. Om dat te illustreren gaan we eerst terug in de tijd. Het is logisch dat de ambtenaren, die door de Nederlandse regering naar Indië werden uitgezonden, alsook militairen en predikanten, in hun sociaal-culturele bagage de behoefte aan genootschaps- en verenigingsactiviteiten meenamen. Dat het genootschap lang als enige op de voorgrond stond, betekende niet dat andere genootschappelijke behoeften in Batavia uitbleven of onderdrukt werden. Net als in het vaderland is echter van deze activiteiten maar ten dele iets in de archieven en bibliotheken overgeleverd, omdat de genootschappen of gezelschappen veelal klein waren en niet te zeer de openbaarheid zochten. Verder bestonden ze veelal kort of lieten na notulen bij te houden.

Een diploma van het Genootschap van Natuur-Onderzoekers te Batavia onder de zinspreuk 'Der Schepping eerste hoofdgebod, Verpligt ons tot natuurgenot', uitgegeven aan de 23-jarige Alexander Willem Nimrod en ondertekend door voorzitter Midas en geheimschrijver Lord Byron op 4 augustus 1826, is een aanwijzing voor het bestaan van wat een speelse variant op het serieuze genootschap in Batavia moet zijn geweest. De luxe uitvoering van het diploma met een twintig versregels tellende tekst, met een fraai rood stempel en met een humoristisch signalement van het nieuwe lid Nimrod, doet vermoeden dat het diploma niet zo maar een incidentele grap is geweest. Had een groep Bataviase burgers een studentikoos schertsgenootschap opgericht? De behoefte aan geheimzinnigheid werd duidelijk aangegeven door de schuilnamen, terwijl een 48-regelige, eveneens gedrukte en rijmende eed, door het nieuwe lid uit te spreken, een verwijzing naar de beslotenheid van de vrijmetselarij was. Meer dan dit ene diploma is van dit genootschap van 'Natuur-Onderzoekers' niet bekend, zodat we moeilijk kunnen besluiten dat het louter tot vermaak en scherts was opgericht of dat er bijkomende serieuze doelstellingen waren. Het moet betekenen dat in die vroege jaren van het herstelde Nederlandse gezag op Java het Bataviaasch Genootschap niet alle sociale en wetenschappelijke aspiraties kon opnemen. J.C. Baud, in wiens bezit het diploma kwam, noteerde achterop dat het hem in Nederland was overhandigd 'ten bewijze van de neiging die bij de voorname ambtenaren te Batavia heerscht, om hun tijd nuttig te besteden'. In die notitie ging hij aan het schertsende, humoristische karakter van het document (en dus wellicht van het genootschap als geheel) voorbij. ${ }^{31}$ Baud, die zelf in 1833 lid en bij zijn vertrek in 1836 honorair lid van het Bataviaasch Genootschap werd, legde geen verband met deze oudere instelling. ${ }^{32}$ In 1826 was hij in Den Haag werkzaam geweest. Vandaar dat het aannemelijk is dat hij niet zelf bij dit

$31 \quad$ NA, Collectie J.C. Baud, 2.21.007.58, nummer 1077 (5).

32 De collectie Baud bevat onder nummer 1078 twee diploma's van hemzelf als lid en honorair lid van het Bataviaasch Genootschap. 
gezelschap betrokken was. Vermoedelijk heeft het Genootschap van NatuurOnderzoekers geen lang leven geleid.

Van het ernstig bedoelde Natuur- en Letterkunde Beoefenend Genootschap te Batavia, onder de zinspreuk 'Studio et Labore', waarvan de gedrukte wetten op 1 augustus 1831 door voorzitter J.C. Meder en secretaris C.J. Loman zijn ondertekend, weten we ook niet veel. ${ }^{33}$ Het genootschap wilde 'aangename bijeenkomsten' verzorgen en de leden op eene voor elkander nuttige wijze bezig houden'. Het bepaalde dat het verhandelingen (lezingen) wilde houden, vooral over de geschiedenis van Oost-Indië, van Java in het bijzonder, en stelde zich voor een bibliotheek en een museum op te richten. Uit de heel gedetailleerde regels blijkt dat het houden van leerzame vergaderingen met spreekbeurten en het rondzenden van boeken het eerst werden aangevat, zodat het genootschap het karakter van een leesgezelschap leek te krijgen. De kosten (vijf gulden per maand) naast een entreegeld van vijfentwintig gulden geven al aan dat het genootschap kapitaal nodig had om aankopen te kunnen doen, om met de rondzending van lectuur te beginnen. Het lidmaatschap was niet goedkoop. Het genootschap was in 1828 opgericht en telde in 1833 zeventien gewone en 23 corresponderende leden. ${ }^{34}$ Onder de honoraire leden waren onder anderen Van der Vinne en de sultan van Soemenep. Met corresponderende leden in Nederland en Indië was het geen louter leesclubje van beperkte omvang. In een brief van maart 1833 schreef oud-gouverneurgeneraal Van der Capellen aan Van der Vinne: 'De berigten aangaande het gezelschap Studio \& Labore las ik met het grootste genoegen'. ${ }^{35}$ De gegevens over dit genootschap zijn toch voldoende om aan te nemen dat het meer dan een eendagsvlinder was. De Haan signaleert in 1833 nog een leesgezelschap 'Tot nut en uitspanning' (De Haan 1935a, I:536). Hoewel de bronnen voor deze gegevens schaars zijn, bewijzen ze dat het genootschap in de jaren twintig en dertig al concurrenten kreeg. Nadere gegevens over genootschappen en gezelschappen in de periode 1816-1846 zijn zeer gewenst, juist als blijkt dat sommige, zoals 'Studio et Labore', op een terrein leken te werken dat nauw verwant was aan dat van het Bataviaasch Genootschap en daardoor ook dezelfde mensen aansprak.

Van de behoefte om in gezelschap te lezen en te discussiëren getuigt de ironische beschrijving van gezellige bijeenkomsten in Batavia, gekoppeld aan een serieus voorstel, zoals dat door Munnich werd geformuleerd in 'De problematieke oprigting van een Leesmuseum te Batavia, nog onder geene zinspreuk' (1846). Drie heren op een gezellige bijeenkomst, 'waar eerst thee

33 Wetten Studio et Labore 1831 (exemplaar KITLV dd 133).

34 Deze schaarse gegevens zijn ontleend aan de Almanak van Nederlandsch Indië (1833).

35 ANRI KBG Dir 0087, vergadering 20-2-1834, bijlage 63. Brief uit Vollenhove, maart 1833 aan J. van der Vinne. 
gedronken en over koffij gesproken werd' komen tot de conclusie 'dat het hier uiterst moeielijk is zoo veel wetenschappelijke sujetten in gezelschap bijeen te treffen, als er nodig zijn om den avond nuttig en aangenaam te doen omvliegen'. In dit verband krijgt het oude genootschap ervan langs.

Instellingen als het Bataviaasch Genootschap zijn meer conservatoriën, archieven der wetenschap te noemen, waar ze zich slechts nu en dan in haar galagewaad in het openbaar mag vertoonen; hoewel ik niet wil ontkennen, dat zulks hier en daar anders konde zijn, aangezien in mijn oog de wetenschap, die zich geheel opsluit, bijkans een doelloos en onnut bestaan heeft, en onze vergaarde kennis even goed een deel moet uitmaken van het volk als van de hooggeleerde heren (TNI 8, II:5767).

Misschien was de toevoeging van 'nog onder geene zinspreuk' wel een knipoog naar het genootschap. Dat had wel een plechtige zinspreuk, 'Tot nut van het gemeen', maar wat betekende dat, als het niets voor de maatschappij deed? Batavia had op dat moment geen leesmuseum zoals Munnich zich dat voorstelde: een leeszaal met 'de nieuwste en beste periodieken uit Europa in alle takken van wetenschap, kunst en bellettrie, zowel dagbladen als tijdschriften'. Die leeszaal moest dan overdag en 's avonds geopend zijn en daarnaast zou er een ruimte moeten zijn voor gesprekken, discussies, met een of twee vaste avonden per week waarop men 'een uitgezocht lezend en ook sprekend gezelschap [kon] ontmoeten' (TNI 8, II:578-9).

Het Wetenschappelijk Genootschap onder de zinspreuk 'Tot Nut en Beschaving' en de 'Vereeniging Musis' leken in 1847 een vervulling van Munnichs wensen. Van de twee zou Musis de meeste sporen nalaten. In 1856 werd het negende jaarverslag uitgebracht van deze vereniging die vooral een leesgezelschap was, in welker kring het houden van leerzame spreekbeurten een vaste gewoonte en zelfs een plicht van de leden was. Munnich was zelf een van de oprichters. Hij had dus serieus gewerkt aan zijn 'Leesmuseum'. Tot de mede-oprichters behoorden J. Millard, A.N. Teengs en J. Einthoven, allen door de voorzitters genoemd als sprekers op de verenigingsavonden. Van de oprichters was alleen Munnich in 1847 lid van het Bataviaasch Genootschap. Helaas zijn van deze interessante vereniging alleen de wetten en twee jaarverslagen overgeleverd. ${ }^{36}$ Twee jaar na de oprichting had de vereniging slechts twaalf gewone leden, tien buitengewone en een honorair lid. Van Hoëvell

\footnotetext{
36 Reglement Musis 1848 (exemplaren KITLV dd 189 en Perpunas B 342 a). Het KITLV bezit bovendien de twee verslagen van 1849 en 1851: Verslag van den staat der werkzaamheden van de Vereeniging Musis (dd 158). De gedrukte Catalogus van de bibliotheek van het Bataviaasch Genootschap (Van der Chijs 1864) vermeldt ook een reglement van 'Musis' van 1854 en het negende verslag uit 1856 . De vereniging zal dus tot minstens 1856 een regelmatig leven hebben geleid. Millard werd genoemd in het verslag van 1849, Munnich in dat van 1851.
} 
was de vereniging goed gezind geweest en zijn vertrek had zijn vrienden van Musis leed gedaan. Verder was Eduard Douwes Dekker kort lid geweest. Hij had zijn 'Brokstukken uit het dagboek van een oud man' afgestaan. Of hij die ook had voorgedragen, vermeldt het verslag van 1849 niet, wel dat hij een album had achtergelaten 'versierd met een smaakvol opschrift, [in] de hand zijner beminnelijke echtgenoot'. Verder had Douwes Dekker de avonden van Musis verlevendigd door het vrije debat te introduceren, 'het spreken voor de vuist' 37

Musis was vooral een leesgezelschap met levendige verenigingsavonden, met voordrachten en debatten. Het had in 1849 abonnementen op 23 tijdschriften, terwijl er nog zeven in bestelling waren. In 1851 had het abonnementen op 36 tijdschrijften in vier talen. De 'leesinrigting' was daarmee een voorname activiteit en voldeed zo te zien aan Munnichs wensen op dat punt. Daarvoor betaalden de leden tien gulden bij de aanvang en maandelijks vijf gulden. In het begin bestond er een uitgebreid systeem van boetes voor het niet nakomen van verplichtingen, wat echter in 1848 al werd gematigd. Musis probeerde een aanvulling te zijn op de kennelijk niet als leesmuseum of leesinrichting functionerende bibliotheek van het Bataviaasch Genootschap. Aan de leesbehoefte van de genootschapsleden Bosch, Munnich, Bleeker, Versteeg en Netscher, allen lid van Musis, voldeed de bibliotheek aan de Rijswijkstraat niet. Vandaar de gang naar de uitgebreide voorziening van Musis. Het beperkte aantal leden (twaalf in het tweede jaar) wijst erop dat Musis klein wilde blijven, waardoor de vlotte beschikbaarheid van de lectuurmappen gegarandeerd was. De tijdschriften die rondgezonden werden, kwamen ten dele ook in de bibliotheek van het Bataviaasch Genootschap voor. Musis moeten we daarom vooral zien als een particuliere aanvulling op de bibliotheek van het genootschap en als een signaal aan het bestuur dat er nog wel wat veranderd diende te worden.

Hoewel het eveneens in 1847 opgerichte 'Tot Nut en Beschaving' zich veel nadrukkelijker op het terrein van het Bataviaasch Genootschap leek te gaan bewegen - het stelde zich ten doel 'de beoefening en verspreiding van kunsten en wetenschappen bevorderlijk te zijn' - pakte dit genootschap niet uit als een serieuze concurrent. Uit het op 8 mei 1847 door een buitengewone vergadering van de leden vastgesteld reglement, ondertekend door secretaris T.C.A. Hagenaar, blijkt dat de ambities niet gingen in de richting van een museum, maar vooral gericht waren op het houden van voordrachten op leerzame avonden door de werkende leden en pas op de tweede plaats het bijhouden van een bibliotheek en archief ter beschikking van de leden. Over het rondzenden van kranten en tijdschriften zegt het reglement 
niets. De lidmaatschapsgelden waren lager. De leden betaalden vijf gulden entreegeld en verder maandelijks een contributie van drie gulden, waarbij ze verplicht waren spreekbeurten te houden. ${ }^{38}$ Dit genootschap probeerde een ander publiek aan te spreken. Hagenaar was geen lid van het Bataviaasch Genootschap.

Een Reglement voor het leesgezelschap 'Utile et Dulce' (1849), 39 wijst er nog eens op dat de bibliotheek van het Genootschap niet voldeed aan de behoeften van een leesgierig publiek. Musis en Utile zijn hoogstwaarschijnlijk slechts enkele van een grotere groep leesgezelschappen, die met een economische bedoeling waren opgericht. 'Studio et Labore' (1828) was een oudere voorganger. Abonnementen waren duur, maar vooral de verzending naar Indië deed een aanslag op de portemonnee. Leesgezelschappen losten dat probleem op. De verslagen van Musis tonen aan dat er voor een kleine groep lezers een ruim aanbod ter beschikking kwam. Voor Utile, waarvan het aantal leden bij de aanvang op maximaal 25 was vastgesteld, zal dat evenzeer hebben gegolden. De groei en bloei van deze leesgezelschappen (in $1864 \mathrm{kwam}$ er een juridisch leesgezelschap bij, ${ }^{40}$ in allerlei plaatsen in Indië bloeiden leesgezelschappen op) liet het Bataviaasch Genootschap ongemoeid. Het genootschap speelde met de bibliotheek niet in op een nieuw publiek, terwijl de leesbehoefte duidelijk aanwezig was. Het stelde de bibliotheek wel open, maar leende niet uit. De leestrommel, waarop men zich abonneerde en van de genoegens waarvan met thuis kon genieten, voldeed beter dan een leeszaal aan de Rijswijkstraat. Andere bibliotheken, zoals die van het Nut en de Batavia British Library (1853) laten zien dat er op leesgebied, naast de leesgezelschappen, voor verschillende groepen voorzieningen ontstonden. Het Genootschap stond met zijn bibliotheek niet meer alleen en was onvoldoende toegankelijk. Maar lezen was niet het enige. Bijeenkomen, discussiëren, leerzame en onderhoudende avonden beleggen was een tweede, niet minder belangrijke doelstelling. In dat opzicht voldeed het genootschap evenmin. De Haan meldt dat er in 1859 zoveel leesgezelschappen in Batavia waren dat de boekenverkoop eronder leed (De Haan 1935a, I:536). We mogen aannemen dat het ook voordien al zo was. Men had zich dus georganiseerd.

\footnotetext{
38 Reglement Tot Nut en Beschaving 1847 (exemplaar Perpusnas B 342 q).

39 Reglement Utile et Dulce 1849 (exemplaar Perpusnas B 342 g). De Perpustakaan Nasional bezit onder dit nummer (B 342) een map met een groot aantal brochures met reglementen, wetten, enz., van sociaal-cultureel-wetenschappelijke organisaties in Batavia niet alleen, maar ook in de buitengewesten, vanaf 1847.

$40 \quad$ Reglement Juridisch Leesgezelschap 1864 (exemplaar Perpusnas B 342 i).
} 


\section{Concurrerende verenigingen en dubbellidmaatschappen}

Waren de al eerder genoemde Natuurkundige Vereeniging (1850), de Vereeniging ter bevordering der Geneeskundige Wetenschappen (1851) en de Nederlandsch-Indische Maatschappij van Nijverheid (1853), alle drie grotendeels scheppingen van Bleeker, nu juist wel concurrenten van het Bataviaasch Genootschap? Om die vraag te beantwoorden, moeten we hun ontstaansgeschiedenis wat nader bezien en vooral kijken naar de personen die bij de oprichting betrokken waren. Verder is het ledenbestand van de nieuwe verenigingen interessant. In hoeverre ging het om dezelfde personen die ook van het genootschap deel uitmaakten?

De Natuurkundige Vereeniging gaat terug tot 19 juli 1850. Op die datum werd besloten tot de oprichting van een vereniging die zich zou bezighouden met de 'natuurkundige wetenschappen in den uitgebreidsten zin, [waarbij] op den voorgrond moest staan, de nasporing der natuur van Nederlandsch Indië' (Natuurkundig Tijdschrift 2:2). Zes van de acht oprichters waren zelf lid van het Bataviaasch Genootschap: Bleeker, J.H. Croockewit, J.P. Cornets de Groot, P.J. Maier, P. Melvill van Carnbee en C. Swaving. In een brief aan het genootschap van dezelfde datum verzochten de oprichters om steun. Voor het uitbrengen van een eigen tijdschrift hadden ze geen geld en dus vroegen zij het genootschap de kosten op zich te nemen. De uitgaven werden begroot op $f 1.600$ per jaar, terwijl aan inkomsten zo'n $f 1.000$ werd verwacht. Het genootschap zag het tijdschrift als een interessant project en steunde de uitgave. Wel werd bedongen dat de leden van het Bataviaasch Genootschap, als tegenprestatie voor het steunpakket, aanspraak konden maken op een exemplaar van het tijdschrift, een collectief abonnement als het ware. ${ }^{41}$ Later zou het bestuur nog spijt krijgen van deze ruimhartigheid, want de kosten zouden lang niet tegen de inkomsten opwegen.

Van frustratie onder de natuurkundigen ten tijde van de oprichting, over bijvoorbeeld beperkingen die zij van het genootschap ondervonden, blijkt niets. Wel mogen we veronderstellen dat de aandacht voor de oudheidkunde en voor de studie van talen en teksten, die in het genootschap in de jaren 1840 sterk naar voren was gekomen, in de ogen van de natuurkundigen het karakter van het genootschap had veranderd. De behoefte aan een eigen vereniging zal daardoor mede gevoed zijn. Uit het feit echter dat het genootschap een gunstige beslissing nam inzake het tijdschrift, blijkt dat de Natuurkundige Vereeniging niet als een bedreiging werd gezien. Bleeker werd voorzitter van de nieuwe vereniging, de voorzitter van het genootschap Bosch werd er tot

41 Zowel de brief van de oprichters als het antwoord van het genootschap, waarschijnlijk door secretaris Bleeker opgesteld, die ook de brief aan het genootschap opstelde, staan afgedrukt in het Natuurkundig Tijdschrift 2:5-12. 
erelid benoemd en en de medicus G. Wassink, bestuurslid van het genootschap, werd gewoon lid. Ten tijde van de tweede algemene vergadering van de vereniging (1852) waren zes van de negen bestuursleden tevens lid van het genootschap. Van de 59 gewone leden van de vereniging waren er 27 tevens lid van het genootschap. Ook van de corresponderende leden (elf in 1852) waren er vijf corresponderend lid van het genootschap (Natuurkundig Tijdschrift 3:20-3).

In de aanvang vroeg de vereniging geen contributie: alle kosten werden door de dirigerende leden en door het Bataviaasch Genootschap gedragen. Er werd geen drempel aangebracht, waar het genootschap met veertig gulden contributie en een entreegeld van tweeëntwintig gulden nog steeds een hoge grens trok tussen leden en niet-leden. J. Hageman, ambtenaar te Soerabaija en buitengewoon lid van het genootschap omdat voor hem de contributie voor het gewone lidmaatschap te hoog was, kon tot de vereniging direct als gewoon lid toetreden.

De vereniging had vooral aantrekkingskracht op ingenieurs van het mijnwezen, officieren van gezondheid en andere geneeskundigen, apothekers, officieren van de artillerie en de genie en hun vakbroeders bij de marine. Met niet meer dan drie residenten en twee controleurs waren de ambtenaren van het binnenlands bestuur in 1852 in vergelijking met het genootschap slecht vertegenwoordigd. De dubbellidmaatschappen bij de gewone leden lagen vooral in de kringen van ingenieurs, officieren van gezondheid en hun vakbroeders, technici dus in vergelijking tot veel van hun ambtenaren-collega's.

Bleeker, die met steun van het genootschap nu bij de vereniging een nieuw medium had voor zijn vissenstudies, stuurde, zoals we eerder gezien hebben, juist niet aan op een scherpe afbakening van werkterrein tussen genootschap en vereniging. Dit zou in de lijn van de verwachtingen hebben gelegen, opdat de vereniging met overgenomen taken niet in een concurrentiepositie zou hoeven te komen met de bijna 75-jarige zusterorganisatie. Sterker nog, Bleeker zou tot het einde van zijn verblijf in Indië juist de samensmelting van alle takken van wetenschap in een Bataviase academie bepleiten.

Toen hij in 1851 met zijn collega's een aparte vereniging van geneeskundigen oprichtte, leidde dat niet direct tot het weglopen van de geneeskundigen bij het genootschap. De Geneeskundige Dienst was in de jaren 1849-1860 sterk vertegenwoordigd in het genootschapsbestuur. Voor concurrentie werd niet gevreesd. In de notulen van het genootschap lezen we opvallend weinig over de nieuwe organisaties. Van bezorgdheid voor de eigen positie door het zich uitbreidende veld van verenigingen en organisaties, is geen sprake. Voorlopig kon het genootschap met 411 leden in 1852 tegenover de 81 leden van de jonge Natuurkundige Vereeniging ook wel gerust zijn. Net als bij het veel kleinere Musis was er een duidelijke overlapping met de leden van het genootschap. Er bleek plaats te zijn voor meer organisaties dan het aloude genootschap alleen. 
Hetzelfde kan geconcludeerd worden ten aanzien van de in 1853 opgerichte Nederlandsch-Indische Maatschappij van Nijverheid. Het ontstaan daarvan was te danken aan een in de kring van de Natuurkundige Vereeniging geboren plan om een tentoonstelling te houden van 'produkten der natuur en der industrie van den Indischen Archipel'. De eerste ideeën daartoe werden al in 1851 gelanceerd. In 1852 stemde het gouvernement ermee in. Op 6 maart 1852 werd een circulaire opgesteld en verspreid waaronder de namen stonden van drieëntwintig commissieleden die zich belastten met de organisatie van de tentoonstelling (Natuurkundig Tijdschrift 3:126-31). Vijftien van hen waren tevens lid van het genootschap. Onmiddellijk na de opening van de tentoonstelling, die groot enthousiasme verwekte, nam het commissielid Bleeker het initiatief tot het oprichten van de Maatschappij van Nijverheid. Het tijdelijke karakter van de tentoonstelling moest worden doorbroken, aldus Bleeker. Er moest een permanente opstelling van dit soort producten komen in een Museum voor Landbouw en Nijverheid, mogelijk door het als tijdelijk bedoelde tentoonstellingsgebouw een vaste bestemming te geven (Tijdschrift voor Nijverheid 1:2-4). Voor de realisering daarvan was een organisatie nodig, waartoe op 2 december 1853 de maatschappij werd opgericht.

Van de achttien bestuursleden van de nieuwe maatschappij waren er acht tevens lid van het genootschap. Drie van de achttien bestuursleden hadden tevens zitting in het genootschapsbestuur: Bleeker, de oud-hoofdingenieur van de waterstaat J. Tromp en de ontvanger van de inkomende en uitgaande rechten E.A. Schill. Dubbellidmaatschappen kwamen natuurlijk ook voor in de kringen van de gewone leden. 25 van de 195 gewone leden van de maatschappij waren ook bij het genootschap lid. Daarmee was de overlapping bij deze organisatie minder sterk dan die tussen het genootschap en de Natuurkundige Vereeniging (Tijdschrift voor Nijverheid 1:164-74). Van deze 25 dubbelleden waren er slechts drie koopman, wat een indicatie is voor het verschil van het ledenbestand van het genootschap en de maatschappij. Van het bestuur van de laatste waren vijf personen koopman, industrieel of fabrikant, wat niet verwondert, gezien het werkterrein van de maatschappij. Van de 195 gewone leden van de maatschappij waren er 67 koopman, particulier, boekhandelaar, fabrikant of planter, ruim een derde. Ook opvallend is de aanwezigheid van onderwijzers in de gelederen van de maatschappij, terwijl de contributie van dertig gulden per jaar niet gering was. Bijna 200 gewone (betalende) leden in een jaar tijd, was een goede indicatie voor de aantrekkingskracht van de Maatschappij van Nijverheid. De maatschappij had een ander ledenbestand dan het genootschap dat gedomineerd werd door ambtenaren van het binnenlands bestuur en van de Bataviase overheidsdiensten, militairen, geneeskundigen en vertegenwoordigers van de rechterlijke macht, vooral uit de hogere rangen. Het genootschap leunde ook daardoor tegen de overheid aan, in tegenstelling tot de Maatschappij van 
Nijverheid, die sterker wortelde in het bedrijfsleven.

Dat de Maatschappij van Nijverheid en de Natuurkundige Vereeniging onderling veel overlappende lidmaatschappen kenden, is vanzelfsprekend, gezien de voorgeschiedenis. Van de achttien bestuursleden van de maatschappij waren er slechts twee geen lid van de vereniging. Dubbele bestuurslidmaatschappen waren er ook: Bleeker, de Bataviase havenmeester J. Groll, laborant bij het scheikundig laboratorium Maier en luitenant ter zee G.F. de Bruijn Kops zaten bij maatschappij en vereniging in het bestuur.

Kampioen-overlapper was de chef van de Geneeskundige Dienst Wassink. Hij was gewoon lid van de Maatschappij van Nijverheid en van de Natuurkundige Vereeniging, vice-president van het Bataviaasch Genootschap, president van de Vereeniging ter bevordering der Geneeskundige Wetenschappen en president van de Maatschappij tot Nut van het Algemeen. In 1862 zou hij ook voorzitter worden van het Bataviaasch Genootschap. Bleeker was voorzitter van de Natuurkundige Vereeniging, secretaris van het genootschap, bestuurslid van de Maatschappij van Nijverheid en van de Vereeniging ter bevordering der geneeskundige wetenschappen. Hij had in 1854 zitting in vier besturen.

Dat het opvallende ledenverlies van het genootschap tussen 1852 en 1855 veroorzaakt werd door de komst van concurrenten, zou een te eenvoudige conclusie zijn. Zoals gezegd veroorzaakte Bleekers voorstel tot verdriedubbeling van de genootschappelijke contributie heel wat schade in de gelederen van de betalende, gewone leden. Dat er in korte tijd meer keuze was gekomen door de komst van nieuwe organisaties, zal zeker een effect hebben gehad, maar in 1861 was het aantal betalende leden bij het genootschap weer op peil (185 op een totaal aantal leden van 367). Als de concurrentie enige invloed heeft gehad op het ledental, dan niet blijvend. Over de concurrentie op het werkterrein van het genootschap hebben we het al gehad. Het bestaan van de nieuwe organisaties zette het genootschap aan tot nadenken en tot het afperken van het eigen werkterrein, maar die beweging was al voor 1850 ingezet. Alleen daardoor kon het iets van de unieke positie redden waar het zo trots op was. Het succes van de nieuwe verenigingen, die alle drie in korte tijd een aanzienlijk ledental hadden, had het genootschap sneller tot bezinning moeten brengen over de doelstellingen en het werkterrein. Dat deed het echter aanvankelijk te weinig zodat het proces van specialisatie en beperking zich te langzaam voltrok. Het genootschap evolueerde te langzaam en raakte zelfs enigszins geïsoleerd. Bij de grote Bataviase nijverheidstentoonstelling (1853) had het geen andere rol dan die van bescheiden inzender.

In de eigen notulen komen maar weinig verwijzingen voor naar de nieuwe instellingen. Dat de veranderingen in werkterrein en doelstellingen rond 1860 toch binnen het genootschap hun beslag kregen, werd eerder door de ontwikkelingen buiten dan binnen het genootschap veroorzaakt. Het genootschap 
moest wel meegaan met de tijd, al deed het dat schoorvoetend. De komst van vier nieuwe Bataviase tijdschriften in een periode van vier jaar (1851-1854), spreekbuizen van even zovele organisaties, maakte het noodzakelijk dat het genootschapstijdschrift - een van de vier - zich beperkte tot de Indische taal-, land- en volkenkunde.

De toename van het aantal afdelingen van de Maatschappij tot Nut van 't Algemeen (in 1833 alleen nog in Soerabaija, in 1852 in Batavia, Semarang, Buitenzorg en Banjoemas) laat zien dat deze maatschappij evenzeer in een behoefte voorzag. De overeenkomst in de naam van de maatschappij met de zinspreuk van het genootschap stoorde kennelijk niemand. Van een bijzonder contact tussen het genootschap en het 'Nut' in Indië blijkt uit de genootschapsnotulen niets. En dat terwijl drie van de vijf Nuts-bestuursleden, te weten Wassink, Bleeker en de predikant Van Hengel, ook in het bestuur van het genootschap zaten. Overigens is het opvallend dat de Bataviase afdeling van het Nut pas na 1850 tot stand kwam, juist in de periode dat ook de andere verenigingen opkwamen. Het aanzicht van Batavia was echt veranderd. Er lijkt meer vrijheid van en behoefte aan vereniging te worden gevoeld.

Al met al zien we een niet zo actief genootschap, dat te langzaam reageerde op de veranderingen om zich heen. Waren de gezelschappen en genootschappen van voor 1848 nog klein en zeker niet bedreigend geweest, de nieuwe organisaties stonden sterk en zelfverzekerd in de sociaal-wetenschappelijke werkelijkheid van Batavia. Bovendien bewogen ze zich op een terrein dat tevoren (groten)deels door het genootschap was beploegd. In die zin was er concurrentie gekomen. Toch zou het genootschap op termijn zijn positie versterken. Terwijl de Natuurkundige Vereeniging en Maatschappij van Nijverheid bij elkaar introkken in een woonhuis op Rijswijk, wist het genootschap zelfstandig te blijven en als enige van de overheid opnieuw een eigen gebouw te krijgen.

Ten tijde van de opening van het nieuwe genootschapsgebouw (1867) waren de verhoudingen tussen de verenigingen bestendigd. Er waren verschuivingen, maar deze waren niet dramatisch. Nog steeds waren drie van de elf leden van het genootschapsbestuur ook bestuurslid bij de (inmiddels) Koninklijke Natuurkundige Vereeniging: de gepensioneerde geografisch ingenieur G.A. de Lange, de oud-marineman G.F. de Bruijn Kops en de conrector van het gymnasium Koning Willem III, L.W.G. de Roo. Met de Maatschappij van Nijverheid waren er eveneens drie overlappende bestuursplaatsen: opnieuw De Lange, verder Van der Chijs en de factorij-man N.P. van den Berg. Ook tussen Maatschappij van Nijverheid en Natuurkundige Vereeniging waren er drie overlappende bestuursleden. De Lange zat in alle drie besturen en was dus net als Wassink in de jaren 1850 het meest actief. Inmiddels was de Natuurkundige Vereeniging groter geworden dan het genootschap. Zij telde 413 leden. 25 van de gewone leden waren tevens lid 
van het genootschap. Als we alle leden meerekenen, ook honoraire en correponderende leden, waren er 38 overlappende lidmaatschappen. Dat was naar verhouding minder dan in de beginjaren, waaruit we mogen concluderen dat voor een aantal personen het dubbele lidmaatschap geen zin had. Overigens moet bij het grote ledental van de Natuurkundige Vereeniging worden aangetekend dat zij nog steeds de leden buiten Nederlands-Indië (verlofgangers) meerekende, wat het genootschap sinds 1864 niet meer deed. Met de Maatschappij van Nijverheid telde het genootschap in 1867 dertig overlappende lidmaatschappen, terwijl de maatschappij kleiner was. Het lijkt alsof de aanraking tussen de maatschappij en het genootschap in 1867 iets sterker was dan tussen het genootschap en de natuurkundigen. De Almanak van Nederlandsch Indië geeft voor 1867 de volgende aantallen op: Natuurkundige Vereeniging 413 leden, Bataviaasch Genootschap 308 leden en Maatschappij van Nijverheid 237. ${ }^{42}$ Met de kleinere Geneeskundige Vereeniging (135 leden in 1867) waren er geen overlappende bestuursplaatsen en nauwelijks meer overlappingen in de rangen van de gewone leden. De overlappingen tussen bestuurs- en gewone leden laten zien dat er zo'n vijftien jaar na de oprichting van de Natuurkundige Vereeniging en de Maatschappij van Nijverheid nog steeds aanraking was tussen deze twee belangrijke instellingen en het genootschap. Ongeveer 10 tot $15 \%$ van de leden van het genootschap was aangesloten bij een zusterorganisatie. Aan het ledental van de verschillende verenigingen kunnen we, in relatie tot een nog steeds kleine Europese bevolkingsgroep, zien dat de drang om zich aan te sluiten groot was.

\section{De relatie met de overheid}

In de drukkerijkwestie van 1847-1848 had het gouvernement duidelijk laten merken waar de grenzen lagen. Een al te eigenzinnig optredend genootschap was de les gelezen en voorzitter Van Hoëvell was het verblijf in de kolonie onmogelijk gemaakt. Het genootschap mocht dan een zelfstandige organisatie zijn, het feit dat het in een overheidsgebouw gehuisvest was en een jaarlijkse subsidie ontving, betekende dat omzichtigheid in de relatie met het gouvernement geboden was. De opeenvolgende gouverneurs-generaal waren bereid het beschermheerschap van de organisatie te vervullen. Hoge ambtenaren tot leden van de Raad van Indië en militairen tot de rang van de commandant van het Indische leger bekleedden het voorzitterschap. Voor het overige bezetten hogere ambtenaren en militairen en een enkele predikant de

\footnotetext{
42 De aantallen voor het jaar 1867 zijn ontleend aan de Regerings-Almanak voor Nederlandsch Indië (1867).
} 
bestuursfuncties, zij het dan in hun particuliere hoedanigheid. Het betekende dat de zelfstandigheid ten opzichte van de overheid zijn grenzen kende. Het kon natuurlijk in de bestuursvergaderingen handig zijn, zo'n concentratie van hoge ambtenaren. Het leverde tijdwinst op omdat informatie er sneller door op tafel kwam en in de discussie sommige bestuursleden even hun ambtelijke pet konden opzetten om aan te geven welke mogelijkheden er bij de overheid zouden kunnen liggen of welke moeilijkheden men kon ontmoeten. Landeigenaren of firmanten van handelshuizen ontbraken nagenoeg geheel in het bestuur. Daardoor hing er ondanks de formele zelfstandigheid iets 'gouvernementeels' om het genootschap heen. Het is hier dan ook de plaats juist de aspecten van de relatie 'genootschap-overheid' ter sprake te brengen: de adviesfunctie die het genootschap vervulde, de hulp die de overheid gaf bij de collectievorming en bij het ter beschikking stellen van stukken uit het gouvernementsarchief en tenslotte de financiële afhankelijkheid.

\section{Het genootschap als adviseur}

Een bezoek van gouverneur-generaal Rochussen aan de Boroboedoer in 1847 had hem ervan overtuigd dat er een taak weggelegd was voor de overheid om het tempelcomplex te documenteren. Het leidde in 1849 tot de beslissing om alle beelden en bas-reliëfs in tekeningen te laten vastleggen en vervolgens te laten lithograferen. Dit besluit volgde op het project uit 1845 om Adolphe Schaefer de tempel te laten fotograferen. ${ }^{43}$ Met Schaefers missie had het genootschap van doen gehad, nu kreeg het ook met het teken- en lithografeerproject te maken.

Schaefer was in 1844 door de enthousiaste Baud opgedragen naar Indië te gaan om daar met zijn heliografisch toestel van Daguerre afbeeldingen te maken van 'tempels, inscriptiën en andere oudheden, natuurgezigten, gebouwen, enz.' 44 Aan Schaefers opdracht was in 1841 een soortgelijke opdracht aan de chirurgijn Munnich voorafgegaan, die als eerste in opdracht van het gouvernement Daguerres procédé toepaste in Indië. Munnichs opdracht was goeddeels mislukt. ${ }^{45}$ Schaefer kreeg bij zijn vertrek apparatuur mee ter waarde van $f$ 6.073, die na voltooiing van de opdracht zijn eigendom zou worden, maar in ruil waarvoor hij foto's moest leveren. Hij liet bovendien in Nederland een schuld achter, overgenomen door het ministerie, die hij

\footnotetext{
43 Zie over Schaefer een biografische schets met een tiental afbeeldingen van Schaefers foto's (Moeshart 1998). Van Moeshart is ook 'A. Schaefer and the Borobudur' (1991).

$44 \quad$ NA Koloniën, verbaal 16-2-1844 no 21/96.

45 Zie over Munnichs reis, in Toekang Potret 1989:16. Het genootschapsarchief bevat een verslag van Munnichs reis, tweede deel (ANRI KBG Dir 1509, omslag 1843). Afschriften van beide delen van Munnichs verslag in NA Koloniën verbaal 3-11-1843 no 3 (1536).
} 
eveneens moest aflossen met de afbeeldingen die hij ging maken. ${ }^{46} \mathrm{Na}$ zijn aankomst in Batavia was op 10 augustus 1844 de hulp van het genootschap ingeroepen. Het gouvernement wilde weten welke voorwerpen het eerst in aanmerking kwamen om afgebeeld te worden. Verder wilde het weten of de door Schaefer opgegeven prijzen van $f 50$ tot $f 150$ per opname aannemelijk waren. Het genootschap had in september 1844 geadviseerd dat Schaefer eerst bij de Boroboedoer aan de slag zou gaan. Verder had het laten weten dat het niets met zekerheid over de prijzen kon zeggen, maar dat Schaefers opgaven oneindig hoger leken dan wat in Europa gerekend werd voor fotografische afbeeldingen. ${ }^{47}$ Maandenlang moest Schaefer wachten op een regeling, die uiteindelijk in januari 1845 leidde tot de opdracht om eerst de archeologische collectie van het genootschap in beeld te brengen voor een bedrag van $f$ 800. Dat bedrag zou Schaefer niet in handen krijgen, maar afgetrokken worden van zijn schulden. Wel kreeg hij een voorschot van $f 325$ per maand. Het was overigens niet het idee van het genootschap, maar van het lid van de Raad van Indië, J.F.W. van Nes, die in de jaren twintig al bestuurslid was en in 1844 was herbenoemd. Zo maakte Schaefer in de eerste maanden van 184566 afbeeldingen van oudheden en andere voorwerpen in het museum op Rijswijk, afbeeldingen die gelukkigerwijze alle bewaard zijn gebleven in het Leidse Prentenkabinet. ${ }^{48}$

Schaefer maakte zijn opnames bijna allemaal buiten. Hij spande een donkere lap tegen een paar bamboepalen en gebruikte die als achtergrond. Daardoor komen de voorwerpen goed tot hun recht. De stenen voorwerpen zijn veelal op een geïmproviseerde sokkel geplaatst, slechts enkele voorwerpen staan op een stenen ombouw van het museum. Twee kleinere beelden staan in het grint. Een serie houten Balinese sculpturen zijn op een rond tafeltje geplaatst. Twee afbeeldingen zijn niet buiten gemaakt, maar in het museum. Beide gelden een enorme lingga, een stenen fallus, die vermoedelijk te zwaar was om naar buiten gedragen te worden. Deze opnames zijn interessant omdat zij ons een blik gunnen op andere voorwerpen, die ter zijde staan, onder andere op een boeddha die van de Boroboedoer afkomstig kan zijn. Het meest fascinerend zijn echter de vitrinekasten op de achtergrond. Hier zien we de enig bekende foto's van de collectie, zoals die in 1845 in het museum, de voormalige kolfbaan, was opgesteld. In de vitrines zien we in het ene geval

\footnotetext{
46 Een goede samenvatting in Rochussens brief aan de Minister van Koloniën van 6-10-1850, NA Koloniën verbaal 10-2-1851 no 48.

47 Brief van het genootschap aan het gouvernement, 26-9-1844 vermeld in gouvernementsbesluit 27-1-1845 no 5, ANRI KBG Dir 1510 omslag 1845.

$48 \mathrm{Nu}$ in het Prentenkabinet van de Leidse Universiteit. Ze zijn alle afgebeeld op de website 'Early Photography 1839-1860'. Met dank aan Joke Pronk die mij zeer behulpzaam was bij het verkrijgen van afbeeldingen.
} 
maskers en in het andere geval schilden. Kennelijk waren archeologische en etnologische voorwerpen in het museum in elkaars buurt opgesteld.

Een interessante vergelijkingsmogelijkheid bieden Schaefers daguerréotypieën met de lithografische afbeeldingen die bij Friederich zijn te zien bij diens vervolg van de beschrijving der Javaanse oudheden (Verhandelingen 23). De Doerga die al in 1846-1847 was beschreven, maar pas in 1850 was gelithografeerd door de genie-lithograaf J. Herben, blijkt in de opname van Schaefer veel beter te bestuderen. De nog niet erg ver ontwikkelde daguerréotypie won het in 1845 al van de lithografie, die opnieuw in 1850 werd gebruikt. ${ }^{49}$

Nadat Schaefer zijn opnames van de collectie van het genootschap had afgerond, werd het advies van het genootschap gerealiseerd en maakte hij 58 afbeeldingen van de Boroboedoer. Daarmee was voor het genootschap de zaak met Schaefer afgedaan. De 66 Bataviase afbeeldingen werden met de 58 Boroboedoer-platen in 1848 naar Nederland verscheept. De complete afbeelding van de tempel zou volgens Schaefer vier of vijf jaar in beslag nemen en $f 150.000$ gaan kosten. Dat mega-project ging het gouvernement uit de weg en in 1850 werd ten langen leste de schuld van $f 17.480$ door het gouvernement gesaneerd. Schaefer had met zijn fotografie in Semarang, Soerabaija en op Madoera niet genoeg kunnen verdienen om ook maar iets van zijn schulden af te lossen. Het genootschap had geadviseerd, maar verder bij de afbeeldingen weinig baat gehad. Schaefers missie was mislukt, al danken we er 124 vroege foto's aan die van groot belang zijn voor de oudheidkundige studie.

Rochussen moest in 1849 wel besluiten dat voor fotografische vastlegging van de Boroboedoer de tijd nog niet rijp was. Vandaar het besluit tot het aftekenen en lithograferen over te gaan. Het gouvernementsbesluit hierover werd aan het genootschap gestuurd met de vraag aan te geven hoe het het beste zou kunnen worden uitgevoerd. Daarbij kwam het verzoek of het genootschap wilde zorgen voor de begeleidende tekst, voor de bekendmaking en de verzending van de uitgave. In feite kreeg het genootschap het aanbod om als editeur en uitgever op te treden. Er werd meteen nagedacht over de adviseurs, die zich over de uitleggende tekst moesten buigen: de sultan van Soemenep, Friederich, C.F. Winter, Cohen Stuart, Gericke, D.H. Cannaerts, kenners van Javaanse taal en oudheden. Aan de deskundige begeleiding zou serieuze aandacht worden besteed. 50

De lithografische inrichting van het geniekantoor had ter voorbereiding van het besluit een paar proefdrukken gemaakt en de directeur van de genie,

49 Van Hoëvell en Friederich, 'Beredeneerde beschrijving der Javaansche monumenten', no 126, in VBG 21(1846-7). Verder in het vervolg ervan door Friederich, 'Javaansche Oudheden', afbeelding 17, in VBG 23 (1850). Moeshart 1998 beeldt de Doerga af bij zijn biografische schets.

50 ANRI KBG Dir 0168, vergadering 24-4-1849, punt 1 der binnengekomen stukken. Het gouvernementsbesluit was van 31-3-1849 nr 4. Zie ook Koloniaal Verslag 1851:77-8. 
tevens bestuurslid, Vaijnes van Brakell, had op zich genomen een advies aan de regering voor te bereiden. In februari $1850 \mathrm{kwam}$ hij daarmee voor de dag. Het leek al weer een mega-project te zullen worden: er zouden 500 litho's worden gemaakt in een oplage van 500 stuks (dus 250.000 afdrukken) waarvoor de intekenaren $f 164$ per serie zouden moeten neerleggen. Dat zou $f 82.000$ opbrengen. De kosten, heel nauwkeurig berekend, zouden $f 52.227$ bedragen, dus het project was bij 500 intekenaren uitvoerbaar. In het lithograferen zouden 7424 werkdagen gaan zitten. Als er met vijf graveurs zou worden gewerkt, zou de genie het project in vijf jaar klaar kunnen hebben.

Het project zou een derde gaan kosten van Schaefers voorgestelde fotografische vastlegging. De commandant van het Indische leger, om advies gevraagd, zag er niets in en adviseerde om het lithograferen in Nederland te laten uitvoeren. Vaijnes gaf zich niet zo gauw gewonnen en probeerde nog de drukkerij van het weeshuis in Parapattan in te schakelen, waar 'élèves' tot graveur zouden kunnen worden opgeleid, maar de omvang en de kosten van het project schrokken het gouvernement af. ${ }^{51}$ Het bestuur van het genootschap had wel een commissie benoemd die het tekenwerk moest begeleiden en had de tekenaars ter oriëntatie een exemplaar van de Verhandelingen gestuurd, waarin het een en ander over de oudheden stond. ${ }^{52}$ Daarna kwam het er niet meer op terug. De genie-tekenaar F.C. Wilsen tekende in opdracht van de regering met zijn collega Schönberg Müller vier jaren lang de bas-reliëfs af. Hun werk kwam pas in 1873 in C. Leemans' Bôrô-Boedoer ter beschikking. Het was in Den Haag uitgevoerd. Het genootschap kon wel van Wilsens beschouwing over de Boroboedoer gebruik maken. Die kwam in de eerste jaargang van het Tijdschrift te staan. ${ }^{53}$ Van het lithografeerproject wordt in de notulen niets meer vernomen, maar het tekent de zienswijze van het gouvernement dat in eerste instantie aan het genootschap werd gedacht als begeleidende instantie en uitgever van het resultaat. Evenzo kwamen Munnichs rapporten ter beschikking van het genootschap en werd in Schaefers geval om advies gevraagd. Doordat Schaefers daguerréotypieën naar Nederland werden verscheept, kon er in Batavia geen gebruik van worden gemaakt. De vraag is in hoeverre Friederich ze heeft kunnen gebruiken voor zij verscheept werden. Pas in de jaren 1870 zou de fotograaf Isidore van Kinsbergen met meer succes foto's maken van de Boroboedoer in opdracht van het Genootschap, dertig jaar na de minder succesvolle missies van Schaefer en Munnich.

Als gevolg van de veranderingen in de Grondwet van 1848 was de regering verplicht het parlement te informeren over de toestand in de koloniën. Vanaf het jaar 1849 kwam daarvoor jaarlijks een Koloniaal Verslag beschikbaar waar-

51 ANRI KBG Dir 0176, vergadering 28-2-1850, punt 2.5 en de bijlagen 3-5.

52 ANRI KBG Dir 0169, vergadering 29-5-1849, punt 1 en 2.

53 Zie over Wilsen ENI 4, s.v. Wilsen en TBG 1:235-303, voor zijn Boroboedoer-studie. 
voor de Algemene Secretarie de bouwstenen leverde. Engelbertus de Waal (1821-1905), referendaris bij de secretarie, die later nog minister van koloniën zou worden, was in de eerste jaren de samensteller van dat verslag (N.P. van den Berg 1906:67-8). De Waal was in de jaren veertig als ambtenaar tegelijk redacteur van De Kopiïst (1842-1844) en het Indisch Magazijn (1844-1846) geweest, maar had het met zijn baas, Visscher, aan de stok gekregen over de vrijheid van drukpers, waarna hij had besloten te stoppen met zijn tijdschrift. Tot 1852 werd het genootschap bij het opstellen van het Koloniaal Verslag niet betrokken. Voor het verslag over dat jaar echter werd het gevraagd om te helpen door een bijdrage te leveren voor zover het de kunsten en wetenschappen aanging. Tot die tijd had de ijverige De Waal het zelf afgekund. Voor 1849 had hij zich beperkt tot een heel kleine paragraaf, voor 1850 had hij eenvoudig gemeld dat er weinig belangrijks was voorgevallen. Pas voor het jaar 1851 was zijn bijdrage over kunsten en wetenschappen rijk aan informatie. Hij putte toen uit gouvernementsbesluiten over de werkzaamheden van H. von Dewall, C.M. Schwaner en S.H. de Lange, die de buitengewesten hadden bezocht, en over die van de taal- en oudheidkundigen Cohen Stuart en Friederich. De paragraaf over 1852 had een heel andere structuur, aangedragen door secretaris Bleeker. Deze stelde een lijst samen van instellingen, die werkzaam waren op het terrein van kunsten en wetenschappen, alsook een lijst van periodieken en kranten en vulde die aan met wetenswaardigheden, onder andere over zichzelf en het genootschap. Zijn bouwstenen werden door De Waal gebruikt. Vanaf dat jaar zou het genootschap steeds gevraagd worden om een bijdrage. Het genootschap was voor de overheid een bron van informatie op dit terrein. ${ }^{54}$

In juni 1858 werd een brief van het gouvernement besproken over een project dat al in 1851 was gestart, maar waarbij het genootschap tot dan toe niet betrokken was geweest. De Indische regering wilde leer- en leesboekjes voor de inheemse scholen gaan produceren, in eerste instantie in het Javaans (1851), in 1858 ook voor het Maleis. De vraag aan het genootschap was, of het voorafgaande aan het toekennen van geldprijzen voor de meest geschikte boekjes een oordeel zou willen geven over de inzendingen. Bleeker had direct instemmend geantwoord. ${ }^{55}$ De eerste beoordeling door het genootschap moest worden gegeven naar aanleiding van een Maleis aardrijkskundeboekje dat door de ijverige commies bij de Algemene Secretarie, het redactie- en bestuurslid Netscher was geschreven. Adjunct-bibliothecaris en kenner van

\footnotetext{
54 ANRI KBG Dir 0197, vergadering 22-2-1853, punt 4 vermeldt een brief van de gouverneurgeneraal van 30-1-1853 met dat verzoek. De aantekeningen van Bleeker over 1852 zijn terechtgekomen in ANRI KBG Dir 0202, vergadering 28-3-1854, bijlage, en dienden later ook weer als basis voor de volgende jaren.

55 TBG 8:102, vergadering 19 juli (lees juni) 1858.
} 
het Maleis en het Javaans, Friederich, had er positief over geoordeeld en dus ging er een gunstig advies naar het gouvernement. Tegelijkertijd werd er negatief geadviseerd over een godsdienstboekje van W. Gibson: 'minder geschikt om in handen van eene mohamedaanse schooljeugd' te worden gegeven. Over het waarom van de mindere geschiktheid werd niet uitgeweid. ${ }^{56}$ Netscher leverde tweemaal manuscripten, die door Friederich of Cohen Stuart werden beoordeeld. Andere keren trad Netscher zelf als beoordelaar van andermans werk op. Zo moest in december 1858 een serie van zijn rekenboekjes beoordeeld worden, terwijl hijzelf als beoordelaar van een Maleis leerboekje optrad, in november 1859 nog eens voor de Maleise fabelcollectie van Raden Bagoes Moedjarad uit Solo. ${ }^{57}$ Voor ambtenaren als Netscher, was het vervaardigen van zulke leerboekjes een mogelijkheid om hun salaris aan te vullen.

Een ander project waarbij het gouvernement het genootschap in 1859 inschakelde, was het verzamelen van inscripties op oudheidkundige resten op Java en Sumatra ten behoeve van een Corpus Inscriptorum. Het initiatief daartoe was genomen door het Koninklijk Instituut voor Taal-, Land- en Volkenkunde te Delft, waarna de minister van koloniën het Indische gouvernement aan het werk had gezet. Besloten werd op voorstel van het genootschap de hoofden van het gewestelijk bestuur op de beide eilanden om hulp te vragen. Nog hetzelfde jaar ging een gedrukte circulaire uit en in het eropvolgende jaar kwamen antwoorden binnen die door het bestuur werden verzameld. ${ }^{58}$ Aan dit project zou in 1863 door Friederich verder worden gewerkt.

\section{Collectioneren}

Schakelde het gouvernement het genootschap in voor advies, omgekeerd wist het genootschap ook het gouvernement in te schakelen, met name als het ging om het uitbreiden van de verzamelingen. In de jaren veertig was op die manier de belangrijke verzameling oudheidkundige voorwerpen tot stand gekomen. Ook was de uitzending van Friederich naar Bali in 1846 door het gouvernement goedgekeurd en gefinancierd, wat voor de verzamelingen opnieuw vruchtbaar was geweest. Toen nu in december 1858 sprake was van de Bonische expeditie werd eerst de commandant van het Indische leger en later ook leider van de tweede expeditie tegen Boni, generaal J. van Swieten, bij acclamatie tot lid uitgeroepen. Direct daaropvolgend werd ter sprake

56 TBG 8:288, vergadering 16-9-1858.

57 TBG 9:34, vergadering 4-12-1858; TBG 9:438, vergadering 17-11-1859.

58 TBG 9:226, vergadering 14-5-1859; TBG 9:241, vergadering 6-8-1859; TBG 9:440, vergadering 17-11-1859. Verder TBG 10:10, vergadering 3-12-1859. 
gebracht 'het dienstbaar maken der op handen zijnde expeditie tegen Boni aan de belangen der taal-, land en volkenkunde en aan die van 's Genootschaps museum'. Bestuurslid W.F. Versteeg, kapitein van de genie, die mee zou gaan naar Boni, was 'bij voorraad geheel bereid de belangen des Genootschaps naar vermogen te behartigen'. ${ }^{59}$ In mei 1859 resulteerde het al in 'eenige bonische manuscripten, waaronder een bonisch heldendicht Djaja-lengkara, in het paleis der koningin van Boni tijdens de jongste expeditie tegen Boni gevonden'. Via een bij de expeditie betrokken officier, kolonel Waleson, waren deze in handen gekomen van Netscher. ${ }^{60}$ Het verzamelen van voorwerpen die als oorlogsbuit in handen van de troepen kwamen, was overigens in de geschiedenis van het genootschap al in 1780 bekend, toen de zegels en een aantal manuscripten van de vorst van Goa in genootschapsbezit kwamen via Joan Smith, destijds een van de directeuren van het genootschap.

In dezelfde tijd dat van de Bonische expeditie gebruik werd gemaakt, schonk Bleeker een houten versiering van het paleis van de sultan van Djambi, kort tevoren veroverd door 'onze troepen'. Toen werd ook de aandacht gevestigd op buitgemaakte wapens, die uit tweeërlei oogpunt voor het museum van belang waren: uit etnologisch oogpunt, als ook 'omdat door de plaatsing daarvan in een openbaar museum de herinnering aan de wapenfeiten van land- en zeemagt in deze gewesten verlevendigd wordt'. Besloten werd het gouvernement te vragen om een exemplaar van de wapens, veroverd tijdens de Djambische krijg van 1858, te mogen ontvangen als ook een exemplaar van de verschillende wapens uit vroegere expedities. ${ }^{61}$ Daardoor kwamen in 1859-1860 diverse keren wapens, waaronder geschut, binnen. De opvoedende functie van het museum was breder geworden en had een nationalistische dimensie gekregen.

In andere gevallen ging het bij het collectioneren om voorwerpen die bij het gouvernement binnen waren gekomen of van het bestaan waarvan het op de hoogte was gebracht. Zo waren er bijvoorbeeld vondsten van goud en andere edelmetalen, munten dan wel sieraden met oudheidkundige waarde. Het stelde dan het genootschap voor de keuze: was het geïnteresseerd, dan kon het de voorwerpen tegen betaling van de vooraf vastgestelde waarde overnemen. Was het niet geïnteresseerd, dan gingen de voorwerpen weer terug naar het gouvernement. In het geval van koop door het genootschap ging een deel van de aankoopsom naar de vinder, veelal een Javaanse boer.

Het navolgende overzicht van twee jaren (1849 en 1859) laat zien hoe gevarieerd, omvangrijk en belangrijk de aanwinsten voor het genootschap konden zijn, die door bemiddeling van de overheid binnenkwamen. De lijst 
is gebaseerd op de notulen. ${ }^{62}$

Lijst van aanwinsten 1849 door bemiddeling van het gouvernement verkregen

1 een monster stofgoud en 100 mineralogische voorwerpen van Borneo, via algemeen secretaris Visscher; uit Borneo meegezonden etnografica waren zoekgeraakt;

2 vijf zilveren munten, beoordeeld door de sultan van Soemenep, afkomstig uit Poerwokerto;

3 de algemeen secretaris attendeert op twee stenen beelden achter het residentshuis te Bandjarnegara, mogelijk voor kabinet van oudheden van belang; later wordt een ervan overgenomen;

4 aarden pot met 112 gouden en zilveren voorwerpen, opgegraven in Kedong Kidang ter waarde van $f$ 640; het gouvernementsbesluit zegt dat het genootschap het voor twee derde van de waarde mag overnemen;

5. de resident van Batavia biedt voorwerpen aan die gebruikt zijn bij de stadsboeijen voor het ten uitvoer leggen van lijfstraffen; het genootschap wijst de voorwerpen van historisch belang aan, maar neemt die niet direct over;

6 de algemeen secretaris vraagt naar de waarde van drie hindoe-beelden uit Borneo, die al bij het genootschap zijn binnengekomen;

7 achttien beelden uit het tijdperk van Madjapahit via de overleden resident van Soerabaija, D.F.W. Pietermaat;

8 een beeld van een stier (Nandi) uit Pontianak, via de oud assistent-resident D.W.C. baron van Lynden. ${ }^{63}$

Lijst van aanwinsten 1859 door bemiddeling van het gouvernement verkregen

1 Vier delen van een gamelanspel uit de residentie Jepara; worden niet overgenomen wegens niet bewezen oudheidkundige waarde;

2 twee met goud gemonteerde pieken, door de vorst van Kota Waringin aan de resident van de Zuid-Ooster afdeling van Borneo aangeboden;

3 verschillende vuurmonden veroverd tijdens de Djambische expeditie, aangeboden door de commandant van de marine;

4 vier geschutsmonden veroverd tijdens de Lampongse expeditie, aangeboden door de commandant van het leger;

62 Aangetekend moet worden dat in sommige gevallen niet duidelijk is of een persoon, die zich rechtstreeks tot het genootschap wendde dan wel via een van de bestuursleden, de aanbieding van voorwerpen op persoonlijke titel dan wel in functie deed. Als duidelijk is, dat een aanwinst op persoonlijke titel is geschonken, is die niet in de navolgende lijsten opgenomen aangezien het ons hier om gouvernementele aanwinsten gaat.

63 Nummer 7 en 8, misschien al vóór 1849 binnengekomen, worden vermeld in VBG 22:10. De notulen van 1849 bevatten als bijlage ook een niet gedateerde lijst van vragen naar de achtergrond van de zending Merbaboe-manuscripten, die in zes kisten aan het genootschap waren gestuurd. Aangezien deze zaak pas in 1850 begon te spelen, ga ik ervan uit dat dit document verkeerd geplaatst is. Zie voor de vermeldingen 1-6, ANRI KBG Dir 0164, vergadering 30-1-1849, Dir 0169, vergadering 29-5-1849, Dir 0171, vergadering 28-8-1849 en Dir 0172 vergadering 27-111849. 
521 voorwerpen, voornamelijk handwapens en lichte geschutssoorten veroverd bij de expeditie tegen Reteh (Riouw) en een rijk bewerkte sirihdoos;

6 enige Bonische manuscripten, gevonden in het paleis van de koningin van Boni tijdens de jongste expeditie, van kolonel Waleson via Netscher;

7 enige Chinese muntjes van Bangka, enige Boetonse muntjes en Atjehse ringen, van gouverneur Schaap van Celebes via Netscher;

8 enige Bonische drinkpotjes en een wierookbakje, gevonden in het paleis van de koningin van Boni, aangeboden door Netscher;

9 een kanon met Javaans opschrift uit het oorlogsmagazijn te Semarang, van het militair departement;

10 enkele zilveren, gouden en glazen voorwerpen, opgegraven door Hamat Soorjan te Wonojoso;

11 twee oude zilveren munten van Fort Sorg, aangeboden door de resident van de Westerafdeling van Borneo;

12 een oude koperen klok uit Madoera, aangeboden ter overname door de resident van Madoera via het gouvernement; wegens gebrek aan oudheidkundige waarde afgewezen;

13 drie beelden en twee stenen met inscriptie via de resident van Pasoeroean, na aandringen van Netscher; ook een stenen beeld uit Trawas van jhr. H.C. van der Wijck;

1431 oude zilveren muntjes, opgegraven in Djokjakarta, ter overname aangeboden;

15 acht door Netscher bij Mendoet aangewezen beelden en twee op het erf van de regent van Magelang door hem aangewezen beelden. ${ }^{64}$

Wat opvalt bij vergelijking van de lijsten, is dat er in 1859 beduidend meer aanwinsten-vermeldingen zijn. Uiteraard zegt dat nog niets over het belang van de binnengekomen voorwerpen. Ten tweede valt de toegenomen medewerking op, die het gouvernement verleende. Dit had te maken met het uitbreiden van het overheidsingrijpen in de archipel. Er viel steeds meer te rapporteren, er kwamen ook steeds meer etnografische voorwerpen binnen. Ten derde is de groeiende golf aanwinsten in tijd van militaire expedities opvallend, zodra het genootschap die mogelijkheid begon te benutten. Tenslotte komt de rol van een actief verzamelaar als Netscher naar voren: hij kwam voorwerpen op het spoor en wist die op de juiste manier via gouvernementsingrijpen voor het genootschap te verwerven. Op reis met gouverneur-

64 Niet opgenomen zijn munten, geschonken door $\mathrm{H}$. von Dewall en twee door hem ter overname aangeboden gouden versierselen, omdat die particulier lijken te zijn aangeboden (TBG 9:220, vergadering 9-4-1859). Evenmin tientallen door Netscher, deels namens andere personen, onder anderen de vorsten van Surakarta en Yogyakarta, aangeboden voorwerpen, om dezelfde reden ( TBG 9:432, vergadering 7-10-1859). Zie voor de vermeldingen 1-15 TBG 9: 50, 52-4, vergadering 19-3-1859, TBG 9:220, 227, 233-4, 236, 240, 242-4, 246, vergadering 9-4-1859, TBG 9:426, 429-30, 432, vergadering 3-9-1859. 
generaal Pahud naar Midden- en Oost-Java wist hij de genootschapsbelangen goed te behartigen. Hij schreef uit Pamakassan en Malang over oudheidkundige voorwerpen die naar Batavia zouden worden gezonden. Netscher trad in dit opzicht duidelijk in de voetsporen van Van Hoëvell. ${ }^{65}$

Gunstig voor de collectievorming was het gouvernementsbesluit van 11 december 1858 over het lot van geschenken die inheemse vorsten of groten aanboden aan de gouverneur-generaal of zijn vertegenwoordigers bij wijze van huldebetoon Het ging veelal om wapens, kledingstukken en kleine waardevolle voorwerpen. De betrokken ambtenaren mochten de geschenken tegen de getaxeerde waarde overnemen. Waren zij daarin niet geïnteresseerd, dan zouden die voorwerpen in een speciale afdeling van het genootschapsmuseum worden geplaatst. ${ }^{66}$ Ambtenaren mochten geschenken dus niet zonder meer voor zichzelf houden. Een geschenk van de vorst van Kota Waringin (1859) was het eerste dat ingevolge dit gouvernementsbesluit de collectie van het genootschap verrijkte. Het museum had er zo een depotfunctie bijgekregen.

Handelde het zojuist genoemde besluit over het ontvangen van geschenken, het gouvernement nam in 1859 ook een besluit over het uitlokken van tegengeschenken. De indruk was ontstaan dat sommige ambtenaren en officieren een spierinkje uitwierpen naar vorsten en organisaties in het buitenland om een kabeljauw te vangen. Op 13 mei 1859 werd besloten deze praktijk aan banden te leggen. Netscher signaleerde dit besluit, dat zijns inziens negatief kon uitwerken in het wetenschappelijk verkeer van Nederlands-Indië met het buitenland. Hij was bang, dat het genootschap minder vrij zou zijn om bepaalde voorwerpen te ruilen met andere genootschappen of met musea. Besloten werd om het gouvernement voor te stellen dat het bedoelde besluit niet in het nadeel van de belangen van kunsten en wetenschappen mocht uitvallen. ${ }^{67}$ De bedenkingen van het genootschap werden door het gouvernement aan de minister van koloniën overgebracht, omdat het besluit was ingegeven door een koninklijke machtiging. Die had beperkingen afgekondigd ten aanzien van de manier waarop ambtenaren en officieren geschenken aan vreemde vorsten of in het buitenland gevestigde genootschappen zouden aanbieden. ${ }^{68}$ In 1860 kwam de ministeriële geruststelling: de bepaling was niet bedoeld om het wetenschappelijk verkeer van Nederlands-Indië met het buitenland te belemmeren, maar om de 'zucht om eereteekenen en gunsten

65 Brieven van Netscher, 1-8-1859 (Pamakassan) en 5-9-1859 (Malang) in ANRI KBG Mus 0028, omslag 1850-1860.

66 TBG 9:43, vergadering 5-2-1859; Gouvernementsbesluit 11-12-1858 nr 77.

67 TBG 9:428-9, vergadering 7-10-1859; Gouvernementsbesluit 13-5-1859, nr 121.

68 TBG 9:439-40, vergadering 17-11-1859, waar verwezen wordt naar het Nederlandsch Staatsblad 1859 nr 30. 
van buitenlandsche vorsten en genootschappen, ten nadeele van de ontwikkeling der wetenschap in de kolonie, na te jagen' aan banden te leggen. ${ }^{69}$ Het was dus eerder bedoeld om het Indonesische erfgoed niet oneigenlijk te gebruiken en gedrag van bepaalde ambtenaren in te perken. Ook in dit geval was het de actieve Netscher, die het initiatief nam.

\section{Overheidssubsidie}

Collectievorming bracht kosten met zich mee, vooral als het genootschap niet uitsluitend van schenkingen afhankelijk wilde zijn, maar ook zelf voorwerpen en boeken wilde aanschaffen. Inkomsten naast de contributie van leden kende het genootschap nauwelijks. Incidenteel waren er giften, maar de kosten van de uitgave van de Verhandelingen waren aanzienlijk gestegen, vooral sinds die op een ruimer kwarto-formaat uitkwamen en met litho's waren geïllustreerd. De edities van Javaanse en Maleise teksten brachten extra kosten met zich mee. De subsidie die het genootschap sinds 1835 jaarlijks ontving, aanvankelijk bedoeld voor de kosten van het museum, bedroeg sinds 1846 $f 2.200 .{ }^{70}$ Dat bedrag was onvoldoende geworden en dus werd op 4 april 1851 een verzoek tot verhoging gericht tot het gouvernement. ${ }^{11}$ De nieuwe algemeen secretaris, A. Prins, liet weten, dat eerst moest worden aangetoond dat ondanks spaarzaam beheer het bestaan van het genootschap in gevaar kwam. Daarop merkte zijn voorganger Visscher, die zelf net in de Raad van Indië was aangetreden, tegen het bestuur op, dat een verzoek om een eenmalige gift meer kans zou maken. ${ }^{72}$ In november 1851 ging er een brief uit naar het gouvernement met een verzoek om een som ineens van $f 10.000$ ter verlichting van de financiële druk, maar de algemeen secretaris reageerde direct afwijzend. Pas als het genootschap zijn financiën op orde had met een duurzame regeling, zou van zo'n som ineens sprake kunnen zijn. ${ }^{73}$

Om de financiële druk te verlichten werd aan de overheid een aanbod gedaan om voor $f 3.000$ een aankoop te doen van door het genootschap uitgegeven edities van Maleise en Javaanse teksten. Daartoe werd inder-

\footnotetext{
69 TBG 10:448, vergadering 28-7-1860.

70 In 1835 was de subsidie op $f 2.400$ per jaar gesteld. Door de herziening van het muntstelsel van 1846 werd dit $f 2.200$.

71 ANRI KBG Dir 0185, vergadering 4-3-1851, punt 4.r; Dir 0186, vergadering 25-3-1851, punt 1. Het besluit werd genomen op 4 maart, maar de brief ging pas een maand later uit. Zie Dir 0188, vergadering 26-10-1851 waar de brief van 4-3-1851 en het antwoord van 20-6-1851 worden vermeld.

72 ANRI KBG Dir 0188, vergadering 26-10-1851, punt 2, brief van de algemeen secretaris van 20-6-1851. De brief zelf is niet als bijlage bijgesloten.

73 ANRI KBG Dir 0190, vergadering 24-2-1852, bijlage 31-33.
} 
daad overgegaan, maar slechts voor een bedrag van $f 1.484 .^{74}$ In september 1856 sprong het gouvernement nog eens bij met een bedrag van $f 3.515$ 'als tegemoetkoming in de kosten van uitgave, in de vier eerste deelen van 's genootschaps Tijdschrift voor taal-, land- en volkenkunde, van stukken, ter plaatsing aangeboden uit 's gouvernements archief'. Daartoe was eerder door het genootschap zelf een rekest ingediend. Bij de oprichting van het tijdschrift had het bestuur gevraagd om medewerking van het gouvernement bij het fourneren van kopij, zoals ook het Indisch Archief van Buddingh op het gouvernementsarchief had kunnen rekenen. Toen was echter alleen uitgegaan van een beroep op stukken, waarvoor de Algemene Secretarie een rijke bron was. $\mathrm{Nu}$ ging het gouvernement voor de plaatsing van zijn eigen stukken in het tijdschrift betalen. ${ }^{75}$

Het was duidelijk dat de Indische regering bereid bleef te helpen, maar een verhoging van de jaarlijkse subsidie zat er niet in voordat het genootschap de financiën, naar de smaak van het gouvernement, op orde had. Voorzitter Visscher had bij dit alles steeds twee petten op en moest regeringsbelang en genootschapsbelang met elkaar in overeenstemming brengen. Dit blijkt uit de wijze waarop hij bij de algemene vergadering op 23 juli 1856 begrip probeerde te wekken voor de positie van het gouvernement. De oprichting van 'meerdere zusterinstellingen' (bedoeld werden de Natuurkundige Vereeniging en de Maatschappij van Nijverheid) had tot een beperking van de 'meermalen betoonde hulpvaardigheid' van de kant van de overheid geleid. Visscher sloeg al met al een pessimistische toon aan. De werkkring van het genootschap was door de nieuwe organisaties ingeperkt. 'Het is niet zonder leedwezen, dat ik den twijfel moet uiten, of het Genootschap wel in dien verminderden werkkring werkzaam gebleven is, en niet heeft moeten ondervinden, dat te veel verdeeling van krachten, in meerdere of mindere mate tot kwijning leidt.' Van Visschers woorden gaat weinig bezieling uit, terwijl mannen als Bleeker, Netscher en Munnich steeds enthousiasme opbrachten voor initiatieven die het genootschap konden verlevendigen. Visschers vertrek in begin 1857 gaf tenminste die enthousiasten wat lucht (TBG 6:268-70).

De situatie werd aan het einde van 1858 zo precair dat het bestuur zich opnieuw tot de regering wendde met een verzoek om steun bij de sanering van de financiën. Het vroeg om $f 18.000$ ineens en een verhoging van de jaarlijkse subsidie tot $f 7.940$ ingaande het jaar 1859. Het gunstige besluit viel op 6 mei 1859. Het genootschap kreeg het gevraagde bedrag van $f 18.000$ en de

\footnotetext{
74 ANRI KBG Dir 0190, vergadering 24-2-1852, punt 9 van de ingekomen stukken; verder Dir 0191, vergadering 30-3-1852, punt 3/b en Dir 0192, vergadering 5-4-1852, bijlage nr 10, conceptbrief 7-1-1852 over dit onderwerp.

75 ANRI KBG Dir 0189, vergadering 30-12-1851, punt 2/a. Over de betaling van $f 3.515,30, T B G$ 7:184-5, vergadering 23-2-1857.
} 
subsidie werd, voorlopig voor de periode 1859-1863, vastgesteld op $f 8.000$ per jaar. ${ }^{76} \mathrm{Na}$ Visschers vertrek woei er een andere wind. Mogelijk had de nieuwe voorzitter, P.J.B. de Perez, ook vice-president van de Raad van Indië, de beslissing gunstig beïnvloed. ${ }^{77}$

Zo was in 1859 de financiële situatie opgeklaard, al had het bijna een decennium moeten duren. De afhankelijkheid van de Indische regering was er des te groter door geworden. De jaarlijkse subsidie was slechts tot 1863 vastgesteld en zou bij de verlenging ervan weer ter sprake komen. Verder had de regering al eens geprobeerd om subsidieverlening te koppelen aan voorwaarden, zoals de samenvoeging van het genootschap met de Natuurkundige Vereeniging en de Maatschappij van Nijverheid mede in verband met het betrekken van een gezamenlijk, nieuw gebouw. De positie van het genootschap werd in de loop van deze periode hoe langer hoe meer die van een afhankelijke semi-overheidsinstantie. Van onafhankelijkheid was geen sprake. $\mathrm{Nu}$ was dat ook in het verleden in beperkte mate het geval geweest. Niet alleen was de financiële band te sterk, ook de huisvesting speelde een rol. Daarbij kwam de publicatietaak in het tijdschrift, weliswaar niet van gouvernementsbesluiten, dan toch van stukken uit het gouvernementsarchief en wel tegen een vergoeding. Collectievorming zonder de voortdurende steun van het gouvernement zou armetierige resultaten opleveren. De Waal mocht dan in het Koloniaal Verslag van 1849 melden dat het gouvernement 'geene regtstreekse bemoeijenis heeft met het beheer en de verrigtingen dezer instelling', de praktijk was een tiental jaren later ingrijpend veranderd, al bleef het genootschap formeel een 'particuliere instelling' (Koloniaal Verslag 1849:109).

\section{Financiën}

Is in de voorgaande paragraaf de overheidssubsidiëring ter sprake gekomen, de genootschapsfinanciën moeten nog wel wat nader worden toegelicht. De voortgang van het genootschappelijk leven en vooral de presentatie naar buiten toe waren zeer afhankelijk van geldzaken. Voorzitter Buddingh kon in maart 1849 de leden ter algemene vergadering over de financiën nog laconiek voorhouden:

Gij zult die niet zoo gunstig, en ook niet zo ongunstig vinden, als misschien deze of gene zich voorstelt. Maar in een geleerde Instelling dient het geld niet om een

76 TBG 9:6-8, 21-32, vergadering 6-11-1858; TBG 9:225-6, vergadering 14-5-1859, gouvernementsbesluit 6-5-1859 nr 6.

$77 \quad$ Na koninklijke bekrachtiging sprak het gouvernementsbesluit van 3-8-1860 van $f 18.000$ ineens en een subsidie van $f 8.000$ per jaar over de jaren 1861-1863. Mogelijk zo, omdat de bedragen voor 1859-1860 al waren uitbetaald? 
kapitaal te maken maar om besteed te worden ten nutte der Instelling. En dit geschiedt. (VBG 22:19.)

$\mathrm{Nu}$ had Buddingh ook reden om gerust te zijn. Net was de drukkerij van het genootschap, die zoveel vrucht had afgeworpen maar ook voor veel hoofdbrekens had gezorgd, voor $f 10.000$ verkocht aan de boekhandelaar Lange. Die zou voor $f 24$ per vel druks de uitgaven van het genootschap gaan verzorgen. De drukkerij bleef overigens nog lange tijd in een van de lokalen van het genootschap gevestigd, waarvoor de firma Lange zeshonderd gulden per jaar aan huur betaalde. In de loop van 1849-1851 verslechterde de situatie echter snel. Aan de inkomstenkant waren de subsidie van de regering ( $f$ 2.200) en de contributie van de gewone leden ( $f 5.120$ in 1848) de enige regelmatige inkomsten. ${ }^{78}$ Aan de uitgavenkant stond $f 3.000$ per jaar voor de bibliothecaris en de secretaris. ${ }^{79}$ Toen Lange begon te drukken - drie dikke kwarto-delen van de Verhandelingen in vier jaar tijd (1849-1853), het Tijdschrift vanaf 1852 - liepen de kosten snel op. Bovendien waren na het crisisjaar 1848 andere activiteiten hervat. Er werden boeken en tijdschriften besteld bij Kruseman in Haarlem, Kemink in Utrecht, Friedländer in Berlijn, later bij Brockhaus in Leipzig. De uitbreiding van de bibliotheek gold vooral de oosterse talen en culturen, boeken die nodig waren ten behoeve van de werkzaamheden van Friederich en anderen. De uitgave van tekstedities en de beschrijving van de handschriften en oudheidkundige voorwerpen vroegen om een goede handbibliotheek. Toen die boeken binnen begonnen te komen, waren rekeningen van boven de duizend gulden geen uitzondering. ${ }^{80}$ Daarbij was het genootschap ruimhartig opgetreden tegenover de Natuurkundige Vereeniging door de kosten van haar nieuwe tijdschrift op zich te nemen. Die kosten zouden al snel oplopen tot ongeveer duizend gulden per jaargang. ${ }^{81}$

Geen wonder dus dat in 1851 gedacht werd aan een beroep op het gouvernement voor een verhoging van de subsidie. Het reageerde, zoals we reeds zagen, afwijzend. Dus moest het bestuur bezuinigingen doorvoeren

\footnotetext{
78 In 1852 begrootte het bestuur de contributie-inkomsten optimistisch op $f$ 7.000.

79 ANRI KBG Dir 0161, vergadering 27-7-1848, bijlage 1; Dir 0190, vergadering 24-2-1852, bijlage 31. In 1852 beliepen de uitgaven voor secretaris en bibliothecaris $f 3.000$ maar toen wel met Friederichs toelage erbij.

80 Op 27-8-1850 werd er een rekening van Kruseman, Haarlem vermeld van $f 756$ voor boeken (ANRI KBG Dir 0180, vergadering 27-8-1850, punt 7.1). In februari 1852 waren er rekeningen van Kemink van $f$ 2.977,30 en $f$ 454,15 (ANRI KBG Dir 0190, vergadering 24-2-1852, bijlage 1, 8 en 9). Op 30-1-1849 had het genootschap nog een schuld van $f 1.262$ aan Kemink (ANRI KBG Dir 0164, vergadering 30-1-1849, bijlagen 5-7).

81 ANRI KBG Dir 0180, vergadering 27-8-1850, punt 5; Dir 0183, vergadering 29-10-1850, punt 6 vermeldt de dankbrief van Bleeker (voorzitter) aan het genootschap. In 1853 werd de bijdrage voor jaargang 1-4 vastgesteld op maximaal f 4.000 (Dir 0197, vergadering 22-2-1853, punt 2).
} 
en nieuwe inkomsten genereren. Bestuurslid L.W.C. Keuchenius, de latere minister van koloniën, stelde in oktober 1851 voor om een leesbibliotheek op te richten. ${ }^{82}$ Dat was kennelijk een activiteit waar voordeel uit te halen was (lezen tegen betaling), maar het denkbeeld kreeg geen enthousiast onthaal. Zijn voorstel gaf aan dat de bestaande bibliotheek in de Rijswijkstraat geenszins een 'leesbibliotheek' was, niet toegankelijk voor een groot publiek en evenmin aantrekkelijk, misschien wel te 'wetenschappelijk'. In december 1851 kwam Keuchenius met het voorstel om een eigen tijdschrift, waarover al in de jaren 1830 was gepraat, op te richten, ook nu weer in het kader van een discussie over de financiën. Ook het tijdschrift werd kennelijk door hem gezien als een winstmaker. Aldus werd besloten. Opvallend is wel dat het besluit werd genomen ruim een jaar nadat de eerste aflevering van het Natuurkundig Tijdschrift was verschenen en vijf maanden nadat het nieuwe Delftse Instituut had besloten zijn Bijdragen tot de Taal-, Land-en Volkenkunde van Neêrlandsch Indië te gaan uitgeven. De concurrentie zat het genootschap op de hielen, het kon niet achterblijven. ${ }^{83}$

Een andere uitweg om uit de financiële moeilijkheden te komen, was een beroep te doen op de leden. Bestuurslid Wassink stelde al in oktober 1851 voor om donaties te vragen. Daartoe werd in december besloten. Er ging een intekenlijst onder de leden rond om een gift te vragen boven de jaarlijkse contributie. De bestuursleden gaven het voorbeeld en tekenden in voor $f 80$ per persoon. Sommige van hen vroegen bovendien een rekening voor het Natuurkundig Tijdschrift en wilden het dus niet langer gratis ontvangen. ${ }^{84}$ Ook op de kleintjes werd gelet: Voorzitter Bosch stelde voor om voortaan thuis bij een van de leden te gaan vergaderen. Dat spaarde uitgaven voor licht. ${ }^{85}$

De intekenactie was tamelijk succesvol. De nieuwe beschermheer, gouverneur-generaal A.J. Duymaer van Twist, vroeg om een lijst en tekende in voor $f 500$ per jaar. Bleeker kon op 27 april 1852 melden dat voor dat jaar al voor $f 4.090$ was opgehaald (VBG 24:26). Waar de landvoogd voorging, konden de ingezetenen niet achterblijven. Een legaat van $f 1.000$ gaf in hetzelfde jaar nog wat meer lucht. ${ }^{86}$ Het plan echter om de contributie te verhogen leed schipbreuk. Al kregen de leden sinds kort twee tijdschriften naast de

82 ANRI KBG Dir 0188, vergadering 26-10-1851, punt 2. Het idee van een leesbibliotheek werd door Keuchenius opgebracht tijdens de discussie over de brief van de algemeen secretaris van 20-6-1851 over de afwijzing van de verhoging van de subsidie.

83 ANRI KBG Dir 0189, vergadering 30-12-1851, punt 2. Zie verder Knaap 1994:637. Het Natuurkundig Tijdschrift had in oktober 1850 al het licht gezien. Zie Natuurkundig Tijdschrift 2:12.

84 ANRI KBG Dir 0189, vergadering 30-12-1851, punt 2-3.

85 ANRI KBG Dir 0190, vergadering 24-2-1852, punt 14.

86 Van J. Schill, lid van het genootschap, vermoedelijk familie van bestuurslid E.A. Schill. Zie ANRI KBG Dir 0195, vergadering 26-10-1852, punt 7. 
Verhandelingen, het eigen Tijdschrift en zijn natuurkundige broer, zo'n verhoging was velen te gortig. De genoemde maatregelen losten het probleem niet op. Het genootschap leefde op te grote voet. Rekeningen van de drukkerij Lange van ruim $f 7.500$ in 1853, $f 3.800$ voor 1854 en $f 9.000$ in 1855 waren duidelijke signalen aan het genootschap dat het zo niet langer ging. ${ }^{87}$

In een brief van 6 november 1858 aan het gouvernement moest het genootschapsbestuur toegeven dat het de schulden niet meer kon betalen. Bij Kemink in Utrecht stond het voor $f 6.352$ in het krijt, bij Lange voor $f 24.896$, bij de Natuurkundige Vereeniging voor $f 1.680$ terwijl het voor dat jaar nog achterstallige betalingen verwachtte voor $f 1.600$. Tegoed was het nog een bedrag van $f 16.492$ onder andere van de Natuurkundige Vereeniging, aan intekengelden, contributie en subsidie. Het tekort van ruim $f 18.000$ achtte het onoverbrugbaar. De begroting voor 1859 die meegestuurd werd in dezelfde brief, zag er voor sommige onderdelen, zoals de uitgaven voor de aanschaf van boeken voor de bibliotheek $(f 1.500)$ en voorwerpen voor het museum $(f 500)$ bepaald zuinig uit. Van de uitgaven van $f 16.940$ was meer dan de helft voor de Verhandelingen ( $f$ 4.000,-), het Tijdschrift ( $f$ 5.000), en het collectieve abonnement op het Natuurkundig Tijdschrift ( $f$ 1.680). Honoraria voor de secretaris en de bibliothecaris (ieder $f 1.200$ ) vormden de belangrijkste andere uitgaven.

Aan contributie dacht het bestuur $f 6.400$ binnen te krijgen, aan intekeningen op het Tijdschrift door niet-leden $f 2.000$ en het rekende op de subsidie van $f$ 2.200. Een structureel tekort van $f 5.940$ dreigde het genootschap naast de schuld van $f 18.000$ noodnottig te worden. Het resultaat hebben wij zojuist beschreven. Het gouvernement kwam met ruime gelden over de brug. Daarmee was het genootschap voorlopig weer gered. Dat de regering een nog veel grotere som zou moeten reserveren voor de huisvesting van het genootschap, moet zij geweten hebben. De bouwvallige toestand van de gebouwen achter en naast de Harmonie was haar bekend.

\section{Verzamelingen}

Het museum was vooral sinds het actieve verzamelbeleid van de jaren 1840 in omvang toegenomen. In de notulen komen het verzamelen, het beheren en beschrijven van de verzamelingen en het publiceren van catalogi met regelmaat aan de orde. Op dit terrein waren in het bijzonder enkele bestuursleden actief: bibliothecaris-secretaris-redacteur Bleeker, bibliothecaris-redacteur en bestuurslid Munnich, adjunct-bibliothecaris en bestuurslid Friederich en

87 ANRI KBG Dir 0197, vergadering 22-2-1853, bijlage 32; Dir 0203, vergadering 27-6-1854, correspondentie w.; Dir 0207, vergadering 30-1-1855, correspondentie r. 
secretaris-redacteur Netscher. Aan hen hebben de verzamelingen veel te danken, aan Bleeker en Netscher wellicht het meest. Achtereenvolgens zullen aan de orde komen: het verzamelen, het beschrijven en bekendmaken van de verzamelingen en tenslotte de huisvesting.

Al vóór 1849 waren beslissingen genomen die het verzamelterrein inperkten: het museum had geen natuurhistorische afdeling meer, planten- en dierenrijk vielen buiten het gebied dat het wilde bestrijken. Een uitzondering was gemaakt voor de mineralen en schelpenverzameling. In het in 1861 grotendeels door Netscher samengestelde 'Overzigt van den staat van het Bataviaasch Genootschap' werden vier afdelingen van het museum onderscheiden: oudheden, etnologie, geologie en numismatiek. Had Bleeker in 1853 nog vastgesteld dat sinds het afstoten van de zoölogische afdeling vooral de oudheden en de afdeling geologie aan omvang hadden gewonnen (VBG 25:12), Netscher moest acht jaar later constateren dat de geologische afdeling 'sedert vele jaren stationair is gebleven', voornamelijk omdat er weinig aan de natuurwetenschappen was gedaan. ${ }^{88}$ Hij noemde Bleekers vissen als uitzondering. Tussen 1848 en 1852 waren nog wel geologische aanwinsten gemeld: meer dan honderd voorwerpen uit Borneo, verzameld door H. von Gaffron en nog eens ruim honderd uit Australië door F. von Sommer (VBG 22:11-2). De aanwinsten van tin uit Billiton (van J.P. Cornets de Groot) en bruinkool van Midden-Java (van J.E. van Leeuwen) in 1852 behoorden tot de laatste op het gebied van de aardwetenschap (VBG 24:13-4). Terwijl het in 1849 nog heette dat Von Sommer zijn collectie niet alleen had gecatalogiseerd en geëtiketteerd, ja zelfs in de kasten van het 'Geologisch Museum' had gerangschikt, moest een wat treurige Bleeker in 1853 toegeven dat het van een algemene catalogus van de geologische afdeling niet snel zou komen. Van verschillende, eerder verworven voorwerpen die in kisten bewaard waren, ontbraken nu aanwijzingen over de herkomst (VBG 22:14; VBG 24:12). Deze mededeling luidde het einde in van de geologische verzameling. De Natuurkundige Vereeniging had de fakkel op dit terrein overgenomen.

Anders was het gesteld met de oudheden. De aandacht daarvoor werd uit verschillende hoeken gestimuleerd: de Tweede Kamer sprak zich in 1854 uit over de zorg voor de oudheden, terwijl ook de directeur van het Museum van Oudheden te Leiden, C. Leemans, de regering aansprak op haar verantwoordelijkheid voor deze zaak. Het nieuw opgerichte Koninklijk Instituut in Delft probeerde de minister van koloniën zowel warm te maken voor onderzoek naar de oudheden te Singosari als voor een Javaans-Sumatraans Corpus

88 'Overzigt' 1862:173. Het overzicht is niet gesigneerd, maar in het verslag van de algemene vergadering van 16-11-1861 (TBG 12:152-3), waar het is voorgelezen, wordt Netscher als de auteur aangewezen. De toenmalige secretaris, T.H. der Kinderen, zal verantwoordelijk zijn geweest voor de passages waarin Netscher met ere wordt genoemd. 
Inscriptionum (TBG 12:185). In alle gevallen werd het genootschap door het gouvernement op de hoogte gesteld en gestimuleerd om zich ervoor in te spannen. Het genootschap wist daardoor dat er kapers op de kust konden zijn. Het Leidse Museum van Oudheden verzamelde zelf, de Delftenaren wilden graag publiceren over de oudheden.

De stroom van oudheidkundige voorwerpen begon na Van Hoëvells actieve acquisitie tijdens zijn reis over Java van 1843. De achttien beelden uit Soerabaija (1849), volgden op een bezoek van Van Hoëvell aan resident Pietermaat tijdens zijn reis van 1847. Ook het beeld van de stier Nandi dat baron Van Lynden uit Borneo stuurde (1849), is nog als een aanwinst uit de periode-Van Hoëvell te beschouwen. Onder het voorzitterschap van Buddingh bood de Algemene Secretarie direct weer voorwerpen aan. ${ }^{89}$ Visscher zelf tipte in 1849 het bestuur over twee beelden op het terrein van het residentiehuis van Bandjarnegara, die hij daar had gezien. J. Hageman uit Soerabaija stuurde in 1851 vier beelden uit de tijd van Madjapahit, waarvan direct een beschrijving werd gegeven in de Verhandelingen. ${ }^{90}$ Een kleine verzameling metalen hindoe-voorwerpen uit de nalatenschap van assistent-resident G.J.P. Carlier kon in 1858 voor honderd gulden worden aangekocht. ${ }^{91}$ Netschers reis in het gevolg van gouverneur-generaal Pahud leverde in 1859 alleen al zestien beelden op. En dan waren er de diverse opgegraven vondsten. Veelal ging het om munten en sieraden, soms stammend uit een ver verleden. Meestal leek de informatie van de bestuursambtenaren in hun brieven aan het gouvernement genoeg. Als er niet van 'oudheidkundige waarde' werd gerept, hoefden de voorwerpen niet naar Batavia te worden gestuurd voor verdere verificatie. Het bestuur moest vaak afgaan op de lokale beoordeling van de waarde van de vondst.

Het genootschap was actief op dit terrein, maar niet altijd succesvol. Brieven gingen uit naar de residenten van Kediri, Bagelen en Banjoemas om de overdracht te vragen van beelden die voor het residentiehuis te Kediri stonden en om informatie te krijgen over beelden die in een kloof van het Diëng-plateau waren gegooid. De resident van Kediri antwoordde prompt dat hij de beelden niet kon afstaan uit 'beduchtheid voor de waarschijnlijke gevolgen'. Op de bevolking zou het een 'zeer onaangenamen indruk teweegbrengen, daar zij uit bijgelovigheid zeer aan dezelven gehecht is, en zich zoude verbeelden, dat met het verlies van de oudheden ook een gedeelte

\footnotetext{
89 ANRI KBG Dir 0162, vergadering 22-9-1848, ingekomen stukken $\mathrm{f}$ (goud en zilver uit Poerwokerto), g (tekeningen van buddhistische zonnewijzers uit Surakarta), bijlagen 30 en 38.

90 ANRI KBG Dir 0169, vergadering 29-5-1849, punt 5; ANRI KBG Dir 0188, vergadering 26-10-1851, punt 5a. Beschrijving in VBG 24:10-1.

91 TBG 8:102, vergadering 19-6-1858. In het opschrift van deze notulen heet de vergadering gehouden te zijn in juli. Dit moet een vergissing zijn voor juni.
} 
van haar geluk vervlogen was. ${ }^{92}$ Dus bleven de oudheden te Kediri, terwijl de voorwerpen die zich in een kloof van het Diëng-plateau zouden hebben bevonden, of niet te vinden waren dan wel te zeer beschadigd bleken. ${ }^{93}$ Afbeeldingen van oudheden uit de belangrijke collectie Engelhard, die zich naar Netscher te weten was gekomen in het bezit van diens dochter, de weduwe Droop, bevonden, waren te duur. Kopiëren van de verzameling tekeningen zou volgens Netscher $f 250$ gaan kosten en dat vond de directie te veel. De weduwe vroeg daarop de tekeningen terug. ${ }^{94}$

Een belangrijke stap vooruit in het verder verzamelen was de beredeneerde beschrijving van de collectie oudheden in het museum, die Van Hoëvell en Friederich hadden gepubliceerd (VBG 21, 1846-47) en die Friederich vervolgde in 1850 (VBG 23, 1850). In de eerste aflevering waren 96 metalen en 39 stenen voorwerpen beschreven. In 1850 voegde Friederich er nog 38 beschrijvingen van beelden en inscripties in steen aan toe. Aan de twee afleveringen waren bovendien 42 litho's toegevoegd, die door de lithografische inrichting van de genie waren gemaakt. ${ }^{95}$ Voor het eerst kon men buiten Batavia zien wat er in het museum aan oudheden was verzameld. Toch was de verzameling verre van compleet gecatalogiseerd. In 1848 waren er immers al 400 archeologische objecten geweest. De beschrijving kwam nu uit op 173. Rond 1860 moet de verzameling zeker 450 objecten hebben geteld, munten niet meegerekend.

Tezamen met de catalogus van de Arabische handschriften en de publicaties van Friederich over Javaanse oudheden en over Bali, vergrootte deze beschrijving niet alleen de waarde van de Verhandelingen, het stelde een ieder die interesse had in oudheden in staat vergelijkingen te maken. Oudheidkundigen zoals de predikant J. Brumund, die in 1857 op reis was over Java en die door het genootschap van documentatie werd voorzien, waren zodoende beter toegerust. ${ }^{96}$ Documentatie werd als steeds belangrijker gezien. In de 'Desiderata' van 1858 riep het genootschap via de Javasche Courant op tot het inzenden van een nieuwe lijst van ruïnes van tempels en andere gebouwen, van beschreven stenen, van zowel zorgvuldig als ruw bewerkte stenen beelden. De lijsten uit de jaren veertig, toen op last van het gouvernement gemaakt, voldeden niet meer. $\mathrm{Nu}$ ging via de krant een oproep uit die een groter publiek bereikte (Javasche Courant 16 en 20-10-1858).

92 ANRI KBG Dir 0188, vergadering 26-10-1851, punt 4 en bijlagen 21 en 22; Dir 0189, vergadering 30-12-1851, punt 4e en bijlage 6, brief resident Kediri, 16-12-1851.

93 Drie brieven uit Bagelen en Banjoemas, dd 9 en 7-1-1852, zie ANRI KBG Dir 0190, vergadering 24-2-1852, bijlagen 12-14.

94 TBG 7:458, vergadering 27-7-1857. TBG 8:315-6, vergadering 2-10-1858. TBG 9:39, vergadering 4-12-1858.

95 Het genootschap betaalde er $f 736$ voor. ANRI KBG Dir 0180, vergadering 27-8-1850, punt 7.2.

96 TBG 7:257, vergadering 18-5-1857. 
De etnologische collectie was met de oudheidkundige de snelst groeiende. Netscher kon in 1861 tevreden vaststellen dat de etnologische verzameling sinds 1853 was verviervoudigd (TBG 12:174). Hij meldde niet hoeveel voorwerpen er toen geteld werden. Zelf had hij in diverse aanwinsten de hand gehad. Hij nam er het initiatief voor of schonk eenvoudig zelf voorwerpen. In 1854 kocht hij een aantal overgebleven voorwerpen aan na afloop van de Bataviase Nijverheidstentoonstelling (1853). Het is duidelijk dat Netscher zelf op het idee was gekomen om de tentoongestelde objecten aan de collectie toe te voegen. De gouverneur-generaal schonk later nog een aantal voorwerpen, die ongeschikt waren bevonden om naar de Nijverheidstentoonstelling in Arnhem te worden gezonden. ${ }^{97}$ Het genootschap kreeg kennelijk wel de tweede keus.

Netscher stelde ook de advertentie voor de krant op die in mei 1857 in het Nederlands, Javaans en Maleis verscheen en waarin zowel Europese ingezetenen als inheemse hoofden werden opgeroepen mee te werken aan de verwerving van etnologische voorwerpen voor de collectie. ${ }^{98}$ Het bestuur wendde zich nu niet langer uitsluitend tot de leden of tot de bestuursambtenaren in de buitengewesten, maar richtte een oproep tot het publiek onder het kopje 'Etnographisch museum'. Het wees op de lacunes in het museum en vroeg met name om wapens, kledingstukken, huisraad, gereedschappen op het gebied van landbouw, visserij en jacht, modellen van vaartuigen en om oude en nieuwe munten. In het algemeen vroeg het voorwerpen om de nijverheid van de inheemsen aanschouwelijk te kunnen maken, met beschrijvingen van de herkomst en opgave van het gebruik en het materiaal, waarvan het gemaakt was (Javasche Courant 20-6-1857).

Netscher was alweer degene die in 1858 de al genoemde 'Desiderata' van het genootschap opstelde, die zowel in het Tijdschrift als in de Javasche Courant verschenen en waarin opgave werd gedaan van wat de belangrijkste aandachtspunten waren voor de verzamelingen van het genootschap. ${ }^{99}$ Tot die desiderata behoorden zowel algemene beschrijvingen van gewesten en van oudheidkundige resten, alsook etnografische voorwerpen, waarbij zowel de streek als de aard van de voorwerpen waren gespecificeerd. Netscher wilde graag een compleet angklung-spel uit de Preanger, alsook striklansen en metalen pantsers uit Celebes (Javasche Courant 9, 16 en 20-10-1858). Het initiatief voor een grote aankoop van lansen en krissen uit de vendutie van G.C. van Rijck, door het gouvernement gesteund met een bedrag van $f$ 500,

97 ANRI KBG Dir 0202, vergadering 28-3-1854, punt 5.e, en bijlagen 24-26; Dir 0203, vergadering 27-6-1854, punt 3.s en v en Dir 0204, vergadering 25-7-1854, punt 2.k.

98 TBG 7:257, vergadering 18-5-1857.

99 TBG 8:283, vergadering 3-7-1858; TBG 8: 292-3, vergadering 16-9-1858 
kwam ook van Netscher. ${ }^{100}$ De militaire expedities uit de jaren 1850-1860 naar Djambi, Riouw en Celebes leverden eveneens veel voorwerpen op.

De groei van de etnologische collectie vroeg daarom ook om beschrijving, indeling en een betere opstelling. In 1858 leverde C.B.H. von Rosenberg daarvoor een belangrijke bijdrage. Hij had een index opgesteld van de etnologische voorwerpen uit Sumatra, de Molukken, Nieuw-Guinea en Timor. 'Na veel zoekens ben ik in geslaagd, om alle voorwerpen uit gemelde landen bijeen te krijgen', zo meldde hij aan het bestuur. ${ }^{101}$ Von Rosenberg (18171888) was al sinds 1840 in Indië, waar hij als militair naartoe was gekomen. Hij kende Sumatra goed na een zestienjarig verblijf op het eiland. Hij maakte ettelijke reizen naar de eilanden voor de Westkust. Sinds 1856 was hij in Batavia werkzaam bij het Topografisch Bureau. Vanuit Batavia verkende hij het Oosten van de archipel. In 1858 was hij van de partij toen de expeditie naar Nieuw-Guinea werd uitgerust. Von Rosenberg kwam als een geschenk uit de hemel, waar in het museum de voorwerpen zich maar opstapelden (Bakels en De Jonge 2001:11-2; ENI 3 s.v. Rosenberg). De catalogus van de voorwerpen van Palembang, Java en Bali was overigens al door Netscher bewerkt, zodat alleen Borneo en Celebes nog op beschrijvers wachtten. Von Rosenberg had voor de inrichting van de verzameling en voor de opstelling in het museum een verdeling in acht regio's voorgesteld: Sumatra, Java, Borneo, Celebes, de Molukken, Nieuw-Guinea, Timor en Bali. Ook deed hij een voorstel voor een nummering. 'I.B.10' betekende: Sumatra (I), Nias (B), volgnummer van het voorwerp (10). ${ }^{102}$ Pas in de jaren 1860 voltooide de jonge Levyssohn Norman het werk aan de catalogus. In 1868 verscheen die in druk (Katalogus ethnologische afdeeling 1868).

\section{Persoonlijkheden: Netscher en Munnich}

Elisa Netscher (1825-1880) was zelf de grootste aanwinst voor het genootschap. Hij was in 1842 in Batavia aangekomen en pas in 1848 als klerk bij de Algemene Secretarie aangesteld. ${ }^{103}$ Hij klom daar op tot referendaris (1858) en gouvernements-secretaris (1860) om uiteindelijk jarenlang op Sumatra werkzaam te zijn: als resident van Riouw (1861-1870) en gouverneur van Sumatra's Westkust (1870-1878). Hij eindigde zijn loopbaan als lid van de Raad van Indië en stierf in 1880 in Batavia.

100 TBG 7:253, vergadering 18-5-1857.

101 ANRI KBG Mus 0028, brief van Von Rosenberg aan het bestuur 26-12-1858.

102 ANRI KBG Mus 0028, omslag 2, bevat de papieren van Von Rosenberg.

103 ENI 3:17 (s.v. Netscher) zegt: 1848. Het stamboek van Netscher bij het NA lijkt te zeggen: 1850. Zie NA Stamboeken Oost-Indische Ambtenaren, s.v. Netscher, folio 384 en vervolg 661. 
Tijdens de bestuursvergadering van 24 april 1852 stelde Bleeker voor dat Netscher tot lid zou worden benoemd. Ook Netschers ambtelijke chef, algemeen secretaris A. Prins, werd voorgesteld als lid. ${ }^{104}$ In de algemene vergadering van dezelfde dag maakte Bleeker bekend dat Netscher was toegevoegd aan het driemanschap Bleeker, Keuchenius en Munnich, dat de redactie vormde van het Tijdschrift voor Indische Taal-, Land-en Volkenkunde in oprichting. Netscher begon aldus als redactielid en droeg aan de eerste jaargang meteen ook als auteur bij. Hij zou de ziel van het Tijdschrift worden. In maart 1854 werd hij tot kandidaat-bestuurslid benoemd en in de algemene vergadering van 24 april 1855 gekozen. Vanaf januari 1855 woonde hij de bestuursvergaderingen bij. ${ }^{105}$ In minder dan drie jaar was Netscher tot de kern van het genootschap doorgedrongen.

Meteen werd duidelijk hoe groot deze aanwinst was. Hij was actief begonnen met het verzamelen van munten. De muntenverzameling was zijn geesteskind. Hij stelde in 1857 voor een verzameling koperen munten en papiergeld, die bij de Algemene Secretarie gedeponeerd was, over te nemen en vroeg in september 1858 dan ook of hij 'speciaal belast kon worden met de zorg over het kabinet', welk verzoek door het bestuur maar al te graag werd ingewilligd. Hij gaf toen tegelijk een overzicht van wat het genootschap aan Indische munten en penningen bezat, het eerste, in het Tijdschrift gedrukte overzicht van deze verzameling. ${ }^{106}$ De uitgebreide beschrijving volgde in samenwerking met de latere landsarchivaris J.A. van der Chijs - in de Verhandelingen in 1864. Hij legde ook de contacten met P.O. van der Chijs, de vader van de zoëven genoemde, zelf beheerder van het munt- en penningkabinet van de Leidse Universiteit, waarmee het tot een uitwisseling kwam. ${ }^{107}$ Netscher stelde in 1858 aan het bestuur voor om een verzameling portretten aan te leggen van personen, die in Indië hoge posities hadden bekleed of zich op het terrein van kunsten en wetenschappen verdienstelijk hadden gemaakt, en stelde direct ook een paar portretten ter beschikking. ${ }^{108}$ Ook was hij degene die via de krant om etnologische voorwerpen liet rondvragen (1857) en die in 1858 de Desiderata formuleerde.

104 ANRI KBG Dir 0193, vergadering 24-4-1852, punt 5.

105 ANRI KBG Dir 0202, vergadering 28-3-1854, punt 3. In 1854 was er geen algemene vergadering, dus moest Netscher tot 1855 wachten op zijn installatie als bestuurslid. Zie ook Dir 0205, vergadering 3-10-1854, punt 1.o. voor de beslissing dat hij als redactielid wordt uitgenodigd. ANRI KBG Dir 0207, vergadering 30-1-1855. Netscher wordt voor het eerst vermeld als vertegenwoordigend redactielid bij het verslag van de algemene vergadering van 24-4-1855, Dir 0210, punt 4 .

106 TBG 7:187, vergadering 23-2-1857, punt 21; TBG 8: 295-6, vergadering 16-9-1858, punt 3.

$107 \mathrm{Al}$ in 1856 had Netscher daar een nota over geschreven (TBG 7:247-8, vergadering 6-4-1857, punt 3.8).

108 TBG 8:283, vergadering 3-7-1858, punt 6; TBG8:293-4, vergadering 16-9-1858, punt 2.15. 
Netscher werd door het gouvernement toegevoegd aan vice-president van de Raad van Indië en regeringscommissaris voor de zaken van Celebes, De Perez, toen deze in begin 1859 naar Celebes vertrok om de expeditie naar Boni te volgen. Tevoren was al in december 1858 dezelfde De Perez in zijn hoedanigheid van genootschapsvoorzitter door het bestuur gemachtigd van de expeditie gebruik te maken voor de belangen van het genootschap. Op 19 maart moest Netscher vanuit Badjoa het overlijden van De Perez melden, waarna de opperbevelhebber van de latere, tweede Bonische expeditie, generaal Van Swieten de nieuwe genootschapsvoorzitter werd. ${ }^{109}$ Toen Boni uiteindelijk in 1860 onder zijn leiding onderworpen werd, was het genootschap opnieuw goed vertegenwoordigd. Direct na de terugkeer van Netscher uit Celebes - op de vergadering van 14 mei 1859 was hij er weer - kwamen ook de eerste Bonische voorwerpen bij het genootschap binnen. Netscher werd bedankt voor zijn bemoeienissen. Bij zijn aankondiging in juli 1859 van zijn reis over Java in het gevolg van Pahud liet hij weten wederom voor het genootschap 'bereidvaardig' te zijn. Op de vergadering van 7 oktober al bracht hij diverse geschenken in, onder andere van de Javaanse vorsten, een bewijs dat hij ook op zijn reis naar Midden-Java de belangen van het genootschap had behartigd. ${ }^{110}$

Het op handen zijnde vertrek van Bleeker, dat hij eerst op 7 april 1859 bekendmaakte, met het verzoek hem van het redacteurschap van de Verhandelingen en van het mederedacteurschap van het Tijdschrift te ontslaan, zou voor het bestuur een grotere klap geweest, als niet Netscher bereid was geweest om de taak van Bleeker voor wat betreft de Verhandelingen over te nemen. In de tijdschriftredactie bleven Netscher en Munnich samen over. ${ }^{111}$ Bij het vertrek van Bleeker in juli 1860, nam Netscher het secretariaat over, terwijl hij het toezicht over het museum eigenlijk al uitoefende. ${ }^{112}$ Bij het vertrek van Munnich in januari 1861 kreeg Netscher Van der Chijs naast zich in de redactie van het tijdschrift, die tevens Munnich als bibliothecaris opvolgde. ${ }^{113}$ Na zijn benoeming tot resident van Riouw woonde Netscher op 4 mei 1861 zijn laatste vergadering bij. Het secretariaat werd overgenomen door T.H. der Kinderen. Netschers vertrek betekende niet dat hij voor het genootschap

109 TBG 9:38-9, vergadering 4-12-1858, punt 9 (benoeming Van Swieten tot lid) en 10; TBG 9:220, vergadering 19-3-1859, punt 4.1 (overlijden De Perez); TBG 9:238, vergadering 4-6-1859, punt 17 (verkiezing van Van Swieten tot voorzitter); TBG 9:436, vergadering 2-10-1859, punt 9. Van Swieten meldt daar zijn afwezigheid vanwege de tweede Bonische expeditie.

110 TBG 9:246, vergadering 6-8-1859, punt 3.15; TBG 9:432, vergadering 7-10-1859, punt 7.

111 TBG 9:222, vergadering 9-4-1859, punt 4.7; TBG 9:431, vergadering 7-10-1859, punt 6. Keuchenius was al in 1854 om gezondheidsredenen naar Nederland vertrokken. De redactie bestond sindsdien uit drie leden.

112 Voor de verkiezing van Netscher tot secretaris: TBG 10:444, vergadering 28-7-1860.

113 TBG 10:410-1, vergadering 5-1-1861, punt 10 en 20. 
verloren was, integendeel, maar zijn stuwende kracht als redacteur, bestuurslid, secretaris en conservator zou het genootschap zeer missen. Zowel aan de Verhandelingen als aan het Tijdschrift zou hij blijven bijdragen, terwijl de genootschappelijke verzamelingen van hem zouden blijven profiteren. Door zijn ruim vijftienjarig verblijf op Sumatra, zouden de verzamelingen Riouwse en West-Sumatraanse voorwerpen blijven groeien. Na 1860 zouden Van der Chijs en Der Kinderen in veel opzichten de plaats van het duo BleekerNetscher innemen.

Naast Bleeker en Netscher was Jurriaan Munnich (1817-1865) een steunpilaar van het genootschap in de periode 1849-1860. Hij was in al 1841 in Batavia aangekomen als chirurgijn der derde klasse met een speciale opdracht van het Ministerie van Koloniën om te proberen het nieuwe fenomeen van de fotografie in de tropen toe te passen. In Nederland had hij daar ervaring mee opgedaan. Zijn oudere broer Johan was een belangrijke fotograaf en had de leiding over de Haarlemse studio Munnich en Ermerins (Veen 1998). Jurriaan zal van zijn broer de nieuwe techniek hebben leren kennen. Hij ging naar Midden-Java met zijn 'heliografisch toestel van Daguerre', maar zijn missie mislukte grotendeels. De techniek moest eerst verbeteren vooraleer er geslaagde opnames konden worden gemaakt. Voor een opname in Madioen, een van de best gelukte, had Munnich een belichtingstijd van 26 minuten nodig. Hij was wel de eerste fotograaf die de oudheden op de gevoelige plaat probeerde vast te leggen (Toekang Potret 1989:16). In november 1842 had de Algemene Secretarie het genootschap een technisch verslag van Munnichs bevindingen gestuurd. Het genootschap was geïnteresseerd geraakt en had om een bijbehorend reisverslag gevraagd. Dat had het ontvangen samen met voorbeelden van de gemaakte foto's. Munnich, door het genootschap gevraagd zijn reisverslag plus zijn aantekeningen over de fotografie tot één samenhangende tekst te bewerken, liet in juli 1843 vanuit Semarang weten dat hij daar geen tijd voor had. ${ }^{114}$ Daardoor miste het genootschap een kans om in de Verhandelingen over het belang van de fotografie voor het documenteren van de oudheden op Java te berichten. Overigens had E. de Waal in De Kopiïst al in 1842 uit Munnichs Nederlandse rapport over de nieuwe techniek gepubliceerd (De Waal 1842a). Na Munnichs missie zou Adolph Schaefer in 1845 met een nieuw toestel meer succes hebben. Zijn Schaefers foto's bewaard, die van Munnich zijn helaas verloren gegaan.

114 Brief van Munnich, 11-7-1843 uit Semarang in ANRI KBG Dir 0138, vergadering 20-7-1843, punt 1 en bijlage 1. Verder Dir 0134, vergadering 9-2-1843, punt 1 en bijl. 1; Dir 0136, vergadering 21-3-1843, punt 2 (waar het gouvernementsbesluit 3-3-1843 nr 3 wordt gemeld, waarbij zowel de verslagen als de foto's aan het genootschap ter beschikking werden gesteld.); Dir 0137, vergadering 27-5-1843, punt 3. De brief van de algemeen secretaris, dd 11-11-1842 aan het genootschap met de eerste melding over Munnichs rapportage in Dir 0133, vergadering1-12-1842, punt 2. 
Na zijn fotografische reis werkte Munnich als geneeskundige in Semarang en Batavia. Van zijn liefde voor en behoefte aan poëzie getuigt een in 1842 geschreven bijdrage in het Tijdschrift voor Neêrland's Indië: 'Iets omtrent de beoefening der poezy in Neêrlandsch Indië'. Hem was sinds zijn aankomst weinig gebleken van de beoefening van de dichtkunst in Indië. Onder verwijzing naar een uitspraak van zijn vriend Nicolaas Beets hoopte hij met zijn oproep daaraan iets te veranderen (TNI 5, I:237-47). In hetzelfde tijdschrift publiceerde hij in 1843 een dichtfragment 'De Lawoe', waarvoor hij op reis inspiratie had opgedaan en waarmee hij getuigde van zijn bereidheid om de lier te hanteren. ${ }^{115}$ Zijn oproep om meer poëzie had trouwens gehoor gevonden. Jaarboekjes als Lakschmi (1840-1842, onder redactie van Buddingh), Warnasarie, Letterkundig (later: Indisch) Jaarboekje (1848-1858, onder redactie van Munnich en L. Tollens), en Biäng-lala, Indisch Leeskabinet tot Aangenaam en Gezellig Onderhoud (1852-1855, onder redactie van W. Ritter en L. Tollens), namen gedichten op en verlevendigden zodoende het prozaïsche Batavia (Tromp 1987). Tesamen met Munnichs al eerder aangehaalde stuk over een op te richten leesmuseum en zijn activiteiten binnen de Vereeniging Musis, waarvan hij mede-oprichter was, liet hij zich met deze literaire en leesactiviteiten kennen als een buitenbeentje in Batavia.

Munnich was in 1846 lid geworden. ${ }^{116} \mathrm{Hij}$ was toen officier van gezondheid en had binnen het genootschap voordrachten gehouden over het menselijk lichaam, gebruik makend van een 'kunstlijk', een nieuwigheid van Franse oorsprong waarmee in het geneeskunde-onderwijs werd gewerkt. Hij nam in 1848 de secretarisplaats waar ${ }^{117}$, maar woonde na Bleekers terugkeer de bestuursvergaderingen niet meer bij. De bibliothecarisplaats was intussen ingenomen door een andere medicus, P.J. de Wilde. In 1851 keerde Munnich terug als opvolger van De Wilde en daarmee zette hij het bibliotheekwerk van Bleeker voort. In 1852 werd Munnich eindelijk zelf tot bestuurslid gekozen. ${ }^{118}$

Munnich bleef actief als publicist en droeg bij aan het Tijdschrift voor Nederlandsch Indië, onder meer schrijvend over gevoelige onderwerpen als

115 TNI 6 II:439-42. Het verscheen ook in het jaarboekje Aurora. Ook in het Indisch Magazijn, opvolger van De Kopiïst publiceerde hij gedichten. Zie 'Barakotta' in Indisch Magazijn 2, I:173-205, 2, II:212.

116 ANRI KBG Dir 0147, Algemene Vergadering 14-1-1846, verslag achter dat van de vergadering van 15-12-1845.

117 ANRI KBG Dir 0159, vergadering 27-3-1848, punt 1. Aanvankelijk was Bleeker vervangen door bibliothecaris P.J. de Wilde. Munnich was zijn collega Bleeker in 1847 al voorgegaan in een melding aan het Journal of the Indian Archipelago (1:168-9), dat er problemen waren met het drukken van het Natuur- en Geneeskundig Archief, maar hij had zich voorzichtiger dan Bleeker uitgedrukt, dus deed het hem geen kwaad.

118 ANRI KBG Dir 0185, vergadering 4-3-1851, punt 3. De Wilde legde het bibliothecariaat neer en werd weer gewoon contribuerend lid, ANRI KBG Dir 0193, vergadering 24-4-1852, punt 6. 
het onderwijs in Brits-Indië (1850) en de vrijheid van drukpers (1851). In 1852 was hij eervol ontslagen als officier van gezondheid en benoemd tot commies bij de Algemene Secretarie. Hij klom daar op tot hoofdcommies en werd in 1856 lid van de boedelkamer om tenslotte, na een ziekteverlof van twee jaar (1861-1863), te eindigen als vendumeester. Het zat hem echter niet mee. Hij werd opnieuw ziek en kreeg dientengevolge in 1865 opnieuw verlof. Kort na aankomst in Nederland overleed hij. Hij is een interessant publicist. Voor het genootschap was hij als redacteur, bestuurslid en bibliothecaris van belang, maar zijn activiteiten als redacteur van jaarboekjes en zijn andere verenigingswerk (Musis) maken hem nog interessanter.

\section{De bibliotheek}

Bleeker had sinds zijn aantreden als bibliothecaris veel tijd besteed aan de boeken. Het bibliothecariaat was een betaalde bijbaan, dus mocht het genootschap er iets van verwachten. Zijn systematische catalogus, gedrukt in 1846, bevatte 1115 titels en legde de basis voor de werkzaamheden van zijn opvolgers. Tegelijkertijd werd duidelijk dat er nog veel ontbrak en dat veel verloren was gegaan. Bleeker constateerde dat in zijn geschiedkundig overzicht van 1853 (VBG 25:12). Er was vanaf 1847 gezorgd voor de publicatie van aanwinstenlijsten, eerst in de Verhandelingen, vanaf 1856 in het Tijdschrift. ${ }^{119}$ Munnich zorgde voor de tweede druk van de systematische catalogus in 1853 . Toen waren er 1785 titels. Toen Van der Chijs in 1864 de derde druk verzorgde, waren dat er, volgens diens telling, 5386 (Van der Chijs 1864:5).

Munnich hield bij aan welke genootschappen, maatschappijen, instituten en academies het tijdschrift werd gestuurd, van welke meestentijds publicaties werden terugontvangen. In een kattebelletje aan Bleeker van april 1855 bij een lijst van die 87 instellingen en twaalf redacties van periodieken gaf hij als schatting op dat er 1200 tot 1800 nieuwe titels dankzij die contacten, aan

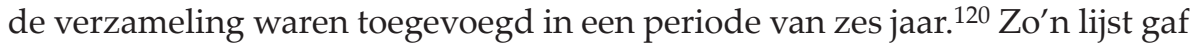
het genootschap natuurlijk status. Het onderhield contacten met instellingen in Nederland, Engeland, België, Frankrijk, Duitsland, Zwitserland, Italië, Spanje, Portugal, Rusland, Denemarken, Zweden, Noorwegen, de Verenigde Staten, Brazilië, Brits-Indië, China en de Filippijnen. De lijst werd niet zonder trots als een 'Berigt' in het tijdschrift gepubliceerd. ${ }^{121}$

119 VBG 21 tot en met 26, waarin bijna 1300 nieuwe titels worden vermeld. TBG 5:1 voor de eerste 'Opgave der boekwerken' (aanwinsten).

120 ANRI KBG Dir 0209, ongedateerd briefje bij een lijst, vergadering 11-4-1855, bijlage 12 en 13. De lijst telt 55 instellingen, maar in TBG 3:5 komt Munnich zelf tot 87 instellingen.

121 TBG 3:1-4, met een mededeling, ondertekend door M[unnich]. 
B I B L I O T H E C A E

\section{SOCIETATIS ARTIUM SCIENTIARUMqUE} QUAE BATAVIAE FLORET,

GATALOGUS SYSTEMATICUS

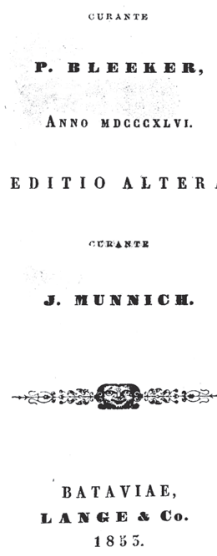

Titelpagina van de tweede druk van de bibliotheekcatalogus door J. Munnich, 1853 (collectie KITLV Leiden)
Over het acquisitiebeleid vóór 1848 komen we niet veel te weten. Het bestuur gaf in 1849 te kennen de Indische Bibliotheek 'de Bibliotheek van werken over Indië' - compleet te willen maken. In 1850 meldde Buddingh tevreden dat er een flinke boekbestelling in Nederland was gedaan, dat incomplete tijdschriften waren aangevuld en dat brochures en vlugschriften waren aangekocht. Tot de bestelde boeken hoorde een 55-tal titels dat Friederich had opgegeven, enerzijds van belang voor de studie van Indische oudheden, vooral de mythologie, anderzijds boeken die, in het enigszins houterige Nederlands van Friederich, 'behooren in iedere openbare boekerij te zijn, en zijn onmisbaar voor de behandeling van Arabische handschriften' ${ }^{122}$ Daarmee was een stap gezet op weg naar de Indische Bibliotheek (VBG 22:17, 23:12-3).

Pas echt belangrijk was de verzameling handschriften. Deze werd door Buddingh in 1849 op vierhonderd stuks geschat (VBG 22:18). De aanwinst van 357 Kawi-handschriften, bijna allemaal op bamboe, van de priester Pak Djame, die op de hellingen van de Merbaboe woonde en daarom aangeduid als de Merbaboe-handschriften, was een gebeurtenis voor het genootschap. Ze werden voor het eerst vermeld in de notulen van januari 1850 in een verslag van Friederich, die het bestuur aanraadde pogingen te ondernemen ze in bezit te krijgen. Een brief aan de resident van Kadoe van 2 februari 1850 moest dat resultaat opleveren. Die antwoordde direct dat de handschriften Poesaka (een erfstuk) waren en niet verkocht, maar wel geschonken konden worden. Hij meldde dat hij op 6 januari 1848 het gouvernement al had voorgesteld om in het bezit van de collectie te komen. Een tegengeschenk in 
goud van $f 500$ zou tot de aanwinst kunnen leiden. ${ }^{123}$ In augustus 1850 werd door algemeen secretaris Visscher gemeld dat geprobeerd zou worden de handschriften te verwerven. Het gouvernement was uiteindelijk goedkoper uit dan de resident van Kadoe had geschat: een gouden sirihdoos met inscriptie ter waarde van $f 350$ bezegelde de overdracht (Koloniaal Verslag 1851:79). In de laatste maanden van 1850 moeten de handschriften bij het genootschap binnen zijn gekomen, want op 7 januari 1851 presenteerde Friederich al een nota waarin hij de merkwaardigheden van de handschriften opsomde en aangaf dat er veel onduidelijk was, voor de oplossing waarvan hij naar Bali zou moeten. ${ }^{124}$ Pas op de algemene vergadering van 27 april 1852 werd door Bleeker de belangrijke aanwinst openbaar gemaakt. ${ }^{125}$ In 1850 was de handschriftencollectie dus bijna verdub-

CA'TALOGUS

DER

\section{B I B L I O T H E E K}

VAN HET

BITIIIMSCH GETOOTSCHAP IN KUNSTRI GI WETELSCHAPPEN,

Dook

Mr. J. A. VAN DER CHIJS,

Bibliothecaria.

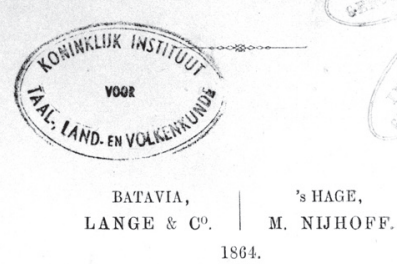

Titelpagina van de derde druk van de bibliotheekcatalogus door J.A. van der

Chijs, 1864 (collectie KITLV Leiden) beld.

Bij deze grote aanwinst verbleekten de kleinere, maar ze waren er natuurlijk wel. Friederich was eind 1852 naar Bandoeng gegaan om twaalf manuscripten op lontarbladen te bekijken die bij een bezoek van de gouverneur-generaal waren vertoond en die zo belangrijk leken dat er kopieën van moesten worden gemaakt. Friederich rapporteerde in februari 1853, dat ze hem van groot belang leken. Het is niet duidelijk uit de notulen op te maken of het genootschap zich met kopieën tevreden moest stellen, of dat het in tweede instantie

123 ANRI KBG Dir 0175, vergadering 29-1-1850, punt 2.9, bijlage 15. ANRI KBG Dir 0176, vergadering 26-2-1850, punt 2.2, bijlage 1 .

124 ANRI KBG Dir 0180, vergadering 27-8-1850, punt 3 over de melding van Visscher. Nadien in 1850 geen enkele vermelding meer van deze handschriften. ANRI KBG Dir 0184, vergadering 7-1-1851, punt 3.d over Friederichs nota, die niet is bijgevoegd.

125 VBG 24:6, Bleekers 'Verslag', waar hij uit Friederichs nota put. Recentelijk over deze collectie: Kuntara Wiryamartana en Van der Molen 2001. De onduidelijkheid die zij over de datum van verwerving signaleren, kan worden weggenomen. 
toch de handschriften zelf in bezit kreeg. In ieder geval werd de regent van Bandoeng tot lid gemaakt. ${ }^{126}$ Ook Netscher spande zich in voor de bibliotheek. In 1853 schonk hij een Redjangs handschrift, in 1854 een paar Maleise boeken en gaf hij een aantal titels op van Maleise boeken die in de bibliotheek ontbraken, in 1857 weer een paar Maleise werken en een Lampongs handschrift dat hij uit de nalatenschap van J.E.H. Juch had gekregen voor het genootschap. ${ }^{127}$ En zoals Netscher waren er meer. De bibliotheek en de handschriftenverzameling kregen langzamerhand de status die het genootschap nastreefde.

Voor wie was het bedoeld? Welk publiek bezocht het museum en de bibliotheek? De verwijzingen naar de publieke functie van het genootschap, naast het uitgeven van zijn publicaties, zijn zeer gering. In de Verhandelingen van 1849 werd achter de ledenlijst eenvoudigweg herinnerd aan de openingstijden: het museum alleen op dinsdag en vrijdag van 8.00 tot 12.00 uur en de bibliotheek van maandag tot zaterdag op dezelfde tijden. Het museum, toen nog steeds in de voormalige kolfbaan aan de oostzijde van de Harmonie op Rijswijk gevestigd, zal voor het publiek toegankelijk zijn geweest, niet uitsluitend voor de leden. Maar mochten kinderen komen kijken, al dan niet onder geleide? Waren Indonesiërs welkom? Dat is onduidelijk, al konden de Indonesische leden natuurlijk moeilijk geweigerd worden. Wat als de leden van de Maleise gemeente van de predikanten Van Hoëvell en Buddingh wilden komen kijken? De notulen zeggen er niets over. Het feit dat er na 1850 verschillende andere bibliotheken opengingen, waaronder die van het Nut, alsook de verdere opkomst van leesgezelschappen, suggereert dat de publieke functie van de genootschapsbibliotheek niet voldeed.

Toen in 1858 de gedachte opkwam dat inheemse wapens, veroverd tijdens verschillende expedities, de herinnering aan die expedities levend konden houden als ze in een 'openbaar museum' geplaatst werden, waren daarin mede Indonesische bezoekers begrepen, of hoefde alleen bij de Nederlandse bezoekers ontzag te worden opgewekt? Wat voor zin had het de nationalistische snaar te beroeren, als er nauwelijks bezoekers kwamen? Ze moeten er dus wel geweest zijn. Over bezoekers, aantallen, wie het waren en aan wat voor bezoekersreglementen ze zich dienden te houden, daarover melden de notulen niets.

De bibliotheek was, blijkens het voorwoord van de gedrukte catalogus van 1846, voor de leden toegankelijk. Buddingh beklaagde zich in 1849 over het gedrag van de gebruikers, die boeken niet terugbrachten, zelfs na aangemaand te zijn en na oproepen in de krant. Verder schetste hij dat de collectie

126 ANRI KBG Dir 0195, vergadering 26-10-1852, punt 2 en bijlage 1. ANRI KBG Dir 0197, vergadering 22-2-1853, punt 3. ANRI KBG Dir 0199, vergadering 25-6-1853, punt 2.

127 ANRI KBG Dir 0197, vergadering 22-2-1853, bijlage 10 en 11. ANRI KBG Dir 0202, vergadering 28-3-1854, punt 5.d. Verder TBG 7:457, vergadering 27-7-1857, punt 7-8. 
nogal te lijden had gehad door vandalisme: boeken waren slecht behandeld, prenten waren uit de boeken gescheurd. Al met al een verklaring voor het feit dat boeken nadien niet werden uitgeleend. Uitzonderingen waren alleen in heel dringende gevallen mogelijk tegen het tekenen van een reçu (VBG 22:12-3). Ook Van der Tuuk, we zagen het reeds, meldde in 1849 na zijn bezoek aan de bibliotheek het vandalistische bezoekersgedrag en merkte op dat hij vooral lege kasten zag, waar eertijds boeken moesten hebben gestaan (Groeneboer 2002:87-8, 91).

De collectie, iets meer dan 1100 titels in 1846, nog geen 2000 in 1853, was niet die van de gemiddelde leesbibliotheek. Voor zover er al verstrooiende lectuur in aanwezig was, zoals de jaarboekjes Warnasarie, Lakschmi en Biänglala, waren die er omdat ze in Batavia waren gedrukt en door de auteurs/ samenstellers ervan waren geschonken. In de aanwinstenlijsten tot 1854 kwamen soortgelijke titels bijna niet voor. Van de aanwinsten in de periode 1848-1853 was minder dan vijf procent van een verstrooiend karakter. Vele aanwinsten waren tijdschriften, seriewerken, jaarboeken van genootschappen. Een kwart van de aanwinsten ging op aan deze categorie. Als we bezien hoeveel aanwinsten echt thuishoorden in de 'Indische Bibliotheek' die het bestuur in de woorden van Buddingh (1849) voor ogen stond, komen we uit op ongeveer de helft, waarbij tijdschriften die zich met Indië bezighielden en de publicaties van genootschappen die dat deden, zijn meegeteld. De bibliotheek was in 1853 dus maar voor de helft een op Indië gespecialiseerde bibliotheek. Dat was wel een verschuiving ten opzichte van 1846. Wanneer we de catalogus uit dat jaar bekijken is van de 1115 titels maar ongeveer veertig procent werkelijk in de Indische bibliotheek op zijn plaats. Niet alleen was de bibliotheek dus uitgebreid, bij de uitbreidingen had men zich vooral gericht op boeken die pasten bij het werkterrein van het genootschap. Voor het overige was er van allerlei, maar overwegend boeken over wetenschappelijke onderwerpen. Deze waren deels geschonken door de corresponderende leden die zo hun lidmaatschap wilden waarmaken. Deels waren ze aangeschaft voor de wetenschappelijke activiteiten van de bestuursleden. De vele vissenpublicaties, waaronder boeken over zoetwatervissen in Zwitserland en de vissen van Sicilië waren uiteraard voor Bleeker bedoeld. Ook de opgave van aanwinsten in het Tijdschrift laten zien dat de bibliotheek weliswaar meer 'Indisch' werd, maar vreemde eenden bleven voorbij vliegen.

Pas bij de lang aangehouden bekendmaking van het nieuwe Algemeen Reglement, dat in 1862 van kracht werd, werd tevens een reglement van orde uitgevaardigd, waarin bekend werd gemaakt dat het museum, dat inmiddels weer in de Rijswijkstraat was teruggekeerd, en de bibliotheek voor 'een iegelijk' geopend waren. Ook voor Indonesiërs? Er waren Indonesische leden, maar die woonden doorgaans ver weg. Het uitlenen van boeken werd in 1862 
alleen toegestaan aan leden of door tussenkomst van leden. De bibliotheek was vanaf dat moment niet vaker dan twee maal per week open, het museum nog maar een maal per week (TBG 12:200-3). Dit had te maken met de krappe behuizing van de verzamelingen sinds de sluiting van het museumgebouw. Tot 1867 moest het genootschap wachten op verbetering daarvan.

\section{Gebouwen}

De huisvesting was een voortdurend terugkerend onderwerp. Het genootschap had behoefte aan een vergaderruimte, ruimte voor de bibliotheek en voor het museum. Het geologisch kabinet en de bibliotheek waren gehuisvest in het gebouw aan de Rijswijkstraat, achter de Harmonie, dat ten tijde van Raffles was gebouwd en dat in 1814 was betrokken. Daar was ook de vergaderzaal, terwijl het gebouw verder onderdak bood aan de drukkerij, al was die in 1849 overgenomen door Lange. Verder was er een woonhuis voor de toezichthouder op hetzelfde terrein. De oudheidkundige en etnologische verzamelingen waren in de voormalige kolfbaan gehuisvest, het gebouw naast de Harmonie op Rijswijk. Voor de kostbaarheden (goud en zilver, wapens met edelstenen, kostbare munten) vreesde men te zeer, dan dat ze in de Rijswijkstraat konden worden bewaard. Die waren bij de penningmeester of bij de directeur van het museum thuis ondergebracht.

De behoefte aan een behoorlijk gebouw voor de kunsten en wetenschappen werd in november 1853 onder de aandacht van het publiek gebracht door de geografisch ingenieur S.H. de Lange, bestuurslid van de Natuurkundige Vereeniging, tijdens een bijzondere ledenvergadering van die vereniging in het gebouw van de Bataviase nijverheidstentoonstelling. Het als tijdelijk bedoelde gebouw van die tentoontelling had zoveel enthousiasme opgewekt, dat bij de vereniging de hoop was gaan leven dat de tentoonstelling kon leiden tot een permanent museum en dat het gebouw behouden kon blijven. Dit laatste bleek niet realiseerbaar. Daarom meldde De Lange dat de in oprichting zijnde, uit de tentoonstelling voortkomende Maatschappij van Nijverheid een eigen gebouw nodig zou hebben. Direct daarop vervolgde hij met:

Het Bataviaasch Genootschap van Kunsten en Wetenschappen, dat eerwaardig gedenkteeken van den wetenschappelijken zin onzer voorgangers, eenig in de geschiedenis der koloniën van alle volken, kan zich niet op het bezit van een gebouw, zijner waardig, beroemen. De toonkunst, die edele onder hare zusters en die sedert weinige jaaren hier eene ontwikkeling heeft ondergaan, die de stoutste verwachting te boven streeft, roept luide om een' tempel voor hare priesters en vereerders. ${ }^{128}$

128 Verslag van de vergadering van de Natuurkundige Vereeniging in Natuurkundig Tijdschrift voor Nederlandsch Indie 5:249-84, het citaat op 282-3. 
Het bestuur van de Natuurkundige Vereeniging had nu de hoop dat uit de baten van de tentoonstelling - een groot deel van de produkten en voorwerpen zou in maart 1854 worden geveild - de hoeksteen zou kunnen worden betaald van een gebouw, dat 'in alle deze behoeften voorziet'. Bedoeld werden de behoeften van de nieuwe maatschappij, van het oude genootschap en van de nog jonge Maatschappij van Toonkunst.

Het idee van een gezamenlijk gebouw werd serieus aangepakt. In oktober 1854 kreeg het genootschapsbestuur er lucht van dat de Natuurkundige Vereeniging en de Nederlandsch-Indische Maatschappij voor Nijverheid, samen met de Maatschappij van Toonkunst en de Bataviasche Wedloopsociëteit de koppen bij elkaar hadden gestoken om te komen tot de oprichting van een gemeenschappelijk gebouw. Vice-voorzitter Wassink stelde voor dat het genootschap zou toetreden tot dat gezelschap. Voorzitter Visscher zou zich buigen over de eigendomsrechten van de genootschapsgebouwen, want direct was het idee van een eventuele verkoop ervan opgekomen. Daarmee hoopte men kapitaal in te brengen in het nieuwe consortium. ${ }^{129}$ Kennelijk was het bestuur vergeten dat men in overheidsgebouwen huisde, een vergissing die in de jaren veertig al eens was voorgekomen. Bestuurswisselingen waren niet goed voor het genootschappelijk geheugen. Dezelfde maand werd nog een brief naar het 'kommittee tot daarstelling van een gebouw van vereenigde maatschappijen' gestuurd om te vragen naar de voorwaarden waaronder het genootschap zou kunnen toetreden. Het bestuur gaf alvast aan dat het minstens 12.000 vierkante voeten (ongeveer $1300 \mathrm{~m}^{2}$ ) nodig zou hebben, verdeeld over drie lokalen. ${ }^{130}$ Blijkbaar werd gedacht aan ruimtes voor het bestuur (vergaderen), voor de bibliotheek en voor het museum. Helaas weidden de notulen niet uit over dit onderwerp, waar we nu juist erg graag zouden willen weten hoe het pakket van eisen van het genootschap er in dit stadium uitzag. Wassink werd afgevaardigd om met het comité te gaan overleggen. Intussen werd het museumgebouw op kosten van het gouvernement gerepareerd, want de staat van onderhoud liet veel te wensen over. ${ }^{131}$ In de algemene vergadering van 24 april 1855 gaf voorzitter Visscher te kennen dat er nog geen bevredigende resultaten waren van het overleg. Tijdens de algemene vergadering van 23 juli 1856 refereerde hij helemaal niet meer aan een gezamenlijk gebouw, al had hij het wel over de huisvesting, die dringend een oplossing behoefde. Hulp inroepen bij de overheid zag hij als onvermijdelijk, maar hij gaf aan dat er 'op eene bescheidene wijze' een beroep op zou wor-

\footnotetext{
129 ANRI KBG Dir 0205, vergadering 3-10-1854, punt 2.

130 ANRI KBG Dir 0206, vergadering 31-10-1854, punt 2.7. De brief is niet bij de stukken te vinden.

131 ANRI KBG Dir 0207, vergadering 30-1-1855, punt 2.k.; Dir 0208, vergadering 27-3-1855, punt 3.1.
} 
den gedaan. ${ }^{132}$ Van het plan voor een gemeenschappelijk gebouw zou niets komen, al had het wel de belangstelling van het gouvernement gewekt.

Werd in 1854 nog gedacht aan verkoop van gebouwen, het bestuur zag in april 1857 in dat het gouvernement volledig eigenaar was. De chef van de eerste waterstaatsafdeling werd nu gevraagd te constateren dat de gebouwen bouwvallig waren, om vervolgens voorstellen te doen voor reparaties en voor een verandering van de indeling van de beschikbare ruimte. ${ }^{133}$ In juli 1857 moest het museumgebouw, de voormalige kolfbaan op Rijswijk, wegens bouwvalligheid ontruimd worden. Afbraak van dat gebouw was op den duur de enige oplossing. ${ }^{134}$ De collecties verhuisden weer naar het genootschapshuis in de Rijswijkstraat.

In juni 1857 doorkruiste het gouvernement alle herstel- of bouwplannen door het genootschap, de Natuurkundige Vereniging en de Maatschappij van Nijverheid voor te houden dat een 'vereeniging dier ligchamen hoogst wenschelijk was', wilden de drie in de toekomst kunnen rekenen op financiële steun. Het gouvernement dacht aan een organisatie naar het voorbeeld van de Koninklijke Akademie te Amsterdam 'onder ééne hoofdleiding' en met één gebouw. Het was alweer een akademieplan, na dat van Bleeker in 1847, wie het als muziek in de oren zal hebben geklonken. Het idee van een gezamenlijk gebouw was in gouvernementsgedachten geëvolueerd tot het plan van een fusie. Het nodigde de drie organisaties uit om hun mening erover te formuleren. ${ }^{135}$

Voor het overleg dat volgde tussen het genootschap, de vereniging en de maatschappij, zal het een voordeel geweest zijn dat genootschapsafgevaardigde Bleeker tevens voorzitter was van de Natuurkundige Vereeniging en bestuurslid van de Maatschappij van Nijverheid. Ook directielid G.F. de Bruijn Kops zat al in twee van de drie besturen. ${ }^{136}$ Uit het consortium voor het beoogde gezamenlijke gebouw waren toonkunst en paardenrennen weggevallen. Die konden moeilijk opgaan in een organisatie die naar het voorbeeld van de Akademie van Wetenschappen tot stand moest komen. In juli 1857 werd er uitgebreid geconfereerd door de drie partijen en werd besloten dat samenvoeging niet in het belang van de wetenschap, noch in dat van hun organisaties was. Aan de uitvoerbaarheid van het project werd getwijfeld, aan de bezuinigingen die het zou opleveren eveneens, terwijl 'drie waardige en aan de behoeften der drie genoemde genootschappen beantwoordende

TBG 4:199, algemene vergadering 24-4-1854; TBG 6:270, algemene vergadering 23-7-1856.

TBG 7:248-50, vergadering 6-4-1857.

TBG 7:454-5, vergadering 23-7-1857.

TBG 8:97-9, vergadering 19-6-1858. De brief van de fungerend eerste gouvernementstaris J.W.C. Diepenheim werd in zijn geheel geciteerd in de notulen.

TBG 8:282-3, vergadering 3-7-1858. 
gebouwen' konden worden opgetrokken voor 'een ton gouds minder' dan een groot algemeen gebouw. ${ }^{137}$ Kennelijk zag het gouvernement niet dadelijk mogelijkheden om de onwilligen tot de samenvoeging te bewegen. Daarom besloot het eerst een oplossing voor het genootschap te zoeken. In december 1858 werd de directeur van Burgerlijke Openbare Werken en de resident van Batavia opgedragen met het genootschap naar een 'voor den lande minst bezwarende wijze' uit te zien om in de behoeften te voorzien die door de bouwvalligheid van de bestaande gebouwen was ontstaan. ${ }^{138}$ Eerst werd een plattegrond gemaakt van de bestaande gebouwen, daarna een plan, dat voorzag in de afbraak van het inmiddels lege museum en het optrekken van een nieuw gebouw op hetzelfde terrein. Dat nieuwe gebouw zou eerst tijdelijk door het genootschap worden betrokken, zodat het gebouw in de Rijswijkstraat kon worden verbouwd, opdat het genootschap daarin kon terugkeren. Het nieuwe gebouw zou, mocht dit zo lopen, in tweede instantie voor de Natuurkundige Vereeniging en de Maatschappij van Nijverheid bedoeld zijn. Het idee was dus dat het genootschap in de Rijswijkstraat één vernieuwd gebouw zou betrekken, nadat het tijdelijk in een nieuw op te trekken gebouw zou zijn gehuisvest. Dat nieuwe gebouw - op de plaats van de af te breken kolfbaan - was begroot op $f$ 25.500. ${ }^{139}$ Inmiddels was het augustus 1859 en het genootschap had sinds twee jaar geen museumgebouw. Het genootschapshuis in de Rijswijkstraat leek volgens Netscher meer een pakhuis dan een museum (TBG 12:168).

Toen bleek dat de begroting van $f 25.500$ veel hoger zou uitkomen, trad het gouvernement in overleg met de regering in Den Haag. ${ }^{140}$ Die koppelde de toekenning van de subsidie aan het genootschap aan het eerder opgekomen idee van de samenvoeging. Als die fusie bij het aflopen van de subsidie aan het einde van 1863 niet zou zijn gerealiseerd, zou het gouvernement voortaan nog maar aan één organisatie subsidie toekennen. ${ }^{141}$ Dat dreigement schudde het bestuur niet meteen wakker. Het had immers nog tijd tot eind 1863. De Natuurkundige Vereeniging, door het gouvernement van hetzelfde voornemen op de hoogte gebracht, had slechts subsidietoezeggingen tot eind 1861 en moest dus maar het initiatief nemen. In oktober 1860 was de toestand van het overgebleven gebouw in de Rijswijkstraat dusdanig verslechterd, dat ook daar gedacht werd aan ontruiming. ${ }^{142}$ In arren moede werd besloten naar een beslissing hierover al vastgelegd.

140 TBG 12:171. Hierover kom ik in de genootschapsnotulen niets tegen.

141 TBG 10:451-2, vergadering 1-9-1860.

142 TBG 10:461-2, vergadering 6-10-1860.

TBG 8:301-13, vergadering 2-10-1858.

TBG 9:43-4, vergadering 5-2-1859.$$
\text { TBG 10:461-2, vergadering 6-10-1860. }
$$

TBG 9:240-1, vergadering 6-8-1859. Het gouvernementsbesluit van 29-7-1859 nr 4 had de 
alternatief om te zien. Het woonhuis van C. Hultman, oud-president van het Hooggerechtshof, aan het Koningsplein zou te koop zijn. Na drie huizen te hebben onderzocht bleek dat van Hultman - vraagprijs $f 45.000$ - het meest geschikt. Huizen langs het Molenvliet en op Noordwijk vielen af. Overmoedig vroeg het genootschap een renteloos voorschot aan uit 's Lands Kas van $f$ 45.000. ${ }^{143}$ Dit werd nog in december 1860 door de regering afgewezen: geen verzoek zou kunnen worden ingewilligd hangende de kwestie van de samenvoeging van de drie organisaties. Nader aandringen van het genootschap op een voorziening, gezien de slechte toestand van het gebouw en gezien de zorg die het genootschap droeg voor de verzamelingen, haalde niets uit. Het gouvernement was niet van plan voorzieningen te treffen zolang de samensmelting niet was gerealiseerd. Zelfs de door de toestand van museum teleurgestelde bezoeker Lord Elgin werd door het genootschap in de strijd gebruikt:

en zij kan niet verbergen, dat het haar zeer heeft gegriefd, onlangs te vernemen dat Lord Elgin, die 's Genootschaps museum bezocht, zich vond te leur gesteld door dien de opeenhooping van voorwerpen hem niet toeliet het merkwaardige behoorlijk te bezichtigen. ${ }^{144}$

In oktober 1861 besloot het bestuur opnieuw een commissie aan het werk te zetten om te zien hoe de samenvoeging van de drie maatschappijen in Batavia zou kunnen worden uitgevoerd zonder het wezen en de aard van die organisaties aan te tasten. Verder werd de directeur van Burgerlijke Openbare Werken gevraagd om voorzorgsmaatregelen te nemen opdat de eigendommen van het genootschap niet zouden worden beschadigd. ${ }^{145}$ De commissie bestond uit de drie juristen uit het genootschapsbestuur, Van der Chijs, H. Rochussen en de nieuwe secretaris Der Kinderen. Geen bittere, maar diplomatieke formuleringen sluiten het paragraafje 'Gebouwen' af in het historisch overzicht dat op 16 november 1861 door secretaris Der Kinderen aan de algemene vergadering werd voorgelezen. $\mathrm{Nu}$ moest het genootschap voorzichtig manoevreren om zowel een goede behuizing te krijgen, als zijn zelfstandigheid te behouden en het gouvernement niet voor het hoofd te stoten. Intussen zat het al vier jaar in een 'pakhuis', dat verveloos was en dat verpest werd door de stank van duizenden vleermuizen op zolder. Het was er overvol doordat de etnologische en oudheidkundige verzameling ernaartoe waren overgebracht, terwijl een aantal grotere, oudheidkundige voorwerpen buiten in de regen bleef staan (TBG 12:168-73). De lange gang naar een nieuw gebouw was pas ingezet.

143 TBG 11:395-6, vergadering 3-11-1860.

144 TBG 11:419-20, vergadering 2-3-1861. Het citaat komt niet in de gedrukte notulen voor, maar komt uit de minuut van de brief van 21-2-1861 aan het gouvernement, ANRI KBG Dir 250, vergadering 2-3-1861.

145 TBG 12:144-5, vergadering 13-7-1861, punt II.b. 
Publicaties: tekstuitgaven

De Verhandelingen waren naast het museum en de bibliotheek het medium waaraan het genootschap belang kon ontlenen. Met deze publicatie trad het de wereld in, de geleerde wereld zelfs, waar de betekenis van het museum en de bibliotheek tot Batavia beperkt bleef. Aan de delen 22-28 die tussen 1849 en 1860 verschenen, kunnen we vaststellen waarmee het genootschap naar buiten wilde treden. Ze laten zien dat de lijn van tekstedities in Indonesische talen, die in de voorgaande periode was ingezet met Van Hoëvells editie plus vertaling van de Sjä̈r Bidasari (1843) en de tekstedities van Gericke en Winter, werd voortgezet. In de zeven delen Verhandelingen komen in zes opnieuw tekstedities voor: twee uitgaven van Oud-Javaanse teksten en een facsimile van een Balinese tekst, verzorgd door Friederich, edities van Javaanse teksten door J.J. den Hollander en Winter, en ten slotte de tweedelige uitgave door Cohen Stuart van het Javaanse heldendicht Brata Joeda. Deze teksten namen een groot deel van de kloeke boekdelen in beslag; ruim 1500 pagina's druk was aan de teksten en de vertalingen ervan gewijd. De belangstelling voor het Javaans hing mede samen met het belang dat door de overheid aan die taal werd gehecht, naast en boven het Maleis. Ambtenaren in Soerakarta waren, ook na het opheffen van het Instituut voor het Javaans, bezig met het bestuderen van de taal en het maken van vertalingen en een woordenboek. Dat gebeurde in opdracht van de overheid (Winter, Cohen Stuart) of van het Nederlands Bijbelgenootschap (Gericke tot 1847). Zij wijdden een deel van hun tijd aan de editeursarbeid, waarvan het genootschap profiteerde.

Tekstedities in de Verhandelingen (1849-1860)

\begin{tabular}{lllll}
\hline Deel & Jaar & Titel & Taal & Editeur \\
\hline 22 & 1849 & Wrettasantjaja & Balinees & Friederich \\
23 & 1850 & Ardjoena-Wiwoho & Oud-Javaans & Friederich \\
24 & 1852 & Manik-Maja & Javaans & Den Hollander \\
24 & 1852 & Boma Kawja & Oud-Javaans & Friederich \\
25 & 1853 & Hangling Darmo & Javaans & Winter \\
$27-28$ & 1860 & Brata Joeda & Javaans & Cohen Stuart \\
\hline
\end{tabular}

Bleekers vissen, in de hier beschreven periode met ruim 1000 bladzijden en 29 opstellen in vijf delen (22-26) ruim vertegenwoordigd, zwommen meer en meer in vreemd water. Naast de tekstuitgaven namen verhandelingen over oudheden, inscripties en geschiedenis, en land- en volkenkundige beschrijvingen de resterende pagina's in. De in deel 22 verschenen geologische bijdrage van J.R. Logan was misschien in eerste instantie bedoeld geweest voor Bleekers Natuur- en Geneeskundig Archief, dat na 1847 niet meer 
verscheen. Bleeker, hoofdredacteur ervan, was met Logans bijdrage blijven zitten. Verder moest de redactie wel eens een noodgreep doen als beloofde kopij uitbleef. Dan was de beschikbaarheid van een van Bleekers opstellen een uitkomst. Twee bijdragen waren belangrijk voor de ontsluiting van de collecties: Friederichs tweede deel van de beschrijvende catalogus der oudheden in het museum en zijn catalogus van de Arabische manuscripten. F. von Sommers catalogus van zijn eigen geologische schenking was net als de vissen minder op zijn plaats tussen de tekstedities. De geologische voorwerpen waren bovendien afkomstig uit Nieuw-Holland (Australië).

De verschijningsfrequentie van de Verhandelingen was niet erg groot: zeven delen in twaalf jaar, maar lag op hetzelfde niveau als in de periode 1836-1847. In vergelijking met voorgaande perioden was er één groot verschil: vanaf 1852 had het genootschap er met de komst van het Tijdschrift een medium bij, zodat lange tussenpozen minder gevoeld werden. Het tijdschrift kon de leden bezighouden. Uitgeversproblemen bieden voor een deel de verklaring voor uitstel en het niet nakomen van beloften. Roorda van Eysinga's uitgave en vertaling van de Brata Joeda, aangekondigd voor deel 22 (1849) zou uiteindelijk pas, maar dan in een hele nieuwe jas, als Cohen Stuarts editie in 1860 (deel 27-28) verschijnen. De oorspronkelijke editeur zou zich door zijn 'contractbreuk' de woede van het bestuur op de hals halen.

\section{Persoonlijkheden: Roorda van Eysinga en Friederich}

Philippus Pieter Roorda van Eysinga (1796-1856) was in 1819 als militair in Batavia aangekomen, maar wijdde zich vanaf 1820 geheel aan de inheemse talen, eerst als kwekeling, daarna als commies bij het Departement van Inlandse Zaken, later als hoofdcommies bij de Algemene Secretarie. In deel 10 van de Verhandelingen (1825) publiceerde hij een teksteditie van de Maleise Hikajat Isma Jatim. Terug in Nederland (1830) kreeg hij een eredoctoraat van de Leidse universiteit en werd hij hoogleraar in de taal-, land- en volkenkunde van Nederlands-Indië aan de Koninklijke Militaire Academie in Breda (1836). In 1843 keerde hij terug naar Indië, waar hij werkte aan een MaleisNederlands woordenboek (ENI 3:636; Fasseur 1993:58). In 1844 bood hij het genootschap aan om een tekst te editeren, welk aanbod werd aangenomen. ${ }^{146}$ Voor de Verhandelingen had hij eerst een achttiende-eeuwse Javaanse kroniek op het oog, maar het werd uiteindelijk een Javaans heldendicht, Brata Joeda (VBG 20:16 en 21:7). Jammer genoeg komen we de geschiedenis van deze

146 ANRI KBG Dir 0142, vergadering 18-7-1844, punt 10; ANRI KBG Dir 0992, correspondentie 1844, juli-okt. nummer 11, concept dankbrief van de secretaris aan Roorda, 26-8-1844. 
teksteditie plus vertaling in de notulen pas op het spoor als er al problemen zijn. Zo blijven de afspraken die Van Hoëvell en Roorda van Eysinga maakten over de uitgave in het duister.

Roorda vroeg in september 1848 om de tweehonderd exemplaren van de Javaanse tekst van de Brata Joeda, die hij had afgeleverd en waarover hij met Van Hoëvell afspraken zei te hebben gemaakt. De laatste zat toen op de boot naar Nederland. Het bestuur, dat kennelijk de bui voelde hangen, antwoordde dat hij die kon krijgen, zodra hij de Nederlandse vertaling van de Javaanse tekst had ingediend. ${ }^{147}$ Roorda deed het voorstel om 'op juridische voet' over de uitgave van alweer een volgende tekst te overleggen. Intussen leverde hij zijn vertaling van de Brata Joeda in en kreeg zijn tweehonderd exemplaren van de inmiddels gedrukte Javaanse tekst. Het bestuur wilde na het succes van de Wiwoho en de Romo opnieuw in de Verhandelingen de tekstuitgave met de vertaling presenteren en daarnaast op een aparte Javaanse editie laten inschrijven.

Het genootschap was druk bezig met het verspreiden van de intekenlijsten voor de losse verkoop (zes gulden per stuk), niet wetend dat Roorda zijn tweehonderd exemplaren razendsnel aan de man bracht voor tien gulden per exemplaar. In januari 1849 bleek dat de vogel gevlogen was, of liever gezegd: weggevaren, onder medeneming van zijn vertaling. 'Eene mooije streek, in mijn oog ten minste een valsche', in de woorden van het hoofd van de drukkerij van Lange, Meijer. ${ }^{148}$ Roorda had de titel, de opdracht en de inleiding voor het werk, waarvan de vertaling deels al afgedrukt was, aan de drukker in handen gegeven, hem een ontvangstbewijs laten tekenen en had vervolgens, onder het voorwendsel dat hij nog een blaadje aan de kopij van het restant van de vertaling moest toevoegen, zijn hele vertaling uit de drukkerij van Lange meegenomen. Direct daarop was hij naar de haven vertrokken. Hij had het bestuur laten weten dat hij de rest van de vertaling, het deel dat nog niet gedrukt was, en de aantekeningen uit Nederland zou toesturen. De vertaling was weg. Roorda zou hem in 1849 in Leiden laten drukken.

Roorda van Eysinga was het genootschap voor geweest en had de intekening van het genootschap doorkruist. De verwarring was totaal: de resident van Soerakarta stuurde de intekenlijsten aan het genootschap terug, want Roorda zelf had al veertig intekenaren kunnen noteren. De resident van Soerabaija vroeg hoe het nu zat met het prijsverschil van de 'twee uitgaven'. ${ }^{149}$ De residenten van Pasoeroean en Bagelen hadden het geld van hun intekenaren op de genootschapsuitgave naar Roorda van Eysinga gestuurd. Het genootschap voelde zich niet verantwoordelijk en vroeg deze residenten 
het geld opnieuw te voldoen. ${ }^{150}$ Roorda bleek in oktober 1848 ook nog bibliothecaris De Wilde in het ootje te hebben genomen. Hij had nog acht extra exemplaren van de Javaanse tekst laten ophalen. De zaken liepen kennelijk goed. Toen hij een rekening kreeg voor $f 48$, zei hij dat dit verrekend kon worden met de $f 50$ die het genootschap hem nog schuldig was voor een Javaanse klerk. Penningmeester Rudolph had hem daarvoor niet willen betalen, maar nu was Roorda hem via de bibliothecaris te slim af geweest. ${ }^{151}$

Er waren nog meer stenen des aanstoots tussen het genootschap en Roorda van Eysinga. Hij bleek de inzender te zijn van een op een genootschapsprijsvraag uit 1842 ingestuurd Soendanees woordenboek. Met zijn vertrek in het vooruitzicht, vroeg hij 'namens de inzender' om de uitslag, maar het genootschap kon hem alleen laten weten dat de beoordelaar, het lid Cannaerts, vanuit Cheribon negatief over de wetenschappelijke waarde ervan had geadviseerd. In december 1848 vocht Roorda 'namens de inzender' het oordeel aan: bij de uitschrijving van de prijsvraag in deel 19 van de Verhandelingen (1843) had niets gestaan over 'wetenschappelijk'. Hij omschreef het handelen als 'inconsequent' omdat deze eis er later aan zou zijn toegevoegd. Ook vroeg hij een ingezonden antwoord op de prijsvraag naar de afkomst van de Maleijers terug. Tot overmaat van ramp kon het genootschap dat stuk niet terugvinden. ${ }^{152}$ Roorda bleek voor zijn vertrek ook nog interesse te hebben getoond voor de overname van de drukkerij. In zijn aanbod daartoe noemde hij zich 'oprigter en directeur van 's Gouvernements inlandsche drukkerij op Kantor Baroe geweest zijnde en al wat daarmede in verband staat verstaande'. Hij was daarmee één van de vier bieders op de drukkerij, maar voor het bestuur telde zijn bod niet mee. ${ }^{153}$

Het gewoonlijk nogal diplomatieke genootschap kon zich de behandeling door Roorda rond de uitgave van de Brata Joeda niet laten welgevallen. In zijn jaarrede van 8 maart 1849 deed voorzitter Buddingh voor de algemene vergadering de geschiedenis nauwkeurig uit de doeken en in deel 22 van de Verhandelingen verscheen Buddinghs verslag in druk. Ook het Soendanese woordenboek kwam ter sprake, maar hier liet het genootschap hoffelijk niet doorklinken dat Roorda de maker was. De spreuk, waaronder hij het woordenboek had ingestuurd nam het wel op: 'Ons leven is streven; Veel jaren te

150 ANRI KBG Dir 0178, vergadering 30-4-1850, punt 2.7 en bijlage 2.

151 ANRI KBG Dir 0172-4, vergadering 27-11-1849, bijlagen $11,14-15$ achter het verslag.

152 ANRI KBG Dir 0160, brief van Roorda 24-8-1848 bij vergadering 20-11-1848, bijlage 20 en bijlage 48-50, onder andere een brief en beoordeling door Cannaerts; ANRI KBG Dir 0164, vergadering 30-1-1849, punt 1, 4, bijlage 1, 2 en 15. In het TNI was in 1844 al in afleveringen een lang artikel van Roorda verschenen gebaseerd op de Soelaleto 'S-salathina. Roorda zei dat hij achter de prijsinzending onder de spreuk 'Est desint Vires' schuil ging.

153 ANRI KBG Mus 0027, omslag 1848, brief van Roorda 27-7-1848. Op 2-10-1848 schreven Bosch en Godefroy dat ze voor Lange hadden gekozen. Hun brief bij die van Roorda. 
wroeten, moog de uitkomst verzoeten. En komt de kroon der Eere, dan zij mijn dank aan den Heere!' Het had voorzitter Buddingh nogal onaangenaam getroffen, dat Roorda na dit alles zijn vertaling van het heldendicht ('onze vertaling' volgens Buddingh) aan het genootschap in de Leidse uitgave cadeau had gedaan, alsof er niets aan vooraf was gegaan.

De laatste zure Roorda-appel betrof de kwaliteit van de vertaling - voor zover die al was afgedrukt - en ook van de Javaanse tekst van de Brata Joeda, die in de drukkerij lag opgestapeld, en waarvan Roorda er al 206 aan de man had gebracht. Cohen Stuart, die tot de opluchting van het genootschap het werk zou voltooien, kwam al snel tot de conclusie dat hij het helemaal over moest doen. Eerst werd besloten Roorda's vertaling maar te laten liggen en Cohen Stuart te vragen een heel nieuwe te leveren met kritische aanmerkingen bij de (al afgedrukte) Javaanse tekst. ${ }^{154}$ De Roorda-uitgave werd in afwachting daarvan niet verspreid. In 1851 gaf het genootschap te kennen geen bezwaar te hebben tegen het drukken van een complete, nieuwe uitgave. ${ }^{155}$ Doordat Cohen Stuart dus helemaal opnieuw begon, maar ook door zijn vele andere werkzaamheden, zou het nog tien jaar duren eer de beloofde editie, zou verschijnen. Vele malen werd erover gecorrespondeerd, verschillende malen moest het genootschap de leden en intekenaren om begrip vragen voor het uitstel van de uitgave.

De tekstedities en de vertalingen waren in eerste instantie gericht geweest op de leden, overwegend Europeanen, in Indië en in Europa, en werden uitgegeven als delen van de serie Verhandelingen. De aparte oplagen van de tekst zonder vertaling werden ruim gepland, zodat er op ingetekend kon worden en daarmee bereikte het genootschap meer Indonesiërs dan die paar regenten die lid waren. De inschrijvingslijsten op de Javaanse teksten werden enthousiast ontvangen. Roorda van Eysinga was via de inschrijving op zijn uitgave van de Brata Joeda in korte tijd meer dan tweehonderd exemplaren kwijt en meer dan $f 2.000$ rijk geworden, uiteraard bijna uitsluitend aan Javaanse lezers, want wie anders dan enkele taalambtenaren waren in staat het Javaanse schrift te lezen? Op de intekening van dezelfde Brata Joeda, maar nu van het genootschap stuurde de resident van Madioen eind 1848 een lijst met 51 namen, voor 62 exemplaren, terwijl er in Batavia maar op 24 exemplaren werd ingetekend. ${ }^{156} \mathrm{Op}$ de intekening voor de Ardjoena-Wiwoho van Friederich werd in 1851 alleen al in Soerakarta voor 42 exemplaren ingetekend. De lijst bevat uitsluitend Javaanse namen. ${ }^{157}$ Soerabaija tekende op 47 exemplaren in, de sultan van Soemenep voor zes. Slechts drie exemplaren

ANRI KBG Dir 0167, vergadering 27-3-1849, punt 1.

ANRI KBG Dir 0188, vergadering 26-10-1851, punt 1 en bijlage 19 en 20.

ANRI KBG Dir 0164, vergadering 30-1-1849, punt 2 en bijlage 8-9, 13-14, 19, 26-27, 29.

ANRI KBG Dir 0187, vergadering 3-6-1851, bijlage 52. 
gingen naar Nederlandse intekenaren in Soerabaija. Hetzelfde gold voor Poerworedjo, Banjoemas, Buitenzorg. ${ }^{158}$ Nederlandse namen waren sterk in de minderheid of soms zelfs helemaal afwezig. Deze titeluitgaven waren dus bestemd voor een nieuw, Indonesisch lezerspubliek. Leden kregen de tweetalige uitgave in de Verhandelingen.

Er waren ook complicaties. De resident van Djokjakarta stuurde op 23 augustus 184934 van de 36 exemplaren van Friederichs uitgave van de KawiBalinese Wretta-Sentjaja terug, omdat die voor de Djokjase groten 'onleesbaar [was] en door hen daarop is ingetekend in de veronderstelling, dat hetzelve zoude geschreven zijn met gewone Javaansche Caracter'. En de resident van Rembang rapporteerde dat de intekening op de Ardjoena-Wiwoho slecht verliep, omdat de Wretta-Sentjaja door niemand gelezen kon worden. ${ }^{159}$ Het bestuur had niet voorzien dat de Balinese tekst voor Javanen niet leesbaar zou zijn.

Het succes van de inschrijvingen op de Javaanse en zelfs op de Kawiteksten bracht het bestuur in 1852 op de gedachte om het gouvernement aan te bieden een flinke aankoop te doen van deze uitgaven, die het als relatiegeschenk aan Javaanse groten cadeau kon doen. Natuurlijk motiveerde het de aanbieding niet als een opruiming.

De bedoeling van het genootschap met de uitgave dezer dichtwerken is niet alleen geweest om het Maleisch, Javaansch en Kawi meer bekend te doen worden onder de Europeanen in Indië en Europa, maar ook door deze uitgezochte inheemsche lettervruchten beschavend te werken op de Javanen en reeds zijn talrijke exemplaren van genoemde werken onder de Javanen der hoogere standen verspreid. [...] Iedere Javaan van eenige beschaving heeft eene onmiskenbare neiging tot beoefening der Javaansche literatuur, en hoe gebrekkig ook zijne manuskripten en fragmenten van manuskripten zijn, heeft hij daarvoor eene onbepaalde achting. Het lijdt geen twijfel of zijne zucht voor de dichtwerken van zijne voorvaderen moet aanmerkelijk verhoogd worden, wanneer hij in het bezit wordt gesteld van volledige werken, fraai gedrukt en in het algemeen eenen zeer zuiveren tekst aanbiedende. ${ }^{160}$

Het gouvernement kocht driehonderd exemplaren van vier verschillende uitgaven van Gericke, Winter en Friederich. ${ }^{161}$ Het genootschap had zich in de positie geplaatst van een instantie die de beschaving van de inheemse bevolking nastreefde. Op de jaarvergadering van 27 april 1852 presenteerde secre-

158 ANRI KBG Dir 0184, vergadering 7-1-1851, bijlage 21-27.

159 ANRI KBG Dir 0172-4, vergadering 27-11-1849, tweede omslag met correspondentie, nr 18, voor de brief uit Yogyakarta 23-8-1849. ANRI KBG Dir 0183, vergadering 29-10-1850, bijlage 54, brief van 25-10-1849 van de resident van Rembang.

160 ANRI KBG Dir 0192, vergadering 5-4-1852, bijlage 10.

161 ANRI KBG Dir 0191, vergadering 30-3-1852, punt 3.b en bijlage 17 en 18. 
taris Bleeker dit beschavingsoffensief zelfs als een apart onderwerp onder het kopje 'Beschaving der Inlandsche bevolkingen' waarbij hij voor een deel dezelfde woorden gebruikte als die waarmee het bestuur het gouvernement had overgehaald tot de aanschaf van driehonderd boekdelen. De Javanen zouden door de uitgaven van het genootschap zelfs het Kawi weer machtig worden en wat was daar niet voor moois van te verwachten.

Door de verspreiding dier werken wordt de Javaan dan ook allengskens in staat gesteld, om de oude, bijna verloren geraakte, taal zijner dichters en priesters, het Kawi, weder magtig te worden en het kan niet missen of de dichterlijke en verheven stijl der werken, in die taal geschreven, moet een' weldadigen invloed hebben op zijne denkbeelden en karakter en zijne verkeerde neigingen meer en meer tegengaan.

Het verheven standpunt van het genootschap, zijn hoge roeping, komt uit de woorden van Bleeker duidelijk tot uiting. Bleeker ging niet verder op de 'verkeerde neigingen' in (VBG 24:12). De overheid was in 1851 begonnen met de uitgave van Javaanse leesboeken voor de inheemse bevolking. Het beschavingsoffensief van overheid en genootschap ging dus hand in hand.

Bibliothecarissen, redacteuren van de Verhandelingen, directeuren van het museum, secretarissen, zij hadden allemaal deeltijdfuncties. Niemand was voltijds voor het genootschap beschikbaar, behalve enkele slaven, mandoers, oppassers en opzichters. Predikanten hadden veel tijd in het genootschap gestoken: Lenting, Van Hoëvell, Buddingh, in een eerdere periode Van Iperen en Ross. Ook sommige ambtenaren van het binnenlands bestuur waren bevlogen: Van der Vinne en Netscher. Militaire geneeskundigen als Bleeker en Munnich, lieten zich evenmin onbetuigd, maar zij allen deden het genootschap 'erbij'. De eerste genootschapsfunctionaris die zich voltijds aan de wetenschappelijke arbeid kon wijden, was Rudolph Hermann Theodor Friederich. ${ }^{162}$ Hij werd geboren in Koblenz in 1817, zijn vader was officier en Ober-Telegraphen-Inspektor. Friederich Jr. volgde na het gymnasium in Schulpforta (1831-1834), voorbereidend wetenschappelijk onderwijs in zijn geboortestad (1834-1836) en studeerde klassieke talen en letterkunde in Berlijn (1836), daarna Arabisch en Sanskriet in Bonn bij de beroemde orientalist Christiaan Lassen. Hij keerde terug naar Berlijn waar hij naar zijn zeggen twee jaar lang niet in de gelegenheid was de studie van de oosterse talen in volle omvang voort te zetten. Wat dat betekende, blijft onduidelijk. Zat hij in een geestelijke impasse, had hij geldzorgen? Hoe dan ook, hij was enkele maanden werkzaam in het privatissimum Sanskriet van de hoogleraar J. Gildemeister en maakte zich nuttig in de universiteitsbibliotheek van 
Bonn. Friederich rondde zijn studie niet af. Het wordt niet duidelijk waarom niet. Hij had geen zin om onderwijzer te worden, werd door Lassen bij de Nederlandse regering en bij Taco Roorda aanbevolen, omdat hij naar Indië wilde, maar Roorda zag geen kans hem bij het Bijbelgenootschap of bij het Indische gouvernement geplaatst te krijgen. Ten einde raad nam Friederich in 1844 dienst als soldaat in Harderwijk, tegen de zin van zijn ouders. Hij werd vóór zijn vertrek naar Indië bevorderd tot sergeant en vertrok aan het eind van het jaar. Onderweg leerde hij Maleis en Javaans. Dankzij een handgeschreven curriculum van vier pagina's in het archief van het genootschap, in een Nederlands vol germanismen, zijn we goed over Friederichs jonge jaren geïnformeerd. ${ }^{163}$

Hij werd in 1845 in Batavia tewerkgesteld bij het militair depot in een administratieve functie, die ver beneden zijn capaciteiten lag en niet paste bij zijn ambities. Hij meldde zich bij het genootschap, waarna Van Hoëvell het bestuur op 20 mei 1845 op de man attendeerde. Op 22 mei schreef hij zijn curriculum en overhandigde dat met getuigschriften en diploma's van Schulpforta, Koblenz, Bonn en Berlijn aan Van Hoëvell. Kort daarop was hij, na tussenkomst van bestuurslid en commandant van het Indische leger Cochius, werkzaam in de bibliotheek om het werk voort te zetten aan de catalogus van de oosterse handschriften, waaraan eerder door Van der Vlis en Toewater was gewerkt. ${ }^{164}$ In december 1845 al was het eerste deel van deze catalogus, de Arabische handschriften, klaar. ${ }^{165}$ Van Hoëvell was zeer tevreden en stelde voor Friederich tot adjunct-bibliothecaris te benoemen en zijn vergoeding van $f 50$ te verhogen tot $f 100$ per maand. ${ }^{166}$ Friederich werkte tegelijkertijd aan de beschrijving van het oudheidkundig kabinet van het genootschap (VBG 21:102).

In februari 1846 besloot het gouvernement Friederich toe te staan mee te reizen met de op handen zijnde expeditie tegen de vorst van Boeleleng. Daarmee was de kennis over Bali, vooral de bestudering van het Balinees in verband met het Oud-Javaans, gediend. Friederich was een voorbeeld van een wetenschapper die meereisde met de militairen. Een illuster opvolger zou aan het einde van de eeuw C. Snouck Hurgronje zijn, die met Van Heutsz

163 ANRI KBG Dir 0145, vergadering 20-5-1845, punt 8 en bijlage 22.

164 Misschien was Friederich in april al op proef te werk gesteld, want het gouvernementsbesluit 9-7-1845 $\mathrm{nr}$ 23, in antwoord op een schrijven van het genootschap van 16 juni, kent hem een vergoeding toe van $f 50$ per maand te rekenen vanaf april 1845. Lang zal Friederich dus niet op het militair depot hebben gewerkt. ANRI KBG Dir-146, vergadering 24-9-1845, punt 3. Brief van het genootschap aan de gouverneur-generaal, 10-6-1845 in ANRI KBG Dir 0993, correspondentie januari-juli $1845 \mathrm{nr}$ 13. Daar ook in map correspondentie september-december nr 12, verzoek aan de thesaurier om $f 50$ per maand aan Friederich te betalen vanaf april 1845 .

165 Pas verschenen in VBG 25 (1853).

166 ANRI KBG Dir 0147, vergadering 15-12-1845, punt 3 van de voorstellen van de voorzitter. 
meeging naar Atjeh. De reis naar Bali maakte Friederich in opdracht van het gouvernement. ${ }^{167} \mathrm{Hij}$ rapporteerde dan ook uitvoerig aan de regering, maar Van Hoëvell werd wel door de reiziger op de hoogte gehouden en wist in 1847 na zijn korte verblijf op Bali, waar hij Friederich had ontmoet, te melden dat deze opschoot met zijn Balische studies en dat er een publicatie voor de Verhandelingen op handen was. ${ }^{168}$ Het genootschap beijverde zich steeds bij het gouvernement om de geldelijke positie van de adjunct-bibliothecaris-opreis te verbeteren. In maart 1848 werd hij door het gouvernement benoemd tot translateur en tolk voor de Balische zaken op een daggeld van $f 10$. Het genootschap feliciteerde hem en vroeg hem tegelijk om adjunct-biliothecaris te blijven. ${ }^{169}$ Friederich bleef twee jaar op Bali en verdiepte zich in taal en cultuur. Zijn verslagen hierover (een tweetal in Verhandelingen 22 en 23) en een teksteditie van een Balinees handschrift van de Kawi Ardjoena-Wiwoho getuigen van zijn werkzaamheden. Hij nam handschriften mee van Bali en schonk er verschillende van aan het genootschap. Een deel van zijn aantekeningen, vooruitgestuurd naar Batavia, was in 1848 door Van Hoëvell naar Nederland meegenomen, die deze in 1849 in zijn Tijdschrift voor Nederlandsch Indie en in het verslag over zijn reis van 1847 begon te publiceren.

In september 1848 was Friederich weer terug in Batavia en het genootschap deed direct een beroep op het gouvernement om hem opnieuw te mogen inzetten voor de beschrijving van de oudheidkundige verzameling en de oosterse handschriften. Aan de Verhandelingen (22-26) zou Friederich bijna 550 pagina's bijdragen, voor het grootste deel vruchten van zijn verblijf op Bali en van zijn onderzoek naar het Oud-Javaans. ${ }^{170} \mathrm{Hij}$ trof in de Rijswijkstraat een veranderd genootschap aan. Friederich had zich vooral met Van Hoëvell verstaan, die op zijn beurt niet uitvoerig verslag had gedaan aan zijn medebestuursleden. Van Hoëvell had de misplaatste sergeant uit het militaire depot geplukt en hem werk verschaft op zijn niveau. Met de voorzitter-predikant

167 ANRI KBG Dir 0147-8, vergadering 23-4-1846, punt 3.b. Friederich kreeg $f 400$ uitrustingskosten en $f 50$ per maand. In mei had het genootschap het gouvernement gevraagd de vergoeding van $f 50$ op de dag van het besluit (28 februari 1846) te laten ingaan. In oktober vroeg het aan het gouvernement het maandbedrag voor de duur van de expeditie tot $f 150$ te verhogen. ANRI KBG Dir 0148, vergadering 3-11-1846, punt 3.a. ANRI KBG Dir 0994, correspondentie januari-mei $1846 \mathrm{nr}$ 12, voor het verzoek om de vergoeding al op 28 februari te laten ingaan. Het gouvernement stemde in met de verhoging tot $f$ 150. In april 1847 deed penningmeester Rudolph verslag over de periode januari 1846-april 1847 waaruit blijkt dat Friederich $f$ 2295,20 had ontvangen aan tractement en voorschotten. ANRI KBG Dir 0155, correspondentie 1847- $4 \mathrm{nr}$ 8.

168 Van Hoëvell ontmoette Friederich in Koeta ten huize van handelsagent Lange (Van Hoëvell 1849-54, III:5-9).

169 ANRI KBG Dir 0159, vergadering 27-3-1848, punt 2.b.

170 Gouvernementsbesluit 6-10-1848 nr 2 gaat over Friederichs aanstelling bij het genootschap. Zie ANRI KBG Dir 0163, vergadering 20-11-1848, punt 1. 
had hij het eerste deel van de oudkundige verzameling gepubliceerd (VBG 21), nadat hij al eerder (1846) in het Tijdschrift voor Neêrland's Indië over Roorda van Eysinga en het Sanskriet had geschreven, zijn eerste publicatie. In hetzelfde tijdschrift had ook zijn eerste stuk over Bali gestaan (1847). Met Van Hoëvell had hij zich schriftelijk over de financiën verstaan. Maar Van Hoëvell was weg en Friederich kon alleen maar naar afspraken en brieven verwijzen.

Hijzelf was een belangrijk gespreksonderwerp tijdens de eerste bestuursvergadering na zijn terugkomst. Hij had veel financiële zaken te regelen. Vóór zijn vertrek had hij een voorschot ontvangen van $f$ 1.650. Penningmeester Rudolph had met hem overlegd, waaruit bleek dat de adjunct-bibliothecaris niet had begrepen dat zijn genootschapsvergoeding van honderd gulden per maand tijdens zijn verblijf op Bali was opgehouden. Hij dacht dat de vergoeding van het gouvernement bovenop die van het genootschap was gekomen en had op te grote voet geleefd. Er vond een gedeeltelijke sanering van de schuld plaats, Friederich zou voorlopig op $f 50$ per maand komen te werken. Visscher - alert op de manier waarop de naam van Van Hoëvell kon worden geschaad - zette Friederich in voor zijn offensief en liet de wetenschappelijk medewerker precies opgeven dat hij Van Hoëvell diverse berichten en vier verhandelingen over Bali had gestuurd, over kasten, weduwenverbranding, vorstenfamilies en over de geschiedenis van Bali. ${ }^{171}$

Het genootschapsbestuur begreep dat Friederich belangrijk bleef voor de wetenschappelijke openlegging van de collecties, voor tekstedities en studies. Het deed er dan ook alles aan om hem te behouden. Het adviseerde het gouvernement in juni 1849 over een extra toelage van $f 50$ per maand voor de gedetacheerde medewerker, die tot een schamel inkomen was teruggevallen. Dankbaar formuleerde Friederich op de manier van een rekest:

geeft eerbiedigst te kennen R.H.Th. Friedrich, dat hij vernomen heeft, hoe gunstig een advijs, gevraagd door het hooge Gouvernement, over zijn laatst rekwest, door de Directie gegeven is, en betuigt zijn diep gevoelden dank voor dit nieuw bewijs van beschermende belangstelling, die hem gedurende zijn verblijf in Indië altijd gebleken is.

Voor het overige ging de brief weer over zijn aantekeningen over Bali die de weerspannige vroegere voorzitter naar Groningen had meegenomen. ${ }^{172}$ Ondertussen was Friederich in 1849 in de ledenlijst zijn titel van adjunctbibliothecaris kwijtgeraakt en werd hij aangeduid als 'Toegevoegd voor de

171 ANRI KBG Dir 0162, vergadering 22-9-1848, ingekomen stukken c en d, bijlage 4-20. Nr 20 is een verzoek van 23-9-1848 om Friederich opnieuw bij het genootschap te werk te kunnen stellen. Zie ook bijlage 27.

172 ANRI KBG Dir 0169, vergadering 29-5-1849, punt 12, en ANRI KBG Dir 0174, vergadering 27-11-1849, correspondentie, tweede omslag nr 7. 
Oostersche Bibliotheek en Oudheden' (VBG 22:1). Het wordt niet duidelijk uit de notulen waaraan deze demotie was toe te schrijven. Had het nog met Van Hoëvell te maken, van wie het voorstel was gekomen Friederich tot adjunct-bibliothecaris te benoemen? In de jaarlijkse verslagen van de voorzitter of secretaris (1849-1853) werd telkens in extenso van zijn bevindingen met betrekking tot de aanwinsten gebruik gemaakt. Hij was als geen ander thuis in de handschriftencollectie en wist wat de waarde van de oudheidkundige verzameling was. Hij stelde boekenlijsten op voor de bestellingen in Berlijn, Leipzig en Utrecht, boeken die hij voor zijn werk ten behoeve van de beschrijving van de handschriften en de oudheden nodig had. Toch broedde hij op een verandering. Al in november 1850 diende hij een verslag in met een verzoek bij het gouvernement een nieuwe zending naar Bali te bewerken waar hij zich hoopte bezig te kunnen houden met het voorbereiden van een Kawi-woordenboek (dat later door Van der Tuuk zou worden gemaakt) en met het vertalen van Balinese wetboeken. Aangezien tijdens zijn eerste reis daarheen de financiën ontoereikend waren, begrootte hij zijn kosten nu op $f 400$ tot $f 500$ per maand. Het genootschap liet hem echter niet gaan. Eerst wilde het de catalogus van de Arabische en Maleise handschriften voltooid zien, begrijpelijk, waar die al zoveel jaren in bewerking was. Het feit dat het genootschap hem niet liet gaan, verbitterde Friederich. Daarbij kwam zijn penibele financiële situatie en het feit dat hij zich ondergewaardeerd voelde. Hij schreef op 5 april 1852 een pittige brief aan Bleeker:

Ik heb al sedert eenigen tijd de bedoeling gehad om niet langer de koelie van het Bat. Gen. te zijn. Dank heb ik er nog niet van gevonden, en de verscheidene Praesidenten van dat Instituut hebben mij nog altijd maar met de groote eer voor mij (zijnde ik in dien tijd sergeant) en met 'viel schönen reden' afgeprijst. Ik ben het nonsense moede; ik zou graag voor Uzelven iets willen doen, maar niet op last van ezels (b.v. de groote bruggenbouwer). Ik zal mijn bestaan anderwaarts rijkelijk vinden, en zal op zulke plaatsen altijd als 'gentleman' behandeld worden, hetgeen mij hier niet ten deele vindt. (Cursivering van Friederich.)

Friederich, die zich zelf aanduidde als 'toegevoegd voor Antiquiteiten enz. maar die nooit de eer zal hebben, om meer te worden', gaf naast hoofdingenieur Tromp (de grote bruggenbouwer), het bestuurslid in wiens huis de vergadering plaatsvond, ook bibliothecaris Munnich ervan langs: een 'slechte arts, ongelukkige dichter en een bibliothecaris zonder eenige kunde van boeken'. Bleeker had wel gezorgd dat de brief gevolgd was door verontschuldigingen, maar had de zaak niet buiten de vergadering gehouden. Friederich beriep zich op zijn reumatiek en erkende dat hij zich onwellevend had gedragen. ${ }^{173}$ 
De verontschuldigingen werden geaccepteerd, maar er ging wel een waarschuwing naar de 'toegevoegde voor de antiquiteiten'. Dat hij zich ondergewaardeerd voelde, was duidelijk.

Toen de storm weer wat geluwd was, stelde voorzitter Bosch voor dat de adjunct-bibliothecaris - zijn titel kreeg hij weer terug - de bestuursvergaderingen zou gaan bijwonen. Friederich, kort daarop in Bandoeng om Kawi-handschriften te bekijken, kreeg een bedrag van driehonderd gulden vanwege zijn buitengewone wetenschappelijke werkzaamheden en tijdens een tweede bezoek aan Bandoeng (mei-juli 1853) schreef hij Bleeker hartelijke brieven, onder andere over de warmte van Batavia die hem van zijn reumatiek zou afhelpen. ${ }^{174}$ Vanaf december 1853 woonde hij de bestuursvergaderingen bij. ${ }^{175}$ De vrede tussen Friederich en het genootschap was getekend. Het genootschap adviseerde ook steeds positief op verzoeken van het gouvernement om aan te geven of het op Friederichs rekesten om verbetering van zijn salaris in moest gaan. In januari 1854 zat hij op $f 250$ per maand. ${ }^{176}$ Nadat hij in de vergaderingen steeds gerapporteerd had over de voortgang van zijn werkzaamheden, durfde de adjunct-bibliothecaris op 3 oktober 1854 zijn positie in het bestuur ter discussie te stellen. Kon hij de door het vertrek van Vaijnes van Brakell vacant geworden bestuursplaats niet innemen? Het bestuur besloot met Friederich op de gang - dat dat verzoek gerechtvaardigd was. Eindelijk volgde dus de erkenning voor Friederich die al sinds jaren als geen ander wist wat het genootschap in huis had op het gebied van manuscripten en oudheden en die bovendien de Bali-deskundige was. Formeel was Friederich geen militair meer, al in 1851 was hij overgegaan in de civiele dienst. In 1854 probeerde hij een vergelijkbare postie te verkrijgen als de taalambtenaar Cohen Stuart, met de daarbij behorende betaling. Bleeker, kennelijk steeds de vertrouwde van Friederich in het bestuur, stelde er een brief over op aan de Raad van Indië. Het bestuur hechtte aan de titel, ambtenaar voor de inheemse talen, niet zoveel waarde. Was het bang Friederich dan te verliezen? Hij zou kunnen proberen naar Bali te gaan voor zijn Kawi-woordenboek. Maar voor de financiële kant van de zaak had het begrip en het stelde voor hem op $f 400$ per maand te zetten en het geleidelijk tot $f 500$ te verhogen. ${ }^{177}$

$\mathrm{Na}$ zijn studie over inscripties op Java en Sumatra droeg Friederich niet meer bij aan de Verhandelingen, maar hij was wel als editeur betrokken bij

174 ANRI KBG Dir 0197, vergadering 22-2-1853, punt 3; ANRI KBG Dir 0198, vergadering 29-31853, punt 3; ANRI KBG Dir 0200 vergadering 25-10-1853, punt 12 en bijlage 27 en 30.

175 Voorzitter Bosch had dat op 26-10-1852 al voorgesteld, maar door ziekte en afwezigheid kwam het er pas in december 1853 van. ANRI KBG Dir 0195, vergadering 26-10-1852, punt 3.

176 ANRI KBG Dir 0202, vergadering 28-3-1854, punt 5.n; ANRI KBG Dir 0203, vergadering 27-6-1854, punt 3.t.

177 ANRI KBG Dir 0207, vergadering 30-1-1855, bijlage 1-5. 
Cohen Stuarts uitgave van de Brata Joeda (1860) en overlegde regelmatig met landeigenaar Jonathan Rigg over diens Soendanees-Engels woordenboek (1862), dat na het afgewezen woordenboek van Roorda van Eysinga wel aan de criteria van het genootschap voldeed. Friederich droeg bij aan het Tijdschrift, maar publiceerde daarin geen grotere artikelen. De erkenning van de kant van de Koninklijke Nederlandsche Akademie van Wetenschappen te Amsterdam, die hem tot correspondent maakte van de letterkundige afdeling, liet Netscher fijntjes noteren voor de man die geen bibliothecaris mocht worden omdat Munnich maar geen plaats maakte. ${ }^{178}$ Nadat hij aan het eind van 1859 voor het laatst tevergeefs had geprobeerd zijn positie (toen $f 500$ per maand) te verbeteren, kondigde hij in juni 1860 aan vanwege zijn gezondheid naar Europa te willen teruggaan. Hij bood zijn ontslag aan als bestuurslid, wilde wel gewoon lid blijven en liet een aantal onafgemaakte werkzaamheden bij het bestuur achter. ${ }^{179} \mathrm{Hij}$ sloot zijn terugkeer niet uit en bood aan om zijn aantekeningen over Riggs Soendanese woordenboek te vervolgen. Toen hij in 1863 terugkwam in Indië, werkte hij aan een speciale regeringsopdracht naar de inscripties op stenen en monumenten op Java en Sumatra. Eindelijk had hij zijn vrijheid gevonden. In 1869 vroeg hij ontslag uit 's lands dienst. Hij overleed in 1875. Zijn plaats in het genootschap werd in 1860 niet opgevuld. Met hem en Netscher, die kort daarop naar Riouw vertrok, verloor het genootschap kort na elkaar twee voor de collecties zeer waardevolle medewerkers. Als het bestuur van het begin af aan grootmoediger was opgetreden, had het nog meer van Friederichs wetenschappelijke kwaliteiten kunnen profiteren. Hij deed waarschijnlijk voor de boeken grotendeels het werk waarmee Munnich als vrijetijdsmedewerker eer inlegde. Friederichs houding tegenover het genootschap zou anders zijn geweest als hij eerder bestuurslid was geworden en als hém en niet Munnich de bibliothecarisplaats was gegund.

\section{Het KITLV en het Tijdschrift voor Indische Taal-, Land-en Volkenkunde}

Het bestuur moet al in de loop van 1851 gehoord hebben van de oprichtingsplannen voor het Koninklijk Instituut voor Taal-, Land- en Volkenkunde (KITLV) in Delft, afkomstig van oud-gouverneur-generaal en erelid van het genootschap, Baud, en diens medestanders G. Simons en Taco Roorda. Het nieuwe instituut zou verbonden worden aan de Koninklijke Akademie in dezelfde stad, waar de opleiding voor bestuursambtenaren en ingenieurs

179 TBG 10, vergadering 2-6-1860. Zie ook TBG 9:425 en TBG 10:20. 
voor Indië was gevestigd (J.C. Baud 1853). De postverbindingen waren sinds de invoering van de landmail in 1846 sterk verbeterd, dus kon het niet anders of de circulaire van de drie oprichters van 3 februari 1851 was binnen enkele maanden ook in Batavia bekend. Niettemin treffen we pas bij het verslag van de vergadering van 26 oktober 1852 in het genootschapsarchief de eerste stukken aan die betrekking hebben op het Delftse instituut. ${ }^{180}$ Uit het verslag zelf van deze vergadering blijkt niet dat er toen over werd gesproken. Het lijkt welhaast onmogelijk dat de zaak niet al eerder aan de orde kwam.

De ontvangst van de berichten over het KITLV in Batavia verliep niet zoals Baud had gehoopt. De brieven en circulaires, die in november 1851 aan de gouverneur-generaal, de opperbevelhebber van het leger, de leden van de Raad van Indië en aan de algemeen secretaris waren gestuurd, arriveerden in april 1852 in Batavia, maar werden toen een tijdje vastgehouden. Gouverneurgeneraal Duymaer van Twist kreeg zijn brief pas op 17 juli onder ogen. Hij reageerde positief op de berichtgeving over het nieuwe instituut en nam het hem aangeboden lidmaatschap aan. In zijn brief van 18 juli 1852 refereerde hij aan het tijdschrift van het Bataviaasch Genootschap dat in oprichting was, door hem aangeduid als 'een tijdschrift van gelijke strekking' als de Bijdragen die de Delftenaren gingen uitgeven. Overigens sprak hij de verwachting uit dat er voor twee van die tijdschriften voldoende ruimte zou zijn. ${ }^{181}$ Zo blij als Baud en de zijnen waren met de reacties van de gouverneur-generaal en van algemeen secretaris Prins op de Delftse brieven, zo verwonderd waren zij over het oponthoud van april tot juli, een stilte die zij in verband brachten met het nieuw opgerichte tijdschrift in Batavia. In december 1852 werd in Delft geconcludeerd dat het nieuwe instituut in Batavia op tegenwerking was gestuit. $^{182}$

Het KITLV zou met zijn Bijdragen en Werken mededinger worden naar de gunsten van dezelfde beheerders van kopij, het Bataviase gouvernement en het ministerie van koloniën in Den Haag voorop. Die Bataviase bron van kopij was voor de redactie van de Verhandelingen en van het nieuwe Tijdschrift veel gemakkelijker toegankelijk dan voor de collega's in het verre Nederland. Vandaar dat Baud zich van het begin af aan van koninklijke bescherming had verzekerd en het ministerie van koloniën voor zijn project had weten te interesseren (Kuitenbrouwer 2001:15-53). Het genootschap in Batavia moest

180 ANRI KBG Dir 0195, vergadering 26-10-1852, bijlage 14-18 bestaande uit de circulaire van Baud, Simons en Roorda, 3-2-1851, de toespraak van Baud bij de oprichtingsvergadering van 4-6-1851, de gedrukte brief van voorzitter Baud van oktober 1851, een gedrukt reglement en een eerste ledenlijst.

181 Archief KITLV 236, Eerste Copieboek, brieven van 14-11-1851, nr 1-5. Zie ook in hetzelfde archief 93, verslagen bestuursvergaderingen, vergadering 30-9-1851 en 17-12-1852. Brief van Duymaer van Twist afgedrukt in BKI 2:7.

182 Archief KITLV 93, vergadering 17-12-1852. 
notabene tot 1923 wachten eer het het predikaat 'koninklijk' mocht voeren, en dat terwijl de Natuurkundige Vereeniging in Batavia al tien jaar al de oprichting het koninklijke stempel ontving.

De overeenkomst tussen de bedoelingen van het KITLV-bestuur en die van het genootschap was de gouverneur-generaal meteen opgevallen. In Delft werd gepikeerd gereageerd op de plannen van het genootschap. Voorzitter Baud stelde voor om Duymaer van Twist te vragen of hij een verklaring had voor de vertraging die de Delftse post had ondervonden. De oprichting in Batavia was 'allezins geschikt om aan die onverklaarbare vertraging in de bestelling van dit dezerzijdsche pakket eene bijzondere betekenis te geven', aldus werd in het bestuur geconcludeerd. ${ }^{183}$ Baud schreef in diplomatieke, maar duidelijke woorden in gelijke zin aan de gouverneur-generaal.

Allezins gepast is de aanmerking van U.E. dat op het gebied der wetenschap geen andere naijver moet bestaan, dan een zoodanige, die strekt tot eendragtige bevordering van het gemeenschappelijke doel. Deze door Uwe E. aangewezen gedragslijn zal het Instituut blijven volgen, ook dan wanneer de verrassende oprigting, te Batavia, van het concurrente en geheel homonyme tijdschrift, in Uwer Exc. brief bedoeld, zich niet mogt kunnen zuiveren van den schijn van onvriendelijkheid, thans daarop klevende. ${ }^{184}$

In Delft kon men niet op de hoogte zijn van de voorgeschiedenis van het Bataviase tijdschrift. De oprichting werd er gezien als een snelle stap om de nieuwe Delftse periodiek de loef af te steken. Daarmee was de sfeer in de beginfase al bedorven.

Het genootschap had op 30 december 1851, zes maanden na de oprichtingsvergadering in Delft, het besluit genomen om zelf een tijdschrift uit te geven, gewijd aan de 'land-, taal- en volkenkunde en statistiek van NederlandschIndië'. Het plan was al eerder besproken, maar aangehouden. Het is in een ander verband al vermeld, dat de beslissing over de oprichting gebeurde in de context van een uitgebreide discussie over de financiële problemen. Het tijdschrift werd gezien als een manier om geld te verdienen. Er zouden immers lezers komen buiten de kring van de leden: intekenaren, abonnees. Keuchenius, Munnich en Bleeker namen de redactie van het nieuwe tijdschrift op zich. ${ }^{185}$ Vooralsnog werd de geboorte niet aan het publiek bekend gemaakt. Wel stuurde het genootschap op 23 januari 1852 een brief aan de gouverneur-generaal, waarin het vroeg om steun voor de nieuwe periodiek in de vorm van kopijverstrekking uit het archief van de Algemene Secretarie, waarop het gouvernement op 6 maart positief reageerde. Het genootschap 
was het KITLV dus voor. Keuchenius, met 30 jaar de jongste van het gezelschap, bood aan het contact te onderhouden met de hoofdambtenaren ter secretarie. Hij zou dan de kopij in ontvangst nemen. Hij stelde in de vergadering van 30 maart 1852 het probleem van de redactionele onafhankelijkheid ten opzichte van het genootschapsbestuur aan de orde. Dit was ongetwijfeld nog een nawee van de problemen in 1847-1848 over de drukpers, toen het bestuur geen verantwoordelijkheid had willen nemen. De redactie werd echter door het bestuur 'de meest mogelijke vrijheid van werking toegestaan' ${ }^{186}$ De kosten dacht men grotendeels uit de intekening van niet-leden te dekken. De geboorteaankondiging werd uiteindelijk aan de leden gedaan door secretaris Bleeker tijdens de algemene vergadering op 27 april 1852. De redactie bleek toen uitgebreid te zijn met Netscher, die als commies bij de Algemene Secretarie goed op de hoogte was van wat daar aan mogelijke kopij voorhanden kwam. Was het toeval dat juist toen de brieven over de Delftse oprichting al in Batavia waren? Wie mogelijk voor het achterhouden verantwoordelijk was, is niet bekend. Van kwade opzet was zo te zien bij het genootschap geen sprake, al was de oprichting van het KITLV waarschijnlijk toch een factor die in december 1851 meespeelde bij de beslissing om met een eigen tijdschrift te komen.

Het was een zeer productieve tijd voor het genootschap. De Verhandelingen kwamen in 1852 én in 1853 uit. Ook Munnichs tweede druk van de bibliotheekcatalogus verscheen in 1853, tegelijk met de eerste jaargang van het tijdschrift. In het eerste jaar komen we uit de notulen niet veel te weten over de nieuwe publicatie. Dat zal wel met de bevochten onafhankelijkheid te maken hebben. In de naam van het tijdschrift was de 'statistiek' vervallen, maar als Tijdschrift voor Indische Taal-, Land-en Volkenkunde leek het wel erg op de naam die de Delftenaren voor de Bijdragen tot de Taal-, Land-en Volkenkunde van Neêrlandsch Indië hadden gekozen. Al had het genootschap dan nu een eigen tijdschrift - in de tweede helft van 1852 zag de eerste aflevering het licht een voortrekker had het zich niet betoond. De Natuurkundige Vereeniging had haar Natuurkundig Tijdschrift voor Nederlandsch Indie al in 1850 aan haar leden én aan de leden van het Bataviaasch Genootschap kunnen tonen. In het jaar daarna had de Vereeniging ter bevordering van de Geneeskundige Wetenschap in Nederlandsch Indië de eerste afleveringen van haar eigen tijdschrift het licht doen zien. Nieuwe, jonge organisaties waren slagvaardiger dan het oude genootschap.

In oktober 1853 had het KITLV zich tot het Bataviaasch Genootschap gewend en het de eerste jaargang van de Bijdragen toegestuurd. Als dank

186 ANRI KBG Dir 0191, vergadering 30-3-1852, punt 3.a en bijlage 14 (concept van 23-1-1852 aan de gouverneur-generaal). 
stuurde het genootschapsbestuur op 28 juni 1854 het eerste deel van het Tijdschrift naar Delft. Het genootschap had de Bijdragen aanvankelijk via de boekhandel in Nederland betrokken, maar nu er van een uitwisseling van publicaties sprake was, hoefde dat niet meer. Het initiatief voor de uitwisseling kwam dus uit Delft. ${ }^{187}$ In september 1854 werd in het KITLV-bestuur de brief uit Batavia besproken en werd de 'wederkerige toezegging van hare werken' genoteerd. 188

Kijken we nu naar het tijdschrift zelf. Netscher was de enige van de vier redactieleden die in de eerste jaargang zelf als auteur optrad met een vertaling van een kroniek van Sambas en Soekadana en een met H. von Dewall gemaakte bewerking van de papieren van C.M. Schwaner over Tanah Boemboe (Borneo). De eerste jaargang was gewijd aan geschiedenis (17e-19e eeuw) en land- en volkenkunde, inclusief statistiek. Geschreven werd over Malang, Java in het algemeen, de Aroe-eilanden, Billiton, de Dayaks, de Mentawai-eilanden. Voor de oudheidkunde tekenden Wilsen (zijn Boroboedoer-studie) en Friederich. De laatste droeg een stuk bij over de inscriptie op de zogenaamde Batoe Toelis te Buitenzorg en rapporteerde met Netscher over de door hem in de Preanger bekeken Kawi-handschriften. De eerste jaargang leunde sterk op wat Netscher uit de Algemene Secretarie had kunnen meenemen. Taalkunde was afwezig, op de historische bijdragen van Friederich na. Er was geen overheersende aandacht voor Java.

Netscher vulde zelf grotendeels de rubriek 'Berigten' die in de tweede jaargang begon en waarin kort nieuws verscheen over recente vondsten, mededelingen over inscripties, munten, over de betekenis van een woord, kortom een rubriek die de aantrekkelijkheid van het blad sterk vergrootte. Friederich droeg hier ook aan bij. Niet iedereen hoefde meteen in de langere studies te duiken, ook korter nieuws werd geplaatst. Dat zou spoedig ook gelden voor berichten over het genootschap: lijsten met de namen van de organisaties met wie het boeken uitwisselde, de verslagen van de algemene vergaderingen van 1855 en 1856 en vanaf jaargang 7 (1858) de notulen van de bestuursvergaderingen. Die notulen betrokken de leden meer dan in het verleden bij het bestuurswerk. De leden hadden op de algemene vergaderingen de mogelijkheid om te interveniëren en hadden stukken om op te reageren.

Eind 1853 was er al onmin in de redactie. Volgens Bleeker, Netscher en Munnich kon de redactie beter opgedragen worden aan twee personen. Vier was onwerkbaar. Keuchenius was het daar niet mee eens, weet de opgetreden vertraging in de verschijning niet aan structurele, maar aan tijdelijke omstandigheden en verdween uit de redactie toen hij in 1854 met ziekteverlof naar

188 Archief KITLV 93, vergadering 16-9-1854. 
Nederland vertrok. Een paar maanden later was Bleeker tegen de plaatsing van G.F. de Bruijn Kops' artikel over de fauna van Riouw. Mogelijk had hij dat liever in het Natuurkundig Tijdschrift opgenomen gezien. Desondanks werd het geplaatst door Netscher en Munnich (TBG 2:271). Netscher pleitte voor redactiebeslissingen bij meerderheid van stemmen. Hij gaf aan hoeveel hij en hoe weinig anderen aan jaargang 1 en 2 hadden bijgedragen en hoe druk hij met de auteurs had gecorrespondeerd. Bleeker, die zich nu terugtrok uit de redactie, werd door het bestuur overgehaald te blijven, maar hij wilde alleen terugkeren als een van de redactieleden (hij of een ander) de leiding zou krijgen. Netscher deed een ander voorstel: de redactie zou eenhoofdig worden - het laat zich raden wie hij in gedachten had - en deze redacteur zou de bestuursvergaderingen bijwonen. Het bestuur was niet voor een eenhoofdige redactie, maar als compromis stelde Bleeker voor dat Netscher de leiding zou krijgen over de driekoppige ploeg. Hij mocht echter geen titel dragen. Kennelijk zou dat teveel op het passeren van Bleeker hebben geleken. Netscher kreeg als vertegenwoordigend redactielid wel toegang tot de bestuursvergaderingen en werd kandidaat-bestuurslid. Bleeker had zich neergelegd bij Netschers ambities en zal gezien hebben dat de man kwaliteiten had. Hijzelf had met zijn diverse genootschappen en tijdschriften de handen meer dan vol. Netscher werd de facto hoofdredacteur, al mocht het niet zo heten. Het compromis pakte voor Netscher en het tijdschrift goed uit. Hij legde zich bij de beslissing van het bestuur neer, hoewel zijn eerdere brief over het onderwerp als een ultimatum leest. ${ }^{189}$ Netscher, Bleeker en Munnich bleven formeel gedrieën de redactie voeren, in de praktijk deed Netscher het werk.

Was het contact tussen KITLV en het genootschap gelegd, er dreigde wel een donkere wolk aan de horizon. Het KITLV had nauwe banden met het ministerie van koloniën, waar het kopij van hoopte te betrekken, maar toch moesten de Bijdragen na een paar jaar al ingekrompen worden door kopijgebrek (Kuitenbrouwer 2001:32-3; Knaap 1994:639). Het publiceren van stukken uit de Indische archieven was al onderwerp van een briefwisseling tussen het Delftse bestuur en het ministerie in oktober $1854 .{ }^{190}$ In 1855 had gouverneurgeneraal Duymaer van Twist voorgesteld een verdeling over de twee instituten te doen: de stukken daterend van vóór 1816 zouden voor de Bijdragen en die van recenter datum voor het Tijdschrift bestemd kunnen worden, een salomonsoordeel dat niet beide partijen tevreden stelde. Het KITLV had grote

189 ANRI KBG Dir 0202, vergadering 28-3-1854, punt 5 en bijlage 2; ANRI KBG Dir 203, vergadering 27-6-1854, punt 6; ANRI KBG Dir 0204, vergadering 25-7-1854, punt 2.n en bijlage 4; ANRI KBG Dir 0205, vergadering 3-10-1854, bijlage 23 en 24.

190 Archief KITLV 236, nr 51 23-10-1854 aan het ministerie van koloniën in antwoord op een brief van hetzelfde ministerie van 17-10-1854. 
bezwaren. Het wilde niet gedwongen zijn zich te beperken. Bovendien waren de stukken van recenter datum veel aantrekkelijker, juist omdat ze actueel waren. ${ }^{191}$ Een jaar later legde het KITLV zich toch neer bij de door de gouverneur-generaal bedachte verdeling en wachtte af wat er uit Batavia voor publicatie zou overkomen. ${ }^{192}$ Het probleem van de kopij bleef spelen. Het KITLV vond dat het tijdschrift van het genootschap bevoorrecht werd doordat het aantrekkelijker stukken kon publiceren, terwijl het Tijdschrift alleen de leden van het genootschap bereikte en buiten die kring beperkt circuleerde. De gouverneur-generaal, intussen was dat C.F. Pahud, vond dat die stukken over actuele zaken nu juist belangrijk waren voor de jonge ambtenaren in Indië, een reden om ze voor het Tijdschrift te bestemmen. Het KITLV repliceerde daarop dat ze juist van belang waren voor de ambtenaren die in Nederland in opleiding waren, in Delft uiteraard. ${ }^{193}$ De discussie leidde er zelfs toe, dat er tijdelijk helemaal geen stukken aan de Indische tijdschriften werden afgestaan. De gouverneur-generaal besloot ten slotte op 11 april 1857 tot een oplossing waarbij hij door het kantoor van de Algemene Secretarie liet selecteren welke stukken voor Delft en welke voor Batavia ter beschikking kwamen. Een nota daarover zou dan aan beide instituten worden gestuurd. Het gevaar van verdubbeling leek bezworen. ${ }^{194}$ Het KITLV bleef echter beducht dat het alleen historisch materiaal zou toegeschoven krijgen. De minister van koloniën schreef aan de gouverneur-generaal dat het KITLV niet mocht worden achtergesteld. ${ }^{195}$ Vreemd was wel dat de beslissing over publicatie nu nog minder bij de redacties leek te liggen. Zij hadden een instantie boven zich gekregen, die een verdeelsleutel op geschikte stukken ging toepassen. Uit het feit dat nergens uit de Bataviase notulen onvrede blijkt met wat de redactie kreeg toebedeeld, mogen we afleiden, dat de onvrede meer in Delft dan in Batavia heerste.

De problemen over de kopij en de afgunst op het welvaren van het Bataviase Tijdschrift waren mede de oorzaak van de uitval van de Delftse secretaris J. Pijnappel tijdens de bestuursvergadering in Delft van 18 april 1857. Hij zei zich zorgen te maken over de 'schrikwekkende hoogte' die het aantal genootschappen in Indië dreigde te bereiken en vergeleek de situatie met die aan het einde van de zestiende eeuw, toen diverse voorcompagnieën elkaar beconcurreerden. Hij wees op de bloedarmoede bij de diverse

191 Archief KITLV 236, nr 62 dd 22-7-1855 aan het ministerie van koloniën.

192 Archief KITLV 236, nr 77, dd 13-10-1856 aan het ministerie van koloniën.

193 NA, Koloniën verbaal 12-10-1857 nr 1/1183.

194 TBG 7:185, vergadering 23-2-1857; TBG 7:255, vergadering 18-5-1857.

195 NA, Koloniën verbaal 12-10-1857 nr 1/1183, brief van de minister van koloniën aan de gouverneur-generaal over een brief van het KITLV, 1-10-1857 aan de minister over vijf uit Batavia ontvangen stukken, waarvan er vier ongeschikt voor publicatie waren. Brief van het KITLV aan de minisiter van koloniën ook in Archief KITLV 236 nr 103. 
Indische tijdschriften, die was ontstaan. Het 'kwaad' zou zich echter vanzelf wel weer herstellen, aldus zijn Darwinistische veronderstelling. De nogal vreemde uitval van Pijnappel had in 1857 tot een scherp redactioneel commentaar in de Java-bode aanleiding gegeven, dat waarschijnlijk uit de pen van redacteur L. Tollens was gevloeid. Daarin waren Pijnappels angsten voldoende ontzenuwd (Java-bode 8-12-1858). Jurriaan Munnich had niet kunnen nalaten de zaak in het Tijdschrift voor Nederlandsch Indië nog eens uitgebreider aan de orde te stellen. Hij maakte in zijn repliek handig gebruik van het in de Java-bode verschenen commentaar, waarin de Delftse secretaris van naijver en partijgeest was beschuldigd. Hoewel Munnich niet uit naam van het Bataviaasch Genootschap reageerde, leest zijn verdediging toch als een antwoord van het genootschap aan Pijnappel. Munnich vond dat het KITLVbestuur met de woorden van de secretaris had ingestemd door het verslag goed te keuren en het te publiceren. Hij zei Pijnappel persoonlijk niets te kunnen verwijten, omdat die nog nooit in Indië was geweest. Verder schetste hij in het kort hoe heilzaam het ontstaan van nieuwe verenigingen op het Bataviaasch Genootschap had uitgewerkt, terwijl hij de nieuwe organisaties op het gebied van natuurwetenschappen, geneeskunde en nijverheid prees om hun actieve verzamel- en publicatiearbeid. Dat de Indische tijdschriften, naar de woorden van Pijnappel, aan 'atrophie' zouden lijden, achtte hij voldoende weerlegd. ${ }^{196}$

Als we nu de eerste serie van twaalf jaargangen (tot 1861) van het Bataviase tijdschrift bekijken, dan blijkt Netscher de meeste bijdragen op zijn naam te hebben staan: $64 .{ }^{197}$ Hieronder bevindt zich een flink aantal kortere bijdragen, berichten en mededelingen van een halve pagina tot twee of drie pagina's. Netscher schreef over zijn grote hobby, munten en papiergeld, over inscripties, over geschiedenis en over Sumatra, maar eigenlijk schreef hij over van alles, zoals het de best ingevoerde redacteur betaamde. Bleeker en Munnich waren afwezig als auteurs. Tweede veelschrijver was Johannes Hageman Jcz. (1817-1871), beambte bij het Soerabaijase residentskantoor en griffier van de Landraad aldaar, die eerst onderdak had gevonden voor zijn vele artikelen over Java in Buddinghs Indisch Archief, maar die na de opheffing van dat tijdschrift dakloos was. Hageman droeg twintig artikelen bij aan de jaargangen 1-12, bijna uitsluitend over Javaanse zaken: geschiedenis en tijdrekening, onder andere. Hij was vanaf de eerste jaargang present. Hij zette met het derde deel van zijn 'Algemeene geschiedenis van Java' de serie uit het Indisch Archief

196 TNI 21 II:101-108: 'Het oordeel van het Koninklijk instituut voor de Taal-, Land- en Volkenkunde van Nederlandsch Indië, over de wetenschappelijke instellingen aldaar'.

197 Niet meegeteld de bijdragen die alleen met N. ondertekend zijn. Gewoonlijk tekende Netscher met E.N. Evenmin meegerekend zijn de anonieme bijdragen en de bijdragen van de redactie. Het getal zal mogelijk nog hoger liggen. 
voort, die hij aanvankelijk in boekvorm en verkort aan boekhandelaar Lange had willen aanbieden. Hij bood zijn dikke manuscript over de Java-oorlog eveneens aan het genootschap aan. Het dateerde al van 1848, maar was bij de drukkerij van Oliphant in Semarang blijven liggen. Het genootschap durfde de publicatie niet aan en liet Hageman in december 1851 weten dat het zich distantieerde, 'omdat de direktie zich niet verantwoordelijk kan achten voor talrijke voorstellingen van zaken, welker gezag aan twijfel onderhevig is'. ${ }^{198}$ Hageman bood vier hindoebeelden aan, maar dit aanbod had het bestuur niet kunnen vermurwen. Wel werd zijn studie over de vroege geschiedenis van Malakka en de oorlogen tussen de Portugezen en de Maleiers geplaatst in de Verhandelingen $(24,1852)$. Hageman kwam terug op zijn 'Java-oorlog' en vroeg het genootschap de drukkosten voor zijn rekening te nemen. Vreemd genoeg overwoog het bestuur dit, ondanks de aanvankelijk geuite bezwaren, en het droeg Bleeker op zich daarover met Lange en Co te verstaan. Uiteindelijk drukte Lange, op kosten van het genootschap, Hagemans Geschiedenis van den oorlog op Java van 1825-1830 (1856), al werd in de uitgave op geen enkele wijze melding gemaakt van de betrokkenheid van het genootschap. Misschien dat de vier hindoe-beelden dan toch iets hadden bewerkt. ${ }^{199}$

Friederich schreef een aantal bijdragen over inscripties en oudheden, dertien in getal, de meeste over Javaanse inscripties. De tekenaar Wilsen droeg vier artikelen bij over de Boroboedoer en andere oudheden. Verder waren sommige auteurs welhaast correspondenten voor bepaalde regio's: de ambtenaren C. Bosscher over de Molukken (acht bijdragen) en Von Rosenberg met vier bijdragen over Sumatra. Afwezig waren bijdragen over het Javaans die men van Cohen Stuart, J.A. Wilkens en C.F.Winter had mogen verwachten. Cohen Stuart schreef wel over de tijdrekening op Java en ging met H. von Dewall in discussie over het Maleis. Winter droeg één artikel bij over de titels van de Javaanse adel, maar als we bedenken dat dit drietal dé deskundigen van het Javaans was, is dit wel weinig. Van der Tuuk droeg evenmin bij. Netscher schreef wel kort over de Batakse taalstudie. Overigens had Van der Tuuk via Netscher, die hij in Batavia had leren kennen voor hij naar de Bataklanden vertrok, contact met het genootschap. Hij adviseerde het in 1853 om het Batakse woordenboek dat via A. van der Hart was binnengekomen niet te publiceren. Zijn uitgebreide brief van 10 mei 1853 had aanleiding kunnen geven tot een vruchtbare correspondentie en wellicht tot bijdragen in het Tijdschrift, ware het niet dat het bestuur het advies van de taalkundige

198 ANRI KBG Dir 0184, vergadering 7-1-1851, bijlage 19; ANRI KBG Dir 0185, vergadering 25-3-1851, bijlage 1-2; ANRI KBG Dir 0188, vergadering 26-10-1851, punt 3 en bijlage 7, afwijzingsbrief, 2-12-1851.

199 ANRI KBG Dir 0188, vergadering 26-1-1851, punt 5a en bijlage 1 over de hindoe-beelden. ANRI KBG Dir 0189, vergadering 30-12-1851, punt 4c. 
ongelegen kwam. Het had gedacht eer te kunnen inleggen met de uitgave van het woordenboek en nu kwam Van der Tuuk roet in het eten gooien. Het weigerde hem inzage in het volledige handschrift, waardoor de verhouding verstoord raakte (Groeneboer 2002:176-9, 192-3, 415-7).

Net als in de eerste jaargang zijn de latere jaargangen tot 1861 zeer gevarieerd. Er is belangstelling voor de buitengewesten (Sumatra, Borneo, Celebes, de Molukken); Java voert niet de boventoon. Er is veel aandacht voor geschiedenis, voor munten, oudheden, waaronder inscripties. Nieuw-Guinea komt nog nauwelijks aan bod, maar de ophanden zijnde expeditie daarheen van 1858 werd wel door het genootschap als een kans gezien. De deelnemers kregen een brief en het feit dat J.H. Croockewit en Von Rosenberg - beiden hadden al bijgedragen aan het tijdschrift - meegingen, stemde het bestuur en de redactie hoopvol. 200

Een kans op een interessant Indonesisch gezichtspunt op de Java-oorlog, van de regent van Karanganjar, Raden Adipati Ario Djojo di Ningrat, die aan de zijde van Dipo Negoro had gevochten, liet het bestuur zich toch ontgaan. Die regent had zijn bevindingen en herinneringen te boek gesteld na aanmoediging door de voorzitter, legercommandant generaal De Stuers, die zelf als adjudant van De Kock in de Java-oorlog had gevochten en daarover had gepubliceerd. Het Maleise manuscript, doorspekt met Javaanse woorden, was in september 1858 aangebracht door het bestuurslid A. Weitzel, destijds adjudant van De Stuers. Het wekt wel verwondering dat het om een Maleis manuscript ging van een Javaanse regent. Een uitgave werd overwogen, de controleur F. Beijerinck in Cheribon werd gevraagd om het in het Nederlands te vertalen. ${ }^{201}$ Beijerinck nam het verzoek aan, ${ }^{202}$ maar maakte de vertaling maar gedeeltelijk af. Hij vond het verhaal van de regent van Karanganjar verward en alleen te volgen voor wie bekend was met het terrein van de strijd en bovendien bekend was met de vorstelijke families van Solo en Djokjakarta. ${ }^{203}$ De ijverige Hageman, die inmiddels de genootschapscorrepondent voor Oostelijk Java was geworden, werd gevraagd de vertaling te voltooien. ${ }^{204}$ Nog voor Hageman in mei 1859 aan het werk toog, reageerde hij

200 TBG 8:5-6, vergadering 28-12-1857.

201 TBG 8:290-1, vergadering 16-9-1858.

202 TBG 9:9, vergadering 6-11-1858.

203 Brief van Beijerinck aan het bestuur, Soekaboemi, 9-4-1859, met een 'Mislukte proeve eener vertaling van eene historie van den Java-oorlog 1825-1830. Opgesteld door den Regent-Adhipati Karanganjar' in ANRI KBG Varia 0006. Beijerinck bleek de paragrafen 1-32 te hebben vertaald. De kwalificatie 'mislukt' is van Beijerinck zelf.

204 Hageman had gevraagd om buitengewoon lid van het genootschap (zonder contributieverplichting) te mogen blijven en had zijn diensten als correspondent voor Oostelijk Java aangeboden. Het bestuur had daar positief op gereageerd. ANRI KBG Dir 0230, vergadering 14-5-1859. Bij de geschreven notulen brief van Hageman 25-4-1859 en het antwoord van het bestuur 17-5- 
bij het bestuur op een brief van Beijerinck, waarin die het vertaalwerk opgaf. Daarin toont Hageman zich bewust van de oriëntalistische zienswijze van het bestuur én Beijerinck.

De beoordeling in het tijdschrift, en in den brief van den heer B., is echter eenigsinds voorbarig te achten. De Javaan heeft als Javaan geschreven; zoo schreef de Majoor de Stuers den oorlog als schoonzoon van eenen schoonvader [generaal de Kock, HG]; de Luit. Weitzel schreef dit als adjudant van den vroegeren schrijver [de Stuers, HG]. Beiden schreven in Holland en waren Hollandsch, dachten Hollandsch, van den eenzijdigen Hollandschen kant, uit Hollandschen papieren, Hollandschen rapporten, Hollandschen monden met Hollandschen hersenen, Hollandsch redenerende. Welligt heeft 'mijn oorlog van Java' eveneens dusdanige Hollandsche beoordeelaars gevonden. Die man, de schrijver van 't handschrift, was een mijner bronnen; zijne broeders, zwagers, neven, magen, waren mijne bronnen en berigtgevers. Ik meen dat ik onder mijne papieren dergelijke stukken bewaard heb; mijn vergelijk zal echter de waarde voorzeker verhoogen, en daar 't mij toeschijnt, dat de heer B. de historie van den 'oorlog van Java' nimmer belangstellend heeft ingezien, zoo moge het door Z.Ed. opgeworpen bezwaar aannemelijk worden geacht.- Ik dank echter het Gen. van mij den door Z.Ed. onoverkomelijk geachten arbeid te hebben opgedragen. ${ }^{205}$

Hagemans interessante mening had het genootschap kunnen aanzetten tot de publicatie van het manuscript. De correspondent van Oostelijk Java voltooide inderdaad de vertaling in minder dan een jaar. ${ }^{206}$ Toen die werd aangeboden, nam de nieuwe voorzitter, generaal J. van Swieten, commandant van het Indische leger en opvolger van De Stuers in zowel de militaire als de genootschapsfunctie, de tekst mee. Hij wilde die graag inzien. Bleeker schreef er in mei 1860 een briefje over aan Van Swieten, waarmee hij de overdracht van de vertaling vastlegde. ${ }^{207}$ Hageman vroeg in mei 1861 nog eens wat er van zijn vertaling was geworden. In november van hetzelfde jaar schreef Hageman aan het genootschap, dat het handschrift intussen in het Delftse tijdschrift was gepubliceerd. Dat laatste wekt opnieuw verwondering, aangezien het betreffende handschrift, waar Taco Roorda een beschrijving geeft, van een heel andere hand afkomstig is. In Batavia was het heel stil geworden rond Hagemans vertaling. Van Swieten zei niets, of het werd buiten de notulen gehouden. In augustus 1862 kondigde hij zijn vertrek en zijn aftreden als voorzitter aan. Van het relaas van de regent van Karanganjar, werd niets meer

1859.

205 ANRI KBG Dir 0231, vergadering 4-6-1859, brief van Hageman, 23-5-1859.

206 Op 2-4-1860 bood Hageman de vertaling aan het bestuur aan. ANRI KBG Varia 0006, brief van die datum.

207 Was Bleeker zich bewust van het gevaar dat er school in de overdracht van de vertaling aan Van Swieten? Brief van Bleeker, 17-5-1860 in ANRI KBG Dir 0239, vergadering 12-5-1860. 
vernomen. ${ }^{208}$ Een voorbeeld van de opzettelijke verdwijning van een andere kijk op de gebeurtenissen uit de Java-oorlog? Tegelijk een gemiste kans om al in de eerste tien jaar een bijdrage van een Indonesiër op te nemen. Ook uit het geval van Hagemans eigen moeilijkheden om 'zijn oorlog van Java' gedrukt te krijgen, blijkt dat die oorlog nog te vers in het geheugen lag. Het vrije woord had zo zijn beperkingen. De gedrukte notulen van deze episode geven de zaken verkort weer. De archiefstukken vormen in dit geval een waardevolle aanvulling op de notulen in het Tijdschrift.

Het Tijdschrift maakte een heel gevarieerde indruk. Korte bijdragen verhoogden die verscheidenheid aan onderwerpen. De geregelde verschijning maakte het ook mogelijk om te reageren en gaf de lezers de kans om de discussie tussen vakgenoten mee te maken: Von Dewall en Cohen Stuart schreven over het Maleis en Friederich en Hageman over een pilaar van Modjopahit. ${ }^{209}$ Het feit dat het genootschap naast de Verhandelingen nu een eigen tijdschrift had, droeg zeker bij tot de kwaliteitsverbetering van de werkzaamheden van het genootschap. De leden waren beter op de hoogte van wat er aan aanwinsten binnenkwam en konden daar vragen over stellen. Het genootschap had daardoor aan openheid gewonnen.

De periode 1849-1860 was er een van consolidatie na het vertrek van Van Hoëvell, maar tegelijkertijd van voortbouwen op de door hem ingeslagen weg en van koersveranderingen, die overigens al voor 1849 waren aangekondigd. De aandacht voor de talen, vooral van het Javaans en Oud-Javaans, bleek duidelijk uit de verschillende tekstedities en vertalingen. Het genootschap nam afscheid van de natuurwetenschappen, al kon het om Bleekers vissen niet heen. Het concentreerde zich op de taal-, land- en volkenkunde van de archipel. Daardoor kwamen eerst Bali, Borneo, Sumatra en Celebes in zicht, vervolgens Timor, de Molukken en Nieuw-Guinea. Financiële steun, maar ook logistieke hulp (gebouwen, opbouwen van de collecties) bond het genootschap aan het gouvernement. Terwijl het de collecties uitbreidde en naast de Verhandelingen ook een eigen tijdschrift begon, zich specialiseerde en professionaliseerde, zag het zich geplaatst tegenover een moeilijk probleem dat niet voor 1860 oplosbaar bleek: de vervanging van de bouwvallige panden achter en naast de Harmonie. Dat zou pas in de periode 1861-1867 worden opgelost.

208 TBG 9:225, vergadering 14-5-1859; TBG 9:236, vergadering 4-6-1859; TBG 10:295-6, vergadering 12-5-1860; TBG 11:434-5, vergadering 1-6-1861. Brief van 11-11-1861 van Hageman aan het bestuur, ANRI KBG Dir 0259, vergadering 14-12-1861. Vergelijk Taco Roorda's inleiding op het 'Verhaal van de oorsprong en het begin van den opstand van Dipa-Negara, volgens een Javaansch handschrift', BKI 7:137-9, het handschrift aldaar gepubliceerd, 140-227. De auteur heet Raden Adipati Tjakra-Negara.

209 TBG 6:37, 156, 507, 535; TBG 7:172,176, 178, 287, 447; TBG 8: 327; TBG 9: 420. 


\section{HoofDSTUK VII}

\section{Naar een tempel aan het Koningsplein (1861-1867)}

Aan het genootschap was door oprichter Radermacher in 1779 een woonbedrijfspand aan de Grote Rivier geschonken. Het kreeg een kant en klaar genootschapshuis en museum in de schoot geworpen. Raffles had in 1814 van een nieuw gebouw achter de sociëteit de Harmonie de bestemming veranderd. In plaats van winkels en eethuizen te huisvesten, was het pand aan de Rijswijkstraat onderdak gaan bieden aan het genootschap. De periode die we nu bespreken, wordt gemarkeerd door de bouw van een eigen, als museum en genootschapshuis ontworpen gebouw. Dat nieuwe gebouw zou een einde maken aan een lange reeks problemen en het genootschap de mogelijkheid bieden zich verder te ontplooien, niet meer geremd door een te kleine en slechte behuizing. Met voldoende ruimte konden eindelijk de collecties in hun volle omvang worden getoond. Het publiek kon gestimuleerd worden om te komen kijken. Het genootschap, dat zich beroemde op zijn ouderdom en op de publicaties, kon nu proberen aan het publiek te tonen dat die reputatie ook door de collecties gedragen werd.

De niet zo vlotte bouwgeschiedenis domineert dit tijdperk dat echter evenzeer andere belangrijke wapenfeiten telt: grotere aandacht voor de oudheden, aandacht voor de inheemse talen, uitbouw van de collectie etnografica en tenslotte een stabilisering van het publicatiebeleid. In zeven jaar verschenen vier delen Verhandelingen, zeven jaargangen van het Tijdschrift en vijf bundels Notulen van vergaderingen, een nieuwigheid. We kunnen met recht zeggen dat het genootschap in 1867 volgroeid was. Het kon in een eigen gebouw aan de bloeiperiode beginnen, waarop nog steeds de reputatie van de organisatie is gefundeerd: de jaren 1868-1950. Omdat de interessante bouwgeschiedenis en de ingebruikneming van de nieuwe 'tempel' tevens het einde van dit tijdperk kenmerken en het begin van een nieuw, komt dat aspect aan het eind van dit hoofdstuk aan de orde. Eerst kijken we naar de organisatie zelf en naar de zojuist genoemde wapenfeiten. 


\section{Een bestuur van ambtenaren}

Aan het begin van de hier beschreven periode werden de bestuurszetels in de Rijswijkstraat verdeeld tussen militairen en ambtenaren. Aan het eind van dezelfde periode, toen die zetels aan het Koningsplein waren neergezet, hadden de ambtenaren het heft in handen. Bij deze verschuiving verdwenen in betrekkelijk korte tijd twee soorten bestuursleden uit beeld, die in het verleden nogal prominent aanwezig waren: de predikanten en de militaire geneeskundigen. De verschuiving valt samen met de grotere bureaucratisering en het toenemen van bestuurstaken door de overheid. De instelling in Batavia van departementen van bestuur kreeg in 1866 haar beslag. Toen werd ook het Departement van Onderwijs, Eeredienst en Nijverheid ingesteld dat zich in het vervolg ook met de zaken van taal-, land en volkenkunde, kunsten en wetenschappen, kortom met het genootschap, zou bezighouden. In plaats van brieven van de eerste gouvernementssecretaris, kreeg het bestuur de overheidspost voortaan van de directeur van dat nieuwe departement.

Op 1 januari 1861 waren tien van de elf bestuursplaatsen bezet. Twee generaals hadden de leiding: voorzitter was de opperbevelhebber van het leger, J. van Swieten, terwijl G. Wassink, hoofd van de Geneeskundige Dienst, vice-voorzitter was. Thesaurier was de hoofd-intendant van de militaire administratie, J.J. van Emmerik. De andere militairen waren de genie-officier Versteeg en de oud-luitenant-ter-zee G.F. de Bruijn Kops, directeur van het Bataviase Prauwenveer. De enige predikant in het bestuur, J. Brumund, was al wel terug van zijn Europees verlof, maar hij zou pas in mei 1861 zijn plaats opnieuw innemen. Meer dan bovengenoemde militairen was hij om zijn kennis van de oudheidkunde en taal- en volkenkunde in het bestuur gekomen, al werd Versteegs naam wel genoemd in verband met het maken van de oudheidkundige kaart. Wassinks aanwezigheid leek er meer een van traditie: zijn voorgangers bij de dienst Fritze, Godefroij en Bosch hadden ook in het bestuur gezeten. Een machtig voorzitter als de legeraanvoerder gaf het genootschap aanzien. Hem kon niet gemakkelijk iets geweigerd worden.

De hoogste ambtenaar-niet militair in 1861 was het lid van de Raad van Indië, jhr. H.C. van der Wijck. De hoofdcommiezen bij de Algemene Secretarie, Netscher en Van der Chijs, de griffier van de beide gerechtshoven, Der Kinderen en tenslotte oud-geografisch-ingenieur G.A. de Lange completeerden de groep ambtenaren. Van dezen had Netscher zich sinds zijn intrede in het bestuur (1855) zeer verdienstelijk gemaakt. Hij zou echter spoedig verhuizen naar zijn nieuwe standplaats in Riouw. Van der Chijs en Der Kinderen, de laatste nog geen jaar in het bestuur, zouden zich voor veel zaken inzetten.

Kijken we naar het bestuur op 1 januari 1868, dan wordt de verschuiving zichtbaar. Vier personen hadden de acht jaar overleefd: naast Der Kinderen 
en Van der Chijs aan het hoofd, waren dat De Lange en De Bruijn Kops. De nieuwelingen waren Levyssohn Norman (1862) en W. Stortenbeker (1862), de eerste hoofdcommies, de laatste commies bij de Algemene Secretarie, verder de commies bij de Faktorij, N.P. van den Berg (1863), het lid van de Raad van Indië, Alexander Loudon (1864) en de conrector van het gymnasium Koning Willem III, L.W.G. de Roo (1865). In 1867 kwamen daar nog bij het lid van de Rekenkamer J.S. van Coevorden en tenslotte het hoofd van het Topografisch Bureau, A.W. Egter van Wissekerke, een oud-militair. Het tableau de la troupe laat duidelijk zien dat de ambtenaren de militairen nagenoeg hadden uitgeschakeld. Alleen De Bruijn Kops en Egter van Wissekerke hadden een militair verleden.

Na het vertrek van Van Swieten in augustus 1862 was Wassink voorzitter geworden. Met diens dood in november 1864 verdween de laatste militair van de voorzitterszetel. Hij werd opgevolgd door Alexander Loudon, tot dat moment gewoon lid, die zelf in 1868 in Batavia zou overlijden. Vice-voorzitter Der Kinderen, procureur-generaal van het Hooggerechtshof, nam toen de voorzittershamer over, die hij negentien jaar zou vasthouden, een record in de genootschapsgeschiedenis.

\section{De relatie met de overheid}

Deze lijst met namen en functies dient niet zo zeer een behoefte aan volledigheid, als wel ter adstructie van de hiervoor genoemde verschuiving. $\mathrm{Na}$ de dood van Brumund kwam er geen nieuwe predikant in het bestuur, er werden geen particulieren voorgedragen. De kunstenaars Van Kinsbergen en Raden Saleh werden geen bestuurslid. Er was geen plaats voor journalisten in het bestuur. De hierboven niet genoemde namen - er waren 24 bestuursleden in de besproken periode, sommigen waren weer snel verdwenen - waren personen die dit beeld niet aantasten. De overmacht van ambtenaren van de Algemene Secretarie met hun collega's, onder aanvoering van twee leden van de Raad van Indië, waarborgde een goed contact met het gouvernement, zonder welke het genootschap niet kon leven. De jaarlijkse subsidie van $f 8.000$ verzekerde het voortbestaan van het genootschap, dat anders failliet was gegaan. De bouw van het museum-genootschapsgebouw op gouvernementskosten, zorgde ervoor dat de afhankelijkheid van het genootschap van het gouvernement nog groter werd. Dat ten tijde van de opening van het museum zeven van de elf bestuursleden ambtenaren van het gouvernement waren, naast twee oud-militairen, een onderwijsman en een faktorij-beambte, geeft duidelijk aan dat de band tussen gouvernement en genootschap weer net zo hecht was als ten tijde van de oprichting (1778). Soms was die ook wel eens nauwer dan men van een formeel zelfstandige organisatie ten opzichte 
van zijn subsidiegever zou verwachten.

Andere factoren versterken nog de indruk van de grote overheidsbetrokkenheid. De ambtenaar voor het Javaans, Cohen Stuart, erelid en conservator voor de oosterse handschriften, was geen bestuurslid maar woonde wel bijna alle bestuursvergaderingen bij. Hij formuleerde voor het genootschap belangrijke adviezen aan het gouvernement, zijn werkgever, onder andere over taalen onderwijsbeleid. Het moet voor het toekijkende publiek steeds minder duidelijk zijn geweest, dat het genootschap zelfstandig was, gedragen door leden, die het bestuursoptreden tijdens de algemene vergaderingen mochten bevragen. Dat gebeurde dan ook nauwelijks. De algemene vergaderingen werden niet door een grote groep leden bezocht en het bestuur had een aantal taken van weleer, zoals het benoemen van nieuwe leden, aan zich getrokken. Deze bijeenkomsten hadden dan ook meer het karakter van verslaggeving dan van verantwoording afleggen. Na 1866 duurde het vijf jaar voor er weer een algemene vergadering werd belegd. Van het betrekken van de leden bij een openingsceremonie van het nieuwe gebouw in 1867, blijkt niets. Dit bevestigt het beeld van een semi-overheidsinstelling die een aantal taken uitvoert, waarvoor in de bestuursstructuur van het gouvernement in Batavia anders geen orgaan zou zijn. Het beheer over een museum en het verzorgen van publicaties op het gebied van de taal-, land- en volkenkunde behoorden daartoe. Het kon tevens contacten onderhouden met organisaties in de regio en in Europa, waarvoor anders het secretariaat van het gouvernement en later het Departement van Onderwijs ambtenaren had moeten aanstellen. Als het genootschap de hoofden van gewestelijk bestuur aanschreef met het verzoek om opgaven te sturen voor de oudheidkundige kaart, om gegevens over etnografica, om een woordenlijst ingevuld terug te krijgen, voor hoeveel van de betrokkenen was het dan niets anders dan de verlengde arm van het gouvernement of de arm van het gouvernement zelf?

\section{Het bestuur en de leden}

Het bestuur besloot over het lidmaatschap van nieuwe leden, terwijl het zelf ook besloot over de voordrachten voor het opvullen van open plaatsen in de eigen gelederen. De leden, die nog steeds veertig gulden lidmaatschapsgeld per jaar betaalden, speelden een marginale rol. Soms leek het wel dat hun belangrijkste functie was om die bijdrage te voldoen en de publicaties in ontvangst te nemen. Hoeveel van de leden lazen de Verhandelingen, het Tijdschrift, de Notulen? Was voor het merendeel van hen het lidmaatschap niet eenvoudig iets dat erbij hoorde, waar men als ambtenaar niet goed onderuit kon? Een vrijbuiter als Van der Tuuk hoefde zich van zo iets niets aan te trekken. Hij werd geen lid toen hij in Indië was, al werd hij in 1866 wel verkozen 
tot corresponderend lid, toen hij tussen zijn bezoeken aan Sumatra en Bali in een aantal jaren in Amsterdam verbleef. Het aantal leden dat een actieve rol speelde buiten het bestuur, was zeer beperkt. In de laatste jaren waren het Holle, Riedel, Netscher (oud-bestuurslid), Cohen Stuart en Raden Saleh.

In 1861 had het genootschap 358 leden. In 1853 waren dat er 341 geweest. Van die leden betaalden in 1861 alleen de 184 gewone leden binnen NederlandsIndië de contributie. De 25 honoraire leden, de 109 corresponderende leden en de 34 gewone leden buiten Nederlands-Indië (verlofgangers) betaalden die niet. De zes buitengewone leden betaalden evenmin contributie (TBG 12:160). De kernleden waren de gewone leden in Nederlands-Indië, 193 bij de aanvang van 1868. Dat wees op een vrij stabiel ledental. Weliswaar waren er ieder jaar vrij veel afzeggingen, er kwamen ook steeds genoeg nieuwe leden bij. In 1866 meldde het bestuur aan de algemene vergadering dat het 20 leden had verloren en dat er 35 nieuwe leden bij waren gekomen (Notulen 4:139). Dat verlies werd verklaard door overlijden of vertrek naar patria.

De leden, het bestuur, het waren ook in de periode 1861-1867 in grote meerderheid Nederlandse mannen, die als ambtenaar of militair in Batavia of de buitengewesten werkzaam waren. Een lijstje van de nieuwe Indonesische leden in deze jaren is snel gegeven:

1863 Radhen Adhipatie Tjokro Negoro, oud-regent van Poerworedjo (b.l.) Hadjie Mahamad Moesa, hoofdpanghoeloe van Limbangan (b.l.)

1864 Radhen Toemenggong Danoe Koesoemoe, regent van Malang (g.1.) ${ }^{1}$ Radhen Adhipatie Soerio Koesoemoe Adi Noto, te Soemedang (g.l.)

1865 Raden Saleh, kunstschilder te Batavia (g.l.)

Radhen Adipati Aria Koesoema Diningrat, regent van Galoe (g.l.)

1866 Toemenggong Wira Adek Daha, regent van Soekapura (g.1.) Raden Saleh (e.l.) ${ }^{2}$

(b.l. buitengewoon lid g.l. gewoon lid e.l. erelid)

In de notulen van 1861-1867 komen alleen en passant twee andere Indonesische leden ter sprake: het buitengewoon lid R.A. Ario Donoe Diningrat uit Magelang en het erelid Pangeran Adipati Mangkoe Negoro uit Soerakarta. Van zes Indonesische leden in 1861 was dat aantal in 1867 opgelopen tot twaalf op een totaal van 305 leden. De Indonesische leden waren tegenover Nederlandse ambtenaren in het genootschap in een overduidelijke minder-

1 Zijn lidmaatschap was van korte duur. Hij zegde op 27-12-1866 weer op. Notulen 4:276.

$2 \quad$ Notulen 1:131, 2:99, 101, 3:127, 4:135, 216. 
heidspositie. In de periferie waren zij nog minder bij de zaken betrokken dan de Bataviase leden dat waren. Hun stem werd nauwelijks gehoord. Raden Saleh was door zijn drieëntwintig jaren durend verblijf in Nederland en zijn bevoorrechte behandeling aldaar in een bijzondere positie op het moment van terugkomst (Spaanjaard 1998:15-21). Vandaar dat naar hem geluisterd werd. De inschakeling van Ida Ketoet Anom uit Boeleleng, door Van Kinsbergen 'meegebragt' uit Bali (1866) in een gezelschap van nog vier andere Balinezen, was een poging om 'Balische geleerdheid' in te schakelen bij het verklaren van de inhoud van de handschriften van dat eiland. Het is een van de weinige voorbeelden van actieve betrokkenheid van inheemsen bij de zaken van het genootschap. Van Ketoet Anoms kennis van het Kawi profiteerde het genootschap maar met mate. De zending liep op een teleurstelling uit voor wat het Kawi betreft, al werd van hem wel gebruik gemaakt voor het catalogiseren van de handschriften en van de Balinese etnologische voorwerpen. De vijf Balinezen bij Van Kinsbergen in huis zullen een schilderachtig tafereel hebben opgeleverd (Notulen 4:103, 149-50). Van Kinsbergen maakte er een prachtig portret van. Het genootschap stond in dit geval open voor de deskundigheid van Indonesiërs.

De grootste uitdaging voor het bestuur en het genootschap als geheel was om verder te professionaliseren, het beheer van het museum te verbeteren en de collecties beter open te leggen. Dat zou ook in het overblijvende deel van de negentiende eeuw vooral door Nederlanders worden aangepakt.

\section{Een nieuw reglement}

Op 16 november 1861 keurde de algemene vergadering van het genootschap een nieuw reglement goed, dat op 1 januari 1862 van kracht werd. Het verving de oude wetten van 1823, die onbruikbaar waren geworden. Eerdere pogingen om nieuwe wetten vast te stellen, waren vooral uitgegaan van oudsecretaris Bleeker. Zijn ideeën over een koloniale academie van wetenschappen vonden geen weerklank in het genootschapsbestuur. Zijn voorstellen om het ledental drastisch te beperken en de contributie aanzienlijk te verhogen leden schipbreuk op de reacties van de leden zelf. Daarna was de zaak blijven rusten, al bleef het duidelijk dat het genootschap niet langer kon steunen op het reglement dat door Van der Vinne onder het beschermheerschap van Van der Capellen was vastgesteld.

Het meest opvallende aan het nieuwe reglement is de terugkeer in de tekst van de rol van het gouvernement en daarmee de erkenning dat de overheid een belangrijke plaats innam. In 1823 was die rol helemaal uit de tekst verdwenen, wat ten opzichte van de eerdere formuleringen in wetten en grondwetten een grote verandering was geweest. Het reglement van 1861 
noemde zelfs in de aanhef meteen het gouvernement. 'Onder de bescherming der regering van Nederlandsch-Indië stelt het genootschap zich ten doel bevordering van kennis en wetenschap'. De naam van het genootschap en de zinspreuk, 'Tot nut van 't Algemeen', bleven gehandhaafd, maar in het eerste artikel werden de kunsten niet genoemd. Door nadrukkelijk kennis en wetenschap te omschrijven als het werkterrein van het genootschap werd bevestigd dat de kunsten vooral in de langzamerhand verouderde betekenis van 'kennis en kunde' dienden te worden opgevat. Een genootschap dat zich richtte op schone kunsten had nooit in de bedoeling gelegen. Het bestuur van 1861 legde daarmee het sinds lang gevoerde beleid in het reglement vast.

Nog drie andere punten waren anders dan in 1823. De 'voortplanting en uitbreiding van beschaving en verlichting in de Nederlandsch-Oost-Indische bezittingen' werd geschrapt. De tekst van 1861 was veel kaler en zakelijker en voor de beschavende arbeid hoefde geen plaats te worden ingeruimd. Door kennis en wetenschap te bevorderen werkte men al 'beschavend en verlichtend'. Uit het werkterrein van het genootschap viel nu ook de natuurlijke historie zo goed als weg, een wetenschapsterrein dat immers al jaren eerder door de Natuurkundige Vereeniging was overgenomen. Alleen de mineralogische verzameling bestond nog. Verder werd niet meer gesproken over het bevorderen van de landbouw, de economie en de nijverheid. Ook die terreinen hadden in de Nederlandsch-Indische Maatschappij van Nijverheid hun eigen organisatievorm gevonden. Het genootschap wilde een moderne organisatie met wetenschappelijke doelstellingen zijn en schudde een stuk van het verleden definitief van zich af. Het werkterrein werd in vier punten omschreven, zaken die in hoofdzaak gebleven waren:

a. de geschiedenis, talen, oudheden, zeden, gewoonten en instellingen der Indische en andere Oostersche volkeren;

b. de aardrijkskundige gesteldheid van den Indischen Archipel;

c. de geschiedenis der Nederlanders in Indië; en

d. de statistiek van Nederlandsch-Indië, in verband met de staathuishoudkunde (TBG 12:193).

De volken, talen, zeden, oudheden en geschiedenis van de Indische gewesten hadden al in 1778 de belangstelling van het genootschap gehad. In dat opzicht is het begrijpelijk dat het bestuur in 1861 de band met de oprichters wilde bewaren door de naam van het genootschap ongewijzigd te laten. Er was geen sprake van een radicale breuk met het verleden. Het vereenvoudigde reglement, dat in zeventien artikelen kon vastleggen waar in 1823 nog vijfenveertig artikelen voor nodig waren, vroeg wel om nadere bepalingen van een aantal huishoudelijke zaken. Daarom kreeg het bestuur mandaat om een reglement van orde vast te stellen, wat al op 4 januari 1862 gebeurde (TBG 12:199-206).

Wat de werkzaamheden betreft werd het uitbrengen van verslagen over het werkterrein van het genootschap, op verzoek van de regering of anderen, 
voorop gesteld. Daarna volgde het uitgeven van een of meer tijdschriften en bundels met verhandelingen. Prijsvragen uitschrijven werd als mogelijkheid nog steeds vermeld. Verder zou het genootschap 'zooveel mogelijk zijne verzameling van natuur- en kunstvoortbrengselen uitbreiden, vooral in verband met de onderwerpen, aan welke het zijn bijzondere zorg wijdt' (TBG 12:194). Die onderwerpen, punt a tot en met $d$, waren al in het eerste artikel opgesomd. Tenslotte wilde het genootschap met zusterinstellingen die elders gevestigd waren, tot uitwisseling van uitgaven blijven komen.

De categorieën leden bleven onveranderd: gewone, buitengewone, corresponderende en ereleden. Belangstelling in kunsten en wetenschappen vormde de enige voorwaarde voor het lidmaatschap. 'Braafheid, verdiensten en kundigheden', die in 1823 nog voorop hadden gestaan voor aspirant-leden, verdwenen. Het lidmaatschapsgeld bleef onveranderd veertig gulden per jaar bedragen, alleen te betalen door de gewone leden in Nederland-Indië. Het bestuur van elf leden telde een voorzitter, ondervoorzitter, secretaris, bibliothecaris, penningmeester, een of meer directeuren van de verzamelingen en een directeur van de gebouwen. Het secretariaat, het bibliothecarisambt en het penningmeesterschap waren bezoldigd, elk met honderd gulden per maand. Het bestuur was oppermachtig. Het besliste over de benoeming van nieuwe leden, waartoe eertijds de algemene ledenvergadering gemachtigd was. Die vergaderingen beperkten zich nu tot het doen van mededelingen en voorstellen (maar niet over nieuwe leden), het bespreken van wetenschappelijke onderwerpen, het houden van lezingen en het uitreiken van beloningen voor bekroonde prijsvragen (TBG 12:196-7). Dat laatste kwam echter in de praktijk niet meer voor. De laatste prijsvraag was in 1852 uitgeschreven. De gewone leden waren, als zij naar de algemene vergaderingen zouden komen, eigenlijk tot luisteraars geworden. Het is veelzeggend dat op de algemene vergadering van 16 november 1861, waar dit alles werd besloten, slechts vier gewone leden aanwezig waren, terwijl de tien zittende bestuursleden er wel allen waren. Het zittende bestuur had zichzelf in een nog prominenter positie geplaatst dan voorgaande besturen al hadden gedaan. In het reglement was dat bovendien vastgelegd.

In het nieuwe reglement werd over een beschermheer niet gesproken, maar op de algemene vergadering van 16 november werd besloten om de nieuwe gouverneur-generaal, L.A.J.W baron Sloet van de Beele, het beschermheerschap aan te bieden, zoals ook met zijn voorgangers was gebeurd. Daarbij werd in de overwegingen gememoreerd dat de gouverneur-generaal en de leden van de Raad van Indië eertijds de directie van het genootschap uitmaakten, maar dat 'ten gevolge van veranderde omstandigheden, de directie niet meer in handen was van de regering'. ${ }^{3}$ Sloet van de Beele zou in december al instemmen. 
De man die zich over het nieuwe reglement had gebogen, was de jurist Timon Henricus der Kinderen. Hij was in 1823 in Den Haag geboren en was in 1847 in Leiden in de rechten gepromoveerd. Na een korte periode als advocaat in Den Haag werkzaam te zijn geweest, vertrok hij naar Batavia, waar hij in september 1849 als eerste commies bij het parket van de procureurgeneraal kwam te werken. Na een korte tijd in Soerabaija als griffier bij de Raad van Justitie te heben gewerkt, werd hij in 1854 benoemd tot griffier en in 1861 tot raadsheer bij het Hooggerechtshof in Batavia. Zijn carrière zou hij vervolgen als procureur-generaal (1866), directeur van het nieuw opgerichte Departement van Justitie (1869), president van het Hooggerechtshof (1871) om te eindigen als lid van de Raad van Indië (1872-1887). In dat laatste jaar vroeg hij om gezondheidsredenen verlof aan. Der Kinderen was een hardwerkend en bekwaam jurist, die aan de wieg stond van veel wetgevende maatregelen. In 1863 was hij benoemd tot regeringscommissaris tot het ontwerpen van een regeling van het rechtswezen in de buitenbezittingen. Daaraan werkte hij vele jaren naast zijn zojuist opgesomde functies. Als gevolg daarvan kwam tussen 1875 (West-Sumatra) en 1892 (Billiton) een hele serie, aan de verschillende eilanden en streken aangepaste regelingen tot stand (L.W.C. van den Berg 1899).

Der Kinderen was spoedig na zijn overkomst lid geworden van het genootschap (1850), maar in het bestuur werd pas een plaats voor hem gevonden in juli 1860, toen Bleeker aftrad als secretaris. Netscher nam toen het secretariaat over en Der Kinderen werd gewoon bestuurslid. Zijn eerste taak in het bestuur kreeg hij in februari 1861, toen hem werd verzocht een nieuwe 'wet' voor het genootschap te ontwerpen. ${ }^{4}$ Dat deed hij snel en vaardig, zodat nog met ingang van 1862 het nieuwe reglement in werking kon treden. Het voldeed de hele lange bestuursperiode van Der Kinderen en hoefde pas in 1888 vervangen te worden. Na Netschers vertrek naar Riouw nam Der Kinderen in mei 1861 het secretariaat over, terwijl hij ook voorlopig de redactie van de Verhandelingen en het directeurschap van het museum op zich nam. In 1864 werd Der Kinderen tot vice-voorzitter gekozen, toen Van der Wijck naar Nederland vertrok. Na de dood van Alexander Loudon werd hij voorzitter, van december 1868 tot juli 1887, bijna negentien jaar. Hij was door zijn lange ambtsperiode in Batavia, zijn langdurig lidmaatschap van de Raad van Indië en zijn juridische vakkennis een autoriteit in de hoofdplaats en daarbij paste het voorzitterschap van het genootschap. Met zevenentwintig jaar in het bestuur domineert zijn persoonlijkheid een kwart eeuw genootschapsgeschiedenis. Het honderdjarig bestaan (1878) viel midden in de periode van zijn voorzitterschap en werd dan ook door hem geregisseerd. 
Der Kinderen kwam niet terug naar Indië. In Nederland zette hij zich onder meer in voor de armenzorg. Ook was hij bijna negen jaar voorzitter van het KITLV en bestuurslid van het Indisch Genootschap. In 1898 overleed hij, het einde van een welbesteed leven (L.W.C. van den Berg 1899:206-7).

\section{Beheer en behoud van oudheden op Java}

De aandacht voor de oudheidkundige resten op Java had al onder gouverneur-generaal Van der Capellen geleid tot het instellen van een oudheidkundige commissie (1822), die overigens tot niets kwam. In de jaren 1830 werd door de directeur van het Rijksmuseum van Oudheden in Leiden, de hoogleraar archeologie Caspar Reuvens (1793-1835), gewezen op de noodzaak van maatregelen en daarna door zijn opvolger bij het museum, Conrad Leemans (1809-1893), opnieuw. Weliswaar had het gouvernement vanaf 1840 meer structurele maatregelen genomen, die neerkwamen op een uitvoerverbod van oudheidkundige voorwerpen, maar de naleving daarvan liet zeer veel te wensen over. De belangstelling werd binnen het genootschap vooral gedragen door eenlingen, zoals Van Hoëvell, die op zijn reizen tempelresten bezocht en ervoor zorgde dat verspreide stenen en beelden naar Batavia werden vervoerd. In de periode van de bouw van het museum ontwikkelde de overheid steeds duidelijker een door maatregelen onderbouwd en met subsidies gedoteerd beleid voor het beheer en behoud van de oudheidkundige resten. Terwijl het nog tot 1901 duurde eer er een apart overheidsorgaan zou komen dat deze zorg op zich nam, de nieuwe Oudheidkundige Commissie, werd het genootschap meer en meer de voorloper van deze instelling. Het gaf gevraagd en ongevraagd advies aan het gouvernement in Batavia en nam initiatieven die van visie en ambities getuigden. Met de oudheidkundige missie van Brumund en het werk voor een oudheidkundige kaart, de samenstelling van een collectie inscripties en de opdracht voor het documenteren van de oudheden aan de fotograaf Van Kinsbergen kreeg de zorg voor oudheden op Java naast de zorg voor de eigen oudheidkundige afdeling in het museum een duidelijker gezicht. Zo vonden het genootschap en de overheid ieder hun plaats op dit verwaarloosde terrein.

$\mathrm{Nu}$ was vóór 1860 ook wel iets gedaan, maar het had allemaal veel tijd gekost. Een brief van de minister van koloniën van 25 november 1853 over het onderwerp had in april 1854 geleid tot het verzoek van het gouvernement aan het genootschap om daar 'haar gevoelen' over uit te brengen. Daarna had dat verzoek precies drie jaar onbeantwoord gelegen. ${ }^{5}$ Toen het in 1857 eindelijk tot 
iets kwam, ging het advies van het genootschap de regering te ver. Het stelde namelijk voor te bepalen, dat alle oudheidkundige voorwerpen die zich op publiek terrein bevonden, voortaan als openbaar eigendom zouden worden beschouwd en dat vernieling, beschadiging of wegvoering ervan strafbaar zou worden. Verder zouden oudheidkundige voorwerpen in particulier bezit niet zonder meer van Java mogen worden meegenomen. Eerst zou daarvoor toestemming van de gouverneur-generaal moeten worden verkregen. Uitvoer naar Nederland zou wel gemakkelijker worden, maar dan wilde het genootschap vooraf in de gelegenheid zijn gesteld om met de eigenaars te overleggen over overname (TBG 12:184-6). Het is jammer voor het genootschap, dat deze verregaande voorstellen niet door het gouvernement werden overgenomen. Er had toen al een duidelijke rol voor de initiatiefnemers kunnen zijn weggelegd: een oudheidkundige inspectiedienst. Wel profiteerde het genootschap sinds 1855 van een maatregel, waardoor het gouvernement beschikte over opgegraven munten en andere waardevolle voorwerpen. Daardoor groeide de collectie van munten en kleinere voorwerpen van edelmetalen, die tegen betaling van de overheid werden overgenomen. In 1861 vroeg het genootschap in aanvulling hierop aan de hoofden van het gewestelijk bestuur dat ook vondsten van 'voorwerpen in steen en onedele metalen' aan het genootschap zouden worden gemeld. Het had de indruk gekregen dat de regeringsmaatregel van 1855 te strikt werd uitgelegd (TBG 12:186-7).

Het voorzitterschap van F.V.A. ridder De Stuers, die in 1857 de hamer overnam van het weinig toeschietelijke lid van de Raad van Indië Visscher, werkte voor de oudheden gunstig. Juist onder Visscher was het verzoek om advies over de Javaanse oudheden drie jaar blijven liggen. De Stuers, zelf geïnteresseerd in het beheer van cultuurgoed, in het bijzonder in het behoud van de oudheden op Java, had op een reis over het eiland (1857) kunnen zien dat er veel moest worden gedaan. Her en der waren hem door bestuursambtenaren beloften gedaan dat er beter op de zaken zou worden gepast (TBG 12:186-7). Tenslotte had het genootschap in 1858 een oproep geplaatst om opgaven te ontvangen van overblijfselen 'uit Java's voortijd', te onderscheiden in 'ruïnen van groote en kleine tempels, ruïnen van andere gebouwen, beschreven steenen, zorgvuldig bewerkte steenen beelden en ruw bewerkte steenen beelden'. Een soortgelijke oproep aan de hoofden van gewestelijk bestuur ten behoeve van een samen te stellen oudheidkundige kaart van Java, ging eind 1860 uit (TBG 12:187-8).

Een hele reeks gebeurtenissen op het terrein van het oudheidkundig onderzoek kwam voort uit beslissingen die werden uitgelokt door een nota van de al genoemde directeur van het Rijksmuseum van Oudheden in Leiden, Leemans, en een tweede van de conservator bij hetzelfde museum, L.J.F. Janssen. Janssen had op 1 augustus 1861 in Leiden de laatste hand gelegd aan een nota getiteld 'Iets over de bevordering van de kennis der Oudheden, en 
in het algemeen van den vroegeren beschavingstoestand onzer Oost-Indische bezittingen'. Bij het samenstellen van zijn nota had hij gebruik gemaakt van gegevens, die hij van de net in patria teruggekeerde genootschapssecretaris Bleeker had ontvangen. Bleeker had Janssen onder meer onderhouden over de noodzaak om te komen tot een Indisch museum voor de verschillende organisaties in Batavia. ${ }^{6}$ Op 6 augustus 1861 had Leemans vanuit zijn zomerverblijf te Zaltbommel een tweede nota aan die van zijn conservator toegevoegd, bedoeld voor de nieuw benoemde gouverneur-generaal Sloet van de Beele, die later die maand naar Batavia zou vertrekken. Deed Janssen verslag van zijn gespek met Bleeker, Leemans had uitgebreid met Friederich gesproken, ook al met oog op de speciale opdracht die deze bij terugkeer naar Indië zou krijgen. Janssen en Leemans drongen aan op drie maatregelen:

1 het samenstellen van een oudheidkundige statistiek, in de zin van een beredeneerd overzicht gebaseerd op een nauwkeurige opname,

2 het actief verzamelen in Indië ten behoeve van het Museum van Oudheden in Leiden van zowel archeologische als etnologische voorwerpen, en

3 het maken van tekeningen van monumenten en het afdrukken van inscripties.

Leemans had geen hoge pet op van musea onder de tropenhemel: 'Van Museums op Java stel ik mij niet veel, op zijn meest slechts eene tijdelijke werking, voor. [...] Een goed Museum van Natuurlijke Historie schijnt daar, in dat klimaat, en de onveranderlijke omstandigheden, onmogelijk te zijn'. Oudheden waren minder problematisch, maar waren in Batavia slechts in beperkte kring van nut, aldus de Leidse directeur. Verder werkte de voortdurende wisseling van personeel 'zeer nadeelig op de onafgebroken, naauwkeurige zorg voor een Museum'. Daar voegde Leemans het voorbeeld bij van een in het museum van het genootschap zoekgeraakte, bronzen beker met Kawi-inscriptie.

De nota's werden op 8 januari 1862 door het gouvernement aan het genootschap aangeboden met het verzoek om advies. ${ }^{7}$ Uiteraard stonden in deze nota's de belangen van het onderzoek in Nederland en van de collecties in Leiden voorop. Leemans had in zijn nota hoog opgegeven van het vertrouwen dat hij stelde in Sloet van de Beele, de 'zoo verlichten, kundigen, scherpzinnigen man'. Even vanzelfsprekend is het dat het genootschap in zijn advies de belangen van het onderzoek op Java en van de collecties in Batavia voorop zou plaatsen. $\mathrm{Nu}$ ging het erom dat te doen op een overtuigende manier, opdat de belangen van Batavia niet ondergeschikt zouden worden gemaakt aan die van Leiden.

6 De nota's van Janssen en Leemans zijn te vinden in het ANRI Archief Algemene Secretarie bij het gouvernementsbesluit 24-5-1862 no 2.

7 TBG 12:514, vergadering 5-4-1862. 
Tussen januari en april 1862 werd binnen het bestuur uitgebreid overlegd over het advies, dat op 22 april aan Sloet van de Beele kon uitgaan. Het bestuur wees de bestaande, oudere gegevens, die zouden moeten dienen voor een oudheidkundig-statistisch overzicht, als onbruikbaar van de hand. Die gegevens waren grotendeels binnengekomen na een oproep van het gouvernement aan de plaatselijke autoriteiten in 1840. Ook de gegevens waarover het genootschap zelf beschikte naar aanleiding van een soortgelijke oproep uit 1860 waren onvoldoende. Het noemde de sinds 1840 bereikte resultaten ronduit 'zeer onbeduidend' (TBG 12:518). Dit stond in schril contrast tot de uitmuntende opgave, waarover Leemans zei te beschikken. Als enig mogelijke oplossing om te komen tot goede gegevens voor een oudheidkundig overzicht, zag het genootschap, dat aan een onderlegd oudheidkundige de opdracht zou worden gegeven om alles persoonlijk te gaan zien, beschrijven, uitleggen en toelichten. En dat zou niet moeten resulteren in 'eene dorre statistiek, maar eene in alle bijzonderheden afdalende beschrijving'. Na het formuleren van deze 'terms of reference' kon het bestuur met een bijbehorende persoon voor de dag komen: de predikant J.F.G. Brumund. Hij was de juiste man voor zo'n opdracht. Hij zou ontslag moeten krijgen als predikant en het laatste jaar voor zijn pensionering kunnen gebruiken voor een lange reis langs Java's monumenten en opgravingen. Het kader van Brumunds opdracht werd al in het advies aan het gouvernement opgenomen.

Een tweede aspect, het maken van afbeeldingen van monumenten en kopieën van inscripties, zou het beste via het nieuwe middel van de fotografie kunnen gebeuren. De voorstellen van Leemans en Janssen: afgaan op de tekeningen van Wilsen en kurkmodellen van de tempels laten maken door iemand uit Zutphen, werden van de hand gewezen. Leemans zag niets in de fotografie en was in dit opzicht behoudend, al was eigenbelang daaraan niet vreemd. Zijn Boroboedoer-studie met lithografieën moest nog verschijnen. Hij beschouwde het hele fotografie-project als weggegooid geld. Het genootschap stelde echter voor dat er in Europa een drietal 'uitstekende, wetenschappelijke photographisten (TBG 12:524)' zou worden opgeleid. Deze moderne methode van documenteren was veruit de beste. $\mathrm{Zij}$ zouden dan op aanwijzing van Brumund foto's moeten maken.

De derde aanbeveling van Leemans en Janssen, het verzamelen van archeologische en etnologische voorwerpen vooral voor het museum in Leiden, was door de Leidenaren aangekleed met een tweetal, al gesignaleerde argumenten: de verzameling in Batavia was voor een te beperkte kring voor wetenschappelijk onderzoek toegankelijk en de voortdurende wisseling in het bestuur werkte nadelig op de zorg voor het museum. Daardoor zouden voorwerpen wegraken (TBG 12:527). Het bestuur in Batavia stelde zich listig op door de argumenten te ondergraven, maar eerst toonde het zijn goede wil. Het had inderdaad als gevolg van de regeringsmaatregel van 1855 nogal 
wat opgegraven voorwerpen kunnen aankopen. Het had echter lang niet alles overgenomen. De niet overgenomen voorwerpen hadden door Leiden kunnen worden aangekocht. Het genootschap had wel bij die aankoop willen bemiddelen. Verder wilde het meewerken aan de vervaardiging van afgietsels van inscripties uit het museum in Batavia ten behoeve van Leiden. Ook zou het bestuur de leden van het genootschap kunnen vragen of zij instemden met het afstaan van doubletten aan de Leidse broeders. 'Maar op den voorgrond staat en moet blijven staan het museum van het genootschap' (TBG 12:526-7).

De aanbeveling van Leemans werd vervolgens door het bestuur uitgekleed: het bestuur kon moeilijk van eenzijdigheid bij het verzamelen worden beschuldigd. Eén enkel bezoek aan het museum zou volstaan om dat te zien. Bovendien was de voortdurende wisseling van bestuursleden juist een garantie dat niet één specialisme de overhand zou krijgen, dat niet 'eene afkeurenswaardige, éénzijdige rigting, lang dure'. Voorwaar een vondst, het nadeel volgens Leemans werd in een voordeel omgekeerd (TBG 12:527). Tenslotte werd de aantijging van de vermiste Kawi-beker met een persoonlijk argument gepareerd door de aangesproken persoon, de gouverneur-generaal, tot getuige te roepen.

En wat de zorg voor de verzameling betreft, die is zoo goed als hare ellendige, bekrompene woning slechts toelaat en de heer Leemans zou ongetwijfeld leed gevoelen over zijne aantijging van het verdwijnen van de zoogenoemden kawibeker, wanneer hij eens in de gelegenheid ware de verzameling te bezoeken en hem dan, onder een schat van merkwaardige oudheidkundige voorwerpen, mede die zoo zeldzame beker werd aangewezen, gelijk hij ook aan Uwe Excellentie, toen $\mathrm{Zij}$ het museum met een bezoek vereerde, werd vertoond (TBG 12:527-8).

Leemans en Janssen kregen en passant nog ingewreven dat geen enkele wetenschapper Batavia verliet zonder het museum van het genootschap te bezoeken. De gouverneur-generaal werd herinnerd aan de problematiek van de behuizing, maar vast stond dat het genootschap trots mocht zijn op zijn verzameling. Heel Nederlands-Indië had er recht op dat het museum de bewaarplaats zou blijven van Indië's oudheden: 'zij moet de hulpbron zijn en blijven van menigen jeugdigen Indischen geleerde' en 'een der eerste sieraden van Batavia' (TBG 12:528).

De argumentatie en de aanbevelingen van Leemans en Janssen waren - naar het gevoel van het bestuur - misschien op overtuigende wijze ondergraven, erg sterk komen de tegenargumenten niet over. Wie moest men zich voorstellen bij 'menigen jeugdigen Indischen geleerde'? Het gymnasium Koning Willem III had nog maar net zijn poorten geopend. En de omkering van Leemans' argument - veel afwisseling in het bestuur behoedde voor eenzijdigheid - was ook niet sterk. Toch is in de lange brief aan de gouverneur- 
generaal het nodige retorische vernuft gemengd met wat minzaamheid. Waarschijnlijk had secretaris Der Kinderen de hand in de formulering van het advies. Het museum in Leiden had nu de tweede keuze bij beschikbaar gekomen, opgegraven voorwerpen. Het kon doubletten en afgietsels van inscripties krijgen en etnologische voorwerpen konden voor Leiden verzameld worden 'zonder benadeeling van de belangen des genootschaps reeds zoo schoone, ethnographische verzameling' (TBG 12:529-30).

Het lange beleidsstuk reikte het gouvernement in antwoord op de drie gevraagde maatregelen van Leemans en Janssen een serie concrete adviezen aan. De belangrijkste waren de volgende.

1 Brumund zou de opdracht moeten krijgen om een beschrijving te maken van de hindoe-oudheden op Java. Hij zou het genootschap opgaven moeten doen voor het samenstellen van een oudheidkundige kaart, moeten aangeven welke beelden en gedenkstenen naar Batavia konden worden overgebracht en welke oudheden en inscripties moesten worden afgebeeld. De predikant zou daarvoor ontslag moeten nemen en met behoud van alle faciliteiten op reis kunnen gaan, tijdens welke reis hij alle hulp van de plaatselijke autoriteiten zou moeten krijgen.

2 Drie fotografen zouden onder toezicht van het genootschap op Brumunds aanwijzingen afbeeldingen moeten maken. Zowel Brumunds beschrijving als de foto's zouden ter beschikking komen van het genootschap.

3 Door Brumund aangewezen voorwerpen zouden door de hoofden van gewestelijk bestuur naar Batavia worden gestuurd, aan het adres van het genootschap. Die hoofden zouden ook opgeroepen moeten worden om etnologische voorwerpen te verzamelen. Het genootschap zou dan aan de regering opgeven welke van de voorwerpen het wenste te behouden en welke naar Leiden konden worden doorgestuurd.

4 Het genootschap tekende aan bereid te zijn aankopen te doen voor Leiden, afgietsels te maken en doubletten af te staan.

Sloet van de Beele noteerde op het origineel van de brief van het genootschap van 22 april 1862: 'Een goed rapport en voorstel dat ik reeds aan zoude nemen zoo het regelen der financien mij duidelijk was. Daarover wensch ik met spoed den Directeur te hooren, terwijl de alg. Secretarie mij het noodige licht kunne geven. ${ }^{8}$ Het gouvernement had daarna niet veel tijd nodig om de zaak af te handelen. Op 5 mei 1862 ging al een brief aan Brumund uit om diens ontslagaanvrage als predikant uit te lokken, op 24 mei van hetzelfde jaar gevolgd door een gouvernementsbesluit, dat de aanbevelingen van het genootschap grotendeels volgde. Alleen het uitbreiden van de opdracht

8 In het handschrift van de gouverneur-generaal op de brief van 22-4-1862. ANRI Archief Algemene Secretarie bij gouvernementsbesluit 24-5-1862 no 2. 
aan Brumund met een taak voor drie fotografen werd in beraad gehouden. Daarover werd eerst advies gevraagd aan de adviseur voor technische zaken van het ministerie van koloniën, T.J. Stieltjes, die in Indië verbleef voor spoorwegaangelegenheden en die over de fotograaf Elias beschikte. ${ }^{9}$

De positie van het genootschap was versterkt. Het museum in Leiden moest voorlopig afwachten met welke voorstellen het genootschap zou komen voor het doorzenden van oudheidkundige en etnologische voorwerpen. Niet alleen was Brumund een jaar lang voor de opdracht beschikbaar, het genootschap zou zowel over zijn beschrijving als over de statistische gegevens voor de oudheidkundige kaart komen te beschikken. Verder mocht verwacht worden dat er nogal wat voorwerpen naar Batavia zouden verhuizen. Anders dan de reizen van Van Hoëvell in de jaren 1840, die kerkelijke reizen waren, die hij voor een deel gebruikte voor het uitleven van zijn oudheidkundige belangstelling, was zijn ambtgenoot Brumund nu geheel voor het oudheidkundig onderzoek vrijgemaakt. Na Friederich had het genootschap zo voor het eerst weer iemand die zich voltijds aan onderzoek kon wijden. Op voorstel van de directeur van financiën kreeg hij daarvoor zijn tractement van $f$ 500, plus een verhoging van $f 450$ en een toelage voor het huishouden van $f$ 160. Tezamen $f 1.110$ per maand. ${ }^{10}$

Jan Frederik Gerrit Brumund was in 1814 in Amsterdam geboren. Hij studeerde theologie in Utrecht en werd in 1840 tot predikant voor Nederlands-Indië aangesteld. Zijn eerste standplaats was Soerakarta (1841), zijn laatste standplaats vóór zijn terugkeer naar Batavia in 1854, was Ambon (Nieuwenhuis 1978:130-2). Hij was naast predikant ook schrijver. Een reisimpressie van Bantam verscheen al in 1840 in het Tijdschrift voor Neêrland's Indië, gevolgd door stukken over de Aroe-eilanden en het Aroes. Hij had voor hij naar Soerakarta ging zeker Van Hoëvell in Batavia ontmoet, met wie hij zijn belangstelling voor land, volk en oudheden deelde. In twee bundels Indiana over de archeologische resten op Java (1853-54) had de predikant zich laten kennen als een goed oudheidkundige. Krom is in zijn Inleiding tot de HindoeJavaansche Kunst (1923) zeer positief over Brumund als oudheidkundige (Krom 1923, I:14-7). Brumund was, mede op grond van zijn publicaties na zijn terugkomst te Batavia op 24 april 1855 tot bestuurslid benoemd, in dezelfde vergadering als Netscher, Friederich en De Stuers. ${ }^{11}$ In februari 1857 verzocht hij ontslag als bestuurslid, in verband met een reis over Java, wegens een

9 Gouvernementsbesluit 24-5-1862 no 2 in TBG 12 (1862):552-7. Origineel in Archief Algemene Secretarie.

10 Het voorstel van de directeur van financiën 14-5-1862 zit bij het bedoelde gouvernementsbesluit.

11 ANRI KBG Dir 0209, vergadering 11-4-1855, punt 3; Dir 0210, vergadering 24-4-1855, punt 4; TBG 4:199. 
opdracht van het gouvernement om een beschrijving van de Boroboedoer te leveren, bedoeld ter ondersteuning van de in Nederland te publiceren tekeningen van Wilsen en Schönberg Müller. Zijn grote beschrijving zou echter tot zijn teleurstelling niet de hoofdmoot van de monumentale BôrôBoedoer van Leemans (1873) vormen, al maakte de Leidse museumdirecteur van Brumunds gegevens wel gebruik. Toen Brumund in Nederland was (1858-1859), stond hij verschillende opstellen af aan Van Hoëvell voor diens tijdschrift. Vóór zijn vertrek had hij het genootschap van zijn Javaanse reis verslag gedaan, onder andere over Singosari, en zijn Boroboedoer-stuk aangeboden, als het gouvernement daar toestemming voor zou geven, hetgeen niet gebeurde. ${ }^{12}$ We treffen in het tijdschrift van het genootschap in de eerste jaargangen van hem alleen een verhaal aan over een Molukse reis, maar van hem niets over de Boroboedoer, Penataran of Singosari of andere Javaanse oudheden. Zijn stukken kwamen in de eigen bundels Indiana terecht en in Van Hoëvells tijdschrift in Nederland.

Eenmaal terug in Batavia werd Brumund op 4 mei 1861 herbenoemd tot bestuurslid. ${ }^{13}$ Hij woonde echter geen vergaderingen bij tot die van 5 april 1862, toen zijn nieuwe opdracht werd besproken. Zijn afwezigheid bij de bestuursvergaderingen van 1861 en de eerste maanden van 1862 is opvallend. Met de nieuwe regeringsopdracht, die nauw aan het genootschap was verbonden, was hij weer helemaal terug in het bestuur. Eind juni 1862 was hij op reis.

In augustus deed hij verslag van zijn bezoek aan K.F. Holle met wie hij in Garoet Kawi-handschriften had bekeken. In oktober had hij plannen om over te steken naar Bali, waarvoor zijn opdracht, die zich tot Java beperkte, enigszins moest worden aangepast. In januari 1863 stuurde hij vanuit Pasoeroean verschillende stukken over Bantam, Buitenzorg en de Preanger Regentschappen, naast bijdragen voor de oudheidkundige kaart. Ook stuurde hij een lijst van te fotograferen objecten en deed hij opgave van de voorwerpen die naar Batavia zouden kunnen worden vervoerd. Hij meldde dat hij bezoeken had afgelegd aan Cheribon, Tegal, Pekalongan, Semarang, Pati, Rembang, Soerabaija, Pasoeroean, Banjoewangi en Bali, Panaroekan, Besoeki en Probolinggo. In februari 1863 stuurde hij nog twee brieven met het vervolg van de beschrijving van de oudheden in de Preanger Regentschappen, Cheribon, Tegal, Semarang en Bagelen. Hij was in Oost-Java opgehouden door de west-moesson, maar gebruikte zijn tijd door aan de beschrijving te werken (Notulen 1:17, 37, 90, 98). Brumund had het eerste half jaar goed gebruikt en veel gezien. Het genootschap had alle reden om opgeto- 
gen te zijn en het koesterde de verwachting dat Brumund zijn reis binnen het hem gegeven jaar zou voltooien. Groot was de schok toen op 13 maart 1863 het telegram van de resident van Pasoeroean, H.A. van der Poel, het bestuur inlichtte over het overlijden van Brumund in Malang, ten gevolge van een verwaarloosde leverontsteking. ${ }^{14}$ Het verlies voor het genootschap en voor de oudheidkunde op dat moment was groot.

Het bestuur benoemde een commissie om de stukken van Brumund te onderzoeken. Tevens zou die commissie bezien of een aanbod van Hageman uit Soerabaija om Brumunds opdracht af te maken, serieus genomen moest worden. ${ }^{15}$ Hageman zou die opdracht niet krijgen. Een deel van Brumunds aantekeningen over Bali zou direct gepubliceerd worden in het tijdschrift van het genootschap, een ander deel over hetzelfde eiland zou door de commissie worden bewerkt, terwijl een begin zou worden gemaakt met het drukken van Brumunds grote beschrijving over de oudheden op Java. ${ }^{16}$ Het verscheen als 'Bijdragen tot de kennis van het Hindoeisme op Java' pas in 1868 in de Verhandelingen. ${ }^{17}$

Mocht Hageman, in Soerabaija woonachtig als ambteloos burger, de opdracht van Brumund niet afmaken omdat hij daarvoor te weinig gekwalificeerd was? Op die vraag geven de notulen geen antwoord. Wie wel gekwalificeerd leek om de opdracht af te maken, was de voormalige adjunctbibliothecaris en eertijds bestuurslid, Friederich. Hij was in 1863, niet lang na het overlijden van Brumund teruggekomen van zijn ziekteverlof en had zich gemeld bij het genootschap met het verzoek om inzage te krijgen in de aantekeningen in het genootschapsarchief over oudheden. Ook vroeg hij toestemming om de inscripties in het museum af te drukken (Notulen 1:223). Friederich had namelijk bij zijn terugkeer naar Indië een regeringsopdracht meegekregen om inscripties op Java, Sumatra en Bali te verzamelen. Die opdracht had hij in den brede met Leemans besproken. ${ }^{18}$ Friederich mocht uiteindelijk terugreizen in het gezelschap van vier, in het Rijksmuseum van Oudheden in Leiden getrainde militairen, die afgietsels en afdruksels hadden leren maken en die ook tekeningen en opmetingen konden leveren. Deze opdracht was serieus voorbereid en Friederich had maar liefst vier assistenten meegekregen, terwijl Brumund alleen op reis was gegaan. Het

14 Notulen 1:109. Twee telegrammen van resident H.A. van der Poel, 13 en 14 maart 1863 in ANRI KBG Dir 0273, vergadering 24-3-1863.

$15 \quad$ Notulen 1:182, vergdering 18-4-1863.

16 Notulen 2:114-5, vergadering 30-4-1864.

17 VBG 33 (1868). Of er door de commissie nog veel aan gedaan moest worden, blijkt niet. Maar kennelijk was het manuscript niet meteen publicabel. Het genootschap liet in de delen 31 en 32 (1864 en 1865-1866) andere opstellen voor gaan.

18 Zie daarover Leemans' nota voor Sloet van de Beele, 6-8-1861, in ANRI Archief Algemene Secretarie, gouvernementsbesluit 24-5-1862 $\mathrm{nr} 2$. 
genootschap mocht, gezien het verleden, verwachten dat de interesse bij de voormalige adjunct-bibliothecaris om zijn oude stoel weer te bezetten niet groot was. Het bood Friederich dan ook geen plaats als bestuurslid aan. Maar kwam het niet in het bestuur op om Friederichs opdracht te combineren met de werkzaamheden die Brumund niet had kunnen afronden? Mogelijk bedankte Friederich zelf voor de eer. Hij was nu zelfstandig onderzoeker, niet gekoppeld aan het genootschap, dat hem zolang klein had gehouden.

Overigens was het verzamelen van inscripties ten behoeve van een corpus inscriptionum door Friederich zelf ter sprake gebracht in zijn publikatie 'Over inscripties van Java en Sumatra, voor het eerst ontcijferd' (VBG 26). Toen het Delftse Instituut de suggestie opnieuw deed, nam het genootschap die in 1859 over. ${ }^{19}$ Het stelde het gouvernement voor aan de hoofden van gewestelijk bestuur opdracht te geven tot het verzamelen van kopieën van inscripties. Er ging in november 1859 een circulaire over uit, nadat het gouvernement had aangegeven dat Friederich de binnenkomende kopieën zou kunnen verzamelen. Daarop kwamen nog hetzelfde jaar 1859 de eerste reacties binnen. In 1863 was het genootschap niet langer verantwoordelijk voor de verzamelen, ontcijferen en eventueel publiceren van inscripties. Dat was nu Friederichs taak. Zijn collectie afdruksels en kopieën van inscripties kwam na zijn ontslag in 1869 bij het genootschap terecht en vormde daar een belangrijke studiecollectie. Er was dan wel een corpus, de publicatie ervan liet nog op zich wachten.

Een project dat door de dood van Brumund eveneens verzandde, was het samenstellen van een oudheidkundige kaart. In november 1861 werd de algemene vergadering nog optimistisch voorgehouden dat die kaart zou worden gemaakt door Netscher en Versteeg op basis van de opgaven die daarover uit de verschillende gewesten op Java zouden binnenkomen (TBG 12:187-8). Het belang van zo'n kaart voor verder onderzoek was evident. Met die kaart in de hand zou de verspreiding van het hindoeïsme over Java in één oogopslag kunnen worden gevisualiseerd, een misschien wat optimistische gedachte. Toen bleek dat de inzendingen uit de gewesten tegenvielen, dan wel onbetrouwbaar waren, werd het project geïncorporeerd in de opdracht aan Brumund. Die opdracht zou dan een beschrijving én een oudheidkundige kaart opleveren. Na de dood van Brumund werkte een commissie wel aan zijn nalatenschap, maar zij concentreerde zich op de aantekeningen over Bali en de beschrijving van de oudheden op Java. De 'antiquarische kaart' ging weer een tijd de kast in.

Een project dat wel afgerond werd en dat rechtstreeks voortkwam uit de

19 Het gouvernement vroeg het genootschap op 14-4-1859 om advies. Het genootschap vergaderde erover op 14-5-1859. Zie TBG 9:226. 
opdracht aan Brumund, was de nevenopdracht aan de fotograaf Isidore van Kinsbergen. In het gouvernementsbesluit over de opdracht aan Brumund was het door het Bataviaasch Genootschap voorgestelde aantrekken van drie fotografen aangehouden in afwachting van het advies van Stieltjes over het inzetten van de fotograaf Elias. De naam van Elias werd echter niet meer genoemd.

Van Kinsbergen was geboren in 1821 in Brugge. Hij had zich bekwaamd in de zang- en schilderkunst en was en in 1851 met een operagezelschap naar Batavia gekomen. Daar raakte als decoratieschilder en zanger hij verbonden aan de Bataviase schouwburg. Hij was zich in Batavia gaan interesseren voor de fotografie, waartoe hij in de leer was gegaan bij Antoine Lecouteux. Fotografie werd gezien als een kunstvorm, dus bleef Van Kinsbergen in zijn branche werkzaam. In februari 1862 was hij zo bedreven dat hij als fotograaf mee kon op een diplomatieke reis naar Siam in het gevolg van algemeen secretaris Alexander Loudon. Aansluitend maakte hij in juni-juli 1862 een reis mee met gouverneur-generaal Sloet van de Beele naar Midden- en Oost-Java en Bali. Daarvan terug bood de gouverneur-generaal enkele van de door Van Kinsbergen gemaakte 'photographische afbeeldingen' van de Boroboedoer en de Prambanan-tempels aan het genootschap aan. Die werden begeleid door een brief van de eerste gouvernementssecretaris van 13 september 1862, waarbij deze meedeelde dat aan Van Kinsbergen was gevraagd of hij bereid was om mee te werken aan het vastleggen van de oudheden en inscripties die Brumund aan het beschrijven was. Sloet van de Beele nam op dat moment het initiatief om het fotografisch deel van de missie van Brumund te realiseren, echter op een andere wijze dan het genootschap had voorgesteld. Van Kinsbergen had er, onder bepaalde voorwaarden, wel oren naar. Het genootschap zag er, gezien de hoge kwaliteit van de geschonken foto's, veel in en koppelde er het voorstel aan vast dat Van Kinsbergen een assistent naast zich zou krijgen die hij zou moeten opleiden in de kunst. ${ }^{20}$

Nadat de directeur van financiën bezwaren had geuit tegen de voorwaarden die Van Kinsbergen had gesteld en een commissie van het genootschap met de fotograaf had onderhandeld, kwam het tot een definitief voorstel en een gouvernementsbesluit. Uiteindelijk werd op 2 december 1862 een overeenkomst gesloten tussen Van Kinsbergen en voorzitter Gerrit Wassink, waarbij het genootschap namens de regering optrad. ${ }^{21}$ De fotograaf zou drie

20 Notulen 1:5-6, vergadering 20-9-1862. Over Van Kinsbergen de studie en catalogus van zijn foto's door Theuns-de Boer en Asser (2005)

$21 \quad$ Notulen 1:36 (vergadering 11-10-1862), 40 (vergadering 22-11-1862), 57 (vergadering 27-121862) met gouvernementsbesluit 2-12-1862. Op 23-1-1863 blijkt de overeenkomst gesloten te zijn (Notulen 1:72). Het genootschapsexemplaar van de overeenkomst, getekend door Van Kinsbergen en Wassink, bevindt zich in een mapje Kinsbergiana in ANRI KBG Mus 0029. 
jaar over zijn opdracht mogen doen. Hij kreeg een maandelijkse vergoeding van $f 800$ in het eerste jaar, oplopend tot $f 1.000$ in het derde jaar. Ook mocht hij gebruik maken van gouvernements- en regentspaarden en van particuliere postpaarden. Van de door het genootschap opgegeven oudheidkundige objecten moest hij opnamen maken en aan het eind van iedere maand van ieder goedgekeurd cliché zes afdrukken leveren. Een interessante bepaling was nog dat elk door het genootschap afgekeurd cliché de fotograaf een boete van $f 100$ zou kosten. De financiering kwam, net als bij Brumunds missie, van het gouvernement. Fotograferen was niet goedkoop, dus werd er rekening mee gehouden dat het in het voor de opdracht aangewezen begrotingshoofdstuk genoemde bedrag van $f 37.500$ niet voldoende zou zijn. Dan zou aanvulling gevonden worden bij de post 'onvoorzien' van hetzelfde hoofdstuk. Zo had het genootschap begin 1863 een oudheidkundige én een fotograaf in dienst. Gouvernement en genootschap zaten op één lijn en de verwachtingen waren hooggespannen. De dood van Brumund in maart 1863 was een zware tegenvaller, maar het hinderde de opdracht aan de fotograaf niet. Zijn vertrek was vastgesteld op april 1863. Hij zou Brumunds reis als het ware nadoen en zou bij de uitvoering van zijn opdracht op de vingers gekeken worden door een commissie van maar liefst vier bestuursleden: Der Kinderen, Van der Chijs, Levyssohn Norman en Stortenbeker. ${ }^{22}$ In juli 1863 kwamen de eerste (21) foto's binnen, 'uitstekende photographische afbeeldingen', gemaakt in de residentie Buitenzorg. ${ }^{23}$

Terwijl Van Kinsbergen op reis was, stelde de commissie voor hoe het zou moeten met de clichés en de afdrukken van de foto's die hij maakte. Zij stelde voor van de zes afdrukken die Van Kinsbergen van iedere opname zou leveren, de eerste voor de koning te bestemmen, en de andere voor het genootschap zelf, voor het museum van oudheden in Leiden, en de resterende voor de Société Asiatique (Parijs), de Royal Asiatic Society of Bengal (Calcutta) en de Royal Asiatic Society of Great Britain and Ireland (Londen). Het was de bedoeling de foto's uit te geven bij de beschrijving van Brumund. Ze stonden niet op zich zelf. De regering - bang dat Van Kinsbergen teveel foto's zou gaan maken, waardoor de kosten te hoog zouden uitkomen - werd gerustgesteld: alleen wat bij Brumunds beschrijving zou horen, zou worden gefotografeerd. ${ }^{24}$ De kwaliteit van de door de gouverneur-generaal geschonken foto's en van de eenentwintig opnames die als eerste onderdeel van de genootschapsopdracht binnenkwamen, deed het bestuur beseffen dat de regering met de keuze voor deze fotograaf een schot in de roos had gedaan.

\footnotetext{
22 Notulen 1:99 (vergadering 27-3-1863), 145-6 (algemene vergadering 27-3-1863) en 191 (vergadering 18-4-1863).

$23 \quad$ Notulen 1:226, vergadering 3-7-1863.

24 Notulen 1:231-2 (vergadering 1-8-1863) en 286 (vergadering 24-10-1863).
} 
Vandaar dat over de verspreiding naar vier belangrijke instellingen al in een vroeg stadium werd beslist. De naam van het genootschap zou daardoor verder gevestigd worden als een instelling op het gebied van oudheidkunde. Om de resultaten echter niet tot de kleine kring van specialisten te beperken, onderzocht het genootschap de mogelijkheid om via een lithografisch procédé een ruimere verspreiding te verzekeren. De driehonderd foto's uit de opdracht zouden in een oplage van zeshonderd exemplaren (in totaal 180.000 afdrukken) in Brussel kunnen worden vermenigvuldigd. ${ }^{25}$

Van Kinsbergen werkte langzamer dan het genootschap had gehoopt. Enerzijds was het fotografisch procédé bewerkelijk. Anderzijds stelde de fotograaf hoge eisen aan zich zelf. Bij de Boroboedoer stonden verschillende bomen in de weg, zodat een opname van de tempel als geheel, vanuit de hoek die Van Kinsbergen had gekozen, onuitvoerbaar was. Dan moesten die bomen maar gekapt worden. Ook daarmee bemoeide het genootschap zich. ${ }^{26}$ In juli 1864 te Diëng aangekomen verwonderde Van Kinsbergen zich over de tempels daar. Hij liet de aarde rond de gebouwen weggraven en ontdekte dat een aanzienlijk gedeelte ervan onder het grondoppervlak gelegen was. Dat leidde tot een compleet opgravingsproject, waarbij de fotograaf zich ontwikkelde tot archeoloog. Op 1 augustus lichtte hij daar het genootschap over in. Hij stuurde tekeningen mee en deed voorstellen voor de voortgang van het project. Van Kinsbergens lange brief is een zeer levendig verslag en geeft herhaaldelijke blijk van het grote enthousiasme van de fotograaf-archeoloog. ${ }^{27}$ Het gouvernement gaf op 2 september 1864 de resident van Bagelen, C. Castens, opdracht met zijn eerstaanwezend ingenieur naar Diëng te reizen om met Van Kinsbergen te overleggen over de verdere uitgraving van de ruïnes aldaar. Er werd direct geld gerserveerd voor het project. Het genootschap was door het doortastende optreden van de ondernemende Van Kinsbergen een eigen archeologische opgraving rijk. Het uitgebreide verslag dat de amateurarcheoloog op 30 september 1864 vanuit Wonosobo naar Batavia stuurde, begeleid door tweeënzestig opnames die hij aldaar gemaakt had, laat zien dat hij naast de camera ook de pen vaardig hanteerde. Levendig ('Stel u voor mijne heeren!'), alsof hij het woord voerde op een vergadering, beschreef hij de gebeurtenissen, die aanleiding hadden gegeven tot de uitgraving, vanaf het moment van zijn eerste kennismaking met het gebied. ${ }^{28}$ Dit verslag, dat gepubliceerd werd, maar ook de niet in de Notulen afgedrukte brieven die

\footnotetext{
25 Notulen 2:19, vergadering 9-1-1864.

26 Notulen 2:89, vergadering 2-4-1864.

27 In het genootschapsarchief over de jaren 1863-1867 bevinden zich interessante brieven en tekeningen van Van Kinsbergen, alsmede enkele foto's. Brief van 1-8-1864 in ANRI KBG Dir 0292, waarbij een viertal belangrijke schetsen van Diëng.

28 Notulen 2:261-9, vergadering 5-11-1864.
} 
zich in het genootschapsarchief bevinden, laten zien dat hij de kennis over Diëng sinds het bezoek van Brumund en diens aantekeningen erover, vooruit had gebracht. De beschrijving van het complex van tempels was sinds de uitgraving aanzienlijk bijgesteld en de onderlinge verhouding tussen de verschillende tempels veel duidelijker geworden. Men durfde nu van een tempelstad te spreken. In het volgende jaar, mei 1865, vond het genootschap dat een commissie van drie bestuursleden, Rochussen, Levyssohn Norman en Van den Berg, poolshoogte moest gaan nemen te Diëng, om het gouvernement beter te kunnen adviseren over het vervolg van het project. ${ }^{29}$ In het jaarverslag van het genootschap in de Javasche Courant werd ruime aandacht besteed aan Van Kinsbergens werkzaamheden te Diëng. Het genootschap was daarover zo tevreden, dat hij de titel van 'photograaf des Genootschaps' verwierf. De enthousiaste secretaris Levyssohn Norman, noemde het gebied 'het Benares van Midden-Java'. ${ }^{30}$

Van Kinsbergen vervolgde zijn 'kunstreizen', zoals deze missie door het gouvernement werd aangeduid. Zijn status werd hoe langer hoe meer die van de fotograaf-kunstenaar én deskundige-archeoloog. Hem werd toegestaan

uit de steenbrokken, in den omtrek der Hindoe-tempels en bouwvallen verspreid liggende, ten behoeve van het museum van het Bataviaasch genootschap zoodanige uit te kiezen, als uit een architectonisch oogpunt door hem bijzonder merkwaardig worden geacht. ${ }^{31}$

Deze interessante bij-opdrachten en nevenactiviteiten vertraagden de aflevering van de driehonderd foto's. In juli 1866 moest de opdracht daarom met een jaar worden verlengd tegen een vergoeding van $f 1000$ per maand en $f 200$ voor transportkosten. (De dagloners die op Diëng het graafwerk verrichtten, verdienden $f 0,25$ tot $f 0,30$ per dag. ${ }^{32}$ ) Op 25 september 1866 schreef het genootschap een ongeduldige brief over zijn verblijf van twee maanden in Batavia. Van hem werd verwacht dat hij onverwijld het reizen zou hervatten. Van Kinsbergen antwoordde op 16 oktober en verklaarde zich bereid te vertrekken. ${ }^{33}$ In november 1866 ging hij voor zijn vierde contractjaar op pad. In januari 1867 meldde het genootschap dat het al twee maanden niets van hem had vernomen. Pas in juli kwamen er 167 opnames uit Kediri, Penataran en omgeving. In Penataran waren opnieuw opgravingswerkzaamheden nodig

29 Notulen 3:43, vergadering 7-4-1865. Verslag van die commissie in Notulen 3:108, vergadering 7-7-1865.

30 Javasche Courant, extra bijvoegsel 20-6-1865, nr 50, p. 2-3. De benoeming was geschied op 10-2-1865, Notulen 3:26.

$31 \quad$ Notulen 3:3, vergadering 10-2-1865.

32 Notulen 4:188, vergadering 31-7-1866.

33 ANRI KBG Mus 0029, conceptbrief aan van Kinsbergen. Uit zijn bijgevoegde antwoord van 16-10-1866 blijkt de genootschapsbrief te dateren van 25-9-1866. 
geweest. Toen de foto's in september 1867 op het Koningsplein werden bekeken, bleek het bestuur weer uitermate tevreden. Het had dan lang moeten wachten, de kwaliteit van het afgeleverde werk was zeer hoog. ${ }^{34}$ Nog lang na het afronden van zijn reis talmde Van Kinsbergen met het maken van de zes contractueel vastgelegde afdrukken van ieder cliché. Pas in februari 1872, ruim negen jaar na het sluiten van het contract, leverde de fotograaf de eerste complete set van 332 foto's af, waarna er nog vijf sets moesten volgen. De naam van de fotograaf was echter na het uitkomen van dit album Oudheden van Java gevestigd, ook internationaal. Dat hij sommige plaatsen zeer uitgebreid opnam (tientallen foto's van Diëng en Penataran), terwijl andere belangrijke plaatsen (Prambanan) met maar enkele foto's vertegenwoordigd waren en andere helemaal niet, had de begeleidingscommissie niet kunnen voorkomen. ${ }^{35}$ Het was in belangrijke mate een gevolg van de koppeling van Van Kinsbergens werk aan de uitkomsten van Brumunds reis en diens plotselinge dood. De predikant was van plan geweest om ook de Boroboedoer weer te bezoeken, maar was daar niet meer aan toe gekomen. Verder was de fotograaf een eigenzinnig man en maakte hij zijn eigen keuzes. Daarbij had het genootschap hem ook meer vrijheid gelaten dan in 1862 was afgesproken, en wel als teken van vertrouwen van de kant van het bestuur. Het maakte niet uit voor de manier waarop de foto's werden ontvangen, die nog steeds gelden als belangrijke documenten in de geschiedenis van de bestudering van de oudheden op Java. ${ }^{36}$ Losse afdrukken werden in Batavia via de studio van Ernst en Co te koop aangeboden, waardoor ook een ruimer publiek er kennis mee kon maken.

Van Kinsbergen kreeg in 1872 nog een tweede opdracht om veertig foto's te maken voor een album over de Boroboedoer. ${ }^{37}$ Conrad Leemans kon niet nalaten een en ander aan te merken op de Oudheden van Java, toen de foto's Leiden bereikten. De opdracht voor de Boroboedoer-foto's vond hij zelfs een onnodige geldverspilling. Zijn eigen Bôrô-Boedoer met de litho's naar de tekeningen van Wilsen was net uit en maakte verdere documentering overbodig. Het weerhield het genootschap er niet van om met trots voort te werken aan het tweede album van de 'photograaf des Genootschaps'. Dat Leemans zich erover beklaagde, dat hij niet was gehoord in de aanloop tot het verlenen van de tweede opdracht - hij was immers dé expert ter zake van die tempel - tekent de rivaliteit die hij voelde tussen het genootschap

34 Notulen 4: 249, vergadering 30-10-1866; Notulen 5:10 (vergadering 29-1-1867), 23 (vergadering 26-3-1867), 75 (vergadering 30-7-1867) en 86 (vergadering 22-9-1867).

35 Van Kinsbergen 1872, in Notulen 10:bijlage 2 bij vergadering 5-3-1872.

36 Zie over het belang van Van Kinsbergens 'Photographiën naar oudheden van Java': Krom 1923, I: 20-3; Theuns-de Boer en Asser 2005.

37 Van Kinsbergen 1874 in Notulen 12:bijlage f bij vergadering 9-6-1874. 
en zijn eigen museum. Leemans' opmerkingen leidden zelfs tot vragen van de minister van koloniën, of het Boroboedoer-project van Van Kinsbergen wel door moest gaan (1873). Leemans was echter niet kleinzielig en erkende dat Van Kinsbergens Oudheden 'eene onschatbare bijdraag tot de kennis van den oorspronkelijken [staat der oudheden] en eene wezenlijke winst voor de wetenschap' vormde. ${ }^{38}$ Het feit dat de uitvoering van het Boroboedoerproject ook weer aanleiding gaf tot opgravingen en herstelwerkzaamheden ${ }^{39}$ bevestigde de positie van het genootschap als de organisatie die zich met hulp van de overheid bezighield met oudheidkundig onderzoek, opgravingen en restauraties op Java. De glasnegatieven van Van Kinsbergen zijn in het begin van de twintigste eeuw door het genootschap overgedragen aan de Oudheidkundige Dienst, de organisatie die in 1913 voor het beheer van de oudheden was opgericht (nu Dinas Purbakala), waar ze nu nog zijn. De taken van het genootschap op het terrein van de oudheden hadden zich toen verzelfstandigd.

Het bestuur raakte door de missies van Brumund en Van Kinsbergen steeds beter op de hoogte van de toestand van de oudheden, vooral van de deplorabele toestand van sommige tempelruïnes. Diëng en Penataran kwamen erdoor op de archeologische kaart te staan. Vooral de alertheid van bibliothecaris Van der Chijs, die rechtstreeks in contact stond met Van Kinsbergen, treft in de bestuursverslagen. Het genootschap werd daardoor een waakhond. Van der Chijs' opmerking in 1863 over Brumunds observatie over het afbreken van de Bagong-tempel (Diëng) - stenen van die tempel werden op de markt in Batoer verkocht - was aanleiding tot een brief aan het gouvernement, waarna dat maatregelen nam om de oudheden beter te beschermen. ${ }^{40}$ Daarbij kwam het genootschap terug op eigen voorstellen uit 1860 voor het betere beheer van oudheden op Java. Het gouvernement ging niet over tot strafbaarstelling, maar gebruikte termen als 'met leedwezen' om aan te duiden dat de zorg voor de oudheden niet was zoals gewenst. Het deed een beroep op de 'goeden wil en den wetenschappelijken zin der hoofden van gewestelijk en plaatselijk bestuur'. Dat moest voldoende zijn om te leiden tot beter onderhoud en moest roof en vernieling voorkomen. Dat echter geen sancties werden getroffen, verzwakte het standpunt van de regering. ${ }^{41}$

In 1865 was het opnieuw Van der Chijs die de zorg voor de oudheden

38 Notulen 11:102-4 (vergadering 19-8-1873) en 162 (vergadering 22-12-1873). In de notulen is de brief van Leemans geciteerd. Enkele woorden lijken echter te zijn weggevallen, die ik hier tussen vierkante haken heb gereconstrueerd.

39 Verslag van Van Kinsbergen over zijn Boroboedoer-opdracht in Notulen 12 :71-6, vergadering 9-6-1874.

$40 \quad$ Notulen 1:190-1, vergadring 18-4-1863.

41 Notulen 1:242-8, vergadering 12-9-1863. Daar wordt het gouvernementsbesluit van 18-81863 geciteerd. 
onder de aandacht van het bestuur bracht, waarna hij in januari 1866 adviseerde om het gouvernement een aantal maatregelen voor te stellen. Eerst gaf hij een reeks tempels en ruïnes op die voor geregeld onderhoud in aanmerking kwamen. Daarna vroeg hij vooral aandacht voor de verzorging van het Prambanan-complex en wees op de 'fraaije beelden van Loro Djonggrang, die men gaarne in 's genootschaps museum voorgoed bewaard zag.' 42 Dat gebeurde niet. De betreffende beelden bevinden zich nog steeds in situ. Hij adviseerde ook nader onderzoek naar de tempels op de hellingen van de Lawoe en de Smeroe. Dat beelden beter konden blijven waar ze waren, was te Batavia niet doorgedrongen. Tijdens dezelfde vergadering van januari 1866, waarin Van der Chijs' advies werd besproken, werd ook geprobeerd om de beelden op het terrein van het residentshuis te Kediri en een kolossale Ganesha uit Blitar voor het museum te verkrijgen. ${ }^{43}$ Voor wat betreft die in Kediri was dat in 1851 al eens geprobeerd. De Ganesha staat nog steeds in Blitar.

Het duidelijkst komt de rol van adviserend lichaam in oudheidkundige zaken tot uiting in de rol die het genootschap speelde bij de opgravingen te Diëng, die door Van Kinsbergen waren begonnen. Diens verslag had het genootschap er in augustus 1864 meteen toe aangezet het gouvernement maatregelen in overweging te geven. De begonnen opgraving moest worden voortgezet, er moest een budget voor worden vastgesteld, de lokale autoriteiten moesten verantwoordelijk worden voor de uitvoering van het project. ${ }^{44}$ Een uitgebreider verslag van 30 september 1864 - Van Kinsbergen was toen ruim twee maanden aan het werk op Diëng - bewerkte de rest. Het genootschap werd gevraagd om advies te geven over de aanbevelingen van de resident van Bagelen, Castens, die onder meer de reconstructie van een afwateringskanaal en een administratieve herindeling van residenties voorstond. De grens tussen de residenties Bagelen en Banjoemas liep precies over het plateau, wat de goede uitvoering van het opgravingsproject bemoeilijkte. Daarop stuurde het genootschap in mei 1865 de al genoemde commissie van drie bestuursleden naar Diëng om ter plaatse te beoordelen of de aanbevelingen van Castens opgevolgd moesten worden. ${ }^{45}$ In het verslag van die commissie week zij nogal af van de de mening van de resident. De herindeling was wel een goed idee, maar moest niet lopende het opgravingswerk worden doorgevoerd. Het afwateringskanaal moest niet worden gerestaureerd. Het gouvernementsbesluit van 4 maart 1866 volgde bijna geheel de aanbevelingen van de commissie van drie en van het genootschapsbestuur. Het opgravings-

$42 \quad$ Notulen 4:7-9, vergadering 16-1-1866.

43 Notulen 4:9, vergadering 16-1-1866.

44 Notulen 2:226, vergadering 16-9-1864.

$45 \quad$ Notulen 3:43, vergadering 7-4-1865. 
project werd gedoteerd met een subsidie van $f 5.000$ en de uitvoering werd in handen gegeven van Kiay Soero Semito uit Batoer, terwijl de eerstaanwezend ingenieur van Bagelen, G.A. Pet, maandelijks de voortgang zou inspecteren en daarvan het gouvernement via het genootschap verslag zou doen. ${ }^{46}$ In de loop van 1866 zou Pet, inmiddels tot lid benoemd van het genootschap, rapporteren over de voortgang van de opgravingen (Notulen 4:176, 187, 232, 257, 5:44, 60, 88, 6:54). Het genootschap ontving intussen de al door Van Kinsbergen opgegraven kleinere voorwerpen voor het museum, terwijl de grotere stenen en beelden bij de Passangrahan te Diëng bleven. Later zou een deel van die verzameling alsnog naar Batavia verhuizen. Diëng was aldus het paradepaardje van het genootschap. Het belang van het complex is nog steeds groot, getuige het aantal bezoekers dat het nog in onze eeuw trekt. Het 'project Diëng' was tegelijk het concrete bewijs aan het adres van de bezorgde Leemans dat het bestuur, ondanks wisselingen, in staat was in nauwe samenwerking met het gouvernement te zorgen voor de Javaanse oudheden. Op het gebied van het beheer van oudheden op Java speelde het genootschap nu een centrale rol. Gouverneur-generaal Sloet van de Beele was op dit terrein een actieve factor. Hij was persoonlijk geïnteresseerd in de zorg voor Java's oudheden en koos voor een zwaardere rol voor het genootschap in Batavia boven de verre Leemans in Leiden. Hij stelde ook belang in de foto's die Van Kinsbergen op Java maakte en liet die naar zich toebrengen om ze te kunnen bekijken. Van Kinsbergen begeleidde de gouverneur-generaal op een van zijn reizen. Als beschermheer van het genootschap kan Sloet het best vergeleken worden met zijn voorganger Van der Capellen, een halve eeuw eerder.

\section{Verzamelingen: archeologische voorwerpen}

De kommervolle omstandigheden waaronder de museumcollecties en de bibliotheek tot eind 1867 waren ondergebracht, waren nog geen reden om de verzameltaak te verwaarlozen, die het genootschap zich gesteld had. Onderhuurder Lange, die in 1848 de drukkerij had overgenomen en in de bijgebouwen was blijven werken, beklaagde zich in juni 1862 over de slechte staat van de door hem gehuurde ruimtes, waarvoor het genootschap nog zeshonderd gulden per jaar aan huur ontving. ${ }^{47}$ In 1865 koos de drukker eieren voor zijn geld en vertrok, ook al met het oog op de op handen zijnde verhuizing van het genootschap. ${ }^{48}$ Door Langes vertrek was meer ruimte beschikbaar.

$46 \quad$ Notulen 4:82, vergadering 27-3-1866.

47 TBG 12:563, vergadering 7-6-1862.

48 Het verslag van 11-5-1865 in Notulen 3:69 vermeldt het vertrek van Lange. 
In de periode van vijfeneenhalf jaar, gelegen tussen de beslissing over de nieuwbouw en het betrekken van het gebouw, was het genootschap bepaald actief op acquisitie-gebied. Het deed bovendien zijn best om de collecties fatsoenlijk uit te stallen. Het mocht dan op een pakhuis lijken, er heerste orde. Brumund had vóór zijn vertrek op zijn grote reis van 1862 de oudheidkundige verzameling bekeken en de beelden 'in fraaije groepen gerangschikt naar de goden of het tijdvak dat deze vertegenwoordigen'. Verder heerste in de kasten het geografische principe: 'zoveel mogelijk steeds alles bijeen wat tot dezelfde landstreek behoort'. ${ }^{49}$ Jammer genoeg beschikken we niet over beschrijvingen door bezoekers aan de Rijswijkstraat in deze periode en evenmin over foto's, waaruit we ons een beter beeld kunnen vormen. De geruststelling uit eigen bestuurskring (1862), dat de nieuwe beschermheer, Sloet van de Beele, zelf had kunnen vaststellen dat de collecties er goed bijstonden, leest als een bezwering en was vooral bedoeld om het toen dreigende oprukken van de Leidse confraters af te wenden. ${ }^{50}$

De gedrukte notulen, tot augustus 1862 in het Tijdschrift, daarna in aparte jaarbundels Notulen, bieden ons een ingang tot het onderwerp van de aanwinsten, maar het beeld van de werkelijke toestand in het museum in de laatste jaren van de Rijswijkstraat wordt er niet veel scherper op. De registers op deze notulen door de hoofd-ingenieur chef der telegrafie, H.L. Janssen (1868), en J.A. van der Chijs (1879) zijn een godsgeschenk. De afdelingen 'oudheden' en 'land- en volkenkunde' nemen in deze registers de meeste plaats in, gevolgd door 'taal- en letterkunde' in het eerste en de 'bibliotheek' in het tweede register. De onvolprezen Van der Chijs zou de hele rest van de 19e eeuw ijverig registers blijven maken, waar we nu nog de vruchten van plukken. Zijn drie registers $(1879,1889,1899)$ zijn voor de hele periode van 1867 tot 1898 een belangrijke ingang tot de genootschapsgeschiedenis. Na zijn aftreden als bestuurslid in 1900 - hij stierf in 1905 - is soortgelijke arbeid voor latere perioden niet meer ondernomen. Uitgebreide lijsten en overzichten achterin ieder deel vormen de tijdrovende zoekmiddelen voor de Notulen na 1898.

Bepalen we ons eerst tot de oudheidkundige collectie. Die was vooral op Java gericht. Op het gebied van de oudheidkunde had Java natuurlijk door de rijke bewoningsgeschiedenis het meeste te bieden, zowel aan resten van grote als kleine tempelcomplexen. Daarbij vergeleken liepen de buitengewesten achter. Die waren minder geëxploreerd, ook dunner bezaaid met ambtenaren en militairen, die het genootschap moesten voorzien van materiaal, aanwijzingen, gegevens, aanwinsten. Vooral Midden-Java, de residenties Banjoemas, 
Bagelen en Kadoe, leverde aanwinsten op. Daarop volgde de omgeving van Soerabaija, Pasoeroean, Malang en Probolinggo. Van deze gebieden was Bagelen veruit het best vertegenwoordigd. Het bezoek van Brumund, maar vooral de erop gevolgde, door Van Kinsbergen begonnen opgravingen op Diëng, betekenden de start van een ware schatgraverij.

De toenemende stroom aanwinsten die via het gouvernement binnenkwam als gevolg van de overheidsmaatregel van 1855, vraagt om nadere beschouwing. Om het verloren gaan van opgegraven objecten, tegen te gaan, had het gouvernement in dat jaar bepaald dat het kon besluiten wat er met opgegraven geld of waardevolle voorwerpen zou moeten gebeuren. Het kwam neer op een meldingsplicht voor de bestuursambtenaren die van vondsten lucht kregen. ${ }^{51}$ De vondst werd dan aan het bestuur van het genootschap voorgelegd met de vraag of het er belangstelling voor had en of het bereid was ervoor te betalen. Omdat de betaling was gebaseerd op de metaalwaarde van het voorwerp, waren de prijzen voor het bestuur aantrekkelijk. Er was nog nauwelijks een markt die bepaalde hoe de artistieke of oudheidkundige waarde kon worden gekapitaliseerd. Een andere mogelijkheid was, als het genootschap van overname afzag, de openbare verkoop van de vondst. Op basis van deze regeling was een praktijk ontstaan waarbij het genootschap een aanbod kreeg, dat het beoordeelde (kopen of niet?). In 1861 voegde het genootschap in een brief aan de hoofden van de gewesten eigener beweging aan deze praktijk toe dat het niet alleen in vondsten in edele metalen, maar ook in opgegraven voorwerpen in steen en niet-edele metalen was geïnteresseerd. ${ }^{52} \mathrm{Na}$ het gouvernementsbesluit van 1862 over de reis van Brumund was ook de aankoop voor Leiden een van de mogelijkheden geworden.

In 1857 kwamen nog maar vier van deze aanbiedingen van het gouvernement binnen, terwijl bij een vijfde niet vermeld staat of het een aanbod van het gouvernement was. ${ }^{53}$ In 1861 was de stroom nog steeds tamelijk beperkt: er is van slechts drie vondsten sprake. Het ging om drie koperen voorwerpen, een metalen klok en een ring met een boeddha-afbeelding. Het eerste voorwerp,

\footnotetext{
51 TBG 12:186, algemene vergadering 16-11-1861.

52 TBG 12:186-7, algemene vergadering 16-11-1861.

53 TBG 7:186, vermeldt een brief van de eerste gouvernements-secretaris van 28-10-1856 over acht goudwerken uit Probolinggo. Een brief van dezelfde van 13-11-1856 over 'eenige goud- en zilverwerken' gevonden in Geling (Jepara), aangekocht voor $f$ 35,92 en 27 duiten. Een soortgelijke brief van 16-12-1856 bood een aarden pot aan met zes bellen en een stuk kristal. De koop werd gesloten voor $f$ 20. Dit alles ter vergadering van 23-2-1857 (Notulen 7:187). Van de eerstgenoemde goudwerken werd op de vergadering van 6-4-1857 een gouden 'kroon- of koeloetornament' gemeld als gekocht (Notulen 7:250). Op 27-7-1857 werden twee oude gouden oorringen uit de buurt van Bidara-Cina gekocht voor $f 15$ gekocht. Niet vermeld wordt of het een aanbieding van het gouvernement is (Notulen 7:457). Tenslotte kwam er aan het eind van het jaar nog een brief binnen van het gouvernement, 20-11-1857 over drie koperen schenkbladen, een potje en een bidkrans, die voor $f 13$ werden overgenomen (TBG 8:2, vergadering 28-12-1857).
} 
afkomstig van Bangka, werd als niet waardevol genoeg afgeslagen, de andere, beide uit Bagelen afkomstig, werden voor respectievelijk $f 20$ en $f 100$ aangekocht. ${ }^{54}$ Het jaar 1861 leek armetierig te zijn voor de oudheidkundige aanwinsten, maar wel kwamen in dat jaar de Bandjarmasinse rijkssieraden binnen, die historisch-antropologisch interessant waren. Een probleem vormt hierbij dat aan de term 'oudheidkunde' een ruime betekenis werd gegeven, zodat voorwerpen die wij in de twintigste eeuw niet als 'oudheidkundige aanwinst' zouden bestempelen, dat in de negentiende eeuw wel konden zijn.

Pas echt ging de stroom aanbiedingen via het gouvernement vloeien in 1863. Toen kwamen er meer dan twintig binnen. Toen ook werd van voorwerpen voor het eerst gemeld dat zij aan de antiquarische of archeologische verzameling werden toegevoegd, waarbij de oudere geschiedenis van de nieuwere gescheiden leek te zijn. ${ }^{55}$ In maart 1863 meldde het jaarverslag dat er sinds november 1861 vijftien oudheidkundige voorwerpen waren aangekocht (Notulen 1:162). Het lijkt alsof de komst van Sloet van de Beele in oktober 1861 direct tot grotere activiteit aanleiding had gegeven. In de rest van het jaar 1863 volgden nog zestien meldingen (Notulen 1:179, 193, 249, 283, 287). Daarbij werden voor het eerst ook de belangen van Leiden in de gaten gehouden. Pas als het genootschap in Batavia van aankoop afzag, suggereerde het aan het gouvernement om het besproken voorwerp voor Leiden aan te kopen. Zo kon bijvoorbeeld een gouden ring uit Banjoemas met een metaalwaarde van $f 40$, waarvan al voorbeelden in de collectie te vinden waren, voor Leiden worden bestemd (Notulen 1:41, 65-6). De opbrengst ging steeds, naar de formulering van het gouvernementsbesluit, 'voor de helft naar de vinder en voor de wederhelft naar het bestuur der dessa, waar het voorwerp gevonden is, ter verdeeling onder de bewoners dier dessa of om ten meesten nutte van de gemeente te worden aangewend' (Notulen 1:66). Zo was een mooi midden gevonden tussen de belangen van de vinder en de belangen van de gemeenschap. Wat de rol bleef van de vrije markt, van opkopers die zelf de vinders wisten op te sporen of bij wie de vinders zelf hun vondsten kwamen aanbieden, is moeilijk na te gaan. Zo'n markt is er ongetwijfeld geweest.

Tot de belangwekkendste aankopen van deze periode behoort een in 1863 in de residentie Kadoe, dessa Paingan opgegraven gouden boeddha-beeldje op een zilveren voetstuk met een zilveren rugplaat, waarvan de metaalwaarde op $f 732$ werd geschat. Het is in werkelijkheid een vierarmige Wisnu van bijna 19 centimeter hoogte. Om de uitzonderlijke kwaliteit van het beeldje besloot het genootschap op het aanbod van de regering in te gaan, 'al gaat

54 TBG 11:420, vergadering 2-3-1861 voor de aangeboden koperen voorwerpen. De metalen (bronzen?) klok wordt gemeld in de vergadering van 13-7-1861, TBG 12:118. Daar ook de eerste vermelding van de gouden boeddha-ring. (Pagina 133 en 143 voor de sluiting van de koop.)

55 Notulen 1:71 (antiquarisch) en 76-7 (archeologisch), vergadering 23-1-1863 en 24-2-1863. 
de overname dan ook met belangrijke geldelijke opofferingen gepaard. ${ }^{56}$ In januari 1864 was de overname een feit. Het beeldje kon worden gerepareerd en werd vervolgens, om de waarde, bij de thesaurier in bewaring gegeven. Bij de jaarvergadering van 30 april 1864 werd het als een van de mooiste beeldjes uit de collectie naar voren geschoven. Het werd tentoongesteld in het Nederlandse paviljoen op de Internationale Koloniale Tentoonstelling in Parijs in 1931, waar het als door een wonder, als enige van de voorwerpen uit de Bataviase schatkamer, ontkwam aan de brand, zij het beschadigd. De conservator van de oudheidkundige afdeling schreef in 1931, nadat de schamele resten van de bruikleen waren terugontvangen in het museum, over de schade geleden in de schatkamer:

Niet minder dan veertien gouden en vier zilveren godenbeeldjes werden door de brand vernietigd, meer dan twee derde van wat de collectie in totaal aan deze voorwerpen bezat. Het eenige beeldje waarvan een - zwaar verminkt - overblijfsel werd terugontvangen is no. 486 , staande vierarmige Wisnu. ${ }^{57}$

Het beeldje verloor in de brand de zilveren rugplaat, maar het zilveren voetstuk bleef gespaard. Het was in 1992 te zien op de tentoonstelling 'Het Goddelijk gezicht van Indonesië' in de Nieuwe Kerk te Amsterdam. ${ }^{58}$

Zelfs niet in de buurt van die hoge waarde van voornoemd beeldje kwam een gouden armband die in Rembang was gevonden en waarop twee tekens gegrift stonden, die de aandacht van het bestuur trokken. Voor $f 225$ nam het gouvernement de armband ten behoeve van het museum over. ${ }^{59}$ Het kon ook anders aflopen. In 1866 vond Pak Boengeng in de dessa Goenoeng Toegil (Probolinggo) een koperen busje met gouden en andere metalen voorwerpen dat het genootschap werd aangeboden voor $f 275$. Het genootschap wilde er niet meer voor geven dan de metaalwaarde, $f$ 185,11. Het gouvernement kwam er nog eens op terug: in Probolinggo zouden de voorwerpen voor circa $f 275$ verkocht kunnen worden. Het genootschap zwichtte niet en dus ging het busje met inhoud naar Probolinggo terug voor een verkoping, waarvan de opbrengst voor de helft naar Pak Boengeng zou gaan. In 1865 zag het genootschap twee keer van een kostbare vondst af ten gunste van Leiden: $f$ 160,65 en $f 115,25$ voor tweeëntwintig gouden boeddha-voorwerpen, vierendertig zilveren munten en nog eens elf gouden voorwerpen, alle uit de residentie

56 Notulen 1:305-6, vergadering 12-12-1863. Het beeldje was gevonden ten oosten van de dessa Paingan, residentie Kadoe en aan het genootschap aangeboden bij een brief van de eerste gouvernementssecretaris dd 2-11-1863.

57 Bosch en Le Roux 1931:672. Over de tentoonstelling en de brand: Bloembergen 2003:271316.

58 Fontein 1990:205-6, waar overigens in verband met dit voorwerp aan de brand, noch aan de schade gerefereerd wordt. Bij Fontein ook een afbeelding.

$59 \quad$ Notulen 1:81 (vergadering 24-2-1863) en 179 (vergadering 18-4-1863). 
Bagelen afkomstig. ${ }^{60}$

Al met al was het onderwerp 'overname' van opgegraven waardevolle voorwerpen niet meer weg te denken uit de bestuursvergaderingen. Het was echter niet de enige manier waarop de collectie werd aangevuld. Schenking bleef de meest voorkomende manier. Tegenover de vijftien aangekochte oudheidkundige voorwerpen, die het jaarverslag van 1863 meldde, stonden er drieëntwintig die door diverse personen waren geschonken. Vooraan stond gouverneur-generaal Sloet van de Beele, die vanaf zijn eerste reis naar Midden- en Oost-Java, de reis waarop hij Van Kinsbergen meenam, de belangen van het genootschap in het oog hield. Vier stenen met inscripties en twee voetstukken van lingga's (Soerabaija), vijf metalen voorwerpen uit Kadoe, en koperen, gouden en stenen sieraden van de landen van de Mangkoe Negoro, alle gemeld in de notulen van 2 augustus 1862, vonden hun weg naar het museum. ${ }^{61}$ Precies een jaar later was Sloet van de Beele weer in Midden-Java, waarvandaan hij een nieuwe schenking van onder meer twee inscripties en twee Nandi's meenam, terwijl de regent en de resident van Bandjar Negara aan Sloet in totaal zeven andere archeologische voorwerpen meegaven. ${ }^{62}$ Van een reis naar Oost-Java aan het eind van 1865 bracht de beschermheer wederom een aantal beelden en stenen mee, terwijl hij ook de aandacht vestigde op de grote beelden te Singosari, die al door Van Kinsbergen waren gefotografeerd.

Den resident heb ik opgedragen te onderzoeken, wat bij onderhandsche uitbesteding het vervoer van die voorwerpen met kleinere van Malang en een grooten beschreeven steen van Ngantang naar Soerabaija zoude kosten. Zijn die voorwerpen eens daar, dan zal dat vervoer naar hier weinig bezwaar opleveren. ${ }^{63}$

Het is duidelijk dat Sloet een voorstander was van het samenbrengen van archeologische vondsten in Batavia. Het denkbeeld dat beelden en stenen beter konden blijven waar zij waren, was niet aan hem besteed. Het citaat tekent Sloets belangstelling voor de zaken van het genootschap. Hij liet blijken dat hij zijn beschermheerschap serieus nam. Dat hij de taken van het museum breder zag dan het nog niet lang tevoren definitief afgeperkte gebied van de taal-, land- en volkenkunde van de archipel, blijkt uit andere schenkingen, waaronder een bronzen medaille geslagen door de provincie Gelderland ter herinnering van de hulp geboden door Willem III bij de watersnood van 1861 (Notulen 1:177). Sloet van de Beeles vertrek in oktober 1866 kwam een jaar vóór het gereedkomen van het museum aan het Koningsplein. Terug in Nederland

$60 \quad$ Notulen 3 (1865):35-6, 91, 131, 155.

61 TBG 12:586. Zie ook Notulen 1:162, jaarverslag.

62 Notulen 1:238, vergadering 1-8-1863.

63 Notulen 4:1-2, vergadering 16-1-1866. 
zette hij Van der Tuuk in voor de bestudering van zijn collectie Lampongse handschriften, terwijl hij voor de Koninklijke Akademie te Amsterdam sprak over de studie van de inheemse talen (Groeneboer 2002). De vergelijking met Van der Capellen dringt zich weer op. Deze immers toonde tijdens, maar ook na zijn Indische verblijf weer terug in patria, belangstelling voor de taal-, land- en volkenkunde van Nederlands-Indië.

Anderen, bestuursleden én gewone leden, behoorden eveneens tot de begunstigers van het genootschap. De tot erelid benoemde Netscher stuurde in 1862 vanuit zijn nieuwe standplaats Riouw een gebeeldhouwde kop en een gebakken steen, afkomstig van een hindoe-ruïne bij Kota Pinang (Siak). ${ }^{64}$ Van der Chijs droeg onder meer twee boeddha-hoofden bij, vermoedelijk van de Boroboedoer afkomstig en later nog een hindoe-kris (Notulen 2:264, 315). Het gewoon lid, de gouvernementssecretaris A. Loudon, bracht in januari 1862 vier kleine stenen Ganesha's aan, aangeduid als 'voorwerpen van ethnologischen aard', en een paar maanden later nog eens vijf beelden uit de hindoe-tijd. Toen hij later dat jaar terugkwam van zijn gezantschapsreis naar Siam nam hij diverse Thaise voorwerpen mee voor de collectie. ${ }^{65}$ Loudon werd in november 1864 tot bestuurslid en direct tot voorzitter gekozen. Zijn belangstelling voor het genootschap was voldoende geweest om hem meteen op deze post te brengen.

De fotograaf van het genootschap, Van Kinsbergen, droeg vruchten van zijn opgravingen bij Diëng aan. ${ }^{66}$ Ook schilder en genootschapslid Raden Saleh droeg oudheden bij. Door hem aangeboden koperen platen met inscripties werden bij de jaarvergadering van 1866 speciaal vermeld vanwege hun ouderdom (Notulen 4:145). De lijst is niet volledig, maar geeft aan hoeveel particuliere personen konden verwerven. Er ging veel van hand tot hand en veel bleef in particulier bezit. Het voorbeeld van beschermheer Sloet van de Beele had in ieder geval het effect dat het tot navolging opriep. De overheid zelf was uiteraard een groot leverancier van voorwerpen.

Het is niet eenvoudig om, ondanks al deze meldingen in de notulen, een beeld te krijgen van wat er in de periode tot de opening van het nieuwe museum binnenkwam. De omschrijvingen zijn veelal vaag. Nummers en precieze aanduidingen van de herkomst ontbreken in de notulen. Dateringen worden zelden gegeven, terwijl, om de zaak nog ingewikkelder te maken, archeologische en etnologische aanwinsten door elkaar worden opgesomd, zodat soms op basis van de vage omschrijving niet valt op te maken om wat voor een aanwinst het gaat. Toch werd ook hier, stapsgewijs, vooruitgang

64 TBG 12:228, vergadering 7-6-1862.

65 TBG 12:229 (vergadering 4-1-1862), 536 (vergadering 5-4-1862) en 548 (vergadering 3-51862).

66 Notulen 3:25, vergadering 10-2-1865; 4:87, vergadering 27-3-1866. 
geboekt. Levyssohn Normans Katalogus van de ethnologische afdeeling (1868) bracht een scheiding aan in de collectie. Dat Levyssohn Norman deze catalogus samenstelde en dat deze gedrukt werd, is nog bewonderenswaardiger als we dit afzetten tegen de lijdensweg die de catalogus van de archeologische afdeling wachtte. W.P. Groeneveldt kreeg in 1877 toestemming om tot drukken ervan over te gaan. ${ }^{67}$ Hoewel deze lijdensweg grotendeels buiten het tijdsbestek van dit boek valt, dient er hier enige aandacht aan te worden besteed omdat de naam van Friederich er aan verbonden is.

Friederich had zich in juni 1863 gemeld bij het genootschap en vond het bestuur bereid van Brumunds papieren afschriften te laten maken ten behoeve van zijn regeringsopdracht. ${ }^{68}$ Daarmee leek de verhouding tussen de voormalige adjunct-bibliothecaris en het genootschap weer in orde. $\mathrm{Na}$ 1863 bleef Friederich uit het blikveld van het genootschap. Over de vorderingen die hij maakte bij het verzamelen van inscripties en de bestudering ervan leest men in de notulen niets. Sloet van de Beele schreef in 1866 in zijn lijvige memorie van overgave over de verplichting die Friederich had om halfjaarlijks over de voortgang van de opdracht te rapporteren. 'Hieraan heeft hij nimmer voldaan, niettegenstaande herhaalde aanmaningen.' Hij voegde er vergoelijkend aan toe, 'dat het aan geleerden, die zich met een onderzoek van grooten omvang bezig houden, moeijelijk te vergen is op gezette tijden verslag van hunnen arbeid te doen'. ${ }^{69}$ Toen Friederich in juni 1868 eindelijk met een verslag kwam, was dat voor de directeur van onderwijs, L.W.J. de Waal, aanleiding om advies te vragen aan het genootschap, onder meer omtrent de vraag 'welke maatregelen zouden kunnen worden genomen om van de aan de ambtenaar Friederich opgedragen werkzaamheden spoedige en goede uitkomsten te verkrijgen'. ${ }^{70}$ Het oordeel van het genootschap was hard. Friederich kon beter van zijn taak worden ontheven.

Eene opdragt als die van de Regering aan de Heer Friederich is geheel eene zaak van vertrouwen. Wordt dat beschaamd en blijven alle aansporingen vruchteloos, dan is, dunkt ons, de eenige afdoende maatregel, die te nemen valt, aan zoodanige opdragt een einde te maken.

Het verslag van Friederich van juni 1868 werd 'een uiterst schrale oogst van vijfjarigen wetenschappelijke nasporingen' genoemd.

67 De voltooiing van de catalogus zou nog tien jaar vergen (Notulen 15:118-9, vergadering 7-81877).

68 Notulen 1:223-6, brief van Friederich, 26-6-1863.

69 NA Koloniën 2.10.03 nr 24 'Overzicht van den Staatkundigen toestand van Nederlandsch Indië op het tijdstip der aftreding van den Gouverneur Generaal Sloet van de Beele.' 1866, p. 1471-2.

70 ANRI KBG Dir 0997, citaat uit het antwoord van het genootschap, 4-3-1869 nr 24. 
Van de hem oorspronkelijk opgedragen verzameling, bewerking en verklaring der oud Ind. opschriften op steen en in metaal, welke steeds door hem als hoofdzaak had behoren te worden aangemerkt, vindt men daarin nagenoeg geen spoor. [...] Het geheel draagt het kenmerk van met overhaasting te zijn zamengesteld om tot bevrediging der Regering toch maar het een en ander te leveren. Grote wetenschappelijke waarde heeft het niet. ${ }^{71}$

Gezien het persoonlijke karakter van de zaak, werden de stukken over de beëindiging van de opdracht niet in de Notulen geplaatst. In het archief zijn ze echter te vinden. ${ }^{72}$ In februari 1869 had Friederich een aanvrage gedaan om met ziekteverlof te kunnen gaan. Dat verzoek werd niet ingewilligd. Friederich werd eervol ontslagen waarna in juni 1869 het besluit volgde hem pensioen te verlenen. Dat er teleurstelling was over het niet afronden van de inscriptie-opdracht, is duidelijk (Krom 1923, I:17-8).

Voordat het tot Friederichs ontslag kwam, had het genootschap nog eens een beroep op hem gedaan. Toen eind 1867 de archeologische verzameling in het nieuwe museum zou worden opgesteld, deed zich de behoefte aan een catalogus van die collectie opnieuw voelen, te meer waar die van de etnologische collectie door Levyssohn Norman al was gemaakt. Het was Cohen Stuart, die op 14 januari 1868 voorstelde

den heer R.H.Th. Friederich uit te noodigen, om den catalogus der archeologische verzamelingen des Genootschaps, waarmede hij reeds voor 20 jaren met Dr. W.R. van Hoëvell een aanvang heeft gemaakt, te willen voltooien en de daartoe behoorende voorwerpen tevens te rangschikken. ${ }^{73}$

Friederich werd door dit voorstel, dat direct werd aangenomen, opnieuw aan het genootschap verbonden met een belangrijke taak. Hij liet op 20 maart weten de opdracht 'volgaarne' te willen aannemen, maar eerst een reactie te willen afwachten van de gouverneur-generaal, in wiens opdracht hij de inscriptie-verzameling aanlegde. ${ }^{74}$ In mei van dat zelfde jaar bleek uit een rapportage van sergeant N.W. Hoepermans, een van de militairen die Friederich bij zijn inscriptie-opdracht ter zijde stonden, dat er al tweehonderdtwintig stenen en achthonderd bronzen waren beschreven en gerangschikt. Hoepermans was van 1 april tot 21 mei 1868 in het museum werkzaam en de ordening was mogelijk geheel van zijn hand. ${ }^{75}$

71 ANRI KBG Dir 0997, citaat uit het antwoord van het genootschap, 4-3-1869 nr 24.

Notulen 6:86, vergadering 1-12-1868; 7:16, vergadering 4-3-1869.

Notulen 6:10. De brief aan Friederich van dezelfde datum in ANRI KBG Dir 0997, uitgaande brieven $1868 \mathrm{nr} 9$.

$74 \quad$ Notulen 6:24, brief van Friederich van 20-3-1868.

75 Friederich vroeg op 13-6-1868 vanuit Buitenzorg aan het genootschap een verklaring dat Hoepermans tussen 1-4 en 21-5-1868 werkzaam was geweest 'aan het Archeologisch Museum van het Bataviaasch Genootschap (ANRI KBG Dir 0998). Tijdens de vergadering van 26-5- 
Op het werk dat Van Hoëvell en Friederich al in de jaren 1840 aan de verzameling hadden verricht, werd voortgebouwd. Van de ruim honderdzeventig voorwerpen, beschreven op een collectie van circa vierhonderd in 1850, naar de meer dan duizend die Hoepermans in mei 1868 meldde, was een enorme vooruitgang. Drie bronzen werden als vermist opgegeven. Friederich antwoordde op 13 juni 1868 op een vraag van het bestuur of hij zich iets wist te herinneren van de vermissingen. Hij verwees naar wat er twintig jaar eerder was gepasseerd rond vermiste bronzen en handschriften. Van Hoëvell zou de zestienarmige Brahma (nummer 59 van de catalogus) mee naar huis hebben genomen. Ook voor een vermiste beker met tekens van de dierenriem en voor twintig Maleise manuscripten wees Friederich beschuldigend naar Van Hoëvell, maar de vermiste Shiva en Boeddha (nummers 23 en 90 van de catalogus) waren volgens hem na Van Hoëvells vertrek nog aanwezig geweest. De notulen noemen geen namen, al kan het niet anders of de naam van Van Hoëvell moet in de vergadering gevallen zijn. Het bestuur liet de zaak liever rusten. Een omstandig rapport over de oudheidkundige verzameling, dat Friederich in het vooruitzicht stelde, was op dat moment belangrijker. ${ }^{76}$

Hoepermans was degene die het werk deed. Het is de vraag of Friederich zich überhaupt in het museum liet zien. Hoepermans was begonnen als tekenaar en opmeter, opgeleid in Leiden in het maken van afdrukken van inscripties. Hij had zich in de loop van de meer dan vijf jaar waarin hij in Friederichs kielzog werkzaam was geweest, opgewerkt tot een deskundige. Hij was degene die de lijsten van de verzameling, het basiswerk voor de catalogus, had opgesteld, die begin 1869, 'sedert geruimen tijd bij zijn chef Dr R.H.Th. Friederich in behandeling' waren. ${ }^{77}$ De analogie met de in 1845 door Van Hoëvell uit het genie-depot geplukte Friederich, die zich daarna tot wetenschappelijk ambtenaar had opgewerkt, dringt zich op, vooral als men leest dat het Hoepermans was die in april 1869 de catalogus van de archeologische verzameling indiende. Hij stuurde tevens drie archeologische opstellen in. De assistent had de plaats van de meester ingenomen (Notulen 7:2).

Terwijl het genootschap nog hoopte dat Friederichs bewerking van de lijst van Hoepermans iets zou opleveren dat op een catalogus zou lijken, besloot het gouvernement tot Friederichs ontslag. Aandringen op het afronden van de catalogus, zoals het bestuur in januari en maart 1869 deed, had geen zin

1868 werd Hoepermans' brief van 17-5-1868 besproken. Daarin werden de aantallen beelden genoemd, alsook de vermissingen gemeld. Notulen 6:48-9.

76 Notulen 6:63, brief van Friederich van 13-6-1868. De originele brief is te vinden in de bundel correspondentie over de jaren 1867-1868 (ANRI KBG Dir 0998). Over de collectie Van Hoëvell recentelijk: Legêne 2005.

$77 \quad$ Notulen 7:8, vergadering 5-1-1869, brief van Hoepermans van 25-12-1868. 
meer. ${ }^{78}$ Het ontslag doorkruiste alle hoop op een bijdrage van Friederich. Het gouvernement stond de papieren en goederen van Friederich en Hoepermans aan het genootschap af, die er een commissie van drie personen op afstuurde. Het bestuur bleef zitten met een catalogus waarvan het driemanschap, de bestuursleden J.J. van Limburg Brouwer, Stortenbeker en Cohen Stuart, oordeelde dat die 'eene algeheele omwerking' diende te ondergaan. Hoepermans zou gepolst kunnen worden om te zien of hij daar, op aanwijzingen van de directeur van het museum, Levyssohn Norman, toe bereid was, echter niet dan nadat het gouvernement eerst over de toekomst van de sergeant-zonderbaas had besloten. ${ }^{79}$ De slotsom voor het genootschap was somber. Het had geen gedrukte catalogus, wel in handschrift de aanzet tot een catalogus. Het had een zeventigtal afdrukken van verspreide inscripties, maar geen persoon die deze collectie kon publiceren. Een stapel papieren en aantekeningen, aanzetten tot artikelen en studies, maar slechts een paar publicabele artikelen, twee van Friederich (1870 en 1875) en een van Hoepermans (1874, TBG 19, 21 en 23; Krom 1923, I:18). Friederich ging terug naar Nederland, Hoepermans maakte de catalogus niet af. Levyssohn Norman had wel een ingedeelde, genummerde en gerubriceerde archeologische collectie. Een van de commissieleden, Van Limburg Brouwer, zette later het werk aan de catalogus voort. In 1874 werd hem gevraagd hoe het daarmee stond, waarop hij vanuit Fort de Kock antwoordde dat hij het onmogelijk kon voltooien zonder eerst enige tijd in Batavia te verblijven (Notulen 12:11, 35). Pas in 1877 werd, zoals reeds vermeld, het werk aan de catalogus afgemaakt door Groeneveldt, al duurde het nog tien jaar voordat de oudheidkundigen die in handen konden nemen (Groeneveldt 1887). Dat de collectie toen bestond uit 2024 voorwerpen, waarvan 1856 in steen en metaal, waaronder 639 beelden, geeft aan dat de aanwinsten sinds 1850 de collectie hadden doen vervijfvoudigen.

Verzamelingen: etnologische voorwerpen

Zoveel als er te doen was over de catalogus van Friederich en Hoepermans, die in gewijzigde vorm pas in 1887 verscheen, zo weinig is er te vertellen over de voorgeschiedenis van de catalogus van de etnologische afdeling, die al in 1868 beschikbaar kwam en die de bezoeker van het nieuwe museum direct van dienst kon zijn. Bij het vertrek van Netscher naar Riouw in mei 1861 had Der Kinderen zowel de secretarisplaats bezet als de zorg voor het museum op zijn schouders genomen. ${ }^{80}$ Toen in juni 1862 bleek dat Der Kinderens drukke

78 Twee brieven van het bestuur aan Friederich, 5-1-1869 nr 8 en 4-3-1869 nr 23 in ANRI KBG Dir 0997.

79 Verslag van de commissie in Notulen 7:bijlagen $\mathrm{M}$ en $\mathrm{N}$.

80 TBG 11:432, vergadering 4-5-1861. 


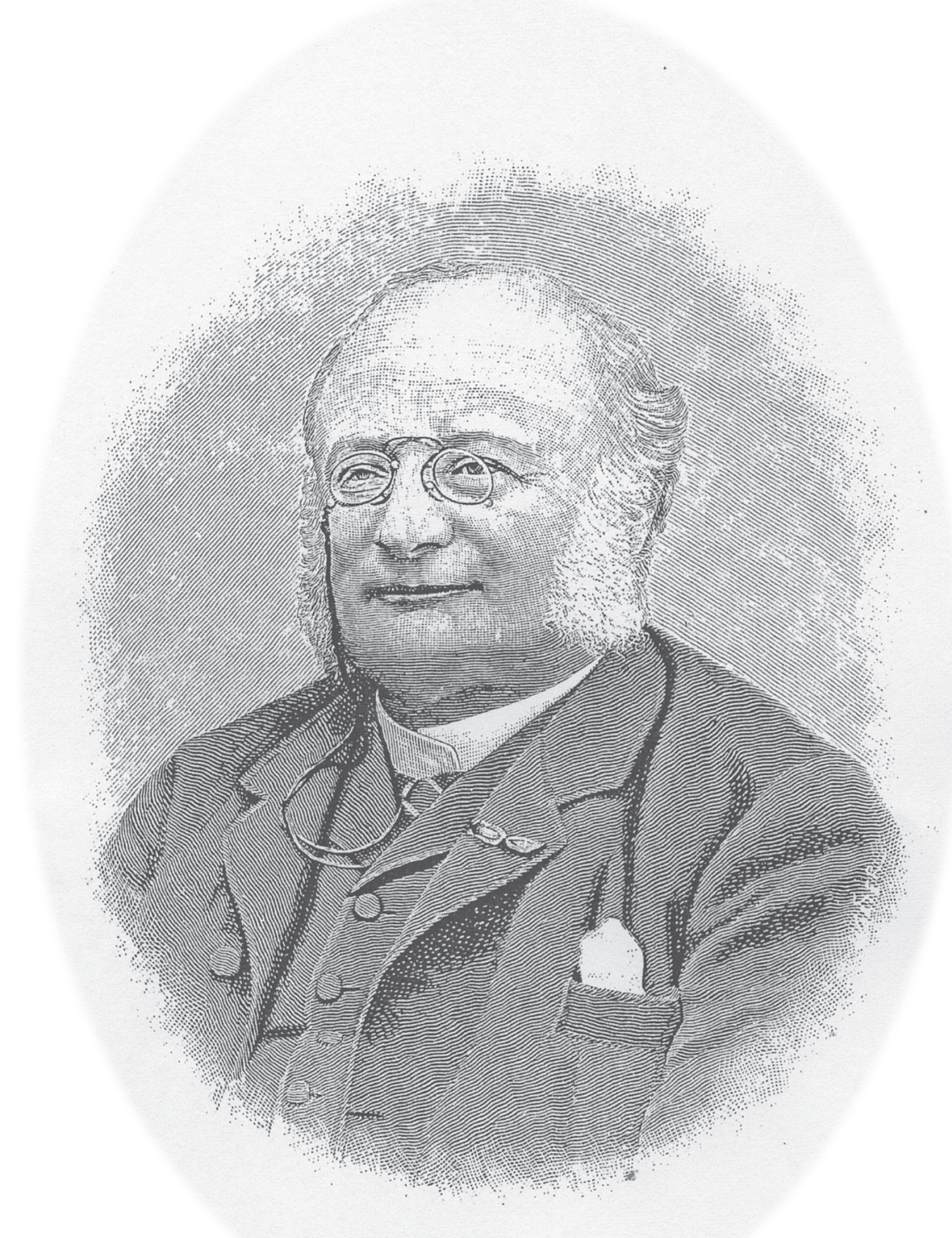

Portret van Henry David Levyssohn Norman, directeur van het museum en secretaris van het genootschap, lithografie uit Eigen Haard

(collectie RKD/Iconografisch Bureau Den Haag) 
ambtsbezigheden het hem onmogelijk maakten beide functies te blijven vervullen, was de plaats van directeur over de 'natuur- en kunstverzameling' van het genootschap overgenomen door de jeugdige referendaris bij de Algemene Secretarie, Henry David Levyssohn Norman (1836-1892) ${ }^{81}$

Levyssohn Norman was in Den Haag geboren. Hij studeerde rechten in Leiden, waar hij in 1857 promoveerde op een proefschrift over De Britsche heerschappij over Java en onderhoorigheden 1811-1816. Het jaar daarna slaagde hij tevens voor het Delftse examen voor Oost-Indisch ambtenaar, waarna hij nog vóór het einde van 1858 in Batavia arriveerde. Daar kwam hij te werken bij de Algemene Secretarie, waar hij in korte tijd opklom tot hoofdcommies en referendaris. Met hem trof het genootschap, dat hem in april 1862 tot bestuurslid had gekozen, het buitengewoon. De 25-jarige directeur had volgens het nieuwe reglement onder meer de zorg voor de catalogisering van de etnologische collectie tot taak. Dat vatte hij serieus op. In maart 1863 was het catalogiseerwerk zelfs al voor een groot deel klaar. De voorwerpen van de buitengewesten waren alle beschreven en de directie hoopte binnen een jaar de gedrukte catalogus te kunnen aanbieden. ${ }^{82} \mathrm{Nu}$ had Levyssohn Norman kunnen profiteren van voorwerk dat door Von Gaffron, Netscher en vooral Von Rosenberg was verricht. Von Rosenberg had in 1858 een indeling voor de catalogus gepresenteerd. In 1864 heette de etnologische catalogus van directeur Levyssohn Norman bijna voltooid. De publicatie werd nog opgehouden doordat de herkomst van sommige voorwerpen niet te achterhalen was. Ook hoopte de directie toen nog de catalogus van de mineralogische collectie aan het geheel te kunnen toevoegen (Notulen 2:136). In 1865 werd dat probleem in ieder geval opgelost, toen deze deelcollectie aan de Natuurkundige Vereeniging werd overgedragen. Toch zou het nog tot 1868 duren eer Levyssohn Normans catalogus zou verschijnen. ${ }^{83}$ Dat was echter, zoals al gezegd, een snelle sprong vooruit vergeleken bij de treurige gang die de catalogus van de oudheidkundige verzameling doormaakte. Dat Levyssohn Norman, inmiddels opgeklommen tot gouvernementssecretaris en secretaris van de Raad van Indië, zijn functie als directeur van het museum behield en in 1864 zelfs de post van secretaris van het genootschapsbestuur erbij nam, is een aanwijzing voor zijn bijzondere toewijding aan het genootschap. ${ }^{84}$ De Koninklijke Akademie te Amsterdam erkende zijn verdiensten

\footnotetext{
81 TBG 12:550, vergadering 7-6-1862. In 1862 was er weer niet van het 'museum' sprake.

TBG 1:161, vergadering 27-3-1863.

Notulen 3:67-9 over het afstoten van de mineralogische verzameling.

Over de bestuurswijziging van 6-8-1864, veroorzaakt door de benoeming van Van der Chijs tot inspecteur van het Indisch onderwijs, waardoor secretaris Mr. W. Stortenbeker de bibliothecarisplaats van Van der Chijs overnam en Levyssohn Norman de plek van Stortenbeker erbij nam, Notulen 2:214-5.
} 
door hem tot correspondent te benoemen. In mei 1869 legde hij zijn functie als directeur van het museum neer. Pas in oktober 1869, met zijn bevordering tot directeur van Binnenlands Bestuur in het vooruitzicht, verzocht hij het bestuur om een opvolger voor hem te zoeken als secretaris. Dat werd toen Van Limburg Brouwer, die hem in mei ook als directeur van het museum was opgevolgd. ${ }^{55}$ Levyssohn Norman werd later algemeen secretaris en beëindigde zijn Indische carrière als lid van de Raad van Indië (1877-1884). Zoals hij als genootschapssecretaris diende onder voorzitter A. Loudon, was hij als algemeen secretaris de rechterhand van diens broer, gouverneurgeneraal James Loudon. Het sympathieke levensbericht van de hand van zijn medebestuurslid, de latere directeur van de faktorij van de Nederlandsche Handelsmaatschappij, N.P. van den Berg, schetst een beeld van een zeer sociaal en bewogen man, die belang stelde in toneel en muziek (N.P. van den Berg 1895).

Als we de etnologische verzameling wat nader willen bekijken, zijn er naast de catalogus van 1868 natuurlijk ook weer de notulen. Afgaande op de meldingen in het register van Janssen, dat we overigens met voorzichtigheid moeten gebruiken, geldt voor de periode 1857-1866 dat de aandacht niet op Java geconcentreerd was. Anders dan bij de oudheidkundige verzameling, waar Java nu eenmaal een concentratie aan primaire bronnen bezat, was de etnologische aandacht juist naar buiten gericht. De aandacht ging in overgrote mate naar Sumatra, Borneo, Celebes en de kleinere eilanden. Dat komt overeen met de veranderingen die het gouvernement in de loop van het decennium 1850-1860 langzaam toeliet. Er kwam meer belangstelling voor de buitengewesten, waardoor verschillende gebieden binnen het aandachtsveld van militairen, bestuursambtenaren en zendelingen-missionarissen kwamen, meer dan in de periode tot 1850 het geval was geweest. Zo weerspiegelen de contacten met de wereld buiten Java, die het genootschap had, de veranderingen in de archipel, zelfs nog vóór de grote, op exploratie gerichte expedities van de jaren 1870. De Jong wijst in zijn Waaier van het fortuin op het geleidelijk binnen de Nederlandse invloedskring komen van Bangka, West-Borneo, Zuidoost-Sumatra en Ceram. Hij licht toe hoe in de tweede helft van de jaren vijftig Timor, Flores, de Molukken, Bone en Bandjermasin het doelwit werden, terwijl in de jaren 1860 Sumatra's Oostkust, Siak, de Lampongs en Deli binnen de Nederlandse invloedssfeer geraakten (De Jong 1998:233-41). Door de notulen en het Tijdschrift lopend, ziet men, net als in de collectie etnografica de aandacht van Java wegdrijven naar de hierboven genoemde gebieden.

85 Over H.D. Levyssohn Norman: ENI s.v. Levyssohn Norman. Over zijn aftreden als directeur van het museum, Notulen 7:33-4 (vergadering 4-5-1869) en als secretaris Notulen 7:51 (vergadering 5-10-1869). Op 18-12-1869 volgde zijn bevordering tot directeur van het Binnenlands Bestuur. 
In de Verhandelingen is deze verschuiving minder duidelijk, doordat er minder frequent delen verschenen en de grote monografieën voor een deel bibliografisch van aard waren, dan wel als catalogus fungeerden. De tekstedities waren vooral op het Javaans en het Chinees gericht.

Als we kijken naar het actieve verzamelbeleid, dan zien we dat nog steeds gegrepen werd naar het aloude middel van de circulaire, waarin leden en bestuursambtenaren gevraagd werd om voorwerpen te verzamelen en naar Batavia te zenden. In dat opzicht was er sinds 1779, toen de directie de eerste vragenlijst uitstuurde, niets veranderd. Toen Netscher in 1857 een oproep opstelde, had men, door de Javaanse en Maleise vertaling ervan in de krant te plaatsen, ook Indonesische inzenders proberen te bereiken. ${ }^{86}$ Een jaar later kwam naar aanleiding van een zeer geprezen monografie over de zuidelijke districten van het regentschap Tjiandjoer door controleur T.W. Hoogeveen, de gedachte op om opnieuw een circulaire te laten rondgaan, nu gericht op de controleurs, om soortgelijke arbeid uit te lokken voor 'de meest verschillende gedeelten van Java'. Het bestuur zag toen bezwaren, hoewel het van mening bleef dat de circulaire wel dé manier bleef om 'van tijd tot tijd de aandacht openbaar te vestigen op meerdere punten, tot de ethnologie, statistiek, archaeologie en linguistiek van den indischen archipel betrekking hebbende, waaromtrent de wetenschap gegevens of nader kennis verlangt' ${ }^{87}$ Daarop werd in september 1858 wel een circulaire opgesteld, waarin een aantal desiderata van het genootschap werd opgegeven. Naast precieze opgaven van oudheidkundige aard, vroeg het genootschap naar wapens, kledingstukken, versierselen, talismannen. Het gaf daarbij de gewesten op, waarvan de collectie aanvulling verdiende: 'Atjeh, Oostkust van Sumatra, Palembang, Lampongs, Bangka, Zuidelijk en Oostelijk Celebes, Menado, den ganschen Molukschen archipel, Nieuw Guinea, Timor, Bali, Lombok en verdere oostelijke eilanden'. ${ }^{88}$ Java behoefde kennelijk geen aandacht.

Een aanschrijving van het genootschap of een van het gouvernement, dat maakte nogal verschil, vooral voor de aangesproken hoofden van de verschillende gewesten, die in hun ambtsijver nu eenmaal meer letten op de verzoeken uit Buitenzorg dan op die afkomstig van een particuliere instelling als het Bataviaasch Genootschap. Van het gouvernementsbesluit van 24 mei 1862 waarin de hele opdracht aan Brumund lag besloten en waarin ook de etnologie aandacht kreeg, mocht meer worden verwacht. De hoofden van gewestelijk bestuur werden - naar de woorden van het gouvernementsbesluit - uitgenodigd 'om ten behoeve van het gouvernement, zoveel hun zulks

86 TBG 7:257, vergadering 18-5-1857.

87 TBG 8:104, vergadering 19-6-1858. Het lijkt goed mogelijk dat het alweer Netscher was die de zaak aankaartte.

88 TBG 8:293, vergadering 16-9-1858. 
mogelijk is, ethnographische verzamelingen te maken, met last om die aan het Bataviaasch Genootschap van Kunsten en Wetenschappen op te zenden'. ${ }^{89} \mathrm{Al}$ gauw bleek dat de aanschrijving eerder vragen had opgeroepen dan dat ze residenten aan het werk had gezet. Op een collectie voorwerpen uit Deli na, die door de altijd ijverige resident van Riouw, Netscher, was gestuurd, had het bestuur tevergeefs op inzendingen gewacht. Toen op initiatief van Der Kinderen op 4 september 1863 een herinnering aan de gewestelijke bestuurshoofden was uitgegaan, kwamen de reacties snel binnen, in oktober drie, in december nog eens zes andere (Notulen 1:298, 319).

Het ging niet om voorwerpen, want de (assistent-)residenten bleken met de aanschrijving van het gouvernement problemen te hebben gehad. Die was te vaag geweest dan dat zij ermee uit de voeten konden. De resident van de Lampongse districten, F.M.G. van Cattenburch, had het in zijn brief van 20 oktober 1863 kernachtig uitgedrukt. De zinssnede 'zooveel zulks mogelijks is' uit het gouvernementsbesluit had hem tot de slotsom doen komen dat het aanleggen van de etnologische verzameling kosteloos moest gebeuren. 'Welligt is het gouvernement in het denkbeeld, dat die verzameling, misschien met moeite, maar altijd zonder groote uitgaven te vorderen, te maken zou zijn' (Notulen 1:319). De Lampongse resident sneed aansluitend een stel relevante vragen aan: als het niet kosteloos hoefde, voor wiens rekening kon dan worden ingekocht, en wie zou de inkopen beoordelen? Kon het eenmaal aangekochte door het Bataviaasch Genootschap worden afgewezen? Hoe zat het dan met de gemaakte kosten? Ter illustratie lichtte hij toe dat er in de Lampongs veel van buiten werd aangevoerd, dat dus niet authentiek Lampongs was, en dat het oorspronkelijk Lampongse, zoals de hoofdtooien van jonge meisjes, kostbaar was. Het bestuur moest zich daarbij een bedrag tot $f 300$ voorstellen, terwijl oor-, hals- en armversieringen eveneens duur zouden uitvallen (Notulen 1:320-1).

Het bestuur begreep dat er iets moest gebeuren, wilde men nog enig profijt trekken van de gouvernementele aanschrijving over het verzamelen uit 1862. Het wilde bij nadere circulaire uitleg geven over wat men onder een etnologische verzameling verstond. Verder wilde het de regering een mededeling ontlokken over de kosten. Tenslotte wilde het bestuur het bezwaar van gebrek aan tijd, dat door sommigen was aangevoerd, opheffen door verzamelgebieden aan te geven waarop de ijverigen zich in eerste instantie zouden moeten richten. Zo kwam er een prioriteitenlijst die begon met inheemse wapens en daarna muziekinstrumenten, vervolgens kledingstukken en lijfsieraden, daarna landbouwgereedschappen en huisraad (Notulen 1:323). In februari 1864 moest het gouvernement toegeven dat het bij de aanschrijving 
van mei 1862 het probleem van de kosten, die het aanleggen van een verzameling etnografica met zich zou meebrengen, had onderschat.

De regering kan niet ontkennen, dat $\mathrm{Zij}$ bij het doen van bovenbedoelde uitnoodiging op eenige welwillendheid gerekend heeft; evenwel is $\mathrm{Zij}$ genegen om de voorwerpen, die niet anders dan tegen betaling te verkrijgen zijn voor de daarvoor gestelde prijzen over te nemen, in welk geval alsdan bepaalde voorstellen van UwEdG. tegemoet worden gezien. ${ }^{90}$

Het bestuur van het genootschap liet daarop op 15 april 1864 een circulaire uitgaan om de zaak van het verzamelen nog eens uit te leggen en aan te geven dat de prioriteit bij inheemse wapens zou komen te liggen. Daarop reageerde prompt in juni resident Van Cattenburch met de geruststellende mededeling dat hij begonnen was met het verzamelen en dat hij binnenkort drie soorten wapens zou aanbieden. ${ }^{91}$

Daarmee leek de zaak voor een ieder duidelijk geworden. Dat dacht Levyssohn Norman niet. Hij wees er tegen het einde van 1864 op dat er weinig reacties op de circulaire van 15 april waren binnengekomen en weet dat aan de omslachtige werkwijze die bij die circulaire was vastgesteld. De gewestelijke bestuurders moesten eerst een opgave doen van de wapens die zij wilden inzenden, met tekeningen plus een opgave van de kosten, waarna het genootschap zou aangeven welke daarvan daadwerkelijk konden worden aangekocht. Levyssohn Norman vond het een onpraktische werkwijze en dacht dat het beter helemaal aan de hoofden van bestuur kon worden overgelaten. ${ }^{92}$ Een collectie van bijna driehonderd voorwerpen uit de residentie Kadoe was de eerste inzending die na de circulaire van 15 april binnenkwam. De controleurs E.D. Levyssohn Norman, van Magelang en broer van de directeur van het museum, en W.L.H.A. de Harloff, van Prapak, hadden tot tevredenheid van hun eigen resident en het genootschapsbestuur niet alleen de verzameling bijeengebracht, maar ook een 'met zorg uitgewerkte catalogus' ervan meegestuurd. Deze was zo nuttig dat Cohen Stuart er nog de suggestie bij deed de namen van de voorwerpen ook in het Javaanse schrift in de catalogus op te nemen, naast de Latijnse karakters waarin ze waren opgenomen. ${ }^{93}$

Wapens waren al sinds 1859 een aandachtspunt geweest. In het vorige hoofdstuk werd al het besluit gememoreerd om wapens, kledingstukken en

\footnotetext{
90 Notulen 2:60, vergadering 12-3-1864. De circulaire aan de gewestelijke besturen waaruit geciteerd wordt, is van 8-2-1864 $\mathrm{nr} 274$.

$91 \quad$ Notulen 2:173-4, vergadering 11-6-1864.

92 Notulen 2:304, vergadering 5-11-1864.

93 Notulen 2:205, 257 en 303. De resident had in eerste instantie aangekondigd dat alle vier controleurs van zijn residentie doende waren (brief van 18-7-1864). Per brief van 19-10-1864 waren het er twee, die hun collectie bleken ingestuurd te hebben.
} 
andere voorwerpen, die als huldeblijk aan de vertegenwoordigers van het bestuur werden aangeboden vanwege hun historische waarde als een aparte afdeling aan de verzameling van het genootschap toe te voegen. ${ }^{94}$ Daarna was de maatregel gevolgd op grond waarvan bij expedities veroverde wapens in de genootschapsverzameling konden terechtkomen. ${ }^{95}$ Daarbij gevoegd kwam nu de aanschrijving over wapens, die op 15 april 1864 van het genootschap was uitgegaan. Tussen 1859 en 1866 zijn er al zo'n vijftigtal meldingen van binnengekomen wapens. Bij sommige van deze meldingen ging het om grotere groepen voorwerpen, zodat het al met al om honderden afzonderlijke exemplaren ging. De resident van Madoera, N.D. Lammers van Toorenburg, bracht het bestuur op het idee om contact te zoeken met kantoren van justitie en politie waar zich inheemse wapens zouden kunnen bevinden. Tegen deze manier om de verzameling uit te breiden had het gouvernement echter bezwaar (Notulen 2:187, 222).

Een ander specialisatiepunt in de collectie vormde een groep 'bewerktuigde wigvormige stenen' of wiggen, die binnen het belangstellingsgebied van het genootschap waren gekomen door een schenking van 86 van die stenen door A.W. Kinder de Camercq, bij diens vertrek naar Europa in 1862. De inzender wees erop dat de stenen bekend waren als 'batoe goentoer' (donderstenen) en beval nader onderzoek aan. Hij twijfelde er niet aan of zijn stenen, die in West- en Midden-Java waren opgegraven, behoorden tot een pre-hindoeïstische periode. Hij wees op hun gebruik als vuurstenen bij de bevolking. ${ }^{96}$ Hoewel de ouderdom van deze wiggen eerder een plaats in een prehistorische verzameling rechtvaardigde, is het begrijpelijk dat het actieve gebruik dat ervan werd gemaakt door de bevolking ze voorlopig in de etnologische collectie deden belanden. Het bestuur liet er geen gras over groeien en stuurde een circulaire om de leden op deze merkwaardige stenen te wijzen en inzendingen uit te lokken. ${ }^{97}$ Beschermheer Sloet betoonde zich weer een ijverig inzender. Hij stuurde eerst een Djokjase wigge en in december 1863 nog eens elf van die vuurstenen, pijlpunten en mesjes die in Ede (Gelderland) waren gevonden en die op verzoek van Sloet door de directeur van het Leidse Rijksmuseum van Oudheden waren gestuurd. Ze konden dan dienen voor de vergelijkende etnologie in Nederlands-Indië. Nog weer later stuurde de gouverneur-generaal een Overijsselse wigge, die van Sloets broer, B.W.A.E. baron Sloet tot Oldhuis, afkomstig was, met hetzelfde doel. ${ }^{98}$ De wiggencir-

TBG 9:9, 43, vergadering 6-11-1858 en 5-2-1859.

TBG 9:37, 42, vergadering 5-2-1859.

Notulen 1:48-9, vergadering 22-11-1862.

Notulen 1:153. De circulaire was van 1-1-1863.

Notulen 1:153 (voor de Djokjase wigge), 308 (voor de Edese) en Notulen 2:236 voor de Overijsselse. 
culaire had een positief effect. Vóór het eind van 1864 waren er nog eens acht andere inzendingen en bleek de collectie sinds de schenking door Kinder de Camercq verdubbeld. ${ }^{99}$ Op zijn beurt zorgde het bestuur er weer voor dat de Britse arts J. Barnard Davis uit Shelton een tiental Javase donderstenen ontving voor diens vergelijkend onderzoek. ${ }^{100}$

Was de circulaire voor de etnologische verzameling een belangrijk hulpmiddel, het bestuur vatte de zaken ook gerichter aan door onderzoekers persoonlijk aan te schrijven en hen om medewerking te verzoeken. Deze werkwijze had in 1856 van de exploratiereis naar Nieuw-Guinea 'een gansch museum' opgeleverd van voorwerpen van dat eiland (TBG 12:175-6). A. Bernstein, die in oktober 1860 tot lid was benoemd, omdat zijn ornithologisch onderzoek in de Grote Oost hem op zijn reizen in de gelegenheid zou stellen de belangen van het genootschap te behartigen, kreeg in juni 1862 een herinnering aan het verzoek om medewerking met de vraag op te geven wat hij er tot dan aan gedaan had. ${ }^{101}$ Toen hij daarop van zijn reis naar de Molukken en Nieuw-Guinea verslag deed, was dit nogal ontmoedigend. Hij had zo goed als niets voor het genootschap kunnen bemachtigen. Zijn vermelding echter van bepaalde doodsbeenkisten van de Tabellorezen en van Alfoerse schilden maakte het bestuur nieuwsgierig. De vermelding dat hij op reis zou gaan naar Halmaheira leidde tot het besluit hem $f 300$ toe te zenden met het verzoek zo'n Tabellorese doodsbeenkist en een collectie Alfoerse schilden aan te schaffen, alsook andere voorwerpen die hij op zijn reizen nog mocht tegenkomen. ${ }^{102}$ Verder werd de bioloog-geoloog-cartograaf Von Rosenberg in 1862 door het gouvernement als ambtenaar 'speciaal belast met het doen van reizen in het belang van natuurkundige onderzoekingen'. ${ }^{103}$ Het bestuur verzocht hem op zijn reis naar de Tanimbar-eilanden de belangen van het genootschap indachtig te zijn (Notulen 1:151-2). Von Rosenberg had echter lucht gekregen van de gunstige aanbieding van $f 300$ aan Bernstein, die hem het aankopen van voorwerpen gemakkelijker zou maken en vroeg dus bij het gouvernement of hij niet op dezelfde wijze kon worden behandeld. Bernstein bleek indertijd echter het geld weer te hebben teruggestuurd, omdat hij bereid was kosteloos voorwerpen aan het genootschap af te staan. Zo was de $f 300$ weer terug en kon nu voor Von Rosenberg worden gebruikt. ${ }^{104}$ In oktober 1864 greep het gouvernement, dat kennelijk uit het geval van Bernstein de lucht

\footnotetext{
99 De meldingen zijn toegankelijk via het Register op de Notulen over de jaren 1857-1866, Janssen 1867:29.

100 Notulen 3:107, vergadering 7-7-1865.

101 TBG 10:464, vergadering 6-10-1860; Notulen 12:567, vergadering 7-6- 1862.

102 Notulen 1:87-90, brief van 18-12-1862.

103 Over Rosenberg ENI (s.v. Rosenberg), waar ook het citaat uit afkomstig is. Verder Bakels en De Jonge 2001:11.

104 Notulen 2:223-4, vergadering 16-9-1864.
} 
van 'bijklussen' had gekregen, in en bracht onder Von Rosenbergs aandacht dat de door hem verzamelde etnologische voorwerpen eigendom waren van het gouvernement en dat hij dubbelen moest afstaan aan het museum van het genootschap. Tegelijkertijd liet het gouvernement Von Rosenberg weten dat het genootschap bereid was etnologische voorwerpen die hij zou verwerven, te bekostigen. ${ }^{105}$ Van al dit gekrakeel werd het museum uiteindelijk niet veel wijzer. Bernstein schonk in 1864 een aantal Halmaheirase voorwerpen, en zag daarbij fijntjes af van de mogelijkheid om een beroep te doen op gelden. ${ }^{106}$ Daarbij waren Alfoerse schilden, waarover eerder was gecorrespondeerd. Von Rosenberg droeg in 1864 een verzameling voorwerpen uit de residentie Menado en in 1866 een verzameling voorwerpen van de Aroe-eilanden bij. ${ }^{107}$ Vooral de Leidse collecties profiteerden van Von Rosenbergs reizen.

In tegenstelling tot de gouvernementele reizigers en natuuronderzoekers Von Rosenberg en Bernstein, die nogal wat over en weer correspondeerden eer het genootschap ook werkelijk voorwerpen van hen ontving, was de controleur van Tondano, later assistent-resident van Gorontalo, Johann Gerard Friedrich Riedel een ambtenaar die met de geringste aansporing van het genootschap activiteiten aan de dag legde, voor zowel het Tijdschrift als het museum. Riedel was in 1832 geboren in Tondano en was na een opleiding in Nederland in 1853 als ambtenaar naar Indië gekomen. Eenmaal terug in zijn geboortestreek legde hij zich toe op de taal en op de gebruiken van de Minahasa. Hij betekende veel voor de ontwikkeling van de handel in Gorontalo. De Minahasa was het genootschap niet onbekend, want de resident van Menado, A.J.F. Jansen, had in de jaren vijftig een tweetal artikelen over talen en dialecten en over de landbouw in de Minahasa aan het Tijdschrift bijgedragen. In 1862 was een rapport van de commissaris voor de residentie Menado, K.H. Tutein Nolthenius over verenigingen in de Minahasa ter beschikking gekomen en Van der Chijs, altijd alert, had gewezen op de mogelijkheid om informatie over de Alfoeren bij Riedel in te winnen (Notulen 1:32, 215). Deze reageerde daar in 1863 op met een artikel onder de titel 'Iets omtrent het landschap Bolaäng Mongondouw'. In hetzelfde jaar stuurde hij voor het eerst een verzameling voorwerpen uit Gorontalo, waaronder donderstenen die ter plaatse als amuletten werden gebruikt, gevolgd door een in 1864 via de resident van Menado aangeboden grotere verzameling van voorwerpen van de Tooen-oen Boeloe-stam. ${ }^{108}$ Hij stuurde ook een opstel over de stenen graven in de Minahasa mee en vermeldde dat

105 Notulen 2:242-3, brieven van 29-10-1864, waarvan het genootschap afschriften ontving.

106 Notulen 2:71-2, vergadering 12-3-1864.

107 Notulen 2:38, vergadering 9-2-1864; 4:95-6, vergadering 27-3-1866.

108 Notulen 2:36, brieven van Riedel van 23 en 26-12-1863; Notulen 2:81 en volgende een catalogus van de in april 1864 aangekomen voorwerpen. 
hij zich onledig hield met de vergelijkende taalstudie en al in zes streektalen boekjes had vervaardigd. Die durfde hij niet aan te bieden aan het gouvernement omdat de gouvernementsbesluiten over bekronen en drukken van leerboekjes in inheemse talen alleen over het Javaans, Maleis en Soendanees spraken. Riedel had daaruit afgeleid dat er geen beleid was, gericht op het stimuleren van andere streektalen. Mede door zijn aandacht voor de stenen graven (tiewoekar) kwam het genootschap in het bezit van zo'n grafsteen (Notulen 3:86). In 1864 stuurde Riedel twee beeldjes, een opstel over een ordalium, een soort godsgericht, en een grote verzameling voorwerpen uit vier verschillende landschappen van de Minahasa (Notulen 2:165, 170, 233). In 1866 opnieuw artikelen voor zowel het Tijdschrift als voor de Verhandelingen, als ook voorwerpen voor het museum (Notulen 4:31, 180, 251). Riedel was in alle opzichten het ideale, actieve lid voor het genootschap. Zowel taalkundige studies als historisch-etnologische opstellen vloeiden uit zijn pen. Hij was een systematisch verzamelaar en - geboortig uit de streek - precies de regiovertegenwoordiger, die het genootschap idealiter zich in andere streken ook zou wensen. De verzameling etnografische voorwerpen uit de Minahasa van het museum groeide dan ook aanzienlijk dankzij Riedel. Zijn overplaatsing naar Billiton, waar hij assistent-resident werd, was in zekere zin een verlies. In juni 1871 werd Riedel tot erelid benoemd. ${ }^{109} \mathrm{Hij}$ werd resident in Timor en later in Ambon en bleef na zijn pensionering in Indië wonen. Hij stierf in 1911 in Batavia (ENI s.v. Riedel).

Een bijzondere collectie in het museum vormde de verzameling rijkssieraden van de sultan van Bandjarmasin. De opvolgingsperikelen aan het Bandjarmasinse hof hadden vanaf 1852 tot problemen met het koloniale bestuur geleid, die uiteindelijk voerden tot de ondergang van dat rijk. In 1860 lijfde het gouvernement het grondgebied van Bandjarmasin in en verloren de rijkssieraden, symbolen van de waardigheid van de sultan, die in de laatste jaren in feite de leenman was geweest van het gouvernement, in de ogen van het koloniale bestuur hun betekenis. Ze werden hem afgepakt - het gouvernement sprak van 'afpakking' - en naar Batavia overgebracht. ${ }^{110} \mathrm{De}$ 'procesverbalen van afpakking' werden in juli 1861 door het gouvernement aan het genootschap gestuurd met het aanbod om daaruit voor het museum 'zoodanige voorwerpen te kiezen, welke uit een archeologisch oogpunt als zeldzaamheden dienden te worden bewaard'. Hoewel de eerste gouvernementssecretaris het archeologische belang in zijn brief als motief aanduidde, was er eerder sprake van een historisch-etnologisch belang. Het genootschap mocht vrijelijk kiezen. Alleen de in de collectie begrepen zeventig karaats

110 Zie een samenvatting van de Bandjarmasinse krijg in ENI 1:135-6. 
diamant wilde het gouvernement behouden. ${ }^{111}$ De commissie uit het bestuur, die met de lange lijst gewapend de voorwerpen in de provisiepakhuizen ging bekijken, kwam tot de conclusie dat de collectie bijeen moest blijven en dat het genootschap die in haar geheel wilde overnemen. Daarin bewilligde het gouvernement en zo kwam het genootschap na de bezittingen van de afgezette Bantamse sultan in het bezit van die van de Bandjarmasinse. ${ }^{112}$ In 1862 kwamen daar nog wapens bij van een van de hoofdpersonen in de voortgaande perikelen, prins Hidajat-Oelah, die op grond van de bepaling van 1858 over de plaatsing in het museum van buitgemaakte wapens, werden overgedragen. ${ }^{113}$ Ook in 1863 kwamen er nog krissen en met diamanten bezette sieraden binnen (Notulen 1:193, 220, 283). Dit bezit was echter niet altijd definitief. In 1864 kreeg een van de belanghebbenden in de strijd om de troon, sultan Tamdjid Illah, zijn zwaard Parang Sondrek, weer terug. ${ }^{114}$ Het omstreden bezit was in handen van sommigen een pijnlijke zaak. In 1865 deed de resident van de Zuid- en Ooster-afdeling van Borneo, kolonel E.C.F. Happé, afstand van het recht om een Bandjarmasinse kris en een lans tot het einde van zijn leven in bezit te houden, een recht dat hem bij koninklijke machtiging als een beloning voor bewezen diensten was verleend. Bij nader inzien bezwaarde het bezit Happé, zodat hij er van afzag en de twee wapens alsnog aan de collectie in het museum werden toegevoegd. Dat gebeurde ook met twee andere wapens die in hetzelfde jaar in de nalatenschap van de overleden regent van Martapoera werden aangetroffen en waarop de regent noch zijn nakomelingen, naar de mening van het gouvernement, aanspraak konden maken. Die wapens gingen eveneens naar Batavia. ${ }^{115}$ Hetzelfde zou in 1865 nog eens gebeuren met een kris en twee houten beelden. De collectie Bandjarmasinse kroongoederen groeide daardoor steeds verder aan (Notulen 3:91, 130).

Op dezelfde manier als aan de Bandjarmasinse collectie voorwerpen werden toegevoegd, gebeurde dat in 1865 met enkele goederen van de afgezette sultan van Bantam, die al tientallen jaren in het museum waren. Een met spiegels bekleed ledikant, een kistje met handschriften dat onder dat ledikant werd bewaard, een lans met een vlag en vijftien metalen bekkens gingen over van de regent van Serang naar de collectie Bantamse goederen in het museum. ${ }^{116}$ De rijkssieraden van Bone ondergingen niet hetzelfde lot.

111 De diamant zou later in Nederland op 38 karaats worden gesteld en leverde bij een veiling in $1898 f 5.620$ op, veel minder dan men gedacht had (Fasseur 1995:109-11).

112 TBG 12:122, vergadering 13-7-1861; 12:136, vergadering 13-7-1861; 12:219, vergadering 14-12-1861.

113 Notulen 1:33, vergadering 11-10-1862.

114 Notulen 2:174, vergadering 11-6-1864.

115 Notulen 3:79, vergadering 11-5-1865.

116 Notulen 3:130-1, vergadering 19-9-1865. 
Zij gingen niet over naar het Bataviaasch Genootschap, al mocht dat er wel de beschrijving van hebben en afbeeldingen publiceren (TBG 10:317, 448; Notulen 1:301).

De etnologische afdeling groeide aldus op verschillende manieren aan. Waar de oudheidkundige collectie op Java geconcentreerd was, richtte de etnologische zich juist op de andere eilanden, waar nog zoveel te ontdekken was, letterlijk door ontdekkingsreizigers. Ook oorlogsbuit speelde hier meer dan op Java, waar met het einde van de Java-oorlog (1830) geen nieuwe vijandelijkheden tegen de vorsten meer waren ondernomen. Toch bleek de verzameling bij de presentatie van de catalogus in 1868 Javaanser van kleur dan men uit het voorgaande zou verwachten. De grote collectie van de controleurs Levyssohn Norman en De Harloff, die bovendien zelf voor goede documentatie hadden gezorgd, nam meer dan een kwart van de catalogus in beslag. Van Sumatra waren de Westkust en de Lampongs het best vertegenwoordigd. Onder West-Java werden de Bantamse rijkssieraden opgenomen. Onder de Zuid-Ooster-Afdeling van Borneo de Bandjarmasinse rijkssieraden. Bali en Lombok waren slecht vertegenwoordigd, dit ondanks de arbeid die Friederich in de jaren 1840 had ondernomen. Museumdirecteur Levyssohn Norman had in zijn heel korte verantwoording op verschillende problemen gewezen. Zo had hij hulp ingeroepen van Indonesiërs die in Batavia waren om bepaalde objecten te kunnen thuisbrengen, waarbij hem meermalen tegenstrijdige informatie was gegeven. Vandaar dat de catalogus, die in het museum klaarlag, was doorschoten met wit papier, opdat bezoekers correcties en aanvullingen kwijt konden. ${ }^{117}$

\section{Publicaties: Indische taalkunde}

De bevordering van de studie van de inheemse talen bleef een voorname doelstelling van het genootschap. In de jaarverslagen die tussen 1863 en 1866 verschenen, werd dat onderwerp steeds als eerste behandeld, vóór de berichten over oudheidkunde en etnologie, en vóór het nieuws over de publicaties van het genootschap. Onder het kopje 'Indische Taalkunde' kwamen verschillende aspecten aan de orde: het werk aan woordenboeken en spraakkunsten van talen van de archipel, vergelijkend taalonderzoek, tekstedities, school- en leesboeken in de inheemse talen voor onderwijs en volksontwikkeling en tenslotte het verzamelen van handschriften en inscripties voor het museum.

Kijken we naar de publicaties, de Verhandelingen voorop, dan is voor

117 Inleiding van twee pagina's door Levyssohn Norman in Katalogus ethnologische afdeeling 1868. 
taalkunde, in deze ruime zin opgevat, veruit de meeste plaats ingeruimd. In de delen 29-33 (1862-1868) werd de helft van de beschikbare pagina's aan de Indische taalkunde besteed. Het Soendanese woordenboek van Jonathan Rigg springt daarin naar voren, maar ook Von Dewalls studie naar vormveranderingen in het Maleis. Als we de periode iets ruimer nemen, de delen 27-35 (1860-1870), dan domineren de tekstedities boven de strikt taalkundige disciplines: de Brata-Joeda (27-28), de Lajang Damar Woelan (30), de Hsi Yuan Lu (30, vertaling), de Hoa Tsien Ki (32, vertaling) en de Ardjoena-sasra-baoe (34). De Verhandelingen waren in die jaren verder gewijd aan etnologie (Nias en de Chinese bevolkingsgroep), de oudheden (Brumunds studie), de numismatiek (Netschers en Van der Chijs' Munten van Nederlandsch-Indië) en geschiedenis (Netscher over Djohor en Siak). ${ }^{118}$ Met de nadruk op taalkunde, inclusief tekstedities, werd aldus de lijn van de jaren 1840 en 1850 doorgetrokken. Overigens was het genootschap in de periode 1860-1870 met negen delen Verhandelingen zeer productief.

In het Tijdschrift was de taalkunde veel minder prominent aanwezig. Daar domineren de etnologische studies, reisbeschrijvingen en geschiedenis. Daar geldt bovendien, in afwijking van de Verhandelingen die nogal op Java gericht waren, een gerichtheid op de buitengewesten. We kunnen dus zeggen dat de Verhandelingen in deze jaren vooral aan de taalkunde-in-ruime-zin plaats boden, terwijl het Tijdschrift de land- en volkenkunde voor zijn rekening nam.

Riggs Soendanese woordenboek was de enige lexicografische bijdrage, een vakgebied dat er trouwens in het algemeen bekaaid afkwam. In de jaren 1840 was nog er een woordenboek van het Favorlangs (van Formosa) verschenen en een aparte Formosaanse woordenlijst. Een lexicografische traditie was er nauwelijks binnen de publicaties. Woordenboeken kwamen echter wel ter sprake, al leidde het niet vaak tot publiceren. Riggs woordenboek had lang moeten wachten. Friederich had er vele editeursuren aan besteed, maar het kon de Soenda-kenner Daniël Koorders niet bekoren. Hij besprak het woordenboek nogal streng in de Java-Bode. Overigens nam het bestuur dit goed op. Koorders' commentaar kon de wetenschap alleen maar vooruit helpen (Notulen 1:133-4). Van het Javaanse woordenboek waar C.F. Winter en J.A. Wilkens sinds 1844 in opdracht van het gouvernement aan werkten, kon in 1865 het manuscript van de eerste letters in Batavia worden bekeken. Het bestuur wilde zich met het gouvernement over de uitgave in afleveringen verstaan, maar Wilkens, die sinds de dood van Winter in 1859 het woordenboek verder alleen bewerkte, voelde daar niet voor. Het woordenboek zou

118 Tussen 1862-1868 waren de pagina's als volgt verdeeld: tekstedities 204, taalkunde in striktere zin 779, etnologie 348, numismatiek 230, oudheidkunde 309, geschiedenis 81 . De delen uit 1860 en 1870 bevatten nog eens 1713 pagina's tekstedities. 
uiteindelijk nooit verschijnen, maar in manuscript in Leiden terecht komen en daar het materiaal vormen voor latere lexicografen (Notulen 2:103, 3:55). Een Kawi-Javaans woordenboek van L. Rhemrev, een Nias' woordenboek van A.H. Intveld (Notulen 1:138-9), een Alfoers woordenboek van J.S. van Coevorden (Notulen 2:107) en een Nederlands-Mafoors (Papoeaas) woordenboek van Geisler en Jaesrich (Notulen 4:154) kwamen wel ter sprake, maar raakten weer vergeten. Er werd dus wel aan woordenboeken gewerkt, maar ze werden niet afgemaakt of bleven buiten het zicht van het genootschap. Van der Tuuk zou hier als lexicograaf voor het Batak en het Kawi-Balinees torenhoog bovenuit steken, maar met hem had het genootschap in deze periode nauwelijks contact, omdat hij in Amsterdam zat. Zijn publicaties, te beginnen met die over het Lampongs, verschenen in het Tijdschrift pas tussen 1869 en 1884 (Groeneboer 2002:891-7).

De projecten van Karel Frederik Holle (1829-1896) kregen wel de nodige aandacht. Deze kleurrijke en aan het Soendanees toegewijde theeplanter had in 1857 voor het eerst over Soendanese poëzie geschreven in het tijdschrift van het genootschap (TBG 6:114). In maart 1859 stuurde hij 101 Soendanese spreekwoorden in, die eveneens in het tijdschrift terechtkwamen. ${ }^{119}$ Holle werd in 1860 lid van het genootschap. Vanuit Garoet benaderde hij het bestuur op 6 augustus 1862 met twee plannen op het gebied van de vergelijkende taalkunde: het samenstellen van een 'vergelijkende woordenlijst van alle in Nederl. Indië gesproken wordende inlandsche talen en dialecten' en een overzicht van 'alle in de Nederl. Indischen Archipel in gebruik of in gebruik geweest zijnde letterschriften' (Notulen 1:13-4). Voor de woordenlijst dacht het genootschap tweehonderd woorden nodig te hebben. Het werden er honderdvijftig, waarvan Holle de Soendanese vertaling vaststelde, waarna de lijst naar vijf taalkundigen ging. Men hoopte aldus een zestal talen of taalgroepen te bestrijken. ${ }^{120}$ Een jaar later kon men al tevreden toezien op inzendingen van vijftien talen en dialecten (Notulen 2:106). In 1865 besloot het bestuur voor het Javaans de diepte in te gaan. De inzending van W.Palmer van den Broek uit Soerakarta werd aan alle hoofden van gewestelijk bestuur op Java gezonden om te zien of het Javaans in hun gewest afweek van het Solose taaleigen (Notulen 3:55). Er was duidelijk enthousiasme over Holles project. Het bestuur werkte mee. De residenten van Java eveneens. In 1865 bleven inzendingen binnenkomen (Notulen 3:85, 100, 106, 133, 144, 151-2). Van der Chijs die met voorzitter A. Loudon in 1866 aanwezig was bij de opening van de kweekschool voor inheemse onderwijzers in Bandoeng, de eerste in

119 TBG 9:220, vergadering 9-4-1859. De spreekwoorden in TBG 10:62.

120 Notulen 1:139-40. Het ging om H. von DeWall (Maleis), W. Palmer van den Broek (Javaans), H.N. van der Tuuk (Bataks), B.F. Matthes (Boeginees, Makassaars, andere talen van Celebes) en J.G.F. Riedel (Alfoers en andere talen van de Minahasa). 
zijn fuctie van inspecteur van het inheemse onderwijs, de tweede als lid van de Raad van Indië, had op zich genomen om met Holle te confereren over de tot op dat moment binnengekomen lijsten. ${ }^{121}$ Holle was ook een drijvende kracht achter de oprichting van de Bandoengse kweekschool.

Zes jaar later moest Van der Chijs, inmiddels vice-voorzitter geworden, bekennen dat het gesprek met Holle in 1866 wel had plaatsgevonden, maar dat voorzitter Loudon, die inmiddels was overleden, aan de directie daarvan geen verslag had uitgebracht. ${ }^{122}$ Het rapport van Van der Chijs uit 1872 eindigde met een vraag: 'Welke is de tegenwoordige toestand dier zaak, waaraan indertijd te veel moeite en kosten zijn besteed om haar onafgedaan te laten?' Het project dat tussen 1862-1865 veel enthousiasme had opgewekt, was verzand. Dat was niet te wijten aan Holle die onvermoeibaar doorwerkte aan zijn projecten.

Het tweede, op het terrein van de historisch-vergelijkende taalwetenschap gelegen project, het overzicht van de Indische letterschriften, werd in 1877 door Holle in Buitenzorg uitgegeven op kosten van het Bataviaasch Genootschap, onder de titel: Tabel van oud- en nieuw-Indische alphabetten. Een uitgebreidere uitgave volgde in 1882. ${ }^{123}$ Van den Berges biografie van Holle besteedt terecht ruime aandacht aan Holles verdienste voor de paleografie van Indonesië, waaraan hij met zijn Tabel bijdroeg. Het was een belangrijk hulpmiddel voor iedereen die Indonesische inscripties of handschriften wilde lezen. Van den Berge oordeelde mild over het Bataviaasch Genootschap, terwijl dat het woordenlijstenproject van 1862 lelijk liet verzanden (Van den Berge 1998). Onvermoeibaar stelde Holle in 1880 aan het genootschap een nieuw, groter woordenlijstenproject voor dat pas in 1894 leidde tot de publicatie van een Blanco woordenlijst ten behoeve van taalvorschers in den Nederlandsch-Indischen archipel. Niet gehinderd door enige slechte herinnering aan het verzande project ging een hele nieuwe generatie aan de slag met wat terecht genoemd werd: Holles woordenlijst. Tussen 1895 en 1898 kwamen tientallen inzendingen binnen. Holle mocht dit niet meer beleven. Hij stierf in 1896 (Van den Berge 1998:187-8). Pas in 1980 zouden de lijsten door W.A.L. Stokhof worden gepubliceerd.

Overigens was het Van der Tuuk die naast Holle het belang van woordenlijsten inzag voor de vergelijkende taalstudie. Nadat hij in de Lampongse districten in opdracht van het gouvernement veldwerk had gedaan (1868-1869), verscheen van hem in het Tijdschrift een 'Proeve van een vergelijkende woordenlijst van de Lampongsche tongvallen', terwijl hij in die periode in verschil- 
lende brieven van zijn bevindingen over het Lampongs verslag deed. ${ }^{124}$ Ook schreef hij aan Holle, met wie hij voor zijn vertrek naar Sumatra in Garoet over diens woordenlijsten en alfabetten had gesproken. In 1872 deed Van der Tuuk nog eens een voorstel aan het genootschap om woordenlijsten rond te zenden in verband met het onderzoek naar de Sumatraanse talen (Notulen 10:150). Toen zat Van der Tuuk echter al op Bali en deed hij dit voorstel in verband met zijn eigen onderzoek naar het Kawi. De gang van zaken met Holles woordenlijst laat zien dat binnen het genootschap in de jaren 18621868 wel aanvankelijk enthousiasme werd opgebracht voor dit belangrijke project, maar dat een tekort aan mankracht en vakmanschap verhinderde het binnen redelijke tijd af te ronden.

Tot de taalkunde rekende het genootschap ook de adviserende taak die het in 1858 op verzoek van het gouvernement op zich had genomen om leer- en leesboekjes in het Javaans en Maleis voor het inheemse onderwijs te beoordelen om te zien of zij voor de uitgeloofde premies in aanmerking kwamen. ${ }^{125}$ Van dat oordeel hing af of het gouvernement tot het drukken van die boekjes bij de Landsdrukkerij overging. Tot 1868 werden aan het genootschap achtentwintig manuscripten ter beoordeling voorgelegd. De kampioenmededinger naar de premie van het gouvernement was de assistent-resident van Gorontalo, Riedel, van wie het genootschap vier inzendingen te beoordelen kreeg. Goede tweeden waren de predikant bij de inheemse gemeente te Depok en latere hoogleraar Maleis te Delft, J.R.P.F. Gonggrijp, verder de Semarangse zendeling, later onderwijzer en lector Maleis te Leiden, H.C. Klinkert en tenslotte de klerk-commies A.A. Voorneman. De enige genootschapsman die meedeed, was Netscher, van wie twee keer een inzending beoordeeld werd. Toen hij echter naar Riouw vertrok als resident, was hij niet meer in een positie om naar deze prijzen mee te dingen. Slechts twee van de te beoordelen inzendingen waren van Indonesiërs: Raden Bagoes Moedjarad uit Soerakarta en Raden Moehamed Hoesein, de hoofd-panghoeloe van Krawang. Het merendeel van de boekjes was in het Maleis.

De goede bedoelingen van het gouvernement en de positieve beoordeling die het genootschap over sommige werkjes gaf, konden niet voorkomen dat het project in een slecht licht kwam te staan door het oordeel dat Klinkert, zelf inmiddels als bijbelvertaler in dienst van het Nederlandsch Bijbelgenootschap getreden en in Riouw woonachtig, erover velde in de Bijdragen van het Koninklijk Instituut (1866) en de bijval, die hij daarop kreeg van Van der Tuuk in De Gids (1866). 'Dat gemors van Europeanen in de inlandsche talen, wan-

124 Groeneboer 2002:22-4 en briefnummers 191, 195, 196, 198, 199, 200, 202. Publicaties van Van der Tuuk in TBG vermeld in Groeneboers 'Lijst van publicaties Van der Tuuk', nrs 1869, 1870a en 1872a.

125 TBG 8:102, vergadering 19 juli - lees juni - 1858. 
neer zal men toch ten onzent inzien, dat het ons zoogenaamd moreel overwigt in de waagschaal stelt?', aldus collega bijbelvertaler Van der Tuuk over de beoordeling door Klinkert (Groeneboer 2002:533). Indirect kregen ook de beoordelaars van het genootschap een veeg uit de pan. Zij hadden immers, om verschillende redenen en met kracht van argumenten, over sommige van de door Klinkert bekritiseerde boekjes uitspraken gedaan, waarna het gouvernement had besloten tot de uitgave ervan. In de notulen kon iedereen nazien dat het vooral om Netscher ging, maar ook om Friederich, voorzitter Wassink, Brumund, Van der Chijs en Levyssohn Norman, die als beoordelaren namens het genootschap optraden. Aan de hoge taalvaardigheidseisen van Klinkert en Van der Tuuk voldeden deze bestuursleden niet. ${ }^{126}$ Ook Cohen Stuart was een 'vijand van al zulke boeken en boekjes voor schoolgebruik, welke in stede van beschaving te bevorderen, taalbederf in de hand werken, of wegens volslagen onverstaanbaarheid zonder eenigen invloed blijven' (Kern 1877:8).

Van der Tuuk zou in 1872 het genootschap adviseren de rapporten die het aan het gouvernement uitbracht over schoolboekjes openbaar te maken. Dat vond het genootschap te riskant en dus werd besloten het niet te doen. ${ }^{127}$ Wel had het genootschap al jaren eerder besloten zich in te zetten voor een betere verspreiding van de leesboekjes. Het gaf de gouverneur-generaal op 1 oktober 1862 in overweging 'de voor de inlanders ter landsdrukkerij uitgegeven wordende boekwerkjes meer algemeen en overal in de binnenlanden verkrijgbaar te doen stellen'. Op 23 maart 1863 besloot het gouvernement dit in ieder geval voor Java en Madoera te doen en met de verkoop de onderwijzers van de inheemse scholen, de zoutverkooppakhuismeesters en de koffiepakhuismeesters te belasten, die dan tien procent van de opbrengst zouden ontvangen. Verder moesten de residenten erop letten of er voldoende voorraad was (Notulen 1:137-8). Het succes dat Holle behaald had met de verkoop van Soendanees leesmateriaal was de aanleiding geweest tot het ongevraagde advies aan het gouvernement.

Ging het bij Klinkert, Van der Tuuk en Cohen Stuart vooral om het taalkundig falen van de vertalers, een heel andere kwestie was de inhoud van sommige schoolboekjes, die eveneens in het geding kwam. In 1858, bij een van de eerste adviezen, deed dit probleem zich al voor naar aanleiding van een boekje van Gibson. Omdat het 'van meer zuiver godsdienstigen aard'

126 Zie de beoordelingen in de notulen van de boekjes van R. Bagoes Moedjarad TBG 9:438 en TBG 10:15; van Voorneman TBG 10:308, 454 en TBG 11:402; van Martens TBG 10:312, 314, 446, 454 en TBG 11:413; van Gonggrijp TBG 11:420, 423 en TBG 12:208; van Voorneman TBG 11:438 en TBG 12:215; van Riedel TBG 12:217, 504, 539 en Notulen 2:154; van R. Moehamad Hoesin Notulen 1:289, 2:210, 231, 282.

127 Notulen 10:102, brief van Van der Tuuk, 20-6-1872. 
was, werd het voor de schooljeugd minder geschikt geacht. ${ }^{128}$ Daarmee kwam het genootschap direct terecht in het debat over de plaats van de islam in de Indonesische samenleving en de rol van zending en missie. Holle, die zich op verzoek van het gouvernement over Soendanese schoolboeken had gebogen, kwam over hetzelfde onderwerp in 1863 in conflict met de als theoloog opgeleide ambtenaar Koorders naar aanleiding van een boekje voor de Soendanese schooljeugd, dat vanuit een christelijk perpectief niet rechtzinnig was (Van den Berge 1998:122).

Het erelid Cohen Stuart deed in 1867 het voorstel om naast de Verhandelingen en het Tijdschrift nog met een aparte serie tekstuitgaven te beginnen onder de serietitel Werken, in navolging van het KITLV. De Verhandelingen zouden dan niet langer tekstedities bevatten, maar meer aan de uitkomst van wetenschappelijk onderzoek gewijd zijn. Cohen Stuart was onder meer op zijn voorstel gekomen doordat Klinkert had gewezen op de wenselijkheid van een aparte uitgave van de Sadjara Malajoe, terwijl Holle aanbeval om lontarhandschriften uit de Soenda-landen, die door Raden Saleh waren geschonken, uit te geven (Notulen 5:23-6).

Het bestuur besloot naar aanleiding van een nota van Cohen Stuart en boekhandelaar Lange om van dit plan vooralsnog af te zien. Men was bang dat de gouvernementssubsidie van $f 8.000$ per jaar niet zeker was en dus durfde het bestuur deze dure nieuwigheid niet aan (Notulen 5:26). Het lijkt er echter meer op dat het bestuur bang was zijn vingers te branden aan de Sadjara Malajoe. Holle vond in de gepubliceerde nota van Cohen Stuart aanleiding om op de inhoud van de Sadjara Malajoe in te gaan, die het ongewenste effect zou kunnen bewerken dat deze uitgave 'meer de herinnering aan de grootheid van het Maleische vorstenhuis, dan het bewustzijn, dat zij onder ons beter af zijn, bij de onder ons gezag staande Maleijers zal bevorderen' ${ }^{129}$ Holle verwees naar de kritiek van Klinkert op de schoolboekjes en bepleitte dat een midden zou worden gevonden tussen de belangen van de inhoud en die van de zuiverheid van de taal. Klinkert zelf, alsdus Holle, had boter op zijn hoofd als vertaler in het Maleis van enkele van die boekjes.

In de briefwisseling die volgde, steeds gericht tot het bestuur van het genootschap, komt Holle vooral als volksopvoeder en Cohen Stuart als cultuurrelativist naar voren. De paternalistische Holle gaf niet hoog op van de intellectuele capaciteiten van de inheemse, 'wiens politieke en godsdienstige horizont niet verder reikt dan zijn neus'. Voor hem waren de behoeften aan opvoedend materiaal, in de vorm van school- en leesboekjes, zo groot dat hij bereid was om desnoods de mindere kwaliteit van de gebruikte taal voor

128 TBG 8:288 vermeldt niet meer dan deze motivering. De notulen in ANRI KBG Dir 0223 (vergadering 16-9-1858) komen overeen met de gedrukte notulen.

129 Brief van Holle 29-6-1868, Notulen 7:Bijlage A, vergadering 5-1-1869, p. ii. 
lief te nemen. 'Wat baat het mij, of de drinkbeker van goud is, als hij vergift bevat? Dan drink ik liever water uit een behaarde klapperdop, al is dit niet kraakhelder!'130 Cohen Stuart erkende wel dat Holle niet rechtstreeks partij koos voor het 'brabbelmaleis' van sommige schoolboekjes, 'maar de geheele strekking van zijn vertoog brengt toch [...] eene mate van inschikkelijkheid op dit punt met zich, waarmede ik mij bezwaarlijk zou kunnen vereenigen'. ${ }^{131}$ De taalambtenaar Cohen Stuart ging vervolgens over tot commentaar op Klinkerts bespreking van de Maleise schoolboekjes, die Holle had aangezwengeld. Hij vond Klinkerts kritiek voor een deel gezocht, voor een deel ongegrond, vond dat de commentator het hier en daar rechtstreeks bij het verkeerde eind had, maar erkende dat er ook veel behartigenswaardigs in diens bespreking zat. Cohen Stuart nam liever afstand van het door het gouvernement geïnstigeerde systeem van prijsuitreiking aan wie ook maar enigszins geschikte schoolboekjes leverde, dan dat hij verder de discussie met Klinkert aanging. Hij kon trouwens niet nalaten en passant te vermelden dat hij voor geen van de besproken schoolboekjes als genootschaps- of gouvernementsbeoordelaar verantwoordelijk was. Hij vond dat het schrijven en vertalen van school- en leesboekjes voor het inheemse onderwijs alleen door moedertaalsprekers of door inschakeling van hen kon gebeuren en kon melden dat het vigerende systeem bij de overheid al in heroverweging was. ${ }^{132}$ Het onderwerp was in april 1868 zelfs al in de Tweede Kamer ter sprake geweest, toen de tot kamerlid gekozen Koorders, geen vriend van Holle, probeerde de begroting van het departement van koloniën te amenderen op het punt van het inheemse onderwijs in een poging om het bestaande systeem van schoolboekproductie met prijstoekenning de nek om te draaien (Van den Berge 1998:134-5). Overigens prees Cohen Stuart Holle zeer, omdat hij voor de Soendanese school- en leesboekjes wél inheemse schrijvers en vertalers had ingeschakeld.

Zo gematigd als Cohen Stuart zijn standpunt voor wat betreft de schoolboekjes naar voren bracht, zo radikaal wees hij het door Holle voorgestelde ingrijpen op het gebied van uitgaven voor het grote publiek af. Hij vond dat er geen sprake van censuur kon zijn, hoe goedbedoeld ook. Hij vond de door Holle genoemde voorbeelden, onder andere uit de Sadjara Malajoe, van hetzelfde kaliber als wat in de Nederlandse school- en volksliteratuur voorkwam. ${ }^{133}$ Hij vreesde dat bij het volgen van Holles adviezen alleen nog 'bloemlezingen of gezuiverde uitgaven' konden worden toegelaten en dat denkbeeld wees hij pertinent van de hand. Dit punt was natuurlijk voor het

Notulen 7:Bijlage A, vergadering 5-1-1869, p. ii.

Notulen 7:Bijlage B, brief van Cohen Stuart dd 7-7-1868, pp. vi-viii.

Notulen 7:Bijlage B, vergadering 5-1-1869, pp. viii-xi.

Notulen 7:Bijlage B bij de vergadering 5-1-1869, brief van Cohen Stuart, pp. iv-v. 
bestuur de reden geweest om de discussie tussen Holle en Cohen Stuart in de Notulen op te nemen. Tegelijk was het meegenomen dat Cohen Stuart Klinkert van repliek diende, waar het genootschap immers, als beoordelende instantie, in de zaak van de kwaliteit van de gepubliceerde schoolboekjes, niet vrij te pleiten was van medeverantwoordelijkheid. Ondertussen was het voorstel van de nieuwe serie uitgaven ('Werken') om financiële redenen in de ijskast gezet, wat het bestuur goed zal zijn uitgekomen, omdat ondertussen de discussie over de inhoud van de uit te geven werken kon uitrazen. In de bestuursvergaderingen kwam een en ander ongetwijfeld uitgebreider ter sprake dan de korte mededeling van het ter zake genomen besluit doet vermoeden. De omstandigheid dat het bestuur grotendeels uit ambtenaren van het gouvernement bestond en dat onderwerpen als onderwijs en volksopvoeding belangrijk waren, geeft aanleiding om dit te denken. Van der Chijs was er als inspecteur van het inheemse onderwijs het meest direct bij betrokken. Het feit dat het bestuur besloot de discussie Holle-Cohen Stuart te publiceren en er een honderdtal extra exemplaren als brochure van te drukken, geeft aan dat het onderwerp belangrijk genoeg was om breed te worden bediscussieerd. ${ }^{134}$ Een nadere brief van Holle over het onderwerp van 28 juni 1869 werd onderwerp van correspondentie tussen Van Limburg Brouwer en Holle om te kijken naar 'hetgeen uit deze bijdrage ter opname in het Tijdschrift kan worden genomen, met weglating van hetgeen tot verder geschrijf over het onderwerp zou kunnen aanleiding geven'. Voor het bestuur was de discussie gesloten. ${ }^{135}$ In andere media woekerde de discussie levendig voort (Van den Berge 1998:137-40).

De discussie tussen Holle en Cohen Stuart kan niet los gezien worden van de algemene gedachtenvorming die in de jaren 1860 gaande was over het inheemse onderwijs, over de taal die zou worden gebruikt in de inheemse scholen alsook over de manier waarop inheemse onderwijzers zouden worden opgeleid. In dat verband waren de school- en leesboekjes in de streektalen al vóór de kritiek van Klinkert en de bijval van Van der Tuuk aan de orde geweest. Niet toevallig waren het weer verzoeken van Holle, de altijd actieve ijveraar voor het Soendanees, die de discussie op gang hadden gebracht. Het ging om het voorstel om bestaande Maleise, Javaanse en Soendanese leerboekjes te laten vertalen in het Lampongs, Bataks en Makassaars en een tweede voorstel om een door Holle zelf vervaardigde lettertafel voor het Bataks te laten drukken ter verspreiding in de Bataklanden. Het gouvernement zag bezwaren en legde de zaak voor advies aan het genootschap voor, dat in een brief, opgesteld door Levyssohn Norman, aandrong op een 
grondige regeling van het inheemse onderwijs in de streektalen, op de opleiding van een 'keurbende' van Indonesiërs in Nederland, die dan later op de kweekscholen in de archipel zouden kunnen lesgeven en die veel beter dan de overwegend Nederlandse schoolboekenschrijvers in staat zou zijn tot het maken van geschikt lesmateriaal in de streektalen. Cohen Stuart wijdde aan de ontwerpbrief van Levyssohn Norman een aparte nota, waaruit bleek dat hij over zo'n opleiding van een keurbende in Nederland anders dacht. Hij stelde toen ook, naar aanleiding van het voorstel om schoolboekjes te vertalen in andere streektalen, het hele systeem van schoolboekproductie aan de orde, waarvan hij geen voorstander was. Het Bataviaasch Genootschap was aldus op een veel breder terrein gaan adviseren dan dat van de (studie van) de taal-, land- en volkenkunde in strikte zin. Het gaf adviezen waarop het gouvernement zijn onderwijsbeleid of beleidsveranderingen op dat terrein mede baseerde. ${ }^{136}$

\section{Verzamelingen: handschriften en inscripties}

Het laatste onderwerp dat tot de Indische taalkunde werd gerekend, vormde de collectie handschriften en inscripties, een belangrijke bron voor zowel historische als vergelijkende taalstudie, maar tevens voor de oudheidkunde en etnologie van belang. Het behoud en de uitbreiding van de collectie alsook de bestudering ervan voor de bovengenoemde vakken komen als onderwerpen in deze periode gedurig aan de orde. De collectie vormde een moeilijk tot een geheel te smeden verzameling, doordat de 'beschreven stenen' en de koperen platen met inscripties bij de beelden werden bewaard als onderdeel van de collectie oudheden, terwijl de handschriften op papier, palmblad en andere materialen bij de boeken in de bibliotheek waren opgeborgen. De handschriftenverzameling, inscripties in steen en koper nu even niet meegerekend, profiteerde in deze periode niet van grote aanwinsten, zoals dat in het verleden het geval was geweest. Was er in het begin van de jaren 1850 sprake van ongeveer 750 handschriften, grotendeels afkomstig uit de collectie van de sultan van Bantam en uit de Merbaboe-aanwinst, begin 1870 kwamen Cohen Start en Van der Chijs niet veel verder dan 780 stuks, waarvan 87 Javaanse, 53 Maleise, 130 Arabische en 508 op palmblad. ${ }^{137}$ Ter vergelijking: de Algemene Secretarie gaf in 1867 op dat zij beschikte over een verzameling

136 Notulen 4:32-50 voor de brief van Levyssohn Norman, en 51-80 voor Cohen Stuarts nota. Hieruit blijkt dat het systeem van prijstoekenning al eerder ter discussie stond. Zie ook Groeneboer 1993:193.

137 Verslag van de commissie Van der Chijs/Cohen Stuart in Notulen 8:15-8, vergadering 1-21870 . 
van 59 Maleise en Arabische handschriften, terwijl Klinkert vanuit Riouw opgaf over 81 Maleise handschriften te beschikken (Notulen 5:41-3, 4:191). De eerste gedrukte catalogus was die geweest van de Arabische handschriften door Friederich, in 1853 in de Verhandelingen verschenen. De tweede uitgave, weer van alleen de Arabische manuscripten, zou in 1873 door L.W.C van den Berg worden verzorgd (L.W.C. van den Berg 1873, 1877).

Friederich, de eerste conservator van de oosterse handschriften, vertrok in 1860 met verlof naar Europa. Hij werd pas in in maart 1864 opgevolgd door Cohen Stuart, vooral bekend met het Javaans door zijn jarenlange verblijf in Soerakarta. Naast Van der Chijs, die sinds januari 1861 bibliothecaris was, werd aan Cohen Stuart de zorg voor de collectie handschriften toevertrouwd. Toen hij zich in 1863, nog vóór hij formeel tot conservator werd aangesteld, over de handschriften boog, kwam hij maar tot vijftien (uitsluitend) Javaanse en 26 Arabisch-Javaanse en Maleis-Javaanse handschriften, een opgave die slechts een deel van de collectie omvatte. Als javanicus had hij voor deze manuscripten natuurlijk de meeste aandacht. Hij hield zich in eerste instantie niet bezig met de Maleise, Arabische, Balinese en andere handschriften. Hij boog zich wel over de koperen platen met Oud-Javaanse inscripties en ging onder meer ten rade bij Raden Pandji Soerja Widjaja, de Balinees Ida Ketoet Anom en Raden Pandji Koesoemo Adji Negoro, de patih van Tjiamis, voor ophelderingen, waar zijn kennis te kort schoot (Notulen 1:264-5 noten, 2:113). Het lithograferen of fotograferen van inscripties, in steen of koper, werd overwogen en door hem onderzocht, als een manier om wetenschappers in de gelegenheid te stellen nieuw gevonden inscripties te vergelijken met die in verzamelingen in Indië en Europa. ${ }^{138}$

Pas bij de algemene vergadering van 1864 viel er, mede dankzij de nieuw aangestelde conservator, iets substantieels te melden over de verzameling. In het jaarverslag had de verzameling nu een apart kopje gekregen, 'handschriften en inscriptiën', teken van de waardigheid van deze deelcollectie. Toen werden nieuwe aanwinsten gemeld, onder andere een handschrift van Pangeran Dipo Negoro, dat van het gouvernement ter vertaling was verkegen en waarop Cohen Stuart veel later nog zijn tanden zou stukbijten. ${ }^{139}$ Van de Merbaboe, dessa Bedakkan, kwam via de directeur van het museum, Levyssohn Norman, een verzameling lontarbladen binnen, terwijl andere schenkers (Sloet van de Beele, Pangeran Ario Soerjo Negoro, Holle, Teijsman, Diemont) een of enkele handschriften afstonden (Notulen 2:109-11). In 1865 en 1866 meldde het genootschap weinig aanwinsten. De oproep die het geplaatst had bij de leden en in de dagbladen, was nauwelijks beantwoord. Er was

138 Notulen 1:261, vergadering 12-9-1862; 2:112, algemene vergadering 30-4-1864.

139 Notulen 2:109, algemene vergadering 30-4-1864. Brief van Cohen Stuart aan Van der Tuuk, 19-11-1868 (Groeneboer 2002:185) over de vertaling van deze 'Babad Diponegoro'. 
vooral gevraagd naar historische babads, waarvan men aannam dat er daar veel van te verwerven waren. Wel was via Sloet van de Beele een Javaans manuscript met de Bedojo-zangen binnengekomen. In 1866 herhaalde het bestuur de oproep aan de leden, maar toen was er wat meer te melden. Er waren eenentwintig koperen platen bijgekomen, onder meer door een opgraving van vijftien platen bij Soerabaija en schenkingen van Pangeran Ngabehi en Raden Saleh. De collectie van voor-Mohammedaanse, koperen platen was door deze aanwinst opgelopen tot zevenendertig. Ook werd er toen gewerkt aan het afschrijven van een collectie Kawi-handschriften in Tjiboeroei, waarvan het bestaan door Holle was gesignaleerd. Toch vond het bestuur dat de pogingen om de verzameling uit te breiden in dat jaar 'vooralsnog niet die medewerking hadden ondervonden, waarop men gemeend had te mogen rekenen'. Vandaar dat de leden ('Mijne Heeren') nog eens van harte werden aangespoord (Notulen 3:59, 4:154-6).

Het had niet aan Raden Saleh gelegen dat het genootschap over het gebrek aan aanwinsten klaagde. De bekende schilder was met toestemming van het gouvernement in 1865 op een 'kunstreis' over Java vertrokken, waarbij hij verzocht had zich ook nuttig te mogen maken door oudheden en manuscripten te verzamelen die zich in het bezit van de inheemse bevolking bevonden. Cohen Stuart zag er veel in en toen de reis aan Raden Saleh werd toegestaan was het deze conservator die de reiziger instrueerde over de wensen van het genootschap. Raden Saleh werd tot lid van het genootschap benoemd. ${ }^{140} \mathrm{Hij}$ kwam onder meer terug met honderdvijftig oudheidkundige voorwerpen en achtendertig manuscripten op palmblad. De laatste werden op de algemene vergadering van 26 juni 1866 getoond aan de eenentwintig aanwezigen, onder wie Raden Saleh zelf. De schilder werd bij die gelegenheid tot erelid benoemd, nog geen jaar nadat hem het lidmaatschap was gegund. Waar hij mee terugkwam van zijn 'kunstreis' was voor de afdeling handschriften dan ook veruit de grootste aanwinst in vijf jaar tijd, al moesten sommige bamboehandschriften, nadat ze afgeschreven waren, weer naar de rechtmatige bezitters terug. Naast Raden Saleh waren vooral Holle en Sloet van de Beele voor de verzameling handschriften actief. De gulle schenkers waren inmiddels dus niet meer uitsluitend Europeanen. Het ontbreken echter van een gedrukte catalogus van de handschriften, alsook het uitblijven van een editie van de belangrijkste inscripties bevorderde het gebruik van de collectie niet, noch de kennis van wetenschappers in Europa en elders van wat de collectie te bieden had. 
Gebouwen: 'Een sieraad voor Nêerlandsch Indië's hoofdstad' (Uhlenbeck)

\section{Batavia}

In 1861 zag het er voor de toekomst van het genootschap somber uit. De regering bevestigde in september nog eens dat het niet zou betalen aan voorzieningen in de vorm van gebouwen voor de in Batavia gevestigde, belangrijkste organisaties, als ze niet tot een fusie zouden besluiten. Het bestuur nam er in de vergadering van 5 oktober nota van en besloot de commissie-Van der Chijs-Rochussen-Der Kinderen aan het werk te zetten om te zien of de al door het bestuur afgewezen fusie toch te realiseren zou zijn. ${ }^{141}$ Tijdens de algemene vergadering van 16 november werd in vogelvlucht (1853-1861) de sombere werkelijkheid door secretaris Der Kinderen nog eens aan de leden voorgehouden.

De nieuwe landvoogd, de in oktober 1861 aangetreden baron Sloet van de Beele, had het beschermheerschap van zijn voorganger Pahud overgenomen (Kern 1892). Sloet, die als een ijverig amateur-wetenschapper bekend stond, had nog voor het eind van het jaar met de aanbieding van de erefunctie ingestemd, 'niet slechts om eene gewoonte te volgen, maar uit warme belangstelling in alles wat wetenschap en kunsten betreft', aldus de nieuwe beschermheer in zijn acceptatiebrief. Hij was meteen het 'pakhuis' aan de Rijswijkstraat gaan bezoeken. ${ }^{142} \mathrm{Hij}$ was er door bibliothecaris Van der Chijs en secretaris, tevens conservator, Der Kinderen rondgeleid en had er ruim anderhalf uur de tijd voor genomen. Het was kennelijk geen erg formeel bezoek, want genootschapsvoorzitter Van Swieten en vice-voorzitter Wassink ontbraken. Dat door bibliothecaris en secretaris, de een bestuursambtenaar, de ander rechterlijk ambtenaar, bij hun hoogste baas de nood van het genootschap naar voren was gebracht, lijkt vanzelfsprekend. ${ }^{143}$ Zowel de slechte staat van de gebouwen als de door de regering in de Den Haag en door het gouvernement in Batavia beoogde samensmelting van de drie belangrijkste gesubsidieerde, particuliere organisaties zullen zijn besproken, al zeggen de notulen daar niets over. Rapporteerde de commissie-Van der Chijs in januari 1862 nog over de mogelijke uitweg uit de impasse tussen genootschap en overheid met betrekking tot de fusie in een rapport dat in het bestuur werd

\footnotetext{
141 TBG 12:144-5, vergadering 5-10-1861.

142 TBG 12:168. De term 'pakhuis' werd gebruikt door secretaris Der Kinderen in zijn 'Overzigt over de jaren 1853-1861', grotendeels door Netscher opgesteld en voorgelezen tijdens de algemene vergadering 16-11-1861. De acceptatiebrief van Sloet werd vermeld in TBG 12:222, vergadering 4-1-1862, maar niet in de notulen opgenomen. De door Sloet eigenhandig geschreven brief, waaruit het citaat, in ANRI KBG Dir 0260, vergadering 4-1-1862.

143 TBG 12:153-4, vergadering 16-11-1861, en 222-3, vergadering 4-1-1862.
} 
rondgelezen, in de eropvolgende maanden meldden de notulen niets meer over het commissievoorstel. ${ }^{144}$

Het rapport bestond uit een negentiental 'Concept-voorwaarden van vereeniging der drie te Batavia gevestigde wetenschappelijke ligchamen' en werd op 15 april 1862 door Der Kinderen aan de Natuurkundige Vereeniging en de Maatschppij van Nijverheid gestuurd. Wat de commissie voorstelde was eerder een federatie van drie organisaties, dan een echte fusie. De drie zouden zich verenigen tot één, maar wel blijven bestaan uit drie onderscheiden afdelingen. De afdelingen zouden ieder beurtelings de voorzitter leveren en ieder een eigen bestuur, eigen wetten en eigen geldmiddelen houden. Dat alles zou onder één hoofdbestuur moeten functioneren, dat gevormd zou worden uit de drie voorzitters, secretarissen en penningmeesters. In het voorstel was zoveel mogelijk geprobeerd het eigen karakter van de bestaande organisaties te handhaven. Heikele kwesties, zoals een nieuwe naam en de hoogte van de contributie waren nog niet opgelost. Al met al maakt het voorstel een nogal zwakke indruk. ${ }^{145}$ Namens de Natuurkundige Vereeniging antwoordde secretaris Versteeg in mei 1862 dat zijn bestuur zich van advies zou onthouden. Pas als de voorwaarden door het genootschap zelf zouden zijn aangenomen, aangeboden aan de regering en dan weer door de regering aan de vereniging gestuurd, zou zijn vereniging een mening willen geven. Namens de Maatschappij van Nijverheid hadden voorzitter $H$. de Bruijn en bestuurslid Netscher laten weten dat de voorwaarden door de algemene vergadering van de maatschappij op 17 april 1862 waren aangenomen. ${ }^{146}$ Met deze brieven werd, afgaande op de gedrukte notulen, niets gedaan. Ze kwamen zelfs niet ter sprake. Het heeft er alle schijn van dat informeel bekend was dat een uitweg uit de ontstane impasse in de maak was.

\section{Den Hagg}

Die uitweg werd niet in Batavia, maar in Den Haag gevonden en wel door de nieuwe minister van koloniën, de nog maar net in patria teruggekeerde Gerard Hendrik Uhlenbeck (1815-1888). Uhlenbeck was in Colombo geboren, had in Nederland een technische opleiding gevolgd, om in 1837 als tweede luitenant van de genie naar Indië te vertrekken. Als adjudant van de directeur van de genie in Batavia begon hij zijn carrière. Hij was één van de

\footnotetext{
144 TBG 12:227, vergadering 4-1-1862.

145 Concept-voorwaarden met de aanbiedingsbrief van Der Kinderen aan de Natuurkundige Vereeniging en de Maatschappij van Nijverheid, 15-4-1862, in ANRI KBG Dir 1517, omslag 40 (1862).

146 Brief van Versteeg van mei 1862 (geen datum) en brief van De Bruijn en Netscher, 26-5-1862 in ANRI KBG Dir 1517, omslag 40 (1862).
} 
ondertekenaars van het rekest aan de koning van 25 mei 1848, waarin om de afschaffing van het radikaal werd gevraagd. Beroepsmatig was hij betrokken bij de voorbereidingen voor de spoorwegaanleg in de Vorstenlanden in de jaren veertig. In 1853 werd hij benoemd tot chef van de Waterstaat en 's Lands Civiele Werken. Die dienst werd in 1855 omgevormd tot Departement van Burgerlijke Openbare Werken (BOW), waarvan Uhlenbeck de eerste directeur werd (Ravesteijn en Kops 2004). Hij nam toen ontslag uit militaire dienst. Onder zijn toezicht was in 1858 door ingenieur P.J.G. Beijerinck een ontwerp gemaakt voor een nieuw gebouw op het Harmoniecomplex ten behoeve van het genoootschap. Dat plan werd niet verwezenlijkt, omdat het te duur was en omdat de overheid eerst de al besproken fusie gerealiseerd wilde zien. Uhlenbeck werd betrekkelijk laat lid van het genootschap, namelijk op 4 juni 1859, in dezelfde vergadering als H.D. Levyssohn Norman. ${ }^{147}$ Toen Uhlenbeck in april 1861 met verlof naar Nederland vertrok, was hij goed op de hoogte van de bouwvalligheid van het bestaande genootschapshuis. Hij wist dat het museum, de voormalige kolfbaan, was ontruimd en dat de toestand van het gebouw in de Rijswijkstraat nijpend was. Uhlenbeck was voorzitter geweest van de Maatschappij van Nijverheid en uit dien hoofde was hij goed bekend met de problematiek van de 'fusie der maatschappijen'. Op 1 februari 1862 trad hij in het nieuwe, door Thorbecke geleide kabinet aan als minister van koloniën.

Als gouverneur-generaal trof hij een andere spoorwegman aan: Sloet van de Beele, voormalig voorzitter van de raad van toezicht op de spoorwegdiensten in Nederland. Sloet was eind augustus 1861 naar Indië vertrokken en mogelijk had hij Uhlenbeck in zijn periode van voorbereidingen op het vertrek ontmoet. Sloets bezoek aan het pakhuis in de Rijswijkstraat is veelbetekenend geweest voor de toekomst van het genootschap. Daardoor kende hij de situatie net zo goed als Uhlenbeck. Vermoedelijk stond Sloet van het begin af aan niet achter het idee van de door Pahud voorgestane fusie.

Precies een maand na zijn aantreden als minister nam Uhlenbeck het initiatief. Het genootschap had in hem geen beter vriend en pleitbezorger kunnen wensen. Op 1 maart 1862 schreef hij een notitie, waarin hij zonder omwegen voorop stelde:

Ik wensch dat de daarstelling van een nieuw gebouw voor museum etc., en de bijeenkomsten van het Bataviaasch genootschap van kunsten en wetenschappen tot een onderwerp van voordragt aan den Koning worde gemaakt; en naar aanleiding van de hier berustende stukken [...] worde voorgesteld: op het tegenwoordige emplacement een nieuw, doelmatig en om aan de

147 TBG 9:238, vergadering 4-6-1859. Tijdens dezelfde vergadering werd A. Prins tot bestuurslid en generaal Van Swieten tot voorzitter gekozen, terwijl hijzelf afwezig was. 


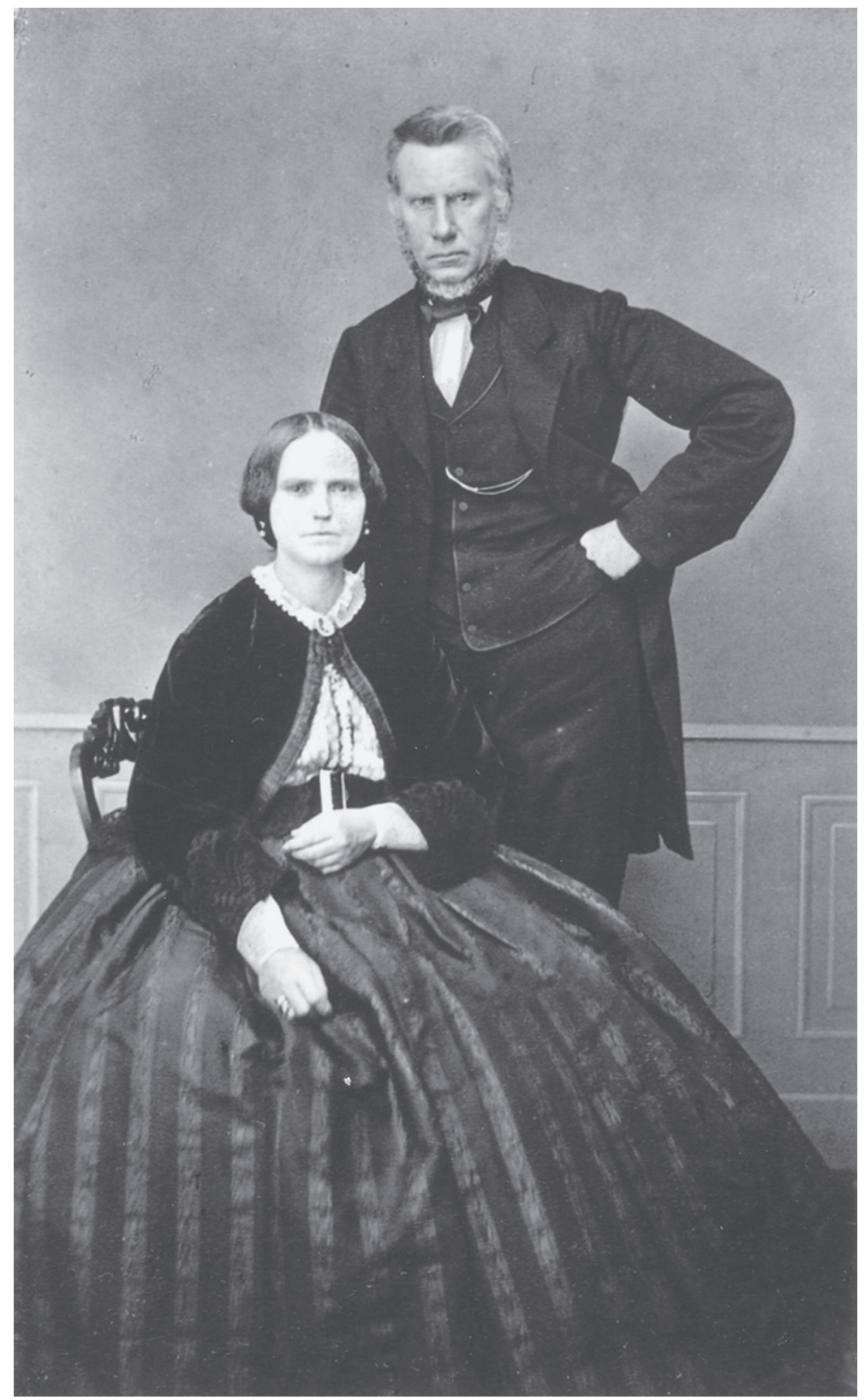

Dubbelportret van Gerhard Hendrik Uhlenbeck, directeur van BOW en later minister van koloniën, en zijn echtgenote, Maria Catharina Godin (carte de visite, collectie RKD/Iconografisch Bureau Den Haag D 3447) 
behoeften gedurende plusminus een kwart eeuw te bevredigen gebouw; om te strekken tot museum en bewaarplaats van gouvernements geschenken, zoomede boekerij, behoorende aan en staande onder toezigt van het Bat.gen.

Uhlenbeck gaf direct enkele randvoorwaarden aan: het gebouw moest in 1863-1864 gerealiseerd worden en mocht $f 175.000$ gaan kosten. Het genootschap zou het onbezwaard vruchtgebruik krijgen en bovendien in 1863-1864 $f 2.400$ extra subsidie ontvangen om tijdelijke huisvesting te huren. ${ }^{148}$ De ambtenaren van het ministerie kwamen direct in actie en leverden de minister in de maand april drie nota's: A. over de wenselijkheid van de samensmelting van wetenschappelijke lichamen in Nederlands-Indië, B. over de bouw van een museum voor het genootschap, en C. over 's Lands Plantentuin in Buitenzorg. Uhlenbeck wees op 18 april 1862 resoluut de eerste rapporteur terecht: 'De ondergetekende wenscht van landswege slechts één gebouw te doen daarstellen voor het oudste der in Indië gevestigde wetenschappelijke genootschappen.' Hij wilde niet meer met de gouverneur-generaal over de samensmelting van de drie organisaties in briefwisseling treden. Voor een alternatief, de oprichting van een geheel nieuwe door het rijk aangestuurde Indische academie van wetenschappen, achtte hij de tijd nog lang niet rijp. ${ }^{149}$ De schrijver van nota B kreeg op dezelfde dag van zijn minister een soortgelijke afwijzing te lezen.

Schrijver dezer nota zal ontwaren uit de in het rapport aan de Koning gemaakte veranderingen [...] dat ik niet beoog eene ineensmelting der drie vereenigingen en beschouwe dat zij zeer gevoegelijk en met meer vrucht naast elkander kunnen bestaan en bloeijen.

Op nota $C$ had Uhlenbeck al een paar dagen eerder geschreven dat hij de zaak van de Buitenzorgse plantentuin helemaal buiten deze kwestie wilde laten en die aan de Indische regering wilde overlaten. ${ }^{150}$

Op 19 april 1862 legde Uhlenbeck de zaak aan Koning Willem III voor. In de brief verwees hij naar eerdere beschikkingen van de koning inzake subsidieverlening aan de wetenschappelijke organisaties in Batavia. Hij legde uit dat het genootschap in een bouwvallige ruimte gehuisvest was en onvoldoende plaats had voor 'de niet onbelangrijke bibliotheek, de niet onaanzienlijke verzameling van het genootschap van voorwerpen, voornamelijk op de land- en volkenkunde van Nederlandsch Indië betrekking hebbende'. Verder suggereerde hij dat vreemde bezoekers een 'treurig denkbeeld' kon-

A.
NA Koloniën verbaal 19-4-1862 nr 35 bevat deze notitie van 1-3-1862.

NA Koloniën verbaal 19-4-1862 nr 35, notitie van Uhlenbeck, 18-4-1862 op p. 36 van rapport

Nota's B en C met Uhlenbecks commentaar in NA Koloiën verbaal 19-4-1862 nr 35. 
den krijgen van de belangstelling in Indië voor zulke zaken, een argument dat Uhlenbeck in 1859 al naar voren had gebracht om toenmalige plannen voor nieuwbouw kracht bij te zetten. Vervolgens wees hij het idee van de samensmelting af met als argument onder meer dat hij persoonlijk goed op de hoogte was met de stand van zaken in Batavia. Tenslotte stelde hij vast dat er geen gouvernementsmuseum was en dat de Indische regering voorwerpen van belang steeds ter bewaring aan het genootschap gaf. Daarna kwam zijn voorstel om te besluiten tot het oprichten van het gebouw

om te strekken tot museum en bewaarplaats van gouvernementsgeschenken en voor de boekerij, behoorende aan en staande onder toezigt van het Genootschap, zoomede voor zijne openbare en bijzondere bijeenkomsten en vergaderingen. ${ }^{151}$

De financiële kaders waren zoals hierboven door Uhlenbeck al op 1 maart 1862 vastgesteld.

De koning reageerde op 22 april 1862 instemmend, zodat Uhlenbeck op 24 april (de 84e verjaardag van het genootschap) aan Sloet van de Beele het goede nieuws kon berichten. Hij voegde er nog persoonlijk aan toe:

Het is mij zeer aangenaam Uwer Exc. deze mededeeling te mogen doen, en op deze wijze te hebben mogen medewerken tot de vervulling eener behoefte, welke in Indië sedert jaren was gevoeld. [...] terwijl ik ook de wensch uitdruk, dat er naar zal worden gestreefd om het nieuw opterigten gebouw, met vermijding van alle onnodige weelde, toch een sieraad voor Nêerlandsch Indië's hoofdstad te doen zijn. ${ }^{152}$

Met het vorstelijke besluit waren eerdere plannen, zoals het nog door Uhlenbeck in 1859 gedane voorstel om op het kolfbaanemplacement te beginnen met de stichting van een nieuw gebouw voor $f 25.500$ als tijdelijke huisvesting voor het genootschap, van de baan. Eerst zou nu het gebouw in de Rijswijkstraat worden afgebroken en daar zou dan in twee jaar tijd de nieuwbouw verrijzen.

\section{Batavia}

Het gouvernementsbesluit van 22 juni 1862, dat op de beslissing uit Den Haag was gebaseerd, gaf in Batavia bekendheid aan de verrassende ontwikkeling. Genootschapsbestuur en gouvernement konden nu aan de slag. Het bestuur belegde een vergadering met Uhlenbecks opvolger als directeur BOW, $\mathrm{H}$. de Bruijn, en schreef een brief aan Sloet van de Beele met verzoek om door

152 NA Koloniën verbaal 24-4-1862 nr 41, waarbij ook het Koninklijk Kabinetsrescript van 22-41862 no 44.1. 
tussenkomst van de minister van koloniën de dank van genootschap aan de koning over te brengen. ${ }^{153}$ Op 8 augustus 1862 vond een eerste vergadering plaats met de directeur BOW. Daarbij werd een pakket van eisen opgesteld, waaruit men zich een beeld kan vormen van het gewicht dat aan de verschillende afdelingen werd gehecht. De volgende ruimtes zouden het nieuwe gebouw vullen (de afmetingen zijn in vierkante meters).

Beoogde indeling van het nieuwe museum (situatie 1862) ${ }^{154}$

\author{
hoofdgebouw \\ bibliotheekzaal \\ leeszaal \\ kamer bibliothecaris \\ archeologische zaal \\ kamer munten/penningen \\ kamer voor kostbaarheden \\ 2 open loodsen (grote voorwerpen) \\ vergaderzaal \\ kamer voor archief/secretaris \\ kamer voor de concierge \\ bijgebouwen \\ woonruimte concierge \\ magazijn \\ 6 bediendenwoningen met keuken \\ 2 latrines ('inodores') \\ 1 wagenloods voor 24 wagens
}

Voor zover er indicaties voor de afmetingen waren vastgesteld, gingen de wensen van het bestuur uit naar een gebouwencomplex met een vloeroppervlak van circa 2.400 vierkante meter (bijgebouwen meegerekend), waarvan de 'zalen' ongeveer 65\% in beslag zouden nemen, de bibliotheek niet meegerekend. De genootschapsnotulen zeggen niet veel over de overige behoeften

153 Brief aan directeur BOW, 14-7-1862 en brief aan de gouverneur-generaal, 15-7-1862 in ANRI KBG Dir 0996, uitgaande correspondentie, nr 179 en 190.

154 TBG 12:589-90, vergadering 8-8-1862. De afmetingen zijn in vierkante ellen opgegeven, hier omgerekend naar vierkante meters. 
voor het gebouw. Er werd aandacht gevraagd voor licht en lucht in de zalen, voor een goede verhouding tussen hoogte en vloeroppervlak en voor de mogelijkheid om de archeologische voorwerpen amfitheatergewijs te kunnen opstellen. Er werd wel aan werkruimte voor de bibliothecaris, secretaris en de concierge gedacht, een werkruimte voor de directeur van het museum werd niet in het programma opgenomen.

In oktober bleek de directeur van BOW problemen te hebben om het program van eisen uit te voeren op het terrein aan de Rijswijkstraat. Daarnaast leek hij ook met het geld niet uit te komen. Hij suggereerde het genootschap de eisen te matigen, minder gericht op de toekomst, meer conform de bestaande situatie. Het genootschap moest zich, met andere woorden, met een kleiner gebouw tevreden stellen. De Bruijn stelde voor om een alternatieve locatie te zoeken aan een van de kanten van het Koningsplein. Tevens stelde hij voor om aan het project een prijsvraag te verbinden. Het bestuur nam de suggestie van het Koningsplein direct over en vroeg de gouverneur-generaal op 15 oktober 1862 op de voorwaarde van de locatie, die van het oude gebouw, zoals dat in het koninklijk besluit was vastgelegd, terug te komen. De zuidzijde van het Koningsplein leek de ideale plek te zijn. Verder hoopte het te kunnen gebruik maken van de opbrengst van een openbare verkoping van het gebouw aan de Rijswijkstraat, waardoor de beschikbare bouwsom groter zou uitvallen. Tenslotte ging het met het prijsvraagidee akkoord. ${ }^{155}$ Een paar dagen later nam De Bruijn in een brief aan de gouverneur-generaal de voorstellen van het bestuur over. Overigens week hij daarmee af van de ideeën die zijn ondergeschikte, hoofdingenieur Beijerinck, had geventileerd. Die was namelijk op 22 september uitgekomen op een plek aan de westzijde van het Koningsplein.

Gouverneur-generaal Sloet van de Beele moest nu met minister Uhlenbeck overleggen over de bouwlocatie. In een brief van 11 november $1862 \mathrm{kwam}$ hij met een sluwe vondst voor de dag. Hij confronteerde zijn minister met een brief van de directeur BOW van 2 april 1858 (toen: Uhlenbeck) waarin over het emplacement in de Rijswijkstraat gesteld werd: 'Dan rijst de vraag of aan de bouw van nieuwe, beter ingerigte en dus ook meer aan de tegenwoordige behoefte geëvenredigde lokalen op een ander, ruimer terrein niet verreweg de voorkeur moet worden gegeven'. Sloet was het helemaal met het genootschap en met Uhlenbecks ideeën uit 1858 eens dat tot een andere locatie moest worden besloten. Het bestaande gebouw verkopen en de opbrengst aan de beschikbare bouwsom toevoegen, ging hem echter te ver. Interessant zijn de stedebouwkundige ideeën die Sloet onder Uhlenbecks aandacht bracht. In de

155 Notulen 1:35-6, vergadering 11-10-1862. De brief aan de gouverneur-generaal, 15-10-1862 nr 256 in ANRI KBG Dir 0996, correspondentie 1861-1864. Afschrift in NA Koloniën verbaal 3-1$1863 \mathrm{nr} 45 / 10 \mathrm{~b}$. 
brief schetst hij een herinrichting van het Koningsplein met midden op het plein een nieuw 'hotel' voor de gouverneur-generaal, aan de noordkant een nieuw gebouw voor de algemene secretarie en aan de zuidzijde het nieuwe gebouw voor het genootschap. Daarmee zou een fraaie indeling van het plein ontstaan met monumentale gebouwen. Sloet sloot af met het voorstel om in ieder geval de beperking tot de locatie in de Rijswijkstraat direct in te trekken. ${ }^{156}$

\section{Den Haag}

Uhlenbecks dagen als minister waren inmiddels geteld. Zijn liberale ideeën en zijn ministeriële onervarenheid ondervonden tegenstand in het parlement. Zijn voorstel voor een nieuwe regeling voor de cultuurondernemingen werd veel te radicaal gevonden. De Eerste Kamer keurde de begroting van koloniën af en Uhlenbeck diende zijn ontslag in. Op 3 januari 1863 werd hem dat verleend. Daags tevoren had hij de koning voorgesteld om conform de voorstellen van Sloet van de Beele de voorwaarde 'ter plaatse van het tegenwoordige gebouw' in te trekken. Op 3 januari had de koning ingestemd en nog vóór Uhlenbeck het ministerie voorgoed verliet, had hij Sloet geschreven dat het genootschap niet meer gebonden was aan de oude locatie in de Rijswijkstraat. ${ }^{157}$ Uhlenbeck wilde met deze stap kennelijk voorkomen dat de bouw van het nieuwe museum vertraging zou oplopen doordat zijn opvolger misschien anders over de zaak zou denken. Het genootschap was Uhlenbeck veel dank verschuldigd voor deze tijdige beslissing. Het benoemde de oud-minister tot erelid en stuurde hem daarvan in een dankbrief bericht. Uhlenbeck reageerde vanuit Den Haag opgetogen op zijn erelidmaatschap:

Een heugelijke dag zal het voorzeker zijn, wanneer de eerste steen van het gebouw voor het genootschap bestemd wordt gelegd; maar nog verblijdender zal het zijn, wanneer het voltooid tot Sieraad strekt van Java's hoofdstad, en feestelijk kan worden ingewijd. ${ }^{158}$

156 NA Koloniën verbaal 3-1-1863 no 45/10b, waarin de brief van de gouverneur-generaal aan de minister van koloniën, 11-11-1862 no 898/12.

157 NA Koloniën verbaal 2-1-1863 nr 7 en verbaal 3-1-1863 nr 45/10b waarin ook het koninklijk kabinetsrescript van 3-1-1863 nr 80.

158 ANRI KBG 0996, 5-3-1863 nr 346. Zie ook Notulen 1:77-8, vergadering 24-2-1863. De dankbrief van Uhlenbeck van 13-5-1863 bevindt zich in de bundel correspondentie over 1863, ANRI KBG Dir 0281. 


\section{Batavia}

In afwachting van de beslissing uit Den Haag over de locatie werden het conceptprogramma en de prijsvraag uitgewerkt, uitgaande van de gedachte dat het wel goed zou komen. In januari 1863 werden deze in de krant gepubliceerd (Javasche Courant 24, 28 en 31-1-1863). De formulering van de prijsvraag, waarvoor de inzendingen op 1 juni 1863 binnen moesten zijn, geeft interessante aanwijzingen voor de veranderingen die ten aanzien van het pakket van eisen van augustus 1862 waren aangebracht. De bouwsom van $f 175.000$ en een langwerpig vierkant of rechthoekige vorm werden als beperkingen aangegeven, maar het aantal idealiter te realiseren vierkante meters werd niet genoemd. Daarin waren de inzenders kennelijk vrij. Wel werd gevraagd om een gebouw dat van alle kanten 'een schoon bouwkundig karakter zou bezitten', waaruit af te lezen valt dat de locatie op Koningsplein-Zuid nog steeds favoriet was. Daar kon een vrijstaand gebouw verrijzen waarop de toeschouwer van vier zijden zicht had. In de bibliotheek moesten 8.000 banden geplaatst kunnen worden in de boekenkasten die het genootschap uit de Rijswijkstraat zou meenemen. Een uitbreiding tot 20.000 banden moest mogelijk zijn. Verder moest de etnologische verzameling drie maal zoveel ruimte krijgen als de archeologische. De vergaderzaal zou iets kleiner mogen zijn dan het archeologische kabinet. Het mineralogisch kabinet en de leeszaal mochten iets kleiner zijn dan de vergaderzaal, en de kamers voor de munten en penningen en voor de kostbaarheden op hun beurt weer iets kleiner. De bibliothecaris en de secretaris zouden nog weer kleiner gehuisvest worden. Voor grote voorwerpen zouden op het terrein nog een of twee open, maar wel overdekte gebouwen nodig zijn, ter grote van de ruimte voor het archeologisch kabinet. Meest opvallend is wel dat de oppervlakte van het hoofdgebouw - in augustus 1862 nog begroot op 2.400 vierkante meter - niet in de prijsvraagopgave was opgenomen.

In maart werd de zevenkoppige commissie ter beoordeling van de te verwachten inzendingen geformeerd. Ze bestond uit genootschapsvoorzitter Wassink en -secretaris Der Kinderen, die van hun kant ook de directeur van BOW, De Bruijn, voorstelden als lid. Deze droeg zijn ondergeschikten, de ingenieurs P.J.G. Beijerinck, jhr. W.F.H.F. de Raders en C.F. Deeleman, naast de genie-kapitein Versteeg (erelid van het genootschap) voor. ${ }^{159}$ Tijdens de algemene vergadering van het genootschap van 27 maart 1863 werd de optimistische verwachting uitgesproken dat binnen twee jaar het nieuwe gebouw kon worden betrokken. ${ }^{160}$ Het zouden er ruim vier worden.

160 Notulen 1:165-9, algemene vergadering 27-3-1863. 
De rest van 1863 ging heen met het wachten op en met het beoordelen van prijsvraaginzendingen. In februari 1864 stelde de Raad van Indië vast dat het jaar 1863 was verlopen zonder dat een voorstel was goedgekeurd. ${ }^{161}$ Hoe de wel ingediende voorstellen er dan uit zagen, komen we nergens aan de weet. Ruim anderhalf jaar na het vorstelijk gebaar bleken er eerst allerlei problemen uit de weg te moeten worden geruimd. Het hoofdprobleem was gelegen in het beoogde terrein op de zuidkant van het Koningsplein, een ruim en van vier kanten zichtbaar perceel waarop een gebouw zou moeten komen dat aan vier zijden de uitstraling van een sieraad had. Dat zou het te duur maken. Het gouvernement had een alternatief bedacht: een terrein aan de westkant van het plein, maar niet op het centrale plein zelf, maar aan de andere kant van de weg die het plein omsloot, op de plek waar vroeger de stallen van de Bataviasche Race-club hadden gestaan. ${ }^{162}$ Door een van de ingenieurs van het departement van De Bruijn was een alternatief plan uitgewerkt voor het bedoelde perceel, waarvan het genootschap inzage kreeg. Het genootschapsbestuur bedacht allerlei bezwaren en uitwegen. Het vond het perceel op de zuidkant van het plein veel geschikter. Een gebouw met één front was minder een 'sieraad' dan een gebouw met vier fronten. Het perceel aan de westkant zou te klein zijn en bovendien grensde het aan een stinkende sloot, 'het wel niet steeds welriekend spruitje Menteng'. Het bestuur zou, als het zelf kon beschikken over de $f 175.000$, het hele project wel onder zijn hoede nemen, zoals Holle ook de kweekschool voor inheemse onderwijzers te Bandoeng had mogen bouwen. ${ }^{163}$ De gouverneur-generaal nam nu snel een besluit. Op 23 februari koos hij tegen de zin van het genootschap voor het perceel aan de westzijde van het plein, waar het gebouw, nu het Nationaal Museum van Indonesië, nog steeds staat. Hij gaf het genootschap het project niet in handen, het zou een BOW-project blijven, en hij vroeg het bestuur vóór 15 april 1864 bezwaren tegen de klaarliggende plannen in te dienen. ${ }^{164}$ Het was bijna twee jaar na de beslissing in Den Haag en er was nog geen spade in de grond gezet.

Zoals in 1858 een project was gepresenteerd, dat door ingenieur Beijerinck was ontworpen, zo bleek nu de eerste ingenieur bij hetzelfde departement, De Raders, zelf lid van de prijsvraagcommissie, de ontwerper te zijn van een gebouw dat op Koningsplein-West zou verrijzen. ${ }^{165}$ De prijsvraag was helemaal van de baan. Het bestuur maakte haast met het doen van voorstellen voor veranderingen in De Raders' project: liever één grote zaal voor de

165 Notulen 2:56, vergadering 12-3-1864.

Notulen 2:1-2, vergadering 9-1-1864.

Notulen 2:4-5, vergadering 9-1-1864.
ANRI Algemene Secretarie besluit 23-2-1864; Advies Raad van Indië, 12-2-1864.

ANRI Algemene Secretarie besluit 23-1-1864 nr 1. Zie ook Notulen 2:52-3, vergadering 12-3- 
etnologische afdeling dan verschillende kleinere; liever geen binnengangen, maar open galerijen en een vestibule met een marmeren vloer en met bovenlicht; liever een andere verdeling van de ruimtes over het gebouw, een andere aansluiting van de vestibule op de binnengalerijen en nog enkele, kleinere punten. De Raders kreeg deze suggesties toegestuurd, vergezeld van tekeningen van de bestuursleden Levyssohn Norman en P. van Swieten, directeur van het Gymnasium Koning Willem III en pas sinds 1863 lid van het bestuur, en een samenvattende nota van Versteeg. ${ }^{166}$ Op basis van de tekening van Van Swieten werd op 22 maart 1864 een discussie met architect De Raders gevoerd. ${ }^{167}$ Die stuurde nog in april het definitieve project aan het bestuur, ${ }^{168}$ waarna nog enig overleg volgde en de gouverneur-generaal op 30 juli 1864 het project definitief goedkeurde. ${ }^{169}$ Eindelijk kon de bouw beginnen.

Bij gebrek aan een uitgebreide beschrijving met tekeningen van de architect moeten we ons een voorstelling maken van het gebouw aan de hand van plattegronden (1877), van de eerste foto's en van beschrijvingen. Heel beeldend gaf secretaris Levyssohn Norman, tevens directeur van het museum, tijdens de algemene vergadering van 30 april 1865 een beschrijving van een virtuele wandeling door het nieuwe gebouw, waarvan de echte bezichtiging nog tot 1867 moest wachten (Notulen 3:76-8). Hij kon melden dat de vloeren er lagen, dat het in 1865 onder dak zou komen en eind 1866 gereed zou zijn.

Het gebouw zou het aanzien krijgen van een Griekse tempel met Dorische zuilen. Men zou tussen de zuilen door een paar treden oplopen om in de met marmer beklede vestibule aan te landen, het gevoel hebbend dat men in een tempel binnentrad, van waaruit men door een colonnade zou treden in de archeologische afdeling, recht achter de ingang. Daar zou men de hindoe-tijd binnenstappen. Daarom was achter de vestibule voor een Indische bouworde gekozen, in afwijking van de Grieks-Dorische van het geheel. In de archeologische afdeling kwamen dan op naar de muren toe oplopende trappen - amfitheatergewijs - de voorwerpen te staan. Aan de voorzijde van het gebouw zouden aan weerskanten van de vestibule telkens twee ruimtes zijn: links een grote vergaderzaal en een kleinere voor de munten en penningen, rechts een grote zaal voor de etnologische afdeling en een kleinere voor de kostbaarheden van het genootschap. De rest van de linkervleugel werd bijna helemaal in beslag genomen door de bibliotheek, de leeszaal en de werkruimte van de bibliothecaris over drie verschillende ruimtes verdeeld. De rechtervleugel zou worden gedomineerd door een tweede grote etnologische

\footnotetext{
166 Notulen 2:54-5, vergadering 12-3-1864.

167 Notulen 2:74-5, vergadering 22-3-1864.

168 Notulen 2:156, vergadering 7-5-1864.

169 ANRI Algemene Secretarie besluit 30-7-1864 nr 13 bevat wel de tekst van het besluit, maar geen tekeningen. Zie ook Notulen 2:200-2, vergadering 6-8-1864.
} 
zaal die tot de achterzijde van het gebouw zou doorlopen.

Men moest zich het museum dus voorstellen als een centraal, tempelachtig gedeelte, waarachter de oudheden een plaats zouden vinden voorzien van twee gelijke vleugels, waarvan de ene zou worden gebruikt voor vergaderen, boekenopslag, lezen en voor het munten- en penningenkabinet, terwijl de rechtervleugel geheel als tentoonstellingsruimte gebruikt zou worden. De vleugels zouden zowel aan de binnenzijde als aan de buitenkant van het gebouw worden gesierd met dezelfde Dorische zuilen, die ook de voorkant kenmerken, waardoor het idee van een Griekse tempel versterkt werd. De zes zuilen van het voorportaal en de vijftien van de zijkanten gaven het geheel een statig, plechtig uiterlijk, met reminiscenties aan de Griekse tempels op Sicilië. De zuilen kwamen zowel in de vestibule als in de galerijen aan de binnentuin terug. Met recht een tempel voor de muzen.

Men verwondere zich er niet over dat Levyssohn Norman tijdens zijn wandeling het mineralogische kabinet oversloeg: dat was begin 1865 overgedragen aan de Koninklijke Natuurkundige Vereeniging, waardoor er extra ruimte beschikbaar kwam voor de andere delen van de verzamelingen.

Achter de vleugels was nog terrein beschikbaar voor een tuin, onder meer voor de grote en zware voorwerpen, terwijl achter op het perceel, niet ver van het spruitje Menteng, het magazijn, de wagenloods, de conciergewoning en de bediendenvertrekken kwamen. Het gebouw zou aan de voorzijde 56 meter breed zijn, de vleugels zouden 32 meter diep en 16 meter breed worden. Van de in eerste instantie gevraagde 2.400 vierkante meter waren er in het hoofdgebouw circa 1.800 gerealiseerd. Op een foto uit circa 1868, waarschijnlijk genomen nog voor de ingebruikneming, ziet men het gebouw haast zonder beplanting en kan men zich dus goed voorstellen hoe de proporties zijn geweest in de oorspronkelijke staat (Merrillees 2000:183). De foto is vermoedelijk gemaakt door de genootschapsfotograaf Van Kinsbergen, al wordt hij ook aan Woodbury and Page toegeschreven. Andere foto's uit dezelfde periode zijn gemaakt door J.A. Meessen. De Van Kinsbergen-opname is echter van betere kwaliteit. ${ }^{170}$

Over de bouwgeschiedenis zeggen de genootschapsnotulen niet veel. In 1865 werden op suggestie van het bestuurslid N.P. van den Berg nog enkele kleine veranderingen aangebracht, maar deze hadden slechts te maken met het voorterrein en een dakgoot. ${ }^{171}$ Waarom de bouw zo lang duurde, kan men dus niet uit het genootschapsarchief of uit de gedrukte notulen vernemen. Sloet van de Beele vermeldde in zijn overdrachtsdocument van oktober 1866, bestemd voor zijn opvolger Pieter Mijer, dat het ruwe metselwerk gereed was, maar dat 
bestellingen uit Europa de voltooiing vertraagden. ${ }^{172}$ Pas in september 1867 is er sprake van het betrekken van het gebouw: er werd een eerste vergadering gehouden van het bestuur, waarna een bezichtiging plaats vond. We mogen aannemen dat het grotendeels klaar was, maar toch vergaderde het bestuur een maand later weer in het gebouw van de Natuurkundige Vereeniging, waar het vanaf december 1864 steeds was bijeengekomen. Kennelijk was nog niet alles gereed om het bestuur voor zijn maandelijkse vergaderingen voorgoed te huisvesten. Het gebouw in de Rijswijkstraat was na mei 1861 niet meer voor vergaderen gebruikt. Het zou na het vertrek van het genootschap in gebruik worden genomen door het Mijnwezen. Nog weer later zou er het kadaster van Batavia in gevestigd worden. Het zal wel eerst zijn opgeknapt, want zelfs de algemene vergaderingen hadden bij voorzitters of vice-voorzitters thuis plaatsgevonden, zo slecht was langzamerhand het genootschapshuis er aan toe geweest. Op 29 oktober 1867 heette het echter dat het nieuwe gebouw betrokken was. ${ }^{173}$ Over de verhuizing van de verzamelingen horen wij weinig of niets. Vooruitlopend op de overbrenging van de collecties had het bestuur aan de directie van Onderwijs, Eeredienst en Nijverheid voor 1868 een bedrag van $f 2.000$ extra aan subsidie gevraagd, de helft bedoeld voor de aankoop van nieuwe kasten, de andere helft om de verhuizing te bekostigen. ${ }^{174}$

In november 1867 bezocht gouverneur-generaal Mijer, die zelf bij zijn eerdere verblijf in Batavia jarenlang bestuurslid was geweest, het nieuwe gebouw. Hij was het met het bestuur eens dat de beeldengalerij achter de vestibule aangepast moest worden. ${ }^{175}$ De opstelling van de archeologische afdeling voldeed niet. In maart 1868 werd besloten voorlopig van verbouwen af te zien, omdat de behoefte ertoe, gezien de omvang van de verzamelingen, niet groot was. Tijdens deze vergadering besloot het bestuur het museum open te stellen voor publiek: zondag, dinsdag en donderdag van 8.00 tot 12.00 uur. Hiermee kwam het tot een wel heel weinig ceremonieel einde van de bouwgeschiedenis en een begin dat - van de kant van het bestuur - niet getuigde van veel gevoel voor public relations en promotie. ${ }^{176}$ Er vond zelfs geen algemene vergadering van de leden plaats, wat men bij het bereiken van deze mijlpaal in de genootschapsgeschiedenis had mogen verwachten.

Met het Grieks-Dorische, monumentale uiterlijk behoorde het museum tot de grotere openbare gebouwen van Batavia. De bouwstijl paste mooi bij de

172 Sloet van de Beele, 'Overzicht van den staatkundigen toestand van Nederlandsch Indië'.

NA Koloniën 2.10.03 no 24, p. 1485-6.

173 Notulen 5:96, vergadering 29-10-1867.

174 Brieven van het bestuur, 25-5-1867 nr 24 en 16-10-1867 nr 53 in ANRI KBG Dir 0997, pp.

233-4 en 255.

175 Notulen 5:101-2, vergadering 28-11-1867.

176 Notulen 6:18-9, vergadering 8-3-1868. 
grote toegang tot het Europese kerkhof op Tanah Abang (1844), het gebouw van het Hooggerechtshof aan het Waterlooplein (1848) en dat van de ernaast gelegen Loge De Ster van het Oosten (1858). Ook de later gebouwde onderkomens van de Raad van Justitie aan het Stadhuisplein (1870) en het Paleis Koningsplein (1879) passen in de serie van monumentale gebouwen die door het departement van BOW zijn neergezet met een indrukwekkende zuilengalerij naar de straat- of pleinkant. En dan noemen we in dit verband alleen de belangrijkste openbare bouwwerken. De ingenieurs van de waterstaat en van $\mathrm{BOW}$ hadden zo voor een coherent bouwprogramma gezorgd, dat het aanzien van Batavia tot in de twintigste eeuw zou bepalen.

De Koninklijke Natuurkundige Vereeniging, die zo vriendelijk was om jarenlang vergaderruimte af te staan aan het genootschap, had een zwervend bestaan geleid. In 1863 kocht het samen met de Maatschappij van Nijverheid, met wie het al 'samen had gewoond' op Noordwijk, een huis aan Koningsplein-Zuid, aan de andere kant van de weg die het plein omsloot en precies tegenover de droomlocatie van het bestuur van het genootschap. Het was een bestaand huis waarvoor $f 50.000$ was betaald en waar de vereniging in 1950, bij het 100-jarig bestaan, nog steeds in gevestigd was (Willekes Macdonald 1950:20-1). Zo waren er in korte tijd zowel aan de westkant als aan de zuidkant van het plein musea gevestigd, want zowel de vereniging als de maatschappij hield er een museum op na, zij wel onder één dak. Het genootschap was aan het samenwonen ontkomen.

Even weinig als we van de bouwgeschiedenis weten, valt er op basis van de genootschapsnotulen te zeggen over de inrichting. De eerste foto's van het interieur dateren pas van 1878. Wij zouden in die notulen verslagen hebben verwacht over de verdeling van de collecties over de beschikbare ruimtes en over de manier waarop een en ander ging worden opgesteld. Van het pakhuis, waar alles opgepropt stond, kreeg het genootschap de beschikking over duidelijk gescheiden ruimtes, waarbij de verschillende vleugels mogelijkheden boden om per collectie accenten aan te brengen. In plaats van tevreden gesteld te worden met verslagen van discussies of toch minstens verwijzingen naar de verschillende mogelijkheden, vinden we praktisch niets. Tijdens Levyssohn Normans denkbeeldige rondleiding door het gebouw in mei 1865 meldde hij dat het bestuur van plan was in de vestibule de kanonnen op te stellen, die voor de kraton in Martapoera hadden gestaan en die na de val van Bandjarmasin door het gouvernement met de Bandjarmasinse regalia waren overgedragen ter bewaring in het museum. De kanonnen, bekend onder de naam Sri Bandjar, zouden zo de bezoeker imponeren en herinneren aan de Bandjarmasinse krijg (Notulen 3:76-7). Bibliothecaris Stortenbeker adviseerde in januari 1866 de bibliotheek te reorganiseren en tijdschriften en boeken die 'buiten de werkkring des genootschaps' lagen, niet langer aan te houden. In augustus eropvolgend besloot het bestuur om in die zin te handelen en 
de bedoelde werken ook niet meer naar het nieuwe gebouw mee te nemen, maar aan andere geleerde genootschappen over te doen. Tegelijkertijd gaf Stortenbeker een lange lijst op van relevante werken die nog ontbraken. ${ }^{177}$ In 1867-1868 werden kasten, stellingen, rekken besteld, maar zo weinig dat het niet anders kan of men deed het in eerste instantie grotendeels met de oude inboedel uit de Rijswijkstraat. ${ }^{178}$ In maart 1868 vermeldden de notulen wel een bijdrage die fotograaf Van Kinsbergen zou leveren aan de inrichting van het museum. Die nam de uitnodiging van voorzitter Loudon aan om een ontwerp te leveren voor zes nissen in de vestibule, waar vermoedelijk de monumentale boeddha's zouden komen te staan, die nu nog steeds de toeschouwer bij binnenkomst treffen. Van Kinsbergen zou tevens de nieuwe directeur van de gebouwen van het genootschap, Egter van Wissekerke, helpen met het aanbrengen van verbeteringen in de beeldengalerij. ${ }^{179}$ Van Kinsbergen met zijn theaterachtergrond zou zeker een meer dramatische opstelling kunnen leveren van het aanwezige hindoe-beeldenmateriaal. De opstelling van personen op zijn fotografische portretten uit dezelfde periode levert daar het bewijs van. Of Van Kinsbergen en Friederich elkaar bij het rangschikken van de beelden in de weg liepen, zeggen de notulen niet. Friederich was immers twee maanden eerder ook gevraagd zich met de opstelling van de archeologische collectie bezig te houden. Het is eerder waarschijnlijk dat Van Kinsbergen Hoepermans in het museum tegenkwam. ${ }^{180}$

Pas in 1869 was er, naar aanleiding van het rapport van de commissie tot opname van het museum enig zicht op wat er ter discussie stond. ${ }^{181}$ Commissieleden Van der Chijs en L.J.J. Michielsen, de laatste kommies bij de Algemene Secretarie en lid van het genootschap, rapporteerden toen over de stand van zaken in het museum. Zij vonden de metalen platen en stenen met inscripties in het portaal, maar ook de voorwerpen in het midden van de beeldengalerij en in de loods voor grote voorwerpen te laag opgesteld. Zij schonken aandacht aan de lelijke papieren etiketten op de beelden en suggereerden geschilderde nummers of blikken etiketten te gebruiken. Zij stelden ook een herschikking van de beelden voor. Antiek en modern zouden moeten worden gescheiden, alsook Javaans en niet-Javaans. De commissie maakte met geen woord melding van de werkzaamheden van Friederich of Van Kinsbergen in de archeologische galerij. Het blijft een vraag of die zich ooit met de rangschikking van de objecten hebben bemoeid.

ring 1-9-1868); 72 (vergadering 6-10-1868).

179 Notulen 8:19, vergadering 8-3-1868.

180 Notulen 8:10, vergadering 14-1-1868.

181 Notulen 7:22-5, vergadering 6-4-1869. 
Van de etnologische verzameling, waar het geografische indelingscriterium heerste dat ook in Levyssohn Normans catalogus (1868) gevolgd was, vond de commissie dat deze toen al leed onder plaatsgebrek. Het beval uitbreiding van de etnologische zaal aan. De commissie vroeg aandacht voor het probleem van de conservering. Veel van de voorwerpen in deze afdeling waren van niet-duurzame materialen gemaakt. Luchten door de kasten open te zetten was de maatregel waartoe men zich nu beperkte, maar dat was niet genoeg. Restauratie van sommige modellen van huizen werd aanbevolen, terwijl tot de overplaatsing van sommige natuurhistorische voorwerpen naar de collectie van de Koninklijke Natuurkundige Vereeniging werd geadviseerd. Er was wel een lijst van Hoepermans van de oudheidkundige verzameling, maar de eerste gedrukte catalogus ervan zou pas in 1887 worden uitgegeven. De commissie beval tenslotte een catalogus van de manuscripten aan. De opmerkingen van de commissie geven enig inzicht in de problemen waarmee de directeur van het museum, Levyssohn Norman, in het nieuwe gebouw te kampen had.

Het voorstel van de commissie om de etnologische zaal uit te breiden geeft aan dat de nieuwbouw al heel snel niet meer voldeed. Ideeën over uitbreiding werden in 1870 besproken: de commissaris van de gebouwen dacht aan een dwarsgalerij die de linker- en rechtervleugel zou kunnen verbinden, een voorstel, waardoor een vierkant blok zou onstaan. ${ }^{182}$ De binnenplaats zou dan aan vier zijden omsloten worden. Daarvoor werd een plan uitgewerkt waarvoor in 1871 een bedrag van $f 35.000$ werd aangevraagd. Een jaar later werd dat bedrag door Den Haag toegekend. ${ }^{183}$ Nog een jaar zou het duren voordat het bestuur besloot tot de uitvoering van de uitbreiding over te gaan, zij het op een andere wijze. De twee vleugels werden verlengd naar de achterzijde toe en van een dwarsgalerij werd afgezien. ${ }^{184}$ Het museum zou worden voorzien van een aanbouw van acht meter aan de linker bibliotheekvleugel en van 22 meter aan de rechter, etnologische vleugel, waardoor het geheel asymetrisch werd. Achter de leeszaal en de kamer van de bibliothecaris ontstond extra ruimte voor boekenopslag. De grote etnologische zaal werd bijna verdubbeld tot een lengte van 48 bij 16 meter. Er kwamen zuilen bij aan de zijkanten om de eenheid van het geheel te bewaren. ${ }^{185}$ Minder fraai was nu dat de twee vleugels niet meer tot gelijke hoogte in het achterterrein uitstaken.

182 Notulen 8:53, vergadering 3-5-1870.

183 Notulen 9:74, vergadering 7-11-1871;10:136, vergadering 19-11-1872.

184 Notulen 11:11, vergadering 4-2-1873; 37, vergadering 11-3-1873; 41, vergadering 28-3-1873;

128 , vergadering 7-10-1873.

185 In het Gedenkboek van 1878 ziet men deze situatie afgebeeld op de plattegrond van de situatie in 1877. 
Een nieuw begin

Het genootschap was op een lang verwacht moment en op een onverwachte manier aan een nieuw gebouw gekomen. Het relaas van de periode 1857-1861 leest als een somber verhaal. Er leek voor het genootschap niet te ontkomen aan de door de subsidiegever opgelegde fusie, die tegelijkertijd het einde zou betekenen van meer dan tachtig jaar zelfstandig bestaan. Het genootschap kroop echter door het oog van de naald, dankzij het feit dat bouwkundig ingenieur en directeur van BOW in Batavia, Uhlenbeck, tijdens zijn verlof in Nederland minister van koloniën werd en het dossier van het Bataviaasch Genootschap meteen ter hand nam. Hij schoof het idee van een samensmelting van drie verenigingen terzijde. Dat de minister op dat ogenblik in de cultuurman en amateur-wetenschapper, gouverneur-generaal Sloet van de Beele een bondgenoot trof, kwam prachtig uit. Het in zijn voortbestaan bedreigde genootschap kreeg zo een nieuwe kans op een centrale plek aan het Koningsplein. Het kortstondige ministerschap van Uhlenbeck speelde daarbij het genootschap in de kaart.

Het is hier niet de plaats om de bouwgeschiedenis van het museum annex genootschapsgebouw verder te volgen. Dat is eerder op zijn plaats in het vervolg van de geschiedenis, die in 1868 moet aanvangen. Wel opvallend is, dat na al die jaren van wachten en bouwen, het volume zo snel te gering was. Even opvallend is, dat er uit de notulen zo weinig te bespeuren is van de kwalitatieve impuls die men uit het betrekken van een nieuwe gebouw had mogen verwachten. Dat de collecties van de Harmonie naar het Koningsplein verhuisden had aanleiding kunnen geven tot herinventarisatie, waardoor veel aan het licht was gekomen: gebreken, vermissingen, om maar iets te noemen. Alleen de etnologische afdeling kreeg meteen een catalogus, de goede timing daarvan kwam voor rekening van de directeur, Levyssohn Norman. Aan de catalogisering van de archeologische collectie werd gewerkt. Verder werd naar de bibliotheek gekeken: wat moest mee en wat kon weg? Voor het overige is van een herbeschouwing van de collectie, die men bij een andere opstelling in een nieuwe ruimte mocht verwachten, zo goed als niets in de notulen te vinden. De commissie Van der Chijs-Michielsen was in 1869 de eerste die kritisch naar de voorwerpen en naar de opstelling keek en zelfs het verslag van die commissie doet pover aan. Wel is een enkele blik in de notulen vanaf 1868 voldoende om te zien dat de uitbreiding van de collectie voortdurend de aandacht van het bestuur had. Aanwinsten stroomden binnen.

De vraag is of men - de activiteiten van het genootschap vanaf 1861 overziend - positief kan zijn over de manier waarop de verhuizing werd voorbereid. Werden alle kansen waargenomen om over de collectie na te denken? Werden verschillende manieren van presentatie overwogen? Werd gekeken naar hoe andere archeologische en volkenkundige musea het pro- 
bleem van de opstelling hadden opgelost? Uiteraard kunnen we deze vragen niet beantwoorden waar de notulen van het genootschap ons hierop geen antwoord geven. Als we echter naar de andere onderwerpen in deze periode kijken, naast die van nieuwbouw en verhuizing, blijkt het bestuur in de jaren 1861-1868 vooral op het gebied van het verzamelen, op dat van de zorg voor oudheden en taalstudie niet had stilgezeten. Daarmee kon het verdergaan in een tempel aan het Koningsplein. 
Hans Groot - 978-90-04-25380-3

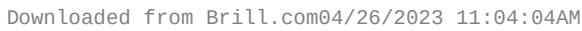
via free access 


\section{Lijst van gebruikte afkortingen}

$\begin{array}{ll}\text { Alg. Secr. } & \text { Algemene Secretarie } \\ \text { ANRI } & \text { Arsip Nasional Republik Indonesia } \\ \text { BKI } & \text { Bijdragen tot de Taal-, Land-en Volkenkunde van Nederlands-Indië } \\ \text { CMC } & \text { Cultureel Maçonniek Centrum 'Prins Frederik' } \\ \text { ENI } & \text { Encyclopaedie van Nederlandsch-Indië } \\ \text { Gouv.bt } & \text { Gouvernementsbesluit } \\ \text { HMW } & \text { Hollandse Maatschappij der Wetenschappen } \\ \text { Jaarboek } & \text { Jaarboek [van het] Koninklijk Bataviaasch Genootschap } \\ \text { KB } & \text { Koninklijke Bibliotheek } \\ \text { KBG } & \text { Archief Bataviaasch Genootschap } \\ \text { KITLV } & \text { Koninklijk Instituut voor Taal-, Land- en Volkenkunde } \\ \text { Kol. } & \text { Archief Ministerie van Koloniën (Nationaal Archief Den Haag) } \\ \text { KZGW } & \text { Koninklijk Zeeuws Genootschap der Wetenschappen } \\ \text { NA } & \text { Nationaal Archief (Den Haag) } \\ \text { NNBW } & \text { Nieuw Nederlandsch Biografisch Woordenboek } \\ \text { Notulen } & \text { Notulen van de algemeene en bestuurs-vergaderingen van het } \\ & \text { Bataviaasch Genootschap } \\ \text { OIOC } & \text { Oriental and India Office Collections (Londen) } \\ \text { Perpusnas } & \text { Perpustakaan Nasional (Jakarta) } \\ \text { RANH } & \text { Rijksarchief Noord-Holland } \\ \text { RAZ } & \text { Rijksarchief Zeeland } \\ \text { TBG } & \text { Tijdschrift voor Indische Taal-, Land-en Volkenkunde } \\ \text { TNI } & \text { Tijdschrift voor Neêrland's Indië } \\ \text { TvG } & \text { Tijdschrift voor Geschiedenis } \\ \text { UBA } & \text { Universiteitsbibliotheek Amsterdam } \\ \text { UBL } & \text { Universiteitsbibliotheek Leiden } \\ \text { VBG } & \text { Verhandelingen van het Bataviaasch Genootschap } \\ \text { WNT } & \text { Woordenboek der Nederlandsche Taal } \\ & \end{array}$


Hans Groot - 978-90-04-25380-3

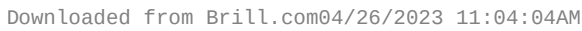
via free access 


\section{BIJLAGE 1}

\section{Leden en vergaderingen}

Leden Bataviaasch Genootschap 1779-1794

\begin{tabular}{lrrrrrrr}
\hline & 1779 & 1780 & 1781 & 1786 & 1790 & 1792 & 1794 \\
\hline Directeuren & 16 & 16 & 13 & 13 & 14 & 13 & 18 \\
Dirigerende leden & 9 & 9 & 9 & 8 & 8 & 7 & 10 \\
Leden in Batavia & 94 & 90 & 87 & 87 & 90 & 83 & 92 \\
Leden op de buitenkantoren & 73 & 86 & 98 & 98 & 97 & 92 & 84 \\
\cline { 2 - 7 } Totaal & 192 & 201 & 207 & 206 & 209 & 195 & 204 \\
\hline
\end{tabular}

Opgave volgens de Verhandelingen 1-7 


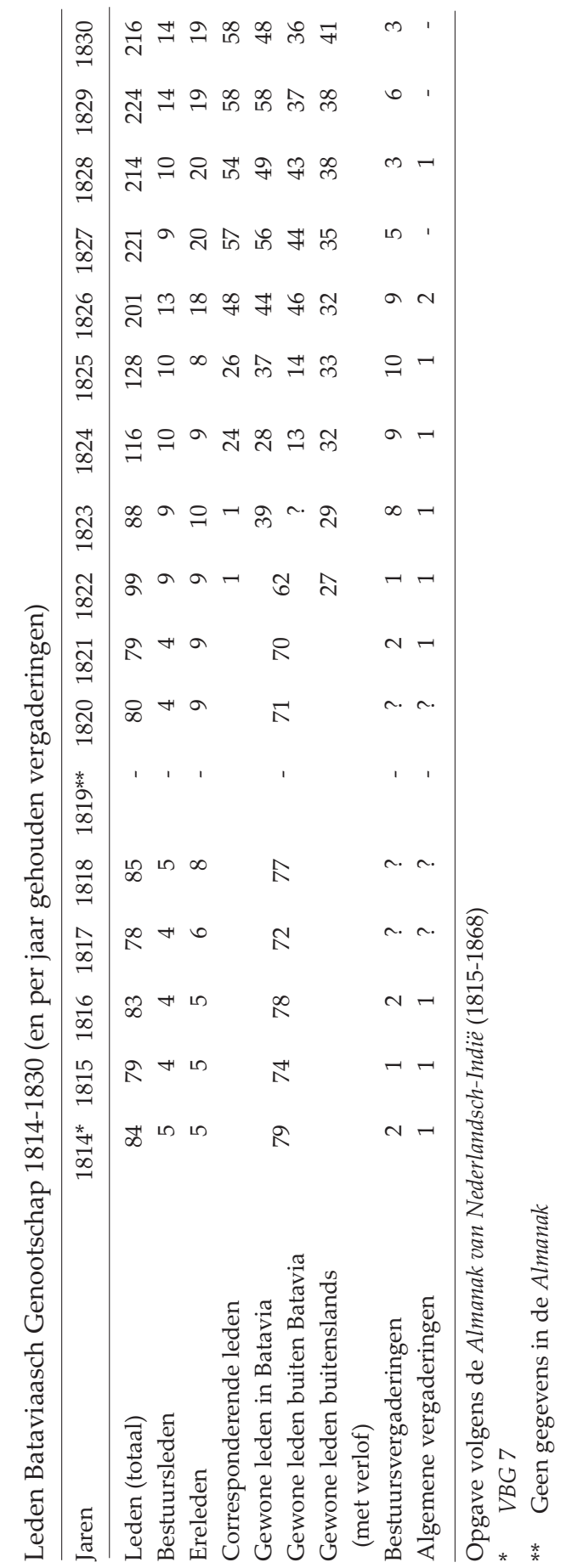




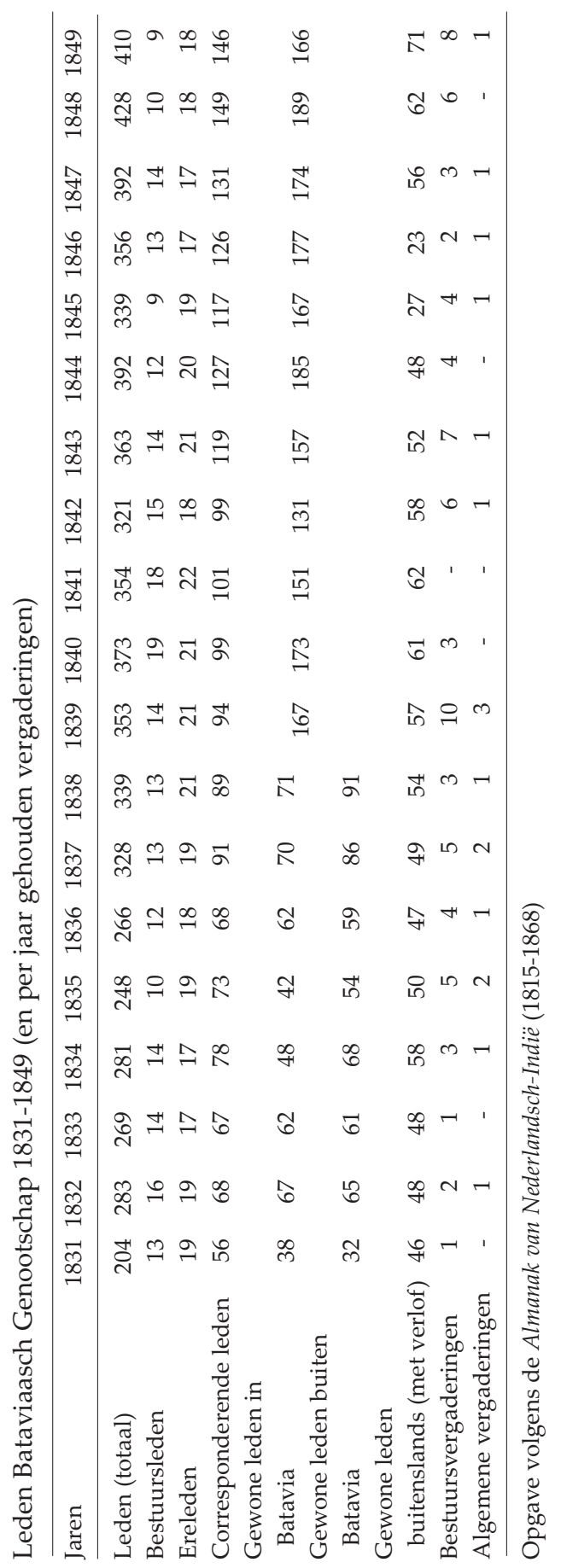




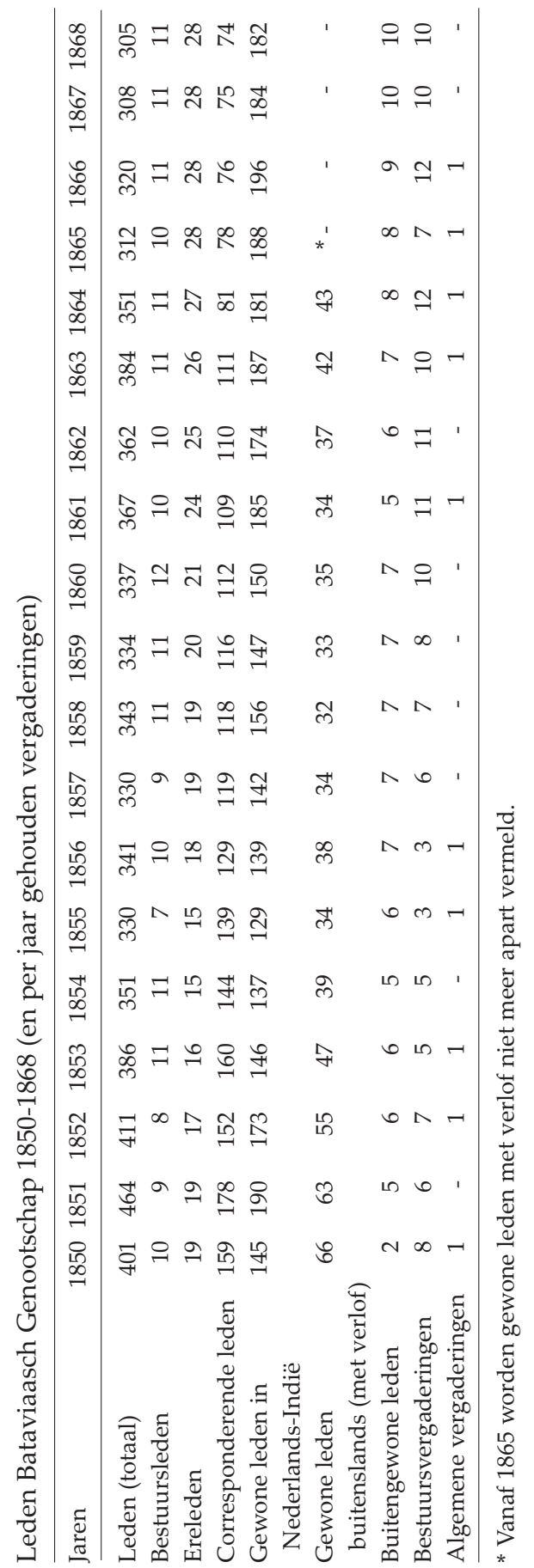




\section{Bijlage 2}

\section{Drukwerk van de pers van het Bataviaasch Genootschap 1843-1848}

\section{Toelichting}

Deze lijst bevat het traceerbare drukwerk, dat in de jaren 1843-1848 van de persen van het Bataviaasch Genootschap is gekomen. Daarbij moet opgemerkt dat een mogelijk grotere hoeveelheid 'stukken van geringen omvang, welke slechts tot bepaalde einden voor den handel en ten gerieve van particulieren moeten dienen, zoo als manifesten, rekeningen, uitklaringen, catalogussen en dergelijke' niet traceerbaar is, vanwege het vluchtige karakter ervan. Omdat voor dit vluchtige drukwerk toestemming was verleend en het conflict met het gouvernement juist om het 'andere' drukwerk ging, is dat in de lijst opgenomen. Op grond van deze lijst is het mogelijk een indruk te krijgen van de hoeveelheid werk die in de drukkerij werd verzet. Voor het overige zij verwezen naar hoofdstuk 5 .

Van de met een asterisk $\left({ }^{*}\right)$ gemerkte titels heb ik geen exemplaar in handen gehad.

Seriewerken, zoals de Verhandelingen, jaarlijkse verslagen en tijdschriften, zijn onder het jaar van uitkomen telkens opnieuw opgenomen.

$1 \quad$ Extract uit het register der Handelingen en Resolutien van besturende leden van het Bataviaasch Genootschap van Kunsten en Wetenschappen.

[Ter drukkerij van het Bataviaasch Genootschap, na 20 juli 1843] 8 $8^{\circ} 15 \mathrm{p}$. ANRI ABG 196 bij verg. 20-7-1843, punt 6.

2 Extract uit het register der Besluiten van den Gouverneur Generaal van Nederlandsch Indië.

[Ter drukkerij van het Bataviaasch Genootschap, na 5 oktober 1843] $8^{\circ} .3 \mathrm{p}$. ANRI ABG 196 bij verg. 20-7-1843.

3 S.A. Buddingh, Kerkelijke toespraak aan de hervormde en luthersche gemeenten, bij gelegenheid der inwijding van het orgel in de Willemskerk te Batavia, op den 16den Julij 1843 gehouden door Dr.S.A. Buddingh, V.D.M. Uitgegeven tot ondersteuning van een behoeftig huisgezin.

Ter drukkerij van het Bataviaasch Genootschap. 1843. $8^{\circ} .32$ p.

Voorwoord van de schrijver gedateerd: 16-10-1843.

KITLV q 228; Perpusnas XXIX 30 
Bijwet voor de Z.A. Loge De Ster in het Oosten, werkende in het O. van Batavia. [vignet]

Ter drukkerij van het Bataviaasch Genootschap. 1843. $8^{\circ} .62$ p.

KITLV dd 128 (fotokopie Bibl.Theol. coll. S.J. Maastricht 3190 E 41)

5 W.R. van Hoëvell, Verslag van den staat der werkzaamheden van het Bataviaasch Genootschap van Kunsten en Wetenschappen, gelezen in de algemeene vergadering des genootschaps op den 5den october 1843. Door W.R. van Hoëvell, VicePresident des Genootschaps.

Ter drukkerij van het Bataviaasch Genootschap. 1843. $8^{\circ} .72+$ II p.

KITLV dd 929; Perpusnas B 32/3

6 Verhandelingen van het Bataviaasch Genootschap van Kunsten en Wetenschappen. 19de deel. Batavia [drukkerij van het Bataviaasch Genootschap] 1843.

$8^{\circ}$. ii + xcviii + iv $+128+$ xlii $+167+422$ p.

KITLV leeszaal; Perpusnas B 25/19.

(Van de teksteditie Sjaïr Bidasari is de Maleise tekst gezet en gedrukt door de Landsdrukkerij, de rest van het deel is gedrukt op de pers van het Bat. Gen.)

$7 \quad$ The tenth Annual Report of the board of directors of the Parapattan Orphan Asylum; founded in the year 1832, for the board, clothing, and education of the orphans and other children, left destitute in this part of India. Translated from the Dutch. Printed at the press of the Batavia Society of Arts and Sciences. 1843. $8^{\circ} .29$ p. Perpusnas B 316 - 1843 Eng.

(Nederlands origineel gedrukt door Ukena \& Co, Batavia 1843.)

1 Sjaïr Bidasari, oorspronkelijk Maleisch gedicht, met eene Vertaling en Aanteekeningen; uitgegeven door W.R. van Hoëvell, theol. Doct., Vice-President van het Bataviaasch Genootschap en Predikant te Batavia. [vignet]

Batavia, ter drukkerij van het Bataviaasch Genootschap. 1844.

$8^{\circ} .2$ delen. Dl. 1: ii + xlii +167 (Maleise tekst gedrukt door de Landsdrukkerij)

D1. 2: 421 + ii. Titeluitgave van VBG 91, 1843 no 6, 2e stuk.

KITLV hh 689; Perpusnas XXXII 97

2 Tijdschrift voor Neêrland's Indië. Zesde jaargang.

Batavia, ter drukkerij van het Bataviaasch Genootschap. 1844.

8․ 4 delen. Dl. 1: 570 p. Dl. 2: 442 p. Dl. 3: 348 p. Dl. 4: 396 p.

KITLV leeszaal; Perpusnas A191/1844

3 Natuur-en Geneeskundig Archief voor Neêrland's Indië. Eerste jaargang.

Batavia, ter drukkerij van het Bataviaasch Genootschap. 1844. $8^{\circ}$. xii + vi + $639 \mathrm{p}$.

KITLV TS 511 [K $61 \mathrm{C}]$

4 Bijdragen tot de geneeskundige topographie van Batavia. Door P. Bleeker; Offic. van Gezondh. bij het Geneesk. Bestuur in Nederl. Indië, lid en bibliothecaris van het Bataviaasch Genootschap van Kunst. en Wetensch. 2 stukken. [vignet]

Batavia, ter drukkerij van het Bataviaasch Genootschap. $1844.8^{\circ}$. ii +80 p. en 169-220.

KITLV 632 C 5; Perpusnas XXI 623. Overdrukken uit Natuur-en Geneeskundig Archief 1, 1844 no 3, p. 1-80 en 169-220. 
Eerder ook verschenen in TNI 1843, 2, p. 281-332, 640-58 en TNI 1844, 1, p. 45178, en 2, 97-140.

5 Bijdrage tot de kennis der genees- en artsenijmengkunde onder de Chineezen in het algemeen en onder die te Batavia in het bijzonder, door P. Bleeker. [vignet]

Batavia: ter drukkerij van het Bataviaasch Genootschap. 1844 . $8^{\circ}$. ii + p. $257-$ 284.

UBL 607 B 8. Overdruk uit 1844, 3?

P. Mijer, Gedenkboek der feestelijke vereeniging van oud-studenten der vaderlandsche hoogeschoolen, gehouden te Batavia, den tweeden augustus 1844. Uitgegeven ten voordeele van het Weeshuis te Parapattan.

Batavia, ter drukkerij van het Bataviaasch Genootschap. $1844.8^{\circ}$. vi + $190+\mathrm{ii}+5$ lithografieën.

KITLV dd 21; Perpusnas XXII 502

Studentenliederen gezongen op het oud-studentenfeest, gevierd te Batavia op den 2den Augustus, 1844. [vignet]

Batavia, ter drukkerij van het Bataviaasch Genootschap, 1844. $8^{\circ} .24$ p.

KB 6 F 7. (Titeluitgave van deel III van Gedenkboek, 1844 no 7, zie hierboven)

8 De Nachtwacht, blijspel in één bedrijf, naar het hoogduitsch van Theodor Körner, door S. van Deventer, JSzoon. [vignet]

Batavia, ter drukkerij van het Bataviaasch Genootschap. $1844.8^{\circ} 47 \mathrm{p}$.

UBL 1097 C 82

9 Verslag der feestviering van het vijf en zeventig-jarig grondwettig bestaan der vrijmetselarij te Batavia, gehouden op den 16den November 1844 (g.s.) [vignet]

Batavia, ter drukkerij van het Bataviaasch Genootschap. $8^{\circ} .104 \mathrm{p}$.

CMC Den Haag; Perpusnas 345 a 12

10 Elfde jaarlijksch verslag der directie van het weeshuis te Parapattan, opgerigt in 't jaar 1832, voor de voeding, kleeding en opvoeding van weezen en andere verlatene kinderen in dit gedeelte van Indië. Eleventh Annual Report etc.

Ter drukkerij van het Bataviaasch Genootschap van kunsten en wetenschappen. 1844.

$8^{\circ} .67 \mathrm{p}$.

Perpusnas B 3161844 (Engelse en Nederlandse tekst)

*11 Bouchardy, Lazaro. Tooneelspel in vier bedrijven, met een voorspel; naar het Fransch: Lazare le patre.

Batavia, ter drukkerij van het Bataviaasch Genootschap. 1844. $8^{\circ} 3+204$ p.

Van der Chijs, Proeve, p, 76, no 18.

Perpusnas XL 105, echter niet beschikbaar.

12 W.C.H. toe Water, Nagelaten leerreden van wijlen -, theol.doct. en predikant te Semarang. Uitgegeven en van een levensberigt voorzien door W.R. van Hoëvell, theol. doct. en predikant te Batavia.

Batavia, ter drukkerij van het Bataviaasch Genootschap. 1844. $8^{\circ}$. [xii] + xxxviii + $[2]+235 \mathrm{p}$.

Perpusnas XXIX 64

13 Wiwoho of Mintorogo, een Javaansch gedicht uitgegeven en van eene vertaling en aantekeningen voorzien door J.F.C. Gericke.

$8^{\circ}$. ii + xxxiii $+98+179$ (Javaanse en Nederlandse tekst)

Perpusnas xxxiii 112. Titeluitgave van VBG 20, 1845 no 1, 2e stuk 
Perpusnas XXXIII 3 en XXXIII 81 alleen Javaanse tekst op groot papier, $176 \mathrm{p}$.

${ }^{*} 14$ Alphabetisch woordenlijstje en vertaling van al de woorden die voorkomen in het Fransch lees- en vertaalboekje, door G. Verhulp.

Batavia, drukkerij van het Bataviaasch Genootschap. $12^{\circ} .55 \mathrm{p}$.

Van der Chijs, Proeve, Supplement 1, p. 37; niet in de catalogus Perpusnas

*15 Catalogus eener belangrijke verzameling van vogels toebehoorende aan het Bataviaasch Genootschap van Kunsten en Wetenschappen, welke verkogt zal worden op de 3den Junij 1844, in een der zalen van de Harmonie.

Ter drukkerij van het Bataviaasch Genootschap. 1844

Perpusnas catalogusnummer XLII 247, echter niet beschikbaar.

1 Verhandelingen van het Bataviaasch Genootschap van Kunsten en Wetenschappen. 20e deel.

Batavia, [drukkerij van het Batviaasch Genootschap] 1844 [maar verschenen in 1845].

$8^{\circ}$ ii + vi $+94+$ xxxiii $+175+98$ p.

KITLV leeszaal; Perpusnas B 25 / 20

(Van de teksteditie van Wiwoho in dit deel is de Javaanse tekst gezet en gedrukt door de Landsdrukkerij, de rest van het deel is gedrukt door de pers van het Bat. Gen.)

2 Tijdschrift voor Neêrland's Indië. Zevende jaargang.

Batavia, ter drukkerij van het Bataviaasch Genootschap. 1845.

$8^{\circ} 4$ dln. Dl. 1: 422 p. Dl. 2: 570 p. Dl. 3: 484 p. Dl. 4.461 p.

KITLV leeszaal; Perpusnas A 1911845

3 Natuur-en Geneeskundig Archief voor Neêrland's Indië. Tweede jaargang.

Batavia, ter drukkerij van het Bataviaasch Genootschap. 1845. $8^{\circ}$. iv + vi + $711 \mathrm{p}$.

KITLV TS 511 [ K 61 C]

$4 \quad$ Nieuwe Indische verhalen en herinneringen uit vroegeren en lateren tijd, door W.L. Ritter. I. Deel / II. Deel.

Batavia, ter drukkerij van het Bataviaasch Genootschap. 1845. $8^{\circ}$. Dl. 1: [vi] + iv + 267 p. Dl. 2: [iv] + ii + 299 p.

KITLV cc 37

5 Twaalfde jaarlijksch verslag van de directie van het weeshuis te Parapattan, opgerigt in 't jaar 1832, voor de voeding, kleeding en opvoeding van weezen en andere verlatene kinderen in dit gedeelte van Indië. Twelfth Annual Report etc.

Batavia, ter drukkerij van het Bataviaasch Genootschap. [1845]. $8^{\circ} .54$ p.

Perpusnas B 3161845 (Engelse en Nederlandse tekst)

${ }^{*} 6$ Verslag van het lijkfeest, gehouden in de Z.A. Loge De Ster in het Oosten, gevestigd te Batavia. [B.H.M. de Kock]

Batavia, ter drukkerij van het Bataviaasch Genootschap, 1845. $8^{\circ} .34$ p.

Van der Chijs, Proeve, p. 79, no. 30.

Perpusnas B 345 a1, echter niet beschikbaar.

*7 Catalogus der boekwerken, enz. van de Z.A. Loge De Ster in het Oosten. 
Batavia, drukkerij van het Bataviaasch Genootschap. 1845. $8^{\circ} .28$ p.

Van der Chijs, Proeve, Supplement 1, p. 38. Niet in catalogus Perpusnas.

*8 W.C.H. toe Water, Nagelaten leerredenen. 2e dr

Batavia, drukkerij van het Bataviaasch Genootschap. 1845

Van der Chijs, Proeve, Supplement 2 p. 45. Niet in catalogus Perpusnas.

9 P. Bleeker, Brieven over Java; door Bleeker. (Et parva utilia.) [vignet].

Batavia, 1845. (1e serie) $8^{\circ}$. iv + 207-40, 353-61, 381-427, 1-17, 19-28, 4 tabellen.

Perpusnas XXI 231

(Overdruk uit TNI 7 (1845) dl. 1-3. Impressum geeft geen drukkersnaam.)

1 P. Bleeker, Bibliothecae Societatis Artium Scientiarumque Quae Bataviae floret, Catalogus Systematicus curante Bleeker. [vignet]

Typis Societ. Art. Scient. Batav. 1846. 8․ $8+85$ p.

KITLV bb 76

2 Tijdschrift voor Neêrland's Indië. Achtste jaargang.

Batavia, ter drukkerij van het Bataviaasch Genootschap. 1846.

8․ Dl. 1: 399 p. Dl. 2: 606 p. Dl. 3: 400 p. Dl. 4: 394 p.

KITLV leeszaal; Perpusnas A 191

3 Natuur-en Geneeskundig Archief voor Neêrland's Indië. Derde jaargang.

Batavia, ter drukkerij van het Bataviaasch Genootschap, 1846. $8^{\circ}$. iv $+v+$ plano +617 .

KITLV TS 511

4 Tijdschrift ter bevordering van Christelijken zin in Neêrland's Indië. Onder medewerking van de heeren predikanten in Neêrland's Indië, en ten voordeele van het weeshuis te Parapattan uitgegeven door Dr. W.R. van Hoëvell, Theol. Doct. en Predikant te Batavia.

Batavia, ter drukkerij van het Bataviaasch Genootschap. 1846-47. (alleen jaargang 1 verschenen, titelpagina verzameldeel heeft 1846-1847, maar aflevering 4 heeft apart titelblad met 1846]

$8^{\circ}$. Dl. 1: iv $+i v+x v+i i+154$ p. Dl. 2: $i i+i i+i v+176$ p. Dl. $3: i i+i i+171$ p. $D l$ 4: $\mathrm{ii}+\mathrm{ii}+192+1 \mathrm{p}$.

KITLV TS 512

5 Desiderata van het Bataviaasch Genootschap van Kunsten en Wetenschappen. [vignet]

Batavia, ter drukkerij van het Bataviaasch Genootschap. 1846. $8^{\circ}$. ii + ii +34 p.

KB Broch. 1024

6 Verslag van het verhandelde in de algemeene vergadering van het Nederlandsch OostIndisch Bijbelgenootschap. Op donderdag de 9den Julij 1846, des avonds ten zeven ure, in de Willemskerk te Batavia.

Batavia, ter drukkerij van het Bataviaasch Genootschap. 1846. $8^{\circ} .70$ p.

KITLV q 44

7 De doodstraf getoetst aan gezonde rede en menschkunde, aan godsdienst en redelijkheid, aan maatschappelijk belang, aan bijbel en evangelie. Door S.A. Buddingh. (De opbrengst der uitgave is bestemd voor het genootschap tot zedelijke verbetering 
der gevangenen.)

Batavia, ter drukkerij van het Bataviaasch Genootschap. 1846. $8^{\circ}$ [iv] + 54 p. KITLV Z 142; Perpusnas XXVII 63

8 J.T. Canter Visscher, Index op het Staatsblad van Neêrland's Indië; loopende van 1816 tot 1844; gevolgd van eene chronologische opgave der bepalingen, die door latere verordeningen of door tijdsverloop als vervallen kunnen beschouwd worden; opgemaakt en met toestemming van het gouvernement uitgegeven door J.T. Canter Visscher, President van het Collegie van Boedelmeesters te Batavia. [vignet]

Batavia, ter drukkerij van het Bataviaasch Genootschap. 1846. $4^{\circ} \mathrm{x}+\mathrm{ii}+151 \mathrm{p}$. UBL 3929 A 50

9 De inwijding der Christenkerk te Serang, hoofdplaats der residentie Bantam, op den 20sten September 1846, door W.R. van Hoëvell.

Batavia, ter drukkerij, van het Bataviaasch Genootschap. 1846. $8^{\circ}$. ii +38 p.

KITLV q 38; Perpusnas XXIX 221

10 De bijbel in Indië. Redevoering gehouden in de algemeene vergadering van het Nederlandsch Oost-Indisch Bijbelgenootschap, op donderdag den 9den Julij, des avonds ten zeven ure, in de Willemskerk te Batavia, door W.R. van Hoëvell. [vignet]

Batavia, ter drukkerij van het Bataviaasch Genootschap. 1846. $8^{\circ} .52$ p.

KITLV q 275

11 Oost-Indische bloempjes. Gedichtjes voor de Nederlandsch-Indische jeugd, door J. van Soest.

Batavia, ter drukkerij van het Bataviaasch Genootschap. 1846. $8^{\circ}$. viii +109 p. UBA 1044 D 10, UBL 1293 F 50

12 Verzameling der Battahsche wetten en instellingen in Mandheling en Pertibie, gevolgd door een overzigt van land en volk in die streken; door T.J. Willer. [vignet]

Batavia, ter drukkerij van het Bataviaasch Genootschap. 1846. $8^{\circ}$. [ii] + vi + $280 \mathrm{p}$.

KITLV c 138

(Titeluitgave, zie ook TNI 8 (1846) dl 2, p. 145-424, 606.)

13 Welkom in het weeshuis te Parapattan. Een liedje aan Z. Excell. den Heere J.J. Rochussen, Minister van Staat, Gouverneur Generaal van Neêrland's Indië, bij hoogstdeszelfs bezoek in genoemd gesticht, op dinsdag den 20sten Januarij 1846, toegezonden door de weezen. [vignet]

Batavia, ter drukkerij van het Bataviaasch Genootschap. 1846. $8^{\circ}$ ii +4 p.

KITLV dd 247

14 Hoe oud zijt gij? Godsdienstige overdenking naar Genesis 47: 8b; door S.A. Buddingh, Theol. Doct. en Predikant te Batavia. [vignet]

Batavia, ter drukkerij van het Bataviaasch Genootschap. 1846. $8^{\circ}$ ii +32 p. KB 1162 B 50

15 S.A. Buddingh, Geschiedkundig overzigt van het Bataviaasch Genootschap van Kunsten en Wetenschappen, voorgelezen in de algemeene vergadering van het genootschap op den 14den januarij 1846.

Batavia [drukkerij van het Genootschap] 1846. $8^{\circ}$. p. 259-275.

KITLV dd 766; Perpusnas XXII 313

(Overdruk van TNI 8 (1846) dl 1) 
Dertiende jaarlijksch verslag van de directie van het weeshuis te Parapattan, opgerigt in 't jaar 1832, voor de voeding, kleeding en opvoeding van weezen en andere verlatenen kinderen in dit gedeelte van Indië. Thirteenth Annual Report etc. Batavia, ter drukkerij van het Bataviaasch Genootschap. 1846. $8^{\circ} .80+4$ p. Perpusnas B 3161847 (Engelse en Nederlandse tekst, beschadigd exemplaar, titelpagina en p. 3-6 ontbreken, titel analoog aan serie overgenomen.)

1735 Statements of exports from Java and Madura for as many articles of trade, being mostly, if not all, the produce of Netherland's India with indication of countries whereto; from the beginning of 1825 to the end of the year 1845. Extracted from the yearly government reports, and published for the benefit of the Batavia Parapattan Orphan Asylum, by a member of the direction for that asylum, in August 1846. 35 Etats d'exportations etc.

Geen drukker vermeld, maar mogelijk ook gedrukt bij het BG gezien: 'and published for the benefit of the Batavia Parapattan orphan asylum, by a member of the direction of that asylum'. $4^{\circ}$. oblong, 30 dubbelbladen.

Perpusnas XXVI 792 (ex. met opdracht voor W.R. van Hoëvell door F. Embrechts, die de staten compileerde.)

18 S.L. Heymann, Opmerkingen over de acclimatisatie. door -, Dirigerend officier van gezondheid. [vignet].

Batavia, ter drukkerij van het Bataviaasch Genootschap. 1846. $8^{\circ}$. p. 311-359

Overdruk uit Natuur- en Geneeskundig Archief 3 (1846).

Perpusnas XX 136 (geen titelblad, wel gedrukt omslag)

19 [J.J.L.L.] Jacobson, Bijdrage tot de theekultuur, door -. Batavia, ter drukkerij van het Bataviaasch Genootschap. 1846. $8^{\circ} .30$ p. met twee ingevoegde tabellen

Overdruk TNI 8 (1846) dl 2.

Perpusnas XI 132

1 Verhandelingen van het Bataviaasch Genootschap van Kunsten en Wetenschappen. 21ste deel. 1e gedeelte / 2e gedeelte. [vignet]

Batavia, ter drukkerij van het Bataviaasch Genootschap. 1846-1847. [maar gezien het voorwoord pas verschenen in 1847]. $8^{\circ}$. Dl. 1 : ii $+115+60+33+12+$ xxviii + $131 \mathrm{p}$.

D1. 2: ii $+28+596$ p.

KITLV leeszaal; Perpusnas B 25/21

2 Tijdschrift voor Neêrland's Indië. Negende jaargang.

Batavia, ter drukkerij van het Bataviaasch Genootschap. 1847. $8^{\circ}$. Dl. 1: 388 p. Dl. 2: 428 p. Dl. 3: 392 p. Dl. 4: 574 p.

KITLV leeszaal; Perpusnas A 191

3 Natuur-en Geneeskundig Archief voor Neêrland's Indië. Vierde jaargang.

Batavia, ter drukkerij van het Bataviaasch Genootschap, 1847.

$8^{\circ} .2$ afl. verschenen. $255 \mathrm{p}+$ plano.

KITLV TS 511

4 Twaalftal kerkelijke reden, van S.A. Buddingh, Theol. Doct. en Predikant te Batavia. Uitgegeven ten voordeele van het Parapattan-Weezen-gesticht. [vignet]

Batavia, ter drukkerij van het Bataviaasch Genootschap. 1847. $8^{\circ}$. ii + xviii + i + i 
$+\mathrm{iii}+\mathrm{ii}+261 \mathrm{p}$.

KB 3190 D 31; Perpusnas XXIX 63 (ex. op groot papier)

5 Veertiende jaarlijksch verslag van de directie van het Parapattan Weezen Gesticht, opgerigt in 't jaar 1832, voor de voeding, kleeding en opvoeding van weezen en andere verlatene kinderen in dit gedeelte van Indië. Fourteenth Annual Report etc.

Batavia, ter drukkerij van het Bataviaasch Genootschap. 1847. $8^{\circ} .83$ p. met litho's

UBL V 8701846 (14) [1847]

6 Zeemans-gids voor de straten Banka en Gaspar, door H.D.A. Smits. Uitgegeven van wege de kommissie tot verbetering der Indische zee-kaarten, enz. [vignet]

Batavia, ter drukkerij van het Bataviaasch Genootschap. 1847. $4^{\circ}$. xvi $+56+$ [i] p.

KITLV x 122

$7 \quad$ Onderzoek naar de reden, waarom Jezus verboden heeft hem als den Christus openbaar te maken. Door S.A. Buddingh, Theol.Doct. en Pred. te Batavia.

Batavia, ter drukkerij van het Bataviaasch Genootschap, 1847. $8^{\circ} .40$ p.

Perpusnas XXIX 512

8 M. Mistral, Chronique théatrale concernant monsieur Robert, directeur du théatre Français à Batavia.

Batavia, Imprimerie de Lange \& Co. 1847. [maar gedrukt op de pers van het BG].

$8^{\circ} 12 \mathrm{p}$.

Perpusnas B $342 \mathrm{p}$

*9 Hikayat Sultan Abdoel Moeloek, uitgegeven en vertaald door P.P. Roorda van Eysinga.

Batavia, ter drukkerij van het Bataviaasch Genootschap. 1847. $8^{\circ} .150$ p. (alleen Maleise tekst?)

Van der Chijs, Proeve, p. 84, no 32

(Gedeeltelijke titeluitgave van editie in TNI 9 (1847), dl. 4. p. 285-526)

Perpusnas XXXII is editie 1858 van hetzelfde werk.

10 Verzameling van eene menigte noodzakelijke zamenspraken met inlanders van allerlei klassen, in de laag Maleische taal; voorafgegaan door een beknopte spraakkunst dier taal; zoo als dat alles door den lageren Maleijer wordt gesproken en verstaan, en zulks tot gemak van velen; door [W.A.P. Roorda van Eysinga].

Batavia, ter drukkerij van Lange \& Co. 1847. [maar gedrukt op de persen van het BG].

$12^{\circ}$. viii $+80 \mathrm{p}$.

Perpusnas XLVI 699

*11 W.R. van Hoëvell, Geloofshelden uit de eerste eeuwen van de christelijke kerk.

Batavia, ter drukkerij van het Bataviaasch Genootschap. 1847. $8^{\circ} .84$ p.

(Overdruk uit Tijdschrift ter bevordering van christelijken zin, 1e jg, iii, p. 97.)

Van der Chijs, Proeve, Supplement 1, p. 39. Niet in catalogus Perpusnas.

12 Bijdragen tot de kennis van de nopal-kultuur en van de cochenelle-teelt op Java; door L. Monod de Froideville.

Batavia, ter drukkerij van het Bataviaasch Genootschap. 1847. $8^{\circ}$. ii $+78+$ tabel en gedrukt omslag. 
Perpusnas XI 118

(Titeluitgave van TNI 9 (1847), dl 2, p. 207-84, 299.)

13 [Romo, een Javaansch gedicht naar de bewerking van Joso Dhipoero, uitgegeven en vertaald door C.F. Winter.] Titelpagina ontbreekt

(Titeluitgave van 1847 / 1, 2e deel. (alleen de Javaanse tekst) $8^{\circ} .596$ p.

Perpusnas XXXIII 28

14 CXXVI Tableaux, démontrant le commerce de l'ile de Java avec 38 différents pays, tant pour les importations que les exportations, de 1825 à 1845. Extraits des rapports annuels du gouvernement par F.A.E. [= Embrechts] de Batavia. CXXVI Statements, showing the trade of Java with 38 different countries etc.

Batavia, à l'imprimérie de la Société Batave des Arts et des Sciences. f ${ }^{\circ} .105$ p. Perpusnas $24^{*}$

$1 \quad$ Warnasarie 1848. Letterkundig jaarboekje uitgegeven door I. Munnich.

[Batavia, drukkerij van het Bataviaasch Genootschap] 1848. $8^{\circ}$. [i] + [i] + 299 p. KITLV cc 31

2 Tijdschrift voor Neêrland's Indië. Tiende jaargang.

Batavia, ter drukkerij van het Bataviaasch Genootschap. 1848. $8^{\circ} .1$ deel verschenen. 399 p.

KITLV leeszaal; Perpusnas A 191/1848.

3 Ontleed-en natuurkundige beschouwingen over het menschelijk ligchaam en leeven, naar aanleiding van demonstratiën op het kunstkadaver van Dr. Anzoux, gehouden in het Bataviaasch Genootschap van Kunsten en Wetenschappen door J. Munnich, Officier van Gezondheid. Uitgegeven ten voordeele van het Parapattan-Weeshuis te Batavia. Eerste deel [ niet verder verschenen]

Batavia, ter drukkerij van het Bataviaasch Genootschap. 1848. $8^{\circ}$ vi + ix + $436 \mathrm{p}$.

\section{UBA 658 F 1}

4 Versjes gezongen bij het examen door de weezen van het Parapattan Weezen-Gesticht, in de Willemskerk op den 10den Mei 1848. [vignet]

Batavia, ter drukkerij van het Bataviaasch Genootschap. 1848. $8^{\circ} .8$ p.

KITLV dd 248

$5 \quad$ Inwendige comsumptie van zout [op] Java en Madura, van af 1827 tot en met 1847. Uitvoer van zout van Java en Madura, van af 1814 tot 1847. Met nog eenige andere inlichtingen omtrent het artikel zout. [vignet]

Batavia, ter drukkerij van het Bataviaasch Genootschap. 1848. $\mathrm{f}^{\circ}$. [i] +8.

KITLV o 202

6 Zeemansgids voor de eilanden en vaarwaters beoosten Java, gevolgd door eene methode, om door hoekmeting nabij de oppervlakte der zee, de hoogten van bergen en omgekeerd hunnen afstanden te berekenen; door H.D.A. Smits, luitenant-ter-zee 2 de klasse, belast met het beheer van het depot zeekaarten, boeken, enz. secretaris der kommissie tot verbetering der Indische zeekaarten. [vignet] Batavia, ter drukkerij van het Bataviaasch Genootschap. 1848.

A seaman's guide for the islands and straits eastward of Java, etc.

$4^{\circ} . i+x i+x i+54+54+i+i+8+8+17+1 p$. 
UBL 1856 C 16 (Nederlandse en Engelse tekst)

$7 \quad$ Wat belooft de water-geneeskunde voor de gezondheid en welvaart van het Europesche ras in tropische gewesten? Door F.A.C. Waitz, Med.Dr. Uitgegeven ten voordeele van het Parapattan weezen-gesticht op Rijswijk.

Batavia, ter drukkerij van het Bataviaasch Genootschap. 1848. $8^{\circ}$ [viii] $+180 \mathrm{p}$. KITLV z 49

8 Geschiedenis van Sultan Abdoel Moeloek, Koning van Barbarije. Bezongen in het hedendaagsch Djohorsch Maleisch door zijne hoogheid Radja Ali Hadji, Onderkoning van Riouw. Vrij vertaald door Dr. P.P. Roorda van Eijsinga, Ridder in de orde van den Nederlandschen Leeuw.

Batavia, ter drukkerij van het Bataviaasch Genootschap. 1848. $8^{\circ}+89$ p.

UBA 487 B 37; UBL C 15 (alleen Nederlandse tekst)

(Titeluitgave van TNI 1847 IV)

9 Vijftiende jaarlijksch verslag van de directie van het Parapattan weezen gesticht, opgericht in het jaar 1832, voor de voeding, kleeding en opvoeding van weezen en andere verlatenen kinderen in dit gedeelte van Indië. Fifteenth Annual Report etc.

Batavia, ter drukkerij van het Bataviaasch Genootschap. 1848. $8^{\circ} .55$ p. (Engelse en Nederlandse tekst)

Perpusnas B 3161848 


\section{Bibliografie}

Lijst van gebruikte archieven

Jakarta

Arsip Nasional Republik Indonesia (ANRI)

Archief Koninklijk Bataviaasch Genootschap van Kunsten en Wetenschappen

Archief Algemene Secretarie

Familie-archief Beth

Londen

Oriental and India Office Collections (OIOC)

Mackenzie Collection

Raffles Collection

Nationaal Archief (NA)

VOC-Archief

Archief Ministerie van Koloniën (Kol.)

Archief Baud

Archief Vosmaer

Den Haag

Koninklijk Huisarchief

Archief Stadhouder Willem V

Haarlem

Rijksarchief Noord-Holland (RANH)

Archief Hollandsche Maatschappij der Wetenschappen (HMW)

Middelburg

Rijksarchief Zeeland

Archief Koninklijk Zeeuws Genootschap der Wetenschappen (KZGW)

Kerkeraadsarchief Classis Walcheren

Leiden

Koninklijk Instituut voor Taal-, Land- en Volkenkunde

Archief KITLV 
Literatuur

Abhandlungen

$1782 \quad$ Abhandlungen der Gesellschaft der Künste und Wissenschaften in Batavia. Erster Theil. Aus den Holländischem übersetzt und mit Anmerkungen und Zusätzen versehen. Leipzig: Weygand. [Exemplaar UBL 2301 G 3.]

Almanak

1817-68 Almanak van Nederlandsch Indië, vervolgd als Almanak en Naamregister, vanaf 1866 als Regerings-Almanak

Bakels, J. en N. de Jonge

2001

Indië ontdekt; Expedities en onderzoek in de Oost en de West. Leiden: KITLV Uitgeverij.

Bastin, J.

1990 'The natural history researches of Thomas Horsfield (1773-1859); First American naturalist of Indonesia', in: Th. Horsfield, Zoological researches in Java and the neighbouring islands, pp. 1-97. Singapore: Oxford University Press.

Bastin, J. en D.T. Moore

1982 'The geological researches of Dr. Thomas Horsfield in Indonesia 18011819', Bulletin of the British Museum (Natural History), Historical Series 10-3:75-115.

Baud, J.C.

1853

'Aanspraak tot opening van de eerste algemeene vergadering van het Koninklijk Instituut voor de Taal-, Land- en Volkenkunde van Neêrlandsch-Indië; gehouden op den 4den Junij 1851', Bijdragen tot de Taal-, Land-en Volkenkunde 1:1-6.

Baud, W.A.

1983 De semi-officiële en particuliere briefwisseling tussen J.C. Baud en J.J. Rochussen 1845-1851 en enige daarop betrekking hebbende andere stukken. Assen:

Baudet, H. en C. Fasseur

Van Gorcum. Twee delen. [Proefschrift Rijksuniversiteit Leiden.]

1977 'Koloniale bedrijvigheid', in: J.H. van Stuijvenberg (red.), De economische geschiedenis van Nederland, pp. 309-50. Groningen: WoltersNoordhoff.

Beckingham, C.F.

1979 'A history of the Royal Asiatic Society, 1823-1973', in: S. Simmonds and S. Digby (red.), The Royal Asiatic Society; Its history and treasures, pp. 1-77. Leiden/London: Brill.

Berg, L.W.C. van den

1873 Codicum Arabicorum in bibliotheca Societatis Artium et Scientiarum quae in Bataviae floret asservatorum. Catalogum inchoatum a R. Friederich absolvit indiscibusque instruxit [...]. Bataviae: Bruining et Wijt, Hagae Comitis: Nijhoff.

1877 Verslag van eene verzameling Maleische, Arabische, Javaansche en andere handschriften, door de regering van Nederlandsch Indië aan het Bataviaasch Genootschap van Kunsten en Wetenschappen afgestaan. Batavia: Bruining, Den Haag: Nijhoff. 

ven medeleden, Maatschappij der Nederlandsche Letterkunde, pp. 158-209. Leiden: Brill.

Berg, N.P. van den

1895 'Levensbericht van Mr. H.D. Levyssohn Norman', Levensberichten der afgestorven medeleden, Maatschappij der Nederlandsche Letterkunde, pp. 527-70. Leiden: Brill.

1906 'Levensbericht van E. de Waal', Levensberichten der afgestorven medeleden, Maatschappij der Nederlandsche Letterkunde, pp. 58-126. Leiden: Brill.

Berg, W. van den

1983 'Het literaire genootschapsleven in de eerste helft van de negentiende eeuw', De Negentiende Eeuw 7:146-78.

Berge, T. van den

1998 Karel Frederik Holle, theeplanter in Indië 1829-1896. Amsterdam: Bert Bakker.

Berigt Radermacher

1859 'Berigt [over] Mr. Jacob Cornelis Matheus Radermacher', Tijdschrift voor Indische Taal-, Land-en Volkenkunde (TBG) 8:75-6.

Berkel, K. van

1993

'Een onwillige mecenas? De rol van de VOC bij het natuurwetenschappelijk onderzoek in de zeventiende eeuw', in: J. Bethlehem en A.C. Meijer (red.), VOC en cultuur; Wetenschappelijke en culturele relaties tussen Europa en Azië ten tijde van de Verenigde Oost-Indische Compagnie, pp. 39-58. Amsterdam: Schiphouwer en Brinkman.

1998 Citaten uit het boek der natuur: Opstellen over Nederlandse wetenschapsgeschiedenis. Amsterdam: Bert Bakker.

2000 (red.) Het oude Instituut en de nieuwe Akademie; Overheid en wetenschapsbeoefening omtrent het midden van de negentiende eeuw. Amsterdam: Koninklijke Nederlandse Akademie van Wetenschappen.

2004

'Stuwende kracht of deftig ornament?; Enige inleidende opmerkingen', in: K. van Berkel (red.), De Akademie en de Tweede Gouden Eeuw, pp. 7-14. Amsterdam: Koninklijke Nederlandse Akademie van Wetenschappen.

Bernet Kempers, A.J.

1979 'Het Bataviaasch Genootschap van 1778', Spiegel Historiael 14:165-73.

1981 'A short history of the time-honoured library; The library of the Bataviaasch Genootschap', in M. van Doorn (red.), Improving access to Indonesian collections in the Netherlands; contributions to a survey of Dutch literary and documentation activities in the field of Indonesian studies, pp. 7-10. Leiden: Centre for the history of European expansion, Amsterdam: Koninklijk Instituut voor de Tropen. [Intercontinenta 2.]

Bethlehem, J. en A.C. Meijer

1993 VOC en cultuur; Wetenschappelijke en culturele relaties tussen Europa en Azië ten tijde van de Verenigde Oost-Indische Compagnie. Amsterdam: Schiphouwer en Brinkman. 
Bie, J.P. de en J. Loosjes (red.)

1919-49 Biographisch woordenboek van protestantsche godgeleerden in Nederland. 's-Gravenhage: Nijhoff. Zes delen.

Bierens de Haan, J.A.

$1952 \quad$ Van Oeconomische Tak tot Nederlandsche Maatschappij voor Nijverheid en Handel 1777-1952. Haarlem: Tjeenk Willink.

1970 De Hollandsche Maatschappij der Wetenschappen 1752-1952. Tweede druk. Haarlem: Tjeenk Willink. [Met supplement 1952-1970.]

Bijdragen tot de Taal-, Land-en Volkenkunde

1852-65 Bijdragen tot de Taal-, Land-en Volkenkunde van Neêrland's Indië, Deel $1-12$.

Blake, D.

1991

'Colin Mackenzie; Collector extraordinary', The British Library Journal 17:128-50.

Bleeker, P.

1846 Bibliothecae Societatis Artium Scientiarumque quae Bataviae floret, catalogus systematicus. Batavia: Societ. Art. Scientiarumque.

1852 'Verslag der werkzaamheden van het Bataviaasch Genootschap van Kunsten en Wetenschappen, van september 1850 tot april 1852, namens het bestuur des Genootschaps voorgelezen in de algemeene vergadering op den 27sten april 1852', in: Verhandelingen van het Bataviaasch Genootschap van Kunsten en Wetenschappen (VBG) 24:1-34.

1853a Bibliothecae Societatis Artium Scientiarumque quae Bataviae floret, catalogus systematicus. Editio altera curante J. Munnich. Catalogus van de bibliotheek van het Bataviaasch Genootschap van Kunsten en Wetenschappen. [Tweede uitgave door J. Munnich. Batavia: Lange.]

1853b 'Overzigt der geschiedenis van het Bataviaasch Genootschap van Kunsten en Wetenschappen van 1778-1853', in: Verhandelingen van het Bataviaasch Genootschap van Kunsten en Wetenschappen (VBG) 25:1-24.

1877 Bleeker, P., 'Levensbericht van Pieter Bleeker', in: Jaarboek Akademie van Wetenschappen te Amsterdam, pp. 5-55.

Bloembergen, $\mathrm{M}$.

2003 De koloniale vertoning; Nederland en Indië op de wereldtentoonstellingen (1880-1931). Amsterdam: Wereldbibliotheek.

Blussé, L. en I. Ooms (red.)

$2002 \quad K e n n i s$ en Compagnie; De Verenigde Oost-Indische Compagnie en de moderne wetenschap. Amsterdam: Balans.

Boelman, H.A.L.

1936 Bijdrage tot de geschiedenis der geneeskruidcultuur in Nederlandsch OostIndië. Leiden: Van Doesburgh. [Proefschrift Rijksuniversiteit Utrecht.]

Bosch, F.D.K.

1930 'The debt of archeology to Raffles', Inter-Ocean 11-3:133-5.

Bosch, F.D.K. en C.C.F.M. le Roux

1931 'Wat in Parijs verloren ging', Tijdschrift voor Indische Taal-, Land- en Volkenkunde (TBG) 71:663-83. 
Bosma, U. en R. Raben

2003 De oude Indische wereld 1500-1920. Amsterdam: Bert Bakker.

Brandes, J.C.A. zie W.P. Groenevelt

Brug, P.H. van der

$1994 \quad$ Malaria en malaise; De VOC in Batavia in de 18e eeuw. Amsterdam: Bataafsche Leeuw.

Bruijn, J.G. de

1977 Inventaris van de prijsvragen uitgeschreven door de Hollandsche Maatschappij der Wetenschappen 1753-1917. Haarlem: Hollandse Maatschappij der Wetenschappen, Groningen: Tjeenk Willink.

Bruijn, M. de en B. Kist

2001 Johannes Rach 1720-1783; Artist in Indonesia and Asia. Jakarta: National Library, Amsterdam: Rijksmuseum.

Bruijn, M. de en R. Raben

$2004 \quad$ The world of Jan Brandes 1743-1808; Drawings of a Dutch traveller in Batavia, Ceylon and Southern Africa. Zwolle: Waanders, Amsterdam: Rijksmuseum

Buddingh, D.

1870 'Levensbericht van Dr. Stephaan Adriaan Buddingh', Levensberichten der afgestorven medeleden, Maatschappij der Nederlandsche Letterkunde, pp. 234-84. Leiden: Brill.

[Buddingh, S.A.]

1839 Batavia's Genootschap van Kunsten en Wetenschappen. Batavia: s.n. [Koninklijke Bibliotheek Pamflet 27651.]

Buddingh, S.A.

1846 'Geschiedkundig overzigt van het Bataviaasch Genootschap van Kunsten en Wetenschappen, voorgelezen in de algemeene vergadering van het Genootschap op den 14den januarij 1846'. Batavia: s.n. [Ook in Tijdschrift voor Neêrland's Indie (TNI) 8, I:259-75.]

18501 'I-IV. schap van Kunsten en Wetenschappen, gelezen in de algemeene vergadering op den 13den september 1850', in: Verhandelingen van het Bataviaasch Genootschap van Kunsten en Wetenschappen (VBG) 23:1-25.

Buursma, J.H.

1978 Nederlandse geleerde genootschappen opgericht in de 18e eeuw. Uithoorn: s.n. [Bibliografische Bijdragen 7.]

Buijnsters, P.J.

1984 'Nederlandse leesgezelschappen uit de 18e eeuw', in: P.J. Buijnsters, Nederlandse literatuur van de achttiende eeuw; Veertien verkenningen, pp. 183-98. Utrecht: HES.

Carstens, R. 2008

Durch Asien im Horizont des Goethekreises; Neue Facetten im Wirken Goethes. Hamburg: Kovač. 
Catalogus Bataviasche bibliotheecq

1752 Catalogus van alle boeken en manuscripten, welke behooren tot de Bataviasche bibliotheecq. Batavia: Heusler. [Exemplaar London British Library, OIOC W 4856.]

Catalogus ethnologische afdeeling

$1877 \quad$ Catalogus der ethnologische afdeeling van het museum van het Bataviaasch Genootschap van Kunsten en Wetenschappen. Tweede druk [door J.A. van der Chijs]. Batavia: Bruining.

Catalogus gedenkpenningen

1903-06 Catalogus der Nederlandse en op Nederland betrekking hebbende gedenkpenningen. 's-Gravenhage: Koninklijk Kabinet van Munten, Penningen en Gesneden Steenen. Twee delen.

Catalogus Indische landbouw en nijverheid

1829 Catalogus der voorwerpen van Nederlandsch Indische landbouw en nijverheid in 1829, op de te Batavia gehoudene tentoonstelling geëxposeerd. Batavia: Landsdrukkerij. [Exemplaar KITLV-bibliotheek.]

Catalogus numismatische afdeeling

1869 Catalogus der numismatische afdeeling van het museum van het Bataviaasch Genootschap van Kunsten en Wetenschappen. Voorwoord door J.A. van Catalogus van der Vorm der Chijs. Batavia: Lange. [Tweede druk, Batavia 1877.]

1731 Catalogus van verscheide wel geconditioneerde, zo Hebreische, Griekse, Arabische, Chaldaise, Maleydse, Mallabaarse, Latynse, Fransche Engelsche als Nederduytsche boeken, nagelaten by wylen de Eerw. Petrus van der Vorm [...]. Batavia: Welsing en Fronenbroek. [Exemplaar collectie-Groeneboer.]

Catalogus verzameling vogels

$1844 \quad$ Catalogus eener belangrijke verzameling van vogels toebehoorende aan het Bataviaasch Genootschap van Kunsten en Wetenschappen, welke verkogt zal worden op den 3den Junij 1844, in een der zalen van de Harmonie. Batavia: Bataviaasch Genootschap. [Exemplaar Perpusnas XLII 247 vermist.]

Chronique théatrale

1847 Chronique théatrale concernant Monsieur Robert, directeur du théatre français à Batavia, par M. Mistral. Batavia: Lange. [Exemplaar Perpusnas B 342.]

Chijs, J.A. van der

1862 'Alphabetische inhoudsopgave van de twaalf eerste deelen van het Tijdschrift voor Indische Taal-, Land- en Volkenkunde', Tijdschrift voor Indische Taal-, Land-en Volkenkunde (TBG) 12:595-620.

1864 Catalogus der bibliotheek van het Bataviaasch Genootschap van Kunsten en Wetenschappen. Batavia: Lange, 's Hage: Nijhoff. [Eerste vervolg met de catalogus der Maleische, Javaansche en Kawi-handschriften, door A.B. Cohen Stuart, 1872; tweede vervolg, 1877.]

1874

'Alphabetisch-systematische inhouds-opgave van deel XIII tot en met XXIV van het Tijdschrift voor Indische Taal-, Land- en Volkenkunde', TBG 24:589-616.

1879 Register op de notulen der vergaderingen van het Bataviaasch Genootschap van Kunsten en Wetenschappen, over de jaren 1867 tot en met 1878. 
Batavia: Bruining. [Deel over de jaren 1879-1888 door dezelfde, Batavia: Albrecht en Rusche, 's Hage: Nijhoff, 1889. Deel 1889-1898 door dezelfde, Batavia: Albrecht, 's Hage: Nijhoff, 1899.]

1885-1900 Nederlandsch-Indisch plakaatboek, 1602-1811. Uitgegeven door het Bataviaasch Genootschap van Kunsten en Wetenschappen met medewerking van de Nederlandsch-Indische regering. Batavia: Landsdrukkerij, 's Hage: Nijhoff. Zeventien delen.

1936 'Geschiedenis van de bibliotheek van het Bataviaasch Genootschap', Jaarboek 3:235-41.

Chijs, J.A. van der, zie ook Catalogus ethnologische afdeeling, tweede druk.

Chijs, J.A. van der, zie ook Catalogus numismatische afdeeling, 1869.

Chijs, J.A. van der, zie ook Netscher, De munten (1863).

Cohen Stuart, A.B., zie J.A. van der Chijs 1864, Catalogus der bibliotheek (vervolgen 1872-1877).

Cornets de Groot, J.P.

1838 Overzigt der reis in Nederlandsch Indië, door Zijne Koninklijke Hoogheid Prins Willem Frederik Hendrik der Nederlanden, gedurende het jaar 1837. Batavia: Landsdrukkerij.

Daendels

1991

Daendels, Herman Willem Daendels 1762-1818; Geldersman - patriot Jacobijn - hereboer - maarschalk - gouverneur; Van Hattem naar St. George del Mina. Utrecht: Matrijs. [Catalogus tentoonstelling Rijksmuseum Amsterdam.]

Davids, C.A. 1993

'Navigeren in Azië; De uitwisseling van kennis tussen Aziaten en navigatiepersoneel bij de voorcompagnieën en de VOC, 1596-1795', in: J. Bethlehem en A.C. Meijer, VOC en cultuur; Wetenschappelijke en culturele relaties tussen Europa en Azië ten tijde van de Verenigde Oost-Indische Compagnie, pp. 17-37. Amsterdam: Schiphouwer en Brinkman.

De Schaepdrijver, S.C.M. zie H.W. van den Doel

Delden, E.E. van

1990

Tijdschrift voor Nederlandsch Indië 1838-1866. Amsterdam: Koninklijk Instituut voor de Tropen. [Klein Repertorium 5.]

1993 Acht algemene tijdschriften 1834-1864. Amsterdam: Koninklijk Instituut voor de Tropen. [Klein Repertorium 7.]

Desiderata

1846 Desiderata van het Bataviaasch Genootschap van Kunsten en Wetenschappen. Batavia: Bataviaasch Genootschap, 1846. (Exemplaar Koninklijke Bibliotheek Brochure 1024.)

Deventer, S. van

1884 'Levensbericht van Mr. Pieter Mijer', in: Levensberichten der afgestorven medeleden, Maatschappij der Nederlandsche Letterkunde, pp. 71-92. Leiden: Brill.

Doel, H.W. van den

$1996 \quad$ Het rijk van Insulinde; Opkomst en ondergang van een Nederlandse kolonie. Amsterdam: Prometheus. 
Doel, H.W. van den en S.C.M. De Schaepdrijver

1996

'Een Britse oriëntalist in Indië; Thomas Stamford Raffles (1781-1826)', in: M.Ph. Bosschenbroek, M.E.H.M. Mout en C. Musterd (red.), Historici in de politiek, pp. 12-35. Leiden: Centrum Moderne Geschiedenis.

Domis, H.J.

1827 Journaal eener reis van Welerie naar het gebergte Praauw. Samarang: Karto di Wirio. [Exemplaar Perpusnas XXXI 580.]

1829-32 Aanteekeningen. Pasoeroean-Sourabaya: Tjokro di Wirio. Zeven delen. [Exemplaar Perpusnas XXXI 235, deel 6 ontbreekt; exemplaar KITLV b 57 alleen deel 2-4.]

1836 De residentie Passoeroeang op het eiland Java. 's-Gravenhage: De Groot. [KITLV b 56.]

Dijk, C. van 1993a

'Tussen koloniale handel en wetenschap; De volkenkundige musea in Nederland in de negentiende eeuw', Tijdscrhift voor Geschiedenis 105:346-66.

1993b 'De VOC en de kennis van de taal- en volkenkunde van insulair ZuidOost-Azië', in: J. Bethlehem en A.C. Meijer (red.), VOC en cultuur; Wetenschappelijke en culturele relaties tussen Europa en Azië ten tijde van de Verenigde Oost-Indische Compagnie, pp. 59-76. Amsterdam: Schiphouwer en Brinkman.

Effert, R.

2003

Volkenkundig verzamelen; Het Koninklijk Kabinet van Zeldzaamheden en het Rijks Ethnographisch Museum (1816-1883). Proefschrift Rijksuniversiteit Leiden.

Encyclopaedie Nederlandsch West-Indië

1914-17 Encyclopaedie van Nederlandsch West-Indië. 's-Gravenhage: Nijhoff, Leiden: Brill. Twee delen.

Encyclopedie van Zeeland

1982-84 Encyclopedie van Zeeland. Middelburg: Koninklijk Zeeuws Genootschap van Wetenschappen. Drie delen.

ENI

1917-40 Encyclopaedie van Nederlandsch-Indië. Tweede druk. 's-Gravenhage: Nijhoff, Leiden: Brill. Acht delen, twee supplementen.

Fasseur, C.

$1978 \quad$ Kultuurstelsel en koloniale baten; De Nederlandse exploitatie van Java 18401860. Tweede druk. Leiden: Universitaire Pers.

1993 De indologen; Ambtenaren voor de Oost 1825-1950. Amsterdam: Bert Bakker.

1995 De weg naar het paradijs en andere Indische geschiedenissen. Amsterdam: Bert Bakker.

1997

'Een varensgast', in: C. Fasseur, Indischgasten, pp. 231-47. Amsterdam: Bert Bakker.

Fasseur, C. zie ook H. Baudet

Fontein, J.

1990

The sculpture of Indonesia. With essays by R. Soekmono and Edi Sedyawati. Washington: National Gallery of Art, New York: Abrams. 
Friederich, R.H.Th.

1850 'Javaansche oudheden', in: Verhandelingen van het Bataviaasch Genootschap van Kunsten en Wetenschappen (VBG) 23:1-32.

1859 'Beschrijving van een metalen Çivabeeld', Tijdschrift voor Indische Taal-, Land-en Volkenkunde (TBG) 8:72-5.

1870a 'Aanteekeningen over de hoofd-tempels in Kadoe en Djokdjokarta', Tijdschrift voor Indische Taal-, Land- en Volkenkunde (TBG) 19:411-21.

1870b 'Over de omgeving van het Oengaran-Gebergte', Tijdschrift voor Indische Taal-, Land-en Volkenkunde (TBG) 19:501-20.

Friederich, R.H.Th. zie ook W.R. van Hoëvell en R.H.Th. Friederich, 'Beredeneerde beschrijving'

Gaastra, F.

1991 De geschiedenis van de VOC. Tweede druk. Zutphen: Walburg.

Gedenkboek zie T.H. der Kinderen

Gediking, P.

'Het Koninklijk Bataviaasch Genootschap van Kunsten en Wetenschappen (Royal Batavia Society of Arts and Sciences)', Inter-Ocean 10:1-8.

Gelder, R. van

1997

Het Oost-Indisch avontuur; Duitsers in dienst van de VOC. Nijmegen: SUN.

Geleerden en leken

2002 Geleerden en leken; De wereld van de Hollandsche Maatschappij der Wetenschappen 1840-1880. Haarlem: Hollandsche Maatschappij der Wetenschappen.

Gelman Taylor, J.

1988 Smeltkroes Batavia; Europeanen en Euraziaten in de Nederlandse vestigingen in Azië. Groningen: Wolters-Noordhoff.

Gerritsen, W.P.

1997

Het Koninklijk Instituut (1808-1851) en de bevordering van wetenschap en kunst. Amsterdam: Koninklijke Nederlandse Akademie der Wetenschappen.

Goor, J. van

1993a

De Nederlandse koloniën; Geschiedenis van de Nederlandse expansie 16001975. 's-Gravenhage: Staatsdrukkerij.

1993b 'Handel en wetenschap', in: J. Bethlehem en A.C. Meijer (red.), VOC en cultuur; Wetenschappelijke en culturele relaties tussen Europa en Azië ten tijde van de Verenigde Oost-Indische Compagnie, pp. 1-16. Amsterdam: Schiphouwer en Brinkman.

Graaf, D. de

1998

'Jacobus van der Steege (1746-1812); Het merkwaardige leven van een Groninger "doctor medicinea", Triakel 11-3:15-9.

Groeneboer, K 1993

Weg tot het Westen; het Nederlands voor Indië, 1600-1950; Een taalpolitieke geschiedenis. Leiden: KITLV Uitgeverij. [Verhandelingen 158.]

2002

Een vorst onder de taalgeleerden; Herman Neubronner van der Tuuk, afgevaardigde voor Indië van het Nederlandsch Bijbelgenootschap,1847-1873; Een bronnenpublicatie. Leiden: KITLV Uitgeverij. 
Groenevelt, W.P.

1887 Catalogus der archeologische verzameling van het Bataviaasch Genootschap van Kunsten en Wetenschappen; Met aantekeningen omtrent de op verschillende voorwerpen voorkomende inscripties en een voorlopige inventaris der beschreven steenen door J.C.A. Brandes. Batavia: Albrecht.

Grond-wetten

$1791 \quad G r o n d-w e t t e n$ van het Bataviaasch Genootschap der Kunsten en Wetenschappen. Batavia. [Exemplaar Perpusnas B 32/1a.]

Groot, $\mathrm{H}$. 2004

Haan, F. de 1910-12

'De band met thuis; Brieven van Josua van Iperen van de Kaap en uit Batavia (1778-1780)', in: M van Kempen, P. Verkruijsse en A. Zuiderweg (red.), Wandelaar onder de palmen; Opstellen over koloniale en postkoloniale literatuur en cultuur opgedragen aan Bert Paasman, pp. 335-47. Leiden: KITLV Uitgeverij.

$1935 \mathrm{a}$

Priangan; De Preanger-Regentschappen onder het Nederlandsch bestuur tot 1811. Batavia: Kolff, 's-Gravenhage: Nijhoff. Vier delen.

$1935 b$ Oud Batavia. Tweede, herziene druk. Bandoeng: Nix. Twee delen.

Hageman, J.

1856 Geschiedenis van den oorlog op Java van 1825 tot 1830. Batavia: Lange.

Handelingen Letterkunde

$1782 \quad H a n d e l i n g e n$ van de Maatschappy der Nederlandsche Letterkunde te Leyden. Hardiati, Endang Sri en Pieter ter Keurs

2005 Warisan budaya bersama. Amsterdam: Koninklijk Instituut voor de Tropen en De Nieuwe Kerk.

Harmonie

1842 'Javasche schetsen; Batavia De Harmonie', De Kopiïst 1, I:29-46.

Hoëvell, W.R. van

1839 'Geschiedkundig overzigt van de beoefening van kunsten en wetenschappen in Neêrland's Indië', Tijdschrift voor Neêrland's Indië (TNI) 2:1-115.

1843 Verslag van den staat der werkzaamheden van het Bataviaasch Genootschap van Kunsten en Wetenschappen, gelezen in de algemeene vergadering des Genootschaps op den 5den October 1843. Batavia: Bataviaasch Genootschap. [Ook in Verhandelingen van het Bataviaasch Genootschap van Kunsten en Wetenschappen (VBG) 19:xix-lxxxix.]

1844

'Verslag van den staat der werkzaamheden van het Bataviaasch Genootschap van Kunsten en Wetenschappen, gelezen in de algemeene vergadering op den 4 den februarij $1845^{\prime}$, in: Verhandelingen van het Bataviaasch Genootschap van Kunsten en Wetenschappen (VBG) 20:1-94.

1846-47 'Verslag van den staat der werkzaamheden van het Bataviaasch Genootschap van Kunsten en Wetenschappen, gelezen in de algemeene vergadering op den 8sten mei 1847', in: Verhandelingen van het Bataviaasch Genootschap van Kunsten en Wetenschappen (VBG) 21, I:1-115. 
1848. Singapore: Mission Press. Ook verschenen als: Afscheidsrede, gehouden te Batavia in de Willemskerk den 6 Augustus 1848. Groningen: Roelfsema.

1849-54 Reis over Java, Madura en Bali, in het midden van 1847. Redactie P.J. Veth. Amsterdam: Van Kampen. Drie delen.

Hoëvell, W.R. van en R. Friederich

1846-47 'Beredeneerde beschrijving der Javaansche monumenten van het kabinet van oudheden van het Bataviaasch Genootschap van Kunsten en Wetenschappen', Eerste gedeelte, in: Verhandelingen van het Bataviaasch Genootschap van Kunsten en Wetenschappen (VBG) 21, I:i-xxviii, 1-131.

Hoepermans, $\mathrm{H}$.

1872 'Het Hindoe rijk van Doho', Tijdschrift voor Indische Taal-, Land-en Volkenkunde (TBG) 21:146-68.

Hogendorp, D. van

$1800 \quad$ Berigt van den tegenwoordigen toestand der Bataafsche bezittingen in OostIndiën en den koophandel op dezelve. Gedrukt voor den auteur. Z.p.: z.n.

Holle, K.F.

1877 Tabel van oud- en nieuw-Indische alphabetten. Uitgegeven voor rekening van het Bataviaasch Genootschap van Kunsten en Wetenschappen. Buitenzorg: Lange.

$1882 \quad$ Tabel van oud-en nieuw-Indische alphabetten; Bijdrage tot de paleographie van Nederlandsch-Indië. Uitgegeven door het Bataviaasch Genootschap van Kunsten en Wetenschappen. Batavia: Bruining, 's Hage: Nijhoff.

Hooykaas, G.J.

2000

'Thorbecke, het Instituut en de Akademie', in: K. van Berkel (red), Het oude Instituut en de nieuwe Akademie; Overheid en wetenschapsbeoefening omtrent het midden van de negentiende eeuw, pp. 11-38. Amsterdam: Horsfield, Th. Koninklijke Nederlandse Akademie van Wetenschappen.

1838-52 Plantae Javanicae rariores, descriptae iconibusque illustratae, ques in insula Java, annis 1802-1818, legit et investigavit [...] e siccis descriptiones et characteres plurimarum elaboravit Joannis J. Bennet; Observationes structuram et affinitates praesertim respicientes passim adjecit Robert Brown. London: Allen.

$1990 \quad$ Zoological researches in Java and the neighbouring islands. Reprint. Singapore: Oxford University Press.

1991 'Letter to the editor; 31-12-1829', in: Sophia Raffles, Memoir of the life and public services of Sir Thomas Stamford Raffles. Introduction by J. Bastin, pp. 602-32. Singapore: Oxford University Press.

Indisch Magazijn

1844-46 Indisch Magazijn.

Inter-Ocean

$1930 \quad$ Inter-Ocean 11-3 [Raffles-nummer].

Iperen, J. Van

1779a Afscheid van de classis Walcheren, en de gemeente van Ter Veere, nevens de eerste leerrede op het Oost-Indische compagnies-schip Europa. Amsterdam: Allart. 
1779b Intreê-rede te Batavia, over II Timoth: I. Vs 7; Uitgesprooken, in de Hollandsche Kerk, den 7 den Maart, 1779. Batavia: Dominicus.

1779c Inleidings-redenvoering tot zyne openbare lessen, over de wysbegeerte en fraaije letteren, uitgesprooken, in de binnen-Portugeesche Kerk, den 29 Mei, 1779. Batavia: Dominicus.

1780 'De belemmeringen, treurgezang' gevolgd door een 'Toezang aan het Bataviaasch Genootschap', in: Verhandelingen van het Bataviaasch Genootschap van Kunsten en Wetenschappen (VBG) 2:151-61.

Jaarboek

1933-51 Jaarboek [van het] Koninklijk Bataviaasch Genootschap van Kunsten en Wetenschappen. Tien delen.

Janssen, H.L.

1867

'Register der vergaderingen van het Bataviaasch Genootschap van Kunsten en Wetenschappen, over de jaren 1857 tot 1866', Notulen 5:160. [Vervolgd door J.A. van der Chijs.]

Java-Bode

$1858 \quad$ Java-Bode.

Java Directory

1815-16 The Java Half-Yearly (Annual) Directory and Almanac.

Java Government Gazette

1812-16 Java Government Gazette.

Javasche Courant

1828-68 Javasche Courant.

Jong, J.J.P. de

1998 De waaier van het fortuin; De Nederlanders in Azië en de Indonesische Archi-

Jonge, A. de en W.W. Mijnhardt pel 1595-1950. Den Haag: Staatsdrukkerij.

1983 'Het genootschapsonderzoek in Nederland', De Negentiende Eeuw 7:253-9. [Ook in Documentatieblad Werkgroep 18e Eeuw 15:215-21.]

Jonge, N. de zie Bakels, J.

Journal Indian Archipelago

1847-48 Journal of the Indian Archipelago and Eastern Asia. Vol. 1-2.

Kalff, S.

1899 'Jacob Radermacher en zijne stichting', TNI 3:474-511. [Tweede Nieuwe Serie.]

Katalogus ethnologische afdeeling

$1868 \quad$ Katalogus der ethnologische afdeeling van het museum van het Bataviaasch Genootschap van Kunsten en Wetenschappen [door H.D. Levyssohn Norman]. Batavia: Lange.

Katalogus tentoonstelling natuur en industrie

$1853 \quad$ Katalogus der tentoonstelling van produkten der natuur en der industrie van den Indischen archipel, te houden te Batavia in Oktober en November 1853.

Batavia: Lange. [Exemplaar KITLV a 90.]

Kemp, P.H. van der

$1911 \quad$ Oost-Indië's herstel in 1816. 's-Gravenhage: Nijhoff. 

29:388-410.

1918 Oost-Indië's inwendig bestuur van 1817 op 1818. 's-Gravenhage: Nijhoff.

Kempen, M. van

2002 Een geschiedenis van de Surinaamse literatuur. Paramaribo. Vijf delen.

Kerkhoff, A.H.M.

1989 'De organisatie van de militaire en burgerlijke geneeskundige dienst in de negentiende eeuw', in: G.M. van Heeteren, A. de Knecht-van Eekelen en M.J.D. Poulissen (red.), Nederlandse geneeskunde in de Indische

Kern, $\mathrm{H}$. archipel 1816-1942, pp. 7-22. Amsterdam: Rodopi.

1877

1892

'Levensschets van A.B. Cohen Stuart', in: Levensberichten der afgestorven medeleden, Maatschappij der Nederlandsche Letterkunde, pp. 3-25. Leiden: Brill.

'Levensbericht van L.A.J.W. baron Sloet van de Beele', in: Levensberichten der afgestorven medeleden, Maatschappij der Nederlandsche Letterkunde, pp. 1-34. Leiden: Brill.

Keurs, P. ter zie Endang Sri Hardiati

Kinderen, T.H. der

1878

Het Bataviaasch Genootschap van Kunsten en Wetenschappen gedurende de eerste eeuw van zijn bestaan 1778-1878; Gedenkboek. Deel 1. Batavia: Ernst. [Niet verder verschenen.]

Kinderen, T.H. der zie Overzigt 1862

Kinsbergen, I. van

1872 'Catalogus der photographiën naar oudheden van Java', Notulen 10, bijlage B.

1874 'Catalogus der photografiën naar de tempel-ruïne Boroboedoer (residentie Kadoe)', Notulen 12, bijlage F.

Kist, B. zie Bruijn, M. de

Klein, P.W.

1998

Een beeld van een academie; Mensen en momenten uit de geschiedenis van het Koninklijk Instituut en de Koninklijke Nederlandse Akademie van Wetenschappen. Amsterdam: Koninklijke Nederlandse Aademie van Wetenschappen.

Kloek, J.J.

1983 'Literaire genootschappen, 1748-1800', Documentatieblad Werkgroep 18e Eeuw 15:21-89.

Kloek, J.J. en W.W. Mijnhardt

$20011800-$ Blauwdrukken voor een samenleving. Den Haag: Staatsdrukkerij. [Nederlandse cultuur in Europese context.]

Knaap, G.

1994

'One hundred fifty volumes of Bijdragen', Bijdragen tot de Taal-, Land-en Volkenkunde 150:637-52.

Knolle, P.

1983

'Het Departement der tekenkunde van Felix Meritis, 1777-1889', Documentatieblad Werkgroep 18e Eeuw 15:141-96. 
Koloniaal Verslag

1848-67 Verslag van het beheer en den staat der koloniën.

Kop, J. zie Ravesteijn, W.

Kouwenhoven, A. en M. Forler

$2000 \quad$ Siebold en Japan; Zijn leven en werk. Leiden: Hotei.

Krom, N.J.

1923

Inleiding tot de Hindoe-Javaansche kunst. Tweede druk. 's-Gravenhage:

Krul, W.E.

2000 Nijhoff. Drie delen.

Kuitenbrouwer, $\mathrm{M}$.

2001 Tussen oriëntalisme en wetenschap; Het KITLV in historisch verband (18512001). Leiden: KITLV Uitgeverij.

Legêne, $S$.

2005 Nu of nooit; Over de actualiteit van museale collecties. Amsterdam: Amsterdam University Press.

Levenschets

1855

'Levenschets van Mr. J.C.M. Radermacher', Handelingen Indisch Genootschap 2:337-63.

Levyssohn Norman, H.D. zie Katalogus ethnologische afdeeling.

Lian The and P. Van der Veur

1973 The Verhandelingen van het Bataviaasch Genootschap; An annotated content analysis. Athens Ohio: Ohio University. [Papers in International Stu-

Lieburg, M.J. van dies, Southeast Asia Series 26.]

1985 Het Bataafsch Genootschap der Proefondervindelijke Wijsbegeerte te Rotterdam, 1769-1984; Een bibliografisch en documenterend overzicht. Amsterdam: Rodopi. [Nieuwe Nederlandse Bijdragen tot de Geschiedenis der Geneeskunde en Natuurwetenschappen 18.]

Loos-Haaxman, J. de

$1928 \quad$ Johannes Rach en zijn werk; De topografische beschrijving der teekeningen, met medewerking van W. Fruin-Mees door P.C. Bloys van Treslong Prins. Uitgegeven bij gelegenheid van het 150-jarig bestaan van het Koninklijk Bataviaasch Genootschap van Kunsten en Wetenschappen Mackenzie, W.C. op 24 april 1928. Batavia: Kolff.

$1952 \quad$ Colonel Colin Mackenzie; First Surveyor-General of India. Foreword by R.H. Phillimore. Edinburgh: Chambers.

Malayan Miscellanies

1820-22 Malayan Miscellanies. Bencoolen: Sumatran Mission Press. Vol. 1-2.

Meer, G. van der

1977

'Drie gouden erepenningen', De Beeldenaar 1:3-5. 

eeuw', Documentatieblad Werkgroep 18e Eeuw 15:1-20.

Meulen, D. van der

2002 Multatuli; Leven en werk van Eduard Douwes Dekker. Nijmegen: SUN.

Melvill de Carnbee, P.

1844 'Iets over de Nederlandschen sterrenkundige Johan Maurits Mohr te Batavia', Tijdschrift voor Neêrland's Indië (TNI) 6, IV:172-9.

Merrillees, S.

2000

Batavia in 19th century photographs. Singapore: Archipelago Press.

Meijer, A.C. zie J. Bethlehem

Mistral zie Chronique

Mitra, Rajendralala

1885 Centenary review of the Asiatic Society of Bengal. Calcutta: Asiatic Society.

Moeshart, H.J.

1991

'A. Schaefer and the Borobudur', in: J. Levy Reed (red.), Toward independence; A century of Indonesia photographed. San Francisco: The Friends of Photography.

1998

'Aldolphe Schaefer', Geschiedenis van de Nederlandse fotografie 5:1-7, $\mathrm{a}-\mathrm{b}$.

Molen. W. van der zie Kuntara Wiryamartana

Moulin, D. de

1989 'Teaching of medicine in the Dutch East Indies', in: G.M. van Heeteren, A. de Knecht-van Eekelen en M.J.D. Poulissen (red.), Nederlandse geneesMunnich, J. kunde in de Indische archipel 1816-1942, pp. 22-31. Amsterdam: Rodopi.

1843

1846

1859

'Iets omtrent de beoefening der poezy in Neêrlandsch Indië', Tijdschrift voor Neêrland's Indië (TNI) 5, I:237-47.

'De problematieke oprigting van een leesmuseum te Batavia, nog onder geene zinspreuk', Tijdschrift voor Neêrland's Indië (TNI) 8, II:57580 .

'Het oordeel van het Koninklijk Instituut voor Taal-, Land- en Volkenkunde van Nederlandsch Indië, over de wetenschappelijke instellingen, aldaar', Tijdschrift voor Neêrlandsch Indië (TNI) 21, II:101-8.

Munnich, J. zie P. Bleeker 1853 (Bibliothecae)

Musis, Vereeniging Musis, zie: Reglement en Verslag

Mijer, P.

1860 'Levensberigt van Jean Chrétien baron Baud', in: Levensberigten der afgestorvene medeleden, Maatschappij der Nederlandsche Letterkunde, pp. 28-118. Leiden: Brill.

1872

Rede door den afgetredenen gouverneur-generaal van Nederlandsch Indië Mr. P. Mijer, uitgesproken in de vergadering van den Raad van Nederlandsch Indië, op Maandag 1 Januarij 1872. Utrecht: Kemink.

Mijnhardt, W.W.

1978 'Veertig jaar cultuurbevordering; Teylers Stichting 1778-1815', in: W.W. Mijnhardt en A.J. Wichers (red.), Om het Algemeen Volksgeluk, 'Teyler' 
1778-1978; Studies en bijdragen over Teylers Stichting naar aanleiding van het tweede eeuwfeest, pp. 58-101. Haarlem: Schuyt.

1983 'Het Nederlandse genootschap in de achttiende en vroege negentiende eeuw', De Negentiende Eeuw 7:76-101.

1986 'De Nederlandse vrijmetselarij in de achttiende eeuw', Documentatieblad Werkgroep 18e Eeuw 18-1:87-108.

1988 Tot Heil van 't Menschdom; Culturele genootschappen in Nederland, 17501815. Amsterdam: Rodopi. [Nieuwe Nederlandse Bijdragen tot de Geschiedenis der Geneeskunde en der Natuurwetenschappen 24.]

1994 'Genootschappen en de Verlichting; Een repliek', De Achttiende Eeuw 26:101-14.

1997 'Het Volk van Nederland eischt verlichting; Franse hervormingsijver en Nederlandse wetenschapsbeoefening (1795-1815)', in: W.P. Gerritsen (red.), Het Koninklijk Instituut (1808-1851) en de bevordering van wetenschap en kunst, pp. 13-20. Amsterdam: Koninklijke Nederlandse Akademie van Wetenschappen.

2004 'De Akademie in het culturele landschap rond 1900', in: K. van Berkel (red.), De Akademie en de Tweede Gouden Eeuw, pp. 15-41. Amsterdam: Koninklijke Nederlandse Akademie van Wetenschappen.

Mijnhardt, W.W. en A.J. Wichers (red.)

1984 Om het Algemeen Volksgeluk; Twee eeuwen particulier initiatief 1784-1984; Gedenkboek ter gelegenheid van het 200-jarig bestaan van de Maatschappij tot Nut van 't Algemeen. Edam: Maatschappij tot Nut van 't Algemeen.

Mijnhardt, W.W. zie ook J.J. Kloek

Mijnhardt, W.W. zie ook A. de Jonge

Naamboek

$1783 \quad$ Naamboek Indiasche Regeering.

Nagtglas, F.

1890

Levensberichten van Zeeuwen; Zijnde een vervolg op P. de la Rue, geletterd, staatkundig en heldhaftig Zeeland. Deel 1. Middelburg: Altorffer.

Natuur-en Geneeskundig Archief

1844-47 Natuur-en Geneeskundig Archief voor Neêrland's Indië.

Natuurkundig Tijdschrift

1850-53 Natuurkundig Tijdschrift voor Nederlandsch Indië.

Netscher, E. zie Overzigt 1862

Netscher, E. en J.A. van der Chijs

1863 De munten van Nederlandsch-Indië, beschreven en afgebeeld. Uitgegeven door het Bataviaasch Genootschap van Kunsten en Wetenschappen. Batavia. [Ook als Verhandelingen van het Bataviaasch Genootschap van Kunsten en Wetenschappen (VBG) 31 (1864).]

Nieuwenhuys, R.

1978 Oost-Indische spiegel. Derde druk. Amsterdam: Querido. [Eerste druk 1972.]

NNBW

1911-37 Nieuw Nederlandsch biografisch woordenboek. Leiden: Sijthoff. Tien delen. 
Notulen

1862-1921 Notulen van de algemeene en bestuursvergaderingen van het Bataviaasch Genootschap van Kunsten en Wetenschappen. Negenenvijftig delen.

Nut, Tot Nut en Beschaving zie Reglement

Ontwerp reglement

1861 Algemeen reglement voor het Bataviaasch Genootschap van Kunsten en Wetenschappen, opgerigt op den 24sten April 1778. [Batavia; exemplaar Perpusnas B 32/1d.]

Ontwerp van wetten

1852 Ontwerp van wetten voor het Bataviaasch Genootschap van Kunsten en Wetenschappen. [Batavia; exemplaar Perpusnas B 32/1c.]

Overzigt

1862

'Overzigt van den staat van het Bataviaasch Genootschap van Kunsten en Wetenschappen over de jaren 1853 tot 1861', Tijdschrift voor Indische Taal-, Land- en Volkenkunde (TBG) 12:155-92.

Pott, P.H.

1962

Naar wijder horizon; Kaleidoscoop op ons beeld van de buitenwereld. 's-Gravenhage: Mouton.

Prins, B. de 2002

Voor koning en keizer; Leonard du Bus de Gisignies 1780-1849, CommissarisGeneraal van Nederlands-Indië. Amsterdam: Balans. [Proefschrift Rijksuniversiteit Leiden.]

Programma 1778

Programma van het Bataviaasch Genootschap tot nut van Kunsten en Wetenschappen in het gemeen, doch in het byzonder, ter bevorderinge van de welvaart der Oostersche volkplantingen van den Staat der Verënigde Nederlanden; [...] Opgericht te Batavia den 24sten April 1778. [...]. Batavia: Heemen. [Exemplaar London BL OIOC T 39068.]

$1782 \quad$ Programma van het Bataviaasch Genootschap, opgericht te Batavia in 1778. Voor den Jaare 1782. [Batavia; exemplaar Perpusnas B 32/2, UB Groningen PEJ 2a-16216281.]

1783 Programma van het Bataviaasch Genootschap, opgericht te Batavia in 1778. Voor den Jaare 1782. Rotterdam: Arrenberg, Amsterdam: Allart. [Exemplaar NA VOC 4837I.]

$1791 \quad$ Programma [van het Bataviaasch Genootschap van Kunsten en Wetenschappen] voor het jaar 1791. [Batavia; exemplaar ANRI Familie-archief Beth T 93 B 713/9, 9Bis.]

1823 'Programma en kort verslag van het Bataviaasch Genootschap van Kunsten en Wetenschappen voor het jaar 1823', Bataviasche Courant 1-11-1823.

1825 [Programma] 'Bataviaasch Genootschap van Kunsten en Wetenschappen', Bataviasche Courant 9-2-1825.

1826 [Programma] 'Bataviaasch Genootschap van Kunsten en Wetenschappen', Bataviasche Courant 18-1-1826.

1827 [Programma] 'Bataviaasch Genootschap van Kunsten en Wetenschappen', Bataviasche Courant 10-1-1827. 
Prysuragen

Prysvragen opgegeven door het Batavia's Genootschap der Konsten en Weetenschappen, in deszelfs Algemeene Vergadering, gehouden op den 8 Maart

Raben, R. 1790. [Batavia; exemplaar ANRI Familie-archief Beth T 93 B 713/3.]

1996

Batavia and Colombo; The ethnic and spatial order of two colonial cities 16001800. Proefschrift, Rijksuniversiteit Leiden, Leiden

Raben, R. zie ook M. de Bruijn

Raben, R. zie ook U. Bosma

Raffles, Lady Sophia

1991 Memoir of the life and public services of Sir Thomas Stamford Raffles. Introduction by J. Bastin. Singapore: Oxford University Press.

Raffles, Th. S.

1994 The history of Java. Complete text with introduction by John Bastin. Kuala Lumpur: Oxford University Press. [Oorspronkelijk uitgegeven London: Murray, 1817.]

Rajendralala Mitra zie Mitra

Ravesteijn, W. en J. Kop (red.)

2004 Bouwen in de archipel; Burgerlijke openbare werken in Nederlands-Indie en Indonesië 1800-2000. Zutphen: Walburg.

Recensie

1853 'Verhandelingen van het Bataviaasch Genootschap van Kunsten en Wetenschappen; Deel 22 en 23: Batavia 1849-1850', [Recensie in] TijdRegerings-almanak schrift voor Neêrlandsch Indië (TNI) 15:65-70.

1865-70 Regerings-almanak voor Nederlandsch Indië.

Reglement zie ook Grond-wetten 1791

Reglement zie ook Wetten 1823

Reglement zie ook Ontwerp 1852, 1861

Reglement

1862 Algemeen reglement en reglement van orde voor het Bataviaasch Genootschap van Kunsten en Wetenschappen, opgerigt op den 24sten april 1788 [...] Batavia: Lange. [Exemplaar Perpusnas B 32/1; Herdruk Batavia 1874; exemplaar Perpusnas B 32/1e ex.3.]

Reglement Juridisch Leesgezelschap

1864 Reglement voor het Juridisch Leesgezelschap te Batavia. Batavia. [ExemReglement Musis plaar Perpusnas B342 1.]

1848 Reglement voor de Vereeniging Musis. Batavia: Lange. [Exemplaar KITLV dd 189.]

Reglement Nut en Beschaving

1847 Reglement voor het Wetenschappelijk Genootschap onder de zinspreuk 'Tot Nut en Beschaving'. Batavia: Lange. [Exemplaar Perpusnas B 342 q.] 
Reglement Utile et Dulce

1849 Reglement voor het Leesgezelschap 'Utile et Dulce'. Batavia. [Exemplaar Perpusnas B 342 g.]

Reinwardt, C.G.C. zie W.H. de Vriese Reis

Reitsma, H.

1979

'De beginjaren van Felix Meritis, 1777-1795', Documentatieblad Werkgroep 18e Eeuw, nr. 41-42:101-40.

Roorda, T.

1860

'Verhaal van de oorsprong en het begin van de opstand van DipaNegara, volgens een Javaansch handschrift', Bijdragen tot de Taal-, Landen Volkenkunde 7:137-227.

Roorda van Eysinga Jr., W.A.P.

$1847 \quad$ Verzameling van eene menigte noodzakelijke zamenspraken met inlanders van allerlei klassen, in de laag Maleische taal; Voorafgegaan door eene beknopte spraakkunst van die taal; Zoo als dat alles door den lageren Maleijer wordt gesproken en verstaan, en zulks tot gemak van velen. Batavia: Lange. [Exemplaar Perpusnas XLVI 699.]

Roux, C.C.F.M. le

1932 'Goethe 1832-1932; Eerelid van het Bataviaasch Genootschap van Kunsten en Wetenschappen', Tijdschrift voor Indische Taal-, Land- en Volkenkunde (TBG) 72:1-12.

Scalliet, M.O.

1995

1999 'Twee eeuwen Vereenigde Oost-Indische Compagnie; Europese schil-

Antoine Payen; Peintre des Indes Orientales; Vie et écrits d'un artiste du XIXe siècle (1792-1853). Leiden: Centrum voor Niet-Westerse Studies. [Proefschrift Rijksuniversiteit Leiden.] ders in Oost-Indië in de zeventiende en achttiende eeuw', in: K. van Brakel, M.-O. Scalliet en D. van Duren, Indië omlijst; Vier eeuwen schilderkunst in Nederlands-Indië, pp. 13-38. Amsterdam: Koninklijk Instituut voor de Tropen.

Schrieke, B.

1930 'The influence of Raffles' administration on Java', Inter-Ocean 11-3:11520.

Schutte, G.J.

1974

De Nederlandse patriotten en de koloniën. Groningen: Tjeenk Willink.

Senerpont Domis, W.J.C. de

1827

Hollandsch en Javaansch woordenboekje, behelzende de woorden, die in de dagelijksche verkeering het meeste te pas komen. Semarang: Tjokro di Wirio. Drie delen. Deel 2 door H.F. de Senerpont Domis. [Exemplaar KITLV Mgg 79.]

Seyn, E. de 1935

Dictionnaire biographique des sciences, des lettres et des arts en Belgique. Deel 1. Bruxelles: L'Avenir.

Singeling, C.B.F.

1986 'Literaire genootschappen 1748-1800; Aanvullingen en correcties', Documentatieblad Werkgroep 18e Eeuw 18-1:65-74. 

Nederland, 1750-1800. Amsterdam: Rodopi. [Proefschrift Rijksuniversiteit Utrecht.]

Sliggers, B.C. en A.A. Wertheim

$1994 \quad$ Een vorstelijke dierentuin; De menagerie van Willem V/le zoo du prince. La ménagerie du stadhouder Guillaume V. Haarlem: Teylers Museum, Zwolle: Waanders.

Sliggers, B.C. en M.H. Besselink (red.)

2002 Het verdwenen museum; Natuurhistorische verzamelingen 1750-1850. Blaricum: V+K, Haarlem: Teylers Museum.

Snelders, H.A.M.

1979 'Het Bataviaasch Genootschap van Kunsten en Wetenschappen in de periode 1778-1816', Documentatieblad Werkgroep 18e Eeuw, nr. 41-42:6290.

1983a 'De natuurwetenschappen in de lokale wetenschappelijke genootschappen uit de eerste helft van de negentiende eeuw', De Negentiende Eeuw 7:102-22.

1983b 'Het Departement van Natuurkunde van de Maatschappij van Verdiensten Felix Meritis in het eerste kwart van zijn bestaan', Documenta-

Soest, G.H. van tieblad Werkgroep 18e eeuw 15:197-222.

1879 'Dr. W.R. baron van Hoëvell', in: G.H. van Soest, Mannen van betekenis, pp. 199-232. Haarlem: Tjeenk Willink. [Ook verschenen in het Tijdschrift voor Nederlandsch-Indië (1879).]

Spanjaard, H.

1988

Het ideaal van een moderne Indonesische schilderkunst 1900-1995; De creatie van een nationale cultuuridentiteit. Proefschrift Rijksuniversiteit, Leiden.

Spiegel van de tijd

$1994 \quad$ Spiegel van de tijd; 225 jaar verzamelen door het Koninklijk Zeeuwsch Genootschap der Wetenschappen. Middelburg: Zeeuws Museum.

Stapelkamp, H.

1986 'De rol van Van Hoëvell in de Bataviase Mei-beweging van 1848', Jambatan 4-3:11-20.

Steenis, C.G.G.J. van

1990 'Dedication [to the memory of Carl Ludwig Blume]', in: Flora Malesiana, series I, volume 10:6-41.

Steur, J.J.

1984 Herstel en ondergang; De voorstellen tot redres van de VOC 1740-1795. Utrecht: HES.

Stevens, Th. 1994

Vrijmetselarij en samenleving in Nederlands-Indië en Indonesië 1764-1962. Hilversum: Verloren.

Studio et Labore zie Wetten (1831)

Swellengrebel, J.L. 
Tempel, K. van der

1980 'Wij hebben amok in ons schip'; Aziaten in opstand tijdens drie terugreizen op het einde van de achttiende eeuw', in: J.R. Bruijn en E.S. van Eyck van Heslinga (red.), Muiterij; Oproer en berechting op schepen van de VOC, pp. 123-47. Haarlem: De Boer Maritiem.

Termorshuizen, G.

1998 'De bittere waarheden van Henri Lion', in: Th. D'haen en G. Termorshuizen (red.), De geest van Multatuli; Proteststemmen in vroegere Europese koloniën, pp. 81-100. Leiden: Vakgroep Talen en Culturen van ZuidoostAzië en Oceanië. [Semaian 17.]

$2001 \quad J o u r n a l i s t e n$ en heethoofden; Een geschiedenis van de Indisch-Nederlandse dagbladpers, 1744-1905. Amsterdam: Nijgh en van Ditmar, Leiden: KITLV Uitgeverij.

The zie Lian The

Theuns-de Boer, G. en S. Asser

2005 Isidore van Kinsbergen (1821-1905), foto pionier en theatermaker in Nederlands-Indie/Photo pioneer and theatre maker in the Dutch East Indies. Zaltbommel: Aprilis, Leiden: KITLV Uitgeverij, Amsterdam: Huis Marseille.

Timmer, F.M.

1988 'Drie averechts; De Van Hogendorps in Oost-Indië', Indische Letteren 3:142-54.

Toekang Potret

1989 Toekang potret; 100 jaar fotografie in Nederlands Indië 1839-1939/100 years of photography in the Dutch Indies 1839-1939. Amsterdam: Fragment.

Treasures

1997

Treasures of the National Museum Jakarta. Jakarta: Buku Antar Bangsa.

Tromp, I.

1987 'Biäng-lala, Indisch leeskabinet tot aangenaam en gezellig onderhoud, 1852-1855', Indische letteren 2:101-15.

Troostenburg de Bruyn, C.A.L. van

1884 De Hervormde Kerk in Nederlandsch-Oost-Indië onder de Oost-Indische compagnie (1602-1795). Arnhem: Tjeenk Willink.

Tijdschrift voor Nijverheid

$1854 \quad$ Tijdschrift voor Nijverheid in Nederlandsch Indië.

Utile et Dulce zie Reglement

Van der Veur, P. zie Lian The

$V B G$

1779-1950 Verhandelingen van het Bataviaasch Genootschap van Kunsten en Wetenschappen. Batavia. Negenenzeventig delen.

Veen, A.

1998 'Munnich en Ermerins', in: Geschiedenis van de Nederlandse fotografie, s.v.

Veer, P. van 't

1958 'Een revolutiejaar, Indische stijl; Wolter Robert baron van Hoëvell, 1812-1879', in: P. van 't Veer, Geen blad voor de mond; Vijf radicalen uit de negentiende eeuw, pp. 101-44. Amsterdam: Arbeiderspers. 
Velde, P.G.E.I.J. van de

1998 'Roependen in de woestijn; Van Hoëvell en Veth als baanbrekers van de nieuwe koloniale politiek, 1846-1850', in: Th. D'haen en G. Termorshuizen (red.), De geest van Multatuli; Proteststemmen in vroegere Europese koloniën, pp. 52-80. Leiden: Vakgroep Talen en Culturen van ZuidoostAzië en Oceanië. [Semaian 17.]

2000 Een Indische liefde; P.J. Veth (1814-1895) en de inburgering van NederlandsIndië. Amsterdam: Balans.

Verhoeven, F.R.J.

1939 'De jonge jaren van de Harmonie; Uit de geschiedenis eener Bataviasche Sociëteit', Koloniale Studiën 23:517-54.

Vermeulen, H.F.

1996 Taal-, land-en volkenkunde in de achttiende eeuw. Leiden: Oosters Genootschap in Nederland.

Vermij, R.

1993

'Genootschappen en de Verlichting; Enkele overwegingen', De Achttiende Eeuw 25:3-23.

1999 'Nieuwe wijn in oude zakken? Iets over de plaats en functie van genootschappen in de maatschappij van het ancien régime', Tijdschrift voor Geschiedenis 112:24-46.

Verslag honderdjarig bestaan

$1878 \quad$ Verslag der viering van het honderdjarig bestaan van het Bataviaasch Genootschap van Kunsten en Wetenschappen op 1 Juni 1878. Batavia: Landsdrukkerij.

Verslag honderdvijftigsten gedenkdag

1928 Verslag der viering van den 150sten gedenkdag [van het] Koninklijk Bataviaasch Genootschap van Kunsten en Wetenschappen 1778 - 24 April - 1928. Weltevreden/Batavia: Kolff.

Verslag Vereeniging Musis

1849-51 Verslag van den Staat der werkzaamheden van de Vereeniging Musis. Batavia: Lange. [Exemplaar 1849/51 KITLV dd 158.]

Veth, P.J.

1857

'Het Bataviaasch Genootschap van Kunsten en Wetenschappen', De Gids 21, I:217-49, 356-72, 687-704; 21, II:3-23.

1884a 'Caspar George Carl Reinwardt', in: P.J. Veth, Ontdekkers en onderzoekers; Zevental levensschetsen, pp. 95-149. Leiden: Brill.

1884b 'Wolter Robert van Hoëvell', in: P.J. Veth, Ontdekkers en onderzoekers; Zevental levensschetsen, pp. 234-94. Leiden: Brill. [Eerder verschenen in De Nederlandsche Spectator 1879.]

1885 'Johan Mauritz Mohr', De Gids 49, III:55-87.

Veth, P.J. zie W.R. van Hoëvell, Reis over Java

Visser, R.P.W.

'De Nederlandse geleerde genootschappen in de 18e eeuw', Documentatieblad Werkgroep 18e Eeuw, 7:175-86.

2002 'De prijsvragen van de Hollandsche Maatschappij 1840-1880; Koersverandering en neergang', in: R.A.M. Aerts (red.) Geleerden en leken; 
De wereld van de Hollandsche Maatschappij der Wetenschappen 1840-1880. Haarlem: Hollandsche Maatschappij der Wetenschappen, Rotterdam: Werkgroep 19e eeuw.

Vorm, P. van der zie Catalogus van der Vorm

Vriese, W.H. de

1858 'Levensberigt van C.G.C. Reinwardt', in: C.G.C. Reinwardt (red.), Reis naar het oostelijk gedeelte van den Indischen Archipel, in het jaar 1821, uit zijn nagelaten aanteekeningen opgesteld door W.H. de Vriese, met een levensberigt en bijlagen. Amsterdam: Muller.

Waal, E. de

$1842 \mathrm{a}$

'Photographie', De Kopiïst 1, I:627-91.

1842b 'Eerste openbare vergadering van het Bataviasche Genootschap voor Kunsten en Wetenschappen', De Kopiïst 1, II:94-102.

Wachter, $\mathrm{H}$. 1781

Lyk- en Lof-rede op den wel eerwaarden en zeer geleerden heere Josua van Iperen [...], dirigeerend lid en secretaris van het Bataviaasche Genootschap en predikant te Batavia; Uitgesproken op saturdag, den 28 February 1780, in de Kasteels-Kerk aldaar. Amsterdam: Allart.

Wall, V.T. van de

1930 'The influence of Marianne Raffles on European society in Java (18121814)', Inter-Ocean 11-3:136-45.

Weatherbee, E.

1978

'Raffles' sources for traditional Javanese historiography and the Mackenzie collections', Indonesia 26:63-93.

Westers, $\mathrm{O}$.

2003

Welsprekende burgers; Rederijkers in de negentiende eeuw. Nijmegen: Vantilt.

Wetten

1823

Nieuwe wetten voor het Bataviaasch Genootschap van Kunsten en Wetenschappen. [Batavia; exemplaar Perpusnas B 32 /1b; drukproef voor Verhandelingen van het Bataviaasch Genootschap van Kunsten en Wetenschappen 9.]

Wetten Maatschappij van Nijverheid

$1854 \quad$ Wetten van de Nederlandsch-Indische Maatschappij van Nijverheid; Opgerigt te Batavia 2 December 1853. Batavia: Lange.

Wetten Studio et Labore

1831 Wetten voor het Natuur-en leer-kunde beoefenend genootschap te Batavia. Onder de zinspreuk; Studio et Labore. Batavia. [Exemplaar KITLV dd 133.]

Wichers, A.J. zie W.W. Mijnhardt en A.J. Wichers, Om het Algemeen Volksgeluk Willekes Macdonald, P.J.

1950

'De Koninklijke Natuurkundige Vereeniging in Nederlands-Indië', in: Een eeuw natuurwetenschap in Indonesië 1850-1950; Gedenkboek Koninklijke Natuurkundige Vereeniging. Djakarta: Koninklijke Natuurkundige Vereniging. 
Wiryamartana, Kuntara en W. van der Molen

2001 'The Merapi-Merbabu manuscripts; A neglected collection', Bijdragen tot de Taal-, Land-en Volkenkunde 157:51-64.

Wurmb, F. von

$1794 \quad$ Briefe des Herrn von Wurmb und des Herrn Baron von Wolzogen auf ihren Reisen nach Afrika und Ostindien in den Jahren 1774 bis 1792. Gotha: EttinWurtzburg, C.E. ger. [Exemplaar KITLV k 59.]

1984 Raffles of the eastern isles. Singapore: Oxford University Press.

Wijnmalen, T.C.L.

1871 'Levensbericht van Jhr. Dr. Philip Franz von Siebold', Levensberichten der afgestorven medeleden, Maatschappij der Nederlandsche Letterkunde, pp. 265-88. Leiden: Brill.

Zandvliet, $\mathrm{K}$.

2002

De Nederlandse ontmoeting met Azië 1600-1950. Amsterdam: Rijksmuseum, Zwolle: Waanders.

Zonneveld, P. van

1992

“"Het altaar van de kunst brandt veilig onder de palmen"; Rederijkerskamers in Nederlands-Indië omstreeks 1850', Indische Letteren 7:10914.

Zuidervaart, H.J.

1999 Van 'Konstgenoten' en hemelse fenomenen; Nederlandse sterrenkunde in de achttiende eeuw. Rotterdam: Erasmus.

Zuiderweg, A.

1991 'Jacobus Cornelis Mattheus Radermacher (1741-1783), een notabel wetenschapper te Batavia', Indische letteren 6:161-77.

2000 'Een verblijfplaats voor onsterfelijken; Een impressie van het culturele en literaire leven op Batavia (1619-1811)', Literatuur 2000-3:132-41. 


\section{Register}

Aa, C.C.N. van der 72-3, 79, 84, 87

Aantekeningen (Domis) 241-2

Abhandlungen 1782117

Académie de Marine (Batavia) 24

Académie des Sciences (Parijs) 49, 101

Academie van Wetenschappen en

Schoone Kunsten (Batavia) 58, 352

Achilles (Amsterdam) 59

Addison, J. 47

Adi Ningrat, Tommegong Ario Prewiro 354

Adimongolo 229

Aengler, Ph. 124

afbeeldingen van monumenten $446-8$

Afrika 103

Afrikaanse leden 355

Afscheidsrede 343

Agon, Sulthan van Bantam 77

Agung, Sultan 77

Ainslie, D. 171, 175

Akwasi Boachi 355

Alderwerelt, M.R. van 254

Alembert, D' 132

Alesum, C. 187

Alfoeren 480

Alfoers woordenboek 485

Alfoerse schilden 479-80

algemeene geschiedenis van Java 430

Algemene Konst- en Letterbode 48

Algemene Secretarie 12, 180, 208, 257,

273, 310, 328, 333-4, 336, 340, 347, 355,

$380,387,393,397,399,401,425-7,429$,

436-7, 449, 473, 492, 510

algemene vergaderingen $4,6,81-2,87$, $103,146,148,152,159,171-2,197-8$,

202, 206-7, 209-10, 219-20, 234-5, 276,
278-9, 281, 283, 286-7, 295, 314, 319,

$329,335,344-5,356-7,362,371,388$,

397, 414, 438-40, 442, 493-6, 503-4, 506, 508

Alkmaar 39

Allart, J. 100, 102-3, 117, 135, 141

Almanak van Nederlandsch Indië 253, 2856, 375

Almeida, J.F. d' 30

Alphen, D.F. van 92, 254

Alphen, H. van 92

Alting, W.A. 69, 73, 75-6, 79, 89, 129,

140, 144, 147-9, 158

Amboinsche Kruidboek 26

Ambon 18, 35, 68, 97, 125, 130, 133, 140, 162, 279, 450, 481

American Philosophical Society

(Philadelphia) 228

Amfioensociëteit 16, 144

Amiens 18, 161

Amstelveen 79

Amsterdam 9, 12, 29, 34, 44-5, 57, 59-63, 74, 85, 88, 100, 102, 117, 129-30, 185, 193, 215, 218, 227-8, 408, 439, 450, 465, 485

Andriesse 225

Angelbeek, C. van 237

Anom, Ida Ketoet 440, 493

Antwerpen 228, 253

Arabische bibliotheek 297

Arabische manuscripten 274, 296-7, 304, 402, 421, 493

Arabische taalstudie 209, 296

archeologie 5, 296, 305

Archeologische commissie zie Oudheidkundige commissie 
archeologische voorwerpen zie oudheid-

kundige voorwerpen

architectuur 29

Ardjoena-sasra-baoe 484

Ardjoena-Wiwoho 325, 411, 415-6, 419

Argensola, B.L. de 347

Arnhem 67

Arnold, Chr. 160

Arntzenius, R.H. 212

Aroe-eilanden 427, 450, 480

Arrenberg, R. 100, 102-3, 115, 117, 122, 135, 141

Arsip Nasional Republik Indonesia

(Nationaal Archief) ix, 1, 3, 10

Asiatic Society (Calcutta) 2, 150-2, 196, 201, 207

Asiatick Researches 152

Assey, Ch. 171

Atheneum Illustre (Amsterdam) 215

Atjeh 419,475

atlas 133

Atlas Ichtyologique des Indes Orientales 359, 361

Australië 392

Aziatische leden 354

Azië 17, 26, 29, 52, 67, 94, 103, 112

Bacheracht, J. 71

Badjoa 398

Bagelen 310-1, 314, 323, 393, 413, 451, 460-1, 463-4, 466

Bagong-tempel 459

Baker, G.P. 175

Baldaeus, Philippus 27

Bali 22, 174-6, 329, 331, 335, 346, 394, 396, 434, 439-40, 451-2, 454, 475, 483

Balinees 411, 418

Balinese handschriften 347, 419

Balinese teksten 411

Banda 18, 97

Bandjarmasin 20, 97, 474, 482, 509

Bandjarmasin, Sultan van 481

Bandjarmasinse regalia 464, 481-3, 509

Bandjarnegara 383, 393, 466

Bandoeng 191, 336, 355, 404, 422, 485, 505

Bangka 174, 274, 384, 464, 474-5

Banjoemas 315, 323, 374, 393, 416, 460,
462,464

Banjoewangi 451

Banks, J. 30-1, 101, 175, 181

Bantam 77, 97, 272-5, 323, 328, 330, 347, 450-1

Bantam, Sultan van 263, 272-4, 296, 328, 482, 492

Bantamse manuscripten 274

Bantamse rijkssieraden 274

Barnard Davis, J. 479

Bartlo, S. 77, 80, 128

Bastin, J. 163, 176

Bataafsch Genootschap der Proefondervindelijke Wijsbegeerte (Rotterdam) 40, 56, 71, 76, 78-80, 111-2, 114, 227

Bataafse Republiek 3, 17-8, 56, 185

Batak 331, 485, 491

Batakse taalstudie 431

Batakse woordenboek 431

Batavia British Library 369

Bataviaasch Handelsblad 361

Bataviaasch Liefhebberij-toneel 364

Bataviaasch Museum van Natuurlijke Historie 267, 294

Batavian Asiatic Society 167

Bataviasche Bibliotheecq 35

Bataviasche Courant 190, 232, 241-2, 252

Bataviasche Koloniale Courant 166

Bataviase Bovenlanden 69, 99, 108, 120

Bataviase Kerkenraad 34

Bataviase Nouvelles 29

Bataviase Nijverheidstentoonstelling 395

Bataviase Ommelanden 15-6, 108, 117, 120, 133

Bataviase Race-club 505

Bataviase Schouwburg 330, 454

Batoe Toelis 427

Batoer 459, 461

Baud, J.Chr. 21-2, 174, 254, 258-64, 272, 282-3, 285, 287-8, 308-9, 324, 340, 344, $365,376,423-5$

Baumhauer, C.M. 235, 254

Becker, J.F. 346

Bedakkan 493

Bedenkingen over den tegenwoordigen staat der Nederlandsche Oost Indische Maatschappij in Indië 66-7 
Bedojo-zangen 494

Beekman, W. 139

Beets, N. 400

bekroonde prijsvragen 108-14, 120

Bekstein, E.R.C. van 133

Benares 457

Bengalen 18, 71-2, 75, 97, 228, 230

Bengkoelen 176-7, 181, 278

Berg, L.W.C. van den 444, 493

Berg, N.P. van den $6,374,437,457,474$, 507

Berg, W. van den 42-3

Berge, T. van den 486

Berigt van den tegenwoordigen toestand in Oost-Indiën 157, 159

Berkel, K. van 25

Berlijn 101, 103, 331, 389, 417-8, 421

Bernet Kempers, A.J. 9-10

Bernstein, A. 479-80

beschermheer 6-7, 14, 217, 230, 238-9, 266-7, 285, 288, 442

beschermheerschap $87,170,189,332$, $375,440,495$

Beschryving van Japan 27

Besoeki 354, 451

bestuur 5-7, 9, 14, 74, 76-7, 87, 159, 1901, 194-5, 197-9, 202-4, 207-8, 211-2, 231, 234-5, 264, 276, 279, 283, 292, 301, 309, $334,337,340-1,349-58,360,376,379$, $407,422-3,426,428,436-40,442-3,447-$ 8,508

bestuursvergaderingen 10-1, 63, 81-2, $88,96,106,149,158,161-2,237-8,249$, $263,319,328,335,337,340,376,422$, 428

Beth 111

Beijerinck, F. 432-3

Beijerinck, P.J.G. 497, 502, 504-5

Biäng-lala 400, 405

Biblioteca Indica 152

bibliothecaris 166, 188, 218-9, 221, 391, 401, 414, 417, 419-23, 442, 453, 493, 495, 506

Bibliotheek van de Academie van Marine 35

bibliotheek Bataviaasch Genootschap 1, 12-3, 123-4, 126-7, 131, 133-5, 137, 146, 166, 168, 198, 203, 204-6, 218-21, 230,
237, 267, 269-71, 276, 282, 295, 306, 329-30, 335, 340, 368-9, 390, 401-7, 411, 418, 461, 492, 499, 504, 506, 509, 512

bibliotheek Kerkenraad 34, 37

Bibliotheek van de Maatschappij Tot Nut van het Algemeen 369

bibliotheek Raad van Justitie 34

bibliotheek Seminarium Theologicum 35,37

bibliotheekcatalogus 318, 331, 426

Bicker, L. 109, 111, 120-1

Bidasari 320

Bik, A.J. 192, 206, 214, 247, 255, 261-2, 273, 282, 293

Biliton 392, 427, 443, 481

biologie 125

Birma 222

Blanco woordenlijst ten behoeve van de taalvorsers 486

Blandford 246

Blauwdrukken voor een samenleving 39, 47

Bleeker, P. 2, 5, 10, 316-8, 325-9, 336-7, 340, 347, 349-54, 356-63, 368, 370-4, $380,382,387,390-2,397-401,403,408$, 411-2, 417, 421-2, 425-8, 433-4, 440, 446

Bleiswijk, P. van 102

Bletterman, J.H. 212

Blitar 460

Blom, G. 191, 222, 232, 234

Blomhert, E. 77, 80

Blomhoff, J.C. 269

Blume, C.L. 191, 194, 208-9, 214-6, 221, 223-4, 228-9, 237, 243-6, 268, 356

Blumenbach, J.T. 254

Bock, A. de 99, 148

Bodjonegoro 355

Boeckholtz, J. van 221

Boeddha 470, 510

boeken 123, 127, 134, 269

Boekzaal der Geleerde Wereld 228

Boeleleng 418

Boengeng, Pak 465

Boers, C.J. 127, 133, 140

Boers, F.W. 102-3

Bogor zie Buitenzorg

Boie, H. 247

Bolaäng Mongondouw 480

Bolt 337 
Boma Kawja 411

Boni 381-2, 384, 398, 474

Bonische expeditie 398

Bonische manuscripten 382, 384

Bonn 244, 331, 417-8

Bonn, A. 40, 45

Bonnet, G. 100

Bontius, J. 26, 34

Bor, P. 220

Borneo 22, 173-4, 221, 347, 383-4, 392-3, $396,427,432,434,474,483$

Borneose zeldzaamheden 222

Bôrô-Boedoer zie Boroboedoer

Boroboedoer 182, 314, 376-9, 427, 431, $447,451,454-5,458-9,467$

bosbouw 185

Bosch, A.J. 67

Bosch, J. van den 20-1, 231-2, 239, 250-1, 254, 259, 285

Bosch, W. 338, 340, 343-5, 349, 351-2, $357,360,368,370,390,422,436$

Bosma, B. 44

Bosscha, H. 187

Bosscher, C. 431

botanie 128

botanische tuin (Batavia) 236, 254

Bougainville, L.A. de 30

Bouhon, J. 74

Bousquet, J. 222, 232, 234-6, 248, 250-1, 257, 259, 276, 279, 286

Bowier, J. 189, 191

Braam Houckgeest, E.A. van 89

Braarda, C. 35, 37

Brahma 347, 470

Brandes, J. 28

Brata Joeda 411-5, 423, 484

Breda 412

Breda, J.G.S. van 216

Brest van Kempen, J.J. 291-3, 296, 304

Breton, H. 74, 76

British Museum (Londen) 127

Britsche heerschappij over Java en onderhoorigheden 1811-1816 473

Brockhaus 389

Bromo 33

Brug, P.H. van der 107

Brugge 454

Brummen 243
Brumund, J.F.G. $357,394,436-7,444$, 447, 449-53, 455, 457-9, 462-3, 468, 475, 484, 488

Brunswijk, Hertog van 102

Brussel 185, 227-8, 232, 455

Bruijn, H. de 496, 500, 502, 504-5

Bruijn, P. de 136

Bruijn Kops, G.F. de 373-4, 408, 428, 436-7

Buddingh, S.A. 291, 293, 296-7, 316-7, 331, 335, 342, 344-6, 349-52, 357, 360, 388-9, 400, 404-5, 414-5, 417, 430

Bürcke,W.A. 212

Bürger, H. 251, 266, 282, 293

Buffon, G. 130

Buitennieuwpoortstraat 55

buitengewone leden $7,100,103,356$, 439,442

Buitenzorg 189-91, 194, 215, 221, 224, 228, 236, 243, 245, 256-7, 302, 321, 332, 374, 416, 427, 451, 455, 475, 486, 499

Burgerlijke Openbare Werken 255, 40910, 497-8, 500-2, 504-5, 509

Burgh, J. van der 96, 140

Burke 224

Burman, N.L. 101, 130

Bus, Ch.L. du 235

Bus, L.H. du 235

Bus de Gisignies, L. du 20, 231-7, 239, 254-7, 260, 269-70, 272, 279, 285-6, 288, 299

Busching, A.F. 101

Buijnsters, P.J. 39

Buijskes, A.A. 19-20, 189, 254, 275, 314

Buijskes, G. 191, 234-5

Bijbelgenootschap zie NederlandschOost-Indisch Bijbelgenootschap

bijbelvertaling 33-4

Bijdragen tot de kennis van het Hindoeisme op Java 452

Bijdragen tot de Taal-, Land-, en Volkenkunde van Neêrlandsch Indië 390, 424-8, 433

Bijdragen van het Koninklijk Instituut 487

Bijlon, D. 120

Byron, Lord 365 
Calcutta 2, 150-2, 168-9, 174, 182, 196, 201, 207, 228, 324, 455

Camper, P. 101

Cannaerts, D.H. 378, 414

Canton 212, 228

Capellen, C.A.G.P. baron van der 5, 8, 19-20, 183, 185, 187-90, 193-5, 197, 202, 208-10, 213, 217-8, 220, 222, 224, 229$32,234,236,238-9,243-4,255,259,268$, 272, 275, 285-8, 291, 354, 366, 440, 444, 461

Capellen, E.J.J. van der 291

Carlier, G.J.P. 393

Carstens, R. 252

Castens, C. 455,460

catalogi 391

catalogus 1778 124, 130-1

catalogus 1779 130-1, 134

catalogus 1783134

catalogus Arabische handschriften 394, $412,418,421$

Catalogus Bataviasche Bibliotheecq 35-6

catalogus boekenverzameling 401-3

catalogus etnologisch kabinet 396, 4735, 511-2

catalogus Maleise handschriften 421

catalogus manuscripten 421

catalogus oosterse handschriften 331, 418

catalogus oudheidkundige verzameling 394, 412, 421, 468-71, 473, 511-2

catalogus Van der Vorm 35

Cats, J. 37

Cattenburch, F.M.G. van 476-7

Celebes 22, 174, 176, 384, 395-6, 398, 432, 434,474

Cellarius, J.J. 133

Centraal Museum zie Museum Pusat

Ceram 474

Ceylon 16, 18, 24-5, 32, 71-2, 75, 97, 111, 130, 144

Chassé, P.T. 222

Cheribon 97, 102, 175, 323, 336, 414, 432, 451

China 18,89

Chinees 105, 484

Chinsurah 212, 228-30

Choisie, La (loge Batavia) 52-3, 67, 150
Chronique théatrale 336

Chun, H.L.E. 299-301, 303-6, 317, 319, 331

Chijs, J.A. van der 5-7, 10, 133, 374, 397, 399, 401, 403, 410, 436-7, 455, 459-60, $462,467,480,484-6,488,491,493,495-$ 6, 510

Chijs, P.O. van der 397

circulaire 98-9, 130, 135-7, 260, 262, 267$72,475,478$

circulaire 177888

Clarissa 47

Cochin 144-5

Cochius, F.D. 233, 293, 328, 331, 337, 349, 418

Coevorden, J.S. van 437, 485

Cohen Stuart, A.B. 356, 378, 380-1, 4112, 415, 422-3, 431, 434, 438-9, 469, 471, 477, 488-93

College van Curatoren en Scholarchen 24

College van Heemraden 16

Collegie der Scavanten (Utrecht) 45

Colombo 143, 496

commissaris-generaal 233-5, 237-8, 248

commissie-generaal 148, 162, 185, 188, 196, 218

commissie tot opname van het museum 510-2

Commissiën tot Ondersteuning van

Behoeftige Christenen 293, 364

communicatiegemeenschap 47, 51, 54

Concordia (Batavia) 364

Concordia (Paramaribo) 150

Condorcet, Marquis de 101

Conservator 298, 438, 493, 495

contributie 103, 139-40, 149, 154, 159, 172, 195, 198, 201-2, 285, 353-4, 358, $371,391,438-40,496$

Cook, J. 30-1

Cornelius, H.C. 182

Cornets de Groot, A.D. 278, 280, 305, 332, 370, 392

Coromandel 97

Coromandelkust 17-8

Corpus Inscriptionum 381, 392

correspondenten 7, 100-1, 103, 139, 211

corresponderende leden 7,62, 111, 189, 
$211,225,230,285,351,353,356,366$, $371,375,439,442$

Cossigny, D.Ch. de 100

Couperus, A. 136, 173

Craan, J. 68, 73, 75-6

Crawfurd, J. 167, 240

Croockewit, J.H. 370, 432

cultuurstelsel 21-2, 287

Cuthbertson, J. 129, 135

Daendels, H.W. 19-20, 55, 160, 165-6, 170, 178, 189, 196, 256, 272

Daguerre, L.J.M. 309, 376, 399

Danckerts, S. 26

Danoe Koesoemoe, R. Toemenggong 439

Danoe Ningrat, R.A.A. 356

David, koning 120

Dayak 278, 329, 346-7, 427

Dayakse wapens 222

Deeleman, C.F. 504

Deiman, J.R. 113

Deken, A. 48

delfstoffenrijk 353

Delft 228, 321, 323-4, 381, 392, 423-5, $427,429,433,473,487$

Deli 474,476

Demak 355

De medicina Indorum 26

Den Haag 22, 53, 61-2, 66, 84-5, 88, 102, $185,187,212,227-8,242,250,259,261$, 269, 284, 307, 321, 343, 365, 379, 424, $443,473,495-500,503-4,511$

Departement van Justitie 443

Departement van Onderwijs en Eredienst $61,130,436,438,508$

Depok 487

depot 385

Description de l'Egypte 217

Deshima 243-9, 252, 268, 355, 363

Desiderata 335, 394-5, 397, 475

Deventer 291

DeWall, H. von 380, 427, 431, 434, 484

Diard, P. 265-6, 293

dichtgenootschappen 41, 59, 356

Diderot, D. 132, 271

Diemont 493

Diëng 311, 393-4, 455, 457-61, 467 dierenrijk 129, 131, 353

dierkunde 120, 130, 185

dilettantengenootschappen 42-4, 54

dilettantensociabiliteit 42 , zie ook genootschappelijkheid

Dinas Purbakala zie Oudheidkundige Dienst

Diponegoro, Pangeran 239, 493

directeuren 7, 103, 159, 199, 417, 473-4, 506, 511

directie Landbouw, Kunsten en Wetenschappen 196, 215

dirigerende leden 203, 207

Djaja-lengkara 382

Djajadiningrat, Ario Hoesein 9

Djambi 396

Djambi, sultan van 382

Djambische expeditie 383

Djambische krijg 382

Djame, Pak 402

Djohor 484

Djojo di Ningrat, R.A.A. 432-4

Djokjakarta 169, 174, 311, 314, 356, 384, $416,432,478$

Docendo Docemur (Paramaribo) 150

Döckers, W.M. 158, 198

Döllinger, I. 244

Doelstellingen 93-5, 198-201

Doerga 312, 378

Dokter Djawa-school 360-1

Dollond, P. 32

Domis, H.J. 238-43, 277

donderstenen 478-80

doodsbeenkisten 479

Doornik, F.H. 315

Doornik, J.E. van 195-6

Doorninck, van 278

Dorsman, J. 121, 142

Douwes Dekker, E. 22, 368

Drontheim 145

Droop 394

drukkerij Bataviaasch Genootschap 298301, 303-4, 306, 315-27, 331-3, 335-42, $344-5,389,414,461$

drukkerij van de Engelse zending te

Parapattan 301, 303

dubbellidmaatschap 370-5

Dulx, G.P. le 122, 147 
Duurkoop, J.A. 108-10, 120

Duymaer van Twist, A.J. 390, 424-5, 428

Dijk, C. van 26-7

East India Company 2, 151-2, 167, 169

Eckhout, A. 28, 236

economie 210, 441

Edam 41, 50

Ede 478

Eendragt 364

Eensgezintheid (Paramaribo) 150

Eerens, D.J. de 259, 285, 293

Effen, J. van 47

Egter van Wissekerke, A.W. 437, 510

Egyptische mummie 133, 145

Eilbracht, C.L. 129-30

Eilbracht, J. 129

Einthoven, J. 367

Ekenholm, J. 191

electriseermachine 148

Elgin, Lord 410

Elias 450, 454

Elout, C.Th. 19-20, 187, 189, 254

Emmerik, J.J. van 436

Encyclopédie 132, 271

Engeland 3, 17-8, 25, 82, 89

Engelhard, N. 165, 173, 182, 188, 193, 219, 240, 268, 394

Engelman, J. 83

Engels bestuur 186

Engelse weeshuis 316-7, 331, 379

Engelse zending 299

Enschede \& Zonen 321

Epitome Linguae Japonicae (Von Siebold) 244

Eppingen 30

ereleden $7,230,233-5,266-7,285,343$, 438,442

Ermerins zie Munnich \& Ermerins

Ernst \& Co 458

etnographie 295-6, 352, 383, 435, 438

etnologie 13, 296, 330-1, 392, 483-4, 492

etnologische afdeling 506-8

etnologische verzameling 261, 297, 307,

326-7, 329, 362, 395, 397, 406, 410, 440,

446-7, 449-50, 471, 504, 511

Euler, J.E. 101

Europa 100-1, 103, 106 exercitiegenootschappen 41

extra-ordinaire leden zie buitengewone leden

Eys, P.L. van 99

Fagel, H. 102

Falck, A.R. 254

Falck, I. 71-2, 75, 133

fantasmagorie 225

Fasseur, C. 21

Fau de la Longue, D. du 108-9

Fauna Japonica (Von Siebold) 251

Favorlangs (Formosaans)-Duits woordenboek 299, 305, 484

Felix Meritis 32, 44

Fendall, J. 19, 165, 181, 187-8

Fidèle Sincérité, La (loge Batavia) 53

Filippijnen 174

filologie 305,352

financiën 10, 138, 149, 160, 281, 303, 337, 347, 387-91

Fischer, L.E. 222

Flora (Blume) 237

Flora Japonica (Von Siebold) 251

Flores 474

Fockens, W. 76

Formosa 484

Fort de Kock 471

Fort Sorg 384

fotograaf van het genootschap 457

fotografie $309,376-9,399-400,447$, 449$50,454-61,507,510$

Franeker 83, 228

Frankrijk 17-8, 41, 49

Franse tijd 14

Fransen van de Putte, I.D. 22

Friederich, R.H.T. 325, 331, 335, 346, 378-81, 389, 391, 394, 402-3, 412-23, 427, 431, 434, 446, 450, 452-3, 468-71, 483-4, 488, 493, 510

Friedländer 389

Fritze, E.A. 235, 249-50, 257, 265-6, 2734, 280, 293-6, 298, 436

Frijkenius, S. 148

Führi, E. 319, 339-40, 342

Gaastra, F.S. 16-7

Gaffron, H. von 392, 473 
Gallas, C.M. 67

Galoe 439

gamelan 273-4, 328, 383

Ganesha 460,467

Garoet 451, 485, 487

gebedsformules 175

gebouwen 123-8, 177-80, 263, 329-32,

406-10, 495-511

Gede 224

Gedenkboek Bataviaasch Genootschap 1, 3-8, 10-1

Gedenkboek van oud-studenten 316

Gediking, P. 8

Geemen, P. van 123

Geer, W.C.E. baron de 332

Geisler 485

Gelder, D.H.R. van 265, 281

geleerde genootschappen $38,40,42,51$, $57-8,65,104,153$

geleerdensociabiliteit 42, 45-6, 49, 356

Gelman Taylor, J. 53-4

geneeskrachtige kruiden 164

geneeskunde 9, 117, 125, 130, 164, 209, $278,363,430$

Geneeskundige Dienst 189, 191, 260, 357, 359-60, 373

Geneeskundige Vereeniging 375

Genootschap ter bevordering van de

Natuurlijke Historie (Paramaribo) 150

Genootschap ter bevordering van Nuttige Kunsten en Wetenschappen (Vlissingen) 91

Genootschap ter bevordering van het Vaderlandsch Regt (Groningen) 100

Genootschap tot Nut en Beschaving (Batavia) 364, 367-8

Genootschap van Kunsten en Wetenschappen (Edam) 91

Genootschap van Natuur-Onderzoekers (Batavia) 226, 365-6

Genootschap van Surinaamsche Landbouw (Paramaribo) 150

Genootschap van Waterloo (Brussel, Batavia) 20, 232, 237, 239, 276

Genootschap voor mineralogie (Jena) 253

Genootschap voor oudheidkunde

(Batavia) 262 genootschappelijkheid 45-8, 53, 55, 104

genootschapsarchief $3,10-2,161-2,176$,

191, 193, 195, 247, 268, 277, 315, 319,

$418,424,452$

genootschapshuis 13, 123-4, 126, 128-9,

$135,142,160,166,169,179,208,212$,

222, 233, 264, 304, 327, 435, 437, 497,

508 , zie ook gebouwen

genootschapsleven 364-9

genootschapsonderzoek 9, 13, 38-9

genootschapspenning 63

genootschapstuin 123, 125, 128

Gent 216, 228

Gentse universiteit 215

geografie $9,27,117,441$

geologie 164, 185, 392

geologisch kabinet 335, 345, 392, 406

geologische verzameling 363, 412

geologische vondsten 357

geraamte 134

gereedschappen 395

Gericke, J.F.C. 278, 305, 320, 322-5, 378,

411,416

geschiedenis 120, 432, 441, 484

Geschiedenis van den oorlog op Java van 1825-1830 431

geschiedkundige afdeling 13

Gevers, P. 77, 80

gewone leden $7,100,103,211,230,285$,

$351-4,356,366,371-2,439,442$

gewone leden buiten de hoofdplaats 230

gewone leden buitenslands 230, 351,

354, 439

gezondheid 185, 209

Gibson, W. 381, 488

Gids, De 4, 487

Gildemeister, J. 417

Gisseler van Lenteloo 225

Goa 27, 133, 382

Goase handschriften en regalia 133

Godefroij, P.J. 353, 357, 360, 436

Godin, M.C. 498

godsdienstwetenschap 27

Goenoeng Parang 224

Goenoeng Toegil (Probolinggo) 465

Goetbloed, D. 99

Goethe, J.W. von 7, 252-4

Göttingen 228, 254 
Goldberg, J. 187

Goldman, J.C. 221

Gonashi 246

Gonggrijp, J.R.P.F. 487

Goor, J. van 25, 27

Gorontalo 480, 487

Gotha 100, 103

gouvernement (Batavia) 61

gouverneur-generaal 15, 23-4, 63, 65,

67, 86-8, 95, 157, 179, 194-5, 198-9, 203, $210,215,217,243,310,316,321,328$, $332,339,343,347,375,424-5,442,445$, $448,503,505-6$

Graaff, H.J. van der 189, 219

graanpakhuis 66

Graeff, jhr. A.C.D. de 332

Gratieaen, J. 120

Green, V. 30-1

Groeneboer, K. 16

Groeneveldt, W.P. 6, 468, 471

Groll, J. 373

Grondeler 142

grondwetten zie reglementen

Groningen 30, 77, 79, 83, 100, 133, 215, $218,227-8,291,346,420$

Groningse universiteit 31, 190, 227

Groot, H. de 47

Groote, J. de 100

Grootoosten (Den Haag) 52-3

Grote Postweg 19

Grote Rivier 435

Grote Winkel 66

Guitard, H. 147

Gymnasium (Berlijn) 101

Gymnasium Koning Willem III (Batavia) 2, 21, 24, 294, 374, 437, 448, 506

Haan, F. de 29, 35, 37, 55, 66, 79, 366, 369

Haarlem 17, 30-1, 33, 38-9, 41-4, 49-50, 56-7, 63, 69-80, 83-6, 91, 93, 100, 102-5, 107, 112-4, 134, 144, 146, 148, 153-4, $160,206,215,218,225,228,254,271$, 389

Haarlemsche Courant 228

Haeck 222

Hageman, J. 53, 371, 393, 430-4, 452

Hagenaar, T.C.A. 368-9
Halewijn, M.H. 265, 293, 300-4, 306, 315

Halmaheira 174, 479-80

Ham, W.A. van der 311, 322

Hamat Soorjan 384

handschriften zie manuscripten

Hangling Darmo 411

Happart, G. 299

Happé, E.C.F. 482

Hardeland, A. 346

Harderwijk 67, 69, 83, 133, 418

Haren, C. van 77

Haren, O.Z. van 77

Harloff, W.L.H.A. de 477, 483

Harmonie, De 55, 177-8, 180, 188, 190, $212,257,260,286,289,306,309,329$, $338,340,345,350,364,404,406,434-5$, 497,512

Hart, A. van der 431

Hartman, C.L. 311

Hasselquist, F. 130

Hasskarl, K. 299

Heemen, E. 117

Heemskerk, J. van 98

Heerenlogement 55

Heidelberg 253

Hellevoetssluis 144

Hendrik, Prins 266-7, 287-8, 291

Hengel, F.U. van 357, 374

Hennert, P. 101

Herben, J. 378

Heren Zeventien 15, 23, 87, 149, 199

hervormingsgezinde genootschappen 42,44

Heutsz, J.B. van 418

Heuvel, H.H. van den 44,72

Heydt, J.W. 28

Hidajat-Oelah, Prins 482

Hikajat Isma Jatim 412

Hikayat Sultan Abdul Muluk 325

hindoe-beelden 240, 383, 393, 431

hindoe-kris 467

hindoe-oudheden 449

hindoeïsme 453

Historie van Mejuffrow Sara Burgerhart 47

History of Java 167, 176, 181-2, 280, 325

History of Sumatra 167

Hoa Tsien Ki 484

Hoepermans, N.W. 469-71, 510 
Hoesein, R. Moehamed 487

Hoëvell, G.W.W. baron van 291

Hoëvell, W.R. baron van 4-5, 8, 10, 12, $22,25,28,161,163,256,280,283-4$, 289-94, 296-9, 302, 304, 309-11, 314-7, $319,326-47,349-51,354,357,359-60$, $367,375,385,393-4,404,411,413$, 41721, 434, 444, 450-1, 470

Hoff, A.E. van 't 30

Hoffmann, Chr. 162

Hofstede, P. 101

Hogendorp, C.S.W. graaf van 222, 308

Hogendorp, D. van 19, 77, 157-9, 187, 198

Hogendorp, G.K. van 77, 254

Hogendorp, W. van 77-80, 101, 106, 111, $120,134,153,157,162$

Hoge Regering 3, 14-5, 23, 30, 34, 63, 65, 76, 87-8, 92-3, 95, 98-9, 108, 136, 149, $159,198-9,202-3,268$

Holland 41, 50, 71, 79, 154

Hollander, J.J. den 411

Hollandsche Maatschappij der Wetenschappen (Haarlem) 30-1, 38, 40-1, 43, 61, 69-70, 72-6, 78-9, 83, 87, 93, 104-5, $112,114,141,145,215,225,227-8,254$, 271

Hollandsche Spectator 47

Hollandse archieven 188

Hollandse Kerk 126

Hollands-Javaans woordenboekje 241

Holle, K.F. 439, 451, 485-91, 493-4, 505

Holtzhey, J.G. 63, 135

honorair beschermheer 231, 235, 237, 239

honoraire leden $189,351,353,356,366$, 375,439

Hoofdcommissie van Landbouw 254-5

Hoofdcommissie van Onderwijs 260, $276,283,293$

Hoofdcommissie van Weldadigheid 364

Hooft, P.C. 220

Hoogeveen, T.W. 475

hooggerechtshof 191, 443, 509

Hooijman, J. 32, 73, 75, 77-80, 108, 112,

$117,122,128,134,146-7,153,155$

Hope, Th. 30-1, 67

Hora Siccama, J.F. 349
Horner, L. 299

Hornstedt, C.F. 128, 142

Horsfield, Th. 162-8, 170, 173-4, 181-2, $187,214,228,356$

Hortus Indicus Malabaricus 26

Hougly 97, 129

Houtman, F. de 26

Hsi Yuan Lu 484

huisraad 395, 476

Hultman, C. 410

Humboldt, W. von 175, 220, 291, 356

Hutcheson, F. 47

ichtyologie 327

Ijen-plateau 165

Imhoff, G.W. baron van 23-4, 29, 110

India $17-8,101$

Indiana 450-1

Indisch Archief 350, 360, 362, 387, 430

Indisch Bijbelgenootschap 297, 317, 339

Indisch Genootschap 361, 444

Indisch Magazijn 333, 380

Indisch Museum 257, 267, 446

Indische Bibliotheek 402, 405

Indische letterschriften 485-6

Indische taal- en letterkunde 324

Indische tentoonstelling van voortbrengselen van vlijt en nijverheid 255-6

Indonesische bronnen 210

Indonesische leden 354, 405, 439

inheems onderwijs 491-2

Inleiding tot de Hindoe-Javaansche Kunst 450

inscripties 125, 221, 376, 381, 384, 422-3, 427, 430-2, 444, 446, 452-4, 466-7, 469, $486,492-4$

Instituut voor de Javaanse taal (Soerakarta) 294, 322, 324, 411

instrumenten 126

Internationale Koloniale Tentoonstelling (Parijs) 465

Intveld, A.H. 485

Iperen, J. van 2, 63, 65, 73-5, 77, 80, 82-7, 110-1, 117, 120-1, 131, 133-4, 136-7, 145, $147,153,417$

Isi Saka Sotels 251

Islam 489

Isma Jatiem 237 
Italiaanse academies 42

jacht 395

Jacobi, Chr. 108-9, 120

Jacobs 142

Jaesrich 485

Jakarta ix, 3, 12, 14, 63

Jakatra 15

Jansen, A.J.F. 480

Janssen, H.L. 462

Janssen, L.J.F. 445-9

Janssens, J.W. 165-6, 174, 239, 259

Japan 174, 212, 228-9, 243-52, 269, 276, 278,355

Japans papier 133

Japansche Vroedkunde, Beantwoording (Von Siebold) 244

Japanse flora 248

Japanse geneeskunde 244, 251

Japanse leden 355

Japanse naturalia 247-50

Japanse rariteiten 250

Japanse taalkunde 245-8, 250

Japanse verzamelingen 61

Japanse volkenkunde 246-8, 250-1

Japanse voorwerpen 68

Japanse zending 145

Japin, A. 355

Java 15, 19-20, 22, 33, 68, 102, 130, 149,

$162-3,167-9,175,177,182,185-6,192$,

194, 225, 235, 238, 266, 268, 287, 308,

$310,320,322,336,338,365-6,381,394$,

396, 422-3, 427, 430, 432, 444-61, 488

Java Auxiliary Bible Society 179, 182

Java Benevolent Society 182, 286

Java Government Gazette 19, 166, 168, 170-1

Java-Bode 430, 484

Java-oorlog 20, 231, 238, 278, 431-4

Javaans 105, 174, 209, 222, 411, 418, 431, $434,485,487$

Javaans schrift 175

Javaans woordenboek 325, 484

Javaanse bronnen 210

Javaanse edities 386

Javaanse geschiedenis 117, 209, 278

Javaanse handschriften 296-7, 304-5

Javaanse leesboeken 417, 491
Javaanse letterkunde 210

Javaanse muziekinstrumenten 69, 132

Javaanse oudheden 33, 182, 214-5, 261,

294, 308-9, 331, 378, 445

Javaanse spraakkunst 278, 280, 305

Javaanse taal 34, 209, 378

Javaanse taalstudie 209, 296

Javaanse teksten 411, 416

Javaasch Medewerkend Bijbel-

genootschap 188, 286

Javaasch Medewerkend Zendeling

Genootschap 293, 364

Javaasch Menschlievend Genootschap 188, 286

Javaasch Weldadig Genootschap 229, 232, 286

Javasche Bank 299

Javasche Courant 334-5, 343, 351, 394-5, 457

Jena 253

Jepara 383

Jerusalem 120

Jones, W. 2, 129-30, 151, 175, 324

Jong, J.J.P. de 16, 474

Jonge, A. de 38

Journaal eener reis van Welerie naar het gebergte Praauw (Domis) 241-2

Journal of the Indian Archipelago 359

jubileumbijeenkomst 1853 354-5

Juch, J.E.H. 404

Junghuhn, F.W. 291, 298-9, 329, 333, 356

Kaap, de 78, 84-5, 97, 102, 133, 212, 228

Kaap Verdische eilanden 216

kabinet Bataviaasch Genootschap 6, 12, 123-4, 131, 203, 205, 218, 220-2, 230, 261

Kabinet van Liefhebberijen van Teylers Genootschap (Haarlem) 113

Kabinet van Natuurlijke Historie, 's Lands (Amsterdam) 61, 185

kabinet van oudheden (Batavia) 192, 206, 221, 268, 383

kabinet van zeldzaamheden 264

Kadoe 310-1, 314-5, 323, 402-3, 463-4

Kaempfer, E. 27, 175

Kalialang 311

Kamer van 1844 (Amsterdam) 59-60 
Kan, J. van 1,8

Kanter, J. de 211, 225

Karanganjar 432-3

Karto Di Wirio 241

Kas, 's Lands 216

Kasteel van Batavia 15-6, 19, 23, 33-4, $54,76,89,99,123,125,147-8,153,199$, 206

Kasteelbibliotheek 34-5

Kasteele, R.P. van de 269

Katalogus van de ethnologische afdeeling 468

Katsura Gawa Hoken 229, 244, 354

Kawi 440, 446, 448, 485, 487

Kawi-handschriften 305, 402, 422, 427, 451

Kawi-inscripties 175-6

Kawi-Javaans woordenboek 485

Kawi-teksten 416

Kawi-woordenboek 421-2

Kediri 323, 393-4, 457, 460

Kedong Kidang 383

Kemink 389

Kempen, M. van 150-1

Kent, W. 187

Keuchenius, L.W.C. 354, 390, 397, 425-7

Keijzer, C. de 110

Kinder de Camercq, A.W. 478-9

Kinderen, T. H. der 3-8, 10-1, 16, 75, 149, 161, 398-9, 410, 436-7, 443-4, 449, 455, $471,476,495-6,504$

Kinsbergen, I. van 437, 440, 444, 454-61, 463, 466-7, 507, 510

Kintsius 101

Kirckhoff, J.R.L. von 253

KITLV 259, 354, 361, 381, 390, 392, 423-4, $444,453,489$

Klaproth, J. 249

kledingstukken 271, 273, 395, 476-7

Klerk, R. de 55, 66-7, 72-6, 86, 89, 101

Klinkert, H.C. 487-91, 493

Kloek, J.J. 38-9, 43, 47-51, 54, 104

Kloprogge, J. 160

KNIL 357, 359, 375, 424, 433

Kniphof, J.H. 130

Koblenz 417-8

Kock, C. de 109, 111

Kock, H.M. de 189, 213, 220-2, 231-2,
236-9, 272, 432-3

Koesoema Diningrat R.A.A. 439

Koesoemo Adji Negoro, R. Pandji 493

Kokoseilanden 278

kolfbaan 179-80, 257, 259-60, 264, 272, 304, 313, 377, 406, 408-9, 497, 500

Kollegie van Natuur-Onderzoekinge (Paramaribo) 150-1

Koloniaal Museum van Natuurlijke Geschiedenis (Batavia) 296

Koloniaal Verslag 379-80, 388

Koningsplein ix-x, 2, 13, 180, 410, 436, $458,466,502-5,509,512-3$

koningstijger 295

Koninklijk Huis 61

Koninklijk Instituut (Delft) 190

Koninklijk Instituut voor Taal-, Land- en Volkenkunde (Delft) zie KITLV

Koninklijk Kabinet van Zeldzaamheden (Den Haag) 61-2, 236, 250, 260, 269, 295, 307

Koninklijk Museum (Amsterdam) 29, 61,250

Koninklijk Nederlandsch Instituut van Wetenschappen, Letterkunde en Schoone Kunsten (Amsterdam) 57-8, 92, 218, 227, 353, 408

Koninklijke Akademie (Delft) 324, 423

Koninklijke Akademie van Wetenschappen (Amsterdam) 57, 61-2, 92, 353, 361, 423, 467, 473

Koninklijke Bibliotheek (Den Haag) 61

Koninklijke Militaire Academie (Breda) 412

Koninkrijk Holland 3, 18, 56, 185

Koninkrijk der Nederlanden 3, 14, 77, 88, 185, 189

Konstgenootschap (Utrecht) 43

koophandel 200

Koorders, D. 484, 489-90

kopieën van inscripties 446-9, 452-3

Kopiïst, De 333, 380, 399

Kops, E.J. 212

Korthals, P.W. 299

kostbaarheden 273, 382, 406, 445, 504

Kota Waringin, vorst van 383, 385

Kraaijenhoff, C.R.F. 254

Kraspoekoel 78 
kratonbibliotheek 168

Kriel, S.C. 71

Krom, N.J. 33, 450

kruiden- en plantentuin (Batavia) 128

Kruseman 389

Krijgsman, D. 140

Kunst en Letterbode 228

kunsten en wetenschappen 200, 211, 436,442

kunstgenootschappen 50

Kunsthistorisch onderzoek 28

Kunstnijverheid 270

kweekscholen voor ambtenaren 21

kweekscholen voor inheemse artsen 21

kweekscholen voor onderwijzers 21

Laclé, H.N. 74, 77, 79-80, 121-2, 146

Lajang Damar Woelan 484

Lakschmi 350, 400, 405

Lammers van Toorenburg, N.D. 478

Lampongs 474-6, 483, 485-7, 491

Lampongse expeditie 383

Lampongse handschriften 467

land- en volkenkunde 34, 427, 499

landbouw 9, 117, 125, 185, 200, 210, 352, 395, 441

landbouwgereedschappen 476

landbouwkundige genootschappen 1501

landkaarten 133

Landsdrukkerij 208, 213-4, 233-4, 237, 291-2, 298-300, 303-6, 320-1, 323, 331, $333,414,487-8$

Lange \& Co 336-7, 341-2, 344, 389, 406, $413,431,461,489$

Lange, G.A. de 374, 436-7

Lange, S.H. de 380, 406

Laschenskie 280-1

Lassen, Chr. 325, 347, 356, 417-8

latijnse school 23, 67, 83, 143

Lawoe 460

Lazinchy zie Laschenskie

Lecouteux, A. 454

leden 5-7, 14, 87, 95-6, 98-100, 123, 135, $148,154,162,212,285-8,351,438-40$

ledenlijst 98-9, 163, 170

Leemans, C. 309-10, 379, 392, 444-9, 4512, 458-9, 461 leer- en leesboekjes voor de inheemse scholen 380-1, 481, 487-90

leesbibliotheek 390

leesgezelschap 'Tot nut en uitspanning'

(Batavia) 55

leesgezelschap 'Utile et Dulce' (Batavia) 369

leesgezelschappen 39-41, 50-1, 55, 58,

134, 150-1, 356, 364, 366, 369, 404

leesmuseum 366-8, 400

leeszaal 504, 506

Leeuwarden 79

Leeuwen, J.E. van 392

Leiden 59, 62-3, 67, 83-4, 144, 193, 212, 215-6, 228, 250-1, 260, 268, 294, 298, $307-9,316,326,349,357,361,392,413$, 443-9, 452, 455, 458, 461, 463-5, 470, 473, 478

Leids Prentenkabinet 377

Leidse universiteit 31, 361, 397, 412

Leipzig 389, 421

Leistman, J. 160

Lembaga Kebudajaan Indonesia 2

Lenting, D. 189, 191, 209-10, 221-3, 234-

6 , 239, 242, 246, 249-50, 252, 260, 270-2, 275-82, 286-8, 291-2, 298, 417

Leschenault de la Tour, J.B.L.C.Th. 165

letterkunde 105, 120, 150, 317, 400

letterkundige genootschappen $38,41-2$, 50-1, 151

letterkundige werkzaamheden 250

Letterkundige Uitspanningen 150

Leupe, P.A. 30

Leuven 216

Levyssohn Norman, E.D. 477, 483

Levyssohn Norman, H.D. 396, 437, 455, 457, 468-9, 471-4, 477, 483, 488, 491-3, 497, 506-7, 509, 511-2

Leijdecker, M. 27, 34, 277

Leyden, J. 167, 173, 182

lezingen 191, 278-9, 282, 297, 367, 369, 400

Lian The 8

Lichtenberg, G.C. 100

lidmaatschap 198, 201-2

liefhebberijtoneel 60

Liem Tiam Sing 356

Lillo 83-4 
Limbangan 439

Limburg Brouwer, J.J. van 471, 474, 491

Lingga 278,313

Linnaeus, C. 125

Lion, H.J. 361

lithografische inrichting van het geniekantoor 378, 394

Locke, J. 47

Lodewijk Napoleon 56-7, 61

Logan, J.R. 411-2

Loman, C.J. 366

Lombok 333, 475, 483

Londen 17, 31, 40, 70, 103, 127, 167, 169, $174-7,181,455$

Lons, C.A. 33

Loro Djonggrang 460

Loten, J.G. 32

Loudon, A. 437, 443, 454, 467, 474, 4856,510

Loudon, J. 474

Luc, J. de 130

Luik 253

Lutzow, B.F.W. baron von 171, 180, 188

Lynden, D.W.C. baron van 383, 393

Lynden van Blitterswijk, W.C.H. baron van 102

Maanen, P.J. van 113

Maatschappij der Nederlandsche

Letterkunde (Leiden) 84

Maatschappij der Verdiensten 'Felix

Meritis' (Amsterdam) 32, 44

Maatschappij tot Nut van 't Algemeen

(Edam, Amsterdam) 39, 41-2, 50-1, 56,

58-9, 91, 150, 364, 373-4

Maatschappij tot Uitgave van Javaansche

Monumenten 262

Maatschappij van Nijverheid 362-3, 373-

5, 387-8, 406, 408-9, 496-7, 509

Maatschappij van Toonkunst (Batavia)

364, 407

MacGillavry, H. 305

Mackenzie, C. 167-71, 173, 182, 186-7, 228,240

Mackenzie Collection 168

Macklot, H. 247

Madioen 399, 415

Madjapahit 383, 393
Madoera 336, 338, 378, 384, 478, 488

Magelang 238-9, 356, 439, 477

Maier, P.J. 329, 370, 373

Makassaars 491

Makassaarse handschriften 133

Makassaarse regalia 133

Makassar 97, 102, 112, 134

Malabar 97, 144

Malabar en Choromandel [...] en Ceylon, Naauwkeurige Beschryvinge van 27

Malabarkust 16, 18, 76

Malakka 18, 97, 136, 167, 218, 227-8, 431

Malang 385, 427, 439, 452, 463

Malayan Branch (Royal Asiatic Society Singapore) 180

Malayan miscellanies 34, 176

Maleis 105, 210, 380, 411, 434, 484, 487

Maleis woordenboek 26, 237, 277, 412

Maleise boeken 132, 404, 432

Maleise bijbel 29-30, 34, 37

Maleise edities 386

Maleise handschriften 296, 304, 347, 421, 470

Maleise samenspraken 336-7

Maleise schoolboekjes 490-1

Maleise spraakkunst 34, 237

Maleise taalstudie 209, 296

Mangkoenegoro, Pangeran Adhipati

Ario 356, 439, 466

Manik-Maja 411

manuscripten 35, 123, 126, 130, 133-4, 175, 219, 269-70, 273, 402-4, 470, 482, $486,492-4$

manuscripten op lontarbladen 403

Maria (Balinese slaaf) 127, 142

Mars (slaaf) 142

Marsden, W. 165, 167, 254

Martapoera 482, 509

Marum, M. van 56, 85, 113, 148, 227

mathematische instrumenten 132

Maurisse, P.S. 191, 194-7, 198, 208, 211-

2, 215-6, 220-2, 227-8, 232, 245-6, 252,

276-7, 279

Mauritius 100, 212, 228

Mauritshuis 61

Max Havelaar 22

Mayor, J. 305

Medan Merdeka Barat ix, 2 
Meder, J.C. 352, 366

Medhurst, H.W. 296-7, 299-300, 303-4

Meer, P. van der 271-2

Meer van Kuffeler, F.C. van der 59-60

Meerman van der Goes, D.A. 102

Meessen, J.A. 507

Meester Cornelis 168

Melvill van Carnbee, P. 370

Menado 279, 475, 480

Mendoet 384

Mentawai-eilanden 427

Merbaboe 240, 278, 493

Merbaboe-handschriften 402, 492

Merkus, P. 189, 222, 235, 254, 259, 261-2, 276, 280-5, 287-8, 293, 302, 306, 326, $328,334,344$

mestiezencultuur 53

meteorologie 42

Metternach, H. 143

Metzlar, J.C. 74, 121, 139, 147

Meijer, J.D. 254, 413

Meyer, J. de 77, 80

Meylan, G.F. 220-1, 248, 278

Michielsen, L.J.J. 280, 510

Midas 365

Middelburg 26, 40, 42, 56-7, 60, 66, 83, 143, 227

Midden-Java 27, 309, 311, 326, 385, 392, 398-9, 454, 457, 462, 466, 478

Milburn, W. 254

Militaire Eendracht, De (Batavia) 190

Millard, J. 367

Millies, H.C. 347

Milne, W. 228

Mimazunzo 246

Minahasa 480-1

mineralen 129, 132, 326, 329, 357, 363, 392

mineralogisch kabinet 345, 504, 507

mineralogische afdelingen 13

mineralogische verzameling 441, 473

Ministerie voor het publiek onderwijs, nationale nijverheid en de kolonien 227, 259

Minto, Lord 9, 19, 167-70, 172, 174, 180, $188,199,231$

missie 489

Modjopahit 434
Moedjarad, R. Bagoes 381, 487

Moens, A. 16, 74, 76, 78, 81-2, 89, 111, 122, 133, 138, 140-1, 143-7, 155, 157, 160

Moesa, Hadjie Mahamad 439

Mohr, J.M. 29-33, 71, 132, 153

Mohr, dochter van J.M. 33

Molenvliet 410

Molenvlietse Dijk 30

Molukken 20, 275, 279, 396, 431-2, 434, 474-5

Montaigne 220

Moors Hospitaal 55

Mossel, J. 29, 31, 71, 128

Motman, F.H.C. van 329-30

Mounier, D.L. 322, 325

Müller, M.J.E. 357

Mulder, G.J. 62

Muller 221

Multatuli zie E. Douwes Dekker

Munnich \& Ermerins 399

Munnich, Johan 399

Munnich, Jurriaan 309, 343, 349, 352, 356-7, 363, 366-8, 376, 379, 387, 391, 397-402, 417, 421, 423, 425-8, 430

munten 384, 395, 397, 427, 430, 432, 445, 504

Munten van Nederlandsch-Indie 484

Muntinghe, H.W. 173, 180, 219-20, 222

Museum Bataviaasch Genootschap 6, 138, 171, 218, 220-2, 237, 260-7, 269-71, 282-3, 288-9, 302, 304, 315, 326-7, 329$30,335,340,345,377,382,386,391-2$, 404, 406-7, 409, 411-2, 435, 437, 443, $452,457,462,466,469,471,480,482$, 497, 499, 501, 507

Museum Gajah 2

Museum Nasional (Nationaal Museum) ix-x, 1-2, 12-4, 63, 180, 192, 198, 205-6, 273-4, 505

Museum Pusat (Centraal Museum) 1

Museum van Natuurlijke Voorwerpen (Batavia) 307

Museum van Oudheden (Batavia) 307

Museum voor Landbouw en Nijverheid (Batavia) 372

Museum voor Natuurlijke Historie (Leiden) 361, 446 
Museum voor natuurlijke historie, oudheden, zeldzaamheden (Batavia) 261, 265, 268, 271-2, 283, 326

Museum voor Volkenkunde (Leiden) 62, 193, 252

Museum Weltevreden 237, 254, 256-7 museumbesluit 260-1, 264-5, 268, 272, $283,288,308-9$

museumplan 256-7, 259-60, 270, 272 muziekinstrumenten 134, 137, 476 muziekverenigingen 58, 60

Mijer, P. 291, 293, 296-7, 300-2, 310, 3167, 322, 326-7, 338, 340-2, 349, 507-8

Mijnhardt, W.W. 38-44, 46-52, 54, 58, 60-1, 104

Naerssen, C. van 158, 160, 173

Nagai Ginba Ka Nami 356

Nagasaki 161, 243, 246, 248

Nagtglas, F. 84

Nahuis, G.H. 277

Nandi 393, 466

Napoleon 217, 233

Nassau-Weilburg, Prins van 102-3

Nationaal Archief zie Arsip Nasional Republik Indonesia

Nationaal Museum zie Museum Nasional

Nationaal Volkenkundig Museum 12

Nationale Bibliotheek zie Perpustakaan Nasional

Nationale Vergadering 56

naturalia 126, 132, 136-7, 205, 215, 218, 330

Naturaliënkabinet (Haarlem) 71, 113, 126-7

Natuur-en Geneeskundig Archief 316, 35960,411

Natuur- en Letterkunde Beoefenend Genootschap Studio et Labore (Batavia) 366, 369

Natuur- en Scheikundig Genootschap (Groningen) 227

natuurhistorische afdeling 392

natuurkunde 125, 131, 295

Natuurkundig Tijdschrift voor Nederlandsch-Indie 360, 370, 390-1, 426, 428

Natuurkundige Commissie over
Nederlandsch-Indië 182, 236, 247, 255, 257, 260, 264-5, 268, 293-6, 298-9, 304, 307,326

natuurkundige genootschappen 41,50 , 356

natuurkundige instrumenten 134, 146, 205, 225

Natuurkundige Vereeniging in Nederlandsch-Indië 353, 355, 360-3, 370-5, 387-9, 391-2, 406-9, 425-6, 441, 473, 496, $507-9,511$

natuurkundigen 165

natuurlijke historie 186, 200-1, 295-6, 308, 441

natuurwetenschappen 30, 352-3, 362-3, 430, 434

navigatiekunde 27

Nederburgh, S.C. 18, 148-9, 158

Nederlands-Mafoors (Papoeaas) woordenboek 485

Nederlands-Maleis woordenboek 136

Nederlandsch Bijbelgenootschap 304, 487

Nederlandsch Koloniaal Museum 266-7, 294

Nederlandsch-Indische Maatschappij van Nijverheid 355, 370, 372, 407, 441

Nederlandsch-Oost-Indisch Bijbelgenootschap 293, 364

Nederlandsche Handel-Maatschappij 20, 259

Nederlandsche Staatscourant 228

Nees van Esenbeck, T.F.J. 244

Negapatnam 17

Negara-wanggie 336

Nes, J.F.W. van 377

Netscher, E. 7, 355-6, 362, 368, 380, 382, 384-5, 387, 392, 394-9, 404, 409, 417, 423, 426-8, 430-1, 436, 439, 443, 450, $453,467,471,473,475-6,484,487-8$, 496

Neubronner van der Tuuk, H. 347, 405, 421, 431-2, 438, 467, 485-8, 491

Ngabehi, Pangeran 494

Ngantang 466

Nias 484-5

Nielen, P.M. van 109, 111, 120-1

Nieuwe Inrigting/New Regulations zie 
reglementen

Nieuwe Kerk (Amsterdam) 465

Nieuwe Wetten zie reglementen

Nieuw-Guinea 174, 396, 432, 434, 475, 479

Nieuw-Zeeland 221

Nil Volentibus Arduum (Amsterdam) 45

Nimrod, A.W. 365

Nippon (Von Siebold) 251

Noord-Oost-kust van Java 96-7, 140, 165

Noordwijk 410, 509

Noronha, F. 122

Noto Kosoemo, Penambahan van Sumenep 229, 354

Notulen Bataviaasch Genootschap 3, 5, 10-1, 350-1, 383, 391, 403, 421, 435, 438, $455,462,469,491$

numismatiek 392, 484

numismatische afdeling 13

Nut en inspanning, Tot (Batavia) 366

Nut en Vergenoegen, Tot (Paramaribo) 150

Nutsdepartementen 58, zie ook Maatschappij tot Nut van 't Algemeen

Nuttig en Aangenaam (Paramaribo) 150

Nuttig en Vermakelyk (Paramaribo) 150

nijverheid 125, 210, 430, 441

nijverheidstentoonstelling 372-3, 395, 406-7

Ockerstein, J.B. 227

Oeconomische Tak (Haarlem) 41, 44, 50, 72-4, 78, 84, 86, 94, 104-5, 151, 154

Oengaran 240, 311

Oliphant 431

onderwijs 21, 23, 185

onderwijscommissie 317

Onrust 78, 140

Oost-Java 164-5, 175, 193, 275, 385, 454, 466

Oostelijk Celebes 475

Oosterling, De 242

oosterse handschriften 297, 347, 438

oosterse talen 105, 131, 296

Oostkust van Sumatra 475

Openbaarheid in koloniale aangelegenheden, De 344
Open-Deure tot het verborgen Heydendom, De 27

opleiding voor ambtenaren 323-4

opvoeding 185

Oriental and India Office Collections

(British Library) 11, 35, 93, 168

Oud en Nieuw Oost-Indien 27

oudheden 125, 200, 308-15, 328, 330, 376-7, 392, 402, 431-2, 435, 441, 444-61, 484, 494

Oudheden van Java 458-9

oudhedenbesluit 308-10

oudheidkunde 13, 173, 295-6, 308, 331, $427,483,492$

oudheidkundig museum 326

oudheidkundige afdeling 508

Oudheidkundige Commissie 192-3, 206, 214, 221, 261-3, 308-9, 444

Oudheidkundige Dienst 12, 263, 459

oudheidkundige kaart 438, 444-5, 449, 451,453

oudheidkundige verzameling 288,308 $5,327,329,335,345,406,410,420-1$, $444,449,462,474,483,504,506,510-1$

oudheidkundige voorwerpen 192, 268, 270, 275, 297, 381, 383-5, 393, 446-7, 450, 461-71, 494, 502

Overbeek, D.A. 212, 222, 229-30

Overdijk, B.N. 265, 298, 326

Overhand, P.J. 315

Overmeer Fisscher, J. van 269

Overstraten, P.G. van 19, 139

Padang 18, 59, 97

Padangse sabel 222

Paets van Troostwijk, A. 113

Pahud, C.F. 291, 385, 393, 398, 429, 495, 497

Paingan 464

Pajitan 275

Pakoe Natta Ningrat Logo 354

Palakka, Aro 133

paleis Koningsplein 509

Palembang 20, 97, 209, 278, 396, 475

Palm, J. van der 56, 127, 135, 142

Palmer van den Broek, W. 485

Pamakassan 385

Panaroekan 451 
Papandajan 31, 33

Paradeplaats 256

Paramaribo 38, 150-1

Parang Sondrek 482

Parapattan 299, 301, 316, 379

Paringauw, J. 117

Parra, P. van der 29, 31-3, 71, 86-7

Parijs 40, 49, 70, 103, 228, 359, 455, 465

Paschen, J. 171

Pasoeroean 238, 241-2, 323, 384, 413, 451-2, 463

Pati 451

Payen, A. 192, 206, 214, 255, 261, 268

Peereboom, J. 222

Peitsch, J.G. 282

Pekalongan 310-1, 451

Peking 101

Penang 167, 228

Penataran 451, 457-9

penningen 504

penningmeester $138,214,282,337-8$, 342, 442

Perez, P.J.B. de 351, 388, 398

Perpustakaan Nasional (Nationaal

Bibliotheek) ix-x, 1-2, 12, 14, 29, 315

Perret, A. 222, 278

Perzische grammatica $129-30$

Perzische manuscripten 132

Pet, G.A. 461

Petersburg, St. 103

Petersburgse Academie 101

Petit, E. 218

Petten 93

Philadelphia 218, 228

Philosophical Transactions 31

Physica (Alkmaar) 39

physische instrumenten 132, 330

Pietermaat, D.F.W. 383, 393

Pilon, J.B. 108-10

Pinang, Kota 467

Pinket van Haak, D.W. 192, 206, 209-10, 214-5, 221, 261

plaatsbeschrijving 117

plant- en dierkunde 185, 353

plantenrijk 129, 131, 353

Plantentuin, 's Lands (Buitenzorg) 189, 215, 236, 243, 256, 293, 499

Plantentuin Weltevreden 254-6 plantkunde 117, 125, 131, 164, 185

Plein van Waterloo 256

Plered 233

Pleuren, B. van 133, 140

Pluim Mentz, N. 280, 293

Poel, H.A. van der 452

Poelman, P. 110

Poelman, S. 110

Poerwokerto 383

Poerworedjo 315, 439

Poleman 212, 416

politieke genootschappen 41,43

politieke gezelschappen 43,50

Pondok Gede 78

Pontianak 383

Poock, J. 76

Popkens, D. 222

Portugese boeken 132

Portugese bijbel 29-30, 37

Portugese grammatica 89

Post, F. 28

Prambanan 173, 454, 458, 460

Prapak 477

Prawiera Adie Ningrat, R.A.A. 229

Preanger 395, 451

preciosa 274

Prins, A. 386, 397, 424

Probolinggo 451, 463, 465

profielen 133

programma 123

Programma (1778) 33, 63, 65, 73-6, 81, 86, $88-90,92-7,98-9,101,105-8,110,112$, 115, 136, 147, 198

Programma (1782) 127

Programma (1791) 146

Programma (1814-1816) 170

Programma (1923) 196

protestvergadering 22 mei 1845 338, 340-3, 350

Provinciaal Utrechtsch Genootschap van Konsten en Wetenschappen 40, 71, 91, 111, 227

prijsvragen 5-6, 45, 50, 61, 70-1, 79, 81, 104-15, 152, 198-99, 204-5, 207, 209-11, $276,278,362,414,442,502,504-5$

publicaties 115-23, 171, 173-7, 197, 211, 298-302, 315-25, 335, 411-2, 435, 483-92

publieksgenootschappen 43-4, 50, 58, 104 
publiekssociabiliteit 45-6, 49-50, zie ook genootschappelijkheid

Puy, J. du 188, 198, 274

Pijnappel, J. 429-30

\section{Quarles van Ufford, P.N. van 254}

Raad der Aziatische Bezittingen 79

Raad van Justitie 68, 191, 509

Raad van Nederlands-Indië $65,86,144$, 148, 159, 203, 281, 287, 332, 350, 375, 424, 437, 442-3, 445, 505

Raben, R. 16

Rach, J. 28-9

raden van Indië 15, 23, 75, 87, 154, 157, 199

Radermacher, D. (neef van Jacobus) 66, 69,103

Radermacher, F.R. (zoon van Jacobus) 103

Radermacher, Jacobus 5, 7-8, 10, 12, 16, 32-3, 52-3, 55, 65-70, 72-6, 78-82, 86, 89, 91, 97, 99, 101-4, 106-8, 117, 120-30, $132-5,138,140-8,150,152-3,155,157$, $167,170,173,198,202,206,261,267$, 435

Radermacher, J.C. (broer van Jacobus) 66, 103

Radermacher, J.C. (vader van Jacobus) 52,66

Radermacher, S. (oom van Jacobus) 66

Radermacher, S.J. (broer van Jacobus) 97

Raders, jhr. W.F.H.F. de 504-6

Radijs, K. 232, 253

Raffles, Th.S. 5, 7-8, 11, 19-20, 33, 82, 149, 152, 160-1, 164-83, 187-8, 197, 199, 202, 210, 212-3, 218, 227-8, 232, 234, $240,259,267,272,280,285,324-5,406$, 435

Raquet, S. 143

rariteiten 134

Rau, S. 133

Recensent ook der Recensenten 228 redacteur 417, 425-8

Rederijkerskamer voor Uiterlijke Welsprekendheid (Leiden) 59 rederijkerskamers 56, 58-60 Reede tot Drakestein, H.A. van 26
Rees, P. van 336

reformistische genootschappen 43,50 , 104

regeringsreglement 22

registers 462

reglementen 5-6, 87-8, 136, 160, 172, 186, 197-207, 352, 405, 440-4

Reinking, G. 221

Reinwardt, C.G.C. $61,162-3,182,185-91$, 192-6, 208, 212, 215-6, 218, 221, 223-5, 254-5, 268, 276, 356

Reitsma, H. 44

Reijnst, jhr J.C. 321, 328-9, 344

relatie met andere genootschappen 22530,385

relatie tot de overheid $14,86,129,171$, 198-9, 212-8, 233-9, 332-45, 352-3, 375$88,407-10,437-8,440-1$

Rembang 78, 416, 451, 465

Remusat 249

Republiek der Nederlanden 14-5, 17, 30-2, 37, 39, 42, 45-6, 48-9, 52, 54, 65-7, 69-71, 78, 82-3, 86, 88-9, 93, 100-1, 103, $106,111,113,127-8,141,149,153-4$

Reteh (Riouw) 384

Reuvens, C.J.C. 62, 261-3, 268, 444

Rhede, P.J. van 99

Rhemrev, L. 485

Rhetorica (Batavia) 60

Richardson, S. 47

Riedel, F.J. 92

Riedel, J.G.F. 439, 480-1, 487

Riemsdijk, J. van 29, 72, 86, 162, 188

Riesz, C.J. 310

Rigg, J. 423, 484

Riouw 396, 398, 423, 428, 436, 443, 467, 471, 476, 487, 493

Ritter, W.L. 317, 336, 400

Rochussen, H. 410

Rochussen, J.J. 60, 321, 332, 339, 344, $359,376,378,457,495-6$

Rogerius, A. 27

Romo 320-3, 325, 331, 413

Roo, H. de 110

Roo, L.W.G. de 6, 374, 437

Roorda, T. 321, 418, 423, 433

Roorda van Eysinga, P.P. 237, 325, 342, $412-7,420,423$ 
Roorda van Eysinga, W.A.P. 336-7

Roos, E. 281

Rosenberg, C.B.H. baron von 396, 431-2, $473,479-80$

Ross, J.Th. 72, 75, 111, 138-9, 142, 147, 149, 155, 158-61, 163, 165, 171, 173, 180, 188, 190-2, 196, 198, 254, 417

Roti 125

Rotterdam 17, 40, 43, 49, 56-57, 60, 69, 71, 74, 76-9, 86, 91, 100, 102-4, 107, 111$5,122,134,153-4,229$

Roux, C.C.F.M. le 252

Royal Academy (Londen) 101

Royal Asiatic Society of Bengal (Calcutta) 455

Royal Asiatic Society of Great Britain and Ireland (Londen) 180, 241, 455

Royal Society (Londen) 31, 38, 45, 181

Royer, J.Th. 61

Rudolph, M. 337, 342, 414, 420

Rumphius, G.E. 26

Rijck, A. van 33, 111, 123, 174

Rijck, G.C. van 395

Rijks Etnografisch Museum (Leiden) 62, 252

Rijksmuseum zie Koninklijk Museum (Amsterdam)

Rijksmuseum van Oudheden (Leiden) $62,193,268,307,309,392-3,444-6,449-$ $50,452,455,459,478$

Rijksmuseum voor Natuurlijke Historie (Leiden) 62, 250, 260, 294, 307

Rijkspenningenkabinet (Leiden) 63

Rijswijk 177-8, 208, 257, 264, 286, 320, 374, 404, 406, 408

Rijswijkstraat 178-9, 189, 213, 217, 223, 264, 268, 286, 309, 312, 317, 328-9, 331, 357, 368-9, 390, 405-6, 408-9, 419, 435-6, $462,497,502-3,508$

Sadjara Malajoe 489-90

Sadjara Radja Djawa 229

Salak 224

Salatiga 240, 242, 278, 311

Saleh, R. 437, 439-40, 467, 489, 494

Sambas 427

Sancigny, E. de 308

Sanskriet 246, 420
Sanskrietse manuscripten 132

Saxe, C. 138-40, 146-7

Scalliet, M.O. 28

Schaap 384

Schaefer, A. 312-3, 376-9, 399

Schauw 130

schedels 137, 222

Scheidens, E. 101, 133

Scheidius, E. zie E. Scheidens

schelpen 326, 329-30, 357, 392

Schepenbank 16

schilderijengalerij van Willem V (Den Haag) 127

Schill, E.A. 372

Schill, J. 147, 158, 171, 198

Schippers, Th. 69, 76

Schlegel, W. von 325

Schmidt auf Altenstadt, J.G.O.S. von 311

Schneither, J. 194-5, 222, 235, 257

Schönberg Müller 379, 451

schone kunsten 352

Schoor, J. van der 259, 283-4

Schouwman, F. 128, 147, 158, 160

Schrader 281

Schroeder, N.G. 133

Schulpforta 417-8

Schultens, H.A. 101

Schwaner, C.M. 380

Schwaner, L. 307, 427

secretariaat $85,188,275$

secretaris 10, 123, 127, 138-9, 142, 159-61, 189-90, 195-6, 202-3, 207, 214, 219, 225, 234, 302, 332-4, 339, 341, 344, 349, 391, $417,424,442,495,506$

Semarang 33, 139, 193, 225, 239, 241, 275, 310-1, 314-5, 323, 336, 340, 349, $352,359,374,378,384,399-400,431$, 451,487

Seminarium Theologicum (Batavia) 24, 29-30, 35

Senegalese boeken 132

Senerpont, Domis, H.F. de 241

Senerpont, Domis, W.J.C. de 241

Serang 482

Serière, G. de 218-23, 235, 242

Seton, A. 254

Sevenhoven, J.I. van 166, 169, 171, 180, 188-90, 209, 221, 266, 287-8, 306 
Severijn, Jufr. 223

Shelton 479

Shiva 470

Siak $467,474,484$

Siam 454,467

Siam, Koning van 2

Siberg, J. 19, 148-9, 162, 188

Siebold, Ph.F. von 62, 212, 229, 237, 239, 242-52, 269, 278, 282, 308, 356

Sieburgh, G.J. 220, 252

sieraden 476

Simons, G. 423

Sincérité, La (loge Den Haag) 52

Singapore 174, 359

Singapore Institute 174

Singeling, C.B.F. 38

Singosari 193, 268, 392, 451

Sjaïr Bidasari 305-6, 320, 324-5, 411

Sloet tot Oldhuis, B.W.A.E. baron 478

Sloet van de Beele, L.A.J.W. baron 22, 442, 446-7, 449, 454, 461-2, 464, 466-8, $478,493-5,497,500,502-3,507,512$

Smeroe 460

Smit, juwelier 274

Smith, D.J. 33, 67, 76, 132-3, 140

Smith, J.D. 382

Smith, predikant 144

Snelders, H.A.M. 9-10, 120

Snell 267

Snouck Hurgronje, C. 418

sociabiliteit zie genootschappelijkheid

Société Asiatique (Parijs) 455

Society for the Encouragement of Arts, Manufactured and Commerce (Londen) 72

soeka rame 274

Soekadana 427

Soekapura 439

Soekoe 304-5, 308

Soembawa 359

Soemedang 439

Soemenep, sultan van $366,378,383,415$, zie ook Noto Kosoemo

Soenda 484

Soendanees 485, 488-9, 491

Soendanees-Engels woordenboek 414, 423, 484

Soendanese handschriften 489
Soendanese taalstudie 296

Soerabaija 59, 235, 238, 241, 273, 349, $353,371,374,378,383,393,413,415-6$, $430,443,451-2,463,494$

Soerakarta 59-60, 165, 174, 294, 304-5, $311,322-5,411,413,415,439,450,485$, 487, 493

Soeria Karta Adinegoro, R. Toemengong 355

Soerio Koesoemoe Adi Noto, R.A. 439

Soerio Sasra Ningrat, Pangeran Adhipati Ario 356

Soerja Widjaja, R. Pandji 493

Soerjo Negoro, Pangeran Ario 493

Soero Semito, Kiay 461

Soesoehoenan 322-3

Solo 381, 432, 485

Sommer, F. von 392, 412

Sophronisba 78

Souratte 97

Spectacle Français 190

Speelman, C. 27

Stadhouderlijk Kabinet (Den Haag) 68, 137

stadhouderlijke verzamelingen 61

Stadhuisplein 509

statistiek 427, 441, 446-7

Steege, J. van der 77, 79-80, 115, 128-9, 134, 153, 162

Steele, J. 47

Ster van het Oosten, De (loge Balatia) 509

sterrenkunde 27, 29-31, 84

Stevens, Th. 53

Stieltjes, T.J. 450, 454

Stipriaan Luïcius, A. van 113

Stockum, H. van 76

Stokhof, W.A.L. 486

Storm, G. van der 214

Stortenbeker, W. 437, 455, 471, 509

Straatsburg 253

studentengezelschap zie Rederijkerskamer voor Uiterlijke Welsprekendheid

Studio et Labore zie Natuur- en Letterkunde Beoefenend Genootschap

Stuers, F.V.A. ridder de 351, 357, 432-3, 445,450 
Sturler, J.W. de 212, 243, 268

subsidie 216, 260, 262, 264, 294, 315, 375, 386-9, 391, 409, 499

Sumatra 22, 97, 176-7, 181, 381, 396, 399, 422-3, 430-2, 434, 439, 452-3, 474, 487

Sumatran Mission Press 176

Surat 18

Surinaamsche Lettervrinden

(Paramaribo) 150-1

Swaving, J. 360, 370

Swieten, J. van 351, 357, 381, 398, 433, 436-7, 495, 506

Swinden, J.H. van 130

taal- en letterkunde 308

taal- en volkenkunde 436

taal-, land- en volkenkunde 4, 13-4, 34, $37,60,88,125,130,173,186,201,243$, $271,289,353,357,362-3,382,412,425$, $434,436,438,441,467,492$

taalambtenaar 422

taalkunde 5, 120, 209, 315, 320-5, 328, $331,345,370,427,434-5,438,467,480-$ $1,483-92$

taalstudie 200, 305

Tabel van oud-en nieuw-Indische alphabetten 486

Tabellorezen 479

Tamdjid Illah, Sultan 482

Tamigens, bapak 281

Tamilse boeken 132

Tanah Abang 509

Tanah Boemboe (Borneo) 427

Tanimbar-eilanden 479

Tankuwang Prahu 224

techniek 9, 352

Teengs, A.N. 367

Tegal 323, 451

teken- en schilderkunst 29

tekstedities 320-5, 331, 340, 345, 370, $386,411-7,423,434,475,484,489$

Temminck, C.J. 62, 212, 268, 294

Tengger $165,175,242,278$

Ternate 97,133

Terne, C. 109, 111, 113, 120, 123, 174

Tesseire, A. 120, 122, 147, 158, 160

Teylers Genootschap (Haarlem) 39

Teylers Museum (Haarlem) 63, 145
Teylers Stichting (Haarlem) 42, 91

Teijsman, J.E. 493

Theorie der schoone kunsten en wetenschappen 92

Theunisse 216

Thorbecke, J.R. 57, 62, 340, 351

Thunberg, C.P. 80, 101, 128, 253

Tidore, Sultan van 274

Tiedeman, J. 222, 293

Timor 97, 125, 396, 434, 474-5, 481

Tirto Noto, R.A. 355

Titus (Balinese slaaf) 127, 142

Tjeenk, J. 84, 144-5

Tjetto 304-5, 308

Tjiamis 493

Tjiandjoer 475

Tjiboeroei 494

Tjikao 224

Tjokro Di Wirio 241

Tjokro Negoro, R.A. 439

Tjondro Adi Negoro, Pangeran Aria 355

Tobias, J.H. 254

toegepaste kunst 29

Toenggoel 336

Toewater, W.C.H. 331, 334, 418

Tollens, L. 400, 430

Tondano 480

toneelverenigingen 58-9

Tooen-oen Boeloe-stam 480

Tooneel Gezelschap (Batavia) 190

Tot Heil van 't Menschdom 39

Transactions zie Verhandelingen

Tranquebar 101

Travers, Th.O. 181

Trawas 384

Tromp, J. 222, 254-7, 260, 264, 266, 273, 282, 293, 299, 330, 342, 372, 421

Trowt, Th. 175

Tuin Du Bus 256, 271

Tutein Nolthenius, K.H. 480

Twaalftal Kerkelijke Reden 335

Tweede Kamer 343

Tijdeman, H.W. 212

tijdrekening op Java 431

Tijdschrift Bataviaasch Genootschap 1, 3-6, 10-2, 280, 282, 356, 379, 389, 391, 395, 405, 412, 423, 435, 438, 462, 474, 480-1, 484-6, 489, 491 
Tijdschrift ter bevordering van Christelijken zin 317

Tijdschrift voor Indische Taal-, Land-en Volkenkunde 252, 291, 296, 351, 362-3, 387, 397-9, 423-4

Tijdschrift voor Nederlandsch-Indië 8-9, 280, 346, 350, 361, 400, 419, 430, 451

Tijdschrift voor Neêrland's-Indië 4, 291-2, 297, 299, 303-4, 316-7, 325, 332-4, 336, 340-1, 350, 359, 400, 420, 450

Tijdschrift voor Nijverheid 372

Tijgersgracht 35

Uhlenbeck, G.H. 495-500, 502-3, 512 universiteitsbibliotheek Bonn 417

Uppsala 80, 101, 103, 128, 228, 253

Utrecht (provincie) 41, 50

Utrecht (stad) 17, 38-9, 42-3, 45, 49, 57, 71-2, 91, 100, 133, 212, 215-6, 228, 389, 421,450

Utrechtse Universiteit 361

vaartuigen 395

Vaderlandsche Letteroefeningen 48, 228

Valck, F.G. 311, 314

Valentijn, F. 27, 271

Vaijnes van Brakell, R.B.G. de 357, 379, 422

Veere 83-5

Velde, P. van de 289

Vereeniging Musis (Batavia) 364, 367-9, 371, 400-1

Vereeniging ter Bevordering der Geneeskundige Wetenschappen (Batavia) 360, 370-1, 373, 426

verenigingsleven 364-9

vergadering 5

Verhandelingen (Haarlem) 33, 70, 84, 134

Verhandelingen Bataviaasch Genootschap $1-5,8-9,33,43,63,73,75,78-80,82,86-$ 7, 92-3, 96, 98, 102-4, 111, 113, 115-23, 131, 134-6, 147, 149, 153, 159, 161, 164, $167,170,173,175-6,181-2,190-1,196$, 204-5, 208, 210-4, 218, 224-5, 228-30, 233-4, 236-8, 240-2, 244-6, 248-9, 251-3, 261, 267, 276-80, 282, 288, 291-2, 297$303,305-8,316-7,321-3,325,327,331$, $334-6,342$, 344, 351-2, 356, 359, 362-3,
$379,386,389,391,393-4,398,401,404$, 411-6, 419, 422, 426, 434-5, 438, 443, 452, 481, 483-4, 489, 493

Verhandelingen Zeeuwsch Genootschap 130, 134

Verhoeven, F.R.J. 180

Vermeer, T. 88, 146-8, 155

Vermeulen, H.F. 34

Vermij, R. 45-6, 49

Véron 30

Versteegh, W.F. 368, 382, 436, 453, 496, 504, 506

vertalingen 434

Vertueuse, La (loge Batavia) 53

Verijsel, H. 66

Verijsel, M.S. 66

verzameling Horsfield 170

verzameling Mohr 132

verzameling naturalia en zeldzaamheden 218

verzameling portretten 397

verzameling Radermacher 69, 132, 206, 261

verzameling sultan van Bandjarmasin 481

verzameling sultan van Bantam 263,

272-4, 296, 328, 482, 492

verzameling Valck 311, 314

verzameling Von Siebold 249-50, 308

verzamelingen 5, 81, 126-7, 129-38, 166,

168, 205-6, 221-5, 263, 267-75, 294-8,

308-15, 357, 381-6, 391-6, 447, 461-83, 492-4, 499

Veth, P.J. 3-5, 7, 10, 193, 289, 344

Veur, P. van der 8-9, 53

vice-voorzitter 189-90, 203, 207

Vinne, J. van der 11, 189, 191, 193-7, 1989, 202-3, 209, 213-4, 219, 221-5, 227-8, 232-40, 242-3, 245-7, 249-52, 256-7, 259-60, 268, 272, 275-84, 287, 296, 3002, 304-6, 308-9, 321, 326, 329, 366, 417, 440

Vishnu 133, 222

Visscher, C. 265, 273-4, 282, 293, 298, $302,319,332,334,339,341-4,347,349-$ $51,354,357,360,383,386-8,393,403$, 407, 420, 445

Visser, R.P.W. 38-40, 150 
visserij 125, 395

Vlis, C.J. van der 304-5, 308, 316, 331, 418

Vlissingen 17, 40, 42-3, 49, 67, 69, 71, 74, 76-7, 79, 84, 86, 100, 102-4, 107, 112-4, 131, 134, 144-5, 153-4, 206

VOC 2-3, 9, 14-20, 23-9, 33-5, 43, 66, 72, $82,85,87-9,91,94-7,99-100,103,117$, 134, 144, 148-9, 151-3, 159, 199, 202-3, 272,285

Vogelaar, J.J. 160

vogels 327

Vogelzaal 329

volkenkunde 117, 137, 200, 278, 308

Voltaire 120, 132

Vondel, J. van den 37

Voorneman, A.A. 487

voorzitter 157-9, 170, 188, 195, 202-3, 207

Vorm, P. van der 34-5, 37

Vorstenlanden 497

Vos, J. 76

Vos, J.A. 101

Vos, J.R. 228-9

Vosmaer, A. 68, 101, 137

vrijmetselaarsloge 41, 50, 52, 55, 66, 316

vrijmetselarij 39, 42, 53, 55, 67, 104, 152, 317

Waaier van het fortuin 474

Waal, E. de 333, 380, 399

Waal, L.W.J. de 468

Wachter, H. 109, 111

Wagenaar, J. 220

Waitz, A. 291

Waleson 382, 384

Wallich, N. 212

wapens 221-2, 271, 273, 382-5, 395, 404, 476-8, 482

Warem, De 124

Warem Jr., J. van 124

Warnasari 400, 405

Wasmuth, J. 108-9

Wassink, G. 357, 371, 373-4, 390, 407, 436-7, 454, 488, 495, 504

Water, J. te $84-5,87,122,131,144-5$

Waterloo 232

Waterloo, S.F. 239-40

Waterlooplein 257, 260, 271, 509
Waterstaat 260, 497

Wedding, Ph. 160-2, 188-91, 194-5, 208, 210, 212, 218, 222, 227, 232, 276-7

Wedloop Sociëteit (Batavia) 364, 407

Wees- en Boedelkamer 16

Weinmann, J.W. 132

Weitzel, A. 432-3

Welgevare, G. 138, 147

Welter, Ch. 180

Weltevreden ix, 19, 55, 170, 177, 236

Wenen 228

Weppelman, P. 121

Werken (Delft) 489, 491

Werken der Academie van Schoone Kunsten en Wetenschappen van Batavia 352, 424

Werkgroep Achttiende Eeuw 38

Werkgroep Genootschappen 38

Werkgroep Negentiende Eeuw 38-9

werktuigbouwkunde 270

werktuigen 270

werktuigkunde 105

Werndly, G.H. 34

West Indische Encyclopedie 150

West-Borneo 474

West-Java 31, 478, 483

West-Sumatra 20, 136, 443, 483

Westers, O. 56, 58

Westpalm, S. 66

wetenschap 25-7

wetten zie reglementen

Wetten (1791) 123

Wickevoort Crommelin, J.P. van 254

Wiegerman, J.H. 81-2, 89, 122, 143, 1489, 158

Wiese, A.H. 19, 158, 160

wiggen 478

Wilde, F. de 140-1

Wilde, P.J. de 400, 414

Wilhelmus Botanicus zie Katsura Gawa Hoken

Wilkens, J.A. 322, 325, 431, 484

Willem I, Koning 57, 61, 255, 268

Willem II, Koning 340, 343, 497

Willem III, Koning 466, 497, 499-500, 503

Willem V, Stadhouder 18, 40, 43, 68, 701, 78-9, 82, 87-9, 101-2, 110, 131, 133, $144,148,170,177$ 
Willemskerk 7

Willer, T.J. 331

Wilsen, F.C. $356,379,427,431,447,451$, 458

Wimmercrantz, S.W. 110

Winter, A.F. 221

Winter, C.F. 320-2, 324-5, 331, 356, 378, $411,416,431,484$

Winter, J.A. 325

Wira Adek Daha, Toemenggong 439

Wis- en Natuurkunde, genootschap 150

Wisnu 464

Wiwoho 320, 322-3, 325, 413

Wolf, B. 108-9, 120

Wolff, B. 48

Wonojoso 384

Wonosobo 455

Woodbury \& Page 507

Woordenboek der Nederlandsche Taal 40

woordenlijsten 486

Wrettasantjaja 411, 416

Writs, W. 44

Würzburg 243-4

Wurmb, F. baron von 30, 32, 73, 75, 77-

$80,82,108,121,124-9,132,134,136-7$, $139,141,153$

Wijck, jhr. C.van der 283, 291, 293, 349, 353, 357

Wijck, jhr. H.C. van der 384, 436, 443
Ysseldijk, W.H. van 188

Zeeland 41, 50, 60, 66-7, 69, 91, 102, 145, 154, 218

Zeeuwsch Genootschap der Wetenschappen (Vlissingen) 40, 42, 45, 56, $60,69,71,84,91,112-4,128,133,141$, $144,190,211,225,227,271$

zeevaartschool 29

Zeist 282

zeldzaamheden 205, 218, 222, 269-70

Zendelinggenootschap 232

zending 489

Zierikzee 144

Zollinger, H. 333

Zomerdijk, L. 160

Zonneveld, P. van 59

Zoological researches in Java, and the neighbouring islands 163

zoölogisch kabinet 259, 315, 327, 345, 392

zoölogische verzameling 13, 326-7, 357

Zuid-Afrikaanse pieken 222

Zuidoost Sumatra 474

Zuidelijk Celebes 475

Zuiderweg, A. 10, 53

Zutphen 447

Zwarte met het witte hart, De 355

Zweedse academie 271 